


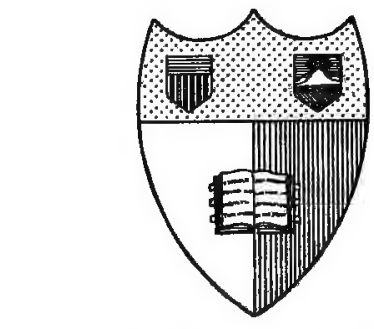

\section{Garnell Alniuergity Tithrary}

Jthaca, Nem Gaxk

BOUGHT WITH THE INCOME OF THE

\section{SAGE ENDOWMENT FUND}

THE GIFT OF

\section{HENRY W. SAGE}

1891

\section{ALBERT R. MANN LIBRARY}

New York State Colleges

OF

Agriculture and Human Ecology

AT

CORNELl UnIVERSITY 


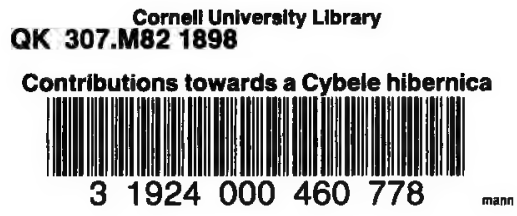




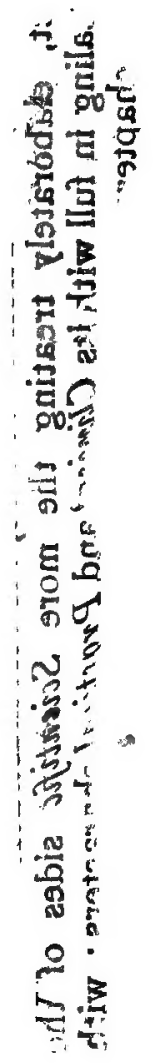


CYBELE HIBERNICA. 


\section{Cornell University Library}

The original of this book is in the Cornell University Library.

There are no known copyright restrictions in the United States on the use of the text. 

Missing Page 


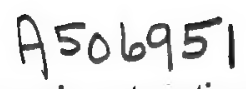

' Hane variæ gentes antiquo more sacrorum

Idæam vocitant matrem, Phrygiasque catervas

Dant comites, quia primum ex ollis finibus edunt

Per terrarum orbes fruges cœepisse creari."

Lucretius de Nat. Rerum, Lib. ii. 611.

During the summer months I used to perambulate in Company of ingenious Men, both of the Clergy and Laity, to have ocular Demonstration of the Plants themselves in their native Soil, where Nature regaled our Senses with her Gaiety and Garnishes, which makes some Resemblance of the paradisiacal State.

\section{Cateb Threltetid,}

Synops. Stirp. Hibernicarum. 


\section{PREFACE.}

For many years before his death in the spring of 1895, the publication of a new edition of Cybele Hibernica was kept steadily in view by the surviving editor of the first edition, our valued friend, Alexander Goodman More. So early as 1885, the Royal Irish Academy had associated itself with the undertaking by granting him a sum of fifty pounds for the preparation of a report on the Distribution of Plants in Ireland, it being understood that this report should form the groundwork of the new edition. When two years later he was obliged by severe and long continued illness to resign the curatorship of the Dublin Natural History Museum, it was hoped by all interested in Irish botany that health and strength might be granted him to finish the onerous work he had taken in hand. But as time passed, it became more and more perceptible that his failing bodily powers were unequal to the task. The intervals of comparatively good health which he enjoyed in his retirement enabled him, indeed, to bring together a large mass of material, published and unpublished, and to decide many doubtful points which his unrivalled judgment peculiarly fitted him for dealing with. This material, with his annotations, was embodied in an interleaved copy of the first edition, to be presented in due course to the Royal Irish Academy and to serve as the report which he had been commissioned by that body to prepare. But beyond this point his flagging energies failed to carry him; and when he finally passed away from us, the work remained sadly incomplete. He had taken steps, however, to ensure that his undertaking should not die with him. He had set apart private funds to meet the expenses of publication, and left among his papers 
an expression of his wish that the present editors should take up and complete the work which filled so large a place in his thoughts towards the close of his life. Obedience to a wish so expressed was for us a simple duty, and we undertook its discharge all the more cheerfully, as we felt that the close intimacy which we had enjoyed with our friend in his latter years had given us a fuller acquaintance with his views than was possessed by other Irish botanists.

In carrying on the work to its conclusion it has been our aim to give full effect to these views so far as they are known to us. Outside the limits so set, we have freely exercised our own judgment, with the result that several innovations have been introduced. As some of these may give rise to unfavourable criticism, it seems only just that we should mention them here, and accept full responsibility for them. The more important of these new features, many of which will be further explained in the Introduction, fall under nine headings :-(1) Re-arrangement of the orders, genera, and species in accordance with the sequence adopted in the ninth edition of the London Catalogue, 1895 ; (2) Extension of the scope of the work so as to include the Characea; (3) The use of Roman numerals to denote the districts; (4) Reference to the soil-relations of plants where well-marked; (5) Systematic indication of the sources whence previously published records are drawn; (6) Vertical ranges of all species not distinctly lowland; (7) Introduction of the more widely current Irish plant-names; (8) The relegation to one comprehensive appendix of all plants not entitled to a place in the body of the work; and (9) The inclusion in a single index of the scientific names, synonyms and trivial names of all plants referred to. For the revision of the nomenclature, too, we accept responsibility, as well as for the expansion and re-casting of the Introduction.

Some of these innovations, and notably that which deals with the citation of previously published records, have added seriously to the labour of digesting the large mass of material accumulated by the researches of a whole generation of Irish botanists; and the result has been to delay for upwards of two years the completion of a work which could only be taken up in our leisure hours. But this 
delay has been rather advantageous than otherwise, since it has enabled us with the ready help of some valued correspondents to secure much further information, the need of which became apparent only as the work went on.

In the first place, our thanks are due to Miss Frances $\boldsymbol{M}$. More, for unwearied assistance in the preparation of this new edition. A botanist of no mean attainments herself, she has been able to give us material help in the examination of her brother's books, manuscripts, and correspondence; while her general acquaintance with his views has qualified. her to make many suggestions of which we have not been slow to profit. For much additional information, as to the range of plants in north-east Ireland, and for aid in clearing up many obscure points in the botanical literature relating to that district, we are indebted to Mr. S. A. Stewart, of Belfast, who has at all times most cheerfully placed at our disposal his wide and accurate knowledge of the northern flora. Plant lists kindly prepared for us by Mrs. Leebody, of Londonderry, have been of much service in extending the known northern range of many species. At the opposite extremity of the island, in south-west Cork, valuable assistance has been rendered us by a competent botanist, Mr. R. $A$. Phillips, who has earned our warmest thanks by the unfailing zeal and courtesy with which he has followed up the many troublesome inquiries we have asked him to undertake. In the west, Miss M. F. Jackson, of Lisloughrey, Cong, has kindly supplied us with lists of plants observed chiefly round the head of Lough Corrib, and with some notes on current Irish plant-names. The labour of consulting and extracting from the earlier and less accessible works on the Irish flora has been lightened for us by Mr. C. B. Moffat's friendly aid; the Rev. Wm. Colgan, of Inveran, Iar-Connaught, has helped us in the determination of current Irish plant-names; Mr. F. W. Moore, Director of the Glasnevin Botanic Gardens, has freely placed at our disposal the manuscripts and specimens of his father, the late Dr. David Moore; Dr. E.P. Wright, Professor of Botany in Trinity College, Dublin, has kindly given us facility of access to his botanical library, and supplied us with many interesting references to specimens preserved in the extensive 
herbarium under his control; while Dr. T, Johnson has rendered us. similar service in connection with the library and collections in his keeping in the Dublin Science and Art Museum. For notes supplied and for assistance given us in many other ways we are also indebted to Mr. R. M. Barrington, of Fassaroe; to Sir F.W. Brady, Bart.; to $M r . F . W . B u r b i d g e$, curator of the Botanic Garden of Trinity College, Dublin; to Mr. G. H. Carpenter, of the Science and Art Museum; to Miss M. Chearnley, of Cappoquin ; to the late Mr. $F$. $E$. Currey, of Lismore; to the Rev. C. F. d'Arcy, of Ballymena; to Mr. J. H. Davies, of Lisburn; to the Rev. W. W. Flemyng, of Portlaw, Waterford; to $\boldsymbol{M}$. Michel Gandoger, of Arnas, Villefranche; to the Rev. T. Hartley, of Borris, Carlow; to Mrs. M. E. Joyce, of St. Cleran's, Craughwell; to Miss Kinahan and to Miss A. G. Kinahan; to the Rev.H.W. Lett, of Aghaderg; to Miss Manders; to Mr. P. B. O' Kelly, of Ballyvaughan; to Mr. R. Lloyd Praeger; to Mr. R. P. Fowell, and to the Rev. C. H. Waddell, of Saintfield.

Nor are our thanks exclusively due to Irish botanists. Assistance in many ways has been given us by English correspondents as well. More especially are we under obligation to Mr. Arthur Bennett, of Croydon, whose unwearied courtesy, under what we fear must have been rather importunate demands on his leisure, we cannot too warmly acknowledge. But for the information freely supplied by him, and which he alone of all British botanists was in a position to supply, it would have been impossible for us to institute, on recent and trustworthy data, those comparisons on various points between the English and Irish floras which we hope will be found to add to the interest of our Introduction. Mr. James Britten, of the British Museum, has kindly given us extracts from sume of the earlier botanical works not readily accessible in Dublin, and from the manuscripts of Robert Brown in his possession; the Rev. E. S. Marshall has communicated to us some notes on the flora of South Wexford; the Rev. W. Moyle Rogers has permitted us to make use of many unpublished localities for the Irish Rubi; and Messrs. H. and $J$. Groves have given us their assistance in deciding some points of difficulty in the genera Callitriche and Zannichellia, 
and have enabled us to fill up from their unpublished notes several gaps in the distribution of the Irish Characea. If we have succeeded in our endeavour to make this edition a full and accurate guide to plant distribution in Ireland, no small share of that success is due to the help of these valued correspondents, both English and Irish.

A comparison of the first with the present edition of this work will at once show how great an advance has been made in Irish topographical botany within the last thirty years. Amongst the influences which have contributed to this progress the foremost place must be given to the unobtrusive encouragement and guidance which was at all times freely given to the less experienced Irish botanists by Alexander Goodman More. His efforts to stimulate the younger generation of explorers were supported by the Royal Irish Academy, whose grants in aid of the botanical survey of Ireland were for the most part allocated in accordance with his views. By means of these grants a series of exhaustive and trustworthy reports on previously unexplored, or imperfectly explored, areas were procured. The mountain groups of Magillicuddy's Reeks, of the Brandon peninsula, of Galway and Mayo, of the Galtees, the Commeraghs, the Knockmealdowns, Ben Bulben, and the Mournes; the shores of Lough Erne, Lough Allen, Lough Ree, and the Shannon estuary; the coasts of Waterford and Wexford; the islands of Inishbofin, Rathlin, Lambay, and the Blaskets; all these have been carefully surveyed under the Academy's well-considered scheme. And these researches have been largely supplemented of late by the more purely voluntary labours of many botanists, British as well as Irish, so that little is now wanting to complete our knowledge of the distribution of our flora, at least in its wider aspects. The next step in advance must be in the direction of a Topographical Botany of Ireland on the lines of H. C. Watson's work dealing with the county distribution of plants in Great Britain; and such a work, we are glad to know, has already been taken in hands by one who is well qualified to bring it to a successful issue.

No attempt will be made here to estimate the precise share contributed by each of many field-workers to the advance in Irish 
botany which is marked by the publication of the present edition. The broad results alone are of general interest; but it seems only just that particular mention should be made of the services of Henry C. Hart, who has done more to further our knowledge of Irish plant distribution than any other explorer of recent years.

In selecting from the large mass of records, many thousands in number, on which the present edition is based, a steady endeavour has been made to preserve the historical element while giving full prominence to the results of modern research. The great majority of the earlier records of unquestioned authority, dating chiefly from about the beginning of the present century, have been retained, but wherever possible each has been associated with a recent record for the same locality. In all cases, and they are not few, where such a revival of the older record has been effected, all the intermediate records have been passed over, and a considerable conden. sation of the matter has thus been brought about. At the same time recourse has been had, throughout, to the original or earliest records as distinguished from the numerous apparent confirmations in later works, which are in reality nothing more than unavowed quotations from the originals. In this way a still further condensation has been made, and the space so gained has been given up to modern records showing the extension to new districts of the rarer species. With many of the less rare plants this extension might no doubt have been shown by simply inserting in its proper place the number of the new district. But it has seemed preferable, even at the risk of unduly expanding the text, to justify this extension of range by definite records. And, indeed, in some instances localities have been given in this edition for plants which were considered by the authors of the original work as not sufficiently rare to be so treated. One result of this procedure has been to oblige us in some cases to base the claim of a species to a place in a certain district on the naked statement in the first edition that it had been found to occur there. But this failure of ours to discover a definite district record for the plant must not be taken as throwing the least doubt on the accuracy of the entry in the first edition, 
though it may, perhaps, be generally accepted as evidence of the local rarity of the plant.

No lengthy list of plants added to the Irish flora can be pointed to as the fruit of botanical research within the last quarter of a century, the period which has elapsed since the publication of Recent Additions to the Flora of Ireland. Neglecting numerous segregate Brambles and Hawkweeds recently detected, the additions to our phanerogamic flora number only the 18 species and subspecies set forth in the following list, one-third of them more or less open to suspicion of being introduced :-

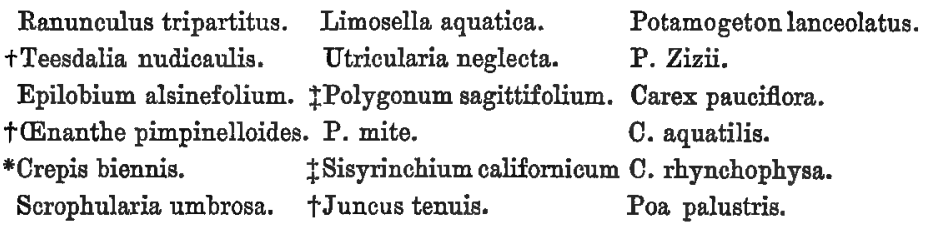

Within the same period the following six species of Characece have been added to those known to occur in Ireland: Chara connivens, C. contraria, C. denudata, C. canescens, Nitella Nordstetiana, and $N$. tenuissima.

This apparent gain is fully balanced, and indeed overbalanced, by the exclusion of plants admitted to the first edition on evidence which further inquiry has shown to be insufficient. It is rather in the great extension of range given to the large majority of the rarer species and in the increased recognition of the more critical plantforms that the results of the botanical activity of this period is manifested. How great this extension of range has been, a comparison of the distribution tables in the two editions will at once make evident, while the increased attention paid to critical forms will appear from the frequent records for varieties to be found in the text of the present edition.

In conclusion, we would impress on all who make use of this book the necessity of first studying the explanatory sections of the Introduction, a knowlege of which is essential to a right understanding of the text. While far from claiming immunity from 
xii

PREFACE,

error in the treatment of so complex a subject, we hope that the pains which have been taken to secure accuracy may have succeeded in making the work what we desire it to be, a trustworthy guide to the topographical botany of our island, and a fitting memorial of Alexander Goodman More.

Nathantel Colgan.

Regrnatd W. Scotity.

Dubln, August, 1898. 


\section{PREFACE}

TO THE FIRST EDITION (1866).

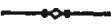

Is explanation of the title which we have adopted, as the name of Cybele may not, like that of Flora, be familar to our readers, it will be well to premise that Cybele was worshipped formerly as the goddess of the Earth in Asia. Her name was first introduced in connexion with modern botany by Mr. H. C. Watson, who considered that it might appropriately express the distribution of plants upon the Earth's surface, and who accordingly employed it as the title of his great work, "Cybele Britannica."

The present work originated in a desire to furnish not only a revised list of the wild plants of Ireland, but also a classified summary of their localities. Thirty years having now elapsed since the publication of Mackay's "Fllora Hibernica," within which period many additions have been made to Irish Botany, many plants have become better known, and the range of others has been greatly extended. With the view of meeting the requirements of Geographical Botany, we have endeavoured to arrange our imaterials somewhat after the plan of $\mathrm{Mr}$. Watson's "Cybele Britannica" (whence our title); and thus we hope that the details collected will be found methodized in such order as to be available to those who study the range of plants, while the traveller will also be able to use our book as a botanist's guide through. Ireland. With three excellent and portable "Floras" in the hands of British Botanists, it has been thought unnecessary to draw up fresh descriptions of the Trish species; this would have too much increased the bulk of our volume without adding to its usefulness. 
And, as some additional species may be hereafter found in Ireland, we believe that the use of some book containing descriptions of the entire series of British plants will be found advantageous.

Our scope being thus limited, we have endeavoured to include, in a compendious form, as much information respecting the localities and range of Irish plants as can be given within a short compass. On account of the fewness of the observations hitherto made on the upper and lower limits of the elevation of plants, we have preferred to reserve the complete details of this part of our subject for a future edition. And here we would especially recommend this interesting branch of study to those of our botanists who are in the habit of spending a part of the summer in a mountainous district. A rough estimate of the upper and lower limits may be made from the Ordnance Survey map, on which the heights are carefully laid. down, but it is especially desired that careful observations of both upper and lower limits be taken with the barometer (or sympiesometer) in each of our mountain districts separately, since this is the only way to secure data for a just estimate of the influence of climate on the upper and lower limits of plants, as the "zones" and "regions" in Donegal must range to very different heights from those in Kerry or the East of Ireland. We believe that little is gained by the statement that a species descends to sea-level in one district, while it ascends to 3000 feet in another; it is only by comparing both upper and lower limits in each different range of hills, or at least in each of the chief groups that any useful results can be expected. The elevation of many species is carefully noted in the MS. catalogue of the Flora of the county of Londonderry, drawn up under the directions of the officers of the former Ordnance Survey of Ireland; and Dr. Dickie's " Flora of Ulster" is another source from which we have frequently drawn-we can only regret that more details were not given by so accurate and careful an observer.

For the localities, we have encleavoured to lay the foundations altogether afresh upon recent and reliable authority, having received from numerous correspondents, some twenty tolerably complete county lists. With these we have incorporated most of 
the stations given in the works of Threlkeld, K'Eogh, Browne, Wade, and in the Floras of Lady Kane, Mackay, Power, Dickie, and Tate. Reference has also been made to many detached papers, and to private contributions which have been furnished from various quarters. Feeling convinced that such is the only course by which a reliable work ean be produced, we have not hesitated to discard many species considered as Irish, but respecting which we have not succeeded in obtaining authentic information or specimens. By this course, more is left open for the investigation of those observers who may consent to assist in the preparation of a more complete work, which we trust will yet be accomplished as the requirements of science shall demand. It is to the botanists of Ireland that we especially appeal; there is an ample field yet open in the exploration of the flora of their native country; and if our book serves but to mark one step in advance it will not have been compiled in vain.

In every case of doubt no pains have been spared to try and arrive at the truth, and we trust that our many correspondents will accept our thankful acknowledgment for the unwearied courtesy with which they have replied to close and troublesome inquiries. To Mr. Tsaas Carroll, the well-known botanist of Cork; to Professor George Dickie, of Aberdeen; to the late Right Hon. J. Wynne, of Hazelwood; to the Rev. Samuel Madden; to Mr. T. Chandlee; to $M r$. S. A. Stewart, of Belfast; to Miss S. Grubb, of Clonmel; to Mr. F. J. Foot, of the Geological Survey of Ireland; to Mr. John Douglas; to the Rev. T. Warren, of Ennis; to.Mr. J. Morrison; to Admiral Jones; to Professor Melville, of Galway; to Mr. David Orr; to Mr. J. Sullivan, of the College, Cork (who jointly with the late Professor E. Murphy, furnished a list of the plants of Cork county); we are especially indebted for localities. From Professor C. C. Babington, of Cambridge, and $M r$. H. C. Watson we have received assistance of various kinds. Our valued friends, Mr.W.Carruthers, of the British Museum, and the Rev. W. W. Newbould, have constantly aided us, both in the revision of our proof sheets and by consulting the works of the earlier English botanists, not accessible in Dublin; to $M r$. Newbould we are further indebted for a 
transcript of Dr. Patrick Browne's catalogue, Mr.M. J.' O'Kelly, of Rochestown, has very kindly allowed us to consult an interleaved copy of the "Irish Flora," which formerly belonged to the late Mr. John White, and contains many notes left by him. We are bound especially to acknowledge our obligations to $D r, E$. Perceval Wright and $M r$. W. Archer, who have given us the best of their advice and support, both in planning and in carrying out this first attempt at a Cybele Hibernica.

To the British Association for the advancement of Science our thanks are due for a grant of $£ 25$ towards the publication of our book; nor are we less grateful to the many friends whose subscriptions have enabled us to bring out our work in a shorter time than could have been otherwise accomplished.

All communications respecting the discovery of new localities for rare species, or the occurrence of any plant in a district not entered in our tables, together with observations on the mountain altitudes of the different species will be most thankfully received and acknowledged by

$$
\left.\begin{array}{l}
\text { D. Moore, or } \\
\text { Aldex. G. MoRe, }
\end{array}\right\} \text { Glasnevin. }
$$




\section{CON'TENTS.}

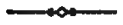

List of the Principal Booms, Papers, MSS., and Hrgharta Relating to the Flora of Ireland, . . . . . xix INTRODUCTION :-

I. POSTTION AND PHTSICAL FEATURES OF IRELAND, . XXXVii II. CLIMATE, • • • • • • • •

III. THE IRTSH AND ENGLISH FLORAS COMPARED, . • $\quad$ xl IV. IRISH PLANTS NOT FOUND IV GREAT BRITATN, . • xlvii v. PREVALENT ORDERS IN THE IRISH FL'ORA, . . . lii VT. PLANTS ENDEMTIC TN IRETAND, . . . . . l liii VII. TOPOGRAPHICAL GROUPS IN THE IRISH FLORA; . . liv VIIT. TRISH BOTANICAL DISTRICTS, · • . • IVi IX. BOTANICAT MYAP OF IRELAND, • . . . . l lXix X. EXPLANATORY NOTES ON THE TEXT, . . . . l IXX

Table of Distribution in the Districts, . . . 1xxvii Text :-Ranunculacea to Chabaceie, . , . , 1-470 APPENDIX :-EXCLUDED SPECLES, • • . . . . 471-520

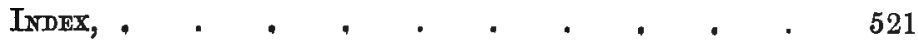




\section{ERRATA.}

Page 77, for I. aquifoliom read I. Aquifolium.

$\therefore \quad 325$, at foot, omit S. laurina, entered in error. See Appendix, p. 509.

, 375, insert VI. in District heading for P. heterophyllus.

, 439, for H. tunbrigense read $\mathbf{H}$. tunbridgense. 


\title{
ALPHABETICAL LIST
}

\author{
OF THE
}

\section{PRINCIPAL B00KS, PAPERS, MSS., AND HERBARIA}

\author{
RELATING TO THE FLORA OF IRELAND.
}

Quotations from the various papers, ete., are distinguished in the body of this work by the contractions printed in italics on the righthand margin of this list.

\section{Allin, Rev. Thomas:}

Irish Plants.-Journ. of Bot. 1871, p. 18.

Plants of Co. Cork.-Journ. of Bot. 1871, pp. 111 and 173......Allin 2871 . Irish Plants.-Journ. of Bot. 1872, pp. 269 and $376 \ldots \ldots \ldots$ Allin 1872. Plants of Co. Cort.-Journ. of Bot. 1873, pp. 49, 174, 207,

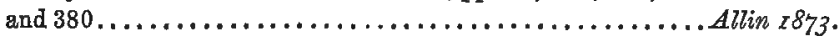
Notes on the Flora of Cork.-Journ. of Bot. 1873, p. 196.

A new Irish locality for: Spiranthes romanzoviana.-Journ. of Bot. 1873, p. 308.

Plants of Co. Cork. -Journ. of Bot. 1874, pp. 57 and $279 . \ldots$...Allin 1874 . The Flowering Plants and Ferns of the County Cork. Weston-super-Mare, 1883. A flora of the county founded on Dr. Power's Flora (1845) with numerous new localities, contributed chiefly by the author and by $\mathrm{Mr}$. Isaac Carroll................................Allin's Cork.

\section{Anderson, T. :}

A. short account of the Flora around Clonmel.-Bot. Soc. Edin. Proc., reported in Bot. Gazette, vol. rIr. p. 39. 1851.

\section{Andrews, William :}

Botanical Excursion in Clare and Kerry.-Dublin Nat. His. Soc. Proc., reported in Ann. of Nat: His. vol: vr. p. 382, 1841.

Observations on the Botany of Great Aran Island.-Journ. of Bot. 1845, p. 569.

Notice of Elymus europies at Mount Merrion, near Dublin.-Nat. His. Rev. 0. S. ४ैol. I. p. 156,1854 :

Additions to the Irish Flora.-Nat. His. Rev. O. S. vol. I. p. 230, 1854.

Ferns of Killarney.-Nat. His. Rev. 0. S. vol. III. p. 53, 1856. 
Andrews, William-continued.

On the distinct habits of Hymenophyllum.-Nat. His. Rev. O. S. vol. vr. p. $433,1859$.

On some Irish Saxifrages.-Dublin Nat, His. Soc. Proc. vol. II. p. 84, 1871.

Annals of Natural History, London, 1839, etc..............Ann. Nat. His.

Anonymous, Annotations in MS. in the Cuvierian Soeiety's copy of Power's Flora of Cork, giving many additional localities, with dates, for the rares Cork plants..........................Annot. in Flor. Cork. Annotations in MS. in a copy of Threlkeld's Synopsis, preserved in the library of R.I.A. Dublin, giving many ancient records of interest for the rarer Irish plants. . .............................. in Threlkeld.

Babington, Professor C. C. :

List of Plants observed in Connemara, \&c.-Loudon's Mag. of Nat. His. vol. 1x. p. $129,1836 \ldots \ldots \ldots \ldots \ldots \ldots \ldots \ldots \ldots \ldots$. Babington 1836 . On the Botany of Erris. -Mag: of Zool. \& Bot. vol. II. p. 199, 1838.

On Spiranthes cernua.-Linnæan Soc. Trans. vol. xIx. p. 262.

On the Recent Additions to the Flora of Ireland.-Ann. of Nat. His. VI. p. $328,1841$.

Hints towards a Cybele Hibernica.-Nat. His. Rev. O. S. vol. vr. p. 533, 1859.

Herbarium preserved at Cambridge,-The labels of the more interesting Irish plants were transçribed by the late Professor Babington and the late Thomas H. Corry into the latter's copy of "Cybele Hibernica" for

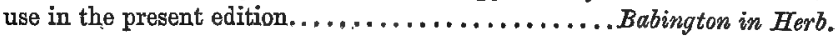

Backhouse, James :

Monograph of the British Hieracia. York, 1856.........Backhouse $\mathrm{x} 856$.

Baily, Miss :

The Irish Flora.-Dublin 1833. The first complete descriptive Florn of Ireland, the localities being contributed by $\mathrm{Mr}$. 'John White. Published anonymously, but ascribed to Miss Baily (afterwards Lady

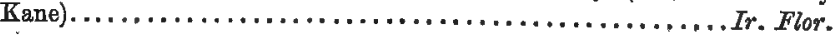

Balfour, Professor J. H. :

Botanical Trip to Ireland.-Phytol. 0. S. vol. IV. p. $1005,1853$.

Notes of an Excursion to Connemara in September, 1874 .-Edin. Bot. Soc. Trans. xir. p. $371,1875 \ldots \ldots \ldots \ldots \ldots \ldots \ldots \ldots \ldots$................ Balfour 5875 .

Ball, John :

Botanical Notes of a Tour in Ireland.-Ann. of Nat. His. vol. Ir. p. 28,

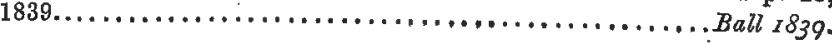

Barrett-Hamilton, G. E. IH.:

Clinopodium valgare in Wexford.-Journ. of Bot. 1887, p. 348. 
Barrett-Hamilton, G. E. H., and Glascott, Miss L. S. .

Plants found near New Ross, Ireland.-Journ. of Bot. 1889, p. 4.

B.-H.\& G. 1889 .

Plants found near Kilmanock, Co. Wexford.-Journ. of Bot. 1890, p. 87.

Barrett-Hamilton, G. E. H., and Moffat, C. B. .

B. - H. \& G. 1890 .

Notes on Wexford Plants.-Journ. of Bot. 1892, p. 198...B.-H. \& M. 1892 .

The Characteristic Plants of County Wexford.-Ir. Nat. 1892, p. 156.

Barrington, R. M., M.A. :

B.-H. M. I892a.

On some. Plants recorded from Ireland.-Journ. of Bot. 1872, p. 108.

Plants of West Ireland collected by J. Reilly.-Journ. of Bot. 1877, p. 179.

The Plants of Tory Island, County Donegal.-Journ. of Bot. 1879, p. 263. Barrington 1879 .

Report on the Flora of the Blasket Istands, County Cork--R. I. A. Proc. 2nd Ser. vol. Irr. p. $368,1881 \ldots \ldots \ldots \ldots \ldots \ldots \ldots$ Barrington 1881 .

Report on the Flora of the Shores of Lough Erne.--R.I.A. Proc. 2nd Ser, vol. 1v. p. $1,1884 \ldots \ldots \ldots \ldots \ldots \ldots \ldots \ldots \ldots \ldots$. . . . . . . . . . . . . . . . . .

Epilobium alsinefolium in Ireland.-Journ. of Bot. 1884, p. 247.

Barrington, R. M., and Vowell, R. P.:

Report on the Flora of Ben Bulben and the adjoining mountain Range, \&o.R.I.A. Proc. 2nd Ser. vol. Iv. p. $493,1885 \ldots \ldots \ldots \ldots \ldots$....... $V .7885$. Report on the Flora of the Shores of Lough Ree.-R.I.A. Proc. 2nd Ser. vol. Iv. p. $693,1887 \ldots \ldots \ldots \ldots \ldots \ldots \ldots \ldots \ldots \ldots \ldots \ldots . \&$ V. 1887.

See also under Hart.

Belfast Naturalists Field Club Proceedings,............ B. N. F. G. Proc. Bennett, Arthur, F.L.S. :

Notes on Isoetes.-Journ. of Bot. 1887, p. 207.

Carex aquatilis and its British forms.-Ir. Nat. 1892, p. 48 .. Bennett 1892. Notes on British Plants.-Journ. of Bot. 1897, pp. 244 and 259.

\section{Botanical :}

Exehange Club, London, Reports of, 1867-78.

Exchange Club of the British Isles, Reports of, 1879-97....B. Ex. C. Rep. Exchange Club, Watson's, Reports of, 1885-1897....Wats. B. Ex. C. Rep.

\section{Botany :}

London Journal of, edited by Sir W. J. Hooker, 1842-1848.

Journal of, British and Foreign, London, 1863-1898.........Journ. of Bot.

Brenan, Rev: S. A. :

Irish Plants (Saxifraga Hirculus, Allosurus crispus, \&e.).-Journ. of Bot. 1884 , p. 278.

Irish Rubi._Journ. of Bot. 1895, p. $26 \ldots \ldots \ldots \ldots \ldots$....... Brenan 1895 .

Britten, James, F.L.S. :

Euphorbia hiberna in County Donegal.-Journ. of Bot. 1891, p. 357. 


\section{Browne, Patrick, M.D. :}

Fasciculus Plantarum Hibernice.-A catalogue of plants observed chiefly in the counties of Mayo and Galway, 1788. MS. in possession of the Linnæean Soc. of London......................Brown Fascic.

\section{Brown, Robert :}

Manuscript Descriptions of Plants, 2 vols. folio. Includes many Irish species collected by the afterwards famous botanist during his stay in North Ireland in 1797 and $1800 \ldots \ldots \ldots \ldots \ldots \ldots$................ Manuscript Journal kept in Ireland during the year 1800 . Contains some interesting notes on Irish plants. This and the preceding MS. are nnw in the Botanical Dept., Brit. Museum...................... Mrow

Butler, Cecil, M.A. :

New stations of Irish Plants.-Journ. of Bot. 1890, p. 361 . ... Butler r89o.

\section{Carroll, Isaac :}

Notes on new or scarce Irish Plants._Phytol. O.S. vol. v. p. 76, 1854,

Notes on scarce Irish Plants.-Phytol. N.S. vol. II. p. 76, 1857,

Oarroll 1857 .

Carr, Professor J. W. :

See under Praeger.

Carter, Charles :

Botanical Ramble in Ireland.-Phytol. 0. S. vol. II. p. 512, 1846.

Chandlee, Thomas:

Euphorbia Cyparissias in King's County.-Ir. Nat. 1893, p. 250.

Herbarium preserved at the Science and Art Muserm, Dublin, contains a good series of plants from the South of Ireland........ Herb. Chandlee.

Colby, Thomas :

Ordnanee Survey of Londonderry.-Vol. x. Memoir of Parish of Templemore, contains short notes of Derry plants by David Moore at pp. 9-11 and 6-8

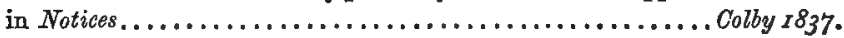

Colgan, Nathaniel, M.R.I.A. .

Saussurea alpina in County Wicklow.-Journ. of Bot. 1885, p. 157.

The Shamrock, an Attempt to fix its Species.-Ir. Nat. 1892, p. 95.

Ajuga pyranidalis in the Aran Isles.-Journ. of Bot. 1892, p. 310.

Notes on the Flora of the Aran Isles.-Ir. Nat. 1893, pp. 75 and 106.

The Shamroek, a further Attempt to fix its Species.-Ir. Nat. 1893, p. 207.

Notes on the Flora of Co. Dublin.-Ir. Nat. 1893, p. 283......N. C. 1893.

Carex axillaris in Co. Dublin.-Ir. Nat. 1894, p. 202.

Artemisia Stelleriana in Ireland.-Jourm. of Bot. 1894, pp. 22 and 104.

Further Notes on the Flora of County Dublin.-Ir. Nat. 1895, p. 54,

The Orchids of County Dublin.-Ir. Nat. 1895, p. 193,

N.C. 1895

Serophutaria unbrosa in Iretand.-Ir. Nat. 1896, p. 182. 
Colgan, Nathaniel, M.R.I.A.-continued.

Flora of the Ox Mountains, County Sligo.-Ir. Nat. 1896, p. 301,

Euphrasia Salisburgensis in Ireland.-Ir. Nat. 1897, p. 105.

N.C. 1896 .

On the Flora of the Shores of Lough Derg.-Ir. Nat. 1897, p. 189,

Corry, Thomas H., M.A. :

N.C. 1897 .

Notes of a Botanical Ramble in County Clare, Ireland, in 1879.-Belfast,

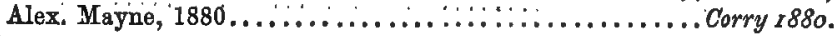

Fumaria muralis in Ireland.-Journ. of Bot. 1882, p. 86.

Potamogeton Zizii in Ireland.-Journ. of Bot. 1882, p. 86.

On some rare Irish Plants.-Journ. of Bot. 1882, p. 222 . . . . . Corry 1882. New Irish Rubi.-Journ. of Bot. 1883, p. 52.

On the Heights attained by Plants on Ben Bulben; contributed by A. G. More.-R.I.A. Proc. 2nd Ser. vol. Iv. p. 73, 1884 . . . . . . . Corry 1884.

Cuthbert, H. G. :

Hymenophyllim tumbridgense in County Wexford.-Ir. Nat. 1892, pp. 168 and 181.

D'Alton, John :

History of the County of Dublin $(2838)$. - The numerous records in this work for the less common plants are all taken from the Irish Flora and Mackay's Flora Hibernica, and grouped according to localities.

Davies, John H. :

Poterium Sanguisorba in the North of Ireland. -Ir. Nat. 1892, p. 81.

Galium erectum and G. Mollugo in North-East Ireland.-Ir. Nat. 1897, p. 259.

Epilobium roseum Native in Ireland.-Ir. Nat. 1898, p. 7.

Delap, Rev. Alex. H.:

Trichomanes radicans in County Tyrone.-Journ. of Bot. 1892, p. 121.

The Tree Mallow in Ireland on Little Stelligs.-Ir. Nat. 1893, p. 112.

Dickie, George M.D. :

A Flora of Ulster and Botanists' Guide to the North of Ireland. Belfast, 1864. A most valuable contribution to the knowledge of the geographical distribution of plants in the North of Ireland..............Flor. Ulst.

Douglas, John :

Collection of Plants made near Straffan, Kildare.

Dowd, M. :

MLalva borealis near Dublin.-Journ. of' Bot. 1870, p. 323 :

Druce, G. C., F.I.S. :

The Segregates of Spergula arvensis; both forms in Ireland. -Journ. of Bot. 1891, p. 173.

- Notes on the Flor of Cork, Kerry, and Dublin.-Journ. of Bot. 1891,

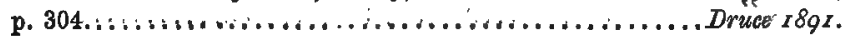


Drummond, James :

Native Plants in Co. Cork.-Munster Farmer's Magazine, vols. vi. and vIr. Nos. 21, 22, 23, 25, 26 (1818-20)....... Drummond $I 818-19$ \& -20 .

Focke, Dr. W. O. :

List of British and Irish Rubi in Herb. of late Mr. John Ball.-Journ. of Bot. 1891, p. 163............................. Focke 189 . .

Foot, Frederick J. :

On the Ferns of West Clare.-Nat. His. Rev. 0. S. vol. vIr. p. 36, 1860.

On the Distribution of Plants in Burren, Clare.-R. I. A. Trans. vol. xxIv.

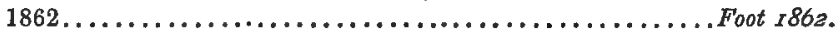

Botanical Notes in the Midland Counties of Treland.-Dublin Nat. His. Sos. Proc. 1864-65........................................... ${ }_{1} 865$. Hymenophyllum Wilsoni near Boyle, ge.-Dublin Nat. His. Soc. Proc. V. p. $66,1865-66$.

Forbes, Professor Edward :

On the Connexion between the Distribution of the existing Fauna and Flora of the British Isles, and the geological Changes which have affected their Area.-Geological Survey of Great Britain, Memoirs, vol. I. p. 336, 1846.

Fryer, Alfred :

Irish Potamogetons.—Journ. of Bot. 1889, p. 183.

Gage, Miss C. :

Plants of Rathlin Istand.-Bot. Soc. Edin. Proc. reported in Ann. of Nat. His. v. p. $145,1850$.

Glascott, Miss L. S. .

See under Barrett-Hamilton.

Graham, Professor Robert :

An Account of an Excursion to the West of Ireland,-Bot. Soc. Edin. 3rd Annual Report, p. $54,1840 \ldots \ldots \ldots \ldots \ldots \ldots \ldots$. Graham I 840 .

Groves, Messrs. H. and J., F.L.S.:

Review of the British Characea.-Journ. of Bot. 1880, pp. 97, $129,161 \ldots \ldots \ldots \ldots \ldots \ldots \ldots \ldots \ldots \ldots \ldots \ldots \ldots \ldots$. Groves $r 880$.

Notes on British Characee, Journ. of Bot.'1881, p. 353 ........Groves 1881 .

\begin{tabular}{|c|c|c|c|c|c|}
\hline$"$ & $"$ & " & $"$ & ", & 1883, p. $20 \ldots \ldots$ Groves $I 883$. \\
\hline ", & $"$ & " & $"$ & , & 1....... Groves 1884 . \\
\hline "' & $"$ & $"$ & $"$ & " & $81 \ldots . .$. Groves 1885 . \\
\hline$"$ & $" 9$ & $"$ & $"$ & ", & 1886 , p. $\quad 1 . \ldots \ldots$ Groves $I 886$. \\
\hline " & $"$ & $"$ & $"$ & $"$ & 1887, p. $146 \ldots$ \\
\hline 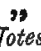 & $" 3$ & sen & ", & ", & Groves $r 890$ \\
\hline
\end{tabular}


Groves, Messrs. H. and J., F.L.S.-continued.

The Distribution of the Characea in Ireland.-Ir. Nat. 1895, pp. 7 and 37, Groves 2895 .

Notes on British Characee, 1890-94.-Journ. of Bot. 1895, p. 289,

Groves 1895 a.

Hanbury, F. J., F.L.S. :

Further Notes on Hieracia nen to Britain.-Journ. of Bot. 1892, pp. 129, 165,258 , and 366 .

Harris, Walter :

The Ancient and Present State of the County of Down, 1744.-Chap. XI. contains a catalogue of forty rare plants which was probably contributed by Isaau Butler.

Hart, H. C., F.L.S. :

Alchemilla alpina, \&c., in Wicklow.--Journ. of Bot. 1873, p. 175.

Euphorbia hiberna, Equisetum trachyodon; \&c., in County Galway.-Journ. of Bot. 1873, p. 338......................... Hart 1873 .

A List of Plants found in the Islands of Aran, Gatway Bay. Dublin, 1875............................................ 1875 . On the Flora of North-western Donegal.-Journ. of Bot. 1879, pp. 77, $106,143,183 \ldots \ldots \ldots \ldots \ldots \ldots \ldots \ldots \ldots \ldots \ldots \ldots \ldots$. Eart $x 879$.

On the Flora of North-western Donegat.-Journ. of Bot. 1880, pp. 271,

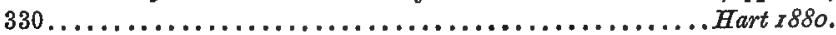

On the Botany of the Galtee Mountains, County Tipperary.-R.I.A. Proc. 2nd Ser. vol. III. p. 392, 1881.......................Hart 1881 .

On the Plants of North Aran Island, County Donegal.-Journ. of Bot. 1881, p. 19.

A Botanical ramble along the Slaney and up the East Coast of Wexford.Journ. of Bot. 1881, p. 338..................... F art I 88 I a. On some rare Plants in County Donegal.-Journ. of Bot. 1881, p. 233, Hart $588 \mathrm{I}$.

Notes on Irish Plants found in Limerick and Tipperary.-Journ. of Bot. 1881, p. $167 \ldots \ldots \ldots \ldots \ldots \ldots \ldots \ldots \ldots \ldots \ldots \ldots$ Hart ${ }_{18} 88_{1} \gamma$. Report on the Botany of the Magillicuddy's Reeks, County Kerry.R.I.A. Proc. 2nd Ser. vol. IIr. p. 573, $1882 \ldots \ldots \ldots \ldots \ldots$ Hart 1882. Notes on Mountain Plants in Kerry.-Journ. of Bot. 1882, p. 174, Hart $r 882$ a.

Flora of Croaghgorm Range in Donegal.-Journ. of Bot. 1882, p. 233. Lycopodium alpinum in County Wicklow.-Journ. of Bot. 1883, p. 153. On the Flora of Innishowen, County Donegal.-Journ. of Bot. 1883, pp. 47, $75,150,170,205$, and $275 \ldots \ldots \ldots \ldots \ldots \ldots \ldots \ldots$ Hart $188_{3}$. Report on the Flora of the Mayo and Gahway Mountains.-R.I.A. Proc. 2nd Ser. vol. III. p. 694, 1883...................Hart $r 88 z \alpha$. Report on the Flora of the Wexford and Waterford Coasts.-Roy. Dublin Soc. Scientific Proc. N.S. 1v. p. 117, 1883. (A Report to the R.I.A., published by error in R.D.S. Proc.) .............. Hart $\pi 88_{3} \beta$. 
Hart, H. C., F.L.S.-continued.

Notes on the Flora of Lambay Island, County Dublin,-R.I.A. Proc. 2nd Ser. vol. mr. p. $670,1883 \ldots \ldots \ldots \ldots \ldots \ldots \ldots \ldots \ldots \ldots$ Hart $z 883$. . Notes on the Plants of some of the Mountain Ranges of Ireland.-R.I.A. Proc. and Ser. vol. 5r. p. 211, 1884................. Hart 8884 .

Trichomanes radicans in Donegal._Journ. of Bot. 1884, p. 213.

On the Botany of the Barrow.-Journ. of Bot. 1885, p. 9...... Hart 1885 . On the Botany of the River Suir.-Roy. Dublin Soc. Scient. Proc. Iv. p. $326,1885 \ldots \ldots \ldots \ldots \ldots \ldots \ldots \ldots \ldots \ldots$ Hart 1885 a. Report on the Flora of South-west Donegal._R.I.A. Proc. 2nd Ser. vol. Iv. p. $443,1885 \ldots \ldots \ldots \ldots \ldots \ldots \ldots \ldots \ldots \ldots$ Hart $1885 \gamma$. Botanical Notes along the Rivers Nore and Blackwater, etc.-Journ. of Bot.

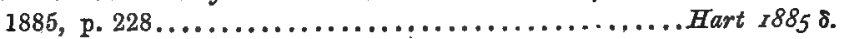
Irish Hawkweeds. -Journ. of Bot. 1886, p. 47...........Hart I 886 a.. Further Report on the Flora of Southern Donegal.-R.I.A. Proc. 2nd Ser. vol. rv. p. 568, 1886....................... Hart 1886 . The Flora of Howth. Dublin, 1887 .................. Hor. Howth. Rare Plants from Co. Tyrone.-Journ. of Bot. 1887, p. 325....Hart 1887 . On the Range of Flowering Plants and Ferns on the Mountains of Ireland. (A summary of all his observations on Irish mountains.)-R. I. A. Proc. 3rd Ser. vol. I., p. 512. 1891 .......................... Hart.

Euphorbia hiberna in County Donegal.-Journ. of Bot. 1891, p. 357.

Stachys Betonica in County Donegal.-Tourn. of Bot. 1892, p. 281.

Helianthemum vulgare in Ireland.-Journ. of Bot. 1893, p. 218.

Notes on Co. Dublin Plants.-Journ, of Bat. 1897, p., 346,..... Hart I897.

Hart, H. C., and Barrington, R. M, ;

Rediscovery of Rubus Chamamorus in Ireland.-Journ. of. Bot. 1892, p. 279, and Ir. Nat. 1892, p. 124.

Hart, W. E. :

On the Occurrence and Geological Relations of certain Ferns in the County of Donegal.-Dublin Nat. His. Soc. Proc. IV. p. 247, 1865.

Corydalis clavieulata in County Donegal.-Journ. of Bot. 1874, p. 184.

Harvey, Professor W. H. :

Memoir, of, with Selections from his Journal and Correspondence, 1869.

Harvey's Memoir.

Horbarium of Plants found near Limerick.-Made about 1834, and now in the possession of Dr. E. P. Wright, Trin. Coll. Dublin. . Herb. Harvey.

\section{Herbarium,}

of British Museum.-Contains many. Irish specimens of great interest, collected by Lhwyd, Robert Brown, and others.

Thomas Chandlee.- See under Chandlee.

Glasnevin Botanio Gardens.-See under Moore, David.

of Professor W. H. Harvey.-See under Harvey.

of J. T. Mackay.-See under Mackay. 
Herbarium-continued.

of Alexander G. More.-See under More.

of Science and Art Museum, Dublin.-See under Chandlee and Moore.

of Trinity. College, Dublir.-The British section of this important collection contains several Irish specimens of interest.............Herb. T.C.D.

Fincks, Rev. T. D. :

On early Contributions to the Flora of Ireland.-Ann. of Nat. His. vI. pp. 1 and $126,1841$.

Hind, W. M. :

A List of the more interesting Plants found lately near Belfast.-Phytol.

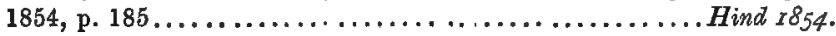

How, William :

Phytologia Britannica. London, 1650. Contuins the earliest printed records of Irish plants, contributed chiefly by the Rev. Richard Heaton.

Irish Academy, Royal, Proceedings of, $1872-92 \ldots \ldots \ldots \ldots \ldots$. . I. A. Proc.

Irish Naturalist, $1892-98 \ldots \ldots \ldots \ldots \ldots \ldots \ldots \ldots \ldots \ldots \ldots$. . . . . . . . .

K'Eogh, John, M.D. :

Botanica Universalis Hibernica. Cork, 1735. An alphabetical list of Irish plants, with numerous notes on their supposed medical virtues, and

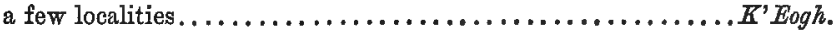

Kinahan, Professor J. R. :

A List of Ferns and their Allies found in County Dublin.-Phytol. 0. S. vol. v. p. 196, 1854.

On the Distribution of Ferns in Ireland.-Nat. His. Rev. 0. S. vol. v. p. $175,1858 \ldots \ldots \ldots \ldots \ldots \ldots \ldots \ldots \ldots \ldots \ldots \ldots$. Kinahan 1858 . Addenda to the above.-Nat. His. Rev, vol. vir. p. 39, 1860.

On Hymenophyllum.-Nat. His. Rev. O. S. vol. VI. p. 441, 1859.

Kinahan, G. H., M.R.I.A. :

Ferns of Killaloe, etc.-Nat. His. Rev. 0. S. vol. vir. p. $401,1860$.

Ferns of Lough Derg._-Dublin Quarterly Journ. of Science, vol. II. p. 333, 1861.

On Ferns observed in West Connarght and South-West Mayo.-Dublin Nat.

His. Soc. Proc. vi. p. 67, 1871.

Knowles, Miss M. C. :

Flowering Plants of County Tyrone.-Ir. Nat. 1897, p. 83.

Leebody, Mrs. M. J. :

Spiranthes romanzoviana in County Londonderry.-Ir. Nat. 1893, p. 228. 
Levinge, H. C., M.A. :

Potamogeton lanceolatus in Ireland.-Journ. of Bot. 1891, p. 344.

Neotinea intacta in Co. Clare.-Journ. of Bot. 1892, p. 194... Levinge 5892.

Limosella aquatica in Ire7and.-Journ. of Bot. 1893, p. 309.

The Plants of Westmeath.-Ir. Nat. 1894, pp. 77, 96, and 128,

The Plants of Westmeath.-Ir. Nat. 1895, p. 64............Levinge 1895 .

Ley, Rev. Augustin :

Thatietrum alpinum in Kerry.-Journ. of Bot. 1887, p. 374.

\section{Ihwyd, Edward:}

Some further Observations relating to the Antiquities and Natural History of Ireland.-Philosoph. Trans. vol. xxvIr. p. 524, 1712.

Lindsey, Miss K. M. :

Collection of Plants made in Mayo and Connenara.

.Iinton, Rev. E. F. :

Naias flexilis at Killarney.-Journ. of Bot. 1886, p. 83 .

Carex trinervis in Ireland.-Journ. of Bot. 1888, p. 56.

Linton, Rev. E. F., and Linton, Rev. W. R. .

Notes on a Botanical Tour in West Ireland.-Journ. of Bot. 1886, p. 18, Linton 1886 .

Westmeath Plants.-Journ. of Bot. 1896, p. $119 \ldots \ldots \ldots \ldots$ Linton $r 8 g 6$.

Longfield, C. :

Lycopodium inundatum in County Cork.-Journ. of Bot. 1873, p. 381.

Mackay, Jas. Townsend, LL.D. :

A Systematic Catalogee of Rare Plants found in Ireland.-Roy. Dublin Soc. Trans. vol. v. p. 127, 1806......................Mack. Rar. Catalogue of the Plants found in Ireland.-R.I.A. Trans. vol. xIv. 1825. Important as the first complete list of all the native plants of Ireland, Mack. Cat.

Flora Hibernica. Dublin, 1836. In its time, the standard descriptive work on the Flora of Ireland. The localities given are usually few, and no attempt is made to estimate the range and frequency of the plants.

Flor. Hib.

$A$ brief View of the Botany of Ireland, as an Appendix to Frazer's Handbook for Travellers in Iraland, 1854.

Additions to the Plants of Ireland.-Nat. His. Rev. 0. S. vol. v1. p. 537,

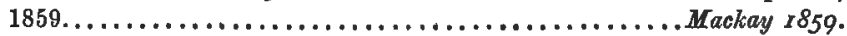
Additional Plants for Flora Hibernica.-Nat. His. Rev. O. S. vol. vir. p. $443,1860$. 
Mackay, Jas. Townsend, LL.D.-continued.

Herbarium, preserved in Trinity College, Dublin. This collection unfortunately was prepared in the latter years of Dr. Mackay's life, and nany of the plants are known to have been derived from the Botanic Gardens, and were inserted only with the view of representing the species. The localities given on the labels were merely copied from Flora Hibernica, so that the collection is almost useless for elucidating any critical question......................... Herb. Mackay.

Maffett, Miss :

Collection of Plants made in the North of Ireland.

Marshall, Rev. E. S. :

Irish Plants collected in Jume, I896.-Journ. of Bot. 1896, p. 496,

Marshall $\mathbf{z} 896$.

Sisyrinchium californicum in Ireland.-Journ. of Bot. 1896, p. 366.

Some Plants observed in Co. Wexford, 1897.-Journ of Bot. 1898, p. 46,

Marshall 1898 .

Marshall, Rev. E. S., and Shoolbred, W. A. :

Irish Plants observed in July, 2895 .-Journ. of Bot. 1896, p. 250,

M. S. 2896 .

M'Ardle, David :

The Plants of Dalley Lsland.-Ir. Nat. 1892, p. 133.

Millen, W. :

Loealities of Plants observed near Belfast.-Phytol. O. S. vol. Iv. p. 363, 1851.

Moffat, C. B., B.A. :

Plants near Ballyhyland, Co. Wexford.-Journ. of Bot. 1889, p. 105, Moffat $I 889$.

Life and Letters of Alexander Goodman More. Dublin, 1898. An excellent memoir, containing much valuable matter relating to the history of Irish botany during the last thirty years.

See also under Barrett-Hamilton.

Molyneux, Thos., M.D. :

Appendix to Threlkeld's Synopsis Stirpium Hibernicarum.-See sub Threlkeld.

Notices of a few rare Irish Plants, in his account of the discovery of the horns of the Irish Elk.-Phil. Trans. No. 227, 1697.

Moore, David, Pri.D. :

Manuscript Catalogue of Plants observed in the county of Londonderry in 1834 and 1835 . A bound MS. of 145 pp., including Phanerogams and Cryptogams now preserved in the Library, Glasnevin Botanic Gardens, Dublin......................................Moore MS.

Botany of the parish of Templemore, in Colby's Ordnance Survey of the county of Londonderry, pp. 9-11 and pp. 6-8, plates 4, 5 of Notices,

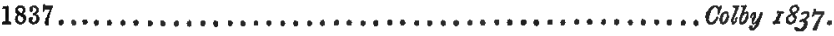


Moore, David, Рн.D.-continued.

Equisetum variegatum and other Plants in Ireland.-Phytol. O. S. vol. II. p. $129,1845$.

On the Distribution of Erica mediterranea in Ireland, etc.-Phytol. 0. S. vol. I7. p. 597, 1852.

A new Irish Equisetum.-Phytol. 0. S. vol. v. p. 17, 1854.

Ajuga pyramidalis, etc., in Aran.-Phytol. O. S. rol. v. p. 189, 1854.

Observations ons same Plants considered by Alphonse de Candolle alien to Great Britain.-Nat. His. Rev. O. S. vol. vr. p. 155, 1859.

Observations on the prevailing and rare Plants of Erris.-Nat. His. Rev. O. S. vol. vil. p. $414,1860$.

On some Plants supposed to be Additions to the Irish Flora.-Dublin Univ-

Zool, and Bot. Assoc. Proc. vol. II. p. 85, 1863.

Neotinea intacta. A recent Addition to the British Flora.-Journ. of Bot. 1864, p. 228, and R I.A. Proc. vol. Ix. p. 105, 1865.

Potamogeton nitess as an Irish Plant.-Journ. of Bot. 1864, p. 325.

Inula salicina in Ireland.-Journ. of Bot. 1865, p. 333.

Trifolizm glomeratum in Ireland.-Journ. of Bot. 1870, p. 192.

Notes on some Irish Plants.-Journ. of Bot. 1871, p. 299.

On a new species of Isoetes (I. Morei) from Ireiand.-Journ. of Bot. 1878, p. 353 .

Herbarium, prepared for the Ordnance Survey, and containing a nearly complete series of the wild plants of Derry and Antrim, ncw preserved in the Science and Art Museum, Dublin ............. Herb. Moore.

Herbarium, containing plants from various parts of Ireland, now preserved in the Botanic Gardens, Glasnevin...............Herb. Glasnevin.

Moore, David, and More, A. G.:

Contributions towards a Cybele Hibernica. Dublin 1866...........Cyb. On the Climate, Flora, and Crops of Ireland.-Internat. Bot. Congress Report, 1866.

Phanerogamic Plants and Ferns of Dublin and Wicklow, in Brit. Assoc. Guide to the County of Dublin, pp. 186-219, 1878, also in Roy. Dublin Soc. Proc. N.S. 1. p. 190................... Moore \& More, 1878 .

Moore, Charles :

Collection of Plants made when attached to the Ordnance Survey in Donegal................................Herb. C. Moore.

Moore, Thomas:

Nature-printed British Ferns. 2 vols. 870. 1855. Contains much information respecting the localities of Ferns in Ireland.... T. Moore 1855 .

More, Alex. Goodman, F.R.S. Edin. :

Notes on the Flora of Castle Taylor, Gahway.-Bot. Soc. Edin. Proc.

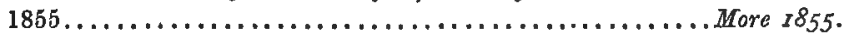

Localities. for some. Plants observed in Ireland.-Nat. His. Rev. O.S. vol. vil. p. $434,1860 \ldots \ldots \ldots \ldots \ldots \ldots \ldots \ldots \ldots \ldots$.................... 1860 .

Note on the Discovery of Neotinea intacta.-Bot. Soc. Edin. Trans. vol. vII. p. 265,1865 . 
More, Alex. Goodman, F.R.S., Edin.-continued.

Trifolium subterranerem in Ireland.-Journ. of Bot. 1868, p. 208.

Note on Equisetum Moorei, etc.-Journ. of Bot. 1868, p. 253.

Discovery of Scirpus parvulus in Ireland.-Journ. of Bot. 1868, pp. 254 and 321 .

Hippophe thamnoides in Ireland.-Journ. of Bot. 1868, pp. 255 and 373.

Discovery of Aira uliginosa at Roundstone-Journ. of Bot. 1869, p. 265.

On Recent Additions to the Flora of Ireland.-R.I.A. Proc. 2nd Ser.

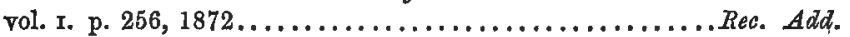

An Abridgment of the preceding Paper with a few Additions.-Journ. of Bot. 1873, pp. 115 and $142 \ldots \ldots \ldots \ldots \ldots \ldots \ldots$................... 1873 . A new station for Erica Mackaiana.-Journ. of Bot. 1874, p. 306.

Report on the Flora of Inish Bofin, Galway.-R.I.A. Proc. 2nd Ser.

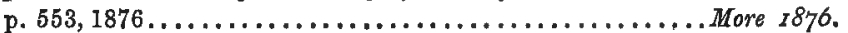

Lycopodium inundatum in Kerry.-Journ. of Bot. 1876, p. 373.

Naias flexilis in Kerry.-Journ. of Bot. 1877, p. 350.

Trifolium maritimum in Ireland.-Journ. of Bot. 1880, p. 233.

Sisyrinchium Bermudianum in Ferry.-Journ. of Bot. 1882, p. 8.

Aira alpina in Kerry.--Journ. of Bot. 1882, p. 87.

Erica mediterranea var. hibernica, etc., in Achill Ysland.-Journ. of Bot. 1889, p. 118.

Cuscuta Epithymum in Ireland.-Journ. of Bot. 1892, p. 14.

Vacinium Vitis-Idae at low level in County Westmeath.-Journ. of Bot. 1892 , p. 88.

Characteristic and Rare Plants of Southern Ireland.-In Guy's Pictorial Guide for South of Ireland. Cork 1893.

The above reprinted, with corrections in Journ. of Bot. 1893, p. 299.

Herbarium, containing many plants collected in various parts of Ireland.

See also under Moore; David.

Herb. More.

Murphy, Professor E. :

Contributions towards a Flora Hibernica.-Loudon's Mag. of Nat. His. vol.

I. p. $436,1829 \ldots \ldots \ldots \ldots \ldots \ldots \ldots \ldots \ldots \ldots \ldots \ldots$. Murphy $I 8 z q$.

Inurray, R. P.:

Arabis ciliata in Clare.-Journ. of Bot. 1887, p. 183.

\section{Fatural History}

Review (Old Series), 7 vols. London, $1854-60 \ldots . . . \ldots$.... Nat. His. Rev.

Nowman, Edward :

History of British Ferns.-1st Ed. $1840 \ldots \ldots \ldots \ldots$...........

A History of British Ferns and allied Plants.-2nd Ed. 1844.

Newman 1844

Notes on Irish Natural History, especially Ferns._Charlesworth's Mag. of Nat. His. vols. III. and Iv. 1839-40.

A New Irish Equisetum (E. Moorei).-Phytol. O. S. vol. v. p. 17, 1853.

Contributions towards the Bistory of an Irish Asplenium (A. acutum).-

Phytol. 0. S. vol. v, p, 37, 1853. 
Nowers, J. E. and Wells, J. G. :

The Plants of the Aran Islands, Galway Bay.-Journ. of Bot. 1892, p. 180. Nowers \& Wells $78 g z$.

Ogilby, Leslie:

Notes of a Botanical Ramble in Connemara and Arran.-Phytol. vol. Ir. p. $345,1845 \ldots \ldots \ldots \ldots \ldots \ldots \ldots \ldots \ldots \ldots \ldots$....................... 1845 .

Oliver, Professor Daniel :

Notes of a Botanieal Ramble in Ireland.-Phytol. vol. Iv. p. 124, 1851. Oliver $185 \mathrm{I}$.

Botanical Notes of a Week in Ireland.-Phytol. vol. rv. p. 676, 1852.

Oliver 1852 .

O'Mahony, Rev. Thaddeus:

Notes of a Botanical Excursion in Clare.-Dublin Nat. His. Soc. Proc. vol. I. p. 30, 1860. (Paper read June 1852.).......... O'Mahony 7860.

Phillips, R. A. :

Allium Scorodoprasum in County Corl.-Ir. Nat. 1893, p. 23.

Orobanche minor in County Cork.-Ir. Nat. 1893, p. 23.

The Charateristies of the Flora of County Cork.-Journ. of Cork His. and Archæological Soc., vol. III. p. 274, 1894.

Rare Plants in West Cork.-Ir. Nat. 1894, p. 205 .......... Phillips 1894 .

Some Waifs and Strays of the Cork Flora.-Ir. Nat. 1895, p. 332.

Phillips, W. H., and Praeger, R. Ll. .

The Ferns of Ulster.-Belfast Nat. Field Club Proc. Appendix for 188586-87...................................

Phytologia, Britannica-see under How, William.

Phytologist: Old Series, conducted by George Luxford and Edward Newman.

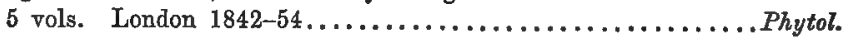

New Series, edited by Alexander Irvine, London, 1855, etc........Phytol.

Power, Thomas, M.D. :

The Botanists Guide for the County of Cork, in contributions towards the Fauna and Flora of Cork. Cork 1845. A complete and extensive list of the plants found wild in the county of Cork, chiefly in the immediate vicinity of the city itself........................Flor. Cork.

Praeger, R. Ll., B.A. :

Carex aquatilis at Shane's Castle, County Antrim.-Journ. of Bot. 1892, p. 153.

Spiranthes Romanzoffana in the North of Ireland.-Journ. of Bot. 1892, p. 272.

In Camp on Lough Erne.-Ir. Nat. 1892, p. $110 \ldots . . . .$. Praeger $189 z$. A new Irish Sedge (Carex rhynohophysa).-Journ, of Bot. 1893, p. 33. 
Praeger, R. Ll., B.A.-continued.

The Flora of County Armagh.-Ir. Nat. 1893, pp. 34, 59, etc.

Praeger 7893 .

The Flora of Rathlin (some additions to Mr. S. A. Stewart's list of 1884 in R.I.A. Proc.).-Ir. Nat. 1893, p. 53.

Eleocharis acicularis in Queen's County, etc.-Ir. Nat. 1893, p. 276.

Local Botanical Notes._Belfast Nat. Field Club Rep. 1892-93, pp. 532-8. Queen's County Plants.-Ir. Nat. 1893, p. 321.

Irish Rubi.-Journ. of Bot. 1894, pp. 75 and 359 ........Praeger 5894 . Notes on the Flora of Aranmore.-Ir. Nat. 1895, p. 249...... Praeger 1895 . On the Botanical Subdivision of Ireland.-Ir. Nat. 1896, p. 29, and Journ. of Bot. 1896, p. 57.

Flowering Plants and Fascular Cryptogams of Clonbroek.-Ir. Nat. 1896.

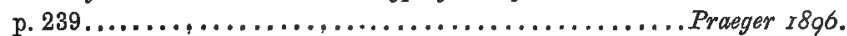

Irish Plants, collected chiefly in the Province of Leinster in $1806 .-\mathrm{Ir}$. Nat. 1897, p. $89 \ldots \ldots \ldots \ldots \ldots \ldots \ldots \ldots \ldots \ldots \ldots \ldots$ Prateger 1897 .

Praeger, R. Ll., and Carr, Professor J. W. :

The Phanerogams, Ferns, etc., of the Irish Field Club Union Excursion to Galway.-Ir. Nat. 1895, p. 246..................P. \& C. 1895 . See also under Phillips, W. H., and Stewart, S. A.

Ray, Rev. John :

Historia Plantarum, 1686-1704.

Synopsis Stirpium Britannicarun.-Ed. II. 1696, and Ed. III. 1724. These works of Ray contain a few references to Irish plants, chiefly contributed by Mr. Sherard.

Reichenbach, Professor H. G.:

On Neotinea intacta.-Journ. of Bot. 1865, p. 1.

Reynell, Miss E. :

Collection of Plants made in Westmeath.

Ridley, H. W. :

Kerry Plants.-Journ. of Bot. 1884, p. 91.

Rutty, John, M.D.:

An Essay towards a Natural History of the County of Dublin, 1772.-Contains lists of plants, chiefly those used as food or in medicine; only a few special localities are given..................Rutty's Dublin.

Sampson, Rer. G. V. :

Statistical Survey of the Counity of Londondery. Dublin 1802. A list of plants is given in the Appendix................ Sampson 1802 . Memoir explanatory of the Chart and Survey of Londonderry. 1814. ' List of Plants, pp. 152-171, 
Scully, Reginald, F.L.S.:

Notes on some Kerry plants. -Journ. of Bot. 1888, p. $71 \ldots$...R.W.S 1888 . Further notes on the Kerry Flora.-Journ. of Bot. 1889 , p. 85 . . R. W. S. 1889 . Juncus tenuis in Kerry.--Journ. of Bot. 1889, p. 335.

Plants found in Kerry, 1889 .- -Journ. of Bot. 1890, p. 110..R.W.S. I 890 . Plants found in Kerry, $x 890 .-$ Journ. of Bot. 1891, p. 143..R.W.S. I 891 . Ancient and Unverified Kerry Records.-Journ. of Bot. 1891, p. 324. Asplenium lanceolatum in Kerry.-Journ. of Bot. 1893, p. 20.

Festuca sylvatica in County Cork. -Journ. of Bot. 1893, p. 56.

Some Cork Aliens.-Ir. Nat. 1895, p. 20.

Chara canescens in Ireland.-Ir. Nat. 1895, p. 50.

Shoolbred, W. A., M.R.C.S. :

A Botanical Trip to County Antrim.-Ir. Nat. 1894; pp. 146 and 167,

See also under Marshall, Rev. E. S.

Shoolbred 1894 .

sigerson, G., M.D. :

Additions to the Flora of the tenth Botanical District, Ireland.-R.I.A. Proc. 2nd Ser. vol. Ir. p. 192, 1872.

Sim, John :

Remarks on the Flora of Ireland.-Phytol. N.:S. vol. IIr. p. 353, 1859.

Smith, Charles, M.D. .

Ancient and present State of the County and City of Waterford, 1st Ed. Dublin, 1746............................Smith's Waterford.

Ancient and present Slate of the County and City of Cork, ] st Ed. Dublin,

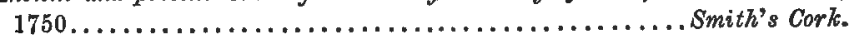
Ancient and present State of the County of Kerry, 1st Ed. Dublin, 1756,

Smith, W. G. :

Smith's Kerry.

Discovery of Cuscuta Trifolii in Ireland.-Dublin Nat. His. Soc. Proc. v. p. 198, 1868-69.

Stewart, S. A., F.B.S., Edin. :

On some rare or overlooked Plants in the neighbourhood of Belfast.-Belfast

Nat. Field Club Proc. 1865-66.

$A$ visit to Dungiven and the Sperrin Mountains.-Belfast Nat. Field Club, Proc. 1868-69.

Report on the Botany of the Mountainous portion of Fermanagh, west of Lough Erne.-R. I. A. Proc. 2nd Ser. vol. IIr. p. 531, 1882.

Stewart 1882.

Report on the Botany of the Island of Rathlin, County Antrim.-R. I. A. Proc. 2nd Ser. vol. IV. p. 82, 1884................. Stewart I884. Saxifraga Hirculus in Ireland.-Journ. of Bot. 1884, p. 302.

Carex aquatitis in Ireland.-Journ. of Bot. 1885, p. 49.

Report on the Botany of Lough Allen and the Slieveanierin Mountains.R. I. A. Proc. 2nd Ser. vol. Iv. p. 426, $1885 \ldots \ldots \ldots \ldots \ldots$ Stewart 1885 . 
Stewart, S. A., F.B.S. Edinb.-continued.

Irish Hieracia.-Journ. of Bot. 1886, p. 83.

Report on the Botany of South Clare and the Shannon.-R. I. A. Proc. 3rd Ser. vol. I. p. 343, $1890 \ldots \ldots \ldots \ldots \ldots \ldots \ldots \ldots \ldots \ldots$. . . . . . . . . . . . . . Lowest limit of Vaccininum Vitis-Idaca in Ireland...Journ. of Bot. 1892. p. 121.

Notes on the Flora of North-east Ireland.-Ir. Nat. 1894, pp. 35 and 52.

Stewart, S. A. and Corry, T. H. :

Stewart 1894 .

A Flora of the North-east of Ireland. Belfast, 1888.-The most valuable local Irish Flora hitherto produced..................Flor. N.E.

Stewart, S. A. and Praeger, R. Ll. :

Report on the Botany of the Mourne Mountains, County Down.-R. I. A. Proc. 3rd. Ser. vol. Ir. p. 335, $1892 \ldots \ldots \ldots \ldots \ldots \ldots \ldots$....... \& $P$. $18 q 2$.

Supplement to the Flora of the North-east of Ireland.-Printed as an appendix to Proc. Belfast Nat. Field Club, 1894-95............S. \& P. 1895 .

\section{Tate, Ralph :}

Flora Belfastiensis.-Belfast 1863. A small catalogue of the plants notice, in the immediate neighbourhood of Belfast..............Flor. Belf.

The Flora of Ireland, with special reference to Olster.-Belfast Nat. Field Club Proc. 1866-67.

Addenda to the Cybele Hiberniea.-Journ. of Bot. 1870, p. 81 .

Templeton, John, A.L.S. :

On a new Species"of Rose (R. Hiberniea Smith).-Roy. Dublin Soc. Trans. III. p. 162, with plate, 1802.

Catalogue of the Native Plants of Ireland. A small MS. volume, with a few pen-and-ink drawings of plants and numerous localities, chiefly in North-east Ireland; drawn up between 1793 and 1820. Now in the library of R. I. A. Dublin.................... Templeton MSS.

Journal, in M.S., kept from 1806 to 1820 , contains notes of plants observed the counties of Sligo and Dublin, as well as in north-east Ireland.

Threlkeld, Caleb., M.D.:

Synopsis Stirpium Hibernicarum. Dublin 1726. This is the earliest work on the botany of Ireland. It is an alphabetical list of native Irish (and British) plants, with notices of their medicinal properties and many localities chiefly in the neighbourhood of Dublin........... Threlkeld. Annotations in MS., in a copy of the above in the R. I. Academy's Library, giving many records of interest for the rurer Irish plants.

Annot. in Threlkeld.

Tighe, W. :

Statistical Observations relating to the County of Filkenny, 1802. A list of plants is given at pp. 207 and 359.

Plants of Coast of Wexford.-Roy. Dublin Soc. Trans. vol. IIr. p. 147, 1802. 
Townsend, Frederick, M.A. :

Euphrasia Salisburgensis (Funk.) native in Ireland.--Journ. of Bot., 1897, p. 441.

Monograph of the British.Species of Euphrasia.-Journ. of Bot., Sept., Oct., Nor., and Dec., 1897.

Vowell, Richard P. See under Barrington.

Wade, Walter, M.D. :

Catalogus systematicus. Plantarum indigenarum in comitatu Dublinensi inventarum.-Dublin, 1794. A descriptive Flora, in Latin, arranged according to the Linnæan system. It contains many localities, but does not include the Sedges or Ferns..................... Wade Dubl.

Catalogus Plantarum rariorum in comitatu Gallovidia.-Dublin Soc. Trans. 1. part 2, $1801 \ldots \ldots \ldots \ldots \ldots \ldots \ldots \ldots \ldots \ldots \ldots \ldots$. . . . . . Fallovid.

Plante Rariores in Hibernia Invente.-Dublin Soc. Trans. vol. Iv. 1804. A tolerably full list of the scarcer plants observed by Dr. Wade in various parts of Ireland, chiefly Connemara, Cork, and Kerry, but several of the species appear to have been imperfectly determined,

\section{Watson :}

Wade Rar.

See under Botanical Exchange Club.

Wells, J. G. :

See under Nowers.

\section{White, John :}

An Essay on the Indigenous Grasses of Ireland.-Dublin, 1808. Chiefly descriptive and agricultural, but contains several stations not recorded elsewhere........................................... 2808 .

Whitla, F. .

Annotations in an interleaved copy of Flowa Hibernica, giving many dates, not elsewhere obtainable, for Templeton's records.......... Whitla MS.

Woods, Joseph :

Some Notes made during a Tour through a part of Ireland.-Phytol. N. S, vol. I. pp. 121, 156, and 207, 1855.

Wright, Professor E. Perceval:

Notes on the Flora of the Islands of Arran.-Dublin Nat. His. Soc. Proc. Y. p. $96,1866-67$.

Wynne, Right Hon. John :

Adiantum Capillus-Veneris in Leitrim.-Nat. His. Rev. O. S. vol. Iv. p. 69,1855 . 


\section{INTRODUCTION.}

\section{$\rightarrow$ \\ I. Position and Phystcat Features of Ireuand.}

IreTAND, the most western of the British Isles, extends from North Latitude $51^{\circ} 26^{\prime}$ to $55^{\circ} 21^{\prime}$ and from West Longitude $5^{\circ} 20^{\prime}$ to $10^{\circ} 26^{\prime}$. In form the island is roughly rhomboidal, with a greater diagonal of 302 miles, and a lesser of 210 miles, the total area being 32,531 square miles. More truly insular in position than Great Britain, Ireland is bounded on the north, west, and south by the Atlantic Ocean, and on the east is separated from England by a sea-channel, ranging in breadth from 47 to 138 miles. At its northeastern extremity, however, it is divided from southern Scotland by a much narrower channel, varying in width from 13 to 23 miles. The western coasts are much broken, and on this side almost all of the larger islands are found, such as Achill Island, Valentia, the South Isles of Aran, Clare Island, and North Aran. The eastern shores are far less broken.

As regards its surface features, Ireland may be fairly represented as a central plain flanked by mountain groups, disposed towards or along the coasts. With a few exceptions, such as the Slieve Bloom range in Queen's County, the Galtees in Tipperary, Mount Leinster and Blackstairs in Wexford, Cuilceagh in Cavan, and Keeper Mountain in Limerick, the chief mountains lie quite close to the coasts. The highest summits are found in the southwest in county Kerry, where the fine rock mass of Magillicuddy's Reeks rises in Carrantuohill to a height of 3414 feet, while farther west Mount Brandon reaches to upwards of 3100 feet. Elevations such as these are but rarely approached in other parts of the island. In the Wicklow mountain group on the east coast, Lugnaquilla reaches to 3039 feet; and in the Galtees towards the south, Galtymore to 3015 feet; but elsewhere in Ireland there are no summits 
attaining to 3000 feet, though in Mayo, Waterford, and Wexford some points are to be found slightly exceeding 2600 feet, and Slieve Donard in the Mournes reaches almost to 2800 feet.

In their petrological character, the numerous Irish mountain groups are sufficiently varied. Granite is abundant in the Dublin and Wicklow mountains and in those of Down and Donegal; sandstones occur in Kerry, Tipperary, the Slieve Bloom range and elsewhere; quartz rock is abundant in the Galway and Mayo groups and in Donegal; mica-slate is of frequent occurrence; large masses of elevated limestone are found in Clare, Sligo, and Fermanagh, and basalt covers a wide area in Antrim and Derry. Chalk is conspicuously absent, for though exposed in cliffs at some points along the Antrim coast, it is always capped with basalt, and cannot be said to have any true outcrop in Ireland. Timestone prevails almost throughout the central plain, but is usually covered by extensive peat bogs or by drift accumulations frequently disposed in the characteristic form of eskers or gravel mounds and ridges. The area occupied by peat-bogs is very large, and has been estimated at 4400 square miles, or 13.5 per cent. of the total surface of the island. Somewhat more than half of this bog-area is lowland. Much of the remainder lies at elevations between 1000 and 2000 feet above sea-level.

The area of the country under water, chiefly in the form of lakes, is little short of 1000 square miles, or fully 3 per cent. of the whole surface. Rare and usually insignificant in the east, the lakes become frequent towards the centre, and well-nigh innumerable in some parts of the west, as in Connemara, Clare, and West Mayo. A comparison of the four western counties, Kerry, Clare, Galway, and Mayo, with an equal area of the eastern counties shows the water-surface of the western counties to be fully four times as large as that of the eastern. In the north-east is the low-lying and shallow Lough Neagh, with an area of 153 square miles, the largest fresh-water surface in the British Isles. Owing to the comparatively small extent of the country and the peculiar disposition of the mountain-groups, most of the numerous Irish rivers have small basins and short courses. But there is one notable exception in the Shannon. This fine river, the longest in the British Isles, and, perhaps, the largest in volume, has a roughly north and south course of about 250 miles, and widens in its middle and lower reaches into the imposing river-lakes known as Lough Ree and Lough Derg. 
As compared with England, the most salient general features of Ireland are its large extent of peat-bog and lake-surface, its vast central limestone plain of low elevation, and the absence of chalk. Further details as to the more local physical features will be given in section VIII. of this Introduction dealing with the Irish Botanical Districts.

\section{Climate.}

Owing to its insular position the climate of Ireland, especially in the west, is more moist and equable than in the rest of Europe under the same degrees of latitude. From observations made at sixteen stations in the year 1851, it appears that the mean annual temperature of Ireland is a little over $50^{\circ}$ Fahrenheit, which is the same as the arerage in South Britain. But it is not the mean temperature of any country so much as the extreme ranges which affect in summer the ripening of fruit and crops, and in winter the preservation of tender plants. There is a striking difference between Ireland and Great Britain in this respect; for the mean temperature of the summer months being $2^{\circ}$ Fahrenheit lower in Ireland, the ripening of corn and fruit is later and more uncertain than in England, and wheat, which is cultivated successfully throughout nearly all England, is in many parts of Ireland a precarious crop, especially in the western counties. The Spanish chestnut, the wainut, and the fig, seldom fully ripen their fruit. On the other hand, the winter temperature being about $2^{\circ}$ higher in Ireland, some plants thrive and flourish with us which would be killed by the cold, dry frost of an English winter. Even in the county of Dublin, some species which are natives of the western coast of Ireland-for example, Simethis bicolor and Erica Mackaii-suffer much from frost when planted out in the open air in the Botanic Garden at Glasnevin.

The temperature of Ireland decreases from south to north at the rate of about three-quarters of a degree for each degree of latitude. A sensible decrease is also experienced from west to east, especially in winter. This greater mildness and equability of the climate in the west as compared with the east of Ireland, and in Ireland generally, when compared with the rest of Europe under the same degrees of latitude, was formerly attributed to the moderating influence of the great warm ocean current, the Gulf Stream. But it is now held by the best authorities that this current does not extend eastward from the American coast beyond $50^{\circ}$ west longitude, 
so that its effect on Irish climate must be quite inappreciable. It is probably to the prevailing south-west winds, travelling over wide ocean areas before they impinge on the Irish coast, that our more equable and humid climate is due. Experiments conducted by Dr. Humphrey Lloyd, in 1851, showed that the temperature of the sea off the west coast of Ireland exceeded that of the air on land by $1.8^{\circ}$ Fahrenheit in summer and $5.7^{\circ}$ in winter.

The influence of the vapour-laden south-west winds is clearly shown in the distribution of the Irish rain-fall, which reaches its. maximum in the south-west, where the lofty Kerry mountains act as condensers, while it decreases in a marked degree towards the east and north. The mean annual rain-fall at Valentia for the six years, $1890-95$, was $53 \cdot 6$ inches, while in wet years, both here and at Killarney, another south-western station, the total annual rainfall has risen to 61 inches. For the same six years the mean at Markree, in Sligo, a western station some 150 miles northward of Valentia, was 40.5 inches. On the eastern side of the island, Dublin city for the same period gave a mean of 26.5 inches, and Armagh of $29 \cdot 3$ inches. The amount of the decrease in rain-fall from west to east varies greatly according to the position with respect to mountain masses of the stations compared, and the number of stations for which statistics are available is too small to permit of any trustworthy average being arrived at for the west and east coasts. But we are concerned here only with the broad features of the Irish climate, and one of these is unquestionably the general contrast in humidity between west and east.

To these climatic differences between the two sides of the island, certain differences in the vegetation may be directly ascribed, as well as differences in the respective floras. In the west, the proportion of the vegetation, or total mass of plant life, which is made. up of individuals belonging to the moisture-loving orders-Cyperaceæ, Rushes, Ferns, \&c.--is much larger than in the east; and a few species, which are confined to the west and south-west, such as. Sibthorpia europaca, Microcala filiformis, and Saxifraga Geum, are perhaps so confined by the absence elsewhere in Ireland of the degree of humidity and equability of climate necessary to their maintenance.

\section{The Irish and English Floras compared.}

Viewed as a whole, the flora of Ireland may be regarded as an incomplete English flora, as this in its turn may be regarded as an 
incomplete west European or French flora. It is in the species which it lacks that the Irish flora chiefly differs from the English; and the vast majority of the English plants which are absent from Ireland are common or widespread in western continental Europe. Taking as standard the third edition of Hooker's Students Flora of the British Isles, published in 1884, we find that, in round numbers, 1420 species and sub-species of Flowering Plants and Vascular Cryptograms, either native or fully naturalized, occur in England and Wales, against 1000 in Ireland.* In making this comparison, care has been taken to exclude with equal severity from the floras of the two areas all introduced plants not fully naturalized, so that the ratio of 70 to 100 may be taken as a fairly accurate expression of the relative richness of the two floras. It will be seen that the comparison here made is one of Ireland with England. and Wales only, so that the areas compared are less glaringly dissimilar in extent and in range of latitude, and consequent range of climates, than would be the case if the comparison were made with Great Britain as a whole. The flora of Great Britain, on the standard already mentioned, numbers 1480 species and sub-species, the ratio of the total Irish flora to this being $67 \cdot 5$ to 100 .

British Type.-Almost all of the commonest indigenous plants of England, the British Type species of Watson, are found in Ireland, where, as in England, they make up what may be called the groundwork of the flora. Out of a total of 544 plants of this type found in England and Wales, only the following eight species are wanting in Ireland:-

\section{British Type Plants absent from Ireland.}

Helianthemum vulgare. Genista anglica. Potentilla verna.

\author{
Chrysosplenium alterni- \\ folium. \\ Erythræa littoralis.
}

Paris quadrifolia.

Juncus compressus. Avena pratensis.

English and Germanic Types.-But when we come to the less widespread groups or types in the English flora, such as the English Type made up of plants which have their chief prevalence in England and particularly in its more southern provinces, to the Germanic, Intermediate, Scottish, and Atlantio types which find their chie: development respectively in East England, in Middle Britain, in North Britain, and in West and South-west England, and to the

* The Characece are excluded from both the English and Irish totals. 
Highland Type or mountain plants, the deficiencies of the Irish flora become at once more prominent. The following table, based on Watson's Compendium of the Cybele Britannica, 1870, is designed to. show the comparative richness of the English and Irish floras under these various types. The exclusion from this table of the Highland and Scottish type plants absent from England and Wales has diminished the total number of these types by some 58 species.

\section{Representation of Watson's Botanical Types in England} and Wales, and in Ireland.

\begin{tabular}{|c|c|c|c|c|c|c|c|c|c|}
\hline \multirow{3}{*}{$\begin{array}{l}\text { British, } \\
\text { English, }\end{array}$} & \multicolumn{2}{|c|}{ Type. } & \multicolumn{2}{|c|}{$\begin{array}{l}\text { Number in } \\
\text { England and } \\
\text { Wales. }\end{array}$} & \multicolumn{4}{|c|}{$\begin{array}{l}\text { Number } \\
\text { in } \\
\text { Ireland. }\end{array}$} & \\
\hline & . & . & 544 & & 536 & or & 98 & per & cent. \\
\hline & . & . & 381 & & 246 & or & $64 \cdot 5$ & , & " \\
\hline Scottish a & ate & diate, & 98 & & 62 & or & 63.3 & , & " \\
\hline Highland, & . & . & 67 & & 41 & or & $61 \cdot 2$ & , & ," \\
\hline Atlantic, & . & . & 62 & . & 34 & or & $55 \cdot 0$ & , & ", \\
\hline Germanic, & . & . & 102 & . & 12 & or & $11 \cdot 7$ & , , & ", \\
\hline
\end{tabular}

The extreme poverty of the Irish flora in Germanic Type plants, or plants chiefly prevalent in the provinces of East England bordering on the German Ocean, is the most striking feature in this comparative table. The following list shows all the species of this type which can be accepted as Irish. Of the total number of 12 plants in this list, four are certainly or probably introduced; of the remaining eight, six are rare; and four, Astragalus hypoglottis, Limosella aquatica, Glyceria Borreri, and Polygonum mite, extremely so.

\section{Germanic Type Plants in Ireland.}

Astragalus hypoglottis. fGalium erectum. *Crepis biennis.

C. taraxacifolia.
*Senecio viscosus. Hypopithys multiflora. Limosella aquatica. Teucrium Scordium.
Polygonum mite.

Orchis pyramidalis.

Glyceria Borreri. †Bromus erectus.

Existing climatic influences would seem to have played but a subordinate part in producing this remarkable poverty of East England plants in Ireland, or, indeed, the large deficiencies of species of the English type. The main cause is more obscure, and must be sought for in the geological history of the British Isles. There is a strong body of evidence to show, that Ireland, as an island, is of much 
greater antiquity than Great Britain, or, to express the same fact in other words, to show that Great Britain maintained its land connection with the Continent long after it had lost its land connection with Ireland. As a consequence of this longer insulation of the more western island, the stream of migration, by which we may assume the British Isles to have received from the Continent their present plant population, or, at least, the great bulk of it, at or towards the close of the last Glacial Period, was, in the case of Treland, cut off much earlier than in the case of Great Britain. The advance guard of aggressive species, the British type and a large section of the English type, had time to push westward into Ireland before its eastward land-connections were broken down; but the rear-guard of more slowly spreading species found their westward progress checked by the land subsidence which created the Irish sea. The mass of this rear-guard was probably formed of the Germanic type plants, a group so little aggressive in character that it seems to have been quite unable to push its way, as a whole, across England in the face of the more hardy settlers who had gone before and occupied the ground.

Highland Type.-While we may find in such considerations as these at least a partial explanation of the large deficiencies of the Irish flora in the Germanic and English types, it is rather to existing unfavourable climatic conditions that we should attribute the chief influence in producing its deficiencies in the Highland type. Not only are the Irish mountains inferior on the whole in elevation to the Welsh and Cumbrian mountains, but their distribution is such as to prevent the production of the possible maximum of alpine conditions. The highest Irish summits, the Magillicuddy's Reeks, are placed in the extreme south-west of the island, where latitude and the moderating influence of the large adjacent ocean area combine to bring about perhaps the minimum of alpine conditions which could be produced anywhere in Ireland by a mountain mass of such elevation. In England, on the contrary, the Cumbrian summits, while little inferior in elevation to the Reeks, lie some $2 \frac{1}{2}$ degrees of latitude farther northward, and the Snowdon group in Wales, with an elevation some 150 feet greater than the Reeks, lies northward of them by a full degree of latitude. In north Ireland, moreover, the mountain groups are fully 600 feet inferior in elevation to the English groups under the same parallel of latitude. Such being the position of the Irish 
mountains, their deficiencies in species of the Highland type can hardly be considered anomalous.

A glance at the following list of the plants of this type found in Ireland, numbering $\mathbf{4 1}$ in all, will show that they have a marked tendency to a western distribution. Neglecting two species which are confined to the north, it will be seen from the prefixed letters W. and E., that while no less than 36 of the species occur in West Ireland, only 27 are found in the East. Of the 36 species found in the West, 12 are absent from the East; of the 27 found in the East, only 3 are absent from the West.

\section{Highland Type Plants in Ireland.}

$\begin{array}{llll}\text { W. Thalictrum alpinum. } & \text { W.E. } & \text { Hieracium gothicum. } \\ \text { W.E. Subularia aquatica. } & \text { E. } & \text { H. corymbosum. } \\ \text { W.E. Draba incana. } & \text { W. } & \text { Arctostaphylos Uva-ursi. } \\ \text { W. } & \text { Arabis petræa. } & \text { W.E. } & \text { Vaccinium Vitis-Idæa. } \\ \text { W.E. Silene acaulis. } & \text { W. } & \text { Polygonum viviparum. } \\ \text { W.E. Dryas octopetala. } & \text { W. } & \text { Oxyria digyna. } \\ \text { N. } & \text { Rubus Chamæmorus. } & \text { W.E. Salix herbacea. } \\ \text { W.E. Alchemilla alpina. } & \text { W.E. Juniperus nana. } \\ \text { W.E. Saxifraga oppositifolia. } & \text { E. } & \text { Carex pauciflora. } \\ \text { W. } & \text { S. nivalis. } & \text { W.E. C. rigida. } \\ \text { W.E. S. stelläris. } & \text { W.E. C. aquatilis. } \\ \text { W.E. S. aizoides. } & \text { W. } & \text { Deschampsia alpina. } \\ \text { W.E. Sedum Rhodiola. } & \text { W. } & \text { Poa alpina. } \\ \text { W. } & \text { Epilobium alsinefolium. } & \text { W.E. Cryptogramme crispa. } \\ \text { W.E. Galium boreale. } & \text { W. } & \text { Aspidium Lonchitis. } \\ \text { W.E. Saussurea alpina. } & \text { W. } & \text { Asplenium viride. } \\ \text { W.玉. Hieracium anglicum. } & \text { W.E. Lycopodium alpinum. } \\ \text { W.E. H. iricum. } & \text { W.E. Selaginella selaginoides. } \\ \text { N. } & \text { H. prenanthoides. } & \text { W.E. Isoetes lacustris. } \\ \text { W.E. H. crocatum. } & & \end{array}$

All of the 12 Highland Type plants which in Ireland are confined to the West, occur in West England or Wales, so that it is hard to account for their absence from East Ireland if we assume them to have made part of a great plant migration spreading westward from the European continent across England into Ireland, towards the close of the last Glacial Period. The difference in the character of the eastern and western mountain groups of Ireland certainly seems inadequate to account for these absences. But we are hardly justified in supposing the glaciation of Ireland to have completely denuded the country of its plant population. The existence 
at the present day of a littoral flora in Greenland, where the conditions may be taken as fairly typical of those which obtained in Ireland during the Glacial Period, renders it not improbable that a similar flora made up of Highland, that is Arctic or sub-Arctic species, may have maintained itself in some favoured spots along our sea-board, while the country, as a whole, lay buried under an ice-sheet. If we conceive the Irish Highland Type plants of today to be derived from such a remnant of our ancient flora, maintaining itself chiefly along the western Atlantic sea-board, where the climatic conditions were probably most favourable during the last Glacial Period, and retreating to its present mountain stations on the advent of a milder climate, then the absence from East Ireland of the 12 Highland species common to West Ireland and West England may become somewhat less perplexing. But in considering this, as all other problems in plant distribution it must always be borne in mind that the causes in operation have been highly complex. Past geological changes; present climate and configuration of the surface; accidental or occasional means of transport across sea-channels; constitution of soils : all of these have had a share in bringing about the existing disposition of the Irish Highland flora.

The following ten species of this Highland group, or just onefourth of the total number, descend in Ireland to, or almost to, sea-level :-
Draba incana.
Galium. boreale.
Juniperus nana.
Dryas octopetala.
Hieracium anglicum.
Sesleria cærulea.
Saxifraga aizoides.
ㅍ.ᅭ. iricum.
Selaginella selaginoides.
Sedum Rhodiola.

Scottish and Intermediate Types.-As was shown in the comparative table on p. xlii, 64 per cent. of these types, combined, representing the boreal element in the English flora, is found in Ireland. The Irish plants of these types are set out in the following list :-

\section{Scottish and Intermediate Type Plants in Ireland.}

Thalictrum minus.

Trollius europæus.

Helianthemum canum.

Viola lutea.

Sagina subulata.
Arenaria verna.

Geranium sylvaticum.

Vicia Orobus.

V. sylvatica.

Prunus Padus.
Potentilla fruticosa.

Rubus saxatilis.

Poterium officinale.

Rosa hibernica.

Saxifraga Hirculus. 
Scottish and Intermediate Type Plants in Ireland-continued.

$\begin{array}{lll}\text { Saxifraga hypnoides. } & \text { Pyrola secunda. } & \text { Potamogeton filiformis. } \\ \text { Parnassia palustris. } & \text { Gentiana verna. } & \text { P. prælongus. } \\ \text { Drosera anglica. } & \text { Mertensia maritima. } & \text { P. nitens. } \\ \text { Callitriche auturnalis. } & \text { Melampyrum sylvaticum. } & \text { Eriocaulon septangulare. } \\ \text { Circæa alpina. } & \text { Pinguicula vulgaris. } & \text { Scirpus rufus. } \\ \text { Myrrhis odorata. } & \text { Orobanche rubra. } & \text { Carex dioica. } \\ \text { Ligusticum scoticum. } & \text { Ajuga pyramidalis. } & \text { C. limosa. } \\ \text { Galium sylvestre. } & \text { Lamium intermedium. } & \text { C. fliformis. } \\ \text { Antennaria dioica. } & \text { Galeopsis versicolor. } & \text { Festuca sylvatica. } \\ \text { Crepis paludosa. } & \text { Empetrum nigrum. } & \text { Elymus arenarius. } \\ \text { Lobelia Dortmanna. } & \text { Salix pentandra. } & \text { Polypodium Phegopteris. } \\ \text { Andromeda polifolia. } & \text { S. nigricans. } & \text { P. Dryopteris. } \\ \text { Pyrola rotundifolia. } & \text { S. phylicifolia. } & \text { Equisetum pratense. } \\ \text { P. media. } & \text { Listera cordata. } & \text { E. hyemale. } \\ \text { P. minor. } & \text { Habenaria albida. } & \text { E. variegatum. }\end{array}$

In its Irish distribution, this group shows no decided tendency to a northward prevalence. If we take latitude $541^{\circ}$ as marking the southward limit of northern species in Ireland, we find that no less than 50 out of the 60 Scottish and Intermediate Type plants set out in the above list range southward to or below this limit, while 25 reach to or below latitude $52^{\circ}$. A little more than half of the total of 60 species in the group is made up of plants which become perceptibly more frequent towards the north of Ireland, though this increase in frequency is in many cases by no means strongly marked. Only 8 of the 60 fail to reach so far south as $54 \frac{1}{2}^{\circ}$, and can be regarded as truly boreal in Ireland. These are :Trollius europaus, Geranium sylvatioum, Rosa hibernica, Ligustioum scoticum, Pyrola secunda, Melampyrum sylvaticum, Salix nigricans, and Equisetum pratense.

Atlantic Type.-The name of this type, selected by Watson, as were all his other type-names, solely with a view to exhibiting the salient features in the distribution of plants in Great Britain, is singularly unhappy when used with reference to the Irish flora. One would naturally expect to find an Atlantic group of plants very fully represented in an island possessing, as Ireland does, a long extended line of Atlantic sea-board, and would also expect to find the group absent from, or at least but little developed in, East Ireland. But, as has been shown (p. xlii), only 34 out of a total of 62 , or 55 per cent. of the group, occur in Ireland. Of these 34, no less than 26 are found in the east. Still, in Ireland, the group 
shows a tendency to an Atlantic distribution thus far, that while only one species, Soilla verna is confined to the East as opposed to the South and West, eight species, Carum verticillatum, Bartsia viscosa, Sibthorpia europea, Asparagus officinalis, Rhynchospora fusca, Bromus madritensis, Asplenium lanceolatum, and Adiantum Capillus-Veneris, which occur in the South or West, are absent from the East. At the same time, many of the species found in the East become more abundant in the South and West. In the following list the letter $\mathrm{E}$. denotes the species of this type which are found in East Ireland.

\section{Atlantic Type Plants in Ireland.}

E. Meconopsis cambrica.

E. Coronopus didyma.

E. Mathiola sinuata.

E. Raphanus maritimus.

E. Viola Curtisii.

E. Linum angustifolium.

E. Lavatera arborea.

E. Hypericum Androsæmum.

E. H. elodes.

E. Erodium maritimum.

E. E. moschatum.

E. Sedum anglicum.

E. Cotyledon Umbilicus. Carum verticillatum.

E. Crithmum maritimum.

E. Rubia peregrina.

E. Inula crithmoides.
E. Wahlenbergia hederacea.

E. Statice occidentalis. Bartsia viscosa. Sibthorpia europæa.

E. Pinguicula Iusitanica.

E. Euphorbia Paralias.

E. E. portlandica. Asparagus officinalis.

E. Scilla verna.

E. Scirpus Savii. Rhynchospora fusca. Bromus madritensis.

E. Hymenophyllum tunbridgense.

E. H. unilaterale. Adiantum Capillus-Veneris. Asplenium lanceolatum.

E. Lastræa æmula.

If the name, Norman type, proposed by Forbes for this group, be used instead of Atlantic type, then its imperfect development in Ireland will cease to arrest attention, and an explanation will suggest itself similar to that already offered here for the more striking deficiency in Ireland of the Germanic type plants.

\section{Irish Plants not fotnd in Great Britatn.}

While distinguished from the flora of England above all by its comparative poverty, the Irish flora possesses at the same time a positive element of difference in the presence of a small number of interesting plants, nowhere found in Great Britain. These 
Hibernian type plants, as they have been named, are set out in the following list:-

Saxifraga umbrosa.

S. Geum.

Arbutus Unedo.

Pinguicula grandiflora.

Dabeocia polifolia.

Erica mediterranea.

E. Mackaii.
Ranunculus tripartitus.

Arenaria ciliata.

Inula salicina.

Euphrasia Salisburgensis.

Habenaria intacta.

Spiranthes Romanzoffiana.

Sisyrinchium angustifolium.

Carex rhynchophysa.

To these may be added two Irish species of Characee, Chara denudata, and Nitella Nordstetiana, which, so far as the present evidence shows, are absent from England.

Cantabrian Growp.-To the seven plants placed in the first column of this list, the name Cantabrian group may be conveniently given. In Ireland all of these are western or south-western, and range under our favourable conditions of climate to a higher northern latitude than they reach anywhere on the European continent. Some of them are found sparingly in Western France so far north as the Loire, but the group finds its nearest full development, as a whole, some 600 miles south of Ireland in the maritime highlands of Cantabria and Galicia in Northern Spain. The most wide-spread of all is Saxifraga umbrosa, the common London Pride of English gardens. This ranges from the east of Waterford, south-west to Kerry, and thence at intervals along the Atlantic coast to the extreme north of Donegal. The other members of the group are confined to much more limited areas, and from the point of view of distribution in Ireland divide themselves into two sub-groups, a south-western and a western.

The first of these sub-groups is made up of the three species, Arbutus Unedo, Saxifraga Geum, and Pinguicula grandiflora, and is confined to those parts of the counties of Cork and Kerry which form the extreme south-western angle of the island. The most southern in character of these three species, Arbutus Unedo, the Wull known Strawberry Tree, is in Ireland the rarest and the most restricted in range. Save at the Killarney Lalres, where it grows in great luxuriance, it occurs only in scattered groups or individuals, and at all or most of its outlying stations seems doomed to early extinction. The other species are far more abundant and widespread, the beautiful Pinguicula grandiflora making in early summer a striking ornament both of the lowland bogs and of the dripping 
mountain gullies and rock-shelves in many parts of Cork and Kerry. To this south-western sub-group may be added Saxifraga hirsuta, a plant intermediate between $S$. umbrosa and $S$. Geum, but entitled to rank only as a variety. This is of frequent occurrence in the south-west.

Almost a full degree of latitude separates the northern limit of this division of the Cantabrian group from the southern limit of the second or western division. The latter is made up of the three heaths, Erica mediterranea, Dabeocia polifolia, and Erica Mackaii, whose area of distribution in Ireland is confined to the western parts of the counties of Mayo and Galway. The so-called Mediterranean Heath, which, in spite of its name, is nowhere found in the Mediterranean region, occurs abundantly in West Ireland in many stations, from Roundstone in Galway northward to Belmullet in Mayo, over a distance of some 60 miles. Here its early flowering character is well preserved, the plant being usually found in full bloom with us towards the middle of March. The more beautiful Dabeocia polifolia, the Connemara or Saint Dabeoc's Heath is quite as widely distributed in the district, for while its northward range from Galway Bay to Curraun Achill falls considerably short of that of the Mediterranean Heath, its inland extension is much greater. The third member of this sub-group, Erica Mackaii, which occurs in the neighbourhood of Roundstone, is apparently much rarer than either of the others, and its claims to specific rank are perhaps little stronger than those of Saxifraga hirsuta. It can hardly be regarded as more than a sub-species of $E$. Tetralix. The exclusively western distribution of this Cantabrian group in Ireland is shown graphically on the botanical map issued with this edition.

Origin of the Cantabrian Group.-Of the many problems in plant distribution, presented by a study of the Irish flora, perhaps none is more perplexing, certainly none has excited more interest or speculation, than the remarkable isolation in Ireland of this Cantabrian group at the extreme northern and western limit of its present European range. It is only in past geological changes that we can hope to find a solution of this problem. The members of the group are undoubtedly indigenous in Ireland; and the hypothesis which regards them as relics of a once widespread pre-glacial flora seems to be the one which, however open to objection, presents the least difficulty. Under this view we may assume the group to have ranged in pre-glacial times from the southward into that part of the 
westward extension of the European continent which succeeding changes of land-level have converted into the insular Ireland of to-day. Then, as now, the members of the group were no doubt largely sub-littoral or marginal in their distribution, and their northern march was made along the western coasts of the old pre-glacial Europe. Their survival in Ireland throughout the Glacial Period may have been rendered possible by the prevalence of an exceptionally mild climate in some favoured spots along our western sea-board, co-existent as in the case of modern Greenland, with generally rigorous conditions close at hand. The absence at the same time of such an exceptional climate over a large part of Western France or of that portion of the old continent most closely coincident with the Western France of to-day, may have led to the extinction of the species there over wide areas. Vestiges of the group are still found along this assumed old line of march as far north almost as the Loire in Western France, while two species closely related to the group by distribution and sub-littoral habitat, Erica vagans and $E$. ciliaris, range from Portugal and Northern Spain into Normandy and South-west England.

The high northern latitude attained by this Cantabrian group in Ireland shows the exceptional mildness of our insular climate, and this is further illustrated by the range of another Hibernian type species, Habenaria intacta, which occurs in many stations, and often abundantly, in Galway, Clare, and Mayo. The following table shows the extreme northern limits reached in Ireland and on the European continent by this section of the Hibernian type species :-

Northern Limits of the Cantabrian Group.

\begin{tabular}{|c|c|c|c|c|c|}
\hline & \multicolumn{2}{|c|}{$\begin{array}{l}\text { On the European } \\
\text { Continent. }\end{array}$} & & \multicolumn{2}{|c|}{ In Ireland. } \\
\hline Habenaria intacta, & $43 \frac{1}{2}^{\circ}$ & Lat. & & $53 \frac{12^{\circ}}{}$ & I. Lat. \\
\hline Saxifraga umbrosa, & $45 \frac{1}{2}^{\circ}$ & $"$ & • & $55 \frac{1}{4}^{\circ}$ & , \\
\hline Erica mediterranea, & $45 \frac{10}{2}$ & , & . & $54 \frac{1}{4}^{\circ}$ & $"$ \\
\hline Dabeocia polifolia, & $45 \frac{1}{2}^{\circ}$ &, & . & $64^{\circ}$ & , \\
\hline Saxifraga Geum, & $43 \frac{3}{4}^{\circ}$ & $"$, & • & $522^{\circ}$ & , \\
\hline Arbutus Unedo, & $46^{\circ}$ & $"$ & 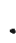 & $52^{\circ}$ & 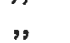 \\
\hline Pinguicula grandiflora, & $47 \frac{1}{2}^{\circ}$ & $"$ & • & $52 \frac{10}{4}$ & $"$ \\
\hline Erica Mackaii, . . & $492^{\circ}$ & $"$ & • & $531^{\circ}$ & , \\
\hline
\end{tabular}

North American Group.- Neither in Ireland nor outside of it do the remaining members of the Hibernian type, i.e. Spiranthes 
Romansoffana, Sisyrinchium angustifolium, Arenaria oiliata, Inula salicina, Euphrasia Salisburgensis, and Carex rhynchophysa, form any natural botanical group. They have no common focus in Ireland or elsewhere. If, however, we join with the first two, three other Irish species, none of which is peculiar in the British Isles, to Ireland, we have the following small group of North American character whose presence with us gives rise to another most difficult problem in distribution :-

\section{North American Group.}

\section{Spiranthes Romanzoffiana}

$\dagger$ Sisyrinchium angustifolium.
Eriocaulon septangulare.

Naias flexilis.

$\uparrow$ Juncus tenuis.

While the species of the Cantabrian group are beyond all question indigenous in Ireland, there is reason to suspect that two of these North American plants, the Sisyrinchium and the Junous, may have been introduced. As for the remaining three species of the North American group, no doubt has ever been raised as to their indigenous standing in Ireland. The rare Spiranthes Romansofiana, an orchid unknown elsewhere in Europe, occurs in Ireland in the counties of Armagh and Derry in the north, and Cork in the extreme south-west, an interval of more than 200 miles, separating its northern and southern stations. In North America, as in Kamtschatka, its only known Asiatic station, this species is sub-arctic in range. Far more abundant in Ireland is Eriocaulon septangulare. This extends at intervals all along our west coasts from Adrigole in Cork to the Rosses in Donegal, and occurs in great profusion in most of the lakes of Iar Connaught and. Connemara in West Galway. The third undoubtedly indigenous member of this American group, Naias flexilis, is rare in Ireland. So far, it has been discovered in only three of our lakes, one in Galway, and two in Kerry, but it is a plant of rather deep water, not easily detected, and further dredging of our numerous western lakes may much extend its range in Ireland. This species occurs in Perthshire and Skye in Scotland, and in several stations in Northern Europe; but the Eriocaulon fails to reach the European continent, and in Great Britain is confined to the Scotch islands of Skye and Coll.

Every attempt to explain the presence in Ireland, of these northern American species, as they may be considered, is beset with difficulty. It seems best on the whole to regard them as relics of 
an ancient immigration into Ireland in a direction roughly speaking contrary to that followed by the Cantabrian group, as relics, in fact, of a dispersion from the Arctic or Sub-Arctic regions, which, in one of its lines, was probably carried on along an old land extension connecting Greenland, Spitzbergen, and Scandinavia with Scotland and Ireland. Along the same path, too, may perhaps have travelled three of the four remaining Hibernian type plants, Arenaria ciliata of the high limestone plateau of Ben Bulben, Euphrasia Salisburgensis of the low-level limestone of Clare and Galway, and Carex rhynohophysa, recently discovered in Armagh, all three decidedly northern or alpine in character.

The last of the Hibernian type plants, Inula salicina, confined in the British Isles to the shores and islands of Lough Derg on the Shannon, is extremely widespread in Europe, ranging from Scandinavia to the Italian peninsula, and from middle Russia to Portugal. The remarkable isolation of this species in Ireland seems to defy explanation.

\section{Pretalent Ordirs in the Irish Flora.}

The more truly insular position of Ireland and the resulting contrast in its climate with that of England would lead us to expect some differences in the distribution of the plants of both countries amongst the various natural orders. A detailed comparison of the two floras justifies this expectation. Differences, quite appreciable if in no case very large, are found to exist in the numerical proportions borne by the total of species in several of the Orders to the total flora of each country; and these differences usually lie in the direction suggested by $\dot{a}$ priori considerations. The subjoined table, founded on the present work, on the 3rd Edition of Hooker's Student's Flora of the British Isles and on Nyman's Conspectus Flore Europace, shows the extent of these differences, and at the same time the wide divergences in the ratios of the larger Orders to the total floras when the relatively small insular areas of Ireland and England are compared with the European continent. In estimating the percentages, the total floras of Ireland, of England, and of Europe, inclusive of the Phanerogams and Vascular Cryptogams, have been taken, in round numbers, as 1000,1420 , and 11,530 species and sub-species, and the orders are arranged in accordance with their size in Ireland. Orders containing less than 2 per cent. of the total Irish flora have not been taken into consideration. 
Number of species and sub-species in each of the prevalent Natural Orders in Ireland, in England, and in Europe, with their percentage ratios to the total floras.

\begin{tabular}{|c|c|c|c|c|c|c|c|c|c|}
\hline & & & & & & nbers a & ind perc & ges. & \\
\hline Orders. & & & & In Ire & tand. & In En & gland. & In $\mathrm{I}$ & Curope. \\
\hline Compositæ, & - & - & . & 83 & $8 \cdot 3$ & 112 & $7 \cdot 88$ & 1676 & $14 \cdot 5$ \\
\hline Gramineæ, & - & - & . & 76 & $7 \cdot 6$ & 102 & $7 \cdot 18$ & 672 & $5 \cdot 8$ \\
\hline Cyperaceæ, & . & . & - & 70 & $7 \cdot 0$ & 88 & 6.2 & 285 & $2 \cdot 47$ \\
\hline Rosaceæ, & . & & • & 62 & $6 \cdot 2$ & 76 & $5 \cdot 3$ & 429 & $3 \cdot 7$ \\
\hline Cruciferæ, & . & • & . & 43 & $4 \cdot 3$ & 62 & $4 \cdot 36$ & 648 & $5 \cdot 6$ \\
\hline Leguminosæ, & - & . & • & 39 & $3 \cdot 9$ & 68 & $4 \cdot 8$ & 970 & $8 \cdot 4$ \\
\hline Labiatæ, & . & . & . & 37 & $3 \cdot 7$ & 52 & $3 \cdot 6$ & 506 & $4 \cdot 39$ \\
\hline Caryophyllex, & - & . & . & 36 & $3 \cdot 6$ & 53 & $3 \cdot 7$ & 623 & $5 \cdot 4$ \\
\hline Umbelliferæ, & - & - & - & 36 & $3 \cdot 6$ & 56 & $4 \cdot 0$ & 586 & $5 \cdot 0$ \\
\hline Scrophularineæ, & & . & . & 36 & $3 \cdot 6$ & 49 & $3 \cdot 45$ & 475 & $4 \cdot 1$ \\
\hline Filices, . & . & . & - & 32 & $3 \cdot 2$ & 41 & $2 \cdot 88$ & 93 & 0.8 \\
\hline Naiadacex, & . & . & . & 31 & $3 \cdot 1$ & 37 & $2 \cdot 6$ & 60 & 0.52 \\
\hline Ranunculaceæ, & & . & - & 26 & $2 \cdot 6$ & 36 & $2 \cdot 5$ & 316 & $2 \cdot 7$ \\
\hline Orchideæ, & . & . & - & 24 & $2 \cdot 4$ & 40 & $2 \cdot 8$ & 124 & 1.07 \\
\hline Polygonacex, & . & - & . & 23 & $2 \cdot 3$ & 28 & $2 \cdot 0$ & 90 & 0.77 \\
\hline
\end{tabular}

Diversities of opinion as to the limits of species must always introduce an element of uncertainty into estimates such as that given in the foregoing table; but in the present instance the authorities made use of are not so widely at variance in their views on this point as to make the results to any serious degree untrustworthy. In the case of the order Composite, however, the process of segregation in the genus Hieracium has been carried so much farther by Continental botanists than by Hooker, our species standard for England and Treland, that the percentage ratio of that order for Europe is no doubt overstated, perhaps by so much as one per cent.

\section{Plants endemic in Ireland.}

The endeavour to establish the existence of peculiar plant-forms in Ireland is of great interest in connection with the theory of organic evolution. A few Irish plants have been proposed as truly endemic, or peculiar to the island, but they are all of them more or 
less critical, and can be confidently discriminated only by those who have made a special study of the genus to which each form may belong. So small is the number of such specialists and so large is the field over which the inquiry must range, that the proverbial difficulty of proving a negative becomes in such cases little short of an impossibility. However long and however conscientious the search may have been, we can never assert with confidence of any of these supposed endemic forms that they do not occur outside of the area to which they are supposed to be peculiar. So we can only say of the following plants, supposed to be peculiar to Ireland, that the best authorities have hitherto been unable to establish their occurrence elsewhere. There can be little doubt that the result of further study of the more critical forms of other countries will be to reduce the number of these supposed endemic Irish plants.

\section{Plants endemic in Ireland.}

Polygala vulgaris var. GRANDifLora. Potamogeton Kirkji.

P. lanceolatus var. HIBERNICUs.

Calamagrostis stricta var. HooxerI. Equisetum Moorei.

Isoetes lacustris var. MoнrI.

Several forms of Rubus and Hieracium, proposed as peculiar to Ireland, have been deliberately excluded from this list. Whatever the value of these may be, it is obvious that the time has not yet come for the expression of any confident opinion as to their distribution either in Ireland or outside of it.

\section{Topographicad Groups in the Irish Flora.}

In the preceding paragraphs the external relations of the Irish flora have been discussed at some length; in the present a glance will be taken at what may be termed its internal relations. While the great mass of Irish plants show a tendency to range throughout the island, no less than 423 being at present known to occur in all 12 districts, and 82 in 11 districts, some small groups affect an exclusively eastern or western distribution, as others affect a distribution exclusively northern or southern. If we class as Northern all plants not found south of latitude $54 \frac{1}{2}^{\circ} \mathrm{N}$., as Southern those not found north of latitude $521_{2}^{\circ} \mathrm{N}$., as Eastern those not found west of longitude $7^{\circ} \mathrm{W}$., and as Western those not found east of longitude $8^{\circ} \mathrm{W}$., we shall have the following divisions of the flora, which for want of a more accurate term may be conveniently called topographical groups. 
Western Plants.

(Not found East of Longitude $8^{\circ} \mathrm{W}$.)

Thalictrum alpinum.

Ranunculus tripartitus.

Arabis petræa.

Helianthemum guttatum.

H. vineale.

Viola stagnina.

Arenaria ciliata.

Astragalus hypoglottis.

Lathyrus maritimus.

Spiræa Filipendula.

Potentilla fruticosa.

Rosa micrantha.

Saxifraga nivalis.

S. Geum.

Epilobium alsinefolium.

Galium sylvestre.

Inula salicina.

*Senecio squalidus.

Hieracium Gibsoni.
Arbutus Unedo.

Erica Mackaii.

E. mediterranea.

Dabeocia polifulia.

Microcala filiformis.

Gentiana verna.

Limosella aquatica.

Sibthorpia europæa.

Euphrasia Salisburgensis.

Pinguicula granditlora.

Thymus Chamædrys.

Teucrium Scordium.

Ajuga pyramidalis.

Oxyria digyna.

Epipactis atro-rubens.

Habenaria intacta.

†Sisyrinchium angustifolium.
Simethis bicolor.

iAllium Babingtonii.

$\$$ A. Soorodoprasum.

†Juncus tenuis.

Potamogeton lanceolatus.

P. Kirkii.

Naias flexilis.

Eriocaulon septangulare.

Rhynchospora fusca.

Carex punctata.

Deschampsia discolor.

Poa alpina.

Adiantum Capillus-Veneris.

Asplenium lanceolatum.

Polystichum Lonchitis.

Lycopodium inundatum.

Isoetes echinospora.

Nitella Nordstedtiana.

\section{Southern Plants.}

(Not found North of Latitude $52 \frac{10}{2} \mathrm{~N}$.)

Ranunculus tripartitus.

†Lepidium latifolium.

Lathyrus maritimus.

Rosa micrantha.

Saxifraga Geum.

Diotis candidissima.

*Senecio squalidus.
Arbutus Unedo.

Microcala filiformis. $\ddagger$ Antirrhinum Orontium.

Sibthorpia europæa.

Pinguicula grandiflora. ¥Rumex pulcher.

Simethis bicolor.
Asparagus officinalis. †Allium Scorodoprasum.

Carex punctata. Asplenium lanceolatum. Chara connivens.

C. canescens.

Nitella Nordstedtiana.

It will be seen from a study of these lists that more than threefourths of the southern plants are inclided in the western group, or, in other words, that the great majority of the distinctively southern species are confined to the south-west, where the two arbitrary topographical divisions of south and west Ireland overlap. Only three of the southern plants, Diotis candidissima, Asparagus officinalis, and Chara connivens are confined to the south-east. 


\section{Eastern Plants.}

(Not found West of Longtitude $7^{\circ} \mathrm{W}$.)

Thalictrum dunense.

Ranunculus fluitans.

Barbarea intermedia.

†Sisymbrium Irio.

tTeesdalia nudicaulis.

Elatine Hydropiper.

Hypericum hirsutum.

Geranium sylvaticum.

G. pratense.

Trigonella ornithopodioides.

†Trifolium subterraneum.

$\dagger$ T. glomeratum.

Rosa hibernica.

R. glauca.

Saxifraga granulata.
Adoxa Moschatellina.

*Senecio viscosus.

S. erucifolius.

Hieracium flocculosum.

H. prenanthoides.

H. strictum.

H. anratum.

H. corymbosum.

Pyrola secunda.

$¥$ \#ottonia palustris.

Myosotis collina.

Scrophularia umbrosa.

Atriplex farinosa.

Scilla verna.

Colchicum autumnale.

*Acorus Calamus.
Potamogeton fluitans.

Zannichellia polycarpa.

Carex pauciflora.

C. elongata.

C. divisa.

C. Buxbaumii.

C. rhyncophysa.

Calamagrostis stricta.

Poa palustris.

Glyceria Borreri.

Festuca uniglumis.

Equisetum Moorei.

Chara connivens.

Tolypella prolifera.

T. intricata.

Nitella gracilis.

\section{Northern Plants.}

(Not found South of Latitude $54 \frac{1}{2}^{\circ} \mathrm{N}$.)

Raniunculus fluitans.

Trollius europæus.

†Teesdalia nudicaulis.

Geranium sylvaticum.

G. pratense.

Rubus Chamæmorus.

Rosa hibernica.
Adoxa Mosehatellina.

Ligusticum scoticum.

Hieracium prenanthoides.

Pyrola secunda.

Melampyrum sylvaticum.

Ulmus montana.

Salix nigricans.
Potamogeton fluitans.

Zannichellia polycarpa.

Carex pauciflora.

C. Buxbauraii.

C. rhynchophysa.

Calamagrostis stricta.

Equisetum pratense.

Almost three-fourths of the Northern Plants are confined to the north-east, this group showing a tendency to an eastern distribution hardly less strongly marked than that shown by the Southern group to a western distribution. Whatever the origin of these topographical groups may have been, they may be taken as an expression of existing climatic differences. Their maintenance as groups depends chiefly on the permanence of the recognized diversities of moisture and temperature which distinguish the East from the West and the North from the South.

\section{Irish Botanical Districts.}

The division of Ireland into botanical provinces or districts adopted in this work is that proposed by the late Professor Babington in a 
Paper read before the Dublin University Zoological and Botanical Association in 1859.' To avoid confusion, the word 'district' has been selected here to denote these botanical divisions, the word 'province,' used by Watson in his Cybele Britannica for a similar purpose, being applied in Ireland to the larger political divisions of the country, known as Ulster, Leinster, Munster, and Connaught. In Babington's original scheme the Irish divisions were numbered consecutively with the British, from XIX. (South Atlantic) to XXX. (Ulster Coast). For good reasons, however, these numbers were rejected by the authors of the first edition of this work in favour of the separate series from I. to XII., which has been adhered to in the present edition. In area, the Irish districts, which are set out below in one general view, correspond much more closely to Watson's sub-provinces than to his provinces. ${ }^{2}$

\begin{tabular}{|c|c|c|}
\hline Districts. & Extension. & $\begin{array}{l}\text { Approx. } \\
\text { area in sq. } \\
\text { miles. }\end{array}$ \\
\hline
\end{tabular}

I. South Atlantic. Kerry and South Cork. - 3143

II. Blackwater. - * North Cork, Waterford, 3181

$\begin{array}{llll}\text { South Tipperary. } & & \\ \text { III. Barrow. ․ . . Kilkenny, Carlow, Queen's } & 1805 & 641\end{array}$

IV. Leinster Coast. - Wexford and Wicklow. - $1677 \quad 771$

ヤ. Liffey and Boyne. Kildare, Dublin, Louth, $2230 \quad 797$ Meath.

VI. Lower Shannon. - Limerick, Clare, East Gal- $\quad 3989 \quad 767$

VII. Upper Shannon. - N. Tipperary, King's Co., $\quad 2700 \quad 624$

$\begin{array}{ccc}\text { Westmeath, Longford. } & \\ \text { VIII. North Atlantic. . } \quad \text { West Galway, West Mayo. } & 2146 & 698\end{array}$

IX. North Connaught. East Mayo, Sligo, Leitrim, $3086 \quad 697$ and Roscommon.

X. Erne. - . . - Cavan, Armagh, Ferman- $3733 \quad 681$

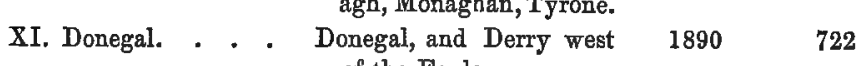

XII. Ulster Coast. . . Down, Antrim, and Derry. $\quad 2862 \quad 816$

I Hints towards a Cybele Hibernica.-Nat. Hist. Rev., vI., 1859, p. 533.

${ }^{2}$ In preparing this tabular view of the Irish Districts and their Floras, Hooker's Sludent's Flora of the British Isles, 3rd Ed., has been taken as standard for the Hawkweed species, while the fructicose Rubi have been counted as a single species occurring in all the Districts. 
The figures in the third and fourth columns of this table illustrate the truism in distribution that, over certain limits, increase in the size of an area has little effect in increasing the variety of a flora. The statistics show at the same time, that, as regards the Irish botanical divisions, the richness of the various district floras depends above all on the fact whether a district is maritime or inland. The exclusively maritime flora of Ireland numbers about 80 species. All of these must necessarily be wanting in a wholly inland district, such as the Upper Shannon, and a great majority of them in the Barrow and Erne districts, which have no true seaboard, though gaining imperfect access to maritime conditions in a few miles of salt estuary. Such comparisons of district floras as may be drawn from the foregoing table are based on the assumption that all the, areas compared have been fairly well explored. It would have been idle to make any such assumption when the first edition of this work was published: it may be made now with some confdence that the results arrived at will not be far wide of the truth, though further exploration of some of the Districts, and notably of III., VII., and X., is desirable.

In the following paragraphs an attempt has been made to epitomize the physical and botanical features of each of the twelve districts.

DISTRICT I.-SOUTH ATLANTIC.

Kerry and South Cork. ${ }^{1}$

Area, 3143 square miles.-Flora, 826 species and sub-species.

Maritime, occupying the extreme south-west of the island, the coast being broken by the deep inlets of Dingle Bay, Kenmare River, and Bantry Bay. The highest summits in Ireland are found here, Carrantuohill in the Magillicuddy's Reeks, reaching to 3404 feet and Mount Brandon in the Dingle peninsula to 3120 feet. Other high points in Kerry are Baurtregaum, 2796 feet, in Slieve Mish; Mangerton, 2754 feet, south of Killarney; and Coomacarrea, 2542 feet, in the Iveragh mountains. Lakes are numerous in Kerry, but none of them is of the first magnitude, the largest being Lough Leane (better known as the Lower Lake, Killarney), Lough Currane,

1 The northern boundary of South Cork runs along the west shore of Cork Harbour, and up the river Lee and its tributary the Sullane, to the Kerry
border. 
and Caragh Lake. In addition to the Lee, which forms the boundary between North and South Cork, there is only one considerable river, the Bandon. In this district the insular climatic conditions characteristic of Ireland, moisture and mild and equable temperature, reach their maximum. There is a marked southern element in the flora, but considering the elevation of the mountains, the Highland type is but poorly represented by 24 out of the 41 species occurring in Ireland, the lofty mass of the Reeks yielding but 12 of these. The Hieracia are conspicuously rare here, as they are generally throughout the south of Ireland. No less than 10 species are peculiar in Ireland to this district, and of these three, Saxifraga Geum, Arbutus Onedo, and Simethis bicolor, reach here their extreme northern limit for Europe.

\section{Characteristic or Rare Plants. ${ }^{1}$}

Thalictrum alpinum. Ranunculzs tripastitus. †Lepidium latifolium.

Helianthemum guttatum. Lathyrus naritimus. Ornithopus perpusillus. $\dagger \mathbf{E}$. amygdaloides. Alchemilla alpina. Saxifraga Geum.

S. umbrosa.

Carum verticillatum.

Saussurea alpina.

Wahlenbergia hederacea.

Arbutus Unedo.

Hypopithys multiflora.

Microcala filiformis.

Linaria repens.
Sibthorpia europaa.

Bartsia viscosa.

Pinguicula grandiflora.

Polygonum viviparum.

Euphorbia hiberna.

Spiranthes Romanzoffiana.

†Sisyrinchium angustifolium.

Simethis bicolor.

†Allium Scorodoprasum. $\dagger$ Juncus tenuis.

Zostera nana.

Naias flexilis.

Scirpus parvulus.
Carex Bconninghauseniana.

C. aquatilis.

C. punctata.

Poa alpina.

Hymenophyllum tunbridgense.

Trichomanes radicans.

Asplenium lanceolatum. Aspidium Lonchitis. Equisetum Wilsoni. Lycopodium inundatum. Isoetes echinospora. Pilularia globulifera. Chara canescens. Nitella Nordstedtiana.

DISTRICT II.-BLACKWATER.

\section{North Cork, Waterford, South Tipperary. ${ }^{2}$}

Area, 3181 square miles.-Flora, 762 species and sub-species.

Maritime, with shores less bold and broken than in the South Atlantic district. The Commeragh mountains, in Waterford, rise

${ }^{1}$ In this and the following District lists the plants in italics are peculiar to the district. Rare, means rare for Ireland.

2 Tipperary is divided into North and South by the Great Southern and Western Railway. 
to 2597 feet; the Knockmealdown mountains, between Waterford and Tipperary, to 2609 feet; and the Galtees, on the borders of Tipperary and Limerick, to 3015 feet. The district is without lakes, but includes two large rivers, the Blackwater and the Suir. The southern character of the flora shown in District I. is maintained here, but is less strongly marked, some of the most characteristic species, such as Arbutus Onedo, Miorocala filiformis, Sibthorpia europae, and Simethis bicolor having disappeared. At the same time a large falling off in the Highland type plants is observed, only 12 species of this group occurring against 24 in District I.; while the Hieracia have sunk from 8 species down to 3 . Only one peculiar species occurs, Bromus madritensis, and this is probably an introduction.

\section{Charaeteristic or Rare Plants.}

†Ranunculus parviflorus. *Sedum album.

Brassica nigra.

Corydalis claviculata.

Nasturtium sylvestre.

* Barbarea præeox.

Arabis petræa.

Geranium rotundifolium. Vaccinium Vitis-Idæa.

* Medicago maculata.

Saxifraga Geum.

S. umbrosa.
*S. dasyphyllum.

Carum verticillatum.

* Centranthus ruber.

Diotis candidissima.

*Senecio squalidus.
Bartsia viscosa.

Pinguicula grandiflora.

†Antirrhinum Orontium.

$\ddagger$ Rumex pulcher.

Euphorbia hiberna.

Asparagus officinalis.

†Allium Scorodoprasum.

Juncus acutus.

Rhynohosphora fusca.

†romus madritensis.

Asplenium lanceolatum.

DISTRICT III.-BARROW.

Kilkenny, Carlow, Queen's County.

Area, 1805 square miles.-Flora, 641 species and sub-species.

Inland, save for a few miles of estuary in county Kilkenny, affording a small number of maxitime species. On the south-east border of county Carlow are Mount Leinster, 2610 feet, and Blackstairs, 2409 feet; but the summits belong to the adjoining county, Wexford. To the north-west are the Slieve Bloom Mountains, in Queen's County, with Ard Erin, 1733 feet, and Barna, 1661 feet. Though as yet insufficiently explored, this would appear to be the poorest in rare species of all the Irish botanical districts. There are but three Highland type plants and three Hieracia, including the ubiquitous $H$. Pilosella. The only peculiar species is Colchioum autumnale. 


\section{Characteristic or Rare Plants.}

Thalictrum flavum.

Cochlearia anglica.

Nasturtium sylvestre.

Stellaria palustris.

Saxifraga Hirculus.

Campanula 'Trachelium.
Galeopsis angustifolia.

Polygonum maculatum.

Ophrys muscifera.

Cephalanthera ensifolia.

Colchicum autumnale.

Potamogeton nitens.
Scirpus sylvaticus.

Carex axillaris.

Hymenophylium Tunbridgense.

Equisetum hyemale.

DISTRICT IV.- LEDNSTER COAST.

\section{Wexford and Wicklow.}

Area, 1677 square miles.-Flora, 771 species and sub-species.

Maritime. Mountainous towards the north, with extensive stretches of sandy coast on the south and south-east. In county Wicklow are Lugnaquilla, 3039 feet, the highest summit in East Ireland, Mullaghcleevaun, 2783 feet, and Thonalagee, 2684 feet, with many other points over 2000 feet; in Wexford are Mount Leinster, 2610 feet, and Blackstairs, 2409 feet, both extending into District III. With the exception of the Slaney, all the rivers are unimportant. The poverty of Highland type plants is perhaps the most peculiar feature in the flora. Notwithstanding the large mass and general high elevation of the Wicklow Mountains they yield but 12 out of the total of 41 Highland type plants found in Ireland. The Hieracia number 9 and the peculiar species 5 .

\section{Characteristic or Rare Plants.}

$\begin{array}{lll}\text { Ranunoulus Lenormandi. } & \text { Saxifraga granulata. } & \text { Chenopodium rubrum. } \\ \text { Corydalis claviculata. } & \text { Sedum Rhodiola. } & \text { Rumex maritimus. } \\ \text { Mathiola sinuata. } & \text { Epilobium angustifolium. } & \text { Asparagus officinalis. } \\ \text { Viola lutea. } & \text { Inula crithmoides. } & \text { Scilla verna. } \\ \text { V. hirta. } & \text { Diotis candidissima. } & \text { Juncus acutus. } \\ \text { Spergularia rubra. } & \text { Saussurea alpina. } & \text { Zostera nana. } \\ \text { Trigonella ornithopodi- } & \text { †Picris echioides. } & \text { Scirpus parvulus. } \\ \text { oides. } & \text { †Lactuca muralis. } & \text { Carex divisa. } \\ \text { Trifolium subterraneum. } & \text { Wahlenbergia hederacea. } & \text { Glyceria Borreri. } \\ \text { †T glomeratum. } & \text { Myosotis collina. } & \text { Festuca uniglumis. } \\ \text { T. striatum. } & \text { †Linaria Elatine. } & \text { Equisetum Moorei. } \\ \text { T. fragiferum. } & \text { Orobanche major. } & \text { Lycopodium alpinum. } \\ \text { Ornithopus perpusillus. } & \text { †Calamintha Acinos. } & \text { Chara connivens. } \\ \text { Vicia lathyroides. } & \text { Salvia Verbenaca. } & \text { C. canescens. } \\ \text { Alchemilla alpina. } & \text { Lamium Galeobdolon. } & \text { Nitella gracilis. }\end{array}$


DISTRICT V.-ITFFEY AND BOYNE.

Fildare, Dublin, Louth, Meath.

Area, 2230 square miles.-Flora, 797 species and sub-species.

Maritime. Chiefly lowland, with small mountain areas to the south and north. The highest summits are Kippure, 2473 feet, and Seecawn, 2128 feet, in the south; and Carlingford Mountain, 1935 feet, in the north. The greater part of the district belongs to the basins of the rivers Boyne and Liffey. The flora is a rich one, but presents no very marked features. Introduced plants are numerous; the Highland type species are reduced to 6, Saxifraga stellaris, Hieracium anglicum, Vaccinium Vitis-Idaa, Carex aquatilis, Cryptogramme orispa, and Selaginella selaginoides; and 5 plants, Sisymbrium Irio, Scrophularia umbrosa, Poa palustris, Tolypella prolifera, and $T$. intricata are peculiar to the district.

\section{Characteristic or Rare Plants.}

$\begin{array}{lll}\begin{array}{l}\text { Thalictrum dunense. } \\ \text { Corydalis claviculata. }\end{array} & \begin{array}{c}\text { Erigeron acre. } \\ \text { Inula crithmoides. }\end{array} & \begin{array}{c}\text { Hydrocharis } \\ \text { ranæ. }\end{array} \\ \text { ISisymbrium Sophia. } & \text { Artemisia maritima. } & \text { Scilla verna. } \\ \text { †S. Irio. } & \text { *Senecio viscosus. } & \text { Zostera nana. } \\ \text { Viola hirta. } & \text { S. erucifolius. } & \text { Carex divisa. } \\ \text { V. lutea. } & \text { †Picris echioides. } & \text { C. axillaris. } \\ \text { Hypericum hirsutum. } & \text { Crepis taraxacifolia. } & \text { C. aquatilis. } \\ \text { Trifolium scabrum. } & \text { Cynoglossum officinale. } & \text { Poa palustris. } \\ \text { T. striatum. } & \text { Myosotis collina. } & \text { P. nemoralis. } \\ \text { Ornithopus perpusillus. } & \text { Scrophularia umbrosa. } & \text { Glyeeria Borreri. } \\ \text { Trigonella ornithopodi- } & \text { Salvia Verbenaca. } & \text { Festuca uniglumis. } \\ \text { oides. } & \text { Lamium Galeobdolon. } & \text { †Bromus erectus. } \\ \text { †Melilotus officinalis. } & \text { Galeopsis angustifolia. } & \text { Elymus arenarius. } \\ \text { Vicia lathyroides. } & \text { Atriplex farinosa. } & \text { Cryptogramme crispa. } \\ \text { Chærophyllum temulum. } & \text { A. portulacoides. } & \text { Tolypella prolifera. } \\ \text { Saxifraga granulata. } & \text { Mercurialis annua. } & \text { T. intricata. }\end{array}$

DISTRICT VI.-LOWER SHANNON.

Limerick, Clare, East Galway. ${ }^{1}$

Area, 3989 sq. miles.-Flora, 767 species and sub-species.

Maritime, including the Aran Islands in Galway Bay. The most distinctive physical feature is the large extent of limestone

${ }^{1}$ In Galway the division into East and West is defined by the river Corrib, and a line through the centre of Lough Corrib. 
outcrop in Clare, East Galway, and the Aran Islands. This formation rises to a height of 1075 feet in Slieve Carran in the Burren district of Clare, but much of it is quite low-level and disposed in the characteristic form of tabular and deeply crevassed masses of almost naked rock, locally known as "crags." In the south-east, Carrig-na-binnian and Thumpadour, at the western extremity of the Galtee mountain group, rise to 2712 and 2570 feet respectively. The west shore of Lough Derg and the greater part of the east shore of Lough Corrib belong to this district, which lies almost altogether in the basin of the Shannon, and smaller lakes are frequent in Clare and East Galway. The flora is rich in rare plants, some of which, notably Gentiana verna and Dryas octopetala occur in great profusion, while calcicole, or limestone species, are numerous and abundant. No less than six plants are peculiar to the district, and three of these, Astragalus hypoglottis, Ajuga pyramidalis, and Potamogeton lanceolatus are among the rarest in Ireland. There are 7 Hieracia and 8 plants of the Highland type.

\section{Characteristic or Rare Plants.}

Mathiola sinuata.

Heliantbemum vineale.

Viola birta.

$V$. stagnina.

Cerastium arvense.

Arenaria verna.

Geranium sanguineum.

Rhamnus catharticus.

R. Frangula.

Astragalus hypoglottis. Spirca Filipendula.

Dryas octopetala.

Potentilla fruticosa.

Poterium Sanguisorba.

Saxifraga hypnoides.

Cornus sanguinea.

Rubia peregrina.
Galium sylvestre.

G. boreale.

Asperula cynanchica.

Inula salicina.

Artemisia maritima.

Carlina vulgaris.

Carduus nutans.

Centaurea Scabiosa.

Hieraeium Gibsoni.

Arctostaphylos Uva-ursi.

Pyrola media.

Hypopithys multiflora.

Chlora perfoliata.

Gentiana verna.

Limosella aquatica.

Euphrasia Salisburgensis.

Orobanç he rubra.
Teucrium Scordium.

Ajuga pyramidalis.

Euphorbia hiberna.

Spiranthes autumnalis.

Epipactis atro-rubers.

Habenaria intacta.

†Sisyrinchium angustifolium.

†Allium Babingtonii.

Potamogeton lanceolatus.

Rhynchospora fusea.

Calamagrostis Epigeios.

Sesleria cærulea.

Adiantum Capillus-Veneris.

Chara tomentosa.

Nitella tenuissima.

DISTRICT VII.- DPPER SHANNON.

North Tipperary, King's County, Westmeath, Longford. Area, 2700 square miles.-Flora, 624 species and sub-species.

Inland : the only one of the twelve botanical districts absolutely cut off from the sea. Lowland for the most part, with extensive 
peat-bogs and numerous lakes. The eastern shores of the great Shannon river-expansions, Lough Ree and Lough Derg, belong to this district, and in Westmeath are the smaller lakes, Ennel, Derevaragh, and Owel. The south-western extremity is mountainous or hilly. Here Slievekimalta or Keeper mountain rises to 2278 feet, Mauherslieve, to 1783 feet, and the Devil's Bit, to 1583 feet. Its strictly inland position and the absence of any elevated mountain region of considerable extent combine to make this the poorest of all the Irish botanical districts, though, no doubt, further exploration will add many species to its flora. There are but three peculiar species; Highland type plants are reduced to 4 and Hieracia to 3. The most salient botanical feature of the district is, perhaps, the abundance of certain species characteristic of marshes and wet peat-bogs, yet rare in many parts of Ireland, such as Stellaria palustris, Lathyrus palustris, Galium uliginosum, Vacoinium Oxycoccus, Andromeda Polifolia, Carex teretiuscula and C. fliformis.

\section{Characteristic or Rare Plants.}

Stellaria palustris.

Lathyrus palustris.

Saxifraga Hirculus.

Cicuta virosa.

Galium boreale.

G. uliginosum.

Inula salicina.

Vaccinium Vitis-Idæa.
Vaccinium Oxycoccus.

Andromeda Polifolia.

Pyrola rotundifolia.

Teucrium Scordium.

Ceratophylium demersum.

Hydrocharis Morsus-ranæ.

Cephalanthera ensifolia.

Ophrys muscifera.
Lemna polyrhiza.

Potamogeton Friesii.

P. fliformis.

Carex teretiuscula.

C. paradoxa.

Chara tomentosa.

C. denudata.

Nitella tenuissima.

\section{DISTRICT VIII.-NORTH ATLANTIC.}

\section{West Galway, West Mayo. ${ }^{1}$}

Area, 2146 sq. miles.-Flora, 698 species and sub-species.

Maritime. A district of mountain, lake, and bog, with a very broken rocky coast and numerous islands and islets. Mweelrea, at the mouth of the striking fiord, known as Killary Harbour, rises to 2688 feet; Nephin, farther north, to 2646 feet; Croaghpatrick, or the Reek, near Westport, to 2510 feet; Ben Baun, in the Twelve Bens, to 2395 feet; Slieve More, in Achill Island, to 2204 feet; and numer-

${ }^{1}$ Mayo is divided into East and West by Lough Mask, and the course of the river Aille, thence the line passes through Castlebar, descending through Lough
Cullen and by the river Moy to the sea at Ballina. 
ous other points, to 2000 feet and upwards. The western shores of Lough Corrib and Lough Mask belong to this district. Smaller lakes and lakelets are frequent all over the surface, snd become wellnigh innumerable in Connemara and Iar Connaught. Owing to the great extent of unreclaimed mountain and bog, the flora is preponderantly native. Many of the most interesting Irish plants occur in profusion, especially the heaths, Erica mediterranea and Dabeocia polifolia, which are nowhere found in Great Britain, and reach here their extreme northern limit for Europe, and Eriocaulon septangulare, known elsewhere in Europe only in the Scotch islands of Skye and Coll. No less than 26 Highland type plants are found in the district with 8 Hieracia, and 4 peculiar plants.

\section{Characteristic or Rare Plants.}

Thalictrum alpinum. Draba incana. Subularia aquatica. Helianthemum guttatum. Sagina subulata. Elatine hexandra. Vicia Orobus. Dryas octopetala. Potentilla fruticosa. Poterium officinale. Saxifraga oppositifolia.
Saxifraga umbrosa. Asperula cynanchica.

Saussurea alpina.

Arctostaphylos Uva-ursi. Carex aquatilis.

Erica Mackaii.

E. mediterranea.

Dabeocia polifolia.

Gentiana verna.

Euphorbia hiberna. Potamogeton Kirkii. Zostera nana.
Naias flexilis.

Eriocaulon septangulare. Rhynchospora fusca.

Deschampsia discolor. Aspidium Lonchitis. Lycopodium inundatum. L. alpinum. Isoetes echinospora. Pilularia globulifera. Adiantum Capillus.Veneris.

DISTRICT IX.- NORTH CONNAUGHT.

East Mayo, Sligo, Leitrim, Roscommon.

Area, 3086 sq. miles-Flora, 697 species and sub-species.

Maritime. The most striking physical feature is the great cliffscarped plateau of Ben Bulben in Sligo and Leitrim, where the limestone reaches to upwards of 2000 feet, a height to which this formation approaches nowhere else in Ireland. The chief summits in this plateau are Truskmore, 2143 feet; Annacoona, 1963 feet; and Ben Bulben proper, 1722 feet. In the extreme west, the Ox mountains, of primitive formation, reach to 1778 feet in Knockachree. Lakes are numerous. The west shores of Lough Ree belong to the district; also Loughs Allen and Bofin on the upper Shannon, and Loughs Gill, Melvin, Arrow, and Gara in Sligo. No less than 28 Highland type plants, out of a total of 41 for all Ireland, occur in 
the district, and of these 23 are found within the narrow limits of the Ben Bulben mountain group. The marked alpine character of the flora at moderate elevations on this isolated limestone mass is the most salient feature in the botany of the district. There are 7 Hieracia and 3 peculiar species, one of the three, Saxifraga nivalis, being the rarest of all the Irish alpine plants; another, Arenaria ciliata, finding on Ben Bulben its only station in the British Isles. The rare orchid Habenaria intacta, also unknown in Great Britain, reaches in this district its extreme northern limit for Europe.

Characteristic or Rare Plants.

Thalictrum alpinum.

Arabis petræa.

Draba incana.

Silene acaulis. Arenaria ciliata.

Dryas octopetala.

Potentilla fruticosa.

Saxifraga nivalis.

S. aizoides.
Saxifraga hypnoides.

Epilobium angustifolium.

E. alsinefolium.

Pyrola media.

Hypopithys multiflora.

Gentiana verna.

Euphrasia Salisburgensis.

Teucrium Scordium.

Polsgonum viviparum.
Habenaria intacta.

Galium sylvestre.

Carex aquatilis.

Poa alpina.

Adiantum Capillus-Veneris Aspidium Lonchitis.

Asplenium viride.

Polypodium Dryopteris.

Chara tomentosa.

DISTRICT X. 一 ERNE.

\section{Fermanagh, Cavan, Armagh, Monaghan, Tyrone.}

Area, 3733 sq. miles.-Flora, 681 species and sub-species.

Inland, save for a few miles of salt marsh along the estuary of the Newry river in the south-east. A large district with diversified physical features. In the west and south-west, the Erne basin offers a widespread and complex lake system, including Upper and Lower Lough Erne, Lough Macnean, Lough Oughter, and Lough Gowna. In the east, the south and south-west shores of Lough Neagh, belong to the district. On the northern boundary are the Sperrin mountains, with Sawel, 2240 feet; Meenard, 2061 feet; and Dart, 2040 feet; but only the southern slopes of this range belong to the district. In the south-west are Cuilceagh, 2188 feet; Tiltinbane, 1949 feet; and Slievenakilla, 1793 feet. There is a large area of limestone in Fermanagh, rising in many places to a height of about 1000 feet. In spite of the large extent of the district and the diversity of its surface, the flora is poor. Highland type plants number only 17 ; there are 7 Hieracia and 5 peculiar species. 


\section{Characteristic or Rare Plants.}

$\begin{array}{ccl}\text { Caltha radicans. } & \text { Pyrola media. } & \text { Scirpus sylvaticus. } \\ \text { Cardamine amara. } & \text { *Veronica peregrina. } & \text { Carex elongata. } \\ \text { Cochlearia anglica. } & \text { Polygonum mite. } & \text { C. aquatilis. } \\ \text { †Teesdalia nudicaulis. } & \text { Mercurialis perennis. } & \text { C. rhynoophysa. } \\ \text { Lathyrus palustris. } & \text { †Stratiotes aloides. } & \text { Calamagrostis stricta. } \\ \text { Rubus chamæmorus. } & \text { Spiranthes Romanzoffiana. Trichomanes radicans. } \\ \text { Dryas octopetala. } & \text { Typha angustifolia. } & \text { Cryptogramme crispa. } \\ \text { Circæa alpina. } & \text { Sagittaria sagittifolia. } & \text { Lycopodium alpinum. } \\ \text { Cicuta virosa. } & \text { Butomus umbellatus. } & \text { Pilularia globulifera. } \\ \text { Vaccinium Oxycoccus. } & \text { Potamogeton fuitans. } & \end{array}$

DISTRICT XI.-DONEGAL.

Donegal, and Derry west of the Foyle.

Area, 1890 sq. miles.-Flora, 722 species and sub-species.

Maritime, with very broken coasts and deep sea inlets. The islands of North Aran, Tory, and Inishtrahul belong to this district. The whole surface is mountainous or hilly, with numerous lakes and streams, the Finn, a branch of the Foyle, being the only river of importance. The chief summits are Errigal, 2466 feet; Slieve Snacht West, 2240 feet; and Muckish, 2197 feet, towards the northwest; Slieve Snacht, 2019 feet, in the north; Croaghgorm, 2219 feet, and Slieve League, 1972 feet, in the south. This is the most northern of the Irish botanical districts, with a flora in which the Highland type is strongly represented by 30 species, or three-fourths of the total for all Ireland. Of these 30 species, no less than 20 are found congregated in the neighbourhood of Slieve League within a radius of one mile, and, with one exception, at heights not exceeding 1500 feet. Such an association of alpine plants at comparatively low-levels is altogether unexampled elsewhere in Ireland, and sets in a strong light the northern character of the flora of this district. The contrast with the large and lofty mass of the Kerry Reeks with their alpine flora of 12 species is most striking; and perhaps still more striking is the contrast with the extended and elevated group of the Mourne mountains, which, while they lie but half a legree of latitude southward of Slieve League, yield, as the Reeks do, only 12 alpine or Highland species. In this district Saxifraga umbrosa and Euphorbia hiberna reach, in the Inishowen peninsula, their extreme northern limit for Europe. The only peculiar species is Trollius europaus. 


\section{Characteristic or Rare Plants.}

Thalictrum alpinum.

Trollius europaus.

Corydalis claviculata.

Cardamine amara.

Draba incana.

Silene acaulis.

Elatine hexandra.

Vicia lathyroides.

Dryas octopetala.

Saxifraga oppositifolia.

$S$. aizoides.

Epilobium angustifolium. Euphorbia hiberna.

Saussurea alpina.

Pyrola media.

Bartsia viscosa.

Orobanche rubra.
Cephalanthera ensifolia.

Typha angustifolia.

Zostera nana.

Aretostaphylos Uva-ursi. Eriocaulon septangulare.

Mertensia maritima.

* Veronica peregrina.

Melampyrim sylvaticum. Cryptogramme crispa.

Polygonum viviparum.

Aspidium Lonchitis.

Equisetum pratense.

Lycopodium alpinum.

DISTRICT XII.- ULSTER COAST.

Down, Antrim, Derry.

Area, 2862 sq. miles-Flora, 816 species and sub-species.

Maritime, with large areas of mountainous or hilly country. The great development of the basalt in Antrim and Derry distinguishes this from all the other Irish botanical districts. Some 1200 square miles are covered by a vast sheet of this volcanic rock which, in some places, has a thickness of more than 1000 feet. The chief summits of the basaltic region are Mullaghmore, 1825 feet, Ben Bradagh, 1536 feet, and Ben Evenagh, 1260 feet, in Derry; with Trostan, 1817 feet, Slievenanee, 1782 feet, Divis, 1567 feet, and Agnew's Hill, 1558 feet, in Antrim. The famous Giant's Causeway and the fine columnar sea cliffs of Bengore and Fair Head, in North Antrim, belong to this formation. The highest summits in the district are found in the south-east in the picturesque granite massif of the Mourne mountains with Slieve Donard, 2796 feet; Slieve Commedagh, 2512 feet; Slieve Bingian, 2449 feet; and Slieve Bearnagh, 2394 feet. Chalk, underlying the basalt, appears in many places along the Antrim coast and on Rathlin Island, but has no true outcrop and no influence on the flora. The northern and eastern shores of Lough Neagh belong to the district. There are no other lakes of any importance, and the only considerable rivers are the Bann and the Lagan. Though by its position not on the whole so northern as District XI., the flora of this district has perhaps a more northern character. It has, indeed, but 29 Highland type plants to 30 in Donegal; but this deficiency is counterbalanced by the greater 
number of its Hieracium species and forms, and of its Scottish and Intermediate type plants which may be taken as representing the boreal element in our flora. Out of a total for all Ireland of 29 species and forms of Hieracium, District XII. has 26 against 15 in Donegal, while the number of the Scottish and. Intermediate type plants taken together is 49 in XII., to 43 in XI., out of a total of 60 for all Ireland. There are 10 peculiar species, of which the most interesting are Adoxa Moschatellina and Carex Buxbaumii, both, it is to be feared, on the rerge of extinction.

\section{Characteristic or Rare Plants.}

Ranunculus fuitons.

Barbarea intermedia. Cardamine amara.

Silene acaulis.

Arenaria verna.

Elatine Hydropiper.

Geranium sylvaticum.

G. pratense.

Vicia Orobus.

V. lathyroides.

Rubus chamæmorus. Dryas octopetala.

Rosa hibernica.

R. glauca.

Saxifraga Hirculus.
Saxifraga aizoides.
Orobanche rubra.
Epilobium angustifolium. Atriplex farinosa.
Cicuta virosa.
Salix nigricans.
Carum verticillatum.
Ligusticum scoticum.
Adoxa Moschatellina.
Spiranthes Romanzoffiana.
Typha angustifolia.
$\dagger$ Galium Cruciata.
Saussurea alpina.
*Acorus Calamus.
Pyrola media.
Zannichellia polycarpa.
Carex panciflora.
P. minor.
P. secunda.
C. Buxbaumii.
C. aquatilis.
Calamagrostis stricta.
†Hottonia palustris.
Mertensia maritima.
Myosotis collina.
Cryptogramme crispa.
Polypodium Dryopteris.
Equisetum pratense.
Melampyrum sylvaticum. Pilularia globulifera.

\section{Botanical Map of Iretand.}

The map issued with this work is designed to serve two purposes, first to mark the precise limits of the Irish Botanical Districts, second, to show clearly the range of the more interesting plants, especially the Hibernian Type species discussed in Section IV. of the Introduction. The manner in which the twelve districts are defined on the map needs no explanation; but the significance of the curved lines of distribution may not be apparent to all. These lines are intended to show the eastern limits of the various plants selected for this graphic treatment. Thus Eriocaulon septangulare is only found in those parts of the island lying to the westward of the long sinuous line marked with its name; Habenaria intacta, only to the westward of the shorter and more abruptly curved line marked with its name, and so on with the other species so treated. It is scarcely necessary to say that the range of each species within 
the defined limits is by no means continuous. With the wider ranging species, Saxifraga umbrosa, Euphorbia hiberna, and Eriocaulon septangulare, it is, indeed, remarkably discontinuous; and the longer breaks in the range of these plants are indicated by carrying out to sea the appropriate curved line for each. For instance, Euphorbia hiberna, the Irish Spurge, is shown to have a fairly continuous range in the south-west, to disappear for a long interval in the west, where it occurs only in the island of Inishturk, and to re-appear for a space in northern Donegal. The known. Irish area occupied by some of the species is so inconsiderable that they cannot properly be said to have any range, and the position of these is indicated by a loop (Inula salicina), or even by a dot (Arenaria ciliata). The remarkable restriction of the Hibernian type plants to the west and south-west of the island was first shown by this system of distribution curves in the original edition of this work. In the present, the curves have been carefully revised, so as to bring them into conformity with the latest information.

\section{Explanatory Nomes on the Text.}

Nomenclature.-In revising for this second edition the nomenclature adopted in the first, the law of priority has not been invariably followed. A widely familiar and long established name has always been allowed to stand when the only reason to be urged against its retention was the existence of an earlier published name, long since become obsolete or never admitted to general currency. Whatever may be the final result of the resuscitation of such obsolete or still-born names in obedience to the strict letter of the law of priority, the immediate effect must be to cause that confusion which the law was designed to prevent or to remove. The present work makes no claim to be regarded as an authority in nomenclature. It seeks to be intelligible and easy of reference for all who are likely to make use of it; and these ends, it seems to the editors, may best be secured by retaining, despite of their illegality, many well-known and long-established names. These names are, perhaps, doomed to extinction in the not very distant future; but it may be confidently predicted that they will remain familiar long after this work has served its purpose and been laid aside as obsolete.

Native Plant Names.-As a rule, only such native names as are widely current in the Irish-speaking districts of Ireland have been 
introduced into the following pages, and it should be borne in mind that what is given is little better than a selection from a large body of names, many of which are of more local extension or of less precise application. A phonetic rendering of the Irish has been added, but in many cases, and, above all, in dealing with the gutturals so impracticable for English speech-organs, this conveys very imperfectly the sound of the native name. The meaning also is given unless where it is hopelessly obscure. Every Irish plant-name received into the text has been ascertained by personal inquiries carried on in the counties of Kerry, Clare, Galway, and Donegal to be in actual use among the Irish-speaking peasantry, and the greatest pains have been taken to insure accuracy of application. Lack of time for more extended inquiry has unfortunately obliged us to leave this feature of the text incomplete. The further study of the subject is earnestly recommended to Irish botanists, especially those resident in the West.

Trivial Names.-Although names in the English tongue have been given for almost every species in the text, many of these are not trivial names or, indeed, English names in any true sense of the words. They are often merely translations of the scientific names, but it has seemed best to give them a place in a work which may be frequently consulted by unscientific readers.

Aggregates and $S u b$-species.-In a few instances aggregate species have been retained, either because the known district extension of the aggregate was greater than the joint known extension of the segregates, or because there was as great a difficulty in selecting any . one of the segregates as type to which the others might be subordinated as sub-species as there was in allowing all the segregates to take equal rank as species. Sub-species are distinguished by printing the name in italics in the centre of the page; varieties are preceded by the contraction Var., the name of the author being affixed in brackets where the plant was originally proposed by him as a species. Where a hybrid or suspected hybrid plant has been named on the ordinary binomial system, this name has in all cases been retained, followed by the names of the supposed or ascertained parents, thus:-Stachys ambigua Smith-S. palustris $\times$ sylvatica.

District Distribution.-For the commoner species the distribution is shown simply by the insertion of the district numbers at the head of the paragraph. In the case of rarer plants, definite localities are given for each district in which they are ascertained to occur. Where the plant is locally abundant or common, definite 
localities are given only for the districts in which it is rare. The inclusion in brackets of a district number at the head of a paragraph indicates that the plant is doubtfully established, or perhaps extinct in that district. The district distribution as shown at the head of each paragraph includes that of all the Irish varieties as well as of the type.

Native and Non-native Plants.-In the text the numerous plants known or suspected to have been introduced by human agency, whether accidental or intentional, are distinguished from the apparently native plants by the usual signs, $\dagger, \ddagger$, or *. The first of these denotes that the plant to whose name it is affixed is open to a slight suspicion of having been introduced by the agency of man, the second that it was probably, and the third that it was certainly so introduced. Perhaps not one of the non-native plants known to occur in several of the Irish botanical districts stands on precisely the same footing in each. While apparently all but native in one district, a plant may be obviously introduced in another; and since it is beyond the scope of this work to exhibit the standing of each non-native species in the various districts in which it may occur, the sign selected in the text is that which denotes for each of such species its highest standing in any part of Ireland-that is to say, its standing most closely approaching to true nativity.

Range in Latitude.-In tracing the range in latitude of Irish plants, the island has been assumed to lie between the parallels of $51 \frac{1}{2}^{\circ}$ and $55 \frac{1}{4}^{\circ}$ North latitude, the extent of land lying north and south of these limits being inconsiderable. Within these limits the range of each species has been ascertained to the nearest quarter degree. With some of the rarer or more local plants the range has been given with greater precision. It has not, however, been thought necessary to give the range in longitude for each species. Those which have a distinctively eastern and western distribution will be found set out in the section (VII.) of this Introduction dealing with Topographical Groups.

Botanical Types.-For the purpose of comparison with the British Flora, Watson's botanical type-names have been given for each species save those peculiar in the British Isles to Ireland. These have been classed under the name Hibernian type. To the explanation of Watson's types already given in a previous paragraph of the Introduction, it may be added here that the union of two type-names, as in the compounds, British-English and EnglishGermanic, indicates that the plant so classed, while belonging to the 
type indicated by the first component in the compound name, has a tendency to enter the type indicated by the second component.

Flowering Seasons.-In the case of wide-ranging species the periods given are a mean between the northern and southern flowering seasons for Ireland. In the peculiarly mild and equable Irish climate the flowering period of many species is prolonged far beyond what is usual under the more continental conditions which obtain in Great Britain, and to a greater or less degree the absence throughout southern and south-western Ireland of any well-defined winter season makes it difficult to fix the precise limits of the flowering periods.

Relations of Soils and Plants.-In the following pages special attention has been drawn to the effect exercised by the varied constitution of soils on the distribution of plants. While the great mass of the commoner or ubiquitous species exhibit, as a necessary condition of their wide range, an almost absolute indifference in this respect, some smaller groups of plants show in various degrees a preference for, or an aversion from, certain soils. Though very strongly marked in many cases, this preference or aversion perhaps in no instance reaches to absolute exclusiveness. Broadly speaking, the presence or absence of lime in a soil would appear to be the most potent and prevalent cause of the observed preference or aversion, and the terms calcicole and calcifuge most fitly express this relation of plants and soils. A calcicole species is one which inhabits by preference a soil containing lime in sufficient quantity to give a brisk effervescence with acids; a calcifuge species is one which avoids such a soil; and the use of these terms does not imply the adoption of any theory as to the precise action of the lime whether direct (chemical) or indirect (mechanical). Following the example of M. Contejean, ${ }^{1}$ from whom the use of these convenient terms has been borrowed, an attempt has been made in this work to divide the calcicole and calcifuge species into groups corresponding to the strength of the observed preference or aversion. These groups have been distinguished by the letters $A, B$, and $C$. A species marked Calcifuge $A$ is one which very rarely appears on soils containing an appreciable proportion of lime; a species marked Calcifuge $B$, though it may appear not infrequently on lime soils, is invariably found in far greater abundance and luxuriance on soils from which lime is absent; and a species classed as Calcifuge $C$ is one which, though occurring freely in both calcareous and non-calcareous soils,

${ }^{3}$ Geographic Botanique-Infuenee du terrain sur la Vegetation.-Ch. Contejean, Paris, 1881. 
is appreciably more abundant in the latter. Similarly, but in an inverse sense, the terms Calcicole $A$, Calcicole $B$, and Calcicole $C$ denote the preference of certain species for limestone soils. Such preferences are less frequent and less strongly marked than are the aversions shown by the calcifuge group. In other words, the repulsive influence of lime on one group is much stronger than its attractive influence on the other. The classification of the Irish calcifuge and calcicole species adopted in the text, though founded exclusively on observations made in Ireland, will be found to agree closely with the results arrived at by Continental observers. Whatever the value of this tentative grouping may be, it will serve at least to draw the attention of Irish botanists to a neglected, though deeply interesting, branch of their science.

Range in Altitude.- Since the publication of the first edition of this work a large mass of material dealing with the vertical range of plants in the various mountain groups of Ireland has been accumulated, and this material has been largely availed of in the present edition. For every species not distinctly lowland, that is to say, confined habitually to levels not exceeding 500 feet, the highest observed altitudes in Northern, Middle, and Southern Ireland have been given. Along with these maximum altitudes, the descent of such species to sea-level in North and South Ireland is also stated whenever it is ascertained to occur, it being assumed that a plant which reaches sea-level in the North and in the South, say in Antrim and in Cork, will also reach the same level, in all the intervening latitudes, and, indeed, all round the Irish coasts where suitable stations occur. Plants observed between actual sea-level and a height of 50 feet above it are classed as sea-level.

For various reasons, chief amongst which are the insufficient height of the mountains, and the rarity and unequal distribution of the Highland type species, every effort to deduce from the Irish statistics, alone, any law of relation between latitude and vertical range of plants seems doomed to disappointment. Nevertheless, the statistics have been rather fully given in the text in the hope that they may be found useful for comparison with similar statistics for Great Britain. Three papers have been largely drawn on for the Irish vertical ranges, Mr. H. C. Hart's Range of Flowering Plants and Ferns on the Mountains of Ireland, Messrs. Barrington and Vowell's Report on the Flora of Ben Bulben, and Messrs. Stewart and Praeger's Report on the Botany of the Mourne Mountains, quotations from these being distinguished respectively by the contractions Hart, $B . \& V$, and $S . \& P$. In addition to the printed 
papers quoted from, a large mass of unpublished notes by the editors and others have been made use of.

Citation of Published Records.-In quoting from the numerous papers on Irish botany published within the last thirty years, the necessity for some contracted scheme of reference very soon became apparent. It was decided to adopt one which would show at once the author of the paper and the date of its publication, thus giving the authority for the plant and the approximate date of its discovery. The author's surname directly followed by the date of his paper gave in almost all instances a clear and concise reference. Only in the case of double authorship was it found necessary to resort to the use of initials. Where an author was found to have published two or more papers in the same year these were distinguished by Greek letters affixed to the contraction. In illustration of this scheme the following instances may be taken: Hart 1883 , denotes a paper published by Mr. H. C. Hart in 1883, the precise title and place of publication being found by reference to the Alphabetical List of Papers Again, Hart I883 a, and Hart I883 $\beta$, denote second and third papers published by the same author in the same year, the particulars of title and place of publication being found, as before, by reference to the list. As an instance of double authorship, the contraction B. \& $T .1885$ denotes Messrs. Barrington and Vowell's Report on the Flora of Ben Bulben, published in $1885 ; S . \& P . I 892$, Messrs. Stewart and Praeger's Report on the Flora of the Mourne Mountains, and so on through the various papers quoted from. The various books, papers, journals, \&c., denoted by the contractions used, whether in this or in the first edition, may be readily found by reference to the Alphabetical List. Throughout the text, observations made by the editors of the first edition are distinguished by the names, Moore or More, those made by the editors of the present edition by the initials $N$. C. or $R$. W. $S$.; and with a very few exceptions, such as, Rev., Prof., Miss, and Mrs., all titles and appellations have been discarded for the sake of brevity. In the case of observations by well-known Irish botanists here published for the first time, the surname alone is used. Thus Hart, affixed to entries in the present edition, without any date following the name, denotes a hitherto unpublished record by H. C. Hart, the author of the numerous papers set out in the Alphabetical List, and similarly with the names Barrington, Stewart, Levinge, Praeger, Phillips, and others, and with the initials $N$. C. and $R$. W. S. In general, where an entry concludes with a personal name and nothing more, the entry must be taken as a record here published 
for the first time. The observations recorded in the various books and papers quoted from have usually been made by the respective authors of the books or papers. Where exceptions to this rule occur, the name of the observer precedes, in parentheses, the contracted reference to the book or paper; thus $(G$. H. Kinahan $): R e c . A d d$. denotes an observation made by Mr. G. H. Kinahan, and first published in Recent Additions to the Flora of Ireland, in 1872.

Appendix.-All plants recorded as Irish, but in our opinion not fully entitled to a place in the flora, have been relegated to one comprehensive Appendix. There are some obrious disadvantages inseparable from this arrangement, since it groups together such diverse categories as exrors, casuals, escapes, and semi-naturalized species; but the facility of reference which it secures will, it is hoped, be found to more than counterbalance these disadvantages. In many instances the question whether a plant should take its place in the text or in the Appendix could only be answered confidently after a tedious weighing of the often imperfect or distorted evidence: in a few it could hardly be answered with confidence at all, and the final decision merely expresses the preponderance on one side or the other of conflicting sets of probabilities.

A good deal of historical interest attaches to the first recognition of an alien species which eventually succeeds in winning a permanent place in a flora. But the difficulty of forecasting which of the many candidates for admission may be destined to effect a permanent lodgment is only too obvious. Some subtle mutual fitness between the immigrant species and the complex set of new conditions it encounters in a new country may at any time give rise to an unexpected addition to a flora. Hence it has seemed best in drawing up this Appendix to admit many plants whose prospects of final establishment may at present appear but slender. Along with these, a place has been given to a considerable number of aliens already semi-naturalized and almost entitled to rank as members of the flora, full details being given as to the present standing of both classes. Attention is thus drawn to the material which may be expected to feed the future growth of the Irish flora, and to do this must be regarded as amongst the chief ends to be served by this Appendix. 


\section{DISTRIBUTION IN THE DISTRICTS.}

[Sub-species are printed in italics.]

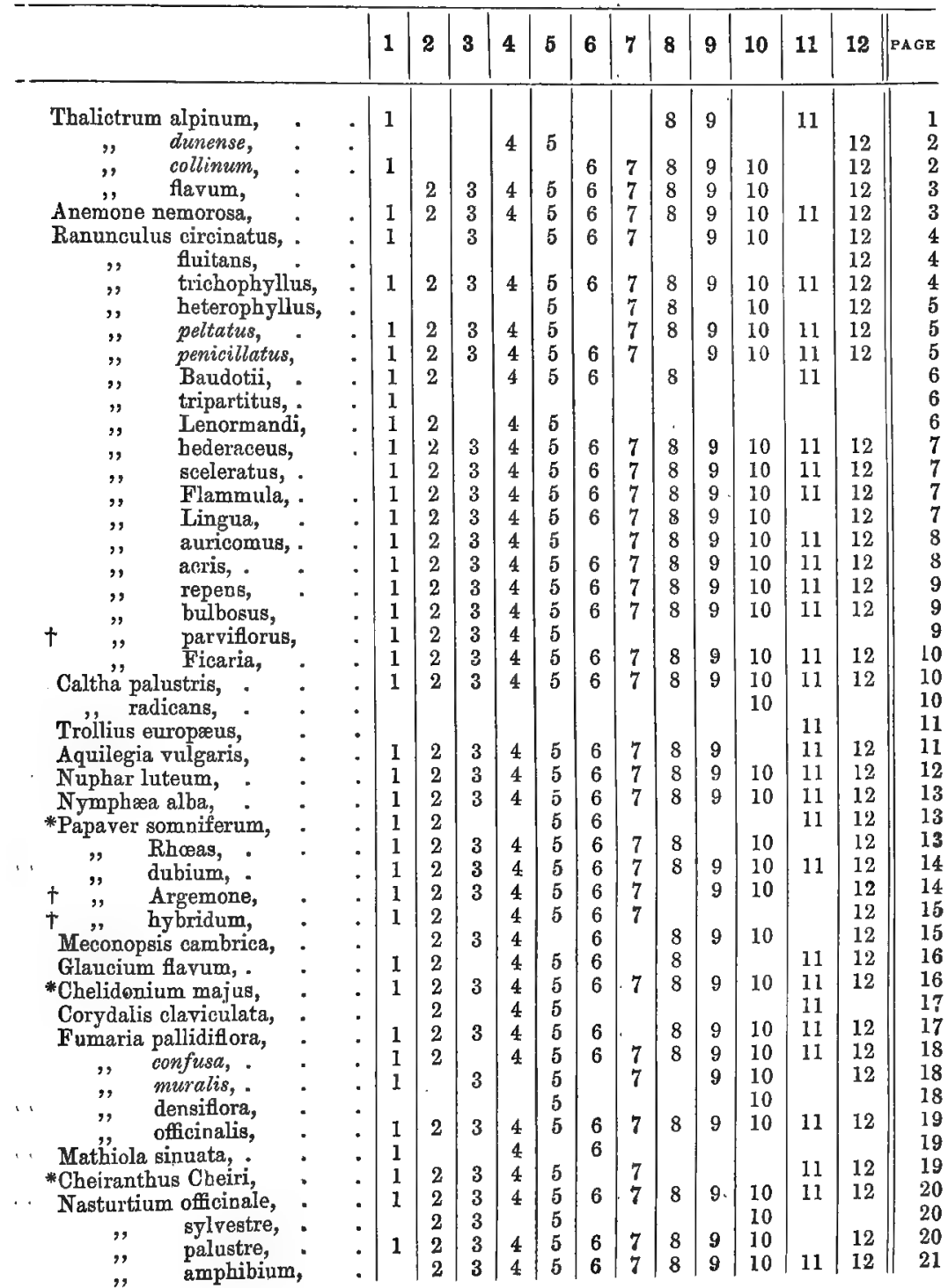




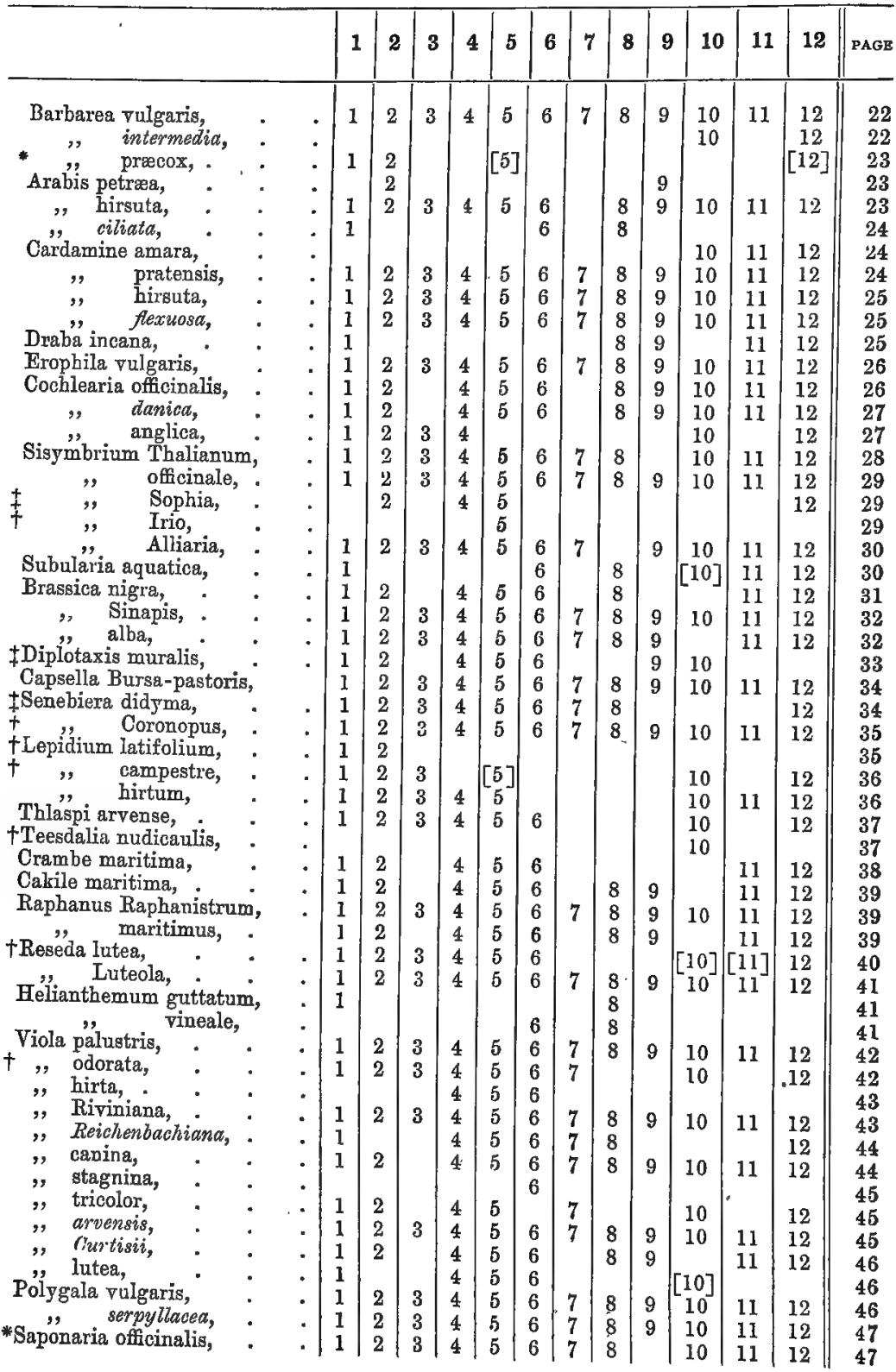




\section{\begin{tabular}{|l|l|l|l|l|l|l|l|l|l|l|l|l|}
1 & 2 & 3 & 4 & 5 & 6 & 7 & 8 & 9 & 10 & 11 & 12 & PAGE \\
\hline
\end{tabular}

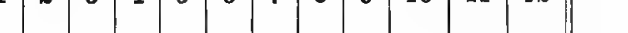

Silene Cucubalus,

$+"$ maritima

$+2$

$$
\text { ", anglica, }
$$

acaulis, . . 1

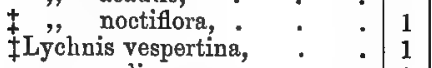

", diurna,

$"$ Flos-cuculi, - . 1120304

‡ " Githago,

Githago,

"semidecandrum,

" glomeratum,

Stellaria media,

$$
\text { triviale, }
$$

, Holostea,

", palustris,

" graminea,

", uliginosa,

Arenaria verna

$=\quad \begin{aligned} & \text { trinervia, } \\ & " \quad \text { serpyllifolia, } \\ & \text { ciliata }\end{aligned}$

" peploides,

Sagina apetala,

" maritima, :

", ciliata,

", procumbens,

", subulata,

" nodosa,

Spergula arvensis,

Spergularia rubra

$$
\begin{array}{ll} 
& \text { media, } \\
, & \text { salina, } \\
\text { rupestris, } &
\end{array}
$$

Montia fontana,

Elatine hexandra,

Hy" Hydropiper,

ypericum Androsæmum,

", perforatum,

$"$ dubium, tetrapterum,

" humifusum, ", pulchrum,

$"$ elodes,
officinalis,

¥Althæa officinalis,

†Malva moschata,

" sylvestris,

", rotundifolia,

Radiola linoides,

Linum eatharticum,

Geranium sanguineum,

\begin{tabular}{llllllllllll|l|l}
. & 1 & 2 & 3 & 4 & 5 & 6 & 7 & 8 & 9 & 10
\end{tabular}

12

\begin{tabular}{l|l}
2 & 3 \\
2 & 3
\end{tabular}

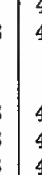

\begin{tabular}{l|l|l|}
4 & 5 & 6
\end{tabular}

\begin{tabular}{l|l|}
5 \\
5
\end{tabular}

- 1125

1

- 12

1

- 1125

- 112

- 12

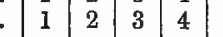

- $\begin{array}{llll} & & 2 & 3 \\ & 1 & 2 & 3\end{array} \mid$

\begin{tabular}{ll|l|l}
1 & 2 & 3 & 4
\end{tabular}

\begin{tabular}{ll|l|l|l}
- & 1 & 2 & 3 & 4 \\
\hline
\end{tabular}

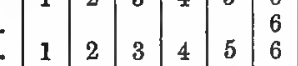

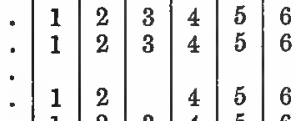

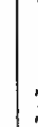

8
8

\begin{tabular}{l|l}
8 & 9 \\
8 & \\
& 9
\end{tabular}

1112

10

11

$11 \quad 12$

$11 \quad 12$

112

\begin{tabular}{ll|l|l|l|l|l|}
7 & 8 & 9 & 10 & 12 \\
\hline & 7 & 8 & 9 & 11 & 12
\end{tabular}

\begin{tabular}{|l|l|l|l|l|l|l|}
6 & 7 & 8 & 9 & 10 & 11 & 12 \\
6 & 7 & 8 & 9 & 10 & 11 & 12
\end{tabular}

47

48

48

49

49

50

50
51

.51

52
52

52

52

53

53

54

54

55

55

55

อ6

56

57

57

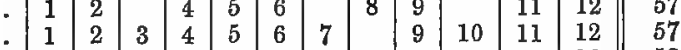

- \begin{tabular}{lll|l|l|l|l|l|l|l|l|l|l|l}
1 & 2 & & 4 & 5 & 6 & & 8 & 9 & 10 & 11 & 12 & 58
\end{tabular}

\begin{tabular}{ll|lllll|l|l|l|l|l|l|l|l} 
- 1 & & 3 & 4 & 5 & 6 & & & & & & 12 & 58
\end{tabular}

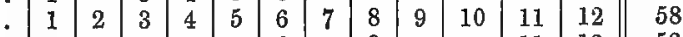

\begin{tabular}{lllll|l|l|l|l|l|l|l|l|}
$\cdot$ & 1 & & & & & 6 & & 8 & & & 11 & 12 \\
\hline
\end{tabular}

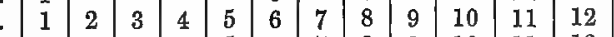

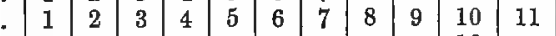

\begin{tabular}{llll|l|l|l|l|}
- & 1 & 2 & 3 & 4 & & \\
1 & 2 & & 4 & 5 & 6
\end{tabular}

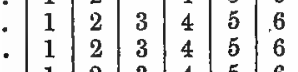

\begin{tabular}{lll|l|l|l|l|l|l|l|l|}
\hline & 1 & 2 & 3 & 4 & 5 & 6 & 7 & 8 & 9 & 10 \\
\hline
\end{tabular}

1

\begin{tabular}{llllllllll|l|l|}
.$\cdot$ & 1 & 2 & 3 & 4 & 5 & 6 & 7 & 8 & 9 & 10 \\
.- & 1 & 2 & 3 & 4 & 5 & 6 & 7 & 8 & 9 & 10 \\
\hline & 2 & 3 & 4 & 5 & 6 & 7 & 8 & 9 & 10
\end{tabular}

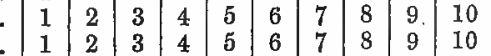

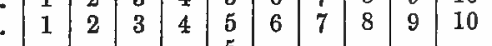

$\begin{array}{lllllllll}\text { - } & 1 & 2 & 3 & 4 & 5 & 6\end{array}$

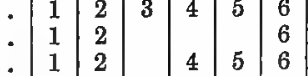

- 112

- 1102

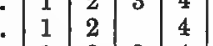

\begin{tabular}{ll|l|l|l|l|l}
-1 & 2 & 3 & 4 & 5 & 6 \\
- & 1 & 2 & 3 & 4 & 5 & 6 \\
& & & 4 & 5 & 6
\end{tabular}

8
8
8
8

\begin{tabular}{|l|l|l|l|} 
& & 11 & 12 \\
12 \\
9
\end{tabular}

58

59

59

59
59

60

60

60

61

61

62

62

63

63

64

64

64

64

64

65

65

66

67

67

68

69

69

70 


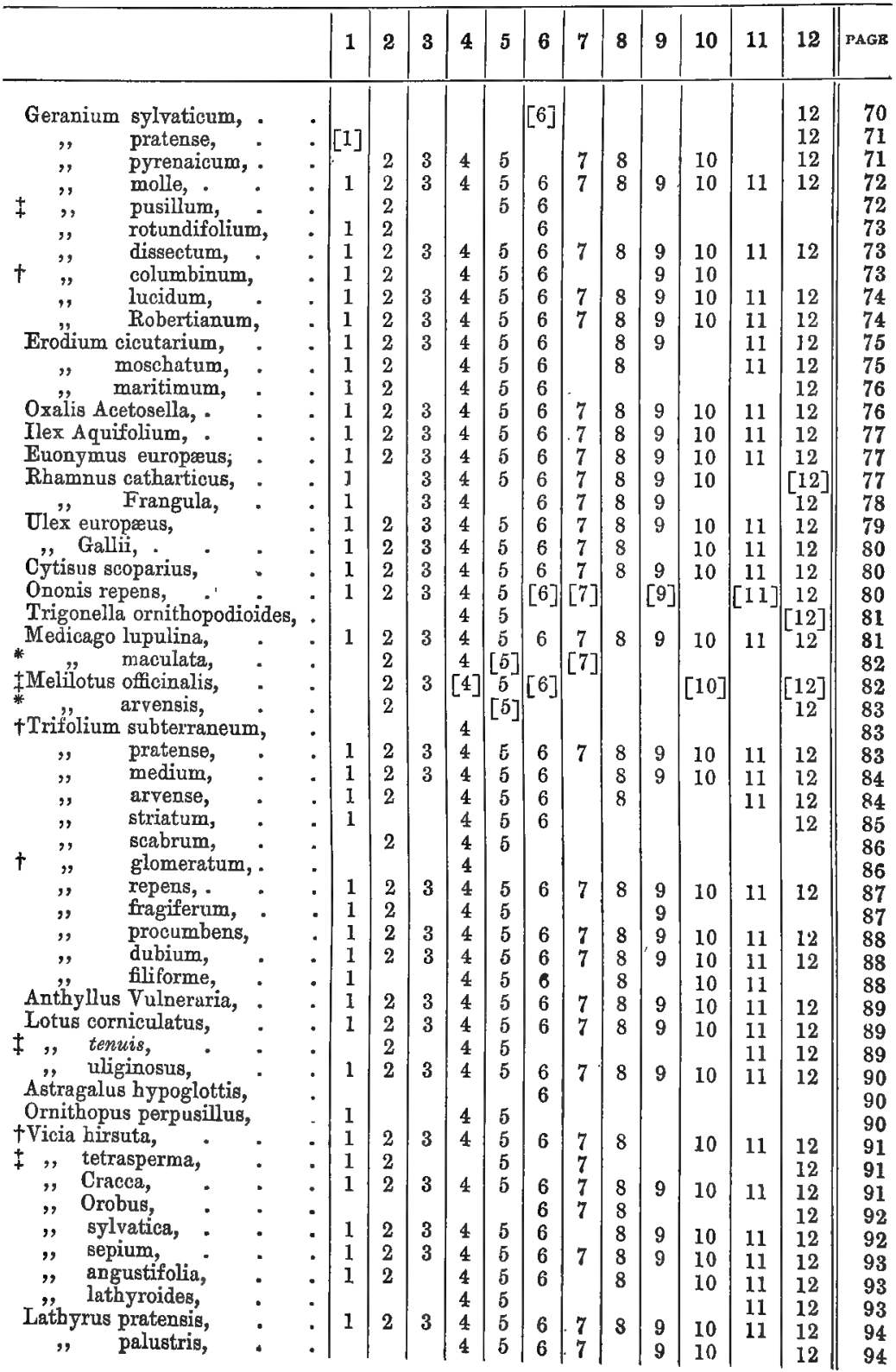




\begin{tabular}{|l|l|l|l|l|l|l|l|l|l|l|l||l}
1 & 2 & 3 & 4 & 5 & 6 & 7 & 8 & 9 & 10 & 11 & 12 & PAGE \\
\hline
\end{tabular}

Lathyrus maritimus,

- " macrorrhizus, ,

, aviur

" Cerasus,

, Padus

Spiræa Vlmaria, :

", Filipendula,

Rubus Idæus,

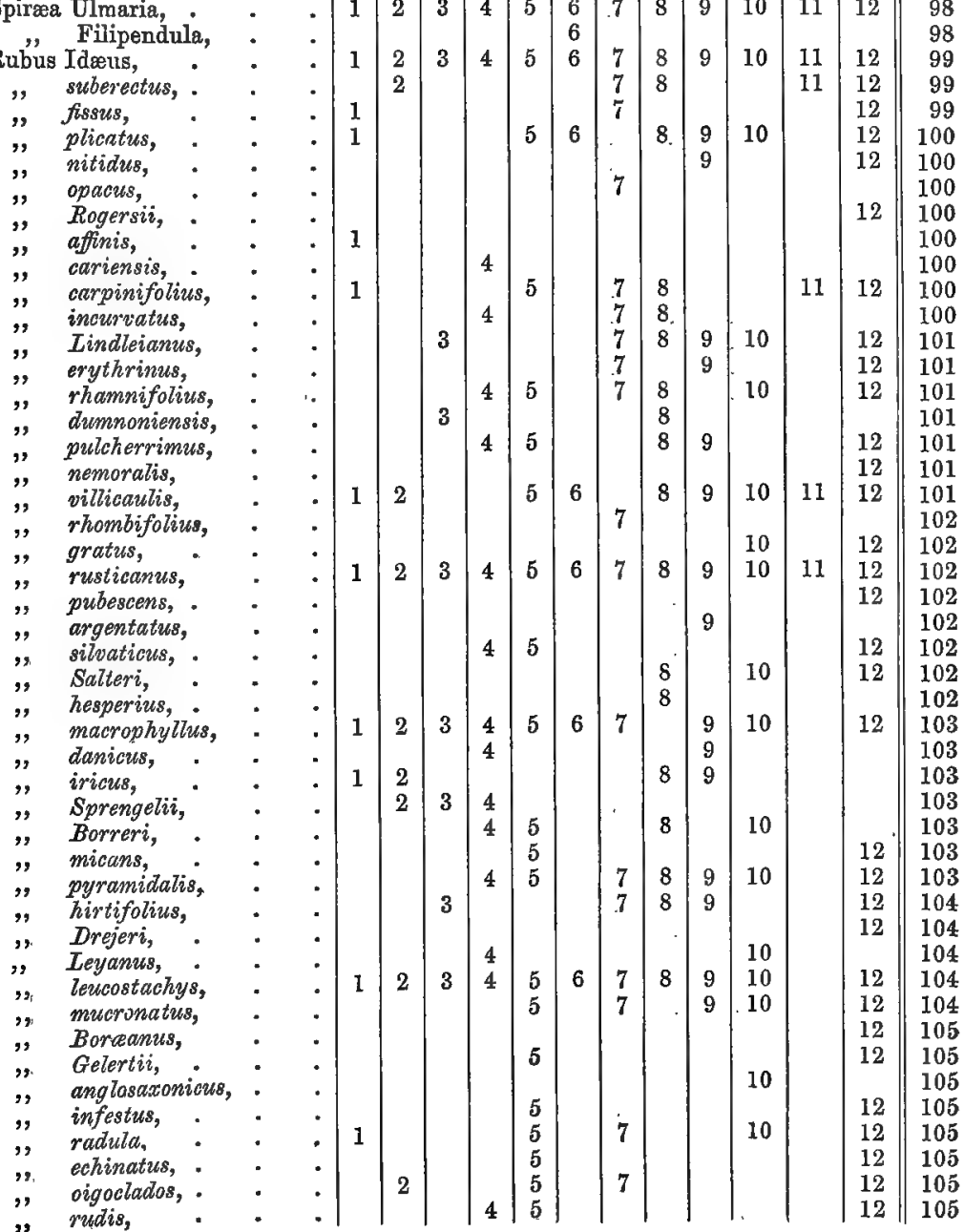




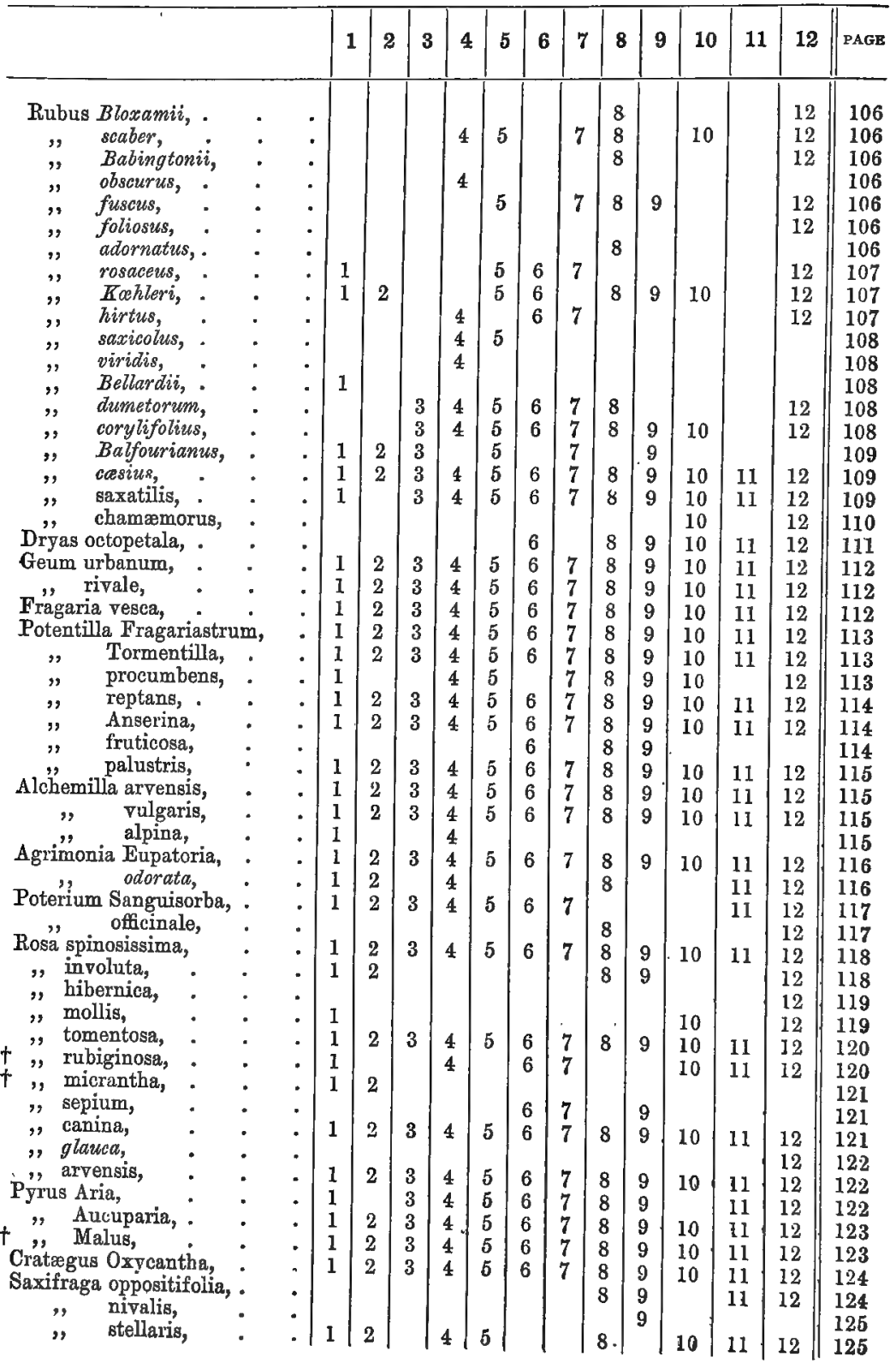


Saxifraga Geum,

"umbrosa, : $\quad: \quad 112$

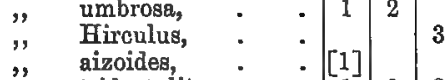

$$
\text { ", }
$$$$
\text { " }
$$

". hypnoides,

Chrysosplenium oppositifolium

Parnassia palustris,

Cotyledon Ombilicus,

Sedum Rhodiola, .

† " Telephium,

* ", album,

* ", dasyphyllum,

" anglicum,

", acre,

* ", reflexum, :

Drosera rotundifolia,

", intermedia,

Hippuris vulgaris,

Myriophyllum verticillatum,

Calli alterniflorum,

$$
\begin{aligned}
& \text { spicatum, } \\
& \text { alterniflorum, }
\end{aligned}
$$

Callitriche vernalis

Peplis' Portutumnalis, .

$$
\begin{array}{lll|l|l}
\text { vernalis, } & : & : & & \\
\text { hamanalis } & \cdot & : & 1 & 2 \\
\text { obtusangula, } & : & : & 1 & 2 \\
\text { autumnalis, : } & : & 1 &
\end{array}
$$

Eythrum Salioaria,

\begin{tabular}{l|l|l|l|l|l|l|l|l|l|l}
$\cdot$ & 1 & 2 & & 4 & 5 & & 7 & & & \\
- & 1 & 2 & 3 & 4 & 5 & 6 & 7 & 8 & 9 & 10 \\
& 1 & 9 & 3 & 4 & 5 & 6 & 7 & 8 & 9 & 10
\end{tabular}

$$
\begin{aligned}
& \text { hirsutum, :- } \\
& \text { parviflorum, : }
\end{aligned}
$$

" parviflorum,

\section{roseum,}

obscurum,

palustre,

alsinefolium,

Circæa Iutetiana

Hy'drocotyle vulgaris,

Eryngium maxitimum, .

Sanicula europæa,

Conium maculatum,

†Smyrnium Olusatrum, :

Apium graveolens,

, nodiflorum,

, inundatum,

Cieuta virosa,

Carum verticillatum,

Sium latifolium, ,

, angustifolium,

$\downarrow$ \#̈gopodium Podagraria,

Pimpinella Saxifraga,

\begin{tabular}{ll|l|l|l|l|l|l|l|l|l|l|l|l}
$:$ & 1 & 2 & 3 & 4 & 5 & 6 & 7 & 8 & 9 & 10 & 11 & 12 & 141 \\
$:$ & 1 & 2 & 3 & 4 & 5 & 6 & 7 & 8 & 9 & 10 & 11 & 12 & 142 \\
$:$ & 1 & 2 & 3 & 4 & 5 & 6 & 7 & 8 & 9 & 10 & 11 & 12 & 143 \\
$:$ & 1 & 2 & 3 & 4 & 5 & 6 & 7 & 8 & 9 & 10 & 11 & 12 & 143 \\
$:$ & & & & & 5 & & & & & & & 12 & 143 \\
$:$ & 1 & 2 & 3 & 4 & 5 & 6 & 7 & 8 & 9 & 10 & 11 & 12 & 144 \\
$:$ & 1 & 2 & 3 & 4 & 5 & 6 & 7 & 8 & 9 & 10 & 11 & 12 & 144 \\
$:$ & 1 & 2 & 3 & 4 & 5 & 6 & 7 & 8 & 9 & & & & 144 \\
$:$ & 1 & & & & 5 & & & 8 & 9 & 10 & 11 & 12 & 144 \\
$:$ & 1 & 2 & 3 & 4 & 5 & 6 & 7 & 8 & 9 & 10 & 11 & 12 & 145 \\
$:$ & 1 & 2 & & 4 & 5 & 6 & & 8 & & & 11 & 12 & 146 \\
$:$ & 1 & 2 & 3 & 4 & 5 & 6 & 7 & 8 & 9 & 10 & 11 & 12 & 146 \\
$:$ & 1 & 2 & 3 & 4 & 5 & 6 & 7 & 8 & 9 & 10 & 11 & 12 \\
$:$ & 1 & 2 & 3 & 4 & 5 & 6 & 7 & 8 & 9 & 10 & 11 & 12 & 146 \\
$:$ & 1 & 2 & 3 & 4 & 5 & 6 & & 8 & 9 & 10 & 11 & 12 & 147 \\
$:$ & 1 & 2 & 3 & 4 & 5 & 6 & 7 & 8 & 9 & 10 & 11 & 12 & 147 \\
$:$ & 1 & 2 & 3 & 4 & 5 & 6 & 7 & 8 & 9 & 10 & 11 & 12 & 148 \\
$:$ & & & & & 5 & & 7 & & 9 & 10 & & 12 & 148 \\
$:$ & 1 & 2 & & & 5 & & & & 9 & & 11 & 12 & 149 \\
$:$ & & & & & 5 & 6 & 7 & & 9 & 10 & 11 & 12 & 150 \\
$:$ & 1 & 2 & 3 & 4 & 5 & 6 & 7 & 8 & 9 & 10 & 11 & 12 & 150 \\
$:$ & 1 & 2 & 3 & 4 & 5 & 6 & 7 & 8 & 9 & 10 & 11 & 12 & 150 \\
$:$ & 1 & 2 & 3 & 4 & 5 & 6 & 7 & 8 & 9 & 10 & 11 & 12 & 151
\end{tabular}




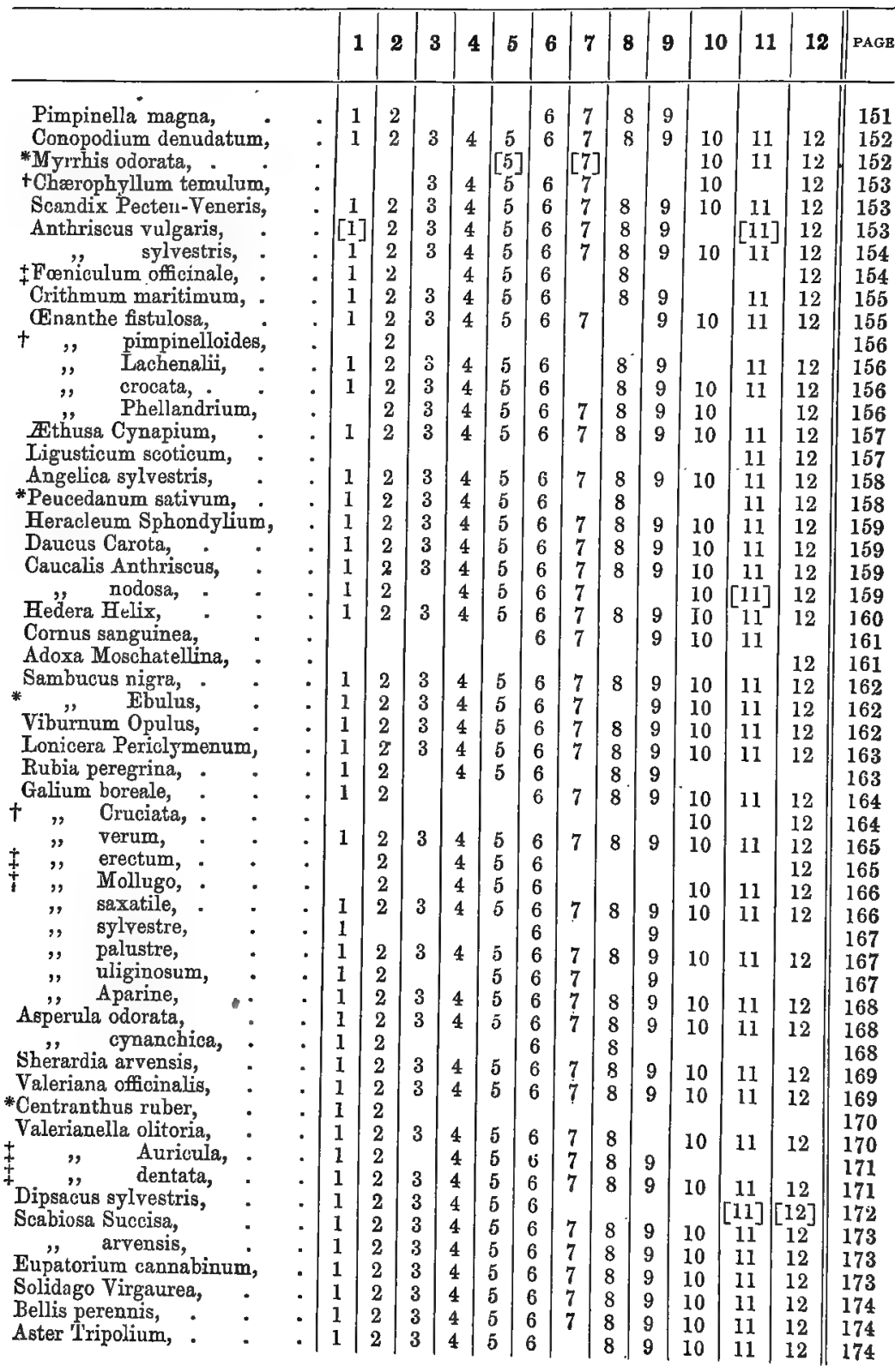




\section{\begin{tabular}{ll|l|l|l|l|l|l|l|l|l|l||l}
1 & 2 & 3 & 4 & 5 & 6 & 7 & 8 & 9 & 10 & 11 & 12 & PAGE
\end{tabular}}

Erigeron acre,

Filago germanica

" minima,

Antennaria dioica

Gnaphalium uliginosum,

*Inula 'Helenium, sylvaticum

"salicina,

" crithmoides, $\quad: \quad \cdot{ }^{\prime} \quad{ }_{2}$

Pulicaria dysenterica,

Bidens cernua,

A "hill tripartita, .

Millefolium,

, Ptarmica,

Diotis candidissima,

†nthemis Cotula, nobilis,

Chrysanthemum segetum,

Matricaria inodora,

Leucanthemum,

† " Chamomilla,

*Tanacetum vulgare,

+Artemisia Absinthium, vulgaris, " maritima,

Tussilago Farfara,

*Petasites fragrans,

Senecio vulgaris, officinalis,

* ,' sylvaticus

* ", viscosus,

", squalidus,

", Jacobæa,

, aquaticus,

Carlina vulgaris,

†Arctium majus,

\begin{tabular}{lll|l|l|l|l}
$"$ nemorosum, & $:$ & $:$ & & & & \\
$" \quad$ minus, & $:$ & $\cdot$ & 1 & 2 & 3 & 4 \\
& intermedium, : & $:$ & 1 & 2 & 3 & 4
\end{tabular}

Carduus pycnocephalus,

+ ," nutans,

+ " crispus,

Cnicus lanceolatus,

, palustris,

", pratensis,

,' arvensis,

* Silybum Marianum

Saussurea alpina,

Centaurea nigra,

* ", Cyanus,

†Cichorium Intybus,

Lapsana communis,

+Picris echioides,

- $\begin{array}{lll}1 & 2 \\ 1 & 2 \\ 1 & 2\end{array}$

\begin{tabular}{|l|l|l|l|l|l|l|}
3 & 4 & 5 & 6 & 7 & 8 & 9 \\
\hline & 4 & 5 & 6 & 7 & 8 & 9 \\
\hline
\end{tabular}

$\begin{array}{lllllllllllll}3 & 4 & 5 & 6 & 7 & 8 & 9 & 10 & 11 & 12 & 176\end{array}$

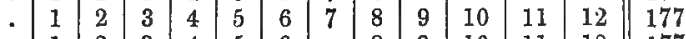

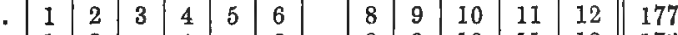

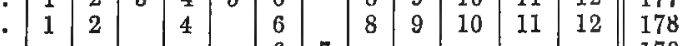

- \begin{tabular}{lll|l|l|l|l|l|l|l|l|l|l}
1 & 2 & & 4 & 5 & 6 & 7 & & & & & & \\
179
\end{tabular}

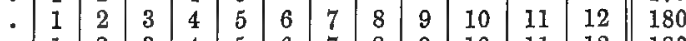

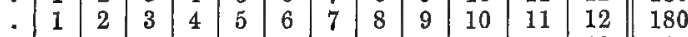

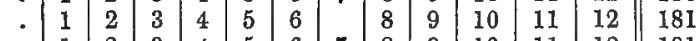

\begin{tabular}{ll|l|l|l|l|l|l|l|l|l|l|l|}
. & 1 & 2 & 3 & 4 & 5 & 6 & 7 & 8 & 9 & 10 & 11 & 12
\end{tabular}

$\begin{array}{lllllllllllllllll}- & 1 & 2 & 3 & 4 & 5 & 6 & 7 & 8 & 9 & 10 & 11 & 12\end{array}$

. $\quad 12$

4
4

- \begin{tabular}{llll}
1 & 2 & 3 & 4 \\
1 & 2 & 3 & 4 \\
\hline
\end{tabular}

\begin{tabular}{l|l|l|l|}
6 & 7 & 8
\end{tabular}

1

2

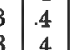

5

6

\begin{tabular}{|l|l|l}
7 & 8 \\
7 & 8 \\
\hline & 8
\end{tabular}

$[11$

11] [12]

181

181

181

$\begin{array}{lll}1 & 2 \\ 1 & 2\end{array}$

\begin{tabular}{ll|l|l|l|l|l|l|l|l|l|}
3 & 4 & 5 & 6 & 7 & 8 & 9 & 10 & 11 & 12 & 183
\end{tabular}

\begin{tabular}{llll|l|l|l|l|l|l|l|l|l|l}
. & 1 & & 3 & & 5 & 6 & 7 & 8 & 9 & 10 & 11 & 12 & 183 \\
\hline & & 3 & & 5 & 6 & & & & 10 & & 12 & 184
\end{tabular}

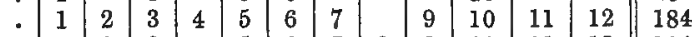

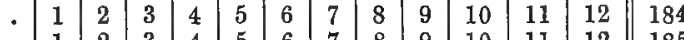

\begin{tabular}{ll|l|l|l|l|l}
- & 1 & 2 & 3 & 4 & 5 & 6 \\
\hline
\end{tabular}

7 \begin{tabular}{c|c|c|c}
7 & 9 & 10
\end{tabular}

11

12

185

185

\begin{tabular}{ll|l|l|l|l|l}
- & 1 & 2 & 3 & 4 & 5 & 6 \\
1 & 2 & 3 & 4 & 5 & 6 \\
\hline & 1 & 2 & 3 & 4 & 5 & 6
\end{tabular}

7 \begin{tabular}{c|c|c}
{$[8$} \\
8 & 9 & 10
\end{tabular}

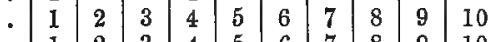

$11 \quad 12$

186

$1112 \quad 186$

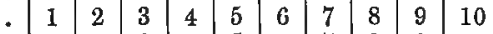

$11 \quad 12$

186

\begin{tabular}{llllll|l||l}
7 & 8 & 9 & 10 & 11 & 12 & 186 \\
187
\end{tabular}

12

[12

187

188

188

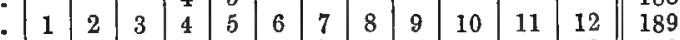

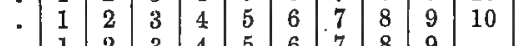

$11 \quad 12$

189

$11 \quad 12 \quad 190$

$12 \quad 191$

12191

\begin{tabular}{ll|l|l}
7 & 8 & 9
\end{tabular}

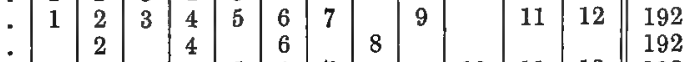

\begin{tabular}{llll|l|l|l|l|l|l|l|l|l||l}
- & & & 3 & & 5 & 6 & 7 & & & 10 & 11 & 12 & 193 \\
\hline & 2 & 3 & 4 & 5 & 6 & 7 & 8 & 9 & 10 & 11 & 12 & 193
\end{tabular}

\begin{tabular}{lllllllllll|l|l|l|l||}
. & 1 & 2 & 3 & 4 & 5 & 6 & 7 & 8 & 9 & 10 & 11 & 12 & 194
\end{tabular}

\begin{tabular}{llllllllllll|l|l|l|l}
- & 1 & 2 & 3 & 4 & 5 & 6 & 7 & 8 & 9 & 10 & 11 & 12 & 194
\end{tabular}

\begin{tabular}{lllllllllllll|l|l|l|l}
- & 1 & 2 & 3 & 4 & 5 & 6 & 7 & 8 & 9 & 10 & 11 & 12 & 194
\end{tabular}

\begin{tabular}{rl|l|l|l|l|l|l|l|l|l|l|l|l|l}
$\cdot$ & 1 & 2 & 3 & 4 & 5 & 6 & 7 & 8 & & 10 & & 12 & 195 \\
\hline & 1 & 2 & & 4 & & & & 8 & & & 11 & 12 & 195
\end{tabular}

\begin{tabular}{llll|l|l|l|l|l|l|l|l|l|l}
. & 1 & 2 & & 4 & & & & 8 & & & 11 & 12 & 195 \\
1 & 2 & 3 & 4 & 5 & 6 & 7 & 8 & 9 & 10 & 11 & 12 & 196
\end{tabular}

\begin{tabular}{rlllllll|l|l|l|l|l|l||l}
$\cdot$ & 1 & 2 & 3 & 4 & 5 & 6 & & 8 & 9 & & & & 196 \\
197
\end{tabular}

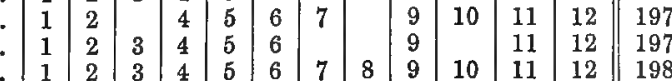

$\cdot$\begin{tabular}{lll|lll|l}
1 & 2 & 3 & 4 & 5 & 6 \\
1 & 2 & & 4 & 5 &
\end{tabular}

g

12 || 198 


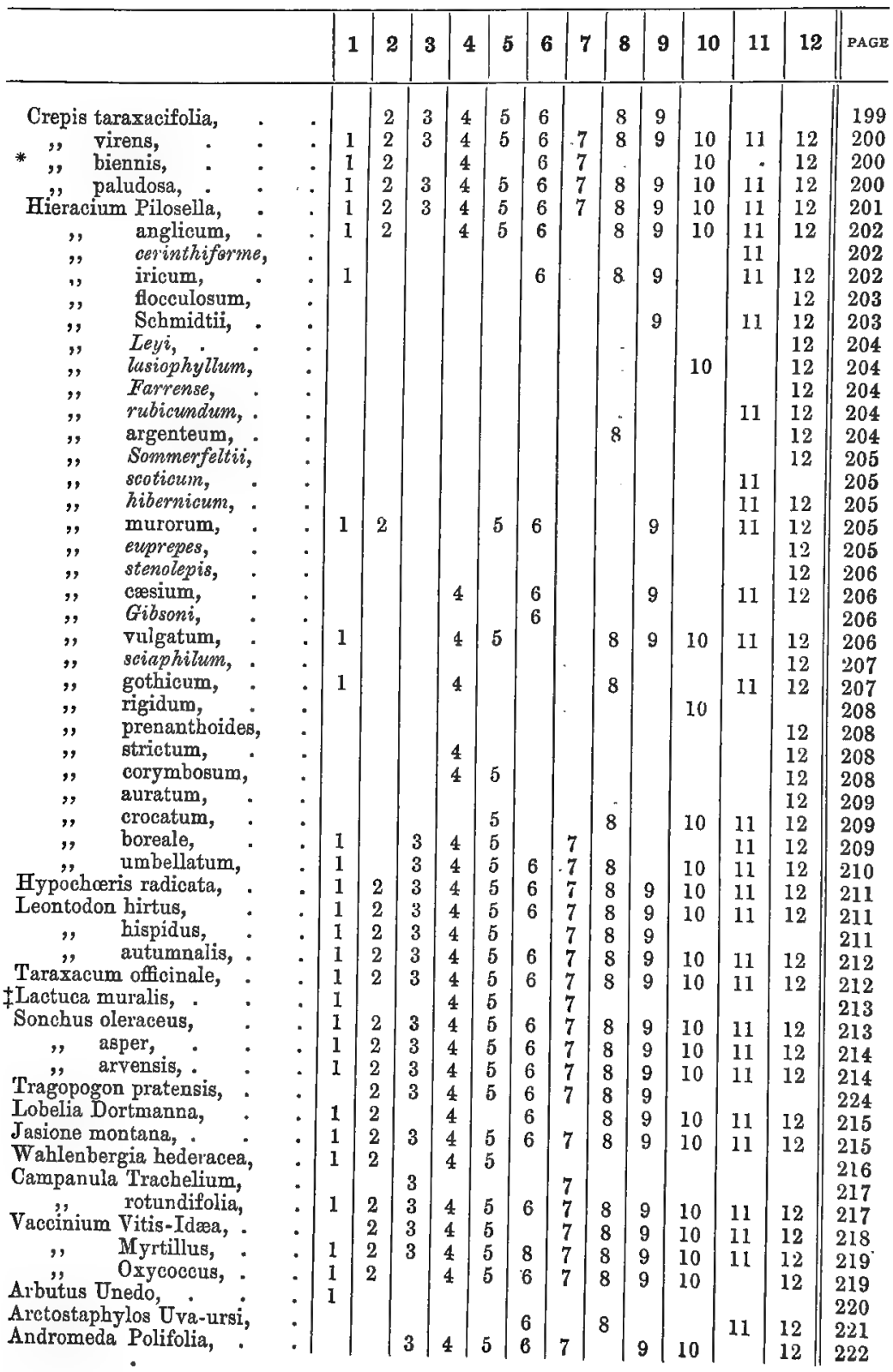




\begin{tabular}{|c|c|c|c|c|c|c|c|c|c|c|c|c|c|c|c|}
\hline & & & 1 & 2 & 3 & 4 & 5 & 6 & 7 & 8 & 9 & 10 & 11 & 12 & PAGR \\
\hline Calluna vul & & & 1 & 2 & 3 & 4 & 5 & 6 & 7 & 8 & 9 & 10 & 11 & 12 & 223 \\
\hline Erica Tetralix, & & & 1 & 2 & 3 & & 5 & 6 & 7 & 8 & 9 & 10 & 11 & 12 & 223 \\
\hline "Mackaii, & . & & & & & & & & & 8 & & & & & 223 \\
\hline " cinerea, . & - & - & 1 & 2 & 3 & 4 & 5 & 6 & 7 & 8 & 9 & 10 & 11 & 12 & 224 \\
\hline ", mediterranea, & & & & & & & & & & 8 & & & & & 224 \\
\hline Dabeocia polifolia, & & & & & & & & & 7 & & 9 & & & & $\begin{array}{l}225 \\
226\end{array}$ \\
\hline ", media, & & & & & & & & 6 & & & 9 & 10 & 11 & 12 & 227 \\
\hline ", minor, . & & & & & & 4 & & & 7 & & & & & & 227 \\
\hline H"̈popithys multiflora, & • & . & 1 & & & & 5 & 6 & & & 9 & & & & $\begin{array}{l}228 \\
228\end{array}$ \\
\hline Statice rarif & . & . & 1 & 2 & 3 & 4 & 5 & 6 & & 8 & & 10 & 11 & 12 & 229 \\
\hline$\Rightarrow \quad 00 c$ & . & & 1 & 2 & & 4 & 5 & 6 & & & & & 11 & & 230 \\
\hline Armeria $\mathrm{n}$ & • & . & 1 & 2 & 3 & 4 & 5 & 6 & & 8 & 9 & 10 & 11 & 12 & 230 \\
\hline \pm Hottonia & - & - & & & & & & & & & & & & & 231 \\
\hline Primula vul & & 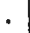 & 1 & 2 & 3 & 4 & 5 & 6 & 7 & 8 & 9 & 10 & 11 & 12 & 231 \\
\hline,$\quad$ of & & & 1 & 2 & 3 & 4 & 5 & 6 & .7 & 8 & 9 & 10 & 11 & & 232 \\
\hline Lysimachia vulgaris, & & . & 1 & 2 & 3 & 4 & 5 & 6 & 7 & 8 & 9 & 10 & 11 & 12 & 232 \\
\hline * ," Nummulari & & to & & & & & & 6 & & & 9 & 10 & 11 & & 233 \\
\hline & & - & 1 & 2 & 3 & 4 & 5 & 6 & 7 & 8 & 9 & 10 & 11 & 12 & 233 \\
\hline Glaux maritim & & . & 1 & 2 & 3 & 4 & 5 & 6 & & 8 & 9 & 10 & 11 & 12 & 233 \\
\hline Anagallis arv & & . & 1 & 2 & 3 & 4 & 5 & 6 & 7 & 8 & 9 & 10 & 11 & & 234 \\
\hline , $\quad$ t & & . & 1 & 2 & 3 & 4 & 5 & 6 & 7 & 8 & 9 & 10 & 11 & 12 & 234 \\
\hline Cent & & & 1 & 2 & & & 5 & 6 & & 8 & 9 & 10 & 11 & 12 & 234 \\
\hline Samolus Valerandi, & & . & 1 & 2 & 3 & 4 & 5 & 6 & 7 & 8 & 9 & 10 & 11 & 12 & 235 \\
\hline Fraxinus exc & & 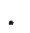 & 1 & 2 & 3 & 4 & 5 & 6 & 7 & 8 & 9 & 10 & 11 & & 236 \\
\hline Ligus & & . & 1 & 2 & 3 & 4 & 5 & 6 & 7 & & 9 & 10 & 11 & 12 & 236 \\
\hline Mic & & & 1 & & & & & & & & & & & & 236 \\
\hline Chlora perfoli & . & 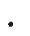 & 1 & 2 & 3 & 4 & 5 & 6 & 7 & 8 & 9 & & & & 237 \\
\hline Erythræa Cen & & . & 1 & 2 & 3 & 4 & 5 & 6 & 7 & 8 & 9 & 10 & 11 & 12 & 238 \\
\hline ", puls & & & 1 & 2 & & 4 & 5 & & & & & & & & 238 \\
\hline Gentiana vern: & & & & & & & & 6 & & $\begin{array}{l}8 \\
8\end{array}$ & 9 & & & & 238 \\
\hline$"$ & & & 1 & 2 & 3 & 4 & 5 & $\begin{array}{l}6 \\
5\end{array}$ & 7 & $\begin{array}{l}8 \\
8\end{array}$ & 9 & 10 & 11 & & $\begin{array}{l}209 \\
240\end{array}$ \\
\hline Menyanth & & & $\begin{array}{l}1 \\
1\end{array}$ & $\begin{array}{l}2 \\
2\end{array}$ & $\begin{array}{l}3 \\
3\end{array}$ & $\begin{array}{l}4 \\
4\end{array}$ & $\begin{array}{l}0 \\
5\end{array}$ & 6 & 7 & 8 & 9 & 10 & 11 & & 240 \\
\hline Cyn & & ( & $\hat{l}$ & 2 & 3 & 4 & 5 & & & & & & & & 240 \\
\hline tSym & & . & 1 & 2 & 3 & 4 & 5 & 6 & 7 & 8 & 9 & 10 & 11 & 12 & 241 \\
\hline & & & 1] & [2] & & & [5] & & & & & [10] & [11] & & 241 \\
\hline Lycopsis & & & & 2 & 3 & 4 & 5 & & & & 9 & & 11 & & 242 \\
\hline Mertensia & & & & & & 4 & 5 & & & & & & Il & & 242 \\
\hline Myosotis ca & & & 1 & 2 & 3 & 4 & 5 & 6 & 7 & 8 & 9 & 10 & 11 & 1 & 243 \\
\hline - & & & 1 & 2 & 3 & 4 & 5 & 6 & 7 & 8 & 9 & 10 & 11 & 2 & 244 \\
\hline , & & 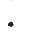 & 1 & 2 & & 4 & 5 & 6 & & 8 & 9 & 10 & 11 & & 244 \\
\hline is & & & 1 & 2 & 3 & 4 & 5 & 6 & 7 & 8 & 9 & 10 & 11 & 12 & 244 \\
\hline & & & & & & 4 & 5 & & & & & & & & 244 \\
\hline ", versicolor, & & & 1 & 2 & 3 & 4 & 5 & 6 & 7 & 8 & 9 & 10 & 11 & & 245 \\
\hline Lithospermum officinale & & & 1 & 2 & 3 & 4 & 5 & 6 & 7 & 8 & 9 & 10 & 11 & 12 & 245 \\
\hline & & & 1 & 2 & 3 & 4 & 5 & 6 & 7 & & 9 & 10 & 11 & 12 & 246 \\
\hline Echiur & & $*^{*}$ & 1 & 2 & & 4 & 5 & 6 & & & & & & 12 & 247 \\
\hline Calystegia sepium, & & & 1 & 2 & 3 & 4 & 5 & 6 & 7 & 8 & 9 & 10 & 11 & & 247 \\
\hline & & & 1 & 2 & & 4 & 5 & 6 & & & & & 11 & & 248 \\
\hline & & & 1 & 2 & 3 & 4 & 5 & 6 & 7 & 8 & 9 & 10 & 11 & 12 & 248 \\
\hline +Cuscuta Epi & - & & 1 & 2 & & 4 & 5 & 6 & & & & & 11 & & 249 \\
\hline Solanum Dulcamara, & - & & 1 & 2 & 3 & 4 & 5 & 6 & 7 & 8 & 9 & 10 & 11 & 12 & 250 \\
\hline шg口, & & & & 2 & & & 5 & & 7 & & & & & 12 & \\
\hline
\end{tabular}




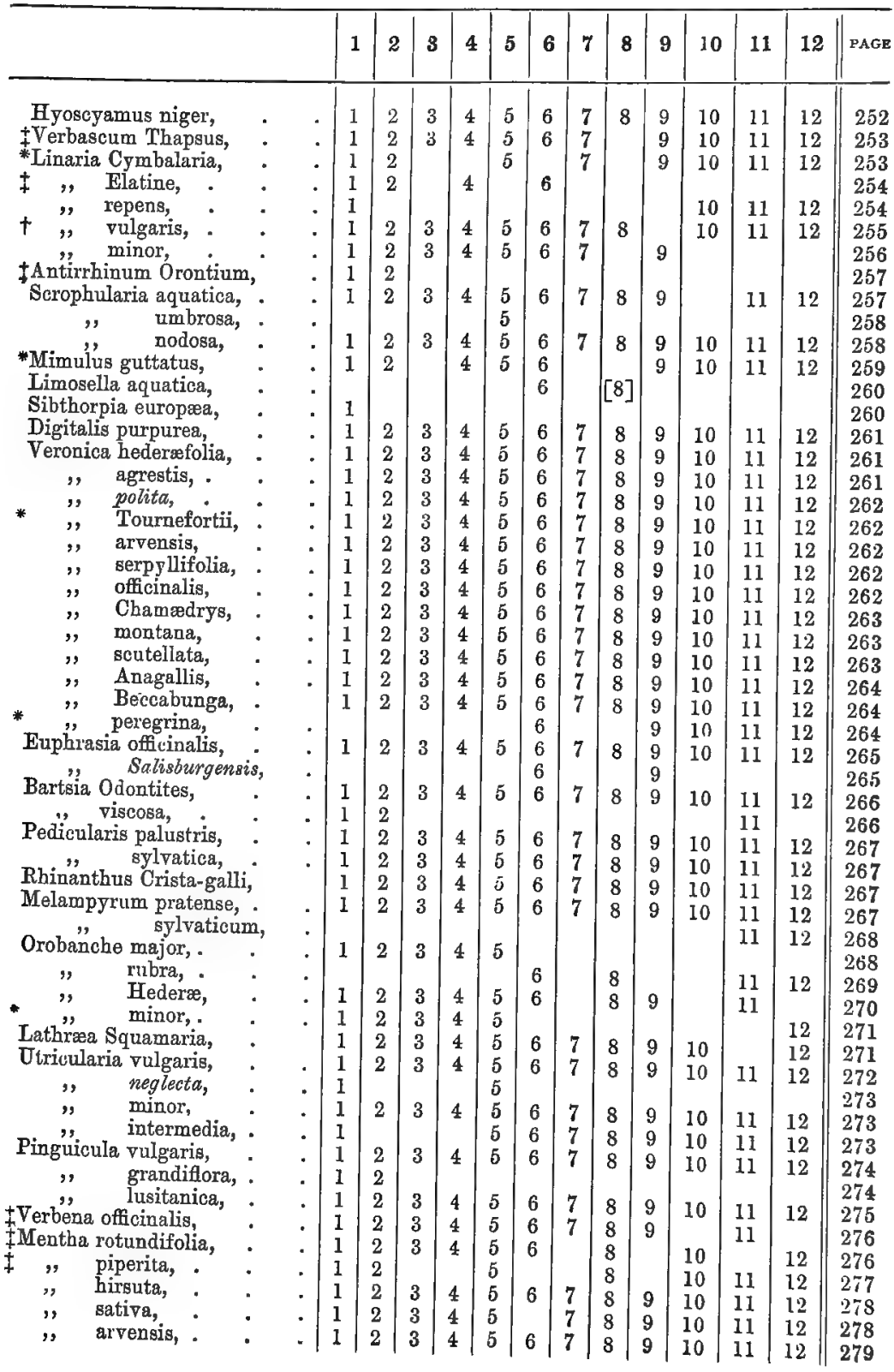




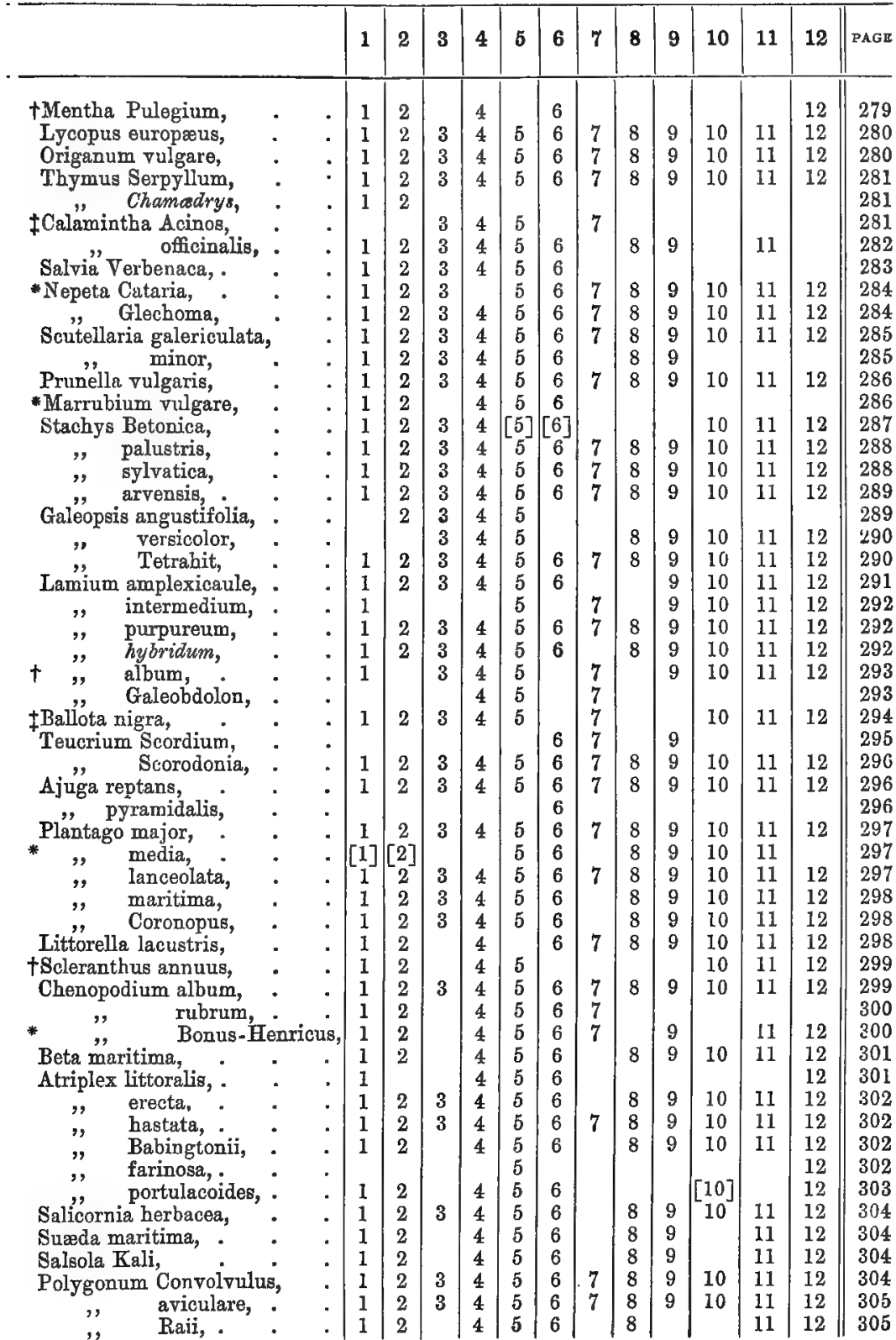




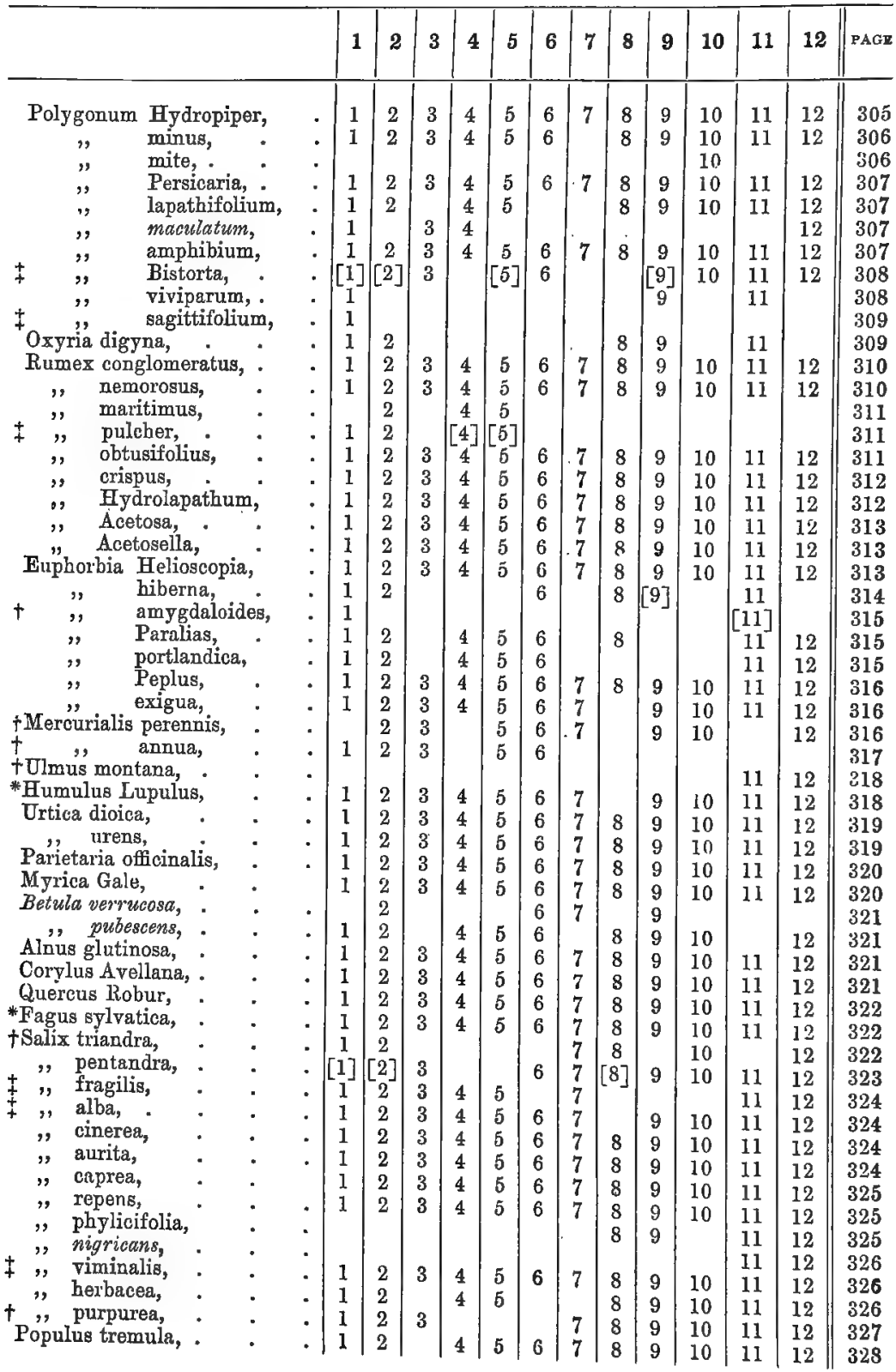




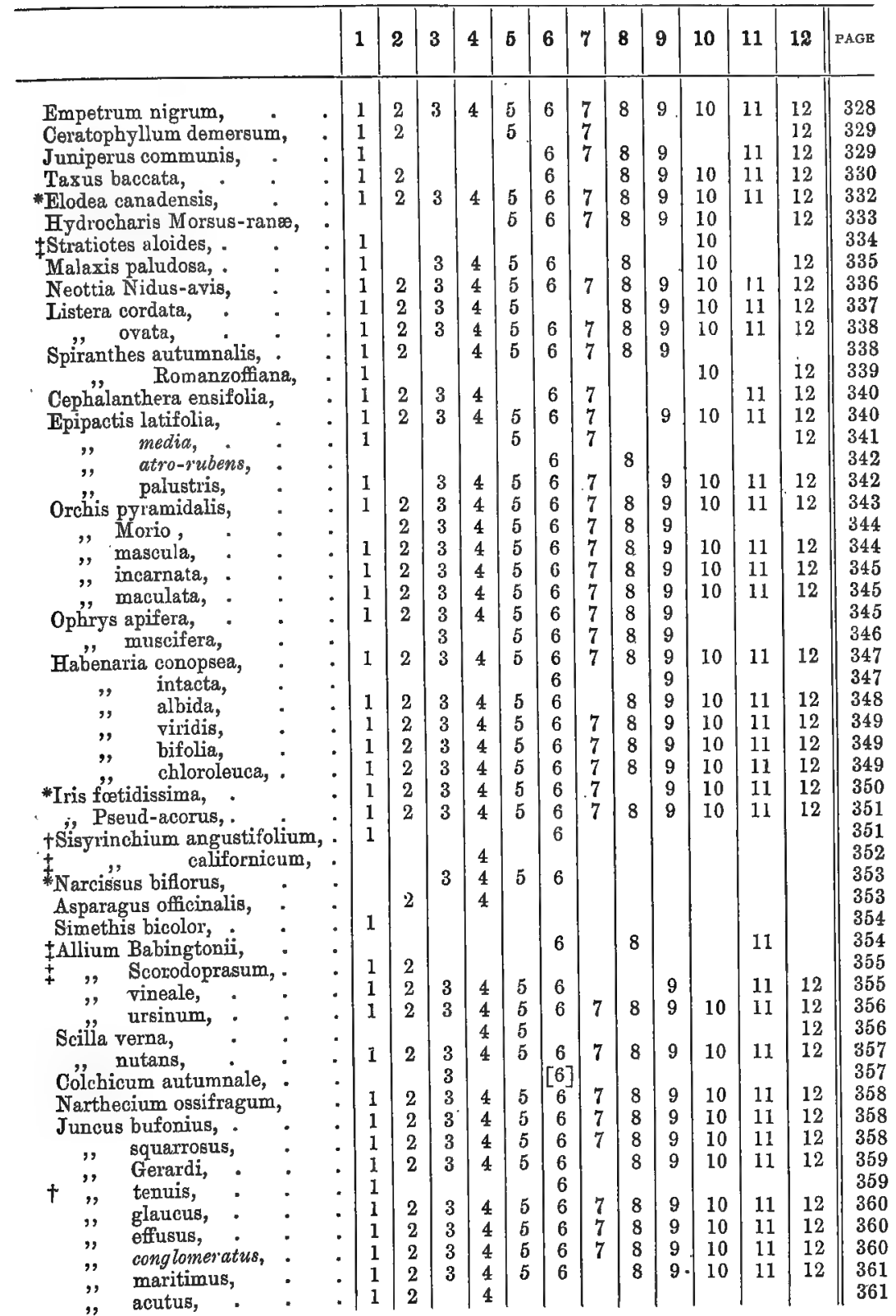




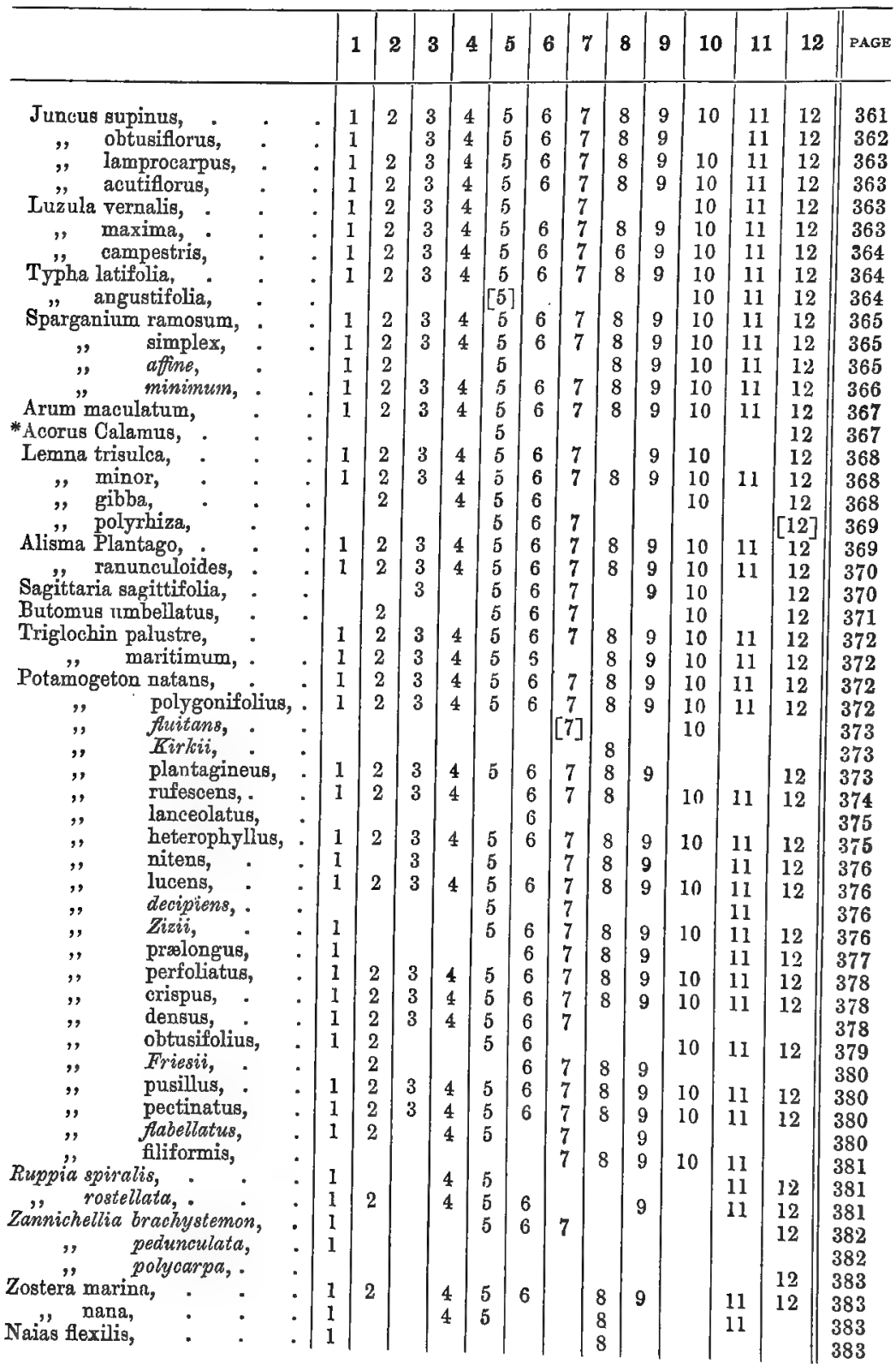




\section{\begin{tabular}{l|l|l|l|l|l|l|l|l|l|l|l||l}
1 & 2 & 3 & 4 & 5 & 6 & 7 & 8 & 9 & 10 & 11 & 12 & PAGE
\end{tabular}}

Eriocaulon septangulare,

Eleocharis acicularis,

" palustris,

, uniglumis,

" multicaulis,

Scirpus pauciflorus,

,) cœespitosu

" parvulus,

"Savii,

" setaceus,

"Tabernomontan

" maritimus,

" sylvaticus,

1" rufus,

Eriophorum vaginatum,

, angustifolium,

1 latifolium, .

Rhynchospora fusca,

Schonus nigricans,
Cladium mariscus,
Carex dioica,

\begin{tabular}{|c|c|c|c|}
\hline & & & \\
\hline & pulicaris, & - & \\
\hline & paucifora, & . & - \\
\hline , & divisa, . & - & - \\
\hline 39 & disticha, & - & - \\
\hline , & arenaria, & - & - \\
\hline "3 & teretiuscula & & - \\
\hline ? & paradoxa, & $\cdot$ & $\cdot$ \\
\hline , & vulpina, & . & - \\
\hline 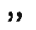 & muricata, & . & . \\
\hline 2 & divulsa, & . & . \\
\hline , & echinata, & - & - \\
\hline & remota, & - & - \\
\hline 9 & axillaris, & & \\
\hline ", & Bœnningha & & \\
\hline " & elongata, & - & - \\
\hline " & curta, - & • & • \\
\hline " & Buxbaumii & $\dot{0}$ & : \\
\hline 3 & Hudsonii, & . & . \\
\hline$"$ & acuta, : & - & \\
\hline " & trinervis, & - & . \\
\hline , & rigida, : & - & - \\
\hline ", & aquatilis, & - & - \\
\hline " & vulgaris, & - & - \\
\hline "9 & glauca, & - & 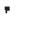 \\
\hline ני & 1mostifor & • & \\
\hline & præcox, & : & \\
\hline & pallescens, & 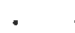 & \\
\hline & panicea, & - & . \\
\hline
\end{tabular}

\section{1}

- 1

- 13

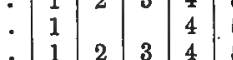

- 1

- 1

- 1

- 1

: 1

- 12

- 11203045

: 1

:

- 1

2

3

2

\begin{tabular}{lll}
3 & 4 \\
\hline
\end{tabular}

\begin{tabular}{ll|l|l}
3 & 4 \\
3 & 4
\end{tabular} 


\begin{tabular}{|c|c|c|c|c|c|c|c|c|c|c|c|c|c|c|c|c|}
\hline & & & & 1 & 2 & 3 & 4 & 5 & 6 & 7 & 8 & 9 & 10 & 11 & 12 & PAGE \\
\hline Carex pendula, & . & • & . & 1 & 2 & 3 & 4 & 5 & 6 & 7 & & 9 & 10 & 11 & 12 & 404 \\
\hline ", strigosa, & . & - & . & 1 & 2 & 3 & 4 & อิ & & & & 9 & 10 & 11 & 12 & 405 \\
\hline " sylvatica, & . & . & . & 1 & 2 & 3 & 4 & 5 & 6 & 7 & 8 & 9 & 10 & 11 & 12 & 405 \\
\hline ", lævigata, & - & - & - & 1 & 2 & 3 & 4 & 5 & 6 & 7 & 8 & 9 & 10 & 11 & 12 & 406 \\
\hline ", binervis, & - & - & . & 1 & 2 & 3 & 4 & 5 & 6 & 7 & 8 & 9 & 10 & 11 & 12 & 406 \\
\hline$"$ distans, & - & • & • & 1 & 2 & & 4 & 5 & 6 & & 8 & 9 & 10 & 11 & 12 & 407 \\
\hline " punctata, & & $\cdot$ & & 1 & & & & & & & & & & & & 407 \\
\hline ", Hornschuch & liana, & - & . & 1 & 2 & 3 & 4 & 5 & 6 & 7 & 8 & 9 & 10 & 11 & 12 & 407 \\
\hline ", extensa, & - & - & • & 1 & 2 & 3 & 4 & 5 & 6 & & 8 & & & 11 & 12 & 407 \\
\hline "flava, : & - & - & - & 1 & 2 & 3 & 4 & 5 & 6 & 7 & 8 & 9 & 10 & 11 & 12 & 408 \\
\hline ", filiformis, & - & - & . & 1 & & 3 & & 5 & 6 & 7 & 8 & 9 & 10 & 11 & {$[12]$} & 408 \\
\hline ", hirta, . & - & . & . & 1 & 2 & 3 & 4 & 5 & 6 & 7 & 8 & 9 & 10 & 11 & 12 & 409 \\
\hline "Pseudo-cype & erus, & - & . & 1 & 2 & 3 & 4 & 5 & 6 & 7 & 8 & 9 & 10 & & 12 & 409 \\
\hline " paludosa, & $\cdot$ & - & . & 1 & 2 & 3 & 4 & 5 & 6 & 7 & & 9 & 10 & & 12 & 410 \\
\hline " riparia, & - & - & . & 1 & 2 & 3 & 4 & 5 & 6 & 7 & & & 10 & 11 & 12 & 411 \\
\hline " ampullacea, & & - & - & 1 & 2 & 3 & 4 & 5 & 6 & 7 & 8 & 9 & 10 & 11 & 12 & 411 \\
\hline $\begin{array}{l}\text { "rhyncophysa, } \\
\text { "vesicaria. }\end{array}$ & & - & - & & & & & & & & & & 10 & & & 412 \\
\hline $\begin{array}{l}\text { vesicaria, } \\
\text { Phalaris arundinao }\end{array}$ & & • & - & 1 & 2 & 3 & 4 & 5 & 6 & 7 & 8 & 9 & 10 & 11 & 12 & 412 \\
\hline & cea, & . & - & 1 & 2 & 3 & 4 & 5 & 6 & 7 & 8 & 9 & 10 & 11 & 12 & 413 \\
\hline $\begin{array}{l}\text { Anthoxanthum odo } \\
\text { Alopecurus genicul }\end{array}$ & loratu & & • & 1 & 2 & 3 & 4 & 5 & 6 & 7 & 8 & 9 & 10 & 11 & 12 & 413 \\
\hline $\begin{array}{l}\text { Alopecurus genicul } \\
\text { pratens }\end{array}$ & llatus, & & - & 1 & 2 & 3 & 4 & $\mathbf{5}$ & 6 & 7 & 8 & 9 & 10 & 11 & 12 & 413 \\
\hline Milium effusum, & sis, & - & . & 1 & 2 & 3 & 4 & 5 & 6 & 7 & 8 & 9 & 10 & 11 & 12 & 413 \\
\hline $\begin{array}{l}\text { Milium effusum, } \\
\text { Phleum pratense, }\end{array}$ & $\cdot$ & . & - & 1 & 2 & 3 & 4 & & & 7 & 8 & 9 & 10 & 11 & 12 & 414 \\
\hline & & - & - & 1 & 2 & 3 & 4 & 5 & 6 & 7 & 8 & 9 & 10 & 11 & 12 & 414 \\
\hline Agrostis canina, & & $\dot{0}$ & - & 1 & $\begin{array}{l}2 \\
2\end{array}$ & 3 & 4 & 5 & 6 & & & 9 & & 11 & 12 & 415 \\
\hline " alba, & - & - & • & 1 & 2 & $\begin{array}{l}5 \\
3\end{array}$ & $\begin{array}{l}4 \\
4\end{array}$ & $\begin{array}{l}5 \\
5\end{array}$ & $\begin{array}{l}6 \\
6\end{array}$ & 7 & $\begin{array}{l}8 \\
8\end{array}$ & $\begin{array}{l}9 \\
9\end{array}$ & $\begin{array}{l}10 \\
10\end{array}$ & $\begin{array}{l}11 \\
11\end{array}$ & 12 & 415 \\
\hline " vulgaris, & & . & - & 1 & 2 & 3 & 4 & 5 & 6 & 7 & 8 & 9 & 10 & 11 & 12 & $\begin{array}{l}416 \\
416\end{array}$ \\
\hline Calamagrostis Epig & geios, & & - & & & & & & 6 & & 8 & & & & 12 & .416 \\
\hline Psamma arenaria, & eta, & $\dot{.}$ & • & 1 & 2 & & 4 & & 6 & & & & 10 & & 12 & 417 \\
\hline Aira caryophyllea, & & . & & $i$ & 2 & 3 & 4 & $\frac{D}{5}$ & $\begin{array}{l}6 \\
6\end{array}$ & 7 & $\begin{array}{l}8 \\
8\end{array}$ & 9 & & 11 & 12 & 417 \\
\hline "præcox, . & & - & . & 1 & 2 & 3 & 4 & 5 & 6 & 7 & $\begin{array}{l}\circ \\
8\end{array}$ & $\begin{array}{l}9 \\
9\end{array}$ & 10 & 11 & 12 & 417 \\
\hline Deschampsia cæspi & itosa, & & . & 1 & 2 & 3 & 4 & 5 & 6 & 7 & 8 & 9 & 10 & 11 & 12 & 418 \\
\hline$" \quad$ alpin & & & & 1 & & & & & & & 8 & & & 11 & 12 & 418 \\
\hline $\begin{array}{l}\text { discol } \\
\text { flexu }\end{array}$ & & & & & & & & & & & 8 & & & & & $\begin{array}{l}418 \\
418\end{array}$ \\
\hline Holcu' mollis, & Losa, & & & 1 & 2 & 3 & 4 & 5 & 6 & 7 & 8. & 9 & 10 & 11 & 12 & 419 \\
\hline $\begin{array}{l}\text { Holcus mollis, } \\
\text { lanatus, }\end{array}$ & • & - & & 1 & 2 & 3 & 4 & 5 & 6 & 7 & 8 & 9 & 10 & 11 & 12 & 419 \\
\hline Trisetum flavescen & & & & 1 & 2 & 3 & 4 & 5 & 6 & 7 & 8 & 9 & 10 & 11 & 12 & 419 \\
\hline $\begin{array}{l}\text { Trisetum flavescen } \\
\text { Avena pubescens, }\end{array}$ & & & & 1 & 2 & 3 & 4 & 5 & 6 & 7 & 8 & 9 & 10 & & 12 & 419 \\
\hline $\begin{array}{l}\text { Avena pubescens, } \\
\text { Arrhenatherum ave }\end{array}$ & & & - & 1 & 2 & 3 & 4 & 5 & 6 & 7 & 8 & 9 & 10 & 11 & 12 & 420 \\
\hline & enace & $\mathrm{m}$ & - & 1 & 2 & 3 & 4 & 5 & 6 & 7 & 8 & 9 & 10 & 11 & 12 & 420 \\
\hline $\begin{array}{l}\text { Triodia decumbens, } \\
\text { Phragmites commu }\end{array}$ & & - & - & 1 & 2 & 3 & 4 & 5 & 6 & 7 & 8 & 9 & 10 & 11 & 12 & 420 \\
\hline & Inis, & $\cdot$ & & 1 & 2 & 3 & 4 & 5 & 6 & 7 & 8 & 9 & 10 & 11 & 12 & 420 \\
\hline Cynosurus cristatus & & - & & & & & & & 6 & 7 & 8 & 9 & 10 & 11 & & 421 \\
\hline Kœleria cristata, & & * & & 1 & 2 & 3 & 4 & 5 & 6 & 7 & 8 & 9 & 10 . & 11 & 12 & 421 \\
\hline Molinia cærulea, & & : & & 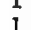 & 2 & & 4 & 5 & 6 & 7 & 8 & 9 & & 11 & 12 & 422 \\
\hline Catabrosa aquatica, & & & & 1 & 2 & 3 & 4 & 5 & 6 & 7 & 8 & 9 & 10 & 11 & 12 & 422 \\
\hline Melica uniflora, & & : & & 1 & 2 & 3 & 4 & 5 & 6 & 7 & 8 & 9 & 10 & 11 & 12 & 422 \\
\hline Dactylis glomerata, & & : & & 1 & 2 & 3 & 4 & 5 & 6 & 7 & 8 & 9 & 10 & 11 & 12 & 422 \\
\hline Briza media,. & $?$ & : & - & 1 & 2 & 3 & 4 & 5 & 6 & 7 & 8 & 9 & 10 & 11 & 12 & 423 \\
\hline Poa annua, & • & - & & $\frac{1}{1}$ & $\begin{array}{l}2 \\
2\end{array}$ & $\begin{array}{l}3 \\
3\end{array}$ & 4 & 5 & 6 & 7 & 8 & 9 & 10 & 11 & 12 & 423 \\
\hline " alpina, : & - & . & & 1 & & & & 5 & 6 & 7 & 8 & 9 & 10 & 11 & 12 & 423 \\
\hline " nemoralis, & & & & & & & & 5 & 6 & 7 & & & & & 12 & $\begin{array}{l}423 \\
424\end{array}$ \\
\hline
\end{tabular}




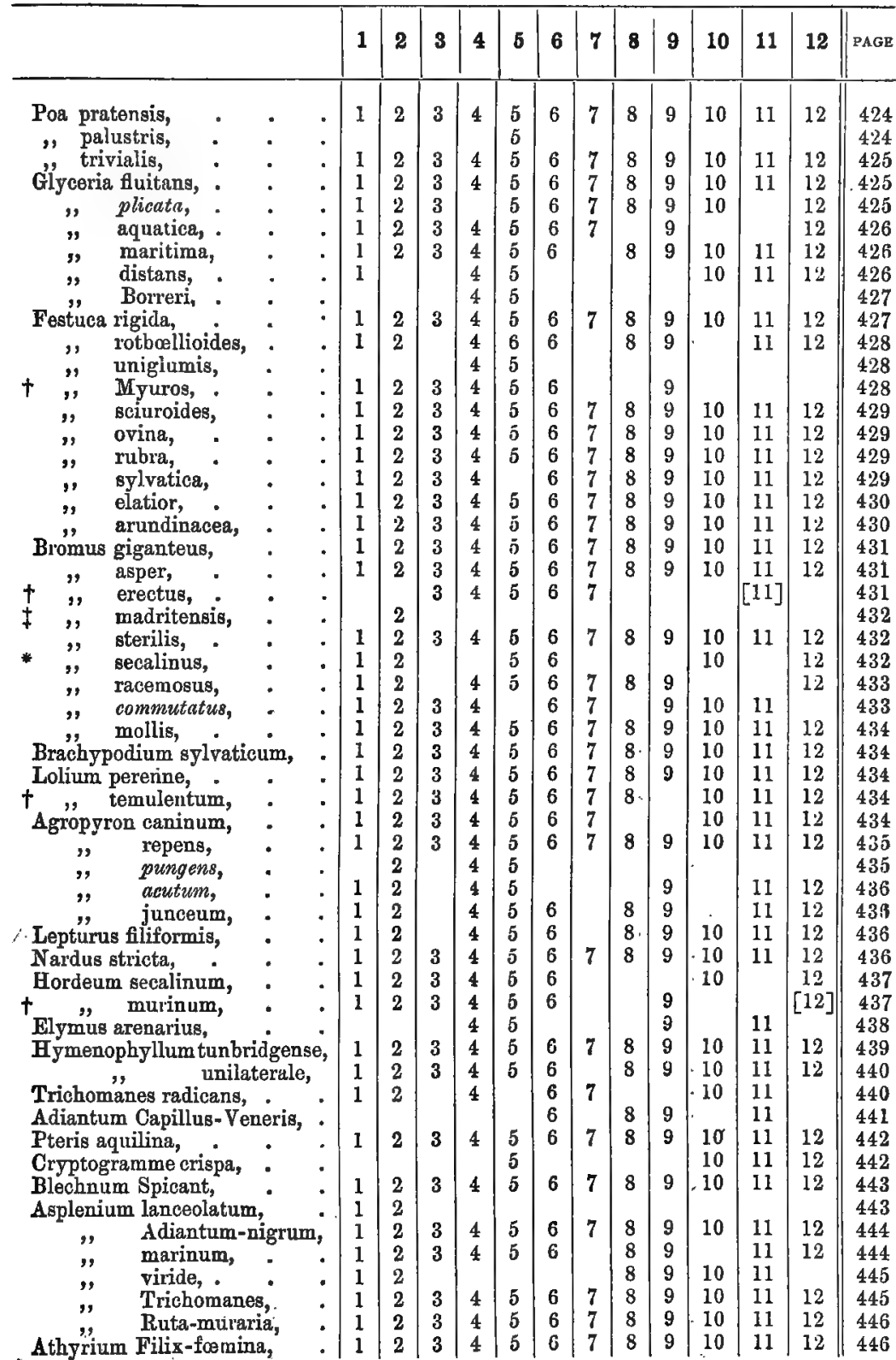




\begin{tabular}{|c|c|c|c|c|c|c|c|c|c|c|c|c|c|c|c|}
\hline & & & 1 & 2 & 3 & 4 & $\mathbf{5}$ & 6 & 7 & 8 & 9 & 10 & 11 & 12 & PAGH \\
\hline Ceterach officinarum, & & & 1 & 2 & 3 & 4 & 5 & 6 & 7 & 8 & 9 & 10 & 11 & 12 & 446 \\
\hline Scolopendrium vulgare, & $\cdot$ & & 1 & 2 & 3 & 4 & 5 & 6 & 7 & 8 & 9 & 10 & 11 & 12 & 446 \\
\hline Cystopteris fragilis, & - & & 1 & 2 & 3 & 4 & 5 & 6 & 7 & 8 & 9 & 10 & 11 & 12 & 447 \\
\hline Aspidium Lonchitis, & - & . & 1 & & & & & & & 8 & 9 & & 11 & & 448 \\
\hline ," aculeatum, & . & . & 1 & 2 & 3 & 4 & 5 & 6 & 7 & 8 & 9 & 10 & 11 & 12 & 448 \\
\hline , angulare, & . & & 1 & & 3 & 4 & 5 & 6 & 7 & 8 & 9 & 10 & 11 & 12 & 449 \\
\hline Lastrea Thelypteris, & - & . & 1 & & & 4 & 5 & 6 & 7 & 8 & 9 & 10 & 11 & 12 & 449 \\
\hline$"$ Oreopteris, & • & & 1 & 2 & 3 & 4 & 5 & 6 & 7 & 8 & 9 & 10 & 11 & 12 & 450 \\
\hline Filix-mas, & . & & 1 & 2 & 3 & 4 & 5 & 6 & 7 & 8 & 9 & 10 & 11 & 12 & 450 \\
\hline spinulosa, . & . & & 1 & 2 & 3 & 4 & 5 & 6 & 7 & 8 & 9 & 10 & 11 & 12 & 450 \\
\hline "dilatata, . & - & & 1 & 2 & 3 & 4 & 5 & 6 & 7 & 8 & 9 & 10 & 11 & 12 & 451 \\
\hline$\Rightarrow$ xmula, . & - & & 1 & 2 & 3 & 4 & 5 & 6 & 7 & 8 & 9 & 10 & 11 & 12 & 451 \\
\hline Polypodium vulgare, & & & 1 & 2 & 3 & 4 & 5 & 6 & 7 & 8 . & 9 & 10 & 11 & 12 & 451 \\
\hline , Dryopteris & & & & & & 4 & & 6 & & & 9 & & & [12] & 452 \\
\hline " Phegopteri & & & 1 & 2 & 3 & 4 & 5 & 6 & & 8 & 9 & 10 & 11 & 12 & 452 \\
\hline Osmunda regalis, & . & & 1 & 2 & 3 & 4 & 5 & 6 & .7 & 8 & 9 & 10 & 11 & 12 & 453 \\
\hline Ophioglossum vulgatum & & & 1 & 2 & 3 & 4 & 5 & 6 & 7 & 8 & 9 & 10 & 11 & 12 & 453 \\
\hline Botrychium I & - & & 1 & 2 & 3 & 4 & 5 & 6 & 7 & 8 & 9 & 10 & 11 & 12 & 454 \\
\hline Equísetum maxi & - & & 1 & 2 & 3 & 4 & 5 & 6 & 7 & 8 . & 9 & 10 & 11 & 12 & 454 \\
\hline , arvense, & : & - & 1 & 2 & 3 & 4 & o & 6 & 7 & 8 & 9 & 10 & 11 & 12 & 454 \\
\hline $\begin{array}{l}\text { prat } \\
\text { sylv }\end{array}$ & : & & & & & & 5 & 6 & 7 & 8 & 9 & 10 & & & $\begin{array}{l}455 \\
455\end{array}$ \\
\hline $\begin{array}{l}\text { sylvaticum } \\
\text { palustre, }\end{array}$ & . & & 1 & $\begin{array}{l}2 \\
2\end{array}$ & $\begin{array}{l}3 \\
3\end{array}$ & $\begin{array}{l}4 \\
4\end{array}$ & $\begin{array}{l}0 \\
5\end{array}$ & 6 & 7 & 8 & 9 & 10 & $\begin{array}{l}11 \\
11\end{array}$ & $\begin{array}{l}12 \\
12\end{array}$ & $\begin{array}{l}400 \\
455\end{array}$ \\
\hline $\begin{array}{l}\text { paustre, } \\
\text { limosum, }\end{array}$ & . & & 1 & 2 & 3 & $\begin{array}{l}4 \\
4\end{array}$ & 5 & 6 & 7 & 8 & 9 & 10 & 11 & $\begin{array}{l}12 \\
12\end{array}$ & 456 \\
\hline hyemale, & . & - & 1 & & 3 & 4 & 5 & & 7 & & & 10 & 11 & 12 & 456 \\
\hline Moorei, & - & & & & & 4 & & & & & & & & & 457 \\
\hline ", tract & . & & 1 & 2 & & & & 6 & & 8. & 9 & & & 12 & 457 \\
\hline "variegatum, & & & 1 & & 3 & & 5 & 6 & 7 & 8 & 9 & & 11 & 12 & 458 \\
\hline $\begin{array}{c}\text { Lycopodium Selago, } \\
\text { inundatum }\end{array}$ & - & " & 1 & 2 & 3 & 4 & 5 & 6 & 7 & $\begin{array}{l}8 \\
8\end{array}$ & 9 & 10 & 11 & 12 & 459 \\
\hline clavatum, & ? & & 1 & [2] & 3 & 4 & 5 & & 7 & 8. & 9 & 10 & 11 & 12 & $\begin{array}{l}409 \\
459\end{array}$ \\
\hline ", alpinum, & $\cdot$ & & 1 & & & 4 & & & & 8 & 9 & 10 & 11 & 12 & 460 \\
\hline Selaginella selaginoides & & - & 1 & & 3 & 4 & 5 & 6 & 7 & 8 & 9 & 10 & 11 & 12 & 461 \\
\hline Isoetes lacustris, & - & - & 1 & 2 & & 4 & & & & 8. & 9 & 10 & 11 & 12 & 461 \\
\hline $\begin{array}{l}\text { echinospor'a, } \\
\text { Pilularia globulifera, }\end{array}$ & • & & $\begin{array}{l}1 \\
1\end{array}$ & & & & & & & $\begin{array}{l}8 \\
8\end{array}$ & & 10 & & & $\begin{array}{l}462 \\
462\end{array}$ \\
\hline Chara fragilis, - & - & - & 1 & 2 & 3 & 4 & 5 & 6 & 7 & 8. & 9 & 10 & 11 & 12 & 463 \\
\hline ,, connivens, . & & & & & & 4 & & & & & & & & & 464 \\
\hline aspera, ${ }^{\circ}$ & - & & 1 & & 3 & 4 & 5 & 6 & 7 & 8. & 9 & 10 & 11 & 12 & 464 \\
\hline " polyacantha, & - & & & 2 & 3 & 4 & 5 & 6 & 7 & 8. & 9 & 10 & & & 464 \\
\hline $\begin{array}{l}\text { " contraria, } \\
\text { denudata, }\end{array}$ & • & • & 1 & & 3 & & & 6 & 7 & 8 & 9 & 10 & & 12 & $\begin{array}{l}465 \\
465\end{array}$ \\
\hline tomentosa, . & . & & & & & & & 6 & 7 & & 9 & & & & 46 \\
\hline hispida, . & - & - & 1 & 2 & 3 & 4 & 5 & 6 & 7 & 8 & 9 & 10 & & 12 & 466 \\
\hline " vu]garis, & - & - & 1 & 2 & 3 & 4 & 5 & 6 & 7 & 8 & 9 & 10 & 11 & 12 & 467 \\
\hline Tólypella glomerata, & & & 1 & & & 4 & & & & & & & & & 467 \\
\hline " prolifera, & & & & & & 4 & 5 & 6 & 7 & & 9 & & & & $\begin{array}{l}467 \\
468\end{array}$ \\
\hline $\begin{array}{l}\text { intricata, } \\
\text { Nitella Nordstedtiana, }\end{array}$ & . & & 1 & & & & 5 & & & & & & & & 468 \\
\hline " tenuissima, & . & & & & & & & 6 & 7 & & & & & & $\begin{array}{l}468 \\
469\end{array}$ \\
\hline " grac1 & - & • & & & & 4 & & & & & & & & & 469 \\
\hline $\begin{array}{l}\text { " trans } \\
" \quad \text { flexil }\end{array}$ & - & - & 1 & & & & & & & 8 & 0 & 10 & & 12 & 469 \\
\hline " opaca, & - & & 1 & 2 & 3 & 4 & 5 & 6 & 7 & 8 & 9 & $\begin{array}{l}10 \\
10\end{array}$ & 11 & 12 & $\begin{array}{l}470 \\
470\end{array}$ \\
\hline
\end{tabular}




\section{CONTRIBUTIONS}

\section{TOWARDS A \\ CYBELE HIBERNICA.}

DICOTYLEDONES.

ORDER I.-RANUNCULACER.

THALICTRUM Linn.

1. T. alpinum Linn.-Alpine Meadov-Rue.

Districts I. - - - - - VIII. IX. - XI. Lat. 52 $2^{\circ} 55^{\circ}$. West Ireland. Type, Highland.

Wet rocks and grassy slopes on mountains; rare. Fl. JulyAugust.

I. Brandon mountain, Kerry (Rev. A. Ley): Journ. of Bot. 7887.-VIII. Mountains above Kylemore Castle, Connemara (Moore): Rec. Add. Croaghpatrick, in Mayo; Muckanaght (Twelve Bens), Benchoona and Maumeen, in Galway : Hart r883a. Near the summit of Lettery mountain, Ballinahinch, 1800: Wade Gallovid.-and in 1882: Hart 1883 a.-IX. Near the summit of Ben Bulben: Murphy I829. Cliffs at Anna Coona over Gleniff: B. \& V. r885.-XI. Poisoned Glen, Dunlewy and Slieve League: Hart $1885 \gamma$. Blue Stack mountains in several places: Hart I88 $\beta$. Slieve Snacht west, 1884: N. C. Alt mountain near Ardara: Hart 1886.

From 900 to $2150 \mathrm{ft}$. in Donegal (Hart); at $1930 \mathrm{ft}$. in Sligo (B.\& V.); 1300-2110 ft. in Galway (Hart); at $2000 \mathrm{ft}$. in Kerry (Rev. A. Ley).

First found by Wade, on Ben Lettery, in 1800. 
2. T. minus Linn. (Aggregate).-Lesser Meadow-Rue.

Districts I. II. III. IV. V. VI. VII. VIII. IX. X. XI. XII. Lat. 51 $\frac{3}{4}^{\circ}-55 \frac{1}{4}^{\circ}$. Throughout Ireland. Type, Scottish-British.

Stony places and sand-hills; local. Fl. June-August.

T. drenense Dum.

Districts - - IV. V. - - - - - XII. Lat. $521^{\circ}-551^{\circ}$. East Ireland only.

Sand-hills and sandy shores; local. Fl. June-Juty.

IV. South of Cahore Point and on to Courtown, Wexford: Hart I88I a. Kiltennel, Wexford (Miss E. M. Farmer); sandhills north of Arklow (More): Rec. Add.-V. On Ireland's Eye, Howth: Wade Rar. 1804-and in 1882: N. C. Portrane and Malahide, Co. Dublin; More. Near Rob's Walls, Malahide, 1897 ; Miss S. Colgan. Sand-hills at Rush: Miss A. G. Kinahan.XII. Near Newcastle, 1793 (Templeton): Whitla MS.-and in 1878 (Corry): Flor. N.-E. Sand-hills near Portrush, Antrim, 1852 : Babington in Herb. In profusion on Ballykinler sands east of Dundrum (Stewart); also sparingly at Ballycastle (Corry): Flor. $N$. $E$.

T. collinum Wallr.

Distxicts I. - - - VI. VII. VIII. IX. X. - XII. Lat. $52^{\circ}-54 \frac{1}{2}^{\circ}$. From South to North.

Rocky lake shores and on mountain cliffs; local. Fl. JulyAugust.

I. Ross island; shore of Middle Lake and Mangerton mountain, Killarney; $R$. W. S.-VI. Rocks at Black Head, Clare (P. $B$. O'Kelly): Wats. B. Ex. Club Rep. 2894. Among rocks at the mouth of the Rossmore river, Lough Derg (C.J. Lilly): Ir. Nat. I896.-VII. Abundant on limestone rocks at Slevoir Point, Lough Derg, Tipperary : N.C. 1897.-VIII. Mweelrea and Glencullen in Mayo; Ben Choona, Galway: Hart 1883 a. Shore of Lough Corrib below Carn Seefin: P. \& C. 1895. By the river at Oughterard very luxuriant, and north shore of the Narrow Lake, west of Lough Mask: M. \&S. I806.-IX. North face of Ben Bulben; Anna Coona and cliffs of Glenade, nowhere plentiful: B. \& V. 1885 . Limestone rocks, south of Lough Mask: $M . \& S$. 1806. - $\mathbf{X}$. Sparingly on Goat Island and at Gubbaroe Point, Kesh: Barrington 1884.-XII. By Kilbroney river; on Pigeon Rock mountain and on Cove mountain: S. \& P. I 892. 
Although the numerous Irish records for T. floxuosum (Bernh.), T. majus (Smith), T. Koohii (Fries) and T. calcareum (Jord.) should, no doubt, be referred to this sub-species, it has seemed best to put under it only such plants as have been verified by competent authority either as T. collinum (Wallr.), or as the perhaps scarcely distinct $T$. montanum of the same author.

\section{T. flavum Linn.-Marsh Meadow-Rue.}

Districts - II. III. IV. V. VI. VII. VIII. IX. X: - XII. Lat. $52 \frac{1}{4}^{\circ}-54 \frac{3}{4}^{\circ}$. From South to North. Type, English.

Lowland. River sides, ditches and marshy places; rather rare. Fl. June-July.

II. In several places along the river Suir from Camus Bridge to Clonmel : Hart I885 a.-III. In marshy grounds in Sir Robert Staples' woods, Queen's Co.: Mack. Rar. Ditch near the river Barrow, below Athy; $R . W . S$. By the Nore at Bennett's Bridge: Hart $I_{885} \delta$. Meadows by the Barrow at Ullard wood, Kilkenny, 1896 ; Rev. T. Hartley.-IV. Marshy fields by the Morrough of Wicklow: Moore \& More 7878 .-V. By the river Boyne, between the Obelisk and Slane : Ir. Flor. Boyne, near Navan : R.W.S.VI. Garryland, near Gort: More 1855--VII. Plentifully on the banks of the Inny river, Longford: Foot 1865. Ladestown, near Lough Ennel (Levinge) and Dysart, near Delvin (Miss E. Reynell): Levinge I894. Abundant on the banks of the Borrisokane river, Co. Tipperary (C. J. Lilly) : Ir. Nat. 1896.-VIII. Recorded for this district in first edition of $C y b$., but no locality available.-IX. Banks of the Suck, near Ballinasloe, Roscommon : Praeger 1896. X. On Killygowan island, upper Lough Erne: Barrington $1884 .-$ XII. Near Toom Bridge, Derry : Moore MIS. Shane's Castle (Corry), Cranfield Point (Stewart) and other stations round Lough Neagh : Flor. N.-E. Langford Lodge, Antrim: S. \& P. 1895.

\section{ANEMONE Linn.}

\section{A. nemorosa Linn.-Wood Anemone.}

Districts I. II. III. IV. V. VI. VII. VIII. IX. X. XI. XII. Lat. $51 \frac{1}{2}^{\circ}-55 \frac{1}{4}^{\circ}$. Throughout Ireland. Type, British.

Woods, hedge-banks, and shady places; rather common. Fl. March-May.

Sea-level in N. Derry and S. Cork. To $1450 \mathrm{ft}$. in Derry (Hart); to $1800 \mathrm{ft}$. in Louth (Flor. N.-E.); to $2080 \mathrm{ft}$. in Wicklow (Hart). 
A state of this species with light-blue flowers, resembling those of $A$. apennina, grows abundantly in Glenshalane, Cappoquin, and Ounashad Glen, Lismore, and is found to retain its colour under cultivation ( $F, E$. Currey).

\section{RANUNCULUS Linn.}

1. R. circinatus Sibth.-Rigid Water-Cronfoot.

R. divarioatus Schrank.-Batrachium divaricatum Wimm. Districts I. - III, - V. VI. VII. - IX. X. - XII. Lat. $52^{\circ}-54 \frac{1}{2}{ }^{\circ}$. South to North. Type, English-Germanic.

Lowland. Pools, streams, and canals; rather rare. Fl. MayJune.

I. In the Lough of Cork: Flor. Cork-but not seen there recently.-III, In the river Barrow, near Monasterevan (Moore): Cyb. In the Grand Canal at Portarlington, Queen's Co.: Praeger 7897.- $\nabla$. In the Liffey, near Chapelizod (More), and near Straffan, Kildare (J. Douglas): Cyb. Plentiful in the Royal and Grand Canals, Co. Dublin, 1895; N. C. Lough Crew, near Oldcastle, Meath : Praeger 1897.-VI. Near Limerick (Prof. Harvey): Cyb. Inchiquin Lake, Co. Clare, 1892: Levinge._VII. Drains by Inny river, near Ballymahon, and in the Royal Canal, Longford : $B . \& \vec{V}$. 1887. Brittas Lake, Knock Drin, Westmeath : Levinge 1895.IX. River Suck, at Mount Talbot, Roscommon; Levinge. X. Abundant in Derryadd Bay, Lough Neagh: Praeger 1893.XII. In the Lagan canal, near Lough Neagh (Prasger): B.N.F.C. Proc, 1892-93.

2. R. fluitans Lamk,-Long-leaved Water-Crowfoot.

District - - - - - - - - - XII. Lat. 54 $\frac{3}{4}^{\circ}$. North-east. Antrim only. Type, English.

Lowland. In swift streams; very rare. Fl. June-August.

XII. Plentiful in the Sixmilewater close to Dunadry station, and lower down to Muckamore; also a little distance above where the river empties into Lough Neagh (Stewart): Flor. N.-E.

\section{- 3. R. trichophyllus Chaix.-Hair-leaved Water-Crowfoot.}

Batrachium trichophyllum F, Schultz.

Districts I. IY. III. IV, Y. VI. VII. VIII. IX. X. XI. XII. Lat. $51 \frac{1}{2}^{\circ}-55 \frac{1}{4}^{\circ}$. Throughout Ireland. Type, English. ? 
Lowland. Still waters in lakes, pools, and quarry holes; frequent. Fl. May-June.

The form with floating leaves, variously named $R$. Godronii (Gren.), R. Drouettii (Godr.), and R. radians (Rev.), has been found in Westmeath, Louth, King's Co., Donegal, Keiry, Dublin, Galway, and Mayo.

4. R. heterophyllus Fries.-Common Water-Crowfoot.

Districts - - - V. - VII. VIII. - X. - XII. Lat. $53^{\circ}-55^{\circ}$. Middle and North Ireland.

Lowland. Still waters or slow streams; frequent. $F$. MayJuly.

V. Frequent in Co. Dublin; N.C.-VII. In Lough Ree: B.\& V. I887.-VIII. Between Clonbur and Lough Mask: M. \& S. 1896.-X. Ditches on Devenish, Lough Erne: Barrington I884.XII. Copeland Island, Groomsport, and Clandeboye Lake, Down (Stewart); shore of Lough Neagh, near Crumlin (Corry), \&c.; frequent in the north-east: Flor. $N$.-E.

Probably more widely distributed than would appear from the foregoing records.

Var. triphyluos (Wallr.).-V. Near Baldoyle, Co. Dublin; W. T. Dyer \& More.

R. peltatus Fries.

Batrachium truncatum Dum.

Districts I. II. III. IV. V. - VII. VIII. IX. X. XI. XII. Lat. $51 \frac{1}{2}^{\circ}-55^{\circ}$. Throughout Ireland probably.

Lowland. Lakes and slow streams; frequent. Fl. May-A ugust.

The distribution here given includes that of $R$. floribundus (Bab.) which has been recorded from Districts III. IV. V. VIII. IX. and XII.

Var. TRuncatus Hiern.-XII. Near Saintfield and Lough Mann, Co. Down (Rev. C. H. Waddell) : S. \& P. I895.

\section{R. penicillatus Dum.}

R. pseudo-fuitans Bab. (Man. 6th Ed.).

Districts I. II. III. IV. V. VI. VII. - IX. X. XI. XII. Lat. $52 \frac{1}{2}^{\circ}-54 \frac{1}{4}^{\circ}$; Throughout Ireland probably.

In swift streams; frequent. Fl. May-July.

To $750 \mathrm{ft}$. in Dublin (N.C.) but usually lowland. 


\section{R. Baudotii Godr.-Maritime Water-Crowfoot.}

Batrachium Baudotii F. Schultz.

Districts I. II. - IV. V. VI. - VIII. - - XI. Lat. $511^{\circ}-551^{\circ}$. From South to North.

Brackish pools and ditches near the sea, also occasionally inland; local. Fl. May-August.

I. Near Castlegregory, Kerry (Moore): $C y b$. Blennerville and Banna : R. W. S. 1889. Kilkern lake, Rosscarbery, Cork, 1891, and-II. Near Ballyvodock, Cork, 1896; Phillips. By the railway, near Waterford (Babington): Cyb.-IV. Lady's Island lake, Wexford : Hart 1883 B. Pools near Wexford Harbour, 1897 ; Rev. E. S. Marshall.-V. Pools near Baldoyle station, Dublin: Flor. Howth.-VI. By the Fergus at Ennis: Stewart 189o. Near Galway (Moore): Cyb. Rock pools, Inishmaan, Aran Isles, 1892; N.C. Oughtmama and Inchiquin lakes, Clare (Levinge): Wats. $B$. Ex. C.Rep. 1894.-VIII. Inishbofin: More 1876.-XI. Tory Island : Barrington 1879. Kildoney Point, Ballyshannon: Hart $1885 \gamma$.

Var. confusus Godr.-II. Pools near Cork: Carroll 7854.V. Brackish pools near Sutton, Co. Dublin, $1882: R$. P. Vowell.

6. R. tripartitus DC.-Three-lobed Water-Crowfoot.

District I.

Lat. $51 \frac{1}{2}^{\circ}$. South Cork only.

Lakes and pools near the sea; very rare. Fl. April-May.

I. Plentifully in a small lake near the sea to the south of Baltimore, Co. Cork, 1896 (Phillips) : Ir. Nat. 2896, p. 166.

Vair. INTERirEDIU: (Knaf).-I. Roadside pool near Adrigole, Cork, 1894; Phillips.

In the Journal of Botany, I896 (p. I77) Messrs. A. \& J. Groves state that the Baltimore specimens closely resemble in all respects the plant of western France. So far, this is the only known station in the British Isles for typical $R$. tripartitus.

7. R. Lenormandi F. Schultz,-Greater Ivy-leaved Crowfoot. R. conosus Godr.

Districts I. II. - IV. V. - - - - - Lat. $51 \frac{1}{2}^{\circ}-53 \frac{1}{4}^{\circ}$. Southern half of Ireland. Type, English.

Moist, sandy, and gravelly places; also in Sphagnum plashes in the mountains; locally abundant. $F$. June-August. Calcifuge $A$.

I. Gap of Dunloe, 1858: Herb. Babington. Near Lough Caragh: More. Killorglin, Rossbeigh, Glencar, and several places 
about Killarney : $R$. W. S. I889. Near Skibbereen, S. Cork, 1896; Phillips.-II. Frequent near Fermoy, Cork (T. Chandlee); on Galtymore, Tipperary (Moore) : Cyb.-IV. Clohass Bog, Wexford (Miss E. M. Farmer): Rec. Add. Alderton, Wexford: B.-H.\& G. I889. Glenmalure, Lough Dan, \&c.; common in Wicklow (More): Rec. Add.-V. Seecawn; Kippure Mountain, and many other stations in Dublin mountains; $N$. C.

Sea-level in S. Cork and Kerry. To $1900 \mathrm{ft}$. in Wicklow (N.C.).

\section{R. hederaceus Linn.-Ivy-leaved Crovfoot.}

Batrachium hederaceum S. F. Gray.

Districts I. II. III. IV. V. VI. VII. VIII. IX. X. XI. XII. Lat. $51 \frac{1}{2}^{\circ}-551^{\circ}$. Throughout Ireland. Type, British.

In shallow pools and ditches, chiefly on mud; frequent. Fl. April-August. Calcifuge $B$.

Sea-level in N. Antrim and in S. Cork. To $1000 \mathrm{ft}$. in Donegal (Hart); to $1200 \mathrm{ft}$. in Dublin (N.C.).

\section{R. sceleratus Linn.-Celery-leaved Crowfoot.}

Districts I. II. III. IV. V. VI. VII. VIII. IX. X. XI. XII. Lat. $51 \frac{1}{2}^{\circ}-55 x^{\circ}$. Throughout Ireland. Type, British.

Lowland. Ditches, pools, and moist ground, usually on clay soils, and most abundant near the sea; frequent, but local. Fl. June-August.

Rare in many parts of the west and north-west. The curious deep-water form with long-stalked floating leaves is uncommon.

10. R. Flammula Linn.-Lesser Spearwort.

Districts I. II. III. IV. V. VI. VII, VII. IX. X, XI. XII. Lat. $51 \frac{1}{2}^{\circ}-55 \frac{1^{\circ}}{2}$. Throughout Ireland. Type, British,

Watery places; very common. Fl. June-August.

The form pseudo-reptans of Syme is not uncommon, and a specimen from Dromod, Co. Leitrim, approaches to $R$. petiolaris of Marshall : Journ. of Bot. Dec. I892.

Sea-level in N. Antrim and S. Cork. To $2000 \mathrm{ft}$. in Donegal, and to $2500 \mathrm{ft}$. on Galtymore (Hart).

\section{R. Lingua Linn,-Great Spearwort.}

Districts I. II. III. IV. V. VI. VII. VIII. IX. X. - XII. Lat. 52 $2^{\circ}-55 \frac{1}{4}^{\circ}$. From South to North. Type, English-British.

Lowland. Margins of lakes and rivers, and in bog-drains and canals; local and rather rare. Fl. June-July. 
I. Lough Gill, Castlegregory : Hart I884.--II. Blarney river near the castle: Drummond 1819 . Swamp near Clonea, Dungarvan, and by the Suir river, Loughmore: Hart $2883 \beta$. Common in streams and drains about Blenheim: B.-H \& G. I $889 .-^{-}$ III. Foulkscourt bog, Kilkenny (Rev. S. Madden): Cyb. By the Erkina river below Durrow : Hart 1885 8.-IV. Knockie bog and Alderton, Wexford: B.-H. \& G. I889. Murrough of Wicklow (Moore): Cyb.-7. Between Castledermot and Carlow (Carroll): Cyb.-Ardee bog and the Glack bog, near Castlebellingham: Butter 1890 . Banks of the Boyne below Bective: More. Abundant in the Royal Canal, Co. Dublin; R. W. S.-VI. Near Castle Taylor, Galway: More 1855 . By the Fergus above Ennis, Clare: Mack. Rar. Abundant in a marsh at Doonbeg, Clare: Stevoart 1890. By the Shannon at Portumna, Galway, $1896 ;$ N. C.VII. Black river, north of Monasterevan: Hart 1885. Lough Owel : Levinge 1894.-VIII. At Maam, Galway: Babington 1836 . Lake near Letterfrack, Connemara (Moore): Rec. Add.-IX. Lough Key, near Boyle (F.J. Foot): $C y b$. River at Creagh, Ballinrobe: Miss M. F. Jackson.-X. Abounds in the lakes near Drum, Clones (J. Bain) : Rec. Add. Closet river, Armagh (Rev. H. W. Lett): Praeger $1893 .-X I I$. About Portmore Lough and by the Bann above Portglenone, 1796 (Templeton): Whitla MS. Near Dungiven (Mrs. Leebody); Pollramer lake ( $R$. Hanna); and near Ballydugan lake (Praeger): S.\& P. I895.

\section{R. auricomus Linn.-Goldilocks.}

Districts I. II. III. IV. V. - VII. VIII. IX. X. XI. XII. Lat. $52^{\circ}-55^{\circ}$. From South to North. Type, British-English.

Lowland. Woods, thickets and hedgerows; rather local. Fl. April-June.

Very rare in the south-west, and not recently seen in District I. Scarce also in the west.

\section{R. acris Linn.- Opright Crowfoot.}

Districts I. II. III. IV. V. VI. VII. VIII. IX. X. XI. XII. Lat. $51 \frac{1}{2}^{\circ}-551^{\circ}$. Throughout Ireland. Type, British.

Meadows, pastures and hedgerows; abundant. Fl. JuneAugust.

In Ireland the ordinary plant is $R$. tomophyllus of Jordan, a hairy form of the same author's $R$. Borcanus. 
Var. Friestarus Jord. (scarcely distinct from the same author's R. vulgatus).-I. On Mangerton (More): Rec. Add. On Brandon mountain; N.C. Above Kells Lough, west of Rossbehy, Kerry; R. W. S.

Sea-level in N. Donegal and S. Cork. To $1600 \mathrm{ft}$. in Donegal (Hart); to $2850 \mathrm{ft}$. in Wicklow (N.C.); to $2950 \mathrm{ft}$. in Kerry (Hart).

\section{R. repens Linn.-Creeping Crowfoot.}

Hibernicé Feapban (Farra-Bawn).

Distriets I. II. III. IV. V. VI. VII. VIII. IX. X. XI. XII. Lat. $51 \frac{1}{2}^{\circ}-55 \frac{1}{1}^{\circ}$. Throughout Ireland. Type, British.

Damp meadows and pastures, waste places and ditches; abundant. $F l$. May-August.

Sea-level in N. Antrim and S. Cork. To $1600 \mathrm{ft}$. in Donegal and to $2550 \mathrm{ft}$. in Kerry (Hart).

A form with leaves divided into narrow segments recorded under the name tenuisectus from inundated places on the banks of the Blackwater below Mallow (More) and from near Gort (P. $B$. $O$ 'Kelly) is probably $R$. reptabundus (Jord.).

\section{R. bulbosus Linn.-Bulbous Cronfoot.}

Districts I. II. III. IV. V. VI. VII. VIII. IX. X. XI. XII. Lat. $51 \frac{1}{2}^{\circ}-55 \frac{1}{4}^{\circ}$. Throughout Ireland. Type, British-English.

Meadows, pastures, dry banks, and sand-hills; common. Flt. May-July.

Sea-level in N. Donegal and S. Cork. To $600 \mathrm{ft}$. in Donegal (Hart); to $1500 \mathrm{ft}$. in Dublin (N.C.).

Rare in the north-west, though usually common in Ireland.

\section{6. † R. parviflorus Linn.-Small-fowered Crowfoot.}

Districts I. II. III. IV. V. ----Lat. $52^{\circ}-532^{\circ}{ }^{\circ}$. South-east Ireland. Type, English.

Lowland. Cornfields and dry banks; rare and perhaps intros. duced in all stations. Fl. April-June.

I. Near Carrigrohane Castle : Drummond I8zg.-II. Near Cove and by the Glanmire road; Ballyvodock, near Midleton and Ballywilliam, near Poor Head: Flor. Cork. On the ramparts, Spike Island (Carroll) : Cyb. Eastferry, Cork (Rev. T. Allin) : Rec. Add. Brick Island near Carrigtwohil, 1896 ; near Whitegate, 1897 ; Phillips. Rock of Cashel (Miss S. Grubb): Cyb.-III. Near the 
city of Kilkenny (Rev. S. Madden): Cyb.-IV. Saltee Island; Barrington. A troublesome garden weed at Alderton; in a field near Pilltown Stage; near the Island Quay, Co. Wexford: B.-H.\& G. I889. Bank near Rosslare Harbour Station, 1897; Rev. E. S. Marshall.-V. Along the river side at Bray: Wade Rar. 2804. At Bray Common, 1875; Barrington. East side of the Green Hills and ditch side beyond Milltown, Co. Dublin : Wade Rar. Plentiful on the sandy commons between Baldoyle and Howth: Mack. Rar. Cottage garden near Prumplestown, Kildare ( $\mathcal{H}$. Douglas): Rec. Add.

\section{R. Ficaria Linn.-Lesser Celandine.}

Ficarva verna Huds.-F. ranunculoides Roth.

Districts I. II. III. IV. V. VI. VII. VIII. IX. X. XI. XII.

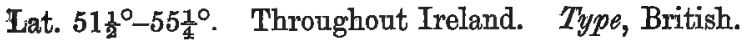

Shady places and damp pastures; common. Fl. March-May.

Sea-level in N. Antrim and S. Cork. To $1500 \mathrm{ft}$. in Donegal and to $2353 \mathrm{ft}$. in Kerry (Hart).

- The variety INOOMBENs of F. Schultz occurs not infrequently, but seems hardly worthy of distinction.

\section{CAITHA Linn.}

1. C. palustris Linn.-Marsh Marigold.

Districts I. II. III. IV. V. VI. VII. VIII. IX. X. XI. XII. Lat. $51 \frac{1}{2}^{\circ}-55 \frac{1}{4}^{\circ}$. Throughout Ireland. Type, British. June.

Marshy places; pools and ditch banks; common. Fl. March-

Sea-level in N. Antrim and S. Cork. To $700 \mathrm{ft}$. in Donegal (Hart); to $1400 \mathrm{ft}$. in Dublin (N.C.); to $1500 \mathrm{ft}$. in the Graltees (Hart).

Var. GUERANGerII (Borean).-I. Stony shores of the Lower Lake of Killarney: $R$. W. S. 1888 . - IX. Glen Iff, north of Ben Bulben (W.T. Dyer) : Rec. Add.

Var. PRocumbens Beck.-VII. Shores of Brittas lake, Knock Drin, Westmeath : Linton 1896.

2. C. radicans Forster.-Creeping Marsh Marigold. District - - - - - - - - X - Lat. 54 $\frac{1}{2}^{\circ}$. Co. Fermanagh only.

Lowland. Muddy lake-shores; very rare. Fl. May-June. 
X. In tolerable plenty on soft mud on the east side of Devenish Island, Lough Erne, near the ruins : Barrington 1884.

In Mackay's Flora Hibernica this plant is recorded as found " on the side of the Bann river, near Portadown; Mr. Templeton." In the absence of any recent corroboration of this, it seems best, however, to base the title of the plant to a place in the Irish flora solely on Mr. Barrington's record. The Lough Erne plant has been verified by such good authorities as Professor Babington, Mr. J. G. Baker, and Rev. W. W. Newbould.

\section{TROLLIUS Linn.}

\section{T. europæus Iinn.-Globe Flower.}

Districts - - - - - - - - - XI. Lat. $54^{\circ} 50^{\prime}-55^{\circ} 5^{\prime}$. Co. Donegal only. Type, Scottish.

Lowland. By lake-margins and river-banks; very rare. $F l$. June-July.

XI. Convoy and Lough Gartan: Murphy I829. Near Raphoe, certainly wild (Murphy) : Cyb. Plentiful on the banks of the river Lennan, which runs out of Lough Gartan, and abundant all along Lough Gartan, 1873: Very Rev. Dean Gwynn. Shore of Lough Fern, and on an island in the lake; also along the river, thence to Ballyarr: Hart 2880 . In several places along the river Finn on both banks; between Drumbo and Cloghann bridge: Hart $1885 \gamma$.

Recorded in Mackay's Catalogue, 1825, as found in the "North of Ireland : Mr. Templeton."

From near sea-level to about $250 \mathrm{ft}$. in Donegal (Hart).

\section{AQUILEGIA Linn.}

\section{A. vulgaris Linn.-Columbine.}

Districts I. II. III. IV. V. VI. VII, VIII. IX. - XI. XII, Lat. $52^{\circ}-541^{\circ}$. South to North. Type, English-Intermediate.

Lowland. In copses, brakes, and rocky pastures; rare. Fl. June. Calcicole $B$.

I. At Killarney, doubtfully indigenous (Babington): Cyb. Blackwater bridge, Kerry, sparingly; R.W. S. I889.-II. Furze brake, Dunscombe's Wood, Co. Cork: Drummond I8Iq. Banks of the Bride river, near Ovens, 1894; Phillips. On rocks near Glanworth, naturalized (T. Chandlee): $C y b$. Furze brake at Iittle Island, 1895; Philtips. Frequent about Blenheim, near Waterford : B.-H.\& G. 7880. -III. At Richmond, Glandine, near 
Kilkenny (Rev. S. Madden); and at Troy's Wood, Kilkenny (P. Duffy): Cyb. Garryhinch, by River Barrow : Hart. 1885.IV. By the Owenduff river, Wexford, far from houses, 1891; G. B.-Hamilton.-V. Knockmaroon Hill, Dublin : Wade, Dubl. Along the waterfall, Leixlip: Ir, Flor. 833 - still there in considerable quantity in $1894 ; N$. C. On a bog near Monasterevan; Praeger. Dollardstown bog, Kildare, a bog recently drained and planted (J. Douglas): Cyb. Abundant in hedges, \&c., on site of this bog, $1889 ; R . W . S$. Mountain above Carlingford, Louth; Rev. C. H. Waddell.-VI. On limestone crags between Ennis and St. John's Well (Rev. T. Warren): Cyb. Near Kilmurvy, Aranmore Island: Hart 1875 . Frequent in rock clefts from Kilmurvy to Bungowla, $1892 ; N . C$. Woods near Clontueskart in Galway: $K^{\prime} E$ ogh. Among gorse, by the stream between Woodford and Lough Derg (M. Dowd) : Rec. Add. Eastern side of Lough Corrib; wild and plentiful (Prof. Melville): Cyb.-VII. Plentiful over a large field at Rutland, near Swinton, King's Co. (Miss Farmer): Rec. Add. Coosan Point, Lough Ree: B.\& V. 1887 . By Lough Dereveragh, under Knock Body, Westmeath: Linton r8g6. VIII. Abundant by a stream south of Thonabracky mountain, near Galway, $1891 ; D r . G$. J. Allman.-IX. On limestone rocks and pastures between Headford and Cong, in a truly wild state (J. Shuttleworth) : Flor. Hib.-XI. Limestone brakes between Beleek and Brown Hall : Hart $1886 .-\mathrm{XII}$. By the Shimna river, near Newcastle: $S . \& P . I 89 z$.

Undoubtedly introduced in most of its eastern stations, in many of which it has become thoroughly naturalized; apparently native in the west.

\section{ORDER II.-NYMPH尼ACE正.}

\section{NUPHAR Smith. \\ 1. N. luteum Smith.-Fellovo Water-Lily.}

Districts I. II. III. IV. V. VI. VII. VIII. IX. X. XI. XII. Lat. $51 \frac{1}{2}^{\circ}-55 \frac{1}{4}^{\circ}$. Throughout Ireland. Type, English-British.

Lakes, ditches, slow streams, and canals; frequent. Fl.June-July.

Sea-level in N. Donegal and in S. Cork. To $700 \mathrm{ft}$. in Donegal and to $800 \mathrm{ft}$. in Kerry (Hart).

More frequent in the east than in the west.

Var. INTERMediom (Ledeb.).-DII. In Cromlyn Lake, Westmeath; More. 


\section{NYMPHAA Linn.}

\section{N. alba Linn.-White Water-Lity.}

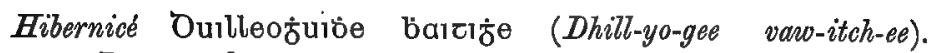
Drowned leaves.

Districts I. II. III. IV. V. VI. VII. VIII. IX. X. XI. XII. Lat. $51 \frac{1}{2}^{\circ}-55 \frac{1}{4}^{\circ}$. Throughout Ireland. Type, British.

Lakes, ditches, and slow streams ; frequent. Fl. June-July.

Sea-level in Derry and S. Cork. To $1000 \mathrm{ft}$. in Donegal (Hart).

Rare in many parts of East Ireland. Though both water-lilies occur in all the districts, they are rarely found growing together in abundance, Nymphaa apparently preferring a peaty bottom.

\section{ORDER III.-PAPAVERACE正.}

PAPAVER Linn.

\section{1. * P. somniferum Linn. Opium Poppy.}

Districts I. II. - - V. VI. ---- XI. XII.

Waste places and sandy fields near the coast; frequent, but seldom thoroughly established. Fl. July-August.

I. Field at Derrynane and waste ground at Killorglin and Ardfert, Kerry : R.W.S. 1889 . Cultivated ground at Kilkern, near Rosscarbery, 1891 and-II. Eastferry, Cork, 1893; Phillips. -V. In Barrens, near Warren House, Howth: Wade Dubl. I794. Waste places and cornfields about Warren House and between Baldoyle and Sutton: Flor. Howth 7887 . Established on sandhills north and south of the Boyne mouth: Prager 1897.-VI. Not infrequent in cultivated fields about the Shannon estuary: Stewart 1890.-XI, Fields about Bundoran, apparently established: Hart I885 \%.-XII. A bundant in a field near Rostrevor : S. \& P. 1895 .

Perhaps entitled to a place in the Irish flora only on account of its persistence for a century in the Howth locality.

\section{P. Rhceas Linn.-Corn Poppy.}

Districts I. II. III. IV. V. VI. VII. VIII. - X. - XII. Lat. $51 \frac{1}{2}^{\circ}-55 \frac{1}{4}^{\circ}$. South and East chiefly. Type, English-British.

Cornfields and waste places; locally abundant. Fl. JuneAugust. Common in the east; rare in the west and north, but rapidly spreading.

Sea-level to $900 \mathrm{ft}$. in Dublin ( $N_{*} C$.). 


\section{P. dubium Linn.--Long Smooth-headed Poppy.}

Districts I. II. III. IV. V. VI. VII. VIII. IX. X. XI. XII. Lat. 51 $\frac{1}{2}^{\circ}-551^{\circ}$. Throughout Ireland. Type, British.

Lowland. Cultivated land and waste places; frequent. $F$. June-July.

Seldom occurs in such abundance as the preceding species.

The Irish plant is usually $P$. Lamottei of Boreau, but $P$. Lecogii of Lamotte is not infrequent. It has been recorded from the following counties-Dublin and Mayo (More), Galway (Prof. Melville), Westmeath (Levinge), Kerry (R.W.S.), and Wexford (C. B. Moffat), and seems to be the only variety which occurs in N.-E. Ireland : Flor. N.-E.

\section{4. † P. Argemone Linn--Prickly Long-headed Poppy.}

Districts I. II. III. IV. V. VI. VII. - IX, X. - XII. Lat. 5120 $-551^{\circ}$. From South to North. Type, British-English.

Lowland. Sandy fields near the coast, also in gravel pits and on railway tracks; rare, especially inland. Fl. May-July.

I. Fields near the Magazine, Cork: Drummond, 1819. Cornfield at the Island, Clonakilty, 1891; Phillips.-II. Railway embankment at Midleton (Rev. T. Allin): Ree. Add-and in 1895; Phillips. Little Island, Cork: Phillips 1895. Ardmore, Waterford (Miss S. Grubb): Cyb.-III. In Carlow (Carroll); Cyb.IV. Near Pilltown, Wexford: B.-H.\& G. 1889. Aughnaclappa, Wexford: Moffat I889. Murrough of Wicklow: Greenwood Pim. Plentiful on the shores near Wicklow (More) : Rec. Add.-V. Cornfields near Kilbarrick church: Mack. Cat. I825-and in 1895; N. C. Rush and Portmarnock: Ir. Flor. 1833-and in $1893 ;$ N. C. Sea-shore near Castlebellingham; Ceoil Butler. Between Laytown and the Boyne mouth; Barrington.-VI. Near Corofin, Clare; Levinge. Gravel-pit south of Ahascragh, E. Galway: Praeger r896.-VII. By shores of Lough Ree, and-IX. Railway at Kiltoom, Roscommon; sparingly in both stations: B.\& V. 1887.$\mathbf{X}$. Gravel-pit at Lurgan, and by the railway N.-E. of Armagh station: Praeger, 1893.-XII. Curran of Larne, also among corn at Malone, 1823: Templeton MS.—and in 1878 (Corry) : Flor. N.-E. Magilligan, Derry (Stewart) and near Lisburn, Aintrim (Moore): $C y b$. Railway bank at Glynn, Antrim (Stewart); sand-pit near Giant's Ring, Down (C. Dickson): Filor. N.-E.

First found by Templeton in 1823, near Belfast. 
5. †P. hybridum Linn.-Prickly Round-headed Poppy.

Districts I. II. - IV. V. VI. VII. - - - XII. Lat. $513^{\circ}-543^{\circ}$. From South to North. Type, English.

Lowland. Cultivated sandy fields and gravelly places; rare. Fl. June-July.

I. Blackrock, and-II. Little Island, Cork, sparingly, 1841 : Flor. Cork. Still at Little Island: Phillips 1895.-IV. Fields near Bray: Templeton MS. At Kilcool, Wicklow (T. Chandlee): Cyb. Murrough of Wicklow, near Killoughter; Levinge.-V. Fields. near Kilbarrick churchyard : Mack. Rar. Sutton and Howth : Flor. Howth. Abundant in sandy fallows, Portrane, 1895; N. C. Skerries (More): Rec. Add.-VI. At Castle Taylor, Galway: More 1855. Cornfields near Black Head, and sparingly near Crusheen, Co. Clare: Corry 1880 . In Co. Clare at Corofin (Levinge); at Muckinish (P.B. O' Kelly); and at Murrough, 1895 (N.C.).VII. Cornfield at Elfeet Bay, Lough Ree; B.\&V. $1887 .-$ XII. Sandy field a little below Hollywood, 1797 : Templeton MS. Coast beyond Groomsport, plentiful: Flor. Belf. 1863-still there about 1888 : Flor. N.-E. Between Killough and Ardglass (Praeger): B. N. F. C. Proc. I8gz-93.

Much rarer than $P$. Argemone, and apparently more abundant along the coast of county Dublin than elsewhere in Ireland.

First found by Templeton in 1797, at Hollywood, Co. Down.

\section{MECONOPSIS Viguier.}

\section{II. cambrica Viguier.-Welsh Poppy.}

Districts - II. III. IV. - VI. - VIII. IX. X. - XII. Lat. $521^{\circ}-55 x^{\circ}$. South to North. Type, Atlantic-Intermediate.

Rocky places on mountains and by rivers ; rare. Fl. June-July.

II. On the Commeragh mountains, Waterford, found sparingly by Mr. J. Poole (I. Carroll): Cyb. Rocks above Coumshingan Lough, in the Commeraghs, 1893, and for several years previously; Rev. W. W. Fleming. Glen above Stone Park, Galtee mountains: Hart 1881 .-III. By the Barrow, in Queen's Co. (Moore): Cyb. Gleudine Gap, Slieve Bloom, Queen's Co., 1897 : Prager.-TV. In the Dargle, 1814: Templeton MS.—and in 1884: Hart. In theDevil's Glen, Wicklow (Moore): Cyb.-still there in 1895; R.W.S. Right bank of Glencree river below Knockree, 1884; Hart.-VI. In the clefts of wet limestone rocks at Poulnagolm, 
near Lisdoonvarna, Clare (Rev. T, Warren): Cyb. Frequent

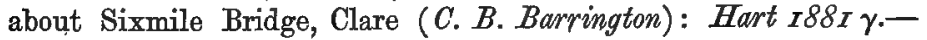
VIII. On the hill above Clifden, Connemara: Flor. Hib. Muckanaght, Twelve Bens, Co. Galway: Hart 1883 a.-IX. Ben Bulben, Sligo : Murphy 1829. On Legale, Sligo (Admiral Jones): $C y b$. Very sparingly on the north side of Ben Bulben, also on King's Mountain, Sligo: B.\& V.r885.-X. Ballyskeagh Hill, Tyrone (Dr. Sigerson): Rec. Add.-XII. Deep valleys in the mountains above Rostrevor, Down, found by John White: Wade Rar. 1804-still there in 1890:S.\&P. I892. Rocks at Fair Head, Antrim, before 1804 (Templeton): Whitla MLS., and in 1884 by Belfast Nat. Field Club, Ballycastle: Flor. Olst. Between Garron Head and Glenariff (Moore): Cyb. Plentiful in Cusheniel Glen, Garron Point (Praeger) : Flor. N.-E. Magilligan Braes (Rev. S. A. Brenan): S.\& P. 1895 .

From $50 \mathrm{ft}$. in Antrim (Flor. $N_{\text {. }}-\dot{E}$.) to $1300 \mathrm{ft}$. in Down (S. \& P.), and to $1500 \mathrm{ft}$. in Galway (Hart).

First found by Templeton before 1804, at Fair Head.

\section{GLAUCIUM Haller.}

\section{G. flavum Crantz.-Horned Poppy.}

G. luteum Scop.

Districts I. II. - IV. V. VI. - VIII. - - XI. XII. Lat. $51_{2}^{1}{ }^{\circ}-54 \frac{1}{2}^{\circ}$. Coasts of almost all Ireland. Type, English British.

Sandy and shingly beaches; local. Fl. June-August.

Locally abundant in Dublin and Wicklow; but rare in many of the other maritime counties, and not hitherto recorded from Antrim, Derry, Sligo, or Mayo.

\section{CHELIDONIUM Linn.}

\section{1. * C. majus Linn.-Celandine.}

Districts I. II. III. IV. V. VI. VII. VIII. IX. X. XI. XII. Lat." $51 \frac{1}{2}^{\circ}-55 \frac{1}{4}{ }^{\circ}$. Throughout Ireland. Type, English-British.

On walls, in hedges, and in waste places, usually near dwellings or ruins; frequent, but nowhere abundant. Fl. May-July.

Undoubtedly introduced in all its stations, though in many of them long established. 
ORDER IV.-FUMARIACEE.

CORYDALIS DC.

1. C. claviculata DC.-White Climbing Fumitory.

Districts - II. - IV. V. - - - - - XI. Lat. 52 -55 . South to North. Type, British-Atlantic.

Lowland. Rocky and bushy places and on thatched roofs; very rare. Fl. May-July. Calcifuge $A$.

II. In the wood on the north side of the river, between Cappoquin and Lismore: Smith's Waterford 1748 . In Macallop Glen, above the Blackwater, near Ballyduff, Waterford, 1877; Moore.-IV. Bray Head; wood at Luggielaw, brought by Dr. Stokes and Mr. Underwood, July, 1802 : Templeton MS. South side of Bray Head, 1884 ; N.C. Rocks west of Luggielaw Lake, 1894 : Praeger 1897. Glen at Kilmartin, near Dunran, Wicklow; More. Cromroe, Ashford, Wicklow; Greenwood Pim. Rocky ground about Bellview, near Delgany, Wicklow : Ir. Flor. Near Enniskerry (More) and at Powerscourt Waterfall (Moore): Cyb. Rocks near Powerscourt Waterfall: Ir. Nat. r897, p. 168. Lugnaquilla, Wicklow, $1887 ; R$. P. Towell.-V. Under hedges above Dundrum, above the Little Dargle, car road to Kilmashogue : Wade Rar. On thatched cabins between Ballinteer and the Little Dargle: Mack. Cat. By-ways leading from Kilgobbin to the Dublin mountains: Ir. Flor. Abundant on a granite talus and amongst burnt gorse in the Dingle, Glenamuck, near Carrickmines, Dublin, 1882-96; N.C. Abundant amongst gorse and rocks, Killiney Hill (Dub. Nat. Field Club) : Ir. Nat. 1894.-XI. Abundant on banks by the roadside and on a thatched roof near Culmore (W. E. Hart) : Journ. of Bot. 1874 .

Chiefly in the counties of Dublin and Wicklow, with two outlying stations in Waterford and Donegal.

First recorded in Smith's Waterford $I 746$.

FUMARIA Linn.

1. F. pallidiflora Jord.-Ramping Fumitory.

F. capreolata Iinn.

Districts I. II. III. IV. V. VI. - VIII. IX. X. XI. XII. Lat. $511^{\circ}-55 \frac{1}{4}^{\circ}$. Throughout Ireland, probably. Type, British.

Cultivated fields and waste and bushy places; wide-spread and locally abundant, Fl. May-September. 
Frequent in districts I. V. VI. and XII., in the counties of Kerry, Clare, Galway, Dublin, Down, and Antrim, and rapidly spreading through the country.

Sea-level in Antrim and S. Cork. To $750 \mathrm{ft}$. in Dublin ( $N$. $C$.).

Var. BORAEI (Jord.).-I. Killarney: Druce I89r.-VI. and IX. On both sides of the Suck in Galway and Roscommon: Praeger I8g6.-XII. At Giant's Ring, Co. Down (Stewoart): Flor. N.-E.

F. confusa Jord.

Districts I. II. - IV. V. VI. VII. VIII. IX. X. XI. XII. Lat. $51 \frac{1}{2}^{\circ}-55 \frac{1}{4}^{\circ}$. Throughout Ireland, probably.

Cultivated land in light soils; frequent. Fl. May-September.

Seems to be less rare than $F$. pallidiflora; but the two plants have not been sufficiently distinguished by many observers. Gathered in Co. Dublin by J. Ball so early as 1837 : Herb. Babington.

Sea-level to $950 \mathrm{ft}$. in Dublin (N.C.).

$F$. muralis Sonder.

Districts I. - III. - V. - VII. - IX. X. - XII. Lat. $51 \frac{1}{2}^{\circ}-55 \frac{1}{4}^{\circ}$. From South to North.

Borders of fields and in waste places; rare. Fl. June-September.

I. Potato field, Inisherkin, Cork, 1896; Phillips.-III. Maryborough esker: Praeger 1897.-V. Cultivated ground on Howth Head, Co. Dublin, 1895 ; N. C. Oldcastle and Trim, Co. Meath and-VII. Common about Edenderry: Praeger I897.-IX. On the banks of the Suck, Roscommon: Praeger $1896 .-\bar{X}$. Gravel pit near Armagh: Praeger 1893.-XII. Rathlin island: Stewart 1884. At Malone, Antrim (Corry): Flor. N.-E. Saintfield, Co. Down (Rev. C. H. Waddell): Wats. B. Ex. C. Rep. I894.

\section{F, densiflora DC.-Dense-flowered Fumitory.}

F. micrantha Lagasca.

Districts - - - - V. - - - X - Lat. $53 \frac{1}{4}^{\circ}-544^{\circ}$. Counties of Armagh and Dublin only.

Cultivated fields; rare. Fl. May-September.

V. Portmarnock, 1890 : Druee 1891 . Field at Finglas Quarry, Co. Dublin: N.C. $1895 .-\mathrm{X}$. Gravel pit near Armagh: Praeger 1893.

It is impossible to decide whether this plant and the preceding (F. muralis) are to be regarded as mere casuals in Ireland, or as plants widely spread and hitherto undistinguished from other species or sub-species of Fumaria. 
3. F. officinalis Linn.-Common Fumitory.

Districts I. II. III. IV. V. VI. VII. VIII. IX. X. XI. XII. Lat. $51 \frac{1}{2}^{\circ}-55 \frac{1}{4}^{\circ}$. Throughout Ireland. Type, British.

Cultivated fields and waste places; frequent. Fl. JuneSeptember.

Sea-level in Donegal and Cork. To $600 \mathrm{ft}$. in Dublin (N.C.).

\section{ORDER V.-CRUCIFER丑.}

MATHIOLA R.Br.

1. M. sinuata $\mathrm{R} . \mathrm{Br}$.-Sea Stock.

Districts I. - - IV. - VI. - - - - - Lat. $52 \frac{1}{2}^{\circ}-53 x^{\circ}$. West and South-east coasts. Type, Atlantic.

Sandy sea-shores; very rare. Fl. June-August.

I. Near Beal Castle, towards the Shannon mouth: Smith's Kerry; not seen recently.-IV. On steep declivities by the sea at Ballyconigar, Co. Wexford, plentiful (Jahn Morrison): Carroll 1854. Still at Ballyconigar and northward along the coast at Tinnyberna and at Kilmuckridge : Hart I88I a.-VI. On a small island called Straw Island, near the South Isles of Aran, Oct., 1805 : Mack. Rar. Straw Island in 1835 (R. Ball); in 1838 (Herb. $J$. Reilly), and in 1894, leaves only (P. B. O'Kelly). "This fine, scarce plant was found at high-watermark about the sand-hills of Dough, Co. Clare, but sparingly, flowering the latter end of Angust": Wade Rar. I804. The sand-hills, here referred to by Wade, are probably those of Lahinch at the mouth of the Ennistymon River. The plant has not since been reported as found there or elsewhere in Co. Clare.

A decreasing species in Ireland, like Crambe maritima, Mertensia maritima, and other maritime plants.

First recorded by Wade in 1804.

\section{CHEIRANTHUS Linn.}

\section{1. * C. Cheiri Linn.-Wallflower.}

Districts I. II. III. IV. V. - VII. - - - XI. XII. old walls and ruins, and on calcareous rocks. Fl. May-June.

II. Covering the rocks at Myrtle Hill, Cork (Carroll): Cyb. Still plentiful in this station in 1896 ; Phillips.-V. Long established on the old castle of Dunsoghly, Co. Dublin, $1894 ;$ N.C.c 2 
VII. Old Toll-gate, Athlone: B.\& T. 2887 . - XI. Well established on Doagh Castle, Co. Donegal : Hart I880.-XII. Carrickfergus Castle: Templeton MS.-Naturalized on ancient buildings at Quoile Castle, Carrickfergus Castle, and Larne: S.\& P. 7895 .

Well established in these, and in similar stations in many parts of Ireland, but in all of them a relic of ancient cultivation.

\section{NASTURTIUM R.Br.}

\section{N. officinale R.Br.-Water Cress.}

Hibernicé biolap (Billar).

Districts I. II. III. IV. V. VI. VII. VIII. IX. X. XI. XII. Lat. $51 \frac{1}{2}^{\circ}-551^{\circ}$. Throughout Ireland. Type, British.

Ditches, streams, and ponds, in shallow water; common. Fl. June-August.

Sea-level in N. Donegal and S. Cork. To $850 \mathrm{ft}$. in Donegal (Hart); to $1000 \mathrm{ft}$. in Dublin (N.C.).

2. N. sylvestre, R. Br.-Narrow-podded Marsh Cress. Districts - II. III. - V. - - - - X. - Lat. $52^{\circ}-544^{\circ}$. South of Ireland chiefly. Type, English.

Lowland. Banks of rivers; rare. Fl. June-August.

II. West bank of the Blackwater, five miles below Lismore, Waterford (Carroll) : Cyb. Banks of the Blackwater a little above Lismore bridge; $R$. $P$. Voroell. Plentiful at Lismore, both above and below the bridge, 1870 and $1896 ; F$. E. Currey. By the Blackwater near Fermoy : Hart $1885 \delta$. River side near Clonmel, Tipperary (IFiss S. Grubb) : Cyb.—and in $1897 ; R$. P. Vowell.III. Along the Nore below Mountrath, Queen's Co., and about five miles below Ballyragget, Kilkenny : Hart I $885 \delta$. By the Barrow below Monasterevan, Queen's Co.; at Ballytegelea bridge, Co. Kilkenny; and-V. Between Old Fort bridge and Cloney bridge, above Athy, Kildare : Hart I885.-X. Banks of Lough Erne (Dr. Scott) : Mack. Rar. Belleisle, Upper Lough Erne; immature, but probably this species: Barrington 7884.

\section{N. palustre DC.-Broad-podded Marsh Cress.}

N. terrestre R. Br.-Roripa palustris Bess.

Districts I. II. III. IV. V. VI. VII. VIII. IX. X. - XII. Lat. $52^{\circ}-55 \frac{1}{4}^{\circ}$. From South to North. Type, British-English.

Lowland. Marshes and watery places; rather rare. Fl. JuneAugust. 
I. Rose Island, Killarney (Hart): Rec. Add. On both sides of Rose Bay, Killarney, and at Blennerville, Tralee: $\boldsymbol{k}$. W. S. 1888 . By the Lee: Flor. Cork-and still there, $1892 ; R$.W.S. By the river Bride at Ovens, 1894, and in the Lough of Cork, 1896; Phillips.-II. In the Blackwater near Lismore: Smith's Waterford. By the Suir above Golden, Tipperary : Hart 1885 a. Near Fermoy, by the Blackwater, \&c. (T. Chandlee): Cyb. Buttevant and Kanturk, North Cork (Rev. T. Allin) : Rec. Add. Dodges Glen, 1894, and at Cloyne and Midleton, 1895; Phillips.-III. Near Fenagh, Carlow ( $R$. Clayton Browne): Rec. Add. Bennett's bridge by the Nore: Hart I885 $\delta$.-IV. Frequent about Enniscorthy (J. Morrison): Rec. Add. By the Pill, Alderton, Wexford; Miss L. S. Glascott.- $\mathrm{V}$. By the river at Ballitore and near Moone, Kildare (Carroll) : Cyb. Tenure Bog; along the river side, Co. Louth : Ir. Flor. Curragha Bog: Wade Rar. Balrothery; Bog of the Ring and Lusk, Co. Dublin: N. C. 1893. Railway at Blackrock, Co. Dublin, 1892; R. W. S.-VI. Near Galway; Levinge. Garryland, near Gort (More): Cyb. Aranmore Island and Inishmaan, Galway Bay : Hart 1875.-VII. Near Lough Iron, Westmeath (Miss $E$. Reynell) : Cyb. Shores of Lough Ennel: Levinge 1894.-VIII. By the Moy near Foxford (More): $C y b$. South of Lough Mask in Galway : M.\&S. I896.-IX. Mount Talbot, Roscommon; Levinge. Lough Allen, rare: Stewart $1885 .-\mathrm{X}$. Shores of Lough Neagh at Maghery, Armagh: Flor. Olst. Shores of Lough Erne: Herb. Mack. Devenish Island, Lough Erne: Barrington 1884 . Canal side near Tyhallen Glebe, Monaghan (Miss Maffet): Cyb. XII. Frequent in Down, Antrim, and Derry : Flor. N.-E.

\section{N. amphibium R.Br.-Water Radish.}

Armoracia amphibia Koch.-Roripa amphizia Bess.

Districts - II. III. IV. V. VI. VII. VIII. IX. X. XI. XII. Lat. 52 $-55 \frac{1}{4}$. From South to North. Type, English.

Lowland. Watery places, rivers, \&c. Fl. June-August.

II. Fermoy, but rare (T. Chandlee): Cyb. By the Suir, about Thurles: Hart I885 a. Left bank of the Blackwater, about three miles above Mallow and-III. By the Erkina river between Durrow and the Nore: Hart $7885 \delta$. By the Barrow, near Carlow and Goresbridge: Hart 1885.-IV. Ditches in the Murrough of Wicklow (Moore) : $C y b .-\nabla$. East bank of river Boyne, opposite Old Bridge: Threlkeld. River Boyne, below Navan, 1892; R. W.S. By the Barrow, above Athy : Hart I885.-VI. Abundantly by the 
Fergus, at Ennis: Stewart 189o. In the Shannon canal at Killaloe, 1896: N. C. $2897 .-V I I$. Shannon Harbour, 1841: Babington in Herb. Frequent in drains all round Lough Ree: $B . \& V_{0} .1887$. River Barrow, about two miles west of Monasterevan : Hart 2885. -VII. Recorded for this District in 1st Ed. Cybele, but no locality available.-IX. Near Hollymount, Mayo: More 1860. Lough Ree: B.\&V. 8887 . Lough Allen: Stewart 1885.-X. Banks of Lough Erne $(D r . S c o t t)$ : Mack. Cat. Common by Lough Erne: Barrington 1884 - - XI. In the Erne river above Ballyshannon, in several places: Hart 1885 \%.-XII. Frequent in Down, Antrim, and Derry : Flor. N.-E.

BARBAREA R. Br.

1. B. vulgaris R.Br.-Bitter Winter Cress.

Districts I. II. III. IV. V. VI. VII. VIII. IX. X. XI. XII. Lat. 51 $\frac{1}{2}^{\circ}-55 \frac{1}{4}^{\circ}$. Throughout Ireland. Type, British-English.

Hedge banks, roadsides, and waste places; frequent. Fl. MayJuly.

Sea-level in N. Antrim and in S. Cork. To 750 ft. in Dublin (N.C.).

Var. arcuata (Reiehb.).-I. Killarney : Druce I89t.-V. Near Coolock, Co. Dublin; N. C.-VI. Near Castle Taylor, Galway: More 1855.-IX. Hollymount, Mayo; More. Rockingham, Roscommon; Moore.-X. Near Loughgall, Armagh : More I860-and in 1892 : Praeger $1893 .-\mathrm{XI}$. By the river Erne: Hart $I 886$.

$B$. intermedia Boreau.

Districts - - - - - - - - X. - XII. Lat. $54^{\circ}-55^{\circ}$. North-east only, in Armagh, Antrim, Down, and Derry.

Lowland. Cultivated fields, sandy banks, and waste ground; frequent. $F l$. May-July.

X. Abundant in cultivated fields near Tartaraghan, Armagh, 1854: More 1860. Not uncommon in Co. Armagh, especially in the north, as at Lurgan, Portadown, and Armagh: Praeger 1893. XII. Fields near Ballymena abont 1836: Cyb. Cave Hill and near Lisburn: Flor. Belf. Templepatrick and abundant about Glenavy, Antrim; Banbridge, Downpatrick, and many other places in Co. Down (Stewart): Flor. N.-E. Kilrea, Co. Derry; (Mrs. Leebody) S.\&P. 7895 . 


\section{2. * B. præcox R. Br.-Early Winter Cress.}

Districts I. II. $--[\mathrm{V}]-$.-- [XII.]

Waysides, waste places, \&c.; rare, and fully established only around Cork. Fl. April-October.

I. Near Kenmare: R.W. S. I890. Passage and many places about Cork: Flor. Cork. At Ovens, 1892; at Carrigrohane, 1896 and near Baltimore, 1897; Phillips.-II. Common about Cork (Carroll): Cyb. At Whitegate and Dunkettle, 1896; at Riverstown, Castletownroche and Dodges Glen, 1897; Phillips. Roadside near Ardmore, Waterford (J. Sullivan) : Cyb.-[V. Established on a garden wall at Lucan, $1867-72$; More.-XII. Cultivated ground at Struell Wells near Downpatrick, Down-(Praeger): B. N. F. C. Proo. 1892-93].

\section{ARABIS Linn.}

\section{A. petræa Lamk.-Mountain Cress.}

Districts - II. - - - - - - IX. - - Lat. $52 \frac{1}{2}^{\circ}-54 \frac{1}{2}^{\circ}$. Leitrim and Tipperary only. Type, Highland.

Alpine rocks; very rare. Fl. July-August.

- II..Sparingly on cliffs about half a mile west of Lough Curra on the Galtee mountains : Hart I88I.-IX. On Glenade mountain, adjoining Ben Bulben in Co. Leitrim (John Wynne): Cyb.—on the same mountain, about fifty plants : $B . \& V . I 885$.

At $1330 \mathrm{ft}$. on Glenade $(B \& P$.); at $2650 \mathrm{ft}$. on the Galtees (Hart).

First found by John Wynne about 1837, on Glenade mountain.

2. A. hirsuta Scop.-Hairy Rock Cress.

Districts I. II. III. IV. V. VI. - VIII. IX. X. XI. XII. Lat. $51 \frac{3}{4}^{\circ}-55 \frac{1}{4}^{\circ}$. Throughout Ireland, almost. Type, British.

Calcareous and basaltic rocks, and on sandhills and walls; local. Fl. June-July. Calcicole $C$.

Sea-level in Derry and in Kerry. To $1250 \mathrm{ft}$. in Derry (Moore); to $1400 \mathrm{ft}$. in Leitrim (N.C.); to $1200 \mathrm{ft}$. in Mayo (Hart).

An abundant species in the limestone districts of Clare, Galway, Sligo, and Leitrim, and frequent on sandhills; but rare in many counties.

Var. GLabrata Syme. - I. In several localities in Kerry; R.W.S.-XI. In sandy pastures at Rossgull, Donegal ; Miss A. G. Kinahan. 
Districts I. $---\overline{\text { VI. }}$ -
Lat. $51 \frac{34^{\circ}}{4}-53 \frac{1}{2}^{\circ}$. West Ireland only.

Sandhills and pastures by the sea; very rare. Fl. July-August.

I. On a sand-bank near the western point of the barony of Bere and on sand-banks near Derrynane, Kerry (Drummond) : Cyb. Sandy banks at Trabeg near Dingle: Hart I884.-VI. In the Great Island of Aran in Galway Bay (Moore): Cyb. Between Ballyvaughan and Black Head, Co. Clare (R. P. Murray): Journ. of Bot. 1887.-VIII. In a sandy pasture field by the sea-side near the house of Anthony O'Flaherty, Esq., at Rinville, Connemara, Oct. 1805: Mack. Rar. (under the name Turritis glabra which is changed to Arabis ciliata in Mack. Cat.). At Roundstone, Connemara (Babington): Cyb. Doge bay near Roundstone: Linton I8g6.

First found by Mackay, at Renvyle, in 1805.

This plant seems very doubtfully entitled to sub-specific rank.

\section{CARDAMINE Linn.}

\section{C. amaral Linn.-Common Bitter Cress.}

Districts - - - - - - - - X. XI. XII. Lat. $54 \frac{1}{2}^{\circ}-55^{\circ}$. North Ireland only. Type, British-Germanic.

Lowland. Marshy places, wet meadows, and by streams; very rare. Fl. May-June.

X. Derryloan graveyard near Cookstown : Flor. Olst. By Derrygorry brook, Favour Royal, Tyrone: Hart 1887.-XI. In a drain leading to the Deele river near Ballindrait; Hart. XII. Wet meadows near Toombridge and by the side of the Moyola river near Castle Dawson (Moore): Flor. Hib. Banks of the Lagan near Belfast: Flor. Olst. By the Lagan Canal and abundant in a marshy wood by Lough Neagh, south of Antrim (Stewart): Flor. N.-E. Belvoir Park, sparingly (T. H. Corry) and marsh at Ballyalloley near Comber (Stewart): Flor. N.-E. Abundant on the Co. Down side of the Lagan at Glenmore, near Lisburn (J. H. Davies): Stewart 1894 .

First found in Ireland by David Moore about 1835.

\section{C. pratensis Linn.-Lady's Smook.}

Districts I. II. III. IV. V. VI. VII. VIII. IX. X. XI. XII. Lat. $51 \frac{1}{2}^{\circ}-551^{\circ}$. Throughout Ireland. Type, British.

Damp meadows and marshy places; common. Fl. April-May. 
Sea-level in N. Antrim and S. Cork. To $2150 \mathrm{ft}$. in Donegal (Hart); to $2800 \mathrm{ft}$. in Wicklow (N.C.); to $2940 \mathrm{ft}$. in Kerry (Hart).

\section{C. hirsuta Linn.-Hairy Bitter Cress.}

Districts I. II. III. IV. V. VI. VII. VIII. IX. X, XI. XII. Lat. $51 \frac{1}{2}^{\circ}-55 \frac{1}{4}^{\circ}$. Throughout Ireland. Type, British.

Waste ground, walls and rocks, in open situations; common. $F l$. March-June.

Sea-level in N. Antrim and S. Cork. To $1450 \mathrm{ft}$. in Derry and to $2100 \mathrm{ft}$. in Mayo (Hart); to $2600 \mathrm{ft}$. in Kerry (N. C.).

C. sylvatica Link.

\section{C. flexcuosa With.}

Districts I. II. III. IV. V. VI. VII. VIII. IX. X. XI. XII. Lat. $51 \frac{1}{2}^{\circ}-55 \frac{1}{4}^{\circ}$. Throughout Ireland.

Woods and moist, shady places; frequent. $F l$. May-June.

Sea-level in N. Donegal and Kerry. To $1000 \mathrm{ft}$. in Dublin (N. C.).

Less common than $C$. hirsuta, but, no doubt, occurs in all the Irish counties.

DRABA Linn.

1. D. incana Linn.-Twisted-podded Whitlow-grass.

Districts I. - - - - - VIII. IX. - XI. XII. Lat. $52^{\circ}-55 \frac{1}{4}$. West and North. Type, Highland.

Mountain rocks and on sand-hills by the sea ; rare. Fl. JuneJuly.

I. Cliffs near the summit of Magillicuddy's Reeks, Kerry, 1805 : Mack. Rar. Cliffs north of Lough Gooagh, Carrantuohil, Reeks: Hart 1882.-VIII. In great luxuriance on the southern shores of Iough Mask (F.J. Foot): Rec. Add.-IX. On Ben Bulben and other mountains near Sligo, 1806: Mack. Rar. Glenade, Leitrim (Admiral Jones): Cyb. Abundant on limestone cliffs on Kesh Corran, Sligo, nine miles north-west of Boyle $(F . J$. Foot): Cyb. Common all over the cliffs in Ben Bulben district: B.\& V. 1885 . On sand-hills near Ben Bulben (Moore) : Cyb. On Knocknarea and. Carrowkee Hill, Sligo, 1897 ; Praeger.-XI. Sandy gronnd by the sea between Buncrana and Fahan, Inishowen : Hart 1883 . Sandhills north-west from Ardara: Hart 1886. Sand-hills near Meevagh, Mulroy Bay; Miss Kinahan.-XII. On the sandy flat of 
Magilligan and on the adjoining mountain, Benevenagh (Moore): Flor. Hib. Sparingly on the higher part of the cliffs, Benevenagh, 1893: Shoolbred I894. Magilligan sand-hills, 1890 (Mrs. Leebody): Stewart I894. Sand-hills a mile north-east of Magilligan railway station, 1894 (Praeger): S.\&P. 1895.

Sea-level in Derry, Donegal and Sligo. To $1150 \mathrm{ft}$. in Derry (Hart); to $1950 \mathrm{ft}$. in Sligo $(B . \& V$.); to $2550 \mathrm{ft}$. in Kerry (Hart).

First found by Mackay, on the Reeks, in 1805.

Var. confusa (Ehrh.).-IX. On Annacoona in the Ben Bulben

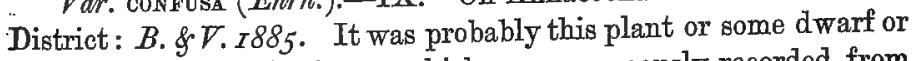
immature form of $D$. incana which was erroneously recorded from Ben Bulben as Draba rupestris (see Appendix).

\section{EROPHILA DC.}

\section{E. vulgaris DC.-Common Whitlow-grass.}

Draba verna Linn.

Districts I. II. III. IV. V. VI. VII. VIII. IX. X. XI. XII. Lat. $52^{\circ}-551^{\circ}$. Throughout Ireland. Type, British.

Walls, rocks, and sandy and gravelly places; frequent and locally abundant. Fl. February-June.

Abundant on the limestone in the Burren district of Clare and on sandhills near the sea; but uncommon in many parts of the country.

- Sea-level in N. Antrim and in Kerry. To $1200 \mathrm{ft.}$ in Down (S.\&P.).

\section{COCHLEARIA Linn.}

\section{C. officinalis Linn.-Seurvy-grass.}

Hibernicé bıolap траб̆a (Billar traw-hĕ).-Strand Water Cress. Districts I. II. - IV. V. VI. - VIII. IX. X. XI. XII. Lat. $51 \frac{1}{2}^{\circ}-55 \frac{1_{4}}{4}$. Coasts of all Ireland. Type, British.

$\mathrm{On}$ rocks and in muddy places near the sea; common. $\mathrm{Fl}$. March-June.

Var. alpina (H. C. Wats.).-I. Brandon mountain, Kerry (Moore) and top of Hungry Hill, Cork (Drummond): Cyb. Carrantuohil : Hart. 1882. Caher mountain in the Reeks and mountains north-east of Lough Currane; N.C. Slieve Mish, Kerry: Hart 1884. On the Galtee mountains (Moore) : Cyb.-VIII. Summit of Ben Lettery, Galway; Stewart.-IX. Frequent on cliffs at a high 
level in Ben Bulben district: B. \& V. $1885 .-\mathrm{XI}$. Poisoned Glen : Hart 1879.-XII. On Ben Evenagh, Derry (Moore): Cyb.

To $800 \mathrm{ft}$. in Donegal (Hart); to $1900 \mathrm{ft}$. in Ben Bulben district $(B . \& V$. ) t to $3100 \mathrm{ft}$. in Kerry (Hart).

\section{C. danica Linn.}

Districts I. II. - IV. V. VI. - VIII. IX. X. XI. XII. Lat. $51 \frac{1}{2}^{\circ}-551^{\circ}$. Coasts of all Ireland. Type, British.

On rocks, walls, banks and roofs, near the sea; locally abun dant. Fl. April-June.

I. On headlands near Dingle, plentiful (Rev. W. M. Hind): Phytol. $1857, p .97$. Near Cahirciveen, Kerry, sparingly; R.W.S. On Cape Clear ; the island of Inishircan and other places: Smith's Cork. At Baltimore, 1896; Phillips.-II. On rocks and walls near Midleton, \&c., and along the coast in abundance: Flor. Cork. Dunmore East, Waterford: B.-H.\& G. 2889.-IV. Bray Head (More) : Cyb. - still there in $1896 ; R$. W. S. West of Hook Head and near Churchtown, Wexford: Hart $1883 \beta$.-V. West Pier, Kingstown; Greenwood Pim. At intervals along the railway from Merrion to Kingstown and wall at Howth Harbour; R.W.S.VI. On a ruin near Kilmurvy, Aranmore (Hart) : Rec. Add. On the walls of Dun Connor, Inishmaan, Aran Islands, $1892 ; N$. C.VIII. On roofs at Galway (Moore) : Cyb. Inishbofin : More I876.IX. Sligo Bay: Flor. Ulst.-X. Estuary of the Newry river, Armagh : Praeger 1893.-XI. Ballyboyle Point, near Donegal, on shingle: Hart I885.-XII. Skerries; Portrush; Downhill, Co.Derry, 1835: Moore MS. Giant's Causeway, 1852: Babington in Herb. Plentiful from Warrenpoint to Greencastle and at Annalong, Down : S. \& P. 1892. Ardglass, Down: Hind 1854. Larne and Glenarm : Flor. Ulst. Portstewart (Mrs. Leebody): S. \& P. 1805 .

Var. GRCNLANDICA (Linn.)-XI. On several of the headlands of Rossgull, Donegal (Hart) : Journ. of Bot., r896, p. 399.

2. C. anglica Linn.-English Scurvy-grass.

Districts I. II. III. IV. - - - - - X. - XII. Lat. $51 \frac{1}{2}^{\circ}-55^{\circ}$. South and North. Type, English.

Muddy estuaries; rare. Fl. May-June.

I. Riverside below Cork: Drummond 1819 . Abundant at Rochestown, Cork, and banks of the Ilen river, Șkibbereen, 1896 ; Phillips.-II. At Killacloyne and Rossmore near Midleton: Flor. Cork. Rossmore; Cork Beg; Glanmire and Tivoli, 1896; Phillips. 
Abundant about Blenheim and shore opposite Waterford city : B.-H. $\& G$. I889.-III. A few plants by the mill at Snowhill, Kilkenny, river Suir: $B .-H . \& G$. $I 890 .-$ IV. In a salt-marsh near Ferrycarrick Bridge, on the estuary of the Slaney (J. Morrison): Ree. Add. Near the New Bridge, Kilmanock; near Alderton; near Killowen and Fisherstown, Wexford: B.-H.\& G. I880. Abundant in Wexford Harbour, 1897 (Var. Hortii); Rev. E. S. Marshall.$X$. Abundant along the shores of the Foyle from a little above Dunnalong, as far as Strabane, Tyrone (Miss M. C. Knowles): Ir. Nat. 7897 -XII. By the Foyle at New Buildings, Derry, 1895: Mrs. Leebody in Herb.

\section{SISYMBRIUM Iinn.}

\section{S. Thalianum J. Gay.-Thale Cress.}

Arabis Thaliana Linn.

Districts I. II. III. IV. V. VI. VII. VIII. - X. XI. XII. Lat. 511 ${ }^{\circ}-551^{\circ}$. From South to North. Type, British-English.

Lowland. Dry banks, rocks, and walls, also in cultivated land; local and rather rare. $F l$. April-August.

I. At Killarney in several places, and about Dingle, Kerry; R.W.S. Near Skibbereen, 1897; Phillips-II. Derry ; Rosscarbery, and at Leap: Allin's Cork. Old walls, Friar's Walk, Cork, (Drummond): Flor. Hib. By the river Funcheon, Cork, 1896, and near Golden, Tipperary; $R . W$. S.-III. Leighlin Bridge, Carlow and Mountrath, Queen's Co.; Praeger.-IV. Bray Head, and abundant near the Manure Works, Wicklow; R.W.S. Fassaroe, Wicklow, $1893 ; N$. C.-V. Old walls near Stepaside, between Dundrum and the Scalp: Mack. Cat. Walls near Kiltiernan, Co. Dublin, $1891 ; R$. P. Towell. Plentiful on the south side of Howth: Moore \& More 1878. About Drumleck, Howth: Flor. Howth.-VI. Aranmore Island; P. B. $O^{\prime} K e l l y$. Abundant in limestone rocks and in cultivated ground around Ballyvaughan, $1895 ; N$. C.-VII. and VIII. Recorded for these Districts in 1st Ed. Cybele but no localities available.-X. Ardmore, Armagh (Rev. $\boldsymbol{H}$. $W$. Lett) and on railway ballast near Portadown: Praeger 1893.-XI. Walls at Pennyburn near Derry (W. E. Hart): Hart r885 $\gamma$--XII. On the Deer Park wall and rocks below the Cave Hill: Templeton MS. Cave Hill and other stations in Antrim (Stewart): Flor. N.-E. Near Derry City (Mrs. Leebody) and Magilligan and Castlerock (Praeger): S. \& P. 2895.

Ascends to $1000 \mathrm{ft}$. in Antrim (Flor. N.-E.). 
2. S. officinale Scop.-Hedge Mustard.

Districts I. II. III. IV. V. VI. VII. VIII. IX. X. XI. XII. Lat. $51 \frac{1}{2}^{\circ}-551^{\circ}$. Throughout Ireland. Type, British.

Waste places, banks, and roadsides; common. Fl. MaySeptember,

Sea-level in N. Antrim and in S. Cork. To $900 \mathrm{ft}$. in Dublin (N. C.).

Seems to be rarer in the West than in the East.

\section{3. $\neq$ S. Sophia Linn.-Flix-eveed.}

Districts - II. - IV. V. - - - - - XII. Lat. $521_{4}^{\circ}-54_{4}^{3}$. East Ireland only. Type, British-English.

Lowland. Sandy cultivated fields and in waste places and on roofs by the sea; rare. $F l$. June-August.

II. Roadside between New Geneva and Passage (Dr. Burker): Templeton MS. Passage, Waterford (Miss S. Grubb): Cyb.IV. Murrough of Wicklow (Moore): Cyb.-V. Upon some of the low thatched cabins at the end of New-street, near Black Pits, Dublin City: Threlkeld. About Portmarnock: Ir. Flor. 1833and in $1894 ; N . C$. At Howth village; on Treland's Eye, and abundant between Sutton and Baldoyle: Flor. Howth. Sand-hills by the creek at Donabate and on the south shore of the estuary below Drogheda (More): Ree. Add. Abundant in sandy fields south of Portrane peninsula opposite Malahide, also at Rogerstown and Rush and on walls and thatched roofs in Rush village, 1893; N. C.-XII. Near Carrickfergus, 1812 (Templeton): Whitla MS. At Magheramorne (Stewart): Flor. N.-E.

Perhaps fully established only in Co. Dublin.

4. † S. Irio Linn.-London Rocket.

Districts - - - - V. - - - - - - Lat. $53 \frac{1}{4}^{\circ}-53 \frac{1}{2}^{\circ}$. County of Dublin only. Type, English-local.

Lowland. Waste places, roadsides and on walls; very local. Fl. May-July.

V. Common about Dublin: Templeton MS. Beside walls going to Glasnevin : Ir. Flor. Roadsides south of Rathfarnham; Clonskeagh and Milltown (More): Ree. Add. By the railway at Sydney Parade, 1867 (W. G. Smith): Herb. Glasnevin. Railway at Lansdowne-road, 1875; Greenwood Pim. Abundant along the railway line from Merrion to Lansdowne-road, $1894 ; N$. C. A few plants at Claremont, Howth: Flor. Howth. Kimmage-road and 
South Circular-road, Dublin, 1892 ; More. By the Dodder river at Rathgar and roadside near Kingsbridge; $R . W . S$. A few plants at Swords and at Kingstown, $1893 ; N$. $C$.

Apparently decreasing about Dublin.

The record in Threlkeld's Synopsis, 1727, under Eruca sylvestris vulgatior: "It grows upon walls, as between Dolphin's Barn and Cork Bridge" (Dublin) should perhaps be referred to this species, though the synonym is for Diplotaxis tenuifolia.

5. S. Alliaria Scop.—Jack by the Hedge.

Alliaria officinalis Andrz.

Districts I. II. III. IV. V. VI. VII. - IX. X. XI. XII. Lat. $52^{\circ}-551^{\circ}$. Throughout Ireland probably. Type, BritishEnglish.

Lowland. Hedgerows and shady places; local. Fl. May-June. Caloicole $C$.

I. Ballycarthy and Ballyseedy near Tralee and several places about Killarney: R.W.S. I889.-II. Wood at Blarney : Drummond I8I9. By the Suir at Knocklofty above Clonmel: Hart 1885 a.-III. By the Slaney near Ballintemple, Carlow: Hart I885 a.-IV. Near Powerscourt, \&c.: Moore \& More 1878.V. Abundant in many parts of the county of Dublin, especially around Knockmaroon and Woodlands, $1894 ; N$. C.-VI. Inishmaan, Aran Islands: Hart ${ }^{2} 875$. A little south of the old lighthouse and in the rectory grounds at Kilronan, Aranmore Island (Prof. Fitsgerald): Praeger 1895.-VII. Common round Lough Ree; R. P. Towell. Knock Drin and Shore of Lough Derevaragh: Levinge 1894.-IX. Foot of cliffs in Glencar, Sligo: B.\&V. 1885 . -X. Woods at Castle Hume, Lough Erne: Barrington 1884. Benburb, Co. Tyrone; Mrs. Leebody.-XI. By the Erne at Cliff, Beleek; very rare in Donegal; Hart.-XII. Frequent in northeast Ireland, in Derry, Antrim, and Down: Flor. N.-E.

Appears to be rare in the western and midland counties.

SUBULARIA Iinn.

1. S. aquatica Linn.-Awl-woort.

Districts I. - - - - VI. - VIII. - [X.] XI. XII. Lat. $52^{\circ}-54 \frac{3}{4}$. West Ireland chiefly. Type, Highland-Scottish.

Shallow lake-margins, chiefly in mountain districts; rare. $F$. July-August.

I. In small lakes at the Gap of Dunloe: Mack. Rar. Coom 
Castle, near Waterville, 1845 (W. H. Harvey): Herb. T.C.D. Lough Calee and Lough Acoose, Magillicuddy's Reeks : Hart 7882. Ardagh Pond and several localities in the Killarney Lakes : R.W.S. 2888. Lough Camclaun, Connor Hill : R.W.S. I89I. In Gougane Barra lake, Cork (Prof. Harvey): Cyb.-VI. Between Milltown and Kilkee, Co. Clare (Moore): Cyb.-VIII. In several small lakes near Ballynahinich, Connemara, 1805: Mack. Rar. Abundant in Ballynahinch and Derryclare lakes: Hart 1883 a. Glendalough lake: Ir. Nat. 2895 . In a lake on Mweelrea mountain, Mayo: Flor. Hib. -and (same station) Lough Lugaloughaun: Hart I883 a. In Lough Coolin, near Clonbur : M.\& S. $1896 .-$ [X. In Lough Neagh, Co. Armagh (Moore): Cyb.-perhaps extinct now.]-XI. Lough-a-Caraban, a little north-west of the Gap of Barnesmore: Murphy I829.-XII. Growing under water in sandy soil in the Irish lake, Lough Neagh . . . near Moyra (Dr. Sherard): Ray Synop. 1696-still there in 1836 ; Colby 1837 . Plentiful along the shores of Lough Neagh between the Lagan canal and Portmore; at Selshan and near the Creagh bog (Moore): Cyb. West side of Lough Beg, between Coney Island and Church Island, 1870 (Stewart): Rec. Add. The latter station appears to be the only one where the plant now survives in District XII., the lowering of the level of Lough Neagh by drainage in 1855 having almost extinguished the species, once so abundant all round its shores.

To $1200 \mathrm{ft}$. in Mayo and $1250 \mathrm{ft}$. in Kerry (Hart). Descends to about $50 \mathrm{ft}$. in Derry and in Kerry.

First discovered by Dr. Sherard in Lough Neagh in 1691 : not previously observed in the British Isles.

From a letter preserved at Oxford it appears that Sherard was at Moyra in 1691, and in Plukenet's Phytographia, Tab. claxxvivi. 1602, the plant is figured, from an Irish specimen, with the note: $d D$. Sherard Inventore ex Hibernid in Angliam muperrime nobis transmissa est.

\section{BRASSICA Linn.}

\section{B. nigra Koch.-Black Mustaird.}

Sinapis nigra Linn.-Brassica sinapioides Roth.

Districts I. II. - IV. V. VI. - VIII. - - XI. XII. Lat. $511^{\circ}-54^{\circ}$. South and South-east chiefly. Type, English.

Lowland. Banks by the sea and in cultivated land and waste places; rare. Fl. June-August. 
I. Abundant near Fenit, Tralee; at Ardfert and Ballyheigue :

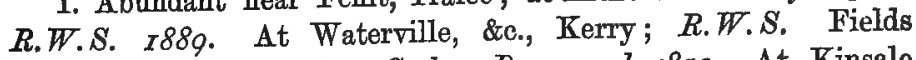
near the Botanic Garden, Cork: Drummond 1819 . At Kinsale (Allin); by the Ilen, Skibbereen, and freely near Bantry (Carroll): Allin's Cork. Crookhaven, 1896; Phillips.-II. East Ferry; Ballycotton: Allin's Cork. Abundant near Queenstown and appears indigenous (Carroll): Cyb. Abindant at Eastferry, Queenstown and Haulbowline, 1896; Phillips.-IV. Frequent in waste ground about Enniscorthy (J. Morrison) : Rec. Add. Banks by the sea between Rosslare and Greenore, Wexford: Hart $1883 \beta$. -V. Portmannock sands and fields near Chapelizod: Mack. Cat. About Rush, Skerries, Swords, \&c., in corn and potato fields: Ir. Flor. Near the wind mill, Skerries, $1895 ; N$. C. Near the sea at Dunany, Louth: Butler I890.-VI. About Killeany, Aran Islands (Hart): Rec. Add. Gleninagh, Clare (Miss Knovoles): P.\& C. I895.-VIII. Inishbofin: More 1876.-XI. By the shore between Kellymard rectory and the Hall, Mount Charles, very rare: Hart I $885 \%$-XII. Cultivated fields on the Curran of Larne (Moore): Rec. Add. Near Belfast and common about Carrickfergus, 1808: Templeton MS. Not now found in these stations and perhaps a mere casual in this district: Flor. $N$.-E.

Perhaps native in the South and South-east, but only a casual north of latitude $54^{\circ}$.

\section{B. Sinapis Visiani-Charlock.}

Hibernicé Pparpeac bulóe (Prash-ack-broee).

Sinapis arvensis Linn.-Brassica Sinapistrum Boiss.

Districts I. II. III. IV. V. VI. VII. VIII. IX. X. XI. XII. Lat. $51 \frac{1}{2}^{\circ}-551^{\circ}$. Throughout Ireland. Type, British.

Cultivated ground and waste places; common. Fl. MayAugust.

Sea-level in N. Antrim and in S. Cork. To $1100 \mathrm{ft}$. in Dublin (N.C.).

\section{B. alba Boiss.-White Mustard.}

Sinapis alba Linn.

Districts I. II. III. IV. V. VI. VII. VIII. IX. - XI. XII. Lat. $51 \frac{1}{2}^{\circ}-54 \frac{3}{4}^{\circ}$. Throughout Ireland, probably. Type, BritishEnglish.

Lowland. Cultivated fields ; local and rather rare. Fl. JuneAugust.

I. In several places about Tralee; R.W. S. I89o. In Co. Cork, 
at Baltimore, 1896 (Phillips) and at Crosshaven (R.W.S.).II. Near Glanworth, Kilcrumper, and Fermoy, rare (T. Chandlee): Cyb.-III. Near Carlow (J. Morrison): Rec. Add. Near Maryborough (Praeger): Ir. Nat. r893.-IV. Near Cheek Point and Wexford: B.-H.\& G. I889. Near Bray, \&c., in Wicklow (Moore): Cyb.-V. Skernies; Kiltiernan, \&c., frequent in county Dublin; N. C. Ballitore, Kildare, frequent (Carroll): Cyb.-VI, Near Castle Taylor, Galway : More I855. Aranmore Island, at Killeany (Hart) : Rec. Add. At Kilronan; Portmurvy; and Seven Churches, Aranmore: Praeger I895. Abundant in cultivation at Murrough and Ballyvaughan, Clare, $1895 ; N . C .-$ VII. Near Athlone: B.\&V. I887.-VIII. Inishbofin: More $1876 .-\mathrm{IX}$. Near Foxford, Mayo (More): Cyb. Frequent in Ben Bulben district: $B . \& \vec{V}$. 1885. Abundant in corn fields, Inishmurray, Sligo (Praeger): Ir. Nat. 7806, p. 277. - XI. Potato field by the Finn river near Glenmore: Hart $1885 \%$-XII. Very common on the lands of Myroe, near Magilligan (W. Tennant): Templeton MS. Abundant in many fields about Killowen near Rostrevor, apparently well naturalized: S.\&P. 1892 .

\section{DIPLOTAXIS DC.}

\section{1. $\ddagger$ D. muralis DC.—Wall Mustard.}

Districts I. II. - IV. V. VI. - - IX. X. - Lat. $51 \frac{1}{2}^{\circ}-54 \frac{1}{4}^{\circ}$. East and South. Type, English.

Lowland. On sandy banks, on railway ballast, and in gravelly places; rare. Fl. May-August.

I. Sparingly, about a mile south of Clonakilty, $1896 ; R$.W. S.II. Lower Glanmire-road, Cork, previous to 1833 (Mr. Alexander) on the railway in same locality : Phillips 1895 . Ardmore, Waterford, on the cliffs and sand (J. Cooke): Cyb. Near Holy Cross, Tipperary; R.P. Vowell.-IV. Railway track near Wicklow, 1890; Levinge.-V. On sandy ditches at Portmarnock, 1837 (J. Johnstone): Mackay 1859. Sandy banks at Baldoyle, plentiful (Moore): Cyb. Portmarnock; Baldoyle and Howth: Moore \& More 1878. All along the railway track, at intervals, from Dublin to Balbriggan, and from Dublin to Howth, $1894 ; N$. C. Gravel pit by the railway at Skerries (Dr. M'Teeney): Praeger 1893 . Abundant on the railway between Dunleer and Castle Bellingham, Louth, 1895; N. C.-VI. On the railway track and adjoining walls east of Galway terminus, 1896, and-IX. On a wall near Sligo harbour, 
$1896 ; N . C .-\mathrm{X}$. On railway ballast at Wellington Cutting near Newry, Armagh, introduced with ballast from Skerries: Praeger I893.

First found by J. Johnstone, at Portmarnock, Co. Dublin, in 1837.

Var, Babingtonin Syme.-V. Near Sutton, Co. Dublin, 1891; Levinge,

\section{CAPSELLA Medik.}

\section{C. Bursa-pastoris Moench.-Shepherd's Purse.}

Districts I. II. III. IV. V. VI. VII. VIII. IX. X. XI. XII. Lat. $51 \frac{1}{2}^{\circ}-55 \frac{1}{4}^{\circ}$. Throughout Ireland. Type, British.

Waste places, walls, and cultivated ground; very common. $F l$. Throughout the year in open winters.

Sea-level in N. Derry and S. Cork. To $1250 \mathrm{ft}$. in Dublin (N.C.).

\section{SENEBIERA DC.}

\section{1. \$S. didyma Persoon.-Lesser Swine's Cress.}

S. pinnatifida DC.-Coronopus didymus Smith.

Districts I. II. III. IV. V. VI. VII. VIII. - - - XII. Lat. $51 \frac{1}{2}{ }^{\circ}-55 \frac{10}{4}$. South and West, chiefly. Type, Atlantic-English.

Lowland. Roadsides and waste places, chiefly near the coast; local, Fl. July-September.

I. At Dingle, Kerry (More): Rec. Add. Blennerville, Tralee: Hart 1884. Dereen; Derrynane; Tarbert, \&c., Kerry: R.W.S. I888, \&0. Roadside near Clark's Bridge, Cork (Mr. William Hinks): Drummond 1819. Skibbereen; Baltimore; Cape Clear; and Crookhaven; Phillips.-II. Near the mill at Fermoy (T. Chandlee); Tramore, Waterford (Carroll): Cyb. Frequent on the Waterford coast, as at Annestown; Ballyroyle Head, \&c.: Hart $1883 \beta$. Plentiful near Clonmel (Miss S. Grubb) : $C y b$.—and in 1882: Hart I885 a. Fethard, Tipperary; $R$. W. S.-III. At Kilmacow, Kilkenny (T. Chandlee) and at Carlow (J. Douglas): Rec. Add. -IV. Fethard; Churchtown; and Duncannon on Wexford coast: Hart $I 883 \beta$. Fisherstown, Wexford : B. - H. \& $\boldsymbol{M}$. I 892 a. Wicklow, near the harbour, $1890 ; R$. Bayly.-V. Abundant by roadsides, Ball's Bridge and Sandymount, oirca 1865; John Bain. By the Dodder above Donnybrook, 1894; Praeger.-VI. At Castle Taylor and Kinvarra, Galway, and at Corofin and Miltown-Malbay, Clare: More $1855 \% 1860$. Abundant on roadsides west of Foynes : 
Stevoart 7890. Abundant round Ballyvaughan, $1895 ; N . C$. Abundant at Gort (M. Dowd): Rec. Add. About the town of Galway (Prof. Melville): Cyb. On Claddagh pier, $1892 ; R$. Bayly. On all three islands of Aran: Nowers \& Wells I892.-VII. By the old castle at Dromineer, Lough Derg, Tipperary, $1896 ; N$. C. -VIII. Inishbofin: More 1876. At the ferry, Achil Sound: Hart I883 a. Newport, Co. Mayo; Miss M. F. Jackson.XII. Introduced with ballast near Larne, 1865 (Stewart): Cyb. Killough, Down (Rev. C. H. Waddell); Giant's Causeway (Miss Knowles); Portstewart (Mrs. Leebody): S.\& P. I895.

Appears to be rapidly spreading round the Irish coasts.

First recorded by Drummond, from Cork, in 1819.

\section{2. †S. Coronopus Poiret.-Swine's Cress.}

Coronopus Ruellii All.-C. procumbens Gilib.

Districts I. II. III. IV. V. VI. VII. VIII. IX. X. XI. XII. Lat. 51졸 $-55 \frac{1}{4}^{\circ}$. Throughout Ireland. Type, English.

Lowland. Waste ground and roadsides, especially near the sea ; rather local. Fl. June-September.

A rare species in inland stations.

\section{LEPIDIUM Linn.}

1. † L. latifolium Linn.-Dittander.

Districts I. II. --------Lat. 51 $12^{\circ}-52^{\circ}$. South of Ireland. Cork only. Type, English.

Lowland. Salt marshes, stony beaches and damp places near the sea; very rare. Fl. July-September.

I. Near the head of Kenmare River: Smith's Kerry I750-not since recorded from Kerry. Abundant near Kinsale (Prof. $\boldsymbol{E}$. Murphy): Cyb. World's End, Kinsale (Allin) and near the old fort there (R. L. Allman): Allin's Cork. Near Kinsale, 1892; Phitlips.-II. Corkbeg, on the east side of Cork harbour: Smith's Cork 1750-still abundant there in 1896; Phillips. Spreading along a causeway between Corkbeg and the mainland, 1895: Phitlips 1895. Spike Island: Flor. Cork. In the parish of Kinsalebeg near the east side of Youghal Harbour: Smith's Waterford 1746 .

Perhaps a relic of ancient cultivation. 


\section{2. $\dagger$ L. campestre R. Br.-Common Pepperwoort.}

Districts I. II. III. - [V. $----\mathrm{X}$. XII. Lat. $52^{\circ}-54 \frac{3}{4}{ }^{\circ}$. South, East, and North. Type, British-English.

Lowland. Cultivated fields and waysides; rare. Fl. JuneAugust.

I. OId walls and dry fields near the Botanic Garden, Cork: Drummond' I8ro-not seen recently in Co. Cork.-II. Near Youghal: Flor. Cork. Near Clonmel (Miss S. Grubb): Cyb. -III. Near "The Rocks," Kilkenny (Rev. S. Madden); one mile west of Carlow (J.Sim): Cyb.-[V. Banks of the canal near Blanchardstown, Dublin (Mr. Johnston): Cyb. Foot of Mount Oriel near Collon ; at Belpatrick; Summer Hill; and Mullaghconlon, Co. Louth: Ir. Flor. Near Clogher Head, Louth: Ball I839].X. Loughall and Tartaraghan, Armagh: More I860. Roadside near Lurgan, Armagh (Stewart) and Tannaghmore, Lurgan: Praeger 1893.-XII. At Largy on shore of Lough Neagh (Mr. Whitla): Flor. Ulst. Near Lough Neagh from Antrim to Glenavy river (Moore) : Cyb. Roadside Glenavy and sandy waste at foot of Glenary river (Stewart): Flor. N.-E. Ram's Island, Lough Neagh (Rev. H. W. Lett): S.\&.P. 189.5. Sparingly in fields at Killowen, Co. Down: S.\&.P. 1892 .

Not reported from District $\nabla$. for nearly thirty years, and the Irish Flora localities should, perhaps, be referred to $L$. hirtum.

\section{L. hirtum Smith.-Smooth-podded Pepperwoort.}

L. Smithii Hooker.

Districts I. II. III. IV. V. ---- X. XI. XII.

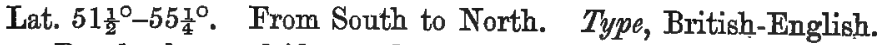

Dry banks, roadsides, and borders of fields; rather rare. Fl. June-August. Calcifuge $B$.

I. Not rare in Kerry; R.W.S. Common in South Cork andII. In North Cork: Allin's Cork. Ballyvoyle Head, Waterford:

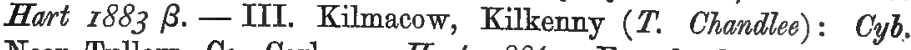
Near Tullow, Co. Carlow: Hart 1886 . Ferrybank, Kilkenny: M. \& S. I896.-IV. Frequent in Wicklow near Arklow, and at Gorey, Wexford (More) : Rec. Add. Frequent throughout Co. Wexford: $B .-H . \& M$. $1892 .-\mathrm{V}$. At Ballitore, Kildare (Carroll): Cyb. Sparingly at Mullaghcreelan Hill, Kildare (J. Douglas): Ree. Add. Frequent in Co. Dublin, $1895 ;$ N.C.-X. Frequent in the granitic and Silurian areas of Co. Armagh: Praeger I893.XI. Roadside near Manorvaughan, Mulroy; extremely rare: Hart 
I880.-XII. Near Ballymena, Antrim, and near Coleraine and by the river Roe, in Derry (Moore):Cyb. Kilrea and Garvagh, Derry (IIrs. Leebody) : S.\&P. 1895 . Common in Co. Down: Fllor. N.-E.

Sea-level in Derry and in S. Cork. To $900 \mathrm{ft}$. in Dublin (N.C.). A.pparently absent from the midland and western counties.

\section{THLASPI Linn.}

\section{T. arvense Linn.-Penny Cress.}

Districts I. II. III. IV. V. VI. - - - X. - XII. Lat. $51 \frac{1}{2}^{\circ}-55 \frac{1}{4}^{\circ}$. From South to North. Type, British.

Lowland. Cultivated fields and by roadsides, usually in light soils; rather rare and uncertain in its appearances. Fl. MayAugust.

I. Ardagh near Roscarbery: Flor. Cork.-II. Rubbish heap by the Lee, Cork City (R.W.S.): Ir. Nat. I895. A garden weed near Fota, Cork; Phillips. Plentifully in the fields near Cappoquin: Smith's Waterford. - III. Side of the road between Ballybracken and Kilkenny: Mack. Rar. Near Freshford, Kilkenny (Rev. S. Madden); Clonmore Castle, Carlow (T. Chandlee): Cyb.IV. Murrough of Wicklow (Moore): Cyb. Frequent near New Ross, Wexford: B.-H.\& G. L889.-V. Near Navan and Nurney, Meath: Annot. in Threlkeld. Bray and elsewhere: Wade Dubl. Cornfield near Clogher Head, Louth: Ball I839. Howth, 1866 and 1881-82: Flor. Howth and in 1896; Miss S. Colgan. In Co. Dublin, sparingly at Bohernabreena, 1893, and abundant in a sandy field at Rush, 1894: N. C. $2895 .-\mathrm{VI}$. Great Island of Aran, Galway Bay (Prof. Melville): Cyb.-in same island, east of Portmurvy : Praeger 1895. At Askeaton, Limerick: Stewart I890.-X. At Loughgall: More 1860 . Roadside between Portadown and Tartaraghan Church, Armagh: Praeger 1893.-XII. Cornfields at Dundrum; among oats near Newcastle, 1799, also among stones at Donaghadee Pier: Templeton MS. Abundant in fields at Killowen, Down: S.\&P. 1892 . Railway bank south of Antrim (D. Redmond) ; Cushendun (Rev. S. A. Brenan): Flor. N.-E. Magilligan: Murphy I829. Umbra Rocks (Moore): Cyb.

\section{TEESDALIA R. Brown.}

1. † T. nudicaulis R. Br.-Naked-stemmed Teesdalia.

District - - - - - - - - - X. - Lat. 541ㅇ․ Co. Tyrone only. Type, British-English.

Lowland. Sandy lake shores; very rare. Fl. May-June. 
X. Abandant on the sandy shore of Lough Neagh at Washing Bay, Co. Tyrone, June, 1896 (Mrs. Leebody): Ir. Nat. I8gb, p. 212.

Open to some suspicion of being introduced in its only recorded station for Ireland. Further examination of the imperfectly explored western shores of Lough Neagh may be expected to extend the range of this species, and it seems entitled, at least, provisionally, to a place in the Irish flora.

\section{CRAMBE Linn.}

\section{C. maritima Linn.-Sea Kale.}

Districts I. II. - IV. V. VI. - - - - XI. XII. Lat. $51 \frac{3}{4}^{\circ}-55 \frac{1}{4}^{\circ}$. From South to North. Type, English.

Sandy and stony sea-shores; very rare. Fl. June.

I. On the shores of Cloghnakilty Bay and other places on the sea coast: Smith's Cork. On the strand near Bantry (Drummond) and by Douglas Channel near Lakelands, 1840 (Dr. Power) : Flor. Cork.-II. A few plants by the Lee between Tivoli and Dunkettle, Cork: Phillips 1895 . By the shore at Harpur's Island near Queenstown Junction, 1897, probably introduced; Phillips.IV. On the Murrough of Wicklow: Annot. in Threlkeld. A few plants at the Breaches, Kilcool, Wicklow, 1868-72 (Hart): Ree. $\boldsymbol{A} d \boldsymbol{d} d$.- not seen there since the latter date.-V. " Upon the sea beach near Dunlary": Threlkeld $x 727$. "It is found on our shore and is in request as a kale": Rutty's Dublin 1772 . On sandy shores at Merrion, Dunleary, and near Warren House on the road to Howth: Wade Dubl. 1794. Railway bank near Killiney (Barrington): Ree. Add. Sea coast between Malahide and Baldoyle: Mack. Cat. 1825 . South side of Howth: Ir. Flor. 1833. Sea shore at Sutton; Levinge. Sparingly on Ireland's Eye, 1894 (Praeger): Ir. Nat. 2895.-VI. "On the shore [Aran Isles] grows ... sea-cabbage," circa 1684: O'Flaherty's Iar Connaught. Isles of Aran, Galway Bay (Prof. Melville): Cyb. Near Kilronan, Aranmore Island: Hart 7875. In the greatest abundance on the beach below the Seven Churches, Aranmore: Praeger 1895. Shingly beach, Murrough near Black Head, Clare, one plant only, $1895 ; N$. C.-XI. On Tory Island, Donegal (Hyndman): Flor. Ulst.-not found there recently. At Norway point in the parish of Clonmany, Donegal, 1839: Herb. C. Moore.-XII. Gravelly shore between Quentin Castle and Knockinelder in the Ards, Co. Down (Rev.J. O' Laverty); about 13 plants found flowering there in 1876 (Stewart): Flor. N.-E. 
A decreasing species throughout Ireland, now extinct in many of the localities given by the earlier botanists, and perhaps an outcast from eultivation in some of its recently recorded stations.

\section{CAKILE.}

1. C. maritima Scop.-Sea Rocket.

Districts I. II. - IV. V. VI. - VIII. IX. - XI. XII. Lat. $511^{\circ}-55 \frac{1}{4}^{\circ}$. Coasts of all Ireland. Type, British. July.

Sandy sea shores; frequent and locally abundant. Fl. June-

\section{RAPHANUS Linn.}

\section{R. Raphanistrum Linn.-Wild Radish.}

Raphanistrum innocuum Med.

Districts I. II. III. IV. V. VI. VII. VIII. IX. X. XI. XII. Lat. $51 \frac{3}{4}^{\circ}-551^{\circ}$. Throughout Ireland. Type, British.

Cultivated fields, chiefly in sandy or peaty soils : frequent. Fl. June-August.

Sea-level in N. Antrim and in Kerry. To $950 \mathrm{ft}$. in Dublin (N.C.).

Though widely distributed, by no means a common species in many parts of the country.

2. R. maritimus Smith.-Sea Radish.

Raphanistrum maritimum Reichb.

Districts I. II. - IV. V. VI. - VIII. IX. - XI. XII. Lat. $51 \frac{1}{2}^{\circ}-551^{\circ}$. Coasts of all Ireland. Type, Atlantic.

Sea-cliffs and sandy shores; rare. Fl. June-September.

I. At Ballybunnion, Kerry : Stewart I89o. Several places near Derrynane and north of Castlegregory, Kerry: R. W. S. I89o, \&c. Shore of Castle Island, Schull Bay: Allin's Cork.-II. Steep limestone cliffs between Kilfarassy Island and Annestown, and between Stradbally and Ballyvoyle Head, Waterford: Hart I883 $\beta$.IV. Ballyconigar, Wexford (J. Morrison): Rec. Add. Coast below Lady's Island and between that and Tacumsin, Wexford: Hart ${ }_{2} 883 \beta$. - V. Banks of the sea under Mr. Hennington's at Howth: Ir. Flor. Near Sutton and Ceanchor: Flor. Howth. Frequent along the Dublin Coast from Portmarnock to Rogerstown, 1894; N. C.-VI. Aranmore Island, Galway Bay (Moore): Cyb. On Aranmore Island and also on Inishmaan : Hart $1875 .-$ VIII. At 
Roundstone, Connemara: Oliver 1851 . Inishbofin and Macdara and Nason Islands, Galway; More.-IX. Near the coast between Sligo and Ballina: Ball I839.-XI. At Inishowen Head and east of Dunaff: Hart 1883.-XII. At the Curran of Larne, 1808: Templeton MS. Rathlin Island, 1850 (Miss Gage)—in great abundance there in 1852: Stewart I884. Shore near Ballywalter (J. H. Davies) and plentiful from Killough to St. John's Point, Down (Stewart): Stevoart 1894 .

\section{ORDER VI.-RESEDACEE.}

\section{RESEDA Linn.}

\section{1. † R. lutea Linn.-Wild Mignonette.}

Districts I. II. III. IV. V. VI. - - - [X.] [XI.] XII. Lat. $52^{\circ}-551^{\circ}$. South and East, chiefly. Type, English-Germanic. - Lowland. Sandy fields and gravelly waste places; rare. Fl. June-August.

I. Kenmare: Druce I80I.-II. By the Bride above Castlelyons, Cork, 1842; above the bridge at Dungarvan, Waterford, 1840: Flor. Cork. In a gravel pit near Midleton, 1895; Phillips. Fairy Hill, Waterford (Miss A. Taylor): Cyb.-III. In Queen's County, by the Barrow below Athy; R.W.S.-IV. On a headland near Tinnyberna, Wexford: Hart I88I a. On the Murrough near Wicklow; Levinge.-V. About Knockmaroon Hills, 1814 : Templeton MS.-and in $1895 ; N . C$. In sandy fields at Sandymount: Wade Dubl. Abundant in the sandy fields about Rush : Ir. Flor.still abundant there in $1895 ; N$. C. Sand-hills at Portrane, 1862 (Moore): Herb. Glasnevin-abundant there in $1895 ; N$. C. Sparingly on the shore at Castlebellingham, Louth; Cecil Butler.VI. South-east of Killeany, Aranmore Island (Hart): Rec. Add. Kilmurvy, Aranmore, $1891 ;$ P.B. O' Kelly.-[X. Railway Station, Cavan; Levinge.-XI. A single plant at Greencastle, Lough Foyle (W. E. Hart) : Hart ${ }_{2} 88_{3}$.] -XII. Banks of the river at Ballyeastle: Flor. Olst. Ballyligg quarries, near Larne, Antrim (Stewart): Cyb. Ballast heaps and quarry spoil-bank at Magheramorne (Stewart); sand-hills at Portrush (Praeger): Flor. N.-E. Certainly naturalized at Ballycastle and probably at Magheramorne: S. \& P. 1895 .

Perhaps fully naturalized only in Districts $\mathrm{V}$. and XII. 


\section{R. Luteola Linn.-Weld; Yellow Wieed.}

Hibernioé buióe món (Bwee more)-Great Yellow [Plant].

Districts I. II. III. IV. V. VI. VII. VIII. IX. X. XI. XII. Lat. $51 \frac{1}{2}^{\circ}-55 \frac{1}{4}^{\circ}$. Throughout Ireland. Type, British-English.

Banks and waste places; frequent. Fl. June-August. Caloicole $B$.

Sea-level to $1000 \mathrm{ft}$. in Dublin (N. C.).

Formerly much cultivated as a dye-stuff in Co. Dublin and elsewhere in Ireland.

\section{ORDER VII.-CISTINE压.}

\section{HELIANTHEMUM Haller.}

\section{H. guttatum Mill.-Spotted Rock-rose.}

Districts I. - - - - - - VIII. - - - Lat. 51 $\frac{1}{2}^{\circ}-53 \frac{1}{2}$. West Ireland: Mayo and Cork. Type, LocalAtlantic.

Lowland. Banks by the sea; very rare. Fl. June-August.

I. At Three Castle Head, Carberry (Miss H. Townsend): Flor . Cork. Rather plentiful in this locality, extending over several acres to the S.-W. of the Castle ruins (T. Chandlee): $C y b$. Still at Three Castle Head, 1896; Phillips.-VIII. Abundant on Inish-. bofin (W. Macmillan): More 1873-and in 1897; Barrington.

Var. BREwerI Planoh.-I. At Three Castle Head, South Cork, 1896; Phillips.-VIII. Plentiful on Inishbofin and Inishark : More $\mathbf{I} 876$.

Typical H. guttatum; though it occurs in the Channel Islands, in the British Isles, proper, appears to be confined to Ireland.

First found in Treland, by Miss Townsend, before 1843.

2. H. vineale Pers.-Hoary Rock-rose.

H. canum (Dun.) Cyb:-H. marifolium (Mill.) var. vineale (Pers.) Lond. Cat. gth Ed.

Districts - - - - - VI. - VIII. - - - İat. $53^{\circ}-53 \frac{1}{x}^{\circ}$. Clare, Aran Isles and Galway. Type, Intermediate-

Atlantic.

Lowland. On limestone rocks; very rare. $F l$. May-July.

VI. Plentiful in the South Isles of Aran : Mack: Rar. (as Cistus Helianthemum). Abundant on the north-east side of Aranmore- 
Island from near Kilronan to Bungowla; absent from Inishmaan and Inisheer (N.C.): Ir. Nat. 1893. In that part of Burren which directly faces the Aran Isles, 1851: O'Mahony 1860. At Glanquin in Burren, Clare (Rev. T. Warren): Cyb.- and in 1879: Corry 5880 . Plentiful on the coast north-east of Poulsallagh, Clare : Foot I864. Still near Poulsallagh and also at Black Head, Clare, 1892: Levinge I892. Sparingly near Muckinish, Ballyvaughan, Clare, $1895 ; P . B$. O'Kelly.-VIII. Sparingly on a limestone bank half a mile west of Salthill, Galway, $1893 ; \boldsymbol{F} . \boldsymbol{K}$. Boyd.

\section{ORDER VIII.-VIOLACEA.}

VIOLA Linn.

\section{V. palustris Linn.-Marsh Violet.}

Districts I. II. III. IV. V. VI. VII. VIII. IX. X. XI. XII. Lat. $51 \frac{1}{2}^{\circ}-55 \frac{1}{4}^{\circ}$. Throughout Ireland. Type, British.

Bogs and marshes, chiefly in mountain districts; frequent. $F$. April-June. Caloifuge $A$.

Sea-level in N. Antrim and S. Cork. To $2000 \mathrm{ft}$. in Donegal (Hart); to $2800 \mathrm{ft}$. in Wicklow (N.C.); to $2550 \mathrm{ft}$. in Kerry (Hart).

\section{2. + V. odorata Linn.-Swost Violet.}

Districts I. II. III. IV. V. VI. VII. - - X. - XII. Lat. 51 $\frac{1}{2}-55^{\circ}$. From South to North. Type, English.

Lowland. Woods, hedges, and roadsides; rare and a doubtful native. Fl. March-April.

I. An escape in Kerry, as in the Green, Tralee; woods at Hillville; Fermoyle, \&c.; R. W. S. Near Cahirmore, Rosscarbery and-II. Near Midleton; Garrycloyne, \&c.: Allin's Cork. At Castletownsend, 1897; Phillips. Plentiful along roadsides neax Tallow, Waterford; R.P. Fowell. Along the Cork road about a mile from Clogheen, Tipperary (Miss S. Grubb): Cyb.-III. Abundant along roadsides in Co. Carlow, and in various parts of the Queen's Co. between Mountmellick and Carlow, apparently indigenous (J. Morrison); on old hedge-banks for several miles along the road between Castlecomer and Athy (R.Mallet): Cyb.-IV. Ballycarney and by the 'Slaney, \&c., in Wexford (Miss E. M. Farmer): Rec. Add. Roadsides near Newtownbarry, Wexford, with both white and blue flowers (J. Morrison): Cyb.-V. Frequent in Co. Dublin, 
but nowhere abundant or indigenous; $N$. C. Near Athy, Kildare, possibly native (Carroll): Cyb. Common on hedge-banks about Kilkea, Kildare, with both white and blue flowers (J. Douglas): Rec. Add. Abundant and apparently native in south-west Kildare, $1890 ; R . W . S .-V I$. Plentiful on gravelly ground by roadsides between Sixmilebridge and Newcastle, Co. Clare: Stewart, 7890.-VII. Wood near the old mill, Knock Drin, Westmeath, well established: Levinge 1894 . Roadside banks near Dromineer, Tipperary, 1896; N.C.-X. Grange; Loughgall; Tyross Hill, \&c., Armagh (Rev. W. F. Johnston): Praeger r893.XII. Not uncommon in Antrim, Down, and Derry, but doubtfully native : Flor. $N \cdot-E$.

\section{V. hirta Linn.-Hairy Violet.}

Districts - - - IV. V. VI. - - - - -

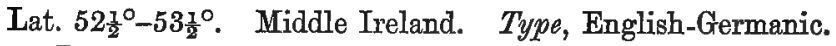

Lowland. Sandy pastures, banks, and bushy places; rare. Fl. April-May. Calcicole $C$.

IV. On dry, gravelly banks a mile below Clohamon, Wexford, on the left bank of the Slaney: Hart 1881 a.- $-\mathrm{V}$. In hilly and bushy pastures in a sandy soil near the shore at Raheny: Wade Dubl. In the Phœnix Park ; on Knockmaroon Hill on the road to Lucan, 1799; among the sand-hills at Baldoyle: Templeton MS. Still abundant at the Baldoyle (Portmarnock) sand-hills, 1895 ; N. C. East side of Howth : Ir. Flor. 1833 , and Flor. Howth 1887. On the Cosh, Sutton, 1873; Greenwood Pim. Sand-hills at Portrane opposite Malahide (More): Rec. Add. A bundant in many parts of the Portrane peninsula, 1894-95; N.C. VI. On the largest South island of Aran [Aranmore] in the crevices of limestone rocks: Mack. Rar. 1806. Abundant in Aranmore island and in Inisheer, $1892 ; N$. C. Plentiful on limestone rocks at Askeaton, and in quarries south-east of Foynes, Co. Limerick: Stewart I890.

\section{V. Riviniana Reichb.-Wood Violet.}

V. syluatica Fries, in part.

Districts I. II. III. IV. V. VI. VII. VIII. IX. X. XI. XII. Lat. $51 \frac{1}{2}^{\circ}-55 \frac{1}{4}^{\circ}$. Throughout Ireland. Type, British.

Hedge-banks, woods, and mountain pastures; common. Fr. April-May.

Sea-level in N. Antrim and S. Cork. To $2000 \mathrm{ft}$. in Donegal, to $2796 \mathrm{ft}$. in Down, and to $3200 \mathrm{ft}$. in Kerry (Hart). 


\section{Reichenbachiana Boreau.}

V. sylvestris Reich.-V. sylvatica Fries, in part. Districts I. - - IV. V. VI. VII. VIII. - - XII. Lat. $52^{\circ}-54 \frac{1}{2}{ }^{\circ}$. From South to North.

Lowland. Woods and hedge-banks; frequent. Fl. MarchApril.

I. Not infrequent in Kerry; R.W.S.-IV. At Powerscourt, Wicklow (MLore): Cyb. Nuke wood near Ballyhack, Wexford: B.-H.\& M. I892. - V. Green Hills, Crumlin; at Knocksedan; Shankill, \&e.; not infrequent in Co. Dublin; N.C.-VI. At Castle Taylor, Galway; More.-VII. Knock Ross by Lough Derevaragh, Westmeath : Linton 1896 .- VIII. Ashford House demesne near Cong: MI.\&S. 1896 . - XII. In Antrim, by the shore of Lough Neagh at Selshan, also in Colin glen, but not common in the county (Stewart): Flor. N.-E.

Very often confounded with $T$. Riviniana, and will no doubt be found to occur throughout Ireland.

\section{V. canina Linn.-Dog Violet.}

Districts I. II. - IV. V. VI. VII. VIII. IX. X. XI. XII. Lat. $5 \frac{3}{4}^{\circ}-55 x^{\circ}$. Throughout Ireland, probably. Type, British.

Lowland. Sandhills and sandy pastures by the sea, also inland on gravelly lake shores; rather rare. $F l$. April-June.

I. By the Lower Lake, Killarney; R.W.S.-II. Near St. Ann's, Blarney (R. Mills) : Rec. Add.-IV. On the Murrough of Wicklow (Moore): Cyb.-V. Sandhills at Portmarnock and Portrane (Moore \& More): Cyb. Abundant on the sandhills at Rush and Portrane, $1894 ; N$. C.-.VI. By the lake at Garryland, Galway (More) : Cyb.-VII. Boggy ground by the Shannon near Clonmacnoise, King's Co. : B.\& V. 1887.-VIII. Shores of Loughs Cullin and Conn, Mayo, and-IX. Shores of Lough Carra, Mayo (More): $C y b .-\mathrm{X}$. Devenish Island and elsewhere about Lough Erne, frequent: Barrington I 884. Shores of, and islets in, Lough Neagh, Co. Armagh (More): Cyb. XI. By the Termon river above Pettigo : Hart 1 886.-XII. Sandhills at Newcastle and Ballykinler, Down; shore of Lough Neagh at Shane's Castle and Selshan, Antrim (Stewart); Portrush sandhills and sandy shore at Cushendall, Antrim (Praeger): Flor. N.-E. 


\section{V. stagnina Kit.-Pale Dog-Violet.}

T. persicafolia Roth.

Districts - - - - - VI. - - - - - Lat. $53^{\circ}-531^{\circ}$ Clare and Galway only. Type, English-Germanic. Lowland. Damp, stony places and boggy pasture land overflowed in winter; very rare. Fl. May-June.

VI. By the lake in Garryland wood near Gort, Co. Galway, and on the borders of several of the "turloughs" 1 in that vicinity, June 1857: More 1855 \& $C y b$. Still at Garryland in 1896; Miss M. F. Jackson. Turlough and Newtown Gort, 1894 (P. B. O'Kelly) : Wats. B. Ex. C. Rep. 1895 . On a turlough near Athenry called Finnerty Moyode, 1889 ; Mrs. M. E. Joyce. At Turlough and Lough Callagh near it, in the parish of Oughtmama, Co. Clare, 1895 ; P. B. O' Kelly.

First found in Ireland by A. G. More, at Garryland, in 1851.

\section{V. tricolor Linn.-Witd Pansy.}

Districts I. II. - IV. V. - VII. - - X. - XII. Lat. $51 \frac{1}{2}^{\circ}-55 \frac{10}{4}$. From South to North. Type, British.

Cultivated ground; rather rare. Fl. May-September.

I. Ballineen; Togher and Castletownsend: Allin's Cork.II. Field near Blarney: Flor. Cork,-IV. Abundantly in a bog at Killoughrum, Wexford: Moffat I889.-V. At Clonsilla and occasional in Co. Dublin, 1895; N.C.-VII. Lisclogher bog-road (Miss Levinge): Levinge 1894.-X. Roadside banks near Lough Neagh, Armagh: More I860. Gubbaroe point, Kesh, Lough Erne: Barrington 1884.-XII. Common in north-east Ireland: FFlor. N.-E.

To $950 \mathrm{ft}$. in Dublin (N.C.), but usually lowland.

No doubt occurs throughout Ireland, but is often confounded with the following sub-species.

\section{V. arvensis Murr.}

Districts I. II. III. IV. V. VI. VII. VIII. IX. X. XI. XII. Iit. $51^{\circ}-551^{\circ}$. Throughout Ireland. Type, British.

Cultivated fields in light soils, also in gravelly places; rather common. Fl. May-September.

Sea-level to $950 \mathrm{ft}$. in Dublin (N.C.).

1 The name "turlough" is applied in the limestone districts of Galway and Clare to hollows which become flooded by underground channels after heavy rains. 
V. Curtisii Forst.

Districts I. II. - IV. V. VI. - VIII. IX. - XI. XII. Lat. $51 \frac{1}{2}^{\circ}-55 \frac{1}{4}^{\circ}$. Coasts of all Ireland. Type, Atlantic.

Sand-hills and sandy pastures by the sea; rather common. Fl. May-September.

Also occurs inland, but rarely, on gravelly or sandy lake-shores, as at Lough Erne, Lough Neagh, and Castlewellan Lake (Barrington I884 and Flor. N.-E.).

\section{V. lutea Huds.-Mountain Pansy.}

Districts I. - - IV. V. VI. - - - [X. ] - Lat. $53^{\circ}-54^{\circ}$. South and Middle Ireland. Type, Scottish.

Upland pastures; very rare. $F l$. June-July.

I. Mountains near Castletown (J. Drummond): Flor. Cork. Mountain passes near Bantry, 1852 ( $J$. Sullivan): Annot. in Flor. Cork.-IV. On the banks of the King's River near Lackan, Wicklow (H. W. D. Dunlop): Rec. Add.-V. On the Hill of Lyons, Dublin (Moore): Cyb. Heath near Ballinascorney, Co. Dublin: Corry 1882. Near Brittas, 1880 (C. Dickson). Near Brittas, 1895 , and near the top of Lugmore, Co. Dublin, $1896 ; N$. C. Dry, grassy top of Dunmurry Hill, Co. Kildare, 1877 : Butler I89o. -VI. On the ascent towards the cliffs of Moher and on the sandhills of Lahinch and Miltown-Malbay (in the latter stations coming near V. Curtisii, but with the stipules of $V$. lutea): More $1860-$ and in $1892 ; H$. C. Levinge.-[X. In the mountainous country around Bealeyborough (Bailioborough, Cavan): Annot. in Threlkeld -not found there recently].

Sea-level to about $700 \mathrm{ft}$. in Clare (More). To $1000 \mathrm{ft}$. in Dublin (N.C.).

\section{ORDER IX.-POLYGALEE.}

POLYGALA Linn.

1. P. vulgaris Linn,-Milk-roort.

Districts I. II. III. IV. V. VI. VII. VIII. IX. X. XI. XII. Lat $57 \frac{1}{2}^{\circ}-55 \frac{1}{4}^{\circ}$. Throughout Ireland. Type, British.

Pastures, gravelly and stony places and on sand-hills; frequent. $F l$. May-August.

Var. GRANDIFLORA Bab.-IX. Cliffs in Glencar and elsewhere in the Ben Bulben district: $B . \& \Gamma_{1}{ }_{2} 885 .-\mathrm{XII}$. On the basaltic cliffs of Ben Evenagh, Derry (Stewart): Flor. N.-E. 
Var. oxrPTERA (Reichb.) is reported from the counties of Antrim, Down, Dublin, Wicklow, Wexford, Kerry, and Galway, and probably occurs on sand-hills all round the coast.

Sea-level in Antrim and S. Cork. To $1200 \mathrm{ft}$. (GRANDDrLoRA) on Ben Bulben $(B . \& V$.).

P. depressa Wend.

$P$. serpyllacea Weihe.

Districts I. II. III. IV. V. VI. VII. VIII. IX. X. XI. XII. Lat. $51 \frac{1}{2}^{\circ}-55 \frac{1}{4}^{\circ}$. Throughout Ireland.

Heaths, bogs, and mountain pastures; frequent. Fl. MayAugust. Calcifuge $A$.

Sea-level in Donegal and S. Cork. To about $2000 \mathrm{ft}$. in Donegal (Flor. Olst.); to 2050 in Wieklow $(N . C$.); to $2800 \mathrm{ft}$. in Kerry (Druce I8gI).

\section{ORDER X.-CARYOPHYLLEE.}

SAPONARIA Linn.

1. *S. officinalis Iinn._Soap-wort.

Districts I. II. III. IV. V. VI. VII. VIII. - X. XI. XII. Lat. 571 $\frac{1}{2}^{\circ}-55 \frac{1}{4}^{\circ}$. From South to North. Type, English.

Lowland. Banks, hedges, riversides, and waste places, usually near houses and always a relic of cultivation; not infrequent. $F$. August-September.

Well established in many parts of the country, as in Co. Dublin along the River Dodder and in its neighbourhood, where it has. maintained itself for 150 years, and in Co. Wicklow along the Dargle and Enniskerry rivers.

\section{SILENE Linn.}

\section{1. s. Cucubalus Wibel.-Bladder Campion.}

S. inflata Smith.

Districts I. II. III. IV. V. VI. VII. VIII. IX. X. XI. XII. Lat. $51 \frac{1}{2}^{\circ}-55 \frac{1}{4}^{\circ}$. Throughout Ireland. Type, British.

Cultivated fields, hedge-banks, and roadsides, chiefly near the sea; frequent. Fl. June-August.

Sea-level to $900 \mathrm{ft}$. in Dublin (N. C.).

In Co. Cork, Mr. R. A. Phillips informs us the Var. PUberuta syme is almost as common as the type. 


\section{S. maritima With.-Sea Campion.}

Districts I. II. - IV. V. VI. - VIII. IX. - XI. XII. Lat. 51 $\frac{1}{2}^{\circ}-55 \frac{1}{4}^{\circ}$. Coasts of all Ireland. Type, British.

Shingly and rocky sea-shores; common, frequent also on mountains near the sea. Fl. June-August.

Occurs abundantly, inland, on Ross Island, Killarney Lakes, at about $70 \mathrm{ft}$. above sea-level.

To $1500 \mathrm{ft}$. in Donegal, and to $2250 \mathrm{ft}$. in Galway (Hart).

\section{3. † S. anglica Linn.-English Catch-Aly.}

Districts I. II. III. IV. V. - - VIII. - X. XI. XII. Lat. $51 \frac{1}{2}^{\circ}-55 \frac{10}{4}$. South to North. Type, English.

Lowland. Cultivated fields, mostly in sandy soil; rare. Fl. June-September.

I. On the east side of the estuary at Trabeg, Dingle: Hart 1884 . Sparingly near Killorglin and Rossbehy, Kerry: R.W.S. 1889 . Near Castletown, Berehaven: Drummond I819-still there: Phillips 1894. Plentiful in cornfields near Schull, 1896; Phillips. At Lissard, Skibbereen; at Toe Head, and abundant in oatfields at Shepperton, Leap and near Kilcrohane; Durrus: Allin's Cork.II. Little Island, near Cork: Flor. Cork. Cornfield near Whitegate, 1895 ; Phillips.-III. Near Carlow (J. Morrison): Cyb.-IV. Abundant in the sandy soil about Ballyconigar (J. Morrison): Carroll 1854. At Curracloa, Wexford, plentiful (Carroll): Cyb. Tinnyberna, Wexford: Hart $1883 \beta .-V$. Sandy fields at Portmarnock, 1869 (Hart): Rec. Add. - and again in 1895; N.C. Plentiful in sandy cornfields by the sea near Castlebellingham: Butler I 89o.-VIII. In cornfields at Oughterard, Galway: Babington $1836 .-\mathrm{X}$. Waste ground near Coalisland, Tyrone (Miss $M$. C. Knowles): Ir. Nat. r897. - XI. About Stroove, Inishowen: Hart 7883.-XII. Fields along the shore side about Kerkeel [Kilkeel], Co. Down (John White): Wade Rar. I804-still there: S.\&P. 1892. Abundant about Greencastle: Ir. Flor. 2833 . Abundant in gravelly places north of Greencastle coastguard station (Stevoart): Flor. N.-E. In great profusion in fields by the course of the Causeway Water, Down: S.\&P. 1892. By the new road to the ferry, Bellaghy, Antrim (R. Tate) : Flor. N.-E. Magilligan, Derry, 1835: Moore MS.-still abundant there (Mrs. Leebody): S.\&P. 1895 . 
4. S. acaulis Linn.-Mossy Campion; Cushion Pink.

Districts - - - - - - - IX. - XI. XII. Lat. $541^{\circ}-55 \frac{1}{4}^{\circ}$. North and North-West. Type, Highland.

Mountain cliffs and rocks; very local. Fl. June-July.

IX. Found on Ben Bulben and on other high mountains near Sligo in September, 1806: Mack. Rar. Mountains of Leitrim and Sligo: Murphy I829. Common on the cliffs north-east of Ben Bulben; abundant on Ben Bulben: B.\&. . 8855 . Abundant on the top of Lug-na-gall, Glencar, Sligo: N.C. $7806 .-\mathrm{XI}$. At Dunaff Head, Donegal (C. Moore); very rare here and in one place only: Hart 1883.-XII. Ben Evenagh, facing Derry Lough, 1805 (Templeton): Whitla MS. In great abundance on Ben Evenagh, 1835 : Moore MS.--still abundant there, 1878 (T. H. Corry) : Flor. N.-E.

From $550 \mathrm{ft}$. in Donegal (Hart); to $1200 \mathrm{ft}$. in Derry (Moore); to $1600 \mathrm{ft}$. in Sligo $(B . \& V$.).

\section{5. † S. noctiflora Linn.-Night-flowering Catoh-fly.}

Districts I. - - - V. - VII. - - X. - XII. Lat. $521^{\circ}-551^{\circ}$. East and North-East, chiefly. Type, EnglishGermanic.

Lowland. Sandy cultivated fields and banks; very rare. $F l$. July-August.

I. Very sparingly near Ballybunnion, Kerry: R.W.S. I890seen there again, about a dozen plants, three years later; $R . W . S$. $-\nabla$. Plentiful in sandy cornfields by the sea near Castlebellingham: Butler I89o. Plentiful in a sandy waste field, west of Mayden Tower, Boyne mouth: Praeger 7897.-VII. Field near Tullamore, King's Co. (Miss Green): Mackay 1859.-X. Gravel pit near the railway $2 \frac{1}{2}$ miles north-east of Armagh : Praeger $2893 .-\mathrm{XII}$. Near the base of one of the drumlins in recently disturbed earth where the new railway is making in the parish of Drumbeg, Co. Down, 1837 , and in a sand-pit on the Lurgan road half a mile from Lisburn (Moore) : Colby 1837. Rough Island, Strangford Lough (Stewart) : Flor. N.-E. At Hollywood, a casual (Praeger): S. \& P. 1895. Sandy cornfield near Magilligan, Derry: Herb. Moore. Gravelly waste ground near Larne Harbour (Praeger): Ir. Nat. I897, p. 299 .

Only a casual in many of its Irish stations. 


\section{LYCHNIS Linn.}

\section{1. $\ddagger$ L. vespertina Sibth.-White Campion.}

L. alba Mill.--L. dioioa $\beta$. Linn.-Melandrium pratense Roehl.

Districts I. II. III. IV. V. - VII. VIII. IX. X. XI. XII. Lat. $51_{\frac{1}{2}}^{\circ}-55 \frac{1}{4}^{\circ}$. South and East, chiefly. Type, British.

Lowland. Cultivated ground and waste places; local. Fl. June-August.

I. Castlelough Bay, Killarney, and sandy field west of Castlegregory; very rare in Kerry : $R$.W.S. $1889 \&$ r89I. Near Baltimoreand Skibbereen, Cork, 1896; Phillips.-II. At Roxboro', Midleton; near Blarney; near the mouth of the Finnisk river, Youghal, \&c., rather rare in Co. Cork : Allin's Cork.-III. Brown's Hill, Carlow (R. Clayton Browne): Reo. Add. Near Mountmellick and by the Barrow at Kilmaroney below Athy: Hart 1885.-IV. About Fethard and Carne, Wexford: B.-H.\& G. I800.-V. Plentiful in sandy fields round Warren House on the road to Howth and everywhere about Baldoyle: Wade Dubl. 1794. Abundant in sandy fields along the coasts of Co. Dublin from Baldoyle to Skerries, 1895 ; N. C.-VII. By the Barrow above Monasterevan: Hart I885.-VIII. Ashford, Cong, a casual; Miss M. F. Jackson.IX. Yew Point and Hudson's Bay, Lough Ree, Roscommon: B. \& V. I887.-X. Waste ground near Coalisland, Tyrone (Miss. M. C. Knowles) : Ir. Nat. 1897.-XI. Near Lough-an-Ure (Hart): Rec. Add. Kinnalough, Horn Head : Hart 1879 . Fintragh Bay and between Ballyshannon and Bundoran: Hart I885 $\gamma$-XII. Hollywood: Flor. Ulst. Roadsides and fields near Templepatrick and railway banks near Larne (Corry); Glendarragh, Antrim ( $D$. Redmond); Castledawson, Derry (Stewart) : Flor. $N_{\cdot}-E$.

\section{L. diurna Sibth.-Red Campion.}

\section{L. dioica a Linn.-Melandrium silvestre Roehl.}

Districts I. II. III. IV. V. VI. VII. VIII. IX. X. XI. XII. Lat. $51 \frac{1}{2}^{\circ}-551^{\circ}$. Throughout Ireland. Type, British. June.

Hedges and woods; frequent and locally abundant. $F l$. May-

I. About Muckross and Killarney and at Kerry Head in several places; very local in Kerry: $R$. W. S. 1889 . Woods at Castlefreke and Myros: Allin's Cork. Plentiful on Cape Clear Island, 1896 ; at Castle Bernard, Bandon, 1897; Phillips.-II. Abundant in the woods, Carrigacunna Castle, Killavallen, rather rare in 
Cork: Allin's Cork. On the Galtee mountains, Tipperary, and on the Commeragh mountains, Waterford: Hart I88I \& I884.III. Recorded for this district in 1st Ed. $C y b$., but no locality arailable.-IV. Powerscourt demesne: Flor. Hib. Very abundant at Courtown, Wexford: Hart 1883 B.-V. Abundant in Lambay Island, Co. Dublin, 1881: Hart $1883 \gamma$-rare elsewhere in Co. Dublin; N. C.-VI. Clonbrock, Co. Galway, 1896; Praeger.VII. Plentiful in Knock Drin woods, Westmeath: Levinge 1894VIII. Inishturk, Mayo: More I876. Ross Hill, shore of Lough Mask; Miss M. F. Jackson.-IX. Plentiful on some of the Ben Bulben cliffs: B.\& V. 1885 . - X. Gubbaroe Point, Kesh, Lough Erne: Barrington 1884. Shore of Lough Neagh at Maghery (Rev. W. F. Johnson); in Tanderagee upper demesne: Praeger 1893.XI. About Kindrum lake, Fanet: Hart 1879 . Coast at Ardmalin south : Hart I883.-XII. Frequent, especially round the coast, in Antrim, Down, and Derry : Flor. N.-E.

Sea-level in N. Antrim and S. Cork. To $1000 \mathrm{ft}$. in Derry $(C y b$.$) ; to 1800 \mathrm{ft}$. in Sligo $\left(B . \& V_{\text {. }}\right)$; to $1700 \mathrm{ft}$. in Tipperary (Hart).

A scarce plant in many parts of the country.

\section{L. Flos-cuculi Iinn.-Ragged Robin.}

Districts I. II. III. IV. V. VI. VII. VIII. IX, X. XI. XII. Lat. 51 $1_{2}^{\circ}-55 \frac{1}{4}^{\circ}$. Throughout Ireland. Type, British.

Marshy places and moist meadows; common. Fl. June-July.

Sea-level in N. Derry and S. Cork. To $1700 \mathrm{ft}$. in Donegal and $1470 \mathrm{ft}$. in Waterford (Hart).

\section{4. $\ddagger$ L. Githago Scop.-Corn Cookle:}

Agrostemma Githago Linn.-Githago segetum Desf.

Districts I. II. III. IV. V. VI. VII. VIII. IX. X. XI. XII. Lat. $52^{\circ}-55 \frac{1}{4}^{\circ}$. Throughout Ireland. Type, British.

Lowland. Cultivated fields, usually in sandy soil; frequent. Fl. June-July.

I. With crops near Dingle and Castlegregory, but rare in Kerry : $\boldsymbol{R}$.W.S. I89I. Blasket Islands: Barrington I88I.II. About Ardmore, Waterford: Hart $I_{8} 88_{3} \beta$.-III. By the Slaney below Ballintemple, Carlow : Hart I88I a.--IV. Cornfields by the sea at Dunbur, Co. Wicklow; Rev. C. $F$. d'Arey. About the coast near Fethard, Wexford : Hart ${ }_{1} 883$ 3.-V. In a close of wheat .... near the Green Hills: Threlkeld. At Portrane and 
Howth, 1895, but rare in Co. Dublin; N. C.-VI. In wheat fields at Croagh and Murrough, Burren; P. B. O'Kelly.-VII. Knock Drin, Westmeath, rare; Levinge-VIII. Frequent about Oughterard; Ifiss M. F. Jackson.-IX. Ballysodare, Sligo; Praeger.$\mathrm{X}$, Recorded for this district in 1st Ed. Cybele but no locality available. XI. Glinsk near Carrowkeel and abundant at Horn Head: Hart 1879 . Between Dunkineely and Killybegs: Hart 1885 \%.-XII. Frequent in north-east Ireland: Flor. N.-E.

Usually introduced with vetches, in which crop it appears to be more abundant than in corn.

\section{CERASTIUM Linn.}

1. C. tetrandrum Curtis-Four-cleft Mouse-ear.

Districts I. II. - IV. V. VI. - VIII. IX. X. XI. XII. Lat. $51 \frac{1}{2}^{\circ}-55 \frac{1}{4}^{\circ}$. Coasts of all Ireland. Type, British.

Sandy or gravelly ground, usually near the sea; frequent. $F l$. April-June.

Almost entirely confined to the neighbourhood of the coast, but has been found inland on the shores of Lough Conn, Mayo (More) and Lough Neagh (Moore); also on dry boggy ground near Hollymount and Foxford, Mayo (More), and on limestone, apparently flooded in winter, south of Lough Mask: Marshall 1806 .

2. C. semidecandrum Linn.-Little Mouse-ear.

Districts I. II. - IV. V. VI. - VIII. IX. - XI. XII. Lat. $51 \frac{3}{4}^{\circ}-55 \frac{1}{4}^{\circ}$. From South to North. Type, British-English.

Sandhills, dry banks, and walls near the sea; not infrequent. Fl. April-May.

To $1100 \mathrm{ft}$. in Derry (Hart).

\section{C. glomeratum Thuill-DBroad-leaved Mouse-ear.}

Districts I. II. III. IV. V. VI. VII. VIII. IX. X. XI. XII. Lat. $51 \frac{1}{2}^{\circ}-55 \frac{1}{4}^{\circ}$. Throughout Ireland. Type, British.

Roadsides and waste places, chiefly in gravelly or sandy soil; rather common. Fl. Maj-August.

Sea-level in Antrim and Cork. To $1600 \mathrm{ft}$. in Dublin (N. C.).

4. C. triviale Link-Common Mouse-ear.

Districts I. II. III. IV. V. VI. VII. VIII. IX. X. XI. XII. Lat, $51 \frac{1}{2}^{\circ}-551^{\circ}$. Throughout Ireland. Type, British.

Pastures, banks, walls, and waste places; very common. Fl. April-October. 
Sea-level in N. Antrim and S. Cork. To $1600 \mathrm{ft}$. in Donegal, to $2450 \mathrm{ft}$. in Mayo (Hart); to $3000 \mathrm{ft}$. in Wicklow (N.C.); to $3100 \mathrm{ft}$. in Kerry (Hart).

Var. HoLOsTEOIDES (Fries)-XII. Abundant in meadows on the south side of the Bann, below the railway bridge at Coleraine (Mrs. Leebody): S.\&P. 1895 .

Var. PentandRom Syme-II. Cork Beg Island, Cork Harbour, 1896; Phitlips.

5. C. arvense Linn.-Large-flowered Mouse-ear.

Districts I. II. - - V. VI. - VIII. - - - XII. Lat. $52^{\circ}-54 \frac{3}{4}^{\circ}$. South to North. Type, British-English.

Lowland. Sandy banks and on rocks, chiefly near the sea; rare, but locally abundant. $F l$. May-July. Caloicole $C$.

I. On the Blasket Islands, Kerry ( $W$. Andrews): $C y b$.- -still there: Barrington I88I.-II. By the shore at Ballyvodock, Midleton, Cork: Flor. Cork-not seen recently in Co. Cork.-V. Abundantly in sandy fields and by roadsides between Clontarf and Howth: Wade Dubl. Abundant at Howth and on Ireland's Eye: Flor. Howth. On Feltrim Hill and at Donabate (More); and plentiful on north side of Lambay Island (Barrington): Rec. Add. Abundant along the Dublin coast from Sutton to Skerries, $1895 ; N$. C. Near the lighthouse at the mouth of the Boyne; Barrington.VI. Aranmore Island ( $W$. Andrews): Journ. of Bot. 1845. On all three islands of Aran : Hart. r875. Frequent in the Burren district of Clare: Foot 1862. Poulsallagh, Clare, 1892; Levinge. South shores of Galway Bay (More): Cyb.-VIII. To the west of Galway, near the shore (Prof. Melville): Cyb. Sparingly by the shore at Inveran, Iar Connaught, $1897 ;$ Rev. W. Colgan.-XII. Plentiful on a sandy bank in Massareene Park ( $D:$ Redmond): Flor. $N .-E$.

The Blasket Islands plant is the glabrous variety ANDREwsII Syme, which is frequent also in the Aran Islands, but seems hardly worthy of distinction.

\section{STELLARIA Linn.}

\section{S. media Vill.-Chickweed.}

Hibernicé Flioo ( $F$ luh).

Districts I. II. III. IV. V. VI. VII. VIII. IX. X. XI. XII.

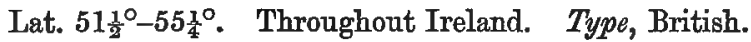

Waste places, cultivated ground, \&c.; very common. Fl. Throughout the year, with open winters. 
Sea-level in N. Donegal and S. Cork. To $2000 \mathrm{ft}$. in Derry (Moore); to $2550 \mathrm{ft}$. in Kerry (Hart).

Var. BoRzana (Jord.)-Alsine pallida (Dum.)-The apetalous sandhill variety is reported from Dublin, Wicklow, Cork, and Kerry, and is probably frequent round the coast.

Var. Neglecta (Weihe) - I. Cahernane, Killarney : R.W.S. 7888 .

\section{S. Holostea Linn.-Greater Stitch-wort.}

Districts I. II. III. IV. V. VI. VII. VIII. IX. X. XI. XII. Lat. 51 $1 \frac{1}{2}-55 \frac{1}{4}^{\circ}$. Throughout Ireland. Type, British.

Hedges, bushy places, and heaths; frequent. Fl. May-June. Calcifuge $C$.

Sea-level in Antrim and S. Cork. To $1300 \mathrm{ft}$. in Wicklow and to $1850 \mathrm{ft}$. in Tipperary (Hart).

\section{S. palustris Retz.-Marsh Stitch-wort.}

\section{S. glanca With.}

Districts - - III. - V. VI. VII. VIII. IX. X. - Lat. $52 \frac{1}{2}^{\circ}-54 \frac{1}{2}^{\circ}$. Middle Ireland. Type, English-British.

Lowland. In bogs and marshes; rare. Fl. May-July.

III. By the Barrow in Queen's Co., below Athy, and frequent along the river at Milford; Bagnalstown; and Borris, Co. Carlow : Hart I885.-V. In Curragha bog, Co. Dublin [extinct ?], and in Tinure Bog, Co. Louth (John White): Mack. Rar. In the Glack bog near Castle Bellingham, Louth: Butler I89o. Rathangan bog, Kildare (P. M Ardle): $C y b$. A little below Athy, Kildare, on the left bank of the Barrow : Hart 1885 . By the Boyne near Bective, Co. Meath: Ir. Nat. 1806, p. zib. Marsh at Kearney's Cross, Louth, 1897 ; Praeger.-VI. Portumna, Galway (Moore): Cyb.VII. North bank of the Barrow, about two miles west of Monasterevan: Hart 1885. East side of Lough Ree in Co. Longford, along the river Inny and at Lanesborough: B.\&V. 1887 . North-west end of Lough Owel and shores of the lake near the Brosna mouth: Levinge 1894.-VIII. Renvi [Renvyle] Connemara: Wade Rar.IX. Knockview, Roscommon (Rev. S. Madden): Cyb. Hollymount, Mayo: More I860. West side of Lough Ree in Co. Roscommon, near Kiltoom, and opposite Lanesborough: $B . \& F .2887$. Near Clonbur, Galway: M.\&S. I896. - X. Plentiful in many places by the shore of Lough Erne, north of Enniskillen, and on the Upper Lake near Crum : Barrington I884. Ballyhaise, Cu. Cavan D. M'Ardle. 
4. S. graminea Linn.-Lesser Stitch-wort.

Districts I. II. III. IV. V. VI. VII. VIII. IX. X. XI, XII. Lat. $51 \frac{1}{2}^{\circ}-55 \frac{1}{4}^{\circ}$. Throughout Ireland. Type, British.

Heathy and bushy places; common. Fl. June-August.

Sea-level in N. Derry and S. Cork. To $1050 \mathrm{ft}$. in Ben Bulben district $(B . \& V$.$) ; to 1250 \mathrm{ft}$. in Wicklow $(N . C$.$) ; to 1350 \mathrm{ft}$. in Tipperary (Bart).

\section{S. uliginosa Murr.-Bog Stitch-wort.}

Districts I. II. III. IV. V. VI. VII. VIII. IX. X. XI. XII. Lat. $51 \frac{1}{2}^{\circ}-55 \frac{10}{4}$. Throughout Ireland. Type, British.

Watery places; common. Fl. May-July. Caloifuge $\boldsymbol{B}$.

Sea-level in Antrim and S. Cork. To $2050 \mathrm{ft}$. in Donegal (Hart); to $2850 \mathrm{ft}$. in Wicklow (N.C.); to $3000 \mathrm{ft}$. in Tipperary (Hart).

\section{ARENARIA Linn.}

\section{A. verna Linn.-Spring Sand-wort.}

Alsine verna Bartl.

Districts - - - - VI. - - - - - XII. Lat. $53^{\circ}-55 \frac{1}{4}^{\circ}$. West and North. Type, Scottish-Intermediate.

Rocky places, near the coast; very local. Fl. May-August.

VI. Island of $\operatorname{Aran}(R . B a l l)$ : Flor. Hib. On all three islands of Aran: Hart 1875. Between Lunenagh Castle and Kilfenora, 'Clare: Flor. Hib. Common in Burren, Clare: Foot 18.62 -and in $1895 ;$ N. C.-XII. Among the fallen rocks of. Benyevenagh: Sampson 1802. Ben Bradagh near Dungiven: Templeton MS.and in 1883: Hart 1884. Magilligan, Derry: Murphy 2829. Plentiful on Ben Evenagh and cliffs on south side of Glenariff: Shoolbred I894. Agnew's Hill and Sallagh Braes, Antrim, 1808 : Templeton MS. Garron Point, Antrim, 1852: Babington in Herb. By Carnlough river and on Fair Head (Praeger); Tievebulliagh (Rev. S. A. Brenan); Lurigethan mountain (Corry); Cushendall (Stewart): Flor, N.-E.

To sea-level in Clare. From $400 \mathrm{ft}$. to $1450 \mathrm{ft}$. in Derry (Hart).

First recorded by Rev. G. V. Sampson in 1802. 


\section{A. trinervia Linn.-Three-norved Sand-wort.}

Mahringia trinervia Clairv.

Districts I. II. III. IV. V. VI. VII. VIII. IX. X. XI. XII.. Lat. $51_{\frac{3}{4}}^{3}-55 \frac{1}{4}^{\circ}$. Throughout Ireland. Type, British-English.

Shady banks and roadsides, and in woods; rather rare, but locally abundant. $F l$. May-July.

I. Garinish Is. near Sneem, \&c.; local in Kerry; $R$.W.S. Rather common in Cork: 'Allin's Cork.-II. Abundant on shady roadsides near Mallow railway bridge; $N$. C.-III. At Camross, Queen's Co.; Praeger.-IV. Ditches between the Dargle and. Bellevue, Wicklow : Ir. Flor.-V. Near Kiltiernan; Athgoe, \&c., but rare in Co. Dublin; $N$. C.-VI. At Ballyvally near Killaloe, Clare, $1896 ; N$. C.-VII. Kilmaglish and Knock Drin: Lovinge 1894. By Lough Derg at Gortmore, Tipperary, 1896; N. C.-VIII.-Recorded for this district in 1st Ed. Cyb. but no locality available.-IX. About Castlemacgarrett, Mayo: Brown, Fasoic. 1788. Glenade mountain, Leitrim : Murphy I829. In one place on. Glenade cliffs: B.\& V. $1885 .--\mathrm{X}$. Strabane Glen, Tyrone: Murphy 1829. Hedges at Loughgall, Armagh: More 1860. Frequent by Lough Erne: Barrington 1884.-XI. Natural woods, townland of Ballybrattan, Upper Moville: Herb. C. Moore.-XII. In Down, Antrim, and Derry, not common, though occasionally abundant: Flor. N.-E.

Apparently a very scarce plant in the West and local in all districts.

\section{A. serpyllifolia Linn,-Thyme-Zeaved Sand-wort.}

Districts I. II. III. IV. V. VI. VII. VIII. IX. X. XI. XII. Lat. $51 \frac{1}{2}^{\circ}-551^{\circ}$. Throughout Ireland. Type, British. July.

Sandy and gravelly places and on walls; frequent. Fl. May-

Far. LePtoclados (Guss.)-I. On the railway at Rochestown, Cork; $R . W . S .-I I$. Little Island and Glanmire ; Phillips.III. At Maryborough; Praeger.-V. At Portrane and Kilgobbin, Dublin; N.C.-VI. At Castle Taylor, Galway; More.-IX. On railway banks, Athlone: $B . \& V_{0}$ 1887. South of Lough Mask, Mayo: M.\&S. $1896 .-\mathrm{X}$. Near Grange, Co. Armagh: Praegor 1893.-XI. At Carraghblagh; Hart.-XII. Groomsport; Hollywood, \&c. (Stewart): Flor. N.-E.

Sea-level to $800 \mathrm{ft}$. in Dublin (N.C.). 


\section{A. ciliata Linn.-Fringed Sand-wort.}

District - - - - - - IX

Lat. $54^{\circ} 20^{\prime}-54^{\circ} 25^{\prime}$. County Sligo only. Type, Hibernian.

Limestone cliffs; very rare. Fl. June-July.

IX. Found on a high mountain adjoining Ben Bulben, near Sligo in Septr. 1806: Mack. Rar. Near Lobiermot cave, above Glen Gorragh on Ben Weisken, Sligo (C. C. Babington): Cyb. Plentiful at Annacoona; a few plants on Seafin mountain and near Lobiermot cave, south-east of Ben Bulben; but not seen on Ben Bulben proper: $B . \& \nabla .1885$. In some quantity on the top of the southern escarpment of Seafin and sparingly to the north-west on cliffs above Glen Goliagh, 1896 ; Rev. C. F. d'Arcy \& N.C.

Ranges from $1200 \mathrm{ft}$. on Seafin to $1950 \mathrm{ft}$. on Annacoona mountain $\left(B, \& . V_{\text {. })}\right.$.

First recorded by Mackay in 1806 but probably found on Ben Bulben by Lhwyd in 1699. A specimen collected by Lhywd near Sligo is preserved in Buddle's Herbarium in the British Museum, and this, very likely, is one of the three or four new plants referred to by Lhwyd in the following passage from his letter dated: "Pensans, Cornwall, August 25, 1700" (Phil. Trans. vol. 27, pp. 524-I7I2):- "In the same neighbourhood [Sligo] on the mountains of Ben Bulben and Ben Buishgen we met with a number of the rare mountain plants of England and Wales and three or four not yet discovered in Britain."

Though the typical plant is not found in Great Britain, the closely allied $\boldsymbol{A}$. norvegica (Gunn) occurs in the Orkneys and Shetlands.

\section{A. peploides Linn.-Sea-Purslane.}

Honkeneja peploides Ehrh.

Districts I. II. - IV. V. VI. - VIII. IX. - XI. XII.

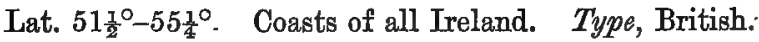

Sandy and gravelly shores; frequent. $F l$. May-July.

\section{SAGINA Linn.}

\section{S. apetala Linn.-Annual Pearl-wort.}

Districts I. II. III. IV. V. VI. VII. - IX. X. XI. XII. Lat. $51 \frac{1}{2}^{\circ}-55 \frac{1}{4}^{\circ}$. Throughout Ireland, probably. Type, English.

Lowland. Walls and dry gravelly places; frequent, but locally rare. Fl. May-July. 


\section{S. maritima Don.}

Districts I. II. - IV. V. VI. - VIII. IX. X. XI. XII. Lat. $51 \frac{1}{2}^{\circ}-55 \frac{1}{4}^{\circ}$. Coasts of all Ireland. Type, British.

Rocks, banks, and sandy and gravelly places by the sea; frequent. $F l$. May-August.

First found in Ireland by Robert Brown, at Ballycastle, Antrim, in 1795. The plant was first recognized as distinct by Brown who, in 1797, described it in MS. from specimens: "growing in bare spots by the sea side at Ballycastle." Brown's MS. and original Irish specimens of the plant are now preserved in the British Museum.

Var. DeNsa (Jord.) -I. Ballybunnion, Kerry: Stewoart I89o.

S. ciliata Fries.

Districts I. - III. IV. V. VI. - - - - - XII. Lat. $51 \frac{3}{4}^{\circ}-55 \frac{1}{4}^{\circ}$. From South to North. Type, English-British.

Banks, walls, and sand-hills near the sea; rare. Fl. JuneAugust.

I. Near Derrynane; near Upper Lake, Killarney; Tralee and other stations in Kerry: $R$.W.S. 7889 .-III. Milford Bridge on the Barrow : Hart I885.-IV. On the bridge at Arklow and near the castle ruin at Wicklow (More): Rec. Add. Rosslare, Wexford, 1897; Rev. E. S. Marshall.-V. Walls near the sea about Dublin (More); banks above Howth (J. Ball): $C y b$. Walls between Howth church and the station: Flor. Howth.-VI. Near Moerne Head, Clare (Moore) : Cyb.-XII. Ballycastle, Antrim, 1852 (Rev. W. W. Newbould \& C. C. Babington): Cyb. - still there in 1882 (Stewart): Flor. N.-E. Sand-hills at Newcastle, Down: S.\&P. I892.

2. S. procumbens Linn.-Procumbent Pearl-wort.

Districts I. II. III. IV. V. VI. VII. VIII. IX. X. XI. XII. Lat. $51 \frac{1}{2}^{\circ}-551^{\circ}$. Throughout Ireland. Type, British.

Waste ground, walls, pastures, and damp gravelly places; frequent. $F l$. May-September.

Sea-level in N. Antrim and S. Cork. To $1700 \mathrm{ft}$. in Donegal (Hart); to $2500 \mathrm{ft}$. in Wicklow (Cyb.).

3. S. subulata Presl-Awol-leaved Pearl-wort.

Districts I. - - - VI. - VIII. - - XI. XII. Lat. $51 \frac{1}{2}^{\circ}-55 \frac{1}{4}^{\circ}$. West and North. Type, Scottish-British.

Heaths and dry pastures, also on rocks and in gravelly places near the sea; rare. Fll. June-August. 
I. Plentiful on Brandon mountain, Kerry (Moore): Cyb. At Glengariff and Bantry (Carroll): Allin's Cork. Above Glen Lough near Adrigole: Hart 18858 . On Doum mountain near Sneem, 1877 ; Carroll. On Hungry Hill, in both Cork and Kerry ; R.W.S. Knockaphuca near Goleen, S. Cork, 1896; Phillips.-VI. Cliffs of Moher, Clare (Carroll): Cyb.- and in 1892; Levinge.-VIII. On Lettery mountain, Connemara: Wade Gallovid. Benchoona, Galway: Hart 1883 a. Near Roundstone: Oliver 1851 . South side of Inishbofin: More 1876. Top of Urrisbeg; More.-XI. Dunaff Head (Hart): Rec. Add. South-east shore of Lough Eske; Glen Head; Mucross Point; and sea cliffs about Slieve League: Hart I883 $\gamma$. -XII. On the side of Muck Island, Antrim, next the sea, 1804: Templeton MS. Between Portstewart and Portrush, 1835 : Moore MS. Fair Head and Rathlin. Island (Moore): Cyb. In many places round the north and west of Rathlin: Stewart 1884 .

Sea-level in Rathlin Island. To $600 \mathrm{ft}$. in Donegal and to $1970 \mathrm{ft}$. in Galway (Hart); to $2100 \mathrm{ft}$. in Kerry (R.W. S.).

\section{S. nodosa Fenzl.-Knotted Spurrey.}

Districts I. II. III. IV. V. VI. VII. VIII. IX. X. XI. XII. Lat. $51 \frac{1}{2}^{\circ}-55 \frac{1}{4}^{\circ}$. Throughout Ireland. Type, British.

Moist, sandy places and in marshes; frequent. Fl. July-Aug.

Sea-level in N. Antrim and S. Cork. To $1000 \mathrm{ft}$. in Dublin $(N . C$.$) .$

\section{SPERGULA Linn.}

\section{S. arvensis Linn.-Corn Spurrey.}

Districts I. II. III. IV. V. VI. VII. VIII. IX. X. XI. XII. Lat. $51 \frac{1}{2}^{\circ}-551^{\circ}$. Throughout Ireland. Type, British.

Cultivated ground in sandy or peaty soil; common. Fl. MayAugust. Calcifuge $B$.

The Irish plant is usually S. sativa (Bœnn.), but the papillose variety, S. vulgaris (Bœnn.), also occurs, as in counties Dublin and Kerry (Druce I89I), and in Cork (Phillips).

Sea-level to $1250 \mathrm{ft}$. in Dublin $(N . C$.).

\section{SPERGULARIA Presl.}

\section{S. rubra PresI-Purple Sand-wort.}

Arenaria rubra a Linn.-Lepigonum rubrum Wahlb.

Districts I. II. III. IV. - - - - X. - XII.

Lowland. Sandy and gravelly places; rare. Fl. June-July. 
I. Kilcolman, Cork: Allin's Cork. Waste ground near the Marina, Cork : Phillips 1895. Roadsides west of Skibbereen, 1896; R.W.S. Railway embankment at Schull, 1896, and-II. Abundant on the Custom House Quay, Cork, 1896, perhaps introduced; Phillips.-III. Gravelly margin of the Barrow above Tinnehinch Bridge, Queen's Co.; Hart.-IV. Strand at Ballyconigar, Wexford (J. Morrison); on Vinegar Hill (H. Robinson): Rec. Add.-still on Vinegar Hill: $B .-H . \& M$. 1892 a.-X. On the railways near Portadown, Newry, and Narrow-water: Praeger 1893.-XII. By the Moyola river near Draperstown, Derry (Moore): Cyb. Shore of Lough Neagh, south-west of Toome, Derry, and sparingly on the shores of Lough Beg, south-east of Toome, Antrim (Stewart): Flor. $N$. E. Abundant on the shores of Lough Island Reary, Down: S. $\&$ P. $x 892$.

Also recorded in Ir. Flor. for district V., along the banks of the canal from Dablin to Castleknock, but not since noticed in that district where it probably occurred as a casual only.

2. S. media Presl-Sea Sand-roort.

Arenaria marginata DC.-Lepigonum marginatum Koch-L. marinum Wahlb.

Districts I. II. - IV. V. VI. - VIII. IX. - XI. XII. Lat. $51 \frac{1}{2}^{\circ}-55 \frac{1}{4}^{\circ}$ - Coasts of all Ireland. Type, British.

Muddy salt-marshes; common. Fl. June-August.

3. S. salina Presl-Intermediate Sand-wort.

Lepigonum salinum Kindb.

Districts I. II. III. IV. V. VI. - VIII. IX. X. XI. XII. Lat. $51 \frac{1}{2}^{\circ}-55 \frac{1}{4}^{\circ}$. Coasts of all Ireland. Type, British.

Banks and waste places by the sea and in salt marshes; frequent. Fl. June-August.

The prevailing form in Ireland is Lepigonum neglectum (Kindb.); L. medium (Fries) also occurs occasionally, being reported from the counties of Galway and Kerry.

4. S. rupestris Lebel-Rock Sand-wort.

Lepigonum rupicola and $L$. rupestre $\mathrm{Kindb}$.

Districts I. II, III. IV. V. VI. - VIII. - - XI. XII. Lat. $51 \frac{1}{2}^{\circ}-55 \frac{1}{4}^{\circ}$. Coasts of all Ireland, probably.

Cliffs and rocky places on the coast; frequent. Fl. JuneAugust. 
To $600 \mathrm{ft}$. in Donegal and to $700 \mathrm{ft}$. in West Ireland (Hart).

In Kerry this species grows profusely on old castles and towers by the coast; R.W.S.

ORDER XI.-PORTULACEE.

MONTIA Linn.-Water Blinks.

1. M. fontana Linn.

Districts I. II. III. IV. V. VI. VII. VIII. IX. X. XI. XII. Lat. $51 \frac{1}{2}^{\circ}-55 \frac{1}{4}^{\circ}$. Throughout Ireland. Type, British.

Watery places and on wet ground; rather common. Fl. MayAugust. Calcifuge $\mathcal{A}$.

Sea-level in N. Derry and in Kerry. To $2050 \mathrm{ft}$. in Donegal (Hart); to $2450 \mathrm{ft}$. in Down (S.\&P.); to $2850 \mathrm{ft}$. in Tipperary (Hart).

Both forms, M. minor (Gmel.) and M. rivularis (Gmel.), occur, but the latter appears to be much the rarer.

\section{ORDER XII.-ELATINE正.}

ELATINE Linn.

1. E. hexandra DC.-Hexandrous Water-wort.

Districts I. - - - - VI. - VIII. - - XI. XII. Lat. 51 $\frac{1}{2}^{\circ}-55 \frac{1}{4}^{\circ}$. West and North Ireland. Type, English.

Margins of lakes and in ditches; rare. Fl. July-September. Calcifuge $A$.

I. Lough Caragh, Kerry (W. Andrews): Rec. Add. -and in $1889 ; \quad R . W . S$. Lough Gouragh, Hag's Glen, Magillicuddy's Reeks; Hart 1882. Clonee Lakes; Killarney Lakes; Lough Currane, \&c., 1889; in most of the lakes in the mountain parts of Kerry: $R . W . S . ~ I 89 o$. By the Bandon river and in Moragh Lakes (C. Longfield); pools near Kilcrohane, Durrus; in Keemore Lake, -Leap and in Drinagh Lake; abundant in Clounties lake, Glandore: Allin's Cork. Lough Allua; Gougane Barra, 1897; Phillips. -VI. Between Miltown-Malbay and Kilrush (C. Carter) and abundant in pools in Dunbeg Bog, Clare (Moore): Cyb.-VIII. In several lakes in Inishbofin: More 7876 . Craigdhu Lough, Roundstone: Praeger 1897 -XI. In Lough Erigh, between Doochary 
Bridge and Glenties: Flor. Ulst. River Clady at Gweedore Hotel: Hart. 7880 . West shore of upper Lough Nacung: Hart $2881 \beta$. Lough Eske (Miss Young): Hart $1885 \gamma$--XII. On the muddy border of Castlewellan Lake, Co. Down, where it was first pointed out to me (Mackay) in 1808 by Mr. Templeton; abundant in Enagh Lough near Derry and by the side of the river Bann below Coleraine (Moore) : Flor. Hib. Macaulay's Lake south of Ballynahinch and abundant in Lough Aghery and Loughinisland, Co. Down (Stewart): Flor. N.-E.

Sea-level in Derry and in S. Cork. To $1100 \mathrm{ft.}$. in Kerry (Hart). 1808.

First found in Ireland by Templeton, in Castlewellan Lake, in

\section{E. Hydropiper Linn.-Octandrous Water-wort.}

District - - - - - - - - - - XII.

Lat. $54 \frac{1}{4}^{\circ}-54 \frac{1}{2}^{\circ}$. North-East only. Type, English-Local.

Lowland. Lake margins and in canals; very rare. Fl. JulyAugust.

XII. In the canal at Newry, 1836 (W. Thompson); in the Lagan canal a little above the first bridge from Lough Neagh, and more abundantly from the bridge to the Lough, September, 1837 (Moore): Colby 1837. In Lough Neagh a little north of the canal (Moore): Cyb. Lagan canal near high-tide water-mark, Co. Antrim, August, 1847 (Dr. Mater): Spec. in Herb. Syme.-the same station as that entered "near Belfast" in Flor. Olst. Plentiful at the north end of Lough Brickland, Co. Down (Rev. H. W. Lett): B.N.F.C.Proc. I8go-qI. The last record is the only recent one for Ireland.

First found, at Newry, by William Thompson in 1836.

\section{ORDER XIII.-HYPERICINEAE.}

HYPERICUM Linn.

1. H. Androsæmum Linn.-Tutsan.

Districts I. II. III. IV. V. VI. VII. VIII. IX. X. XI. XII. Lat. $51 \frac{1}{2}^{\circ}-551^{\circ}$. Throughout Ireland. Type, Atlantic-British.

Bushy and rocky places; frequent. Fl. July-August.

Sea-level in N. Derry and S. Cork. To $1400 \mathrm{ft}$. in Donegal and to $2080 \mathrm{ft}$. in Kerry (Hart).

Nowhere a common plant, though wide-spread in Ireland; 
2. H. perforatum Linn.-Perforated St. John's-wort.

Districts I. II. III. IV. V. VI. VII. VIII. IX. X. XI. XII. Lat. $51 \frac{1}{2}^{\circ}-554^{\circ}$. Throughout Ireland. Type, British.

Copses, hedge-banks, and stony and gravelly places; frequent and locally abundant. Fl. July-August. Calcicole $B$.

Sea-level in Donegal and in Cork. To $1200 \mathrm{ft}$. in Derry (Moore).

Rare in Donegal and in Kerry.

3. H. dubium Leers-Imperforate St. John's-wort.

H. quadrangulum Linn.

Districts I. II. III. IV. V. VI. VII. VIII. IX. X. - XII. Lat. $511_{2}^{\circ}-54 \frac{1}{2}^{\circ}$. Throughout Ireland, probably. Type, EnglishBritish.

Lowland. Thickets and ditch sides; rather rare. Fl. JulyAugust.

I. Killarney (Babington): Cyb. Not rare in Kerry; R.W.S. At Enniskeane; Skibbereen, \&c., Cork; Phillips.-II. Frequent about Fermoy (T. Chandlee); near Clonmel, Waterford (Miss $S$. Grubb): Cyb.-III. Between Cullenagh and Stradbally, Queen's Co., and near Inistiogue, Co. Kilkenny: Mack. Rar. Near Clonegal by the Slaney: Hart $188 \mathrm{I}$ a.-IV. Ballyhyland; Woodbrook, \&c., Co. Wexford: Moffat I889. Near Oroca station, Wicklow (More) : Rec.Add. Plentiful at Aughavanagh, Wicklow; Hart.V. Braganstown, Louth, and Nurney and Athy, Kildare; Praeger.VI. At Castle Taylor ; Garryland; and Kilmacduagh, Galway (More): Cyb. Shore at Askeaton, Limerick: Stewart I8go. Common about Gleninagh, Clare: Ir. Nat. 1895.-VII. Clonad wood near Tullamore, King's Co.: Praeger 1897.-VIII. At Maam and to the west of Clonbur, and-IX. About Clonbur and Cong: $\boldsymbol{M}$. \& S. I896.

Tar. nacodatum Bab.-I. Near Cork, 1852 (J. H. Balf): Herb. Babington.-X. Near Lurgan; Portadown, \&c.; throughout Co. Armagh: Praeger 7893. - XII. North of the second lock, Lagan canal, 1797: Templeton MS. By the Lagan canal abore Lisburn (R. Hanna) and close to Lough Neagh (Rev. H.W. Lett): S.\&P. 1895. Glenmore near Lisburn, Antrim (J. H. Davies): B.N.F.C. Proc. $1892-93$.

In North-East Ireland only the Var. Maculatum occurs, and bat rarely. 
4. H. tetrapterum Fries-Square-stalked St. John's-wort.

$H$. quadratum Stokes- $H$. quadranguhum Smith.

Districts I. II. III. IV. V. VI. VII. VIII. IX. X. XI. XII. Lat. 51 $\frac{1}{2}{ }^{\circ}-55 \frac{1}{4}$. Throughout Ireland. Type, British-English.

In wet and marshy places; common. Fl. July-September.

Sea-level in N. Derry and S. Cork. To $800 \mathrm{ft}$. in Dublin ( $N$. C. .).

5. H. humifusum Linn.-Trailing St. John's-wort.

Districts I. II. III. IV. V. VI. VII. VIII. IX. X. XI. XII. Lat. $51 \frac{1}{2}^{\circ}-55 \frac{1}{4}^{\circ}$. Throughout Ireland. Type, British-English.

Heaths and dry banks; frequent. Fl. July-Aug. Calcifuge $B$.

Sea-level in N. Antrim and S. Cork. To $1000 \mathrm{ft}$. in Derry (Flor. N.-E.); to $1100 \mathrm{ft}$. in Dublin (N.C.).

6. H. pulchrum Linn,- Upright St. John's-wort.

Districts I. II. III. IV. V. VI. VII. VIII. IX. X. XI. XII. Lat. $51 \frac{1}{2}^{\circ}-55 \frac{1}{4}^{\circ}$ Throughout Ireland. Type, British.

Heaths and dry banks; frequent. $F$. June-July. Calcifuge $B$.

Sea-level in Derry and S. Cork. To $1500 \mathrm{ft}$. in Derry (Cyb.); to $2000 \mathrm{ft}$. in Mayo and to $2440 \mathrm{ft}$. in Kerry (Hart).

7. H. hirsutum Linn.-Hairy St. John's-wort.

Districts - - - V. - - - - - XII.

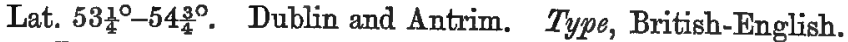

Lowland. Woods and thickets; very rare. Fl. July-August.

V. About Leixlip waterfall, 1799 : Templeton MS. Woods at Woodlands: Mack. Cat. 2825. At the Salmon Leap, Leixlip, and on Knockmaroon hills, 1895; abundant in Woodlands, $1895 ; N$. C. Hedges near Drimnagh, Co. Dublin: N. C. 1893. -XII. "Found at Macedon Point . . . two or three years ago by Mr. R. Tennant. I had looked for it in vain until 1809 when I found it in flower" : Templeton MS. Gathered near this locality in $1893 ; R$. Hanna.

First found in Ireland, by Templeton, near Leixlip, in 1799.

\section{H. elodes Linn.-Marsh St. John's-wort.}

Elodes palustris Spach.

Districts I. II. III. IV. V. VI. - VIII. IX. - XI. XII. Lat. $51 \frac{1}{2}^{\circ}-55 \frac{1}{4}^{\circ}$. From South to North. Type, Atlantic-English.

Wet bogs and bog ditches; frequent and locally abundant. $F l$. July-August. Calcifuge $\mathcal{A}$. 
From 100 to $650 \mathrm{ft}$. in Down (S.\& P.); to $1000 \mathrm{ft}$. in Dublin and Wicklow ( $N . C$. .).

Not common and becoming rare in the North-East: Flor. $\boldsymbol{N} .-\boldsymbol{E}$. Abundant in the West, rare in the East.

\section{ORDER XIV.-MALVACE王.}

ALTHAA Linn.

1. $\ddagger$ A. officinalis Linn.-Marsh Mallow.

Districts I. II. - - - VI. - VIII. - - XI. Lat. $51 \frac{1}{2}^{\circ}-54 \frac{3}{4}^{\circ}$. South and West coasts. Type, English.

Lowland. Salt marshes and ditches near the sea; very local. $F l$. August-September.

I. Sparingly by the roadside south of Ballybunnion, and abundant by damp ditches close to Beal castle: Stewart 7890 . Widely scattered in Kerry, but all stations suspicious; R.W.S. Cape Clear Island: Drummond r820-still there in 1896; Phillips. Coast near Kilbrittain (Carroll): Cyb. On Inisherkin: Allin's Cork-abundant there in 1896; Phillips. At Garrettstown; near Leap; Baltimore; Corrigilihy; escaped from cultivation in most or all of these stations: Allin's Cork.-II. Cable Island near Youghal Harbour: Smith's Cork. In many salt marshes in Co. Cork: Wade Rar. Strand at Kilfarassy, Waterford (Miss $A$. Taylor): $C y b .-\mathrm{VI}$. In prodigious plenty in all the salt marshes about the rivers Shannon and Fergus: Wade Rar. Marshy grounds north side of the Shannon near Limerick: Mack. Cat. Near Lahinch, Co. Clare: More r86o.-VIII. Old Head, south side of Clew Bay, Mayo (Miss S. Grubb) : Cyb.-XI. Plentiful in a marshy pool on Carrickfinn Island, west of Bunbeg: Hart r88o. North-east corner of Glen Bay, near Carrick, thoroughly established : Hart $I 885 \gamma$.

In most, if not all, of its stations an escape from cultivation.

LAVATERA Linn.

1. L. arborea Linn.-Tree Mallowo.

Districts I. II. - IV. V. VI. - VIII. - - - XII. Lat. $511_{2}^{\circ}-551_{4}^{\circ}$. Coasts from South to North. Type, Atlanitic.

Sea-cliffs; rare. Fl. July-September.

I. 'On several of the Blasket Islands: Barrington $288 \mathrm{I}$. On 
the Little Skellig Rock, eight miles from the Kerry mainland (Rev. A. Delap): Ir. Nat. 1893 . Widespread in Kerry, but usually near cottages; R.W.S. Summit of the Bull Rock, Co. Cork; Barrington. Rocks at Summercove, Kinsale, 1894, and at Baltimore, 1896; Phillips.-II. Cable Island, Youghal: Smith's. Cork. Near 'Youghal and Midleton: Allin's Cork. Abundant along the coast from Power Head to Rochespoint, 1895, and on rocks. at Haulbowline, 1896 ; Phillips. West of Newtown Head, Waterford, looking wild along the cliffs: Hart $1883 \beta$. - TV. Raven Point; Rosslare Point; and Kilmichael Point, Wexford, probably introduced: Hart $7883 \beta$. Rocks at Duncannon Fort, Wexford: B.-H. \& G. 1889. Steep rocks at south end of Bray Head: Praeger 1897.-V. On Treland's Eye, opposite Howth: Wade'Rar. I804and in 1897; Praeger. On almost inaccessible cliffs east of Howth: Flor. Howth. Killiney Hill (Carroll) : Cyb. -and in 1893; N. C.VI. On cliffs on the South Isles of Aran: Mack. Cat. In several places along the southern cliffs of Aranmore Island and on the Rock Island, the most western of the group : Hart 7875 . Cliffs at Spanish Point, Clare (C. Carter): Phytol. 1846, p. 514. Near Black Head, Clare; Levinge.-VIII. Abundantly on Galway Bay: Wade Gallovid. On old walls near the harbour of Galway: Mack. Cat.-XII. On the shore at Ballantoy, and grows also in the Sheep. Island, about half a mile from the Ballantoy shore, Sept. 1797: Brown MS. Still on Sheep Island (Rev. S. A. Brenan): S.\&P. 1895. Carrick-a-Raid near Ballintoy, 1800: Templeton MS. On a high rock at the west end of Rathlin Island (Miss Gage): Flor. Ulst. Summit of Stackaniskan, an isolated sea-stack at west end of Rathlin Island (Praeger): Ir. Nat. 2893 .

There seems to be no reason to doubt that this plant is indigenous in many of its stations, though frequently cultivated in cottage gardens round the coast, the cultivated plants being probably derived in many instances from native stations where it has become extinct. A Mediterranean species, spreading northwards. along the west coasts of Europe.

\section{MALVA Linn.}

\section{1. † M. moschata Linn.-Musk Mallow.}

Districts I. II. III. IV. V. VI. VII. VIII. - X. XI. XII. Lat. $51 \frac{1}{2}^{\circ}-54 \frac{3}{4}^{\circ}$. South to North. Type, English-British.

Lowland. Dry banks, waysides, and borders of fields; rare. Fl. July-August. 
I. Near Killorglin and in several stations near Kenmare, Kerry : R. W. S. $1880 \& 1890$. Near Ballinadee; Skibbereen; and Union Hall: Allin's Cork. Kilkern and Castle Freke, 1890; Phillips.II. Midleton and Doneraile: Allin's Cork. Macroom; Greenwood Pim. Near Ballyvolane, 1893, and near Inch, 1895; Phillips. Near Clonmel, rare (T. Chandlee): $C y b$. Tramore and Ardmore, Waterford: Hart $1883 \beta$.-III. Borders of fields along the mailcoach road between Carlow, Kilkenny, and Clonmel: Wade Rar. By the Slaney below Tullow in several places: Hart $788 \mathrm{I}$ a.IV. About Enniscorthy and Wexford (Rev. S. Madden): Cyb. Cahore Point and Lady's Island, coast of Wexford: Hart $1883 . \beta$. Frequent throughout the county of Wexford : B.-H.\&M. I892 a.V. Near Drogheda (J. B. Hamilton): Rec. Add. Old Bawn, Co. Dublin; Praeger.-VI. Glenstal, Co. Limerick : Hart $188 \mathrm{I} \gamma$.VII. On the public road between Moate and Athlone: Wade Rar.VIII. Sparingly at Ashford, Cong; Miss MI. F. Jackson.-X. In fields near Tanderagee: Templeton MS. In the upper and lower demesnes of Tanderagee (Praeger) and fields on . Lough Neagh shore at Deryadd and Raughlan (Rev. H. W. Lett): Praeger 1893.XI. Fields north-east of Lough Eske: Corry I882.-XII. Grey Abbey : Harris's Down I744. Gravel pit at Shane's Castle and by the Crumlin river, Antrim (Moore) : Cyb. Still by Crumlin water; in several stations in Antrim and Derry, "probably often a garden escape" : Flor. N.-E.

Perhaps introduced in all its Irish stations.

\section{M. sylvestris Linn.-Common Mallow.}

Districts I. II. III. IV. V. VI. VII. VIII. IX. X. XI. XII. Lat. 51 $\frac{1}{2}-55 \frac{1}{4}$. Throughout Ireland. Type, British-English.

Lowland. Hedge-banks, waysides, and borders of fields; frequent. $F l$. June-August.

Apparently an escape from cultivation in many places and rare in West Ireland.

\section{M. rotundifolia Linn.-Dwarf Mallow.}

M. vulgaris Fries-M. neglecta Wallr.

Districts I. II. III. IV. V. VI. - VIII. - X. - XII. Lat. 51 $\frac{1}{2}{ }^{\circ}-54 \frac{3}{4}^{\circ}$. From South to North. Type, British-English.

Lowland. Waste places and roadsides, especially near the sea; rather rare. Fl. June-September. 
Scarce in the West and North; very rare in Kerry; and perhaps always introduced in inland stations.

\section{ORDER XV.-IINEE.}

RADIOLA Roth.

\section{R. linoides Roth-All-seed.}

R. millegrana Smith.

Districts I. II. - IV. - VI. - VIII. IX. X. XI. XII. Luat. $51 \frac{1}{2}^{\circ}-55 \frac{13}{4}$ - From South to North. Type, British.

Damp, sandy, or peaty places, mostly. near the sea; locally abundant. Fl. June-August. Caloifuge $A$.

I. At Killarney, \&c.; common near the sea in Kerry, but rare inland; R.W.S. Plentiful about Ballylickey, near Bantry, and near Bandon: Flor. Hib. Clonakilty; Schull, \&c., local in Co. Cork: Allin's Cork. Common in the Schull promontory, 1896 Phallips.-II. Fairy Hill, Waterford (Miss A. Taylor): Cyb. Ballintowtas, Midleton (Rev. T. Allin): Rec. Add.-IV. Greater Saltee Irland, Wexford: Hart I883 B.-VI. Bogs south of Kilkee (Carroll) and Loop Head, Clare (Moore): Cyb. Between Kilrush and Carrigaholt: Stewart I890.-VIII. Plentiful in Inishbofin: More 2876. Achill Island, Mayo (T. Chandlee): Cyb. Frequent about Inveran, Iar Connaught (Rev. W. Colgan) and in Glen Inagh, Connemara; N.C.-IX. By the shore of Lough Cullin, Mayo (More): Cyb. Inishmurray, Sligo (Barrington): Ir. Nat. 1896, p. r77:-X: Abundant on a bog two miles south of Portadown, Armagh : Praeger 1893.-XI. Rosses and Fanet, Donegal: II urphy 1829. Common in Fanet and at Horn Head: Hart 1879 . Tory Island: Barrington I879.-XII. North and east side of Hollywood Warren, Co. Down, 1797 (Templeton): Whitta MS. Along the sides of the rivers about Kilkeel and on the lands of Murlagh, below Newcastle, Co. Down (John White): Wade Rar. Several places between Newcastle and Annalong, Down: S. \& P. I892. Plentiful on andy warrens from Portrush to Downhill, Derry: Moore MS. On the shore of Ushet lake, Rathlin Island: Stevoart 1884 .

To $700 \mathrm{ft}$. in Kerry (Hart), but usually lowland.

Abundant in many parts of the West; very rare in the East. 


\section{IINUM Iinn.}

1. I. catharticum Linn.-Purging Flax.

Hibernicé Miopac̀ (Meeshack).

Districts I. II. III. IV. V. VI. VII. VIII. IX. X. XI. XII. Lat. $51 \frac{1}{2}^{\circ}-55 \frac{1}{4}^{\circ}$. Throughout Treland. Type, British.

Pastures and heaths; common. Fl. June-September.

Sea-level in N. Antrim and S. Cork. To $1450 \mathrm{ft}$. in Derry and to $1500 \mathrm{ft}$. in Tipperary (Hart).

\section{L. angustifolium Huds.-Pale-flowered Flax.}

Districts I. II. III. IV. V. VI. --Lat. $51 \frac{1}{2}^{\circ}-53 \frac{3}{4}^{\circ}$. Southern half of Ireland. Type, Atlantic-English.

Lowland. Gravelly places and dry pastures, chiefly near the sea ; rare. Fl. June-August.

I. Near Killorglin and Rossbehy, Kerry; R.W.S. Near Kinsale (Carroll) : Cyb. Near Timoleague; Ballinadee; Coolmain; and Kinsale : Allin's Cork. Inniscarra; Berehaven; and Crosshaven; Phillips.-II. Not rare near Youghal (Rev. T. Allin): Rec. Add. Rochespoint; East Ferry; Whitegate; Little Island, \&c.; Phillips. Monatrea cliffs opposite Youghal, Co. Waterford; Miss $\boldsymbol{M}$. Chearnley. Ballyernan and Ardmore Head, coast of Waterford: Hart I883 B. Near Powerstown, Co. Tipperary (Miss S. Grubb): $C y b .-I I I$. Near Kilkenny (W. Archer): Rec. Add. Between Newtown Lane, Co. Kilkenny, and Borris, 1892 ; Rev. T. Hartley.IV. Bannow (Barrington); Bloomfield and near Daphne (Miss E. M. Farmer) : Rec. Add. Near Kilmanock; Arthurstown, \&c., Wexford: B.-H.\& G. 1889 . Between Curracloa and Blackwater Head, on high marl banks above the sea: Hart $188 \mathrm{I}$ a. Between Rosslare and Greenore coast of Wexford: Hart $1883 \beta$. South side of Bray Head; N. C.-V. On Knockmaroon Hill and steep banks between Clontarf and Howth (John White): Wade Rar. In fields between Killiney and Bray: Mack. Cat. 7825 . By the railway at the foot of Killiney Hill, $1894 ; N . C$. Below the Needles and Glenaveena and on banks above the sea at the Cliffs: Flor. Hooth. A little north of Gormanstown, Co. Meath (More) : Rec. Add.-VI. Meadow between Woodford and Lough Derg (M. Dowd): Rec. Add.

This is probably the species recorded by Threlkeld (1727) under a synonym for $L$. perenne as found "upon the Lands of Simond's Court." 


\section{ORDER XVI.-GERANIACEZE.}

GERANIUM Linn.

1. G. sanguineum Linn.-Bloody Crane's-bill.

Districts - - IV. V. VI. VII. VIII. IX. - XI. XII. Lat. $53^{\circ}-554^{\circ}$. Middle and North Ireland. Type, British?

Lowland. Rocky and stony places and dry banks, chiefly near the coast; local. Fl. June-August.

IV. Killincarrig and Bray: Ir. Flor. - V. In a close near Simond's Court: Threlkeld. By the shore at Howth and on Killiney Bay, abundant: Wade Dubl. I794. Still in considerable quantity on Howth Head and rather sparingly at the foot of Killiney Hill, $1895 ;$ N. C. Ireland's Eye and Lambay: Ir. Flor. On the south and west sides of Lambay Island: Hart $1883 \gamma$.VI. Throughout the Burren district of Clare: Foot 1862 . In the three Isles of Aran: Hart 7875 -abundant in all three islands, $1892 ; N$. C. Shores of Lough Derg, Galway (Moore): Cyb. Abundant on almost all of the western shores and islands of Lough Derg, $1896 ; N . C$. Abundant on the limestone pastures about Garryland and Castle Taylor, Galway: More 1855.-VII. Abundant on Derry Island; Slevoir Point ; and Gortmore, east shore of Lough Derg, Tipperary, $1896 ; N$. C.-VIII. Near the town of Galway to the north-west (Rev. W. M. Hind) : Cyb. Near Oughterard and-IX. Abundant near Glen Corrib and Ballycurrin, Co. Mayo; Miss M. F. Jackson. At Bridewell near Athlone (Dr. P. Browne): Cyb.-XI. Abundant at Saint John's Point, Killybegs : Hart $1885 \gamma$. Limestone bluffs near Ballyshannon (Mr. Allingham): Hart 1886.-XII. Coast at Portrush, Antrim, and bushy places by the shore near Crawfordsburn: Flor. Ulst.-since verified by Prof. $R$. O. Cunningham in the latter station; very rare in the North-East: Flor. N.-E.

Sea-level in Antrim and Clare. To $1000 \mathrm{ft}$. on the limestone hills of Burren, Clare $(N . C$.$) .$

2. G. sylvaticum Linn.-Wood Crane's-bill.

Districts - - - - [VI.] - - - - XII. Lat. $54^{\circ} 55^{\prime}-55^{\circ}$ : North-East Ireland. Type, Scottish. July.

Lowland. Woods and shady rocks; very rare. Fl. June- 
[VI. Established for many years in several places at Glenstal, Co. Limerick (C. B. Barrington): Hart. $888 \mathrm{I} \gamma$.] XII. On the bank of the river below Glenarm Park, 1800 ; in the little Park at Glenarm plentifully : Templeton MS. Subsequently observed in this station by Moore and Corry, and in 1885 by Praeger: Flor. N.-E. Glen above Miltown at Cairncastle (Praeger): S.\&P. I895. In a small den above Hollywood: Flor. Olst. This latter station is considered to be identical with Marino where the plant grew, but suspiciously near a garden, up to about 1885 : S. \& P. $x 895$.

First found in Ireland by Templeton, at Glenarm, in 1800.

\section{G. pratense Linn.-Meadow Crane's-bill.}

Districts [I. $]------$ - - XII. Lat. $554^{\circ}$. Native in Antrim only. Type, British-English.

Lowland. Dry rocks, banks, and sandy wastes; rare, but locally abundant. Fl. June-August.

[I. Abundant on a rather mountainous road leading from Clonakilty to Rathbarry, and by fields in the vicinity, 1889-90: Phillips 1895.]-XII. A bout Ballintoy; Dunluce Castle and all the north parts of Antrim: Templeton MS. Abundantly at Whitepark, Ballintoy, 1836 (Moore) : Colby I837. Roadside near Ballycastle (Miss S. Grubb): Cyb. On blown sand at Port Bradden (R. Tate): Rec. Add. At Port Ballintrae (G.C. Hyndman) and on limestone near Carrick-a-raide (Corry) : Flor. $N$.-E.

First found in Ireland by Templeton, probably before 1820 .

\section{4. † G. pyrenaicum Linn.-Mountain Crane's-bill.}

Q. perenne Huds.

Districts - II. III. IV. V. - VII. VIII. - X. - XII. Lat. $52^{\circ}-54 \frac{1}{2}^{\circ}$. East Ireland, chiefly. Type, English.

Lowland. Hedge-banks, roadsides, and waste places; local. Fl. May-August.

II. Near Drumtariff Rectory, 1872, and single plants at Charleville and Midleton; casual in Co. Cork: Allin's Cork. Near Passage, Waterford; Miss L. Glascott. Carrick-on-Suir, 1893; Miss H. R. Grubb.-III. Ayresfield; New Park; and near the city of Kilkenny (Rev. S. Madden) : Cyb. By the Barrow below Athy: Hart I885--IV. Near Enniskerry, Wicklow (J. Ball): Cyb. Roadsides near Gorey, Wexford, 1897; Rev. E. S. Marshall.V. Waste places near Dublin, frequent: Mack. Oat. r825. Kilgobbin; Santry; Skerries; Baldoyle; Mulhuddart, \&\&., 1894- 
frequent in Co. Dublin; N. C, Frequent by roadsides near Ballitore, Kildare (Carroll) and common in hedges about Straffan, Kildare (John Douglas): $C y b$. Between Drogheda and the mouth of the Boyne; Barrington. Plentiful near Castlebellingham, Louth: Butler 1890 . Roadside banks near the Hill of Tara, Meath (More): Rec. Add.-VII. Roadside near Killucan, Westmeath (Miss $\boldsymbol{E}$. Reynell): Cyb. Ballymahon churehyard, Westmeath: B.\& $V_{\text {. }}$ 1887. Roadside between Mount Murray and Baronstown (MiseLevinge): Levinge I894.-VIII. Near the town of Belmullet, Mayo (Moore) : Cyb.-X. Roadside, near Newtownstewart, Tyrone (IFiss M. C. Knowles): Ir. Nat. I897-XII. Hedge-side beyond Groomsport, Down (Miss Maffet): Flor. Belf. Plentiful on roadside, south of Portavo House (Stewart); near Strangford (Corry); between Downpatrick and Saul (C. Dickson): Flor N.-E. Roadside near Whitewell quarries, Cave Hill, Antrim (W.D. Donnan): $B . N$. F. C. Proc. $1892-93$.

\section{G. molle Linn.-Dove's-foot Crane's-bill.}

Đistricts I. II. III. IV. V. VI. VII. VIII. IX. X. XI. XII. Lat. 51 $\frac{1}{2}^{\circ}-55 x^{\circ}$. Throughout Ireland. Type, British.

Banks, roadsides, and dry pastures; common. Fl. MayAugust.

Sea-level in Antrim and S. Cork. To $1000 \mathrm{ft}$. in Dublin $\left(N . C_{.}\right)$.

\section{6. $\ddagger$ G. pusillum Linn.-Small-flowered Crane's-bill.}

Districts . - II. - - V. VI. - - - - - Lat. 51 $1_{4}^{\circ}-53 \frac{1}{2}^{\circ}$. Middle Ireland. Type, English-British.

Lowland. Pastures and banks in light soils; very rare. Fl. May-August.

II. At Tramore, Waterford: Herb. T. Chandlee. Near Whitegate, Cork, 1896 ; Phillips.-V. Near the Castle, Lambay Island, in considerable quantity: Hart $I 883 \gamma$-and in $1886 ; R . W . S$. -VI. Miltown-Malbay, Clare, 1830: Harvey's Memoir, p. I5. Waste ground near Ringmoylan, Limerick: Stewart 2890 .

Also recorded from stations in Antrim, but not recently observed in that county and the records require confirmation.

A species likely to be overlooked, and perhaps more frequent than would appear from the above localities. 


\section{G. rotundifolium Linn.-Round-leaved Crane's-bill.}

Districts I. II. - - - VI. ---Lat. $51_{4}^{\circ}-53^{\circ}$. In Co. Cork, chiefly. Type, English.

Lowland. Dry banks, roadsides, and walls; very local. Fl. May-August.

I. By the Bandon river near Ballinadee: Allin's Cork.-II. In several of the small islands near Cove and on the side of the road between Cork and Glanmire: Mack. Rar. About Cork, passim, 1830: Harvey's Memoir, p. I6. Common about Cork, 1896 (in districts I. and II.); Rossmore near Carrigtwohil, 1896; Phillips. Rare about Midleton; Ballyvodock; and near Youghal (Rev. $T$. Allin): Rec. Add.-VI. At Townross near Ballyvaughan, Co. Clare, on walls and on limestone rock, well-established, 1894-1895; P. $B$. O' Kelly.

\section{G. dissectum Linn.-Jagged-leaved Crane's-bill.}

Districts I. II. III. IV. V. VI. VII. VIII. IX. X. XI. XII. Lat. $511_{2}^{\circ}-551_{4}^{\circ}$. Throughout Ireland. Type, British.

Fields, waste ground, and roadsides; frequent. Fl. MaySeptember.

Sea-level N. Derry and S. Cork. To $750 \mathrm{ft}$. in Dublin (N. C.).

9. † G. columbinum Linn.-Long-stalked Crane's-bill.

Districts I. II. - IV. V. VI. - - IX. X. - Lat. $51 \frac{3}{4}^{\circ}-53 \frac{1}{2}^{\circ}$. South and Middle Ireland. Type, EnglishBritish.

Lowland. Dry banks, rocky places, and roadsides; local and rare. Fl. June-July.

I. Near Kilcreagh Castle: Drummond 1820. Near Kilcreagh Abbey; about the Ovens Church on limestone rocks (Carroll); roadside near Rafeen and by the railway near Rochestown ( $T$. Wright): Cyz. Near Ballincollig Castle: Flor. Cork. Kilnagross and Kilmalooda, Cork (R. L. Allman): Allin's Cork. At Ovens, 1894; at Iniscarra, 1895; and roadsides near Inchigeela, 1897; Phillips.-II. Sunday's Well and Shanakiel: Flor. Cork. Near Midleton and Castletown-Roche (Rev.T. Allin): Rec. Add. At Youghal; near Killavullen; and near Bridgetown Abbey: Allin's Cork. Ardgeeha, Tipperary, 1840 (C. Taylor); Ballylinch, Carrickon-Suir, 1864 (J.E. Grubb) : Herb. Chandlee. Near Clonmel (Miss 
S. Grubb): Cyb.-IV. Ditch banks on the Murrough of Wicklow (Moore): Cyb. Near Campile and Whitechurch, Wexford : B.-H. \& G. 1889. On dry upland pastures at Caim; Mangan; Moneyhore; and Courtnacuddy, Wexford: Moffat 1880 . Fisherstown village : $B .-H . \& M .1892 .-\mathrm{V}$. At the foot of Knockmaroon Hills, 1799, and two or three miles from Dundalk on the road leading towards Slieve Gullion: Templeton MS. Feltrim Hill: Ir. Flor. A few plants near Castlebellingham: Butler I89o.-VI. Shore of Lough Derg near Portuman (Moore): Cyb. Pleasure grounds at Castle Taylor: More 1855. At Foynes and plentiful at Askeaton, Limerick: Stewart I 89o. Townross near Ballyvaughan, Clare, 1894; P. B. O'Kelly.-IX. Near the south-east end of Lough Mask, scarce: Marshall I896.-X. Roadside near Urney, Tyrone (Admiral Jones): $C y b$.

Also recorded from stations in Antrim, in some of which the plant may have appeared as a casual; but these records need verification.

10. G. lucidum Linn._Shining Crane's-bill.

Districts I. II. III. IV. V. VI. VII. VIII. IX. X. XI. XII. Lat. $52^{\circ}-551^{\circ}$. Throughout Ireland. Type, British-English. cole $A$.

Rocky places and walls; rather local. Fl. May-July. Calci-

Sea-level to $650 \mathrm{ft}$. in Clare (N.C.).

A widely distributed species occurring in most of the Irish counties, though rare in many. Very abundant on the limestone in Clare, Galway, and the Aran Islands.

\section{G. Robertianum Linn.-Herb Robert.}

Districts I. II. III. IV. V. VI. VII. VIII. IX. X. XI. XII. Lat. $51 \frac{1}{2}^{\circ}-55 \frac{1}{4}^{\circ}$. Throughout Ireland. Type, British.

Hedge-banks, walls, and rocky and waste places; common. Fl. May-September.

Sea-level in N. Antrim and S. Cork. To $650 \mathrm{ft}$. in Donegal (Hart); to $1700 \mathrm{ft}$. in Sligo $\left(B . \& V_{.}\right)$; to $1600 \mathrm{ft}$. in Tipperary
(Hart).

Var. PURPOREUM Forst.-I. About Cork: Flor. Cork.-VI. In the Aran Islands (Prof. $D$. Oliver): Cyb.-VIII. Inishbofin: More 1876 . 


\section{ERODIUM L'Héritier.}

1. E. cicutarium L'Hérit.-Hemlock Stork's-bill.

Districts I. II. III. IV. V. VI. - VIII. IX. - XI. XII. Lat. 51 $1_{2}^{\circ}-55 \frac{1}{4}^{\circ}$. From South to North. Type, British.

Sandy ground, near the sea; frequent. Fl. May-September.

Reaches to $1200 \mathrm{ft}$. on Ben Evenagh, Derry (S. \& P. 1805).

Recorded from the Antrim shores of Lough Neagh (Flor. N.-E.): very rare in such distinctly inland stations.

\section{E. moschatum L'Hérit.-Musky Stork's-bill.}

Districts I. II. - IV. V. VI. - VIII. - - XI. XII. Lat. $51 \frac{1}{2}^{\circ}-551_{4}^{\circ}$. Coasts of nearly all Ireland. Type, Atlantic.

Lowland. Banks, rocky pastures, and waste places; local, and only as a casual, inland. Fl. June-July.

I. Near Cloghane, Kerry (Moore): Cyb. At Dingle (Rev. W. M. Hind) : Phytol. 1857, p. 97. Near Ardfert: R.W. S. 1889. In many places in West Cork, as at Leap ; Glandore; Clonakilty ; \&c., and-II. Frequent on roadsides near Youghal (Rev. T. Allin): Ree. Add. Common on the coasts of Cork, 1896; Phillips. Near Tramore, Waterford: Hart $1883 \beta$.-IV. Curracloa, Wexford ( $\boldsymbol{~}$. Morrison): $C y b$. Banks near the road between Enniskerry and Bray : Ball 1839 -and in $1897 ; R$.W.S. Greenore Point, Wexford; Hart. Roadside at Duncannon, Wexford: B.-H.\& G. I889.V. On the wayside leading to Clontarf: Threlkeld. By the roadside at Artane and near Dunleary; on Bray Commons; near Chapelizod; and at Warren House : Wade Dubl. Sutton and Howth : Flor. Howth.-VI. Roadsides between Lisdoonvarna and cliffs of Moher (Rev. T. Warren): Cyb. At Killeany and Kilronain, Aranmore Island (Hart): Reo. Add. Roadside at Glin, Co. Limerick; R.W. S.-VIII. Dooagh, Achill Island, $1840:$ Babington in Herb. Near Clifden, Connemara (Rev. W. M. Hind): Cyb.near the Wesleyan chapel at same place, 1894; Miss M. F. Jackson. -XI. Roadside at Rathmullan, Donegal (Rev. T. Allin): Ree. Add. Abundantly at the west end of the suburbs of Londonderry, 1795, and-XII. Near Carrickfergus, 1797 : Brown MS. Near Portaferry 1806: Templeton MS. Near Dundrum (Corry) and at Ballycastle (Praeger) : Flor. N.-E. At Annalong, Co. Down: Hart 1884. Waste ground near Killough ( $R$. Hanna): Stewart 1894.

A species often confounded with large forms of $E$. cicutarium. 
3. E. maritimum L'Hérit.—Sea Stork's-bill.

Districts I. II. - IV. V. VI. - - - - XII. Lat. $51 \frac{1}{2}^{\circ}-55 \frac{1}{4}^{\circ}$. Coasts from South to North. Type, AtlanticEnglish.

Lowland. Banks, pastures, and waste places near the sea; rare. Fl. May-August.

I. Ringaskiddy, Cork Harbour (Carroll): Allin's Cork. Bro Head, Crookhaven: Flor. Cork. Schull; Galley Cove; Cape Clear and Inisherkin Islands, 1896 ; Phillips.-II. Strand at Ballycotton: Drummond 18zo. Tramore, Waterford (T. Chandlee): Cyb.IV. Curracloa (J. Morrison) and at Ballyteigue (Rev. S. Madden): $C y b$. Frequent all round the coast of Wexford from Rosslare to Hook Head, especially abundant about Crossfarnoge : Hart $1883 \beta$. On Large Keeragh Island, Wexford: B.-H.\&M. I802. Bray Head; More.-V. Killiney Bay and south-east side of Howth: Wade Rar. Ireland's Eye, 1882; N.C. Frequent all round Lambay Island: Hart $1883 \gamma$. Near the Lighthouse at the mouth of the Boyne; Barrington.-VI. Near Kilronan, Aranmore Island: Nowers \& Wells I892.-XII. Sands about Newcastle, and plentiful on the sandy shores about Kirkiston: Templeton MSS. Sandhills at Newcastle, very rare: S.\&P. 2892 -still at Kirkiston (Rev. C. $\boldsymbol{H}$. Waddell): S.\&.P. I805. Shore opposite Gunn's Island and at Portlabar, north of St. John's Point, also on roadside between Rathmullen and Tyrella (Stewart): F'lor. N.-E. Glenarm and Ballycastle, Antrim, and at Castlerock, Derry: Flor. Ulst.

Also recorded in Smith's Kerry 7756 , from "the strand of Tralee near the spaw," but not recently found in Co. Kerry.

\section{OXALIS Linn.}

\section{0. Acetosella Linn.-Wood Sorrel.}

Hibernicé Seampoz (sham-sōge).

Districts I. II. III. IV. V. VI. VII. VIII. IX. X. XI. XII. Lat. $51 \frac{1}{2}^{\circ}-554^{\circ}$. Throughout Ireland. Type, British.

Woods, thickets, and shady banks; frequent and locally abundant. $F l$. April-May.

Sea-level in N. Donegal and S. Cork. To $2200 \mathrm{ft}$. in Tyrone (Moore); to $2950 \mathrm{ft}$. in Wicklow (Hart); to $2800 \mathrm{ft}$. in Kerry (Druce 189I).

In a paper read before the Linnæan Society in 1830, James E. Bicheno has argued with much ingenuity that the Wood Sorrel was 
the shamrock of the ancient Irish. There appears, however, to be absolutely no evidence that this species was at any time used by the Irish as their national badge. The similarity of the Irish names for this plant, and for the common clovers, $T$. repens and $T$. minus, has perhaps been the source of much confusion in the discussion of the identity of the Irish shamrock.

\section{ORDER XVII.-ILICINE尼.}

ILEX Linn.

\section{I. aquifolium Linn.-Holly:}

Hzbernicé Cuulleann (Cullen).

Districts I. II. III. IV. V. VI. VII. VIII. IX. X. XI. XII. Lat. 511 ${ }^{\circ}-55 \frac{1}{4}^{\circ}$. Throughout Ireland. Type, British.

Woods and heaths; frequent. Fl. May-June.

Sea-level in N. Derry and in Kerry. To $1130 \mathrm{ft}$. in Derry and to $1350 \mathrm{ft}$. in Kerry (Hart); to $1300 \mathrm{ft}$. in Wicklow $(N . C$.).

\section{ORDER XVIII.CELASTRINEE.}

\section{EUONYMUS Linn.}

1. E. europæus Linn.-Spindle-tree.

Districts I. II. III. IV. V. VI. VII. VIII. IX. X. XI. XII. Lat. $51 \frac{1}{2}^{\circ}-55^{\circ}$. Throughout Ireland. Type, English.

Lowland. Rocky places and thickets by lakes and rivers; frequent. Fl. May-June. Calcicole $C$.

Most frequent in the rocky limestone districts and on the borders of lakes in the West.

\section{ORDER XIX.-RHAMNEA.}

\section{RHAMNUS Linn.}

1. R. catharticus Linn.-Purging. Buckthorn.

Districts I. - III. IV. V. VI. VII. VIII. IX. X. - [XII.]. Lat. $52^{\circ}-541^{\circ}$. From South to North. Type, English.

Lowland. Thickets, rocky places, and lalke shores; rave. $\mathrm{Fl}$. May-June. 
I. In the islands of Killarney Lake: Smith's Kerry 1756. Rough Island, Lower Lake, Killarney; More. On most of the islands in the Lower Lake; R.W.S.-III. Cottoner's Brook by Mountmellick, Queen's Co.: Annot. in Threlkeld. Banks of the Barrow, in Queen's Co. and-IV. Shores of Luggelaw and on the Murrough of Wicklow (Moore) : Cyb.-V. Monasterevan: Annot. in Threlkeld. By the Barrow below Monasterevan: Hart $1885 .-$ VI. Near Ballyvaughan; on the shores of lakes near Corofin, Clare: Foot 1862. Rocky pasture at Castle Taylor, Galway : More 1855. North and Middle Aran islands (Hart): Rec. Add. Glanquin, Clare : Corry 1880 . Abundant on the western shore and islands of Lough Derg, Co. Galway, 1896: N. C. 1897.VII. "They" (the berries) "come to us out of the King's Co. in great quantities": Threlkeld. Frequent near Geashill, King's Co. (Praeger) : Ir. Nat. 1894. Plentiful on Lough Ree: B.\&V. 1887. Knock Eyon, Westmeath, rare: Levinge 1894. Abundant on the Bounla and Corrikeen Islands, Lough Derg, and along the eastern shores of the lake, Co. Tipperary, 1896: N.C. 1897.VIII. Islands in Lough Corrib: Wade Gallovid. Shores of Loughs. Corrib and Mask (Prof. Melville) and shores of Lough Cullin, Mayo (More) : Cyb.-IX. On a point of rocky land called Derrynany, Lough Carra, Mayo: Ball 1839. Mote Park and Mount Talbot, Roscommon, 1897; Praeger.-X. Islands in Lough Erne: Mack. Cat. Common on the islands and shores of lower Lough Erne: Barrington I884. Farnham Lough, Co. Cavan: Ir. Nat. I806, p. 194.-[XII. Creagh Island in Lough Beg, \&c., 1835 : Moore MS. Abundant on the shore of Lough Neagh at the place called the Selchin, parish of Glenavy: Horb. Moore. Not recorded recently and apparently extinct, through drainage, in north-east Ireland: Flor. $N .-E$.

\section{R. Frangula Linn.-Alder Buokthorn.}

Frangula vulgaris Reichb.

Districts I. - III. IV. - VI. VII. VIII. IX. - - XII. Lat. $52^{\circ}-54 \frac{3}{4}^{\circ}$. Middle and North-East. Type, English.

Lowland. Heathy and boggy places and on limestone rocks; very rare. Fl. May-June.

I. Sparingly on the north shore of Muckross Lake, Killarney; R.W. S.-III. Plentiful in Mountmellick bog near Cottoner's wood, 1732: Annot. in Threlkeld.-IV. On wet ditch banks at the Murrough of Wicklow (Moore): Cyb.-V. Bog of Athy not far 
from Enfield, Kildare, $1884 ;$ Dr. E. P. Wright.-VI. Near Rock Forest on the borders of Clare and Galway, 1851: O'Mahony I860. Quite prostrate on limestone flags outside Garryland wood near Gort, Galway: More 1855. Glanquin Hills, Clare: Corry I880. A prostrate variety with very small leaves on rocks near Glanquin: Levinge 1892 . Plentiful on Hare Island, Lough Derg, 1896: N. C. 1897.-VII. In a wood near Tullamore, King's Co. (M. $P$. Edgeworth): Cyb.-VIII. On Canova island, Lough Corrib: More I860. Island near Ross Hill, Clonbur, Lough Mask; Miss $\boldsymbol{M}$. $\boldsymbol{F}$. Jackson.-IX. Derrynany Point, Lough Carra, Mayo: Ball 7839. East shore of Lough Mask, $1891 ; R$. P. Vowell.-XII. Side of a lake (Bow Lake) in the townland of Creevytenant, near Ballinahinch, and plenty among other shrubs in a bog near Ballygowan Bridge: Templeton MS. Creagh Island in Lough Beg (Moore): Flor. Hib. At Portglenone and shores of Lough Neagh at Shane's Castle and near Toombridge (Moore): Cyb. Re-discovered at Shane's Castle near the Main River (Prof. R. O. Cunningham) : B. N. F. C. Proe. I890-QI. The last station is the only recent one for district XII., in which this species appears to have become almost extinct through drainage.

\section{ORDER XX.-LEGUMINOS 2 .}

\section{ULEX Linn.}

\section{1. ర. europæus Linn.-Furse; Whin; Gorse.}

\section{Hibernicé $\alpha_{1}$ zeann (Ath-thenn).}

Districts I. II. III. IV. V. VI. VII. VIII. IX. X. XI. XII. Lat. $51 \frac{1}{2}^{\circ}-55 \frac{1}{4}^{\circ}$. Throughout Ireland. Type, British.

Heaths, pastures, and gravelly places; common in the East, local in the West. Fl. March-May, and again September-October.

Sea-level in N. Donegal and S. Cork. To $1450 \mathrm{ft}$. in Derry; to $1600 \mathrm{ft}$. in Wicklow, and to $1470 \mathrm{ft}$. in Kerry (Hart).

The so-called Irish Furze, Ulex striotus of Mackay, which was found growing sparingly in the grounds of Mount Stewart, Newtownards, Co. Down, near the beginning of this century, appears to have been little more than a "sport," and is not now known to occur in a wild state in Ireland. 


\section{U. Gallii Planch.-Dwarf Furze.}

Districts I. II. III. IV. V. VI. VII. VIII. - X. XI. XII. Lat. $51 \frac{1}{2}^{\circ}-55 \frac{1}{4}^{\circ}$. Throughout Ireland, almost. Type, English.

Dry heaths and hilly places; frequent and locally abundant. Fl. August-October. Calcifuge $A$.

Sea-level in N. Antrim and S. Cork. To $1600 \mathrm{ft}$. in Down; to $2150 \mathrm{ft}$. in Wicklow, and to $2200 \mathrm{ft}$. in Kerry (Hart). Ranges much higher in Ireland than in Great Britain, where it reaches its maximum elevation at $750 \mathrm{ft}$. in the Lakes District.

A rare plant in many parts of West Ireland, and usually more frequent near the coast than inland.

\section{CYTISUS Linn.}

\section{C. scoparius Link-Broom.}

Sarothammus scoparius Koch-S. vulgaris Wimm.

Districts I. II. III. IV. V. VI. VII. VIII. IX. X. XI. XII. Lat. $51 \frac{1}{2}^{\circ}-551^{\circ}$. Throughout Ireland. Type, British.

Heaths and billy places; frequent. Fl. May-June. Calcifuge $A$.

Sea level in Derry and S. Cork. To $700 \mathrm{ft}$. in Donegal (Hart); to $1050 \mathrm{ft}$. in Dublin $(N . C$. ); to $1200 \mathrm{ft}$. in Queen's Co. (Hart).

A widespread species, but seldom abundant.

Var. prostratus Baily-V. Edge of sea-cliffs on Ireland's Eye and at Kilrock and Drumleck, Howth: Flor. Howth. This is probably the plant recorded as Genista tinctoria in Flor. Hib.

\section{ONONIS Linn.}

\section{0. repens Linn.-Rest Harrow.}

Districts I. II. III. IV. V. [VI.] [VII.] - [IX.] - [XI.] XII. Lat. $51 \frac{1}{2}^{\circ}-55 \frac{1}{4}^{\circ}$. South to North. Type, British.

Sandhills, gravelly places, dry banks, and borders of fields, chiefly near the sea; locally abundant. $F$. June-August.

I. Very rare and probably introduced in Kerry; R.W. S.[VI. Sparingly at Ballyvaughan, Clare, $1895 ;$ N. C.-VII. Only once seen round Lough Ree, at Ladywell, Westmeath: $B . \& V$. 2887.-IX. A few plants at Lisloughrey, Cong, Co. Mayo; Miss M. F. Jackson.-XI. Between Fahan and Buncrana (W. E. Hart); very rare in Donegal: Hart I886.] -XII. Only one station in Derry 
-Benone, Magilligan (Mrs. Leebody): S.\& P. 1895. Frequent in Down and Antrim, by the coast: Flor. N.-E.

Sea-level to 900 feet in Dublin (N.C.).

Abundant on many parts of the south and east coasts. Casual in the West and North-West.

Var. HORRIDA Lange-II. Bunmahon and Knockmahon, Waterford coast: Hart I883 B.-V. Banks near St. Fintans, Howth, Co. Dublin, $1894 ;$ N.C.

\section{TRIGONELLA Linn.}

\section{T. ornithopodioides DC.-Birds-foot Trefoil.}

T. purpurascens Lamk.-Trifolium ornithopodioides Linn.

Districts - - IV. V. - - - - - [XII.]. Lat. $53^{\circ}-53 \frac{3}{4}^{\circ}$. East coast only. Type, English.

Lowland. Banks and sandy or gravelly pastures near the sea; very rare. $F l$. June-July.

IV. On the gravelly beach by the Murrough of Wicklow : Flor.

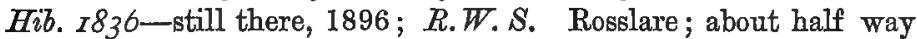
from Greenore Point to Churchtown; near Lady's Island Lake, Wexford: Marshall I898.- - . Near the North Wall: Wade Dubl. Found on the south-east side of Killiney Hill and near Bullock, June 1806: Mack. Rar. Abundant at Killiney Hill and Bullock: Mack, Cat. I825-not recently found in either station. On the summit of Clogher Head, Louth : Ball 2839 . Near the Lighthouse at Howth (Moore) : Cyb. - still there in $1885 ; R . W . S$. Abundant on an old grassy road leading from the Lighthouse road, Howth: Hart I897.- [XII. On a gravelly bank sloping to the sea at the northern end of Hollywood Warren, 1799: Templeton MS.--not found there now : Flor. N.-E.]

\section{MEDICAGO Linn.}

\section{M. Iupulina Iinn,-Black Medick.}

Districts I. II. III. IV. V. VI. VII. VIII. IX, X. XI. XII. Lat. $51 \frac{1}{2}^{\circ}-55 \frac{1}{4}^{\circ}$. Throughout Ireland. Type, British.

Pastures, roadsides, and waste places; rather common. $k l$. May-August.

Abundant in the South and East; rare towards the West and North-West.

From sea-level to $850 \mathrm{ft}$. in Dublin (N.C.). 


\section{2. * M. maculata Sibth.—Spotted Medick.}

M. arabioa All.

Districts [I.] II. - IV. [V.] - [VII.] - - - Lat. $51 \frac{1}{4}^{\circ}-521^{\circ}$. South of Ireland. Type, English.

Lowland. Cultivated land and waste places; very rare. Fl. May-July.

[I. Occasionally seen in cultivated land, as on the Model Farm, Cork, no doubt introduced (Prof. E. Murphy): Cyb.]-II. South side of Little Island by the-shore, 1840 (D. Murray): Flor. Cork. Still at Little Island and plentiful in several places on the banks of the river near Eastferry : Phillips 1895 . At Youghal; $R$. P. Vowelland abundant there in $1896 ; R . W . S .-I V$. Plentiful by the Blackwater, Wexford, 1896 ; Miss M. D'Arcy.-[V. Between Dolphin's Barn and Crumlin, Dublin (Mr. Johnston): Cyb. - not seen recently in Co. Dublin; N. C.-VII. By Lough Ree, a casual only : $B . \& V . .7887$.

\section{MELILOTUS Linn.}

\section{1. $\ddagger \mathbf{M}$. officinalis Lamk.-Common Melilot.}

Districts - II. III. [IV.] V. [VI.] - - [X.] - [XII.] Lat. $52^{\circ}-53 \frac{3}{4}^{\circ}$. South and East. Type, English.

Lowland. Waste places, banks, along railways, and field borders, chiefly near the sea; locally abundant. $F l$. July-August.

II. In Little Island (Drummond): $C y b$.-not observed here recently. A few plants in a pasture field at Ballinacurra, 1870 . (Rev. T. Allin): Rec. Add. Several plants in a field at Knockadoon, near Youghal: Allin's Cork. At Tivoli, near Cork, on waste ground; Little Island; Queenstown Junction, and Midleton; Phillips.-III. By the Kilkenny railway which passes through brackish marshes near.Waterford, plentiful (T. Chandlee): Carroll 1857. Banks near the railway station at Ferrybank, Kilkenny: M. \& S. I896:- [IV. Roadside near Enniscorthy (Miss E. M. Farmer): Rec. Add. Kiltrea and Aughnaclappa, Wexford, in clover and cultivated land, not established: B.-H.\&M. 1892.$]$ V. "In some Closes (which by the Ridges appear to have been plowed) beyond Coulack, copiously": Threlkeld I727. Sandy and bushy banks at Killiney Bay; plentifully about Mayne Bridge, Baldoyle, and in fields round the quarry near Finglas Bridge: Wade Dubl. 1794. Plentiful along the railway embankment north 
of Malahide, and here and there about the sandhills at Portrane and Rush (Moore \& More): Rec. Add. Abundant at intervals along the railway from Raheny to Balbriggan and to Howth; abundant in the sandhills at Rush and along the creeks at Rogerstown, and Malahide; thoroughly established along the coasts in Co. Dublin, $1895 ; N . C .-[V I$. A few plants in a meadow near Ballyvaughan, $1895 ; N . C .-\mathrm{X}$. On the railway at Bessbrook, Armagh, an escape; Praeger.-XII. On the Curran of Larne (Moore): Cyb. Sandhills at Portrush, 1887 (Praeger): Flor. N.-E. Glenariff: Shoolbred I894.] As yet, appears to be fully naturalized only in Co. Dublin.

2. * M. arvensis Wallr.-Field Melilot.

Districts - II. - - [V.] - - - - - XII.

Lowland. Railway banks and waste places; very rare and fully established only in the North-East. Fl. June-August.

II. Near the distillery, Midleton, but not established in Cork : Allin's Cork. Railway side at Cahir in considerable quantity (T. Wright): Carroll 1857 . Railway station at Clonmel (Miss S. $G r u b b): C y b .-[\mathrm{V}$. Occasionally on railway banks and waste places between Howth and Baldoyle, and in waste ground on the Cosh, Sutton; Hart.]-XII. Railway embankment between Kilroot and Whitehead, and between Glynn and Larne, Antrim (R. Tate): Journ. of Bot. 1870 . Still abundant between Kilroot and Larne, and may fairly be considered as naturalized here: S.\& P. 1895 .

\section{TRIFOLIUM Linn.}

\section{1. †T. subterraneum Linn.-Dwarf Trefoil.}

Districts - - IV. - - - - - - - Lat. $53^{\circ}$. County Wicklow only. Type, English.

Gravelly places; very rare. Fl. May-June.

IV. By the riverside at Wicklow, June, 1867 (More): Seeman's. Journ. of Bot. 1868-still there, in some plenty, $1895 ; R . W . S$.

\section{T. pratense Linn.--Red Clover.}

Districts I. II. III. IV. V. VI. VII. VIII. IX. X. XI. XII. Lat. $51 \frac{1}{2}^{\circ}-55 \frac{1}{4}^{\circ}$. Throughout Ireland. Type, British.

Meadows and pastures; common. Fl. May-September.

From sea-level in N. Antrim to $1150 \mathrm{ft}$. in Derry (Hart); sea-level to $1200 \mathrm{ft}$. in Dublin (N.C.). 


\section{T. medium Huds.-Zigzag or Mountain Clover.}

Districts I. II. III. IV. V. VI. - VIII. IX. X. XI. XII. Lat. $52^{\circ}-55 \frac{1}{4}$. Throughout Ireland, probably. Type, British.

Hilly pastures and rocky places; local. Fl. June-August.

I. Coast near Dingle, Kerry : Hart I884. Rocky place by the road between Tralee and Castleisland, very rare in Kerry : $R$.W.S. 1888. Glasheen, and-II. Little Island: Flor. Cork. Banks of the Owbeg near Castletownroche, 1897; Phillips. Near Carrick-onSuir (Miss S. Grubb); Mill Island, Fermoy, rare (T. Chandlee): Cyb.-III. Emo, Queen's Co., 1896; Praeger.--IV. Banks near the sea at Rockfield, Wicklow (Moore) : Cyb. Between Courtown and Gorey: Hart I 881 a.-V. Fields in the Dublin mountains and at their base: Wade Dubl. Roadside at Woodtown, near Mount Pelier, Dublin; R.W.S. Locally abundant in upland pastures in Co. Dublin, as at Saint Ann's and Glassamuckey, Glenasmole, 1895; N. C. Near Ballitore, Kildare (Carroll) : $C y b$. Base of Carlingford Mountain, Louth: Ir. Nat. $1893, p$. 227.-VI. Near the Black Fort, Aranmore Island: Nowers and Wells 2892.-VIII. On the shores of Lough Cullin, and-IX. Near Foxford, Mayo (More): Cyb. Frequent near Skreen and Dromore West, Sligo : N. C. 1806 . -X. Near Castle Hume, Lough Erne: Barrington 1884. Owl Island; Bess Island; and Inishfree, Lough Exne: Praeger, 1802. Navan Fort and Loughnashade lake, Armagh: Praeger 1893.XI. Ballyshannon and Mount Charles, Donegal (Admiral Jones): Cyb. Dunaff Head and Leenane, Lough Swilly; Mucross and Saint John's Point, S.-W. Donegal: Hart 1879 \& $1885 \mathrm{\gamma}$ XII. In County Down at Portavo (Corry) and at Newcastle (Praeger); very rare in this county, frequent in Antrim and Derry: Flor. $N$.-E.

Sea-level in Derry and in Kerry. To $750 \mathrm{ft}$. in Donegal (Hart); to $1000 \mathrm{ft}$. in Derry (Moore).

Apparently local and scarce in most parts of Ireland and very rare in the South; but no doubt is frequently confounded with T. pratense.

\section{T. arvense Linn.-Hare's-foot Trefoit.}

Districts I. II. - IV. V. VI. - VIII. - - XI. XII. Lat. 5110 $-551^{\circ}$. From South to North. Type, British-English.

Lowland. Near the sea, in sandy places and more rarely in rocky ground; rather rare and local. Fl. July-August. 
I. Dry fields at Cahirmore (Miss Hungerford); cliffs at Lislee; on Inisherkin; and cliffs at Siege Cove, Glandore: Allin's Cork.II. Plentiful on Cable Island, Youghal (Rev. T. Allin): Rec. Add. Kilfarassy island; Ballydowane Bay; Helvick Head; Mime Head, and Ardmore Head, Waterford, and-IV. Rosslare, Wexford : Hart I883 $\beta$. Abundant at Ballyconigar, Wexford (Carroll) : Cyb. At Arklow Head, Wicklow: Hart 1881 a.-V. Sandy ground near Merrion: Threlkeld. Abundant in the drifting sands about Rush, Co. Dublin: Wade Rar. I804-still abundant and luxuriant here in $1895 ; N$. C. Sandy pastures near Baldoyle, and at Portmarnock sands abundant: Mack. Cat. Dalkey Island and Lambay Island: Ir. Flor. Bailey Light House; Howth Burrow and between Kilbarrack and Sutton: Flor. Howth. Clogher Head, Louth: Butler I890.-VI. Between the light-house and the old fort in South Island of Aran (Hart) : Rec. Add.-VIII. Inishturk : More I876.XI. At Stroove (W.E. Hart) and west of Malin Head, Inishowen: Hart I883.-XII. Church Bay in Rathlin and on slipped ground at Blackhead: Templeton MS. In Co. Antrim, in sand-pits at Stranmillis (Stewart) and sand-hills at Portrush (Corry); in Co. Down, at Rough Island, east of Comber (Stewart) and at Ringsallin Point east of Dundrum (Corry): Flor. N.-E. Frequent in the sandy fields at Magilligan and by the shores of Lough Neagh, 1835 : Moore MS. Abundant in Magilligan: B. N.F.C. Proc. 1863.

Rare in the West and not recorded from any distinctly inland station except. Lough Neagh.

\section{T. striatum Linn.-Soft Knotted Trefoit.}

Districts I. - - IV. V. VI. - - - - - XII. Lat. 5110 ${ }^{\circ}-543^{\circ}$. From South to North. Type, English.

Lowland. Gravelly banks and rocky pastures, chiefly near the sea; very rare. Fl. May-June.

I. Kilfenora, Tralee Bay; on limestone rocks at Rahaneen Bay, west of Ardfert, Kerry: R.W.S. $1890 \&-9 I$. On the strand at Glandore, Cork (J. Sullivan): Cyb.-IV. Murrough of Wicklow (Moore) : $C y b$. By the river at Wicklow; More. About a mile and a half north of Wicklow, $1886 ; R . W . S$. Coast between Greenore Point and Churchtown, luxuriant and in good quantity, also sparingly on the north side of Wexford Harbour: Marshall 1898. Near Greystones railway station: Praeger 1897.-V. Killiney; Kilbarrack; and Howth (Moore): $C y b$. Sparingly on dry grassy slopes at Carrigeen, Ireland's Eye: Flor. Howth. Plentiful 
on Lambay Island: Hart $1883 \gamma$-and in 1896: Ir. Nat. 1896 , p. x86. Abundant on Feltrim Hill (More) : Rec. Add. On Feltrim Hill, 1893, and at Balcarrig, Portrane, 1894;N.C. On the summit of Clogher Head, Louth: Ball 1839 . Plentiful above the Martello Tower, Sutton (Miss R. Mahaffy): Ir. Nat. 1895.VI. Near the Black Fort; Aranmore Island: Nowers and Wells I892.-XII. On sloping gravelly banks on the shore at Rahanbuoy [Antrim] 1811: Templeton MS. Whitehead (Mr. Millen) and Castle Chichester (G. Diokie): Flor. Ulst. At Whitehead, 1866: Herb. Hyndman. Not seen recently in the North-East: Flor. $N_{\text {. }} \boldsymbol{E}$.

First found by Templeton, in Co. Antrim, in 1811.

6. T. scabrum Linn.-Rough Rigid Trefoil.

Districts - II. - IV. V. - - - - - - - Type, English.
Lat. $52^{\circ}-533^{\circ}$.

Sandy and gravelly places near the sea; rare. Fl. May-July.

II. A bundantly on sand-hills near Youghal, Cork : Allin 1871 .IV. Near Newcastle and Killoughter, Wicklow (More), and between Kilcool and Greystones, Wicklow (Hart): Rec. Add. A little south of Carnivan Head near Fethard, Wexford: Hart r883.V. Gravelly banks on the northern shores of Dublin Bay, 1799 : Templeton MS. Sandy fields on the Sutton side of Howth, Co. Dublin: Wade Rar. In a gravel pit at Sandymount and sandy banks near Kilbarrack Church : Mack. Cat. Killiney (Moore) and on the North Bull (D. Orr) : Rec. Add. Still on the North Bull, abundant, $1892 ; N . C$. Near the sea from below Kilbarrack to Greenfields: Flor. Howth. In the Park near the river at Bray; More. Rocky bank by the shore at Skerries, 1893; Greenwood Pim.

First found by Templeton in 1799.

7. †T. glomeratum Linn.-Round-headed Trefoil.

Districts - - IV.

Lat. $521^{\circ}-53^{\circ}$. Wicklow and Wexford only. Type, English.

Gravelly places; very rare. $F l$. June.

IV. By the river side at Wicklow near the [old] railway station, with T. subterraneum, 1869 (Moore): Journ. of Bot. I87o. Sparingly by the river about a mile and a-half north of the preceding station, 1886 , and still there in $1894 ; R . W . S$. In two sandy pastures near Rosslare House, Wexford; quite plentiful in one of them: Marshall 1898 . 


\section{T. repens Linn.-Dutch Clover; Shamrock.}

Hibernicé Seampós (Sham-rōge).

Districts I. II. III. IV. V. VI. VII. VIII. IX. X. XI. XII. Lat. $51 \frac{1}{2}-55 \frac{1}{6}{ }^{\circ}$. Throughout Ireland. Type, British.

Meadows and pastures; common. $\mathrm{Fl}$. May-September.

Sea-level in Derry and S. Cork. To $1450 \mathrm{ft}$. in Derry (Hart); to $1550 \mathrm{ft}$. in Sligo $\left(B . \& V_{\text {. }}\right)$; to $1700 \mathrm{ft}$. in Tipperary and to 1650 ft. in Kerry (Hart).

This species of clover is the one most generally worn as the shamrock or Irish national badge on St. Patrick's Day, 17th March, though $T$. minus is used very frequently and $T$. pratense and Medicago lupulina, occasionally, for the same purpose. Edward Lhwyd, the celebrated antiquary, one of the earliest investigators of the Irish flora, writing to Tancred Robinson in December 1699 after a recent visit to Ireland, says: "Their Shamrug is the common clover" (Phil. Trans. vol. 27, p. 503). Caleb Threlkeld in his Synopsis of native Irish plants, published in 1727, gives Seamaroge-C"Young Trefoil"—as the Irish name for $T$. pratense album, and says expressly that this is the plant worn by the people in their hats on St. Patrick's Day. K'Eogh in his Botanica Vniversalis Hibernica, 1735, and Wade in his Catalogue of the indigenous plants of the Co. Dublin, 1794, both identify the national badge with the same species, T. repens. Recent inquiry, however, shows that $T$. repens is far from having an exclusive claim to be considered the national badge of Ireland. Out of a number of specimens of certified "shamrocks" collected by $N . C$. in the years 1892 and 1.893 from various Irish counties, 24 were found to belong to $T$. repens and 21 to $T$. minus (Ir. Nat. I892, p. 95 and 1893, p. 207), and in Britten and Holland's Dictionary of English Plant Names, 1886, the latter species is recorded as used in 13 Irish counties.

\section{T. fragiferum Linn.—Strawberry-headed Trefoil.}

Districts I. II. - IV. V. - - - IX. - - Lat. $521^{\circ}-544^{\circ}$. South and East. Type, English.

Lowland. Damp pastures, mostly near the sea; rare and local. Fl. July-September.

I. By the coast near Feohanagh, west of the Dingle promontory, Kerry: Hart 1884. Castlegregory; Barrow; Banna; Ballybunnion, \&c.: R.W. S. ז888, \&c. Beal Point and Tralee Bay: 
Stewart I890.-II. Tramore, Waterford (Miss S. Grubb): Carroll 1857.-IV. Murrough of Wicklow (Moore): Cyb. Fisherstown marsh and near the Pill, Alderton, Co. Wexford: B.-H.\&G. 1889 \& 1890 . Below Loftus Hall on the west side of Hook Head, Wexford : Hart I883 $\beta$.-V. Side of Dublin Bay near Sandymount, 1799 : Templeton $\mathbb{P} S$. Brickfields beyond Clontarf, Co. Dublin, and marshy meadows along the Boyne beyond the obelisk (Co. Louth): Ir. Flor. Coast at the Boyne mouth, Co. Meath; Hart. By the sea at Clogher, Louth: Praeger 1897. Swords, Co. Dublin (Moore): Cyb. Shore at Ballybrack, Dublin, and at Gormanstown and Laytown, Meath (More): Rec. Add. Abundant by the shore south of Raheny, Co. Dublin, 1892 ; marshy hollows by the Grand Canal, Hazelhateh, and by the Tolka river, Mulhuddart, 1893: N. C. $1893 .-$ IX. Drumcliff, Sligo, 1897 ; Praeger.

Apparently absent from Cork and South Kerry; very rare in distinctly inland stations such as Hazelhatch.

First found by Templeton, at Dublin Bay, in 1799.

\section{T. procumbens Linn.-Hop Trefoil.}

Districts I. II. III. IV. V. VI. VII. VIII. IX. X. XI. XII. Lat. $51 \frac{1}{2}^{\circ}-55 \frac{1}{4}$. Throughout Ireland. Type, British.

Lowland. Dry pastures and sandy and gravelly places; frequent. Fl. June-August.

\section{T. dubium Sibth.-Small Yellow Trefoil.}

T. minus Smith.

Hibernicé-Seamnóz (Shamröge).

Districts I. II. III. IV. V. VI. VII. VIII. IX. X. XI. XII. Lat. 51 $1_{2}^{\circ}-551_{4}^{\circ}$. Throughout Ireland. Type, British-English.

Pastures, waste places, walls, \&c. ; common. Fl. May-August.

Sea-level to $1600 \mathrm{ft}$. in Dublin (N. C.).

Worn as the shamrock on St. Patrick's Day in many parts of Ireland-see under T. repens.

\section{T. filiforme Linn.-Slender Fellow Trefoil.}

Districts I. - - IV. V. VI. - VIII. - X. XI. L at. 5210 $-55^{\circ}$. South to North. Type, English.

Lowland. Gravelly pastures, heathy places, and lawns; very. rare. Fl. June-August.

I. Near Kenmare; Seafield, Tralee Bay; by Rahaneen Bay, Ardfert; by the Shannon near Ballylongford, Kerry: R. W. S. I889.- 
IV. On the Murrough of Wicklow (Moore): Cyb. At Arklow (More) : Rec. Add. Lawn at Kilmanock, Wexford, introduced: B.-H.\&M. 1892 . At Carnsore Point and in sandy pastures near Rosslare House, Wexford: Marshall I898.-V. Killiney Hill and Howth (Moore): Cyb. Curragh, Kildare; Praeger.-VI. In Co. Clare: Herb. Moore.-VIII. Leenane, Galway : Babington I836.X. At Tynan Abbey, Armagh (Stewart) : Rec. Add.-XI. Glenalla, Rathmullan, Donegal, perhaps introduced with grass seed: Hart I879.

\section{ANTHYLLIS Linn.}

\section{A. Vulneraria Linn.-Kidney Vetch.}

Districts I. II. III. IV. V. VI. VII. VIII. IX. X. XI. XII. Lat. $51 \frac{1}{2}^{\circ}-55 \frac{1}{4}^{\circ}$. Throughout Ireland. Type, British.

Sandy and gravelly banks and pastures, especially near the sea; frequent. $F l$. June-August. Calcicole $B$.

Sea-level in Derry and S. Cork. To $1150 \mathrm{ft}$. in Derry (Hart); to $1450 \mathrm{ft}$. in Sligo (N.C.).

Var. DILlenII Schulte.-I. At Ardgroom; More. Ballylickey, near Bantry: Mack. Rar. Schull and Sherkin Island; Phillips.II. Little Island : Flor. Cork.

\section{LOTUS Linn.}

1. L. corniculatus Linn.-Common Bird' s-foot Trefoit.

Districts I. II. III. IV. V. VI. VII. VIII. IX. X. XI. XII. Lat. 51 $1_{2}^{\circ}-55 \frac{1}{4}$. Throughout Ireland. Type, British.

Pastures and dry banks; common. Fl. May-August.

Sea-level in N. Antrim and S. Cork. To 1500 ft. in Derry $(C y b$.$) ; to 1600 \mathrm{ft}$. in Dublin (N.C.).

Var. CRASSIFolIUs Persoon - XII. Between Sydenham and Tillysburn, Down, and at Kilroot, Antrim (Stewart): Flor. N.-E. Rosses Bay on the Foyle, Derry (Mrs. Leebody): S.\& P. 1895.

Var. vmuosus Ser.-II. Near Mallow; R. P. Vowell.

$\ddagger$ L. tenuis Waldst. \& Kit.

L. tenuifotius Reichb.

Districts - II. - IV. V. - - - - XI. XII. Lat. $52 x^{\circ}-55 \frac{1}{4}^{\circ}$. From South to North. Type, British-English.

Lowland. Grassy places; rare, and perhaps always introduced. Fl. July. 
II. Waterford, 1858 : Babington in Herb.-IV. Near Alderton House, Wexford (Miss L. Glascott): B.-H.\& G. I889.-V. On the edge of cliffs at Balscadden, Howth (R.P.Vowell) : Flor. Howth.XI. In laid-down grass near Rossapenna hotel (Hart): Journ. of Bot. I892, p. 399.-XII. Railway bank near Larne, Antrim, 1869, an alien (Stewoart): Flor. N.-E.

2. L. uliginosus Schkuhr-Greater Bird's-foot Trefoil.

\section{L. major Smith.}

Districts I. II. III. IV. V. VI. VII. VIII. IX. X. XI. XII. Lat. $51 \frac{1}{2}^{\circ}-551^{\circ}$. Throughout Ireland. Type, British-English.

Damp pastures, ditch-sides, and moist bushy places; locally abundant. Fl. June-August.

Sea-level in N. Derry and S. Cork. To $850 \mathrm{ft}$. in Dublin (N.C.); to $1000 \mathrm{ft}$. in Waterford (Hart).

\section{ASTRAGALUS Linn.}

1. A. hypoglottis Linn.-Purple Milk-Vetch.

A. danicus Retz.

Districts - - - - VI. - - - - - Lat. $53^{\circ} 5^{\prime}-53^{\circ} 8^{\prime}$. Aran Isles only. Type, Germanic-British. June.

Lowland. Sandy and rocky pastures; very rare. Fl. May-

VI. On the largest of the South Isles of Aran [Aranmore] (Messrs. R. Ball \&Wm. Thompson): Flor. Hib. Abundant in sandy pastures near Killeany and in rocky pastures near Kilmurvy, Aranmore, 1892 (N. C.) : Journ. of Bot. $1892, p$. 3TO. On Inishmaan or Middle Island in 1835 (R. Ball): Nat. Hist. Rev. 1858 , p. 23. At the edge of the cliffs at Dun Angus, Aranmore: Praeger 1895 .

First discovered by Ball and Thompson in 1834 .

\section{ORNITHOPUS Linn.}

1. 0. perpusillus Linn.-Bird' s-foot.

Districts I. - - IV. V. - - - - - - Lat. $51 \frac{1}{2}^{\circ}-53 \frac{1}{4}^{\circ}$. South and South-East. Type, British-English.

Lowland. Sandy places and dry banks near the sea; very rare. Fl. May-July. 
I. On rocks by the sea at Goleen near Crookhaven, 1896-97; Phillips.-IV. Sandy soil about Ballycomigar, Wexford: Carroll 1854.- $\mathrm{V}$. Bare sandy pasture fields on the south side of the Hill of Howth: Mack. Rar. Sutton side of the Hill of Howth in great quantity: Flor. Hib. Dry banks at Carrickbrack and between the Light House and Glenuveena, Howth: Flor. Howth.

First recorded by Mackay in 1806.

\section{VICIA Linn.}

Ervum hirsutum Linn.

\section{1. † V. hirsuta Koch-Hairy Tare.}

Districts I. II. III. IV. V. VI. VII. VIII. - X. XI. XII. Lat. $51 \frac{1}{2}^{\circ}-55 \frac{1}{4}^{\circ}$. Throughout Ireland, probably. Type, BritishEnglish.

Lowland. Cultivated fields, dry banks, and bushy places; frequent. Fl. June-August.

2. $¥ \nabla$. tetrasperma Mœnch-Smooth Tare.

V. gemella Crantz-Ervum tetraspermum Linn.

Districts I. II. - - V. - VII. - - - - XII. Lat. 51 $\frac{3}{4}^{\circ}-53 \frac{1}{2}^{\circ}$. Middle and South. Type, English-British.

Lowland. Fields and bushy places; very rare. Fl. June-August.

I. At Blackrock and Passage, Cork (Carroll): Cyb. Lower Cove road, Kinsale, and potato field at the Old fort, Kinsale: Allin's Cork.-II. By the shore at Little Island (D. Murray) : Flor. Cork.V. Knockmaroon Hill (Mr. Johnston): Cyb. - still there in some quantity in bushy places, 1895 , and by the railway near Skerries, 1894; N. C. Ann's Brook, near Drogheda, Meath : Murphy 1829.-VII. In a cornfield near Mullingar (F. J. Foot): Cyb. At Knock Drin, rare: Levinge 1894.-XII. Cornfields at Giant's Ring and by the Lagan cunal below Shaw's Bridge (C. Dickson), introduced : Flor. N.-E.

But for its long presistence in a wild habitat at Knockmaroon this species would seem hardly deserving of a place in the Irish Flora.

\section{V. Cracca Linn.-Tufted Vetch.}

Districts I. II. III. IV. V. VI. VII. VIII. IX. X. XI. XII. Lat. $51 \frac{1}{2}^{\circ}-551^{\circ}$. Throughout Ireland. Type, British.

Bushes, fields, and waste places; common. $F l$. June-August.

Sea-level in N. Antrim and S. Cork. To $1000 \mathrm{ft}$. in Dublin (N.C.); to $1200 \mathrm{ft}$. in Tipperary (Hart). 


\section{V. Orobus DC.-Wood Bitter Vetch.}

Orobus sylvatious Linn.

Districts - - - - VI. VII. VIII. - - - XII: Lat. $53_{4}^{10}-54_{4}^{3}{ }^{\circ}$. Galway, King's Co., and Antrim. Type, ScottishIntermediate.

Rocky and bushy places; very rare. Fl. June-August.

VI. On rough heathery moorland in several places round Castle Lambert, near Athenry, 1888; Mrs. M. E. Joyce.-VII. In a wood within four miles of Cloughjordan, King's Co.: Flor. Hib.-VIII. Bilberry Island and other islands, Lough Corrib: Wade Gallovid-Bilberry Island, 1897 ; Miss M. F. Jackson. Вy a mountain stream north of the Half-way House, Connemara: Ogilby 7845 -XII. One large plant on the basaltic rocks of Sallagh Braes, Antrim, 1873 (Stewart): Guide to Belfast 1874, and seen again in the same station in 1882: B. N. F. C. Proc. $1882-83$.

The record in Ray's Synopsis, Ed. II., I696:-"Orobus syluatious nostras, found near Rostrevor, Dr. Sherard," should perhaps be referred to $\vec{V}$. sylvatica, which grows at Rostrevor, where $\vec{V}$. Orobus has not been observed by any botanist subsequent to Sherard.

\section{V. sylvatica Linn.-Wood Vetch.}

Districts I. II. III. IV. V. VI. - VIII. IX. X. XI. XII. Lat. $51 \frac{3}{4}^{\circ}-551^{\circ}$. Throughout Ireland, probably. Type, ScottishBritish.

Bushy and rocky places; local and rather rare. Fl. JunoAugust.

I. Abundant in the woods south of Ross Island, Killarney: Wade. Rar. Rough Island and Ross Island, Killarney: R.W.S. r889. In a furze-brake near Bantry; by the Lee above Carrigrohan Castle, and-II. Wood by the Blackwater below Fermoy: Drummond 1820 . Ballybrittain, Cork: Herb. T. Chandlee. Ballyvoyle Head and Mime Head, Co. Waterford: Hart $1883 \beta$. III. Wilton, Kilkenny (Rev. S. Madden): Cyb.-IV. Devil's Glen, Wicklow: Flor. Hib. By the coast at Arklow Head, Wicklow and south of Duffcarrig Rocks, Wexford: Hart I88I a.V. In a small wood on the banks of the Dodder near the Gap of Ballinascorney: Maok. Cat. In hilly thickets between Dalkey and the Malpas Obelisk: Wade Dubl. 2794 . In thickets east slope of Killiney Hill, 1894, probably the same station as Wade's; N. C.- 
VI. Ringmoylan Wood, Limerick: Stewart I890. Abundant. in clefts of limestone crags near Caheracloghane Fort, south of Slieve Elva, Clare, 1895 ; P.B. O' Kelly.-VIII. Streamstown, Connemara : Ir. Flor. Doon, at head of Lough Corrib (Prof. Melville): Cyb.IX. Ben Bulben, 1815: Templeton Journ. Cliffs at Glenade and Arroo Mountain, Leitrim: B.\&.V. 1885. Near Houndswood, Mayo; Miss M. F. Jaokson.-X. Near Ballinmallard, Fermanagh: Corry 1882. Isle Namanfin, Lough Erne: Barrington 1884.XI. Culdaff and Horn Head (C. Moore): $C y b$. Glen behind Moville (W. E. Hart): Hart 1883. Ross Gull; Miss Kinahan. Frequent along Donegal Bay : Hart $1883 \gamma$.-XII. In the wood of Rostrevor, 1793 (Templeton): Whitla MS. Banks by the sea near Bloody Bridge, Down: S. \& P. 1802 . Garron Head; Magilligan; Tor Head, and in numerous other stations in Antrim and Derry: Cyb.\&Flor. N.-E.

From sea-level to $700 \mathrm{ft}$. in Derry $(C y b$.$) . To 1350 \mathrm{ft}$. in Leitrim (B.\&. $\nabla$.).

\section{V. sepium Linn.-Bush Vetch.}

Districts I. II. III. IV. V. VI. VII. VIII. IX. X. XI. XII. Lat. $51 \frac{1}{2}^{\circ}-551^{\circ}$. Throughout Ireland. Type, British.

Woods, hedges, and shady banks; common. Fl. May-July.

Sea-level in Derry and S. Cork. To $1850 \mathrm{ft}$. in Mayo (Hart).

\section{7: V. angustifolia Roth-Narrow-leaved Vetch.}

Districts I. II. - IV. V. VI. - VIII. - X. XI. XII. Lat: $51 \frac{1}{2}^{\circ}-551^{\circ}$. From South to North. Type, British-English.

Lowland. Sandy pastures and banks by the sea, also inland on lake shores; frequent. $F l$. May-June.

Occurs in almost all of the maritime counties and inland by Lough Neagh in Armagh, Antrim, and Derry.

\section{V. lathyroides Linn.-Dwarf Spring Vetch.}

Districts - - IV. V. - - - - XI. XII. Lat. 52 $\frac{3^{\circ}}{4}-551^{\circ}$. East and North coasts. Type, British-English.

Lowland. Sandy or gravelly pastures near the sea; very rare. Fl. April-May.

IV. Arklow sands, Wicklow, 1894 (R.W.S.) : Ir. Nat. I895.V. Sandy field near Kilbarrack Church : Mack. Cat. Banks at the sea-shore from Clontarf to Howth and about the Lots, North Wall: 
Ir. Flor. Sandhills at Baldoyle (More) : Cyb. -and in $1885 ;$ N.C. On the Cosh, Sutton: Flor. Howth. East side of Lambay Island: Hart I883 $\gamma$--XI. Dunaff Head, Donegal (Hart): Rec. Add. Sandy ground at Stroove: Hart I883.-XII. Gravelly bank on the shore at Three-mile-water Point near Carrickfergus, 1808: Templeton MS. Sandy shore at Ballyholme, Down, 1829 (G. C. Hyndman): Flor. N.-E. Ballycastle: Flor. Dlst. Sand-hills at Magilligan, Derry (Moore): Cyb.-still there (Mrs. Leebody): S.\&P. 1895 . Warren at Donaghadee, Down, and frequent on sandy shores thence to Ballywalter (Steroart): Rec. Add. \& Flor. N.-E. Ballymacormick Point, Down (Praeger); Cushendun, Antrim (Rev. S. A. Brenan) : S.\&P. 1895 .

\section{LATHYRUS Linn.}

1. L. pratensis Linn.-Meadow Vetchling.

Districts I. II. III. IV. V. VI. VII. VIII. IX. X. XI. XII. Lat. $51 \frac{1}{2}^{\circ}-55 \frac{1}{4}^{\circ}$. Throughout Ireland. Type, British.

Meadows, damp pastures, and bushy places; common. $F l$. June-August.

Sea-level in N. Derry and S. Cork. To $1100 \mathrm{ft}$. in Dublin (N. C.).

\section{L. palustris Linn.-Blue Marsh Vetchling.}

Districts - - IV. V. VI. VII. - IX. X. - XII. Lat. $53^{\circ}-541_{2}^{\circ}$. Middle and North Treland. Type, English.

Lowland. Marshy meadows; very local. Fl. June-July.

IV. Ditch banks by the sea beyond Dunganstown, Wicklow, 1849 (Mr. Rollins): Mackay 1859. Marshy felds near the Murrough of Wicklow (Moore) : Cyb.-V. Plentiful on the shore of Lough Sheelin, Meath: Praeger $7897 .-$ VI. By the Shannon at Portumna, Galway (Moore): Cyb.-VII. Banks of the river Inny and marshy meadows around Lough Ree: B.\&V. 1887 . Northwest corner of Lough Owel, Westmeath, very luxuriant: Levinge I894.-IX. Several places on the west side of the Shannon near Athlone, \&c.: B.\&V. $188 \%$. Lough Key, Roscommon, 1897; Praeger.-X. Abundantly on the shores of Lough Erne, in the counties of Fermanagh and Cavan (Moore): Cyb. Plentiful on the shores of Upper Lough Erne near Belleisle House: Barrington 1884. Island in Lough Neagh near Maghery [Scawdy Island, Tyrone] Rev. G. Robinson: Flor. Olst.-but now extinct. Islets 
in Closet River, Co. Armagh (Rev. H. W. Lett) : Flor. N.-E.-still there in abundance on islets at the mouth of the river and also on its banks half a mile from the mouth: Praegor 1893 . In drains to the west of where the canal enters Lough Neagh, and-XII. In drains at Selchin: Herb. Moore. Not seen in Antrim for perhaps 40 or 50 years and probably extinct through drainage : Flor. $N$.-E.

\section{L. maritimus Bigel.-Sea Pea.}

Pisum maritimum Linn.

Districts I. - - - - - - - - -

Lat. $52^{\circ} 5^{\prime}$. Kerry only. Type, Doubtful or Local.

Pebbly sea-shores; very rare or perhaps extinct. Fl. JulyAugust.

I. "They grow annually on the south point of Inch Island in the Bay of Castlemain in considerable quantities": Smith's Kerry 1756. "I found this on the sand-hills, Bay of Castlemain, in August, 1-804": Mack. Rar. A specimen from this locality, labelled in Mackay's handwriting: "Sand-hills, Bay of Castlemain, 1804 ," is preserved in the herbarium of Admiral Jones in the Science and Art Museum, Dublin. Another specimen, labelled: "Sandhills, Killorglin Bay, 1845," appears in a collection of plants of the district made by a coastguard named John Reilly, and purchased by Mr. R. M. Barrington (Journ. of Bot. 1877, p. I79). A third specimen from $\mathrm{Mr}$. Arthur Bennett's herbarium is labelled: "Ex herbario Guglielmi Andrews. . . . Rosbegh, Kerry, July, 1841." There appears, however, to be no specimen extant gathered later than 1845 , and careful search made along the northern shore of Castlemain Bay by Mr. H. C. Hart in 1883 and along the southern shore by R. W. S. in 1888 has failed to discover any trace of the plant, which has, perhaps, become extinct through a change in the form of the coast.

\section{I. macrorrhizus Wimm.-Heath Pea.}

L. montanus Bernh.-Orobus tuberosus Linn.

Districts I. II. III. IV. V. VI. VII. VIII. IX. X. XI. XII. Lat. $51 \frac{1}{2}^{\circ}-55 \frac{1}{4}^{\circ}$. Throughout Ireland. Type, British.

Heathy, and bushy places, chiefly in hilly districts ; frequent. $F l$. May-July. Calcifuge $A$.

To $1550 \mathrm{ft}$. in Donegal and to $1600 \mathrm{ft}$. in Tipperary (Hart). Var. TENOIFoLIUS Reich. fll.-IV. Near Wooden Bridge, Wicklow; 
R.W.S.-VIII. Near Leenane, Galway, 1894 ; Rev. W. Colgan.XII. Rostrevor, Down: S.\&P. I892. Purdysburn and Knock (Stewart) and other stations in Down: Flor. N.-E.

\section{ORDER XXI.-ROSACEE.}

\section{PRUNUS Linn.}

\section{P. spinosa Linn.-Blackthorn.}

Hibernicé Opaifean (Dhree-ann).

Districts I. II. III. IV. V. VI. VII. VIII. IX. X. XI. XII. Lat. $51 \frac{1}{2}^{\circ}-54 \frac{1}{4}^{\circ}$. Throughout Ireland. Type, British.

Thickets, hedges, and rocky places; common. Fl. April-May.

Sea-level in N. Antrim and S. Cork. To $800 \mathrm{ft}$. in Donegal (Hart); to $1200 \mathrm{ft}$. in Sligo $\left(B . \& V_{\text {. }}\right)$.

$$
\text { * P. insititia Linn.-Bullace. }
$$

Districts I. II. III. - V. VI. VII. VIII. - X. XI. XII. Lat. $51 \frac{3}{4}^{\circ}-55^{\circ}$. From South to North. Type, English.

Lowland. Woods and hedges; rare. $F l$. April-May.

I. Derrynane Wood, Kerry; R.W. S.-II. Near Clonmel (Miss S. Grubb): Cyb.-III. Ballinalina, Kilkenny (Rev. S. Madden): Cyb.-V. Santry Wood: Ir. Flor.-VI. In rocky clefts in the great Island of Aran, Galway Bay $(L$. Ogilby $)$ Cyb..-VII. Roadside hedges near Knock Drin, Westmeath: Linton $2806 .-$ VIII. Bilberry Island, Lough Corrib: Wade Rar.-X. Artigarvan, Tyrone (Dr. Sigerson): Rec. Add.-XI. Ned's Point, Buncrana, and Ballymacgowan, Fanet : Hart I88I $\beta$.-XII. Rostrevor Wood, Down: Ir. Flor. Frequent in many parts of Antrim and Derry (Moore): Cyb. Knock Glen and hedges at Drumbo, Ballymaleidy and between Ballywalter and Grey Abbey (Stewart): Flor. N.-E. May be considered naturalized in this district: S.\&P. 1895 .

Probably planted in the majority of the preceding stations; but further information is much needed as to the standing of this plant in Ireland.

\section{2. $†$ P. avium Linn.-Wild Cherry.}

Districts I. II. III. IV. V. - VII. - IX. X. XI. XII. Lat. $52^{\circ}-55^{\circ}$. From South to North. Type, English.

Lowlund. Woods and hedges; not common and usually in suspicious situations. Fl. A pril-May. 
I. Killarney (Moore) : Cyb.-II. By the Blackwater, in woods ; rather general : Flor. Cork.-III. Kilmacow (T. Chandlee): Cyb. Near Ferrybank, Kilkenny: M.\& S. $x 806 .-I V$. and V. Frequent in Wicklow and Dublin (Moore) : Cyb.-VII. Old wood at Knock Drin, Westmeath: Levinge 1894.-IX. Near Athlone: B.\& $\boldsymbol{V}$. 1887.-X. Lower Holy Hill, Tyrone (Dr. Sigerson): Rec. Add. - About Blaney Bay, Lough Erne: Barrington 1884.-XI. Not infrequent in hedges in Donegal and abundant in some parts, as at 'Pettigoe and Rathmelton; Hart.-XII. Among alder and other native trees on the margin of Lough Neagh: Templeton MSS. Glen of the Crumlin river, Antrim (Corry); Dundonald Glen, Down (Stewart); natural in glens, planted in hedges: Flor. N.-E.

Perhaps native in North Ireland; introduced elsewhere.

\section{3. * P. Cerasus Linn.-Dwarf Cherry.}

Districts 'I. II. III. - V. - VII. VIII. - X. XI. XII. Thickets, hedges, and plantations; rare and nowhere native. Fl. April-May.

I. In South Cork (J. Sullivan): Cyb.-II. At Blarney Lake and by the Lee at Leemount: Flor. Cork. Hallahan's Rock, Fermoy (T. Chandlee): Cyb.-III. At Maryborough; Praeger.V. Hedges near Carrickmines; at Kiltiernan; at Walshestown, Naul hills, and elsewhere in the Co. Dublin, perhaps naturalized in some of its stations ; N. C.-VII. Knock Drin wỏods, Westmeath (Levinge) : Linton 1896 .-VIII. In the demesne of Col. Knox Gore at Ballina (Moore): $C y b .-\mathbf{X}$. Hedges near Loughgall, Armagh, not wild: More I860.-XI. In the townland of Muff, Donegal (C. Moore): Cyb. In hedges, occasionally in a half wild condition, in Co. Donegal; Hart.-XII. Among native trees on the shores of Lough Neagh : Templeton MS. At Draperstown and by the side of the Curley Burn, Derry, 1835: Moore MS. Glendun and Rasharkin and several other places in Antrim, Down, and Derry (Praeger), appearing naturalized in some of its stations: S. \& P. 1895 .

Like $P$. insititia, a plant whose proper standing in Ireland it is hardly possible to determine with the available information.

\section{P. Padus Linn.-Bird Cherry.}

Districts - - - - VI. VII. - IX. X. XI. XII.

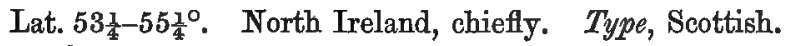

Lowland? Thickets in damp, rocky places; rare. Fl. May-June. 
VI. Sparingly on the banks of the Suck near Ballinasloe: Foot 1865. In profusion in an old wood at Clonbrock, Co, Galway: Praeger I896.-VII. Glenstal, Co. Limerick (C. B. Barrington): Hart $1881 \%$. Knock Drin woods : Levinge I894.-IX. Larkfield, Leitrim (Admiral Jones); in Sligo and Leitrim (J.Wynne): Cyb. A single tree on the shore of Lough Achree, Ox Mountains, Sligo: N. C. $2896 .-\mathrm{X}$. Woods at Favour Royal, Tyrone: Hart $788 \%$. Roadside at Cooneen, N. Fermanagh; Rev.W. J. Browne.-XI. Mintiaghs, Inishowen, 1839 : Herb. C. Moore. Abundant by the river Finn from Lifford to the Reelan water: Hart $1885 \gamma$. Termon river above Pettigoe; river between Ardara and Glenties: Hart 1886. - XII. Glenarm deer-park and on limestone rocks at Sallagh Braes, Antrim: Templeton MS.—still there in 1874: Flor. N.-E. Carnlough Glen (Mr. Hyndman) : Flor. Olst.—and still there about 1887 : Flor. N.-E. Low glens in Glensheisk, Antrim : Ir. Flor.one or two small trees here in 1893: Shoolbred 1894 . On the banks of the Faughan below Cumber, Co. Derry : Templeton MS. By the rivers Faughan, Roe, and Agivey, Derry, 1835 : Moore MS.

Undoubtedly native in North Ireland; but nowhere abundant and apparently decreasing.

\section{SPIR AA Linn.}

\section{S. Ulmaria Linn.-Meadow-Sroet.}

Hibernicé Q1pzioo luaćpa (Air-ž-good loo-ack-ra), Silver of Rushes. Districts I. II. III. IV. V. VI. VII. VIII. IX. X. XI. XII. Lat. $51 \frac{1}{2}^{\circ}-55 \frac{1}{4}^{\circ}$. Throughout Ireland. Type, British.

Damp meadows and borders of streams and ditches; common. Fl. June-August.

Sea-level in N. Derry and S. Cork. To $1700 \mathrm{ft}$. in Sligo $\left(B . \& V_{\text {. }}\right)$; to $2800 \mathrm{ft}$. in Kerry $(N . C$.).

\section{S. Filipendula Linn.-Dropwort.}

Districts ---- VI. $--\overline{-}-\overline{-}-\overline{-}-$

Lowland. Calcareous pastures; very local. Fl. June-July.

VI. "It grows . . . wild in the barony of Burrin": $K^{\prime}$ Eogh 1735. In county Galway near Gort and in the Marquis of Clanricarde's demesne at Portumna (Moore): Phytol. 1845, p. 130. By a lake near Glencolumbkill, Co. Clare, 1851: O'Mahony I860. 
A bundant through Glencolumbkill (F.J. Foot) and in several places thence towards Gort, Co. Galway (G. H. Kinahan): Foot 1862. Boston, North Clare; P. B. O' Kelly. Garryland, Gort: More 1855 .

\section{RUBUS Linn.}

\section{R. Idæus Linn.-Raspberry.}

Districts I. II. III. IV. V. VI. VII. VIII. IX. X, XI. XII. Lat. $51 \frac{1}{2}^{\circ}-55 \frac{1}{4}^{\circ}$. Throughout Ireland. Type, British.

Woods, thickets, and rocky places; frequent and locally abundant. $F l$. June-July. Calcifuge $C$.

Var. ASPERRIMUS Lees.-VII. Knock Drin, Westmeath : Linton 1896.

Sea-level in Derry and S. Cork. To $1600 \mathrm{ft}$. in Derry (Cyb.); to $1800 \mathrm{ft}$. in Leitrim ( $N . C$.$) ; to 1700 \mathrm{ft}$. in Tipperary (Hart).

2. R. fruticosus ${ }^{1}$ Linn. (Aggregate)-Bramble; Blackberry.

Hibernicé Opir (Dhriss).

Districts I. II. III. IV. V. VI. VII. VIII. IX. X. XI. XII. Lat. $51 \frac{1}{2}^{\circ}-551^{\circ}$. Throughout Ireland. Type, British.

Hedges, thickets, heaths, \&c.; very common. Fl. JulySeptember.

Sea-level in N. Antrim and S. Cork. To $1400 \mathrm{ft}$. in Down (S. $\&$ P.); to $1200 \mathrm{ft}$. in Dublin (N.C.).

\section{Group I-Suberecti.}

R. suberectus Anders.

Districts - II. - - - VII. VIII. - - XI. XII.

II. On the Millstreet mountains, Cork (Carroll): Allin's Cork.VII. Knock Drin, Westmeath: Levinge $1894 .-$ VIII. At Headford, Galway: Flor. Hib.-XI. By the Finn and near Pettigoe: Hart I885 \% - -XII. Deer Park, Limavady, Derry (Moore): Cyb.

R. Frssus Lindl.-I. Near Schull, Cork, 1896; Phillips.VII. At Drinmore, Westmeath: Levinge I894.-XII. By the

${ }^{1}$ In the following arrangement of the Irish fruticose Rubi, an attempt has been made to subordinate the more critical or local forms to those which are more distinct or wide-spread. Specialists who may be unable to accept this tentative aggregation will at least find in these pages full details aslito the distribution of the numerous segregates which hav.e been detected in Ireland. 
Foyle, Derry (Moore): Cyb. By Carrickmannan lake, near Saintfield, Down (Stewart) : Flor. N.-EL.

R. plicatus Wh. \& N.

Districts I. - - V. VI. - VIII. IX. X. - XII.

I. Near Clonakilty, Cork (Babington): Allin's Cork. Ballydehob, South Cork, 1896; Phillips.-V. In Co. Meath (Moore): Cyb.-VI. Clonbrock, E. Galway; Praeger.-VIII. and IX. South of Lough Mask : M.\& S. $7896 .-\mathrm{X}$. Church Hill, Armagh : Praeger I893.-XII. Kilrea, Derry (Moore): Cyb. Aughnadaragh near Saintfield, Down (Rev. C. H. Waddell) : S.\& P. 2895 .

Var. HeMIstemon ( $P . J . M u e l l$.$) -VIII. By the river at Maam,$ Galway: M.\&S. I896.-X. Near White Island, Lough Erne: Barrington 1884 .

R. NITrod $W h . \& N$. -IX. Shores of Lough Allen: Stewart 1885.-XII. Margin of Altnadua Lake, Down: S. \& P. 2892.

R. opacus Focke-VII. Crooked Wood, Lough Derevaragh, Westmeath: Linton 1896 .

R. RogersII Linton-XII. In Saintfield demesne and by Aughnadaragh Lake, Down (Rev. C. H. Waddell) : S. \& P. ${ }_{1895}$.

R. affinis Wh. \& N.

Districts I. $---\overline{-}-\overline{-}$
$\quad$ I. Killarney, Kerry $($ Babington $): C y b$.

R. CarIENSIS Rip. \& Genev.-IV. Near Wexford: Marshall I 890.

GrovP II-Rhamnifolii.

R. carpoinifolius Wh. \& $\mathrm{N}$.

Districts I. - - - V. - VII. VIII. - - XI. XII.

I. Turk mountain and Derrynane, Kerry (Babington): Cyb.V. Howth, Co. Dublin (Herb.J. Ball) : Focke I891.-VII. Crooked Wood, Lough Derevaragh, Westmeath: Linton 1896.-VIII. Maam, Galway: Babington 1836 . Inishbofin: More 1876. - XI. Blue Stack mountains; Hart.-XII. By the Lagan canal, Belfast: Corry r882. Cave Hill; Glenshesk; and Rathlin Island (Stewart): Flor. N.-E. Plentiful in Moygannon Glen, Down: S. \& P. I892.

R. Incurtatus Bab.-IV. Near Wexford: Marshall r896.VII. Knock Drin woods, Westmeath: Levinge 1895.-VIII. Near Clonbur: Marshall I8g6. 
R. Lindleianus Lees,

Districts - - III. - - VII. VIII, IX. X. - XII, III. Ferrybank, Kilkenny: M. \& S. I896.-VII. Knock Ross, Westmeath : Levinge I894.-VIII. and IX. South of Lough Mask: M. \&S. r896.-X. Near Lurgan and Armagh: Praeger 1893.XII. In Aghaderg parish, Down (Rev. H. W. Lett) : S. \& P. r895. Glenariff and Glendun: Shoolbred I894. Ballinderry, Derry: Brenan 1895 .

R. ERYTHRINUs Genev.-VII. Knock Drin, Westmeath : Levinge I895.-IX. South of Lough Mask: M. \& S. I896.-XII. Ballinderry, Co. Derry : Brenan 1895.

R. rhamnifolius Wh. \& N.

Districts - - IV. V. - VII. VIII. - X. - XII.

IV. At Rosslare, Wexford : Marshall $1896 .-\mathrm{V}$. Clontarf and Balbriggan, Co. Dublin, and Mornington, Co. Meath: Praeger I894.-VII. Knock Drin, Westmeath : Levinge I895.-VIII. Above Lough Inagh, Connemara (Herb. J. Ball) : Focke I89r. Maam and Clonbur: M. \& S. 1896.-X. Near Armagh: Praeger 1893.XII. Between Belfast and Hollywood, Down; Magilligan, Derry (Herb. J. Ball) : Focke I89I. Glenariff and Glendun, Antrim: Shoolbred 1894 .

R. DUMNONIENsis Bab. - III. Ferrybank, Kilkenny, andVIII. Maam, Galway: $\mathbb{M} . \&$ S. $\pi 896$.

R. pulcherrimus Neum.

Districts - - IV. V. - - VIII. IX. - - XII.

IV. Lough Dan, Wicklow, and-V. Mornington, Meath; and Glenasmole and Balbriggan, Dublin : Praeger I894.-VIII. Maam and Clonbur, and-IX. Cong: M.\&S. 1806.-XII. Lisdalgan, Down (Rev. C. H. Waddell) : Stewart I894. Cave Hill : Glenariff; Glendun, \&c., Antrim: Shoolbred 1894. Ballinderry, Co. Derry : Brenan 2895.

R. Nemoratis P. J. Muell. - XII. By the White Water at Donard, Down, and by the Ghann river, Down : S.\&P. 1895.

To $1000 \mathrm{ft}$. in Dublin (R. pulcherrimus); Praeger.

\section{$R$. villicaulis Koehl.}

Districts I. II. - - V. VI. - VIII. IX. X. XI. XII. I. Killarney, and-II. Waterford (Babington): Cyb.--V. In Co. Meath (Moore): Cyb.-VI. Near Six-Mile Bridge, Clare: 
Stewart I890.-VIII. Inishbofin : More 1876. Maam, Connemara (Babington): Cyb.-IX. Lough Allen: Stewart I885.-X. Lough Neagh and Newry, Armagh: Praeger 1893.-XII. Bushmills, Antrim (Babington): $C y b$. Glenariff and Glendun: Shoolbred 1894. Ballinderry, Co. Derry : Brenan 1895.

Var. SelmerI (Lindeb.) - VIII. and IX. Frequent about Clonbur and Cong: Marshall $7896 .-\mathrm{X}$. Tanderagee, Armagh; Rev. H. W. Lett.-XI. Carrick; F. J. Hanbury.-XII. In several stations in Antrim, Down, and Derry : S.\&P. 1895, \&c.

Var. caltatus (Blox.)-XI. Pettigoe, Donegal: Hart $1885 \gamma$.

R. RномвгFоLros Weihe-VII. Knock Drin, Westmeath; Linton.

R. gratus Focke-X. Ballymore, Armagh, $1894 ;$ Rev. H. W. Lett.-XII. Glendun, Antrim (Rev. H. W. Lett): S. \& P. 1895.

\section{GrovP III-Discolores.}

R. discolor Wh. \& N.

R. rusticanus Merc.

Districts I. II. III. IV. V. VI. VII. VIII. IX. X. XI. XII.

The commonest, perhaps, of all the Irish fruticose $R u b i$ and especially abundant on calcareous soils in the lowlands.

R. pubescens Weihe.

Districts - - - - - - - - - XII.

XII. Carrickmannan near Saintfield, Down (Rev. C. H. Waddell): S.\&P. 1895 .

R. argentatus $P . J$. Muell.-IX. Near Cong: M.\& \$. 1896.

Group IV-Silvatici.

R. sitvatious Wh. \& $\mathrm{N}$.

Districts - - - IV. V. - - - - - - XII.

IV. Lough Dan, Wicklow, and- $\nabla$. Howth, Dublin: Praeger 1894.-XII. Between Milltown and Clonallen, Down (Rev. H. W. Lett): S.\&P. 1895 .

R. Satteri Bab.-DIII. Cromlyn, Connemara ; E. F. Linton.X. Newry, Armagh: Praeger 1893.-XII. At Shrigley, Down (Stewart): Flor. N.-E.

R. HESPERIJ Rogers-VIII. Oughterard; Maam; Cong and Clonbur, Co. Galway (Marshall \& Shoolbred) : Journ. of Bot. 1896, p. 505, where this is described as a new species or variety by Rev. W. Moyle Rogers. 
R. macrophyllus Wh. \& N.

Districts I. II. III. IV. V. VI. VII. - IX. X. - XII. I. Killarney (Babington): $C y b$. Glengariff and Kenmare: Druce ${ }_{2} 891 .-\mathrm{II}$. At Cork Beg; Phillips.-III. Maryborough, Queen's Co.-IV. Luggelaw, Wicklow, and-V. Howth, Co. Dublin: Praeger 1894.-VI. Doonbeg, Clare: Stewart I890.-VII. Portarlington, King's Co. : Praeger 1894.-IX. Lough Allen: Stevart 1885.-XII. Black Mountain, Antrim (Rev. W. M. Hind): Cyb. Several stations in Down, Antrim and Derry : Flor. $N$.-E.

Var. sCHLECHTENDALII ( $W e i h e$ )-I. Killarney, and-IV. Wicklow (Babington): Cyb. Near Wexford : Marshall $1896 .-\mathrm{V}$. Kelly's Glen and Balbriggan, Dublin: Praeger 1894.--VII. Knock Ross, Westmeath: Levinge I894.-X. Near Newry, Armagh: Praeger I893.-XII. Near Castle Espie, Down (Stewart) : Flor. N.-E.

Tar. ampurficaros (Lees)-IV. Enniskerry, Wicklow: Praeger 1894.-VII. Knock Ross, Westmeath: Levinge 1894.-XII. Carnmonej near Belfast (G. Tate) : Flor. Belf.

R. Danicus Focke.-IV. Near Wexford, and-IX. South of Lough Mask : Marshall I8g6.

R. IRICUs Rogers-I. Ballydehob, and-II. Near Whitegate; Phillips.-VIII. Maam and Oughterard, and-IX. South-east of Lough Mask (Marshall \& Shoolbred): Journ. of Bot. I896, p. 506, where this is described by Rev. W. Moyle Rogers as a new species or variety.

\section{R. Sprengetii Weihe.}

Districts - II. III. IV. - - - - - - -

II. Near Mitchelstown, Cork ; Phillips.-III. Furze-clad hill above Ferrybank, Kilkenny: M.\& S. I896.-IV. Sparingly about two miles west of Wexford: Marshall 1806 .

R. BORRERI Bell-Salt.-IV. In several spots near Wexford: Marshall I896.-V. Slieve Thoul, Brittis, Co. Dublin; N.C.VIII. Maam, Co. Galway : M.\& S. I896.-X. By the Dundalk road a mile from Newry, Armagh : Praeger 1893.

R. micass Gren. \& Godr.-V. Howth, Co. Dublin: Praeger 1894.-XII. Ballinderry, Co. Derry : Brenan 1895.

To $1200 \mathrm{ft}$. in Dublin (R. Borreri); N.C.

\section{R. pyramidalis Kalt.}

Districts - - IV. V. - VII. VIII. IX. X. - XII.

IV. Glendalough and Lough Dan, Wicklow, and-V. Monasterevan, Kildare; and Carrickmines; Glenasmole, \&c., Dublin : 
Praeger 1894.-VII. Knock Ross, Westmeath: Levinge 1894.VIII. Locally abundant near Clonbur, and--IX. Banks of Lough Corrib near Cong: M.\&S. I896. Near Dromore West, Sligo, 1896; N. C.-.X. Near Lurgan, Armagh: Praeger 1893.XII. Newtownards, Down, and near Belfast (Stewart) : Flor. N.-E.

R. HIRTrfoures Muell. \& Wirt.-III. Plentiful at Ferrybank, Kilkenny : $M$ I. \& S. I896.-VII. Knock Drin, Westmeath : Linton 2896.-VIII. By Lough Corrib about three miles west of Cong: Marshall I896.-IX. Common round Lough Allen : Stewart 1885.XII. Aghaderg, Down; Rev. H. W. Lett.

R. DreJeri Jens. - XII. Saintfield, Co, Down (Rev. C. H. Waddell) : Journ. of. Bot. 1897 .

R. Leyands Rogers-IV. Near Wexford: Marshall $7896 .-$ X. Ballymore, Co. Armagh (as R. Drejeri) Rev. H. W. Lett: Praieger $\mathbf{2} 893$.

To 1000 feet in Dublin (R. pyramidalis); Praeger.

$R$. leucostachys Schleich.

R. vestitus Weihe.

Districts I. II. III. IV. V. VI. VII. VIII. IX, X. - XII. I. Near Killarney (Babington): Cyb. Schull, South Cork, 1896; Phillips,-II. Fermoy (T. Chandlee): Allin's Cork. At Whitegate, 1897 ; Phitlips.-III. Abundant at Ferrybank, Kilkenny: I. \& S. I896. Maryborough, Queen's Co., and-IV. Enniscorthy, Wexford: Praeger 1894. Frequent by roadsides about Wexford: Marshall 1896.- V. Monasterevan, Kildare, and Kelly's Glen, Dublin: Praeger I894.-VI. Between Kilrush and Moyne Point, Clare: Stewart I89o. - VII. Knock Ross, Westmeath : Linton 1896.-VIII. Connemara (Babington): Cyb. Maam and Oughterard: M. \& S. I896.-IX. Lough Allen and Lough Scur, Leitrim: Stewart 1885. Clonbur and Cong: M. \& S. I896.X. Near Lurgan, Armagh : Praeger 1893.-XII. Cave Hill near Larne, and in Glenariff, Antrim: Shoolbred 1894 . Ballinderry, Co. Derry : Brenan 1895 .

\section{Grotr V-Egregii.}

R. mueronatus Blox.

Districts - - - V. - VII: - IX. X. - XII.

V. Howth and Foxrock, Co. Dublin: Praeger 7894. VII. Knock Drin, \&c., Westmeath : Linton I896.-IX. Wooded 
banks of Lough Corrib, Mayo: M. \& S. 2896.-X. Near Armagh : Praeger 1893.-XII. Whiterock near Belfast (Stewart): Fitor. N.-E. Saintfield, Co. Down (Rev. C. H. Waddell): S.\&P. r895.

R. Borasunds Génev.-XII. Whinny Hill, Aghaderg, Down; Rev. H. W. Lett.

R. GeteRTn, Frider.-V. Brackenstown, Co. Dublin; N. C.XII. Aghaderg Glebe, Loughbrickland, Down (Rev. H. W. Lett): S. \&. P. 1895 .

R. anglosaxonicus Gelert-X. Tartaraghan and Newry, Armagh: Praeger 1893.

R. infestus Weihe-V. Ballybetagh, Co. Dublin; N. C.XII. Cross to Carnabridge and Portrush, Derry; Bailey.

\section{GRoụP VI-Radulæ.}

\section{$R$. radula Weihe.}

Districts I. - - - V. - VII. - - X. - XII, X. Ballymore, Armagh (Rev. H. W. Lett): Praeger 1893.XII. Connswater, Down, and Black Mountain, Antrim (Stewart): Flor. N.-E. Glenariff and Glendun : Shoolbred I894. Ballinderry, Co. Derry : Brenan 1895 .

Var. ECHCNatomes Rogers-I. At Muckross, Kerry; Rev. A. Ley.-V. Walshestown and Ballyboghil, Co. Dublin; N. C.VII. Knock Body, Westmeath: Linton I896.-XII. Aghaderg, Down, and Glenarm, Antrim; Rev. H. W. Lett.

R. echrnatus Lindl.-V. Balbriggan, Co. Dublin: Praeger 7894. Abundant at Walshestown, Naul hills, Co. Dublin, 1895; N.C.-XII. Cave Hill; Glenariff; and Glendun, Antrim: Shoolbred I894.

R. oIgoclados Muell. \& Lefv.-R. Newbouldii Bab.-II, Near Mitchellstown, Cork, 1897 ; Phillips.-V. On Seecawn mountain, Dublin; N. C.-VII. Crooked Wood, Lough Derevaragh, Westmeath: Linton 1896.-XII. Kilrea, Derry (Moore): Cyb.

To $1250 \mathrm{ft}$. in Dublin (R. oigoclados); N. C.

\section{R. rudis Wh. \&N.}

Districts - - IV. V. - - - - - XII.

IV. Wicklow (More): Cyb.-V. New Grange, Co. Meath (Babington): Cyb.-XII. Aghaderg, Loughbrickland, Down (Rev. H. W. Lett) : S.\&P, I895. 


\section{R. Bloxamii Lees.} Districts -------- VIII. --- XII.
VIII. By Lough Corrib, south-west of Cong; Rev. E. S.
Marshall.-XII. Black mountain, near Belfast: Babington, Brit. Rubi.

R. scaber Wh. \& N.

Districts - - IV. V. - VII. VIII. - X. - XII.

IV. Glendalough, Wicklow, and-V. Clontarf, Co. Dublin, and Mornington, Meath: Praeger I894.--VII. Crooked Wood, Lough Derevaragh, Westmeath : Linton $1896 .-$ VIII. About Clonbur and shore of Lough Corrib, west of Cong: Marshall 1896 .-X. Lurgan and Newry, Armagh: Praeger 1893.-XII. Aghaderg, Loughbrickland, Down (Rev. H. W. Lett): S.\& P. 1895 .

R. BabingtonII Bell-Salt.-VIII. Between Clonbur and Mount Gable, Galway: M.\&S. $2896 .-$ XII. Ballintaggart, Co. Down; Rev. H. W. Lett.

R. obscurus Kalt.-IV. Roadside spinney, about two miles west of Wexford; Rev. E. S. Marshall.

\section{$R$. fuscus Wh. \&N.}

Districts - - - V. - VII. VIII. IX. - - XII.

V. Howth and Balbriggan, Co. Dublin: Praeger I894.VII. Knock Drin and Knock Ross, Westmeath: Levinge r894.VIII. and IX. Frequent about Clonbur and Cong: Marshall 1896.-XII. In Aghaderg parish, Co. Down (Rev. H. W. Lett) : S.\&P. 1895 .

Var. macrostachys (P. J. Muell.).-V. Slieve Thoul, Co. Dublin ; N. C.-VII. Knock Rosis, Westmeath : Linton 1896.

To $900 \mathrm{ft}$. in Dublin (N.C.).

R. foliosus Wh. \& N.

R. Guntheri Weihe (Bab. Man.)-R. flexuosus P. J. Muell. Districts - - - - - - - - - XII.

XII. By the road from Garvagh to Kilrea, Derry (Moore): Cyb. By a stream in Tollymore Park, Down (Stewart): Flor, N.-E.

R. adornatus $P$. J. Muell.-VIII. Near Clonbur and near Cong, Galway; Rev. E. S. Marshall. 
GR0UP VII-Kœhleriani.

R. rosaceus Wh. \& N.

Districts I. - - - V. VI. VII. - - - XII.

I. Killarney' (Babington): Cyb.-V. By the Kilakee river, Co. Dublin ; N. C.-VI. Near Rinekirk, Limerick : Stewart I89o.VII. Ladiston, Mullingar (Moore): Cyb.-XII. Near Maralin, Down (Rev. H. W. Lett) : S.\&P. ${ }_{1895 .}$

Var. HYSTRIX ( Wh. \& N.) -I. Killarney (Babington): Cyb. Glengariff: Druce 189T.-V. Carrickmines and Three Rock Mountain, Dublin: Praeger 1894.-VII. Knock Drin, Westmeath: Linton i8g6.-XII. Glenariff, Antrim : Shoolbred I894.

To $1100 \mathrm{ft}$. in Dublin (R. rosaceus); N. O.

\section{R. Koæleri Wh. \& N.}

Districts I. II. - -- V. VI. - VIII. IX. X. - XII.

I. Killarney (Babington): Cyb.-II. Fermoy, Cork (T. Chandlee) : Allin's Cork.--V. Kelly's Glen, Dublin: Praeger I894.VI. Wood at Foynes, Limerick: Stewart I890.--VIII. Between Clonbur and Mount Gable, and at Oughterard, Galway: M.\& \$. 1896.-X. Frequent in Co. Fermanagh: Stevoart 1882. Tanderagee, Armagh; Rev. H. W. Lett.-XII. Carnmoney near Belfast (G. Tate): Cyb. Newcastle, Down: S.\&P. 1892 . Glenariff and Glendun, Antrim: Shoolbred 7894.

Var. Parirdós Bab. - I. Killarney (Babington): Cyb. IX. Lough Allen: Stewart 7885.-X. Tanderagee, Armagh; Rev. H. W. Lett.-XII. Sydenham (Corry) and Cregagh, Down (Stewart): Flor. N.-E.

Var. cognatus $(N . E . B r$.)-VIII. West side of Lough Mask, and-IX. South of Lough Mask in Mayo: M.\&S. I896.XII. Ballintaggart and Whinny Hill, Down; Rev. B. W. Lett.

\section{Group VIII-Bellardiani.}

\section{R. hirtus Wh. \& N.}

Districts - - IV. - VI. VII. - - - - XII.

VI. Kilasolan near Clonbrock, Galway: Praeger 1897. VII. Knock Drin and Knock Ross, Westmeath : Linton 1896.

Var. Kattenbachit (Metsch.)-XII. Ballintaggart, Aghaderg, Down (Rev. H. W. Lett): S. \& P. 1895 . 
Var. Rubignosus (P.J. Muell.) -IV. Abundant to the west and north-west of Wexford : Marshall $I 8 g b$.

R. saxicolds P. J. Muell.-IV. Lough Dan, Co. Wicklow, andV. Raheny; Three Rock Mountain; and Foxrock, Co. Dublin : Praeger 1894 .

R. vIRIDIs Kalt.-IV. Altadore Glen, Wicklow : Praeger 7894.

R. BeLLARDII Wh. \& N.-I. Killarney (Babington): Cyb.

\section{GroUP IX-Cæsii.}

$R$. dumetorum Wh. \& N.

Districts - - III. IV. V. VI. VII. VIII. - - - XII.

III. Ferrybank, Kilkenny: M. \& S. I896.-IV. Roadsides about Wexford : Marshall 2806 .-VII. Knock Drin, Westmeath : Levinge $7894 .-V I I I$. Oughterard and Clonbur, Galway: $\boldsymbol{M}$. \& $\boldsymbol{S}$. 1896.- The foregoing records are chiefly for $R$. ferox (Weihe) taken as type.

Var. DIVERSTFolrus (Lindl.)-III. Portarlington, Queen's Co., and-IV. Luggelaw, Wicklow; Praeger.-V. Monasterevan, Kildare : Praeger 1894.-XII. Aghaderg parish, Down (Rev. H. W. Lett) : S.\&.P. 1895 .

Var. tuberculatus Bab.-R. scabrosus P. J. Muęll.-III. By the river at Kilkenny (Babington): Cyb. Near Portarlington, Queen's Co., and-V. Raheny, Co. Dublin; Praeger. New Grange, Meath (Babington): Cyb.-VI. Wood at Foynes, Limerick : Stewart 1890.--XII. By the Lagan canal near Belfast (Stewart) : Flor. N.-E.

Var. Fasciculatus $P . \quad J$. Muell. $-R$. purpureus Bab.VIII. Roundstone, Connemara (Prof. Oliver) : Cyb.-XX'II. Brett's Glen, Down (Moore) : Cyb. At Comber; Newtownards; and Downpatrick, Down; near Ardtrea, Derry (Stewart): Flor. N.-E.

R. sublustris Lees.

\section{R. corylifolius Smith.}

Districts - - III. IV. V. VI. VII. VIII. IX. X. - XII.

III. At Ferrybank, Kilkenny: $\boldsymbol{M}$ \& S. i8g6. Maryborough, Queen's Co.-IV. Enniskerry, Co. Wicklow, and-V. Balbriggan; Raheny; and Carrickmines, Co. Dublin : Praeger 1.804.VI. Patrick's Well and frequent from Askeaton to Foynes, Co. Limerick: Stewart I890.-VII. Knock Drin woods, Westmeath: Levinge 1895.-VIII. Roundstone (Prof. Oliver): Cyb.-IX. Cong, 
Co. Mayo: M.\&S. 2896.-X. Near Armagh: Praeger 1893.XII. Common in north-east Ireland: Flor. N.-E.

Var. CONJUNGEns $(B a b$.) - Var. CYCLOPHYLLUS Lindeb.-III. Maryborough, Queen's Co., and-V. Howth Junction and Foxrock, Co. Dublin: Praeger 1894.-IX. Roadsides between Clonbur and Cong, Mayo: M.\& S. I806.-X. Tartaraghan, Armagh; Praeger.XII. Lagan side and Carnmoney Hill near Belfast (R. Tate); Woodburn and Bushmills, Antrim (Stewart): Flor. $N$.- $E$.

R. Balfourianus Blox.-I. Killarney (Babington): Cyb.II. Whitegate and Trabolgan, 1897 ; Phillips.-III. Portarlington, Queen's Co., and-V. Howth and Balbriggan, Co. Dublin : Praeger 1894.-VII. Near Mullingar, Westmeath: Levinge I895.IX. By Lough Corrib two miles west of Cong: Marshall 1896 .

To $1400 \mathrm{ft}$. in Down ( $R$. corylifolius) $: S . \& P$.

\section{R. casius Linn.-Dew-berry.}

Districts I. II. III. IV. V. VI. VII. VIII. IX, X. XI. XII. I. Killarney, and-II. Fermoy (Babington): $C y b$.-III. Portarlington, Queen's Co.: Praeger 1894.-IV. Crossfarnoge Point, Wexford: Hart 2883 B.-V. Near Little Forest, Co. Dublin; N. C.-VI. At Castle Taylor, Galway: More 1855. Ballinasloe and Great Island of Aran (Babington): Cyb. On the islands and shores of Lough Derg in Galway, and-VII. In Tipperary : $N$. C. 1897. Knock Ross, Westmeath : Levinge I894--VIII. Banks of Lough Carra: Herb. J. Ball. Shores of Loughs Corrib and Mask; Miss M. F. Jackson.-X. Banks of Lough Neagh, Armagh: More I860.-XI. Banks of the Erne: Herb. J. Ball. Banks of the Foyle above Derry (Moore) : Colby I837.-XII. By Lough Neagh (Babington): $C y b$. Very rare in the North-East: Flor. N.-E.

Var. TENOIs (Bell-Salt.).-IX. On limestone, south of Lough Mask, Majo: M. \& S, I 896 .

Var. ARVENGIS Wallr. - $R$. ligerinus Gener. - XII. Near Doagh, Antrim (Stewart): Flor. N.-E.

Var. INTERmedios Bab.-I. Ballybunnion, Kerry : Stewart I8go.

\section{R. saxatilis Linn.-Stone Bramble.}

Districts I. - III. IV. V. VI. VII. VIII. IX. X. XI. XII. Lat. $52^{\circ}-541_{4}^{\circ}$. West and North, chiefly. Type, Scottish-Highland. Stony places in hilly districts and on the shores of the larger lakes; frequent. Fl. June-July. 
I. Ross Island, Killarney: Wade Rar. Shores of Killarney Lakes (Babington): Cyb.-III. Near the source of the Barrow, Queen's Co.: Hart I885.-IV. Between Lough Dan and Luggelaw and in the Dargle, Co. Wicklow: Ir. Flor.-V. Monasterevan: Threlkeld. Kelly's Glen, Dublin (Moore): Cyb.-VI. Common about Castle Taylor and Garryland, Galway : More 1855. Abundant in Burren, Clare: Foot I862. Shores of Lough Derg near Portumna: N. C. $1897 .-$ VII. In a wood near Edenderry ( $\boldsymbol{M r}$. Heaton): How, Phytologia. Abundant on the shores of Lough Ree, in Westmeath and Longford; at Rathcline and Cashel, Co. Longford: Foot 1865. Abundant at Knock Ross, Westmeath: Levinge I894.-VIII. Bilberry Island, Lough Corrib: Wade Rar. Shores of Loughs Corrib, Cullen, and Conn (More): Cyb. Mweelrea; Croaghpatrick, \&c.: Hart 1883 a. Abundant and fruiting freely on limestone about Lough Mask, in both Galway and Mayo: M. \& S. I896.-IX. By Lough Carra (More): Cyb. Abundant on the shores of Lough Ree in Co. Roscommon: Foot I865. Glenade and Legale, Sligo, and Larkfield, Leitrim (Admiral Jones): Cyb. Trusk; Aroo Mountain and other stations in Ben Bulben district: B. $\& V .{ }_{7885}$. In the Ox mountains, Co. Sligo, $1896 ;$ N. C.X. Frequent about Lough Erne: Barrington 1884. Patton's Glen, Tyrone, and-XI. Glen Hope, Barnesmore mountains (Admiral Jones): Cyb. Ards, Donegal : Murphy I8zo-and in 1879 : Hart 1880 .-XII. Frequent in the North-East: Flor. $N_{\text {. }}-E_{\text {. }}$.

From near sea-level to $1800 \mathrm{ft}$. in Donegal (Hart). To $1650 \mathrm{ft}$. in Sligo $(B . \& V$.) and in Mayo (Hart).

First recorded for the British Isles by How, from Edenderry, in 1650 (Phytologia).

\section{R. chamæmorus Linn.-Cloud-berry.}

Districts - - - - - - - X. - XII. Lat. $5 \frac{3}{4}^{\circ}$. Tyrone and Derry only. Type, Highland.

Boggy mountain heaths; very rare. Fl. June.

X. Plentiful on Glengaroo mountain, Tyrone, 1826: Murphy I829. On the Sperrin mountains, west from Dart, Co. Tyrone, and-XII. On the same mountains in Co. Derry, a small patch only in each station, August, 1892 (Barrington $§ H a r t$ ): Ir. Nat. I892, p. I24.

Sought for in vain by many botanists in the mountains of northern Tyrone, until finally rediscovered by Messrs. Barrington and Hart after the lapse of sixty-six years. 


\section{DRYAS Linn.}

\section{D. octopetala Linn.-Mountain Avens.}

Hibernicé Leazin (Lay-theen-Lay-heen).

Districts - - - - VI. - VIII. IX. X. XI. XII.

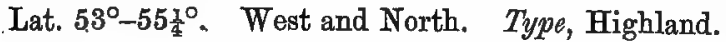

On limestone and basaltic hills, also at low levels in limestone districts on drift banks and in rocky places; locally abundant. Fl. June-July.

VI. "In the mountaines betwixt Gort and Galloway. It makes a pretty shew in the winter with his rough heads like Viorna. Mr. Heaton": How, Phytologia 1650, p. 120. In many places in the Burren Mountains, Co. Clare: Wade Rar. Extremely abundant round Ballyvaughan, Clare, especially to the westward, where it covers the hill tops for miles with a dense carpet, $1895 ; N$. $C$. Plentiful about Castle Taylor, Galway: More 1855.-VIII. On limestone drift at sea-level on Blake Hill (Prof. Melville): Cyb. Still in this station (usually called Gentian Hill) near Salthill, Galway, in 1895 : Ir. Nat. 7895, p. 227. Lisoughter Hill, Recess (Prof. J.W. Carr) : P.\& C. 1895.-IX. Common on Ben Bulben and Ben Buishgen in the neighbourhood of Sligo, 1699 (Lhwyd): Phil. Trans., Vol. 27, p. 524. Legale, Sligo (Admiral Jones): Cyb. Generally distributed all over the Ben Bulben range : B.\&.P. I885.X. At Poulaphuca near Church Hill, Co. Fermanagh : Wade Rar. On the summit of Knockmore, Fermanagh : Stewart I882.- XI. On Slieve League, very rare and barren : Hart $1885 \gamma$.-XII. Northern face of Magilligan rocks, 1796 : Templeton MS. Ben Evenagh, Co. of Derry (D. Moore): Flor. Hib. I836-and in 1878 (Corry): Flor. N.-E. Fairly plentiful on Knock Dhu, Antrim, 1884 and 1897 (Rev. H. W. Lett) : Ir. Nat. I897, p. 280.

Sea-level in Galway. At $1300 \mathrm{ft}$. in Donegal and 1100-1150 ft. in Derry (Hart); 800-1220 ft. in Ben Bulben district (B.\&V.); to $1040 \mathrm{ft}$. in Clare $(N . C$.$) -much less alpine in Ireland than in$ Great Britain.

In Smith's Kerry, 1756 , this plant is recorded as found:- "On the hills near the passage into the upper lake of Killarney," and in the same author's Cork, I750:- "On high grounds between the barony of Muskerry and the County of Kerry." Lhwyd also mentions the plant as common on mountains and heathy grounds in 
Munster (Phil. Trans., Vol. 27). None of these records has been confirmed, and no doubt ąll are errors.

First noticed in Ireland by Rev. Richard Heaton, before 1650.

\section{GEDM Linn.}

1. G. urbanum Linn.-Wood Avens.

Districts I. II. III. IV. V. VI. VII. VIII. IX. X. XI. XII. Lat. 51 $\frac{1}{2}^{\circ}-55 \frac{1}{4}^{\circ}$. Throughout Ireland. Type, British-English.

Hedgerows, woods, and shudy places; common. Fl. JuneJuly.

Sea-level to $800 \mathrm{ft}$. in Dublin (N. C.).

\section{G. rivale Linn.-Water Avens.}

Districts I. II. III. IV. V. VI. VII. VIII. IX. X. XI. XII. Lat. $51 \frac{3}{4}^{\circ}-551^{\circ}$. Throughout Ireland. Type, British-Scottish.

Banks of streams, wet woods, and moist shady places in mountain districts; frequent. Fl. May-July.

Sea-level in Antrim and Kerry. To $1700 \mathrm{ft}$., Ben Bulben $\left(B . \& V_{\text {. }}\right.$ ) ; to $2400 \mathrm{ft}$. in Mayo (Hart); to $2800 \mathrm{ft}$. in Kerry ( $N_{\text {. }} C$.).

$G$. intermedium Ehrh. - G. rivale $\times$ urbanum-III. Wood south of Maryborough: Praeger 1897.-V. Woodlands, Co: Dublin, 1880 ; Hart. Rathangan, Kildare; Cecit Butler.-VI. In Garryland wood near Gort: More 1855.-VII. Rathcline Wood, Lanesborough : $B . \& V \cdot{ }_{1} 887$.-IX. Talus of cliffs, Glenade: $B . \& V$. 2885.-X. In the park at Loughgall manor, Co. Armagh: More r860. White Island, Lough Erne : Barrington 2884.-XII. Carr's Glen, 1806: Templeton MS.-still there in 1888: Flor. N.-E. -Forth river (Miss Maffett) and at Cushendall (C. Moore): Cyb. Glenarm; Upper Colin Glen, \&c. (Stewart): Flor. N.-E.

\section{FRAGARIA Linn.}

\section{F. vesca Linn.-Wild Strawoberry.}

Hibernicé Sut żalman (Sooth thall-oo-an), Ground fruit.

Districts I. II. III. IV. V. VI. VII. VIII. IX. X. XI. XII. Lat. 51 $11^{\circ}-55 x^{\circ}$. Throughout Ireland. Type, British. July.

Hedge-banks, woods, and shady places; common. Fl. May-

Sea-level in N. Derry and S. Cork. To $1450 \mathrm{ft}$. in Derry and to $1400 \mathrm{ft}$. in Tipperary (Hart). 


\section{POTENTILLA Linn.}

1. P. Fragariastrum Ehrh.-Barren Strawberry.

Fragaria sterilis Linn.

Districts I. II. III. IV. V. VI. VII. VIII. IX, X. XI. XII. Lat. $51 \frac{1}{2}^{\circ}-55 \frac{1}{4}{ }^{\circ}$. Throughout Ireland. Type, British.

Hedge-banks, woods, walls, \&c.; common. Fl. April-June. (N.C.).

Sea-level in N. Derry and S. Cork. To $1000 \mathrm{ft}$. in Dublin

\section{P. Tormentilla Neck.-Tormentil.}

Tormentilla erecta Linn.

Districts I. II. III. IV. V. VI. VII. VIII. IX. X. XI. XII. Lat. $51 \frac{1}{2}^{\circ}-55 \frac{1}{4}^{\circ}$. Throughout Ireland. Type, British.

Moors and heathy places; common. Fl. June-August.

Sea-level in N. Antrim and S. Cork. To $2460 \mathrm{ft}$. in Donegal, to $3000 \mathrm{ft}$. in Wicklow, and to $3120 \mathrm{ft}$. in Kerry (Hart).

\section{P. procumbens Sibth.-Trailing Tormentil.}

$P$. nemoralis Nestl.-Tormentilla reptans Linn.

Districts I. - - IV. V. - VII. VIII. IX. X. - XII. Lat. $52^{\circ}-551^{\circ}$. From South to North. Type, British.

Banks and roadsides; frequent (?). Fl. June-August.

I. Ballyphehane: Flor. Cork.-IV. Near Wexford: Marshall I806.-V. Phœnix Park; Howth; and about Santry: Ir. Flor. Frequent in County Dublin; N.C.-VII. Shore of Lough Derevaragh, Westmeath : Linton I896.-VIII. Inishbofin; More.IX. Common about Glencar (R. P. Vowell): B.\&V. 1885.X. Frequent in Co. Armagh : Praeger 1893.-XIL. By Kilbroney river and near Newcastle, Down: $\boldsymbol{S} . \&$ P. 1892. Glenariff; Glendun; and Glenshesk, Antrim: Shoolbred 1894. Sandy fields at the Bann mouth and frequent in Kilrea district, Derry : $S . \& P$. 2895.

Much difference of opinion exists amongst botanists as to the precise standing of $P$. procumbens and it is not without hesitation that we have admitted it to specific rank. The plant is probably frequent throughout Ireland.

The hybrid $P$. prooumbens $\times$ Tormentilla has been observed in Westmeath and Antrim. 


\section{P. reptans Linn.-Creeping Cinque-foit.}

Districts I. II. III. IV. V. VI. VII. VIII. IX. X. XI. XII. Lat. 51 $1 \frac{1}{2}^{\circ}-55 x^{\circ}$. Throughout Ireland. Type, English-British.

Hedge-banks, pastures, \&c.; locally abundant. Fl. June-August. Sea-level to $1000 \mathrm{ft}$. in Dublin (N. C.).

Rare in many parts of west Ireland.

\section{P. Anserina Linn._Silver Weed.}

Hibernicé bpiopzlán (Brisle-el-awn).

Districts I. II. III. IV. V. VI. VII. VIII. IX. X. XI. XII. Lat. $511_{2}^{\circ}-55 \frac{1}{4}$. Throughout Ireland. Type, British.

Roadsides, banks, waste ground, and gravelly places; common. 'Fl. May-July.

Sea-level to $1400 \mathrm{ft}$. in Dublin (N. C.).

\section{P. fruticosa Linn,-Shrubby Cinque-foil.}

Districts - - - - VI. - VIII. IX. - - Lat. $53^{\circ}-53 \frac{1}{2}^{\circ}$. West Ireland. Type, Intermediate-Scottish.

Lowland. Rocky and bushy places; very local. Fl. MayAugust. Caleicole $A$.

VI. Abundantly on the south-east side of the barony of Burren, where it joins the barony of Inchiquin: Wade Rar. On low swampy ground near the bottom of the Burren Mountains (Bindon Blood), and plentiful at Magherinraheen, near Corofin : Mack. Rar. At Rock Forest, county of Clare : Mack. Cat. Near Ballyvaughan, completely covering upwards of two acres of turloughs; also southoast of Glasgeivenagh Hill, north-east of Corofin; sparingly in the Formoyle valley, south of Black Head : Foot 1862 . Still abundant near Ballyvaughan in $1895 ; N$. C. Near Headford, Galway ( $M r$. Shuttleworth): Flor. Hib.-VIII. "Plentifully amongst limestone rocks on the banks of Lough Crib, in the county of Galloway" (Lhwoyd): Phil. Trans.xxvii. p. 524. Amongst rocks on the banks of Lough Corrib, near Lemonfield, Oughterard: Wade Rar.IX. On the north-east shore of Lough Corrib (Moore): Rec. Add. Plentiful in two or three fields between Ballycurrin and Castletown, on the shores of Lough Corrib; Miss M. F. Jackson.

Flowers twice, first towards the end of spring with small flowers, again in early autumn, when the flowers are double the size.

First found by Ihwyd, in 1699, at Lough Corrib. 


\section{P. palustris Scop.-Marsh Cinque-foit.}

P. comarum Nestl._Comarum palustre Linn.

Districts I. II. III. IV. V. VI. VII. VIII. IX. X. XI. XII. Lat. $51 \frac{1}{2}^{\circ}-55 \frac{1}{4}^{\circ}$. Throughout Ireland. Type, British-Scottish.

Marshes, bog-drains, and bog-pools; frequent and locally abundant. $F l$. June-July. Calcifuge $B$.

Sea-level in N. Donegal and S. Kerry. To $1000 \mathrm{ft}$. in Donegal, and to $1500 \mathrm{ft}$. in Tipperary (Hart).

Much more abundant in the West and North than in other parts of Ireland.

\section{ALCHEMILLA, Linn.}

1. A. arvensis Scop.-Parsbey Piert.

District I. II. III. IV. V. VI. VII. VIII. IX, X. XI, XII. I at $51 \frac{1}{2}^{\circ}-55 \frac{1}{4}^{\circ}$. Throughout Ireland. Type, British.

Banks, waste places, and cultivated ground in light soils; frequent. Fl. May-August.

Sea-level in N. Antrim and S. Cork. To $1150 \mathrm{ft}$. in Down (S. $\&$.); to $1300 \mathrm{ft}$. in Dublin and in Kerry (N.C.).

\section{A. vulgaris Linn,-Lady's Mantle.}

Hibernicé bnaz6z Murpe (Brath-öge-Mwirrë), St. Mary's Cloak. Districts I. II. III. IV. V. VI. VII. VIII. IX. X. XI. XII. Lat. $51 \frac{1}{2}^{\circ}-55 \frac{1}{4}^{\circ}$. Throughout Ireland. Type, British.

Pastures, chiefly in hilly or mountain districts; frequent. Fl. May-July.

At sea-level in N. Derry; montane in S. Ireland. To $1700 \mathrm{ft}$. in Derry, and to $2300 \mathrm{ft}$. in Wicklow (Hart); to $2400 \mathrm{ft}$. in Kerry (Druce I89I).

The varieties atPESTRIS (Schmidt) and FIICAULIs (Buser) are reported as frequent in Antrim and Derry: S.\&P. 189.5 .

3. A. alpina Linn.-Alpine Lady's Mantle.

Districts I Lat. $521^{\circ}-53^{\circ}$. Kerry and Wicklow only. Type, Highland.

Mountain cliffs; very rare. $F l$. June-July.

I. "On the mountains of Keri" (Lhwyd): Phil. Trans. xxvii. p. 524. On the cliffs near the summit of Brandon mountain, 
county of Kerry, Sept., 1804: Mack. Rar.—still plentiful on Brandon eliffs, 1894; R.W.S.-IV. On Thonalagee mountain, Co. Wicklow (H. C. Hart) : Journ. of Bot. 1873, p. 275-in some quantity there in $1885 ;$ N.C.

The record in Flor. Hib. for Ben Bulben has never been confirmed, and was probably an error.

At $2000 \mathrm{ft}$. in Wicklow and 2200-2800 ft. in Kerry (Hart); strictly alpine in Ireland.

First found in Ireland by Lhwyd, probably on Brandon mountain, in 1699.

\section{AGRIMONIA Linn.}

\section{A. Eupatoria Linn.-Common Agrimony.}

Districts I. II. III. IV. V. VI. VII. VIII. IX. X. XI. XII. Lat. $51 \frac{1}{2}^{\circ}-55 \frac{1}{4}^{\circ}$. Throughout Ireland. Type, British-English.

Bushy places, waysides, and field-borders; frequent. Fl. JuneAugust.

To $600 \mathrm{ft}$. in Dublin (N.C.); but usually lowland.

\section{A. odorata Mill.}

Districts I. II. - IV. - - - VIII. - - XI. XII. Lat. $51 \frac{1}{2}^{\circ}-554^{\circ}$. From South to North. Type, English.

Lowland. Banks, roadsides, and thickets; rather rare. $F$. June-August. Calcifuge $B$.

I. By the roadside on the north of Dingle Bay, near Dingle, Kerry (D. Oliver): Phytol. I853,p. 1096. By the side of on old road near Valentia $(J . W o o d s): C y b$. Near Castlegregory ; $R$. W. $S$. Ross Island, Killarney: Linton 1886. Near Adrigole, Cork, 1894 ; near Dunworley Bay, 1897, and-II. Near Whitegate, Cork, 1897; Phillips. Near Fermoy (T. Chasdlee): Cyb.-IV. Near Enniskerry, Wicklow, and-VIII. Very fine near Clifden, Connemara (More): Rec. Add. Abundant on the north shore of the Narrow Lake, Lough Mask : M. \& S. I 896 . Plentiful on Bartragh Island, at the mouth of the Moy; More-XI. Glenagiveney Bay, and by the Eanymore water; Hart.-XII. On the shores of Lough Neagh, near Shane's Castle, 1852 (Prof. Babington and Rev. W. W. Newbould); roadside at Haw Hill, north-east of Comber, Down (Stewart); by the river in Glenarm Park (Corry): Flor. N.-E. Glendun: Shoolbred I894. 


\section{POTERIUM Linn.}

\section{P. Sanguisorba Linn.-Lesser Burnet.}

\section{$P$. dictyocarpum Spach.}

Districts I. II. III. IV. V. VI. VII. --- XI. XII. Lat. $51 \frac{3}{4}^{\circ}-54 \frac{1}{2}^{\circ}$. Middle Ireland, chiefly. Type, English.

Pastures, dry banks, and gravelly places; locally abundant. Fl. May-June. Calcicole $B$.

I. Fields near Blackrock (Rev. Dr. Hincks): Flor. Cork. At Palacetown, Kinsale (Rev. J. Stopford), and railway embankments, Woodlands, Bandon: Allin's Cork.-II. Pastures in Little Island : Drummond 1820. In a field near Kilcree, Cloyne (Rev. Mr. Pyne): Cyb. Near Mallow (J. Sullivan): Annot. in Flor. Cork. Near Midleton, 1897 ; Phitlips. - III. Enisnag Glebe, Kilkenny, and Grennan, Queen's Co. (Rev. S. Madden): Cyb.-IV. In several places about Fassaroe near Bray (Barrington): Rec. Add. Bray Head; Greenwood Pim. Knockmore, Wexford; C. B. Moffat.V. On Knockmaroon Hill and on shady banks by the Dodder: Wade Dubl. $x 794$. Abundant at Feltrim Hill, 1893; at Raheny, 1894; for some miles along the Dodder river, 1895 ; on the gravel eskers at Drimnagh and Tymon, 1894, and in many other stations in Co. Dublin; N. C. Gallows Hill near Athy, Kildare (T. Chandlee); rocks at Carton near Maynooth (J. Douglas): Cyb.--VI. At Castle Taylor and Garryland, Galway (More): Cyl. Abundant in all three Aran Islands, 1892, and round Ballyvaughan, Clare, 1895 ; N. C.-VII. Banks near Dromineer, Lough Derg, Tipperary, 1896; N. C.-XI. Ballyshannon (Admiral Jones): Cyb.-XII. In some abundance in a meadow at Glenmore near Lisburn, 1892, and again in 1895 (J. H. Davies) : Ir. Nat. $7892 \&$ 1895-probably introduced in this station, the only one for N.-E. Ireland.

To $900 \mathrm{ft}$. on basalt in Dublin (N.C.); but usually lowland.

2. P. officinale Hooker fil.-Great Burnet.

Sanguisorba officinalis Linn.

Districts - - - - - - VIII. - - - XII. Lat. $\mathbf{5 4}^{\circ}-\mathbf{5 5 ^ { \circ }}$. West and North-East. Type, Intermediate-English.

Lowland. Banks of lakes and rivers and in damp fields; very rare. Fl. June-August.

VIII. On the stony shore of Lough Cullin and of Lough Conn in Mayo, abundantly in many places (More) : Cyb.-XII. On a dry 
bank sloping to the Bann a mile below Agivey in Derry; on small gravelly mounds in the townland of Maddykeel near Rasharkin, Antrim (Moore) : Cyb. Plentiful in a field near Donaghadee, on the inland side of the road to Millisle, Down (Miss Maffett): Cyb. Abundantly on a railway bank near Donaghadee, 1893 ( $J . H$. Davies): Stewart 1894. Near Carnlough (W. Hancock): More 7873. About three miles from Carnlough by the road to Garron Point (C. Dickson): Flor. N.-E.

\section{ROSA Linn.}

1. R. spinosissima Linn.-Burnet Rose.

R. pimpinellifolia Linn.

Districts I. II. III. IV. V. VI. VII. VIII. IX. X. XI. XII. Lat. $51 \frac{1}{2}^{\circ}-551^{\circ}$. Throughout Ireland. Type, British.

Heathy and rocky places, and on sand-hills; frequent near the sea, rarer inland. Fl. May-June.

Sea-level in Derry and in S. Cork. To $1450 \mathrm{ft}$. in Derry (Hart); to $2000 \mathrm{ft}$. in $\operatorname{Down}(S . \& P$.); to $1550 \mathrm{ft}$. in Mayo (Hart); to $1600 \mathrm{ft}$. in Kerry (R.W.S.).

2. R. involuta Smith-Unexpanded Rose.

Districts I. II. - - - - - VIII. IX. - - XII. Lat. $51 \frac{3}{4}^{\circ}-55 \frac{1}{4}^{\circ}$. From South to North. Type, British?

Lowland. Bushy and rocky places; rare. Fl. June-July.

I. Glengariff, Co. Cork (Drummond): Flor. Hib. - and in 1891 : Druce I891.-II. On rough ground near Lismore, Co. Waterford; Miss E. Currey.-VIII. Between Cong and Clonbur: Marshall I896.-IX. On the east shore of Lough Carra, Mayo (More): Cyb.-XII. Near Umbra rocks, Magilligan, and Bennedy Glen, Dungiven (Moore): Flor. Hib. Not infrequent in the glens of Antrim, as at Glenariff; Glenarm; Garron Head; Tor Glen; \&c. (Moore): Cyb. Hedge at Ticloy in the Braid: B. N.F.C. Pros. I87I. Roadside at Racavan near Slemish, Co. Antrim (Steroart): Flor. N.-E. Glendun (Rev. S. A. Brenan); Colin Glen (Steroart): $S . \& P . x 895$. Mountain roads about Hilltown, Co. Down: $S . \& P$. I892.

This rose occurs more frequently in Antrim and Derry than elsewhere in Ireland, usually as the Var. saBnNI Woods, to which most of the above records must be referred. From these two 
counties are also recorded the following varieties:-Doniars and GRACIIIS (Woods), WHSONx (Borrer) and GRaCHESCENs, RoBERTSONI, u更VIGata and Moorei Baker. See Cyb. and Baker's Monog. of the Brit. Roses.

3. R. hibernica Smith-Irish Rose.

Districts - - - - - - - - - - - XII.

Lat. $54 \frac{1}{2}^{\circ}-553^{\circ}$. North-East. Type, Intermediate. July.

Lowland. Hedges and rocky places; very rare. Fl. June-

XII. Left of the road going to Hollywood, south of the Whinny Hill, and on the east side of the Lagan below Stranmillis, Co. Down : Templeton MS. Not now to be found in the latter locality, and only to be met with on the right side of the present road to Hollywood : Flor. $N .-E$. In a glen at Magilligan, Derry : Templeton MS.

Var. GLABRa Baker-XII. Tillysburn, Co. Down (Stewart):

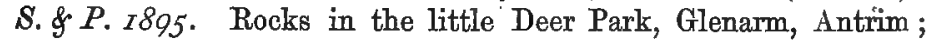
on rocks between Umbra and Ben Evenagh, and on basaltic cliffs on Ben Evenagh, Co. Derry (Moore): Cyb.

From sea-level to $1000 \mathrm{ft}$. on Ben Evenagh, Derry ( $C y b$.).

First found in Ireland at the Hollywood station in 1795 by Templeton, who was awairded a prize of five guineas, Irish currency, by the Dublin Society for the discovery of a new Irish plant. First published in the Dub. Soc. Trans. iii. p. I62. (1802), and afterwards named $R$. hibernica by Smith in 1810 ; Eng. Bot. 2 Ig6.

It is worthy of remark that Mon. Crépin considers $R$. hibernica to be a hybrid between $R$. spinosissima and $R$. canina.

\section{R. mollis Smith-Soft-leaved Rose.}

$R$. mollissima Willd.-R. villosa Linn. in part.

Districts I. - - - - - - - X. - XII. Lat. $51 \frac{3}{4}^{\circ}-551^{\circ}$. Chiefly in the North. Type, British.

Lowland. Bushy and rocky places; rare. Fl. June-July.

I. Glengariff, Co. Cork : Druoe $1891 .-\mathrm{X}$. Devenish Island, Lough Erne: Barrington 1884. About Armagh and near Crossmaglen: Praeger $1893 .-$ XII. By the Causeway Water west of Kilkeel, Down (Stewart): Flor. N.-E. Near Dundrum; by the Quoile at Downpatrick; at Ballynahinch, Co. Down (Stewart): S. \& P. 1895. Numerous localities in Antrim, as at Cave Hill; Glenarm, \&c. (Moore): Cyb. Glendun and Glenshesk, Antrim: Shoolbred I894. Near the base of Umbra rocks, Magilligan (Moore): 
Flor. Hib. In Bennedy Glen near Dungiven and at Draperstown (Moore): Cyb. Common near Kilrea weir, Derry (Praeger): S.\&P. 1895 .

\section{R. tomentosa Smith-Downy-leaved Rose.}

Districts I. II. III. IV. V. VI. VII. VIII. IX. X. XI. XII. Lat. $51 \frac{1}{2}^{\circ}-55 \frac{1}{4}^{\circ}$. Throughout Ireland. Type, British.

Bushy and rocky places; frequent. Fl. June-July.

Sea-level in Derry and S. Cork. To $600 \mathrm{ft}$. in Derry (Cyb.); to $800 \mathrm{ft}$. in Donegal, to $980 \mathrm{ft}$. in Down, and to $1000 \mathrm{ft}$. in Queen's Co. (Hart).

The commonest rose of the northern counties, and frequent in the West and South; rare in many parts of the East and South-East.

Var. SCABRIUSOULA Smith-IV. Near the Seven Churches, Co. Wicklow : Flor. Hib.-X. By Lough Erne: Barrington 1884 .XII. Near Cushendall, Antrim : Shoolbred 1894.

\section{6. † R. rubiginosa Linn.-Sweet Briar.}

Districts I. - - IV. - VI. VII. - - X. XI. XII. Lat. $51 \frac{3}{4}^{\circ}-55 \frac{1}{4}^{\circ}$. South to North. Type, English ?

Lowland. Bushy places; frequent and perhaps native in the North-East; often planted, and apparently introduced in other parts of the country. Fl. June-July.

I. Near Castleisland, \&c., Kerry, probably planted: R.W.S. 1889. By the Dunmanway-road, east of Ballylickey, Bantry, 1878 (Carroll): Herb. Glasnevin. Near Glengariff, Cork: Druce 189ז.IV. Glenmacanass river, a little below the fall; Hart. Near Tinnahinch, Wicklow; Barrington. A plant on Clohass bog, Wexford; Miss E. M. Farmer.-VI. Portumna demesne, Co. Galway; Bolton King.-VII. Hedges in Loughanstown, Westmeath (Groves) : Levinge 1894.-X. Shores of Lough Neagh, \&c., Armagh: Praeger 1893.-XI. Neighbourhood of Derry, probably introduced (W. E. Hart) : Hart I883.-XII. Roadside one mile south of Ballylesson, Down; Carr's Glen, Antrim : Templeton MS. By the river Roe near Newtownlimavady (Moore): Flor. Hib. Abundant on quarry spoil bank at Magheramorne, and in old limestone quarry at Gleno, Antrim, \&c. (Stewart): Flor. N.-E. Frequent in North Derry (Mrs. Leebody): S.\&P. 1895. Recorded from many other stations in Antrim, Dow,n, and Derry in Flor. $N_{0}-E$. and S.\&P. 1895 . 
7. $\dagger$ R. micrantha Smith-Small-flowered Briar.

Districts I. II. - - - - - - - - Lat. 51 $1_{4}^{\circ}-52 \frac{1}{2}^{\circ}$. Cork and Kerry. Type, English.

Lowland. Bushy places; very local. Fl. June-July,

I. Two localities near Tarbert, Co. Kerry, probably planted: R.W. S. I89I. Rather frequent along the Bandon river and about Cork and Kinsale, in the neighbourhood of the coast, and near Bantry (Carroll): Cyb. At Ovens, 1891, and near Kinsale, 1892; Phillips. Hedges near Evergreen, Cork (J. Drummond) andII. By Glanmire Road (Mr. Alexander) : Flor. Cork. Castletownroche and Doneraile, Cork (Carroll): Allin's Cork. Rossmore, 1896, and at Glanmire; Phillips.

8. R. sepium Thuill.-Bush Rose.

Districts - - - - VI. VII. - IX. - - Lat. $53^{\circ}-53 \frac{1}{2}^{\circ}$. Galway and Westmeath.

Lowland. Bushy places; rare and local. Fl. June.

VI. In Portumna demesne, Co. Galway; Bolton King.VII. Knock Eyon and Knock Body, Westmeath: Linton 1896.IX. Abundant by the shore of Lough Corrib two or three miles. south of Cong: Marshall I8g6.

A critical plant with probably a more extended range in Ireland than would appear from the above scanty records.

\section{R. canina Linn.-Dog Rose.}

Districts I. II. III. IV. V. VI. VII. VIII. IX. X. XI. XII. Lat. 511 ${ }^{\circ}-55 \frac{1}{4}^{\circ}$. Throughout Ireland. Type, British.

Hedges, thickets, and waste places; common. Fl. June-July.

Sea-level in Derry and S. Cork. To $1000 \mathrm{ft}$. in Derry (Cyb.).

The materials at our disposal do not enable us to trace the distribution in Ireland of the many forms of this variable rose. The following varieties, however, are recorded in the 1st Ed. of Cybele as identified by Mr. J. G. Baker in a large gathering from the Counties of Antrim and Derry:-LUTETIANa, DUMALIs, URBICA, DUMETORUM, PRUINOSA, ANDEVAGENSTS, VERTICHLACANTHA and BLONDEANA; several of these and $V$ ar. TOMENTELCA have been gathered recently by Mr. S. A. Stewart in North-East Ireland. The variety DUMALIs is also recorded from Westmeath and Kerry, Var. URBICA from Westmeath and DUMETOROM from Kildare. 
Districts - - - - - - - - - XiI.

XII. Near Belfast and at Waterloo near Larne, Co. Antrim (Stewart): S. \& P. I895. Errigal banks near Garvagh and by the side of the river Roe, Co. Derry (Moore): Herb. Glasnevin. The above records have been confirmed by $M$. Crépin.

To this rose, also, should probably be referred the $V$ ar. cosmrocis of $R$. canina gathered in Derry by Dr. Moore and the Var. subcrisTATA Baker recorded from Antrim by W. A. Shoolbred.

\section{R. arvensis Huds. - Traiting Rose.}

Districts I. II. III. IV. V. VI. VII. VIII. IX. X. XI. XII. Lat. 51 $1_{2}^{\circ}-551^{\circ}$. Throughout Ireland. Type, English.

Hedges and thickets; frequent, though quite local in some counties and rare in the North. Fl. June-July.

Sea-level to $700 \mathrm{ft}$. in Dublin $(N . C$.).

The Var. BIBRacteata (Bast.) recorded from several localities, is stated by Mon. Crépin to be merely a form of the inflorescence often occurring on the same bush with the type; see his Révision des Roses de l'Herbier Babington: Journ. of Bot. 1896, p. 178 .

\section{PYRUS Linn.}

\section{P. Aria Ehrh.-White Beam Tree.}

Sorbus Aria Crantz.

Districts I. - III. IV. Y. VI. VII. VIII. IX. - XI. XII. Lat. $52^{\circ}-55 \frac{1}{4}^{\circ}$. From South to North. Type, English-British,

Mountain cliffs, woods, and rocky lake-shores; very local. Fl. May-June.

I. In the county of Kerry, plentifully (Molyneux): App. to Threlkeld. On rocks around Killarney Lake: Smith's Kerry 1756 and in $1896 ; R . W . S .-$ III. Among native wood on Maryborough esker and west of Portarlington: Praeger I897.-IV. Glencree, Wicklow (J. Ball): Cyb. River banks near Rathdrum; Hart. One tree near Kilmanock; also at Alderton, Wexford : B.-H.\&G. I889. - V. Hedges to the west side of Howth: Wade Rar. Howth, on the north-east side, growing out of a rocky mountain : Ir. Flor. 1833. Rocks high up on Dung Hill, Howth, perhaps the same locality as the preceding: Flor. Howth. On a rock near, the 
summit of Ireland's Eye (Praeger): Ir. Nat. I895.-VI. About Castle Taylor and Garryland, Galway, probably not indigenous (More): Cyb. Sparingly on the rocky shore of Lough Derg at Rinmore near Portumna, 1896; N. C.-VII. By the Barrow between Lee Castle and Portarlington: Hart 1885 . On most of the islands in Lough Ree: B.\&V. $1887 .-$ VIII. Many places in Connemara: Wade Gallovid. Shore of Lough Conn, Mayo (More): Cyb. About Clonbur, scarce, but looking wild: M.\& S. $2896-$ this station extends into-IX. On the cliffs of Ben Bulben: Flor. Ulst. One tree on the limestone cliffs over Glencar, 1882: $B . \& V$. 1885.-XI. Mountain thickets at Glenveagh: Hart [88I $\beta$. XII. Little Deer Park, Glenarm, 1808: Templeton MS. Umbra Rocks and between them and Ben Evenagh, Derry, 1835: Moore MS. Near Ballycastle, Antrim (Moore): Cyb. In Glendun, 1868 (S. A. Brenan): B.\&V. 1895 . Almost extinct in north-east Ireland : Flor. N.-E.

Descends to about $100 \mathrm{ft}$. in Galway. Rises to $900 \mathrm{ft}$. in Derry $(C y b:)$ and in Sligo; $\left(B . \& V_{.}\right)$.

The records for Killarney, Glencar, and Ballycastle refer to the Var. RUPrCous Syme, which is probably frequent in Ireland.

2. P. Aucuparia Ehrh.-Mountain Ash; Quicken Tree.

\section{Sorbus Aucuparia Linn.}

Hibernicé Caopíainn (Rweer-ann), Berry Tree.

Districts I. II. III. IV. V. VI. VII. VIII. IX. X. XI. XII.

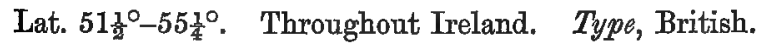

Rocky and heathy places, chiefly in mountain districts; frequent. Fl. May-June. Caloifuge C.

Sea-level in N. Donegal and S. Cork. To $1650 \mathrm{ft}$. in Donegal (Hart); to $1950 \mathrm{ft}$. in Wicklow (N.C.); to $2300 \mathrm{ft}$. in Galway and in Kerry (Hart).

\section{3. † P. Malus Linn.-Crab Apple.}

Districts I. II. III. IV. V. VI. VII. VIII. IX. X. XI. XII. Lat. $51 \frac{1}{2}^{\circ}-55^{\circ}$. Throughout Ireland. Type, English.

Lowland. Hedges and copses; frequent. $F l$. May.

Perhaps native in some stations, but often undoubtedly planted or an escape from cultivation. 


\section{CRAT AEGUS Linn.}

1. C. Oxyacantha Linn.-Hawthorn; White-thorn.

Hibernicé Szeać '̇eal (Skay-ack gee-yal) White Thorn.

Districts I. II. III. IV. V. VI. VII. VIII. IX. X. XI. XII. Lat. $51 \frac{10}{2}-55 \frac{10}{4}$. Throughout Ireland. Type, British.

Hedges, thickets, rocky places, \&c. ; common. Fl. May-June.

Sea-level in Derry and S. Cork. To $1450 \mathrm{ft}$. in Derry (Hart); to $1500 \mathrm{ft}$. in Dublin $(N, C$.); to $1600 \mathrm{ft}$. in Tipperary (Hart).

\section{ORDER XXII. SAXIFRAGE压.}

\section{SAXIFRAGA Linn.}

1. S. oppositifolia Linn.-Purple Saxifrage.

Districts - - - - - - VIII. IX. - XI. XII. Lat. $53 \frac{1}{2}^{\circ}-55 \frac{1}{4}^{\circ}$. West and North. Type, Highland.

Mountain cliffs; rare. Fl. April-May.

VIII. Mountains in Joyce country, near Lough Corrib: Mack. Rar. On Ben Lettery, Connemara (Carroll): Cyb. On Maam Turk, Connemara: Mackay, App. to Frazer. Mweelrea in Mayo, and Muckanaght (Twelve Bens), Galway: Hart I883 a. Lisoughter Hill, Recess, Galway (Prof. J. W. Carr): P.\& C. I895. Abundant on Kylemore mountain, $1897 ;$ Rev. W. Colgan.-IX. On the calcareous mountains of Leitrim and Sligo (Prof. E. Murphy); Glenade, Leitrim (Admiral Jones) : Cyb. AtGlenade; Annacoona; Aroo mountain, \&c.; but not seen on Ben Bulben : B.\& V. 1885 . Abundant on Lug-na-gall, Glencar: $N . C .1896 .-\mathrm{XI}$. At the summit of Bulben, Ennis Owen (Mr. Browne): Wade Rar.-still abundant there: Hart 1883 . In the Poisoned Glen: Hart 1884. Slieve League and sea cliffes at Lehan near it : Hart $1885 \%$. At sealevel on Slieve A tooey near Magheragh: Hart 1886. Slieve Snacht west; N.C.-XII. On Ben Evenagh, Co, of Derry (D. Moore): Flor. Hib. - and in 1882: Hart I884.

From sea-ievel to $1850 \mathrm{ft}$. in Donegal (Hart); 800-1600 ft. in Sligo and Leitrim $(B . \& V$ ) ; from $1000 \mathrm{ft}$. in Galway to $2400 \mathrm{ft}$. in Mayo (Hart).

First found by Robert Brown before 1800, on Bulbein Mt., Innishowen. 
2. S. nivalis Linn.-Alpine Clustered Saxifrage.

Districts - - - - - - IX. - -

Lat. 54 I $^{\circ}$. Sligo only. Type, Highland.

Mountain cliffs; very rare. Fl. July.

IX. Found on Ben Bulben, county of Sligo by John Wynne, Esq., of Hazel Wood: Mackay I859. About thirty plants at one place near Annacoona: $B . \&$ V. I $885_{5}$-probably the same locality as the preceding.

Occurs at $1950 \mathrm{ft}$. on Annacoona, Sligo ( $B . \& V$.).

First found by John Wynne in 1837.

\section{S. stellaris Linn._Starry Saxifrage.}

Districts I. II. - IV. V. - - VIII. - X. XI. XII. Lat. $51 \frac{1}{2}{ }^{\circ}-55^{\circ}$. South to North. Type, Highland.

Wet rocks and marshy places by mountain rills; frequent. Fl. June-August. Caloifuge $A$.

From 500 to $2200 \mathrm{ft}$. in Donegal; to $2450 \mathrm{ft}$. in Mayo (Hart); from $750 \mathrm{ft}$. in Dublin to $3000 \mathrm{ft}$. in Wicklow (N.C.); from $700 \mathrm{ft}$. (N. C.) to $3400 \mathrm{ft}$. in Kerry (Hart).

First found by Lhwyd in 1699 in Kerry : Phil. Trans. vol. 27, p. 524 .

One of the most widely distributed highland plants of Ireland, but apparently quite absent from the limestone mountains of Clare, Sligo, and Leitrim, and from the basalt of Derry and Antrim. Locally abundant in the Mourne Mountains and in the mountains of Wicklow, Kerry, and Donegal.

\section{S. Geum Linn.-Kidney-leaved Saxifrage.}

Districts I. II. - - - - - Lat. $51 \frac{1}{2}^{\circ}-52 \frac{1}{4}^{\circ}$. Kerry and Cork only. Type, Hibernian.

Rocky and damp shady places in mountain districts; locally abundant. Fl. May-July.

I. "On the mountains of Keri in abundance" in 1699 (Lhroyd): Phil. Trans. vol. 27, p. 524. Sparingly on Connor Hill near Dingle and on Turk mountain near the waterfall, 1804; on several mountains in Kerry and on Priest's Leap, Co. Cork, 1805: Mack. Rar. Abundant on Brandon mountain and about Killarney, \&ce. (Moore): Cyb. Baurtregaum, Slieve Mish mountains: Hart 
1882 a. Woods in Valentia Island, $1892 ; N . C$. Widely distributed throughout the mountainous portion of Kerry; $R . W . S$. Mountains between Gouganebarra, and Bantry, Cork ( $J_{\text {. Drum- }}$ mond) : Flor. Cork. On Hungry Hill; by the Eagle's Nest, Glengariff; on Sheep's Head promontory; at Adrigole, \&c.: Allin's Cork. By a stream at Berehaven and abundant at Adrigole, 1894; Phillips.-II. Rocks above Gurtaveha Lake near Millstreet (More): Ree. Add.

From sea-level ( $R . W . S$.$) to 2650 \mathrm{ft}$. (Hart) in Kerry.

First found by Lhwyd, in 1699, in Kerry. Mr. Britten informs us that there is a specimen in Buddle's Herb. (Herb. Sloane, cxxiv. 77) in the British Museum, labelled: A. D. Lhoyd in Hibernid Collect.

Far more restricted in its range than $S$. umbrosa, its area of distribution in Ireland lying within a radius of about 35 miles from Carrantuohil as centre.

Var. HIRSUTA (Linn).-I. On the east side of Mangerton and on several other mountains in Kerry, 1804-5: Mack. Rar. On rocks at the Gap of Dunloe, near Killarney, 1805: Mack. Cat. On Brandon, plentifully (Moore): Cyb. By the waterfall on Hungry Hill, Bantry Bay, Cork, and on Connor Hill, Kerry, 1841 : Babington in Herb. Blackwater Bridge, near Kenmare; Waterville; Torc mountain; Slieve Mish mountains, \&c., Kerry : R.W. S. 1890 , \&c. On the Gouganebarra mountains (J. Drummond): Flor. Cork. Near Glengariff and on Priest's Leap mountain: Allin's Cork. Near Adrigole, 1894 ; pass of Keimaneigh, 1897 ; Phillips.II. Freely on the mountains near Millstreet, Co. Cork (Carroll): Allin's Cork.

Intermediate between S. umbrosa and S. Geum, though approaching more closely to the latter. It is only recorded from stations where both species grow together and is, perhaps, as many botanists consider, a hybrid between the two, though this has never been proved experimentally.

Var. mikgans (Mackay)-I. On a rock near the summit of Turk mountain, Killarney, 1805: Mack. Cat. Connor Hill, Kerry, 1841: Babington in Herb.--in the same station, 1890; R.W.S.

Another form, marked by very blunt and shallow crenations of the leaf margin, seems quite as worthy of varietal distinction as S. elegans. It occurs in rocky gullies at Waterville, Derrynane, and Brandon mountain and in woods at Valentia Island; Eds. 
5. S. umbrosa Linn.-London Pride: None 80 pretty (Ray).

Hibernicé, Cabåipee mabaió puaió (Cabawshthé wadha roo-er) Fox's Cabbage ${ }^{1}$-Cabáipre oaoine maża (Cabawshthé dheenee maw-hë) Good People's Cabbage.

Districts I. II. - - - - VIII. IX. - XI. Lat. $51 \frac{1}{2}^{\circ}-55 \frac{1}{4}^{\circ}$. South and West. Type; Hibernian.

Mountains, woods, and rocky places, chiefly near the coast; locally abundant. Fl. May-July. Caloifuge A.

I. "Grows plentifully here with us in Ireland on a mountain called the Mangerton in Kerry" (Dr. T. Molyneux): Phil. Trans. I697, p. 5zo. On Mangerton and Turc mountains, 1796: Wade Rar.' Gap of Dunloe near Killarney: Mack. Cat. On nearly all the mountains of Kerry; plentiful in the woods at Killarney (Mloore): Cyb. Mangerton; Blackwater Bridge, near Kenmare, \&c. : R.W. S. 1890 . On Great Blasket Island; on Inishvicillane; and on Inishtooskert: Barrington $188 \mathrm{I}$. Common on all the rocks in the western parts of Cork: Smith's Cork 175o. Very common at Glengariff : Mack. Rar. By the sea at Mizen Head, S. Cork; Phillips. Rocks by the Lee above Iniscarra Bridge: Drummond I8Iq-still there in 1895 ; Phillips. Ballydavelin Hill, Carbery (R. W. Townsend): Flor. Cork. - II. On the top of the high mountains of Knockmeledown: Smith's Waterford I746. On Knockmealdown and the Commeragh mountains, Waterford, 1882 : Hart I884. About Lough Borheen in the Galtees: Hart I881.VIII. Very common throughout Connemara: Wade Rar. Found on Croaghpatrick, Mayo, by A. B. Lambert: Templeton MSS. On Mweelrea, Co. Mayo: Flor. Hib. Very abundant on Nephin mountain, Mayo : Flor. Ulst. On the shores of Loughs Cullin and Conn about Pontoon (More): Cyb. Inishbofin and Inishturk: More 5876 . Muckanaght; Ben Corr; Ben Lettery; Ben More, Achil Island, \&c.; on all, summits in Connemara and West Mayo: Hart 2883 a. West side of Lough Mask, $1891 ; R$. P. Powell. Islands in Lough Inagh and Derryclare Lough, Connemara, 1897; N.C.-IX. On the hills north-east of Foxford, Mayo (More) : Cyb.XI. Muckish mountain, Co. Donegal: Templeton MS. On Errigal mountain and at Knockglass, Malin, close by the sea : Flor. Ulst.

${ }^{1}$ The close similarity' in sound of the genitive forms of the Irish words for "Patrick" and "fox" has, no doubt, caused this plant to be erroneously called St. Patrick's Cabbage. Eds. 
In the Poisoned Glen and on a mountain south of Lough Ea, Donegal (N. Moore) : Rec. Add. Slieve Snacht West and Poisoned Glen : Hart I879.

The wide gaps in the range of this species in West Ireland are strikingly coincident with the appearance of the limestone formation in Kerry, Clare, Galway, and Sligo.

From 800 to $2000 \mathrm{ft}$. in Donegal ; sea-level to $2680 \mathrm{ft}$. in Mayo, 1750-2500 ft. in Tipperary, sea-level to $3370 \mathrm{ft}$. in Kerry, 500-2600 ft. in Waterford (Hart).-A mountain plant in almost all of its inland stations, but freely descending to the lowlands near the sea in the West and South-West.

First definitely recorded for Ireland by Dr. T. Molyneux in 1697 and probably observed there some fifty years earlier, as the plant is entered, without any locality, in How's Phytologia, I650.

We cannot, with any confidence, separate the many Irish forms of this variable species into the varieties serRatmoulda Don and punctata Don. When a full series of Irish specimens is examined the finest gradations may be traced from obovate to orbicular in the general outline of the leaf and from crenation to sharp serration in the form of the margin. In no case, however, does the Irish plant exhibit the very blunt crenation and strongly marked cartilaginous leaf margin which appears to be characteristic of the Pyrenean, Spanish, and Portuguese S. umbrosa. In Kerry, Connemara, and Waterford the prevalent leaf-form is one with strongly serrate margins, and truly crenate forms are very rare in Ireland. In Sternberg's Supplement (Prague, 1831) to his Revisio Saxifragarum many of the various leaf-forms of this species and of S. Geum are excellently figured.

\section{S. Hirculus Linn.-Yellow Marsh Saxifrage.}

Districts - - III. - - - VII. VIII. - - - XII. Lat. $53^{\circ}-55^{\circ}$. Middle and North-East. Type, Scottish-Intermediate.

Wet bogs; very rare. Fl. July-August.

III. Bogs near Mountrath, Queen's Co. (J. Morrison): Rec. Add.-VII. In an extensive marsh, three miles from Cloughjordan, -Tipperary : Flor. Hib. Bog of Lisclogher, near Castletown Delvin, Westmeath (Rev. W. A. Reynell) : Cyb.-a few plants still there in 1888 : Levinge r894. On the Bog of Allen, near Portarlington (R. Tucker) : Cyb.-VIII. Bog near Ballycastle, west of Belderrig, Mayo; H. D. B. Dilloyn.-XII. "In a deep flow-bog, townland 
of Glenbuck, parish of Rasharkin, a little west of some low precipices of rocks, one called Whinin Rocks, the other, Lough Rocks, August 1838" (Moore): Label in Ordr. Coll. Rediscovered in 1884 near Lough Naroon, very close to the preceding locality (Rev. S. A. Brenan); plentiful near Garron Point, Antrim (Praeger): Journ of Bot. 1884 .

From $270 \mathrm{ft}$. in Westmeath to $1000 \mathrm{ft}$. in Antrim.

7. S. aizoides Linn.-Yellow Mountain Saxifrage.

Districts [I.] - - - - - IX. - XI. XII. Lat. $54 \frac{1}{4}^{\circ}-55 \frac{1}{4}$. West and North. Type, Highland.

Cliffs and damp places on mountains; rare. Fl. July-August.

[I. Connor cliffs near Dingle, Kerry, 1804: Mack. Rar.-but not seen recently.] -IX. On a mountain near sligo (Rev. Mr. Brinkley); on Ben Bulben and other mountains near Sligo, 1806 : Mack. Rar. On Glenade; Legale; and Ben Whisken, Sligo and Leitrim (Admiral Jones) : Cyb. Abundant everywhere through the mountains in Ben Bulben District: $B . \& V .1885$. On Knockacree, Ox Mountains, Sligo, 1893 ; Miss Kinahan. -XI. In a gully on the north side of Slieve League, Donegal (H.W.D. Dunlop): Rec. Add. Alt mountain near Ardara (Arthwr Brooke): Hart 2886.-XII. Murlough, Antrim (Miss Hincks): Flor. Olst.descending here to sea-level, $1886 ; N$. C. In considerable quantity by streamlets on the north side of Torr Head, Antrim : Corry 1882 .

Sea-level in Antrim to $1550 \mathrm{ft}$. in Donegal (Hart); 350-1600 ft. in Sligo $(B . \& V$.$) .$

\section{S. tridactylites Linn.-Rue-leaved Saxifrage.}

Districts I. II. III. IV. V. VI. VII. VIII. IX. - XI. XII. Lat. $51 \frac{1}{2}^{\circ}-55 \frac{1}{4}^{\circ}$. Throughout Ireland (?). Type, British-English.

Lowland (?). On calcareous and basaltic rocks, on sandhills, and on walls; frequent. Fl. April-June.

Abundant in the limestone districts of Clare and Galway, and reported from most of the Irish counties; in some, however, it appears to be quite local, and is rare in the North-East.

\section{S. granulata Linn.-White Meadow Saxifrage.}

Districts - - - IV. V. - - - - X. - XII. Lat. $52^{3}{ }^{\circ}-55^{\circ}$. East and North-East. Type, British-Intermediate.

.Lowland. Sandhills, pastures, \&c. ; very rare. Fl. May-June. 
IV. On the sandhills south of Mizen Head, Wicklow (Moore): Rec. Add.-still abundant there, $1890 ; R . W . S$. Brittas, Wicklow, 1866 (J. Morrison): Ree. Add.-V. At Slane, Co. Meath (Mr. De Luc): Templeton MS. On sandy ditch-banks between Baldoyle and Portmarnock : Mack. Cat. Near Kilbarrack Church, Co. Dublin: Ir. Flor. Baldoyle race-course, $1896 ; R . W . S .-\mathrm{X}$. On the mound at Rathtrillick, Armagh (Stewart) : Rec.Add.-XII. Abundant in Belvoir Park: B.N.F.C. Proc. 2871 . Castlereagh Hill, Co. Down (Stewart); doubtfully native in both of the above localities: Flor. N.-E. About a mile south of Carnlough, Antrim; also in copses at Springhill, Moneymore, Derry (Moore): Flor. Hib.

\section{S. hypnoides Linn.-Mossy Saxifrage.}

Districts I. II. - - - VI. - VIII. IX. X. XI. XII. Lat. $51 \frac{3}{4}^{\circ}-541_{4}^{\circ}$. South to North. Type, Scottish-Highland.

Rocky places, chiefly in mountain districts; locally abundant. Fl. May-August.

VI. At Castle Taylor and at Garryland, Galway: More 1855. Throughout Burren, Co. Clare: Foot r864. Frequent on the limestone hills round Ballyvaughan, Clare, $1895 ; N$. C. Knockmai mountain near Tuam: $W$ ade Rar.-IX. Plentiful on all the limestone mountains near Sligo: Mack. Cat. Ben Whisken and Glenade, Sligo (Admiral Jones); Kesh Corran (F.J. Foot): Cyb. Common on the cliffs in Ben Bulben district: B.\&V. I885.-X. Hill of Knocknenny, Fermanagh: Wade Rar. Knockmore, Fermanagh: Stewart 1882. Cliffs at Poulaphuca, Lough Erne: Barrington 1884. Limestone rocks at Swanlinbar, Cavan (Dr. Scott): Mack. Rar.-XII. Cave Hill and Sallagh Braes, 1797 (Templeton): Whitla MS. Rocks about the Giant's Causeway: Wade Rar. Deer Park, Glenarm, and abundant in mountain pastures between Torr Point and Ballycastle: Ir. Flor. Basaltic rocks of Knockagh: Flor. Belf. Murlough and Rathlin Island: Flor. Olst. Black Mountain and Woodburn glen (Stewart); Garron Head (Praeger): Flor. N.-E. Ben Bradagh, Derry (Mrs. Leebody): S. \& P. I895.

The above records refer to Var. GEMMIFERA Syme, here taken as. the type; this is apparently confined to the limestone and basalt.

Var. SPONHEMICA (Gmel.) - S. quinquefida Haworth-S. affinis Don-S. hirta Haworth-I. Baurtregaum, Slieve Mish, Co. Kerry : Hart I882 a. On Brandon Mountain : Hart I884. Near the lake in Hag's glen, Magillicuddy's Reeks: Druce $180 \mathrm{r}$.- 
II. On Galtymore, Tipperary (T. Anderson): $C y b$. In various parts of the Galtees: Hart 1881. On the Commeragh mountains, Waterford (J.Grubb): $C y b$. On the Knockmealdown mountains: Hart I884.-XII. Near Cushendall, Antrim: Templeton MS. Garron Head, 1852 (C. C. Babington); Ben Evenagh (Corry): Flor. N.-E.

Var. DECIPIENs (Ehrh.)-I. Slieve Mish mountains, Kerry: R.W.S. 1889 . To this form also Dr. Engler refers gatherings. from the Reeks and Brandon mountain in the same county.

Var. Sternbergir (Willd.)-S. hirta (Smith)-I. Near the summit of Magillicuddy's Reeks, 1805: Mack. Cat.-and in 1881: Hart 1882.-II. Moist rocks on Galtymore, Tipperary, 1805: Mack. Cat.- and in 1880: Hart 1881 .-VI. Limestone cliffs at Black Head, Clare, and in Great Aran Island (More): $C y b$.-XI. Polldoo, North Aran Island, very sparingly (Hart) : Journ. of Bot. I881, p. Iq.

Var. GRENLANDICA (Engl.) -To this, rather than to S. coppitosa (Linn.), should probably be referred the plant gathered by Mackay on-I. Brandon Mountain, 1804 : Mack. Cat.-and again by $E$. $F$. and $W . R$. Linton in 1885 , as also Mr. Hart's plant fromVIII. Muckanaght, Twelve Bens, Galway : Hart I883 a.

In all its forms $S$. hypnoides is absent from East Ireland.

Descends to near sea-level in Clare, to $100 \mathrm{ft}$. in S. Donegal, and to $200 \mathrm{ft}$. in N. Antrim. Ascends to $1450 \mathrm{ft}$. in Derry, to. $2570 \mathrm{ft}$. in Tipperary, and to $3150 \mathrm{ft}$. in Kerry (Hart).

\section{CHRYSOSPLENIUM Linn.}

\section{C. oppositifolium Linn.-Golden Saxifrage.}

Districts I. II. III. IV. V. VI. VII. VIII. IX. X. XI. XII. Lat. $51 \frac{1}{2}^{\circ}-55 \frac{1}{4}^{\circ}$. Throughout Ireland. Type, British-Highland.

Damp shady places, especially in mountain districts; frequent. $F$. March-May. Calcifuge $B$.

Sea-level in N. Antrim and S. Cork. To $2450 \mathrm{ft}$. in Down (S. \&P.); to $3000 \mathrm{ft}$. in Tipperary (Hart).

\section{PARNASSIA Linn.}

1. P. palustris Linn.-Grass of Parnassus.

Districts - II. III. IV. V. VI. VII. VIII. IX. X. XI. XII. Lat. $52^{10}-551^{\circ}$. Throughout Ireland (?). Type, Scottish-British.

Boggy places, damp pastures, stony lake shores, and sand-hills by the sea ; frequent and locally abundant. Fl. July-August. 
Sea-level to $1450 \mathrm{ft}$. in Ben Bulben district (N. C.).

Most frequent on calcareous soils and especially abundant on the shores of Lough Derg $(N . C$.$) and Lough Ree \left(B . \& V .{ }_{1887}\right)$ in the Shannon basin. Apparently absent from Cork and Kerry.

\section{ORDER XXIII.-CRASSULACEE.}

\section{COTYLEDON Linn.}

\section{C. Umbilicus Linn.-Pennywort.}

Umbilicus pendulinus DC.

Districts I. II. III. IV. V. VI. VII. VIII. IX. X. XI. XII. Lat. $51 \frac{1}{2}^{\circ}-55 \frac{1}{4}^{\circ}$. Throughout Ireland. Type, Atlantic-English.

Rocks and walls; frequent and locally abundant, especially in hilly districts and near the sea. Fl. June-August. Calcifuge $B$.

Sea-level in N. Donegal and S. Cork. To $1000 \mathrm{ft}$. in Derry $(C y b$.$) ; to 1500 \mathrm{ft}$. in Louth and Tipperary (Hart).

\section{SEDUM Linn.}

\section{S. Rhodiola DC.-Rose-root.}

Rhodiola rosea Linn.-Sedum roseum Scop.

Districts I. II. - IV. V. VI. - VIII. IX. - XI. XII. Lat. $51 \frac{3}{4}^{\circ}-55 \frac{1}{4}^{\circ}$. From South to North. Type, Highland.

Wet rocks on mountains, and cliffs by the sea; frequent. $F l$. May-August.

I. "On Mangerton mountain . . . on the steep, rocky sides of the horse pool or Poul-na-Coppel": Wade, Rar. Cliffs on Magillicuddy's Reeks and Brandon mountain, Kerry: Mack. Rar. On Mangerton, 1896; on Brandon, 1894, and frequent on the Kerry mountains; R.W.S. On Hungry Hill: Drummond 1820 -and in 1894; Phillips. At Glengariff, and-II. Rocks above Carbanagh Lake, Millstreet: Allin's Corte. Near the summit of Galtymore: Mack. Rar. I806-and in 1880: Hart 188 r. On rocks near the lake at Coumshingan, Waterford (Miss S.Grubb): Cyb.- and in 1883: Hart 1884.-IV. Very sparingly on the south side of Lugnaquilla mountain, Wicklow, $1897 ; N$. C.-V. Near the top of Carlingford mountain, Louth: Ir. Nat. I89,3, p. 227.-VI. In the South Isles of Aran: Mack. Rar. I806. Near Dun Angus and Kilmurvy, Aranmore Island, $1892 ; N . C$. Cliffs of Moher, Clare (More): Cyb.-VIII. On Shanafolia mountain, Connemara: Babington $28_{3} 6$. 
On Muckanaght, Galway, and on Mweelrea; Croaghpatrick, \&c., Mayo: Hart 1883 a. Inishturk: More I876.-IX. Abundant at the edge of the precipice, Ben Bulben, 1815: Templeton, Journal. Abundant on cliffs in Ben Bulben district: B.\&.T. $1885 .-\mathrm{XI}$. On the Donegal mountains: Flor. Hib. Inishowen Head; Culdaff; Malin; shore at Glencolumbkill, \&c. (Dickie): Flor. Olst. Bulbein mountain; Crockaughrim; Muckross Point; Slieve League, \&c. : Hart $1883 \& 1885 \gamma$. - XII. South end of Slemish and north of Rathlin: Templeton MS. Plentiful on cliffs at north-west of Rathlin Island in 1882: Stewart I884. Torr Head and Fair Head, Antrim (Moore) : Cyb. Glenariff, and abundant on the coast north of Torr (Praeger): Flor. N.-E.\&S.\&P. I895. In the Mourne mountains, on Shanlieve and Slievenaglough (Praeger): Flor. N.-E.-on Slieve Muck and Pigeon Rock mountain: S.\& P. I89z.

Sea-level in Kerry and round the west and north coast to Antrim. To $1900 \mathrm{ft}$. in Donegal (Hart); to $1850 \mathrm{ft}$. in Ben Bulben district (B.\&V.); at $2300 \mathrm{ft}$. in Wicklow (N.C.) ; to 2600 ft. in Mayo, $2500 \mathrm{ft}$. in Tipperary, and $3150 \mathrm{ft}$. in Kerry (Hart).

\section{2. $\ddagger \mathbf{S}$. Telephium Linn.-Orpine; Live-long.}

S. maximum sut.

Districts - - - - VI. VII. - - - XI. XII.

Bushy and stony places, banks, \&c. ; rare and nowhere certainly native. Fl. July-August.

VI. On the walls of an old fort called Cahiremond near Kilfenora, Clare: Wade Rar. At Kilfenora, scarce (F.J. Foot): $C y b$. Roadside between Woodford and Lough Derg ( $\boldsymbol{M}$. Dowd): Rec. Add.-VII. On Carberry Island in Lough Ree near Athlone, sparingly; also at Ballinalee, east of Longford, wild: Foot, 1865 XI. Rooskey, in the parish of Clondahorkey, far from garden or house, looking quite wild (Rev. Alex. Stuart): Hart 7885 .XII. Along hedges between Newry and Loughbrickland: Ir. Flor. Ballyholme; Orlock; Mealough Hill, \&c., Down: Flor. Belf. Strand between Newtownards and Mountstewart (Stewart): Flor. N.-E. Near Maghera, Derry; Hollywood Hills; Ballygowan and Downpatrick, Down (Praeger); Ballyclose and Craigbilly, Antrim (Miss Knowles) : S.\&P. I895.

Also recorded from the counties of Cork, Wexford, Carlow, Galway, Sligo, and Cavan; but the records are without recent confirmation, and there is reason to believe that the plant was only a casual in these counties. 


\section{3. * S. album Linn.-White Stonecrop.}

Districts I. II. - - - - $-\overline{-}-\overline{-}-\overline{-}-\overline{-}$
Walls and rocks; fully established in the neighbourhood of Cork only. Fl. July-Angust.

I. Walls near Glandore, 1896; J. Groves, Crosshaven, fully established, 1896 ; Phillips. Glengariff Bridge; G. C. Druee.II. Rocks near Queenstown, plentiful and perfectly naturalized, 1851: Carroll MSS. On Haulbowline Island, Cork Harbour, plentiful $($ Dr. Wood $)$ : Carroll 1854 . On a dry hill at Glanmire, 1830 (Dr. Harvey) : Mackay I859. On cliffs at Summer Hill, Cork (Carroll); on rocks at Fermoy (T. Chandlee): Cyb. Fully established on walls and railway embankments about Tivoli, Glanmire and Queenstown, 1896; Phillips.

Also recorded from Districts X. and XII. for the counties of Armagh and Antrim, but only as an escape, not fully naturalized.

The county Cork plant is usually the Var. micranthum (Bast.).

\section{4. * S. dasyphyllum Linn.-Thick-leaved Stonecrop.}

Districts I. II. - - - - - - - - - - - Cork only. Fl. June-July.

I. Wall by the Douglas road, Cork (Carroll): $C y b$.-II. On an old wall near Blarney Castle: Smith's Cork I750 and Wade Rar. 1804. Walls at Sunday's Well : Drummond 1818 -probably planted here. On limestone rocks and walls at Bromfield, Midleton (Dr. Power) : Flor. Cork. On walls between Midleton and Cloyne (Moore): Cyb. At Carrickshean near Midleton, where it covers a range of limestone hills and appears quite wild (Rev. $T$. Allin): Rec. Add. Old walls between Midleton and Ballinacarra, 1895 ; and abundant and looking native on the Carrickshean hills, 1896 ; Phillips.

\section{S. anglicum Huds.-English Stonecrop.}

Districts I. II. III. IV. V. VI. VII. VIII. IX. X. XI. XII. Lat. $51 \frac{1}{2}-55 \frac{1}{4}$. Throughout Ireland. Type, Atlantic-British.

Banks and rocky places, mostly near the coast; frequent. $\mathrm{Fl}$. June-August.

Sea-level in N. Antrim and S. Cork. To $1150 \mathrm{ft}$. in Derry, $1950 \mathrm{ft}$. in Wicklow, and $2650 \mathrm{ft}$. in Kerry (Hart). 
Generally abundant round the coast; rare inland, but occurs in several stations, as in Carlow, on the Scalp rocks, between Fenagh and Bagnalstown (Rec. $A d d$. ); in the counties of Westmeath and Roscommon ( $F . J$. Foot: $C y b$.); in Co. Armagh, at the western base of Slieve Gullion (Praeger 1893).

\section{S. acre Linn.-Wall Pepper.}

Districts I. II. III. IV. V. VI. VII. VIII. IX. X. XI. XII. Lat. 51 $\frac{1}{2}^{\circ}-55 \frac{1}{4}{ }^{\circ}$. Throughout Ireland. Type, British.

Lowland. Sand-hills, banks, rocks, and walls, chiefly near the sea; frequent. Fl. June-July.

Rare inland; abundant on sandy warrens round the coast.

\section{7. * S. reflexum Linn.-Crooked Stoneorop.}

Districts I. II. III. - V. VI. - - - X. XI. XII.

On roofs and walls and occasionally on rocks near houses; always introduced and not common. Fl. July-August.

I. By the Blackrock road: Flor. Cork.-II. On an old castle near Mallow: Drummond 18 I8. Drummaleen eastle, Mallow (perhaps Drummond's station), and Mogheeley castle by Conna: Allin's Cork. Plentiful on thatched roofs at Mallow (Carroll); on the rock of Cashel (T. Chandlee): Cyb.-III. Wilton, Kilkenny (Rev. S. Madden): Cyb.-V. Upon the tiles of the houses at Chapelizod: Threlkeld. Old walls about Chapelizod plentifully: Wade Dubl. Old walls near Finglas : Mack. Cat.-VI. On thatched roofs at Kilmallock, Co. Limerick (Carroll): Cyb. Walls and roofs at Newmarket, Co. Clare: Stewart $1890 .-\mathrm{X}$. Old walls at Ballytrain, Monaghan, 1805: Templeton MS. Benburb, Tyrone: Flor. Olst. On limestone rocks by the Dungannon road three miles from Armagh: Praeger 1893.- XI. Well established on old walls at Ray ; Rathmelton, \&c. : Hart 1879 . Railway embankment above the Foyle near Carrigans: Hart $1885 \gamma$.-XII. Houses and walls at Antrim; on the shore at Shane's Castle, 1810: Templeton MS. "Many of the old houses in the town of Antrim are covered with it": Flor. Hib. Portmore ruins (Stewart); railway bank south of Antrim (D. Redmond): Flor. $N_{\text {. }}-E$. Plentiful about Carrickfergus $(F$. Whitla): Flor. Hib. In abundance on the rocks by the Roe about two miles above Limavady, 1813: Templeton Journal. In the greatest abundance in the Glen of the Roe at O'Cahan's rocks : Moore MS. 7835 . 


\section{ORDER XXIV.-DROSERACEA.}

\section{DROSERA Linn.}

\section{D. rotundifolia Linn.-Round-leaved Sundew.}

Districts I. II. III. IV. V. VI. VII. VIII. IX. X. XI. XII. Lat. $51 \frac{1}{2}^{\circ}-55 \frac{1}{4}^{\circ}$. Throughout Ireland. Type, British.

Bogs and moist heathy ground; common. Fll. July-August. Calcifuge $A$.

Sea-level in N. Derry and S. Cork. To $1700 \mathrm{ft}$. in Donegal and to $1650 \mathrm{ft}$. in Wicklow (Hart).

\section{D. anglica Huds.-Great Sundew.}

D. longifolia Iinn. in part.

Hibernicé Opuićoin mona (Dhroo-ick-dheen mona), Bog-dew. Districts I. II. III. - V. VI. VII. VIII. IX. X. XI. XII. Lat. $51 \frac{1}{2}^{\circ}-55 \frac{1}{4}^{\circ}$. From South to North. Type, Scottish.

Spongy bogs; common in the West and North, rather rare elsewhere. $F l$. June-August. Calcifuge $A$.

I. Frequent in Kerry; $R$. W. S. At Castletown Berehaven (J. Drummond); found in West Cork only: Flor. Cork. Rooska near Durrus: Allin's Cort. Bogs near Inchigeela, 1858, andII. Bogs near Macroom (J. Sullivan): Annot. in Flor. Cork. Bluefort Bog, Newmarket: Allin I87x.-III. "This was sent me by Mr. Zanche Silliard an Apothecarie of Dublin in Ireland": Parkinson, Theatr. Bot. I640, p. 1053. "Plentifully in a bogge by Edenderry. I gave some of the plant to Zanchie Sylliard, Apoth. of Dublin, which he sent to Mr. Parkinson who ... mentions the said Zanchie as if he had found it" (Mr. Heaton): Horo. Phytol. I650.-V. "On the Bogg by Isaactown in the county of Meath" [near Rathmolyon, south of Trim], Mr. Sherard: App. to Threlkeld. Narraghmore bog, Kildare (Carroll): Cyb. Plentiful in Ardee Bog, Louth: Butler I890.-VII. Lisclogher Bog, Westmeath: Levinge 1894 .

Frequent and locally abundant in Districts VI. VIII. IX. $\mathbf{X}$. XI. and XII.

To $750 \mathrm{ft}$. in Donegal and Galway (Hart); but usually lowland.

First found by Rev. Richard Heaton before 1640, at Edenderry, and first published by Parkinson in Thsatrum Botanicum, 1640 . 
D. obovata M. \& K.-D. anglioa $\times$ rotundifalia-I. Sparingly in Kealboy bog, Glencar, Kerry; R.W.S. Near Glengariff, rare : Druce I89I. Gouganebarra, 1897; Phillips.-VI. Sparingly in a bog north of Carrigaholt, Clare, not so well marked as in north Ireland : Stewart I890.-X. In county Tyrone (W. Mac Mitlan): Flor. N.-E.-XII. Slogan bog near Randalstown, Antrim (Moore): Cyb. Sparingly in a bog above Dunloy, Antrim (Stewart): Flor. N.-E.

\section{D. intermedia Hayne-Long-leaved Sundew.}

\section{D. longifolia Linn. in part.}

Districts I. - III. - - VI. - VIII. IX. X. XI. XII.

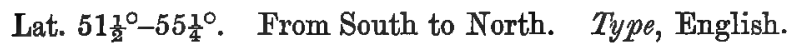

Bogs; locally abundant in the West, very rare in the East. $F$ F. July-August. Calcifuge $A$.

I. VI. VIII. IX. and XI. Frequent, occurring in many stations in Kerry, S. Cork, Clare, Galway, Mayo, and Donegal.-III. Base of Cullenagh, Queen's Co., 1897 ; Praeger.-X. On a mountain near Florence Court, Co. Fermanagh : Flor. Hib.-not recently recorded from this county. In Moyntagh bogs (Mr. Hyndman) : Flor. Olst. Abundant in the bogs south of Annagariff Lake, Co. Armagh: Praeger $7893 .-X I I$. Marshy places at the foot of the Mourne Mountains: Ir. Flor. 1833 . Wet boggy ground by Colligan Bridge on the Kilkeel river, also in a marsh to the south-west and again further up the river near the foot of Slieve Bingian, Mourne mountains: S.\&P. 1892 . The Mourne mountains station is, so far, the only one known for east Ireland.

To $600 \mathrm{ft}$. in Donegal and to $850 \mathrm{ft}$. in Galway (Hart); to. $1000 \mathrm{ft}$. in Clare (N.C.).

\section{ORDER XXV.-HALORAGEF.}

\section{HIPPURIS Linn.}

\section{H. vulgaris Linn.-Mare's-tail.}

Districts I.. II. III. IV. V. VI. VII. VIII. IX. X. XI. XII.

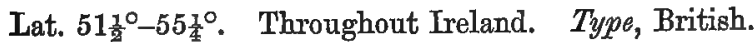

Lowland. Ditches, pools, slow streams, and lake margins; frequent. Fl. June-July.

A widely distributed species, but local in many districts. 


\section{MYRIOPHYLLUM Linn.}

\section{M. verticillatum Linn.-Whorled Water-Milfoil.}

Districts I. II. III. IV. V. VI. VII. VIII. IX. X. XI. XII. Lat. $51 \frac{3}{4}^{\circ}-55 \frac{10}{4}$. Throughout Ireland. Type, English.

Lowland. Ditches, ponds, and canals; wide-spread but local. Fl. June-August.

I. Ballyphehane Bog: Drummond 1820-and in 1896; Phitlips.-II. In Youghal Bog, 1896, but quite rare in Corks ; Phillips.III. Barrow river near Portarlington: Hart 1885.-IV. Ditches on the Murrough of Wicklow: Moore \& More 2878.-V. Ditches along the banks of the [Royal] Canal from the Crossguns to Scribblestown: Ir. Flor. Frequent in the Royal and Grand Canals, Dublin, 1895 ; N. C. Old quarry holes about Finglass Bridge: Ir. Flor. 1833 -and in $1893 ; N$. C. Ballitore, Kildare (Carroll): Cyb. In the Barrow below Monasterevan: Hart 1885.VI. Ballyinch Bog near Tuam: Wade Gallovid. Plentiful about Limerick (W. H. Harvey): Flor. Hib. Ditch by the bridge at Portumna (Stewoart): Rec. Add. River Suck, east of Clonbrock: Praeger 1896.-VII. Bog near Multyfarnham, Westmeath (Moore): Herb. Glasnevin. At the north-west end of Lough Owel: Levinge r894.-VIII. In small lakes by the roadside near Ballynahinch, Connemara: Mack. Rar. Lough Corrib, below Carn Seefin: P.\& C. I895.-IX. Ditches near Hollymount and Lough Carra, Mayo: More I860. Near Ballybay, Lough Ree: B.\&V. 2887 . Lough Gara, Roscommon ; Praeger.-X. Derrygorry Brook, Favour Royal, Tyrone: Hart 1887.-XI. Bog holes between Derry and Fahan, the only locality known in Donegal; Hart.-XII. Bog drains, Portmore Park (F. Whitla): Flor. Ulst. Sparingly in a muddy drain on the south side of Lough Beg (Portmore), the only locality in north-east Ireland (Stewart): Flor. N.-E.

Var. PECTINatum $(D C)-$. VII. Bog of Lynn, Westmeath: Levinge $\mathbf{2 8 9 4 .}$

\section{M. spicatum Linn.-Spiked Water-Milfoil.}

Districts I. II. III. IV. V. VI. VII. - IX. X. XI. XII. Lat. $51 \frac{1}{2}^{\circ}-55^{\circ}$. Throughout Ireland, probably. Type, British.

Lowland. Ponds and ditches; frequent. Fl. June-August.

Apparently not uncommon throughout Ireland, but frequently confounded with the following species. 
3. M. alterniflorum DC.-Alternate-flowered Water-Milfoil.

Districts I. II. III. IV. - VI. VII. VIII. IX. X. XI. XII. Lat. $511_{2}^{\circ}-55 \frac{1}{4}^{\circ}$. Throughout Ireland, probably. Type, British.

Ditches, ponds, and lakes, especially in peaty soil; frequent. Fl. June-August.

Sea-level in N. Antrim and S. Cork. To $1180 \mathrm{ft}$. in Donegal (Hart); to $1330 \mathrm{ft}$. in Sligo (N.C.); to $1200 \mathrm{ft}$. in Mayo (Hart).

\section{CALLITRICHE Linn.}

1. C. verna Linn. (Aggregate)- Water Starwort.

Districts I. II. III. IV. V. VI. VII. VIII. IX. X. XI. XII.

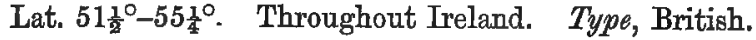

Lakes, pools, ditches, and streams, also on damp ground; common. Fl. May-September.

\section{C. vernatis Koch.}

Districts - - - V. - - - - X. - Lat. $53 \frac{1}{2}^{\circ}-54 \frac{1}{4}^{\circ}$. East Ireland.

Ditches, pools, and slow streams; rare (?). Fl. May-September.

V. Abundant in muddy ditches near Huntstown, Co. Dublin, $1894 ; \boldsymbol{N}$. C.-X. Lower demesne, Tanderagee, Armagh (Rev. $\boldsymbol{H}$. W. Lett): Wats. B. Ex. C. Rep. 2895 .

Probably not infrequent in Ireland, and confounded with other segregates of $C$. verna.

\section{C. stagnalis Scop.}

Districts I. II. - IV. V. VI. VII. VIII. IX. X. XI. XII. Lat. $51 \frac{1}{2}^{\circ}-55 \frac{1}{4}^{\circ}$. Throughout Ireland, probably.

On wet mud and in muddy ditches; common. Fl. May-September.

Sea-level in N. Antrim and in S. Cork. To $1200 \mathrm{ft}$. in Sligo and in Dublin (N.C.); to $1370 \mathrm{ft}$. in Mayo and to $1700 \mathrm{ft}$. in Tipperary (Hart).

The commonest of the Irish Callitriches.

\section{C. hamulata Kuetz.}

Districts I. II. - IV. V. VI. VII. VIII. - X. XI. XII. Lat. 51 $1_{2}^{\circ}-55 \frac{1}{4}^{\circ}$. Throughout Ireland, probably. Type, British.

Lakes, ponds, and streams; frequent. Fl. June-September. Calcifuge $B$. 
I. Common in Kerry; R.W.S. Lough Boy, near the top of Priest's Leap mountain : Allin 1873 . Near Goleen and Enniskeen; Phillips.-II. Ballyscanlon Lake, Waterford; Barrington.IV. Lough Dan, Wicklow; More. Aughnalaur river, near Chapel, Wexford: B.-H.\& G. I890. Kelly's Lough, Lugnaquilla, Wicklow, and $-\nabla$. Hollywood and Loughlinstown, Dublin; N.C.VI. Glenstal, Co. Limerick : Hart I88I. At Rinekirk, Limerick : Stewart I890.-VII. Lough Derevaragh (H. \& J. Groves) : Levinge 1894.-VIII. At Borrishoole and in the Mullet, Mayo (Babington): Cyb. Inishbofin: More 1876 . Lake on Mweelrea; D. MoArdle.X. Bog drain between Poulaphuca and Blaney Bay, Lough Erne: Barrington 1884. Luxuriant at Carrick, Fermanagh: Stewart 1882.-XI. and XII. Common : Hart $x 883$ \& Flor. N.-E.

To $1000 \mathrm{ft}$. in Donegal (Hart); to $1150 \mathrm{ft}$. in Down (S. \& P.); to $1900 \mathrm{ft}$. in Wicklow $(N . C$.$) ; to 1200 \mathrm{ft}$. in Mayo and $1120 \mathrm{ft}$. in Kerry (Hart).

Var. PEDUnculata DC.-I. Near Clonakilty (Babington): Flor. Cork.-II. Near Newbury, Mallow, and near Midleton: Allin's Cork.-IV. Near Rosslare Harbour station, Wexford: Marshall I898.-XII. Marshes by the Quoile below Downpatrick: Flor. N.-E. Mill dam near Hilltown, Down: S.\& P. 2892.

\section{C. obtusangula Le Gall.}

Districts I. II. - IV. V. - VII. - - - - Lat. $51 \frac{3}{4}^{\circ}-53 \frac{1}{2}^{\circ}$. South and Middle Ireland.

Ditches, streams, and lakes; apparently rare. Fl. May-Sept.

I. Abundant in Glanooragh stream, between Killarney and Tralee; in a ditch near Tralee, Kerry: R.W. S. $189 \pi$. Enniskeen, S. Cork, 1896; Phillips.-II. Youghal Bog, 1896; Phillips \& R.W. S.IV. Ditches in the Murrough of Wicklow; Barrington. Ditches at Churchtown and frequent near Rosslare, Wexford: Marshall 1898.- V. Ditch at Maynooth, Kildare: Praeger 1897.-VII. Lough Derevaragh, Westmeath (H.\&J. Groves) : Levinge I894.

\section{C. autumnalis Linn.-Autumnal Starwort.}

Districts I. - - IV. - - - VIII. IX. X. XI. XII. Lat. $52^{\circ}-551^{\circ}$. North and West, chiefly. Type, Scottish.

Ditches and lakes; rare. Fl. June-August.

I. Shore of Ross Island, Lower Lake, Rillarney (More): Reo. Add. Ross Bay and Long Range, Killarney Lakes; pond near Tralee: R.W.S. $1888 .-$ VIII. Cong, Mayo (Babington): Cyb.- 
IX. At the outlet of a small lake, a little east of Foxford, Mayo (More) : Cyb. Plentiful in the river at Sligo: B.\& P. I885.X. At Omagh, and Strabane, Tyrone (Miss Knowles): Praeger I897. Derryadd Bay, Lough Neagh, and Ballylane lake, south of Market Hill, Armagh : Praeger 1893.-XI. Kindrum lake: Hart 1879. Cloonea lake near Ardara: Hart 1886.-XII. Abundant in ditches by the Lagan canal and in Lough Neagh, 1837 ; by the Bann between Lough Neagh and Coleraine, 1835 : Moore MS.\& Herb. At the Salmon Leap above Coleraine; plentiful in Lough Aghery and sparingly in Carrickmannan Lake, Down (Stewart): Flor. N.-E. Castlewellan Lake and Long Lough, Down (Stewart); Derry. Lake, Down; in the rivers at Bushfoot, and at Toome, Antrion (Praeger): S.\&. P. 1895 .

Var. TRUNCATA (Guss.) -IV. Broad ditch and adjacent pool by the railway between Macmine Junction and Macmine Castle, Wexford: Marshall I898.-An interesting restoration to the Irish flora, as the plant gathered by Isaac Carroll at Glansiskin, Co. Cork and referred here by Prof. Babington (Manual 8th Ed.) proves, on re-examination of the Cambridge herbarium specimens by Messrs. H. \& J. Groves, to belong to C. hamulata.

\section{ORDER XXVI.-LYTHRARIEA.}

\section{PEPLIS Linn.}

\section{P. Portula Linn.-Water Purslane.}

Districts I. II. III. IV. V. VI. VII. VIII. IX. X. XI. XII. Lat. $51 \frac{1}{2}^{\circ}-55 \frac{1}{4}^{\circ}$. Throughout Ireland. Type, British.

Watery places and in rills; locally abundant. Fl. JulyAugust. Calcifuge $A$.

Sea-level in Antrim and in Cork. To $1150 \mathrm{ft}$. in Down (S.\& $P$.); to $1200 \mathrm{ft}$. in Dublin $\left(N . C_{\text {. }}\right)$; to $1250 \mathrm{ft}$. in Waterford (Hart).

\section{LYTHRUM Linn.}

\section{I. Salicaria Linn.-Purple Loose-strife.}

Hibernicé Cpeaćzac் (Cray-uk-thuck), Wound plant(?). Districts I. II. III. IV. V. VI. VII. VIII. IX. X. XI. XII. Lat. $51 \frac{1}{2}^{\circ}-55 \frac{1}{4}^{\circ}$. Throughout Ireland. Type, English-British.

Lowland. Ditch-banks, watery places, and peaty fallows; common. Fl. July-August. 


\title{
ORDER XXVII.-ONAGRARIEE.
}

\author{
EPILOBIUM Linn.
}

\section{E. angustifolium Linn.-Rose Bay.}

E. spicatum Lamk.-Chamenerion angustifolium Scop.

Districts - - - IV. - - - - IX. - XI. XII. Lat. $53^{\circ}-55 \frac{1}{4}^{\circ}$. North Ireland, chiefly. Type, British-Scottish.

Rocky places and wet banks; rare and very local. Fl. JulyAugust.

IV. High cliffs overlooking the south-west shore of Lough Nahanagan, Wicklow: Praeger 1897.-IX. Truskmore; cliffs of Glenade; and Aroo mountain, Leitrim: B.\&V.1885.-XI. Ravine at Glen Giveny, Inishowen, and Errigal mountain near Gweedore (Dickie): Flor. Ulster. Cliffs near Glenagiveny: Hart 1883. Blue Stack mountains ; Hart.-XII. Cave Hill, 1793 (Templeton): Whitla MS.- still there, 1896 ; Stewart. Near the head of the Six Mile Water; Skerry rocks; rocks about Murlough ; braes near Carntogher; Ben Bradagh, \&c. : Templeton MS. Rocks at Murlough, $1890 ;$ Rev. C. F. D'Arcy. Rocks between Torr Point and Fair Head: Ir. Flor. Wolf Hill Glen and Woodburn (W.Millen): Find I854. Abundant at Woodburn waterfall (G. C. Hyndman): Flor. N.-E. Ballycastle (Miss Hincks): Flor. Olst. Carrick-aRaide (Miss Reid); steep cliffs at Sallagh Braes and rocks at Red Bay (Stewart); Cushendun and Caramurphy glens (Praeger): Flor. N.- $E$. Scawt Hill; Dunseverick; and several other stations in Antrim (Praeger): S.\&P. 2895 . Not rare along the basaltic range from near Umbra to Clontygearagh, Derry, 1835 : Moore MS. Cliffs of Eagle Mountain and cliffs south of Blue Lough, Down: S.\& P. 1892 .

Sea-level in N. Antrim. To $1100 \mathrm{ft}$. in Derry $(C y b$.$) ; to$ $1500 \mathrm{ft}$. in Down (S.\&P.); 1000-1650 ft. in Leitrim (B.\&V.).

The records for Districts-IV. Among loose rocks at the Scalp, near Enniskerry (Flor. Hib.), and-V. Along a river side near Margate, Collon, Louth (Ir. Flor.), have had no recent confirmation. The plant was probably an escape in both stations, as it is in county Armagh, in which latter county, however, it may have been originally native (see Praeger 1893 ). 


\section{E. hirsutum Linn.-Great Willow Herb.}

Districts I. II. III. IV. V. VI. VII. VIII. IX, X. XI. XII. Lat. 51 $1_{2}^{\circ}-55 \frac{1}{4}^{\circ}$. Throughout Ireland. Type, English-British.

Lowland. Wet places and banks of ditches, rivers, and streams; frequent, but rare in many parts of the West. Fll. July-August.

\section{E. parviflorum Schreb.-Small-flowered Willow Herb.}

Districts I. II. III. IV. V. VI. VII. VIII. IX. X. XI. XII. Lat. $511_{2}^{\circ}-55 \frac{1}{4}^{\circ}$. Throughout Ireland. Type, British-English.

Lowland. Wet places; common. Fl. July-August.

E. parviflorum $\times$ obscurum-I. Glengariff: Druce I89I.

\section{E. montanum Linn.-Smooth Willow Herb.}

Districts I. II. III. IV. V. VI. VII. VIII. IX. X. XI. XII. Lat. $51_{2}^{1}{ }^{\circ}-55 \frac{1}{4}^{\circ}$. Throughout Ireland. Type, British.

Woods, banks, walls, gardens, \&c.; common. Fl. June-A ugust.

Sea-level in N. Derry and S. Cork. To $1600 \mathrm{ft}$. in Ben Bulben district $(B . \& V$. ) t to $1900 \mathrm{ft}$. in Tipperary (Hart).

5. † E. roseum Schreb.-Pale Willow Horb.

Districts - - - V. - - - - XII.

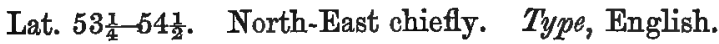

Lowland. Moist walls and damp, shady places; rare. (?) $\mathrm{Fl}$. July-August.

V. Casual on a wet wall near Queensborough, Louth: Praeger 1897. Abundant as a garden weed at Dundrum, Co. Dublin, 1897; Praeger.-XII. In the orchard at Cranmore, 1820 : Templeton MS. Abundant by the towing path between the first and second locks of the Lagan canal (Dr.R. Templeton): Flor. N.-E.-no doubt the same locality as "banks of the Lagan near Cranmore" given in Flor. Ulst. Belfast, 1846 (W. Thompson) : Herb. Babington. Fields near the Ulster railway terminus, Belfast ( $W . H$. Ferguson): Flor. Ulst. On a shaded wall at Ballyskeagh, close by the bridge over the Lagan canal, Down, and in an old plantation by the Lagan at Glenmore, Antrim, 1897 (J. H. Davies) : Ir. Nat. I897, p. 7.

Somewhat uncertain in its appearances and probably often overlooked or confounded with $E$. montanum. Though apparently rare 
in Ireland, there is reason to believe that more careful observation will prove the plant to be of not infrequent occurrence.

\section{E. obscurum Schreb.-Square-stalked Willow Herb.}

$E$. tetragonum Linn. in part-E. virgatum Fries.

Districts I. II. III. IV. V. VI. VII. VIII. IX. X. XI. XII. Lat. $51 \frac{1}{2}^{\circ}-55 \frac{1}{4}^{\circ}$. Throughout Ireland. Type, British.

Damp and marshy places; common. Fl. July-August.

Sea-level in Antrim and Cork. To $1900 \mathrm{ft}$. in Dublin ( $N$. C.).

E. obscurum $\times$ palustre.-I. Glengariff, Cork: Druce I89I.V. Garristown Bog, Co. Dublin ; N. C.-VII. Bog of Linn, Westmeath : Linton I806.-VIII. Oughterard, Galway: M. \& S. I896.XII. Glenariff; Glenshesk; and Giant's Causeway: Shoolbred, I894.

\section{E. palustre Linn.-Marsh Willow Herb.}

Districts I. II. III. IV. V. VI. VII. VIII. IX. X. XI. XII. Lat. 511 ${ }^{\circ}-55 \frac{1}{4}^{\circ}$. Throughout Ireland. Type, British.

In boggy and marshy places; common. Fl. July-August.

Sea-level in N. Antrim and S. Cork. To $2000 \mathrm{ft}$. in Donegal and $2500 \mathrm{ft}$. in Tipperary (Hart).

\section{E. alsinefolium Vill.-Mountain Wizlow Herb.}

Districts - - - - - - - IX. - - Lat. $54^{\circ} \cdot 20^{\prime}$. County Leitrim only. Type, Highland.

Mountain cliffs and rills; very rare. Fl. July.

IX. At the base of the limestone cliffs in Glenade, Co. Leitrim, growing in the springs and at the foot of small trickling waterfalls (Barrington): Journ. of Bot. 1884, p. 247. So far, this is the only Irish station known for the plant.

From 1000 to $1200 \mathrm{ft}$. in Leitrim $(B . \& V$.$) .$

First found in Ireland by Barrington and Vowell in 1884.

\section{CIRCAIA Linn.}

\section{C. lutetiana Linn.-Enchanter's Nightshade.}

Districts I. II. III. IV. V. VI. VII. VIII. IX. X. XI. XII. Lat. $51 \frac{1}{2}^{\circ}-551^{\circ}$. Throughout Ireland. Type, British-English.

Woods, shady places, gardens, \&c. ; frequent. Fl. June-August. To $900 \mathrm{ft}$. in Tipperary (Hart); but usually lowland. 
2. C. alpina Linn.-Alpine Enohanter's Nightshade.

Districts - - - V. - VIII. IX. X. XI. XII. Lat. 531을 $-55 \frac{1}{4}^{\circ}$. North and West. Type, Scottish-Highland.

Shady mountain glens and stony thickets; rare. $F$. JulySeptember.

V. At the base of Carlingford mountain, Louth: Ir. Nat. 1893 , p. 227.-VIII. On the public road at Drimcong, between Galway and Oughterard, and in various mountainous spots in Connemara: Wade Rar: Mountains about Ballinahinch (J. White): Cyb.IX. Ben Bulben (Dickie) : Flor. Ulst. At the foot of the cliffe, Glenade, and on Arroo mountain, Leitrim : B.\&V. $8885 .-\mathrm{X}$. Strabane glen, Tyrone (Admiral Jones): Cyb. Omagh; Newtownstewart; and abundant in Strabane glen, Tyrone, 1896 (Miss M.C. Knowles): Ir. Nat. 1897. Shore of Lough Neagh, south of Ardmore Point, Armagh (Rev. H. W. Lett) : Praeger 1893. Abundant on Inishmacsaint; Dacharne; Gublusk; and other islands in Lough Erne: Praeger 1892.-XI. Inishowen Head (Diokie): Flor. Olst. Plentiful on the hills near Dunfanaghy, Donegal (Prof. E. Murptiy): Cyb. On the hills behind Sesiagh Lake, Dunfanaghy; also in woods by Gartan Lough near Church Hill: Hart 7880.XII. Colin Glen, 1804 (Templeton): Whitla MS.-and in 1896; Stewart. In Glenariff: Templeton MSS. and Shoolbred 1894. Mountains about Glenarm: Ir. Flor. Cave Hill : Flor. Ulst. Cave Hill above the Whitewell quarries; Redhall Glen and Glendun (Stewast): Flor, N.-E. Muff Glen and Desertmartin, Derry, 1835 : Moore MS. Frequent as a garden weed about Belfast: S. \& $P$. 1895. Sparingly at Hollywood and Clandeboye, Down (Praeger): Flor. N.-E. Tollymore Park, Down: S. \&P. 1892. By the Roe near Limavady (Mrs. Leebody): S.\& P. x895.

From 500 to $1600 \mathrm{ft}$. in Leitrim $(B . \& V$.).

Var. INTERMEDIA $(E h r h$.$) - IX. Roadside banks in Glencar,$ Leitrim, $1896 ;$ N.C.-X. On the banks of the Erne near Enniskillen : Ball $183 \dot{9}$. Strabane Glen, Tyrone (Miss M. C. Knowles): Ir. Nat. 1897.-XI.. Shores of Lough. Akibbon near Church Hill; Hart.-XII. .East side of Cave Hill near Belfast: Ball I839. By the path to the caves, Cave Hill (Stewart): Flor. $N .-E$. Glenariff and Glenshesk, Antrim: Shoolbred I894. In Glendun, Antrim, and as a garden weed at Hollywood, Down (Praeger): S.\&P. 1895 . 


\section{ORDER XXVIII.-UMBELIIFER丑.}

\section{HYDROCOTYLE Linn.}

\section{H. vulgaris Linn.-Mars Pennywort.}

Districts I. II. III. IV. V. VI. VII, VIII. IX. X. XI. XII. Lat. $51 \frac{1}{2}^{\circ}-55 \frac{1}{4}$. Throughout Ireland. Type, British.

Marshy and boggy places; common. Fl. May-July. Calcifuge $C$.

Sea-level in N. Derry and S. Cork. To $1500 \mathrm{ft}^{\mathrm{i}}$ in Down $(S . \& P$.$) and in Dublin (N. C.).$

\section{ERYNGIUM Linn.}

1. E. maritimum Linn.-Sea Holly.

Hibernicé Cuוlleann tpaí̄e (Cullen traro), Strand Holly.

Districts I. II. - IV. V. VI. - VIII. - - XI. XII. Lat. $51 \frac{1}{2}^{\circ}-55 \frac{1}{4}^{\circ}$. Coasts of nearly all Ireland. Type, EnglishBritish.

Sandy sea-shores; frequent, but local. Fl. July-August.

\section{SANICULA Linn.}

\section{S. europæa Linn.-Sanicle.}

Districts I. II. III. IV. V. VI. VII. VIII. IX. X. XI. XII. Lat. $51 \frac{1}{2}^{\circ}-55 \frac{1}{4}^{\circ}$. Throughout Ireland. Type, British.

Wrods and bushy places; frequent. Fl. May-July.

Sea-level in N. Derry and S. Cork. To $1500 \mathrm{ft}$. in Down (S.\&P.).

\section{CONIUM Linn.}

\section{C. maculatum Linn.-Hemlock.}

Districts I. II. III. IV. V. VI. VII. VIII, IX, X. XI, XII.

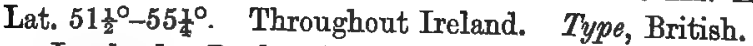

Lowland. Banks, hedges, and waste places; frequent. Fl. June-July.

Abundant near the sea, rare inland, and usually in the neighbourhood of ruins or dwellings. 


\section{SMYRNIUM Linn.}

\section{1. $\ddagger \mathbf{S}$. Olusatrum Linn.-Alexanders.}

Districts I. II. III. IV. V. VI. VII. VIII. IX. X. XI. XII. Lat. $51 \frac{1}{2}^{\circ}-551^{\circ}$. Throughout Ireland. Type, English.

Lowland. Hedges, waste places, and amongst ruins ; frequent. Fl. April-June.

Dr. Rutty, in his Natural History of the County of Dublin; 1772, tells us that this plant: "was formerly blanched in our gardens and eaten with oil, salt, and pepper; but of late has given way to Cellery." Though perhaps introduced in all its localities, it is extremely abundant and has all the appearance of a native in many districts, especially near the sea. Inland, it is much rarer and usually appears as an obviously introduced plant.

\section{APIUM Linn.}

\section{A. graveolens Linn.-Wild Celery.}

Districts I. II. III. IV. V. VI. - VIII. IX. X. XI. XII. Lat. 511일 $-55 \frac{1}{4}^{\circ}$. From South to North. Type, English.

Lowland. Watery places and brackish ditches near the sea; locally abundant. Fl. June-August.

Rare in all its inland stations, where it occurs only as a relic of cultivation.

\section{A. nodiflorum Reichb. fl. -Prooumbent Water-Parsnep.}

Helosciadium nodiflorum Koch.

Districts I. II. III. IV. V. VI. VII, VIII, IX. X, XI. XII. Lat. $51 \frac{1}{2}^{\circ}-55 x^{\circ}$. Throughout Ireland. Type, English.

Ditches, streams, and watery places; common. Fl. JulyAugust.

Sea-level in N. Antrim and S. Cork. To $900 \mathrm{ft}$. in Dublin (N.C.).

Var. ockeatum Bab.-VII. Shore of Lough Owel and Lough Derevaragh, Westmeath : Linton I8g6.

The variety REPENs Hook fil.-Helosciadium repens (Koch)has been recorded from several counties; but there is reason to fear some error of identification. 


\section{A. inundatum Reichb. fll.-Least Marsh-wort.}

Helosciadium inundatum Koch.

Districts I. II. III. IV. V. VI. VII. VIII. IX. X. XI. XII. Lat. $51 \frac{1}{2}^{\circ}-551^{\circ}$. Throughout Ireland. Type, British.

Shallow ponds, ditches, and bog-pits ; frequent. Fl, JuneAugust.

To $700 \mathrm{ft}$. in Kerry (Hart); but usually lowland.

Var. MookeI Syme-X. In the Blackwater at Maghery; near the mouth of the Closet River; in a marsh near Morrow's Point, in the S.-E. corner of Lough Neagh: Praeger 1893.-XII. In drains near Portmore, Antrim (Moore): $C y b$. In drains at Selshan, Antrim, and by the Quoile near Inch Abbey, Down'(Stewart): Flor. N.-E. Marsh at Saul, near Downpatrick, and by the Bann below Kilrea (Praeger): S.\&. P. I895.

This variety is described in Syme's English Botany, vol. iv., 1865 , p. 102 .

\section{CICUTA Linn.}

\section{C. virosa Linn.-Water-Hemlock.}

Districts - - - V. - VII. - IX. X. - XII. Lat. $53 \frac{1}{2}^{\circ}-55 \frac{1}{4}^{\circ}$. Middle and North. Type, English(?).

Lowland. In ditches and by the sides of rivers and lakes; very local. $F l$. June-August.

V. Ardee Bog; along the riverside at Mansfieldtown; and Blackmills, Louth: Ir. Flor. Lough Crew near Oldcastle, Meath : Praeger 1897.-VII. Bog of Linn, near Mullingar: Ir. Flor. By the edge of Lough Ennel near the mouth of the Brosna river: Levinge 1894. Edge of Belvedere Lake, Westmeath, 1891 ; Levinge. On both sides of Lough Ree at Lanesborough: B.\&V. I887-this station extends into - IX. In a lake in the county of Leitrim (Admiral Jones); Gortinty Lough near Drumsna (F.J. Foot): Cyb. Plentiful in Lough Bofin, Leitrim (W. T. Dyer): Rec. Add. Frequent in drains at the south end of Lough Allen : Stewart 1885.X. In Cavan and Fermanagh: Annot. in Threlkeld. "This I found in my travel in the counties of Cavan and Fermanagh" (Dr. Rutty): Nat. His. Dublin, I., p. I7I. About several lakes in Co. Monaghan, and near the foot of the Blackwater, 1805 : Templeton MS. PIentiful in drains and on the banks of Lough Erne, Co. Fermanagh (Dr. Scott) : Mack. Rar. In a marsh at.Crum Castle, Upper Lough 
Erne: Barrington 1884 . On a small island near Maghery and on the shores of Lough Neagh in Armagh (Rev. G. Robinson): Flor. Ust. In Closet River, Armagh (Rev. H. W. Lett); along the shore of Lough Neagh; in the Newry canal; in Mullaghmore Lough and Lough Gilly: Praeger 2893 . In ditches near the lake at Farnham, Cavan: Flor. Hib.-XII. In the Lagan above Lisburn, and drains at Portmore, 1794: Templeton MSS. At Portmore : B. N. F, C. Proo. 1872 . Abundant near Lough Neagh and Lough Beg; by the side of the Bann from Lough Beg to near Coleraine, occasionally (Moor $\varepsilon$ ): Cyb. Legacurry, north-east of Hillsborough, Down, in the mill-dam and down the river: Templeton MS. Drumkee bog, Tullycairne, Down (Corry) : Flor. N.-E.

First discovered by Dr. John Rutty in Cavan and Fermanagh, before 1772 .

\section{CARUM Linn.}

\section{C. verticillatum Koch-Whorled Caraway.}

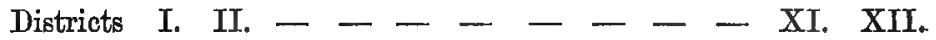
Lat. $51 \frac{3}{4}^{\circ}-55 \frac{1}{4}^{\circ}$. South-West and North. Type, Atlantic.

Moist meadows and salt marshes; locally abundant. Fl. JulyAugust.

I. Found near the Laune Bridge, Killarney, August, 1804, and between Kenmare and Priest's Leap mountain, 1805: Mack. Rar. A common plant in many parts of Kerry; R.DW.S. By the old Kenmare road on Priest's Leap, Co. Cork (Carroll): Allin's Cork. Near Bantry Bay (W. Wilson), and-II. By a roadside west of Millstreet, Cork (Carroll): Flor. Cork.-XI. By Lough Eske, at the north-east corner : Hart $1885 \%$-XII. Bann side below Coleraine, 1797: Templeton MS. Abundant by the Bann, both above and below Coleraine: Moore MS. Very abundant at its Coleraine station, and extends down the Bann to the coast sandhills: $S . \& P$. 1895. Abundant on the headlands at the Giant's Causeway, 1887 (Praeger): Flor. N.-E. By the Lagan near Belfast (Moore): Cyb. Not now found near Belfast: S.\& P. I895. Wet moor at Carnsampson, near Ballycastle (Praeger and Carr): Ir. Nat. 1897, p. 301 .

To $700 \mathrm{ft}$. in Kerry (Hart); but usually lowland.

First found by Templeton in 1797, and first published by Mackay in 1806. 


\section{SIUM Linn.}

1. S. latifolium Linn.-Broad-leaved Water-Parsnep. Districts - - - V. VI. VII. - IX. X. XI. XII. Lat. $52 \frac{s}{4}^{\circ}-55 \frac{1}{4}^{\circ}$. Middle and North. Type, English-Germanic.

Lowland. River-sides, ditches, and watery places; local and rare. Fl. July-August.

V. Boggy places near Slane: Ir. Flor-CVI. By the Shannon near Limerick; near Corofin, Clare; by the Fergus, near Ennis: Mack Rar. Still in the last station: Corry 2880. Dromore Lake near Corofin $(F . J$. Foot): Cyb. Near Tuam and in ditches between Milough and Ballinasloe: Wade Rar. Near the bridge at Portumna (Moore) : Cyb. By the Suck east of Clonbrock: Praeger 1896.-VII. Near Mullingar, Westmeath (F. J. Foot): Cyb. In a ditch near Shannon Harbour: Graham I840. East side of the Shannon at Portumna bridge, Tipperary $(M$. Dowd) : Rec. Add.-IX. In many places around Lough Ree: $B . \& V .{ }_{2} 887 .-X$. On the banks of a river near Lough Erne (Dr. Scott): Mack. Rar. Plentiful near Enniskillen, Lough Erne: Barrington 2884.-XI. Near Culmore, Derry, 1835 : Moore MS.-not seen there recentlyXII. In the large drain at Portmore Park (Templeton): Whitla MrS. West end of Glenarm Park (G. Dickie): Flor. Olst. Between the Bann and Portstewart, and near Lough Neagh in Derry; marsh at Selshan by Lough Neagh, Antrim (Moore): Cyb.

\section{S. angustifolium Linn.-Narrow-leaved Water-Parsnep.}

S. erectum Huds.-Berula angustifolia Koch.

Districts I. II. III. IV. V. VI. VII. VIII. IX. X. XI. XII. Lat. $51 \frac{1}{2}^{\circ}-55^{1}{ }^{\circ}$. Throughout Ireland. Type, English-British.

Lowland. Ditches and marshy places; frequent and locally abundant. Fl. July-September.

Rare in the North, especially in Co. Donegal.

\section{ÆAGOPODIUM Linn.}

\section{1. $\ddagger$ IE. Podagraria Linn.-Gout-weed.}

Districts I. II. III. IV. V. VI. VII. VIII. IX. X. XI. XII. Lat. $51^{\frac{3}{4}}-55^{\circ}$. Throughout Ireland. Type, British-English.

Lowland. Woods, hedges, waste places, by ruins, and in gardens; frequent. $F l$. June-July. 
Rare in the South and West; abundant in many parts of Ulster and East Ireland. Usually occurring in the neighbourhood of dwellings, but thoroughly established and occasionally appearing in wild-looking stations.

\section{PIMPINELLA Linn.}

\section{P. Saxifraga Linn.-Burnet Saxifrage.}

Districts I. II. III. IV. V. VI. VII. VIII. IX, X, XI, XII. Lat. 52 $2^{\circ}-55 \frac{1}{4}^{\circ}$. Throughout Ireland. Type, British.

- Dry pastures, banks, and gravelly places; rather common. Fl. July-August. Calcicole $B$.

Very rare in Kerry and rare in Donegal; common on the limestone, especially in the East and Centre.

From sea-level to $850 \mathrm{ft}$. in Dublin $\left(N . C_{0}\right)$; but usually lowland.

\section{P. magna Linn.-Greater Burnet Saxifrage.}

P. major Huds.

Districts I. II. - - - VI. VII. VIII. IX. - - Lat. $51 \frac{1}{2}^{\circ}-54^{\circ}$. South and West. Type, English-Germanic.

Lowland. Bushy banks; local and rather rare. Fl. JulyAugust. Caleicole $B$.

I. Muckross Woods near the Abbey : Mack. Rar. 1806-and in $1896 ; R . W . S$. At Killarney (Babington): Cyb. Ditchbanks by the road at Ballyferriter, Dingle promontory: Hart. 1884. Near Beaufort bridge; Ballycarty; and several other localities in Kerry; R.W.S. Castletownsend, at the Point, abundantly; rare in South Cork: Allin's Cork.-II. In great plenty about Cork: Smith's Cork. By the rivers Funcheon and Owbeg, North Cork, 1896; R.W.S. Near Buttevant; Charleville; Kilcoleman (Carroll); locally abundant in the north of the county: Allin's Cork. By the Blackwater above Lismore, Waterford: Hart 1885 8.-VI. About the high-road, Rostrevor, Clare: Wade Rar. Scattery Island -opposite Killush, Clare (Moore): Cyb. Near Kilronan, Aranmore Island: Otiver $185 \mathrm{I}$. Abundant in Aranmore Island: Hart 1875. Near Rinekirk and about Foynes, Limerick: Stewart $\mathbf{2} 890$. Plassy near Limerick (Carroll); and Ballingarry, Limerick ( $\boldsymbol{M r}$. Gubbins): $C y b .-V I I$. In North Tipperary, between Boher and Glenstal; at Anna Cooty; and near Newmarket: Hart I88I $\gamma_{--}$ 
VIII. Dangan, beyond Galway: Wade Gallovid. In abundance, half way between Galway and Oughterard: Graham 1840. About Oughterard (Moore) : Cyb.-IX. Plentiful at Cong, Mayo: Wade Gallovid I80I-still plentiful there in 1895 ; Miss M. F. Jackson. Banks of the Moy above Foxford, Mayo (More): Cyb.

\section{CONOPODIUM Koch.}

\section{C. denudatum Koch-Pig-nut.}

Bunium flexuosum With.

Districts I. II. III. IV. V. VI. VII. VIII. IX. X. XI. XII. Lat. $51 \frac{1}{2}^{\circ}-55 \frac{1}{4}^{\circ}$. Throughout Ireland. Type, British.

Woods and pastures; frequent. Fl. May-June.

Sea-level in N. Antrim and S. Cork. To $1300 \mathrm{ft}$. in Ben Bulben district $\left(B . \& V_{?}\right)$.

\section{MYRRHIS Scop.}

1. *M. odorata Scop.-Sweet Cicely.

Districts - - - [V.] - [VII. $]--$ X. XI. X.II.

Waste places, roadsides, \&c.; usually near houses and nowhere native. $F l$. May-July.

[V: Near Oldcastle and other places in county Meath (Rev. Mr. Halpin): Flor. Hib.-VII. Churchyard of Crossadree, Westmeath (Miss $E$. Reynell) : $C y b$. -not recently reported from Districts V. or VII.]-X. Tanderagee, Armagh (Rev. G. Robinson): Flor. Ulst. Roadsides near Eglish Church; at base of Camlough mountain; and at Ballymyre, Armagh : Praeger 1893. Near Monaghan (Miss Maffett) : Cyb.-XI. In Donegal, near Killybegs, \&c., but always near cottages (More): Cyb. Rathmelton and Tully

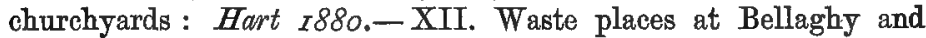
Ballycarry (W. H. Ferguson); in Colin Glen (Diekie); at Ballyronan and Moneymore, Derry (Rev. W. T. Whan): Flor. Ulst. In Co. Down, at Hillsborough and Newtownards (Stewart): Cyb. At Dundonald (Praeger); between Comber and Castle Espie (Corry): Flor. N.-E. Among rocks at Umbra, Magilligan (Moore): Flor. - Hib. Loughbrickland and Annaclone, Down (Rev.W. H. Lett); - Glendun (Rev. S. A. Brenan); Dunseverick; Giant's Causeway, - \&c. (Praeger); and many other stations in Down and Antrim: S. \& $P$. $I 895$. Often found near houses as an escape, but certainly naturalized in some places: Flor. $N$. $E$. 


\section{CH ÆROPHYLLUM Linn.}

\section{1. † C. temulum Linn.-Rough Chervil.}

Districts - - III. IV. V. VI. VII. - - X. - XII. Lat. $52^{3}{ }^{\circ}-55 \frac{1}{4}^{\circ}$. East Ireland, chiefly. Type, British-English.

Lowland. Hedge-banks and roadsides; rare. Fl. June-July.

III. Roadsides near Kilnock, Carlow (Carroll): Cyb. Between Maganey and Carlow, and between Milford and Leighlin Bridge: Hart I885.-IV. Near Kilcool and Killincarrig, Wicklow, 1870; Hart.-V. Plentiful by the roadside a mile north of Dunleer, Louth; Barrington. Roadside a little south of Dundalk: Templeton MSS. Plentiful by roadsides near Mansfieldtown, Louth, $1895 ; N$. C. Laytown; Kilmessan; Navan, \&c., Meath: Praeger 1897. Near -Dublin, at Glasnevin; Donnybrook, \&c. : Ir. Flor. Hedge banks near Coolock (Moore): Cyb. Roadside west of Lucan, Co. Dublin, $1895 ; N$. C. Hedge near Old Connaught (Barrington): Reo. Add. By the Barrow a little above Athy, Kildare: Hart 1885.-VI. At Finnevara, Co. Clare, 1895; P. B. O'Kelly.-VII. Edenderry, King's Co.: Praeger I897.-X. Near Maghery ferry; near Milltown; near Derryadd Bay, \&c., Armagh, chiefly near the shores of Iough Neagh: Praeger I893.-XII. Ballycastle (Miss Hincks): ;Flor. Ulst. On the shores of Lough Neagh near Ballyronan (Moore): $: C y b$. Plentiful on the roadside and on bushy banks of Lough Neagh near Derrymore, Antrim (Stewart): Flor. N.-E.

Doubtfully native in many of its Irish stations.

\section{SCANDIX Linn.}

1. S. Pecten-Veneris Linn-Shepherd's Needle.

Districts I. II. III. IV. V. VI. VII. VIII. IX. X. XI. XII. Lat. $51 \frac{3}{4}^{\circ}-55 \frac{1}{4}^{\circ}$. Throughout Ireland. Type, British-English.

Lowland. Cultivated fields ; frequent. Fl. June-August.

A wide-spread species; but seldom abundant.

ANTHRISCUS Bernh.

1. A. vulgaris Pers.-Beaked Parsley.

Districts [I.] II: III. IV: V. VI. VII. VIII. IX. - [XI.] XII. . Lat. 52 $2^{\circ}-55 \frac{1^{\circ}}{6}$. Throughout Ireland, almost. Type, British.

Lowland. Roadsides, dry banks, and waste places, especially in sandy soil; rather rare. Fl. May-June. 
[I. About Tullig, west of Killorglin, Kerry, the only locality known in the county; R.W.S. Casual in Co. Cork: Allin's Cork.]-II. Ruins near Clonmel; Miss S. Grubb. Fethard, Tipperary; R.W.S.-III. Between Browne's Hill and Carlow, and near Ballinacarrig ( $\boldsymbol{R}$. Clayton Browne); between Mountrath and the railway station $(T$. Chandlee): Rec. Add. Abundant about Jerpoint Abbey, Thomastown; Dr. E. P. Wright. Leighlin Bridge, Carlow: Hart 1885.-IV. Plentiful on the Murrough of Wicklow (Moore) : Cyb. Lady's Island, Wexford: Hart $1883 \beta$.

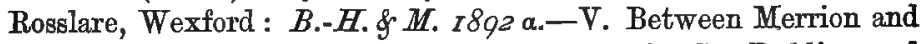
Booterstown: Wade Dubl. 1794. Frequent in Co. Dublin, and abundant at Rush; Skerries; Sutton; Portrane; and other stations on the coast, $1894 ; N . C$. At Betaghstown, coast of Meath; Hart.-VI. About Kilronan, Aranmore Island: Hart 1875.VII. At Kinnegad, Westmeath, 1815: Templeton, Journal. By Lough Ree, near Lanesborough, Longford; and at Coosan Point, Westmeath: B.\& V. I887.-VIII. and IX. About the village of Foxford, Mayo (MFore) : Cyb.-[XI. A casual at Culmore, Inishowen (W.E. Hart); very rare and hardly established in Donegal; Hart.]-XII. Gravelly banks on the Curran of Larne, 1794 (Templeton): Whitla MS.-still there: S.\&P. 2895. Abundant at Magilligan, 1835: Moore MS. At Magilligan, 1878 (Corry); in several stations in Down; but not common in north-east Ireland: Flor. N.-E.

\section{A. sylvestris Hoffm.-Coro-Parsley.}

Charophyllum sylvestre Linn.

Districts I, II. III. IV. V. VI. VII. VIII. IX, X, XI. XII. Lat. $51_{4}^{\circ}-55^{\circ}$. Throughout Ireland. Type, British.

- Hedge-banks, shady plàces, \&c.; common. Fl. April-June.

Sea-level in N. Antrim and in Kerry. To $1500 \mathrm{ft}$. in Sligo (N. C); to $2400 \mathrm{ft}$. in Tipperary (Hart).

Rare in Cork and in Kerry, and in many parts of the West.

\section{FENICULUM Linn.}

\section{1. $\ddagger$ F. officinale All.-Fennel.}

Districts I. II. - IV. V. VI. - VIII. - - - XII. Lat. $51 \frac{1}{2}^{\circ}-541_{4}^{\circ}$. South and South-East, chiefly. Type, English. Lowland. Dry banks and waste places, usually near houses; 
perhaps native on the south coast, but elsewhere rare and obviously introduced. Fl. July-August.

I. On a bridge in the Improvements at Lixnaw, growing wild plentifully: Smith's Kerry. By Barrow Harbour, Kerry; R.W. S. Plentiful from Old Court to Baltimore, Cork, 1896; Phillips. II. Common about the harbour of Cork and apparently indigenous (Carroll); naturalized at Glanworth castle, Fermoy (T. Chandlee); near Clonmel, Tipperary, and Dunmore on the Waterford coast (Miss S. Grubb): Cyb. Waterford coast opposite Youghal: Hart I883 $\beta$. Blenheim Hill; near Creadon Head, \&c., Waterford: B.-H. \& G. I889.-IV. On the coast at Curracloa, Wexford (J. Morrison): Cyb. Coast near Kilmichael Point, Wicklow : Hart I88I a.-V. Killiney; Chapelizod; Clonskeagh, \&c.: Wade Dubl. On rough banks near the Bray river: Templeton MS.-and in 1894; $N$. C. Frequent in Co. Dublin and thoroughly established at Knockmaroon, 1894 ; and above the Ward river at Swords, $1895 ; N$. C.VI. Railway bank in slob-land near Foynes, Limerick: Stewart I89o.-VIII. Near Galway, an escape (Prof. Melville): Cyb.XII. On both sides of Killough Bay, Down (Stewart): Rec. Add.

\section{CRITHMUM Linn.}

\section{C. maritimum Linn.-Samphire.}

Districts I. II. III. IV. V. VI. - VIII. IX. - XI. XII. Lat. $51 \frac{1}{2}^{\circ}-55 x^{\circ}$. Coasts of all Ireland. Type, Atlantic.

By the sea, on rocks, cliffs, and clay banks, also on shingly beaches; frequent. $F$. July-August.

Very rare in District XII., where it occurs only in Co. Down near Bangor and at Kearney Point in the Ards, in both stations very sparingly (Stewart): Ir. Nat. 1896, p. 297.

\section{GNANTHE Linn.}

\section{E. fistulosa Linn.-Common Water-Dropwort.}

Districts I. II. III. IV. V. VI. VII. - IX. X. XI. XII. Lat. 51 $1_{4}^{\circ}-551^{\circ}$. Throughout Ireland, almost. Type, English-British.

Lowland. Ditches, pools, slow streams, and marshy meadows; frequent. Fl. July-August.

Rare in north-east Ireland, very rare in Donegal, and apparently absent from Kerry. 
2. $\boldsymbol{\dagger}$ E. pimpinelloides Linn.-Pimpernel Dropwort.

Districts - II. $--\overline{-}-$ - - - -
Lat. $51^{\circ} 48^{\prime}$. Co. Cork only. Type, English.

Lowland. Pastures near the sea; very rare. Fl. June-August.

II. In some abundance in an extensive pasture field at Trabolgan, Co. Cork, 1896-97; Phillips.

The only locality at present known to Mr. Phillips is a large grazing field sheltered by plantations forming part of the extensive demesne of Trabolgan, where the plant is not free from the suspicion of having been accidentally introduced. Its distribution in England, however, is quite consistent with its appearance as a native in the south of Ireland; and as the plant might easily be mistaken for $Q E$. Lachenalii there is a good reason to expect its discovery in other localities in the South. On the whole, it appears to be entitled, at least, provisionally, to a place in the Irish flora.

The earlier Irish records for this plant in Flor. Hib. should no doubt be referred to the following species.

\section{E. Lachenalii C. Gmel.—Sea-side Dropwort.}

Districts I. II. III. IV. V. VI. - VIII. IX. - XI. XII. Lat. $51 \frac{1}{2}-55 \frac{1}{4}^{\circ}$. Coasts of all Ireland. Type, English-British.

Salt marshes; frequent. Fl. August-September.

\section{E. crocata Linn.-Hemlock Water-Dropwort.}

Districts I. II. III. IV. V. VI. - VIII. IX. X. XI. XII. Lat. $511^{\circ}-551^{\circ}$. Throughout Ireland. Type, British-English.

Ditches, river-banks, \&c. ; frequent. Fl. June-July.

Sea-level in N. Donegal and S. Cork. To $800 \mathrm{ft}$. in Dublin (N. C.); but usually lowland.

\section{E. Phellandrium Lamk.-Fine-leaved Water-Dropwort.}

Phollandirium aquaticum Linn.

Districts - II. III. IV. V. VI. VII. VIII. IX. X. - XII. Lat. $52 \frac{1}{4}^{\circ}-55 x^{\circ}$, Throughout Ireland, almost. Type, EnglishGermanic.

Lowland. Rivers, lakes, canals, \&c. ; frequent. Fl. June-Aug.

Frequent and locally abundant in many of the Irish rivers and lakes, as in the Shannon, Barrow, Nore, Suir, Blackwater, Boyne, 
Fergus, and Bann, and in Loughs Ree, Erne, and Neagh, also in the Royal and Grand Canals in Dublin, and the Lagan canal in Antrim. Rare in the South and West and apparently absent from Donegal and Kerry.

Var. Fudviatnis (Coleman)-V. Grand Canal, Kildare: $C y b$. Royal Canal near Dublin and Lucan, $1890 ; R . W$. S.-VII. Grand Canal between Monasterevan and Portarlington: $C y b$.

\section{ATHUSA Linn.}

1. 玉. Cynapium Linn.-Fool's Parsley.

Districts I. II. III. IV. V. VI. VII. VIII. IX. X. XI. XII.

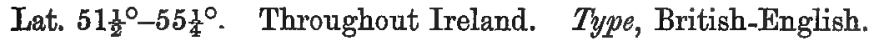

Lowland(?). In cultivated and waste ground; frequent and locally abundant. Fl. July-August.

\section{LIGUSTICUM Linn.}

\section{L. scoticum, Linn.-Scottish Lovage.}

Haloscias scoticum Fries.

Districts -- - - - - - - - XI. XII. Lat. $54 \frac{3}{4}^{\circ}-55 \frac{1}{4}^{\circ}$. North coast of Ireland. Type, Scottish.

Sea-cliffs and rocky shores; rare. Fl. July-August.

XI. Norway Point, Clonmanny, Donegal, 1839 : Herb. C. Moore. In great profusion at Inishowen Head, and at Culdaff and Giveny in the same District (Dickie): Flor. Olst. Downing's Bay near .Carrigart and at Dunaff Head (Hart) : Rec. Add. Cliffs of Erris; Fanet Point; shores of Mulroy Bay at Glinsk and Ballyhooriskey; Melmore Point; Horn Head; and east of Dunfanaghy ; characteristic of the Donegal sea cliffs : Hart 1879 . On Tory Island : Barrington 1879.-XII. On the rocks about Donaghadee and the Copeland Isles, 1793 (Templeton): Whitta MS. Mew Island off Donaghadee (Corry): Flor, N.-E. Garron Head, near Cushendall, Antrim (Moore): Cyb. Between Portstewart and Portrush in several places where the sea-spray washes over it: Moore MS. Sparingly at Downhill, Derry, and still plentiful between Portrush and Portstewart (Mrs. Leebody): S.\&P. I895. Rocks on the shore at Bushfoot, Antrim, 1888 (Praeger); and re-found at Garron Point (Rev. S. A. Brenan) : B. N. F. C. Proc. I892-93.

First found by. Templeton in 1793. 


\section{ANGELICA Linn.}

\section{A. sylvestris Linn.-Wild Angelica.}

Districts I. II. III. IV. V. VI. VII. VIII. IX. X. XI. XII. Lat. 51 $\frac{10}{2}-55 x^{\circ}$. Throughout Ireland. Type, British.

Damp woods, by ditches, and streams, and on moist mountain and sea-cliffs; common. Fl. July-August.

Sea-level in N. Donegal and S. Cork. To $1450 \mathrm{ft}$. in Derry (Hart); to $1700 \mathrm{ft}$. in Ben Bulben district $(B . \& V$.); to $2100 \mathrm{ft}$. in Mayo and $2500 \mathrm{ft}$. in Tipperary (Hart); to $2800 \mathrm{ft}$. in Kerry (N.C.).

\section{PEUCEDANUM Linn.}

\section{1. *P. sativum Benth.-Wild Parsnep.}

Pastinaca sativa Linn.

Districts I. II. III. IV. V. VI. - VIII. - - XI. XII. Lat. $51 \frac{3}{4}^{\circ}-55 \frac{1}{4}^{\circ}$. From South to North. Type, English.

Lowland. Roadsides, quarries, and waste places in light soils; rare in a fully naturalized state. Fl. June-July.

I. Roadsides near Killorglin and the Spa, Tralee; R.W.S. Roadside near Rathclaren rectory, Cork: Allin's Cork.-II. Strand of Little Island, Cork : Drummond I8r8. Near Whitepoint, Cove : Flor. Cork. At Youghal and Ballycotton, 1853 (J. Sullivan): Annot. in Flor. Cork. Roadside at Ballycrenane near Cloyne: Allin's Cork. Abundant on roadsides and in fields near Gearagh, Macroom, 1897 ; Phillips. Near Ardmore, Waterford (Rev. T. Allin): Reo. Add. 1872 - and in 1882: Hart $1883 \beta$. Near Passage, Waterford: B.-H.\&G. 1889 .-III. On the esker near Maryborough; Praeger. Abundant on railway banks near Portarlington, 1896 ; N.C.-IV. Rosslare; Fethard; and Duncannon, Wexford; looking native on sand-hills at Rosslare: Hart $1883 \beta$. By fences near Pilltown stage and near Cheek Point, Wexford:

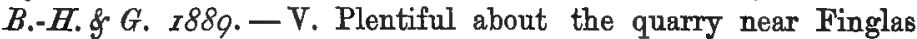
Bridge: Wade Dubl. 7794 -still abundant there and thoroughly naturalized in $1895 ; N . C$. Old and new quarries above Sutton and Howth (J. White); and near Ballitore, Kildare ( $T$. Chandlee): Cyb.-VI. Among ruins at Kilmurvy, Aranmore Island: Hart 1875.-VIII. Roadsides and banks about Newport, Mayo: Hart z883 a.-XI. Donegal Castle (Hart): Rec. Add.-XII. Near the 
foot of the Crumlin river, 1799: Templeton MS. Abundant in sandy cultivated fields at Magilligan, Derry (Moore) : Cyb.-still abundant there and quite naturalized: S. \& P. 1895 .

\section{HERACLEUM Linn.}

\section{H. Sphondylium Linn.-Cow-Parsnep.}

Districts I. II. III. IV. V. VI. VII. VIII. IX. X. XI. XII.

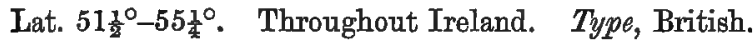

Meadows, hedges, and waste places; common. Fl. JuneAugust.

Sea-level in N. Donegal and S. Cork. To $1450 \mathrm{ft}$. in Derry (Hart); to $1600 \mathrm{ft}$. in Ben Bulben District $(B . \& V$.).

\section{DAUCUS Linn.}

\section{D. Carota Linn.-Wild Carrot.}

Districts I. II. III. IV. V. VI. VII. VIII. IX. X. XI. XII. Lat. $511_{2}^{\circ}-551^{\circ}$. Throughout Ireland. Type, British.

Dry banks, pastures, and waste places, especially near the coast; common. Fl. July-August.

Sea-level in N. Antrim and S. Cork. To $600 \mathrm{ft}$. in Dublin (N. C.); but usually lowland.

\section{CAUCALIS Linn.}

\section{C. Anthriscus Huds.- Upright Hedge-Parsley.}

Toritis Anthriscus Gartn.

Districts I. II. III. IV. V. VI. VII. VIII. IX. X. XI. XII. Lat. $51 \frac{1}{2}^{\circ}-55 \frac{1}{4}^{\circ}$. Throughout Ireland. Type, British-English.

Hedges, waysides, and waste places; common. Fl. JulySeptember.

- Sea-level in Antrim and Cork. . To $900 \mathrm{ft}$. in Dublin ( $N . C_{\text {. }}$ ).

2. C. nodosa Scop.-Frotted Hedge-Parsley.

Toritis nodosa Gærtn.

Districts I. II. - IV. V. VI. VII. - - X. [XI.] XII. Lat. $51 \frac{1}{2}^{\circ}-55 \frac{1}{4}^{\circ}$. From South to North. Type, English.

Lowland. Dry banks, waste places, at foot of walls, \&c.; frequent. FFl. June-August. 
I. By Kenmare Harbour; in several localities about Tralee; Fenit; Ardfert, \&c.; frequent in North Kerry; R.W.S. At Baltimore; on Inish Sherkin; and near Bro Head, 1896; andII. At Ballycotton, 1895, and Glanmire, 1896 ; not infrequent in Co. Cork; Phillips. Fethard, Tipperary; Praeger. Mime Head, Waterford, and-IV. Tinnyberna and Bannow Island, Wexford: Hart $I 883 \beta$. Near Bray; Greenwood Pim.-V. In dry banks below Ringsend, lying upon the ground near the sea; Threlkeld. Donabate; Skerries ; St. Patrick's Island; Drimnagh, \&c. ; frequent in Co. Dublin; N.C.-VI. In the Isles of Aran (Dr.E.P.Wright): Herb. T. C.D. Roadsides near Portumna, 1896; N. C.-VII. Recorded for this District in 1st Ed. Cyb. but no locality available.$\mathbf{X}$. Roadside at Drumintee Chapel, west of Jonesborough, and on the bridge over'the Bann on the borders of Down and Armagh: Praeger 1893.- [XI. Very sparingly and casually introduced near Moville, Donegal; W. E. Hart].-XII. Gravelly banks on the Curran of Larne, 1797 (Templeton): Whitla MS. Ballyronan, Derry (Rev. W.J. Whan); Ballycastle, Antrim (Miss Hincks): Flor. Ulst. Carnlough Bay, Antrim (Moore): Cyb. Frequent in some parts of the Co. Down coast, especially between Ardglass and Clough; roadside near Portbradden and Giant's Causeway, Antrim (Stewart): Flor. N.-E.

Less frequent inland than near the coast.

\section{ORDER XXIX.-ARALIACEE.}

HEDERA Linn.

\section{H. Helix Linn,-Ivy.}

Hibernicé Eıbean (Evvin).

Districts I. II. III. IV. V. VI. VII. VIII. IX. X, XI. XII. Lat. $51 \frac{1}{2}^{\circ}-55 \frac{1}{4}^{\circ}$. Throughout Ireland. Type, British.

Rocks, banks, woods, walls, \&c.; common. Fl. OctoberNovember.

Sea-level in N. Donegal and S. Cark. . To $1740 \mathrm{ft}$. in Mayo (Hart); to. $2000 \mathrm{ft}$. in Down (S.\&P.).

The so-called "Irish ivy" has not yet been found growing in Ireland in any place in which it can be considered native, 


\section{ORDER XXX.-CORNACE王,}

\section{CORNUS Linn.}

\section{C. sanguinea Linn,-Cornel; Dogwood.}

Districts - - - - VI. VII. - IX. X. XI. Lat. $53^{\circ}-541^{\circ}$. West Ireland, chiefly. Type, English.

Hedges, thickets, and rocky places; rare. Fl. June-July.

VI. In crevices of limestone rocks, South Isles of Aran, truly wild : Mack. Cat. \& Flor. Hib. On all three Isles of Aran, especially by the shore west of Killeaney (Hart): Rec. Add. Ballynalacken, Co. Clare: Corry I880. Near Poulsallagh, Clare, 1892; Levinge.-VII. On Bounla Island, Lough Derg, Tipperary, sparingly, but appearing native, $1896 ; N . C$. Knock Ross, Westmeath, well established if not indigenous: Levinge 1894. Hedges four miles west of, and also one mile north of, Philipstown: Praeger $1897 .-$ IX. In considerable quantity on the limestone cliffs of Seafin, Sligo, $1896 ; N . C$. Cliffs of Kesh Corran, Sligo, 1897; Praeger.$X$. On an islet in the lake at Lough Gall manor, Armagh, apparently indigenous: More I860.-XI. Sparingly on the right bank of the Erne and the left bank of the Bundoran river, native : Hart $I 885 \gamma$.

Also recorded from the counties of Cork, Kilkeniny, Carlow, Dublin, and Kildare, where, however, there is reason to suspect that it was planted.

To $900 \mathrm{ft}$. in Sligo $\left(N, C_{\bullet}\right)$, but usually lowland.

\section{ORDER XXXI.-CAPRIFOLIACE正,}

\section{ADOXA ILinn.}

\section{A. Moschatellina Linn.-Moschatel.}

Districts - - - - - - - - - XII.

Lat. $54^{\circ} 35^{\prime}$. Co. Antrim only. Type, British.

Bushy places and shady banks; very rare. Fl. April-May.

XII. "Found on the shaded banks of the Milewater River about a quarter mile above where the tide flows. First observed there by Dr. J. L. Drummond and seen by myself in April, 1820:" Templeton MSS. Cave Hill and Glen of Jennymount [Milewater stream] 
near Belfast (Dr. Drummond \& Mr. Whitla): Flor. Hib. Seen growing sparingly in the Milewater and Jennymount stations, which are practically one, by $T$. $H$. Corry in $1878:$ Flor. $N$.-E. Among bushes in the Deer Park at Cave Hill; and Belvoir Park (Mr. Millen) : Flor. Ulst. Still lingers in one spot by the Milewater, and under one or two fallen rocks in the Deer Park: Flor. N.-E. Almost extinct now : S.\&P. 1895 .

Setting aside the Belvoir Park station as suspicious, there is reason to believe that the plant is (or was) native on Cave Hill and by the Milewater. It seems doomed to early extinction.

\section{SAMBUCUS Linn.}

\section{S. nigra Linn.-Elder.}

Districts I. II. III. IV. V. VI. VII. VIII. IX. X. XI. XII. Lat. 51 $1^{\circ}-55 \frac{1}{4}^{\circ}$. Throughout Ireland. Type, British-English.

Hedges, woods, thickets, \&c. ; frequent. Fl. June-July.

Sea-level to $1100 \mathrm{ft}$. in Dublin (N. C.).

Frequently planted in cottage gardens and rarely occurring in thoroughly wild stations.

\section{2. * S. Ebulus Linn.-Dwarf Elder; Danewort.}

Districts I. II. III. IV. V. VI. VII. - IX. X. XI. XII. Lat. $51 \frac{1}{2}^{\circ}-55 \frac{1}{4}^{\circ}$. Throughout Ireland, almost. Type, English.

Hedges, banks, waysides, rocky places, and about ruins; rather rare and usually in suspicious situations. Fl.July-August. Calcicole $C$.

In most cases a more or less obvious garden outcast or relic of ancient cultivation, but well established in many stations and looking wild enough on limestone crags in Co. Clare.

\section{VIBURNOM Linn.}

\section{V. Opulus Linn.-Guelder Rose.}

Districts I. II. III. IV. V. VI. VII. VIII. IX. X. XI. XII. Lat. $51 \frac{1}{2}^{\circ}-551^{\circ}$. Throughout Ireland. Type, British-English.

Woods, hedges, and bushy or rocky places; frequent. Fl. June-July.

To $1000 \mathrm{ft}$. in Queen's Co. (Hart). 


\section{LONICERA Linn.}

\section{L. Periclymenum Linn.-Woodbine; Honeysuckle.}

Hibernicé Feażloz (Fay-lōge).

Districts I. II. III. IV. V. VI. VII. VIII. IX. X. XI. XII. Lat. $51 \frac{1}{2}^{\circ}-55 \frac{1}{4}^{\circ}$. Throughout Ireland. Type, British.

Woods, hedges, and rocky places; common. Fl. June-August.

Sea-level in N. Derry and S. Cork. To $2000 \mathrm{ft}$. in Down (S.\&.P.); to $1600 \mathrm{ft}$. in Tipperary (Hart).

\section{ORDER XXXII.-RUBIACEE.}

RUBIA Linn.

\section{R. peregrina Linn.-Wild Madder.}

Districts I. II. - IV. V. VI. - VIII. IX. - - Lat. $51 \frac{1}{2}^{\circ}-53 \frac{3}{4}^{\circ}$. South and West, chiefly. Type, Atlantic.

Lowland. Bushy banks and rocky places, usually near the sea; locally abundant. $F^{\prime} l$. June-August. Calcicole $B$.

I. In the island of Inisfallen near Lough-lane: Smith's Kerry. Abundant at Ross; Muckross; and Inisfallen, Killarney: Wade Rar. .804-and in $1890 ; R . W . S$. Near Kenmare; Derrynane; Barrow Harbour, Kerry: R.W.S. I8go. Glengariff and Myros Wood, Cork: Allin's Cork. Near Clonakilty, 1891; and-II. Frequent round Cork Harbour, 1896 ; Phitlips. On all the prominent. bluffs and headlands of the Waterford coast: Hart 1883 .IV. Duncannon; the Nook; Arthurstown, South Wexford: B.-H.\&G. I889. Steep rocks south end of Bray Head: Praeger I897.- V. Near the lead mines, Dalkey: Wade Dubl. I794-and in $1895 ; N . C$. On the Hill of Howth: Wade Rar. I804-still there in 1896 ; Miss S. Colgan.-VI. At Castle Taylor, Galway: More 1855. Abundant in all three Isles of Aran, 1892, and in the Burren district of Clare, $1895 ; N . C$. At Ringmoylan; Askeaton; and Foynes, Limerick: Stewart 1890 .-VIII. Plentiful on the shores of Lough Mask (Prof. Melville): Cyb. Salruck, Galway; and Mweelrea, Mayo: Hart 1883 a.-IX. Banks of Lough Carra, Mayo: Ball I839. South side of Lough Mask, apparently scarce: M. \& S. I896.

Very rare in East Ireland where it appears to be confined to two limited stations on Dublin Bay. Its most inland locality, Lough Mask, is not more than fifteen miles from the nearest sea. 


\section{GALIUM Linn.}

\section{G. boreale Linn.-Northern Bedstraw.}

Districts I. II. - - - VI. VII. VIII. IX. X. XI. XII. Lat. $52^{\circ}-551^{\circ}$.. West and.North, chiefly. Type, Highland.

Moist, rocky places; locally abundant. Fl. June-August. Calcicole $B$.

I. In a marshy spot half way up Mangerton mountain, Kerry : Flor. Hib. Many spots around the Lower Lake and the east end of the Middle Lake, Killarney; R.W.S.-II. In Croan marsh near Clonmel, Waterford (Miss S. Grubb): Cyb.-VI. and VII. Frequent in both districts, occurring in Clare, Galway, Tipperary, Westmeath, and Longford; specially abundant on the shores and islands of Lough Ree $(B . \& V . I 887)$, and of Lough Derg ( $\boldsymbol{N} . \boldsymbol{C}$. 1897).-VIII. Plentiful on islands in Lough Corrib: Wade Gallovid. On Canova Island, Lough Corrib: More I860.-IX. About Castlebar, Mayo: Brown Fascic. 1788. Banks of Lough Carra, Mayo: Ball 1839. Lough Melvin, Leitrim (W. H. Harvey): Herb. T.C.D. Shores of Lough Cullin, Mayo (More): Cyb. By Lough Bofin, Leitrim (W. T. Dyer): Rec. Add. Shore of Lough Ree in Roscommon, and sparingly at Lough Gara in the same county: Foot 2865. - X, On most of the islets in Lower Lough Erne: Barrington 1884. Banks of Lough Neagh, Armagh : More 1860. Ardmore Glebe (Rev, H. W. Lett); Bird Island, Lough Neagh: Praeger 1893.-XI. St, John's Point, Killybegs, and south side of the river at Ballyshannon; very rare in Donegal : Hart I885 \% \& I886.XII. Stony margin of Lough Neagh, a little south of Portmore, 1808 (Templeton): Whitla MS. Frequent, but not general, in Antrim and Derry: Flor. N.-E.

Usually quite lowland in Ireland, descending to sea-level in the West and North, and occurring chiefly round the shores of the larger lakes. The only highland record is that for Mangerton, which is vague and needs confirmation.

\section{2. ‡G. Cruciata Scop.-Cross-wort.}

G. cruciatum With.

Districts - - - - - - - X. - XII.

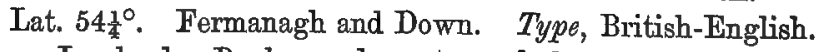

Lowland. Banks, and waste and boggy ground; very rare. Fl. May-June. 
X. Plentiful in boggy ground by the side of a small lake at Colebrooke, Fermanagh, 1869 (T. O. Smith): Rec. Add.XII. Among the rubbish of the Cathedral of Downpatrick: Harris's Down, 1744. Field adjoining the marshes near Downpatrick Cathedral, and on the side of the old Rath, 1842 (Prof. J. E. Hodges); and again gathered near the Cathedral, 1868 (Rev. W. $\mathbb{E}$. Mulgan): Rec. Add. Still plentiful on the side of Downpatrick rath, but no longer to be found at the Cathedral: S.\&P. 1895 .

No doubt introduced at Downpatrick, where, however, it has maintained itself for upwards of 150 years.

\section{G. verum Linn.-Yellow Bedstraw.}

Districts I. II. III. IV. V. VI. VII. VIII. IX. X. XI. XII. Lat. $51 \frac{1}{2}^{\circ}-55 \frac{1}{4}^{\circ}$. Throughout Ireland. Type, British.

Dry banks, and sand-hills and sandy pastures by the sea; rather common. Fl. July-August.

Sea-level in N. Antrim and S. Cork. To $1000 \mathrm{ft}$. in Dublin (N.C.).

4. f G. erectum Huds.- Upright Bedstraw.

Districts - II. - IV. V. VI. - - - - XII. Lat. $51 \frac{3}{4}^{\circ}-55^{\circ}$. South and East. Type, Germanic-English.

Lowland. Pastures, lawns, and banks; rare. Fl' June-July.

II. Sparingly in two lawns near Midleton and Ballinacurra (Rev. T. Allin): Rec. Add. Abundant in pastures at Trabolgan and Roche's Point, 1895; Phillips.-IV. In a field by the railway near Killurin, Wexford; Hart.-V. In a meadow by the Tolka, Glasnevin (Moore \& More); in a field at Stagstown, south of Rathfarnham, Dublin (S. Foot): $C y b$. In the demesne at Kilkea Castle (J. Douglas): Cyb. - VI. Kilmurvy, Aranmore Island, 1894 ; P. B. O'Kelly.-XII. Lawn at Aghaderg Glebe, near Loughbrickland, Down, 1886 (Rev. H. W. Lett); Rowallane lawn, near Saintfield, Down (D. Redmond and Rev. C. H. Waddell); in Co. Antrim at Glenmore Castle park (Dr. Holden); abundant in an old meadow at Glenmore near Lisburn, 1895 (J.H. Davies); at the base of the cliffs at Whitewell, 1896 (Stewart); and in a meadow near the manse at Cullybacky (Miss Knowles \& Dr. Buiok): Ir. Nat. 1897, p. 269 .

Probably introduced with grass-seed in most of its stations, and apparently spreading in Ireland. 


\section{5. † G. Mollugo Linn.-Great Hedge Bedstraw.}

Districts - II. - IV. V. VI. - - - X. XI. XII. Lat. $52 \frac{1}{4}^{\circ}-55 \frac{1}{4}^{\circ}$. From South to North. Type, British-English.

Lowland. Dry banks, bushy places, and pastures; rare. Fl. June-August.

II. By the lawn at Blenheim, Waterford; and-IV. Sparingly in two fields near Alderton, Wexford: B.-H.\& G. 189o. At Rathdrum, 1883, and plentiful in Glencree, 1884; Hart. By the avenue at Vallombrosa, Bray (Barrington) : Rec. Add. Killoughrim, Wexford: Moffat 1889.-V. At Sandymount near the Martello Tower: Mack. Cat. Between Finglass quarries and Glasnevin; common on the lands of Abbeville and Ballymun: Ir. Flor. At Hazelhatch, 1893; Killester and Finglas quarries, 1894; Howth and Crumlin, 1895; not infrequent in Co. Dublin; $N$. C. Kilkea Castle, Kildare (J. Douglas) : Cyb.-VI. Very sparingly at Ballyvaughan, Clare, 1892 ; Levinge.-X. Near Armagh (Rev. W. $F$. Johnson); in several places in Tanderagee upper demesne: Praeger I893.-XI. In laid-down grass near Rossapenna hotel, Donegal (Hart): Journ. of Bot. $1896, p$. 399.-XII. In Mr. Tennant's lawn at Mount Vernon [Belfast], 1797 (Templeton): Whitla MS.perhaps the preceding species rather than this. Near Eglinton, Derry (Mrs. Leebody) : Journ. of Bot. 1892 .

To $900 \mathrm{ft}$. in Dublin (N. C.); but usually lowland.

Var. INSUBRICUM (Gaud.)--V. Near Saint Fintan's, Howth, 1891 ; Levinge. In lawns at Rathmines, 1895-97; N. C.X. Strabane, Tyrone (Miss M. C. Knowles): Ir. Nat. 1897. This variety is probably in all cases introduced with grass seed.

Var. OCHRoLeucum Syme.-G. Mollugo x verum.-IV. At Greystones: Praeger 1897.

\section{G. saxatile Linn.-Heath Bedstraw.}

Districts I. II. III. IV. V. VI. VII. VIII. IX. X. XI. XII, Lat. 51 $\frac{1}{2}-55 \frac{1}{4}$. Throughout Ireland. Type, British. fuge $\mathcal{A}$.

Rocks, heaths, moors, \&c.; common. Il. June-August. Caloi-

Sea-level in N. Antrim and S. Cork. To $2460 \mathrm{ft}$. in Donegal and to $2796 \mathrm{ft}$. in Down (Flor. Ulst.); to $3000 \mathrm{ft}$. in Wicklow and to $3414 \mathrm{ft}$. in Kerry (Hart).

A common plant on most of the mountain summits in Ireland. 


\section{G. sylvestre Poll.-Least Mountain Bedstraw.}

G. pusillum Smith.

Districts I. - - - - VI. - - IX. - - Lat. $52^{\circ}-544^{\circ}$. West Ireland. Type, Intermediate-Highland.

Rocky places and pastures; rare. $F$. June-July. Calcicole $A$.

I. Plentiful on the limestone rocks at Mucrus house (Killarney) 1804-5 : Mack. Rar. In several places on the limestone about the Middle and Lower Lakes of Killarney : R.W. S. I889.-VI. Abundant on rocks at Magherinraheen near Corofin, Clare: Mack. Rar. Abundant on the limestone hills and crags around Ballyvaughan, Clare, $1895 ; N . C$. On all three Isles of Aran: Hart $2875 .-$ IX. At Glenade, Leitrim, rare : $B . \& V .1885$. North-east face of Ben Bulben : Linton 1896.

From sea-level to $1000 \mathrm{ft}$. in Clare $(N . C$.).

There is reason to believe that the records for District XII. (see Flor. $N .-E$.), in which this plant has not been recently observed, should be referred to the preceding species.

\section{G. palustre Linn.-Marsh Bedstraw.}

Districts I. II. III. IV. V. VI. VII. VIII. IX. X. XI. XII. Lat. 511을 $-55 \frac{1}{4}^{\circ}$. Throughout Ireland. Type, Biritish.

Ditches and marshy places; common. $F$. June-August.

The Irish plant is usually $G$. Witheringii (Smith).

Sea-level in N. Derry and S. Cork. To $1000 \mathrm{ft}$. in Donegal (Hart); to $1200 \mathrm{ft}$. in Dublin (N.C.); to $1550 \mathrm{ft}$. in Kerry (Hart).

Var. elongatum (Presl)-V. On the banks of the Boyne near Slane: Cyb.-VII. Brittas Lake, Westmeath: Levinge 1894.$\mathrm{X}$. In the Co. of Cavan: $C y b$.

\section{G. uliginosum Linn.-Rough Marsh Bedstraw.}

Districts I. II. - - V. VI. VII. - IX. - - Lat. $52^{\circ}-532^{\circ}{ }^{\circ}$. West and Middle, chiefly. Type, British-English.

Lowland. Boggy places; very rare. $F l$. July-August.

I. Abundant in Clogherbrian bogs, Tralee; sparingly at Ballycarty east of Tralee: R.W.S. 2888 . By Glanooragh river, north of Killarney: R.W.S. I89I.-II. Bank of a lake at Fota, Cork Harbour, 1895; Phillips.-V. By the mill pond and in a bog at Mount Blake, Ballitore, Kildare (Carroll): $C y b$.-Marsh north of the Curragh, Kildare, 1897; Praeger.-VI. Frequent in bogs near 
the mouth of the Woodford river, Galway, $1896: N$. C. $7897 .-$ VII. Sparingly on a bog near Multyfarnham, Westmeath, 1871-72 (Moore): Rec. Add. Lisclogher bog; Scraw bog, Loughanstown; bog of Lynn; shores of Lough Drin and Lough Owel: Levinge 7894.-IX. Bog between Ballybay and Curry Point, Lough Ree, Roscommon: B.\&V. 1887 .

Also recorded in Wade's Dubl. I794, in Mackay's Cat. I825 and in the Irish Flora, 1833 from many other stations in the counties of Dublin, Wicklow, Kildare, Louth, and Galway, but in the absence of any confirmation of these records it seems inadvisable to repeat them here.

\section{G. Aparine Linn.-Goose Grass; Cleavers.}

Hibernicé lup zapb (Loos-garriv), Rough Plant.

Districts I. II. III. IV. V. VI. VII. VIII. IX. X. XI. XII. Lat. $511^{\circ}-55 \frac{1}{4}^{\circ}$. Throughout Ireland. Type, British.

Hedges and bushy places; common. $F l$. June-August.

Sea-level in N. Antrim and S. Cork. To $950 \mathrm{ft}$. in Dublin (N. C.).

\section{ASPERULA Linn.}

\section{A. odorata Linn.-Woodruff.}

Districts I. II. III. IV. V. VI. VII. VIII. IX. X. XI. XII. Lat. $52^{\circ}-55 \frac{1}{4}^{\circ}$. Throughout Ireland. Type, British.

Woods and shady places; frequent. $F$. May-June.

To $800 \mathrm{ft}$. in Dublin (N.C.), and to $850 \mathrm{ft}$. in Queen's Co. (Hart); but usually lowland.

\section{A. cynanchica Linn.-Squinancy-zoort.}

Districts I. II. - - - VII. - VIII. - - - Lat. $51 \frac{3}{4}^{\circ}-53 \frac{1}{2}^{\circ}$. West Ireland. Type, English.

Rocky places, pastures, and coast sand-hills; locally abundant. Fl. June-July. Calcicole $B$.

I. Plentiful on the sand-hills along the coast of Kerry: Mack. Rar. Brandon Bay; Smerwick harbour; and other stations in the Dingle promontory, Kerry: Hart 2884. On most of the Kerry sand-hills from Ballinaskelligs Bay, northward; $R$.W. S.-II. Near Youghal, Cork (Miss Ball): Flor. Cork. Tramore, Waterford (Rev. S. Madden) : Cyb.-VI. In rocky places in Glanquin, and several 
other parts of the barony of Inchiquin: Wade Rar. Very abundant among the limestone rocks at Corofin, Clare : Mack. Rar. Abundant in the Burren district of Clare, both on limestone hills and sandy places by the shore, $1895 ; N$. $C$. In the large Island of Aran, 1805 : Flor. $H i b$. On all three Isles of Aran : Hart 1875. Plentiful about Castle Taylor, Galway: More I855.-VIII. Sea shore at Aughrus, Connemara: Wade Gallovid. At Roundstone: Oliver $185 \mathrm{I}$. Plentifully on Gentian Hill, west of the city of Galway; F. $K$. Boyd.

Sea-level to $1000 \mathrm{ft}$. in Clare (N.C.).

First definitely recorded by Wade, from Aughrus, in 1801 ; but in Rutty's Nat. Hist. of County Dublin, I772, the plant is set down as native in the country, and is said to have been sent from the South to Dr. Abraham Jenkins, then engaged in the preparation of an Irish Flora which was never published.

\section{SHERARDIA Linn.}

\section{S. arvensis Linn.-Field Madder.}

Districts I. II. III. IV. V. VI, VII. VIII. IX. X. XI. XII.

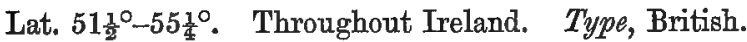

Cultivated ground, dry banks, and waste places; frequent. Fl. May-August.

Sea level in N. Derry and S. Cork. To $1150 \mathrm{ft}$. in Dublin (N.C.).

ORDER XXXIII.-VALERIANE 2 .

VALERIANA Linn.

1. V. officinalis Linn.-Wild Vaterian.

Districts I. II. III. IV. V. VI. VII. VIII. IX. X. XI. XII. Lat. $51 \frac{1}{2}^{\circ}-55 \frac{1}{4}^{\circ}$. Throughout Ireland. Type, British.

- Ditches, river sides, and moist woods; rather common. $\mathrm{Fl}$. June-August.

Sea-level in N. Antrim and S. Cork. To $1400 \mathrm{ft}$. in Donegal and to $1960 \mathrm{ft}$. in Mayo (Hart); to $2500 \mathrm{ft}$. in Wicklow (N. C.); to $2650 \mathrm{ft}$. in Kerry (Hart).

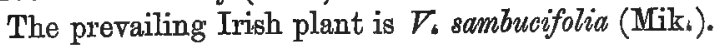


Var. MrkanII (Syme)-V. In Lough Crew demesne, Meath: Praeger $1897 .-$ VI. Sparingly in clefts of limestone rocks on the summit of Cappanawallia mountain, Clare, $1895 ; N$. C.-XII. On Slieve Muck, Mourne mountains, at 1500 ft. : S.\&P. I892. Sparingly by the Lagan at Mazetown, Antrim (Stewart): S.\&P. $\mathbf{I} 895$.

This variety appears to be quite rare in Ireland.

\section{CENTRANTHUS Linn.}

\section{1. * C. ruber DC.-Red Valerian.}

Districts I. II. $-\overline{-}-\overline{-}--\overline{-}-\overline{-}-\overline{-}$
$\quad$ Old walls and on rocks; thoroughly naturalized around Cork City and Harbour only. Fl. May-June.

I. On walls near Cork: Drummond 1818 . Walls at Bandon and Castletownsend; limestone rocks at Carrigrohane; rocks and walls at Blackrock, 1896; Phillips.-II. Plentiful on walls between Cork and Glanmire : Mack. Rar. I806. On rocks and walls at Sunday's Well; the Brickfields and other places round Cork City plentiful: Flor. Cork I845. Abundant about the suburbs of Cork; as at Sunday's Well; Montenotte, \&c.; along the railway embankment and on rocks between Cork and Glanmire; old walls at Youghal; abundant at Queenstown and on the islands in Cork Harbour; at Castleferry and Cloyne, 1896; Phillips.

Also established on old walls about Clonmel, Tipperary; about New Ross and Enniscorthy, Wexford; about Swords; Chapelizod, \&c., Dublin, and frequent elsewhere as a garden escape or outcast, but nowhere freely spreading to wild stations as it does in the neighbourhood of Cork, where the mild climate favours the naturalization of this as of other South.European species.

\section{VALERIANELLA Mœnch.}

\section{V. olitoria Pollich-Corn-Salad.}

Districts I. II. III. IV. V. VI. VII. VIII. - X. XI. XII. Lat. $511^{\circ}-551^{\circ}$. Throughout Ireland, probably. Type, British.

Lowland. Sea-side sands, cultivated ground, and waste places; frequent. Fl. May-July.

Abundant and looking native along sandy sea-coasts in Ulster and in Wexford; apparently rare in the West. 


\section{2. $\ddagger$ V. Auricula DC.-Sharp-fruited Corn-Salad.}

V. rimosa Bast.

Districts I. II. - IV. V. VI. VII. VIII. IX. - - Lat. $51 \frac{1}{2}{ }^{\circ}-54^{\circ}$. South, West, and East. Type, English.

Cultivated ground; rare. Fl. July-August.

I. Near the western head of Clonakilty Bay (Babington): Flor. Cork. Kinsale; Leap; Durrus; Glandore, \&c.: Allin's Cork.II. Waste places at Cove (Prof. Harvey): Cyb. Little Island, Cork, and also in fields at Doughtan's, Waterford (Rev. T. Allin): Ree. $A d d$.-IV. Near the village of Nook, Wexford: B.-H.\& G. 1889.-V. Near Clogher Head, Louth: Ball 1839. Near Castle Bellingham, Louth: Butler I8go. Near Navan, Co. Meath (Moore) : Herb. Glasnevin.-VI. Near Castle Taylor, Galway : More 1855.-VII. Potato field at Edenderry : Praeger 1897.-VIII. Near Oughterard, Galway: Babington 1836.--IX. Near Foxford, Mayo (More): Cyb.

Probably overlooked in many places owing to its resemblance to the following species.

\section{3. $\ddagger$ V. dentata Pollich-Narrow-fruited Corn-Salad.}

\section{Morrisonii DC.}

Districts I. II. III. IV. V. VI. VII. VIII. IX. X. XI. XII. Lat. $51 \frac{1}{2}^{\circ}-55 \frac{1}{4}^{\circ}$. Throughout Ireland. Type, English-British.

Lowland. Cultivated fields and banks; rather rare. Fl. JulyAugust.

I. Fields near Monkstown, Cork: Drummond 1818. Passage; and-II. Càstlemartyr (J. Sullivan): Annot. in Flor. Cork. Little Island: Flor. Cork. Frequent in Co. Cork: Allin's Cork.III. Noreville, Queen's Co. (J. Morrison): Rec. Add. Near Kilmacow, Kilkenny (T. Chandlee): $C y b$. Near Clonegal, Carlow : Hart $188 \mathrm{I}$ a.-IV. Frequent in corn fields about Alderton and Kilmanock, Wexford: B.-H.\&G. 1889 . At Ballycarney, Ferns, Co. Wexford, 1887-90; G. E. J. Greene. Near Bray, Wicklow (Moore): Cyb.-V. Ann's Brook, Meath: Murphy I829. Ballitore, Kildare (Carroll); and corn-fields at Baldoyle, Dublin (Moore): Cyb. Fields above Drumleck; the Needles; and the Cliffs : Flor. Howth. At Lusk; at Donabate; and at Esker near Lucan, 1893; Clonsilla and near Saggard, 1895; frequent in Co.Dublin; N.C.-VI. Near Castle Taylor, Galway: More I 855. Corn-fields near Black Head, Clare: Corry I880.-VII. Near Belvedere Lake, Westmeath 
(Moore): Cyb.-VIII. Cornfield near Oughterard, Galway: Babington 1836 .-IX. Common in cultivated ground, Lough Ree: B.\&D. $7887 .-\mathrm{X}$. Abundant at Oldcastle and Lisnabrin, Cavan (Rev. Mr. Halpin) : Flor. Olst. Near Armagh; near Crossmaglen; and several other stations in Co. Armagh: Praeger 1893.XI. Between Whale Head and Ball Green, Fanet: Hart I880.XII. Sandy places in the Curran of Larne, 1794 (Templeton): Whitta MS. Rathlin Island (Moore): Cyb. North end of Island Magee (Stewart) : Flor. N.-E. Corn-field by Lough Foyle, Derry (Prof. E. Murphy): Cyb. By the Causeway Water at Lisnacree and Maggie's Leap; and abundant about Killowen and Seafield, Down: S.\&P. 5892 .

ORDER XXXIV.-DIPSACEE.

\section{DIPSACUS Linn.}

\section{D. sylvestris Huds.-Wild Teasel.}

Districts I. II. III. IV. V. VI. ---- [XI.] [XII.] Lat. $51 \frac{1}{2}{ }^{\circ}-53 \frac{1}{2}^{\circ}$. Southern half of Ireland. Type, English.

Lowland. Hedge banks and waste places, chiefly near the sea; rather rare. $F l$. July.

I. For a mile or so along the Shannon east of Letter Point, Kerry : R. W.S. I89I. Near Passage, Cork: Drummond I8I8. Plentiful midway between Clonakilty and the Island: Phillips 1895 .-II. In the highways round the city of Cork: Smith's Cork. Near Power Head, 1895, and by the strand at Cork Beg, 1896; Phillips. Frequent throughout the Co. of Waterford: B.-H. \& G. I889.III. Granagh, Kilkenny (T. Chandlee): Cyb. By the Nore at Ballyneale: Hart $2885 \delta$.-IV. Frequent in the Co. Wexford, chiefly near the south coast: B.-H.\&.M. I892.-V. Blackquarries, on the way to Raheny: Wade Dubl. At Raheny; Finglas; Rogerstown; and Portrane, 1893; frequent in Co. Dublin; N.C. Bective and Laytown, Meath; banks by the Boyne about the Obelisk, Louth: Praeger 1897.-VI. By the Shannon below Limerick (Carroll): Cyb. Plentiful by the Shannon above and below Kilrush, Clare; and in several places by the coast near Foynes, Limerick: Stewart I890.-[XI. Roadside near Lifford (Dean Gwynn): Hart I88I $\beta$.-XII. Abundant on a bank by the 
shore near the coastguard station at Greencastle, Down (Stewart): Flor. N.-E. Dry sandy bank at Cranfield, Co. Down, very rare: S.\&. P. I892.]

Abundant in many parts of the South and South-East; but rare and perhaps only a casual in the North.

\section{SCABIOSA Iinn.}

1. S. Succisa Linn.-Devit's Bit Scabious.

Succisa pratensis Mœnch.

Districts I. II. III. IV. V. VI. VII. VIII. IX. X. XI. XII. Lat. $51 \frac{1}{2}^{\circ}-55 \frac{1}{4}^{\circ}$. Throughout Ireland. Type, British.

Damp pastures, moorlands, and mountain heaths; common. Fl. July-September.

Sea-level in N. Derry and S. Cork. To $1800 \mathrm{ft}$. in Donegal and to $2000 \mathrm{ft}$. in Galway (Hart); to $2300 \mathrm{ft}$. in Wicklow (N. C.); to $2650 \mathrm{ft}$. in Kerry (Hart).

2. S. arvensis Linn,-Field Scabious.

Knautia arvensis Coulter-Trichera arvensis Schrad.

Districts I. II. III. IV. V. VI. VII. VIII. IX. X. XI. XII. Lat. $51 \frac{1}{2}-55 \frac{1}{4}^{\circ}$. Throughout Ireland. Type, British.

Pastures, dry banks, and gravelly places ; frequent. Fl. JuneAugust.

To $950 \mathrm{ft}$. in Dublin (N.C.); but usually lowland.

Rare, generally, in the West, and very rare in the North-West.

\section{ORDER XXXV.-COMPOSIT正.}

\section{EOPATORIUM Linn.}

\section{E. cannabinum Linn.-Hemp Agrimony.}

Districts I. II. III. IV. V. VI. VII. VIII. IX. X. XI. XII. Lat. 51 $\frac{1}{2}^{\circ}-551^{\circ}$. Throughout Ireland. Type, British-English. . By ditches and streams and in moist, rocky, and bushy places; frequent. $F l$. July-August.

Sea-level in N. Antrim and S. Cork. To $900 \mathrm{ft}$, in Dublin (N.C.), 


\section{SOLIDAGO Linn.}

\section{S. Virgaurea Linn.-Golden Rod.}

Districts I. II. III. IV. V. VI. VII. VIII. IX. X. XI. XII. Lat. $51 \frac{1}{2}^{\circ}-55^{\circ}$. Throughout Ireland. Type, British.

Heaths, thickets, and rocky places; frequent. Fl. JulySeptember.

Sea-level in N. Donegal and S. Cork. To $2100 \mathrm{ft}$. in Donegal (Hart); to $2450 \mathrm{ft}$. in Down (S.\& P.); to $2900 \mathrm{ft}$. in Wicklow (Hart); to $3300 \mathrm{ft}$. in Kerry (More).

Var. CAMBRICA (Hud8.) - Not uncommon in heathy and rocky ground on the higher mountains.

Var. ANGUSTIFolia Gaud.-XI. By the Reelan water; Hart.XII. By the Bann above Hilltown; and by the river in Tollymore Park: S.\&P. I8g2.

\section{BELLIS Linn.}

\section{B. perennis Linn.-Daisy.}

Hibernicé Noinın (Nön-yeen).

Districts I. II. III. IV. V. VI. VII. VIII. IX. X. XI. XII. Lat. $51 \frac{1}{2}^{\circ}-55 \frac{1}{4}^{\circ}$. Throughout Ireland. Type, British.

Pastures, roadsides, \&c. ; common. Fl. March-October.

Sea-level in N. Antrim and S. Cork. To $1700 \mathrm{ft}$. in Derry (Hart); to $1950 \mathrm{ft}$. in Ben Bulben district $(B . \& V$.); to $2380 \mathrm{ft}$. in Kerry (Hart).

\section{ASTER Linn.}

\section{A. Tripolium Linn.-Sea Starwort.}

Districts I. II. III. IV. V. VI. - VIII. IX. X. XI. XII. Lat. $511^{\circ}-554^{\circ} \cdot$. Coasts of all Ireland. Type, British.

Salt marshes, and banks and rocks by the sea; common. Fl. August-September.

\section{ERIGERON Linn.}

1. E. acre Linn.-Blue Flea-bane.

Districts - II. III. IV. V. VI. VII. VIII. IX. - - XII. Lat. $52 \frac{1}{4}^{\circ}-54 \frac{1}{4}^{\circ}$ - From South to North. Type, English.

Lowland. Dry gravelly pastures, old quarries, walls, and 
sandy banks; rare, but locally abundant. Fl. July-August. Calcicole $B$.

II. Near Clonmel (Moore): Cyb.-III. At Catsrock and quarry near Gaul's Mills (T. Chandlee); near Richmond, Kilkenny (Rev. S. Madden); road-side north. east of Carlow (J. Sim): Cyb. By the Barrow above Tinnehinch Bridge, Queen's Co. : Hart 1885.IV. Along the riverside between Enniskerry and Lough Bray: Ir. Flor. Killanne near Blackstairs mountain, Wexford (Miss $V$. Cooper): B.-H.\&M. I892.-V. "Upon a dry hilly pasture facing the Hutts at the Black Rock": Threlkeld. Near Rathfarnham; between Sandymount and Merrion, \&c.: Wade Dubl. Near the canal a mile from Lucan; banks of the Dodder above Templeogue: Flor, Hib. 1836. By the Grand Canal at Collierstown above Lucan, 1893 ; abundant along the Dodder river from Templeogue to Bohernabreena, 1895; at Killester; Clonsilla, \&c.; frequent in Co. Dublin; N. C. A bout Mullaghcreelan Hill, Kildare (J. Douglas): Cyb._VI. Sparingly near Ballyvaughan, Clare, $1895 ;$ N.C.VII. Gurtalougha, Lough Derg, Tipperary;--VIII. Golden Bay, Lough Corrib, Galway; and-IX. Between Cong Cross and Kilmaine, Mayo; Miss M. F. Jackson.-XII. Sparingly on the sand dunes at Ballykinler, Co. Down (Praeger): Flor. N.-E.

Apparently absent from Cork and Kerry, and much more abundant in the East than in the West.

First recorded by Threlkeld in 1727 .

\section{FILAGO Linn.}

\section{F. germanica Linn.-Common Cudwoed.}

Districts I. II. III. IV. V. VI. VII. VIII. IX. X. XI. XII. Lat. $51 \frac{1}{2}^{\circ}-55 \frac{1}{4}^{\circ}$. Throughout Ireland. Type, British.

Lowland. Dry pastures, and sandy or gravelly places ; frequent. Fl. July-August.

A widely distributed species, but rare over large areas.

\section{F. minima Fries-Least Cudwoed.}

Districts I. II - IV. V. - VIII. - X. XI. XII. Lat. $51 \frac{1}{2}^{\circ}-55 \frac{1}{4}$. From South to North. Type, British.

Lowland. Sandy or gravelly places, \&c.; rare, but locally abundant. Fl. June-August.

I. Drishana, west of the Gap of Dunloe, Kerry : Hart 1882. 
Railway bank at Killamey, and stream bed west of Boolteens, Kerry; R.W.S. Riverside between Bandon and Inishannon: Drummond 1820 . Near Ballinadee Creek, and near Union Hall: Allin 1873 . Near Desert station, and near Ballyvourney: Allin's Cork. At Iniscarra, 1893; Phillips.-II. Dry hills near Fermoy (T. Chandlee); near Clonmel (Miss A. Taylor): Cyb. Rocks near Ballyvourney, Cork, 1897; W. H. Shaw.-IV. Dry banks about the upper Dargle gate, and between Enniskerry and Lough Bray, plentiful : Mack. Cat. Near Drumgoff, and on the Murrough of Wicklow (More) : Rec. Add.-still at Drumgoffi, 1897; N. C. Bray Head, and near the town of Wicklow, 1897; Praeger.

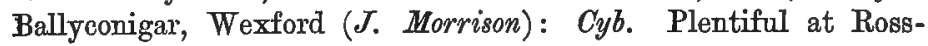
lare, Wexford: Hart I883 B.-V. Granite quarry at Balalley, Three Rock Mountain, Dublin (N. C.): Ir. Nat. 1894. Behind the light-houses at Boyne mouth, Meath : Praeger 1897.VIII. Plentiful on the sandy shore of Lough Mask at Maamtrasna : M. \& S. I896.-X. Sandy ground near Lough Neagh, Armagh : More 1860. In Armagh, by Lough Neagh at Raughlan (Rev. $H$. W. Lett); and at Charleston: Praeger I893. Plentiful on the banks of a stream near Omagh, and on sands of Washing Bay, Lough Neagh, Tyrone (Miss M. C. Knowles): Ir. Nat. 1897.XI.-Sandy warrens near Greencastle, Inishowen, scarce; W. $\boldsymbol{E}$. Hart.-XII. Gravelly bank on the shore of Lough Neagh; in plenty on the new road between Lisburn and Hillsborough, 1802 : Templeton MS. Frequent in north-east Ireland, and abundant on coast sand-hills and the shores of Lough Neagh: Flor. N.-E.

\section{ANTENNARIA Gærtn.}

\section{A. dioica R. Br.-Mountain Cudroeed.}

Gnaphatium dioicum Linn.

Districts I. II. III. IV. V. VI. VII. VIII. IX. X. XI. XII. Lat. $51 \frac{3}{4}^{\circ}-554^{\circ}$. Throughout Ireland. Type, Scottish-British.

Rocky places, sand-hills, heaths and mountain pastures; frequent and locally abundant. $F l$. June-July. Calcicole $C$.

Sea-level in N. Antrim and in Clare. To $1800 \mathrm{ft}$. in Donegal, to $2300 \mathrm{ft}$. in Derry, to $2400 \mathrm{ft}$. in Mayo, and to $2900 \mathrm{ft}$. in Kerry (Hart).

A widely distributed species often very abundant on the limestone, as in the Burren district of Clare and on the shores of Lough Derg, but rare in many parts of Ireland. 


\section{GNAPHALIUM Linn:}

\section{G. uliginosum Linn.-Marsh Cudweed.}

Districts I. II. III. IV. V. VI. VII. VIII. IX. X. XI. XII. Lat. $51 \frac{1}{2}^{\circ}-55 \frac{1}{4}^{\circ}$. Throughout Ireland. Type, British.

Damp places, in sandy, gravelly, or peaty soils; frequent and locally abundant. $F l$. July-August. Calcifuge $A$.

Sea-level in N. Antrim and S. Cork. To $1200 \mathrm{ft}$. in Dublin (N.C.).

\section{G. sylvaticum Linn.-Upright Cudweed.}

Districts I. II. III. IV. V. VI. - VIII. IX. X. XI. XII. Lat. $51 \frac{1}{2}^{\circ}-55 \frac{1}{4}^{\circ}$. Throughout Ireland, probably. Type, British.

Upland pastures and damp, sandy places by the coast, also in fallows in light soils; not infrequent. Fl. July-August.

I. Near Kenmare; Lough Guitane, Killarney, \&c.; rare in Kerry: R.W.S. I889. Near Macroom; at Gouganebarra, 1897 ; W. H. Shaw. Near Ballinadee; at Schull; and-II. Near Ballyrourney and Millstreet; local in Co. Cork: Allin's Cork.-III. In the Co. of Catherlough [Carlow]: Threlkeld. High ground near Myshall, Carlow (R. Clayton Browne): Rec. Add.-IV. Near Shillelagh (Hart): Rec. Add. Near Anamoe, Wicklow; R.W. S. Near Shankill Bridge, Kilbride, Wicklow, $1891 ; N$. C. At Woodbrook, Wexford (Miss V. Cooper) : B.-H.\& M. I89z.-V. On the way up the Carlingford Hills from Omeath, Co. Louth: Hart 1884. Hills west of Saggard Slade, Dublin, $1895 ; N$. C.-VI. At the foot of Glounagaliagh mountain, near Killaloe, Clare, 1896: N. C. 1897.-VIII. On Lettery mountain and other places about Ballinahinch, Connemara: Wade Rar. Near Lough Inagh, Connemara, 1896; N. C. Plentiful near Lough Conn; and-IX. Near Foxford, Mayo (More): $C y b$. Shore of Lough Easky and at Mass Hill, Ox Mountains, Sligo (Rev. C. F. d'Arcy) : N. C. I896.X. Falkland, Monaghan (Miss Maffett): $C y b$. Near Kesh, Lough Erne: Barrington 1884. Derryadd (Rev. H. W. Lett); hills south of Newry, Armagh : Praeger I893. At Omagh; Newtownstewart; and Strabane, Tyrone (Miss M. C. Knowles): Ir. Nat. I897.XI. Shore of Lough Eske; by the Finn above Drumbo, \&c. : Hart I885 \% -XII. Frequent in Antrim, Down, and Derry : Fllor. N.-E. 
Sea-level in Derry and S. Kerry. To $650 \mathrm{ft}$. in Donegal (Hart); to $800 \mathrm{ft}$. in Down (S.\&P.).

A widely distributed species, but rarely occurring in abundance.

\section{INULA Linn.}

\section{1. * I. Helenium Linn.-Elecampane.}

Districts I. II. - IV. - VI. - VIII. IX. X. XI. XII. Lat. $51 \frac{1}{2}^{\circ}-55 \frac{1}{4}^{\circ}$. From South to North. Type, English.

Lowland. Roadside banks, pastures, and waste places, usually near ruins or houses; rare. Fl. July-August.

I. In the barony of Clanmaurice not far from the Abbey of Odorney: Smith's Kerry. About a mile west of Knightstown, Valentia Island (Miss S. Grubb): Cyb. Near the ruins in Church Island, Lough Currane, Waterville, Kerry (More): Rec. Add. I872-and in $1892 ; N$. C. Kenmare; Derrynane; Ardfert, \&c.; widely scattered through Kerry; $R . W . S . \quad$ Near the Leap in West Carbery, also in plenty on Cape Clear Island: Smith's Cork. Ballinadee; Skibbereen; Union Hall, \&c. (Altin); and-II. At Youghal (Carroll); rather rare in Cork: Allin's Cork.-IV. Ballyconigar, Wexford (Carroll); and Whalley Abbey, Wicklow ( $L$. Ogilby): Cyb.-VI. Foot of Shalee Hill near Ennistymon; abundant on the road to St. Bridget's Well, near the Cliffs of Moher, Clare (Rev. T. Warren): Cyb. Turlough Hill, six miles east of Ballyvaughan, 1891; Levinge.-VIII. Plentiful on Cruig Neit Island, Bertraghbuy Bay, Galway: Babington 1836. Roadside near Gurthreeva, Oughterard; and-IX. Near Milford, Mayo; Miss M. F. Jackson. Marshy place three miles from Sligo; Miss $S$. Wynne.-X. Devenish, Lough Erne (J. Johnston): F'lor. Hib.still in this station, about 20 plants : Barrington 1884 . Derryadd (Rev. H. W. Lett); and near Goragh Wood, Armagh: Praeger I893.-XI. Little Binns, Greenfort, Fanet (Hart): $\boldsymbol{R}_{6 c}$. Add. Ballyshannon; Dunkineely; and Glen: Hart $1885 \%$-XII. Apparently wild among limestone rocks between Larne and Garron Head, Antrim (Moore): Cyb. Plentiful by Lough Neagh shore at Cranfield, \&c.; rare in north-east Ireland, but certainly quite naturalized: Flor. N.E.

An old medicinal plant which tenaciously holds its ground in many places, especially in the neighbourhood of church ruins, but shows little tendency to spread. 


\section{I. salicina Linn.-Willow-leaved Inula.}

Districts - - - - VI. VII. - - - -

Lat. $52^{\circ} 55^{\prime}-53^{\circ} 5^{\prime}$. Shores and islands of Lough Derg, in Galway and Tipperary. Type, Hibernian.

Lowland. Rocky and bushy places on limestone; very rare. $F l$. June-July.

VI. "In June, 1843, I went to Portumna, Co. Galway, for the purpose of getting specimens of Teucrium Scordium which grows plentifully on the margins of Lough Derg. When botanizing along the shores of that great river-lake I observed a plant growing sparingly and unknown to me in the flowerless state in which it then was. ... I picked some specimens . . . which remained in my herbarium unnamed ... up to the present year. ... When Dr. Syme saw the specimens he at once suggested that they might prove to be Inula salicina . . . I went this year in August and had the satisfaction of re-discovering the Inula; but could only find two specimens which had flowered and were then seeding" ( $D r . D$. Moore): Journ. of Bot. $1865, p .333$. One plant in an island near Rossmore, Lough Derg, and a few others on the shore of the mainland: Linton I886. On an island in Lough Derg, about three miles south-west of Portumna, and again in considerable quantity on an islet eight miles to the southward in the same lake, 1896 : N. C. r897.-VII. Rocky shores of Lough Derg at Curraghmore, and on Brynas Island, Tipperary, 1895 (C. J. Litly): Ir. Nat. $1896, p .269$.

One of the rarest of our native plants and not found in Great Britain. Widespread on the European continent, from Greece to Norway, and from Western France to Central Russia, reaching its extreme western limit in Ireland.

First discovered by David Moore in 1843.

\section{I. crithmoides Linn,-Golden Samphire.}

Districts I. II. - IV. V. - - - - - Lat. $51 \frac{11}{2}-53 \frac{1}{2}{ }^{\circ}$. South and South-East coasts. Type, AtlanticEnglish.

Rocks and banks by the sea; rare. $F$. July-August.

I. "It grows on the rocks near Bolus Head in Iveragh, and on other parts of the sea-cliffs": Smith's Kerry. On the rocky coast near Dingle (Moore): Cyb. Not seen recently in Kerry; $R . W . S$. Near Castlefreke $(R . W$. Townsend $)$ : Flor. Cork 1845 -still there : 
Allin's Cork 1883.-II. Rocks at Tramore, Waterford, abundant: Carroll 1854. At Ardmore, Waterford (Rev. T. Allin): Rec. Add. Helvick Head to Ardmore Head; frequent along the Waterford coast: Hart $x 883 \beta$.-IV. Greater Saltee Island and at the extreme point of Hook Head, Wexford, plentifully: Hart 1883 B.$\nabla$. Below the Light-house, Howth: Wade Dubl. I794. Seashore at Howth, south side, in muddy places: Mack. Cat. Rocky coast from Kilrock to Bailey Light-house in many places; near the Martello tower, south side of Howth; on Ireland's Eye: Flor. Howth 2887 . At the Cliffs, Howth, 1896; Miss S. Colgan. South side of Killiney Hill, Dublin: Flor. Hib. Dalkey Island ( $W . W a l$ pole): Cyb. 7866 -still there in 1892 (D.M'Ardle): Ir. Nat. I892. On Lambay Island: Ir. Flor. 1833 . Common on most of the coast of Lambay Island: Hart $1883 \gamma$.

\section{PULICARIA` Gærtn.}

\section{P. dysenterica Gærtn.-Fllea-bane.}

Inula dysenterica Linn.

Districts I. II. III. IV. V. VI. VII. VIII. IX. X. XI. XII. Lat. $51 \frac{1}{2}^{\circ}-55 \frac{1}{4}^{\circ}$. Throughout Ireland. Type, English.

Damp pastures and marshy places; frequent. Fl. AugustSeptember. Calcicole $C$.

Sea-level in N. Antrim and S. Cork. To $700 \mathrm{ft}$. in Dublin (N.C.); but usually lowland.

\section{BIDENS Linn.}

\section{B. cernua Linn.-Nodding Bur-Marigold.}

Districts I. II. III. IV. V. VI. VII. VIII. IX. X. XI. XII. Lat. $51 \frac{1}{2}^{\circ}-55 \frac{1}{4}^{\circ}$. Throughout Ireland. Type, English-British.

Lowland. Marshy places, bog-holes, ditches, \&c.; frequent. Fl. August-September.

Rarer in the East than the West, and generally rarer than the following species.

Var. Radiata Sond.-XII. Ballygowan, Down; and Portmore, Antrim: Flor. N.-E. Plentiful at Carrickmannan Lake, Down (Stewart); in the Quoile marshes (Praeger): Stewart $\mathbf{1 8 9 4 .}$

In Ray's Synopsis $1724, p .188$, this variety is set down, on Sherard's authority, as frequent in Ireländ. 
2. B. tripartita Linn.-Trifid Bur-Marigold.

Districts I. II. III. IV. V. VI. - VIII. IX. X. XI. XII. Lat. $51_{2}^{\circ}-55_{4}^{\circ}$. Throughout Ireland, probably. Type, EnglishBritish.

Lowland. Marshy places, bogs, and ditches; frequent. Fl. August-September.

Abundant in many parts of the West, rarer in the East.

\section{ACHILLEA Linn.}

\section{A. Millefolium Linn.-Milfoil.}

Hibernicé đச்ain đ̇alamina (Awher holloona), Earth Father. (?)

Districts I. II. III. IV. V. VI. VII. VIII. IX. X. XI. XII. Lat. $51 \frac{1}{2}^{\circ}-55 \frac{1}{4}^{\circ}$. Throughout Ireland. Type, British.

Pastures, roadsides, dry banks, \&c.; common. Fl. JulySeptember.

Sea-level in Derry and S. Cork. To $1450 \mathrm{ft}$. in Derry, to $2550 \mathrm{ft}$. in Mayo, and to $2380 \mathrm{ft}$. in Kerry (Hart).

\section{A. Ptarmica Linn.-Sneeze-wort.}

Ptarmica vulgaris DC.

Districts I. II. III. IV. V. VI. VII. VIII. IX. X. XI. XII. Lat. $51 \frac{3}{4}^{\circ}-55 \frac{x^{\circ}}{4}$. Throughout Ireland. Type, British.

Damp, gravelly pastures, marshy places, and in peaty and sandy fallows; frequent and locally abundant. $\quad F l$. July-August.

Sea-level in Derry and in Kerry. To $700 \mathrm{ft}$. in Donegal (Hart); to $1100 \mathrm{ft}$. in Dublin (N.C.).

\section{DIOTIS Desf.}

\section{D. candidissima Desf.-Sea Cudweed.}

D. maritima Cass.

Districts - II. - IV. - - - - - - - Lat. $52^{\circ} 5^{\prime}$. Waterford and Wexford only. Type, Atlantic.

Sandy sea-shores; very rare. $\mathrm{Fl}$. August-September.

II. Near Dungannon, Waterford, 1845 (G. J. Allman): R.I.A. Proc. iii. p. 184. Among boulders on the strand at Tramore, Waterford, 1850 : Carroll 1854--IV. "Near Carnsore Point, Co. 
Wexford, from whence I am favoured with specimens by Mr. John Waddy": Syme's Eng. Bot. Ed. 3, 1866 . Near Tacumsin Lake, South Wexford, 1876 ; G. H. Finahan. Sandy coast below Lady's Island Lake and Tacumsin Lake, Wexford, extending for about an English mile: Hart $I 88_{3} \beta$.

Also recorded in Smith's Kerry from the "shores of the strand at Ballyheigh." This record has not been confirmed; and if the plant observed by Smith was properly referred by him to this species it has no doubt since become extinct.

Apparently decreasing in Ireland with other rare littoral species, such as Mertensia maritima, Mathiola sinuata, Crambe maritima, \&c.

First discovered by G. J. Allman in 1845.

\section{ANTHEMIS Linn.}

\section{1. $\ddagger$ A. Cotula Linn.-Stinking Chamomile.}

Districts I. II. III. IV. V. VI. VII. VIII. - - [XI.] [XII.] Lat. $52^{\circ}-54^{\circ}$. From South to North. Type, English-British.

Cultivated ground, roadsides, and waste places; frequent. Fl. July-August.

Like most of our colonists, more abundant in the East than elsewhere. Hardly more than a casual in North Ireland and in the extreme South.

\section{A. nobilis Linn.-Common Chamomite.}

Districts I. II. III. IV. V. - - VIII. - X. XI. XII.

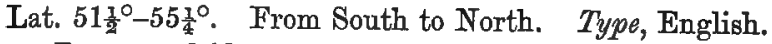

Damp roadsides, pastures, and gravelly places; local. Fl. JulyAugust.

I. Covering whole fields at Calnafersy and plentiful on roadsides near Killarney : Mack. Rar. Killarney; Rossbehy ; Glenflesk, \&c. ; locally abundant in South Kerry; $R$. $W$. S. In the half-barony of Barryroe near the Galley Head: Smith's Cork. Common in southwest Cork: Allin's Cork.-II. Plentiful near Fermoy (T. Chandlee): Cyb. At Kilcoleman (Carroll); and abundant near Midleton (Rev. T. Allin): Allin's Cork. In the parish of Kilrosinta near Ballycaroge: Smith's Waterford r746.-III. Abundant on the Great Heath at Maryborough : Praeger 1897.-IV. End of the Long Hill beyond Enniskerry, Wicklow: Ir. Flor. 1833-and in 1893; N.C. Of frequent occurrence in Wexford, apparently throughout the 
county: $B .-H . \& M$. I892.-V. Gravelly hill slopes in Glenasmole, Co. Dublin, introduced, 1882-92; N. C.-VIII. Gravelly commons and high-road near Renvyle, Connemara : Wade Rar. Near Delphi: $B_{a l l}$ 1839. Shores of Lough Cullin; Mayo (More) : Cyb.-X. Near Maghery, Armagh (Rev.W. T. Johnson) : Praeger I893.-XI. Lower Carraghblagh, Fanet; Lough Salt mountain; Clontallagh, Rossgull : Hart 1879.-XII. At the foot of Tullybranagan mountain, Co. Down (John White): Wade Rar. Gravel pits one mile N.-E. of Comber (Praeger): Flor. N.-E. By Enagh Lough West; and roadside between Moneymore and Ballyronan: Moore MS. Frequent on the banks of Lough Neagh, Antrim (Moore): $C y b$.

Probably introduced in many of its stations; but appears to be native in the South.

\section{CHRYSANTHEMUM Linn.}

1. C. segetum Linn.-Corn Marigold.

Districts I. II. III. IV. V. VI. VII. VIII. IX. X. XI. XII. Lat. $51 \frac{1}{2}^{\circ}-551^{\circ}$. Throughout Ireland. Type, British.

Cultivated ground, especially in sandy or peaty soil; frequent. Fl. June-August.

Sea-level in N. Antrim and S. Cork. To $800 \mathrm{ft}$. in Down (S. \&P.); to $1000 \mathrm{ft}$. in Dublin (N.C.).

\section{C. Leucanthemum Linn.-Ox-Eye; Dog Daisy.}

Leucanthemum vulgare Lamk.

Hibernicé Nionin món (No-nyeen more), Great Daisy.

Districts I. II. III. IV. V. VI. VII. VIII. IX. X. XI. XII. Lat. $51 \frac{1}{2}^{\circ}-55 \frac{1}{4}^{\circ}$. Throughout Ireland. Type, British.

Meadows; pastures, dry banks, \&c. ; common. Fl. June-August.

Sea-level in Derry and Cork. To $1200 \mathrm{ft}$. in Dublin (N.C.).

\section{MATRICARIA Linn.}

1. M. inodora Linn.-Scentless Feverfew.

Pyrethrum inodorum Smith.

Districts I. II. III. IV. V. VI. VII. VIII. IX. X, XI. XII. Lat. $51 \frac{1}{2}^{\circ}-55 \frac{1}{4}^{\circ}$. Throughout Ireland. Type, British.

Lowland. Cultivated ground, waysides, waste places, \&c., especially near the sea; common. Fl. July-August. 
Var. saunNa Bab.-Fleshy-leaved forms gathered at-II. Ballycotton, Cork (Phillips); and-VI. Murrough, Clare (N.C.), appear to belong to this variety. $\boldsymbol{M}$. maritima Linn., as understood by British botanists, has not yet been ascertained to occur in Ireland.

\section{2. $\ddagger$ M. Chamomilla Linn.-Field Chamomite.}

Districts I. - III. - V. VI. - - - X. - XII. Lat. $52 \frac{1}{2}^{\circ}-54 \frac{3}{4}^{\circ}$. From South to North. Type, English.

Lowland. Cultivated fields, roadsides, and waste places; rare and nowhere certainly native. Fll. June-July.

I. Plentifully at Ballybunnion and Beal Point, Kerry : Stewart I89o.-III. Ballyragget on the Nore, introduced: Hart $1885 \delta$. At Maryborough; Praeger.- $\nabla$. Near Raheny Church, abundant; Ir. Flor. Fields near Raheny (Mr. Johnston): Cyb. Gravel pit near Clontarf, Dublin (Praeger): Ir. Nat. I894. Near Edenderry in Kildare and at Kilmessan, Meath: Praeger 1897.-VI. Roadsides east of Clonbrock, Galway, in many places: Praeger 1896.X. Roadside near Richbill and on the railway at Newry, Armagh: Praeger $1893 .-$ XII. Near Dunmurry and in a wheat field at Malone, 1800: Templeton MS. Abundant in an oatfield on the west side of Island Magee, 1880 (Stewart); Larne and Cairncastle

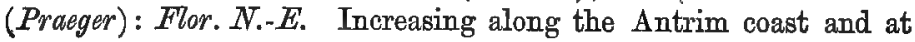
least naturalized there: S.\& P. 1895 .

\section{TANACETUM Linn.}

\section{1. *T. vulgare Linn.-Tansy.}

Districts I. II. III. IV. V. VI. VII. - IX. X. XI. XII. Lowland. Roadsides, banks, waste places, \&c.; frequent, though rarely abundant. Fl. August.

Fully established and long persistent in many of its numerous recorded stations, but always obviously introduced.

\section{ARTEMISIA Linn.}

\section{1. $\ddagger$ A. Absinthium Linn.-Worm-2oood.}

Districts I. II. III. IV. V. VI. VII. VIII. IX. X, XI. XII. Lat. 51 $1^{\circ}-55 \frac{1}{4}^{\circ}$. Throughout Ireland. Type, English-British.

Lowland. Gravelly and sandy sea-shores, roadsides, and waste places; frequent. Fl. July-August. 
Widely distributed and well established in many places, especially by the coast, but rarely occurring in abundance.

\section{A. vulgaris Linn.-Mugeoort.}

Districts I. II. III. IV. V. VI. VII. VIII. IX. X. XI. XII. Lat. $51 \frac{1}{2}^{\circ}-55 \frac{1}{4}^{\circ}$. Throughout Ireland. Type, British.

Lowland. Waste places, field borders, dry banks, \&c.; frequent. Fl. July-September.

Nowhere a common species, and rare and apparently introduced in many parts.

\section{A. maritima Linn.-Sea Worm-wood.}

Districts - - - V. VI. - [VIII.] - - Lat. 5230 $\frac{3}{4}^{\circ}-54^{\circ}$. East and West coasts. Type, English.

Rocky and muddy sea-shores; very rare. Fl. July-August.

v. "Found between Mirrion and the Black Rock. The Country People make it into Sheaves and bring it in Carrs out of the adjacent Countys of Meath and Louth to Dublin, of which our Ale-house keepers make their Purl": Threlkeld 1727 . On the Hill of Howth, 1799 : Templeton MS. On the Sutton side of Howth and on the coast near Portrane, plentiful: Mack. Cat. Rocks by the shore below the Cliffs and Needles, Howth: Flor. Howth. In considerable quiantity over a small area of sea-cliffs at Portrane, $1895 ;$ N. C. On Killiney Hill, south side (Moore) : Cyb. Abundant on cliffs at Sorrento, Dalkey, $1884 ; N$. C. On a low muddy point south side of the estuary of the Boyne below. Drogheda, and sparingly on the adjacent shore (More): Rec. Add.. At Dundalk, 1868 ; J. Marsden. Near Clogher Head, Louth, 1893; Cecil Butler.-VI. In county Clare, at Gleninagh, and on muddy shores at Killadysart and Carron Island, in the Fergus estuary: Corry 7880. Abundant on muddy flats by the shore above Foynes, Limerick: Stewart 189o. At Carranroe, Galway; Rev. F. Warren.[VIII. This grows on one of the islands west of Westport: Brown Fascic. ${ }_{7} 88$ - no recent record. ]

Also recorded by Smith, History of Cork $175^{\circ}$, as growing in great quantities on the sea-coast, but not since found in that county.

Apparently a decreasing species in Ireland, in common with many others of our rarer littoral plants, and was probably abundant on many parts of our coasts in the last century. 


\section{TUSSILAGO Linn.}

\section{T. Farfara Linn.-Coltsfoot.}

Districts I. II. III. IV. V. VI. VII. VIII. IX. X. XI. XII. Lat. $51 \frac{1}{2}^{\circ}-551_{4}^{\circ}$. Throughout Ireland. Type, British.

Moist clay banks, damp fields, and gravelly places; common. $F$. February-April. Calcicole $B$.

Sea-level in N. Derry and S. Cork. To $1700 \mathrm{ft}$. in Ben Bulben district (B.\&V.); to $1900 \mathrm{ft}$. in Down (S.\&P.).

\section{PETASITES Linn.}

1. * P. fragrans Presl-Winter Heliotrope.

Nardosmia fragrans Reichb.

Districts I. II. III. IV. V. VI. ---- XI. XII.

Shady roadsides, moist banks, and waste places; frequent and locally abundant. Fl. December.

A native of Southern Italy, formerly much planted in copses and shrubberies, and frequently rejected on account of its aggressive habit. Now thoroughly established in the country, and abundant along roadsides in many places.

2. P. officinalis Mœnch-Butter Bur.

$P$. vulgaris Desf.

Hibernicé Pubobl (Poob-bole).

Districts I. II. III. IV. V. VI. VII. VIII. IX. X. XI. XII. Lat. $5 \frac{1}{2}^{\circ}-55 \frac{1}{4}^{\circ}$. Throughout Ireland. Type, British-English.

River-banks and damp meadows; frequent. Fl. April-May.

Sea-level in Donegal and Kerry. To $800 \mathrm{ft}$. in Dublin (N. C.); but usually lowland.

\section{SENECIO Linn.}

\section{S. vulgaris Linn.-Groundsel.}

Districts I. II. III. IV. V. VI. VII. VIII. IX. X. XI. XII. Lat. $51 \frac{1}{2}^{\circ}-55 \frac{1}{4}^{\circ}$. Throughout Ireland. Type, British.

Cultivated ground and waste places; common. Fl. Throughout the year. 
Sea-level in N. Donegal and S. Cork. To $1150 \mathrm{ft}$. in Derry and to $1500 \mathrm{ft}$. in Tipperary (Hart).

Var. RADIATUS Koch-I. Abundant about Killarney railway station, Kerry, and along the line: R.W.S. 1890 . About Cork (Carroll): Cyb. Near Ballineen; Schull; Baltimore; and Skibbereen, 1896; and particularly abundant about Passage West; railway at Kilcrea, and abundant along the railway from Cork to Skibbereen, 1897; Phitlips.-II. Frequent about Cork on railways and roadsides, as at Tivoli; near Leemount; at Fota, \&c.; Phillips. On the railway at Dooniskey near Macroom; R.W.S. Clashgariff Bridge near Coachford, 1897; Phillips.

First observed by Isaac Carroll, at Cork, before 1866: $C y b$.

Var. HIBERNICA Syme-S. vulgaris $\times$ squalidus?-I. By the western road, Cork, 1894 ; by. the Marina, and between Cork and Blackrock, 1896 ; and-II. Gravel-pits in Dodge's Glen, 1894-96 ; roadside and railway embankment at Tivoli, 1890-96; Phillips.

Much diversity of opinion exists as to the standing of this interesting plant. Its hybrid origin has been denied by Boswell Syme, who identifies it with S. vernalis (W. \& K.); H. C. Watson has referred it to $S$. crassifotius (Willd.), and, finally, Dr. Focke accepts it as $\boldsymbol{S}$. vulgaris $\times$ squalidus in his work on hybrids. A similar plant has been observed near Tregantle, E. Cornwall.

First noticed near Cork by Carroll who sent specimens to Professor Babington in 1853. See Bot. Ex. Club Reports, 1875$76-77$ and -80 .

\section{S. sylvaticus Linn.-Heath Groundsel.}

Districts I. II. III. IV. V. VI. VII. VIII. IX. X. XI. XII. Lat. $51 \frac{1}{2}^{\circ}-55 \frac{1}{4}^{\circ}$. Throughout Ireland. Type, British.

Heaths, moors, and sandy banks; frequent. Fl. June-August. Calcifuge $A$.

Sea-level in N. Antrim and S. Cork. To $800 \mathrm{ft}$. in Down (S. \&P.); to $1000 \mathrm{ft}$. in Kerry (Hart).

\section{3. * S. viscosus Linn. -Sticky Groundsel.}

Districts - - - - V. - - - - - [XII.]

Gravelly and sandy ground near the sea; very rare. Fl. July September.

V. Sandy places by the sea, especially between Clontarf and Howth: Wade Dubl. 1794. Dry, rubbishy ground in the vicinity of Dublin 
(Dr. Scott) : Mack. Rar. Sandy fields near Kilbarrack Church and Howth: Mack. Cat. Banks by the roadside between the Bailey light-house and Sutton (Moore): Cyb. On the beach, Sutton side of Howth, 1867; More. Still on the beach near Sutton, but in small quantity, 1896; Miss S. Colgan.-[XII. Formerly found in abundance on rubbish heaps at the foot of the Mile water, near the terminus of the Northern Counties railway, Belfast, where it was introduced in 1847 and where it maintained itself for nearly forty years, until the ground was built upon: Flor. $N .-E$.]

Also recorded from near the Basin, Cork, in Flor. Cork, but not found there since.

Appears to have been at one time rather frequent along the northern shores of Dublin Bay where it has now become very rare and seems doomed to early extinction.

\section{4. * S. squalidus Linn.-Wall Ragroort.}

Districts I. II. - - - - - - - - -

Walls, house-roofs, roadsides, and waste places; thoroughly naturalized around Cork city and harbour. Fl. Throughout the year.

I. On walls and house roofs in the southern part of Cork city (Mr. Alexander); perfectly naturalized and most abundant in all parts of the city and suburbs: Flor. Corle 1845. On the town walls of Bandon and Ballinahassig, 1857 (J. Sullivan): Annot. in Flor. Cork. Well established at Kinsale and Bandon (Carroll): Cyb. Plentiful at Cork; at Bandon; at Kinsale junction; at Carrigaline, 1896; railway bank at Crookstown, 1897; and-II. Abundant about Cork and its suburbs, from Sunday's Well to Tivoli ; frequent by the railway and by roadsides thence to Queenstown, 1896 ; near Leemount, 1897 ; Phillips.

A native of Southern Italy now fully established in Co. Cork. The plant was not known to Drummond as wild about Cork in 1820 and probably first became naturalized there some time between that date and 1839 ; see Flor. Cork.

A rather distinct variety with almost entire leaves occurs at Dodge's Glen and at Queenstown; Phillips.

\section{S. erucifolius Linn.-Hoary Ragroort.}

Districts - - IV. V. - - - -

Lowland. Roadsides, dry banks, and hedgerows; locally abundant. Fl. August-September. 
IV. Old Court near Bray, Co. Wicklow (Barrington): Rec. Add.-V. Frequent in dry pastures in Co. Dublin: Wade Dubl. Raheny; Coolock; Santry; Ballymun, \&c.: Ir. Flor. Castleknock; Lucan; Stillorgan; and Tallaght (More): Rec. Add. At Portrane; R. Bayly. Clonsilla; Knockmaroon; Rush, \&c.; frequent throughout the lowlands of Co. Dublin, and especially abundant round Swords and the Malahide estuary, $1895 ; N$.C. Between Drogheda and Dundalk, Louth (Moore): Cyb. North of Leixlip railway station, Kildare; and at Laytown, Meath: Praeger 1897.

Almost confined to Co. Dublin where it is frequent and in some stations abundant.

\section{S. Jacobæa Linn.-Common Ragwort.}

Hizernicé buaċalán buı̇e (Book-a-lawn bwee), Yellow Boy.

Districts I. II. III. IV. V. VI. VII. VIII. IX. X. XI. XII. Lat. $51 \frac{1}{2}^{\circ}-55 \frac{1}{4}^{\circ}$. Throughout Ireland. Type, British.

Pastures, roadsides, waste places, and sand-hills : common. $F l$. June-September.

A pest in pasture lands throughout the country and often completely over-running peaty or sandy fallows.

Sea-level in N. Donegal and S. Cork. To $1450 \mathrm{ft}$. in Derry and to $1630 \mathrm{ft}$. in Mayo (Hart).

Var. Flosculosos (Jord.)-I. Common on the Kerry sand-hills; R.W.S.-II. Near Tramore, Waterford (J. Woods): Phytol. 1855.-IV. Cahore Point; Rosslare, \&c., Wexford: Hart I883 $\beta$.$\nabla$. Most copiously on sands by the shore three or four miles from Drogheda, so that of a thousand plants you shall scarce find one with a radiant flower (Sherard): Ray's Synopsis, I606, p. 82. Still most abundant from the Boyne to Clogher [no doubt Sherard's station], the normal form quite absent, 1896: Praeger 1897.VI. Frequent in Aran (Hart): Rec. Add.-VIII. In several islands off Connemara (More) : Rec. Add.-XI. Abundant on the shore of Trawenagh Bay: Hart I88I $\beta$.

\section{S. aquaticus Huds.-Marsh Ragwort.}

Hibernicé Sam-a-cuppaıje (Sam-vah-curra), Sun of the Marsh (?). Districts I. II. III. IV. V. VI. VII. VIII. IX. X. XI. XII. Lat. 51 ${ }^{\circ}-551^{\circ}$. Throughout Ireland. Type, British.

Watery places, marshes, \&c.; common. Fl. July-A ugust.

Sea-level in N. Donegal and S. Cork. To $1200 \mathrm{ft}$. in Mayo and to $1500 \mathrm{ft}$. in Wicklow (Hart). 


\section{CARLINA Linn.}

1. C. vulgaris Linn.-Carline Thistle.

Districts I. II. III. IV. V. VI. VII. VIII. IX. - XI. XII. Lat. $51 \frac{3}{4}^{\circ}-55 \frac{1}{4}^{\circ}$. Throughout Ireland, almost. Type, EnglishBritish.

Gravelly banks, rocky pastures, and sand-hills; frequent and locally abundant. Fl. July-September. Calcicole $A$.

I. Cliffs by the Passage road (Mr. Alexander); on Inchidony island (W. C. Nash): Flor. Cork. Near Charles Fort, Kinsale, 1894 ; rare in S. Cork; and-II. Limestone hills near Midleton; Roche's Point; Power Head; Little Island, \&c.; frequent round Cork Harbour; Phillips. By the coast at Stradbally, Waterford: Hart ${ }_{1} 883$ B.-III. Near the Black Bog, Carlow ( $R$. Clayton Browne): Rec. Add. Near the source of the Barrow, Queen's Co. : Hart 1885.-IV. Abundant on the coast of Wicklow (Moore) : Cyb. Round the whole coast of Wexford: B.-H.\&.M. $1892 .-\nabla$. Knockmaroon and Portmarnock, Co. Dublin: Wade Dubl. Very abundant on the sand-hills at Portmarnock, 1895, and frequent in the lowlands of Co. Dublin; N.C. Ballitore and Portersize, Kildare (Carroll) : $C y b .-\mathrm{VI}$. Castle Taylor, Galway : More 1855 . In all three Isles of Aran, 1892; abundant round Ballyvaughan, Clare, 1895 ; and on the shores of Lough Derg, Galway, $1896 ; N . C .-$ VII. Knock Eyon and Knock Ross, Westmeath: Levinge 1894 . Gortmore; Drominagh Point; and Ryan's Point, Lough Derg, Tipperary, $1896 ;$ N. C.-VIII. Coast near Galway : Balfour 1875 . Plentiful near Oughterard, Galway; and-IX. Near Cong, Mayo, 1896 ; Miss M. F. Jaekson.-XI. St. John's Point, Killybegs: Hart I885 $\gamma$-XII. Ballycastle, Antrim (Miss Hincks) : Flor. Ulst. Sparingly on sands at Ballykinler, Down, 1887 (Praeger): Flor.N.-E.

To $650 \mathrm{ft}$. in Dublin and to $800 \mathrm{ft}$. in Wicklow $(N . C$. $)$; to 850 ft. in Queen's Co. (Hart); but usually lowland.

Very rare in the North and seems to be absent from Kerry.

ARCTIUM Linn.

1. † A. majus Bernh.-Great Burdock.

A. Lappa Linn. in part-Lappa major Gærtn.

Districts - - - V. - - - X X - -

Roadsides and waste places; rare. $F l$. August. 
V. Roadside near St. Doulough's, Dublin; near Oldcastle, Meath; waste place at Blackrock, Louth; and-X. Roadside near the south-east end of Lough Ramor, Cavan: Praeger 1897 . Roadside two miles east of Loughgall, Armagh : Praeger 1893.

\section{A. nemorosum Lej.}

Districts - - - - V. - - - - X. - XII. Lat. $53 \frac{1}{2}^{\circ}-55 \frac{1}{4}^{\circ}$. In North-East Ireland, chiefly.

Lowland. Waste places, field borders, \&c.; apparently rare. Fl. July-August.

V. On the Burrow, Howth, Co. Dublin (Praeger): Ir. Nat. 2895.-X. Knockmore mountain, Fermanagh : Stewart I882. Near Tynan, 1889, and near Navan Fort, Armagh: Praeger 7893.XII. At Magheramorne, Antrim, 1876 (Stewart): Bot. Ex. C. Rep. 1878. Near Donaghadee and above Newtownards, Down; at foot of Ben Evenagh, Derry (Stewart): Flor. N.-E. . Moygannon and Newcastle, Down; the prevailing Burdock of the Mourne mountains : S. \& P. 1892. Fair Head, Antrim: Shoolbred I894.

\section{A. minus Bernh.-Lesser Burdock.}

Lappa minor DC.

Districts I. II. III. IV. V. VI. VII. VIII. IX. X. XI. XII. Lat. $51 \frac{1}{2}^{\circ}-54 \frac{3}{4}^{\circ}$. Throughout Ireland. Type, British.

Waste places, roadsides, field borders, \&c.; common. Fl. July-August.

Rare in District XII., for which, so far, it has been recorded only from Moygannon and Benderg, Down, and from Crumlin and near Larne, Antrim: S.\& P. 1895 .

Sea-level in Down and S. Cork. To $950 \mathrm{ft}$. in Dublin (N. C.).

\section{A. intermedium Lange.}

Districts I. II. III. IV. V. VI. - VIII. IX. X. XI. XII. Lat. $52^{\circ}-55 \frac{1}{4}^{\circ}$. Throughout Ireland, probably.

Lowland. Roadsides, waste places, \&c.; frequent. Fl. JulyAugust.

I. In the Blasket Islands, Kerry: Barrington I881.-I. \& II. Frequent about Cork (Carroll) : Cyb.-III. At Maryborough, Queen's Co.; and-IV. Near Enniskerry, Wicklow : Praeger 1897.V. Near Malahide, Dublin: N. C. 1895.-VI. Aran Isles, Galway 
Bay (Hart) : Rec. Add.-VIII. On Inishbofin : More 2876.IX. Near Foxford, Mayo (More): Cyb. Frequent by roadsides near Drumshambo, Leitrim : Stewart 1885.-X. Roadside near Washing Bay, Lough Neagh, Tyrone (Miss M. C. Knowles): Ir. Nat. 1897.-XI. In Tory Island: Barrington 1879.-XII. Common on roadsides and in waste ground in Rathlin Island: Steroart 1884. At Benderg Bay and by the old road from Ballinahinch to Drumaness, Co. Down; quarry at Ballygalley Head, Antrim (Stewart); at Magilligan, Derry (M̈rs. Leebody): S.\& P. I895.

\section{CARDUUS Linn.}

\section{C. pycnocephalus Jacq.-Slender-flowered Thistle.}

\section{C. tenuiflorus Curtis.}

Districts I. II. III. IV. V. VI. VII. - IX. - XI. XII. Lat. $51 \frac{1}{2}^{\circ}-55 \frac{1}{4}^{\circ}$. From South to North. Type, English-British.

Lowland. Waste sandy places; locally abundant near the sea, much rarer inland. Fl. June-August.

Very rare in Kerry and in Donegal. Occurs not infrequently in inland stations, but usually in small quantity and apparently as an introduction.

\section{2. † C. nutans Linn.-IIusk Thistle.}

Districts - II. - IV. - VI. - VIII. - - - Lat. $52^{\circ}-53 \frac{3}{4}^{\circ}$. Southern half of Ireland. Type, English.

Lowland. Fields, banks, waysides, and waste places; rare. Fl. July-August. Calcicole $B$.

II. Waste ground on Little Island, Cork: Drummond 2820. Still on Little Island, about fifty plants, and fairly plentiful in cultivated fields and on cliffs at Power Head: Phillips $2895 .-\mathrm{IV}$. On a headland by the sea, about four miles north of Blackwater Head, Wexford: Hart I88I a. In fallows at Aughnaclappa, Wexford: Moffat I889.-VI. By the roadside between Gort and Corofin, sparingly: Maok. Rar. In north Clare (J. Foot): Cyb. Near Kiltartan, Galway (C. Carter): Phytol. 1846, p. 513. Near Castle Taylor, Galway, in some plenty: More 1855. Near Kilronan, Aranmore island: Ogilby 1845. At the Seven Churches, Aranmore island and near the landing place on Middle Island: Hart 1875. Near the abbey, Corcomroe, Clare, $1892 ; P . B . O^{\prime}$ Kelly. On the 
neck of Ilaun-muckinish, Clare, in some quantity, $1895 ; N . C$. VIII. On Clare Island; Hon. Miss E. Lawless.

Also recorded from-I. Near Castletown Berehaven: Flor. Cork.-V. Castle Dillon, Straffan, Kildare; and-XII. Railway bank two miles from Carrickfergus: $C y b$.; but in these stations the plant appears to have been little more than a casual.

\section{3. † C. crispus Linn.-Welted Thistle.}

Districts - - III. - V. VI. VII. - - X. XI. XII. Lat. $53^{\circ}-55 \frac{1}{4}^{\circ}$. Northern half of Ireland, chiefly. Type, BritishEnglish.

Lowland. Dry banks, waste places, \&c.; rare. Fl. July-Aug.

III. At Maryborough, Queen's Co. : Praeger 1897.-V. Roadsides, about two miles south of Dundalk; roadside going to Lucan, and other places about Dublin: Templeton MSS. Finglas; Glasnevin; Ballygall; and Cardiff's Bridge; Dublin: Ir. Flor. At Mulhuddart, 1893 ; Skerries and Sutton, 1895 ; Knockmaroon, \&c.; not infrequent in Co. Dublin; $N . C$. Roadsides near Ballitore, Kildare ( $T$. Chandlee): Cyb. Near Mornington, at the Boyne mouth, Meath; Praeger.-VI. Near Corofin, Clare, 1892 ; Levinge.-VII. In Westmeath close to the borders of Longford (M. P. Edgeworth): Cyb.X. Cremorne, Co. Monaghan, 1805: Templeton MS. Clones, Monaghan; Stewart. Common in the limestone district of Armagh : Praeger 1893.-XI. Roadside near Culdaff, 1839 : Herb. C. Moore. Near Carndonagh; and by the Erne at Belleek; Hart.-XII. Not rare at Magilligan, 1835: Moore MS. Common at Magilligan: S.\&P. 1895. Curran of Larne: Cyb. \& Stewart I894. Fields and waste ground at Killowen, Down: S.\& P. I892.

Seldom occurs in abundance and is obriously introduced in many of its stations. The Irish plant is usually the Var. ACANTHODDEs (Linn.). The Var. PolyanTHEMos (Koch) is apparently rare.

\section{CNICUS Linn.}

\section{C. Ianceolatus Willd.-Spear Thistle.}

Cirsium lanceolatum Scop.

Hibernicé Fożannán (Fohen-awn)-Proċeỏan (Feeo-kay-dhawn). Districts I. II. III. IV. V. VI. VII. VIII. IX. X. XI. XII. Lat. $51 \frac{1}{2}^{\circ}-55 \frac{1}{4}^{\circ}$. Throughout Ireland. Type, British.

Pastures, roadsides, and waste places; common. Fl. July-August. 
Sea-level in Derry and S. Cork. To $1700 \mathrm{ft}$. in Derry (Fart); to $1400 \mathrm{ft}$. in Ben Bulben district $(B . \& . V$.$) .$

\section{C. palustris Willd.-Marsh Thistle.}

Cirsium palustre Scop.

Districts I. II. III. IV. V. VI. VII. VIII. IX. X. XI. XII.

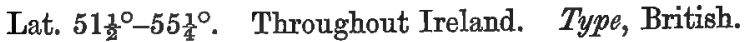

Wet meadows and marshy places; common. Fl. June-August.

Sea-level in N. Antrim and S. Cork. To $1350 \mathrm{ft}$. in Derry (Hart); to $1600 \mathrm{ft}$. in Ben Bulben District (B.\&V.); to $1800 \mathrm{ft}$. in Dublin, and to $2400 \mathrm{ft}$. in Wicklow (N.C.).

C. Forsteri Smith-C. palustris $\times$ pratensis-XII. In Garvagh demiesne, and in wet meadows by the Bann below Jackson Hall, Derry, 1835 : Moore MS.

Peculiar forms of $C$. pratensis have been gathered at Lisdoonvarna, Clare, and at Lough Owel, Westmeath, by $H, C$. Levinge; near Roundstone, by Rev.E. F. Linton; and near Belleisle, Lough Erne, by $R$. M. Barrington; but none of these can with certainty be referred to $C$. Forsteri.

\section{C. pratensis Willd.-Bog Thistle.}

Cirsium anglicum Lamk.

Districts I. II. III. IV. V. VI. VII. VIII. IX. X. XI. XII. Lat. $51 \frac{33^{\circ}}{4}-551^{\circ}$. Throughout Ireland. Type, English.

Boggy pastures; locally abundant. $F$. June-August.

Sea-level in Antrim and Kerry. To $900 \mathrm{ft}$. in Donegal (Flor. Ulst.); to $1650 \mathrm{ft}$. in Sligo $(B . \& V$.); to $1350 \mathrm{ft}$. in Wicklow (Hart).

Rare in the East, and in S. Cork and S. Kerry; abundant in the West and North.

\section{C. arvensis Hoffm,-Creeping Thistle.}

Cirsium arvense Scop.

Districts I. II. III. IV: V. VI. VII. VIII. IX. X. XI. XII. Lat. $51 \frac{1}{2}{ }^{\circ}-55 \frac{1}{4}^{\circ}$ - Throughout Ireland. Type, British.

Fields, waysides, \&c. ; common. Fl. July-August.

Sea-level in Antrim and Cork. To $1200 \mathrm{ft}$. in Dublin ( $N . C$.).

Var. sETosus (Bess.) - XI. In a stubble field by the river Lennan near Kilmacrenan (Rov. T. Allin): Rec. Add. Carndonagh; Glen Alla; Carrick, \&c., not infrequent in Donegal; Hart. 


\section{SILYBUM Vaill.}

\section{1. * S. Marianum Gærtn,-Milk Thistle.}

Districts I. II, III. IV. V. VI. VII. VIII. - X. - XII.

Waste places and cultivated ground, usually near houses or ruins; rare. Fl. July-September.

I. By the ruins at Kilshannig, Castlegregory, Kerry : Hart I884. Magharee Islands; Barrow Harbour; Banna; Beal Castle, \&c., Kerry; R.W. S. Timoleague Abbey, Cork: Drummond I820. Railway cutting near Blackrock, 1897; Phillips. At Glandore (Miss Hungerford); at Courtmacsherry (C. Longfield); andII. Near Mallow ( $T$. Chandlee): Allin's Cork. Near Clonmel (Miss S. Grubb): Cyb. Field side near Tipperary; R.W.S.III. Lacken Hill, Kilkenny (Rev. S. Madden); Rock of Dunamase, Queen's Co. (T. Chandlee) : Cyb.-IV. Near Chapel railway station, Wexford: $\boldsymbol{B} .-H . \& \not M . ~ I 892 .-\mathrm{V}$. Warren House, on the way to Howth: Wade Dubl. Plentiful in the churchyard at Kilbarrack: Mack. Cat. 1825-still there in 1894; N. C. Sandy fields about Rush: Ir. Flor. Donnybrook, Dublin, 1894; More. Near Ballitore, Kildare (J. Morrison) : Cyb. Roadside near Castle Bellingham, Louth: Butler I890.-VI. Askeaton, Limerick: Stewart I890. By the ruins of Muckinish Castle, Clare, 1895; and-VII. By the old church at Dromineer, Lough Derg, Tipperary, $1896 ;$ N. C.VIII. On the beach near Galway (Prof. Melville): $C y b .-X$. In Armagh, at Maghery (Rev. W. F. Tohnson); and at Seagoe (Rev. H. W. Lett): Praeger 1803.-XII. At Magilligan: Sampson 1802. Benone, Magilligan, Derry, 1835: Moore MS. Portbradden and Toomebridge (Stewart): Flor. N.-E. Crawfordsburn, Down; and White Park Bay, Antrim (Praeger) : S.\& P. 1895.

Long established in some of its stations in sandy ground near the sea, butin all cases a more or less obvious relic of ancient cultivation and nowhere occurring in abundance.

\section{SAUSSUREA DC.}

\section{S. alpina DC.-Mountain Saw-2oort.}

Districts I. II. - IV. - - - VIII. - - XI. XII. Lat. $52^{\circ}-55 \frac{1}{4}^{\circ}$. West Ireland, chiefly. Type, Highland.

Wet alpine cliffs and grassy mountain ledges; very rare. $F l$. August. 
I. "On the mountains of Keri" (Lhwyd): Phil. Trans. r7Iz. Cliffs near the summit of Brandon, 1804: Mack. Rar.-abundant here in $1885 ; N . C$. Horse's Glen, Mangerton (Carroll): Cyb.still there in $1889 ; R . W . S$. Mullaghanattin mountain, Glencar, $1885 ; N . C . \quad$ On Coomacarrea mountain, Glanbehy, Kerry, 1892; R.W. S.-II. On Galtymore mountain: Hart r88I. - IV. On Thonalagee mountain, Wicklow, 1884 ( $N$. C.) : Journ. of Bot. I885, p. 157.-VIII. Croaghpatrick in Mayo; Ben Lettery and Muckanaght, Twelve Bens, Galway: Hart 1883a.-XI. Inishowen, Co. Donegal (Mr. Brown) : Templeton MS. [before 1800]. Bulbein mountain, Inishowen: Hart 2880 . Slieve League (Hart); Slieve Snacht West $\left(\boldsymbol{N} . C_{.}\right):$Hart $1885 \gamma$. Mountains near Ardara: Hart 1886. Ballaghgeeha Gap, Dunlewy, 1884; N. C. XII. Sparingly on Slieve Muck North, Mourne mountains: S. \& P. 1802 .

From 1000 to $2000 \mathrm{ft}$. in Donegal, $1320-1700 \mathrm{ft}$. in Galway, and at $2600 \mathrm{ft}$. in Tipperary (Hart) ; 1050-2050 ft. in Wicklow, and $1700-2800 \mathrm{ft}$. in Kerry $\left(N .^{*} C^{\circ}\right)$.

First found by Lhwyd, in Kerry, in 1699.

Like others of our alpine species, descends to a much lower level in Ireland than in Great Britain.

\section{CENTAUREA Linn.}

\section{C. nigra Linn.-Black Knapweed.}

Districts I. II. III. IV. V. VI. VII. VIII. IX. X. XI. XII. Lat. $51 \frac{1}{2}^{\circ}-55 \frac{1}{4}^{\circ}$. Throughout Ireland. Type, British.

Fields and banks; common. Fl. July-September.

Sea-level in N. Antrim and S. Cork. To $800 \mathrm{ft}$. in Donegal (Hart); to $1200 \mathrm{ft}$. in Dublin $\left(N_{.} C_{0}\right)$; to $1500 \mathrm{ft}$. in Kerry (Druce).

Radiant-flowered forms which have been recorded from Kerry, Cork, Queen's Co., Wicklow, Down, and Derry should perhaps be referred to C. decipiens (Thuill.).

\section{C. Scabiosa Linn,-Greater Knaproeed.}

Districts I. II. III. IV. V. VI. - VIII. IX. - - Lat. $51 \frac{3}{4}^{\circ}-53 \frac{1}{2}^{\circ}$. Southern half of Ireland. Type, British-English.

Lowland. Dry banks, waste places, cultivated fields, and pastures; locally abundant. Fl. July-August. Caloicole $B$. 
I. Near Oyster Haven, Kinsale; and-II. At Midleton; Cloyne; and Whitegate, Cork; Phillips. Ardmore Head, Waterford: Hart I883 B.-III. Ayresford, \&c., Kilkenny (Rev. S. Madden) : Cyb. Ballinlaw Ferry, Kilkenny : B.-H. \& G. I889. Stradbally, Queen's Co. (T. Chandlee): Cyb.-IV. In Co. Wicklow, at Greystones (Mrs. G. Dixon); at Kilcool (Hart): Rec. Add. Frequent near Kilmanock, Wexford: B.-H.\& G. $x$ 889.--V. Between Chapelizod and Lucan: Wade Dubl. I794. Near Chapelizod, 1895; at Raheny and Skerries, 1894; Green Hills, \&c.; not infrequent in the lowlands of Co. Dublin; N.C. Ardee, Louth; Praeger.-VI. Near Tuam, \&c., very fine: Wade Gallovid. Common in all three Isles of Aran (Hart): Rec. Add. Most abundant in pastures and cultivated ground about Ballyvaughan, and frequent thence by Corcomroe, Kinvarra, Ardrahan, and Athenry, on to Galway, 1895; N. C. Railway banks, Adare to Ballingrane, and near Askeaton, Limerick: Stewart 1890.-VIII. Sand-hills on Inishbofin: More 1876. Near Ballynahowen and at Firboe, near Spiddal, 1896; Rev. W. Colgan.-IX. Abundant about Cong in Co. Mayo, 1895; Miss M. F. Jackson.

\section{3. * C. Cyanus Linn.-Corn Blue-bottle.}

Districts I. II. - IV. V. VI. VII. - IX. X. XI. XII. Lat. 52 ${ }^{\circ}-55 \frac{1}{4}^{\circ}$. From South to North. Type, British.

Cultivated land; rather rare and local. Fl. June-August.

Sea-level to $600 \mathrm{ft}$. in Derry (Moore MS.); but usually lowland.

Only a casual in many of its stations; most frequent in flax crops.

\section{CICHORIUM Linn.}

\section{1. $\ddagger$ C. Intybus Linn,-Chicory.}

Districts I. II. III. IV. V. VI. - - IX. - XI. XII. Lat. 51 $\frac{10}{2}-55 \frac{10}{2}$. From South to North. Type, English.

Lowland. Cultivated land, dry banks, and waste places; rare. Fl. July-August.

I. Cape Clear Island, 1896 ; near Kilkern ; Castlefreke ; Creagh near Skibbereen, 1897 ; and-II. Great Island; Ballycotton; Guileen, Co. Cork; Phillips. Ardmore Head, Waterford : Hart I883 $\beta$.-III. Near Ballyonskill, Kilkenny (Rev. S. Madden): Rec. Add.-IV. Fields on the Murrough of Wicklow (Moore) : Cyb. On the embankment and sand-hills at north side of Wexford. 
Harbour : Hart I883 $\beta$. Well established at Grange Hill, Arthurstown, Wexford : $B .-H$. \& G. 1889 . Aughnaclappa and Urinsfort, Wexford: Moffatt $7889 .-\mathrm{V}$. Found near Kilmainham Hospital: Threlleld. Banks near the sea-shore south of Malahide (Moore): Cyb. Potato field at Howth, 1896; Miss S. Colgan. Rare and uncertain in its appearances in Co. Dublin; $N$. C. Very common in fields and waste ground about Termonfeckin and below Togher, Louth: Praeger I897.-VI. Glenstal, Limerick (C. B. Barrington): Hart $I 88 I \gamma$. Casual near Ballyvaughan, Clare, $1896 ; \boldsymbol{P} . \boldsymbol{B}$. O'Kelly.-IX. Near Mount Falcon, Ballina; Mrs. U. Enox. Lackafinna, Cong; Miss M. F. Jackson.-XI. Between Rathmelton and Fort Stewart (Dean Gwynn): Hart I880. Near Greencastle, 1896 ; Mrs. Leebody. - XII. Cornfield near Kilkeel, Down : S. \&P. I892. Glynn and Portrush sand-hills; only a casual in the NorthEast (Praeger) : S.\&. P. 1895 .

Usually in sandy ground near the sea; but seldom occurs in abundance.

\section{LAPSANA Linn.}

\section{L. communis Linn.-Nipplewort.}

Districts I. II. III. IV. V. VI. VII. VIII. IX. X. XI. XII. Lat. $51 \frac{1}{2}^{\circ}-551_{4}^{\circ}$. Throughout Ireland. Type, British.

Bushy places, woods, and cultivated ground; rather common. F'l. July-August.

Sea-level in N. Derry and S. Cork. To $950 \mathrm{ft}$. in Dublin (N.C.).

\section{PICRIS Linn.}

\section{1. †P. echioides Linn.-Bristly Ox-tongue.}

Helminthia echioides Gærtn.

Districts I. II. - IV. V. - - - - XII. Lat. $52^{\circ}-54^{\frac{3}{4}}$. South and East, chiefly. Type, English.

Hedge-banks, borders of fields, waste places, \&c.; rare. Fl. July-September.

I. Near Ballincollig Castle, 1854 (J. Sullivan): Annot. in Flor. Cork.-II. Fields in the Little Island: Drummond 1820. Near Youghal (Rev. T. Allin) : Rec. Add. Sparingly near Whitegate, Cork, 1896 ; roadside near Guileen; plentiful in a field near Power Head, 1897 ; Phillips. Roadside between New Geneva and Passage [Waterford]; Dr. Barker: Templeton MSS. On the north side of 
Dungarvan Harbour, Waterford; and-IV. Between Rosslare and Greenore, and near Duncannon, Wexford: Hart 1883 B. Plentiful in a field between Ballinlaw Ferry and the Island Quay, Wexford (Miss L. Glascott): B.-H.\& G. I889. Kilmanock, Wexford ( $G$. Barrett-Hamilton): Ir. Nat. I894.-V. "It is frequent under Hedges and above the Barracks [Dublin] in a Brow to the Westward": Threlkeld I727. Knockmaroon Hill; Howth; Raheny; Kilbarrack, \&c.: Ir. Flor. Not infrequent near Dublin and occasionally along the coast as far north as Drogheda: Flor. Hib. Roadside banks between Swords and Balbriggan (Moore): $C y b$. Near Knockmaroon; More. Plentifully on ditch-banks, and by a quarry at Sutton: Flor. Howth. Now very rare in Co. Dublin and apparently extinet in many of its older stations; $N . C$. Gravelly banks at Laytown, Meath : Praeger I897.-XII. Shore at north end of Island Magee, Antrim (Stewart \& $R$. Tate); and shore of Belfast Bay, half-a-mile above Black Head (Stewart): Rec. Add.

\section{CREPIS Linn.}

\section{C. taraxacifolia Thuill.-Dandelion Hawk's-beard.}

Barkhansia taraxacifolia DC.

Districts - II. III. IV. V. VI. - VIII. IX. - - Lat. $52 \frac{1}{4}^{\circ}-53 \frac{1}{2}^{\circ}$. East Ireland, chiefly. Type, Germanic.

Lowland. Dry banks, field-borders, and oild quarries and gravelpits ; locally abundant. Fl. May-July. Caloicole B.

II. Four or five plants by the Avenue at Blenheim, Waterford: B.-H. \&G. 1889 . At Fethard and north of Clonmel, Tipperary, 1897 ; and-III. Kilkenny town and at Bagnalstown, Carlow, 1897 ; Praeger. By the river at Mountmellick, Queen's Co.; Miss S. Grubb. - IV. Herbert Road, Bray; More. - V. Near Baldoyle; Knockmaroon Hill, and elsewhere: Wade Dubl. (as C. biennis). Phœenix Park; Portmarnock; Kilbarrack; and Howth: Ir. Flor. (as C. biennis). At Leixlip; D. M Ardle. Skerries; Clonsilla; Lucan; Glenasmole, \&c.; frequent almost throughout the lowlands of Co. Dublin, $1895 ;$ N. C.-VI. Roadside near Ballyvaughan, Clare, 1896 ; P. B. O'Kelly.-VIII. Near Ashford bridge, Galway; and-IX. By the Quay road, Lisloughrey, Co. Mayo, 1895; Miss M. F. Jackson.

Sea-level to $650 \mathrm{ft}$. in Dublin $\left(N_{.} C_{0}\right)$; but usually lowland. 


\section{C. virens Linn.-Smooth Haroks-beard.}

Districts I. II. III. IV. V. VI. VII. VIII. IX. X. XI. XII. Lat. $51 \frac{1}{2}^{\circ}-55 \frac{1}{4}^{\circ}$. Throughout Ireland. Type, British.

Banks, walls, hedges, \&c. ; common. Fl. June-September.

Sea-level in Derry and Cork. To $1200 \mathrm{ft}$. in Down (S.\& P.).

\section{3. * C. biennis Linn.-Rough Hawik's-beard.}

Districts I. II. - IV. - VI. VII. - - X. - XII. Lat. $52^{\circ}-55^{\circ}$. From South to North. Type, Germanic.

Lowland. Meadows and pastures; local. Fl. June-July.

I. Abundant by the railway near Vernon Mount, Cork, 1896; Phillips.-II. Near Cappoquin, Waterford, 1880 ; and by the railway near Fermoy, Cork; F. E. Currey.-IV. Field on Bruce's farm, Bray, 1891; More. Almost monopolizing some meadows near Rathdrum, Wicklow, 1893-95; Rev. Wyndham Guinness.VI. Near Tarbert, Co. Limerick: R.W. S. I800.-VII. Abundant in damp fallows near Dromineer, Tipperary, $1896 ; N$. C. Near Geashill, King's Co. (Praeger): Ir. Nat. I894.-X. Near the workhouse, Armagh, 1884; More-still there in 1892: Praeger 1893.XII. Abundant in a meadow near the town dam of Belfast waterworks, 1880 ; by the railway north of Whiteabbes, and in adjoining meadows and pastures, 1884 (Stewart); by the railway at Marino and fields near Cairncastle, 1886 (Praeger); railway at Dunadry, Antrim (More) : Flor. N.-E. Between Crossgar and Downpatrick, Down (Praeger); increasing in the North-East and may be ranked there as naturalized: S.\& P. 1895 .

An aggressive species usually introduced with grass seeds and spreading rapidly in Ireland.

- First found by S. A. Stewart, in Antrim, in 1880.

\section{C. paludosa Mœnch.-Marsh Havole's-beard.}

Hieracium paludosum Linn.

Districts I. II. III. IV. V. VI. VII. VIII. IX, X. XI, XII. Lat. $52^{\circ}-55 \frac{1}{4}^{\circ}$. Throughout Ireland. Type, Scottish-Highland.

Marshy meadows, river banks, and wet, rocky places on mountains; frequent. Fl. June-August.

I. Banks of the Feale above Listowel; very rare in Kerry: R. W. S. 189I.-II. At Coolrue near Fermoy, but very rare 
(T. Chandlee): Cyb. By the river Lickey, Waterford; and by the river near Midleton, Cork (Rev. T. Allin): Ree. Add. Shownagh river near Healy's Bridge, 1895; Phitlipg. Above Gurtaveha lake (Carroll) : Allin's Cork. On Galtymore mountain, Tipperary : Hart 188x. In the Commeragh mountains, Waterford: Hart 7884.-III. By the Barrow between Lea Castle and Portarlington, Queen's Co.: Hart 7885 - - IV. Frequent in the Wicklow mountains (Moore) : $C y b .-\bar{\nabla}$. By rivulets on Kilmashogue mountains: Wade Dubl. I794. Still abundant at Kilmashogue, 1895, and frequent in the upland and mountainous parts of Co. Dublin, as at Lugmore; Athgoe; Kippure; Seecawn mountain, \&c.; $N$. C. At the base of the Carlingford mountains near Omeath, Louth: Hart 1884 . Frequent near Ballitore, Kildare (Carroll): Cyb.-VI. By the Mulcaher river, Glenstal, Limerick: Hart I 88 I $\gamma$. On Glounagalliagh mountain, near Killaloe, Clare, 1896 ; N. C.-VII. Scraw Bog, Loughanstown, and shores of Lough Derevaragh, Westmeath: Levinge 1894.-VIII. By Lough Cullin, \&c., Mayo (More) : Cyb. Islands in Lough Inagh, Connemara, $1897 ; N . C$. On the Twelve Bens and Maam Turk mountains, Galway; and-IX. Croaghpatrick, Mayo: Hart 1883 a. Hollywood and Foxford, Mayo (More): Cyb. On Ben Bulben, Sligo: $B . \& \cdot V$. . 885 . In the Ox mountains, Sligo, $1896 ; N$. C. Frequent in Districts X., XI., and XII.

Sea-level in Donegal and down to $100 \mathrm{ft}$. in Kerry. To $1450 \mathrm{ft}$. in Donegal (Hart); to $1700 \mathrm{ft}$. in Ben Bulben district $(B . \& V$.$) ; to 2350 \mathrm{ft}$. in Wicklow $(N . C$. ); to $2500 \mathrm{ft}$. in Tipperary (Hart).

By no means a common species, though wide-spread and locally abundant. Rare in the South, and apparently absent from S. Kerry and S. Cork.

\section{HIERACIUM Linn.}

\section{H. Pilosella Linn.-Mouse-ear Hawkweed.}

Districts I. II. III. IV. V. VI. VII. VIII. IX. X. XI. XII. Lat. $51 \frac{1}{2}^{\circ}-55 \frac{1}{4}^{\circ}$. Throughout Ireland. Type, British.

Dry banks, pastures,' and rocky places; common. Fl. MayAugust.

Sea-level in N. Derry and S. Cork. To $1300 \mathrm{ft}$. in Derry, and to $1650 \mathrm{ft}$. in Wexford (Hart). 


\section{H. anglicum Fries.}

Districts I. II. - IV. V. VI. - VIII. IX. X. XI. XII. Lat. $51^{\frac{3}{4}}-55^{\frac{1}{4}}{ }^{\circ}$. South to North. Type, Highland.

Mountain cliffs and rocky places; local. Fl. July-August.

I. On many of the Kerry mountains; rare at low elevations but occurs at Muckross Lake, Killarney: R.W. S. 1890. Near Adrigole: Allin's Cork. On several of the Cork mountains; R.W.S.II. On the Galtee mountains, Tipperary : Hart I88I. Rocks above Gurtaveeha Lake, Millstreet, Cork (More): Rec. Add. Commeragh mountains, Waterford: Hart I884.-IV. South slope of Lugnaquilla mountain, Wicklow: Hart $788 \mathrm{I}$ a.-V. Carlingford mountain, Louth : Hart I884.-VI. Glanquin Hills, Clare: Corry 7880. Aranmore Island (Hart): Rec. Add. Burren Hills, Clare, 1892; P. B. O'Kelly.-VIII. Salruck and Muckanaght, Galway; and Westport, and Croaghpatrick, Mayo: Hart 1883 a. Lisoughter, Recess, Galway (Prof. J. W. Carr): P.\& C. 2895.-IX. Ben Bulben, Sligo: B.\&V. $1885 .-\mathrm{X}$. Knockmore; Carrick; Drumbad, \&c.; frequent in Cavan and Fermanagh: Stewart $2892 .-$ XI. Lavagh More; near Lough Belshade; between Glenties and Silver Hill: Hart r88I $\beta$. Meevagh, Rossgull; Miss A. G. Kinahan.-XII. Frequent in Down and Antrim : Flor. $N .-E$.

Var. acutrfoliom Back.-IX. Glenade cliffs, Sligo: $B . \& V$. 1885.-XII. Sallagh Braes, Antrim (Stewart): Flor. N.-E. By the Shimna river above Tollymore Park, and by the stream on Luke's mountain : S.\& P. 2892 .

Var. Longmaracteatum $F$. J. Hanb.-XII. Garron Point and Glenariff, Antrim (Shoolbred): Stewart I894.

Sea-level to $1700 \mathrm{ft}$. in Donegal ( Hart); 200-2000 ft. in Down $(S . \& P$.) ; from $100 \mathrm{ft}$. (R.W.S.) to $2500 \mathrm{ft}$. (Hart) in Kerry.

H. cerinthiforme (Back.) var. HАRTII $F$. J. Hanb.-XI. Slieve League, Donegal : Hart $1885 \gamma$ (as H. cerinthoides a Back.).

This plant is described in the Journ. of Bot. I892, p. I69, by Mr. F. J. Hanbury and dedicated by him to Mr. H. C. Hart, who has done so much to extend our knowledge of the Irish flora.

\section{H. iricum Fries.}

Districts I. - - - VI. - VIII. IX. - XI. XII. Lat. $51 \frac{3}{4}^{\circ}-551^{\circ}$. South to North. Type, Highland. Peculiar to the British Isles.

Rocky places; local. Fl. June-August. 
I. On Mangerton and Purple mountains, Kerry (H. N. Ridley): Journ. of Bot. 1884. Turner's mountain, Kerry : Druce 1891. In several localities about Killarney: $R . W . S . \quad$ r8go. Sugar Loaf mountain, Glengariff (Carroll) : Cyb.-VI. Rocky pasture west of Castle Taylor, Galway: More I860. Glanquin hills and Glancolumbkille, Clare: Corry :1880. Ballyvaughan, Clare, 1892; Levinge.-VIII. Rocky margins of streams on the Twelve Pins of Beannabeola and on Eagle mountain, Connemara : Backhouse 1856. Mweelrea, Mayo; and Benchoona, Kylemore, Galway : Hart I883 a. Locally abundant on Mount Gable near Clonbur: M. \& S. $1896 .-$ IX. Ben Bulben, Sligo: Backhouse 1856. Faughrey mountain, Glencar, Leitrim ; and Knockacree, Ox mountains, Sligo, 1896 ; N. C.XI. Side of Muckish, Donegal (C. Moore) : $C y b$. Slieve League; by river Finn; by Killybegs river; and at Coolcross, Inishowen: Hart $r 885 \gamma$. St. John's Point and near Ballyshannon, Donegal: Hart I886.-XII. Glenariff and Garron Head, Antrim : Backhouse 1856-still plentiful in both stations: Shoolbred I894. Sparingly on Cave Hill; on Rathlin Island; and on Ben Evenagh (Stewart): Flor. N.-E. Basaltic cliffs, Downhill, Derry : S.\& P. I895.

From $100 \mathrm{ft}$. in Antrim to $1100 \mathrm{ft}$. in Derry (Flor. $N .-E$.); to $1350 \mathrm{ft}$. in Leitrim $(N . C.) ; 80-1250 \mathrm{ft}$. in Kerry $(R . W . S$.$) .$

Of the Hieracia apparently peculiar to the British Isles, Mr. Arthur Bennet considers this and $H$. Gibsoni to be the best marked forms (see Wallace's Island Life, ed. ii., pp. $3^{61-2}$ ).

\section{H. flocculosum Backh.}

Districts - - - - - - - - XII.

Lat. $54^{\circ}-55^{\circ}$. Down and Antrim only.

River banks and rocky places; very rare. Fl. July-August.

XII. Sparingly on rocky banks of the Spinkwee river above Tollymore Park (Stewart) : Flor N.-E. By the same stream, more abundantly, on shaded rocks in Tollymore Park: S.\&. P. I892. On the basalt of Sallagh Braes, Antrim, 1886 : Stewart 1894 .

\section{H. Schmidtii Tausch.}

H. pallidum, Fries in part.

Districts - - - - - - IX. - XI. XII.

Lat. $54^{\circ}-55^{\circ}$. North of Ireland only. . Type, Scottish.

Rocky places and mountain cliffs; very rare. Fl. July-August. 
IX. Goat Island, Lough Gill; the Three Bunions over Glencar; Arroo mountain, Glenade: B.\&V. 1885.-XI. Agla mountain, Donegal: Hart $2886 .-\mathrm{XII}$. Granite cliffs of Ben Crom, Mourne mountains: S. \& P. I892. Ballintoy, Co. Antrim (Rev. S. A. Brenan): Ir. Nat. 1806 .

Sea-level to $1300 \mathrm{ft}$. in Sligo $(B . \& V$.). To $1500 \mathrm{ft}$. in Down (Hart).

H. LeYr F. J. Hanb.-XII. Ben Evenagh, Co. Derry, 1893 (Shoolbred): Stewart 7894 (as H. bifidum Tansch).

\section{H. lasiophyllum Koch.}

$H$. crinigerum Fries- $H$. cinerascens Jord.

Districts - - - - - - - - X. - XII. Lat. $54_{4}^{\circ}-55^{\circ}$. Fermanagh, Down, Antrim, and Derry.

Rocky places and sand-hills; rare. Fl. June-July.

$X$. Sparingly at Knockmore; Carrick; and Badmore, Fermanagh: Stewart I882.-XII. Spelga mountain, north-east of Rosstrevor, 1872 (Stevoart); sand-hills at Ballykinler, Down, 1886 (Praeger) : Flor. N.-E. Steep cliffs south of Glenarm (Dickie): Flor. Olst. Glenariff (Moore): Cyb. Cave Hill and Sallagh Braes, Antrim; Ben Bradagh, Derry (Stewart): Flor. N.-E.

Sea-level to $1400 \mathrm{ft}$. in Down (Flor. N.-E.).

H. FARRENSE $F$. J. Hanb.-XII. Basaltic cliffs, Sallagh Braes,

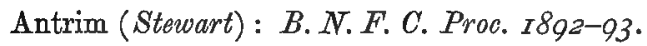

H. RUBicundum $F$. J. Hanb.-XI. Inishowen, Donegal (Hart): Jowrn. of Bot. I892, p. 208.-XII. Sallagh Braes, Antrim (Stewort): B. N. F. C. Proc. I892-93.

\section{H. argenteum Fries.}

Districts - - - - - - VIII. - - - XII. Lat. $53 \frac{1}{2}^{\circ}-54^{\circ}$. Galway and Down only.

Rocky places, and on mountains; very rare. Fl. JulyAugust.

VIII. Muckanaght and Maumeen, Galway: Hart I883a.XII. Abundant on cliffs, Eagle Rock, Slieve Donard; sparingly by the Shimna river in Tollymore Park; on Cove mountain and on Ben Crom, Co. Down: S. \& P. 1892.

From $100 \mathrm{ft}$. to $1700 \mathrm{ft}$. in Down $(S . \& P.) ; 1100-1520 \mathrm{ft}$. in Galway (Hart). 
H. Sommerfeltii Lindeb.

Districts - - - - - - - - - XII.

Lat. 55. County Derry only; very rare.

XII. Ben Evenagh, Derry (Stewart): S.\& P. 1805 .

H. scoricom $F$. J. Hanb.-XI. Grassy banks of the Carrick river, Co. Donegal, near sea-level (Hart and Hanbury): Journ. of Bot. $1893 \&-94$.

H. HIBERNicuM $F$. J. Hanb.-XI. By the Carrick river; and Moynalt near Laghy, Donegal : Hart I885 $\gamma$ \& I886 (as H. argenteum Fries).-XII. By the Causeway-water at Broughnamaddy, Mourne mountains : Hart 1884 (as H. vulgatum Fries).

This plant, which is apparently peculiar to Ireland, has been segregated by Mr. F. J. Hanbury on examination of specimens gathered in the Broughnamaddy station by Messrs. Stewart and Praeger in 1891. It is described and named in the Journ. of Bot. r892, p. 258 .

7. H. murorum Linn.

Districts I. II. - - V. VI. - - IX. - XI. XII. Lat. $52^{\circ}-55 x^{\circ}$. South to North. Type, British.

Rocky places and banks; very rare in the South, but frequent in the North. Fl. June-August.

I. Shady walk near Glenflesk Castle, Killarney, 1889-97; R.W.S.-II. At Castleredmond, near Midleton, Cork: Allin's Cork. Fota, near Cork : Phillips 1895.-V. Carlingford mountain, Louth; Stewart.-VI. Rocks east of Ballyvaughan, Clare; Levinge.IX. Goat Island, Lough Gill; and Ben Bulben: B.\&V. 1885.XI. Donegal (C. Moore): Cyb. Knockalla and Croghanmore, Donegal : Hart 1879 .-XII. Abundant on the basaltic hills of Derry (Moore) : Cyb. Frequent in north-east Ireland: Flor. N.-E.

Var. MICROCladIUM Dahlst.-XII. Newtown Crommelin and Garvagh, Derry (Rev. S. A. Brenan): Ir. Nat. $\pi 8 g 6$.

Var. PACHYPHYLLUM Purchas-XII. Knockagh and Sallagh Braes, Antrim (Stewart): Journ. of Bot. 1895 .

From $100 \mathrm{ft}$. in Antrim to $1400 \mathrm{ft}$. in Down (Flor. $N_{\text {. }}-E$.).

H. EUPREPES F. J. Hanb.-XII. Cave Hill, Antrim, 1845 (Dr. Mateer): Herb. Hanbury. Sallagh Braes (Stewart): B.N.F.C. Proe. I892-93. Bank at Milltown near Red Bay, Antrim: Shoolbred 1894. Ben Evenagh, Derry: Stewart 1894 . 
H. stenolepis Lindeb.

Districts - - - - - - - - - XII.

Lat. $54 \frac{1}{2}^{\circ}-55 \frac{1}{4}^{\circ}$. Antrim and Derry; rare.

XII. Knockagh and Sallagh Braes (Stewart); and on Cave Hill, Antrim (Praeger): B.N.F. C. Proc. I8go-gI. Garron Point and Glenariff, Antrim; and on Ben Evenagh, Derry: Shoolbred I894.

8. H. cæsium Fries.

Districts - - IV. - VI. - - IX. - XI. XII. Lat. $53^{\circ}-554^{\circ}$. Northern half of Ireland.

Rocky places in mountainous districts; rare. Fl. June-August.

IV. Dargle, Co. Wicklow ; Hart.-VI. Rocks east of Ballyvaughan, Clare, 1892; Levinge.-IX. Ben Bulben, Sligo: B. \&V. 1885.-XI. Coolcross, Inishowen : Hart 1885 \%.-XII. Fair Head, Antrim (Babington): $C y b$. Very sparingly on the cliffs of Ben Evenagh, Derry (Stewart): Flor. N.-E. Glenariff, Antrim (Stewart): B.N.F.C. Proc. $8889-90$.

To $1100 \mathrm{ft}$. in Derry (Flor. N.-E.).

H. Gibsoni Backh.

H. hypocharoides Gibs.

Districts - - - - VI. - - - - - -

Lat. $53^{\circ}$. Clare only. Peculiar to the British Isles.

Limestone cliffs; very rare. Fl. July-August.

VI. Glancolumbkille, Co. Clare : Corry I 880.

\section{H. vulgatum Fries.}

H. sylvaticum Smith.

Districts I. - - IV. V. - - VIII. IX. X. XI. XII. Lat. $52^{\circ}-55 \frac{1}{4}^{\circ}$. South to North. Type, British.

Banks, rocks, riversides, \&c. ; frequent in the North, rare elsewhere. Fl. June-August.

I. By Loughs Gall and Duff, Brandon mountain, Kerry : Hart 1884. Horse's Glen, Mangerton, sparingly; R.W. S.-IV. Powerscourt Waterfall and Devil's Glen, Wicklow : Flor. Hib.-V. Banks of the Liffey above Leixlip (More): $C y b$.-also lower down the river near St. Catherine's, Lucan, $1895 ;$ N.C.-VIII. Muckanaght, Twelve Bens, Galway: Hart 1883 a. - IX. Slievenakilla near Lough Allen: Stewart $1885 .-\mathrm{X}$. A few plants on a wall near the 
railway station, Newtownstewart, Tyrone (Miss M. C. Knowles): Ir. Nat $1897 .-X I$. In Donegal, about Dunkineely, \&c., frequent (More): Cyb. Near Lough Doira; Murren, \&c., Fanet: Hart 1879. Crockaughrim and Coolcross, Inishowen: Hart 1883 .XII. Abundant in Derry and frequent in Antrim (Moore): Cyb. River bank at Bryansford, Down (John White): Wade Rar. Dog's Leap, Newtownlimavady, 1809: Templeton MS. Blue Lough; Hares's Gap; and Slieve Muck North, Mourne mountains: $S, \& P$. 1892.

From $50 \mathrm{ft}$. in Antrim (Flor. N.-E.) to $2000 \mathrm{ft}$. in Down (S.\& P.); from $700 \mathrm{ft}$. to $1450 \mathrm{ft}$. in Kerry (Hart).

\section{H. sciaphilum Uechtritz.}

Districts - - - - - - - - XII.

Lat. $543_{4}^{\circ}$. Co. Down only; very rare.

XII. Saintfield, Down (D. Redmond) : S.\& P. 1895 .

\section{H. gothicum Fries.}

Districts I. - - IV. - - VIII. - - XI. XII.

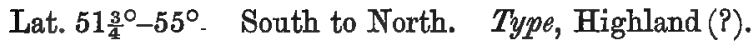

Heathy and rocky places; rare. $F$. July-September.

I. Rocks at Donemark Falls, Bantry (Carroll) : $C y b$. - but not seen recently: Allin's Cork.-IV. Head of Glenmalure, Wicklow (Carroll) : Cyb.-VIII. Connemara, Galway : Backhouse 1856.XI. Crockaughrim and Coolcross, Inishowen : Hart 1883. Killybegs river and river Finn : Hart $2885 \%$.-XII. Near Carrickfergus : Backhouse 1856. Glenballyeamon, Antrim (Moore); and Glenariff near Cushendall (Stewart) : Cyb. Cushendun (Rev. S. A. Brenan): Flor $N$.-E. River banks in Glendun : Shoolbred 1894.

Var. LATIFoLIUM Backh.-XI. Kiltooris Lake, and river at Ardara and Glenties: Hart I886. Killybegs river and Carrick river: Hart $I 885 \%$.

Var. StewartI F. J. Hanb.-XII. By the Bann above Hilltown, and sparingly in Tollymore Park, Down: S. \& P. $x 892$ (as. H. Friesii Hartm.).

This variety is described in the Journ. of Bot. $1892, p .369$, by Mr. F. J. Hanbury, who has named it after the veteran Belfast botanist, Mr. S. A. Stewart. 
11. H. rigidum Hartm.

Districts - - - - - - X. -

Lat. 541으. Fermanagh only. Type, English.

Rocks; very rare. $F l$. August-September.

X. Marble Arch, Florence Court, Fermanagh (Rev. S. A. Brenan): More 2873 .

The Irish plant is $H$. tridentatum (Fries).

\section{H. prenanthoides Vill.}

Districts - - - - - - - - - - XII. Lat. 55 . County of Derry only. Type, Highland.

Rocky places; very rare. Fl. July-August.

XII. Near Garvagh, Co. Derry: Backhouse 1856 . Meadows near Donald's Hill, in the parish of Bovevagh, Derry (Moore): $C y b$.

\section{H. strictum Fries.}

Districts - - - IV. - - - - - - XII. Lat. 53 $-55^{\circ}$. Wicklow, Antrim, and Derry. Type, Highland.

Mountain glens and rocky places; rare. Fl. July-August.

IV. Head of Glenmalure, Wicklow : Carroll $1854 .-\mathrm{XII}$. Garron Head, Antrim: Backhouse 7856 . Garvagh, Derry (Moore): Cyb.

\section{H. corymbosum Fries.}

H. rigidum Backh.

Districts -- - - IV. V. - - - - - - XII. Lat. $53^{\circ}-55^{\circ}$. Wicklow, Louth, Antrim, and Derry. Type, Highland.

Mountain districts; rare. Fl. July-September.

IV. Head of Glenmalure, Wicklow : Carroll I854.- - . Above Omeath, Carlingford mountain, Louth: Hart 1884 (as H. prenanthoides).-XII. Glenariff, Antrim : Backhouse 1856. Garron Head, Antrim (Babington) : $C y b$. By the river Bush, above Bushmills; and on Cave Hill, above Whitewell, Antrim (Stewart): Flor. N.-E. Glendun, Antrim: Shoolbred I894. Copses near Garvagh, Derry (Moore): Cyb. Tircrevan, Derry (Rev. S. A. Brenan): Flor. N.-E. 
15. H. auratum Fries,

Districts - - - - - - - - XII.

Lat. $54^{\circ}-551^{\circ}$. Down and Antrim only.

River banks and rocky places; locally abundant. Fl. July.

XII. Abundant in the Mourne Mountains, Co. Down: S. \&P. 7802. Lough Neagh shore at Cranfield (Stewart); sea cliffs at Cushendun, Antrim (Praeger): B.N.F.C. Proc. 1892-93. In several places on the banks of the river in Glendun, Antrim: Shoolbred 1894 .

From $50 \mathrm{ft}$. in Antrim to $1500 \mathrm{ft}$. in Down (Steroart).

\section{H. crocatum Fries.}

Districts - - - V. - VIII. - X. XI. XII. Lat. $53 \frac{1}{2}^{\circ}-55 \frac{1}{4}^{\circ}$. West and North. Type, Highland.

Mountain glens, cliffs, and rocky places; frequent in Antrim, rare elsewhere. Fl. July-August.

V. Northern base of Carlingford mountain, Louth: Hart 1886 a.-VIII. Ballinahinch, Connemara: Backhouse 1856.-X. By the Mournebeg river, south from Stranorlar, in Co. Tyrone : Hart 1886-this locality also extends into the following districtXI. Near Glenagiveney, Donegal : Hart 1883.-XII. Glenbally, and near Carrickfergus, Antrim: Backhouse 1856. Sparingly in Rademon demesne, Co. Down : B. N. F. C. Proo. 1885. Tollymore Park : Hart I886 a. By the Shimna river and on Pigeon Rock mountain, Down : S. \& P. I892. Ben Evenagh, Derry (Stewart): Cyb. By Owenrigh river near Dungiven, Derry : Hart 1886 a. Not rare in north-east Ireland, and sometimes very luxuriant: Hlor. N.-E.

From $100 \mathrm{ft}$. to $1400 \mathrm{ft}$. in Down (Stewart).

\section{H. boreale Fries.}

H. sabaudum Smith.

Districts I. - III. IV. V. - VII. - - - XI. XII. Lat. $51_{\frac{3}{4}}^{\circ}-55 \frac{1}{4}^{\circ}$. South to North. Type, British-English,

Banks, woods, and rocky places; rare. $F$. August-September.

I. Roughty river above Kilgarvan, Kerry ; R.W. S. Glengariff : Flor. Cork and Babington in Herb.-III. Near Clonegall on the Sląney river, Co. Carlow : Hart I88 0 a. By the river Barrow at 
Graiguenamanagh, Kilkenny - Hart I885.-IV. Plentiful in Glenmalure and at Glendalough, Co. Wicklow (Carroll): Cyb. Devil's Glen and Annamoe river, Wicklow, 1884 ; Hart.-V. Ballitore Hill, Co. Kildare (Carroll): Cyb. Banks of the Dodder above Old Bawn, Co. Dublin, 1896; N. C.-VII. Coosan Point, Lough Ree, Westmeath : B.\&D. $2887 .-\mathrm{XI}$. By the Swilly river near Letterkenny, Donegal ; Hart.-XII. By the Agivey river, below Garvagh, and in Tircreavan glen near Magilligan, Derry (Moore): Cyb. Murlough, and near Glenariff, Antrim: Templeton MS. Glenariff (Babington); and Cave Hill, Antrim (Dr. Mateer): Flor. N.-E. Cairncastle, and rocky mountains between Larne and Glenarm: Ir. Flor. Slievenamaddy or Dog's mountain, Co. Down (John White): Wade Rar. By the Shimna river above Tollymore Park, Down: S. \& P. 2892 .

From $100 \mathrm{ft}$. in Kerry $(R . W . S$.$) to 1300 \mathrm{ft}$. in Wicklow (Hart).

\section{H. umbellatum Linn.}

Districts I. - III. IV. V. VI. VII. VIII. - X. XI. XII. Lat $51 \frac{3}{4}^{\circ}-551^{\circ}$. South to North. Type, English.

Banks and rocky places; rare. $F l$. July-September.

I. Near Dunkerron, Kerry (Backhouse); Galway river near Killarney (Babington): Cyb. In several localities about Killarney, and along the river Caragh, Glencar, Kerry: R.W.S. 1888, \&e. On rocks in Lough Allua, 1897; Phillips.-III. Granagh, Kilkenny (T. Chandlee): Cyb.-TV. Devil's Glen and other places in Wicklow: Flor. Hib. Ballyarthur and Glencree, Co. Wicklow : Ir. Flor. Tigrony mine, Ovoca, Wicklow; Hart.-V. Banks of the Glencullen river, Co. Dublin : N. C. $1803 .-\mathrm{VI}$. By the side of the Woodford river, Lough Derg: Linton 1886 . Abundant on many of the rocky.islets and promontories of Lough Derg, as on Lushag rocks and Long Island, Clare; on Young's Island; Yellow Island ; Hare Island and Farrahill Point, Galway; and-VII. On Scilly Island and Ryan's Point, Tipperary: N. C. 1897. Hare Island, Lough Ree : $B . \& V$. r887.-VIII. By the river above Glen Inagh, Twelve Pins: Ball I839. On Otter Island, Lough Inagh, and rocks in Glen Inagh river, $1897 ; N . C$. On the shores and islands in Lough Corrib and Lough Cullin, Mayo (More): Cyb. Near Maam, Galway (Babington): Cyb.-X. Isle Namanfin, Lough Erne: Barrington $1884 .-\mathrm{XI}$. By the stream at Glenties: Hart I88I $\beta$. By the Carrick river; Lough Eske, \&c. : Hart 2885 \%.- 
XII. On Ben Evenagh, Derry: Moore MS. Glenariff, Antrim (Moore): Cyb. Very rare in the North-East: Flor. N.-E.-no recent records for Derry, Antrim, or Down.

To $1100 \mathrm{ft}$. on Ben Evenagh (Moore MSS.); to $750 \mathrm{ft}$. in Dublin (N. C.); but usually lowland.

Var. cononopifolium (Bernh.)-V. In Co. Dublin, by the Glencullen river, 1893 ; by the Dodder above Old Bawn, $1896 ; N . C$.

Var. FInғoLrom Back.-XII. Harper's [Harbour] Island in Lough Neagh: Backhouse 7856-not found there recently.

\section{HYPOCHERIS Linn.}

\section{H. radicata Linn.-Long-rooted Cat's-ear.}

Districts I. II. III. IV. V. VI. VII. VIII. IX. X. XI. XII. Lat. $51 \frac{1}{2}^{\circ}-55 \frac{1}{4}^{\circ}$. Throughout Ireland. Type, British.

Pastures, waste ground, \&c. ; common. Fl. June-September.

Sea-level in N. Antrim and S. Cork. To $1850 \mathrm{ft}$. in Ben Bulben district $\left(B . \& D_{\text {. }}\right)$; to $2000 \mathrm{ft}$. in Kerry (Druce I89I).

\section{LEONTODON Linn.}

\section{I. hirtus Linn.-Hairy Hawklit.}

Thrincia hirta DC.

Districts I. II. III. IV. V. VI. VII. VIII. IX. X. XI. XII. Lat. 51 $\frac{1}{2}^{\circ}-55 \frac{1}{4}^{\circ}$. Throughout Ireland. Type, English.

Pastures, dry banks, sand-hills, \&c.; frequent and locally abundant. Fl. June-August. Calcicole $B$.

Sea-level to $1000 \mathrm{ft}$. in Dublin (N.C.); but usually lowland.

\section{L. hispidus Linn.-Rough Hawkbit.}

Apargia hispida Willd.-Thrincia hispida Roth.

Districts I. II. III. IV. V. - VII. VIII. IX. - - Lat. $52^{\circ}-533^{\frac{3}{4}}$. Southern half of Ireland. Type, English-British.

Pastures and banks; local. Fl. June-August. Calcicole $B$.

I. At Killarney (Babington); and at Castlegregory, Kerry (Moore): Cyb.-II. Near Fermoy (T. Chandlee): Cyb. Glanmire and Little Island, rare in Cork; Phillips.-III. Near Kilmacow, Kilkenny (T. Chandlee): Cyb. By the Barrow between Mountmellick and Two-mile Bridge : Hart 1885.-IV. Murrough of Wicklow (Moore): 
Cyb. Rosslare and Bannow, Wexford: Hart $5883 \beta$. Abundant at Woodbrook Lawn, Wexford : Moffat $288.9 .-\mathrm{V}$. Abundant at Portmarnock, Co. Dublin: Mack. Cat. Finglas, 1894; Balbriggan and Leixlip, 1895 ; Dodder river near Old Bawn, 1896 ; Killiney, \&c.; frequent and locally abundant in Co. Dublin; $N$. C.VII, Near Creggan Lough, Westmeath: B.\&V. I887. Knock Eyon, Westmeath : Linton I896.-VIII. Near the town of Galway, but rare (Prof. Melville): Cyb. - IX. Near Hollymount, Mayo, sparingly (More): Cyb. Near the rectory, Cong, Co. Mayo, 1896; IFiss $M$. F. Jackson. Also recorded from Districts XI. and XII., but probably in error as the plant has not recently been found in either.

Sea-level to $1000 \mathrm{ft}$. in Dublin ( $N . C$.).

Very rare in the South-West, and rare in the West.

\section{L. autumnalis Linn.-Autumnal Hawkbit.}

Apargia autumnalis Willd.

Districts I. II. III. IV. V. VI. VII. VIII. IX. X. XI. XII. Lat. $511^{\circ}-55 x^{\circ}$. Throughout Ireland. Type, British.

Pastures and heaths; common. Fl. July-September.

Sea-level in N. Antrim and S. Cork. To $1300 \mathrm{ft}$. in Donegal, $2300 \mathrm{ft}$. in Down, $2500 \mathrm{ft}$. in Mayo and Tipperary, and to $3200 \mathrm{ft}$. in Kerry (Hart).

Var. PRATENsIs (Koch)-Apargia Taraxaci Smith-I. On Magillicuddy's Reeks ; on Brandon mountain ; and-II. On Galtymore, Tipperary: Mack. Rar.-IV. On Iugnaquilla, Wicklow (J. Ball): Cyb.-VIII. Ridge above Lough Brawn, Mweelrea : Hart I 883 a.IX. On Ben Bulben, 1885 : Linton 1886.-XI. On Muckish; Blue Stack; and Slieve League; Hart.-XII. On Black mountain and Slieve Donard: Flor. Ulst. On Ben Evenagh, Derry (Moore): Cyb. Slieve Bearnagh, Mourne Mountains : Hart 1884.

\section{TARAXACUM Linn.}

\section{T. officinale Web.-Dandelion.}

\section{Leontodon Taraxacum Linn.}

Hibernicé Cárp cpeapban (cawsh ther-vawn) Bitter-root.

Districts I. II. III. IV. V. VI. VII. VIII. IX, X. XI. XII. Lat. 51 $\frac{1}{2}^{\circ}-55 \frac{1}{4}^{\circ}$. Throughout Ireland. Type, British.

Meadows, pastures, waste places, sand-hills, \&c. ; common. Fl. April-October. 
Sea-level in N. Antrim and S. Cork. To $2210 \mathrm{ft}$. in Donegal, to $2100 \mathrm{ft}$. in Mayo, and to $2650 \mathrm{ft}$. in Kerry (Hart).

Var. eRtThrospermum (Andrs.) - V. Sandy pastures on the Cosh, Sutton, Co. Dublin, 1894; N. C.-XII. Roadside in Glendun, Antrim (Rev. S. A. Brenan): Flor. N.-E.

- Var. Paldstre (DC.)-I. Valentia, Kerry (Rev. S. Madden): Cyb. Connor Hill, Kerry : Babington in Herb. Ballyphehane Bog, Cork: Flor. Cork.-IV. In the Dargle: Flor. Hib.-V. Fuller's Court, Ballitore, Kildare (T. Chandlee) : $C y b$. Three Rock mountain, 1895, and elsewhere in the Co. Dublin; N.C.-IX. Ben Bulben : Flor. Olst.-X. In Co. Tyrone (Dr. Sigerson') : Rec. Add.XII. Drumbo, Down; and Cave Hill, Antrim (Stewart) : Flor. N.-E.

Var. Udư (Jord.) - VI. By the turloughs near Coole Park, Galway; and-IX. Near Foxford, Mayo (More) : Cyb.

\section{LACTUCA Linn.}

1. $\ddagger \mathbf{L}$. muralis Fresen.-Wall Lettuce.

Districts I. - - IV. V. - VII. - - - - Lat. 52 $-53 \frac{1}{2}$. East Ireland, chiefly. Type, English.

Woods, banks, and old walls; very rare. Fl. July-August.

I. Several plants in shrubberies at Glenflesk Castle, Killarney: R.W.S. r890-still there and spreading in $1897 ;$ R.W.S.IV. Roadside leading from Lara Barrack to Clara, Co. Wicklow (Mr. Johnston) : $C y b$. In considerable quantity on walls and by the roadside and in a wood near Lara, $1897 ; R . W . S .-V$. Abundant in the woods at Collon, Louth: Wade Rar.-seen here by Mackay : Flor. Hib. Bank in Saint Anne's demesne, Dollymount, Co. Dublin, 1894; Hart. An escape on walls and banks at Ballitore, Kildare (Carróll): Cyb.-VII. In Ballynagall demesne, Westmeath, and on the demesne wall : Levinge 1895 .

- Doubtfully native in most, if not all, of its stations.'

\section{SONCHUS Linn.}

\section{S. oleraceus Linn.-Sorothist7e.}

Districts I. II. III. IV. V. VI. VII. VIII. IX. X. XI. XII. Lat. $51 \frac{1}{2}^{\circ}-55 \frac{1}{4}^{\circ}$. Throughout Ireland. Type, British.

Cultivated fields, banks, and waste ground; common. Fl. June-Oct. Sea-level in Antrim and Cork. To $1000 \mathrm{ft}$. in Dublin (N.C.). 


\section{S. asper Hoffm.,-Rough Sowthistle.}

Districts I. II. III. IV. V. VI. VII. VIII. IX. X. XI. XII. Lat. 51 $1_{2}^{\circ}-55 \frac{1}{4}^{\circ}$. Throughout Ireland. Type, British.

Cultivated land, hedge banks, and waste places; frequent. Fl. June-September.

Sea-level in N. Antrim and S. Cork. To $900 \mathrm{ft}$. in Ben Bulben district $(\dot{B}, \& V$.$) .$

\section{S. arvensis Linn.-Corn Sowthistle.}

Districts I. II. III. IV. V. VI. VII. VIII. IX. X. XI. XII. Lat. $51 \frac{1}{2}^{\circ}-55 \frac{1}{4}^{\circ}$. Throughout Ireland. Type, British.

Corn-fields, and sandy or gravelly sea shores; rather common. Fl. July-September.

Sea-level to $800 \mathrm{ft}$. in Dublin $(N . C$.$) .$

\section{TRAGOPOGON Linn.}

\section{T. pratensis Linn.-Yellow Goats'-beard.}

Districts - II. III. IV. V. VI. VII. VIII. IX. - - Lat. $52^{\circ}-53 \frac{1}{2}^{\circ}$. Southern half of Ireland. Type, British-English,

Lowland. Pastures, dry banks, and gravel-pits; rather rare. Fl. June-July.

II. Meadows at Glanmire (Mr. Alexander): Flor. Cork. Near Youghal, 1896; T. Farrington. Railway banks near Castletownroche, 1897; Phillips. Near Clonmel and Carrick-on-Suir (Miss S. Grubb) : Cyb.-III. By the Nore near Borris-in-Ossory: Hart I $885 \delta$. -IV. Murrough of Wicklow (Moore) : Cyb.-V. Frequent in Co. Dublin and abundant on railway embankments; $N$. $C$. Near Moone and Ballitore, Kildare (T. Chandlee): Cyb. About Mount Oriel; Strigna; and Tiernan's Hill, Louth: Ir. Flor.VI. Fields near Limerick (Prof. Harvey): Cyb. Between Ballinasloe and Ahascragh, Galway : Praeger I896.-VII. Abundant by the Barrow near Portarlington, King's Co. : Hart 1885.-VIII. Near the town of Galway (Prof. Melville); and-IX. At Hollymount, Mayo (More): Cyb.

Both the type and Far. Mrros (Fries.) are perhaps equally frequent in Ireland, but have not been sufficiently discriminated. 


\section{ORDER XXXVI.-CAMPANULACEF.}

\section{LOBELIA Linn.}

\section{I. Dortmanna Linn.-Water Lobelia.}

Districts I. II. - IV. - VI. - VIII. IX. X. XI. XII. Lat. $51 \frac{1}{2}^{\circ}-55 \frac{1}{4}^{\circ}$. South to North. Type, Scottish-Highland.

Margins of lakes, especially in mountain districts; locally abundant. $F l$. July-Angust. Calcifuge $\boldsymbol{A}$.

I. In most of the mountain lakes of Kerry; R.W.S. Lakes at Gouganebarra, and near Glengariff (Carroll): $C y b$. Shepperton lakes near Skibbereen; Phillips.-II. Ballyscanlon lake near Tramore, Waterford (Miss S. Grubb): Cyb.-IV. Lough Dan, and Glendalough, Wicklow: Ir. Flor. Lower Lough Bray ( $\boldsymbol{V} . \mathcal{A}$. Smith): Cyb.-VI. Between Milltown and Kilrush, Clare ( $C$. Carter): Cyb.-VIII. Common in Connemara; in Loughs Conn and Cullin, Mayo; and-IX. Near Foxford, Mayo (More): Cyb. East side of Lough Mask, $1891 ; R$. P. Vowell. In several lakes in the Ox mountains, Sligo, $1896 ; N . C .-\mathrm{X}$. In Derrylileagh Lake, and in Lough Neagh at Raughlan Point (Rev. H. W. Lett); in Ross Lake and Lough Neagh, north of Bird Island: Praeger 1893.-XI. In many lakes in Donegal: Hart 1879 \& c.-XII. In Lough Neagh at the townland of Kilmore near Moira: Ray Synopsis 2606. Blue Lake and Bingian Lake, Mourne Mountains: Hart 1884. Lough Shannagh and Altnadua Lake, Down: $S \& P$. I892. Lakelet on the summit of Binnagee near Carnlough, Antrim (Praeger): B. N. F. C. Proc. r890-qI. Lough Neagh, Antrim, 1865 (Rev. S, A. Brenan); apparently decreasing in the North-East: Flor. N.-E.

Sea-level in Antrim and Kerry. To $1180 \mathrm{ft}$. in Donegal (Hart); to $1350 \mathrm{ft}$. in Down (S.\&. P.); to $1500 \mathrm{ft}$. in Wicklow, and to $1280 \mathrm{ft}$. in Kerry (Hart).

\section{JASIONE Linn.}

\section{J. montana Linn.-Sheep's Scabious.}

Districts I. II. III. IV. V. VI. VII. VIII. IX. X. XI. XII. Lat. $51 \frac{1}{2}^{\circ}-55 \frac{10}{4}$. Throughout Ireland. Type, British-English.

Heaths, moors, rocks, and sandy banks; frequent. Fl. JuneAugust. Calcifuge $A$. 
Sea-level in N. Antrim and S. Cork. To $1450 \mathrm{ft}$. in Donegal, to $2200 \mathrm{ft}$. in Mayo, to $2500 \mathrm{ft}$. in Tipperary, and to $3127 \mathrm{ft}$. in Kerry (Hart).

\section{WAHLENBERGIA Schrad.}

1. W. hederacea Reichb.-Ivy-leaved Bell-flower.

\section{Campanula hederacea Linn.}

Districts I. II. - IV. V. - - - - - Lat. $51 \frac{3}{4}^{\circ}-534^{\circ}$. South and South-East. Type, Atlantic.

Damp grassy places, and wet shady banks; rare. Fl. JulyAugust. Calcifuge $A$.

I. Very abundant on both sides of the river Flesk, Killarney, from the Finnow river to above Loo Bridge; by the river Roughty near Kenmare, and along the Blackwater, Kenmare Bay: R. $\mathscr{W}$. S. $I 889 \& I 890$. Near Lispole station, towards Connor Hill, Kerry, 1891; Ceoil Butler. Near the old house of Barleyfield near Ballybritton, five miles from Bandon (Dr. Vize): Wade Rar. Plentiful near the river about a mile below Bandon, and in several other places in the neighbourhood: Mack. Rar. By the river Lee : Drummond 18I8. Banks of a stream west of Macroom (Miss J. Harvey) : Rec. Add. Moist fields by the Bandon road two miles south of Kilcreagh Abbey (T. Wright): $C y b$. At Desert; Ballineen; Ballinadee; and Kilbrittain: Allin's Cork. Innishannon and Desert, 1890, and plentiful by the Ilen river, Skibbereen, 1897; Phillips. Pass of Keimaneigh, 1896; Mrs. Hughes.II. Near the Mardyke (Rev. Dr. Hincks); on the bank of the Lee opposite Carrigrohane Castle (D. INurray); by the Lee above Iniscarra (Drummond): Flor. Cork. Near Saint Anne's Hill, Blarney (Miss Boole): Allin's Cork. By the Lee near Castle Inch, 1893 ; Phillips.--IV. Found on Sugar Loaf mountain, Co. Wicklow in 1805 (Dr. Stokes): Mack. Rar. On the west slope of Sugar Loaf, $1884 ; N . C$. Abundant in Glencree near the copse wood: Mack. Cat. r825. In the copse, Glencree, 1881, and abundant on moist banks and along drains by the roadside near the Reformatory School, $1893 ; N . C$. A characteristic plant in the valley of the Urrin, and along the higher feeders of the Boro, Wexford (C. B. - Moffat): B.-H.\&M. 2892 . Marshy meadows by the Bann near Ferns, Wexford: Ir. Nat. 1897, p. 279. Roadside at Clone in the Gold Mine Valley, South Wicklow, 1882; Miss Kinahan.-V. In Glencullen [Co. Dublin] near the bridge (Greenwood Pim): Rec. 
Add.- -spreading along the stream here for half a mile, 1893 , and ascending wet mountain slopes $\mathrm{S} . \mathrm{W}$. of the bridge, $1894\left(N . C_{.}\right)$, here reaching its northern limit in Ireland.

Sea-level in Kerry. To $1000 \mathrm{ft}$. in Dublin (N. C.).

\section{CAMPANULA Linn.}

\section{C. Trachelium Linn.-Nettle-leaved Bell-flower.}

Districts - - III. - - - VII. - - - - Lat. $52^{\circ} 25^{\prime}-52^{\circ} 55^{\prime}$. South-East Ireland. Type, English.

Lowland: In hedges and thickets by rivers; rare. Fl. JulyAugust.

III. Woodstock near Inistiogue [Nore] river: Templeton MS. Woods near the Barrow above New Ross: Mack. Cat. (as C. latifolia). Archer's Grove; Sheestown; Laggbush, all in Kilkenny (Rev. S. Madden): Cyb. By the Nore near Abbeyleix, Queen's Co.; and in Co. Kilkenny, at Ballyragget, at Thomastown, and abundant from below Woodstock to New Ross: Hart 1885 . - VII. On the left bank of the Barrow about a mile above Portarlington, King's Co., in small quantity : Hart $r 885$.

Also recorded for District V. from a ditch bank between Glasnevin and Finglas (Ir. Flor.) where the plant has not been seen recently and was no doubt introduced.

\section{C. rotundifolia Linn.-Hare Bell.}

Hibernicé Meapacán zopm (Mairy-cawn gorrum), Blue Thimble. District I. II. III. IV, V. VI. VII. VIII. IX. X. XI. XII. Lat. $51 \frac{1}{2}-55 \frac{1}{4}^{\circ}$. Throughout:Ireland. Type, British.

: Heaths, dry pastures, sand-hills, and stony places; frequent and locally abundant. $F '$. July-August.

Sea-level in N. Antrim and in Kerry. To $2200 \mathrm{ft}$. in Donegal, to $2450 \mathrm{ft}$. in Down, to $2600 \mathrm{ft}$. in Mayo, and to $3120 \mathrm{ft}$. in Kerry (Hart).

Very rare in Cork and generally more abundant in the West than in the East, and near the coast than inland.

Var. Speciosa More.-VIII. Among the rabbit burrows, south of the harbour, Inishbofin: More I876.-IX. Near Collooney, Co. Sligo ; Levinge-named Var. aRctrca Lange by Mr. J. G. Baker, but perhaps hardly distinct from $V$ ar. sPECIOSA.

- This beautiful and well-marked variety (specrosa) was first 
observed by A. G. More in Inishbofin in 1875 and described and named by him in his report on the flora of the island, read before the R. I. Acad. in April, 1876 : R.I.A. Proc., and Ser., Vol. II., I876.

Vars. LANCLFoLIA Mert. \& Kooh. and HIRTA Rich.-IX. On limestone south of Lough Mask: M. \& S. 1896 .

\section{ORDER XXXVII. VACCINIE压.}

\section{VACCINIUM Linn.}

\section{V. Vitis-Idæa Linn.-Cowberry.}

Hibernicé bpaí̄leбz (Brill-yōge).

Districts - II. III. IV. V. - VII. VIII. IX. X. XI. XII. Lat. $521^{\circ}-551^{\circ}$. From South to North. Type, Highland-Scottish.

Mountain heaths; wide-spread, but local. Fl. June-July. Calcifuge $A$.

II. On Galtymore, Tipperary (Carroll): Cyb.-and in 1880: Hart I88I. Cliffs above the Stilloge Lakes, Commeragh mountains; and-III. Blackstairs mountain, Carlow : Hart I884.IV. Among the heath at Upper Lough Bray, where it was first observed by Mr. Templeton in 1802: Mack. Rar.-still there, 1890; R. W.S. Frequent in Co. Wicklow, as on War Hill, Greenwood Pim; Mullaghcleevaun and Thonalagee, Hart; Croghan Moira and Lugnaquilla; N. C.-V. Carlingford Mountains : Ir. Flor. Near the top of Kippure, Co. Dublin, 1893; N. C.-VII. On Keeper mountain, Tipperary (Admiral Jones): Cyb. On the large bog near Bracklin, Westmeath, 1878 (Moore): Herb. Glasnevin. VIII. On Nephin (Babington); and on Cor Slieve in Erris (Moore) : Cyb. Sparingly on Mweelrea : Hart I883 a.-IX. On Ben Bulben; $1834 ;$; $t$. Hon. John Wynne. Near the top of Truskmore, Ben Bulben, 1896 (Rev. C. F. D'Aroy); and frequent in the Ox mountains, Sligo: N. C. 1896.-X. Bogs at the southern extremity of Lough Neagh: Templeton MS. Heaths near Dungannon, Tyrone (Mr. Campbell) : Flor. Olst. In Cavan and Fermanagh, on Drumbad; Tents Mountain; Cuilceagh, \&c. : Stewart 2882.-XI. On all the higher mountains of Donegal; Hart.-XII. On a bog in Crevetenan near Ballinahinch, 1794 : Templeton MS. On most of the summits of the Mourne mountains: S.\&P. I802. On Slievenanee, Antrim : Flor. Olst. East of Rasharkin, and plentiful near 
it at Lough Naroon (Stewart): Flor. N.-E. Mullaghmore and Ben Bradagh, Derry : Hart 1884 . At about $200 \mathrm{ft}$. between Kilrea and Garvagh, Derry (Praeger): Journ. of Bot. I894.

Apparently absent from the South-West, there being no records, so far, from either Cork or Kerry.

Quite lowland in many of its Irish stations, descending to $200 \mathrm{ft}$. in Derry, to $275 \mathrm{ft}$. in Westmeath and to about $100 \mathrm{ft}$. south of Lough Neagh. Ascends to $2000 \mathrm{ft}$. in Derry (Moore); to $2796 \mathrm{ft}$. in Down (S.\& P.); to $2900 \mathrm{ft}$. in Wicklow (Hart).

\section{V. Myrtillus Linn.-Bilberry; Whortleberry.}

Hibernicé Fpaoćán (Fray-aok-awn).

Districts I. II. III. IV. V. VI. VII. VIII. IX. X. XI. XII. Lat. $51_{2}^{1}{ }^{\circ}-551^{\circ}$. Throughout Ireland. Type, British-Highland.

Heathy woods, bogs, moors, and mountains; common. Fl. AprilMay. Calcifuge $A$.

Descends to $100 \mathrm{ft}$. in N. Antrim, and to sea-level in S. Cork. To $2460 \mathrm{ft}$. in Donegal, and to $2796 \mathrm{ft}$. in Down (Flor. Olst.); to $3000 \mathrm{ft}$. in Wicklow, and to $3414 \mathrm{ft}$. Kerry (Hart).

Excluded from large areas in the Irish lowlands by its strong aversion from limestone soils.

\section{V. Oxycoccus Linn.-Cranberry.}

Oxycoocus palustris Pers.

Districts I. II. - IV. V. VI. VII. VIII. IX. X. - XII. Lat. $51 \frac{3 \frac{3}{4}^{\circ}}{}-55^{\circ}$. South to North. Type, British-Intermediate.

Wet, spongy bogs; locally abundant. Fl. June-July.

I. Sherehee bog near Cloghereen; sparingly in upper Glencar; near Castleisland; very rare in Co. Kerry: $R$. W. S. 7888 \& -89. Bog near Dunmanway (Prof. E. MYurphy) : Cyb. -not seen there since, evidently extremely rare in Co. Cork: Allin's Cork.-II. Glenagad, Waterford ( $R$. Davis); about a mile from Clonmel (Miss S. Grubb): Cyb.-IV. Near Lough Dan and Lough. Bray, Wicklow: Ir. Flor. In Glencree; R. W. S. Plentiful near Roundwood, Wicklow; More.-V. "They" [the berries] "are sent from the Co. Kildare": Rutty's Dublin.-VI. At Castle Taylor: More 1855. Abundant in bogs near Clonbrock, Galway: Praeger I896. Plentiful on parts of Monmor Bog, Clare: Stewart 189o.-VII. Quarry bog, Knock Drin, and exceedingly abundant at Scraw bog, Loughanstown, Westmeath: Levinge 1894.-VIII. Recorded for this District in 1st Ed. Cyb., but no locality available.- 
IX. Hollymount, Mayo; More--X. In sereral stations in Co. Armagh: Praeger 1893. Near Verner's Bridge, Tyrone, 1896; Mrs. Leebody.-XII. Very abundant in bogs by Lough Neagh, between Ballyronan and the mouth of the Moyola, Derry : Moore MS. Abundant above Dunloy and Rasharkin, Antrim (Praeger); Evish, above Glenariff (Rev. S. A. Brenan): S.\& P. 7895 . Marsh at Saul Camp, Downpatrick; north-west of Carnlough, Antrim; near Lough Ouske, Sperrin mountains, Derry (Praeger): B. N.F.C. Proo. $189 z-93$. Becoming rare in the North-East: Flor. N.-E.

To $1000 \mathrm{ft}$. in Antrim (Praeger); but usually lowland.

Appears to have been formerly abundant in Ireland and has, no doubt, been extinguished in many parts by the reclamation of bog lands.

ORDER XXXVIII.-ERICACE正.

\section{ARBUTUS Linn.}

\section{A. Unedo Linn.-Strawberry Tree.}

Districts I. - - - - - - - - Lat. $51^{\circ} 40^{\prime}-52^{\circ}$. South-West Ireland. Type, Hibernian.

Rocky places and boggy woods; locally abundant. Fl. September-October.

I. "Of late dayes found in the West part of Ireland": Parkinson, Theatr. Bot. 1640, pp. 1489-90. "On the mountains of Keri" (Lhwyd): Phil. Trans. I7I2. "It grows in the Co. of Kerry on the Borders of Loghlen [Killarney Lakes]; it groweth also at Glengaruh, in the Bantry in the O'Sullivan's Country": Threlkeld I727. "Wild in the rocky mountains which divide this county [Cork] from Kerry, as also in great quantities round the lake of Killarney": Smith's Cork I750. Islands at the head of the Kenmare river: Smith's Kerry 1756 . "I am told that it is to be met with ... in all the mountainous situations to the west of Bantry Bay, County Cork": Wade Rar. I804. "Very plentiful in most of the wooded mountains about Killarney, in the woods of Mucruss and in several of the islands in the Lower and Upper Lakes, the largest tree being observed in Rough island, where one was found (1805) to measure $9 \frac{1}{2} \mathrm{ft}$. in girth. At Glengariff, County Cork, there are several very large trees": Mack. Rar. I806. By 
the lakes in the barony of Bere (Drummond); Ballyrizzard, Crookhaven (R. W. Townsend) : Flor. Cork-not seen there recently. An old tree on the western declivity of Hungry Hill; island on Lough Inchiquin, south side of Kenmare Bay (Carroll): $C y b$. Near Ardgroom (More) : Allin's Cork. Two or three old, half-dead trees on the south side of Lough Currane: R.W. S. I89o. One old tree on the Reeks below Lough Gooagh : Hart 1882 . One tree on the mountains north of Lough Currane, $1892 ; N . C$. Seven trees in rock-clefts on Adrigole mountain, and two fine specimens near Adrigole village, 1894 ; Phillips. Abundant on the shores and islands of Killarney Lakes, 1896 ; but very rare, and fast becoming extinct, outside the Killarney district; $R . W . S$.

To a little over $500 \mathrm{ft}$. in Kerry (Hart); but usually quite lowland.

First recorded by Parkinson in 1640 .

Confined in Ireland to a very limited area lying well within a radius of 25 miles from Glengariff as centre. Not found in Great Britain. Very rare in south-west France, where it reaches its extreme northern continental limit below Lat. $46^{\circ}$ in Charente Inferieure; abundant in the Spanish Peninsula and all along the Mediterranean. The high northward range of this species in Kerry exhibits in a striking way the peculiar climatic conditions which obtain in South-West Ireland.

\section{ARCTOSTAPHYLOS Adans.}

\section{A. Uva-ursi Spreng.-Bear-berry.}

Arbutus Uva-ursi Linn.

Districts - - - - VI. - VIII. - - XI. XII. Lat. $53^{\circ}-55 \frac{1}{4}^{\circ}$. West and North. Type, Highland.

Mountain heaths and stony pastures; locally abundant. Fl. May.

VI. "It spreads to a vast degree on the limestone rocks on the Burren mountains": Wade Rar. Abundant on the hills west of Ballyvaughan valley, spreading as far as Slieve Elva: Foot 1864, Abundant on the top of Cappanawallia mountain, west of Ballyvaughan, Clare, 1895 ; N.C. Plentiful about Castle Taylor, Galway: More 1855.-VIII. Very common on the mountains of Connemara: Wade Rar. In Co. Mayo, at Benwee Head, 1823, and at Portacloy, 1863; Rt. Hon. John Wynne. On Cor Slieve, Erris (Moore): Cyb. On Mweelrea; Nephin; Nephin Beg; Curraun Achill, and Achill Island, Mayo; abundant on the Twelve 
Bens, Galway; more frequent in Galway than in Mayo: Hart r883 a.-XI. Co. Donegal (Mr. Brown); on Muckish mountain, very plentifully, 1815: Templeton MS. Slieve League; Horn Head; Errigal, \&c.; round the coast of Donegal and on mountains by the coast: Hart 1879 , \& $0 .-$ XII. At Fair Head, plentiful, 1814: Templeton MS. By the northern lake on Fair Head, 1837: G. C. Hyndman in Herb.-the only station in north-eagt Ireland.

From about sea-level in Donegal, Galway, and Mayo, to $1800 \mathrm{ft}$. in Galway and to $1900 \mathrm{ft}$. in Donegal (Hart).

\section{ANDROMEDA Linn.}

\section{A. Polifolia Linn.-Marsh Andromeda.}

Districts - - III. IV. V. VI. VII. - IX. X. - XII. Lat. $52 \frac{3}{4}^{\circ}-54 \frac{1}{2}^{\circ}$. Middle Ireland, chiefly. Type, IntermediateScottish.

Wet peat bogs; frequent. Fl. April-May.

III. Common on bogs in the Queen's Co.: Mack. Rar. Bog near Graigavern, Queen's Co.; Hart. - IV. Mountains between Lough Bray and Luggylaw, 1802: Templeton MS.- and in 1893; Dub. Nat. Field Club. On the north side of Djouce mountain, and on the mountain between Glencree and Glencullen; Hart.-V. On the bog by Issacstown, Co. Meath (Mr. Sherard): Threlkeld App. Bog by Robertstown, Kildare (J. Douglas); and near Ballitore (T. Chandlee): Cyb. On the west side of Kippure mountain, Co. Dublin; Hart -VI. Between Newport and Castleconnell : Mack. Rar. Common in a bog [Co. Clare] opposite Plassey, 1833 (W. $\boldsymbol{H}$. Harvey): Memoir and (Carroll): Cyb. Bog near Woodford, Galway (Moore) : Cyb. Near Clonbrock, Galway : Praeger I896.VII. Annahinch Bog near Parsonstown, King's Co. (G. H. Kinahan): Rec. Add. Frequent in Co. Westmeath: Levinge 1894.IX. Hollymount, Mayo (More): Cyb. Near Ballybay, Roscommon, and many other places on Lough Ree: B.\&V. I887.-X. Near Tartaraghan, Armagh (Rev. G. Robinson): More 1860. Very rare in Armagh: Praeger 1893.-XII. Bog by the road between Grey Abbey and Donaghadee, Down, 1794 (Templeton): Whitla MS. Sparingly in Wolf Island Bog, north of Grey Abbey (Stewart); very rare and destined ere long to become extinct in north-east Ireland: Flor. N.-E. 
Also recorded for the counties of Kerry and Cork, but without definite localities, by Smith (Hist. of Kerry) and by Mackay (Rare Plants). The plant has not been recently recorded for either of these counties.

To $1500 \mathrm{ft}$. in Dublin and Wicklow (N.C.); but usually lowland.

Like many other bog-species appears to be rapidly growing rarer in Ireland with the spread of drainage.

\section{CALLUNA Salisb.}

\section{C. vulgaris Salisb._Ling.}

C. Erica DC.-Erica vulgaris Linn.

Hibernicé Fraoć (Fray-ock).

Districts I. II. III. IV. V. VI. VII. VIII. IX. X. XI. XII. Lat. $51 \frac{1}{2}^{\circ}-55 \frac{1}{4}^{\circ}$. Throughout Ireland. Type, British.

Moors and mountains; common. Fl. July-August. Calcifuge A.

Sea-level in N. Derry and S. Cork. To $2460 \mathrm{ft}$. in Donegal, and to $2796 \mathrm{ft}$. in Down (Flor. Ulst.) ; to $3000 \mathrm{ft}$. in Wicklow, and to $3300 \mathrm{ft}$. in Kerry (Hart).

Var. INCANA Auct.-I. At Ballyburden, Cork (Drummond): Flor. Cork.-II. Near Whitegate, Cork Harbour; Phillips.-V. On Howth Head, Co. Dublin, 1894-97; IIiss L. Colgan.

In a well-marked form, this variety is rare in Ireland.

\section{ERICA Linn.}

\section{E. Tetralix Linn.-Cross-leaved Heath.}

Districts I. II. III. IV. V. VI. VII. VIII. IX. X. XI. XII. Lat. $51 \frac{1}{2}^{\circ}-55 \frac{1}{4}^{\circ}$. Throughout Ireland. Type, British.

Wet moorlands ; common. Fl. June-July. Calcifuge $A$.

Sea-level in N. Donegal and S. Cork. To $1800 \mathrm{ft}$. in Donegal (Hart); to $2050 \mathrm{ft}$. in Down (S.\&P.); to $2200 \mathrm{ft}$. in Wicklow (N. C.); to $1950 \mathrm{ft}$. in Kerry (Hart).

E. Mackaii Hooker.

E. Mackaiana Bab.

Districts - - - - - - VIII. - - - Lat. $53^{\circ} 20^{\prime}-53^{\circ} 25^{\prime}$. Galway only, Type, Hibernian. - Lowland. Wet, boggy heaths ; very rare. Fl. July-August. 
VIII. On the declivity of a hill by the roadside within three miles of Roundstone, Connemara ( $W m$. $\left.M^{3} A l l a\right)$ : Flor. Hib. Abundant by the roadside between Roundstone and Clifden: Graham 1840 . A short mile of Roundstone and close by the hamlet of Letterdife : Ogilby 1845 . On a wet heath called Craigga More, between Roundstone and Clifden: Cyb. A little east of the new police barrack at Carna, eight miles south of Craigga More (More): Journ. Bot. 2874 . Abundant on the islands in Craigga More Lough (Praeger): Ir. Nat. I896.

Apparently very restricted in its range in Ireland, but often separated with difficulty from robust states of $E$. Tetralix, and perhaps more widespread than would appear from the above records. Not found in Great Britain, and on the European continent recorded only from the mountains of Castile and Asturia in the Spanish peninsula. The Irish plant was at one time erroneously considered to be identical with $E$. Watsoni, a hybrid between $\boldsymbol{E}$. ciliaris and $E$. Tetralix, which occurs in Cornwall.

Discovered near Roundstone previously to 1835 by William M'Alla, by whom it was communicated to Mackay. First published. in 1835 in the Companion to the Botanical Magasine (p. 158$)$.

\section{E. cinerea Linn,-Common Heath.}

Hibernicé Fraoċ (Fray-ock).

Districts I. II. III. IV. V. VI. VII. VIII. IX. X. XI. XII. Lat. $51 \frac{1}{2}-55 \frac{1}{4}^{\circ}$. Throughout Ireland. Type, British.

Moors, mountains, \&c.; common. Fl. June-August. Calsifuge $A$.

Sea-level in Derry and S. Cork. To $2200 \mathrm{ft}$. in Derry (Hart); to $2450 \mathrm{ft}$. in Down (S.\&P.); to $2500 \mathrm{ft}$. in Kerry (Hart).

More abundant near the coast than inland, where it gives place to Calluna over large areas of peat bog.

\section{E. mediterranea Linn.-Mediterranean Heath,}

E. hibernica Syme-E. mediterranea Var. hibernica Hooker. Districts - - - - - - VIII. - - - Lat. $53^{\circ} 20^{\prime}-54^{\circ} 15^{\prime}$. Mayo and Galway. Type, Hibernian.

Lowland. Boggy mountain heaths, near the coast; locally abundant. Fl. March-May.

VIII. Boggy ground, Cunnamara, Ireland, covering a space of at least 2 acres (J. T. Mackay): Hooker's Brit. Flor. $2 n d$ Ed, I83I, 
"Detected by our valued friend, J. T. Mackay, Esq., in Septr., 1830, growing on the sides of Urrisbeg mountain, Connemara": Eng. Bot. Supp. Plate 2774, dated July I8t I833. On the western declivity of Urrisbeg mountain near Roundstone, Sept. 1830. Since found by John Wynne, Esq., and others in the district of Erris, Co. Mayo: Flor. Hib. Covering at least a quarter of a million of acres in the Ballycroy mountains, Erris (Moore): Phytol. 1852, p. 597. On Mweelrea, at the mouth of the Killary Harbour, Mayo, 1838 (Simon Foot \& Joseph Hooker): Mack. App. to Frazer 4th Ed. 1854-and in 1882: Hart $7883 \alpha$. Curran Achill and Borrishoole lake: Brit. Flor. Ed. vi. I850. At Mulranny opposite the island of Achill (Lady Louisa Knox): Cyb. All along Achill Sound on the shore of the mainland opposite Achill Island, and thence near the shore as far as the north end of Carrowmore lake in Erris (Moore) : Cyb. At Ridge Point and near Dugort, Achill Island, $1897 ; J$. R. Sheridan. Two miles north of Belmullet and near Belmullet on the Mullet, 1887 ; Hart. Mountains about Kylemore; on each side of Killary Bay; and about Salruck pass ; J. Mac Kinnon.

Usually a robust plant, but a dwarf variety with flowers of a deeper colour occurs in Erris and in Achill Island. In mild winters the Irish plant has been repeatedly observed to flower in January.

Not in Great Britain. Abundant in Portugal and north-west Spain; rare in south-west France, not reaching north of the Gironde; and, in spite of its name, absent from the Mediterranean region.

First found by Mackay, at Urrisbeg, in 1830, and first published in 1831 (Hooker Brit. Flor. and Ed.).

\section{DABEOCIA D. Don.}

\section{D. polifolia D. Don.-St. Dabeoc's Heath.}

Erica dabeocii Linn.-Menziesia polifolia Juss.-Vacoinium cantabrioum Huds.

Hibernicé Fpaoċ na haoin corre (Fray-ack na hain oushë), Onefooted Heath-Fraoć zálloa (Fray-ack gawldhè), Foreign Heath. ${ }^{1}$ Districts - - - - - - - VIII. IX. - - Lat. $53^{\circ} 15^{\prime}-53^{\circ} 55^{\prime}$. Galway and Mayo only. Type, Hibernian. Rocky heaths; locally abundant. Fl. July-August.

1 These native names seem to be quite local. The first is used in the neighbourhood of Oughterard; the second, which may also be rendered "fine" or "elegant" heath, is used. in Glen Inagh. 
VIII. "In most of the mountains of Galloway and Mayo grows an elegant sort of heath, bearing large thyme leaves, a spike of fair purple flowers like some Campanula, and viscous stalks" (Lhwyd): Phi7. Trans. I712. It is frequent . . . in the mountains of Mayo as also through the whole of Hiar Connacht in Galway: Ray, Hist. III., p. 98,1704 . On many of the islets in Lough Corrib; at the foot and sides of the mountains west of Lough Mask; on the Reek, Croaghpatrick: Brown Fascic. 1788 . Island in Lough Mask, $1894 ; R$. Warren. Plentiful within half a mile of the town of Galway, and in many places for forty miles further west: Mack. Rar. In the County of Mayo, between the Killary and Croaghpatrick: Mack. Cat. In great abundance near Delphi in Murrisk: Ball 1839 . On Canova Island, Lough Corrib: More 1860 . Old Head, south side of Clew Bay (Miss $\boldsymbol{K}$. $\boldsymbol{M}$. Lindsay) : Cyb. Sparingly in Curraun Achill; H. D. B. Dillwyn. On the Maamtrasna mountains; on Croaghpatrick; Loughty mountain; Mweelrea; Maamturk and Twelve Bens: Hart I 883 a. Frequent along Galway Bay, from Barna to Inveran, 1895; abundant on low hills near Oughterard and heaths near Derryclare Lough, 1896; abundant at Roundstone and Kylemore, 1897; N.C.-IX. Sparingly between Lisloughry and Lackafinna, Cong, Co. Mayo; Miss M. F. Jackson.

Sea-level to $1900 \mathrm{ft}$. in Galway and Mayo (Hart).

First found by Lhwyd about 1699 and first published by Ray in 1704. Lhwyd's original Irish specimens are preserved in Buddle's Herbarium, British Museum.

Not in Great Britain. Abundant in Northern Spain and in Portugal; rare in south-west France, ceasing south of the Loire: also occurs in a dwarf variety in the Azores.

\section{PYROLA Linn.}

\section{P. rotundifolia Linn.-Round-leaved Winter-green.}

Districts - - - - - VII

Lat. $53^{\circ}-53 \frac{1}{2}{ }^{\circ}$. Central Ireland. Type, Scottish-Germanic.

Lowland. Wet bogs; very rare. Fl. July-August.

VII. "In a Bogge by Roscre in the King's County. Mr. Heaton": How, Phytologia I650 (as P. vulgaris Lob.). Sparingly on large bog near Multyfarnham, Westmeath, 1870 (Moore): Ree. Add. Bog of Lisclogher, Westmeath; Rev. W. Reynell. Abundant in the Scraw Bog, Loughanstown and Ballynegall; and sparingly in Lisclogher Bog, Westmeath : Levinge 1894. 
Though the record for the King's Co. station given by How has never been verified, there can be little doubt that the plant gathered was $P$. rotundifolia.

\section{P. media Sw.-Intermediate Winter-green.}

Districts - - - - VI. - - IX. X. XI. XII. Lat. $53^{\circ}-551^{\circ}$. West and North. Type, Scottish.

Heathy places on mountains; rare. $F$. June-July.

VI. In several places in Burren, Co. Clare, as on hills west of Ballyvaughan; high ground south of Ballyalabawn; summit of Slieve Carran; and near Corranroo: Foot 2864. Cahira hill, Burren, $1892 ; P . B$. O' Kelly. On top of Cappanawallia mountain near Ballyvaughan, $1895 ; N$. C.-IX. In Sligo, on Ben Whisken (Admiral Jones), and near Hazelwood (J. Wynne) : ${ }^{C} C y b .-\mathbf{X}$. Near Pomeroy, Tyrone; Rev. S. A. Brenan-XI. Ards House near Dunfanaghy: Murphy 1820. At Carrablagh; Marble Hill; Carrowkeel; Leat Beg, \&c. : Hart I879 \&0.-XII. On the sides of the hill of Scrabo, near Newtown [probably this species]: Harris's Down, 1744. North-west side of Newtownards Park ; and shrubby islands at Ballygowan Bog, 1793: Templeton MS. On the hill of Conlig, Newtownards: Flor. Olst. and S.\& P. 1895. High-wood at the head of the Six-mile-water, 1794; and at Fair Head, 1815: Templeton MS. Still at Fair Head: Flor. N.-E. I888. Glenarm (Moore): Cyb. Wolf Hill and Crow Glen (Mr. Millen); Black mountain (Mr. Rea) : Flor. Olst. Glen at Cairncastle; and plentiful in Glenarm Deer Park (Praeger); Clinty Hill near Ballymena ( $D$. Redmond): Flor. N.-E. Near Cairn Hill and Irish Hill, Antrim (W. Macmillan): S.\&P. 1895 . Side of a glen in Ballynescreen mountains: Templeton MS. Glen Edra, Derry : Murphy 1820 (as $P$. rotundifolia). In Co. Derry, at Glenedra; Altahoan Glen, Moneymore; and Errigal banks: Moore MS. \&Cyb. Between Kilrea and Garvagh, Derry (Miss Knowles): S. \& P. 1895 .

To $700 \mathrm{ft}$. in Donegal (Hart); to $1075 \mathrm{ft}$. in Clare (Foot).

\section{P. minor Linn.-Lesser Winter-green.}

Districts - - - IV. - - VII. - - - XII. Lat. $52^{\frac{3}{4}}-55^{\circ}$. Middle and North-East. Type, Scottish-British.

Woods, and bushy or heathy places; rare. Fl. June-July.

- IV. In the Vale of Oroca, near the Meeting of the Waters Q 2 
(spec. sent to $D$. Moore) : $C y b .-$ VII. In Westmeath, in Ballynagall demesne, and glen near Tyrrell's Pass (Moore): Cyb.\& Reo. Add.XII. North side of Slemish, 1797 (Templeton): Whitla MS. In Glenariff, 1809: Templeton MS. Re-found in Glenariff (Rev. S. A. Brenan): S.\&P. 1895 . Colin Glen (Stewart); Woodburn Glen; Glendun, \&c.; frequent in Antrim (Moore): Cyb. Cliffs of Cave Hill (Stewart); near Ballymoney (Rev. S. A. Brenan): Flor. N.-E. On Divis, above Crow Glen: B. N. F. C. Proc. 1878. Tollymore Park, Down (Rev. H. W. Lett): S.\&P. 1895. Woods at Lissan and Castle Dawson; Altahoan glen and on Errigal banks, Derry: Moore MS. On the Owbeg river, Derry, near the fall called Linapaste [Lignapeiste], E. Murphy: Flor. Hit.

To $1000 \mathrm{ft}$. in Antrim (Flor. N.-E.).

\section{P. secunda Linn.-Serrated Winter-green.}

Districts - - - - - - - - - X. XII. Lat. $54^{\circ} 50^{\prime}-55^{\circ}$. Derry and Antrim only. Type, Scottish.

Dry, heathy banks; very rare. Fl. July.

XII. On the bank which faces the north of the Agivey river, generally called Errigal banks, above Garvagh, Derry, between the lint-mill and Errigal Bridge, found in considerable quantity, 1835 : Moore MS. Glenarm and Sallagh Braes; also on Agnew's Hill near Larne, Antrim (Moore): Cyb.

Not re-found in Ireland since its first discovery by Dr. Moore, more than sixty years ago, though it has been repeatedly sought for by botanists in the very definite station of Errigal banks. A single sheet of three specimens, rightly named and labelled with the above localities, is preserved in Dr. Moore's herbarium at Glasnevin Botanic Garden.

\section{ORDER XXXIX.-MONOTROPE丑.}

HYPOPITHYS Scop.

1. H. multiflora Scop.-Yellow Bird's-nest.

Monotropa Hypopitys Linn.-Hypopitys Monotropa Crantz.

Distriets I. - - - V. VI. - - IX. - - Lat. $52^{\circ}-541_{4}^{\circ}$. West and South-West, chiefly. Type, GermanicEnglish.

In woods, chiefly of beech and fir; very rare. Fr. July-August. 
I. Under beeches, west of Muckross Abbey, Killarney : $R$. W. S. I89I. - V. At the foot of old pine trees at the Marquis of Drogheda's, Moore Abbey, Kildare: Wade Rar. Under beech trees, St. Catherine's, County of Dublin: Mack. Cat.-VI. Under beech trees at Castle Taylor, Galway: More I855\&Cyb. Onder pine trees in Lord Clancarty's demesne at Ballinasloe (Moore) : Cyb́.--IX. Hazelwood, Sligo (Miss Wynne): Rec. Add.-a great many plants found here in 1871 under an Evergreen Oak; Miss Wynne in litt. One plant in a hazel copse at Dooney Rock, Lough Gill, Sligo: $N$. C. 1896 .

\section{ORDER XL.-PLUMBAGINEA.}

\section{STATICE Linn.}

\section{S. rariflora Drej.-Loose-flowered Sea-lavender.}

\section{S. Bahusiensis Fries.}

Districts I. II. III. IV. V. VI, - VIII. - X. XI. XII. Lat. $51 \frac{1}{2}^{\circ}-54 \frac{3}{4}^{\circ}$. Coasts of all Ireland, nearly. Type, English.

Muddy salt-marshes; frequent and locally abundant. Fl. JulyAugust.

I. Kenmare River; Barrow Harbour; Tarbert; Ballylongford, Kerry, \&c. : R.W. S. $1888 \&-9 I$. Near Goleen; Creagh near Skibbereen; and-II. Little Island; Fota; Saleen; common round Cork Harbour, rare elsewhere in Co. Cork; Phillips.-III. Banks of the Barrow above Ballinlaw Ferry: B.-H.\& G. I889.-IV. By the river at Wicklow, 1897 ; Praeger. South-west corner of Wexford Harbour, very sparingly: Marshall I898.-V. Locally abundant along the coast in County Dublin; $N$. C.-VI. Ringmoylan and Foynes, Limerick: Stewart I89o. Rine point, Gleninagh, Clare, $1895 ; P . B$. O' Kelly.-VIII. Shore at the base of Croaghpatrick, Mayo: Hart 1883 a.-X. Common in the estuary of the Newry river, Armagh: Praeger 1893. - XI. North-east corner of Fintragh Bay (Miss Brook); by the shore between RossyIongan and Donegal: Hart $5885 \%$-XII. Locally abundant in Antrim and Down; not recorded for Derry : Flor. N.-E.

Absent from the extreme North, and generally less abundant than the following species though more widespread. 


\section{S. occidentalis Lloyd-Rock Sea-lavender.}

S. binervosa G. E. Smith.

Districts I. II. - IV. V. VI. - - - XI. Lat. $52^{\circ}-55 \frac{1}{4}^{\circ}$. From South to North. Type, Atlantic-English.

By the sea, on cliffs and clay banks, and more rarely on sandy estuarine deposits or in gravelly places; locally abundant. Fl. July-September.

I. Rocks by the entrance to Barrow Harbour, Kerry; not seen elsewhere in the county: $R$.W. S. 2888 .-II. Ballycotton, Cork (Carroll): Cyb.-IV. Rocks about two miles north of Arklow; and near the Castle at Wicklow (More): Reo. Add. Baginbun Head and Hook Head, Wexford: Hart 1883 B.-V. Abundant on many parts of the County Dublin coast from Killiney to Balbriggan, especially so at Rogerstown, 1893; Portrane, 1894; and on the sands of the North Bull, 1896; N. C. At Laytown, Meath (More): Rec. Add. Clogher Head, Louth (J. Ball) : $C y b$. VI. Rocks by the roadside south of Black Head, Clare (Moore \& More): Cyb. On the west side of Great Aran island (Moore): Cyb.-abundant here from Dun Angus to Bungowla: Hart I875.-XI. On the rocks of Dunargas; and, in one place only, on the west side of Horn Head (C. Moore): Cyb. \& Hart I879. On the mainland opposite Rathlin 0'Beime Island : Hart I885 $\gamma$. Cliffs at Rossgull; Miss Kinahan.

Very rare in Kerry and in Cork, and absent from the NorthEast.

Par. INTERMedis Syme-VI. Near Poulsallagh, Clare 1892; Levinge:

Var. DodaniII (Gir.)-II. Tramore, Waterford (T. Chandlee): Carroll 1854.

\section{ARMERIA Willd.}

1. A. maritima Willd.-Sea Pink; Thrift.

Districts I. II. III. IV. V. VI. - VIII, IX. X, XI, XII. Lat. $51 \frac{1}{2}^{\circ}-55 \frac{1}{4}^{\circ}$. Coasts of all Ireland. Type, British.

Rocks and banks by the sea, also on mountains near the coast; common. Fl. May-July.

Occurs inland at a low level, about $80 \mathrm{ft}$., on Ross Island, Killarney Lakes, and frequently on mountain tops near the coast, as on 
Brandon and Carrantuohill, Kerry; Ben Lettery, Galway; Croaghpatrick and Nephin, Mayo; Muckish and Errigal, Donegal; and Ben Evenagh, Derry. Nowhere found at a greater distance than 10 miles from the sea and apparently confined, as a mountain plant, to the West and North.

To $2460 \mathrm{ft}$. in Donegal (Flor. Ulst.); to $2640 \mathrm{ft}$. in Mayo, and to $3414 \mathrm{ft}$. in Kerry (Hart).

\section{ORDER XLI.-PRIMULACEAE.}

HOTTONIA Linn.

\section{1. $¥$ H. palustris Linn. -Water Violet.}

Districts - - - - - - - - - ẊII. Lat. $54^{\circ} 20^{\prime}-54^{\circ} 35^{\prime}$. Down and Antrim, only. Type, English.

Marshes and stagnant ditches; very rare. $F l$. May-July.

XII. "Found by Mr. Richard Kennedy in the marshy ditches by the right side of the road at Everogue Bridge near Downpatrick" : Templeton MS. Still abundant at Everogue Bridge (Crossgar) Praeger: B. N. F. C. Proe. I890-9I. Plentiful in the drains in the Bog Meadows, Belfast, where it was planted a few years ago (Stewart): Rec. Add. 1872. Introduced at Hollywood and Cushendun; spreading amazingly in the Bog Meadows; probably introduced at no remote date in its original station in Co. Down: Flor. $N$. $E$.

Established for at least three-quarters of a century in the County Down station. The record in Brown's Fascioulus 1788 : "In a watery ditch west of Lough Mask on the road from Ballinrobe to Westport" has not since been verified, and was no doubt an error.

\section{PRIMULA Linn.}

\section{P. vulgaris Huds.-Primrose.}

$P$. acaulis Linn.

Hibernicé bainne bo bleaċeán (Bannyĕbo blaolthawn), Milch cow's milk.

Districts I. II. III. IV. V..VI. VII. VIII. IX. X. XI. XII. Lat. $51 \frac{1}{2}^{\circ}-55 \frac{1}{4}^{\circ}$. Throughout Ireland. Type, British.

Banks, hedgerows, woods, and shady places; common. $F l$. April-May. 
Sea-level in Derry and in Kerry. To $1650 \mathrm{ft}$. in Donegal (Hart); to $2000 \mathrm{ft}$. in Down (S.\& P.); to $2500 \mathrm{ft}$. in Wicklow (Hart); to $2800 \mathrm{ft}$. in Kerry (N.C.).

P. vulgaris $\times$ veris.-I. Near Ovens; and-II. At Rathcooney, Cork; Phillips. - V. Ballynascorney; Donabate, \&c., Dublin; N. C. Near Athy, Kildare; R.W. S.-VI. Near Salthill, Galway; Stewart.-VII. Knock Drin, Westmeath : 'Levinge 1894.

Probably frequent in the eastern districts. Often confounded with the true Oxlip, $P$. elatior (Jacq.), which has not been found in Ireland.

\section{P. officinalis Jacq.-Constip.}

$P$. veris Linn.

Districts I. II. III. IV. V. VI. VII. VIII. IX. X. XI. Lat. $51 \frac{1}{2}^{\circ}-55 \frac{1}{4}^{\circ}$. From South to North. Type, British-English.

Pastures and meadows; locally abundant. Fl. April-May.

Sea-level to $1200 \mathrm{ft}$. in Dublin (N.C.).

A very unequally distributed species, absent from wide areas in many parts of Ireland. Abundant in many of the eastern counties; occurring only as an introduced plant in District XII. ; very rare in Distriet XI. ; local in Kerry, and generally scarce in the West.

\section{LYSIMACHIA Linn.}

\section{L. vulgaris Linn,-Yellow Loose-strife.}

Districts I. II. III. IV. V. VI. VII. VIII. IX. X. XI. XII. Lat. $51_{4}^{\circ}-55^{\circ}$. Throughout Ireland. Type, English-British.

Lowland. Banks of rivers, lake shores, and in ditches and marshy meadows; rather frequent and locally abundant. Fl. July.

I. In several places about Killarney; by the river Laune near Ballymalis Castle; Fermoyle, west of Castlegregory (Rev. Abrm. Isaacs); near Waterville, Kerry : R.W. S. I889, \&c. Ballyphehane and Summerstown bogs: Drummond 1818.-II. Bog near Youghal, 1896; Phillips \&.R.W.S. By the Suir near Cloon bridge and Camus bridge, Tipperary: Hart I885 .-DIII. By the Barrow. between Maganey bridge and Carlow: Hart 1885.-IV. Stream. side in Ballinglen, Wicklow; Miss Kinahan.-V. Quarry hole on the Delvin river, Co. Dublin: N. C. 7893 . Kearney's Cross, Louth, 1897 ; Praeger.-VIII. Banks of Lough Corrib near Maam: Babington 1836 .

A rare plant in all the foregoing districts, especially so in IV., 
V. and VIII., and rare, generally, in the South and East. Common round the shores of many of the larger lakes, as Loughs Neagh and Erne; and Loughs Allen, Ree, and Derg on the Shannon.

\section{2. * L. Nummularia Linn.-Moneywoort.}

Districts - - - VI. - - IX. X. XI. XII. River banks, lake shores, marshes, \&c. ; rare and nowhere native. Fl. July-August.

VI. By the lake at Dromoland, Clare, apparently wild; Rev.T. Warren.-IX. On both sides of the river Suck at Mount Talbot, Roscommon; R. Bayly.-X. River banks near Ardunshin, Fermanagh (Rev. S. A. Brenan), and three miles above Colebrook, Fermanagh (T. O.Smith): Rec. Add. Limestone quarry near Grange, Armagh (Rev. W. F. Johnson) : Prasger I893. -XI. Hedge-bank at Augh-na-gaddy and about a mile thence on a roadside bank on the way to Rathmelton, many years established (Dean Gwynn): Hart r880.-XII. Banks of the Whitehouse stream at Maryville: Hind 7854. Abundant on wet sandy shore a little west of Crumlin waterfoot, Antrim, and in marshes by the Bann above Coleraine, Derry (Stewart); stony banks of the Quoile near Downpatrick ( $C$. Dickson); marsh at Ballyalooley, Down (Praeger); well naturalized by Lough Neagh and the Quoile: Flor. N.-E.

Also recorded from several station in Districts I., II., IV. and V., where, however, the plant seems to have occurred only as a garden escape or outcast without becoming fully established. Nowhere thoroughly naturalized except in District XII.

\section{I. nemorum Linn.-Wood Loose-strife.}

Districts I. II. III. IV. V. VI. VII, VIII. IX. X, XI, XII. Lat. $51 \frac{1}{2}^{\circ}-55 \frac{1}{4}^{\circ}$. Throughout Ireland. Type, British.

Damp shady places; frequent. Fl. May-July.

Sea-level in N. Derry and in S. Cork. To $1550 \mathrm{ft}$. in Donegal, and to $1850 \mathrm{ft}$. in Mayo (Hart); to $2800 \mathrm{ft}$. in Kerry (Druce I89I).

\section{GLAUX Linn,}

\section{G. maritima Linn.-Sea Milkwort.}

Districts I. II. III. IV. V. VI. - VIII. IX. X. XI. XII. Lat. $51 \frac{1}{2}^{\circ}-551^{\circ}$. Coasts of all Ireland. Type, British.

Muddy and gravelly sea-shores; common. Fl. June-July. 


\section{ANAGALLIS Linn.}

\section{A. arvensis Linn.-Scarlet Pimpernel.}

Districts I. II. III. IV. V. VI. VII. VIII. IX. X. XI. XII. Lat. 51 $1_{2}^{\circ}-55 \frac{1}{4}^{\circ}$. Throughout Ireland. Type, British-English.

Corn-fields, sand-hills, and waste places; frequent and locally abundant. Fl. May-August.

Sea-level to $1000 \mathrm{ft}$. in Dublin (N. C.).

Var. cARRUTAA (Schreb.)-II. At Glentown, Glanmire (Carroll) : Annot. in Flor. Cork.-IV. Garden at Bray: Templeton MS. Cornfield at Alderton, Wexford (Miss L. Glascott): B.-H.\& G. I889.V. Sparingly near Kilkea Castle, Kildare (J. Douglas): Rec. Add. At Castle Bellingham, Louth, 1893; Cecil Butler. Sparingly in a cornfield at Portrane, Co. Dublin: N. C. 1895.--VIII. Near Belmont, Galway (Dr. W. King) : Rec. Add.-X. Garden ground at Bessmount, Monaghan (Miss Maffett) : Cyb.-XI. A garden weed at Horn Head : Hart 1879.-XII. Cornfields near Warrenpoint, Down: Flor. Hib. Near Balleevy, Down; Miss E. Malone. Stranmillis-road near Belfast: Stewart 1894.

Of frequent occurrence in cultivated ground, but usually as a casual only.

\section{A. tenella Linn.-Bog Pimpernel.}

Districts I. II. III. IV. V. VI. VII. VIII. IX. X. XI. XII. Lat. $51 \frac{1}{2}{ }^{\circ}-551^{\circ}$. Throughout Ireland. Type, British.

Bogs and damp pastures; frequent. Fl. July-August.

Sea-level in N. Donegal and S. Cork. To $1600 \mathrm{ft}$. in Down $(S . \& P$.$) ; to 1400 \mathrm{ft}$. in Dublin (N.C.).

\section{CENTUNCULUS Linn.}

\section{C. minimus Linn.-Bastard Pimpernel.}

Districts I. II. - - V. VI. - VIII. IX. X. XI. XII. Lat. $51 \frac{1}{2}^{\circ}-55 \frac{1}{4}^{\circ}$. From South to North. Type, English-British.

Lowland. Damp sandy and heathy places and roadsides, mostly near the sea; rare. Fl. June-August.

- I. Castlegregory, Kerry (Moore) :. Cyb. At Killarney : Babington in Herb. Near Ballydarid, Dingle promontory: Hart 7884. On both sides of Kenmare bay, as at Lauragh and Parknasilla; in 
several localities on the north side of Dingle Bay, \&c., Kerry; R.W.S. Plentiful in marshy grounds near Ballylickey, Bantry: Mack. Rar. Shores of Berehaven (More): Rec. Add. Near Clonakilty and in several places near Ballinadee: Allin's Cork. Near Mount Gabriel, Schull, 1894; Phillips.-II. Great Island, Cork (Carroll): Cyb. Ballintowtas near Midleton, Cork (Rev. T. Allin): Rec. Add. At Ballycotton, Cork, 1895; Phillips.V. Damp sandy ground behind the lighthouses at Boyne mouth, Meath: Praeger I897.--VI. Abundant on Dunbeg Bog, Clare, and in boggy ground from Kilkee to Loop Head (Moore): Cyb.VIII. On moist turfy sands near Ballinahinch, Connemara: Wade Gallovid. On the coast near Clifden : Carroll 1857 . On the boge in Erris near Bangor, \&c., Mayo (Moore) : $C y b$. On Inishbofin : More I876.-IX. Between Cliffony and Mullaghmore [Sligo], Mr. Syme: Flor. Ulst.-X. Gubbaroe Point near Kesh, Lough Erne: Barrington 1884. Shore of Lough Neagh south of Bird island, and gravel pit, Derryadd Bay, Armagh: Praeger 1893.XI. Rosses and Fanet, Donegal: Murphy I829. Near Dunglow, between the village and the ferry (Admiral Jones) : $C y b$. Kindrum Lake and Lough Finnegan, Fanet: Hart 1879 . Sessiagh Lake, Dunfanaghy; Stewart.-XII. Plentiful about the lake at Ballygowan bridge [Down], 1807 : Templeton MS. \& (Stewart): Cyb. Abundant on sandy warrens between Downhill and Portstewart, Derry: Moore MSS. Shore of Ushet lake, Rathlin Island: Stewart I884. Dundrum sand-hills; lake shore near Ballynahinch, and other stations in Down; shore of Lough Beg, Derry (Stewart): Flor. N.-E. Abundant at drained site of Ballymartin lake near Annalong, Down: S.\&. P. 1892 .

Not yet recorded for the South-East, where, perhaps, it has been overlooked.

\section{SAMOLUS Linn.}

\section{S. Valerandi Linn.-Brook-weed.}

Districts I. II. III. IV. V. VI. VII. VIII. IX. X. XI. XII. Lat. $51_{2}^{10}-554^{\circ}$. Throughout Ireland. Type, English-British.

Lowland. Moist places by the sea, also inland, especially by lake-shores; frequent. Fl. July-August.

A rare plant in inland stations except around the larger lakes, such as. Lough Ree, Lough Derg, and Lough Erne, where it is abundant. 


\section{ORDER XLII.—OLEACEE.}

\section{FRAXINUS Linn.}

\section{F. excelsior Linn.-Ash.}

Hibernicé Fuınre6z (Finshöge).

Districts I. II. III. IV. V. VI. VII. VIII. IX. X. XI. XII. Lat. $51_{2}^{10}-55 x_{4}^{\circ}$. Throughout Ireland, Type, British.

Woods, hedges, and rocky places; frequent. Fl. April-May.

Sea-level in Derry and Cork. To $800^{\circ} \mathrm{ft}$. in Donegal (Hart); to $1000 \mathrm{ft}$. in Down $(S, \& P$.); to $1300 \mathrm{ft}$. in Wicklow (Hart).

\section{LIGUSTRUM Linn.}

1. I. vulgare Linn.-Privet.

Districts I. II. III. IV. V. VI, VII. - IX. X. XI. XII. Lat. $51 \frac{1}{2}^{\circ}-55^{\circ}$. Throughout Ireland, probably. Type, English.

Sea-cliffs, and in hedges and thickets; frequent as an introduced. plant, very rare as a native. $F$. June-July.

II. Sand-hills near Tramore, Waterford (Miss S. Grubb); cliffs at Tramore (Rev. S. Madden): Cyb. Stradbally to Ballyvoyle Head, and elsewhere on the Waterford coast, native on steep and inacessible cliffs: Hart ${ }_{1} 88_{3} \beta .-\mathrm{V}$. Native on steep grassy cliffs along the east side of Howth: Flor. Howth.

These are the only stations in which the plant has any claim to be regarded as native.

\section{ORDER·XLIII.-GENTIANE五.}

\section{MICROCAĹA Hoffm. \& Link.}

1. M. filiformis Hoffm. \& Link.-Slender Gentianella.

Cicendia fliformis Reichb.

Districts I. - - -

Lat. $51_{2}^{\circ}-52^{\circ}$. South-West, only. Type, English-Atlantic.

Roadsides and moist, sandy, or peaty places; rare. Fl. JulyAugust. Calcifuge $A$. 
I. Rossbehy, Kerry, 1845 (W. H. Harvey): Herb. T.C.D. Roadside between Kenmare and Killarney (Moore): Cyb. Round Ballinskelligs Bay; abundant along Kenmare Bay, \&c., Kerry: R.W. S. I890. Shore of Lough Guitane, Kerry (More): Journ. of Bot. 1876 -and in $1896 ;$ R.W.S. Dursey island, Cork (J.Blashford $):$ Wade. Rar. Marshy ground near Bantry : Drummond 1818 . Glengariff and Castletown Berehaven: Carroll 2854 . Near the shore at Durrus, Dunmanway Bay: Allin 1873 . On Priests' Leap (Carroll); near Skibbereen (Miss Hickie); Desert (C. Longfield): Allin's Cork. At Adrigole, 1894; near Lough Hyne; Mount Gabriel; Baltimore, 1896 ; pass of Keimaneigh, 1897; Phitlips.

From sea-level to $800 \mathrm{ft}$. in Kerry $(R . W . S$.$) .$

Abundant in many places within its very restricted area in the extreme South-West.

First found by J. Blashford, on Dursey island, before 1804 .

\section{CHLORA Linn.}

\section{C. perfoliata Linn.-Yellow-wort.}

Blackstonia perfoliata Huds.

Districts I. II. III. IV. V. VI. VII. VIII. IX. - - Lat. $512_{2}^{\circ}-534^{\circ}$. South and Middle. Type, English.

Gravelly and sandy ground, drift banks, and rocky lake shores; locally abundant. $F l$. July-September. Calcicole $B$.

I. Sparingly about Ballybunnion, Kerry; very rare in the county: R.W.S. 1890. Fields east of Kinsale (C. Longfield); near Oysterhaven : Allin's Cork. Fields near Lislevane, S. Cork; Phillips.-II. By the road and shore at Whitepoint, Great Island (Dr. Scott) : Flor. Cork. Doneraile and Kilcoleman (J. Wright); abundant near Killeagh : Allin's Cork. Frequent in Districts III., IV., V., and VI.-VII. Railway banks between Hill of Down and Killucan, Westmeath, 1896; abundant on the east shores of Lough Derg, Co. Tipperary, 1896 ; N. C.-VIII. Near Clonbur, Galway : M. \& S. I806. Gentian Hill, near Galway: Ir. Nat. I895. Near Inveran, Iar Connaught, West Galway, $1895 ; N$. C.-IX. Recorded for this District in 1st. Ed. $C y b$., but no locality available.

Sea-level to $600 \mathrm{ft}$. in Dublin $(N . C$.); but usually lowland.

Absent from the North and rare in the extreme South; abundant in many parts of Districts V. and VI. in the counties of Dublin, Clare, and Galway. 
ERYTHR 五A Renealm.

\section{E. Centaurium Pers.-Centanury.}

Hibernioé Opeimine Muipe (Dhray-mirě Mwirrě), Mary's Ladder. Districts I. II. III. IV. V. VI. VII. VIII. IX, X. XI. XII. Lat. $51 \frac{1}{2}^{\circ}-55 \frac{1}{4}^{\circ}$. Throughout Ireland. Type British.

Pastures and sandy ground, especially near the sea; frequent. Fl. July-August.

Sea-level to $950 \mathrm{ft}$. in Dublin (N.C.); but usually lowland.

Var. CAPITATA Kooh-I. On most of the Kerry headlands; $\boldsymbol{R}$. W. S.-XII. Sandbanks near the Giant's Causeway: Shoolbred I894.-Probably occurs in exposed situations all round the coasts.

Var. LATIFOLIA (Smith)-II. Ardmore, Waterford (J. Sullivan): $C y b$.-VI. Frequent at Kilkee, Clare (Carroll): $C y b$.-VIII. Belmullet, Mayo; More.-IX. Sligo (Moore): Herb. Glasnevin-Also recorded from other localities by the earlier writers, but recent confirmation is needed.

\section{E. pulchella Fries-Dwarf Centaury.}

Districts I. II. III. IV. V. - - - - - Lat. $51 \frac{1}{2}^{\circ}-531^{\circ}$. South and East. Type English.

Lowland. Sandy sea-shores, chiefly; very rare. Fl. JulySeptember.

I. On Cape Clear Island: Drummond 1818. Shore near Bantry, and strand at Glandore (J. Sullivan): Cyb.-II. Near Youghal (Miss Ball) : Flor. Cork.-III. Dry pasture near Emo, Queen's Co. : Praeger 1897.-IV. Curracloa, Wexford (J. Morrison): Rec. Add. Sand-hills between Rosslare and Rosslare Point; at Carnsore and Baginbun; and on the Greater Saltee Island, Wexford: Hart r883 B.-V. North Bull, Dublin Bay (D. Orr) : Rec. Add.—and in $1894 ; R . W . S$.

First found by Drummond, at Cape Clear, before 1818.

\section{GENTIANA Linn.}

1. G. verna Linn.--Spring Gentian.

Districts - - - - VI. - VIII. IX. - - Lat. $53^{\circ}-53 \frac{3}{4}^{\circ}$. West Ireland only. Type, Intermediate.

Stony pastures and on sand-hills; locally abundant. Fl. AprilMay. Caloieole $A$. 
VI. "On the Mountains between Gort and Galloway abundant, Mr. Heaton" : How, Phytologia 1650. Near Castle Taylor, County Galway: Wade Rar. \& More 1855. Plentiful on the estate of Bindon Blood, Esq., near the Bay of Galway [Burren]; abundant near the town of Galway (Mr. Henry): Mack. Rar. On hilly grounds about eight miles west of Tuam in great abundance: Flor. Hib. Near Kiltartan, Galway (C. Carter): Phytol. 1846, p. 5 I2. Widespread over the Burren limestone and on the shore sand-hills : Foot 1864. Abundant west of Ballyvaughan, Burren, from near sea-level to the mountain summits, $1895 ; N . C$. On moory ground near Cong, Galway; between Gort and Lough Cooter Castle, Galway; in Great Aran Island (Moore) : Cyb. Athenry, Galway: Corry 1880 . In all three islands of Aran : N. C. I893-VIII. On limestone drift to the west of Galway (Prof. Melville): Cyb. On Gentian Hill west of Galway, 1895 [the same station as the preceding]: Ir. Nat. 1895 . Knockshanbally, Moycullen, Galway; Miss M. F. Jackson.-IX. Shores of Lough Carra near Moore Hall: Ball I839-and in 1854: More I860.

Sea-level to $1000 \mathrm{ft}$. in Clare (N.C.); but usually lowland.

Very limited in its eastward range, hardly spreading beyond Athenry. Much more lowland in Ireland than in Great Britain and reaching farther South.

\section{G. Amarella Linn.-Felwort.}

Districts I. II. III. IV. V. VI. VII. VIII. IX. X. XI. XII. Lat. 51 $1_{2}^{\circ}-55 \frac{1}{4}^{\circ}$. Throughout Ireland. Type, British-English.

Pastures; locally abundant. $F l$. July-August. Calcicole $B$.

I. and II. Locally abundant in County Cork: Ailin's Cork.III. At Maryborough, Queen's Co. ; Praeger.-IV., V., VI., and VII. Frequent, occurring in many stations in Wexford, Clare, Galway, Westmeath, and Dublin.-VIII. In the island of Bartia and in other places near Killala: Mack. Rar.-IX. South of Lough Mask in Mayo : M. \& S. 7896 . On the shores of Lough Talt, Sligo: N. C. $1806 .-\mathrm{X}$. Shores of Lower Lough Erne, apparently rare: Barrington 1884.-XI. Abundant on sandy downs between Ballyshannon and Donegal: Hart $I 885 \gamma$-XII. Kenbane Head, Antrim: Templeton MS. In County Derry, on Keady Mountain only: Moore MS. Not found recently in north-east Ireland: S. $\&$ P. 1895 .

Very rare in the North and apparently absent from Kerry. 
3. G. campestris Linn.-Field Gentian.

Districts I. II. III. IV. V. VI. VII. VIII. IX, X. XI. XII. Lat. $51 \frac{1}{2}^{\circ}-557_{4}^{\circ}$. Throughout Ireland. Type, British-Scottish.

Upland pastures, also on sandy shores; frequent. Fl. JulyAugust.

Sea-level in N. Antrim and S. Cork. To $1500 \mathrm{ft}$. in Derry (Hart).

A widely-distributed species, much more common in the West than in the East, and especially abundant on the basalt in Derry and Antrim.

\section{MENYANTHES Linn.}

1. M. trifoliata Linn.-Buck-bean; Bog-bean.

Hibernicé beapnán laćán (Barnawn lockawn), Jagged Ducks' Plant (?).

Districts I. II. III. IV. V. VI. VII. VIII. IX. X. XI. XII. Lat. $51 \frac{1}{2}^{\circ}-55 \frac{1}{4}^{\circ}$. Throughout Ireland. Type, British.

Wet bogs, bog ditches, stagnant pools, and lake margins; common. Fl. May-June.

Sea level in N. Derry and S. Cork. To $2000 \mathrm{ft}$. in Donegal (Hart); to $1600 \mathrm{ft}$. in Down (S.\&P.).

\section{ORDER XIIV. -BORAGINE}

\section{CYNOGLOSSUM Linn.}

1. C. officinale Linn.-Hound's-tongue.

Districts I. II. III. IV. V. ------ XII. Lat. $51 \frac{3}{4}^{\circ}-54 \frac{1}{2}^{\circ}$. From South to North. Type, English-British. : Lowland. Sand-hills and sandy fields by the coast, also inland, by road-sides and in waste places; locally abundant. Fl. June-July.

I. Near Douglas, Cork: Flor. Cork. At Rochestown, Cork; Miss H. A. Martin.-II. Near Whitegate, Cork Harbour, and on the cliffs at Greenland, near Cable Island (Dr. Power): Flor. Cork. Very sparingly along the shore near Youghal: Allin's Cork. Tramore, Waterford, and near Clonmel (Miss S. Grubb); Ardfinane, Tipperary (Miss A. Taylor): Cyb.-III. River View and Sion 
Canal walk, Kilkenny (Rev. S. Madden): $C_{y} b$. Field between Bagnalstown and Slygough, Carlow, $1890 ;$ Rev. T. Hartley.IV. Abundant on the Murrough of Wicklow (Moore): Cyb. In county Wexford, south of Cahore Point; near Ballymoney; Rosslare; Carnsore and Churchtown: Hart I88I $\alpha \&$ I883 $\beta$. Near Fethard, Wexford; Barrington. - V. In Mirrion churchyard: Threlkeld. Abundant about Kilbarrack; near Warren House; in Phoenix Park; at Merrion and elsewhere: Wade Dubl. Sand-hills opposite Malahide : Flor. Hib. Abundant on sand-hills at Rush, 1894, and at Portrane, 1895; in great profusion at Portmarnock sand-hills, $1896 ; N . C$. Sand-hills from Rush to Drogheda, in many places; More. Near Moone, Kildare (Carroll): Cyb. Seashore near Castlebellingham, Louth: Butler 1890.-XII. Sandy shore at Kirkiston and Dundrum, 1793 : Templeton MS. Abundant on the sandy shore of the Ards from Ballywalter to Kennedy's Point (Stewart); sand-hills at Ballykinler, \&c. (Corry); plentiful in County Down, not found in Derry or Antrim : Flor. N.-E.

\section{SYMPHYTUM Linn.}

: $\quad$ 1. S. officinale Linn.-Comfrey.

Districts I. II. III. IV. V. VI. VII. VIII. IX. X. XI. XII. Lat. $51 \frac{1}{2}^{\circ}-55 \frac{1}{4}^{\circ}$. Throughout Ireland. Type, English-British.

Banks of rivers and watery places, also on roadsides and in waste places; frequent. Fl. May-June.

Often cultivated, and though fully established in many places appears to be nowhere certainly indigenous.

\section{ANCHUSA Linn.}

\section{1. *A. sempervirens Linn.-Alkanet.}

Districts [I.] [II.] - [V.] - - [X.] [XI.] XII.

Among ruins, along roadsides, and in hedges or plantations; very rare and nowhere native. $F l$. May-June. - [I. Hedges near Douglas, Cork (Drummond); and-II. Under Blarney Castle (Mr. Alexander): Flor. Cork. At Glanmire (Carroll); not established in Cork: Allin's Cork.-V. Roadside at Leixlip, 1888 (J. S. Gamble): Herb. Levinge.-X. Tanderagee, Armagh: Flor. Ulst.-XI. Churchtown, Upper Fahan : Herb. C. Moore. Established at Clondevaddock churchyard, Fanet (Hart): 
Rec. Add.]-XII. Between Bangor and Portavo, Down; near Portglenone, Antrim; and near Magherafelt, Derry: Templeton MS. Naturalized in the woods at Roe Park; lane leading from Newtownlimavady to Roe Mill; roadside near Ash Park, Derry : Moore MSS. In several places near cottages in Rathlin Island, no doubt introduced: Stewart 1884 . Roadside at Stormount; Braniel; and Conlig, Down (Stewart); not rare in N.-E. Ireland, naturalized in some of its stations, but frequently only a garden escape : Flor. N.-E.

\section{LYCOPSIS Linn.}

\section{L. arvensis Linn.-Fireld Bugloss.}

Anchusa arvensis Bieb.

Districts - II. III. IV. V. - - - IX. - XI. XII. Lat. $52 x^{\circ}-55 x^{\circ}$. From South to North. Type, British.

Sandy fields and banks, mostly near the sea; locally abundant. Fl. June-August.

II. Near Clonmel (Miss S. Grubb); and-III. Three Castles, Kilkenny ( $P$. Duffy): $C y b$. -IV. Sands at Fethard, Wexford: B.-H.\& G. I89o. Raven Point; Rosslare; and Bar of the Lough, Wexford: Hart $1883 \beta$. On the Murrough of Wicklow (Moore): Cyb.-V. Sandy fields near Kilbarrack Church and about Baldoyle, \&c. : Mack. Cat. Very abundant at Portmarnock and Portrane, 1895 ; and frequent along the Dublin coast from Howth to Skerries; N.C.-IX. Mullaghmore, Sligo (Admiral Jones): Cyb.-XI. Near Ardara; at Malin; about Kindrum : Hart 1883 \& a.-XII. Common in Antrim, Down, and Derry, chiefly by the coast : Flor. $N_{0}-E$.

Also recorded for District I. from Evergreen, Co. Cork, in Flor. Cork, but not recently observed in that district.

\section{MERTENSIA Roth.}

\section{M. maritima S. F. Gray-Sea Gromwell.}

Lithospermum maritimum Lehm.-Pulmonaria maritima Linn. Districts - - - IV. V. - - - - - XI. XII. Lat. $53^{\circ}-551^{\circ}$. East and North coasts. Type, Scottish.

Shingly or gravelly sea-shores; very rare. Fl. May-August.

IV. "On the Meuragh of Wicklow; Mr. Sherard": App. to Threlkeld 17a7. Plentiful at the Murrough of Wicklow: Flor. Hib. Not now [1872] plentiful on the Murrough, but occurs near 
Newcastle station, and between Kilcool and the Breaches (More): Rec. Add. Near Kilcool, $1880 ;$ Hart.-V. Very sparingly on the shore near Hampton Bank about a short mile from Balbriggan and at Lough Sheeney, within about a mile of Skerries, county of Dublin: Wade Rar. Coast between Balbriggan and Skerries: Flor. Hib. Not seen for very many years in the County Dublin and probably extinct; $N . C$. Shore of Dundalk Bay, sparingly: Butler I890.-XI. Norway Point, Donegal, 1839 : Herb. C. Moore. Rossgull, south of Rinnafaghla, in profusion: Hart 1880 . Plentiful on the north-east side of Malin Head: Hart $2883 .-\mathrm{XII}$. Shore of Island Magee at Brown's Bay, 1794 (Templeton): Whitla MS. Garron Head, Antrim (Moore) : $C y b$. Shore, half a mile from the Bar of.Dundrum; and in great profusion. on the shore about five miles south of Newcastle, 1799: Templeton MS. Extending for nearly a mile along the beach at Glassdrumman (Templeton's Newcastle station): S.\&P. I892, At Ramullan, 1810 : Templeton MS. A single plant at Rathmullen Point, Down, 1878 (Corry): Flor. $N$.- $E$. Abundant along the gravelly shore-side between Greencastle and the Light House, Co. Down (John White): Wade Rar. Sparingly a.short distance north of the lighthouse at Greencastle (Stewart): Flor. N.-E. On the shore at Ballyaghran, Derry: Sampson 1802. Between Portrush and Portstewart, the same station as the preceding (Mrs. Leebody): S.\& P. 1895. Near Castlerock station, Derry line (Rev. W. T. Whan): Flor. Olst,

Also recorded for District I. from the "Beach near Beal Castle" in Smith's Kerry 7756 , but the plant has not recently been observed in Kerry and is probably extinct in that county, as in county Dublin.

Rapidly decreasing in Ireland with many other of our maritime species, perhaps through changes in the form or level of the shore line.

First found by Sherard, in Wicklow, about 1691.

\section{MYOSOTIS Linn.}

\section{M. cæspitosa F. Schultz.-Tufted Scorpion-grass.}

Districts I. II. III. IV. V. VI. VII. VIII. IX. X. XI. XII. Lat. $51 \frac{1}{2}^{\circ}-55 \frac{1}{4}^{\circ}$. Throughout Ireland. .Type, British.

Watery and boggy places; common. $F$. June-August.

Sea-level in Derry and S. Cork. To $1800 \mathrm{ft}$. in Derry (Hart). 


\section{M. palustris With.-Forget-me-not.}

Districts I. II. III. IV. V. VI. VII. VIII. IX. X. XI. XII. Lat. $51^{1}-551^{\circ}$. Throughout Ireland. Type, British-English.

Lowland. Wet places, usually in muddy soil ; frequent. Fl. June-August.

Not a common species though widely distributed.

Var. strigulosa Reichb. - XII. Cushendun, Co. Antrim: Shoolbred I894.--Perhaps frequent throughont Ireland.

\section{M. repens G. Don-Creeping Scorpion-grass.}

Districts I. II. - IV. V. VI. - VIII. IX. X. XI. XII. Lat. $51 \frac{1}{2}-551^{\circ}$. Throughout Ireland, probably. Type, BritishScottish.

Wet boggy places, especially in mountain districts; frequent. Fl. June--August.

Descends to $150 \mathrm{ft}$. in N. Antrim and to sea-level in Kerry. To $850 \mathrm{ft}$. in Donegal (Hart); to $1000 \mathrm{ft}$. in Down (S.\&P.); to $1370 \mathrm{ft}$. in Mayo (Hart); to $1500 \mathrm{ft}$. in Dublin (N.C.).

\section{M. arvensis Lamk.-Field Scorpion-grass.}

M. intermedia Link.

Districts I. II. III. IV. V. VI. VII. VIII. IX. X. XI. XII. Lat. $51 \frac{1}{2}^{\circ}-55 \frac{1}{4}^{\circ}$. Throughout Ireland. Type, British.

Cultivated ground, banks, copses, \&c.; common. Fl. MayAugust.

Sea-level in Derry and in S. Cork. To $1100 \mathrm{ft}$. in Dublin (N. C.).

Var. onbrosa Bab.-V. In Lucan demesne, Co. Dublin, 1895; N. C.-XI. In sandy ground west of the bridge at Horn Head, Donegal (C. Moore) : $C y b$.-XII. Plentiful at the base of the cliffs between Carrickfergus and Cave Hill; at Glenarm and Sallagh Braes, Antrim (Moore) : C Cyb.-Erroneously recorded in Flor. Hib. and Flor. Ulst. as M. sylvatica, which is not found in Ireland.

\section{II. collina Hoffm.-Early Scorpion-grass.}

Districts - - - IV. V. - - - - - XII. Lat. $52^{\circ}-554^{\circ}$. East Ireland. Type, British.

Sand-hills and dry banks near the sea; rare. $F l$. April-May. 
IV. Abundant on the Murrough of Wicklow (Moore): Cyb. Sand-hills north of Courtown, Wexford, to Arklow Head: Hart I $883 \beta$. Saltee Islands, Wexford; Barrington. Sand-hills at Rosslare, Wexford: B.-H.\&M. I892.-V. In a sandy field at Portmarnock, Dublin (F. Whitla \& J. Johnston): Flor. Hib. Plentiful on sand-hills at Portmarnock and at Malahide (Moore): Cyb.' At Kilbarrack and Ireland's Eye: Flor. Howth. Very abundant all round Lambay Island: Hart 1883 . Between Laytown and the mouth of the Boyne, Co. Meath; Barrington.XII. Sand-hills between Portrush and Dunluce Castle, Antrim, 1836 (Moore) : Flor. Hib. At Portstewart (Miss Davis) : B. N. F.C. Proc. I889-go. Sandy warrens near Bushmills (Moore): Cyb. Locally plentiful on sand-hills at Newcastle, Down.(C. Dickson): Flor. N. E. At Kirkiston, Down (Rev. C. H. Waddell) : S.\&.P. 1895. Gravelly banks at the mouth of the Sixmile river [Lough Neagh]; Praeger: B.N.F. C. Proc. 1892-93-the only distinctly inland station on record for the species.

\section{M. versicolor Reichb.-Parti-coloured Scorpion-grass.}

Districts I. II. III. IV. V. VI. VII. VIII. IX. X. XI. XII. Lat. $51 \frac{1}{2}^{\circ}-55 \frac{1}{4}^{\circ}$. Throughout Ireland. Type, British.

Pastures, banks, waste places, and cultivated ground in light soils ; frequent. Fl. May-July.

Sea-level in N. Antrim and S. Cork. To $1600 \mathrm{ft}$. in Dublin (N. C.).

\section{LITHOSPERMUM Linn.}

\section{L. officinale Linn.-Common Gromwell.}

Districts I. II. III. IV. V. VI. VII. VIII. IX. X. XI. XII. Lat. $52^{\circ}-55 \frac{1}{4}^{\circ}$. Throughout Ireland. Type, British-English.

Lowland. Hedge-banks, waysides, and gravelly waste places; rather rare. Fl. June-August. Calcicole $B$.

I. Roadside west of Macroom: Allin's Cork. Plentiful by roadsides near Gearagh and Toon Bridge, near Macroom, 1897; W. H. Shaw.-II. Field near Dunscombe's Wood (J. Sullivan): Annot. in Flor. Cork. Roxborough near Midleton: Flor. Cork. Near the Owbeg, Castletownroche (Carroll); at Ballyannan, and sparingly at Bridgetown Abbey: Allin's Cork. At Killatty and Glanworth near Fermoy, but rare ( $T$. Chandlee): Cyb. Roadside 
near Lismore, Waterford, 1882; Miss F. W. Currey. 'About Blenheïm, Waterford (Miss L. Glascott) : B.-H.\& G. I889.III. In county Kilkenny, near Sion (Rev. S. Madden); and at Kilmacow (T. Chandlee); at Mountrath, Queen's Co. (J. Carroll): Cyb. Near Maryborough (Praeger): Ir. Nat. I893.-IV. and V. Not infrequent in Wexford, Wicklow, and Dublin.-VI. Near Castle Taylor, Galway (More) : Cyb. Great Aran Island (Hart): Rec. Add. Roadside near Ballyvaughan: Foot 1864.-VII. Edmonton, Westmeath (Miss E. Reynell): Cyb.-VIII. On limestone rocks at Bunowen, Connemara (Carroll) : Cyb.-IX. Between Collooney and Markree, Sligo; $W$. F. de $V$. Kane.-X. Near Loughgall, Armagh: More I860. Ruins of Killeavy Church, Armagh (Rev. H. W. Lett): Praeger 1893. Near Raconnell, Monaghan (Miss Maffett) : Cyb.-XI. Rathmullen and Downing's Bay.(Hart); Ballyhooriskey (Rev. T. Allin): Rec. Add.-XII. By the Foyle above Derry, and by the Bann near Coleraine: Moore MS. In Antrim, at Knockagh (Stewart); and rocky slopes south of Whiterock (C. Dickson); rare in the North-East : Flor, N.-E.

Nowhere an abundant species in Ireland and, though widely distributed, absent over large areas.

\section{L. arvense Linn.-Field Gromwell.}

Districts I. II. III. IV. V. VI. VII. - IX. X. XI. XII. Lat. $51 \frac{1}{2}^{\circ}-54 \frac{3}{4}^{\circ}$. Throughout Ireland, almost. Type, British.

Lowland. Cultivated fields and waste places; rare. Fl. MayJuly.

I. Near Monkstown, Cork: Drummond 1818. At Shepperton (Rev. T. Allin); near Rosscarbery (Miss Hungerford): Allin's Cork.-II. At Fermoy: Herb. T. Chandlee. By the Blackwater, near Villierstown and Killawillin: Hart I885 $\delta$.-III. Between Carlow and Maganey: Hart I885.-IV. Potato fields near Aughnaclappa, Wexford: Moffat I889.-V. Between Drogheda and the Boyne mouth; Barrington. Whitehall, Co. Dublin; Miss A. G. Kinahan-VI. Cornfields at Castle Taylor, Galway (More): Cyb. -VII. Near Lough Slawen, and Clawinch and Black islands, Lough Ree : $B . \& V$. I887.-IX. By the Suck in Roscommon near Ballinasloe: Praeger I896.-X. Tartaraghan, Armagh: More I860.XI. Railway banks between Ballyshannon and Bundoran; by the shore at Wardtown near Ballyshannon: Hart 1886.-XII. At Whitehouse, Antrim (W. Millen) : Hind. 1854. Carrickfergus and 
Hollywood: Flor. Olst. In County Down, between Bangor and Groomsport (Stewart); and at Giant's Ring (C. Dickson); very rare in the North-East: Flor. $N .-E$.

\section{ECHIUM Linn.}

\section{E. vulgare Linn.-Viper's Bugloss.}

Districts I. II. - IV. V. VI. - - - - XII. Lat. $51 \frac{1}{2}^{\circ}-54 \frac{3}{4}^{\circ}$. From South to North. Type, British-English.

Lowland. Sandy fields and waste gravelly places, chiefly near the sea; rare. Fl. June-July.

I. Near Glandore (Rev. T. Allin); near Kinsale junction (Carroll); near Desert (C. Longfield): Allin's Cork. Cape Clear island, 1896 ; and-II. Midleton, 1895 ; Little island; Queenstown junction; Phillips. Near Rahill, Tipperary (Miss S. Grubb): Cyb. On the Waterford coast near Youghal: Hart $788_{3} \beta$.-IV. Frequent in County Wexford: B.-H.\&M. $1892 a$. Common about Wicklow; R. P. Vowell.-V. Frequent along the coast of County Dublin from Portmarnock to Skerries, and abundant at Rogerstown, 1895 ; N. C. Shore at Gormanstown and Laytown, Meath (More) : Rec. Add.-VI. On the railway near Foynes, Limerick (R. D. O'Brien) : Ir. Nat. 1897,p.52.-XII. South-west of Strangford, also south of Rathmullen Point and occasionally to Dundrum, Down; at the Curran of Larne, Antrim (Stewart): Flor. $\boldsymbol{N}$. $\boldsymbol{E}$. Abundant in a field near Wood House, Rosstrevor : S.\&. P. 2892.

Also recorded for Districts III. and XI., but here, as in numerous inland stations where the plant has been observed, it appears to have been only a casual.

\section{ORDER XLV்.-CONVOLVULACE正.}

CALYSTEGIA R. Br.

\section{C. sepium R.Br.-Great Bindroeed.}

Convolvulus sepium Linn.

Districts I. II. III. IV. V. VI. VII. VIII. IX. X, XI. XII. Lat. 51 $\frac{1}{2}^{\circ}-55 \frac{1}{4}^{\circ}$. Throughout Ireland. Type, English-British.

Lowland. Hedge banks, and bushy or rocky places; frequent. Fl. July-August. 


\section{C. Soldanella R.Br.-Sea Bindrveed.}

\section{Convolvulus Soldanella Linn.}

Districts I. II - IV. V. VI. - - - - XI. XII. Lat. 51 $\frac{1}{2}^{\circ}-55 x^{\circ}$. Coasts from South to North. Type, English.

Sandy sea-shores; locally abundant. Fl. June-July.

I. Near Castlegregory, Kerry : Hart I884. Abundant on sandhills north side of Tralee Bay: Stewart I890. On Darrynane; Waterville; and Banna sandhills, \&c., Kerry; R.W.S. Abundant on a strand about two miles east of Lough Hyne, 1889: Phillips 1895. Barley Cove near Mizen Head; and-II. Plentiful on the strand near Youghal, 1891; Phillips.-IV. Shore below Kilinearrick, Co. Wicklow, in abundance: Ir. Flor. Abundant at Courtown; Rosslare; Carnsore, and all along the Wexford coast: Hart 1883 B.-V. Sandy shores of Killiney Bay, Dublin: Wade Dubl. I794-and in 1872; Greenwood Pim. Sparingly on the North Bull, 1895 ; very rare in Co. Dublin; N. C.-VI. Sandhills at Murrough, Co. Clare; W. H. S. Westropp.-XI. Shore at Glencolumbkille: Flor. Ulst. Tramore, near Horn Head; very rare in Donegal: Hart I880.-XII. Sand-hills on the shore at Newcastle, Down, 1795 ; sands beside the salmon weir at Bushfoot, Antrim: Templeton MSS. Cushendun (Mr. Whitla); Ballycastle (Miss Hincks): Flor. Ulst. Benderg Bay near Ardglass (Corry); sparingly on Ballykinler sands (Stewart); still at Bushfoot: Flor. N.-E.

Apparently a decreasing species in Ireland.

\section{CONVOLVULUS Linn.}

\section{C. arvensis Linn._Small Bindroeed.}

Districts I. II. III. IV. V. VI. VII. VIII. IX. X. XI. XII.

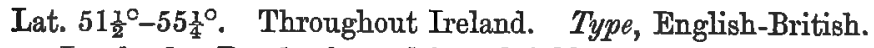

Lowland. Dry banks, cultivated fields, roadsides, and gravelly places ; frequent. $F l$. June-August. Calcicole $C$.

I. Near Spa, Tralee; and at Castlegregory, Kerry : R.W. S. 1889. Goleen and Crookhaven, South Cork; Phillips.-II. Common near Cork (Carroll): Cyb. Clonea near Dungarvan, Waterford: Hart 1883 B. - III. Several places in Kilkenny (Rov. S. Madden): Cyb. Browne's Hill, Carlow; $R$. Clayton Browne.IV. and V. Frequent, especially by the coast, in Wexford, Wicklow, 
and Dublin.-VI. Plentiful near Limerick (Moore): Rec. Add. Near Killeany, Aranmore: Hart 5875 . Frequent near Portumna, Galway, $1896 ; N . C$. -VII. In Westmeath and Longford $(F . J$. Foot): $C y b$. - VIII. Roadside near Knockbane; field near Cong; and-IX. Near Lisloughrey, Mayo; Miss M. F. Jackson. Near Dromore west, and at Castlerock, west of Tubbercurry, Sligo, 1896; N. C.-X. At Enniskillen; Stewart. By the railway at Newtown Butler, Fermanagh, 1896 ; N. C.-XI. Leenane, Lough Swilly; between Ballyshannon and Bundoran, and in numerous other stations; very local in Donegal: Hart 1880 \& c.-XII. In many stations in Antrim, Down, and Derry; but not common : Flor. N.-E.

Abundant by the sea in many places; usually rare, and apparently introduced, inland.

\section{CUSCUTA Linn.}

1. † C. Epithymum Murr.-Thyme Dodder.

Districts I. II. - IV. V. VI. ---- XI. Lat. $52^{\circ}-55 \frac{1}{4}^{\circ}$. Southern half of Ireland, chiefly. Type, English.

In sandy ground near the sea; rare and doubtfully native. Fl. July-September.

I. Banna sand-hills, Kerry, $1887:$ R.W. S. 1888 (as C. Trifotii). - II. In considerable abundance at the west end of the sandhills on the Rabbit Burrow near Tramore, Waterford, 1886-92 (J. E. Grubb) : Journ. of Bot. 1892, p. 14. At the Cliff-road near Tramore, 1892, and on the Cunnigar, Dungarvan, Waterford, 1893 ; J. $E$. Grubb.-XI. Several patches in natural ground near Rossapenna hotel, Donegal (Hart) : Journ. of Bot. I896, p. 399 .

To this species should perhaps be referred the record in Threlkeld's Synopsis under Cuscuta major: "This Herb groweth in great Plenty on the dry sandy Banks near Mayden tower near Drogheda and grows like red Threads on the Tops of the low Grass." No Cuscuta, however, has since been discovered in Threlkeld's locality though sought for by many botanists.

Var. TrIfouri (Bab.)-II. Near Midleton, occasionally : Allin's Cork.-IV. Quite established in clover fields at Fassaroe near Bray (Barrington) : Rec. Add. At Ballyarthur, Co. Wicklow, 1889; R. Bayly. At Aughnaclappa, Wexford: Moffat r889. Abundant in a field near Alderton, Wexford: B.-H.\& G. 1890 . In fair quantity at Ballycarrigeen near Ferns, Wexford, 1893-96; G.E.J. 
Greene.-V. Occupying a few square yards in a field near Ballybrack, Co. Dublin, 1868 (W. G. Smyth); near Kilkea, Kildare (J. Douglas): Rec. Add. On vetches near Sutton, Co. Dublin, 1881 ; Hart. Near Ballyboghill, and abundant in sandy fields at Portrane, Co. Dublin : N. C. 1895 . Sand-hills at Baltray at the Boyne mouth, and sandy ground near Lurgan Green, Louth: Praeger 1897.-VI. Profusely in two sandy fields near Killeany. and Kilmurvy, Aranmore Island: Nowers \& Wells 1892 (as $C$. Epithymum).

Appears to have spread considerably in East Ireland since its first discovery at Ballybrack in 1868.

\section{ORDER XLVI.-SOLANACEE.}

\section{SOLANUM Linn.}

\section{S. Dulcamara Linn.-Bitter-sweet.}

Districts I. II. III. IV. V. VI. VII. VIII. IX. X. XI. XII. Lat. 52 $-55 \frac{10}{4}$. Throughout Ireland. Type, British-English.

Lowland. Wet hedge-rows and shingly shores; rather rare. Fl. June-August.

I. Sparingly about Killarney, perhaps introduced; R.W.S.II. At Bishop's Brook, Cork (Mr. Alexander) : Flor. Cork-still there in 1895, and at Blarney, 1894; Phillips. Near Midleton; rare in Co. Cork: Allin's Cork.-III. Fertagh churchyard, Killkenny "(Rev. S. Madden): Cyb. At Ferrybank, Killenny: M. \& S. I806.-IV. Plentiful in wet hedges near the Murrough of Wicklow (Moore) : Cyb. St. John's near Enniscorthy, Wexford (Miss E. M. Farmer) : Rec. Add.-V. Rather common throughout Co. Dublin and locally abundant; N.C. Straffan, Kildare (J. Douglas): Cyb.-VI. Abundant on the shores of the lakes near Corofin, Clare: Foot 1864. North and Middle Aran Isles: Hart 1875. At Quinn Abbey, Co. Clare: Corry 1880. Near Menlo Castle and Galway: Herb. John Reilly.-VII. Recorded for this District in 1st Ed. Cyb. but no locality available.-VIII. Islets in Lough Mask, Mayo (Prof. Melville): Cyb.-IX. In a wood near Ballinrobe: Browne Fasciculus. In Leitrim, rare (J. Wynne); in East Mayo (More): Cyb. Between Clonbur and Cong: M. \& $S$. I896.-X. Sparingly at Gubbaroe, Lough Erne : Barrington I884. 
Shores of Lurgan lake, and in Armagh Palace demesne: Praegor 1893. In Tyrone, by the canal at Strabane, and by the river Strule at Omagh (Miss M. C. Knowles): Ir. Nat. 1897.XI. Thickets by the Erne opposite Cliff; hedges on the Ballyshannon road near Donegal; river below Laghy: Hart $1886 .-$ XII. In many stations in Down, Antrim, and Derry; but not common: Flor. N.-E.\&S.\& P. I895.

Var. Marinum $B a b$.-I. Waterville; Rossbehy; Fenit; Barrow ; Magharee Islands, \&c.; frequent on the Kerry coast: R.W.S. r888 \& r889.-VI. In Great Aran island (Prof. Oliver): Cyb. Shore at Kilrush, Clare: Stewart I89o.-VIII. At Rynville, Connemara: Flor. Hib.

The typical plant has all the appearance of a native in the East; in the North, South, and West it is more or less obviously introduced in most of its stations, and is often cultivated in cottage gardens.

\section{2. † S. nigrum Iinn.-Black Night-shade.}

Districts I. II. - IV. V. - VII. - - - XII. Lat. $52^{\circ}-55^{\circ}$. South and East. Type, English.

Lowland. Cultivated ground and waste places; very rare and uncertain in its appearances. $F l$. July-September.

I. Sparingly in two stations on Kenmare river, Kerry : R.W.S. 1890.-II. At East Ferry (Dr. Scott); by the middle Glanmire road (Mr. Alexander) : Flor. Cork. By the shore at Rossmore, and on one of the Brown islands, perhaps native in the latter station: Allin's Cork. Near Cappoquin, Waterford; Q. Quinlan.-IV. Shore near Churchtown, Wexford, 1834, and again in 1869; also on sands at Rostonstown (John Waddy): Rec. Add. Rosslare and Bar of the Lough near Bannow, Wexford: Hart $1883 \beta$. Near Wicklow, 1873 ; Hon. Miss Ruthen. Oroca, Wicklow, 1882 ; Miss A. $G$. Kinahan.-V. A very abundant garden weed at Easton Lodge, Monkstown, Co. Dublin, 1873-74; Greenwood Pim.-VII. Edenderry, King's Co., 1854 (T. Chandlee): Cyb. Seen several times in garden ground at Knock Drin, Westmeath : Levinge 1894.XII. In the Copeland islands and on the mainland opposite (Mr. Campbell) : Flor. Hib. Sandy ground near Cushendun, from 1867 to 1871 (Rev. S. A. Brenan): Rec. Add. Not found recently and perhaps only a casual in north-east Ireland: Flor. N.-E.

Apparently not well established anywhere in Ireland save on the Wexford coast. 


\section{HYOSCYAMUS Linn.}

\section{H. niger Linn.-Henbane.}

Districts I. II. III. IV. V. VI. VII. VIII. IX. X. XI. XII.

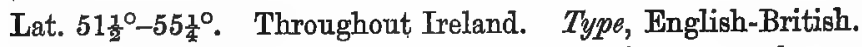

Lowland. Sand-hills on the coast, and in waste places near buildings; rare and uncertain in its appearances. Fl. June-August.

I. Kilshannig ruins, near Castlegregory, Kerry: Hart 1884. Abundant on the Magharee islands and about Fenit, Kerry : R.W. S. ${ }_{I} 888 \& I 889$. Once abundant near the old castle at Carrigrohane, the old abbey of Timoleague, and other places; but now almost

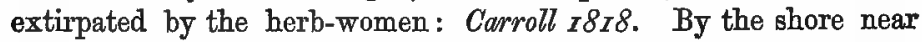
Kilbrittain ( $R . L$. Allman); near Courtmacsherry Bay and on Whiddy Island (Carroll): Allin's Cork. Near Skibbereen; J. J. Wolfe. At Clonalkilty, 1896 ; Mrs. Wolfe. Waste ground near the Marina, Cork, 1892; Phitlips.-II. About Mitchelstown, Cork in great plenty: $K^{\prime}$ Eogh 1735 . On the Brick island, Rossmore; and by the shore at Ring, Youghal: Flor. Cork. Shore opposite. Cable Island: Allin's Cork. Brown island, Rossmore, 1896; Phillips. Dungarvan, Waterford; and near Clonmel (Miss S. Grubb); Holy Cross, Tipperary; and-III. River View and Kilmanagh, Kilkenny (Rev. S. Madden): Cyb. Browne's Hill, Carlow ( $\boldsymbol{R}$. Clayton Browne); Maryborough, Queen's Co. (J. Morrison): Rec. Add.-IV. On the Murrough a little north of Wicklow (More); Bannow, Wexford (Miss Nunn): Rec. Add. Bar of the Lough; Bannow; Rosslare; and Sandeel Bay, Wexford: Hart ${ }_{2} 883 \beta-$ V. Near Sandymount; Clontarf; Howth, \&c. : Wade Dubl. Ireland's Eye, 1872; Greenwood Pim-still abundant there : Hart r897. Lambay island: Hart $1883 \gamma$-abundant there in 1896 : Ir. Nat. 1896. A garden weed at Fairview, Clontarf, 1890-92; Miss A. G. Kinahan. Straffan, Kildare (J. Douglas): Cyb. Sea-shore near Castlebellingham, Louth; Cecil Butler.-VI. Lough Gur, Limerick: Ir. Nat. 1894 . Banks of Kilrush river, Clare; $\boldsymbol{P} . \boldsymbol{B}$. O'Kelly.-VII. Near Rahan, King's County (Rev. J. W. Despard); near Parsonstown (J. White): Cyb.-VIII. Roadside in Connemara (S. Foot); and-IX. The Point, Sligo (Rev. S. Madden): Cyb.X. Near Armagh cathedral (Mr. Thompson): Flor. Olst. Abundant at the ruins of Arboe old church, Tyrone: Flor. N.-E.XI. One plant at Greencastle (W. E. Hart): Hart 1883.- 
XII. Roadside near Ballycastle, Antrim, 1821 (G.C. Hyndman): Flor. N.-E.-still about Ballycastle: S.\&P. I895. At Benone, Magilligan, and side of Lough Neagh above Ballyronan : Moore MS. Millquarter Bay; Killard Point, \&c.; rare in the North-East: Flor, N.-E.

\section{ORDER XLVII.-SCROPHULARINEבE.}

\section{VERBASCUM Linn.}

\section{1. $\ddagger$ V. Thapsus Linn.-Mullein.}

Districts I. II. III. IV. V. VI. VII. - IX. X. XI. XII. Lat. $51 \frac{1}{2}^{\circ}-551^{\circ}$. Throughout Ireland, probably. Type, EnglishBritish.

Lowland. Waste places, old quarries, dry banks, \&c. ; frequent. Fl. June-July. Calcicole $\boldsymbol{B}$.

Widespread but seldom occurring in abundance or in thoroughly wild stations. Much cultivated in cottage gardens and nowhere undoubtedly native in Ireland.

\section{LINARIA Linn.}

1. * L. Cymbalaria Mill.-Ivy-leaved Toad-flax.

Districts I. II. - - V. - VII. - IX. X. XI. XII. old walls; frequent and well established in many stations. Fl. April-October.

I. Abundant about Cahirciveen, Kerry, 1896 ; frequent in Kerry; $R$.W. S. Among grass on the river bank between Bandon and Inishannon, remote from any building; and-II. Common about Cork, 1896 ; Phillips.-V. Old walls about Dindalk: Ir. Flor. Sea wall at Kilbarrack, 1893 ; by railway drains between Booterstowi and Blackrock, 1894; abundant at Lucan and Leixlip, 1895 , and in many other stations in Co. Dublin ; frequent and well established in the county; $N$. C.-VII. Naturalized on Carberry Island, Lough Ree: B.\&V. $1887 .-$ IX. Rocks on Goat Island, Lough Gill; and on houses about Sligo: B.\&.V. 1885.-X. Frequent in Armagh: Praeger 1893.-XI. Rathmullan Abbey and Killydonnelly Abbey: Hart I880.-XII. Common throughout the 
district, an important and ineradicable member of the flora of northeast Ireland: Flor. N.-E.

Introduced in all cases, yet fully naturalized in Ireland, and probably frequent in all the districts.

\section{2. + L. Elatine Mill.-Fluellin.}

Districts I. II. - IV. - VI. - - - - - Lat. $51 \frac{1}{2}^{\circ}-53^{\circ}$. Southern half of Ireland. Type, English.

Lowland. Cultivated ground, usually in sandy soil; rare. Fl. July-September.

I. By the side of the Bandon road, Cork: Drummond 2819 . Near Ballinhassig; Carrigaline (Mr. Alexander); about Monkstown (Dr. Power); Carbery (R. W. Townsend): Flor. Cork. Rather common about Glandore; Ballinadee; Clonakilty, \&c.: Allin's Cork. Lough Hyne, 1892; R. P. Vowell. Schull and Ballyalla near Skibbereen; Crosshaven, 1894; plentiful on Cape Clear island, 1896; Creagh near Skibbereen, 1897; Phillips.II. Near Cove (Dr. Scott) : Flor. Cork. Whitegate; Power Head, 1895 ; Phillips.-IV. Between Bannow and Ballymadder, Wexford (Barrington): Rec. Add. On the shore, Greater Saltee island, Wexford: Hart $2883 \beta$. Abundant in cornfields about Alderton, Wexford (Miss L. Glascott): B.-H. \& G. 1889. Sparingly at Ballycarney, Ferns, Co. Wexford, 1889-91; G. E. J. Greene.VI. Cornfields near Rathkeale, Limerick (Henry Hardy): Mack. Cat. Cultivated fields at Castle Taylor: More 1855. Roadside near Ballyvaughan, Clare (Rev. T. Allin): Ree. Add. Near Ballyvaughan, 1895, in sandy fields at Muckinish ( $P . B$. O' $\left.O_{e} l l y\right)$, and at Newtown Cashel (N.C.).

\section{I. repens Mill.-Creeping Toad-flax.}

L. striata DC.

Districts I. - - - - - - X. XI. XII. Lat. $51 \frac{3}{4}^{\circ}-55^{\circ}$. South and North Type, English.

Lowland. Banks, roadsides, and waste places ; rare. Fil. JulySeptember.

I. On the refuse of an old slate quarry a mile below Bandon, and by the old castle near it, two miles farther down the river, 1805: Mack, Rar. Roadside half way between Bandon and Dunmanway: Drummond I8rg. Inishannon, Cork (J. Wright): Cyb. Frequent near Bandon, extending to beyond Ballineen, also 
to Ballinadee and by the Bandon river, chiefly on the right bank: Allin's Cork. Plentiful along the river bank and the railway between Bandon and Inishannon, 1891; roadside at Desert, 1889; Phillips.-X. Sparingly on and beside the Greenore railway near the canal locks below Newry: Praeger 1893.-XI. Roadside and banks between Glenalla and Rathmelton, also on a rocky hillock west of the road and spreading to adjoining fields : Hart I879.-XII. In a waste field on the ascent of Spelga mountain, above Killowen, Rosstrevor, 1886 (Stewart); stony ditch bank about a mile south of Rosstrevor, 1887 (T. Chandlee): Flor. N.-E. Abundant in fields, on banks, by roadsides, and by the seashore about Killowen and thence to Seafield, Down: S.\& P. 1892 .

Also recorded for III. and V., but probably only a casual or intentionally introduced in these Districts.

First found by Mackay, near Bandon, in 1805.

$L$. sepium Allman-L. repens $\times$ vulgaris-I. By the river Bandon (Dr. G.J. Allman) : F'lor. Cork-plentiful here in 1891; Phillips.

\section{4. † L. vulgaris Mill.-Yellow Toad-flax.}

Districts I. II. III. IV. V. VI. VII. VIII. - X. XI. XII. Lat. $51 \frac{1}{2}^{\circ}-55 x^{\circ}$. Throughout Ireland, almost. Type, BritishEnglish.

Lowland. Waste places, old quarries, road-sides, \&c.; rather rare. Fl. July-September.

I. Sparingly along the east shore of Lower Lake, Killarney, 1892 ; R.W. S. Near Glandore, rare in South Cork; and-II. In the neighbourhood of Cork, Bandon, \&c., not rare: Allin's Cork. By the Youghal road south of Lismore, Waterford, $1896 ; F$. $E$. Currey.-III. Near the Dinan bridge, Kilkenny (Rev. S. Madden): Cyb. Garryhill, Carlow ( $R$. Clayton Browne) : Rec. Add. Between Borris, Carlow, and the foot of Blackstairs : Hart I884.-IV. Murrough of Wicklow (Moore) : Cyb. In fields and on ditches about Rathnew, Wicklow: Praeger 1897. Ballyhyland; Cairn, \&c., Wexford: Mroffat 1889 . Frequent in North Wexford : B.-H.\& $\boldsymbol{M}$. I892 a.-V. Sandy ground near Lissen Hall opposite Malahide: Wade Dubl. Sandy fields between Baldoyle and Howth : Ir. Flor. Knockmaroon Hill (Moore): Cyb. Sparingly, at Knockmaroon, 1893 ; by the sea wall near Kilbarrack, 1893, very rare in county Dublin; N. C.-VI. By the railway at Adare, Limerick : Stewart 
1.800.-VII. Fields near Lough Sheelin, Westmeath (Miss $\boldsymbol{E}$. Reynell) : Cyb.-VIII. To the west of the town of Galway (Prof. Melville) : Cyb.-X. Frequent in Armagh: Praeger $1893 .-$ XI. Tory Island : Barrington 1879. Well established about Leck Beg, Burton Port: Hart I880.-XII. Road-sides at Magilligan and Faughan vale, Derry: Moore MS. Warrenpoint; Downpatrick ; Ballycastle; Broughshane, and in numerous other stations in Down and Antrim: Flor. N.-E.\& S.\& P. 2895 .

Rare in the Centre and West. Often occurring as a garden escape and nowhere certainly native.

\section{L. minor Desf.-Lesser Toad-flax.}

L. viscida Mœnch.

Districts I. II. III. IV. V. VI. VII. - IX. - - Lat. $52^{\circ}-53 \frac{1}{2}^{\circ}$. Southern half of Ireland. Type, English.

Lowland. Along railways and in waste and cultivated grounds; rather frequent. Fl. June-August.

I. At intervals along the railway from where it enters Kerry to Castleisland: R.W.S. 1880-spreading along the Kerry railway tracks, $1896 ; R . W . S .-I I$. Sparingly by the new road near Sunday's Well, Cork (Dr. Woods): Drummond I8Iq. A weed in gardens at Summer Hill and Sunday's Well : Carroll 1854. Abun.dant along the railway from Cork to Queenstown and Youghal, and in a gravel pit at Midleton, 1895 ; Phillips. Lismore, Waterford, $1870 ; F . E$. Currey.-III. Waste ground near Carlow (J. Morrison) : Carroll 1854. Railway banks near Borris, Carlow; Hart. Potato fields at Emo, Queen's Co.: Praeger 7897.IV. Railway banks, Rathdrum and Wicklow; Hart.-V. Stillorgan, Dublin (S. Foot) : Cyb. Near Sydney Parade railway-station, Dublin ( $V . A$. Smith) : Rec. Add. Occasionally as a garden weed about Howth: Flor. Howth. Frequent along the railway lines from Dublin, west to Lucan and south to Bray, 1895; not yet observed on the Northern line; $N$. $C$. Straffan, Kildare ( $J$. Douglas) : Rec. Add. At Greenore, Louth: Ir. Nat. 2893, p. 227. Cultivated land near Carbury, Meath: Praeger 1897.-VI. In County Galway, along the railway at Athenry, 1895, and at Tubber near the Clare border, 1896 ; also-VII. On the railway at Mullingar, at Street, and at Inny junction, Westmeath, $1896 ; N$. C.IX. Railway near Kiltoom, Roscommon : $B . \& F, I 887$.

Abundant and spreading rapidly South and West along the 
railways; much rarer in waste places, or as a weed of cultivation.

First found, near Cork, by Dr. Woods about 1819.

\section{ANTIRRHINUM Linn.}

1. $\ddagger$ A. Orontium Linn.-Lesser Snap-dragon.

Districts I. II. - - - - - - - - Lat. $51 \frac{1}{2}^{\circ}-52^{\circ}$. South Ireland. Type, English.

Lowland. Cultivated and waste ground in light soils; rare. Fl. July-August.

I. Fields near Monkstown, Cork : Drummond 1819 . Newtown, Roscarbery ( $R . W$. Townsend); near the Ovens (Dr. Hincks); about Carrigaline castle (Dr. Power): Flor. Cork. Glandore; Baltimore; Lough Hyne; Myros; not infrequent in potato fields in south Cork: Allin's Cork. Near Lough Hyne, 1889; Baltimore, 1896 ; Phillips.-II. In several fields near Tower village, Blarney (R. Mitls): Rec. Add. In several stations round Cork (Carroll): Allin's Cork. Great Island and near Iniscarra, 1892 ; near Coachford, 1897; Phillips.

Also recorded for V., VI., and XII., but in these districts the plant appears to have occurred only as a casual, and has not been recently observed.

A weed of cultivation fully established in county Cork only.

\section{SCROPHULARIA Linn.}

\section{S. aquatica Linn.-Water Figwort.}

Districts I. II. III. IV. V. VI. VII. VIII. IX. - XI. XII. Lat. $51 \frac{1}{2}^{\circ}-55 \frac{1}{4}^{\circ}$ - Throughout Ireland, almost. Type, English.

Lowland. River banks, wet ditches, and watery places; frequent. Fl. July-August.

I. Burnham bridge near Dingle, Kerry: Hart I884. Ballybunnion and Beal Castle, Kerry : Stewart 1890 . Near West Cove, and near north end of Caragh Lake; very rare in south Kerry; R.W.S. Glengariff, Cork: Hart $1885 \delta$. Goleen; rare in south Cork; Phillips.-II. Frequent in north Cork and south Tipperary.III. In Co. Killkenny, at Kilmacow (T. Chandlee): Rec. Add. At Snowhill, Kilkenny: B.-H. \& G. I89o.-IV. and V. Frequent, occurring in many stations in Wicklow, Wexford, Dublin, Louth, 
and Kildare.-VI. Abundant by the Fergus at Ennis, and several places between Kilrush and Carrigaholt, Clare; also at Foynes, Limerick: Stewart I890. On the rocky shores of Lough Derg at. Bonniveen Point, Galway; and-VII. At Drominagh, Tipperary : N.C. 1897. Rare in Westmeath: Levinge 1894.-VIII. Inishbofin, rare: More 1876 . Bundorragha, at the foot of Mweelrea, Mayo : Hart $7883 \alpha$. Gentian Hill and Oughterard, Galway: Ir. Nat. 1895 . Near Roundstone, $1897 ;$ N. C.-IX. Shores of Lough Allen, rare: Stewart 1885 . Near Drumcliff, Sligo : B.\&.T. $1885 .-$ XI. Frequent in Donegal : Hart 1883, \&c.-XII. Near Cidercourt below Crumlin, and by the Doagh water, Antrim; plentiful by Moygannon river, Warrenpoint, Down (Stewart); very rare in the North-East: Flor. N.-E. Sparingly by Castlewellan Lake, Down (Stewart); by the Bann at Coleraine (Mrs. Leebody): S. \&P. 1895 .

Widespread in Ireland, but rare over large areas, and generally far less abundant than S. nodosa.

Var. cINEREA Dum.-VII. At Donore, Lough Derevaragh, Westmeath: Linton $7896 .-V I I I$. Oughterard; and-IX. Cong: M.\&S. 1896 .

\section{S. umbrosa Dum.-Shade Figwort.}

S. Ehrhartii Stevens-S. alata Gilib.

Districts - - - - V. - - - - - - Lat. $53^{\circ} 20^{\prime}$. County Dublin only. Type, English-Intermediate.

Lowlanḍ. Shady river banks; very rare. Fl. August-Sept.

V. By the Liffey river in Lucan demesne, 1894, and lower down the river on both sides in considerable quantity between Knockmaroon and Woodlands, Co. Dublin, 1895 (N. C.): Ir. Nat. I896, p. 182 .

A rather critical species, perhaps overlooked in other parts of Ireland.

\section{S. nodosa Linn.-Knotted Figwort.}

Districts I. II. III. IV. V. VI. VII. VIII. IX. X. XI. XII. Lat. $51 \frac{1}{2}^{\circ}-55 x^{\circ}$. Throughout Ireland. Type, British.

Hedge banks, woods, ditches, and waste places; rather common. Fl. July-August.

Sea-level in N. Derry and S. Cork. To $900 \mathrm{ft}$. in Dublin $(N . C$.$) .$ 


\section{MIMULUS Linn.}

\section{1. * M. guttatus DC.-Yellow Monkoy-flowor.}

M. Langsdorfii Don.

Districts I. II. - IV. V. VI. - - IX. X. XI. XII. Lowland. Ditches, river sides, and wet places; frequent. $F$. June-September.

I. Abundant along the lake shore, Killarney, below Lake View house: R.W.S. I888. Swampy ground near Bandon, 1897; Phitlips. Well established by the river below Inishannon; and in a bog near Myrtleville, Cork (Carroll) : Cyb.-II. West bank of the Blackwater, between Cappoquin and Toorin, Waterford; Miss $\boldsymbol{M}$. Chearnley.-IV. In the Dargle river near Enniskenry (More) : Rec. Add.-abundant here in 1897;R.W: S.-V. Kelly's Glen, Dublin, planted (Prof. Harvey) : Cyb. Abundant in ditches at the head of Glenasmole [Kelly's Glen] and occasionally thence along the Dodder to Templeogue, $1895 ; N$. C.-VI. Abundant by the Fergus at Ennis, Clare: Stewart I890.-IX. Lough Melvin, Leitrim: $B . \& V . I 885 .-\mathrm{X}$. Shore at Dacharne island and at the mouth of the Ballycassidy river, Lough Erne: Praeger 1802 . Abundant along the Foyle from Dunnalong to Strabane, Tyrone (Miss $\mathbb{M}$. C. Knowles): Ir. Nat. I807.-XI. Near the salmon weir at Ballyshannon (More): $C y b$. Many years established near Tamney in Fanet; in great profusion on ditch banks in Glenveagh : Hart 1879. Near Letterkenny and in profusion at Carrick, Donegal Bay, $1884 ; N . C$. Malinmore; very abundant along the Foyle from Lifford to Carrigans: Hart 1885 \%.-XII. Banks of the Bann between the Cuts and Coleraine (Stewart): Reo. Add. Shane's Castle Park; Carrickfergus commons; by the stream at Glynn (Stewart); Flor. N.-E. Edge of Clandeboye Lake (Praeger); thoroughly naturalized in the North-East: S.\&P. 1895 .

An ornamental garden plant from Western North America; first noticed as an escape in Ireland about 30 years ago. Now fully established in the Irish flora, and especially abundant in the NorthWest. The Irish plant is probably in all cases Var. ARGuTus Greene.

Recorded as an established alien from many stations in Great Britain and the European continent under the erroneous name M. luteus Linn.-See Journ. of Bot. 1895, p. 4 . 


\section{LIMOSELLA Linn.}

\section{L. aquatica Linn.-Mudwort.}

Districts - - - - VI. - [VIII.] - - - Lat. $52^{\circ} 55^{\prime}-53^{\circ} 5^{\prime}$. Clare [and Galway ?] only. Type, GermanicEnglish.

Lowland. Muddy lake margins and moist muddy places; very rare. Fl. July-September.

VI. On the margin of Inchiquin lake near Corofin, Clare, 1893 (P. B. O'Relly) : Journ. of Bot. 7893, p. 309. Near Gort, Galway, in muddy turloughs at Newtown and near Tirnevan chapel; also at Loughmanna, four miles west of Gort, $1894 ; P . B$. O' Kelly. In muddy hollows of limestone rocks four miles from Lisdoonvarna, Clare, 1896 (Greenwood Pim) : Ir. Nat. 7896, p. 297.-[VIII. "Frequently occurring where the water has stood during the winter, county Galway, near Ballinahinch, Connemara": Wade Rar.]

Wade's early record (1804) for Connemara still awaits confirmation, so that the title of this plant to a place in the Irish flora may be considered as for the first time fully established by Mr. O'Kelly's interesting discovery.

\section{SIBTHORPIA Linn.}

\section{S. europæa Linn.-Creeping Sibthorpia.}

Districts I. $--12^{\prime}$. County Kerry only. Type, Atlantic.
Lat. $52^{\circ} 7^{\prime}-52^{\circ} 12^{\prime}$

Moist shady places; very rare and local. Fl. June-September.

I. At the foot of the road over Connor Hill on the [north] side next Tralee Bay, 1805: Mack. Rar. Plentiful from Castlegregory to the base of Brandon mountain (Moore): Cyb. Ditch bank by the roadside east of Anascaul, south side of Dingle promontory, $1888 ; R . W . S$. Sparingly by the Connor Hill road, on the south side towards Dingle; banks at sea-level near Fermoyle, west of Castlegregory, $1888 ; N . C$. On the hill south of Tralee ( $E$. Newman): Charlesworth's Mag. Nat. Hist. 1840. Curraheen, south of Tralee, and Kilelton east of Camp; R.W.S.

From sea-level at Fermoyle $(N . C$.$) to 1700 \mathrm{ft}$. on Connor Hill (Hart).

First found, at Connor Hill, by Mackay in 1805. One of Mackay's original specimens labelled: "Foot of Connor Hill, 
Dingle, Septr. 1805," is preserved in the Admiral Jones herbarium, Science and Art Museum, Dublin.

Confined to the Dingle peninsula, where it has a very restricted. range of some 20 miles from east to west, and 7 miles from north to south.

\section{DIGITALIS Linn.}

\section{D. purpurea Linn.-Fox-glove.}

Hibernicé Lup mop (Loos more), Great Plant-meıpını́ंe puca (Mair-een-yee phoo-ka), Fairy fingers-Meapacán beanz (Mair-a-cawn dharrig), Red Thimble.

Districts I. II. III. IV. V. VI. VII. VIII. IX. X. XI. XII. Lat. 51 $\frac{1}{2}^{\circ}-55 \frac{1^{\circ}}{4}$. Throughout Ireland. Type, British.

Heaths, woods, banks, \&c.; frequent. Fl. June-August. Calcifuge $\mathcal{A}$.

Sea-level in Derry and S. Cork. To $1560 \mathrm{ft}$. in Donegal (Hart); to $1700 \mathrm{ft}$. Ben Bulben district $(B . \& V$.); to $1900 \mathrm{ft}$. in Mayo and to $2250 \mathrm{ft}$. in Kerry (Hart).

\section{VERONICA Linn.}

\section{V. hederæfolia Linn.-Ivy-leaved speedwoll.}

Districts I. II. III. IV. V. VI. VII. VIII. IX. X. XI. XII. Lat. $51 \frac{1}{2}^{\circ}-55 \frac{1}{4}^{\circ}$. Throughout Ireland. Type, British.

Cultivated ground and waste places; common. Fl. MarchAugust.

Sea-level in Donegal and S. Cork. To $950 \mathrm{ft}$. in Dublin (N.C.).

\section{V. agrestis Linn.-Field Speedwell.}

Districts I. II. III. IV. V. VI. VII. VIII. IX. X. XI. XII. Lat. $51 \frac{1}{2}^{\circ}-55 \frac{1}{4}^{\circ}$. Throughout Ireland. Type, British.

Cultivated land, waste places, \&c.; frequent(?). Fl. AprilSeptember.

Though widespread in Ireland, this plant is apparently much rarer than $V$. polita. The two are, so often confounded, however, that it seems imprudent to make any positive general statement as to their relative frequency. 


\section{V. polita Fries.}

Districts I. II. III. IV. V. VI. VII. VIII. IX. X. XI. XII. Lat. $51 \frac{1}{2}^{\circ}-55 \frac{1}{4}^{\circ}$. Throughout Ireland. Type, British-English.

Cultivated ground, waste places, \&c. ; common (?). Fl. Apr.-Sept.

\section{3. *V. Tournefortii C. Gmel.-Persian Speedroell.}

\section{Buxbaumii Ten.-V. persica Poir.}

Districts I. II. III. IV. V. VI. VII. VIII. IX. X. XI. XII. Lat. $51 \frac{1}{2}^{\circ}-55 \frac{1}{4}^{\circ}$. Throughout Ireland. Type, English.

Cultivated land and waste places; common. Fl. March-September.

An introduced weed of cultivated ground which appears to have been first noticed in Ireland, near Cork, before 1845, and has since spread throughout the country.

Sea-level to $950 \mathrm{ft}$. in Dublin ( $N . C_{\text {. }}$ ).

\section{V. arvensis Linn.-Wall Speedwell.}

Districts I. II. III. IV. V. VI. VII. VIII. IX. X. XI. XII. Lat. $51 \frac{1}{2}^{\circ}-55 \frac{1}{4}^{\circ}$. Throughout Ireland. Type, British.

Fields, walls, waste places, \&c.; common. Fl. April-July.

Sea-level in Derry and S. Cork. To $1600 \mathrm{ft}$. in Dublin (N.C.).

\section{V. serpyllifolia Linn.-Thyme-leaved Speedwell.}

Districts I. II. III. IV. V. VI. VII. VIII. IX. X, XI. XII. Lat. $51 \frac{1}{2}^{\circ}-55 \frac{1}{4}^{\circ}$. Throughout Ireland. Type, British.

Moist pastures, heaths, waste places, \&c.; common. Fl. May-July.

Sea-level in N. Derry and S. Cork. To $1450 \mathrm{ft}$. in Derry (Hart); to $1600 \mathrm{ft}$. in Dublin ( $N . C$. ); to $1780 \mathrm{ft}$. in Kerry (Hart).

\section{V. officinalis Linn.-Common Speedroell.}

Districts I. II. III. IV. V. VI. VII. VIII. IX. X. XI. XII. Lat. 51 $\frac{1}{2}-55 \frac{1}{4}$. Throughout Ireland. Type, British.

Heaths, banks, and rocky places in light soils; rather common. Fl. June-August. Calcifuge $C$.

Sea-level in Derry and S. Cork. To $2050 \mathrm{ft}$. in Donegal (Hart); to $2400 \mathrm{ft}$. in Kerry (Druce I89T). 


\section{V. Chamædrys Linn.-Germander Speedwell.}

Districts I. II. III. IV. V. VI. VII. VIII. IX, X. XI, XII. Lat. $51 \frac{1}{2}^{\circ}-55 \frac{1}{4}^{\circ}$. Throughout Ireland. Type, British.

Woods, hedgerows, pastures, \&c.; common. Ill. May-July.

Sea-level in N. Antrim and S. Cork. To $1450 \mathrm{ft}$. in Derry and to $2550 \mathrm{ft}$. in Kerry (Hart).

\section{V. montana Linn,-Mountain Speedwell.}

Districts I. II. III. IV. V. VI. VII. VIII. IX. X. XI. XII. Lat. $51 \frac{1}{2}^{\circ}-55 \frac{1}{4}^{\circ}$. Throughout Ireland. Type, British-English.

Woods and shady places; rather rare. Fl. April-July.

I. Frequent in county Kerry; $R$.W. S. At Cahermore; Leap; Myros; and-II. Frequent in North Cork: Allin's Cork. Kilcommon, Caher, Tipperary ( W. H. Harvey): Herb. T. C. D.-III. At Kells Priory, Kilkenny, and Borris demesne, Carlow, 1897 ; Rev. T. Hartley.-IV. Powerscourt, Wicklow (Moore) : Cyb. Roadside at Mountgarret Hill, New Ross, Wexford: B.-H.\&M. I892.V. Locally abundant in Co. Dublin; N.C. Near Omeath, Louth : Hart 1884.-VI. Ballycar near Ennis, Clare: Stewart $1890 .-$ VII. Knock Drin and Donore, Westmeath: Levinge 1894. Hare Island, Lough Ree: B.\&V. r887.-VIII. About Ballinahinch, Connemara: Wade Rar. On the mountain behind the inn at Maam: Babington 1836 .-IX. In Co. Sligo (J. Wynne): Cyb.$X$. Frequent, occurring in Armagh, Tyrone, and Fermanagh.XI. Bulbein mountain; Brown Hall woods; below Cliff on the Erne river; very local in Donegal : Hart I880 \& I886.-XII. Frequent in Down, Antrim, and Derry: Flor. N.-E.\& S.\&P. 1895 .

Sea-level in N. Donegal and S. Cork. To $1000 \mathrm{ft}$. in Derry ( Hart).

No doubt often passed over as $V$. Chamadrys, and probably more frequent in Ireland than would appear from existing records.

\section{V. scutellata Linn._Marsh Speedwell.}

Districts I. II. III. IV. V. VI. VII. VIII. IX. X. XI. XII. Lat. $51 \frac{1}{2}^{\circ}-55 \frac{1}{4}{ }^{\circ}$. Throughout Ireland. Type, British.

Wet boggy places; frequent. Fl. June-August.

Sea-level in N. Derry and S. Cork. To $1350 \mathrm{ft}$. in Derry (Hart); to $1500 \mathrm{ft}$. in Dublin (N. C.). 


\section{V. Anagallis Linn.-Water Speedwell.}

Districts I. II. III. IV. V. VI. VII. VIII. IX. X. XI. XII. Lat. $51 \frac{3}{4}^{\circ}-55 \frac{1}{4}^{\circ}$. Throughout Ireland. Type, British.

Stagnant ditches and watery places, usually in clay soil ; frequent. Fl. June-August.

Sea-level in N. Antrim and in Kerry. To $900 \mathrm{ft}$. in Dublin (N.C.) ; but usually lowland.

\section{V. Beccabunga Iinn.-Brooklime.}

Districts I. II. III. IV. V. VI. VII. VIII. IX, X. XI. XII. Lat. $51 \frac{1}{2}^{\circ}-55 \frac{1}{4}^{\circ}$. Throughout Ireland. Type, British.

Ditches, streams, and watery places; common. Fl. JulyAngust.

Sea-level in Derry and S. Cork. To $950 \mathrm{ft}$. in Ben Bulben district $(B . \& V$.$) ; to 1200 \mathrm{ft}$. in Dublin $(N . C$.$) .$

12. *V. peregrina Linn.-Wandering Speedwell.

Districts - - - - VI. - - IX. X. XI. XII.

Cultivated ground, \&c.; rare. Fl. May-June.

VI. A garden weed at Chevy Chase, south-east of Gort, Galway: Hart 7873.-IX. In the garden and demesne at Hazelwood, Sligo (Moore): Rec. Add.-X. Abundantly in the demesne at Barnescourt [Baronscourt] near Strabane, Tyrone, 1836, and subsequently in several places between that and Londonderry : $C y b$. In gardens in county Tyrone, at Dungannon, 1895; at Donaghmore, 1895-96; at Favour Royal, 1896; Mrs. Leebody.-XI. Salthill, Mount Charles; Kilderry, Muff, 1870 (Hart); Gweedore (Rev. W. M. Hind): Rec. Add. Gardens at Kiliybegs and Lough Eske Castle: Hart $I 885 \gamma$. The commonest weed in many kitchen gardens in Donegal, as at Glenalla; Horn Head, \&c. ; first noticed by Hart in Donegal about 1870 : Hart I879. Londonderry : Flor. Ulst. 1864 . Abundant in gardens at Duncreggan and Culmore, near Londonderry, 1896; Mrs. Leebody.-XII. A garden weed at Belfast (Rev. W. M. Hind) : Phytol. $1857, p .47$. Has not spread in the NorthEast and is perhaps extinct about Belfast: Flor. N.-E. I888. Abundant on the sand-hills at Magilligan, near cultivated ground, 1897 ; Mrs. Leebody.

An American species which has spread over the greater part of 
Europe and has now become well established as a garden weed in north-west Ireland. Already recorded for four counties in Scotland, but only beginning to make its appearance in England.

\section{EUPHRASIA Linn.}

\section{E. officinalis Linn.-Eyebright.}

Districts I. II. III. IV. V. VI. VII. VIII. IX. X. XI. XII. Lat. $51 \frac{1}{2}^{\circ}-55 \frac{1}{4}^{\circ}$. Throughout Ireland. Type, British.

Heaths and pastures; common. Fl. June-August.

Sea-level in N. Antrim and S. Cork. To $2400 \mathrm{ft}$. in Donegal (Flor. Olst.); to $2930 \mathrm{ft}$. in Wicklow (Hart); to $2990 \mathrm{ft}$. in Kerry (More).

Var. aracilis Fries-V. Oldcastle, Meath: Praeger 1897.VII. Bog banks at the entrance of the Inny river into Lough Derevaragh, Westmeath: Levinge 1894.-VIII. Inishbofin: More 1876.-XII. Rocky banks of the Bloody Bridge river, Down: S.\&P. 1892 . Between Ballyearth and Ballintoy, Antrim: Shoolbred 1894 . Basalt debris on Knockagh (Stewart): S.\&.P. 1895 .

Of the many other segregates of this variable species, E. RostKOVIANA Hayne and E. BREVIPILA Burn. et Grem appear to be the most widesprea in Ireland. E. BOREALIS Towns. and E. NEMOROSA H. Mart. have also been observed.

\section{E. Salisburgensis Funk.}

Districts - - - - VI. - - IX. - - Lat. $53^{\circ}-53 \frac{1}{2}{ }^{\circ}$. West Ireland. Type, Hibernian.

Lowland. Dry rocky places on limestone; rare. Fl. JulyAugust.

VI. On Aran island, 1852: Oliver 1853. About Castle Taylor, Galway (as E. cuprea Jord.) More: $C y b$. Abundant on limestone crags near Ballyvaughan, Clare, 1895 (N. C.): Ir. Nat. 1897 . In rough limestone country by the south-east shore of Lough Corrib near Menlough, Galway, 1892 (H.\&J.Groves): Journ. of Bot. 1897, p. 58.-IX. Near Clonbur on low limestone cliffs south of Lough Mask, Co. Mayo, 1895 (Rev. E. S. Marshall): Journ. of Bot. I896, p. $44 I$.

Widespread and usually alpine or sub-alpine in Europe from Norway to Greece. Lowland in Ireland, hardly reaching above 200 feet. Apparently absent from Great Britain. 


\section{BARTSIA Linn.}

\section{B. Odontites Huds.-Red Bartsia.}

Euphrasia Odontites Linn.-Odontites verna Reichb.-O. rubra Pers. Districts I. II. III. IV. V. VI. VII. VIII. IX. X. XI. XII. Lat. $511^{\circ}-55 \frac{1}{4}^{\circ}$. Throughout Ireland. Type, British.

Fields, roadsides, and waste places; common. Fl. JulyAugust.

Sea-level in Derry and S. Cork. To $1300 \mathrm{ft}$. in Derry (Cyb.); to $1330 \mathrm{ft}$. in Waterford (Hart).

Var. SERotnIs (Reichb.)-XII. Giant's Causeway: Shoolbred 1894.

\section{B. viscosa Linn.-Marsh Bartsia.}

Eufragia visaosa Benth.-Trixago viscosa Stev.

Districts I. II. - $---\infty-\ldots$ XI. Lat. $51 \frac{1}{2}^{\circ}-55^{\circ}$. South-West, chiefly. Type, Atlantic.

Boggy pastures; locally abundant. Fl. July-August.

I. At Calnafersey and near Dingle, Kerry: Mack. Rar. A common plant in Kerry; $R . W . S$. Lough Hyne; Mizen Head; Cape Clare; Inchigeela; Gouganebarra, \&c. ; common in S. Cork ; Phillips.-II. Gortdonaghmore bog, Cloghroe, about six miles from Cork on the road to Killarney: Wade Rar. Near Midleton: Flor. Cork. Near the National school at Kildinan, Fermoy $(T$. Chandlee): Cyb. Near Coachford, 1897; Phillips. Roadsides and adjoining fields between Lismore and the Knockmealdown mountains, Waterford 1880-95; $F . E$. Currey.-XI. Between Inch station and Burnfoot, Lough Swilly (Dean Gwynn); abundant for about a mile here chiefly on land reclaimed from the sea: Hart I881 $\beta$. Near Buncrana, about 300 ft. above sea-level, 1891 ; J. Hunter.

Sea-level in Donegal and in Kerry. To $700 \mathrm{ft}$. in Kerry (Hart); but usually lowland.

First found, by Wade, near Cork, about 1804.

The absence of any intermediate stations in Ireland between Kerry and Donegal, and the comparative rarity of this species, in the latter county, point to its probable introduction into north Ireland from the south of Scotland. 


\section{PEDICULARIS Linn.}

\section{P. palustris Linn.-Marsh Rod Rattle.}

Districts I. II. III. IV. V. VI. VII, VIII. IX, X. XI. XII. Lat. $51 \frac{1}{2}^{\circ}-55 \frac{1}{4}^{\circ}$. Throughout Ireland. Type, British.

Marshes and boggy meadows; frequent. Fl. June-August. Caleifuge $C$.

Sea-level in Derry and S. Cork. To $1400 \mathrm{ft}$. in Derry (Moore); to $1550 \mathrm{ft}$. in Dublin $(N . C$.).

\section{P. sylvatica Linn.-Dwarf Red Rattle.}

Districts I. II. III. IV. V. VI. VII. VIII. IX. X. XI. XII. Lat. $51 \frac{1}{2}^{\circ}-55 \frac{1}{4}^{\circ}$. Throughout Ireland. Type, British.

Moist pastures and heaths; frequent. Fl. May-August. Calcifuge $B$.

Sea-level in Derry and S. Cork. To $2150 \mathrm{ft}$. in Donegal (Hart); to $3000 \mathrm{ft}$. in Kerry (Druce I89I).

\section{RHINANTHUS Linn.}

\section{R. Crista-galli Linn.-Yellow Rattle.}

R. minor Ehrh.

Districts I. II. III. IV. V. VI. VII. VIII. IX. X. XI. XII. Lat. $51 \frac{1}{2}^{\circ}-55 \frac{1}{4}^{\circ}$. Throughout Ireland. Type, British.

Moist meadows and pastures, marshes, \&c. ; common. Fl. June.

Sea-level in Derry and S. Cork. To $1450 \mathrm{ft}$. in Derry, $1630 \mathrm{ft}$. in Mayo, and $2400 \mathrm{ft}$. in Tipperary (Hart).

Var. FaLLAX Wimm. \& Grab.-VII. Bog of the Lynn, near Mullingar, Westmeath: Linton 1896.

\section{MELAMPYRUM Linn.}

\section{M. pratense Linn.-Cow-wheat.}

Districts I. II. III. IV. V. VI. VII. VIII. IX. X. XI. XII. Lat. $51 \frac{1}{2}^{\circ}-55 \frac{1}{4}^{\circ}$. Throughout Ireland. Type, British.

Woods, heaths, and mountains ; frequent. Fl. June-August.

Descends to $100 \mathrm{ft}$. in Antrim and to sea-level in S. Cork. To $2200 \mathrm{ft}$. in Donegal, to $2600 \mathrm{ft}$. in Mayo, to $2800 \mathrm{ft}$. in Wicklow, and to $3150 \mathrm{ft}$. in Kerry (Hart). 
Var. Latifoutom Bab.-VII. Knock Eyon, by Lough Derevaragh, Westmeath: Linton r896.-XII. In the Antrim glens: Shoolbred 1894 .

Var. ERICETORUM D. Oliver-VIII. Near Roundstone, on Urrisbeg, Connemara; and-IX. On Ben Bulben, Sligo (Prof. Oliver): Phytol. iv., pp. $678 \& 1078$.

Var. MONTANUM Johnst.-Generally distributed through the mountain districts of Ireland from South to North.

2. M. sylvaticum Linn.-Wood Cow-wheat.

Districts - - - - - - - - XI. XII. Lat. $54 \frac{1}{4}^{\circ}-55^{\circ}$. North Ireland. Type, Scottish. July.

Upland woods and damp shady glens; very rare. Fl. June-

XI. In a glen north-east of Lough Eske, and in a wood on the west side of the lake: Corry I882.-XII. In Glenarm Park, 1800; in glens at Ballyligg near Larne, and on shrubby ground by the Larne road a little south of Glenarm, 1808; by the Forth river near the Fall: Templeton MS. Glen of Altmore, Cushendall, and Woodburn glen: Flor. Ulst. Glenariff: B. N.F. C. Proc. I866. Still at Glenarm Park; at Cairncastle, 1887 (Praeger): Flor. $N_{\text {. }}-E$. South side of Errigal banks above Garvagh, Derry : Moore MSS.

From 200 to $600 \mathrm{ft}$. in Antrim ( $C y b$.).

First found, at Glenarm, by Templeton in 1800 .

\section{ORDER XLVIII.-OROBANCHEE.}

\section{OROBANCHE Linn.}

\section{0. major Linn.-Greater Broom-rape.}

O. Rapum Thuill.

Districts I. II. III. IV. V. ----Lat. $51 \frac{3}{4}^{\circ}-531^{\circ}$. South and East. Type, English.

Lowland. On the roots of broom and furze; rare. . Fl. JuneAugust.

I. Common near Cork and Bandon: Maok. Rar. On furze at Kinalea, 1856 (J. Sullivan): Annot. in Flor. Cork. Not infrequent along the Bandon river from Dunmanway to near Bandon (C. Longfield); near Manch station (R. L. Allman): Allin's Cork.-- 
II. Broom Hill near Leemount (Mr. Alexander); Mountdesart (Dr. Power) : Flor. Cork. Castlemartyr and Inch Castle (T. Chandlee); near Clonmel (T. Anderson); and-III. Firoda, Kilkenny (Rev. T. W. Despard): Cyb.-IV. In the county of Wicklow: Threlkeld. Near the lake at Luggy-law; at the Seven Churches; Devil's glen, \&c. : Mack. Cat. Between Rathdrum and Lara (Moore); Kilbride, Wicklow (S. Foot): Cyb. Near Ovoca, Wicklow, and between that and Rathdrum; Hart. At the head of Lough Dan, Wicklow, 1883; N.C. . Plentiful in Killoughrum Forest, Wexford, 1887 : Moffat I88q-growing here to upwards of four feet in height, 1890 ; Mroffat. In two stations between New Ross and Kilmanock, Wexford: B.-H.\& G. I89o.-V. On a hill south of Rathfarnham [Dublin]: Annot. in Threlkeld. Near Dunleary [Dublin], among furze (Dr. Young): Templeton MS. Not found recently in Dublin.

First recorded by Threlkeld, from county Wicklow, in 1727.

\section{0. rubra Smith-Red Broom-rape.}

O. Epithymum DC.

Districts - - - - VI. - VIII. - - XI. XII. Lat. $53^{\circ}-55 \frac{1}{4}^{\circ}$. West and North. Type, Scottish-Atlantic.

Rocky places and sandy pastures, parasitical on thyme; local. Fl. June-August.

VI. Near Ballyvaughan, Clare, 1851 : O'Mahony I860. Abundant on the hills south and east of Ballyvaughan: Foot I864. Sandy pastures by the shore at Muckinish near Ballyvaughan, 1895; P. B. O'Kelly. Near Poulsallagh, Clare: Corry I880.-VIII. On a small hill near Woodstock, four miles west of Galway, 1838: Mack. App. to Fraser, 4 th Ed. By the side of Lough Corrib: Graham 1840.-XI. Ards, Donegal : Murphy I820. Fanet Point: Hart 7879 . Downing's Bay and Tramore, 1889; frequent in Rossgull; Miss Kinahan.-XII. On the rocks of the Cave Hill in little parcels of earth on projecting parts of the rock, found before 1793: Templeton MS. In considerable quantity on the basaltic range from Magilligan to Ben Bradagh, Derry, 1835: Moore MS. Cliffs to the south-west of Rathlin Island: Stewart I884. Still plentiful on Cave Hill and frequent on the trap hills of Antrim and Derry : Flor. $N$.-E.

To sea-level in Clare. From 200 to $1000 \mathrm{ft}$. in Derry (Moore).

First found in the British Isles by Templeton, on Cave Hill, before 1793, and first recorded in English Botany in 1807. 


\section{0. Hederæ Duby-Ivy Broom-rape.}

Districts I. II. III. IV. V. VI. - VIII. IX. - XI. Lat. $51 \frac{30}{4}-55 \frac{1}{4}$. From South to North. Type, English-Atlantic.

Lowland. Rocks, walls, banks, and woods, parasitical on ivy; locally abundant. $F l$. June-August.

I. Mucross Abbey and in several islands in the lake at Killarney: Maok. Rar. (as O. minor). Still at Killarney, 1897; also at Rahaneen, Barrow Harbour; at Kilfenora, Fenit; Derrynane; West Cove, Kerry, \&c. ; R.W. S. Near Rochestown; Ballincollig, 1893; Carrigrohane, 1891-96; rare in S. Cork; Phillips.--II. Frequent in Cork; Strabally Cove, Waterford (T. Chandlee): Cyb.-abundant here in 1882: Hart $1883 \beta$. In Co. Waterford, west of Clonmel; Miss S. Grubb. Near Caher, Tipperary, 1897; R. P. Vowell.-III. In Sir Robert Staple's woods, Queen's Co.: Mack. Rar. Abundant at Inistiogue; below Ballyneale by the Nore: Hart $1885 \delta$. -IV. Found in the wood at Luggy-law by Dr. Stokes and $\mathrm{Mr}$. Underwood, 1802: Templeton MS. (as O. minor). Coast at Arklow Head : Hart 1881 a. Sea-cliffs, Silver Strand, Wicklow, 1895 ; Miss A. G. Kinahan.-V. On the side of the road going to Lucan, 1799: Templeton MS. (as O. minor). South side of Howth; plentiful in Palmerston and Leixlip woods: Flor. Hib. (as $O$. minor). Abundant in woods along the Liffey at Woodlands, Lucan, and Leixlip, 1894-95, and occasionally on banks by the sea in Co. Dublin; N.C. Woods at Castle Bellingham, Louth: Butter 1890.-VI. South Isles of Aran: Mack. Rar. 1806. West side of Aranmore island, $1892 ;$ N.C. Between Murrough and Black Head, Clare (W. H. S. Westropp): Corry 1880 . Carrigogonell Castle and Askeaton, Limerick (Prof. Harvey): Cyb. Near Foynes and Askeaton, Limerick: Stewart I890. Abundant on Church Island, Lough Derg, Galway: N. C. 1897.-VIII. At the Killeries, Connemara (W. Andrews): Cyb.-IX. On the ruins of Cong Abbey, Mayo: More I860. Hazelwood, Sligo (Moore): Reo. Add.and in $1896 ; N . C .-\mathrm{XI}$. West shore of Lough Swilly near Rathmelton: Flor. Ulst. Brown Knowe island, between Ray and Rathmelton and shore close by; near Goorey, Malin: Hart I880 \& 1883 . At Fort Stewart, Lough Swilly; Miss A. G. Kinahan.

Very rare in the Midlands and apparently absent from the NorthEast. 
4. * 0. minor Sutt.-Lesser Broom-rape.

Districts I. II. III. IV. V. ------ XII. Lat. $51 \frac{1}{2}^{\circ}-54_{\frac{3}{4}}^{\circ}$. From South to North. Type, English.

In clover fields; locally abundant Fl. June-October.

I. At Ratharoon near Ballinadee: Allin's Cork. Castlefreke and Kilkern, 1890; Kinsale, 1891; Phillips. Abundant in old pastures round Clonakilty; and-II. At East Ferry ; Midleton; and Youghal (Phillips): Ir. Nat. I893, p. 23. Near Trabolgan ( $T$. Wright); near Aghada (Carroll): Cyb. At Dungarvan, Waterford; J. Britten.-III. Near Browne's Hill, Carlow, 1878; $\boldsymbol{R}$. Clayton Browne.-IV. In two fields at Spring Hill, Enniscorthy, Wexford, 1868 (J. Morrison): Rec. Add.-still there in 1890; Barrington. Thoroughly established by the coast near Kilmuckridge, Wexford; left bank of the Slaney above Ballycarney, and near Scarawalsh Bridge : Hart I88I a. Plentiful round Ballycarney, 1887-96; G. E. J. Greene. About Kilmanock and Alderton, Wexford: B.-H. \& G. r889. Abundant about Ballyhyland, Wexford; first observed here in 1868, and now very common in clover fields : Moffat I889.-V. In Co. Dublin, on Shennicks island, Skerries, 1893 (Rev. W. Colgan); abundant at Malahide and at. Portrane, 1894: N. C. $1893 \&$ I895. Near Castle Bellingham, Louth: Butler I89o. Near Athy, Kildare; L. Mc Donnell.XII. Abundant near Ballylesson, Down, 1881 (C. Dixon) : F'lor. N.-E. Abundant by the sea at Craigavad, Down, 1892-93 (H. $C$. Marshall): S.\&P. I895.

Spreading rapidly in Ireland where it appears exclusively on Trifolium pratense. No doubt originally introduced with cloverseed in all its stations, but now fully established.

First observed in Ireland about 1866.

\section{LATHR开A Linn.}

\section{I. Squamaria Linn.-Tooth-wort.}

Districts I. II. III. IV. V. VI. VII. VIII. IX. X. - XII. Lat. $51 \frac{3}{4}^{\circ}-55^{\circ}$. Throughout Ireland, almost. Type, English.

Lowland. Woods and thickets, parasitical on roots of trees; rather rare. Fl. April-May.

I. Ross Island, Killarney : R.W. S. I888. Near Desert, Cork (C. Longfield): Allin's Cork.-II. By the river side near Blarney; 
in several parts on the banks of the Blackwater: Drummond I $8 \mathrm{rq}$. Between Fermoy and Mallow ( $T$. Chandlee): Cyb. Plentiful for a long distance along the Blackwater below Mallow (More): Rec. Add. In the grounds of Toorin, Cappoquin (Miss M. Chearnley); Heywood near Clonmel (Rev. A. H. Delap): 'Ir. Nat. 1896. Near Ounashad glen, Lismore, Waterford, $1896 ; F$. $E$. Currey.III. Castlecomer, Kilkenny ; T. Butler. Burton Hall, Co. Carlow, 1872-75; $R$. Clayton Browne.-IV. Near the Waterfall, Co. Wicklow (Dr. Stokes) : Mack. Rar. Balruddery: Mack. Cat. Ballyarthur woods, Wicklow: Ir. Flor. Baltinglass, Wicklow (Rev. J. $M$. Emerson) : Cyb.-V. In the wood of Saint Catherine's, Co. Dublin [near Leixlip]: Wade Rar. In the woods of Luttrelstown [Woodlands], Co. Dublin : Mack. Rar. At Woodlands, 1893; at Saint Catherine's and in Lucan demesne, $1896 ; N$. C. Ravensdale Park, Louth, 1892 ; Lady Clermont. Woods at Castle Bellingham, plentiful; Cecil Butler. - VI. Near Limerick (Prof. Harvey); Edendale near Ennis, Clare (F.J. Foot); near Ballinasloe (Moore): Cyb. At Saint Clerans, Craughwell, Galway, 1897 ; Mrs. M. E. Joyce. - VII. In woods at Parsonstown (M. Dowd): Rec. Add. Belvedere woods, Westmeath: Levinge 1894. At Geashill Rectory and Clonadd wood, King's Co. (Rev. Canon Russell): Ir. Nat. 1896.VIII. The Wilderness, Ashford, Cong; Miss MI. F. Jackson.IX. In Co. Roscommon (Miss Acton); and-X. Whitepark, Fermanagh (T. O. Smith) : Rec. Add. Loughgall Manor, Armagh : More 1860 . Ardmore glebe and lower demesne, Tanderagee, Armagh, 1896 (Rev. H. W. Lett); Strabane glen, Tyrone, 1896 (Rev. A. H. Delap): Ir. Nat. I806.-XII. Frequent in northeast Ireland: Flor. N.-E. and S.\&.P. 1895.

In Ireland appears to grow indifferently on roots of Elm, Beech, Hazel, Chestnut, and Portugal Laurel.

\section{ORDER XEIX.-LENTIBULARIEZE.}

\section{UTRICULARIA Linn.}

\section{U. vulgaris Linn.-Common Bladderwort.}

Districts I. II. III. IV. V. VI. VII. VIII. IX. X. XI. XII. Lat. $511^{\circ}-551^{\circ}$. Throughout Ireland. Type, British.

Ditches, pools, bog-holes, \&c. ; rather frequent. Fl. June-Aug. 
A widely-distributed species, but rare or absent over considerable areas,

To $800 \mathrm{ft}$. in Kerry (Hart); but usually lowland.

\section{U. neglecta Lehm.}

Districts I.

Pools and ditches; apparently rare. Fl. July-August.

I. Abundant in Ballycarty pond near Tralee, Kerry, 1887: R.W.S. 1888 . Lower Lake shore, Killarney: R.W. S. I89T.V. Pools at the Bog of the Ring and by the Ward river, Chapelmidway, Co. Dublin, 1893 : N. C. 1893 .

Often confounded with the preceding species and perhaps not infrequent in Ireland.

First found in Ireland, near Tralee, by R. W. S. in 1887.

\section{U. minor Linn,-Lesser Bladderwort.}

Districts I. II. III. IV. V. VI. VII. VIII. IX. X. XI. XII. Lat. 51 $1_{2}^{\circ}-55 x^{\circ}$. Throughout Ireland. Type, British.

Ditches, pools, and bog-holes; frequent and locally abundant. Fl. July-August.

Rare in the East, but occurs in Wexford, Wicklow, Carlow, and Louth; frequent in the South and North; rather common in the West and South-West.

To $850 \mathrm{ft}$. in Donegal ( (Aart); but usually lowland.

\section{U. intermedia Hayne.-Intermediate Bladderwort.}

Districts I. - - - V. VI. VII. VIII. IX. X. XI. XII. Lat. $51 \frac{1}{2}^{\circ}-55 \frac{1}{4}^{\circ}$. From South to North. Type, Local-Scottish.

Lowland. Bog-holes, pools, and ditches; rather rare. Fl. August.

I. Not rare in the southern half of Kerry: R.T.S. r89r. Knockskeagh, Leap (Rev. T. Allin): Rec. Add. Near Gurrane lakes, Dunmanway, sparingly; near Glengariff (in flower), very rare in Cork: Allin's Cork.-V. South of Kildare town, and in a marsh north of the Curragh, 1897; Prasger.-VI. Bogs near Crusheen, Clare: Corry 1880.-VII. Tullaghan bog by Lough Owel, Westmeath: Linton $5896 .-$ V.III. Frequent in the Connemara bogs, flowering near Recess Hotel (Carroll): $C y b$. Frequent in the Mweelrea district, Mayo: Hart 1883 a. Bog ditches near Inveran, Iar Connaught, 1895; N.C.-IX. Bog near Lisloughrey, 
Cong, Co. Mayo, 1895; Miss M. F. Jackson.-X. "Observed by Dr. Scott during successive seasons growing in a peat drain near Scottsborough, County of Fermanagh": Mack. Rar. Between Pettigoe and Ballyshannon, Fermanagh ; Hart. Derryquinny Bog, Cavan: Ir. Nat. I896, p. 196.-XI. Frequent in the boggy western and north-western districts of Donegal; Hart.-XII. On a large peat-bog near Rasharkin, Antrim (Moore): Cyb. Abundant in a boggy pool about a mile west of Lough Naroon, Antrim (Praeger): S.\&. P. 1895 .

Frequent in the West, rare in the North and East. Seldom: flowering in Ireland.

First found in the British Isles by Dr. Scott, near Scottsborough, Fermanagh, about 1804 and first published in 1806 in Mack. Rar.

\section{PINGUTCULA Linn.}

\section{P. vulgaris Linn.-Common Butterwort.}

Hibernoé Leic uipze (Lay ishgë), Rot water.

Districts I. II. III. IV. V. VI. VII. VIII. IX. X. XI. XII. Lat. $51 \frac{1}{2}^{\circ}-55 \frac{1}{4}^{\circ}$. Throughout Ireland. Type, Scottish-British.

Bogs and damp heathy or rocky places; frequent. Fl. June.

A rare plant in the South-West, where it gives place to $\dot{P}$. grandiflora, and is found usually at considerable elevations.

Sea-level in N. Antrim and in Dublin. To $1650 \mathrm{ft}$. in Donegal (Hart); to $2000 \mathrm{ft}$. in Down (S.\&P.); to $2500 \mathrm{ft}$. in Wicklow and to $2450 \mathrm{ft}$. in Kerry (Hart).

2. P. grandiflora Lamk.-Large-flowered Butterwort.

Districts I. II. - - - - - - - Lat. $51 \frac{1}{2}^{\circ}-521^{\circ}$. South-West only. Type, Hibernian.

Bogs, marshy ground, and moist rocky places on mountains;. locally abundant. Fl. May-June.

I. Near Kenmare (W. Witson): Flor. Hib. Common at Killarney (Admiral Jones); abundant in many parts of Kerry; Turk mountain; Mangerton; Brandon, \&c. : $C y b$. On Magillicuddy's Reeks (More): Rec. Add. On Baurtregaum mountain, Dingle peninsula; abundant at the head of Killarney Lakes and above the Gap of Dunloe, $1885 ; N . C$. Mountain glens between Castleisland and Listowel: R.W. S. $189 I$. Dereen; Waterville, \&c.; 
not rare in south Kerry; $R . W . S$. Found plentifully in marshy ground in the west part of county Cork by Mr. Drummond : Eng. Bot. 1810 . West side of the Lee above Inniscarrow and about Macromp and Bantry (Mr. Drummond): Mack. Cat. On Bottle Hill : Flor. Cork. Abundant two miles above Iniscarra Bridge, also at Castletown Berehaven, 1894; Ballyalley, south of skibbereen; Phillips. Bog by the new Kinsale road three miles from Cork (J. Sullivan): Annot. in Flor. Cork. Near Ballinhassig (K. J. Shaw); and-II. Near Cloghroe (R. Mills): Allin's Cork. Bank of the Glanmire river about half a mile above Carrignavar, 1849 (J. D. Humphreys): Annot. in Flor. Cork. Gurtaveeha lake near Millstreet, sparingly (More): Rec. Add.

Not found in Great Britain. In Treland, confined to the counties of Cork and Kerry, where it is abundant in many parts of its restricted area and reaches its extreme northern limit for Europe. Ranges on the Continent from Northern Spain to the Jura and the French and Swiss Alps. Perhaps the most beautiful of the Hibernian type plants.

From sea-level (R.W.S.) to $2250 \mathrm{ft}$. in Kerry (Hart).

First found, by James Drummond, near Macroom, in 1809.

The most eastern native station known for this species is at Carrignavar in about $8^{\circ} 30^{\prime} \mathrm{W}$. longitude. There is reason to fear, however, that an attempt made to naturalize the plant much farther to the eastward may ultimately prove successful, and give rise to a mistaken view as to the extension of its natural range. About half a dozen roots having been introduced into a wild piece of bog near the foot of Blackstairs mountain, Co. Wexford, in 1879, were found in 1896 to have increased to 27 plants which flowered freely-see Ir. Nat. 2896, p. 212.

\section{P. Iusitanica Linn.-Pale Butterwort.}

Districts I. II. III. IV. V. VI. VII. VIII. IX. X. XI. XII. Lat. 51 $1_{2}^{\circ}-55 \frac{1}{4}^{\circ}$. Throughout Ireland. Type, Atlantic-Scottish.

Bogs, especially in mountain districts; frequent. Fl. JuneAugust.

Sea-level in Down and in Kerry. To $1000 \mathrm{ft}$. in Donegal (Hart); to $1600 \mathrm{ft}$. in Down (S.\& P.).

Rather common in many parts of the South, West, and North; rarer in the East, and usually more frequent near the coast than inland. 
ORDER L.-VERBENACE正.

\section{VERBENA Linn.}

\section{1. $\ddagger \mathrm{V}$. officinalis Linn.—Vervain.}

Districts I. II. III. IV. V. VI. VII. VIII. IX. - XI. Lat. $51 \frac{1}{2}^{\circ}-54 \frac{1}{2}^{\circ}$. South and Middle, chiefly. Type, English.

Lowland. Roadsides, waste places, and near old buildings; local. Fl. July-August. Caleicole B.

Recorded for a single station, only, in District XI. ; a casual in District XII. Fully established in many places in the South, West, and Centre, but nowhere having the appearance of a native.

\section{ORDER LI.-LABIAT无.}

MENTHA Linn.

1. $\ddagger$ M. rotundifolia Huds.-Round-leaved Mint.

Districts I. II. III. IV. V. VI. - VIII. - X. - XI. Lat. $51 \frac{1}{2}^{\circ}-54 \frac{1}{2}{ }^{\circ}$. From South to North. Type, English.

Lowland. Banks, waste places, by rivers, on roadsides, \&c.; rare. $F l$. August-September.

I. Abundantly by the stream at Fybagh bridge west of Castlemaine Harbour; by an old road through Glencar woods; below Lake View, Killarney; and near Kenmare, Kerry : R.W. S. I89I. Between Macroom and Inchigeela, and near Castletown Berehaven (Carroll): $C y b$. By the road from Bantry to Glengariff; near Adrigole; Glandore and Rosscarbery: Allin's Cork. Near Skibbereen and Goleen, south Cork, 1896; Phillips.-II. Dry bank by the sea-side at Carlisle Fort, near Cove, 1804: Mack. Rar. At Ballyderoon Castle; near Aherne; Quirk's Castle near Fermoy (T. Chandlee): Cyb. By the Blackwater between Lismore and Cappoquin, Waterford, looking wild: Hart $7885 \delta$. Riverside near Kilsheelin, Tipperary (Miss S. Grubb) : Cyb.-III. Roadside near Snow Hill, Kilkenny : B.-H.\& G. I890.—iV. Among ruins at Glendalough: Ir. Flor. Fethard, Wexford (J. Morrison); 
Roundwood, Wicklow (E. Newman): Cyb. Rosdroit, and along the Urrin river, Wexford: Moffat I889.-V. Near Garristown, 1893 ; at Loughlinstown, 1894 ; occasional as a relic of cultivation in Co. Dublin ; N. C.-VI. Roadside bank between Galway and Oranmore (Stewart): Rec. Add.-VIII. Roundstone, Connemara ( $W . M c A l l a): C y b$. Plentiful near a cottage at Ballinaderg bridge, west of Nephin, Mayo (Hart): Reo. Add.-X. Occasional as an escape in Co. Armagh : Praeger 1893.-XII. In Glendarragh, and by the river at Crumlin, Antrim (Moore) : $C y b$. Abundant by the shore south-west of St. John's Point, Down (Stewart): Flor. N.-E. Riverside near Ballynahinch, Down ( $R$. Hanna); near Saul chapel and between Newtownards and Comber, Down (Praeger): S.\&P. I895.

The numerous Irish records for this and for the other cultivated Mints are of very unequal value, and in the absence of full details it is not possible to distinguish the instances in which they appear as well established in wild stations from those where they occur as mere casuals or outcasts.

\section{2. $\ddagger$ M. piperita Linn.-Peppermint.}

Districts I. II. - - V. - - VIII. - X. XI. XII. Lat. $51 \frac{3}{4}^{\circ}-55^{\circ}$. From South to North. Type, English.

Lowland. Wet and marshy places; rare. Fl. July-August.

I. In several localities east of Kenmare, Kerry: R.W.S. I89I. By the Lee near Carrigrohane Castle: Drummond I8IQ. Drain between Carrigaline and the sea, 1851: Carroll 1854. Minane Bridge near Ringabella, Cork; and plentifully by the Lee a mile and a-half above Cork (Carrolt): $C y b$. Between Inishannon and Ballinadee: Allin's Cork.-II. Freely by the Midleton river near Lisgoold and Ballincarrig Bridge; at Ballytrasna, Midleton; at Aldworth, Mallow:Allin's Cork. By the Clashgariff river near Carrigadrohid, 1897; Phillips. Near the Spa, Clonmel, probably naturalized (Miss A. Taylor): Cyb.-V. River side near Ballitore, Kildare: Carroll 1854 . On a bog near Monasterevan, Kildare (Praeger): Ir. Nat. I893. By the Dodder near Rathfarnham, Co. Dublin, $1893 ;$ N.C.-VIII. Banks of rivulets at Streamstown, Connemara: Ir. Flor.-X. At Farnham, Cavan, near the upper end of the lake: Flor. Hib. Near Tartaraghan and Killylea, Armagh: Praeger 1893. -XI. Near Lough Eske; between Ballyshannon and Donegal; near Bundoran: Hart I885 \%.-XII. Side 
of the Curley burn, and on the roadside near Muff, Derry : Moore MS. By the rivulet near Carnmoney Church (Mr. Orr); shore of Lough Neagh at Massareene Park (Diokie): Flor. Olst. Still plentiful by the stream west of Carnmoney Church, and near Antrim on the gravelly shore at the river mouth; well naturalized if not indigenous in the North-East: Flor. N.-E. Plentiful by the old road between Ballynahinch and Drumaness, Down ( $R$. Hanna): S.\& P. 1895 .

Like the preceding species, no doubt derived in all cases from cultivation, but perhaps more fully naturalized.

\section{M. hirsuta Huds.-Common Water Mint.}

\section{M. aquatica Linn.}

Hibernicé Mıpımın oeapz (Mishimeen dharrig), Red Mint.

District I. II. III. IV. V. VI. VII. VIII. IX. X. XI. XII. Lat. $511^{1}{ }^{\circ}-55 \frac{1}{4}^{\circ}$. Throughout Ireland. Type, British.

Watery places; very common. Fl. August-September.

Sea-level in N. Donegal and S. Cork. To $1050 \mathrm{ft}$. in Dublin (N.C.).

\section{M. sativa Linn.-Marsh Mint.}

Districts I. II. III. IV. V. - VII. VIII. IX. X. XI. XII. Lat. $51 \frac{1}{2}^{\circ}-55 \frac{1}{4}^{\circ}$. Throughout Ireland, probably. Type, BritishEnglish.

Lowland. Wet places, river banks, \&c.; frequent. Fl. JulySeptember.

Probably occurs throughout Ireland, but is often overlooked or confounded with the preceding species.

Var. PaLdudsa (Sole)-I. Near Ross Bay, Killarney Lakes: R.W. S. I888.-XII. Limavady junction, Derry (Mrs. Leebody): Stewart 1894 .

Var. SUBGLABRA Baker-I. Lower Lake, Killarney: R.W.S. I888.-VII. Philipstown, King's Co.; and-XII. Knock Iveagh, Down (Rev. H. W. Lett) : Wats. B. Ex. C. Rep. I895.

Var. RUBRA (Smith)-I. By the South Bride, Cork; andIII. Ballintrain, Carlow (Carroll): Cyb.-IV. Clohass Bog and Bloomfield, Wexford (Miss E. M. Farmer): Rec. Add.-The numerous other records for this variety to be found in Ir. Flor., Flor. Hib., \&c., need confirmation. 
Var. aractuIs (Smith)-X. Stony shore of Virginia Water, Cavan: Praeger 1897.

Var. GENTIIs (Linn.)-II. Ditch by the road between Aghada and Cloyne, Cork, 1895; Phillips.-III. By the Mountmellick canal a mile above Portarlington, Queen's Co. : Praeger 1897.

\section{M. arvensis Linn.-Corn Mint.}

Districts I. II. III. IV. V. VI. VII. VIII. IX. X. XI. XII. Lat. $51 \frac{1}{2}^{\circ}-55 \frac{1_{4}}{4}$. Throughout Ireland. Type, British.

Lowland. Cultivated ground, waysides, and waste places; frequent. $F l$. August-September.

\section{6. † M. Palegium Linn.-Penny-royal.}

Districts I. II. - IV. - VI. - - - - XII. Lat. $511_{2}^{\circ}-54_{4}^{30}$. From South to North. Type, English.

Lowland. Marshy meadows, and damp waste places and roadsides; local. Fl. August-September.

I. In moist ground about Lixnaw, in great quantities: Smith's Kerry. In Earl Kenmare's Park near Killarney: Wade Rar. Plentiful near Calnafersy: Mack. Rar. Abundant at Murriagh near Ballynagall, and roadside near Ballydavid, Dingle promontory: Hart 1884. Kenmare; Rossbehy ; near Killorglin; Sherehee, near Killarney, \&c.; widespread in Kerry, but not common: R.W.S. r889, \&6. Roadside between Bandon and Ballinadee; on an island in Schull Bay: Allin's Cork. Near Goleen, 1896; Phillips.II. Pretty frequent on the banks of the Blackwater: Smith's Cork. Abundant at Ballycotton: Drummond I8Iq. Great Island; Imokilly, \&c.: Flor. Cork. Kilshannig; Mallow, \&c.: Allin's Cork.-IV. Fethard, Wexford (J. Morrison); at the base of the Great Sugar Loaf, Wicklow (Moore) : Cyb.-VI. Churchyard at Ennis, and marshy fens about the barony of Islands and Bunratty : Wade Rar. Near the river at Hermitage, Ennis (Rov. T. Warren): $C y b$. At Ennis, 1892 ; Levinge.-XII. Plentiful on the Creagh bog, Lough Beg, and sparingly in wet meadows by the side of Lough Neagh, Co. Derry: Moore MS. Abundant in a damp meadow at the north end of Lough Beg, Antrim (Miss Knowles): S. \& P. 1895 .

Perhaps indigenous in Kerry and Cork; apparently introduced nelsewhere. 


\section{LYCOPUS Linn.}

\section{L. europæus Iinn.--Gipsy-wort.}

Districts I. II. III. IV. V. VI. VII. VIII. IX. X. XI. XII. Lat. $51 \frac{3}{4}-55^{\circ}$. Throughout Ireland. Type, British-English.

Lowland. Ditches, riversides, lake margins, \&c. ; frequent and locally abundant. Fl. July-August.

Widely distributed, but rather rare in many parts of the country; more abundant in the West than in the East.

\section{ORIGANUM Linn.}

\section{0. vulgare Linn.-Wild Marjoram.}

Distriets I. II. III. IV. V. VI. VII. VIII. IX. X. XI. XII. Lat. $51 \frac{3}{4}^{\circ}-55^{\circ}$. Throughout Ireland. Type, British-English.

Lowland. Dry banks and bushy places; frequent and locally abundant. Fl. July-September. Calcicole $B$.

I. About Kenmare; rare in Kerry $\cdot$ R.W.S. 1890 . Kinsale roak, Cork: Drummond 18Iq. Near Ballinadee: Allin's Cork. Near Glengariff, 1894; and near Carrigrohane; Phillips.II. Freely near Castletownroche (Carroll); at Blarney ( $R$. Mills); in several places round Midleton: Allin's Cork. Glanmire, 1891; and East Ferry, 1893; Phillips. Near Fermoy, rare (T. Chandleo): $C y b$. - and in $1896 ; R . W . S .-I I I$. In Kilkenny, at Kilmacow (T. Chandlee), and near Riverview (Rev. S. Madden): Cyb. At Maryborough, Queen's Co. (Praeger): Ir. Nat. 1893.-IV. Abundant between Bray and Enniskerry, Wicklow; N.C. About. Fethard, Wexford: Hart I883 $\beta$.-V., VI., and VII. Frequent, occurring, often abundantly, in Dublin, Kildare, Westmeath, Longford, King's Co., North Tipperary, East Galway, and Clare.VIII. Common round Cong, Co. Galway: Marshall I896.IX. Common near Cong in Co. Mayo; Miss M. F. Jackson.X. Near Loughgall, Armagh (More): Cyb. Abundant a little north of Loughgall; lanes at. Derryhaw, east of Tynan: Praeger 1893.-XI. By a ruined mill on the Erne below Cliff; on an old wall at Brown Hall: Hart. I886.-XII. By the Faughan near Fincairn glen, Derry, very rare: Moore MS. By the river at Shane's Castle demesne, and between Larne and Carrickfergus, 
Antrim (Moore) : Cyb. Walls of Templepatrick graveyard, Down (R. Hanna); at Eglinton, Derry (Mrs. Leebody): S. \& P. I895. Very rare in the North-East, and perhaps introduced or an escape in many of the stations: Flor. N.-E.

Abundant in many places in the southern half of Ireland; rare and apparently introduced in the North.

\section{THYMUS Linn.}

\section{T. Serpyllum Linn.-Wild Thyme.}

Districts I. II. III. IV. V. VI. VII. VIII. IX. X. XI. XII. Lat. $51 \frac{1}{2}^{\circ}-55 \frac{1}{4}^{\circ}$. Throughout Ireland. Type, British.

Barks, rocky places, \&c.; rather common. $F l$. June-August.

Sea-level in N. Donegal and S. Cork. To $1800 \mathrm{ft}$. in Donegal, $2050 \mathrm{ft}$. in Down, $2680 \mathrm{ft}$. in Mayo, and $3230 \mathrm{ft}$. in Kerry (Hart).

Though widespread in Ireland, this species is absent over large areas, and is generally rarer inland than near the coast.

\section{T. Chamadrys Fries.}

Districts I. II. $----\infty---$

Sandhills, \&c.; apparently very rare. $F \mathrm{Fl}$. July-August.

I. Sandhills at Banna near Ardfert, Kerry: R.W. S. I889.II. In a pasture near Whitegate, Cork, 1897 ; Phillips.

CALAMINTHA Linn.

\section{1. $\neq$ C. Acinos Clairv.-Basil Thyme.}

$C$. arvensis Lamk.

Districts - - III. IV. V. - VII

Lat. $52 \frac{1}{2}^{\circ}-53 \frac{1}{2}^{\circ}$. South-East chiefly. Type, British-English.

Lowland. Gravelly places and in cultivated fields in light soils; very rare. Fl. July-August.

III. On the esker, south and north of the railway at Maryborough, Queen's Co.: Praeger 1897.-IV. On the Murrough of Wicklow, on gravelly banks, sparingly (Moore): Cyb. A colonist in clover fields at Knockmore and Mangan, Wexford, and several times in profusion in crops about Ballyhyland, Wexford: Moffat I880, \&6.-V. Near Athy, 1838 (Miss Trench); and in a sandy field at Portmarnock, Dublin, 1840 : Mackay 1859 . Abundant in 
gravelly fields near Thomastown, Kildare; once found sparingly on Mullaghcreelan Hill, Kildare (J. Douglas); at Portrane, 1869 (Hart): Rec. Add. Gravel pit near the Curragh, Kildare, 1897; Praeger. Sparingly in a cornfeld near Clonsilla, Dublin: $N$. C. 1895.-VII. Near St. Martin's Well, Lough Ree: B.\&V. 1887 . Along the Scots road near Nenagh, Tipperary, 1897; R. P. Vowell.

\section{C. officinalis Mœnch-Calamint.}

\section{Melissa Calamintha Linn.}

Districts I. II. III. IV. V. VI. - VIII. IX. - XI. Lat. $511_{2}^{\circ}-54 \frac{1}{2}^{\circ}$. From South to North. Type, English.

Lowland. Dry banks, walls, rocky and gravelly places, roadsides, \&c.; rather rare. $F l$. July-September. Caleicole $A$.

I. At Killarney (Babington); Kenmare (Prof. Harvey): Cyb. At Killarney, 1887; at Kenmare, 1889; also at Clogherbrian near Tralee: R.W. S. $1889 \$ 1890$. Limestone rocks and old castle at Carrigaline; limestone crags at Shanbally, Monkstown; by the shore at Oyster Haven, Kinsale: Flor. Cork. At Leap; Timoleague; near Glengariff; at Whitehall, Skibbereen: Allin's Cork.II. Limestone hills near Midleton; near the Abbey, Ballinacurra : Flor. Cork. Rocks at Blarney, 1856 (J. Sullivan): Annot. in Flor. Cork. Frequent near Fermoy (T. Chandlee); near Clonmel (Miss S. Grubb): $C y b$. By the rivers Funcheon and Owbeg, North Cork, $1896 ;$ R.W.S. Abundant on limestone in North Cork; near the Blackwater, Waterford (Allin): Rec. Add. Shore of Youghal Harbour, Waterford, opposite Youghal: Hart I883 B.III. Beaufort and Wallslough, Kilkenny; Rev. S. Madden.IV. Near Newcastle, Wicklow : Mack. Cat. Steep banks by the river between Enniskerry and the Dargle: Ir. Flor. Plentiful by the riverside near the Island Quay, Wexford: B.-H.\& G. I889.V. Near Luttrelstown and Knockmaroon: Wade Dubl. I794-still at Knockmaroon, $1895 ; N . C$. Road-side near Vallombrosa, Bray, 1894 ; More.-VI. In profusion on the way to the Seven Churches, Aranmore Island: Ogilby 2845. Between the Seven Churches and Kilmurvy, Aranmore: Hart 7875 . Abundant by the road-side in Glanquin, Clare: Corry 1880 . Frequent on limestone crags near Muckinish, Clare, $1895 ; N$. C.-VIII. Ruins of Ochnanew Castle near Oughterard: Graham 2840.-IX. At Cong, Mayo: Wade Gallovid I80I-still there in 1895; Miss M. F. Jackson. Shores of Lough Ree in Roscommon (Foot): Cyb.-XI. Plentiful at a lime- 
stone quarry close to Abbey Assaroe, near Ballyshannon (Mr. Allingham): Hart $1886 .-$ In district XII. this species was once observed in Glendun, Antrim, where it has long since become extinct: Flor. N.-E. \& Stewart 1894 .

Probably introduced in many of its stations in the neighbourhood of ruins, but apparently native on limestone rocks in Kerry, Cork, Clare, and Galway.

\section{SALVIA Linn.}

\section{S. Verbenaca Linn.-Clary.}

Districts I. II. III. IV. V. VI. ----Lat. $51 \frac{1}{2}^{\circ}-53 \frac{3}{4}^{\circ}$. South and South-East. Type, Germanic-Local.

Lowland. Dry banks, waysides, and waste places; rare. Fl. June-September. Calcicole B.

I. Near the Red Strand, Clonakilty (Allin): Rec.Add. At Baltimore (R. L. Allman); sparingly at Old Fort, Kinsale: Allin's Cor\%. Plentiful near Ardfield, Clonakilty, 1890; at Baltimore, 1896; Phillips.-II. Clay Castle, Youghal: Drummond I8I8still there, 1891-95: Phillips 1895. At Bailick, Ballinacurra (Mr. Alexander): Allin's Cork. Plentiful between Youghal Bay and Ardmore, Waterford (T. Wright): Cyb. Clonea near Dungarvan, Waterford: Hart $7883 \beta$.-III. Half a mile west of the town of Kilkenny (John Sim); at Lackenhill, Kilkenny (Rev. S. Madden): Cyb.-IV. Murrough of Wicklow (Moore): Cyb. In Co. Wexford, a little north of Greenore, and at Carnsore and Dungannon : Hart $1883 \beta$. Roadside banks, Rosslare, Wexford: Marshall I896.- $\nabla$. "Upon the Brow below the Hospital of Kilmainham": Threlkeld. Between Long Meadows and Chapelizod; between Rathmines and Milltown: Wade Dubl. I794. By the roadside at Long Meadows, 1893-96; $N$. C. Along the shore from Clontarf to Howth; common at Glasnevin and Cardiff's Bridge; Knockmaroon Hill; Phonix Park: Ir. Flor. Baldoyle, Co. Dublin; More. Abundant on roadside banks between Kilbarrack and Howth, 1896; at Skerries and Cloghran, Co. Dublin, 1893 ; apparently much rarer now than formerly in Co. Dublin; N. C. County Louth golf links, three miles north of Drogheda; Hart.-VI. Askeaton Castle, Limerick (Prof. Harvey) : Cyb.

Almost confined to the neighbourhood of the sea coast and apparently decreasing in Ireland. 


\section{NEPETA Linn.}

\section{1. *N. Cataria Linn.-Cat Mint.}

Districts I. II. III. - V. VI. VII. VIII. IX. X. XI. XII. Lat. $51 \frac{3}{4}^{\circ}-55 \frac{1}{4}^{\circ}$. From South to North. Type, English-Germanic.

Lowland. Waste places, waysides, banks, and near ruins; rare. Fl. July-August.

I. By the old abbey of Timoleague : Drummond 1819-not seen recently in Cork.-II. Near Clonmel, Tipperary (Miss S. $G_{r u b b)}: C y b$.-III. On the banks of the Nore between Thomastown and Inistiogue (Mr. Blashford): Templeton MS. In Kilkenny, at Danesfort and Ballykeeffe (Rev. S. Madden); near Carlow (J. Morrison): Cyb.-V. Ditch near the Curragh of Kildare, 1732: Annot. in Threlkeld. Sandy fields about Rush and Skerries: Ir. Flor.-VI. Roadside north of the Shannon opposite Limerick: Mack. Rar. Roadside near Ballyvaughan, Clare: More 1860. West of Loughrea, Galway: Graham 1840 . Near Kinvarra, Galway, 1892 ; Levinge.-VII. Shannon Bridge, King's Co. : Ir. Flor. Roadside near Ballylucnane, Parsonstown (M. Dowod): Rec. Add.-VIII. Between Newport and Castlebar, Mayo: Ball I839. Between Galway and Oughterard (Moore): Cyb.-IX. "I found this about Perryborough, Roscommon: Browne Fasciculus. Roadside at Cong, Mayo: Wade Gallovid $180 I$ - still there in 1895 ; Miss M. F. Jackson. Roadside at Bracknagh, Lough Ree: B. \& V. 1887.-X. Banks of the Colebrooke river, Fermanagh (T. O. Smith); and-XI. Near Rowross Ferry (Hart): Ree. Add. Waste ground near Port-na-blagh, Dunfanaghy: Hart I880.-XII. Sandy hedge bank at Benone, Magilligan: Moore MSS. One plant on Magilligan sand-hills, 1863 : Flor $N$.-E. Waste places by the shore north of Ardglass, Down (Stevant): Ree. Add.

There is reason to believe that in many of its Irish stations this plant has occurred merely as an escape; in others it has apparently become extinct, and in all it is more or less obviously derived from cultivation.

\section{N. Glechoma Benth.-Ground Ivy.}

Glechoma hederacea Linn.

Districts I. II. III. IV. V. VI. VII. VIII. IX. X. XI. XII. Lat. $51 \frac{1}{2}^{\circ}-55 \frac{1}{4}^{\circ}$. Throughout Ireland. Type, British.

Hedge-banks, woods, \&c.; rather common. Fl. April-June. 
Sea-level in N. Antrim and S. Cork. To $700 \mathrm{ft}$. in Dublin (N. C.) ; but usually lowland.

\section{SCUTELLARIA Linn.}

\section{S. galericulata Linn.-Greater Skull-cap.}

Districts I. II. III. IV. V. VI. VII. VIII. IX. X. XI. XII. Lat. 51술 $-55^{\circ}$. Throughout Ireland. Type, British.

Lowland. River-sides, bog drains, and stony or gravelly lake margins; widespread but local. $F$ l. July-August.

I. and II. Not infrequent in Kerry and in Cork.-III. By the Erkina river, Queen's Co., near its junction with the Nore: Hart I885 $\delta$. In the demesne at Borris Castle, $1896 ;$ Rev. T. Hartley.IV. Ballykean, Wicklow, 1881; Miss A. G. Kinahan.-V. Sparingly by the Royal Canal east of Lucan, Co. Dublin (R.W.S.): N. C. I893.-VI. At Miltown Malbay, Clare, 1830: Harvey's Memoir. Wood at Ballycar, Clare : Stewart 1890.-VII. Northwest end of Lough Owel, Westmeath: Levinge 1894.-VIII. Bilberry island, Lough Corrib, among the stones on the shore; Renvi shore, Connemara: Wade Rar. In bog ditches and on shingle by the shore near the mouth of the Crumlin river, Galway Bay, 1895; Rev. W. Colgan.-IX. In crevices of the limestone south of Lough Mask : M.\&S. I896.--X. Frequent, occurring in the counties of Cavan, Fermanagh, Armagh, and Tyrone, chiefly on lake shores.XI. Shore of Mulroy lake near Carrowkeel: Hart I879. On shingle by the shore between Killybegs and Fintragh: Hart I885 \%.-XII. Derriaghy and Portmore woods, 1794 (Templeton): Whitla MS. Rare in the North-East, but recorded for several stations in Antrim, Down, and Derry : Flor. N.-E. and S.\& P. 1895 .

Nowhere an abundant species, and apparently rarer in the East than in the West.

S. Nicholsoni Taubert-S. galericulata $\times$ minor-I. At Mahony's Point, Killarney Lakes; Levinge.

\section{S. minor Huds._Lesser skull-cap.}

Districts I. II. III. IV. V. VI. - VIII. IX. - - Lat. $51 \frac{1}{2}^{\circ}-54^{\circ}$. Southern half of Ireland. Type, English-Atlantic.

Wet and boggy places; frequent. Fl. July-August. Calcifuge $\mathcal{A}$.

I. and II. Frequent in Cork and Kerry.-III. Near Kilmacow, 
Kilkenny (T. Chandlee): Cyb. Between Borris, Carlow, and the foot of Blackstairs: Hart I884.-IV. Between Rathdrum and Trooperstown; and bog at Lough Bray: Ir. Flor. Plentiful in Glenmalure (Moore) : Cyb. Marsh under Killowen House, Wexford: B.-H.\& G. I889.-V. Howth Head: Flor. Howth. Marsh at south side of Howth Head, 1897; Miss S. Colgan. Ireland's Eye; Miss A. G. Kinahan.-VI. Monmore Bog, Clare ; C. Carter.VIII. and IX. Frequent in Galway and Mayo; reaching its most northern point at Foxford (More).

Sea-level in Dublin and in S. Cork. To $800 \mathrm{ft}$. in Kerry (Hart); but usually lowland.

Quite absent from North Ireland, and rarer in the East than in the West.

\section{PRUNELLA Linn.}

\section{P. vulgaris Linn.-Self-heal.}

Districts I. II. III. IV. V. VI. VII. VIII. IX. X. XI. XII. Lat. $51 \frac{1}{2}^{\circ}-55 \frac{1}{4}^{\circ}$. Throughout Ireland. Type, British.

Damp pastures, waste places, \&c. ; common. Fl. July-August.

Sea level in N. Donegal and S. Cork. To $1750 \mathrm{ft}$. in Derry, and to $1700 \mathrm{ft}$. in Tipperary ( Hart).

\section{MARRUBIUM Linn.}

\section{1. * M. vulgare Linn.-White Horehound.}

Districts I. II. - IV. V. VI. --Lat. $51 \frac{3}{4}^{\circ}-53 \frac{1}{4}^{\circ}$. South and Middle. Type, English.

Lowland. Waste places and roadsides, usually near houses; rare. $F l$. July-September. Caloicole $B$.

I. At Derrynane and Tralee, Kerry, escapes; R.W.S. Strand near Carrigaline: Drummond 1810 -still there in 1896; Phillips. At Currabinny (Carroll): $C y b$. Near Ringaskiddy, very sparingly: Allin's Cork.-II. Great Island, and by the shore at East Ferry: Flor Cork.-IV. Common on the Murrough of Wicklow: Wade Rair. Various places in Wicklow between Dunganstown and the sea: Flor Hib. For some distance along the shore near Bray: Ball r839.-V. Loughlinstown commons: Ir. Flor. Rush, and near Woodlands, Dublin; Miss A. G. Kinahan.-VI. In the Great 
Island of Aran, mostly near villages: Ogilby 1845 . In the inhabited part of Inisheer, Aran Isles : Hart 1875. Abundant about the Seven Churches, Aranmore: Praeger I895. Roadside near Ballyvaughan, Clare: More 1860 . Plentiful along roadsides south of Black Head and north-east of Ballyvaughan, Clare: Foot I864. Roadside near the village of Murrough, Clare (Rev. T. Warren): $C y b$. - still at Murrough in limestone crags near cottages, 1895 ; P. B. O' Kelly.

Much cultivated in cottage gardens and perhaps fully established only in Clare and the Aran Isles.

\section{STACHYS Linn.}

\section{S. Betonica Benth.-Betony.}

Betonica officinalis Linn.

Districts I. II. III. IV. [V.] [VI.] - - X. XI. XII. Lat. $52^{\circ}-55 \frac{1}{4}^{\circ}$. From South to North. Type, English-British.

Lowland. Woods and thickets; very rare. Fl. July-August.

I. Woods at Mucruss: Wade Rar. Ross Woods, and in several of the islands in the Lower Lake of Killarney: Mack. Rar. Kenmare (Prof. Harvey): Cyb. Several places along the river Flesk; in woods of Glenflesk Castle; south of Farranfore; in several spots on the south slopes of Slieve Mish mountains, Kerry : R.W. S. $2888 \&-80$. Mahony's Point, Killarney Lakes; Levinge. In the barony of Bere, Cork: Drummond 1819 -not recently found in Cork.-II. In the wood on the north side of the river between Cappoquin and Lismore: Smith's Waterford. On Bilberry rock near Waterford (Dr. Barker) : Templeton MS. - still there in 1886; A. $R$. Friel.-III. Banks by the roadside at Newrath near Gaul's Mills, Kilkenny (T. Chandlee): Cyb.-IV. Sparingly in a wood at Rosdroit, Wexford; at Curraghmore cross roads, Wexford: B.-H.\&M. I892. Near the head of Bannow Bay, Wexford; W. Mac Millan.-[V. Near Abbotstown, Co. Dublin : Wade Rar.not seen recently in Co. Dublin.-VI. In a wood by the riverside near Corronanagh, Clare: Wade Rar.]-X. On an old fort near Tartaraghan, Armagh (Rev. G. Robinson): Cyb. In considerable abundance on an old wooded rath near Crowhill, 1871, the same station as the preceding: Praeger I893.-XI. Amongst hazel near the east shore of Lough Fern, 1889 (Mrs. Leebody): Journ. of Bot. 1892. At Port Salon; Mrs. Leebody.-XII. Shane's Castle woods 
by Lough Neagh: Wade Rar. Sparingly by the Bann, both above and below the bridge, at Kilrea, Derry, 1835: Moore MS. Refound at Kilrea in $\mathbf{1 8 9 3}$ in some abundance in several pasture fields (Mrs. Leebody): S. \& P. I895. Roadside near Broughshane, Antrim, 1896 (Rev. S. A. Brenan): Ir. Nat. $x 896$.

\section{S. palustris Linn.-Marsh Woundwort.}

Districts I. II. III. IV. V. VI. VII. VIII. IX. X. XI. XII. Lat. $51 \frac{1}{2}^{\circ}-55 \frac{1}{4}^{\circ}$. Throughout Ireland. Type, British.

Damp ground, by rivers and ditches, and in cultivated land; common. Fl. July-August.

Sea-level in N. Antrim and S. Cork. To $800 \mathrm{ft}$. in Donegal (Hart) and in Dublin (N. C. .):

S. ambigua Smith-S. patustris $\times$ sylvatica-I. Ballincollig, Cork (J. Sullivan): Annot. in Floy Cork.-II. Near Trabolgan, 1896; Phillips. Near Fermoy (T. Chandlee); and-III. Archer's grove and Kilmanagh, Killsunny (Rev. S. Madden): Cyb.IV. Greystones, Wicklow; Morte.-V. North of Balscadden, Co. Dublin (Praeger): Ir. Aat.' I894. Glenasmole, Co. Dublin; Greenwood Pim. Brackenstown wood; near Killiney, 1894, \&c.; not infrequent in Co. Dublin; N.C.-VII. Near Ballymahon, Longford: $B . \& P .1887 .-\mathrm{X}$. Roadside at Silverwood, near Lurgan, Armagh (Rev. H. W. Lett) : Praeger $1893 .-\mathrm{XII}$. Near Muff in Faughanvale, Derry: Moore MS. Several stations in Down and Antrim : Flor. N.-E. Roadside bank near Belfast (Stewart): B. Ex. C. Report 1889 .

Probably occurs throughout Ireland in one or other of its forms. The Irish plant is usually closer to S.palustris than to S. sylvatica, and so departs from typical S. ambigua (Smith). To this latter belong Mr. Praeger's plants from Balscaddan and Silverwood and Mr. Stewart's from Belfast.

\section{S. sylvatica Linn.-Hedge Woundroort.}

Districts I. II. III. IV. V. VI. VII. VIII. IX. X. XI. XII. Lat. $511_{2}^{\circ}-55 \frac{11^{\circ}}{\circ}$. Throughout Ireland. Type, British.

Woods, hedges, and shady places; frequent. Fl. JulyAugust.

Sea-level in Derry and S. Cork. To $650 \mathrm{ft}$. in Dublin (N. C.); but usually lowland. 


\section{S. arvensis Linn.-Field Woundwort.}

Districts I. II. III. IV. V. VI. VII. VIII. IX. X. XI. XII. Lat. $511^{\circ}-551^{\circ}$. Throughout Ireland. Type, British.

Cultivated land, especially in light soils; rather frequent and locally abundant. F $F$. August-September. Calcifuge $B$.

Occurring in almost all of the maritime counties and abundantly in many; much rarer inland and less frequent in the East than in the West.

Sea-level in N. Antrim and S. Cork. To $950 \mathrm{ft}$. in Dublin (N.C.); but usually lowland.

\section{GALEOPSIS Linn.}

1. G. angustifolia Ehrh.-Red Hemp-nettle.

G. Ladanum Linn. in part.

Districts - II. III. IV. V. - - - - - Lat. $51 \frac{3}{4}^{\circ}-53 \frac{1}{2}^{\circ}$. South-East, chiefly. Type, English-British.

Lowland. Corn fields and shingly and gravelly places; rare. Fl. August-September. Calcicole $A$.

II. Little Island, Cork, 1854-56 (J. Sullivan) : Annot. in Flor. Cork-not seen recently in Cork.-III. Bellevue and Freshford, Kilkenny (Rev. S. Madden) : $C y b$. On the esker at Maryborough, Queen's Co. (Praeger): Ir. Nat. 1893.-IV. Near Greystones, Wicklow (Moore) : $C y b$. Every year in wheat crops at Fassaroe near Bray (Barrington): Rec. Add. A single plant at Caim, Wexford: Moffat 1889.-V. Among crops near the shore at Malahide, abundantly; by the roadside and in hedge banks and field borders between Chapelizod and Luttrellstown, and elsewhere: Wade Dubl. Feltrim Hill; lands at Peatown; broken grounds at Howth: Ir. Flor. In several stations at Howth, 1869 and 1884 (H(art): Flor. Howth \& MS. Side of Knockmaroon Hill (Mr. Templeton); gravelly banks near Cardiff's Bridge: Flor. Hib. At Dundrum near Dublin (Moore): Cyb. At Skerries, 1892; Dr. MoWeeney. At Clonsilla, 1884: Herb. R. P. Vowell. Gravelly margin of the Dodder, near Old Bawn, Co. Dublin, $1882 ;$ Rev. $W$. Colgan -abundant here in $1896 ; N . C$. By the railway north of Balbriggan and in a cornfield at Portrane, 1894 ; not infrequent in Co. Dublin; N.C. Frequent in cornfields at Ballitore, Kildare 
(J. Douglas): Cyb. Gravel pit near Kilmessan, Meath: Ir. Nat. 7896.

The Irish plant appears to be in all cases $G$. angustifolia. The broad-leaved form $G$. intermedia (Vill.), G. Ladanum of Linn, has not, so far, been ascertained to occur in Ireland.

\section{G. versicolor Curt.-Large-flowered Hemp-nettle.}

G. speciosa Mill.

Districts - - III. IV. V. - - VIII. IX. X. XI. XII. Lat. $52 \frac{3}{4}^{\circ}-55_{\frac{1}{4}}^{\circ}$. North Ireland, chiefly. Type, English-Germanic.

Lowland. Cultivated ground; local. Fl. July-August.

III. Fields near the city of Kilkenny (Rev. S. Madden) : Cyb.IV. At Ferns, Co. Wंexford, 1891-96; G. E. J. Greene.-V. At Termonfeckin and Tullyesker near Drogheda ( $J . B$. Hamitton): Cyb. Ardee, Louth, 1897; Praeger. In potato fields near Glasnevin (Mr. Underwood): Mack. Cat. -not recently found in Co. Dublin.-VIII. Near Foxford, Mayo, but not common (More): Cyb.-IX. In potato fields near Sligo: Mack. Cat.-X. Common in Tyrone: Ball ${ }_{1} 839$. Common about Strabane, Tyrone (Mis8 M. C. Knowles): Ir. Nat. 1897. Tanderagee, Armagh (Rev. C. O'Meara); Bessmount, Monaghan (Miss Maffett) : Cyb.-XI. Frequent in Donegal: Ball 1839 \& Hart 1879 \& $0 .-X I I$. Abundant in many parts of Derry, especially near Dungiven, Kilrea, \&c., 1835 : Moore MS. Sparingly near the railway station, Dungiven, 1885 (Stewart): Flor. N.-E. In Co. Derry, between Kilrea and Maghera (Praeger); at Eglinton and near Enagh Lough (Mrs. Leebody): S.\&P. 1895. Frequent in sandy cornfields near Cushendall, Antrim, $1836:$ Herb. Moore. Still at Cushendall in 1890, also at Glenariff ; Ardclinis ; and Cushendun, Antrim, 1892 (Praeger): B. N. F. C. Proc. $1890-9 I$ \& $7892-93$. At Annalong, Down: Hart I884. At Six-road-ends near Conlig, Down : Stewart I894.

Also recorded for District I. from near Castle Island (Smith's Kerry); and for-II. Near Midleton (Allin's Cork), but the first record was probably an error, and at Midleton the plant appears to have been only a casual.

\section{G. Tetrahit Linn.-Common Hemp-nettle.}

Districts I. II. III. IV. V. VI. VII. VIII. IX. X. XI. XII. Lat. $51 \frac{1}{2}^{\circ}-55 \frac{1}{4}^{\circ}$. Throughout Ireland. Type, British.

Cultivated ground, waysides, \&c., chiefly in light soils; rather common. Fl. July-September. 
A very abundant weed in peaty soils.

Sea-level in Derry and S. Cork. To $700 \mathrm{ft}$. in Derry (Hart); to $1250 \mathrm{ft}$. in Dublin (N.C.).

Var. BIFIDA (Bcenn.). - I. Gouganebarra, S. Cork, 1897; Phillips.

\section{LAMIUM Linn.}

\section{I. amplexicaule Linn.-Henbit.}

Districts I. II. III. IV. V. VI. - - IX. X. XI. XII. Lat. 51골 ${ }^{\circ}-55 \frac{1}{4}^{\circ}$. From South to North. Type, British.

Lowland. Cultivated land and waste places, chiefly in sandy soils; rather rare. Fl. May-August.

I. In the Blasket Isles, Kerry: Barrington $788 \mathrm{r}$. Bro Head and Crookhaven ( $J$. Wright); Roberts' Cove (Carroll); Inish Sherkin and Toe Head: Allin's Cork. Abundant in potato fields between Goleen and Schull, 1880; Carroll. At Crookhaven, 1896; and-II. Plentiful near Ballycroneen, 1895; Phillips. Near Youghal railway station (Carroll): Allin's Cork.-III. At Maryborough, Queen's Co. (Praeger): Ir. Nat. 1893.-IV. Abundant on the Murrough of Wicklow (Moore): $C y b$. Saltee Island, Wexford: Hart 1883 B. Baginbun Head, Wexford : B. $\boldsymbol{H}$. \& $\boldsymbol{M}$. 1892.-V. Sandy and broken fields about Glasnevin; Finglas; Leixlip, \&c., Dublin: Ir. Flor. In sandy fields at Rush, 1893; Howth, Skerries, and Balbriggan, 1894; Portrane, 1895; not infrequent along the coast in Co. Dublin; N.C.-VI. Sparingly in sandy fallows at Muckinish, Ballyvaughan, $1895 ; N$. C.-IX. At Foxford, Mayo (More): Cyb.-X. Grange; Loughgall; Slieve Gullion, \&c., Armagh : Praeger 1893. Washing Bay, Lough Neagh, Tyrone (Miss M. C. Knowles): Ir. Nat. I897.-XI. Rossnakill and Fanet (Hart): Rec. Add. Tory Island: Barrington 1879. Ardmalin; Dooagh Island; and Inch Island, Inishowen: Hart 1883.-XII. By the side of Lough Foyle, Derry: Moore MS. Dungiven, Derry (Mrs. Leebody): S. \& P. 1895. In Co. Down, by Kilbroney river; at Killowen; Knockshee; Greencastle; Kilkeel, \&c.: S. \& P. 1892. In Co. Antrim, at Ballycarry and Glynn (Praeger); and abundant on the Curran of Larne (Stewart): Flor. N.-E.

Appears to be only a casual in Kerry. 
2. I. intermedium Fries-Intermediate Dead-nettle.

Districts I. - - - V. - VII. - IX. X. XI. XII. Lat. $52^{\circ}-55 \frac{1}{4}^{\circ}$. From South to North. Type, Scottish.

Lowland. Cultivated ground and waste places; rather rare. Fl. May-October.

I. Near Iniscarra, Cork, 1894; Phillips.-V. Abundant in sandy fields, at Rush, Co. Dublin : N. C. I895--VII. Lanesborough, Longford : B.\&V. 1887 . - IX. Near the base of Ben Bulben, Sligo : Ball 1839 . Cultivated fields at Mullaghmore, Sligo ( $\mathbb{M r}$. Syme): Flor. Ulst. Near Kinlough, Leitrim, rare: B.\&V. I885.X. Grange near Armagh (Rev. W. F. Johnson); and at Maghery : Praeger $1893 .-\mathrm{XI}$. Tory Island : Barrington 1879. Port-na-blagh, Dunfanaghy ; Ball Green, Rathmelton: Hart 1880. Dooagh Ioland and Ardmalin South: Hart $1883 .-$ XII. Frequent, occurring in numerous stations in Down, Antrim, and Derry : Flor. N.-E. and S.\&P. 1895 .

Apparently rare in Ireland, but no doubt often overlooked.

\section{L. purpureum Linn.-Red Dead-nettle.}

Hibernicé Neanc6rz caoċ (Nee-an-thōge kweeock), Blind Nettle. Districts I. II. III. IV. V. VI. VII. VIII. IX. X. XI. XII. Lat. $51 \frac{1}{2}^{\circ}-55 \frac{1}{4}^{\circ}$. Throughout Treland. Type, British.

Cultivated ground and waste places; common. Fl. AprilOctober.

Sea-level in Derry and S. Cork. To $950 \mathrm{ft}$. in Dublin ( $N . C$.).

\section{L. hybridum Vill.}

L. incisum Willd.

Districts I. II. III. IV. V. VI. - VIII. IX. X. XI. XII. Lat. $51 \frac{1}{2}^{\circ}-551^{\circ}$. Throughout Ireland, probably. Type, British.

Cultivated ground and waste places; not infrequent. Fl. April-September.

Probably occurs throughout Ireland, though much rarer than the preceding species to which, perhaps, not a few of the older records should be referred. 


\section{4. †L. album Linn.-White Dead-nettle.}

Districts I. - III. IV. V. - VII. - IX. X. XI. XII. Lat. 513 $\frac{3}{4}^{\circ}-55 \frac{1}{4}^{\circ}$. From South to North. Type, British-English.

Lowland. Roadsides, hedgerows, banks, \&c.; rare, but locally abundant. Fl. April-September.

I. Cultivated ground near Blackrock (T. Wright): Annot. in Flor. Cork. At Douglas (J. Sullivan): Cyb. Sparingly by the Bandon river far from any garden, 1896; Phillips.-III. Near Maryborough, Queen's Co.; Praeger. At Odogh, Kilkenny; andIV. Enniscorthy, Wexford (Rev. S. Madden): Cyb. Monart, Wexford: Moffat 1889 . Roadside at Clone near Ferns, Wexford, 1896; G. E. J. Greene. Near the bridge at Bray (Barrington): Rec. Add.-V. Glasnevin; Finglas, \&c. . Ir. Flor. Frequent in Co. Dublin and locally abundant, as round Castleknock and Finglas, and between Balbriggan and Balrothery, 1894; round Raheny, 1893, \&c.; N. C. Near Oldcastle, Meath (Moore); frequent near Ballitore, Kildare (Carroll): Cyb. Common about Kilkea, Kildare (J. Douglas); south shore of the Boyne below Drogheda; and near the Hill of Tara, Meath (More): Reo. Add.-VII. Knock Drin, Westmeath: Levinge I894. Banks of the Inny at Finea, Longford; Praeger.-IX. Near Sligo (J. Wynne) : Cyb. At Boyle, Roscommon; Praeger.-X. Abundant near Clones, Monaghan; T. H. Corry. Plentiful about Dungannon, Tyrone, 1896; Mrs. Leebody. Common in the limestone district of Co. Armagh: Praeger x893.-XI. Kilderry, Inishowen (W. E. Hart): Hart 1883.-XII. Frequent in north-east Ireland : Flor. N.-E.

\section{L. Galeobdolon Crantz-Yellow Weasel-snout.}

Galeobdobon luteum Huds.

Districts - - IV. V. - VII. - - - - -

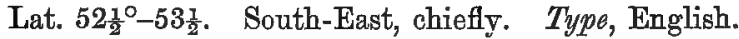

Lowland. Woods and shady damp places; rare, but locally abundant. Fl. April-June.

IV. Common in the lower part of the Dargle, 1804: Templeton MS.-and in $1896 ; R$. W. S. In the Powerscourt woods, Wicklow : Mack. Cat. Near Enniscorthy (J. Morrison): Cyb.-V. Among bushes beyond Roper's Rest: Threlkeld. In the wood at Luttrellstown [Woodlands]; and by hedges between Ballyboghil Bridge and 
Ashtown, and near Cardiff's Bridge : Wade Dubl. Near Rathfarnham (Dr. Aquila Smith); near the Salmon Leap at Leixlip (Moore); near Finglas (Rev. H. G. Carroll): Cyb. Kelly's Glen on the upper Dodder ( $W$. Archer): Rec. Add. Near Tymon Castle, Co. Dublin, 1890; near the old church at Artane, 1892; Miss $\boldsymbol{A}$. G. Kinahan. Near Drimnagh Castle, 1893 ; at Finglas, and very abundant in the demesne at Lucan, 1894; near Santry, 1895; abundant in Saint Catherine's woods, 1896 ; glens above Saggard, \&c.; locally abundant in Co. Dublin; N.C.-VII. Woods at Lough Ennel, Mullingar, Westmeath (Foot) : $C_{y} b$.-not seen there recently.

Chiefly in the southern half of County Dublin and the adjoining parts of County Wicklow.

First recorded by Threlkeld, from near Dublin city, in 1727.

\section{BALLOTA Linn.}

\section{1. $\ddagger$ B. nigra Linn.-Black Horehound.}

Districts I. II. III. IV. V. - VII. - - X. XI. XII. Lat. $51 \frac{3}{4}^{\circ}-55 \frac{1}{4}^{\circ}$. From South to North. Type, English.

Lowland. Hedge banks, roadsides, and waste places, usually near houses; rare. Fl. July-August.

I. Near Carrigaline, Cork: Drummond I819. Blackrock (Mr. Alexander); and-II. Sunday's Well ; East Ferry ; Belvelly Castle, Great Island: Flor. Cork. Ballyvodock, Midleton; Bridgetown Abbey; near Mallow : Allin's Cork. Roadside at Labard, Whitegate; Phillips.-III. Near Maryborough (Praeger): Ir. Nat. I893.-IV. Murrough of Wicklow (Moore): Cyb. Rosslare Point and Rosslare, Wexford: Hart $2883 \beta$.-V. "It grows in the Church-yard at Crumlin and under the Hedges about Glasnevin": Threlkeld. Howth; Kilgobbin, \&c.: Wade Dubl. Near Carrickmines, Dublin, 1887; Dr. MoWeeney. Near Crumlin, 1892; near Chapelizod and about Swords, 1893; well established at Skerries, 1893-95; Balbriggan, \&c. ; frequent in Co. Dublin; N.C. Near Timolin and Cookstown, Kildare (Carroll); near Drogheda (J. B. Hamizton) : Cyb.-VII. Near Turin, Westmeath (Miss E. Reynell): Cyb.-X. Belturbet, Cavan (Moore): Cyb.XI. Between Salthill and Ardnamona (Hart): Rec. Add.XII. Shore near Ardglass: Harris's Down I744. Ballinderry and roadside near Aghalee (Moore): Cyb. Hedges near Coleraine, an 
escape: Moore MS. Mill Bay and Killough Bay, Down (Stewart); Ballycastle and Bushmills (Praeger); and in numerous other stations in Antrim and Down: Flor N.-E. and S.\& P. 1895 .

Much grown in cottage gardens and probably in all cases an escape or outcast from cultivation.

The Irish plant is $B$. foetida (Lamk.). The variety $B$. ruderalis (Sw.) has not, so far, been recorded for Ireland.

\section{TEUCRIUM Linn.}

\section{T. Scordium Linn.-Water Germander.}

Districts - - - - VI. VII. - IX. - - Lat. $52 \frac{3}{4}^{\circ}-53 \frac{3}{4}^{\circ}$. Middle Ireland. Type, Germanic-English.

Lowland. Rocky and gravelly lake shores, also by riversides; locally abundant. Fl. July-August.

VI. On the banks of the Shannon near Limerick: $K^{\prime} E$ Eogh. For several miles along the Shannon above and below Portumna Bridge (Moore) : Phytol. I845, p. I29. Near the bridge at Portumna, and thence along the west shore of Lough Derg, plentiful (Moore): $C y b$. Very abundant along the western shores of Lough Derg and on the adjacent islands from Portumna, Galway, to Rineacrush Point, Clare, 1896: N. C. I897. Edge of a small lake near Glanquin, Clare (P.B. O' Kelly) : Levinge I894.-VII. Marshy grounds near the bridge of Portumna, Tipperary : Mack. Rar. Very abundant along the eastern shore of Lough Derg and on the adjacent islands from Derry island to Ryan's Point, Tipperary, 1896: $N$. C. 1897. Abundant on the islands and shores of Lough Ree, and below the bridge at Athlone on the banks of the Shannon: $B . \& V$. 1887.-IX. Banks of the Shannon near Lanesborough fide $I . B$. [Isaac Butler]: Annot. in Threlkeld. Banks of Lough Ree near Knockroghery, Roscommon; $R$. Bayly.

Also recorded for District II. in Smith's "Cork" and "Waterford," from the "River Bride east of Castle Lyons" and from a "brookside between Lismore and Tallow, Waterford." The plant is again recorded from the Castle Lyons station by Wade (Plante Rariores 7804 ), but as it has not recently been observed either in Cork or Waterford it is to be feared that some mistake was made.

Almost confined to the Shannon basin, where it occurs in great profusion on the shores of Loughs Ree and Derg. 


\section{T. Scorodonia Linn.-Wood Sage.}

Distriets I. II. III. IV. V. VI. VII. VIII. IX. X. XI. XII. Lat. 511을 $-551^{\circ}$. Throughout Ireland. Type, British.

Woods, heaths, and bushy and stony places; locally abundant. Fi. July-August.

Sea-level in Derry and S. Cork. To $1100 \mathrm{ft}$. in Donegal (Hart); to $1400 \mathrm{ft}$. in Down (S.\&P.); to $1600 \mathrm{ft}$. in Tipperary (Hart).

$A$ widespread species, yet absent over large areas.

\section{AJUGA Linn.}

\section{A. reptans Linn.-Common Bugle.}

Districts I. II. III. IV. V. VI. VII. VIII. IX. X. XI. XII. Lat. $51 \frac{1}{2}^{\circ}-55 \frac{1}{4}^{\circ}$. Throughout Ireland. Type, British. June.

Woods and damp shady places; rather common. Fl. May-

Sea-level in Derry and S. Cork. To $650 \mathrm{ft}$. in Derry, to. $1300 \mathrm{ft}$. in Queen's Co., and to $1700 \mathrm{ft}$. in Tipperary (Hart).

\section{A. pyramidalis Linn.-Pyramidal Bugle.}

Districts - - - - VI. - - - - - Lat. $53^{\circ}-53^{\circ} 10^{\prime}$. Clare and Aran Isles only. Type, Scottish.

Lowland. Shady places in limestone rocks; very rare. $F l$. May-June.

VI. Sparingly near Kilronan, on the east side of the Great Island of Aran in Galway Bay (Moore): Phytol. 1854, p. I9o \& Cyb. One plant near Creggacareen, west of Kilronan, Aranmore island, 1892 (N. C.) : Journ. of Bot. $7892, p .3$ ro. Sparingly by the new coast road near Poulsallagh, south of Black Head, Clare : Foot I864. Near Poulsallagh, 1893 ; Dr. Leitch. In abundance near Ballyryan, Clare, 1894 (P. B. O' Kelly): B. Ex. C. Rep. I895.

First found by David Moore, in Aranmore Island, in 1854.

With many other alpine or sub-alpine species, descends to, or near to, sea-level at a low latitude in the Burren district of Clare. Widespread in Scotland and often descending to low levels; but not found south of latitude $54 \frac{1}{2}$ in Great Britain. Sub-alpine in Switzerland and Norway, where it ranges upwards to $5000 \mathrm{ft}$. 


\section{ORDER LII.-PLANTAGINEE.}

PLANTAGO Linn.

\section{P. major Linn.-Way-bread.}

Districts I. II. III. IV. V. VI. VII. VIII. IX, X. XI. XII. Lat. $51 \frac{1}{2}^{\circ}-55 \frac{1}{4}^{\circ}$. Throughout Ireland. Type, British.

Pastures, waysides, and waste places; common. Fl. June-Aug.

Sea-level in N. Antrim and S. Cork. To $1150 \mathrm{ft}$. in Derry (Hart); to $1600 \mathrm{ft.}$ in Dublin (N.C.).

Var. INTERMEDIA (Gilib)-I. Lake shore at Killarney: R.W.S. I888.-V. On the shore at Malahide, Dublin; More.-XII. On the shore of Lough Neagh at Crumlin waterfoot (Stewart): S.\& P. I895.

\section{2. * P. media Linn.-Lamb's Tongue.}

Districts [I.],[II.] - - V. VI. - VIII. IX. X. XI. Lowland. "Pastures, banks, and waysides; rare. Fl. June-Aug. [I. Occasionally near Cork, as at Douglas, \&c. : Allin's Cork.II. One plant on a lawn at Fota, Cork; Phillips.]-V. Abundant in a field and on a furzy bank north of Straffan, Kildare (J.Douglas): Rec. Add. Tennis ground at Kingstown; R.W.S.-VI. Some hundreds of plants in an old pasture near Ballycahill, Clare, 1888; P. B. O'Kelly.-VIII. Near Cong mill-pond; and-IX. Tennis ground at Lisloughrey Mayo; Miss M. $F$. Jackson. Pasture near Hollymount house, Mayo (More): Cyb. Roadside bank near Cliffony, Sligo, $1896 ;$ N.C.-X. Lawn at Allan Rock, Dungannon, Tyrone; Rev. S. A. Brenan.-XI. Near the house at Glenalla: Hart I879.

Probably introduced with grass seed in all cases. Appears to be naturalized in some of its stations and to be spreading in Ireland.

\section{P. lanceolata Linn.-Rib-wort Plantain.}

Hibernicé Slan lur (Slawn loos), Healing Plant.

Districts I. II. III. IV. V. VI. VII. VIII, IX. X. XI. XII. Làt. $51 \frac{1}{2}^{\circ}-55 \frac{1}{4}$. Throughout Ireland. Type, British.

Pastures, waysides, waste places, \&c. ; common. Fl. May-July.

Sea-level in N. Antrim and S. Cork. To $1450 \mathrm{ft}$. in Derry, and to $2250 \mathrm{ft}$. in Mayo (Bart). 


\section{P. maritima Linn.-Sea Plantain.}

Districts I. II. III. IV. V. VI. - VIII. IX. X. XI. XII. Lat. $51 \frac{1}{2}^{\circ}-55 \frac{1}{4}^{\circ}$ - Coasts of all Ireland. Type, British.

Muddy and rocky seashores; common. Also occurs occasionally inland on mountains and lake shores. F'. June-September.

VI. Common on rocky pastures about Castle Taylor '(MLore): Cyb. On Yellow Island and Maunmore, Lough Derg: $N$. C. 7897.-VIII. Shores of Loughs Cullin and Conn, Mayo (More): Cyb. South shore of Lough Mask : M.\&. S. 1896.-IX. Shores of Lough Carra, Mayo (More) : Cyb. Plentiful on many of the cliffs in Ben Bulben District: B. $\&$. I885-XII. On Carntogher, Derry: Moore MS.

Of the above inland stations, Ilaunmore, Lough Derg, is 25 miles, and Carntogher, 16 miles, from the nearest sea.

To $1500 \mathrm{ft}$. in Derry (Moore); to $1650 \mathrm{ft}$. in Donegal, and to $2600 \mathrm{ft}$. in Mayo (Hart).

\section{P. Coronopus Linn.-Buck's Horn Plantain.}

Districts I. II. III. IV. V. VI. - VIII. IX. 'X. XI. XII. Lat. $51 \frac{1}{2}^{\circ}-55 \frac{1}{4}^{\circ}$. Coasts of all Ireland. Type, British.

Pastures, banks, and rocks near the sea; common. Also on basaltic cliffs. Fl. June-August.

From sea-level to $1150 \mathrm{ft}$. in Derry (Hart).

\section{LITTORELIAA Berg.}

\section{L. lacustris Linn.-Shore-weed.}

L. juncea Berg.

Districts I. II. - IV. - VI. VII. VIII. IX. X. XI. XII. Lat. $51 \frac{1}{2}^{\circ}-55 \frac{1}{4}^{\circ}$. From South to North. Type, British.

Sandy or gravelly lake margins; frequent. Fl. June-July.

Descends to $50 \mathrm{ft}$. in Antrim and to sea-level in S. Cork. Ascends to $1050 \mathrm{ft}$. in Donegal (Hart); to $1350 \mathrm{ft}$. in Down $(S . \& P$.$) ; to 1900 \mathrm{ft}$. in Wicklow (N.C.); to $1800 \mathrm{ft}$. in Galway, and to $1850 \mathrm{ft}$. in Tipperary (Hart).

More frequent in mountain than in lowland districts, but occurs in many of the larger low-lying lakes, such as Loughs Ree and Derg on the Shannon, Lough Erne, Lough Neagh, Lough Derevaragh, \&c. Rare in the East. 


\section{ORDER LIII.-ILLECEBRACE五.}

\section{SCLERANTHUS Linn.}

\section{1. †S. annuus Linn.-Knarvel.}

Districts I. II. - IV. V. ---- X. XI. XII. Iat. $51 \frac{1}{2}^{\circ}-55 \frac{1}{4}$. From South to North. Type, British.

Lowland. Corn fields and waste places in sandy or gravelly soils; local. Fl. June-August.

I. At Glandore, and by the Bandon river east of Dunmanway : Allin's Cork. Roadside east of Skibbereen, $1896 ;$ R.W.S.II. Great Island: Flor. Cork. Fields near Blarney (R. Mills): Allin's Cork.-IV. Murrough of Wicklow : Moore \& More 1878 . $V$. Between Baldoyle and Howth; and in and about the Black Quarries on Tiernan's Hill, Collon: Ir. Flor. Near Warren Lodge and Kilbarrack, occasionally : Flor. Howth. On gravelly tracks at Castle Kelly, Glenasmole, Co. Dublin : N. C. I895.-X. Lurgan, Co. Armagh : Hind I854.-XI. Roadside between Croaghross and Rossnakill (Hart): Rec. Add.-XII. In great plenty : Harris's Down 1744. Rostrevor; Dundrum, Down; near Toome, Antrim; Draperstown, Derry; frequent in the North-East: Flor. N.-E.

Rare and uncertain in its appearances outside of District XII.

\section{ORDER LIV.-CHENOPODIACE正.}

\section{CHENOPODIUM Linn.}

1. C. album Linn.-White Goose-foot.

Districts I. II. III. IV. V. VI. VII. VIII. IX. X. XI. XII. Lat. $51 \frac{1}{2}^{\circ}-55 \frac{1}{4}^{\circ}$. Throughout Ireland. Type, British.

Cultivated and waste land; common. Fl. July-September.

From sea-level to $1250 \mathrm{ft}$. in Dublin $(N . C$.).

The forms of this variable species have been little studied in Ireland. C. candicans (Lamk.), the typical form, appears to be the most common, but C. viride (Linn.) is of frequent occurrence. 


\section{C. rubrum Linn.-Red Goose-foot.}

Districts I. II. - IV. V. VI. VII. - - - Lat. $52^{\circ}-53 \frac{1}{2}^{\circ}$. Southern half of Ireland. Type, English-Germanic.

Lowland. Moist ground and waste places, chiefly near the sea; rare. Fl. August-September.

I. Akeragh and Rahaneen near Ardfert, and sparingly near Ballybunnion, Kerry: R.W. S. I888.-II. Spike Island, Cork Harbour (Carroll): $C y b .-\mathrm{IV}$. Waste ground near the sea at Raven Point, Wexford: Hart $188 \mathrm{I}$ a. Rosslare; Bar of the Lough; and abundant on the Great Saltee Island, Wexford: Hart ${ }_{1} 88_{3} \beta$.- -V. By the south bank of the Liffey at its mouth (More); in several places from Howth to the Liffey mouth, and on the coast near Balbriggan (Moore): Cyb. In Co. Dublin, by Brittas ponds; wet ground by the Ward river near Chapelmidway; and by the canal at Hazelhatch: N. C. I893. Abundant in marshy meadows below the railway bridge at Drogheda, and plentiful about Baltray, Louth : Praeger 1897.-VI. On a turlough between Newtown, Gort, and Loughmanna, Clare; P. B. O' Kelly. In great abundance on the muddy margin of the lake at Port Couragh, Aranmore Island : Praeger 1805.-VII. Wet ground by the shores of Lough Drin and Lough Derevaragh, Westmeath: Linton I896.

Var: PSEUDO-BOTRYOIDES H. C. Watson.-I. Among stones at east end of Derrymore island, Tralee Bay, Kerry : $R$.W. S. 1888 II. Waste ground at Kilcoleman Castle, sparingly (Carroll \& Allin): Allin's Cork.-IV. Rosslare sand-hills, Wexford: Marshall I896.

\section{C. Bonus-Henricus Linn.-All-good.}

Districts I. II. - IV. V. VI. VII. - IX. - XI. XII. Lat. $51 \frac{1}{2}^{\circ}-55 \frac{1}{4}^{\circ}$. From South to North. Type, British-English.

Lowland. Roadsides and waste places near dwellings or ruins; frequent. Fl. June-August.

I. At Kenmare and Killarney, but rare in Kerry; $R$.W. S. On the Little Skelligs Rock, eight miles from the Kerry mainland (Rev. A. Delap): Ir. Nat. 1893. Near Kinsale and Durrus: Allin's Cork. Well established near Bandon, 1897; Phillips.II. Roadside at Carrigtwohill: Flor. Cork 1845 -and in 1896; Phillips. On the quays at Cork, $1889-97 ;$ R.W.S. Castletownroche, 1897; Phillips.-IV. Old Connaught, Bray; More. 
Fethard, Wexford: Hart 1883 B.-V. In the town of Glasnevin: Threlkeld. Abundant about Balrothery near Balbriggan, 1894, and not infrequent near hamlets and villages in Co. Dublin; N. C.VI. Abundant in the barony of Tullagh, Clare: $K^{\prime}$ Eogh. At Castle Taylor: More 1855--VII. Near Multyfarnham, Westmeath : Levinge 1894.-IX. Roadside near the Neale, and between Ballinrobe and Creagh, Mayo; Miss M. F. Jackson. Roadside at Ballysodare, Sligo, $1896 ; N$. C.-XI. Plentiful in Culdaff village and by roadsides to the south: Hart 1883 .-XII. In numerous stations in the North-East, but not common: Flor. N.-E. and S.\&.P. 1895.

Long established in many places in the neighbourhood of old churches and monasteries, but in all cases a relic of cultivation.

\section{BETA Linn.}

\section{B. maritima Linn.-Sea-Beet.}

Districts I. II. - IV. V. VI. - VIII. IX. X. XI. XII. Lat. $51 \frac{1}{2}^{\circ}-55 \frac{1}{4}^{\circ}$. Coasts of all Ireland. Type, British-English.

Rocky and gravelly sea-shores; frequent. Fl. July-September.

\section{ATRIPLEX Linn.}

\section{A. littoralis Linn.-Grass-leaved Sea-Orache.}

Districts I. - - IV. V. VI. - - - - - XII. Lat. $52^{\circ}-54 \frac{3}{4}^{\circ}$. Coasts from South to North. Type, British.

Muddy seashores and salt marshes; local. Fl. July-September.

I. Shores of Hop Island (Carroll): Cyb.-IV. At the mouth of the river below Newtown Mountkennedy, Wicklow (Moore): Cyb. Raven Point, Wexford: Hart I88I a. Tacumsin; Kilmore; and Hook Head, Wexford : Hart $2883 \beta$.-V. At the south-west side of Howth: Wade Rar. 7804 -still there in $1895 ; N . C$. Near the mill at Portmarnock, and near Balbriggan (Moore): $C y b$. At the extreme end of the North Bull, Dublin Bay, 1878; More.VI. Scattery island, Shannon estuary: Stewart I890.-XII. Seashore below Bangor, 1797 (Templeton): Whitla MS. Seashore near Newcastle : Hind 2854 . At Newcastle railway station, very rare: S. \& P. 1892. Between Belfast and Hollywood: Ball 1839 . Abundant on the Kinnegar of Hollywood, Down; at Macedon Point and Kilroot, Antrim (Stewart): Flor. $N_{0}-E$. 


\section{A. erecta Huds.-Upright Orache.}

A. patula Linn.

Districts I. II. III. IV. V. VI. - VIII. IX. X. XI. XII. Lat. $51 \frac{1}{2}^{\circ}-55 \frac{1}{4}$. Throughout Ireland, probably. Type, British.

Cultivated and waste ground; common. Fl. July-September.

Var. ANGUSTIFOLIA ' (Smith)-Throughout Ireland and apparently more common than the type.

Sea-level to $1250 \mathrm{ft}$. in Dublin (N.C.).

\section{A. hastata Linn.-Halbert-leaved Orache.}

A. patula Smith.

Districts I. II. III. IV. V. VI. VII. VIII. IX. X. XI. XII. Lat. $51 \frac{1}{2}^{\circ}-55 \frac{1}{4}^{\circ}$. Throughout Ireland. Type, British.

Cultivated and waste ground; frequent. Fl. July-September.

Var. DELTOLEA (Bab.). Recorded from the coasts of Dublin, Wicklow, Waterford, Cork, Donegal, Derry, Antrim, and Down, and probably occurs in all our maritime counties.

\section{A. Babingtonii Woods-Babington's Sea-Orache.}

Districts I. II. - IV. V. VI. - VIII. IX. X. XI. XII. Lat. $511^{\circ}-55 \frac{1}{4}^{\circ}$. Coasts of all Ireland. Type, British.

Gravelly and sandy seashores; common. Fl. July-September.

\section{A. farinosa Dum.-Mealy Sea-Orache.}

A. arenaria Woods-A. Taoiniata Linn. in part.

Districts - - - - V. - - - - - XII. Lat. $53 \frac{1}{2}^{\circ}-55 \frac{1}{4}^{\circ}$. East coast only. Type. British-Local.

Sandy seashores; rare. Fl. July-September.

V. Shore at Knockingen and Balbriggan : Mack. Rar. At the Martello Tower below Sutton, and between Howth and Baldoyle: Ir. Flor.-not seen recently in these stations. Sandy shore at Portrane and Gormanstown, and south bank of the estuary below Drogheda, but quite rare (More): Rec. Add. Sands at the Boyne mouth: Praeger 1897. Several plants at Lurgan Green, Louth, 1893 ; Cecil Butler. Skerries, 1892; D. McArdle.-XII. Shore of Island Magee, 1808; sands north of Newcastle, 1805; and seashore a mile below Bangor: Templeton MS. Still on the shore 
below Bangor at Ballyholme: Flor. N.-E. I888. On the shore near Newcastle: Butler I89o. Hollywood and Groomsport, Down: Flor. Belf. Shore south of Millisle, and still at Groomsport (Praeger): S, \& P. I895. Seashore opposite Gunn's Island, south of Strangford, and sparingly north of Greencastle (Stewart): Flor. N.-E. Red Bay; Cushendun; and Bushfoot, Antrim (Praeger): B. N. F.C. Proc. I892-93. Foraff, Antrim (Miss Knowles): S. \& P. 1895. Whitepark Bay, Antrim (Praeger \& Carr): Ir. Nat. 1897. Decreasing in Ireland, with many others of our littoral species.

\section{A. portulacoides Linn.-Sea Purslane.}

Obione portulacoides Moq.-Halimus portulacoides Wallr.

Districts I. II. - IV. V. VI. - - - [X.] - XII. Lat. 52 $2^{\circ}-541^{10}$. South and East coasts, chiefly. Type, English.

Salt marshes and muddy seashores, also on sea cliffs; locally abundant. Fl. July-September.

I. Near the exit of the river Mang [Maine] not far from Calnafersy: Smith's Kerry. Coast between Dingle and Castlemaine Bay (Moore): Cyb. Sparingly on the shore between Currabinny and Ring, Cork, $1895 ; R . W . S .-I I$. Marsh by the river at Ballinacurra: Flor. Cork. By the mouth of the Fanisk river, Youghal; at Knockadoon; and on the shore near Ahanesk: Allin's Cork. On rocks near Ballycotton, and plentiful in a salt marsh at Rostellan, Cork (Carroll): Cyb. Strand at Cork Beg, 1896, and by the estuary at Saleen; Phitlips. Strand at Tramore, Waterford (Dr. Barker): Templeton MS. \& Cyb. Salt marsh near Helvick Head, Waterford, $1893 ;$ J. E. Grubb.-IV. On an island rock a little north of Cahore Point, Wexford: Hart $188 \mathrm{x}$ a.-V. Among the rocks of Howth facing Dublin Bay, 1799: Templeton MSS. At the Martello Tower below Sutton: Ir. Flor. I833-still there on clay banks and on a sea stack, 1896 ; Miss S. Colgan. Rocks at the south side of Portrane and on the flat shore at the north end; also on the south side of the estuary below Drogheda (More): Rec. Add. At Laytown, Drogheda (Carroll): $C y b$. In great profusion near the head of the Rogerstown estuary, Co. Dublin, $1893 ; N$. C. Salt marsh on the south side of Dundalk Bay: Templeton MS.abundant here in 1896 ; Praeger. Salt marsh near Castle Bellingham, Louth: Butler $1890 .-$ VI. Rhyn Point near Ballyvaughan, Clare, $1895 ; P . B$. O'Kelly.-[X. A single plant near Narrow Water, Co. Armagh : Praeger 1893.]-XII. Plentiful by the canal 
below Narrow Water Castle, Down (Stewoart): B.N.F.C. Proc. 1882-83-abundant here from Newry to near Warrenpoint; plentiful on the shore north of Dundrum, Down (R. Hanna): S.\& P. 2895 .

Very rare in the West and absent from the North.

\section{SALICORNIA Linn.}

1. S. herbacea Linn.-Glass-wort.

Districts I. II. III. IV. V. VI. - VIII. IX. X. XI. XII. Lat. $511_{2}^{\circ}-55 \frac{1}{4}^{\circ}$. Coasts of all Ireland. Type, British.

Muddy seashores; common. $F l$. Angust-September.

The Var. PRocumbens (Smith) is also of frequent occurrence.

\section{SU ADA Forsk.}

1. S. maritima Dum.-Sea Blite.

Chenopodina maritima Moq.-Sohoberia maritima Mey.

Districts I. II. - IV. V. VI. - VIII. IX. - XI. XII. Lat. $51 \frac{1}{2}^{\circ}-55 \frac{1}{4}^{\circ}$. 'Coasts of all Ireland. Type, British.

By the sea in muddy and rocky places; frequent. Fl. July-Sept. To nearly $500 \mathrm{ft}$. on the Tearaght Rock, Kerry: Barrington $188 \mathrm{I}$.

\section{SALSOLA Linn.}

1. S. Kali Linn,-Salt-wort.

Districts I. II. - IV. V. VI. - VIII. IX. - XI. XII. Lat. $51 \frac{1}{2}^{\circ}-55 \frac{1}{4}^{\circ}$. Coasts of all Ireland. Type, British-English.

Sandy sea-shores; frequent. Fl. July-August.

\section{ORDER LV.-POLYGONACEE.}

\section{POLYGONUM Linn.}

\section{P. Convolvulus Linn.-Black Bindweed.}

Districts I. II. III. IV. V. VI. VII. VIII. IX. X. XI. XII. Lat. $51 \frac{1}{2}^{\circ}-55 \frac{1}{4}^{\circ}$. Throughout Ireland. Type, British.

Cultivated ground and waste places; frequent. Fl. July-Sept. Sea-level in Donegal and Cork. To $950 \mathrm{ft}$. in Dublin (N. C.). 


\section{P. aviculare Linn.-Knot-grass.}

Districts I. II. III. IV. V. VI. VII, VIII. IX. X, XI. XII. Lat. $51 \frac{1}{2}^{\circ}-55 \frac{1}{4}^{\circ}$. Throughout Ireland. Type, British.

Fields, waysides, \&c.; common. Fl. June-September.

Sea-level in Donegal and Cork. To $950 \mathrm{ft}$. in Dublin (N.C.).

A very variable species, the different forms of which have been little studied in Ireland. The varieties LITTORAIE ( $\operatorname{Lin} k$ ), ARENASTRUM (Bor.), and RURIVAGUM (Jord.) have been recorded for Co. Down, and are probably frequent throughout Ireland.

\section{P. Raii Bab.-Ray's Sea Knot-gras8.}

$P$. Roberti Loisel.

Districts I. II. - IV. V. VI. - VIII. - - XI. XII. Lat. $51 \frac{3}{4}^{\circ}-55 \frac{1}{4}^{\circ}$. Coasts of all Ireland, probably. Type, British.

Sandy sea-shores; not infrequent. Fl. August-September.

I. Below Camp on the Dingle promontory, Kerry : Hart 1884 . Sandy point near Ardgroom harbour, Cork (More): Rec. Add.II. Ballycotton, and Ring Point, Youghal (as P. maritimum): Flor. Cork. Frequent on the Waterford coast: Cyb. \& Hart I883 B.IV. On the shore of the Murrough of Wicklow (Moore): Cyb. Wexford coast, at Hook Head; Greenore; and Sandeel Bay: Hart 1883 B. - V. Killiney Bay (as $P$. maritimum): Brit. Flor. 1842 . Not infrequent on the coast of Co. Dublin: Cyb.: Flor. Howth, \&o. Shore south of Gormanstown (More): Rec. Add.-VI. Near Kilronan, Aranmore Island : Oliver $185 \mathrm{I}$. In Co. Clare, at Miltown Malbay (Prof. Harvey); and at Lahinch (C. Carter): Cyb.VIII. On the coast near Galway (Prof. Graham): Cyb.-XI. and XII. Not infrequent on the coasts of Donegal, Antrim, and Down.

Some of the above records are probably referable to the $V a r$. ARENASTRUM of the preceding species.

\section{P. Hydropiper Linn.-Biting Persicaria.}

Hibernicé Jluıneac̉ ce1ட (Gloon-yack-tchai), Hot Kneed-plant. Districts I. II. III. IV. V. VI. VII. VIII. IX. X. XI, XII. Lat. $51 \frac{1}{2}^{\circ}-55 \frac{1}{4}^{\circ}$. Throughout Ireland. Type, British.

Watery places and damp waste ground; common. Fl. AugustSeptember, Calcifuge $A$, 
Sea-level in Derry and S. Cork. To $900 \mathrm{ft}$. in Donegal, and to $1500 \mathrm{ft}$. in Tipperary (Hart).

An abundant species in non-calcareous soils, but rare or absent over large areas.

\section{P. minus Huds.-Narrow-leaved Persicaria.}

Districts I. II. III. IV. V. VI. - VIII. IX. X. XI. XII.

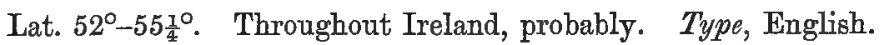

Lowland. Damp, boggy, or gravelly places; rare. Fl. JulySeptember.

I. Shore of Ross Bay, Lower Lake, Killarney: R.W. S. 1888 . Ballincollig Castle near Cork (Carroll): Cyb.-II. Near Cork (Drummond) : Flor. Cork.-III. Wet hollows on the Great Heath of Maryborough, Queen's Co.. Praeger 1897.-IV. Near Enniskerry (J. Ball): Cyb.-V. Near Roberstown, Kildare (Moore): Cyb.-VI. About Tuam, Co. Galway : Ir. Flor.-VIII. and IX. On the shores of Lough Cullin, Mayo (More): Cyb.-IX. Near Sligo (J. Wynne): Cyb.-X. Shores of Castleblayney Lake at Church Hill, Monaghan, 1805: Templeton MS. Sparingly at Gubbaroe Point, Kesh, Lough Erne: Barrington 1884. In Co. Armagh, by the eanal between Scarva and Tanderagee (Stewart); shores of Clay Lake near Keady, and of Lough Neagh at Raughlan Point: Praeger 1893. Plentiful on the shore of Virginia water, Cavan: Praeger 1897.-XI. Near Malin Well, and between Gweedore and Dunglow (Dickie): Flor. Ulst.-XII. Ballygowan Lake, Down, 1807: Templeton MS. Sparingly by the Bann above the Cutts, Co. Derry: Moore MS. Abundant by Mon Lough, Down (Stewart): Cyb. Downpatrick, and by the Newry canal (Stewart); Ballynahinch, and by the lake at Clandeboye (Praeger): Flor. $N$.-E .

Often confounded with the preceding species and perhaps. frequent throughout Ireland.

\section{P. mite Schrank-Mild Persicaria.}

Districts - - - - - - - - X. - Lat. $53 \frac{3}{4}^{\circ}$. Co. Cavan only. Type, Germanic.

Lowland. Stony lake shores; very rare. $F$. August-Sept.

$X$. On the stony shores of Lough Ramor, growing with $P$. minus: Praeger 1897.

Mr. Praeger's locality is, so far, the only one known for Ireland. 


\section{P. Persicaria Linn.-Spotted Persicaria.}

Hibernicé Jlumeać oeanz (gloon-yack dharrig), Red Kneed-Plant. Districts I. II. III. IV. V. VI. VII. VIII. IX. X. XI. XII. Lat. $51 \frac{1}{2}^{\circ}-55 \frac{1}{4}^{\circ}$. Throughout Ireland. Type, British.

Waste and damp ground, and cultivated fields; common. Fl. June-September.

Sea-level in N. Donegal and S. Cork. To $1250 \mathrm{ft}$. in Dublin (N. C.).

\section{P. lapathifolium Linn.-Glandutar Persicaria.}

Districts I. II. - IV. V. - - VIII. IX. X. XI. XII. Lat. $52^{\circ}-55 \frac{1}{4}^{\circ}$. From South to North. Type, British-English.

Lowland. Cultivated ground, especially in peaty soil ; frequent. Fi. July-September.

Not always distinguished from coarse forms of the preceding species and probably occurs throughout Ireland.

\section{P. maculatum Trimen \& Dyer.}

$P$. nodosum Reichb.-P. laxum Bab.

Districts I. - III. IV. - - - - - - XII.

Lowland. Damp gravelly places; rare (?): $F$. July-September.

I. Ballincollig, Cork, 1853 (Carroll): Herb. Babington.III. A few plants on a rubbish heap at Ferrybank, Kilkenny: M. \& S. I896.-IV. One plant on the quay at Wexford: Marshall I896.-XII. Marshy fields north of Dundrum, Co. Down, 1894 (Rev. C. H. Waddell): Ir. Nat. 2895 .

Further observation may be expected to show that this critical plant is frequent in Ireland.

\section{P. amphibium Linn. - Water Bistort.}

Districts I. II. III. IV. V. VI. VII. VIII. IX. X. XI. XII. Lat. $51 \frac{1}{2}^{\circ}-55 \frac{1}{4}^{\circ}$. Throughout Ireland. Type, British.

Lowland. Lakes, ponds, ditches, and slow streams, also on damp ground; frequent. Fl. July-September.

The Var. TERRESTRE (Leers) occurs very frequently. 


\section{0. $\ddagger$ P. Bistorta Linn.-Snake-weed.}

Districts [I.] [II.] III. - [V.] VI. - - [IX.] X. XI. XII. Lat. $51 \frac{3}{4}^{\circ}-55^{\circ}$. From South to North. Type, British-Initermediate.

Lowland: Moist pastures; very rare. Fl. June-September.

[I. In Sir T. Denny's Park near Tralee: Smith's Kerry. Field near Ballylickey, Bantry (Miss Hutchins): Mack. Rar.II. Near Lismore and Tallow on the hill of Slatwood: Smith's Waterford.]-III. In Captain Mitchell's ground by the brook near Stradbally, 1732: Annot. in Threlkeld. In a damp meadow by the river at Stradbally, Queen's Co. (T. Chandlee): $C y b$.-probably the same locality as the preceding. A common weed in an old meadow by the Barrow between Carlow and Maganey: Hart 1885.[V. In a field at Ashtown near Monkstown : Mack. Cat.].VI. Banks of the Suck near Ballinasloe: Foot I865.-[IX. Roadside a little south of the town of Sligo: Flor. Olst.]-X. Near Milltown, Tyrone (Admiral Jones) : $C y b$. In a damp meadow near Ely Lodge, Lough Erne, probably an escape: Barriagton 1884.XI. Castle Wray, Letterkenny (Dean Gwynn): Hart 1881 \%. By the Reelan Water above Reelan Bridge; Mrs. Leebody.-XII. Plentiful on limestone about Springhill, near Moneymore, Derry: Moore MSS. In the meadows near the old castle at Shane's Castle, Antrim (Moore): Cyb. Abundant on the lawn at Kilwaughter (Stewart): Flor. N.-E. Shore of Lough Neagh at Langford Lodge, Antrim (Rev. H. W. Lett) : S.\& P. 1895 .

Formerly much cultivated and apparently introduced in all of its stations, though naturalized in some. Not recently recorded for Districts I. II. V. and IX. where it probably occurred as a casual only.

\section{P. viviparum Linn.-Alpine Bistort.}

Districts I. - - - - - - IX. - XI. Lat. $521^{\circ}-551^{\circ}$. Kerry, Sligo, and Donegal. Type, Highland.

Mountain pastures and wet rocks; very rare. Fl. June-July.

I. Pierasmore ridge, Brandon, Kerry : Hart I884.--IX. On the northern declivity of Ben Bulben, 1826: Murphy r820-and in 1884: B.\&V. 1885. Glenade (Admiral Jones): Cyb. Talus of Ben Whisken (C. Dickson): Corry I884.-XI. Near the top of Bulbein mountain, Inishowen: Hart I880, Slieve League: Hart I885 $\gamma$. 
From 1310 to $1500 \mathrm{ft}$. in Donegal (Hart); 500-1200 ft. in Sligo $\left(B . \& V_{\text {. }}\right.$ ); to $2380 \mathrm{ft}$. in Kerry (Hart).

First found in Ireland by Edmund Murphy, on Ben Bulben, in 1826.

12. $\ddagger$ P. saggitifolium Linn.-Arrow-leaved Tear-thumb.

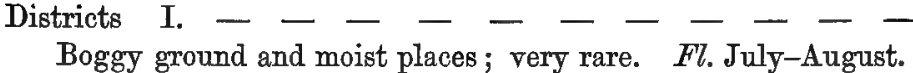

I. Abundant in the stony bed of a small stream at Castle Cove, east of Derrynane, Kerry, 1889 (as $P$. arifolium Iinn) : R.W.S. I89o. In a boggy hollow a mile north of, and inland from, the preceding station, $1892 ; R . W . S$. Very abundant over an area of more than 12 acres close to the latter station, quite filling the ditches, bog-drains, \&c., $1894 ; R . W . S$. and $H$. Synnott. Still abundant but not spreading, $1896 ; R . W . S$.

An annual, strongly prickly species of slender growth, common in low grounds in the northern United States. The proper standing of this plant in the Irish flora is most difficult to determine. While its hard seeds would no doubt lend themselves rather readily to introduction with ballast or grain, the Kerry locality is remote from any of the stations usually affected by aliens, such as harbours, towns, or railway lines. The plant, moreover, is without any beauty or utility which might suggest its intentional introduction. Yet, with our present knowledge of its distribution in Ireland, it cannot be accepted as native, and it seems best to regard it as an alien introduced by some accidental means and now fully established. in a wild locality.

OXYRIA Hill.

1. O. digyna Hill-Mountain Sorrel.

O. reniformis Hook.

Districts I. II. - --- VIII. IX. - XI. Lat. $52^{\circ}-55^{\circ}$. From South to North. Type, Highland.

Wet mountain cliffs; rare. Fl. July-August.

I. On the cliffs upon the highest of the Magillicuddy's Reeks, and Brandon mountain, Kerry, 1804-5: Mack. Rar. In most of the upper gullies of Carrantuohil: Hart 7882 . Abundant on Brandon mountain, $1885 ; N$. C. Connor Hill near Dingle (Moore); on Mangerton (Carroll): Cyb. Coomasaharn mountains near 
Rossbeigh, and on most of the higher Kerry mountains; R.W.S. II. Near the summit of Galtymore, Tipperary : Mack. Rar.-and in 1880: Hart I88I.-VIII. On Lettery mountain, Ballinahinch : Wade Gallovid. Near the summit of Mweelrea, 1838: Mack. App. to Frazer. In Co. Mayo, on Mweelrea; Bengorm; and Croaghpatrick; in Galway, on Muckanaght, Twelve Bens : Hart 1883 a.IX. At the edge of the precipice, Ben Bulben, 1815: Templeton Journat. On the north face of Ben Bulben; on Ben Whisken; at Annacoona, \&c. : B.\&V. 2885 . On Lug-na-gall mountain, Glencar, Sligo: N. C. $2896 .-\mathrm{XI}$. Poisoned Glen, Dunlewy: Hart 1879 . Slieve League: Hart $1885 \%$. Slieve Snacht West, $1885 ; N$. C.

Descends to 550 ft. in Kerry (Hart \& N.C.). From 900 to $1800 \mathrm{ft}$. in Donegal (Hart); 1200-1950 ft. in Sligo (B.\& V.); 1470-2400 ft. in Mayo, 1500-2600 ft. in Tipperary, and 550$3150 \mathrm{ft}$. in Kerry (Hart).

First found by Wade, on Ben Lettery, in 1801.

Confined to West Ireland and nowhere, save in its Galtymore station, occurs at a greater distance than twelve miles from the coast.

\section{RUMEX Linn.}

1. R. conglomeratus Murr.-Sharp-leaved Dock.

Districts I. II. III. IV. V. VI. VII. VIII. IX. X. XI. XII. Lat. $51 \frac{1}{2}^{\circ}-5 \frac{1}{4}^{\circ}$. Throughout Ireland. Type, British.

Lowland (?). Waysides, waste places, fields, \&c. ; common. Fl. June-August.

\section{R. nemorosus Schrad.-Wood Dock.}

$R$. viridis Sibth.

Districts I. II. III. IV. V. VI. VII. VIII. IX. X. XI. XII. Lat. $511^{\circ}-551^{\circ}$. Throughout Ireland. Type, British-English.

Lowland (?). Shady, damp places; common. Fl. June-August.

The typical $\boldsymbol{R}$. sanguineus (Linn.), distinguished from $\boldsymbol{R}$. nemorosus (Schrad.) by its red leaf-veins, appears to be very rare and has been reported only from the following stations:-I. In an old garden at Blackrock; and-II. Great Island, Cork: Flor. Cork.-V. Near Donabate, Co. Dublin, 1895; Praeger.-VI. At Castle Taylor: More 1855.-XII. Near Ballycastle, Antrim: S.\&P. 1895 . 


\section{R. maritimus Linn,-Golden Dock.}

Districts - II. - IV. V. - - - - - - Lat. $52^{\circ}-53 \frac{1}{2}^{\circ}$. South and East. Type, English.

Boggy ground; very rare. Fl. July-August.

II. Sparingly by a bog at Kilcoleman (Rev. T. Allin): Reo. Add. Sparingly on waste ground, Kilcoleman (Carroll): Allin's Cork.-IV. Plentiful at Lady's Island Lake, Wexford: Hart r883 B.-V. Abundant in a bog near Garristown, Co. Dublin (L. Ogilby \& Moore): Cyb. Abundant for two or three miles by the stream at Garristown bog, 1882-83: Flor. Howth App.

Also recorded from near Clay Castle, Youghal (Mack. Cat.) and bogs near Ballycotton (Flor. Cork), but it has not been found recently in either station.

\section{4. $\ddagger$ R. pulcher Linn.-Fiddle Dook.}

.Districts I. II. - [IV.] [V.] - - - - - Lat. $51 \frac{1}{2}^{\circ}-53 \frac{1}{2}^{\circ}$. South and East. Type, English.

Waste gravelly places and roadsides; very rare. Fl. July-Aug.

I. Abundant about Friar's Walk, Cork (Drummond) : Mack. Cat. On Cape Clear Island; plentiful on both sides of the village of Baltimore, and by the roadside a mile north of it, 1897; Phillips. II. At Whitegate; at Cork Beg; on roadside between Whitegate and Fort Carlisle, Cork: Phillips 1895. Abundant in the town of Youghal, 1896; R.W. S.\& Phillips.-[IV. By the harbour at Bray, 1867-72 (Moore) : Rec. Add.-V. Between Kingstown and Dalkey: Ir. Flor. Near Dunleary, \&c. : Flor. Hib. Sparingly near Bullock harbour (More): Cyb. Very sparingly on the shore at Baldoyle, 1868 (More) : Rec. Add. -not seen recently in Districts IV. or V.].

Probably introduced in all its stations; thoroughly established in County Cork only.

\section{R. obtusifolius Linn.-Broad-leaved Dock.}

Hibernicé Cop6ze praiỏe (Copp-öge srawd-yë), Roadside leaf.

Districts I. II. III. IV. V. VI. VII. VIII. IX. X. XI. XII. Lat. $51 \frac{1}{2}^{\circ}-55 \frac{1}{4}^{\circ}$. Throughout Ireland. Type, British.

Waysides, waste places, damp meadows, \&c.; common. Fl. July-September. 
Sea-level in N. Donegal and S. Cork. To $1000 \mathrm{ft}$. in Derry (Hart); to $1350 \mathrm{ft}$. in Wicklow (N.C.).

\section{R. crispus Linn.-Curled Dock.}

Districts I. II. III. IV. V. VI. VII. VIII. IX. X. XI. XII. Lat. $51 \frac{1}{2}^{\circ}-55 \frac{1}{4}^{\circ}$. Throughout Ireland. Type, British.

Waysides, waste places, fields, seashores, \&c. ; common. Fl. June-August.

Sea-level in Antrim and Cork. To $1250 \mathrm{ft}$. in Dublin (N.C.).

Var. TRIGRANULATUS Syme-V. Howth; Skerries, \&c.; frequent on gravelly and sandy seashores in Co. Dublin; N. C.-Probably occurs all round the Irish coasts.

Var. Ac0TUs (Linn.) -R. orispus $\times$ obtusifolius-VII. Knock Drin, Westmeath : Linton $\mathbf{I} 896$.

\section{R. Hydrolapathum Huds,-Water Dock.}

Districts I. II. III. IV. V. VI. VII. VIII. IX. X. XI. XII. Lat. 511 $\frac{1}{2}^{\circ}-55 \frac{1}{4}^{\circ}$. Throughout Ireland. Type, English.

Lowland. Banks of rivers, lakes, and ditches; local. Fl. July-August.

1. Lough Gill, Castlegregory: Hart 1884. Frequent in the marshes about Kinsale, Iniskeen and in the river Bandon: Smith's. Cork. Near Skibbereen; at Garretstown; near the Warren, Rosscarbery: Allin's Cork. Kilkern Castle near Castlefreke, 1891 ; Phillips.-II. Near Doneraile: Smith's Cork. Ballycotton Bog (Carroll): Allin's Cork. Inch bog near Power Head, Cork, 1896; Phillips. Near Castle Widenham, Castletownroche, 1897; W. H. Shaw. Near Passage : Smith's Waterford. Clonee, Waterford: Wade Rar. 1804-and in 1883: Hart 1883 $\beta$. By the Blackwater above Cappoquin, Waterford: Hart $1885 \delta$.-III. By the rivers Slaney, Nore, and Barrow, in Carlow and Kilkenny: Hart I $88 \mathrm{I}$ a, \&o.-IV. Plentiful in ditches on the Murrough of Wicklow (Moore): Cyb. Not infrequent in Co. Wexford.-V. In Co. Dublin, near Malahide (More); between Raheny and Baldoyle (Moore) : Cyb. By the Broad Meadow Water near Rowlestown, Co. Dublin, 1894 ; N. C. Plentiful in a marsh by the Barrow above Athy, Kildare : Hart I885.-VI. Near the bridge of Ballinasloe: Wade Rar. Near Ennis, Clare: Corry I880.-VII. Bog by the Killaloe railway east of O'Brien's Bridge, Tipperary ( $C . B$. 
Barrington): Hart I88I $\gamma$. North-west of Lough Owel, Westmeath: Levinge 1894. By the river Inny, and at Derrymacar, Longford: $B . \& V$. I887. At Mullingar; Dr. E. P. Wright.VIII. Westport, Mayo (Babington): Cyb.-IX. Clooneigh river, Lough Ree, Roscommon: B.\& V. 1887.-X. Banks of Lough Erne: Flor. Hib.-XI. Right bank of the Erne between Ballyshannon and Belleek: Hart $1885 \%$ - - XII. In several stations in Antrim, Down, and Derry, and especially abundant in the marshes at Downpatrick: Flor. N.-E. and S. \& P. 1895 .

\section{R. Acetosa Linn.-Common Sorrel.}

Districts I. II. III. IV. V. VI. VII. VIII. IX, X. XI. XII. Lat. $51 \frac{1}{2}^{\circ}-55 \frac{1}{3}^{\circ}$. Throughout Ireland. Type, British.

Damp shady places, pastures, \&c.; common. Fl. June-August.

Sea-level in Derry and S. Cork. To $2460 \mathrm{ft}$. in Donegal (Flor. Ulst.) ; to $2796 \mathrm{ft}$. in Down (S.\& P.); to $3000 \mathrm{ft}$. in Wicklow and Tipperary, and to $3414 \mathrm{ft}$. in Kerry (Hart).

\section{R. Acetosella Linn.-Sheep's Sorrel.}

Hibernicé Samaö caopa (Samvah-lwweerah), Sheep's Sorrel.

Districts I. II. III. IV. V. VI. VII. VIII. IX. X. XI. XII. Lat. $51 \frac{1}{2}^{\circ}-55 \frac{1}{4}^{\circ}$. Throughout Ireland. Type, British.

Sandy and peaty ground; common. Fl. June-Aug. Calcifuge $A$.

Sea-level in N. Antrim and S. Cork. To $2460 \mathrm{ft}$. in Donegal, to $2790 \mathrm{ft}$. in Down, to $3000 \mathrm{ft}$. in Wicklow and Tipperary, and to 3414 ft. in Kerry (Hart).

Ireland.

A characteristic species on naked mountain tops throughout

ORDER LVI.-EUPHORBIACE无.

EUPHORBIA Linn.

1. E. Helioscopia Linn.-Sun Spurge.

Districts I. II. III. IV. V. VI. VII. VIII. IX. X. XI. XII. Lat. $51 \frac{1}{2}^{\circ}-55 \frac{1}{4}^{\circ}$. Throughout Ireland. Type, British.

Cultivated land; rather common. $\mathrm{Fl}$. June-September.

Sea-level to $950 \mathrm{ft}$. in Dublin (N.C.). 


\section{E. hiberna Linn.-Irish Spurge.}

Tithymalus hibernious (How's Phytologia).

Hibernicé bainne caoin (Bann-yĕ kweean), Mild Milk (?) (ironical). Districts I. II. - - - VI. - VIII. [IX.] - XI. Lat. $51 \frac{1}{2}^{\circ}-55^{\circ}$. South and West. Type, Local-Atlantic.

Woods, thickets, hilly pastures, and rocky places; locally abundant. Fl. April-June.

I. Common on the mountains of Kerry: Smith's Kerry. It grows in immense quantities on the public road between Cork and Killarney, and all about Killarney: Wade Rar. Glens north of Castleisland; abundant along the rivers Feale and Smerlagh; abundant in S. Kerry, less frequent in the north: $R . W . S$. $I 889 \&-9 I$. Found in great plenty all over the county [Cork]: Smith's Cork. Baltimore; Mizen Head; and Cape Clear Island, 1896 ; and-II. Abundant from Cork to within a few miles of Mallow, 1897; Phillips. Frequent in woods and along streams near Fermoy ( $T$. Chandlee), extending east to the valley of the Nier and Cappoquin, Waterford (Miss S. Grubb): Cyb. Colligan glen near Dungarvan, Waterford, 1880 (J. Britten): Hart 1885 . VI. It grows abundantly near Anakirk in the county of Limerick: $K^{\prime} E$ ogh 1736 . At Adare, Co. Limerick: More in litt. 1884. -Abundant along the river at Abbeyfeale, Limerick: R.W. S. I89I. At Derryea, about a mile from Chevy Chase, south-east of Gort, Co. Galway, and abundant by the side of the stream in Chery Chase: Hart $1873 .-$ VIII. Plentiful at the landing place on Inishturk Island (W. Mac Millan): More 1873.-[IX. On Slieve Bane, Roscommon : Brown Fasciculus-not since recorded for this district.]-XI. "Walk'd about a mile up the side of the River at Dunrea-Euphorbia hyberna grows in great abundance, May 31st $1800 "$ : Brown MS. For about 100 yards along the Dunrea river near Buncrana, 1891, found by J. Hunter : Hart, Journ. of Bot.I89I. Among rocks and bushes on the south side of the Poisoned Glen, Dunlewy, in no great quantity, 1867 (N. Moore) : Rec. Addd.

Sea-level to $1800 \mathrm{ft}$. in Kerry (Hart).

Very abundant in Cork and South Kerry, becoming much rarer towards the North. In Donegal the plant attains its extreme northern limit for Europe, ranging here fully eight degrees of latitude northward of its most northern station on the Continent and five degrees northward of its only British station in North Devon. 
Known as Irish to How, in whose Phytologia Britannica, 1650, it appears, without any locality, under the name, Tithymalus hibernicus. It is also mentioned in Ray's Synopsis, 1696, as found in Hibernid, but the earliest definite Irish locality published appears to be that of K'Eogh for county Limerick, 1736. K'Eogh's locality, Anakirk, is perhaps Rinekirk on the Maigue river below Adare.

\section{3. $†$ E. amygdaloides Linn.-Wood Spurge.}

Districts I. - - - - - - - [XI.] Lat. $51 \frac{3}{4}^{\circ}-55^{\circ}($ ?). In Cork [and Donegal] only. Type, English.

Woods and thickets; very rare. Fl. April-May.

I. By the river in the park at Castle Bernard near Bandon, Cork: Drummond 1819 . Freely in Dunderrow wood; on the Bandon river 8 or 9 miles below Castle Bernard Park; and at Roughwood or Bullen's Wood, 3 miles from Kinsale: Allin 1874.- [XI. Extremely rare in Glenalla woods, where it has been known as wild for upwards of twenty years: Hart 1879.$]$

A single plant was also observed growing for some years on the site of a former wood near Springhill, Enniscorthy (Ree. Add.). It is only along the Bandon river that the plant can be regarded as native or, at all events, fully naturalized.

\section{E. Paralias Linn.-Sea Spurge.}

Districts I. II. - IV. V. VI. - VIII. - - XI. XII. Lat. $51_{2}^{\circ}-55 \frac{1}{4}^{\circ}$. Coasts of all Ireland, probably. Type, AtlanticEnglish.

Sandy seashores; local. Fl. June-August.

I., II., IV., and V. Frequent on the coasts of Kerry, Cork, Waterford, Wexford, Wicklow, and Dublin.-VI. Very plentifuI on the South Isles of Aran: Mack. Rar. Near Ballyvaughan, Clare, 1895; and - VIII. Near Inveran, Iar Connaught, 1895; N. C.-XI. In Fanet, Donegal; Hart.-XII. Not uncommon in north-east Ireland: Flor. N.-E.

\section{E. portlandica Linn.-Portland Spurge.}

Districts I. II. - IV. V. VI. - - - - XI. XII. Lat. $511^{\circ}-55 \frac{1}{4}^{\circ}$. Coasts from South to North. Type, Atlantic.

Rocky and sandy sea-coasts; local. Fl. May-July. 
I., II., IV., and V. Frequent on the coasts of Kerry, Cork, Waterford, Wexford, Wicklow, and Dublin.-VI. Aranmore and Inishmaan, Aran Isles: Hart 2875.-XI. Horn Head; Tramore sand-hills; near Marble Hall: Hart 1880. Bottom shore, and Melmore Point, Fanet; sand-hills south of Carrickfad; north-west of Ballyshannon; between Ballyshannon and Bundoran : Hart I879 \& $1885 \%$-XII. At Greencastle: Ir. Flor. Sparingly north of Greencastle, also at Ballykinler and occasionally to Rathmullen, Down; at Portrush, Antrim (Stewart): Flor. N.-E.

Apparently rare in the West, and not yet recorded for Galway, Mayo, Sligo, or Derry.

\section{E. Peplus Linn.-Petty Spurge.}

Districts I. II. III. IV. V. VI. VII. VIII. IX. X. XI. XII. Lat. $51 \frac{1}{2}^{\circ}-55 \frac{1}{4}^{\circ}$. Throughout Ireland. Type, British-English.

Lowland. Cultivated ground and waste places; rather common. Fl. July-August.

\section{E. exigua Linn.-Dwarf Spurge.}

Districts I. II. III. IV. V. VI. VII. - IX. X. XI. XII. Lat. $51 \frac{1}{2}^{\circ}-55 \frac{1}{4}^{\circ}$. Throughout Ireland, probably. Type, EnglishBritish.

Lowland. Cultivated ground in light soils; frequent and locally abundant. Fl. June-August.

Much rarer than the other agrestal spurges, $E$. Hetioscopia and E. Peplus. Not yet recorded for Kerry, West Galway, Mayo, or Sligo.

\section{MERCURIALIS Linn.}

\section{1. † M. perennis Linn.-Dog's Mercury.}

Districts - II. III. - V. VI. VII. - IX. X. - XII. Lat. $52^{\circ}-55 \frac{1}{4}^{\circ}$. Middle to North. Type, British.

Lowland. Woods and bushy places; rare. Fl. April-May.

II. Abundant in one spot in Castle Widenham demesne, Castletownroche, 1897; Phillips.-III. Abundant on the right bank of the Erkina river below Durrow, Queens's Co. : Hart I885 $\delta$. Near Cuffsboro, Abbeyleix, Queen's Co., 1887 ; R. P. Vowell.-V. Hedges near Finglas: Wade Dubl. I794. In considerable quantity on a 
shady ditch bank and by hedgerows near Finglas, $1893 ;$ N. C.VI. In the Kieber Pass, south of Bell Harbour in Burren, Clare $(F, J . F o o t): C y b$. Sparingly at Deelan More, and in considerable quantity at Deelan Beg and Gortyclare, Co. Clare, $1896 ; P . B$. O' Kelly.-VII. Common in the woody grounds about Parsonstown : Ir. Flor. \& (Moore): Cyb.-IX. Two large patches at Hazelwood, Sligo (J. Wynne): $C y b .-\mathbf{X}$. Several large patches by the Cusher river, Tanderagee, lower demesne, Armagh; also in many spots in the lower demesne: Praeger 1893-observed here some 30 years previously by Rev. G. Robinson, and erroneously recorded as for Tartaraghan in Cyb. Glasslough, Co. Monaghan (Miss Young): Hart 1885 8.-XII. In Co. Antrim, in Altaferna Glen near Ballycastle (Moore); and Langford Lodge near Crumlin, Lough Neagh (Miss Maffett): Cyb. Still very abundant at Langford Lodge (Praeger); in quantity on the Dane's Cast elose to Scarva House, Down (Rev. H. W. Lett): S.\&P. I895. By the river at Glynn near Larne, Antrim (Rev. G. Robinson); glen near Loughbrickland, Down (Rev. H. W. Lett) : Flor. N.-E.

Doubtfully native in all of its Irish stations.

\section{2. † M. annua Linn.-French Mercury.}

Districts I. II. III. - V. VI. - - - - Lat. $511_{2}^{\circ}-53 \frac{1}{2}^{\circ}$. Southern half of Ireland. Type, English.

Lowland. Cultivated land and waste places; local. Fl. JuneAugust.

I. On the shore near Beal Castle, plentifully : Smith's Kerry.- not seen recently in Kerry. By the Lough, Cork: Flor. Cork 1845-and still there in 1896 ; Phillips. In some quantity in waste ground and in potato fields at the west end of Baltimore village, 1888-92; C. Longfield.-II. At Sunday's Well : Flor. Cork 1845. Abundant at Sunday's Well and at Tivoli, 1896; Phillips. Very sparingly at Youghal: Allin's Cork. In the ground of Newtown school, Waterford; Miss S. Grubb.-III. Abundant in potato fields near Kilkenny (J. Sim): Cyb.-V. Plentifully in cultivated ground and on rubbish in Dublin: Wade Dubl. Frequent in gardens and cultivated ground in the suburbs of Dublin, and extending north to Howth, south to Merrion, and west to Blanchardstown, 1895; N. C.-VI. Ennis, Co. Clare : Corry 1880 .

More abundant in the neighbourhood of Dublin than elsewhere in Ireland, but perhaps introduced in all its stations. 


\section{ORDER LVII.—URTICACE正.}

\section{OLMUS Linn.}

1. † U. montana With.-Wych Elm.

Districts - - - - - - - - XI. XII. Lat. $54_{4}^{3 \circ}-554^{\circ}$. North Ireland. Type, British.

Woods, hedges, and riversides; rare in the wild state. $F$. March-April.

XI. Apparently native about Brown Hall and in the limestone glens of Moynalt near Laghy : Hart I 886.-XII. "In Colin Glen, \&c., produces young seedlings; in the glen of the Roe river above Limavady": Templeton MSS. Glenarm Deer Park, and other glens in Antrim (Mr. Thompson): Flor. Olst. Frequent in the northern glens of Antrim (MFore): Cyb. Frequent in the North-East in woods and glens, and on river banks, "It is difflcult to distinguish the native from the introduced localities, . . . but it seems certainly wild in many glens": Flor. N.-E.

Planted throughout Ireland and nowhere appearing native or thoroughly naturalized save in Districts XI. \& XII.

\section{HUMULUS Linn.}

\section{1. *H. Lupulus Linn.-Hop.}

Districts I. II. III. IV. V. VI. VII. - IX. X. XI. XII. Lat. $51 \frac{1}{2}^{\circ}-54 \frac{3}{4}^{\circ}$. From South to North. Type, British.

Lowland. Hedges, waysides, and rocky places; rare. Fl. July.

I. Near the Abbey of Killagh: Smith's Kerry. Sparingly in hedges near Waterville and Killorglin, Kerry ; $R . W . S$. At Timoleague (Drummond): Flor. Cork. Glandore and Blind Harbour: Allin's Corli. By the side of fields near Schull, 1884; Phillips.II. Near Fermoy (T. Chandlee); Ardmore, Waterford (Carroll): Cyb.-III. Between Cullenagh and Stradbally, Queen's Co. : Mack. Rar. Attanna and Togher, Queen's Co. (Rev. S. Madden); near Gaul's Mills, Kilkenny (T. Chandlee) : Cyb.-IV. Near the shore at Kilmuckridge, Wexford : Hart I88I a. Sandbanks at Kiltennel near Courtown, Wexford; Miss Farmer. At Ballinaclash, Wexford, $1873-95$; G. E. J. Greene.-V. Along the river Barrow between Bert and Athy : Ir. Flor. Hedges and waste ground at Drumleck: 
Flor. Howth. Hedges near the ruins of Tymon Castle, Co. Dublin, 1882-97; N.C.-VI. Old walls at the west end of Corofin, Clare: Wade Rar. In the South Isles of Aran, among the limestone rocks, 1805: Mack Rar. In several parts of Aranmore, near ruins : Hart 1875 . Near Bunratty Castle, Clare, 1851: O'Mahony r860. Abundant on old walls near Ennis, Clare: Corry I880.VII. Hedges near Nenagh, Tipperary : Mack. Rar. Near Birr, in Tipperary: Wade Rar. Killough Bridge and near Ardfinnan on the Suir : Hart 1885 a.-IX. On an island at Rockingham, Roscommon (Rev. S. Madden); near the old abbey of Mayo (Prof. Melville); near Foxford, Mayo (More); plentiful by roadsides near Sligo (Moore) : Cyb.-X. Hedges near the Callan river west of Loughgall, Armagh: Praeger 1893.-XI. Near Carrick: Hart 1886.-XII. About the ruins of Grey Abbey, Down: Ir. Flor. By a rivulet from Ballymenock to the sea ( $F$. Whitla); escapes from cultivation, not established in the North-East: Flor. $N .-E$.

Chiefly in the neighbourhood of ruins and long established in many stations, but in all cases an obvious relic of cultivation.

\section{URTICA Linn.}

\section{U. dioica Linn.-Great Nettle.}

Hibernicé Neanz6万 (Nyan-thōge).

Districts I. II. III. IV. V. VI. VII. VIII. IX. X. XI. XII. Lat. $51 \frac{1}{2}^{\circ}-55 \frac{1}{4}^{\circ}$. Throughout Ireland. Type, British.

Hedges, waste places, roadsides, foot of walls, \&c.; common. $F$. June-September.

Sea-level in N. Antrim and S. Cork. To $1150 \mathrm{ft}$. in Derry (Hart); to $1500 \mathrm{ft}$. in Dublin (N.C.).

Of this species Threlkeld (Synopsis) quaintly says:- "It may be felt everywhere."

\section{U. urens Linn.-Small Nettle.}

Districts I. II. III. IV. V. VI. VII. VIII. IX. X. XI. XII. Lat. $51^{\frac{1}{2}}{ }^{\circ}-551^{\circ}$. Throughout Ireland. Type, British.

Waste places and cultivated land; frequent. Fl. June-Sept.

Sea-level in N. Antrim and S. Cork. To $750 \mathrm{ft}$. in Dublin (N.C.). 
PARIETARIA Linn.

1. P. officinalis Linn.-Wall Pellitory.

$P$. diffusa Koch.

Districts I. II. III. IV. V. VI. VII. VIII. IX. X. XI. XII. Lat. 51 졸 $055 \frac{1}{4}$. Throughout Ireland. Type, British-English.

Lowland. Old walls, also on rocks; frequent. Fl. JuneSeptember.

Often abundant near the sea; usually rare in inland stations.

ORDER LVIII.-MYRICACEE.

MYRICA Linn.

1. M. Gale Linn.-Bog Myrtle.

Hibernicé Rile6

Districts I. II. III. IV. V. VI. VII. VIII. IX. X. XI. XII. Lat. $51 \frac{1}{2}^{\circ}-55 \frac{1}{4}^{\circ}$. Throughout Ireland. Type, British.

Bogs and moory grounds; frequent and locally abundant. $F$. May.

Sea-level in N. Donegal and S. Cork. To $1000 \mathrm{ft}$. in Donegal (Hart); to $1400 \mathrm{ft}$. in Down (S. \&P.).

\section{ORDER LIX,-CUPULIFERE.}

\section{BETULA Linn.}

1. B. alba Linn. (Aggregate).-Birch.

Hibernicé beic (Bay),

Districts I. II. III. IV. V. VI. VII. VIII. IX, X, XI, XII. Lat. $51 \frac{1}{2}^{\circ}-55 \frac{1}{4}^{\circ}$. Throughout Ireland. Type, British. May.

Heaths, woods, and mountain glens; frequent. Fl. April-

Sea-level in Antrim and Cork. To $1400 \mathrm{ft}$. in $\operatorname{Down}(S . \&$ P.); to $1700 \mathrm{ft}$. in Wicklow (N. C.); to $1500 \mathrm{ft}$. in Mayo (Hart). 
B. verrucosa Ehrh.

Districts - II. - - - VI. VII. - IX. - - -

II. At Queenstown Junction, Cork, 1897; Phillips.-VI. and VII. Frequent on the shores and islands of Lough Derg, in Galway and Tipperary, $1896 ;$ N. C.-IX. In Glencar: B.\&.V. 1885 .

Apparently confined to the lowlands; often planted and much rarer than the following segregate.

B. glutinosa Fries.

\section{B. pubescens Ehrh.}

Districts I. II. - IV. V. VI. - VIII. IX. X. - XII.

I. Frequent in Kerry; $R . W$. S. Gouganebarra; and-II. Whitegate, Cork; Phillips. Near the lake at Blarney (Carroll): Cyb.IV. and V. Frequent in the Wicklow and Dublin mountains.VI. Hare Island; Stony Island, \&c., Lough Derg; andVIII. Islands in Lough Inagh and mountains above it, Connemara; N. C. -IX. Cliffs in Glenade, Leitrim : B.\& V. r885.-X. In Co. Armagh : Praeger 1893.-XII. Frequent in the North-East: Flor. $N \cdot-E$.

The prevailing upland birch, and probably occurs throughout the country.

\section{ALNUS Linn.}

1. A. glutinosa Medic.-Alder.

Hibernicé Feapn6ze (Farn-āge).

Districts I. II. III. IV. V. VI. VII. VIII. IX. X. XI. XII. Lat. $51 \frac{1}{2}^{\circ}-55 \frac{1}{4}^{\circ}$. Throughout Ireland. Type, British.

River banks and wet places; common. Fl. March.

Sea-level in Derry and S. Cork. To $800 \mathrm{ft}$. in Derry (Hart); to $1050 \mathrm{ft}$. in Dublin (N.C.).

\section{CORYLUS Linn.}

\section{C. Avellana Linn.-Hazel.}

Hibernicé Coll (Cull or Cowl).

Districts I. II. III. IV. V. VI. VII. VIII. IX. X. XI. XII. Lat. $51 \frac{1}{2}^{\circ}-55 \frac{1}{4}^{\circ}$. Throughout Ireland. Type, British.

Thickets, rocky places, \&c. ; common. Fl. February-March.

Sea-level in Derry and S. Cork. To $1200 \mathrm{ft}$. in Derry (Moore MS.); to $1300 \mathrm{ft}$. in Wicklow (Hart). 


\section{QUERCUS Linn.}

\section{1, Q. Robur Linn.-Oak.}

\section{Hibernicé Oaın (Darr).}

Districts I. II. III. IV. V. VI. VII. VIII. IX. X. XI. XII. Lat. $51 \frac{1}{2}^{\circ}-55 \frac{1}{4}^{\circ}$. Throughout Ireland. Type, British.

Woods, glens, hedges, and rocky places; common. Fl. April-May.

Sea-level in Donegal and Cork. To $1480 \mathrm{ft}$. in Derry (Hart).

The prevailing Irish oak is Q. pedunculata (Ehrh.). The following variety appears to occur only occasionally.

Var. Sessmiflora (Salisb.).-I. At Killarney (More): Rec. Add. Islands in the Lee at Gearagh, near Macroom; W. H. Shaw.III. By the Nore below Abbeyleix : Hart 1885 $\delta$.-IV. Sparingly at Ballyarthur, Wicklow; R. Bayly.-VIII. Island in Lough Inagh, $1897 ; N . C .-\mathrm{X}$. Banks of the Glenmornan river, Tyrone (Dr. Sigerson): Rec. Add.-XI. Cliff, by the Erne, near Belleek: Hart $5885 \%$-XII. In a few localities in Antrim (Moore): Cyb.

The oak was formerly exceedingly abundant in Ireland as is shown by the frequency of place-names with the prefix or affix, "derry." It is now not common in undoubtedly wild stations.

\section{FAGUS Linn.}

\section{1. * F. sylvatica Linn.-Beech.}

Districts I. II. III. IV. V. VI. VII. VIII. IX. X. XI. XII. Lowland. Woods, hedges, \&c.; common, but nowhere native. F7. April-May.

Extensively planted throughout the country, but freely reproducing itself from seed, though rare in wild stations.

\section{ORDER LX.-SALICINEE.}

\section{SALIX Linn.}

1. †S. triandra Linn.-Almond-leaved Willow.

Districts I. II. - - - - VII. VIII. - X. - XII. Lat. $521^{\circ}-544^{3 \circ}$. From South to North. Type, English-British.

Lowland. Hedges, plantations, \&c.; apparently rare, and a doubtful native. Fl. April-May. 
II. By the river near Castlehyde, Fermoy (Drummond): Flor. Cork. Freely along the Blackwater near Fermoy; often planted but perhaps native in Co. Cork: Allin's Cork.-VII. Ditch bank between Knock Drin and Quarry Bog, Westmeath: Linton I896.$\mathbf{X}$. Wet woods and hedgerows at Florence Court, Co. Fermanagh: Flor. Hib.-XII. In a hedge between Malone and the Falls, and in osier grounds near Portmore Park, Antrim: Templeton MS. Between Malone and the Falls road, and at Portmore (Mr. Whitla): Flor. Ulst. In the bog meadows near Balmoral and (Var. Hoffmani) amongst natural wood by the Sixmilewater at Antrim (Stewart): Flor. N.-E. Also recorded for Districts I. and VIII. in 1st Edition $C y b$, , but no localities are available.

\section{S. pentandra Linn,-Bay Willow.}

Districts [I.] [II.] III. - - VI. VII. [VIII.] IX.X. XI. XII. Lat. $51 \frac{3}{4}^{\circ}-55 \frac{1}{4}^{\circ}$. From South to North. Type, Scottish.

Bushy places and riversides; rare. Fl. May-June.

[I. About Castle Cove and near Sneem, Kerry: R.W. S. 1890 . Dunmanway and Dunboy, Berehaven, Co. Cork (J. Sullivan): Allin's Cork.-II. Natural wood near Blarney (Drummond): Flor. Cork.-considered by Carroll to be not native in South Ireland].III. Many scattered trees in the uncultivated country between Mountmellick and Tullamore (J. Morrison): Rec. Add. Not infrequent along the Nore near Borris-in-Ossory : Hart I $885 \delta$. Monettia bog, and elsewhere along the Barrow : Hart 1885 . Maryborough, Queen's Co.; Praeger.-VI. At the Salmon Leap on the river Anna, near Miltown Malbay, Co. Clare (C. Carter): Cyb. On the banks of the Suck near Ballinasloe, Co. Galway : Foot I865.-VII. Bog of Linn, near Mullingar, Westmeath, in several places: Levinge 1894.-[VIII. By a stream near Clifden, Connemara, perhaps not indigenous (Carroll) : $C y b$.] -IX. In hedges and by ditches in Glen Iff, Ben Bulben, Sligo (W. T. Dyer): Rec. Add. About Grange and Kinlough, planted: $B . \& V \cdot 1885$. Drumkeerin, Leitrim: Stewart 1885.-X. Ditch bank at Florence-court, Fermanagh: Flor. Hib. Derrygonnelly and Carrick, Fermanagh: Stewart I882.XI. Very common about Pettigoe and elsewhere in south-west Donegal: Hart I885.-XII. In a bog west of Ballycastle: Templeton MS. Amongst rocks at Fair Head, Antrim, 1793 (Templeton): Whitla MS. By the river in Glenșhesk, Antrim (Corry): Flor. $N,-E$. By the Yellow Water and by the Kilbroney River, Mourne 
mountains: $S . \&$ P. I892. Frequent about Draperstown, Kilrea, and Garvagh, Derry (Praeger): S.\& P. 1895 .

To $800 \mathrm{ft}$. in Antrim (Stewart); but usually lowland.

Frequent and apparently native in the North; probably planted in the South.

3. $\ddagger$ S. fragilis Linn.-Crack Willow.

Districts I. II. III. IV. V. - VII. - - - XI. XII. Lat. $51 \frac{1}{2}^{\circ}-551^{\circ}$. From South to North. Type, British-English.

Lowland. Hedges, marshy ground, \&c.; frequent but perhaps nowhere truly native. $F l$. April-May.

\section{IS. alba Linn.-White Willow.}

Districts I. II. III. IV. V. VI. VII. - IX. X. XI. XII. Lat. 517을 $-55 \frac{1}{4}^{\circ}$. Throughout Ireland, probably. Type, BritishEnglish.

Lowland. Marshy places; frequent. Fl. April-May. Much planted, but thoroughly naturalized in some stations.

5. S. cinerea Linn.-Gray or Common Sallow.

Districts I. II. III. IV. V. VI. VII. VIII. IX. X. XI. XII. Lat. $51 \frac{1}{2}^{\circ}-55 \frac{1}{4}^{\circ}$. Throughout Ireland. Type, British.

In hedges, wet places, \&c.; common. Fl. March-April.

Sea-level in N. Antrim and S. Cork. To $800 \mathrm{ft}$. in Donegal, to $1350 \mathrm{ft}$. in Mayo, and to $1380 \mathrm{ft}$. in Kerry (Hart).

\section{S. aurita Linn.-Round-eared Sallow.}

Districts I. II. III. IV. V. VI. VII. VIII. IX. X. XI. XII. Lat. $51 \frac{1}{2}^{\circ}-55 \frac{1}{4}^{\circ}$. Throughout Ireland. Type, British.

Wet thickets, heathy places, \&c.; common. Fl. March-April.

Sea-level in N. Antrim and S. Cork. To $1250 \mathrm{ft}$. in Donegal (Hart); to $2100 \mathrm{ft}$. in Ben Bulben district (B.\&V.); to $1700 \mathrm{ft}$. in Wicklow ( $N . C$.).

S. capreola J. Kern.-S. aurita $\times$ caprea-VII. Donore, Lough Derevaragh, Westmeath : Linton 1896.

S. Zutescens A. Kern.-S. aurita $\times$ oinerea-VII. Lough Dereraragh, Westmeath : Linton 1896. 


\section{S. caprea Linn.-Great Sallow.}

Districts I. II. III. IV. V. VI. VII. VIII. IX. X. XI. XII. Lat. 511을 $-551^{\circ}$. Throughout Ireland. Type, British.

Woods, hedges, and rocky places; frequent, but apparently nowhere abundant. $F l$. March-April.

Descends to $150 \mathrm{ft}$. in Antrim and to sea-level in S. Cork. Ascends to $700 \mathrm{ft}$. in Donegal (Hart); to $1400 \mathrm{ft}$. in Leitrim $\left(B . \& V_{0}\right)$; to $1300 \mathrm{ft}$. in Dublin $(N . C$.$) .$

\section{S. repens Linn.-Dwarf Silky Willow.}

Districts I. II. III. IV. V. VI. VII. VIII. IX. X. XI. XII. Lat $511_{2}^{\circ}-551^{\circ}$. Throughout Ireland. Type, British.

Sandy, rocky, or heathy places, by the sea and on moors; frequent in one or other of its many forms. Fl. April-May.

Sea-level in N. Antrim and S. Cork. To $800 \mathrm{ft}$. in Donegal, to $1450 \mathrm{ft}$. in Derry, and $1200 \mathrm{ft}$. in Galway (Hart).

S. ambigua Ehrh. - S. repens $\times$ aurita-I. Near Glengariff, and at Dunboy, Berehaven, Co. Cork : Carroll 1854.-V. On Mont Pelier, Co. Dublin, at 800 ft., 1894; N. C.-VII. Seraw Bog, Knock Drin, Westmeath (Levinge): Linton I896.-VIII. Tully, Connemara: Babington I836.-IX. On the north-west side of Ben Bulben at about $1300 \mathrm{ft}$ : $C y b$.

\section{S. phylicifolia Linn.-Tea-leaved Sallow.}

Districts - - - - - - VIII. IX. - XI. XII. Lat. 5310 $-55^{\circ}$. North and West. Type, Scottish-Highland.

Thickets and rocky places; rare. Fl. April-May.

VIII. By the stream out of Iugaloughawn Lake, Mweelrea, Mayo : Hart 1883 a.-IX. North side of Ben Bulben, Sligo (Moore): Cyb. (as S. procumbens). North face of Ben Bulben, and near Kinlough, Leitrim: B.\&V. 1885.-XI. Shore of Glen Lough, Donegal; Hart.-XII. On the shores of Enagh Lough, Derry, 1834 (Moore) : Flor. Hib. Glenballyeamon, Antrim (Moore): Cyb.

To $1400 \mathrm{ft}$. on Ben Bulben (B.\&V.). From 550 to $1000 \mathrm{ft}$. in. Mayo (Hart).

S. lautina Smith-S. phylicifolia $\times$ caprea-XII. Between Castle Dawson and Bellaghy, Derry (Moore): Flor. Hib. On the shore of Lough Neagh, near Massareene Park, Antrim (Moore): Cyb. 
S. nigricans Smith.

Districts - - - - - - - - XI. XII. Lat. $54_{4}^{3 \circ}-55 \frac{1}{4}^{\circ}$. North Ireland. Type, Scottish-Highland.

Moist and rocky places, in mountain districts; rare. Fl. AprilJune.

XI. Urris mountains, Donegal; C. Moore.-XII. By the side of the Roe above Dungiven, Derry (Moore): Flor. Hib. Rocks at Skerries in the Braid, Antrim, 1809 (Templeton): Whitla MS. Kilwaughter and Glenoe, Antrim (Moore): Flor. Olst. Between Larne and Ballymena; Glendun and Glenariff (Moore) : Cyb.

\section{0. $\ddagger \mathbf{S}$. viminalis Linn.-Osier.}

Districts I. II. III. IV. V. VI. VII. VIII. IX. X. XI. XII. Lat. $51 \frac{1}{2}{ }^{\circ}-55 \frac{1}{4}{ }^{\circ}$. Throughout Ireland. Type, British-English.

By rivers and roadside ditches; frequent. Fl. April-May.

Much cultivated, and though quite naturalised in some parts, is probably nowhere native.

S. Smithiana Willd.-S. viminalis $\times$ caprea-This hybrid, which usually occurs in more wild-looking stations than $S$. viminatis, is frequent from North to South, and has been recorded from all the districts save III., VI., and X.

\section{S. herbacea Linn.-Dwarf Mountain Willow.}

Districts I. II. - IV. V. - - VIII. IX. X. XI. XII. Lat. $51 \frac{3}{4}^{\circ}-55 \frac{1}{4}^{\circ}$. From South to North. Type, Highland.

- On rocks and in grassy places on the higher mountains; local. Fl. June.

I. On the top of Mangerton mountain by the side of Poul-nacoppel, Kerry : Wade Rar. 1804 -still near the top, $1896 ; R . W . S$. Macgillicuddy's Reeks and on most of the Kerry mountains : Hart I882, \&c. Summit of Sugarloaf mountain, Glengariff: Carroll 1854. Priest Leap mountains, Cork. (Carroll): Allin's Cork.II. Near the summit of Galtymore, Tipperary : Mack. Rar. I805and in 1880: Hart $r 88 \mathrm{r}$. Knockmealdown and Commeragh mountains, Waterford: Hart 1884.-IV. Thonalagee and Lugnaquilla mountains, Co. Wicklow: Flor. Hib. Summit of Djouce mountain, Wicklow: Ball 7839 . On Thonalagee and on Table mountain, Wicklow, 1884 ; Rev. C. F. D'Arcy.-V. Sparingly on the summit of Carlingford mountain, Louth : Hart 1884 --VIII. On 
Lettery mountain, and other mountains in Connemara : Mack. Rar. On all the higher mountains in Mayo and Galway: Hart 1883 a.IX. Ben Bulben and Annacoona, Sligo: B.\& $T$. $2885 .-\mathrm{X}$. On Dart mountain (Admiral Jones) : Cyb.-XI. On Bulbein mountain, Innishowen : Wade Rar.-still there, and on all the higher Donegal mountains : Hart I883, \&c.-XII. Scallaree, and Cairn rocks west of Bencrom, and rocks on Slievenamady, Down (John White): Wade Rar. Slieve Donard, and the Diamond mountain: Templeton MS. On most of the Mourne summits: S. \& P. I892. Summit of Slievenanee, Antrim (Mr. Templeton) : Flor. Hib. On Dart mountain and on Clontygeragh, Derry (Moore): Cyb. Ben Evenagh: Ball 2839. Mullaghmore: Hart 1884. Mullasturrakeen and Mullaghclogher, Derry (Praeger) : S. \&.P. 7895.

From $870 \mathrm{ft}$. to $2400 \mathrm{ft}$. in Donegal (Hart); 1700-2796 ft. in Down (S. \&.P.); 1570-2600 ft. in Mayo and Galway, 2370-2950 ft. in Wicklow, and 1800-3050 ft. in Kerry (Hart).

Descends to a lower level in north Ireland than it does anywhere in Great Britain.

S. Moorei H. C. Watson-S. herbacea $\times$ nigricans (?)-XI. Among moss on the top of Muckish mountain, Donegal, 1868 (Moore): Rec. Add. (as S. Grahami Baker). This plant is conjectured by Dr. F. B. White to be a hybrid between $S$. herbacea and $S$. nigricans.

\section{2. †S. purpurea Iinn.-Rose Willon.}

Districts I. II. III. - - - VII. VIII. IX, X. XI, XII. Lat. 51 $\frac{1}{2}^{\circ}-55 \frac{1^{\circ}}{4}$. From South to North. Type, British-English.

Lowland. Hedges, riversides, and wet places; local and a doubtful native. Fl. April-May.

I. Fermoyle near Castlegregory, \&c., Kerry; R.W.S. Near Carrigaline, Cork (Drummond): Flor. Hib.-I. \& II. In several places, but always in suspicious stations (Carroll): Cyb.III. Maryborough, Queen's Co.; Praeger. - VII. Knock Drin, Westmeath: Levinge r894. - VIII. At the mouth of Killery Harbour, Mayo: Flor. Hib.-IX. Between Glencar and Benboo mountain, Sligo: B.\&V. 7885 . Drumshambo, Leitrim: Stewart 1885.-X. Hedges near Florence-court, Fermanagh: Flor. Hib. Banks of Ballycassidy river, Lough Erne: Praeger I892. XI. Mouth of Loughead river, near Killybegs, Donegal: Hart $1885 \gamma$.-XII. In several localities in Down, as at Moneyscalp, Crotlieve, and Lisnacree : S. $\$$ P. 1892 . In Antrim, at Ballycastle, 
and by the shores of Lough Neagh at Shane's Castle (S. Helix Linn.); by the Bann near Coleraine, Derry (Moore): Cyb. By the Forth river; at the base of Knocklayd; south of Giant's Causeway, Antrim (Stewart): Flor. N.-E. Broughshane; Rasharkin; Kinbane Head; and Bushmills, Antrim; roadsides near Upperlands; and frequent on mountain roads above Draperstown, Derry (Praeger) : S.\&.P. 1895 .

The majority of the earlier records are for Var. HoLrx (Linn.).

\section{POPULUS Linn.}

\section{P. tremula Linn.-Aspen.}

Districts I. II. - IV. V. VI. VII. VIII. IX. X. XI. XII. Lat. $53^{\circ}-55 \frac{1}{4}^{\circ}$. Northern half of Ireland, chiefly. Type, British.

Woods, heaths, and rocky places; local. Fl. March-April.

Sea-level in Donegal. To $1450 \mathrm{ft}$. in Antrim (Templeton); to $1200 \mathrm{ft}$. in Down (S.\&P.).

Truly native in mountain glens and rocky places in the North and West. Often planted in the lowlands and nowhere an abundant species.

\section{ORDER LXI.-EMPETRACEA.}

\section{EMPETRUM Linn.}

\section{E. nigrum Linn.-Crow-berry.}

Districts I. II. III. IV. V. VI. VII. VIII. IX. X. XI. XII. Lat. $51 \frac{3}{4}^{\circ}-55 \frac{1}{4}^{\circ}$. Throughout Ireland. Type, Scottish-Highland.

Mountain heaths, also on lowland bogs ; frequent and locally abundant. Fl. Mas.

Sea-level in N. Antrim and Kerry. To $2150 \mathrm{ft}$. in Donegal (Hart); to $2796 \mathrm{ft}$. in Down (Flor. Olst.); to $3000 \mathrm{ft}$. in Wicklow (Moore); and to $3300 \mathrm{ft}$. in Kerry (Hart).

Rare at low levels, but occurs at Lisclogher Bog, Westmeath, about $270 \mathrm{ft}$. (Levinge 1894); in Inishbofin and Inishturk, under $300 \mathrm{ft}$. (More 1876); near sea-level at Fintragh in Donegal (More, $C y b$.$) ; on Brandon mountain, and at Derrynane, and Kerry Head,$ Kerry, to about sea-level $\left(R . W . S . r 89 o\right.$ and $\left.N . C_{.}\right)$, but is usually a mountain plant. 


\section{ORDER LXII.-CERATOPHYLLE正.}

\section{CERATOPHYLLUM Linn.}

\section{C. demersum Linn.-Hornwort.}

Districts I. II. - - V. - VII. - - - - XII. Lat. 52 $-55 \frac{1}{4}^{\circ}$. From South to North. Type, English-British.

Lowland. Lakes, pools, and ditches; very rare. Fl. June-July.

I. Abundant in a pool at the foot of Ross Castle, Killarney Lakes (H. N. Ridley): Journ. of Bot. 1884, p. 92. In the Lough of Cork (D. Murray) : Flor. Cork \& (Carroll) : Cyb.-II. Abundant in deep parts of Blarney Lake (R. Mills): Rec. Add. \& Allin's Cork. Melbrook near Clonmel (Miss A. Taylor): Cyb.-V. Pools near the bridge at Navan (Dr. Seott) : Mack. Rar.-VII. Plentiful in the part of Lough Derevaragh, Westmeath, known as the pond of Donore: Levinge $7894 .-X I I$. Marshy place by the Foyle above Derry: Moore MS. In Lough Leagh near Killyleagh [Down], 1804 ; and lake near Ballynahinch, 1808 : Templeton MS. Ditches by the Quoile below Downpatrick, and in Lough Aghery, four miles west of Ballynahinch (Stewart): Flor. N.-E. Carrickmannan lake near Saintfield, Down (Rev. C. H. Waddell): S.\&P. 1895. In the large lake at the southern end of Rathlin Island, 1795 (Templeton) : Whitla MS.--still in this lake, known as Ushet lake: Stewart 1884 \& Flor. N.-E. In a ditch near Jackson Hall near Coleraine, Derry : Moore MS.

Also recorded in Wade Rar. for-VIII. "Common in Connemara, particularly near Ballinahinch." It has not since been recorded for this district and there is reason to fear that some other aquatic plant was mistaken for it by Wade.

\section{ORDER LXIII.-CONIFER}

JUNIPERUS Linn.

\section{J. communis Linn.-Juniper.}

Districts I. - - - VI. VII. VIII. IX. - XI. XII. Lat. $51_{4}^{\frac{3}{4}}-55 \frac{1}{4}^{\circ}$. West and North, chiefly. Type, British.

Heathy and rocky places, and on mountains; local. Fl. May. 
I. In the mountains of Dunkerron and some few about Killarney Lakes near Mucruss: Smith's Kerry. On a rock called Juniper Island, Killarney Lakes: Wade Rar. Still in Muckross and more abundant about Upper Lake, Killarney, $1897 ; R . W$. S.VI. In Portumna Park: Threlkeld. Plentiful on the shores and islands of Lough Derg, as on Church Island; Rinmore; Stony Island; Farrahill Point; Bushy Island, \&c., Galway; andVII. Gortmore; Slevoir Point; Drominagh; Bounla Island, \&c., Tipperary : N. C. I897.-VIII. On Delphi mountain, Mayo : Hart I883 a. - IX. Sparingly on Knockacree, Ox mountains, Sligo, 1896 ; N. C.-XI. Glenveagh and at Greenfort, Fanet: Hart 1879.

Var. NANA (Willd.)-I. Abundant at the north end of Derrynane Bay, Kerry : R.W. S. I89o. Mountains near Castletown Berehaven: Drummond 1820. Mountains above Glen Lough, Adrigole : Hart $1885 \delta$. Rocks at Dunboy, 1894; Phillips.-VI. "Upon the Rocks neer Kilmadough [Kilmacduagh], Mr. Heaton" : How, Phy-

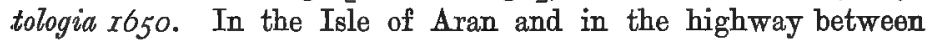
Galloway and Gort: Threlkeld. On Aranmore Island near Dun Angus, and by the shore at Cowrugh; also on Inisheer, 1892 ; $N$. C. On the mountains of Burrin and on rocks near Ardrahan : $K^{\prime}$ Eogh. Abundant in Burren: Foot I864. Castle Taylor, Galway: More 1855.-VIII. Shanafolia mountain and Urrisbeg: Babington 1836. Inishbofin: More 1876 . Curraun Achill; Croaghpatyick; Mweelrea; Maamturk, \&c. : Hart 1883 a.-IX. Cliffe over Glencar and on Ben Bulben: B.\&V. 1885.-XI. Inishowen; Errigal; Slieve League, \&c.; frequent in Donegal: Hart $1879, \& c .-$ XII. Slieve Bearnagh and Commedagh, Down; cliffs south of Carrick-a-raide, Antrim (Corry); Garron Head, Antrim (W. $\boldsymbol{H}$. Phillips), \&c.; not common in the North-East, though in some places abundant : Flor. N.-E.

Sea-level in Donegal, Clare, and Kerry. To $1750 \mathrm{ft.}$ in Donegal (Hart); 1000-2000 ft. in Down (S.\&P.); to $1800 \mathrm{ft}$. in Mayo (Hart); to $1800 \mathrm{ft}$. in Kerry (Druce I89I).

\section{TAXUS Linn.}

\section{T. baccata Linn. - Yew.}

Hibernicé lubap (Yure).

Districts I. II. - - - VI. - VIII. IX. X. XI. XII. Lat. $51 \frac{1}{2}^{\circ}-55 \frac{1}{4}^{\circ}$. From South to North. Type, English.

Rocky places, woods, and mountain cliffs; rare. Fl. March. 
I. "Grew in prodigious quantities on the mountains of all our southern baronies until it was destroyed for making coals for the iron-works": Smith's Kerry r756-still abundant at Muckross and the Upper Lake, Killarney, with many very old dead trees; $R$. W. $S$. "Grows spontaneously in several parts of Carbery. There is one growing on the side of a rocky hill a mile north of Dunmanway where there is scarce any earth to support it yet it is $17 \mathrm{ft}$. in circumference": Smith's Cork I750-still living in 1845: Flor. Cork. Woods near Castletown Berehaven (Rev. Dr. Hincks); above Carrigrohane on the Lee: Fllor. Cork. Mountain near Adrigole, 1894 ; mountain at Lough Hyne, 1896; islands in the river Lee at Geragh, Macroom, 1897; Phillips.-II. In Blamey woods : Fllor. Cort.-VI. Many fine old trees are to be seen in the mountainous woods of Glanquin, Burren : Wade Rar. Some dwarf trees here in 1879: Corry I880. Abundant on steep cliffs in Burren : Foot 1864 . - VIII. Bilberry Island, Lough Corrib : Ir. Flor. Islets in Craigga More Lake, Connemara (Praeger): Ir. Nat. $1896 .-\mathrm{IX}$. Cliffs at Glencar, Sligo, rare : B.\&V. $2885 .-$ $X$. Sparingly on limestone cliffs at Carrick and Knockmore mountains, Fermanagh : Stewart I 882.-XI. In Glen Veagh, and on an island in Lough-an-ure in the Rosses: Hart 1879.-XII. Among the rocks at Glenariff, reduced to a few stunted plants, 1795, but said to have been formerly plentiful : Templeton MSS. Rocks in the little Deer Park, Glenarm, and on the Cave Hill, 1836: Herb. Moore. On Ben Evenagh, Derry, 1835: Moore MS. Extremely rare in the North-East and not seen recently: Flor. N.-E.

To $1200 \mathrm{ft}$ in Derry (Moore MS.).

Now become very rare in the wild state though once abundant in Ireland as is sufficiently shown not only by old records but by the frequency of place-names compounded with " ure." 


\section{MONOCOTYLEDONES.}

\section{ORDER LXIV.-HYDROCHARIDEE.}

\section{ELODEA Michx.}

\section{1. * E. canadensis Michx.-Water Thyme.}

Anacharis Alsinastrum Bab.

Districts I. II. III. IV. V. VI. VII. VIII. IX. X. XI. XU. Lat. $51 \frac{3}{4}^{\circ}-54^{\circ}{ }^{\circ}$. Throughout Ireland.

Lowland. Canals, ponds, lalkes, and ditches, usually in still or slow waters; frequent and locally abundant. Fl. July-August.

I. Sparingly in the river at Listowel, Kerry, 1897, the only locality so far known in the county; R.W.S. Ballyphehane bog (Carroll): Allin's Cork-and in 1896; Phillips.-II. A great nuisance in the river Lee where it. was introduced in 1851 (Prof. Murphy):Cyb. Still plentiful in the Lee, 1896; Phillips. Ponds near Blarney ( $R . M i l l s)$; in the river in Castlemartyr demesne: Allin's Cork.-III. Plentiful in the river [Barrow] at Carlow (Carroll): $C y b$. In the Barrow near Portarlington and opposite St. Mullin's, Kilkenny : Hart I885.-IV. Ponds at Hollybrook, Bray (Barrington): Reo. Add. River Slaney near Enniscorthy, Wexford: Hart I88I a. Pond at Castleboro, Wexford: B.-H.\& M. I892.V. Abundant in the canals near Dublin: $C y b$. . 866 -and in 1898; $R . W . S$. Abundant in the Liffey river, 1893 ; also in bog drains at Garristown, where it was introduced from Lough Erne about 1873 ; frequent in ponds and quarry holes in Co. Dublin; N. C. Pond at Barmeath, Louth: Butler 2890.-VI. In Lough Derg, at Portumna and Mount Shannon, Co. Galway, and near Killaloe, Co. Clare, 1896, but not abundant and said to have much decreased of late: N.C. $2897 .-V I I$. Has spread from the Dublin canals to the river Shannon: Cyb. Lough Ennel; Lough Derevaragh, \&c., Westmeath: Levinge 1894. River Inny, Lough Ree; Shannon at Athlone, \&c., said to be disappearing: B.\&V. $8887 .-V I I I$. Abundant in Loughs Corrib and Mask : M. \& S. $x 896$. Introduced into Lough Corrib about 1861 ; Miss M. $F$. Jackson.-IX. In Lough Allen: Stewart 1885. In Lough Gill river, Sligo: B.\&V. $1885-$ 
scarce, and said to be decreasing rapidly here in $1896 ; N$. C.$X$. Trasna Island, \&c., Lough Erne, but not plentiful and decreasing fast: Barrington 1884.-XI. Abundant in the river Erne between Ballyshannon and Belleek : Hart $1885 \%$-XII. In a pond at Waringstown, Co. Down, about 1836 (John New): Phytol. 7854. Known near Lisburn for more than twenty years: Flor. Dlst. 1864. Lagan canal; Lough Neagh; Portmore Lake; Ballynahinch Lake; Newry canal, \&c.; abundant in the North-East: Flor. $N$. $E$.

Rare or absent in the extreme North and South-West.

A North-American water-weed introduced into Ireland about 1836, and interesting, not only for its remarkably rapid increase, but also for the tendency to an equally rapid decrease which it has shown of late years. The rather full details of its distribution given here will enable future observers to judge whether this tendency be permanent.

What seems to be the earliest appearance of the plant in Ireland (and in the British Isles) is thus recorded in a note by Mr. John New, gardener, communicated to the Bot. Soc. of Edinburgh in Febry., 1854:- "About eighteen years ago the pond at Waringstown was cleared of over-hanging trees, when the Anacharis was immediately observed after the planting of some aquatics, making it necessary several times during the summer to clear it out. It is not known whether it existed in the pond previously to the above date or was introduced with the aquatics at that time": Phytol. I854, p. 88. It is, however, suggested by the authors of the Flora of North-East Ireland that this plant was first introduced with squared timber imported from Canada to Belfast.

\section{HYDROCHARIS Linn.}

\section{H. Morsus-ranæ Linn.-Frog-bit.}

Districts - - - V. VI. VII. VIII. IX. X. - XII. Lat. $53 \frac{1}{2}^{\circ}-54 \frac{1}{2}^{\circ}$. Middle and North, chiefly. Type, English.

Lowland. Bog-holes, ditches, and.slow streams; local. Fl. July-August.

V. Common in the bog of Curragha, Dublin: Wade Rar. 1804 . In bog-pits near Balruddery (Dr. Scott): Mack. Rar. Sparingly in Curragha bog; and in the Broadmeadow Water; and abundant in the Bog of the Ring near Balrothery, Dublin: N.C. 1893 . 
Plentiful near Duleek and in Thomastown Bog, Meath: Flor. Howth App. Abundant in ditches by the Boyne near Slane, and thence to Drogheda (Moore): $C y b$. Plentiful round Castlebellingham, Louth : Butler $1890 .-$ VI. In a marsh by the river Fergus, a little above the bridge at Ennis: Mack. Rar. 1806 -and in 1886: Stewart 1890.-VII. Plentiful in drains about Mullingar: Foot 1865. Bog of the Linn near Mullingar; Quarry Bog, Knock Drin; Scraw Bog, Loughanstown and Ballynagall: Levinge 1894. Doonis Lough and Coosan Lough, Lough Ree, Westmeath: $B . \& F$. 1887. - VIII. Turfy ditches about Ballinahinch, Connemara: Wade Rar.-not since recorded for this District.-IX. Rinanny Point, Lough Ree, Roscommon: $B . \& V .{ }_{1} 887,-\mathrm{X}$. Near Cavan: Flor. Hib. Belturbet (Moore): Cyb. Near Pettigoe, in Fermanagh (Miss Young): Hart I $885 \gamma$. Near Derryadd Bay, Lough Neagh, Armagh (Rev. H. W. Lett): Praeger I893.-XII. In the drains at Portmore Park, 1793 (Templeton): Whitta MS. In a bog hole near Portaferry: Templeton MS. Abundant in some of the drains near the little lake at Portmore: Flor. N.-E. Bog holes at Gawley's Gate, west of Portmore (Praeger): B.N.F.C. Proc. I892-93.

\section{STRATIOTES Iinn.}

\section{1. $\ddagger$ S. aloides Linn.-Water-soldier.}

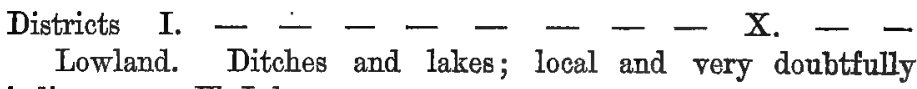
indigenous. $F l$. July.

I. Naturalized in Ballyphehane Bog, probably introduced by Mr. Drummond: Flor. Cork. Still at Ballyphehane, 1896; Phillips.-X. In a drain near Crum Castle on the banks of Lough Erne, 1805 (Dr. Soott); in drains by the side of the road near Castle Sanderson, Cavan: Mack. Rar. Plentiful on the shores of Lough Erne, from Drumgown in Fermanagh to Belturbet in Cavan; profusely where the canal joins Lough Erne; also in lakes between Belturbet and the town of Cavan (Moore): Nat. Hist. Rev. 2859, p. 15 .

Also recorded for-V. Canal near Drogheda (Murphy 28ag); for-VI. or VII. Banks of the Shannon near Portumna (Flor. Hib.); and-XII. Dams at Whitehouse (Flor. Olst.) and Springfield (Flor. Belf.). It has not been observed recently in any of these stations and seems fully established only in the basin of Upper Lough Erne. 


\section{ORDER LXV.-ORCHIDEE.}

\section{MAIAXIS Swartz.}

\section{M. paludosa Swartz.-Bog Orchis.}

Districts I. - III. IV. V. VI. - VIII. - X. - XII. Lat. $51 \frac{3}{4}^{\circ}-55 \frac{10}{4}$ From South to North. Type, British (?).

Spongy bogs, chiefly in mountain districts; rare and local. Fl. July-September.

I. Lough Curralee, Magillicuddy's Reeks : Hart I882. Side of Caragh river near Bealalaw Bridge; near Cahirciveen, and south of Dereen, Kerry; $R . W . S$. Foot of Mullaghanattin mountain, Glencar, Kerry, $1885 ;$ N.C. In a marsh between Priest Leap mountain and Ashgrove, 1805: Mack. Rar. Between Inchigeela and Macroom (J. Sullivan): Cyb.-III. On the wet hills about Old Lochlin, Co. Carlow (Mr. Brinkley): Templeton MS.-IV. Above the waterfall at Powerscourt, and at Tittour and Sugar Loaf mountain : Mack. Cat. Turfy bogs near the mines of Ballymurtagh: Ir. Flor. Abundant on a bog between Lough Dan and the road to Roundwood, Wicklow (Moore); in Glencree ( $T . A$. Smith): Cyb. Upper Lough Bray, 1870; Hart.-V. Marshy places about Kelly's Glen, River Dodder, 1814: Templeton MS. On Glendhu mountain, Co. Dublin, 1884-94; N. C. Above Glencullen, Bridge, 1894; Dr. Leitch. Bog two miles south of Thomastown, Kildare : Praeger 7897.-VI. In a marshy place near Lisdoonvarna; Clare (Rev. T. Warren): Cyb. In a wet bog above Lough Derg, south of Woodford; Hart.-VIII. In Galway [probably near Roundstone]; Mo.Alla : Herb. T.C.D. Base of Carn Seefin, Lough Corrib (J.A. Audley): Ir. Nat. I895.-X. Montiaghs bogs (Mr. Hyndman): Flor. Ulst.-XII. Found on marshy ground ascending Slieve Nanee, 1809: Templeton MS. Rathlin Island (Miss Gage): Flor. Ulst. On an elevated bog above Dunloy, Antrim (Moore): Cyb. Near Lough Naroon, two miles south-west of Dunloy, and sparingly on Fair Head, Antrim (Stewart): Flor. N.-E.

From near sea-level in Clare to $1000 \mathrm{ft}$. in Antrim ( $C y b$.$) ; to$ $1300 \mathrm{ft}$. in Dublin ( $N . C$.$) .$

First found in Ireland by the Rev. Mr. Brinkley, in county Carlow, before 1805 . 


\section{NEOTTIA Linn.}

\section{N. Nidus-avis Rich.-Birl's-nest.}

Districts I. II. III. IV. V. VI. VII. VIII. IX. X. XI. XII. Lat. $51 \frac{3}{4}^{\circ}-55 \frac{1}{4}^{\circ}$. Throughout Ireland. Type, British-English.

Lowland. Shady woods and thickets; rather rare. Fl. JuneJuly.

I. Uragh woods by Inchiquin lake, Kerry : Hart $2885 \delta$. In several places by the roadside at Turc mountain; Muckross demesne; Ross island, Killarney: R.W.S. r889. Woods at Tarbert: R.W.S. $x 89 \pi$.-II. Abundant in beech woods at Cappoquin, Waterford; Miss $\boldsymbol{M}$. Chearnley. Near Lismore; J. Goode.IIT. Sparingly in Borris demesne, Carlow, 1894-96; Rev. T. Hartley.-IV. In the woods at the Dargle, county Wicklow (Prof. Harvey): Cyb. Woods near Powerscourt House, Wicklow, 1897 ; Burrington. Glen half a mile inland from Courtown Harbour, Wexford: Praeger 1897.-V. In the thickets in Luttrels-town wood, county Dublin: Wade Rar.-not found recently in this District.-VI. In Clonbrock wood, Galway: Praeger I896.-VII. Knock Drin, Westmeath : Levinge 1894.-VIII. In the Wilderness, Ashford, Cong, 1895; Miss M. F. Jackson.IX. Woods at Rockingham, Roscommon; and at Hazelwood, Sligo (Moore): Rec. Add.-X. In Farnham woods, Cavan: Flor. Hib. Sparingly near Crum Castle, Lough Erne: Barrington 1884. Gosford Castle demesne, Armagh: Praeger 1893. Favour Royal, Tyrone: Hart 1887-and in 1896; Miss F. Leebody.-XI. Ards wood, Donegal (M. Murphy): Rec. Add. Woods at Brown Hall near Donegal: Hart I886.-XII. Glen at Sinclair's Green, 1807 (Miss $E$. Templeton): Templeton MS. Glen of Altmore, Cushendall (W. Thompson); Glenarm (R. Patterson): Flor. Hib. Errigal banks; Castledawson woods; and at Garvagh, Derry: Moore MS. Colin Glen : Flor. Olst. At Glenarm in 1866, and still in Colin Glen: Flor. N.-E. I888. Tollymore Park and Belvoir Park (C. Diokson); near Crumlin (F. Whitla); Massereene Park (More); near Randalstown (Corry); at Muckamore (Stewart): Flor. N.-E. Woods above Bellarena station, Derry (Mrs. Leebody): Stewart 1894. Glenariff (Praeger): B.N.F.C. Proe. I889-90. Whitehall near Broughshane (Rev. S. A. Brenan): S.\&P. 1805 .

A widely distributed species, usually occurring in beech woods, but seldom in abundance. 
LISTERA R. Br.

1. I. cordata R. Br.-Heart-leaved Twayblade.

Districts I. II. III. IV. V. - - VIII. IX. X. XI. XII. Lat. 52 $2^{\circ}-55 \frac{1}{4}^{\circ}$. From South to North. Type, Scottish-Highland. Boggy heaths in mountain districts; rather rare. Fl. JuneAugust.

I. Feany Valley, Brandon; and Brandon Head and Ballydavid Head, Kerry: Hart 1884. Kells mountain east of Cahirciveen; N.C.\&R.W.S.-II. Between Coumduala and Coumgorra, and at Coumshingaun in the Commeraghs; at Bay Lough in Knockmealdown mountains, Waterford: Hart I884.-III. Near Cullenagh, Queen's Co. (Mr. Bradbury): Mack. Rar. Summit of Arderin, Queen's Co., 1897 ; Praeger.-IV. Upper end of Lower Lough Bray, 1802 (Dr. Stokes): Maek. Rar.—and in $1891 ; R . W . S$. Glencree $(\boldsymbol{V} . A$. Smith) : $C y b$. South of Lough Nahanagan, Wicklow (More): Rec. Add. Maulin mountain, Co. Wicklow; G. V. Hart.-V. Kelly's Glen, Dublin (C. Ball) : Rec. Add. On Feather Bed mountain, 1867 (Hart); frequent on Glendhu mountain; on Kippure; and on the slopes between Kilmashogue and the Three Rock mountain, Co. Dublin : N. C. I895 a. Carlingford mountain, Louth: Hart 1884. In Glencullen, and at Ballinascorney, Co. Dublin; Greenwood Pim. Bog by Lough Sheelin, Meath, at $230 \mathrm{ft}$. elevation: Praeger 1897.--VIII. On Slieve Corr in Erris, Mayo (Moore) : Cyb. Corcogemore, Maam Turk range, Galway: Hart 1883 a.-IX. Frequent on the Ben Bulben range: B.\&V. 1885. Sparingly on Slieveanierin and Slievenakilla, Leitrim: Stewart 1885.-X. Mullaghclogha, Sperrin mountains, Tyrone: Hart 1884 . In county Armagh, on Montiaghs bogs (Rev. H. W. Lett); Camlough mountains; summit of Clermont; and Slieve Gullion: Praeger 1893. On Bessy Bell mountain, Co. Tyrone (IIiss M. C. Knowles): Ir. Nat. I897.-XI. Found at Bulbein mountain, Co. Donegal, by Robert Brown: Mack. Rar. \& Fitor. Ulst. On Slieve League; at Horn Head: Flor. Ulst. Hills near Rathmullen, and on top of Lough Salt mountain: Hart I879. Erris and Slieve Snacht, Innishowen: Hart I883.-XII. Below the rocks of Agnew's Hill, 1804, and on the Clough side of Slievenanee: Templeton MS. On Slieve Bingian, $1885 ;$ Rev. C. $F$. $D$ 'Arcy. On several of the Mourne mountains: S.\&.P. 2892. Slieve Gallion, Derry: Moore MS. Ben Evenagh, Derry (Mrs. 
Leebody): S.\&P. 1895 . On the summit of the Black mountain, Antrim: Flor. Ulst. Brown Hill; Mullaghmore, \&c., Derry (Stewart) : Flor. N.-E.

Descends to $150 \mathrm{ft}$. in Antrim and to $230 \mathrm{ft}$. in Meath. Ascends to $1900 \mathrm{ft}$. in Donegal, and to $2000 \mathrm{ft}$. in Down (Hart); to $2000 \mathrm{ft}$. in Dublin (N.C.).

First found by Robert Brown, in Inishowen, before 1800.

\section{L. ovata R. Br.-Twayblade.}

Districts I. II. III. IV. V. VI. VII. VIII. IX. X. XI. XII. Lat. $51 \frac{3}{4}^{\circ}-55 \frac{1}{4}^{\circ}$. Throughout Ireland. Type, British.

Woods and moist pastures; frequent and locally abundant. Fl. June-July.

Sea-level in Antrim and in Kerry. To $1470 \mathrm{ft}$. in Donegal (Hart); to $1500 \mathrm{ft}$. in Sligo $\left(N . C_{\text {. }}\right.$ ).

\section{SPIRANTHES Rich.}

\section{S. autumnalis Rich.-Fragrant Lady's Tresses.}

Districts I. II. - IV. V. VI. VII. VIII. IX. - - Lat. $51 \frac{1}{2}^{\circ}-53 \frac{3}{4}^{\circ}$. Southern half of Ireland. Type, English.

Lowland. Pastures, especially near the sea; not infrequent. Fl. August-September. Calcicole $B$.

I. By the river Finnehy below Kenmare, 1890; abundant about Barrow Harbour, \&c., Kerry; R.W.S. Beginis, Valentia Harbour; R. Bayly. Three Castle Head, Cork (T. Chandlee): Ree. Add. Near Toe Head; Inish Sherkin; Rabbit Island; Glandore, \&c. : Allin's Cork. Church Cross, Skibbereen; abundant in the extreme south of Cork, reaching to Cape Clear and Mizen Head; Phillips. Crosshaven, Cork Harbour; R.W. S.-II. On the strand at Ballycotton: Drummond I820. Whitepoint, Cove; and on a hill near Midleton (Mr. Alexander): Flor. Cork. Great Island; Roche's Point; Whitegate; Templemichael Glen, \&c.; Phillips. By the Blackwater near Fermoy, $1896 ; R . W . S . \quad$ Near Lecky and by the Blackwater, Waterford (Rev. T. Allin): Rec. Add. Monatrea cliffs and Ardmore cliffs, Waterford, 1895 ; Miss M. Chearnley. Island O'Kane, near Tramore, Waterford; $A$. $R$. Friel. Ballybrado, Tipperary (Prof. Harvey) : Cyb. Cashel, Tipperary, 1896; Miss Butler Lowe. - IV. Frequent near Alderton, Wexford: B.-H.\& G. I889.-V. On Bray Common, 1820: Mack. Cat. \& 
Flor. Hib. Near the shore between Dalkey and Bray, and at Loughlinstown (Moore); Killiney (Miss M. $\left.O^{\prime} K e l l y\right)$ : $O y b$. On the North Bull, Dublin; More.-VI. Over the whole island of Aranmore: Ogilby 1845. Castle Taylor, Galway: More 1855. Frequent at intervals from Murrough, south of Black Head, Clare, by Ballyvaughan round the coast to Kinvarra, Galway, $1895 ; N$. C. In the Park at Portumna; and-VII. Eastern shore of Lough Derg (Moore): Cyb.-VIII. Ashford and Ard near Oughterard, Galway; and-IX. Houndswood, Mayo; Miss M. F. Jackson. Shore of Lough Carra, near Moore Hall, Mayo : Ball 1839.

\section{S. Romanzoffiana Cham.-Irish Lady's Tresses.}

S. gemmipara Lindl.-Neottia gemmipara Smith.

Districts I. - - - - - - - X. - XII. Lat. $51 \frac{3}{4}^{\circ}-55^{\circ}$. Cork, Armagh, and Derry. Type, Hibernian.

Lowland. Moist pastures and worked-out peat bogs ; very rare. Fl. July-August.

I. On the strand of the mainland oppasite the western redoubt, Bere Island, Bantry Bay, August, 1810: Drummond I820 (recorded as a nondescript Neottia). Near Castletown, opposite to Berehaven, 1810 (Mr. Drummond) : Eng. Flor., vol. iv., p. 37, I830 (as Neottia gemmipara). In a rushy meadow sloping to the sea, west of Castletown (Dr. E. P. Wright): Cyb. In many of the pastures and meadows near Castletown: $R e c . A d d$. In wet rushy ground near Berehaven, about three dozens of specimens, 1891 ; Dr. Leitch. In a damp glen east of Dunmanway, about thirty plants, 1873 (Rev. T. Allin); in the neighbourhood of Desert, 1874 (C. Longfield): Allin's Corle.-X. In a wet worked-out bog in the northern part of county Armagh, about a dozen plants, August, 1892 (Praeger): Journ. of Bot. 7892, p. 272. By the river Bann at Kilrea, Derry, July, 1893, about half a dozen plants (Mrr. Leebody): Ir. Nat. 1893, p. 228.

From the point of view of distribution, this is perhaps the most interesting plant in the flora of the British Isles, since it is found nowhere in Europe outside of Ireland. As S. gemmipara (Lindl.) it was long considered distinct from $S$. Romanzoffana (Cham.) and peculiar to Ireland, but the two names are now held to refer to the same species, whose extra-European distribution is Kamtschatka, British North America, and the Northern United States.

First found by J. Drummond near Castletown Berehaven, in 1810. 


\section{CEPHALANTHERA Rich.}

1. C. ensifolia Rich.-Narrow-leaved White Helleborine.

Districts I. II. III. IV. - VI. VII. - - - XI. XII. Lat. $51 \frac{3}{4}^{\circ}-54 \frac{3}{4}^{\circ}$. From South to North. Type, English.

Lowland. Moist woods and copses; rare. Fl. June.

I. Wood at Lickeen House, head of Lough Caragh (Dr. Battersby); wood by the Kenmare road from Killarney (A. Balfe); near Derrycunihy cascade (More): Rec. Add. Still at Derrycunihy in $1891 ; R . W . S . \quad$ East of Brickeen bridge, Muckross, Killarney : R.W.S. 1880. Wood at Glengariff near Bantry: Mack. Cat. \& Flor. Hib. Adrigole, near the base of Hungry Hill (Carroll) : Cyb.II. Curraghmore wood, Waterford (W.W. Flemyng): Ir. Nat. I894.-III. Woods at Ballintemple, by the Slaney, Co. Carlow, 1885; Lady Butler.-IV. In some quantity in a marshy wood at the foot of Carrick mountain, Glenealy, Wicklow, 1897; Jonathan Pim. - VI. Derryvunlam wood near Woodford, Galway; Miss Mathews.-VII. Common on the west shore of Hare Island, and a few plants on Crow Island, Lough Ree : B.\&W. $1887 .-\mathrm{XI}$. Wood near Lough Eske, Donegal (Mrs. Brooke): Cyb. \& Hart I885 r.XII. "Found on a rotten bog by a Lough-side near the Dairyhouse in Crevetenan, Ballina-hinch, Ireland, 1694 (Mr. Sherard)": Ray Synopsis x6g6. Now extinct in this station, the proper name of which is Derry Lough near Derry House, Creevytenent: Flor. N.-E. At Duneen near Antrim, 1835 (George Whitla): Mackay 1859-a vague locality: Duneane is not near Antrim, but is a parish touching on the county of Derry at Toome: Flor. $N_{\text {. }} E$. In woods at Muckamore House near Antrim, sparingly, and at Glenavy near Antrim (Mr. Whitla); in Shane's Castle woods on the shores of Lough Neagh (Moore) : Cyb. Not recently found in northeast Ireland though sought for by several botanists: Flor. $N_{\text {. }}-E$.

First found in Ireland by William Sherard, near Ballynahinch, Co. Down, in 1694.

\section{EPIPACTIS Rich.}

1. E. latifolia All.-Broad-leaved Helleborine.

Districts I. II. III. IV. V. VI, VII. - IX. X. XI. XII. Lat. $51 \frac{1}{2}^{\circ}-55 \frac{1}{4}^{\circ}$. Throughout Ireland, probably. Type, British-Eng.

Lowland. Woods, thickets, \&c. ; rather rare. Fl. July-August. 
I. Woods at Ross, Killarney: Wade Rar. Plentiful near the mines, Mucruss woods, Killarney: Maok. Rar. Sparingly at Whitehall, near Skibbereen: Allin's Cork.-II. Wood at Castlehyde: Drummond $I 8 z 0$. Fermoy (T. Chandlee); at Buttevant; at Carrigacunna and Clifford on the Blackwater: Allin's Cork. In south Tipperary (Miss S. Grubb); and-III. Kilmanagh Rectory, Kilkenny (Rev. S. Madden): Cyb. Dllard wood by the Barrow, Co. Kilkenny, 1897; Rev. T. Hartley.-IV. Enniskerry : Ir. Flor. Lord Monk's demesne, Bray; Greenwood Pim. Powerscourt woods, 1886; N. C.-V. At Collon, Louth: Ir. Flor. About Glasnevin (Moore): Cyb. Near Ballybetagh, and at Abbotstown, Dublin, $1895 ; N . C$. By the Boyne near Navan, $1897 ;$ R.W.S.VI. At Castle Taylor and at Garryland, Galway (More): Cyb. Dromoland demesne near Newmarket, Clare: Corry I880. Woods at Foynes, Limerick: Stewart 1890.-VII. Hare island, Lough Ree: $B . \& V .1887 .-$ IX. Shore of Lough Gill, Sligo: $B . \& \bar{V}$. 1885. Near Liskillen, Ballinrobe, Mayo; D. D. Persse.X. Farnham, Cavan: Flor. Hib. Islands in Lough Erne (Moore): Cyb. Common at Lough Erne: Barrington 1884. In several places at Favour Royal, Tyrone: Hart 1887. At Castle Dillon, Armagh: More 1860. Abundant in Tanderagee demesnes; Gosford Castle, \&c., Armagh : Praeger 1893.-XI. Mount Charles, Donegal (Hart): Rec. Add. Ardnamona and Lough Eske Castle woods: Hart $7885 \%$.-XII. Plantations at Belvoir, 1793 (Templeton): Whitla MS. Abundant about Coleraine and in Bawns Glen, Derry (Moore): Cyb. Clandeboye and Dundonald; also at Gillhall near Dromore, Co. Down (Corry); at Muckamore, \&c., Antrim (Stewart); Ligoniel and Shane's Castle (Corry); frequent in the North-East: Flor. $N .-E$.

\section{E. media Fries.}

Districts I. - - - V. - VII. - - - - XII. Lat. $52^{\circ}-55^{\circ}$. From South to North. Type, English-Germanic.

In woods; apparently rare. Fl. August.

I. At Killarney (Babington): Cyb. Muckross woods, Killarney : Levinge.-V. In county Dublin (Moore): Cyb.-VII. Woods at Knock Drin, Westmeath, one plant: Linton 1896.-XII. Woods in Glenarm Park, Antrim (Stewart): Cyb.

A critical plant, probably more extended in its Irish range than would appear from the above records. 


\section{E. atro-rubens Schultz.}

E. ovalis Bab.-E. rubiginosa Koch.

Districts - - - - - VI. - VIII. - - - Lat. $52 \frac{3}{4}^{\circ}-531_{2}^{\circ}$. Clare and Galway. Type, Intermediate (?).

Crevices of limestone rock; local. Fl. July.

VI. Near the summit of one of the highest limestone mountains in Burren, 1851: O'Mahony, 1860. Abundant on the hills round Ballyvaughan, and near Dromoland, Newmarket-on-Fergus, Clare: Foot I864. Near Ballyryan, Clare, 1891 (P. B. O'Kelly): Wats. B.-Ex. C. Rep. 1892 . Abundant on the summit and upper slopes of Cappanawallia mountain near Ballyvaughan, $1895 ; N$. C.VIII. Sparingly in a rocky valley near Cong: M. \& S. 2896 .

The record in How's Phytologia, 1650, p. 57:-“Helleborine fore atro rubente Park . . . Found by Lysnegeragh. Mr. Heaton" should, perhaps, be referred to this plant. The locality, Lysnegeragh, is probably near Roscrea in King's Co.

From $300 \mathrm{ft}$, to $1000 \mathrm{ft}$. in Burren (N. C.).

\section{E. palustris Crantz-Marsh Helleborine.}

Districts I. - III. IV. V. VI. VII. - IX. X. XI. XII. Lat. $52 \frac{1}{4}^{\circ}-55 \frac{1}{4}^{\circ}$. From South to North. Type, English-British.

Lowland. Bogs and moist grassy places; rather rare. $F$. June-July.

I. Near Clogherbrian, Tralee, and by a small pool south of Tarbert, Kerry : R.W. S. $1888 \& I 89 I$. Ferriter's Cove, Kerry: Babington in Herb.-III. Plentiful in marshes in the Queen's Co. : Mack. Rar. Wilton, Kilkenny (Rev. S. Madden): Cyb. Kilcomney, Borris, Co. Carlow, 1896; Rev. T. Hartley. By the Barrow near Tinnehinch Bridge, Queen's Co.: Hart 1885.-IV. Enniskerry: Ir. Flor. Glencree, Co. Wicklow (G.C. Hyndman): Herb. Babington. Murrough of Wicklow (Moore): Cyb. Raven Point and Cahore Point, Wexford: Hart I88I a.-V. Foot of the Dublin mountains, particularly near Stag's-town and Kingstown: Wade Rar. At Johnstown near Kilgobbin (Dr. Stokes): Mack. Rar. Near Howth: Ir. Flor. Portmarnock (Moore) : Cyb. \& Hart 1897. Glenasmole, Co. Dublin (Rev. C. F. d'Aroy): Ir. Nat. 2895. In several places near Ballitore, Kildare (Carroll): Cyb. At Riverstown, Trim, Co. Meath; Miss Cuppage. Near Castle Bellingham, Louth: Butter I890.-VI. Along the shores of Lough Derg 
(Moore); bog at Kilmacduagh, Galway (More): Cyb. By Lough Derg, at Farrahill Point, Galway: N. C. I897. Doon near Clonbrock, Galway (D. MoArdle): Praeger 1896. Near Ballyvaughan, Clare; P. B. O' Kelly.-VII. Near Killinure Lough, and abundant near Athlone: $B . \& V .{ }_{1887}$. Bellevue, Lough Derg, Tipperary (C. J. Lilly) : Ir. Nat. 1896 . Edge of Glen Lake, Crumlin; Miss L. E. Battersby.-IX. Shores of Lough Carra, Mayo (More): Cyb. Mount Talbot, Roscommon; $R$. Bayly. Shores of Lough Talt, Ox mountains, Sligo : N. C. I896.-X. Island on Lough Erne, opposite Crum Castle (Dr. Scott) : Templeton MS.-XI. On the shore at Horn Head (Prof. E. Murphy): Cyb. Ardnamona woods, and north-west of Ardara: Hart ${ }_{1885} \gamma \&$ \& 886.-XIT. Shore of Belfast Lough, half a mile above Knockmagunney [Knocknagoney] Hill, 1820: Templeton MS. In a low meadow south of Ballintra, Antrim (Moore): $C y b$. Cannot now be found and perhaps extinct in the North-East: Flor. N.-E.

\section{ORCHIS Linn.}

\section{0. pyramidalis Linn.-Pyramidal Orohis.}

Anacamptis pyramidalis Rich.

Districts I. II. III. IV. V. VI. VII. VIII. IX. X, XI. XII. Lat. $51 \frac{1}{2}^{\circ}-55 \frac{1}{4}^{\circ}$. Throughout Ireland. Type, Germanic-English.

Banks, pastures, sand-hills, \&c.; frequent. Fl. June-July. Calcicole $A$.

I., II., III., IV., V., and VI. Frequent, occurring in numerous stations in Kerry, Cork, Waterford, Tipperary, Kilkenny, Queen's Co., Carlow, Wexford, Wicklow, Dublin, Kildare, Clare, and Galway, and often in abundance.-VII. Plentiful at Knock Drin, Westmeath: Levinge 1894.-VIII. On the west side of Galway (Prof. Melville): Cyb.-IX. Roscommon (Rev. S. Madden): Cyb.X. Plentiful about Oldcastle, Cavan: F'lor. Hib. Banks by the side of the road to Ballyshannon a few miles from Enniskillen: Flor. Olst. Loughgall; Castle Dillon, \&c., Armagh: Praeger 1893.-XI. Near Kindrum Lake, Fanet (Hart) : Reo. Add. Near Horn Head House; Marble Hill, Fort Royal, Rathmullan: Hart 1879, \& 0 .-XII. A single specimen at Benone, Magilligan, Derry (Moore) : $C y b$. In some abundance at the eastern end of Magilligan Strand (Mrs. Leebody) : R. N. F. C. Proc. 2802-3. Two plants on the sandy shore at Ballyholme, 1873 (Stewart): Flor. N.-E. 
Sparingly at Magheragall quarries near Lisburn (Praeger): B. N. F.C. Proc. $1890-I$.

Sea-level to $600 \mathrm{ft}$. in Dublin (N.C.); but usually lowland.

\section{0. Morio Linn.-Green-winged Orchis.}

Districts - II. III. IV. V. VI. VII. VIII. IX. - - Lat. $52 \frac{1}{2}^{\circ}-53 \frac{1}{2}^{\circ}$. Middle Ireland. Type, English.

Meadows and pastures; rather rare. Fl. May-June.

II. Holy Cross; Camus Bridge; Twoford Bridge; and about Golden by the Suir in Tipperary: Hart $1885 \alpha$. Very abundant about Fethard, Tipperary, 1897;. Praeger.-III. Castle Inch; Freshford; Kilmanagh, \&c., in Kilkenny (Rev. S. Madden): Cyb. Near the junction of the Nore and Erkina; and by the Barrow near Two Mile Bridge, Queen's Co. : Hart $7885 \& 1885 \delta$. Near the Barrow below Athy, Queen's Co.; R. W. S.-IV. Baltinglass, Wicklow (T. Chandlee); roadside half-way between Woodenbridge and Aughrim, Wicklow (Moore): Cyb. By the Slaney near Enniscorthy, and by its tributary the Bann in Wexford; Hart. Ballyhyland, Wexford: Moffat I889.-V. In profusion at Baldrummond; Portrane; Glenasmole, \&c. ; frequent in Co. Dublin: N.C. 1895 a. Straffan, Kildare (J. Douglas): Cyb. Punchestown, Kildare; Mrs. Shaw. At Killencoole, Louth: Praeger 1897.VI. Near Portumna: Herb. Mackay. Abundant on the "Eskers," near Ballinasloe: Foot 1865.-VII. Near Templemore, Tipperary : Hart I885 a. Kilmaglish and Knock Eyon, Westmeath : Levinge I894.-VIII. Between Clifden and Roundstone (Prof. Melville): $C y b$. Foot of Urrisbeg mountain, Roundstone (W. T. Dyer): Rec. Add.-IX. On the "Eskers," near Athlone, in Roscommon: Foot 1865 .

Sea-level to $1000 \mathrm{ft}$. in Dublin (N. C.).

Scarcer in the West than in the East, and apparently quite absent from the North and South.

\section{0. mascula Linn.-Early Purple Orchis.}

Districts I. II. III. IV. V. VI. VII. VIII. IX. X. XI. XII. Lat. 51 $\frac{1}{2}^{\circ}-55 \frac{1}{4}^{\circ}$. Throughout Ireland. Type, British.

Moist pastures, woods, and banks; frequent. Fl. April-May.

Sea-level in Derry and in Kerry. To $1100 \mathrm{ft}$. in Derry (Mroore MSS.). 


\section{0. incarnata Linn.-Marsh Orchis.}

Districts I. II. III. IV. V. VI. VII. VIII. IX. X. XI. XII. Lat. $511^{\circ}-551^{\circ}$. Throughout Ireland. Type, British.

Boggy places, wet meadows, sand-hills, \&e.; frequent. $\mathrm{Fl}$. June-July. (Hart).

Sea-level to $700 \mathrm{ft}$. in Derry $(C y b$.$) . To 1000 \mathrm{ft}$. in Mayo

Var. angtetifouta Bab.-XII. Sparingly on Carngaver Hill, Down (Stewart): Flor. N.-E.

Trustworthy recent records of $O$. incarnata exist for Districts $I$. IV. V. VI. VII. IX. X. XI. and XII. For the remaining three districts, records are available only for 0 . latifolia in the aggregate sense. These it has been considered advisable to refer to $O$. incarnata, since restricted $O$. latifolia has not yet been satisfactorily shown to occur in Ireland.

\section{0. maculata Linn.-Spotted Orchis.}

Districts I. II. III. IV. V. VI. VII. VIII. IX. X. XI. XII. Lat. $51 \frac{1}{2}^{\circ}-55 \frac{1}{4}^{\circ}$. Throughout Ireland. Type, British.

Heaths, banks, pastures, woods, \&c.; common. Fl. June-July.

Sea-level in Donegal and in S. Cork. To $1950 \mathrm{ft}$. in Donegal (Flor. $U l s t$. ); to $2100 \mathrm{ft}$. in Leitrim (B.\&V.); to $2400 \mathrm{ft}$. in Mayo, and to $2800 \mathrm{ft}$. in Kerry (Hart).

The commonest of the Irish orchids.

\section{OPHRYS Linn.}

\section{0. apifera Huds.-Bee Orchis.}

Districts I. II. III. IV. V. VI. VII. VIII. IX. - - Lat. $51 \frac{1}{2}-544^{1}$. South and Middle. Type, English-Germanic.

Lowland. Pastures, drift banks, sand-hills, \&c.; rather rare. Fl. June-July. Caloicole $A$.

I. Near Castlefreke (Rev. J. Stopford); near Bandon (R. L. Allman); near Blackrock: Allin's Cork. Crosshaven, Co. Cork; R.W.S.-II. Abundant on the clayey grounds about Youghal: Wade Rar. Near Youghal (C. Longfield); Little Island (Carroll); Great Island: Allin's Cork. Within 100 yards of the gate of New Geneva, Co. Waterford (Dr. Barker): Templeton MS. Abundant near Cappoquin, Waterford, 1894; Ifiss MI. Chearnley.-III. By 
the Barrow above Tinnehinch bridge, Queen's Co. : Hart I885.IV. Sand-banks at Kiltennel and Courtown, Wexford (Miss $\boldsymbol{E}$. $\boldsymbol{M}$. Farmer): Rec. Add. Near Kilmanock; Pilltown stage; and Alderton, Wexford: B.-H.\& G. 1889 . At Ardamine and Churchtown, Wexford: Marshall I898.-V. Between Stockoole and St. Doulagh's, Dublin: Wade Rar. Sand-hills near Rush, and in Kenure Park, Co. Dublin; Miss Kinahan. Between Ballybrack and Bray; Praeger. At Skerries, 1892 (Rev. T. B. Gibson); Green Hills, Co. Dublin : N. C. 7895 a.-VI. Castle Taylor, Galway: More 1855. Acres valley near Ballyvaughan: Foot 1864. Drumanora, north of Ennis, Clare: Corry 1880 . North Island of Aran : Nowers \&Wells I892. Doon near Clonbrock, Galway (D. MeArdle): Praeger 1806.-VII. Sparingly on the south-east shore of Lough Ennel, Westmeath : Foot 1865. Round Lough Ree: B.\&V. 1887. Tudenham Park and Knock Drin, Westmeath: Levinge 1894. Frequent in pastures at Borrisokane, Tipperary (C. J. Lilly): Ir. Nat. 1896.-VIII. Gentian Hill near Galway; Miss E. Allman. Ard; shores of Lough Corrib; Ashford; and-IX. Near Glen Corrib, Co. Mayo; Miss M. F. Jackson. Lough Carra, Mayo (Miss K. M. Lindsay); Sligo Harbour (J. Wynne): Cyb.

\section{0. muscifera Huds.-Fly Orchis.}

Districts - - III. - V. VI. VII. VIII. IX. - - Lat. $52_{4}^{3}-53 \frac{1}{2}^{\circ}$. Middle Ireland. Type, English-Germanic.

Lowland. Pastures and bogs; very rare. Fl. June. Calcicole $B$.

III. In the neighbourhood of Castlecomer, 1837 (Rev. Mr. Despard) : Mackay 1859 . On Tullavolta bog near Johnstown, Kilkenny, 1838 (Rev. S. Madden), and in 1843 (Rev. J. Despard): $C y b .-V$. Between Ballitore and Athy, Kildare ( $T$. Chandlee): Carroll 1854. In Kildare, on Dollardstown bog ( $J$. Douglas); at Levitstown and Rosetown ( $F$. Haughton); and near Athy (Miss H(aughton): Cyb.-VI. Not infrequent about Castle Taylor: More 1855. Glen Corrib, near Headford (Miss K. M. Lindsay): Cyb. Base of Glanquin Hills, Clare: Corry 1880. Turlough hills, Clare; P. B. O'Kelly.-VII. Plentiful at Annaghmore, King's Co. (M. P. Edgeworth): Cyb.-VIII. Near Ross lake, on the west side of Lough Corrib (Prof. Melville): Cyb.-IX. A large patch on the shore of Lough Corrib at Lake View, Mayo; Miss M. F. Jackson. 


\section{HABENARIA R. Br.}

\section{H. conopsea Benth.-Fragrant Orohis.}

Gymnadenia conopsea R. Br.

Districts I. II. III. IV. V. VI. VII. VIII. IX, X. XI. XII. Lat. $52^{\circ}-55 \frac{1}{4}^{\circ}$. Throughout Ireland. Type, British.

Clay banks, pastures, and heaths; frequent and locally abundant. Fl. June-July. Calcicole $C$.

I. Near Lough Gill, Castlegregory, Kerry: Hart 2884. South of Tarbert, Kerry: R.W. S. $180 \mathrm{~T}$. Banks of the Lee (Mr. Drummond) : Flor. Cork.-II. Near Clonmel (Miss $\left.S_{n} G r u b b\right): C y b$. At Youghal, near the bog (Dr. C. Ball): Allin's Cork. III. Wilton and Bellvue, Kilkenny (Rev. S. Madden): Cyb. By the Nore near Abbeyleix, and near Durrow, Queen's Co.: Hart I $885 \delta$.-IV. V. VI. VII. VIII. IX. and X. Frequent, occurring in many stations in Wicklow, Dublin, Kildare, Clare, Limerick, Galway, Westmeath, Tipperary, Longford, Sligo, Fermanagh, Monaghan, Armagh, and Tyrone, but apparently very rare in Wexford and in the extreme west of Galway and Mayo. XI. Macamish Point and Marble Hill: Hart 1880. Meevagh, Mulroy Bay; Miss Kinahan. - XII. Abundant at the base of Umbra Rocks, Derry: Moore MS. In numerous stations in Antrim and Down: Flor. N.-E. and S.\& P. 1895 .

Sea-level in Antrim and in Kerry. To $900 \mathrm{ft}$. in Clare ( $N . C$.$) .$ Rare in the South and not recently found in county Cork.

\section{H. intacta Benth.-Close-flowered Orchis.}

Neotinea intacta Reich.-Orchis intacta Link-0. atlantica Willd.Aceras densiftora Boiss.-Tinea cylindracea Biv.

Districts - - - - - VI. - - IX. - - Lat. $53^{\circ} 5^{\prime}-53^{\circ} 30^{\prime}$. Galway, Clare, and Mayo. Type, Hibernian.

Lowland. Rocky pastures on limestone; local and rare. Fl. May.

VI. In a large rocky pasture field, called the "Hunting Course," to the west of the Nut-wood at Castle Taylor, Galway, May, 1864 (Miss F. M. More) : Seeman's Journ. of Bot. I864, p. 228. Plentiful about 3 miles south-west of Castle Taylor; also about 2 miles east of Kinvarra, 1898 ; Mrs. M. E. Joyce. Base of Glanquin Hills, Clare: Corry I880. Around Ballyvaughan, Clare, extending for about 6 miles west and 3 miles east 
of the town; also at Glanquin, 1892 (Levinge): Journ. of Bot. 1892, p. 194. Frequent from near Kinvarra, Galway, to Ballyvaughan, Clare, and from Ballyvaughan to Ballynalackan, Clare, 1893 ; Dr. Leitch.-IX. On the north-east shore of Lough Corrib, not far from Cong, 1872 (Moore): Rec. Add.

Not found in Great Britain, and reaching in Ireland its extreme northern limit for Europe. Distinctly southern in its Continental range, occurring in southern France, the Spanish Peninsula, and along the Mediterranean, eastward to Greece.

First found by Miss Frances M. More, at Castle Taylor, Galway, in 1864 .

3. H. albida R. Br.-White Mountain Orchis.

Gymnadenia albida Rich.

Districts I. II. III. IV. V. VI. - VIII. IX. X. XI. XII. Lat. $52^{\circ}-55 \frac{1}{4}^{\circ}$. Throughout Ireland, almost. Type, Scottish.

Mountain pastures; rather rare. Fl. June-July.

I. Near Rossbeigh ( $J$. Woods); and Gap of Dunloe, Kerry (J. Cooke): Cyb. Sparingly by the River Flesk, and more abundantly where the river Finnow joins it; sparingly in Glencar, Kerry: R.W.S. $1889 \& 1890$.-II. In Dunbullogue Glen, five miles north of Cork, and on a Danish fort in the same district: Flor. Cork. Heathy places near Ballymacarbery, Waterford (Miss S. Grubb): Cyb.-III. In a field between Cullenagh and Stradbally, Queen's Co.: Mack. Rar. By the Barrow above Tinnehinch Bridge: Hart I885. By the Killeen river, Slieve Bloom, 1897; Praeger.-IV. At Luggylaw in a field on the borders of the lake, 1802: Templeton MS. Bog at Oldbridge below Lough Dan, Wicklow; More. In Glencree; R.W.S.-V. Near the Three Rock Mountain : Wade Rar. Glenasmole, 1889; Greenwood Pim.VI. Frequent on high grounds in Burren, 1851: O'Mahony $I 860$. Plentiful about Lisdoonvarna, Clare: Foot 1864 . At Dalystown, south-east Galway, 1897 ; Praeger.-VIII. A little west of Galway, and on the west side of Lough Mask (Prof. Melville): Cyb. On Ben Leir, Glantraigue, Galway; Miss M. F. Jackson. Mweelrea, Mayo: Hart 1883 a.-IX. Near Foxford, Mayo (More): Cyb. Bruse Hill near Mohill, Leitrim (F.J.Foot): Rec. Add. Base of Ben Whisken, very sparingly, and on the talus of King's mountain, Sligo: B.\&V. I885.-X. Pollaphuca, Lough Erne, rare: Barrington 1884. In Tyrone (Admiral Jones) : Cyb.-XI. Not infrequent in southern Donegal; near Dunkineely; Killybegs, \&c. 
(More): Cyb. Near Greencastle, Inishowen (W. E. Hart): Hart I883. Rossgull ; Miss A. G. Kinahan.-XII. Side of a glen in Ballynascreen mountains, Derry, 1800; southern side of the Black Mountain, Antrim, 1803: Templeton MS. A mile east from Ballinure; Squire's Hill; Carrickfergus commons : Flor. Ulst. Plentiful in the townland of Carus, parish of Dungiven, Derry : Moore MS. Carngaver Hill above Holywood, Down, 1883 (Stewart); Scawt Hill, north of Larne (Praeger): Flor. N.-E. On Slemish, Antrim, 1793 (Templeton): Whitla MS. -and plentiful at the southwest base of the mountain in 1896 (Hart) : Ir. Nat. I896. Conlig Hill, Down, 1891 (Praeger); Squires Hill, near Belfast, 1893 ( $W$. H. Patterson); Glenariff, Antrim (Rev. S. A. Brenan): Stewart I894. To $800 \mathrm{ft}$. in Donegal and in Derry (Cyb.).

A widespread species most frequent in the North, but seldom occurring in abundance.

\section{H. viridis R. Br.-Frog Orchis.}

Celoglossum viride Hartm.

Districts I. II. III. IV. V. VI. VII. VIII. IX. X. XI. XII. Lat. $51 \frac{1}{2}^{\circ}-55 \frac{1}{4}^{\circ}$. Throughout Ireland. Type, British-Scottish.

Hilly pastures and sand-hills; not infrequent. F'l. June-July.

Sea-level in N. Donegal and in Kerry. To $1000 \mathrm{ft}$. in Derry (Moore); to $1050 \mathrm{ft}$. in Dublin (N.C.); to $1075 \mathrm{ft}$. in Clare (Foot).

\section{H. bifolia R. Br,-Lesser Butterfly Orchis.}

Platanthera bifolia Rich.

Districts I. II. III. IV. V. VI. VII. VIII. IX. X. XI. XII. Lat. $51 \frac{1}{2}^{\circ}-55 \frac{1}{4}^{\circ}$. Throughout Ireland. Type, British.

Marshy pastures and heaths; rather frequent. Fl. June-July.

Sea-level to $1000 \mathrm{ft}$, in Derry (Stewart).

Apparently rare in the East and generally less frequent thian the following species.

\section{H. chloroleuca Ridley.-Greater Butterfly Orchis.}

H. chlorantha Bab.-Platanthera ohlorantha Custer. Districts I. II. III. IV. V. VI. VII. VIII. IX. X. XI. XII. Lat. $51 \frac{1}{2}^{\circ}-55 \frac{1}{4}^{\circ}$. Throughout Ireland. Type, British.

Boggy fields and moist upland pastures; frequent and locally abundant. Fl. June-August.

From $100 \mathrm{ft}$. to $1000 \mathrm{ft}$. in Derry (Stewart). 
This and the preceding species were not sufficiently distinguished in many of the older records, but recent observation proves them to be both widespread in Ireland, though unequally distributed in many districts.

\section{ORDER LXVI.-IRIDEXE.}

\section{IRIS Linn.}

\section{1. *I. fotidissima Linn._Gladdon; Stinking Iris.}

Districts I. II. III. IV. V. VI. VII. - IX. X. XI. XII. Lat. $52^{\circ}-551^{\circ}$. Throughout Ireland, almost. Type, English.

Hedge-banks, thickets, fields, \&c.; rare and nowhere native. Fl. June-July.

I. Mucruss, Killarney (Admiral Jones): Cyb. Still in Muckross shrubberies in $1897 ; R . W . S .-$ II. Naturalized on limestone rocks at Glanworth, Fermoy (T. Chandlee): Cyb.-III. Field between Ballybracken and Kilkenny: Mack. Rar. Banks of the Barrow near Portarlington: Flor. Hib.-IV. At Fassaro, south of Bray: Wade Rar. At Tythewer, Wicklow: Ir. Flor.-V. Ireland's Eye and Howth: Wade Rar. 1804-still on Ireland's Eye, $1882 ; N . C$. Dalkey; Killiney Bay; Tagony; and abundantly at Scholarstown : Ir. Flor. Cliffs on Lambay Island, looking native: Hart $7883 \gamma$. Abundant at Greenfields, Howth: Flor. Howth. In Narraghmore wood; on a ditch-bank by the road of Ballykillane, Kildare (Carroll): $C y b .-V I$. In Ennis churchyard, Co. Clare: Wade Rar. Margin of Ballycar Lake, near Ennis, looking native: Stewart 1890. Rocky fields near Murrough, Black Head, Clare, 1895 ; P. B. O' Kelly-VII. By a road a little east of Edenderry towards Rathangan, naturalized (Prof. Melville): Cyb.-IX. By the river at Dalgan near Shrule, Co. Mayo; Miss M. F. Jackson.$\mathbf{X}$. At Tartaraghan, Armagh (Stewart); hedge-bank in Armagh Palace demesne: Praeger I893.-XI. Abundantly established at Brown Hall; well established in thickets by the sea at Rathmullan House : Hart 1880 \& 1886 . Plentiful on a ditch bank at Culmore, Derry (Moore): Colby 1837.-XII. Woods at Grey Abbey; along the river below Newcastle, Down: Ir. Flor. Naturalized near Coleraine (Moore): $C y b$. Plentiful in a meadow by the stone cashel at Cushendun: B.N.F.C. Proc. I884.

No doubt in all cases a relic of ancient cultivation. 


\section{Iris Pseud-acorus Linn.-Yellow Flag.}

Hibernicé Cleaptrom (Ellis-thrum); Sellipenom (Shellis-thrum). Districts I. II. III. IV. V. VI. VII. VIII. IX. X. XI. XII. Lat. $51 \frac{1}{2}^{\circ}-55 \frac{1}{4}^{\circ}$. Throughout Ireland. Type, British.

Marshy places, wet meadows, \&c. ; common. Fl. June-July.

Sea-level in Derry and in S. Cork. To $1100 \mathrm{ft}$, in Sligo.(N.C.).

In the Journal of Botany, $189 x, p .304, \mathrm{Mr}$. D. Druce states that the only form of this plant seen by him in South Cork and Kerry was the Var. acoRIrormis (Boreau).

\section{SISYRINCHIUM Linn.}

\section{1. †. angustifolium Mill.-Blue-eyed Grass.}

S. anceps Cav.-S. Bermudiana Linn.

Districts I. - - - - VI. - - - - Lat. $51^{\frac{3}{4}}{ }^{\circ}-53^{\circ}$. Kerry, Cork, and Galway only.

Lowland. Moist pastures and meadows, and boggy and heathy places; very rare. $F$. June-July.

I. In a pasture near a planted copse north-east of Milltown, Kerry (Lady Godfrey); also near Lough Dromin, a mile and a half' south-west of Milltown (Rev. A. Isaac): Journ. of Bot. I882, p. 8 . Still at Milltown in 1890, extending over a limited area; also found in the same year along the river Laune near Killorglin, and above Aughils, west of Castlemaine: R.W.S. $189 I$. On damp rocks by the sea about three miles north-west of Cahirciveen, Kerry, 1892; R.W. S. Near Bere Haven, Bantry Bay, Cork, 1854 (T. O. Eyton): Herb. Bot. Socy. Edin. Ardnacashel, Bantry Bay, 1887 (Miss Alioia Hutchins): Herb. R. P. Towell. Near the edge of a bog ditch a mile east of Gortnavalig House, between the sea and the coach.road from Bantry to Glengariff, 1896; Miss Lena Gyles.VI. "Communicated by the Rev. H. L. Jenner by whom it has been received as an indigenous Irish plant collected in a wood near Woodford, Co. Galway"; Rep. of Proc. of Bot. Soc. Lond. : Phytol. ii., $p .500,1846$. "Gathered in a a coarse meadow half a mile north of the village of Woodford, near Loughrea, in great quantity, and on the race-course near that village, and also in a coarse meadow near the police barrack in Rossmore . . . by James Lynam, Esq., who sent me [Mackay] specimens in Sept. 1847": Mackay 1859. Abundant in marshy meadows and pastures along both sides 
of the river for four miles from Woodford to Rossmore; in fields by the road from Woodford to Portumna; on a hill half a mile northeast from Woodford, 1870 (Prof. E. P. Wright \& M. Dowd): Rec. Add. On the Woodford race-course: Linton 1886 . Rocky shore of Lough Derg at the mouth of the Woodford river, 1895 ( $C . J$. Lilly): Ir. Nat. 1896. Frequent in boggy meadows by the Woodford river about a mile from Lough Derg, 1896: N. C. 1897 .

Also observed growing in a neglected gravel walk near Mullingar, Westmeath, in 1879 (J.R. Simms): Journ. of Bot. I882, p. 8.

A native of temperate North America. Though fully established in thoroughly wild looking stations in Galway and Kerry, the rapid increase of this species as an alien in Queensland and its more recent appearance in northern and western Germany and elsewhere on the European continent forbid its admission as an undoubtedly indigenous member of the Irish flora. Further investigation of its distribution in Ireland may perhaps strengthen its claim to be regarded as native.

First found by James Lynam, at Woodford, in 1845, and published as Irish in the Phytologist in 1846.

\section{2. $\ddagger$ S. californicum Dryand.-Yellow-eyed Grass.}

Districts - - IV. - $-\overline{-}-\overline{-}---$
$\quad$ Marshy land near the sea, in Co. Wexford only; very rare. Fl. June.

IV. In plenty over several acres of partially drained, rushy and marshy meadow land, about a mile north of Rosslare railway station, Wexford, 1896 (Rev. E. S. Marshall): Journ. of Bot. I896, p. 366. -also seen here again in the following year.

Found grawing in the wettest part of the land with Orchis incarnata, Carex distans, Eriophorum, \&c., and in the opinion of the finder either a native or intentionally introduced some years ago. While the occurrence of this plant of Oregon and California in a wild state in Ireland is of great interest, the fact that it has only been discovered quite recently and in a single station in the neighbourhood of a considerable harbour is enough to disqualify it for admission to native rank in the Irish flora. Further knowledge of the habits of this interesting alien and further inquiry as to whether it is or has been cultivated in the vicinity of Wexford Harbour or along the Slaney or other streams discharging into it may be expected to clear up the mystery of its appearance in Ireland. 
ORDER LXVII.-AMARYLLIDE正.

NARCISSUS Linn.

1. *N. biflorus Curtis.-Pale Narcissus.

Districts - - III. IV. V. VI. - - - - - -

Lowland. Grassy places, usually near dwellings or ruins; rare and nowhere native. Fl. May.

III. In a pasture field six miles from Portarlington (Moore): Nat. Hist. Rev. I859, p. 157.-IV. Established in several localities about Bannow, Wexford, 1893; Barrett-Hamilton.-V. Near the Obelisk, Killiney; and near Newtown Park and Cabinteely: Wade Dubl. r794. Plentiful near the Obelisk, Killiney, no doubt planted (More): Cyb. 2866. Fields and meadows between Clontarf and Raheny; about Scribblestown and Finglass : Ir. Flor.-VI. On the east side of the Great Island of Aran, on sandy pasture ground between Kilronan and the sea (Moore): Cyb. Abundant on Inishcaltra or Holy Island, Lough Derg, long established: $N$. C. I897.

In all cases a relic of cultivation, but appears to be fully naturalized in some of its stations.

\section{ORDER LXVIII.-LILIACE正.}

\section{ASPARAGUS Linn.}

1. A. officinalis Linn.-Wild Asparagus.

Districts - II. - IV. - - - - - - - Lat. $52^{\circ} 10^{\prime}$. South-East Ireland. Type, Atlantic.

Sandy ground by the sea; very rare. Fl. August.

II. On the isthmus of Tramore, in the sand: Smith's Waterford I746. On the sand-hills at Tramore, Waterford (Miss Grubb): Carroll 1857.-IV. Abundant on the shore near the town of Wexford (Messrs. MoAlla \& Walker): Mackay 1859. Sand-hills in Ballyteigue Bay, Wexford (Mr. Lewis): Rec. Add. Plentiful on Ballyteigue Burrow, 1876 ; G. H. Kinahan. Bar of the Lough, $2 \Delta$ 
about half way between Crossfarnoge and Bannow; and at Bannow Island, Wexford: Hart $1883 \beta$.

Threlkeld, in his Synopsis, says: "It grows upon the Sea-coasts and sometimes comes to Town [Dublin] for Litter to Goods upon Carrs."

First recorded by Smith, from Tramore, in 1746.

\section{SIMETHIS Kunth.}

\section{S. bicolor Kunth-Variegated Simethis.}

Districts I Lat. $51^{\circ} 45^{\prime}$. South-West, Kerry only. Type, Local-Atlantic.

Lowland. Bushy and grassy places, and in rock-clefts, near the sea; very rare. $\mathrm{Fl}$. May.

I. Hills near Derrynane Abbey, Kerry [on the Abbey Island] (Rev. T. O'Mahony): London Journ. of Bot. vii., p. 571 . On the mainland a little west of Derrynane (Dr. E. P. Wright): Cyb. West side of the Abbey Island, Derrynane; head opposite Kid's island, north of Dexrynane; Lamb's Head, south of Derrynane; in many places by the shore of Kenmare River to eight or nine miles east of Derrynane; and about a mile inland, four miles east of Derrynane: R.W.S. I8go\& $9 I$.

One of the rarest plants in the Irish flora. Ranges on the Continent from Western France by Northern Spain and Portugal eastward along the Mediterranean to Corsica and west Italy. Reaches its northern limit for Europe in Kerry, about one degree of latitude north of its only English station, near Bournemouth in Dorset, where it has, perhaps, become extinct.

First found in Ireland by the Rev. T. O'Mahony in 1848.

\section{ALLIUM Linn.}

\section{1. $\ddagger$ A. Babingtonii Borrer-Bulb-bearing Leek.}

A. Ampeloprasum Var. Babingtonii Hook.-A. Halleri Bab.

Districts - - - - VI. - VIII. - - XI. -

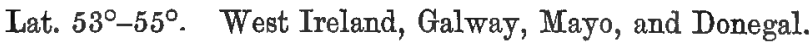

Lowland. Rock-clefts, sandy places, and cultivated land near the coast; rare. Fl. June-July.

VI. In the South Isles of Aran (Messrs. Thomson \& Ball): Flor. $H i b$. (as $A$ arenarium). Near Kilronan, Aranmore, and scattered 
through all three Isles of Aran, in rock-clefts and sandy places (N. C.): Ir. Nat. I893. At Menlough, Galway; More.VIII. Near Roundstone, sparingly: Oliver 1845 . On Tlan Glas opposite Roundstone (Babington): Cyb. On Inish Bofin, among ruins, \&c., in two places: More 1876 . South shore of Clew Bay; More.-XI. At Doagh Beg; near Kilmacrenan; between Ray and Rathmullan : Hart 1880 . Established on the north side of Inver Bay : Hart $1885 \gamma$.

Probably in all cases a relic of ancient cultivation, but looks thoroughly wild in many of its Aran island stations, where it freely propagates itself by means of its numerous bulbils.

\section{2. $\ddagger$ A. Scorodoprasum Linn.-Sand Garlic.}

A. arenarium Smith.

Districts I. II. - - - - - - - - Lat. $51 \frac{1}{2}^{\circ}-521^{\circ}$. South-West. Type, Intermediate-Scottish.

Lowland. Woods and sandy pastures; rare. Fl. June-July.

I. Plentiful in the thickets at Muckross, Killarney (Moore): $C y b$. Thinly scattered through the Muckross shrubberies; in great abundance in the "Green," Tralee, and along the adjoining stream: R.W.S. 1889 . Very abundant in the Derrynane shrubberies; sparingly near an old castle at the head of Kenmare Bay: R.W.S. $I 890$. In profusion in the woods near Bantry; woods at Castlefreke, Rosscarbery (Phillips): Ir. Nat. I893, p. 23.-II. By the shore near the tower at the south side of Foaty Island: Flor. Cork-still at Foaty island in 1895; Phillips. Left bank of the Blackwater above Cregg Castle, Fermoy, and in woods in Norrey's Castle demesne below Mallow: Hart $x 885 \delta$. Above the railway bridge at Mallow; R. P. Vowell.

Probably in all cases a relic of ancient cultivation.

\section{A. vineale Linn.-Crow Garlic.}

Districts I. II. III. IV. V. VI. - - IX. - XI. XII. Lat. $52^{\circ}-55^{\circ}$. From South to North. Type, English-British.

Lowland. Dry pastures and banks; local. Fl. June-July.

I. Sparingly by the Laune near Killorglin, Kerny, but very rare in the county; R.W.S.-II. Fields near Glanmire, Cork: Drummond I8r8. Strand of the Little Island; hedge bank at Ballinamought: Flor. Cork. Plentiful at Inchfield, Fermoy 
(T. Chandlee); near Clonmel by the Suir (Moore): Cyb. By the Owbeg, close to Castletownroche (Carroll): Allin's Cork. Near Tivoli, Cork, 1892; Phillips. On most of the pasture lands in Waterford: Smith's Waterford.-III. Banks of the Nore near Inistioge, Kilkenny: Tighe Statistical 0bs. I802. At Mount Juliet near Thomastown on the Nore: Hart $7885 \delta$. Near Kilmacow, Kilkenny ( $T$. Chandlee): $C y b$. By the Slaney at Aghade, Carlow : Hart I88I a.-IV. Rockfield, Wicklow (Moore): Cyb. By the Slaney between Macmine and Killurin, Wexford: Hart $I 88 I$ a. Near Pilltown Stage and Kilmanock, Wexford:

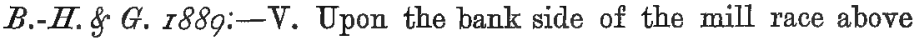
Island Bridge, and in meadows near Ballygriffin in Fingall, copiously: Threlkeld. Plentiful at Greenfields, Howth: Flor. Howth. Broad Meadow near Swords, 1891; Barrington. At Portmarnock and Feltrim Hill, 1893; Green Hills and Portrane, 1895, \&c.; locally abundant in Co. Dublin; $N . C$. By the Boyne above Queensborough, Louth: Praeger $1897 .-V I$. By the Shannon near Loghill, east of Glin, Co. Limerick: R.W.S. I89I.IX. Near Cong church, Co. Mayo; Miss M. F. Jackson.-XI. By the Foyle four miles south of Derry ; Hart.-XII. Along the shore between Hollywood and Bangor (Mr. Millen): Flor. Ulst. Shane's Castle Park (Corry); in some plenty by the Sixwilewater above Antrim (D. Reamond); very rare in the North-East: Flor. N.-E.

Apparently rare in the West and North.

\section{A. ursinum Linn.-Ramsons.}

Hibernicé $\delta$ aipleoz (Gawr-lee-yoge), Garlic.

Districts I. II. III. IV. V. VI. VII. VIII. IX. X. XI. XII. Lat. $51 \frac{1}{2}^{\circ}-55 \frac{1}{4}^{\circ}$. Throughout Ireland. Type, British-English.

Damp woods and thickets; rather frequent. Fl. May-June.

Near sea-level in Antrim and Kerry. To $1050 \mathrm{ft}$. in Leitrim (B.\&V.); to $1000 \mathrm{ft}$. in Queen's Co. (Hart).

\section{SCILLA Linn.}

1. S. verna Huds.—Vernal Squill.

Districts - - - IV. V. - - - - - - XII. Lat. $53^{\circ}-551^{\circ}$. East and North-East. Type, Atlantic-Scottish. May.

Lowland. Rocky pastures on the coast; very local. Fl. April- 
IV. Coast at Rockfield, Wicklow (Moore): $C y b$. Along the lake at the Murrough of Wicklow; W. R. MeNab.-still at Rockfield, 1893, and at the Murrough, $1896 ; R$.W. S.-V. "At Ringsend neere Dublin (Mr. Heaton)": How, Phytologia I65o. Howth and Ireland's Eye: Wade Rar. Killiney Hill: Mack. Cat. On the south side of Howth: Ir. Flor.-very abundant here, 1896 ; N. C. Abundant on the west side of Lambay Island : Hart $2883 \gamma$. Plentiful at Clogher Head and on Castlegar Hill, Louth $(J . B$. Hamilton : $C y b .-X I I$. Abundantly on the rocks and pastures near the Giant's Causeway: Wade Rar. Rocks along the shore from Donaghadee to Bangor, and with pale red flowers on the west side of Ardglass harbour: Templeton MS. Groomsport (Mr. Millen); Rathlin Island (Miss Gage); Portstewart (Rev. W. T. Whan): Flor. Ulst. Frequent in the North-East: Flor. N.-E.

\section{S. nutans Linn.-Blue Bell; Wild Hyacinth.}

Endymion nutans Dum.-Agraphis nutans Link-Soilla festalis Salisb.-Hyacinthus non-scriptus Linn.

Districts I. II. III. IV. V. VI. VII. VIII. IX. X. XI. XII. Lat. $51 \frac{1}{2}^{\circ}-55 \frac{1}{4}^{\circ}$. Throughout Ireland. Type, British.

Woods, thickets, and heaths; frequent and locally abundant. Fl. April-May. Calcifuge $B$.

Sea-level in Derry and S. Cork. To $1350 \mathrm{ft}$. in Ben Bulben district $(B . \& V$.$) ; to 1100 \mathrm{ft}$. in Carlow (Hart).

\section{COLCHICUM Linn.}

\section{C. autumnale Iinn-Meadow Saffron.}

Districts - - III. - - [VI.] - - - - - Lat. $52 \frac{1}{2}^{\circ}-52 \frac{3}{4}^{\circ}$. South-East; Killkenny and Carlow. Type, English.

Lowland. Meadows and pastures; very rare. Fl. Aug.-Sept.

III. On the banks of the Nore between Thomastown and Inistiogue, August, 1799 (J. Blashford); below Inistiogue Bridge, on a flat near the river (Dr. Barker): Templeton MS. Meadows by the river side between Kilkenny and Inistiogue: Flor. Hib. Abundant by the Nore from above Kilkenny to Bennett's Bridge: Hart ${ }_{1} 885 \delta$. Plentiful in low-lying meadows by the King's River, a little below Callan, Kilkenny, 1898; Rev. T. Hartley. Freshford, Mount Juliet, and Knocktopher in the county of Kilkenny, and Poulgower and Warrington near the city of Kilkenny (Rev. S. 
Madden): Cyb. Near Carlow: Flor. Hib.- [VI. Plentiful in moist meadows on the banks of the Shannon below Limerick (Dr. Woods): Mack. Cat. 1825 -no recent record.]

Also recorded in the Irish Flora for Districts V. and XII., from Finglas and Scribblestown, Co. Dublin, and Grey Abbey, Co. Down, in which stations the plant has not been found recently, and probably occurred as a garden escape only.

First found by J. Blashford, on the Nore, in 1799.

\section{NARTHECIUM Mœhr.}

\section{N. ossifragum Huds.-Bog Asphodel.}

Districts I. II. III. IV. V. VI. VII. VIII. IX. X. XI. XII. Lat. $51 \frac{1}{2}^{\circ}-55 \frac{10}{4}$. Throughout Ireland. Type, British.

Bogs and moors; frequent and locally abundant. Fl. JulyAugust. ' Calcifuge $A$.

Sea-level in Derry and Cork. To $2000 \mathrm{ft}$. in Derry (Moore); to $2050 \mathrm{ft}$. in Mayo, $2930 \mathrm{ft}$. in Wicklow, and $2300 \mathrm{ft}$. in Waterford (Hart).

\section{ORDER LXIX.-JUNCACEE.}

\section{JUNCUS Iinn.}

\section{J. bufonius Linn.-Toad Rush.}

Districts I. II. III. IV. V. VI. VII, VIII. IX. X. XI. XII. Lat. $51 \frac{1}{2}^{\circ}-55 \frac{1}{4}^{\circ}$. Throughout Ireland. Type, British.

Damp, sandy, and heathy places, and on ground flooded in winter; rather common. Fl. July-August.

Sea-level in N. Antrim and S. Cork. To $1100 \mathrm{ft}$. in Donegal (Hart); to $1600 \mathrm{ft}$. in Dublin (N.C.).

Var. Fasciculatus Koch. - I. Connor Hill, Dingle, 1848; J. Ball. Glengariff, Cork : Druce I89I.

2. J. squarrosus Linn.-Heath Rush.

Districts I. II. III. IV. V. VI. VII. VIII. IX. X. XI. XII. Lat. $511^{\circ}-55 \frac{1}{4}^{\circ}$. Throughout Ireland. Type, British.

Heaths and moors; common, especially in mountain districts. Fl. June-July. Calcifuge A. 
Sea-level in Derry and in Kerry. To $2150 \mathrm{ft}$. in Donegal (Hort); to $2500 \mathrm{ft}$. in Down (S.\&P.); to $3000 \mathrm{ft}$. in Wicklow (N. C.) ; to $2680 \mathrm{ft}$. in Mayo, and to $3300 \mathrm{ft}$. in Kerry (Hart).

The highest ranging of the Irish Rushes and common on almost all flat mountain tops throughout the country.

\section{J. Gerardi Loisel.—Round-fruited Rush.}

Districts I. II. III. IV. V. VI. - VIII. IX. X. XI. XII. Lat. $51 \frac{1}{2}^{\circ}-55 \frac{1}{4}^{\circ}$. Coasts of all Ireland. Type, British.

Salt-marshes and wet places near the sea ; frequent and locally abundant. Fl. June-August.

Our plant appears to be in all cases $J$. Gerardi (Loisel). True -J. compressus (Jacq.) has not yet been ascertained to occur in Ireland.

\section{4. †J. tenuis Willd.-Slender Rush.}

Districts I. - - - - VI. - - - - Lat. $51 \frac{1}{2}^{\circ}-53^{\circ}$. South-West and West. Cork and Kerry, chiefly.

Lowland. Damp roadsides and beaten tracks, also in woods; locally abundant. Fl. July.

I. By the old road between Caherdaniel and Sneem, one mile inland; in two places by the sea about two miles west of Kenmare, Kerry (R.W.S.): Journ. of Bot. ${ }_{2} 889, p .335$. By the Kenmare and Glengariff road, Kerry, about eight miles from Kenmare and five miles from the nearest sea; in great abundance in the station west of Kenmare, over an area of three-quarters of a mile by a quarter of a mile: $R$.W.S. I89I. In great abundance about Croanshagh bridge near Dereen, and at intervals over an area more than five miles in length from Lehid to the Co. Cork boundary; along an old mountain road in Co. Cork between Adrigole and Dereen, ascending to fully 500 feet; $R$.W.S. Sparingly in woods at Milleove, Castletown, and at Dunboy; and abundantly on damp roadsides and bare spots by a stream at Adrigole, Cork: Phillips 1894.-VI. Salt marsh near Kilronan, Aranmore island, $1894 \&-95 ; P . B$. O' Kelly.

The Irish head-quarters of this species is the wild rocky peninsula between Kenmare River and Bantry Bay, where, in parts, it seems to be the commonest of the Junci, and has at least all the appearance of a native:

First found in Ireland by R. W. S. in 1889. 
In Britton and Brown's Illustrated Flora of the Northern United States, 1806 (Vol. I. p. 386), this interesting plant is set down as occurring "almost throughout North America" and as "now migrating to all parts of the world." On the European Continent it has already been observed in Sweden, Denmark, France, Germany, North Italy, and West and South Russia, and is admittedly introduced in some of its stations. The earliest record for the Continent dates from 1859, the earliest for Great Britain, from 1863, when it was discovered in Renfrew. The fact that it was. first detected in Ireland only so recently as 1889 cannot be accepted as a strong argument against its admission as a native, since it is only of late years that a systematic survey of the flora of Kerry and South Cork has been undertaken. Neither can its predilection for old roads and beaten tracks in South-West Ireland be urged against. its claim to native rank, since these are precisely the habitats it affects in North America. Yet, on the whole, it seems best to regard the plant as an introduction in Ireland, though here a positive decision is even more difficult to arrive at than in the case of Sisyrinchium angustifolium.

\section{J. glaucus Ehrh.-ZHard Rush.}

Districts I. II. III. IV. V. VI. VII. VIII. IX. X. XI. XII. Lat. $52^{\circ}-55 \frac{1}{4}^{\circ}$. Throughout Ireland. Type, English-British.

Lowland. Damp, grassy places; frequent and locally abundant. Fl. July. Calcicole $B$.

Rare in many parts of the country and not recorded, so far, either for S. Cork or S. Kerry.

\section{J. effusus Linn.-Loose-flowered Rush.}

Hibernicé Luaćap (Loo-ack-ar).

Districts I. II. III. IV. V. VI. VII. VIII. IX. X. XI. XII. Lat. $51 \frac{1}{2}^{\circ}-55 \frac{1}{4}^{\circ}$. Throughout Ireland. Type, British.

Wet and marshy places; common. Fl. July-August.

Sea-level in N. Antrim and S. Cork. To $2150 \mathrm{ft}$. in Donegal (Hart); to $2800 \mathrm{ft}$. in Wicklow (N.C.).

\section{J. conglomeratus Linn.}

Districts I. II. III. IV. V. VI. VII. VIII. IX. X. XI. XII. Lat. $51 \frac{1}{2}^{\circ}-55 \frac{1}{4}^{\circ}$. Throughout Ireland. Type, British.

Wet and marshy places; common. Fl. July-August. 
Sea-level in N. Antrim and S. Cork. To $1700 \mathrm{ft}$. in Derry, and to $2350 \mathrm{ft}$. in Kerry (Hart).

$J$. diffusus Hoppe-J. effusus $\times$ glauous Schnitzl-V. In a wet bog on Killakee mountain, Co. Dublin, at $1600 \mathrm{ft}$ : $N$. C. 1895 .

\section{J. maritimus Lamk.-Lesser Sea-Rush.}

Districts I. II. III. IV. V. VI. - VIII. IX. X. XI. XII. Lat. 51 $\frac{10}{2}-55 \frac{10}{4}$. Coasts of all Ireland. Type, British-English.

Salt marshes and muddy seashores ; frequent. Fl. July-August.

\section{J. acutus Linn.-Great Sea-Rush.}

Districts I. II. - IV. Lat. $51 \frac{1}{2}^{\circ}-53^{\circ}$. South and South-East. Type, English-Atlantic.

Sandy and muddy sea-shores; rare. Fl. June.

I. Strand near Timoleague, Cork (Drummond): Flor Cork. Abundantly at Flaxfort a few miles from Timoleague; and on sands at Rosscarbery: Allin 1872. A few plants at Castlefreke sands (Rev. T. Allin): Rec. Add.-still there in $1896 ; R . W . S$. Left bank of the Rowry river, above Millcove harbour, near Glandore: Allin 1874. At Harbour View: Allin's Cork. Abundant at Tralispen near Lough Hyne; Phillips. Seafort near Schull; J. J. Wolfe.-II. On a sand-bank called the Cunnegar near Dungarvan, Waterford: Fllor. Cork I845-and circa 1865 (Professor Murphy): Cyb. Near Tramore, Waterford (Miss S. Grubb): Carroll 1857.-IV. Sandy shores between Wicklow and Arklow (Mr. Hodgins): Mack. Cat. Along the river side between Dunganstown and the seashore, Wicklow - Ir. Flor. Curracloa, Wexford (J. Morrison): Carroll 1854. Raven Point; Curracloa; between Courtown and Kilmichael Point; along all the east coast of Wexford where sand-hills occur, reaching north to near Wicklow Head, and most abundant south of Cahore Point, but not on the south coast of Wexford: Hart I88I $\alpha$.

Has its headquarters in Ireland along the coasts of Wexford and Wicklow.

\section{J. supinus Mœnch-Bog Rush.}

Districts I. II. III. IV. V. VI. VII. VIII. IX. X. XI. XII.

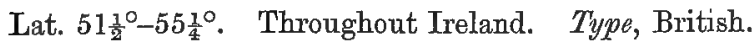

Boggy places, and in mountain lakes and bog pools; frequent. Fl. June-August. Calcifuge $A$. 
Sea-level in Derry and in S. Cork. To $2200 \mathrm{ft}$. in Donegal, and to $2400 \mathrm{ft}$. in Kerry (Hart); to $2850 \mathrm{ft}$. in Wicklow (N. C.).

Var. Fluitans Lamk.-The submerged or floating filiform variety is not infrequent in still mountain lakes. It has been observed in (I) Kerry, and (VIII.) Connemara by More; in (VI.) Clare by Moore; in (XII) the Moune mountains by Stewart \& Praeger; and in (IX.) the Ox mountains by N.C.

\section{J. obtusiflorus Ehrh.-Blunt-flowered Rush.}

Districts I. - III. IV. V. VI. VII. VIII. IX. - XI. XII. Lat. $51 \frac{3}{4}^{\circ}-54 \frac{1}{2}^{\circ}$. Throughout Ireland, probably. Type, English.

Lowland. Boggy places, chiefly near the coast; rather rare. Fl. July-August.

I. Near Dingle, Kerry (Moore): Rec. Add. Coast between Camp and Tralee, Kerry : Hart I884. By Barrow Harbour; and bog at Clogherbrian, Tralee: R.W. S. 1888. Bog near Bandon: Herb. Mackay.-III. Near Emo and Portarlington, Queen's Co.: Praeger $7897 .-$ IV. In marshy fields adjoining the Murrough of Wicklow; and at Killoughter about three miles north of Wicklow (Moore) : Cyb.-V. Shore east of Dollymount, Dublin: Moore \& More I878. Portrane; Saggard; and Garristown, Co. Dublin: N. C. I895. Near Castlebellingham, Louth: Butler I890. Abundant south of Kildare town, 1897 ; Praeger.-VI. Salt marsh at the mouth of the Creagh river, Clare; Moore. Foynes, Limerick: Stewart I890.-VII. Scraw Bog, Loughanstown; Robinstown Tyrrell; and south-east end of Lough Owel, Westmeath: Levinge 1894.-VIII. Boggy slopes at foot of Urrisbeg mountain, Connemara (More): Rec. Add. At Slyne Head, Galway, 1897 ; Barrington. In Co. Mayo, on sands near Belmullet; and-IX. At Moyview; More. Near Lough-a-chree and Dromore West, Sligo: N. C. 1896 . Rosses and Ballysodare, Sligo, 1897; Praeger.-XI. Washpool stream near Ballyshannon; Cavan Garden Lakes; and elsewhere on limestone in south-west Donegal: Hart I885\%-CII. Near the brick-works at Clough on the shore of Dundrum Bay, Down, sparingly (Stewart): Cyb. Marshy places on the Downs at Ardglass, Down (Rev. C. H. Waddell): S. \& P. I895.

Not always distinguished from robust forms of $J$. acutiflorus, and perhaps frequent throughout Ireland. 
11. J. lamprocarpus Ehrh.-Shining-fruited Rush.

Districts I. II. III. IV. V. VI. VII. VIII. IX. X. XI. XII. Lat. $51 \frac{1}{2}^{\circ}-551^{\circ}$. Throughout Ireland. Type, British.

Lowland. Marshy places; rather common. Fl. July-August.

12. J. acutiflorus Ehrh.—Sharp-flowered Rush.

J. sitvaticus Reichb.

Districts I. II. III. IV. V. VI. VII. VIII. IX. X. XI. XII. Lat. $51 \frac{1}{2}^{\circ}-55 \frac{1}{4}$. Throughout Ireland. Type, British.

Bogs and wet or marshy places; common. Fl. June-August.

Sea-level in Derry and Cork. To $1900 \mathrm{ft}$. in Down (S.\&P.); to $2000 \mathrm{ft}$. in Wicklow $(N . C$.$) .$

\section{LUZULA DC.}

\section{L. vernalis DC.-Vernal Wood-rush.}

L. pitosa Willd.

Districts I. II. III. IV. V. - VII. - - X. XI. XII. Lat. $51 \frac{1}{2}^{\circ}-55 \frac{1}{4}^{\circ}$. From South to North. Type, British.

Woods, mountain heaths, \&c. ; rather local. Fl. April-May.

I., II., IV., V., and X. Frequent, occurring in Kerry, Cork, Dublin, Wicklow, King's Co., Fermanagh, and Armagh.-III. By the Nore at Woodstock, Kilkenny: Hart 7885 ס.-VII. Knock Drin; Donore, \&c., Westmeath: Levinge I894. Clonad Wood, King's Co., 1896; Praeger.-XI. Woods at Glenalla; Carraghblagh; and Cliff : Hart I879\& I886.-XII. Common in north-east Ireland: Flor, $N$. $E$.

From sea-level in Wicklow to $1400 \mathrm{ft}$. in Dublin (N. C.).

It is somewhat remarkable that this species has not yet been recorded for any station west of the Shannon.

\section{L. maxima DC.-Great Wood-Rush.}

L. sylvatica Gaud.

Hibernicé Juinneac (Geen-ack), Prickly [plant].

Districts I. II. III. IV. V. VI. VII. VIII. IX. X. XI. XII. Lat. $51 \frac{1}{2}{ }^{\circ}-55 \frac{1}{4}^{\circ}$. Throughout Ireland. Type, British.

Woods, thickets, and rocky or heathy places on mountains; frequent. $F l$. May-June. Calcifuge $B$. 
Sea-level in Derry and S. Cork. To $2460 \mathrm{ft}$. in Donegal, and to $2796 \mathrm{ft}$. in Down (Flor. Ulst.); to $3000 \mathrm{ft}$. in Wicklow (N. C.), and in Tipperary (Hart); to $3414 \mathrm{ft}$. in Kerry (Hart).

\section{I. campestris DC.-Field Wood-Rush.}

Districts I. II. III. IV. V. VI. VII. VIII. IX. X. XI. XII. Lat. $51 \frac{1}{2}^{\circ}-55 \frac{1}{4}^{\circ}$. Throughout Ireland. Type, British.

Dry pastures; common. Fl. April-May.

Sea-level in Derry and in S. Cork. To $2350 \mathrm{ft}$. in Down, $2680 \mathrm{ft}$. in Mayo, and $3070 \mathrm{ft}$. in Kerry (Hart).

Var. erecta (Desv.)-L. multiflora (Lej.) -Throughout Ireland, chiefly on heaths in mountain districts; locally abundant, ranging: with $L$. campestris to $3000 \mathrm{ft}$. in Kerry. Calcifuge $B$.

\section{ORDER LXX.-TYPHACE正.}

TYPHA Linn.

\section{T. latifolia Linn.-Great Reed-Mace.}

Districts I. II. III. IV. V. VI. VII. VIII. IX. X. XI. XII. Lat. 51 $1^{\circ}-551^{\circ}$. Throughout Ireland. Type, British-English.

Lowland. Lakes, ditches, and marshy places; frequent and locally abundant. Fl. June-July.

2. T. angustifolia Linn.-Lesser Reed-Mace.

Districts - - - [V.] - - - X. XI. XII. Lat. $54 \frac{1}{2}^{\circ}-55 \frac{1}{4}^{\circ}$. North Ireland. Type, English.

Lowland. Lakes and ditches; rare. $F l$. July.

[V. Between Sandymount and Merrion, abundantly: Wade Dubl. In the lake at Sandymount: Flor. Hib. Marshes near Irishtown : Ir. Flor.-apparently extinct in all of these stations.]$\mathrm{X}$. Lough Gullion and Closet river, Armagh (Rev. H.W. Lett); Bann mouth, Lough Neagh (J. H. Davies); at the mouth of the Lagan canal, Lough Neagh (Praeger): Praeger $1803 .-\mathrm{XI}$. In twa or three lakes in the north of Fanet; Hart.-XII. Abundant in Lough Hanay, between Lisburn and Saintfield (Mr. Campbell): Flor. Hib. Still abundant in Lough Hanay (Rev. C. H. Waddell): S. \& P. 1895 . In Long Lough north of Ballinahinch, Down, 1884 
(Stewart) : Flor. N.-E. Abundant on the shores of Portmore Lake, Antrim, and at Selchin [Selshan] by Lough Neagh (Moore): Cyb. At Portmore, 1882 (Rev. H. W. Lett): Flor. N.-E. Abundant in Derry Lough near Ballinahinch (Stewart): S. \& P. 1895. Mill dam by the shore at Bishop's Mill, north of Portaferry, Down (Praeger): Ir. Nat. I897, p. 280.

\section{SPARGANIUM Linn.}

1. S. ramosum Huds.--Branched Bur-Reed.

Districts I. II. III. IV. V. VI. VII. VIII. IX. X. XI. XII. Lat. $51 \frac{1}{2}^{\circ}-55 \frac{1}{4}^{\circ}$. Throughout Ireland. Type, British.

Ditches, pools, \&c. ; frequent. $F l$. June-July.

To $600 \mathrm{ft}$. in Donegal (Bart); but usually lowland.

Var. MICROCARPUM Neum.-VII. Near Quarry Bog, Knock Drin, Westmeath : Linton 1806.

Var. NEGLECTUM Beeby.-I. Near Clogherbrian Bog, Tralee: R. W. S. 2889 . - II. Marsh near Power Head, Cork, 1897; Phillips.-V. Canal side east of Maynooth, Kildare; R.W.S.

2. S. simplex Huds.-Unbranched Bur-Reed.

Districts I. II. III. IV. V. VI. VII. VIII. IX. X. XI. XII. Lat. $51 \frac{1}{2}^{\circ}-55 \frac{1}{4}^{\circ}$. Throughout Ireland. Type, British-English.

Lowland. Ditches, streams, canals, \&c.; not infrequent. Fl. July-August.

By no means so frequent as the preceding species and apparently rare in the West.

\section{S. natans Linn.-(aggregate), Floating Bur-reed.}

Districts I. II. III. IV. V. VI. VII. VIII. IX. X. XI. XII. Lat. 51 $\frac{1}{2}{ }^{\circ}-55 \frac{1}{4}$. Throughout Ireland. Type, British-Scottish.

Lakes, bog-holes, and ditches; frequent. Fl. July-August.

\section{S. affine Schnizl.}

Districts I. II. - - V. - - VIII. IX. X. XI. XII. Lat. $51_{2}^{1}{ }^{\circ}-55 \frac{1}{4}^{\circ}$. West and South. Type, British-Scottish.

Lakes in mountainous situations; rather rare. Fl. July-August.

I. Killarney Lakes; Waterville Lake; Clonee Lakes; Lough Brin, \&c., Kerry; R.W.S. Lakelet near the summit of Mount 
Gabriel, Skibbereen; and frequent in bogs in the Schull promontory; Phillips.-II. Ballyscanlon Lake near Tramore, Waterford; Barrington.-V. Whitewood Lough, Co. Meath, 1897 ; Praeger.VIII. Not infrequent near Roundstone, Connemara (Moore): Cyb. Inishbofin: More 1876. Between Newport and Mulranny, and at the base of Croaghpatrick, Mayo; in several places in Connemara, Galway: Hart 1883a.-IX. South-east corner of Lough Mask: M.\& S. 1896 . In Loughs Ramduff and Glendarragh, Ox mountains, Sligo: $N$. C. 1896.-X. In Co. Armagh, near Derryadd Bay, Lough Neagh; Clay Lake, near Keady, \&c.: Praeger 1893.XI. Tory Island: Barrington 1879. Lakes near Slieve League, and Lough Drimly near Culdaff: Flor. Olst. Loughs Keel, Golagh, and Glenveagh; near Mamore Gap: Hart 1879 \& $1880 .-$ XII. Castlewellan Lake, 1808; and in the Moss Hole flow [Cranmore], 1803: Templeton MS. Lakes near Fair Head, Antrim (Moore) : Cyb. Annesboro' Lake, Castlewellan, Down; and mouth of the Sixmilewater, Lough Neagh, Antrim (Stewart): Flor. N.-E. Sparingly in Altnadua Lake, Down: S. \& P. I892.

Sea-level in Mayo to $2100 \mathrm{ft}$. in Donegal (Hart).

\section{S. minimum Fries.}

Districts I. II. III. IV. V. VI. VII. VIII. IX. X. XI. XII. Lat. $51 \frac{1}{2}^{\circ}-55 \frac{1}{4}^{\circ}$. Throughout Ireland.

Lowland. Lakes, ditches, and bogholes; frequent. Fl. JulyAugust.

I. Ross Island, Killarney; streams near Waterville, \&c.; widely distributed in Kerry; $R$. W.S. Plentiful at Three Castle Head and Cape Clear ; Phillips.-II. At Dunsfort and Kilcoleman : Allin's Cork.-III. Bog near Monasterevan, and by the Nore be-

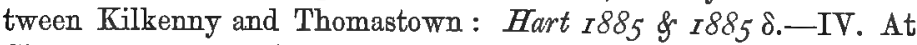
Clohamon, Wexford: Hart I88I a.- - . Bog-holes near Castle Bellingham, Louth; N.C.-VI. Frequent in bogs about Ennis: Stewart I890.-VII. Near Parsonstown (M. Dowd): Ree. Add. Quarry Bog, Knock Drin, Westmeath: Levinge I894.-VIII. At Roundstone; More. Oughterard (Miss Knowles) : P.\& C. I895.IX. Lisloughrey Bay, Lough Mask, 1896 ; Miss $\boldsymbol{M}$. F. Jackson.X. Near Drum, Clones (J. Bain) : Rec. Add. Near Enniskillen, Lough Erne: Barrington I884. Fymore Lake, Favour Royal, Tyrone: Hart 7887 . Loughnashade near Armagh (Rev.W. $F$. Johnson); bog drains south of Portadown: Praeger I893.- 
XI. Ballyhooriskey and Glenalla: Hart 1879 . Very common in Aranmore Island; in Lough Fad, Inishowen: Hart I $880 \& 7883$. Bog drains near Muckish mountain, $1884 ; N$. C.-XII. Lakelets at south-east end of Rathlin Island: Stewart 1884 . Loughnacranagh, Fair Head (Praeger): Flor. N.-E. Bog-holes at the upper end of a lake north-west of Milltown, near Warrenpoint, Down: S.\&.P. r8g2. Near Crossgar, Down (Rev. C. H. Waddell); near Parkmore, Antrim (Rev. S. A. Brenan): S.\&.P. 1895.

\section{ORDER LXXI.-AROIDE正.}

\section{ARUM Linn. \\ 1. A. maculatum Linn.-Cuckoo-pint.}

Districts I. II. III. IV. V. VI. VII. VIII. IX. X. XI. XII.

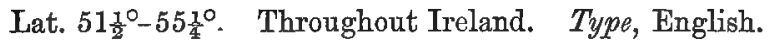

Woods and hedges, also in shady, rocky places; frequent. $F l$. April-May.

To $1000 \mathrm{ft}$. in the Mourne mountains $(S . \& P$.$) ; but usually low-$ land.

\section{ACORUS Linn.}

\section{1. *. Calamus Linn.-Sweet Flag.}

Districts - - - - V. - - - - - - XII.

Lakes and canals; rare and undoubtedly introduced. Fl. JuneJuly.

7. In the river Boyne near Bective: Ir. Nat. 1896, p. 216.XII. Lakes at Hillsborough and Ballinahinch, Down; but most probably planted there: Templeton MS. Profusely on both sides of the Lagan canal for six or seven miles between Lisburn and Moira, Down, 1866 (Stewart): Ree. Add. In the lake at Ballinahinch, 1875 (Stewart): Flor. N.-E. Quite naturalized throughout the course of the Lagan canal: S.\&.P. 1895 .

In Harris's Down, I744, this plant is mentioned as grown in the gardens of Sir John Rawdon at Moira, whence, no doubt, it spread into the Lagan. 


\section{ORDER LXXII.-LEMNACEZE.}

\section{LEMNA Linn.}

\section{I. trisulca Linn.-Ivy-leaved Duckweed.}

Districts I. II. III. IV. V. VI. VII. - IX. X. - XII. Lat. 51 $\frac{3}{4}^{\circ}-55 \frac{10}{4}$. From South to North. Type, English-British.

Lowland. Ditches, pools, bog-holes, canals, \&c., in stagnant water; rather frequent. $F l$. June.

I. In two or three places about Killarney, not noticed elsewhere in Kerry; R.W.S.-II. Buttevant; Fermoy; Youghal; Midleton; \&c.: Allin's Cork. Inch bog near Power Head, Cork, 1895; Phillips. Kilbarry bog near Waterford: B.-H.\& G.I890.-III. Bog near Graigavern, to the south of Monasterevan and in Queen's Co.: Hart 1885.-IV. Ditches on the Murrough of Wicklow (Moore); bog near Enniscorthy, Wexford (Carroll): Cyb. At Kilmanock, and in the Pill of Rathdooney, Rosslare, Wexford: B.-H.\& G. I890.-V. Frequent, occurring in Meath, Louth, and Dublin.-VI. At Tuam: Wade Gallovid. Plentiful near Limerick (Carroll); abundant in drains at Portumna (Moore): Cyb.-VII. Doonis Lough, Lough Ree : B.\& F. 7887 . Kilmaglish and Scraw Bog, Westmeath: Levinge 1894.-IX. Hazelwood near Sligo (Admiral Jones): Cyb. Claremorris lake, Mayo, and adjoining ditches: Marshall I896.-X. Near Crum Castle, Lough Erne: Barrington 1884.-XII. Common in north-east Ireland: Flor. N.-E.

\section{L. minor Linn.-Common Duckweed.}

Districts I. II. III. IV. V. VI. VII. VIII. IX. X. XI. XII. Lat. $51 \frac{1}{2}^{\circ}-55 \frac{1}{4}^{\circ}$. Throughout Ireland. Type, British.

Ponds and ditches; common. Fl. June-July.

Sea-level in N. Antrim and S. Cork. To $850 \mathrm{ft}$. in Dublin $(N . C$.$) .$

\section{L. gibba Linn.-Gibbous Duokweed.}

Districts - II. - IV. V. VI. - - - X. - XII. Lat. $52 \frac{1}{4}^{\circ}-54 \frac{3}{4}^{\circ}$. South to North. Type, English-Germanic.

Lowland. Stagnant ponds and ditches; rare. Fl. June-July. 
II. Plentiful in Kilbarry bog near Waterford: B.-H.\&G. I890.-IV. Ditches at Churchtown, Wexford: Marshall 2898.V. Ardee bog, Louth: Ir. Flor. Bog of Cool, below Ardee (J. White); ponds near Glasnevin (Moore): Cyb. Pond near Ballisk, Donabate; and mill-pond at Balbriggan, Co. Dublin: N. C. $1893 \&$ I895. Drains by the Boyne below Drogheda, Meath; and very abundant in an artificial lake at Beaulieu House near Queensborough, Louth: Praeger 1897.-VI. Near Limerick (Prof. Harvey) : Cyb.-X. In Lough Erne, north of Enniskillen : Barrington 1884. Brackish drains below Newry; and abundant in the Closet river near Lough Neagh, Armagh: Praeger 1893. Drain near Maghery, Lough Neagh, Tyrone, 1896; Mrs. Leebody.XII. Abundant by the Lagan and near Lough Neagh (Moore) : Cyb. Newry canal; by the Quoile below Downpatrick; brackish ditches between Queen's Quay and Connswater (Stewart); Ballycroghan near Bangor (Praeger); Bog Meadows, Belfast (Corry) : Flor. N.-E.

\section{I. polyrhiza Linn.-Greater Duckweed.}

Spirodela polyrhisa Schleid.

Districts - - - - V. VI. VII. - - - [XII.] Lat. $53 \frac{1}{4}^{\circ}-53 \frac{3}{4}^{\circ}$. Middle and North. Type, English.

Lowland. Ditches and pools; rare. Fl. June.

V. Brackish ditch near Irishtown, Dublin (Moore); pond in the Phœnix Park (More) : Cyb.-VI. Common about Limerick (W. $H$. Harvey): Flor. Hib.-VII. Belvedere Lake, Westmeath (Moore); pools near Mullingar $(F . J . F o o t): C y b$. Near Multyfarnham, Westmeath, 1869; Moore. Pond by the roadside near Portnashangan Rectory, Westmeath: Levinge 1894 . Drain near Doonis Lake, Lough Ree : $B . \&$ T. 1887 .- [XII. In a flax-hole below the second lock of the Lagan canal, 1884 (S. M. Malcomson), a modern introduction: Flor. $N_{\text {. }}-E$.]

\section{ORDER LXXIII.-ALISMACE王.}

\section{ALISMA Linn.}

\section{A. Plantago Linn.-Great Water-Plantain.}

Districts I. II. III. IV. V. VI. VII. VIII. IX. X. XI. XII. Lat. $51 \frac{1}{2}^{\circ}-55 \frac{1}{4}^{\circ}$. Throughout Ireland. Type, British.

Lowland. Lakes, ponds, \&c. ; frequent. Fl. July-August. 


\section{A. ranunculoides Linn.-Lesser Water-Plantain.}

Districts I. II. III. IV. V. VI. VII. VIII. IX. X. XI. XII. Lat. $51 \frac{1}{2}^{\circ}-55 \frac{1}{4}^{\circ}$. Throughout Ireland. Type, British.

Lowland. Boggy and marshy places; frequent. Fl. June-July.

Var. REPENs (Davies).-Not infrequent by lake margins in mountainous districts.

\section{SAGITTARIA Linn.}

\section{S. sagittifolia Linn.-Arrow-head.}

Districts - - III. - V. VI. VII. - IX. X. - XII. Lat. $52 \frac{3}{4}^{\circ}-55 \frac{1}{4}^{\circ}$. Middle and North. Type, English.

Lowland. Ditches, rivers, canals, and lakes; local. Fl. JulyAugust.

III. In the Barrow at Carlow ; Greenwood Pim. In the Barrow below Athy in Queen's Co.; $R$. W. S. At Portarlington, Queen's. Co.; Praeger.-V. Holes between Glasnevin and Drumcondra Bridge, Dublin: Ir. F'lor. Not infrequent in the Canals near Dublin (Moore): $C y b$. Abundant in the Royal and Grand Canals, Dublin, 1895; quarry holes by the Tolka river, Dublin; N.C. Black river near Monasterevan, Kildare: Hart $1885 .-\mathrm{VI}$. In the Shannon near Limerick (Carroll): Cyb. Near the harbour, Portumna; and at the mouth of the Woodford river, Lough Derg, Galway: $N$. C. 1897.-VII. In the Shannon above and below Lanesborough, Longford: Wade Rar.-whence it has spread into the Royal Canal : Cyb. Drains near Portumna, Tipperary: Mack. Rar. In the canal west of Longford: Foot I865. Lough Derevaragh; and in the River Inny, Westmeath, plentiful: Levinge $7894 .-$ IX. In Lough Key near Boyle: Foot I865.-X. At the mouth of a small river opening into Lough Erne, Fermanagh; near Dungannon; in the Bann near Portadown, Armagh: Mack. Rar. Verner's Bridge, Armagh (Admiral Jones): Cyb. Abundant along the Lough Neagh shore in Armagh, and in the Blackwater and the Ulster and Newry canals: Praeger 1893. Doon Point, Lough Neagh, Tyrone (Miss M. C. Knowles): Ir. Nat. 1897 . Lake at Killikeen and at Drigget, Co. Cavan (Rev. N. J. Halpin): Flor. Dlst.-XII. In the large drain at Portmore, and other places about Lough Neagh, 1794 (Templeton): Whitla MS. In the Bann at Portglenone: Templeton MS. In a small lake above 
Kilrea, and abundant by the Bann from Toome to near Coleraine, Derry: Moore MS. In the Bann at Toome; pond at Belmont and many places in the Newry canal; also frequent in the Lagan canal from Lough Neagh to near Belfast (Stewart): Flor. N.-E.

Occurs along the whole course of the Shannon and canals issuing from it, whence it has spread southward into the Barrow; also throughout the basin of Lough Neagh.

\section{BUTOMUS Linn.}

\section{B. umbellatus Linn.-Flowering Rush.}

Districts - II. - - V. VI. VII. - - X. - XII. Lat. $51 \frac{3}{4}^{\circ}-54 \frac{1}{2}^{\circ}$. South, Middle, and North-East. Type, English.

Lowland. Rivers, ditches, canals, and lakes, in stagnant water; rare and local. $F l$. June-August.

II. In the Blackwater above the bridge at Fermoy: Drummond 1819. Blackwater near Fermoy : Hart $1885 \delta$. Ballycotton bog, and abundant near Buttevant (Rev. T. Allin): Rec. Add. Near Doneraile and Castletownroche (Carroll); Charleville (Rev. T. Allin): Allin's Cork. Banks of the Blackwater near Lismore, Waterford; F. E. Currey.-V. Ditch near the Grand Canal below Lord Cloncurry's house, Kildare: Mack. Cat. In the Tolka below Glasnevin bridge (Moore); in the Mattack river near Drogheda (J.B. Hamilton); perhaps introduced in both stations: $C y b$. In the Boyne near the Obelisk; Rev. H. G. Carroll.-VI. About the Shannon, and near Corbally bridge, Limerick: Wade Rar. Plentiful near Limerick (Prof. Harvey): Cyb. Banks of the Shannon at Castle Connell; ditches near Corrofin, Clare: Mack. Rar. Marshes about the river Fergus: Wade Rar. Abundant about Ennis (Rev. T. Warren) : Cyb. Near Ennis, 1892; Levinge. Island in Lough Derg near Killaloe (C. B. Barrington): Hart $r 88 \pi \gamma$. Sparingly in bog drains by the Shannon at Killaloe; and-VII. In the Nenagh river near Dromineer, Tipperary : N. C. 1897. In the Brosna at Parsonstown $(M . D o w d): R e c$. Add.-X. Shores of the upper Bann; in the canal near Tanderagee, Armagh (Admiral Jones); in the Blackwater near Maghery (Rev. G. Robinson): Cyb. Abundant along the Lough Neagh shores and connecting waterways, Co. Armagh: Praeger 1893. Doon Point, Lough Neagh, Tyrone (Miss M. C. Knowles): Ir. Nat. I897.-XII. South end of Lough Clay [Lough Leagh] near Killaleagh, Down, 1804 : Templeton 
MS.-and in $1891:$ B. N. F.C. Proc. $1891-97$. In the Lagan near Belfast, but introduced: Flor. Ulst. Abundant in the Lagan canal near Moira and elsewhere; also in the Lake at Ballynahinch, Down (Stewart): Flor. N.-E. Mouth of the Six-Mile Water (W. S. Smith); Crumlin waterfoot (Miss Knowles): S.\&P. 1895 .

Frequently planted and perhaps introduced in many of its stations.

Threlkeld, in his Synopsis, I727, says that this plant was "sent from the Barrow."

\section{ORDER LXXIV.-NAIADACE无.}

\section{TRIGLOCHIN Linn.}

1. T. palustre Linn.-Marsh Arrow-grass.

Districts I. II. III. IV. V. VI. VII. VIII. IX. X. XI. XII. Lat. $51 \frac{1}{2}^{\circ}-55 \frac{1}{4}^{\circ}$. Throughout Ireland. Type, British.

Wet meadows and marshy places; frequent. Fl. June-August.

Sea-level in Derry and S. Cork. To $1000 \mathrm{ft}$. in Donegal and to $1500 \mathrm{ft}$. in Tipperary (Hart).

\section{T. maritimum Linn.-Sea Arrow-grass.}

Districts I. II. III. IV. V. VI. - VIII. IX. X. XI. XII. Lat. $51 \frac{1}{2}^{\circ}-551^{\circ}$. Coasts of all Ireland. Type, British.

Salt marshes; frequent. $F l$. July-August.

\section{POTAMOGETON Linn.}

\section{P. natans Linn.-Floating Pond-weed.}

Districts I. II. III. IV. V. VI. VII. VIII. IX. X. XI. XII. Lat. $511_{2}^{\circ}-551^{\circ}$. Throughout Ireland. Type, British.

Lowland. Ponds, lakes, \&c.; common. Fl. June-July.

\section{P. polygonifolius Pourr.-Oblong-leaved Pond-weed.}

Hibernicé Oulllearz an aban (Dhillisk an ow-ann), River Dulse. Districts I, II. III. IV. V. VI. VII. VIII. IX. X. XI. XII. Lat. $51 \frac{1}{2}^{\circ}-551^{\circ}$. Throughout Ireland. Type, British.

Streams, bog-holes, \&c. ; common. Fl. June-Aug. Calcifuge $A$. 
Var. PSEUdo-FLUTTaNs Syme-I. In several streams in Kerry : R.W. S. $1888-90 .-$ VIII. Lakes and streams at Ballinahinch, Connemara ; characteristic of streams connected with mountain districts (More) : Rec. Add.

Sea-level in N. Antrim and Kerry. To $1550 \mathrm{ft}$. in Down, and to $1500 \mathrm{ft}$. in Kerry (Hart); to $1900 \mathrm{ft}$. in Wicklow (N.C.).

\section{P. Aluitans Roth.}

Districts - - - - - VII. $]-\longrightarrow \mathrm{X} .-$ Lat. $53 \frac{1}{2}-54 \frac{1}{2}{ }^{\circ}$. Counties of Longford (?) and Armagh only.

Lowland. Rivers and lakes; very rare.

[VII. An immature plant found growing abundantly in the River Inny below Ballymahon, Longford, has been doubtfully named $P$. fuitans var. RIVUlaris Lange by Mr. Arthur Bennett: B.\& $\left.V_{\text {. }} 887.\right]$-X. In Lough Neagh, at Maghery, Co. Armagh: Praeger 1803 .

\section{P. Kirkii Syme.}

P. sparganï̈folius (Læst.) Bab. Man.

Districts - - - - - - - VIII. - - - Lat. $53 \frac{1}{2}^{\circ}$. County Galway only. Type, Hibernian.

VIII. In the river at Maam, Galway (T. Kirk) : Bab. Manual 4th Ed., p. 35I, t856. A single patch in the Maam river, July $1895: M . \& S .1896$.

In the Journ. of Bot. $1894, p .377$ Mr. Alfred Fryer states that the Maam plant differs widely from Swedish specimens of $P$. sparganiifolius (Læst.) named by Tiselius, and agrees with Mr. Arthur Bennett as to the propriety of naming the Irish plant $P$. Kirkii Syme.

\section{P. plantagineus Ducr.-Plantain-leaved Pond-weed.}

P. coloratus Hornem.

Districts I. II. III. IV. V. VI. VII. VIII. IX. - - XII. Lat. $51 \frac{1}{2}^{\circ}-55 \frac{14^{\circ}}{}$. South and Middle, chiefly. Type, English-British.

Lowland. Ditches in peaty ground; rather rare. Fl. JuneJuly.

I. Near Bantry (Babington): Cyb.-I. and II. Not infrequent in bogs near Cork (Carroll): Cyb.-III. Near Maryborough; Praeger.-IV. Ditches on the Murrough of Wicklow, and other places in the county (Moore) : Cyb.-V. Plentiful in a ditch near 
the thirteenth lock, south of the Grand Canal, Kildare (J. Douglas); and common in ditches on the bogs among the Dublin mountains (Moore): Cyb. Braganstown and Ardee bogs, Louth, 1897; Praeger.-VI. In ditches in the bog at Kilmacduagh, Galway (More); near Portumna, Galway (Moore): Cyb. Clonbrock river, East Galway: Praeger I896.-VII. In the county Westmeath, near Mullingar, \&c. (Moore): Cyb. Scraw bog, Loughanstown: Levinge I894.-VIII. Near Galway (Prof. Melville); at Roundstone (T. Kirk): Cyb.-IX. Bog ditches near Hollymount, Mayo (More): Cyb.-XII. At Magilligan, Derry, and not infrequent in Antrim (Moore) : Cyb. Not seen recently in north-east Ireland: Flor. N.-E.

4. P. rufescens Schrad.-Reddish Pond-weed.

$P$. alpinus Balb.

Districts I. II. III. IV. - VI. VII. VIII. - X. XI. XII. Lat. $51 \frac{1}{2}^{\circ}-55^{\circ}$. South to North. Type, British.

Lowland. Ditches, lakes, and streams; rare and local. $F l$. June-July.

I. Lower Lake, Killarney; Caragh Lake; near Lixnaw, \&c., Kerry : R.W.S. I888-9I.-II. At Blarney (R. Mills); Kilbree near Midleton; and in the Blackwater at Carrigacunna (Allin); at Buttevant (Carroll): Allin's Cork. Corrin bog near Fermoy (T. Chandlee): Cyb.-III. Ditch near Mountrath, Queen's Co. (J. Morrison): Ree. Add. River Barrow in Queen's Co. below Athy; R.W.S.-IV. Ditches on the Murrough of Wicklow (Moore): Cyb.-VI. Ditches near Limerick, but not common (W.H.Harvey) : Flor. Hib. Saint Senan's Lough, Co. Clare: Stewart I800.-VII. Belvidere Lake, Westmeath (Moore): Cyb. Drain near Ballykeeran: B.\&V. I887. Drain from Lough Drin, Westmeath: Linton I896.-VIII. Near Galway (Prof. Melville): Cyb.-X. Belturbet, Cavan (Moore): Cyb. Carrick Lake, Fermanagh: Stewart 7882 . Stream in Tynan Abbey demesne, Co. Armagh: Praeger 1893.-XI. On the race-course bog near Londonderry (Moore) : $C y b$. Lough Unshagh, near Slieve League, Donegal : Bart 1885 \% -XII. Enagh Lough, and in the river Roe, Derry (Moore): Flor. Hib. In the Lagan canal: Flor. Olst. Ballymena, Antrim (Moore): Cyb. Newry canal; drains by Magherascouse Lake, Down; and Lough Mourne (Stewart); in Sixmilewater at Templepatrick (Corry); Glendun (Rev. S. A. Brenan): Flor. N.-E. In Burren river near Newcastle, Down: S.\& P. 1892 . 
The hybrid $P$. rufescens $\times$ heterophyllus is doubtfully recorded as occurring in Lough Neagh at Maghery, Armagh: Praeger 1893.

\section{P. lanceolatus Smith-Lanceolate-leaved Pond-weed.}

Districts - - - - VI. - - - - - Lat. $53^{\circ}-53 \frac{1}{2}^{\circ}$. Clare and Galway only.

Lowland. Streams; very rare. Fl. July-August.

VI. In Cahira river south of Black Head; Clare (P.B. O' Kelly): Journ. of Bot. I89x, p. 344 :-growing here in a rather strong current on a gravelly bottom: Journ. of Bot. $x 892, p$. r95.

A peculiar form was gathered by Mr. R. LI. Praeger in the Clonbrock river, East Galway in 1896. While placing this in a wide sense under $P$. lanceolatus, Mr. Arthur Bennett suggests that it should be ranked as a variety or form with the name hibernicus: Ir. Nat. $1806, p .213$.

The localities recorded in the first edition of this work are no doubt errors, so that the title of this rare plant, in its typical form, to a place in the Irish flora rests, so far, on Mr. O'Kelly's interesting discovery.

It has been suggested that this Pondweed, which is apparently endemic in the British Isles, is of hybrid origin, i.e. P. heterophyllus $\times$ pusillus, and this should be borne in mind when searching for the plant.

6. P. heterophyllus Schreb.-Tarious-leaved Pond-weed.

$P$. gramineus Fries.

Districts I. II. III. IV. V. - VII. VIII. IX. X. XI. XII. Lat. $52^{\circ}-55 \frac{1}{4}^{\circ}$. Throughout Ireland, probably. Type, BritishEnglish.

Lowland. Ponds, ditches, and rivers; not infrequent. $F l$. June-July.

Var. gRaminifolrus Fries-I. River Laune, Kerry, for nearly its whole course: $R$. W.S. 1890 (as P. nitens var. salicifolius Fries).-II. In the Blackwater near Fermoy, and in its tributaries, the Funcheon and Owbeg, $1896 ; R . W . S .-V$. In the Boyne below Navan, Co. Meath (R.W.S.): B. Ex. C. Report I893.-this is the plant doubtfully referred to $P$. heterophyllus in $C y b$. Ist $E d$., and to $P$. Lonchites (Tuck.) in Rec. Add. In River Liffey near Lucan and Leixlip, Dublin 1894-95; N. C.-VI. and IX. In the River Suck at Mount Talbot, Roscommon; Levinge. 
7. P. nitens Weber-Bright-leaved Pond-weed.

Districts I. - III. - V. - VII. VIII. IX. - XI. XII. Lat. $52^{\circ}-55 \frac{1}{4}$. South to North. Type, Scottish.

Lowland. Lakes and rivers; rare. Fl. June-July.

I. In a large lake at Castlegregory, Kerry, 1864 (Moore) : Journ. of Bot., I864, p. 326. Still at Castlegregory, but not plentiful; near the mouth of the Flesk, Killarney: $R$. W. S. $1888 \& 89 .-$ III. and V. River Barrow about Monasterevan; and-VII. Black river north of Monasterevan: Hart I885 (as P. rufescens). Lough Derevaragh: Levinge 1894.-VIII. Stream from Lough Keel, Achill Island (More): Journ. of Bot. I889.-IX. Lough Bofin, Leitrim, 1871 (W. T. Dyer) : Herb. Brit. Mus.-XI. Stream joining Loughs Akibbon and Gartan, and in Kinny Lough, Fanet; Hart.XII. Lough Aghery, Down, 1887 (Stewart): Flor. N.-E. Annsboro Lake, Down, and in the Sixmilewater, near Antrim : Stewart 1894 .

First recorded for the British Isles by David Moore, from Castlegregory, in 1864.

Var. LATrForids Tis.-I. River Laune near the lake, Killarney: R.W.S. $I 890$ (perhaps a hybrid-P. nitens $\times$ perfoliatus).

\section{P. lucens Linn.-Shining Pond-weed.}

Districts I. II. III. IV. V. VI. VII. VIII. IX. X. XI. XII. Lat. $51 \frac{3}{4}^{\circ}-55 \frac{1}{4}^{\circ}$. Throughout Ireland. Type, English-British.

Lowland. Lakes, rivers, and pools; local. Fl. June-July.

\section{P. decipiens Nolte.}

Districts - - - - V. - VII. - - - XI. Lat. $533^{\circ}-55^{\circ}$. Middle and North. Lowland; apparently rare.

V. In the canal by the Boyne near Navan, 1868.(Charles Bailey): B.Ex. C. Rep. I860-still there, $1897 ; R . W . S$. Royal canal near Clonsilla, Co. Dublin, $1889 ; R . W . S .-$ VII. Lough Dereveragh, fine and plentiful in one spot: Linton I896.XI. Long Lough near Fort Royal, Rathmullan : Hart 1885 \%.

Usually regarded as a hybrid between $P$. lucens and $P$. perfoliatus.

$P$. angustifolius Presl.

$$
\text { P. Zizii Roth. }
$$

Districts I. - - - V. VI. VII. VIII. IX. X. XI. XII. Lat. $52^{\circ}-55^{\circ}$. South to North. Lowland; rather rare. 
I. In a small lake in Muckruss demesne; in the river Laune near Ballymalis Castle, Kerry : R.W. S. I889.-V. Plentiful in the Boyne at Bective, Meath: Praeger 1897.-VI. Lough Senan, Clare: Stewart 1890.-VII. Lough Drin and Lough Dereveragh, Westmeath: Levinge 1894. Plentiful in Lough Ree: B.\&V. I887.-VIII. Locally abundant in Lough Corrib, near Maam: M. \& S. I896.-IX. River at Sligo; and in Glenade Lake: B.\& $\boldsymbol{V}$. 1885. River Suck, Roscommon: Levinge in Herb.-X. Sparingly in the stream connecting Carrick Lake with Bunnahone Lake, near Derrygonnelly, Fermanagh: Stewart r882. Abundant near Kesh river, Lough Erne : Barrington $1884 . \quad$ Lough Neagh, near Kinnegoe (Praeger), near Derryadd Bay (Rev. H. W. Lett) : Praeger 1893.XI. Letter river near Pettigoe: Hart $1885 \gamma$. Lakes in Fanet, Donegal; Hart.-XII. Lough Beg, in both Antrim and Derry (Corry); in the Bann above Coleraine; and in Lough Mourne, Antrim (Stewart): Flor. N.-E. Lough Neagh at Cranfield, and Lagan canal near Blaris (Stewart); in the Bann at Kilrea, Derry (Mrs. Leebody) : S.\& P. I895.

First found by S. A. Stewart, at Derrygonnelly, in 1881.

\section{P. prælongus Wulf,-Long Pond-weed.}

Districts I. - - - VI. VII. VIII. IX. - XI. XII. Lat. $52^{\circ}-55 \frac{1}{4}^{\circ}$. South to North. Type, Scottish-Intermediate.

Lowland. Lakes and ditches; very rare. Fl. June-July.

I. Blackwater, Kerry (Dr. Taylor): $C y b$. Lower Lake, Killarney; and Lough Acoose, Glencar, Co. Kerry: R.W. S. I89T.VI. Plentiful at Castleconnell and Plassy, Limerick, 1834 ( $W . H$. Harvey): Harvey's Memoir, I869.-VII. Lough Owel, Westmeath : Levinge $7894 .-$ VIII. In Lough Cullin, Mayo (More): Cyb. West side of Lough Mask about three miles north of Clonbur: $M$. \& $S$. 1896. Ballinahinch, Galway, 1881; Bolton King. Lough Corrib, 1885 (Rev. R. P. Murray): Herb. Ar. Bennett.-IX. In two lakes east of Foxford (More): Cyb. South-east corner of Lough Mask: M. \& S. 1806 .- XI. Plentiful at the south end of Lough Finn, Donegal : Hart $7886 .-$ XII. Ditches by the Lagan between the first and second locks: Flor. Ulst. Lough Mourne, Antrim: Flor. Belf. In a small lake above Kilrea, Derry (Moore): Flor. Hib. In Lough Neagh, Antrim (Moore): Cyb. In the canal from Belfast to Lisburn, in several places (Stewart): Flor. N.-E. Plentiful in Ushet Lake, Rathlin Island: Stewart 1884. 
First found in Ireland by W. H. Harvey, at Castleconnell, in 1834.

$P$. Babingtonii Ar. Bennett-P. longifolius Bab. $-P$. lucens $\times$ pralongus. - To this hybrid should probably be referred the Lough Corrib plant figured in English Botany Supp. tab. 2847 under the name $P$. longifolius Gay. Only a single floating fragment seems to have been picked up by Mr. J. Bell in 1835, and although it differs in several points from admitted specimens of this hybrid, all these differences, Mr. Arthur Bennett states, may be explained by assuming the fragment to have floated for some time. Mr. Bennett also mentions (Journ. of Bot. 1894, p. 204) that he has specimens of both $P$. lucens and $P$. pralongus from the same lake, and suggests the name $P$. Babingtonii for this hybrid, $P$. longifolius being already occupied.

\section{P. perfoliatus Linn.-Perfoliate Pond-weed.}

Districts I. II. III. IV. V. VI. VII. VIII. IX. X. XI. XII. Lat. $51 \frac{1}{2}^{\circ}-55 \frac{1}{4}^{\circ}$. Throughout Ireland. Type, British. July.

Lowland. Rivers, lakes, ditches, \&c.; frequent. Fl. June-

\section{P. crispus Linn.-Curled Pond-weed.}

Districts I. II. III. IV. V. VI. VII. VIII. IX. X. XI. XII. Lat. $51 \frac{1}{2}^{\circ}-55 \frac{1}{4}^{\circ}$. Throughout Ireland. Type, British-English.

Lowland. Lakes, rivers, canals, and ditches; frequent. Fl. June-July.

Not common in some parts of Ireland, as in Kerry and Donegal.

Var. sERRatus Huds.-XII. In the Bann near Portglenone, Antrim and Derry (Stewart): Flor. N.-E.

$P$. undulatus Wolfg.-P. perfoliatus $\times$ crispus.-XII. Six-mile River above Templepatrick, Antrim (Stewart): S.\&P. $I 895$.

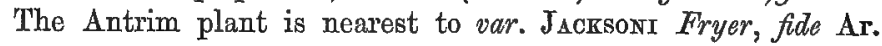
Bennett: Journ. of Bot. 1894, p. 554 .

\section{P. densus Linn.-Opposite-leaved Pond-roeed.}

Districts I. II. III. IV. V. VI. VII. ---Lat. $52^{\circ}-53 \frac{1}{2}^{\circ}$. Southern half of Ireland. Type, English.

Lowland. Rivers, ditches, canals, \&c.; rare and local. $\mathrm{Fl}$. July-August. 
I. Killarney (Babington): Cyb. Ditches near Blennerville, Kerry ; $R$.W.S.-II. In the Suir near Clonmel (Moore); pond at Tubberaheena, Tipperary (Miss A. Taylor): Cyb.-III. In Co. Kilkenny near Waterford (Carroll): $C y b$.-IV. In the Slaney near Enniscorthy ( $J$. Morrison): $C y b$. Pool by the railway above Macmine Junction, Wexford: Marshall I898.-V. In the Grand Canal at Portobello, Dublin (Moore) : Cyb.-and at Hazelhatch, 1893; N. C. Grand Canal, Monasterevan: Hart 1885 . Ditches by the Barrow below Athy, Co. Kildare; R. W. S.-VI. About Limerick, not infrequent ( $W . H$. Harvey): Flor. Hib. In the alluvial flat by the Maigue, from Ferrybridge to Rinekirk, abundantly: Stewart I890.-VII. Dromineer Bay, Lough Derg, and along the shores of islands and both sides of Lough Derg at Killaloe: Hart I88I $\gamma$. Kilbeggan canal, King's Co.: Praeger 1897.

\section{P. obtusifolius Mert. \& Koch-Blunt-leaved Pond-roeed.}

$P$. gramineus Linn.

Districts I. II. - - V. VI. -- X. XI. XII. Lat. $51 \frac{1}{2}-55^{\circ}$. South to North. Type, English-British.

Lowland. Ponds, ditches, bog-drains, \&c.; local and rare. Fl. June-July.

I. Pond near Ross Island, Killarney; R.W.S. Abundant in Ballypheane bog near Cork (Carroll): Cyb. At Shepperton, Leap, sparingly: Allin's Cork. At Union Hall, 1896; J. Groves.II. Near Youghal: Flor. Hib. East Grove, Great Island: Flor. Cork. Corrin bog near Fermoy (T'. Chandlee): Cyb. Bog near Charleville, and in Ballybutler Lake, Cork (Rev. T. Allin): Rec. Add. Bog near Nayfield, Cork, 1896; Phillips.-V. Glack Bog near Castle Bellingham: Butler I890.-VI. Farrihy Lake, Clare; P. B. O'Kelly.-X. Ditches near a lake between Belturbet and Cavan, and ditches communicating with Lough Neagh near Lurgan (ifoore): Cyb. Near Drum, Clones, Co. Monaghan (J. Bain): Rec. Add. Fymore Lake, Favour Royal, Tyrone: Hart 1887 . Several stations in Co. Armagh, as in Drummuckavall Lake; Mullaghmore Lake; lake at Carnagh, near Keady; and abundant at the mouth of the Closet river: Praeger 1893.-XI. Near Killybegs in a deep dike at the narrow end of the lake above St. Catherine: Hart 1886. River at Rathmelton; Praeger.-XII. Apparently more frequent in the North-East than elsewhere in Ireland; see numerous localities in Cyb., Flor. N.-E., and S.\&P. 1895 . 


\section{P. Friesii Rupr.}

Districts - II. - - - VI. VII. VIII. IX. -- - Lat. $52^{\circ}-53 \frac{3}{4}^{\circ}$. South and West, chiefly.

Lowland. Lakes, ponds, and ditches; very rare.

II. Youghal bog, Cork, 1896; Phillips \&R.W. S.-VI. Pond near Foynes, Co. Limerick: Stewart 1890. Lough Derg: Linton r886.-VII. Lough Ennel, and at Lord Longford's landing stage, Lough Derevaragh: Linton 1806.-VIII. Roundstone, Galway: Linton 1886 .- - IX. In Claremorris Lake and adjoining ditches, Mayo: Marshall 1896 .

\section{P. pusillus Linn._Small Pond-weed.}

Districts I. II. III. IV. V. VI. VII. VIII. IX. X. XI. XII. Lat. $51 \frac{1}{2}^{\circ}-55 \frac{1}{4}^{\circ}$. Throughout Ireland. Type, British.

Pools, ditches, lakes, \&c.; frequent. Fl. June-July.

Sea-level in N. Antrim and in Kerry. To $1150 \mathrm{ft}$. in Down and to $1600 \mathrm{ft}$. in Kerry (Hart).

\section{P. pectinatus Linn.-Fennel-leaved Pond-weed.}

Districts I. II. III. IV. V. VI. VII. VIII. IX. X. XI. XII.

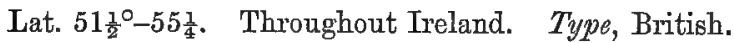

Lowland. Ditches, pools, streams, and lakes, especially near the sea; frequent. Fl. June-July.

\section{P. flabellatus Bab.}

P. interruptus Kit.

Districts I. II. - IV. V. - VII. - IX. - - Lat. $51 \frac{1}{2}^{\circ}-54 \frac{1}{4}^{\circ}$. Southern half of Ireland, chiefly. Local and rare.

I. Castlegregory Lake, \&c., Kerry : R. W. S. 1889 . Clonakilty; and-II. Near Youghal: Allin's Cork. Plentiful at Ballycotton (Carroll); in the river Funcheon near Fermoy, Cork (T. Chandlee); in the Suir near Clonmel (Moore): Cyb.-IV. Ditches on the south side of Wexford Harbour, and frequent about Macmine Junction; Rosslare; Churchtown and Courtown, Wexford: Marshall $1806 \&$ I898.-V. In the canal near Straffan, Kildare (J. Douglas): Cyb.VII. and IX. In the Shannon near Athlone: B.\&V. I887.IX. Glencar Lake, Sligo: B.\& V. 1885 . 
16. P. filiformis Nolte-Slender Pond-weed.

$P$ marinus Linn.

Districts - - - - - VII. VIII. IX, X. XI. Lat. $53 \frac{1}{2}^{\circ}-55^{\circ}$. Northern half of Ireland. Type, Scottish.

Lowland. Lakes and canals; rare and local. Fl. June-July.

VII. Frequent in Lough Ree: $B . \& V$. 1887.--VIII. and IX. Abundant in shallow water in Lough Cullin, at the outlet of the river which falls into the Moy, 1864: More Herb. \& Cyb.$\mathrm{X}$. Between Kinnausy Island and Kesh, Lough Erne: Barrington 1884. In Lough Neagh east of Ardmore Point: Praeger 1893.XI. South side of Kinny Lough, Fanet, Donegal : Hart 1880.

First found by A. G. More, in Lough Cullin, in 1864.

\section{RUPPIA Linn.}

1. R. maritima Linn. (Aggregate)-Tassel Pond-weed.

Districts I. II, - IV. V. VI. - VIII. IX. - XI. XII. Lat, $51 \frac{1}{2}-55 \frac{1}{4}^{\circ}$. Coasts of all Ireland. Type, British.

Brackish pools and ditches; not infrequent. Fl. July-August.

R. spiralis Hartm.

Districts I. - - IV. V. - - - - XI. XII. Lat. $52 \frac{1}{4}^{\circ}-55^{\circ}$. From South to North.

I. In Castlegregory Lake, Kerry, and in the stream from it; brackish ponds by Barrow Harbour, Kerry : R.W. S. I889 \& I89I.IV. Courtown Harbour, Wexford (Praeger): Ir. Nat. I894. Wexford Harbour : Marshall I898.-V. In tidal river-reaches near the head of Malahide estuary, Co. Dublin, abundantly in two stations, near Lissen, Hall and near Newport House: N. C. I893.XI. Near Mulroy House, Donegal; Hart.-XII. Brackish pool at Comber, Co. Down, 1886 ; Magheramorne, Larne, 1897 : Stewart in Herb.

\section{R. rostellata Koch.}

Districts I. II. - IV. V. VI. - - IX. - XI. Lat. $51 \frac{1}{2}^{\circ}-55 \frac{1}{4}^{\circ}$. From South to North.

I. Ballybunnion, Kerry : Stewart 1890 . Common around the Kerry coast: R.W.S. I889. Crookhaven, Cork; Phillips.- 
II. Clonea, Waterford; and-IV. Raven Point, Wexford: Hart I883 $\beta$. Plentiful on mud flats south of Wexford Harbour: Marshall $1896 .-\mathrm{V}$. Pool by the sea at the Quarry, Howth (Praeger): Ir. Nat. I895.-VI. Brackish ditches at Kilrush, Clare, and Foynes, Limerick: Stewart I89o.-IX. Ballysodare, Sligo: Praeger.XI. Brackish ponds near the mouth of the river Erne, Ballyshannon; $R$. P. Vowell.-XII. Plentiful in a salt marsh near Portstewart (Stewart): Flor. N.-E. Stream at Blackstaff Bridge near Kirkcubbin, Down: S.\& P. 1895 .

Many of the older records are for the aggregate $R$. maritima only, and the distribution of the segregates in Ireland is as yet very imperfectly known. $R$. rostellata is apparently much more frequent than $R$. spiralis.

\section{ZANNICHELLIA Linn.}

\section{Z. palustris Linn (aggregate)-Horned Pond-weed.}

District I. II. - IV. V. VI. VII. VIII. IX. X. XI. XII. Lat. $52 \frac{1}{4}^{\circ}-55 \frac{1}{4}{ }^{\circ}$. Throughout Ireland, probably. Type, British.

Rivers, ditches, pools, and lake margins, in still water; rather frequent. Fl. June-August.

Usually near the sea, but occasionally occurs far inland as in Loughs Ree and Derg on the Shannon.

\section{Z. brachystemon Gay.}

Districts I. - - - V. VI. VII. - - - XII.

I. Quarry hole near Castleisland, Kerry, 1888; R.W.S.V. Brackish ditch near Balbriggan; pools by the Dodder near Rathfarnham, Co. Dublin, 1893 ;-VI. Pool on Slieve Elva, Co. Clare, 1895 ; and-VII. Dromineer.Harbour, Lough Derg, 1896 ; N.C.XII. At Blackstaff bridge, Kirkcubbin, Co. Down, 1890; Praeger. In the river Quoile above Downpatrick, 1880 ; Stewart.

To $700 \mathrm{ft}$. in Clare (N.C.); but usually lowland.

This appears to be the commonest of the segregates in Ireland as it is in Great Britain, and probably occurs in all the districts.

\section{Z. pedunculata Reichb.}

Districts I. - - - - - - - - $-\bar{W}$. S 889 . In the
$\quad$ I. Banna and Ballyheigue, Kerry: Cashen river, Kerry; $R . W . S$. 
Z. polycarpa Nolte.

Districts - - - - - - - - - XII.

XII. Abundant in brackish ditches in the long-neglected Victoria Park, and in the reclaimed land between Queen's Quay and the Park [Belfast], 1872 (Stewart): Bot. Ex. Cl. Rep. 1876.

First found in the British Isles, at Belfast, by S. A. Stewart in 1872.

\section{ZOSTERA Linn.}

\section{Z. marina Linn.-Grass-wrack.}

Districts I. II. - IV. V. VI. - VIII. IX. - XI. XII. Lat. $51 \frac{1}{2}^{\circ}-55 \frac{1}{4}^{\circ}$. Coasts of all Ireland. Type, British.

Muddy estuaries and shallow sea shores; common. Fl. JulyAugust.

\section{Z. nana Roth-Dwarf Grass-wraok.}

Districts I. - - IV. V. - - VIII. - - XI. Lat. $52 \frac{1}{4}^{\circ}-55 \frac{1}{4}^{\circ}$. South to North. Type, English.

Muddy estuaries; rare. Fl. July-September.

I. About Spa, Tralee Bay, Kerry: $R$. DT. S. I888.-IV. Plentiful on the mud flats south of Wexford Harbour: Marshall $I 806$.V. On mud in the creek close to the railway station at Baldoyle, Dublin (More): Cyb. Abundant below the Club house, Portmarnock golf links, Dublin : Hart I897. Estuary of the Nanny river above the bridge at Laytown, Meath : Praeger $1897 .-$ VIII. Shore at Gentian Hill, Galway (Miss Hensman \& Prof. T. Johnson): Ir. Nat. 7805.-XI. Abundant on the strand at Ards: Hart. in Herb.

First discovered in Ireland by A. G. More, at Baldoyle, in 1864.

\section{NATAS Linn.}

1. N. flexilis Rostk.-Slender Naiad.

Cautinia flexilis Willd.

Districts I. - - - - - - VIII. - - - Lat. $52^{\circ}-53 \frac{1}{2}^{\circ}$. West Ireland, Kerry and Galway only.

Lowland. In shallow water in lakes; very rare. Fl. August.

I. In the upper end of Lough Caragh, Kerry (More): Journ. of Bot. 1877 - and in $1896 ;$ R. W. S. In Ross Bay, Killarney 
Lakes, 1885 (Rev. E. F. Linton): Journ. of Bot., r886. Muckross shore; Ross Bay; and Victoria Bay, Lower Lake of Killarney: R. W.S. 7888 . - VIII. In a lake near Roundstone, Connemara, between the Clifden coast road and the sea, at a mile or two from the village of Roundstone: Oliver $785 \mathrm{~T}$. In a small lake less than a mile from Roundstone on the way to Urrisbeg (Moore): Cyb. In Lough Cregduff, three-quarters of a mile west of Roundstone (probably Prof. Oliver's station), 1869 (More): Rec. Add. In great plenty in Lough Cregduff, 1885: Linton 1886 -and in 1895 (J. A. Audley \& Praeger): Ir. Nat. 2895. All of the District VIII. records apparently refer to Lough Cregduff.

First discovered in the British Isles, near Roundstone, Connemara, by Daniel Oliver in 1850.

Not found in England. Confined in Scotland to Perthshire and Skye.

ORDER LXXV.-ERIOCAULONEE.

ERIOCAULON Linn.

1. E. septangulare With.-Pipe-wort.

Districts I. - - - - VI. - VIII. - - XI. Lat. $51 \frac{3}{4}{ }^{\circ}-55^{\circ}$. West Ireland. Type, Scottish-Atlantic.

Lakes and bog pools in mountainous districts, usually near the sea; locally abundant. Fl. July-August.

I. Abundant in the Cromeen [Clonee] Lakes eight miles below Kenmare, behind Hungry Hill (Carroll): $C y b$. Inchiquin Iake (T. Wright) : Cyb. Very abundant in the Clonee Lakes and other lakes about Kenmare Bay: R.W.S. I89o. Bog-holes at north end of Lough Caragh, Kerry (Dr. Battersby): Rec. Add. In Lough Caragh and Lough Beg near it: $R$.W. S. 1889. Lough Fadda near Sneem, $1885 ; N . C$. Lake above Glen Lough, north-east of

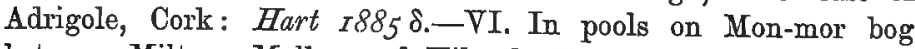
between Miltown Malbay and Kilrush, Clare (C.Carter): Phytol. 1846, p. 514.-VIII. Abundant in Connemara: Wade Gallovid. In small lakes within four miles of Galway on the road to Oughterard; in several small lakes between Newport and Mount Nephin, Mayo: Mack. Rar. Inishbofin: More 1876 . Lakes between Deel Bridge and Corslieve, Mayo: Hart 1883 a. In a 
small lake at the north end of Achill Island: More 2873 . Lakes near Inveran, Iar Connaught, 1895; Lough Inagh; Derryclare Lough, and other lakes in Glen Inagh, $1897 ; N$. C. North side of Lough Mask, $1891 ; R$. P. Vowell. Abundant on the north-west shore of Lough Corrib; in the Narrow Lake, Lough Mask; Lough Coolin near Clonbur; and in Lough-na-Dirkbeg, Maamtrasna: M. \& S. I896.-XI. Abundant in the lakes of the Rosses, Donegal: Murphy 7829. In two small lakes west of Loughanure in the Rosses: Hart 1879 . Lough Berag near Naren, Donegal (Admiral Jones): $C y b$. In a small lake on Kincashla Point; abundant in Lough Aleckmore, north of Trawenagh Bay: Hart 1880 \& I88I $\beta$. Kiltooris Lake near Ardara: Hart 1886.

To $300 \mathrm{ft}$. in Galway (Oliver); to $1000 \mathrm{ft}$. in Cork (Hart); but usually lowland.

First found in Ireland, in Connemara, by Dr. Walter Wade in 1801.

A North American species not found on the European continent, and confined in Great Britain to the islands of Skye and Coll in .Scotland. Extends along nearly the whole west coast of Ireland and is especially abundant in Connemara.

\section{ORDER LXXVI,-CYPERACEAE.}

\section{ELEOCHARIS R.Br.}

\section{E. acicularis $\mathrm{R} . \mathrm{Br}$.-Least Spike-rush.}

Districts I. - III. - V. VI. VII. - IX. X. - XII. Lat. 52 $-55^{\circ}$. From South to North. Type, English-British.

Lowland. Wet sandy lake margins, and edges of rivers and canals; rather frequent. Fl. July-August.

I. Abundant about Castlelough Bay and Muckross shore, Lower Lake of Killarney; also along the river Laune, from near its exit from the Lake to Killorglin: $R . W . S .1888$.- III. In the Grand Canal between Monasterevan and Portarlington, Queen's Co.; and-V. Near Monasterevan, Kildare (Praeger): Ir. Nat, I893.VI. On the banks of Lough Derg near Portumna (Moore): Cyb. Sheckamore Lake and Inchiquin Lake, Co. Clare; $P . B . O^{\prime}$ Kelly.- 
VII. Banks of the Shannon near Portumna Bridge, Tipperary: Mack. Rar. Canal near Philipstown and Edenderry, King's Co.: Praeger 1897.-IX. Near Clooneigh river, Lough Ree: $B . \& F$. 1887.-X. Plentiful near the side of Lough Erne, Co. Fermanagh (Dr. Scott) : Mack. Rar. Devenish Island, Lough Erne, and in one spot on the east side of the lake; rare: Barrington 1884 . Canal at Strabane: Murphy 1829 . Banks of the Ulster canal in Monaghan (Miss Maffett): Cyb. Shores of Lough Neagh in Armagh: More 1860. In Armagh, at Ardmore Glebe (Rev. H.W. Lett); and on the banks of the Closet river: Praeger 1893. In Lough Oughter, Cavan: Praeger $1897 .-\mathrm{XII}$. Near Portmore, and plentiful about Lough Beg: Templeton MS. By the Bann below Portglenone, 1796 (Templeton): Whitla MS. Close to Portmore old church (Stewart): Flor. N.-E. Abundant in the centre of Lough Beg(Praeger): Journ. of Bot. 1803. Plentiful in several places by the Bann, Derry: Moore MS. Banks of the Lagan canal aboveLisburn, and shore of Lough Neagh north of Lurgan (Stewart): Flor. N.-E.

Var. Longionduss H. C. Watson.-V. Plentiful in the Grand Canal, Co. Dublin, from Hazelhatch to Clondalkin : N. C. 1893.

\section{E. palustris R. Br.-Creeping Spike-rush.}

Districts I. II. III. IV. V. VI. VII. VIII. IX. X. XI. XII. Lat. $51 \frac{1}{2}^{\circ}-55 \frac{1}{4}^{\circ}$. Throughout Ireland. Type, British.

Wet and marshy places; frequent. $\mathrm{Fl}$. June-July. (Hart).

Sea-level in Antrim and S. Cork. To $1450 \mathrm{ft}$. in Down E. uniglumis Link.

Districts I. - - IV. V. - - - - - XII. Lat. $52^{\circ}-54 \frac{3}{4}{ }^{\circ}$. From South to North. Type, British-Scottish.

Marshes and ditches near the sea; rare. Fl. July-August.

I. Salt marsh near Rossbeigh, Kerry, 1874 ; Moore. Near Ballydavid Head, Kerry, 1891; Cecil Butler. By the shore between Blennerville and Camp, Kerry: Hart 1884 .- -IV. On the sand-hills. near Arklow, Wicklow (More): Rec. Add. Mouth of the Pill, Alderton, Wexford: B.-H.\&G.1889. Marsh ditches north of Wexford Harbour: Marshall I896.-V. On the shore east of Dollymount, Dublin (M. Dowd): Rec. Add. Salt Marsh at Soldiers ${ }^{2}$ 
Point, Louth : Praeger 1897 . - XII. Sparingly by the shore half amile east of Bangor, Down, 1867 (Stewart): Flor. N.-E.

Var. Watsoni Bab.-IV. Murrough of Wicklow (Dr. D. Moore): Bab. Manual.

\section{E. multicaulis Smith-Many-stalked Spite-rush.}

Districts I. II. III. IV. V. VI. - VIII. IX. X. XI. XII. Lat. $51 \frac{1}{2}^{\circ}-55 \frac{1}{4}^{\circ}$. Throughout Ireland, probably. Type, British.

Spongy bogs, lake shores, \&c. ; frequent. Fl. June-August.

Sea-level in N. Derry and in Kerry. To $925 \mathrm{ft}$. in Donegal, and $1150 \mathrm{ft}$. in Louth (Hart); to $2000 \mathrm{ft}$. in Kerry (Druce I89I).

Apparently more frequent in the West than in the East.

\section{SCIRPUS Linn.}

1. S. pauciflorus Lightf.-Few-flowered Spike-rush.

Districts I. - - - V. VI. VII. VIII. IX. X. XI. XII. Lat. $52^{\circ}-55 \frac{1}{4}^{\circ}$. From South to North. Type, British.

Margins of lakes, and in bogs and marshy places; frequent. Fl. May-August.

Sea-level to $1000 \mathrm{ft}$. in Dublin (N.C.); but usually lowland.

\section{S. cæspitosus Linn._Scaly Spike-rush.}

Districts I. II. III. IV. V. VI. VII. VIII. IX. X. XI. XII. Lat. 51 $\frac{1}{2}^{\circ}-55 \frac{1}{4}^{\circ}$. Throughout Ireland. Type, British-Scottish.

Heaths and moors, especially in mountain districts; common. Fl. May-June. Calcifuge $A$.

Descends to $100 \mathrm{ft}$. in Antrim and in Kerry. Ascends to $2300 \mathrm{ft}$. in Donegal (Hart); to $2500 \mathrm{ft}$. in Down (S.\&P.); to $2900 \mathrm{ft}$. in Wicklow (N.C.); to $3000 \mathrm{ft}$. in Kerry (More).

3. S. parvulus Rom. \& Schult.-Dwarf Spike-rush.

S. nanus Spreng.

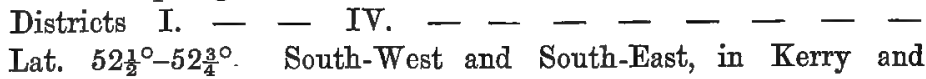
Wicklow.

Muddy estuaries; very rare. Fl. July.

I. Abundant along the tidal portion of the Cashen river near Ballybunnion, Kerry, 1889: R.W. S. $2890 .-\mathrm{IV}$. Abundant at 2 c 2 
Arklow on soft mud overflowed at high tide on the north side of the River Ovoca, 1868 (More): Journ. of Bot. 7868 . Still abundant at Arklow in 1893 and 1896 ; Barrington.

First discovered by A. G. More, at Arklow, in 1868.

\section{S. fluitans Linn.-Floating Spike-rush.}

Districts I. II. III. IV. V. VI. VII. VIII. IX. X. XI. XII. Lat. $51 \frac{1}{2}^{\circ}-55 \frac{1}{4}$. Throughout Ireland. Type, British.

Ditches, bog-drains, lake margins, \&c., in still water; frequent. Fl. June-July. Calcifuge $A$.

Sea-level in N. Antrim and S. Cork. To $1150 \mathrm{ft}$. in Louth (Hart).

\section{S. Savii Seb. et Maur.-Savi's Spike-rush.}

\section{S. cernurs Vahl.}

Districts I. II. III. IV. V. VI, - VIII. IX. X. XI. XII. Lat. $51 \frac{1}{2}^{\circ}-55 \frac{1}{4}^{\circ}$. All round Ireland, near the coast. Type, Atlantic.

Moist places, near the sea; frequent. $\mathrm{Fl}$. July-August.

To $850 \mathrm{ft}$. in Kerry (Hart); but usually lowland.

Though not strictly confined to the coasts, this species rarely occurs at any great distance inland.

\section{S. setaceus Linn.-Bristle-leaved Spike-rush.}

Districts I. II. III. IV. V. VI. VII. VIII. IX. X. XI. XII. Lat. $51 \frac{1}{2}^{\circ}-55 \frac{1}{4}^{\circ}$. Throughout Ireland. Type, British.

Moist gravelly and sandy places; frequent. $F$. July-September.

Sea-level in N. Antrim and in Kerry. To $1400 \mathrm{ft}$. in Dublin $\left(N . C_{\text {. }}\right.$ ) ; to $1250 \mathrm{ft}$. in Waterford (Hart).

\section{S. lacustris Linn.-Bull-rush.}

Hibernicé boz jंeımın (Buck-evvin), Soft Rush.

Districts I. II. III. IV. V. VI. VII. VIII. IX. X. XI. XII. Lat. 51 $1_{2}^{\circ}-55 \frac{1}{4}^{\circ}$. Throughout Ireland. Type, British.

Lowland. Rivers, ponds and lakes; frequent. Fl. June-July.

\section{S. Tabernamontani Gmel.}

Districts I. II. III. IV. V. VI. - VIII. - X. XI. XII. Lat. $51 \frac{1}{2}^{\circ}-55 \frac{1}{4}^{\circ}$. Coasts of all Ireland, probably. Type, EnglishBritish.

Ditches and pools near the sea; frequent. Fr. June-July. 


\section{S. maritimus Linn.-Sea Club-rush.}

Districts I. II. III. IV. V. VI. - VIII. IX. X, XI. XII. Lat. $511_{2}^{\circ}-55 \frac{1}{4}^{\circ}$. Coasts of all Ireland. Type, British-English.

Salt marshes and brackish ditches; frequent. Fl. June-July.

\section{S. sylvaticus Linn.-Wood Club-rush.}

Districts I. II. III. - - VI. VII. - - X. XI. XII. Lat. $52^{\circ}-55 \frac{1}{4}^{\circ}$. From South to North. Type, British-English.

Lowland. Wet meadows and marshy places; local. Fl. JuneJuly.

I. River side about a mile above Cork: Drummond 1818 -still there in 1894, and also between Cork and Carrigrohane; Phillips.III. By the Blackwater near Fermoy (Chandlee): $C y b$. Near Castlelyons and Ahern ( $T$. Chandlee); by the Owbeg from Castletownroche to near Shanballymore (Carroll); by the Bride above Tallow (C. Longfield): Allin's Corl. By the Funshion river, north Cork, $1896 ; R . W . S . \quad$ Right bank of the Suir between Golden and Caher, Tipperary : Hart 1885 a.-III. By the Barrow near Portarlington and above Mountmellick : Hart 1885 -VI. Plassy, near Limerick (Carroll) : Cyb.-VII. By the Barrow near Baylough above Monasterevan, and abundant farther up the river at Garryhinch: Hart 1885.-X. By Lough. Erne near Enniskillen: Flor. Hib. Near Loughgall, Armagh: More 1860. Derrygorry brook, Favour Royal, Tyrone: Hart 7887 . In Co. Armagh, by the river side near Newry (Rev. H.W. Lett); at Maghery; Clare; Tynan Abbey, \&c.: Praeger 1803 . Banks of the Strule near Omagh, Tyrone (Miss M. C. Rnowles): Ir. Nat. 1897.-XI. Abundant by the Termon river above Pettigoe: Hart 1886 . Sparingly by the Glentocher river, Innishowen; Hart.-XII. Frequent in the North-East: Flor. N.-E.

10. S. rufus Schrad.-Brown Club-rush.

Blysmus rufus Panz.

Districts I. - - - V. - - VIII. IX. - XI. XII. Lat. $51 \frac{3}{4}^{\circ}-55 \frac{1}{4}^{\circ}$. South to North. Type, Scottish.

Salt-marshes; rather local, Fl. June-July.

I. In the Dingle peninsula, Kerry, at Castle Gregory, at Castle Gallerus, and estuary between Trabeg and Bull's Head: Hart I884. At Akeragh Lake, Ballyheigue Bay, and at Derrynane estuary, 
Kerry: R.W. S. $1888 \& 1890 .-\mathrm{V}$. Between Baldoyle and Howth, and between Balbriggan and Hampton: Mack. Rar. 7806 -still in these stations, near Howth, 1892, and near Balbriggan, $1895 ;$ N.C. Abundant on the North Bull opposite Dollymount, Dublin (More): Rec. Add.-and in $1893 ;$ N.C. On Lambay Island (R. $\boldsymbol{M}$. Barrington): Hart $2883 \gamma$. Salt marsh north of Portrane, 1893 ; and between Skerries and Lough Shinny, Dublin, 1895; N.C.VIII. Near Custrower Bay, Ballinahinch, Connemara: Wade Rar. Near Killala, Mayo (Moore) : Cyb.-IX. Mouth of Drumcliff river, Sligo, 1882 : T. H.Corry, MS.-XI. Shores of Donegal Bay, at the town of Donegal (Dickie): Flor. Olst. Shore at Glencolumblkill and at Killybegs (More): Cyb. By Lough Swilly near Rathmelton: Hart 1880 . Abundant by Horn Head bridge: Hart I88I $\beta$.XII. On salt and marshy ground occasionally covered at high water near Ballintoy, $1797 \cdot$ Brown MS.-still there in 1895 (Rev. S. A. Brenan): Ir Nat. $1806, p .27$. Between Larne and Ballygally, Antrim, 1808: Templeton MS. Cushendall and Larne Lough (Moore): Cyb. Plentiful by the Foyle at Brook Hall, Derry: Moore MS. By the Bann abore Portstewart, Derry; at Groomsport, Down (Stevoart) : Flor. N.-E.

First found in Ireland, near Ballintoy, by Robert Brown in 1797.

\section{ERIOPHORUM Linn.}

\section{E. vaginatum Linn.-Zare's-tail Cotton-grass.}

Districts I. II. III. IV. V. VI. VII. VIII. IX. X. XI. XII. Lat. $51 \frac{1}{2}^{\circ}-55 \frac{1}{4}^{\circ}$. Throughout Ireland. Type, British-Scottish.

Bogs and moors, chiefly in mountain districts; frequent. $F l$. April-May.

Sea-level in Derry and in Kerry. To $2000 \mathrm{ft}$. in Derry (Moore); to $2100 \mathrm{ft}$. in Sligo $\left(B . \& V_{0}\right)$; to $2800 \mathrm{ft}$. in Wicklow, and to $3000 \mathrm{ft}$. in Tipperary (Hart).

\section{E. angustifolium Roth-Narrow-leaved Cotton-grass.}

Hibernicé blác popeaıc (Blaw-purrthock), Bog Bloom-Cannabán mona (Canna-vawn mona), White-head of the Bog.

Districts I. II. III. IV. V. VI. VII. VIII. IX. X. XI. XII. Lat. $51 \frac{1}{2}^{\circ}-55 \frac{1}{4}^{\circ}$. Throughout Ireland. Type, British.

Boggy and marshy places; common. Fl. May-June.

Sea-level in Derry and in South Cork. To $2200 \mathrm{ft}$. in Derry (Moore); to $2800 \mathrm{ft}$. in Wicklow (Hart). 


\section{E. latifolium Hoppe-Broad-leaved Cotton-grass.}

Districts I. II. - IV. - VI. - VIII. - - XI. XIT. Lat. $51 \frac{3}{4}^{\circ}-54 \frac{3}{4}^{\circ}$. From South to North. Type, British-English.

Lowland. Bogs; rare. Fl. April-May.

I. Banks of the river Laune west of Beaufort bridge; Glencar valley; and near Staigue fort, Kerry: R.W.S. I889 \& 1890. South of Tarbert, Kerry; and north of Adrigole, Cork ; $R$.W. S.II. Swamp by the Suir about three miles below Twoford Bridge between Holycross and Golden, Tipperary: Hart I885 a.IV. Marsh near Enniskerry $(\boldsymbol{M r}$. Winoh) and other places in Co. Wicklow : Flor. Hib.-VI. At Woodlawn near Kilconnell, Galway (E. Hill): Mag. of Zool. \& Bot. II. I24.-VIII. Bog on the north-west side of Urrisbeg mountain near Roundstone, 1869 (More) : Ree. Add. -XI. Plentiful by Lough Sheskinmore, northwest of Ardara: Hart 1886.-XII. On a large flow bog near Rasharkin, Antrim (Moore) : Cyb. Very rare if not extinct in the North-East: Flor. N.-E.

\section{RHYNCHOSPORA Vahl.}

1. R. fusca Rom. \& Schult.-Brown Beal-rush.

Districts I. II. - - - VI. - VIII. IX. - - Lat. $51 \frac{3}{4}^{\circ}-54^{\circ}$. West Ireland. Type, Atlantic.

Lowland. Spongy bogs; locally abundant. $F l$. July-August.

I. Wet bogs near the bottom of Purple mountain, Killarney, 1805: Mack. Rar. Near the base of Connor Hill, Dingle (Moore): Cyb. Locally abundant in south Kerry, rare in north Kerry; R.W.S. Lough Allua, Cork: Drummond 1818 . Near Berehaven (R.W.Townsend); and about Glengariff (C.C. Babington): Flor. Cork. Bogs at Ardgroom (More): Allin's Cork. Adrigole and Glengariff, 1894 ; Phillips.-II. Oldtown bog near New Birmingham, Tipperary; R. P. Fowell.-VI. Dunbeg bog, Clare (Moore): Cyb. Tycooly and Killasolan bogs near Clonbrock, E. Galway: Praeger $1896 .-$ VIII. Near the hill of Cahill, Cunnamara; and in several places between Ballinahinch and Oughterard, 1805: Mack. Rar. Near Kilkerran Bay; Roundstone, \&c., in Connemara (Moore): Cyb. Abundant in several places between Oughterard and Carn Seefin: P.\& C. I 895. In Co. Mayo, near Foxford; and-IX. At Ballinrobe and Hollymount (More): Cyb.

First found by Mackay, at Purple Mountain, Killarney, in 1805. 


\section{R. alba Vahl-White Beak-rush.}

Districts I. II. - IV. V. VI. VII. VIII. IX. X. XI. XII. Lat. $51 \frac{1}{2}^{\circ}-55 \frac{1}{4}^{\circ}$. Throughout Ireland, probably. Type, British.

Wet bogs ; locally abundant. $F l$. July.

Sea-level in N. Antrim and S. Cork. To $1000 \mathrm{ft}$. in Donegal (Hart); to $1225 \mathrm{ft}$. in Down (S.\& P.).

Abundant in many parts of the West and North, but appears to be quite rare in the East.

\section{SCHENUS Linn.}

1. S. nigricans Linn.-Black Bog-rush.

Districts I. II. III. IV. V. VI. VII. VIII. IX. X. XI. XII. Lat. 51 $\frac{1}{2}^{\circ}-55 \frac{1}{4}^{\circ}$. Throughout Ireland. Type, British.

Bogs, wet moors, lake shores, and moist clay banks; frequent. Fl. June.

Sea-level in N. Antrim and S. Cork. To $1100 \mathrm{ft}$. in Donegal (Hart); to $1800 \mathrm{ft}$. in Down $(S . \& P$.); to $1400 \mathrm{ft}$. in Kerry (Hart).

\section{CLADIUM R. Br.}

1. C. mariscus R. Br.-Prickly Twig-rush.

C. germanicum Schrad.

Hibernicé Colōpoc (Colleg-ruch).

Districts I. II. III. IV. V. VI. VII. VIII. IX. X. XI. XII. Lat. $512^{\circ}-551^{\circ}$. Throughout Ireland. Type, English-British.

Lowland. Margins of lakes and marshy places ; frequent in the West, rare in the East. Fl. July.

III. Black Bog near Carlow, and Ardristan Bog near Tullow (R. Clayton Browne): Rec. Add.-IV. On the Murrough of Wick: low (Moore) : Cyb.-V. Side of the river Nanny near Ballygarth, Meath: Maok. Rar. Marshy ground, Castlebellingham, Louth: Butler 1890. Bog by the railway between Navan and Drogheda (Moore); Dolardstown bog ( $J$. Douglas): Cyb.-XII. Lake by the road from Castlewellan to Rathfriland: Templeton MS. Sparingly on the northern margin of Altnadua lake near Castlewellan (no doubt Templeton's station); very rare in District XII. : S. \& $P$. r892. - The foregoing are the only stations for East Ireland. 
CAREX Linn.

\section{C. dioica Linn.-Dicecious Sedge.}

Districts I. - - IV. V. VI. VII. VIII. IX. X. XI. XII. Lat. $51 \frac{3}{4}^{\circ}-551^{\circ}$. From South to North. Type, Scottish-British.

Spongy bogs; rather local. Fl. May-June.

Descends to about $200 \mathrm{ft}$. in Antrim and to sea-level in Kerry. Ascends to $1400 \mathrm{ft}$. in Down (Hart); and to $1650 \mathrm{ft}$. in Ben Bulben district $(B . \& V$. $)$.

\section{C. pulicaris Linn.-Flea Sedge.}

Districts I. II. III. IV. V. VI. VII. VIII. IX. X. XI. XII. Lat. $51 \frac{1}{2}^{\circ}-55 \frac{x^{\circ}}{}{ }^{\circ}$. Throughout Ireland. Type, British.

Heathy and boggy places; frequent. Fl. May-June.

Sea-level in N. Donegal and S. Cork. To $1700 \mathrm{ft}$. in Donegal, and to $2000 \mathrm{ft}$. in Mayo (Hart); to $3000 \mathrm{ft}$. in Kerry (Druce $189 \mathrm{I}$ ).

\section{C. pauciflora Lightf.-Few-flowered Sedge.}

Districts - - - - - - - - - XII.

Lat. 55 . County Antrim only. Type, Highland.

Wet bogs ; very rare. Fl. June-July.

XII. On the mountains near Parkmore at the head of Glenariff, Co. Antrim, at 1000 feet, 1889 (Rev. H. W. Lett): Journ. of Bot. I895, p. 217 .

It is most desirable that further search should be made for this sedge in the northern counties. Its title to a place in the Irish flora is based solely on a single tuft gathered by $\mathrm{Mr}$. Lett at the head of Glenariff, a locality which does not appear to have been examined by any botanist since the date of his interesting discovery in 1889 . The plant is one not unlikely to be passed over as a form of C. pulicaris by those unfamiliar with its appearance, and may be expected to occur in other stations in the upland bogs of North Ireland.

First found in Ireland by the Rev. H. W. Lett in 1889 .

4. C. divisa Huds.-Bracteate Marsh-Sedge.

Districts - - - IV. V. - - - - - - Lat. 52 $x^{\circ}-53 x^{\circ}$ Coasts of Wexford and Dublin. Type, English.

Marshy meadows by the sea; very rare. $F l$. May-June. 
IV. By the new bridge near Dunbrody Abbey; by the Causeway, Fisherstown; near the Pill, Alderton, Wexford (Miss Glascott): B.-H. \& G. 7889 . Ballyvarnay marshes, 1893; G. G. Pill.$\mathrm{V}$. Along the side of a ditch in the marshes of the North Strand, Dublin, in some plenty in 1866 (Moore): Cyb. Nearly extinct in the North Strand station, but two large patches found in 1871 close to the glass works on the north bank of the Liffey (More): Ree. $A d d$. Still in some quantity in the latter station in $1894 ; N . C$.

First discovered in Ireland by David Moore in 1866.

\section{C. disticha Huds.-Soft Sedge.}

C. intermedia Good.

Districts I. II. III. IV. V. VI. VII. VIII. IX. X. XI. XII. Lat. $52^{\circ}-55 \frac{10}{4}$. Throughout Ireland. Type, English-British.

Marshy meadows; frequent. $F$. May-June.

To $750 \mathrm{ft}$. in Dublin (N.C.); to $950 \mathrm{ft}$. in Kerry (Barrington); but usually lowland.

\section{C. arenaria Linn.-Sea Sedge.}

Districts I. II. - IV. V. VI. - VIII. IX. - XI. XII. Lat. $51 \frac{1}{2}^{\circ}-55 \frac{1}{4}^{\circ}$. Coasts of all Ireland. Type, British.

Sandy sea-shores; frequent and locally abundant. Fl. MayJune.

7. C. teretiuscula Good.-Lesser Panicled Sedge.

Districts I. - - - V. VI. VII. VIII. IX. X. XI. XII. Lat. $52 \frac{1}{4}^{\circ}-55 \frac{1}{4}^{\circ}$. From South to North. Type, British-English.

Lowland. Boggy places; rather rare. Fl. June.

I. South-west corner of Lough Gill, Castlegregory, Kerry: Hart 2884 . Smerwick bog near Dingle; Clogherbrian bog near Tralee: R.W.S. $1889 .-\mathrm{V}$. By the Royal Canal above Clonsilla, sparingly : N.C. 1893. Ardee Bog in Meath and Louth; Praeger.VI. Dunbeg bog near Kilrush, Clare; bog near Woodford, Galway (Moore) : Cyb. Near Clonbrock, East Galway: Praeger 2896.VII. Near Belvidere lake, Mullingar (Moore): $C y b$. Plentiful in a large bog near Multyfarnham, Westmeath (Moore): Rec. Add. Lisclogher Bog, Westmeath; More. Scraw Bog and Bog of Linn, frequent in Westmeath: Levinge 1894.-VIII. By a lake about a mile from Newport towards Westport, Mayo: Hart 
2883 a.-IX. Near Hollymount House, Mayo (More): Cyb. Bog near Clonhugh railway station (T. T. Dyer): Rec. Add. Between Claremorris lake and the railway station: Marshall 1896. Lough Arrow, Sligo; Praeger. In many places near Lough Ree : B.\&V. 1887.-X. Lough Muck, Tyrone (Miss M. C. Knowles): Ir. Nat. 1897.-XI. Small lake between Marble Hill and Sesiagh lake near Dunfanaghy: Hart ${ }_{2} 88 \mathrm{I} \beta$. Near Port Salon, \&c.; rare in Donegal; Hart.-XII. Marshy lake at Killymurray, Antrim (Moore): Cyb. Abundant on the marshy margin of Killeleagh lough above Maghera, Derry (Mrs. Leebody \& Praeger): S. \&P. r895.

8. C. paradoxa Willd.-Paradoxical Sedge.

Districts - - - - - VII

Lat. $53^{\circ} 30^{\prime}-53^{\circ} 35^{\prime}$. Westmeath only. Type, Local-Intermediate.

Lowland. Boggy places; very rare. $F l$. June.

VII. Plentiful in the boggy wood at Ladiston, on the shore of Belvidere Lake [Lough Ennel] near Mullingar (Moore): Cyb. Sparingly along the edges of ditches on recently-drained ground at Ladiston (Moore): Rec. Add. Only a few plants left at Ladiston; in the Bog of Linn; and sparingly in the "Scraw Bog," Loughanstown: Levinge 1894 .

\section{C. paniculata Linn.-Panicled Sedge.}

Districts I. II. III. IV. V. VI. VII. VIII. IX. X. XI. XII. Lat. $51 \frac{1}{2}^{\circ}-55 \frac{1}{4}^{\circ}$. Throughout Ireland. Type, British.

Boggy and swampy places ; frequent. Fl. May-June.

Sea-level in N. Derry and S. Cork. To $1900 \mathrm{ft}$. in Tipperary (Hart); but usually lowland.

A widespread species, yet rare over wide areas in many parts of the country.

\section{C. vulpina Linn.-Great Sedge.}

Districts I. II. III. IV. V. VI. VII. VIII. IX. X. XI. XII. Lat. $51 \frac{1}{2}^{\circ}-55 \frac{1}{4}^{\circ}$. Throughout Ireland. Type, British.

Lowland. Wet ditch-banks; rather frequent. Fl. June.

Chiefly in the neighbourhood of the coast, but occurs occasionally far inland, as near Parsonstown (Rec. Add.) and between Tipperary and Cashel (R.W.S.). 


\section{C. muricata Linn.-Prickly Sedgé.}

Districts I. II. III. IV. V. VI. - VIII. - - XII. Lat. $51 \frac{1}{2} 0-54 \frac{1}{2}$. From South to North. Type, British-English.

Lowland. Hedge banks, and gravelly or marshy pastures; rare. Fl. June, Calcicole $C$.

I. At Clogherbrian near Tralee; and near Fenit House, Tralee Bay, Kerry: R.W. S. $1889 \& 189 I$. On Inishbeg and Inish Sherkin ; at Glengariff: Allin's Cork. Near Kinsale, 1892; Phillips.II. Carrick-a-brick near Fermoy ( $T$. Chandlee): Cyb. Not rare about Midleton and Buttevant (Rev. T. Allin): Rec. Add. Ditch banks near Cahir: Mack. Cat.-III. By the Barrow at Shrule Castle above Carlow: Hart 7885 .-IV. By the Slaney, and on a bog near Enniscorthy, Wexford (Carroll): $C y b$. Fassaroe near Bray (Barrington): Rec. Add.-V. Near Step-aside on the way to Holly Park, Dublin (Moore): Cyb. By the Grand Canal at Monasterevan, Kildare: Hart I885.-VI. Knockatien near Ballyvaughan, 1897; P. B. O'Kelly.-VIII. Oughterard, Galway: Babington 1836. - XII. Damp pasture by the shore north-east of the coastguard station at Macedon Point, 1868 and 1885 (Stewart): Rec. Add. \& Flor. N.-E. Marshy pasture near Clowney bridge on the Forth river, Antrim (R. Hanna): Stewart 1894.

\section{C. divulsa Good.-Grey Sedge.}

Districts I. II. III, IV. V. - VII. - - - - Lat. $51 \frac{1}{2}^{\circ}-53 \frac{3}{4}^{\circ}$. Southern half of Ireland. Type, English-Germanic.

Lowland. Hedge banks; not infrequent. Fl. June-July. Calcicole $B$.

I. At Muckross, Killarney (MFore) : Rec. Add. In many places about Killarney; at the head of Kenmare Bay, Kerry: R.W.S. I889\&1890. Inishannon, Cork (Carroll): Cyb. Near Bantry: Allin 1871. At Kinsale and by the river Lee at Cork; Phillips.II. Near Fermoy (Chandlee): Cyb. At Midleton: Allin 187. By the river Owbeg, N. Cork. 1896; abundant by the roadside between Tipperary and Cashel; R.W.S.-III. Brown's Hill, Carlow (R. Clayton Browne): Rec. Add. By the Slaney below Tullow; Hart.-IV. Banks near the Glen of the Downs, Wicklow (Moore): Cyb. At Bray and Delgany, Wicklow; More. Dunbrody Park, Wexford: B.-H. \& G. $1889 .-\mathrm{V}$. Grassy hedges going from Dublin to Killiney Bay, 1814: Templeton MS. Near Stillorgan, 
Dublin (Moore); near Athy, Kildare (Carroll); at Lodge Park, Kildare (J. Douglas): Cyb. Near Killiney Bay, at Swords, at Chapelmidway, and near Balbriggan, 1893 ; near Lucan, 1895, \&c.; frequent in county Dublin; N. C.-VII. Knock Ross, near Lough Derevaragh, Westmeath: Linton 1896 .

\section{C. echinata Murr.-Prickly Sedge.}

C. stellulata Good,

Districts I. II. III. IV. V. VI. VII. VIII. IX. X. XI. XII. Lat. $51 \frac{1}{2}^{\circ}-55 \frac{1_{4}^{\circ}}{\circ}$. Throughout Ireland. Type, British.

Bogs, moors, heaths, \&c. ; common. Fl. May-June.

Sea-level in Derry and in S. Cork. To $2150 \mathrm{ft}$. in Donegal (Hart); to $2800 \mathrm{ft}$. in Wicklow (N.C.); to $2600 \mathrm{ft}$. in Tipperary and to $3300 \mathrm{ft}$. in Kerry (Hart).

\section{C. remota Linn,-Distant-spiked Sedge,}

Districts I. II. III. IV. V. VI. VII. VIII. IX. X. XI. XII. Lat. $51 \frac{1}{2}^{\circ}-55 \frac{1}{4}^{\circ}$. Throughout Ireland. Type, British-English.

Damp shady places, and ditch banks; frequent and locally abundaint. Fl, June.

To $600 \mathrm{ft}$. in Dublin (N.C.); but usually lowland.

\section{C. axillaris Good.-Axillary Sedge.}

C. remota $\times$ vulpina (?)-C. muricata $\times$ remota $(?)$.

Districts I.

III

Lat. $51 \frac{3}{4}^{\circ}-53 \frac{1}{2}^{\circ}$. South and South-East. Type, English.

Lowland. Marshy places; very rare. Fl. June.

I. Salt marsh near Kinsale, 1866 (Carroll): Rec. Add.III. By the Barrow where it skirts Monettia bog above Mountmellick, Queen's Co. : H Hart I885.-V. Sparingly in marshy ground near Malahide, Co. Dublin (N. C.): Ir. Nat. I894, p. 202.

Usually considered to be a hybrid between $C$. muricata and $C$. remota, but, if really a hybrid, more probably its parents are C. vulpina and C. remota.

\section{C. Bœnningshauseniana Weihe.}

C. remota $\times$ paniculata Schwarz,

Districts I. - - - - - - - XI. Lat. $52^{\circ}-54_{4}^{3 \circ}$. Kerry and Donegal. Type, Germanic (?).

Lowland. Shady marshy places; apparently very rare. Fl. June. 
I. Wet wood near Muckross Abbey, Killarney: R.W. S. I889. -XI. By a sunk fence between the Hall and the sea wall, Mount Charles, near Donegal : Hart $1885 \gamma^{*}$

\section{C. elongata Linn.-Ellongated Sedge.}

Districts - - - - - - - X. - [XII.] Lat. $54^{\circ} 10^{\prime}-54^{\circ} 35^{\prime}$. Fermanagh [and Antrim?]. Type, English.

Lowland. Marshy ground; very rare. Fl. June.

$X$. Sparingly in a marsh between Crum Castle and the farmyard, Lough Erne: Barrington 1884.-[XII. Banks of Lough Neagh near Gally's Gate, 1837 (Moore): Mackay 1859. In a wet boggy wood at Selshan on the shore of Lough Neagh near Derrymore House in the parish of Aghagallan, Antrim, 1838 (Moore): $C y b$. The two preceding records for District XII. refer to the same station where the plant is now probably extinct: Flor. N.-E.].

\section{C. curta Good.-White Sedge.}

C. canescens Linn.

Districts I. II. III. IV. V. - - VIII. - X. XI. XII. Lat. 52 $-55 x^{\circ}$. From South to North. Type, British.

Bogs and watery places; rather rare. Fl. June.

I. Marshes at the foot of Mangerton mountain, sparingly: Wade Rar. By the river Finnow where it joins the river Flesk, Kerry: R.W.S. $1889 .-$ II. Ditch banks near Cahir, Tipperary; and-III. Meadow between Cullenagh and Stradbally, Queen's Co.: Mack. Rar.-IV. Near Lough Dan and Roundwood, Wicklow (Moore) : Cyb. Shore of Lough Firrib, Wicklow; More.-V. Foot of the Three Rock mountain above Marley: Ir. Flor. Bog near Navan, Meath: Praeger 7897.-VIII. Swamp between Maam and Lough Corrib : M. \& S. I896.-X. Ditch near Tartaraghan, Armagh (Rev. G. Robinson): More 1860 . In Co. Armagh, at Ardmore (Rev.H.W. Lett); and near Annagarriff Lake: Praeger 1893. Marsh near Crum Castle, Lough Erne, rare: Barrington 1884. Head of Strabane Glen, Tyrone (Miss M. C. Knowles): Ir. Nat. 1897.-XI. In a wet bog near Killybegs (Moore): Cyb. Near Port Salon; at Lough Akibbon, \&c.; Hart.-XII. Frequent, occurring in several stations in Antrim, Down, and Derry: Flor. $N .-E$. and S. \& P. I895.

Sea-level to $1500 \mathrm{ft}$. in Antrim (Flor. N.-E.); to $2100 \mathrm{ft}$. in Wicklow (More). 


\section{C. ovalis Good.-Oval-spiked Sedge.}

C. leporina Linn.

Districts I. II. III. IV. V. VI. VII. VIIT, IX, X, XI. XII. Lat. $51 \frac{1}{2} 55 \frac{1}{4}^{\circ}$. Throughout Ireland. Type, British.

Wet meadows, marshy and boggy places, \&c.; frequent. $F l$. May-June.

Sea-level in N. Antrim and S. Cork. To $1550 \mathrm{ft}$. in Down, and to $2200 \mathrm{ft}$. in Tipperary (Hart).

\section{C. Buxbaumii Wahl.-Hoary Sedge.}

Districts - - - - - - - - XII. Lat. $54 \frac{3}{4}^{\circ}$. Antrim only.

Lowland. Wet gravelly lake shores; very rare. Fl. June-July.

XII. On one of the small islands in Lough Neagh (D. Moore): Compan. to Bot. Mag., 1835, p. 305. "Found by Mr. D. Moore in 1835 on a small island in Lough Neagh near Toom-bridge": Flor. Hib. One small patch found here in 1886 (Stewart): Flor. N.-E.

Up to the year 1895, when it was discovered in Arisaig, West Inverness, this plant was considered to be confined in the British Isles to a single island in Lough Neagh. If not already extinct in its only Irish station, there is reason to fear that it will soon become so.

\section{C. Hudsonii Ar. Benn.-Greater Tufted-Sedge.}

C. stricta Good.-C. caespitosa Gay.

Districts I. II. III. IV. V. VI. VII. VIII. IX. X. XI. XII. Lat. $52^{\circ}-55 \frac{1}{4}^{\circ}$. Throughout Ireland. Type, English-Intermediate.

Lowland. Marshes, ditches, and lake margins; frequent. Fl. May-June.

\section{C. acuta Linn.-Slender-spiked Sedge.}

Districts I. II. - - V. VI. - - - X. - XII. Lat. $52^{\circ}-54 \frac{3}{4}^{\circ}$. From South to North. Type, British-English.

Lowland. Sides of rivers and lakes; local. Fl. May-June.

I. Killarney (Babington): Cyb. Near the mouth of the Flesk river, Lower Lake, Killarney: R.W. S. $1889 .-$ II. Youghal Bog, 1896 ; Phillips \&R.W.S.-V. Banks of the canal at Rathangan, Kildare; by the Boyne near Drogheda (Moore): Cyb. In the Boyne 
at Beaupark and Navan, Meath : Praeger 1897.-VI. Banks of the Shannon and on the shores of Lough Derg, Galway (Moore): Cyb.X. By Lough Neagh at Raughlin, Armagh (Rev. H. W. Lett): Praeger 1893. Killykeen, Lough Oughter, Cavan: Praeger 1897.-XII. By the side of the Lagan above Dromore 1803: Templeton MS. Marshy meadows near Toome-bridge, Derry; by the river near Randalstown and shores of Lough Neagh, Antrim (Moore): Cyb. Abundant in marshes at the south side of Portmore Lake; Lough Neagh north of Lurgan, \&e. (Stewart); rather rare in the North-East: Flor. N.-E.

Var. Mrror Led.-C. tricostata (Fries)-X. Margin of the lake at Loughgall, Co. Armagh, 1877 (Stewart): Nyman Conspec. Supp. ii. 1890 .

\section{C. trinervis Degl.—Three-nerved Sedge.}

Districts

Lat. $53^{\circ} 20^{\prime}$. County Galway only.

Moist ground by the sea; very rare. Fl. July.

VIII. Damp part of an extensive seaside field near Roundstone, Galway (Rev. E. F. Linton): Journ. of Bot.1888, p. 56 .

A critical plant scarcely deserving of specific rank, which seems to have occurred very sparingly in its only known Irish locality.

\section{C. rigida Good.-Stiff Mountain Sedge.}

Districts I. II. III. IV. - - - VIII. IX. X. XI. XII. Lat. $51 \frac{3}{4}^{\circ}-55 \frac{1}{4}^{\circ}$. From South to North. Type, Highland.

Wet and stony places on mountains; local. Fr. June-July.

I. Mangerton and other high mountains in Kerry : Mack. Rar. On Carrantuohill, Kerry: Flor. Hib. On the top of Brandon mountain, Kerry (Moore) : Cyb. Common on the higher mountains of Kerry; R.W.S. Adrigole mountain, Cork, 1894; Phillips.II. Common on the Galtee mountains, Tipperary : Mack. Rar. On Knockmealdown mountains, rare; abundant on the Commeraghs above Stilloge and Coumshingan Lakes; and-III. On Mount Leinster and Blackstairs mountain: Hart r884.-IV. Top of Lugnaquilla, Wicklow (More): Ree. Add.-VIII. On Nephin, Mayo: Flor. Olst. On all the higher Mayo mountains, Mweelrea, Corslieve, \&c, except Croaghpatrick: Hart 1883 a.-IX. Summits of Ben Bulben and Truskmore: B.\&V. I885.-X. Dart mountain and Mullaghclogha, Tyrone: Hart r884. - XI. On Bulben, 
Ennisowen (Mr. Browne): Wade Rar. Common on Bulbein mountain, Inishowen: Hart 1883 . On Muckish and on Errigal : Flor. Ulst. Alt mountain near Ardara; Slieve Atooey; Aghla, above Lough Finn: Hart 1886.-XII. On the top of Lag-nageragh, Co. Derry (Mr. Brown): Templeton MS. Sawel mountain, Derry : Hart 1884 .

From 1000 to $2400 \mathrm{ft}$. in Donegal, $2500-2950 \mathrm{ft}$. in Wicklow, and 1600-2600 ft. in Mayo (Hart). From 2000 to $3300 \mathrm{ft}$. in Kerry (Hart \& Druce I80 1 ).

First found in Ireland by Robert Brown not later than 1800 .

\section{C. aquatilis Wahl.-Water Sedge.}

Districts I. - - - V. - VIII. IX. X. XI. XII. Lat. $52^{\circ}-55^{\circ}$. From South to North. Type, Highland.

Lowland. Margins of lakes and rivers; rather rare. Fl. JuneJuly.

I. Banks of a small stream near the head of Caragh Lake; and : stream near the head of Upper Lake, Killarney : R.W. S. I 889 \& I890.- V. In the river Blackwater, Co. Meath, near the Cavan boundary; and-X. Plentiful in the same river in Co. Cavan, between Lough Ramor and the Meath boundary: Praeger 1897. Banks of the river Finn near Strabane, Tyrone (Miss $M$. C. Knowles): Ir. Nat. 1897.

Var. elation Bab.-Var. Watsoni Syme.-VIIII. Plentiful for twenty or thirty yards by the Maam river, Galway, above the bridge: $M$. \& S. $I 896$.- IX. In a wet thicket on the margin of Lough Allen, on the Roscommon side of the old Shannon bridge at Ballantra: Stewart $1885 \&$ Bennett I892.-XI. By the river Finn : Hart $1885 \gamma$ \& Bennett 1892 . By the river Eske; Hart.XII. By the river Main in Shane's Castle Park (Praeger): Ir. Nat. I892, pp. $4 I \& 49$.

Var. viRescens Anders.-XI. At Doochary Bridge, Donegal, 1886 (Hart): Bennett 7892.

C. hibernica Ar. Bennett-C. aquatilis $\times$ Hudsonii (?)-I. Galway's river, old Kenmare road, Kerry, 1889 (R.W.S.): Journ. of Bot. $1897, p$. 25o, where $\mathrm{Mr}$. Arthur Bennett describes and names the plant, suggesting for it the above hybrid origin.

First found in Ireland (Var. ELATIOR) by S. A. Stewart at Lough Allen, in 1884. 


\section{C. vulgaris Fries-Lesser Tufted Sedge.}

C. Goodenowii J. Gay-C. cespitosa Good.

Districts I. II. III. IV, V. VI. VII. VIII. IX. X. XI. XII. Lat. $51 \frac{1}{2}^{\circ}-55_{\frac{1}{4}}^{\circ}$. Throughout Ireland. Type, British.

Marshy and boggy places; common. Fl. May-June.

Sea-level in N. Derry and S. Cork. To $1450 \mathrm{ft}$. in Down, and to. $2000 \mathrm{ft}$. in Galway (Hart); to $1800 \mathrm{ft}$. in Wicklow (N. C.); to $2500 \mathrm{ft}$. in Tipperary (Hart).

Var. JoNCELLA T. Mr. Fries-I. Near the head of the Upper Lake, Killarney; by Lough Camclaun, Connor Hill, Kerry: R.W. S. I890 \& I89I. Ballyphehane Bog, Cork, 1896 ; Phillips.IV. By the Slaney at Macmine Junction, Wexford: Marshall r898.-VII. Bog of Lynn, Knock Drin, Westmeath: Linton I806.-VIII. Lisoughter near Recess, Galway (Rev. S. A. Brenan): Ir. Nat. 1896.-IX. Swamp opposite Ashford House, Cong: M. \& S. 1896.-XII. Ballintoy, Antrim (Rev. S. A. Brenan): Ir. Nat. 1896 .

\section{C. glauca Scop.-Glaucous Heath-Sedge.}

C. Aacoa Schreb.-C. recurva Huds.

Districts I. II. III. IV. V. VI. VII. VIII. IX. X. XI. XII. Lat. $51 \frac{1}{2}^{\circ}-55 \frac{1}{4}^{\circ}$. Throughout Ireland. Type, British.

Pastures, banks, \&c. in rather dry soil; common. Fl. MayJune. Caleicole $B$.

Sea-level in N. Antrim and S. Cork. To $2000 \mathrm{ft}$. in Ben Bulben. district $\left(B . \& V_{0}\right)$; to $2500 \mathrm{ft}$. in Down (S.\&P.).

Var. stictocaRPa (Smith)-IX. On the north face of Ben Bulben, Sligo: B.\& V. 8885 .

\section{C. limosa Linn.-Drooping Bog-Sedge.}

Districts I. II. - - V. VI. VII. VIII. IX. X. XI, XII. Lat. 511을 $-53 \frac{1}{4}^{\circ}$. From South to North. Type, Scottish.

Wet bogs; rather rare. Fl. June,

I. Widely distributed in county Kerry; R.W. S. Plentiful in bogs between Schull and Ballydehob, Cork, 1896; Phillips. Base of Sugar Loaf mountain, Glengariff ; and-II. Bluefort Bog, Newmarket, Cork: Allin $187 x$.-V. Two miles south of Thomastown, Kildare; in bogs near Carbury and between Athboy and Navan, Meath: Praeger 1897.-VI. Monmore bog, Clare; and bog near. 
Woodford, Galway (Moore): Cyb. Near Crusheen, Clare: Corry 1880. Bog drains at Ballycar, Clare: Stewart I890.-VII. Near Belvedere Lake, Westmeath (Moore) : Cyb. Lisclogher Bog, Westmeath; More. Scraw bog, Loughanstown, Westmeath: Levinge I894.-VIII. On the west side of Lough Corrib: Graham I840. Near Bangor in Erris, Mayo (Moore): Cyb. About the base of Nephin; Mweelrea; and the Twelve Bens in many places: Hart 1883 a. West side of Lough Mask, $1891 ;$ R.P. Vowell. Abundant about Recess, W. Galway: P.\& C. I895.-IX. Bog near Hollymount, Mayo (More): Cyb. Lough Gara, Sligo; Praeger.X. Margin of Lough Ouske, Sperrin Monntains (Praeger): Journ. of Bot. 1892.-XI. Near Killybegs (More): Cyb. Near Ballyshannon; between Glen and Carrick: Hart $1885 \%$-XII. Ballygowan bog near the middle, and in Donaghadee bog, 1804 (Templeton) : Whitla MS. Bog near Saintfield: Flor. Hib: Between Fair Head and Murlough Bay; on the large flow-bog at Rasharkin, Antrim (Moore): Cyb. On the margin of Lough Naroon; still frequent on bogs above Rasharkin; bogs east of Killagan railway station: S. \& P. 1895. Plentiful in a wet marsh on Saul camp ground at Downpatrick (Praeger): B.N.F.C.Proc. I892-93.

Rather frequent in the West; rare in the North and East.

\section{C. pilulifera Linn.-Round-headed Sedge.}

Districts I. II. III. IV. V. VI. VII. VIII. IX, X. XI. XII. Lat. $51 \frac{1}{2}^{\circ}-55 \frac{10}{4}$. Throughout Ireland. Type, British.

Heaths and moors, chiefly in mountain districts ; frequent. Fl. May. Calcifuge $A$.

Sea-level in Down and Kerry. To $2200 \mathrm{ft}$. in Donegal (Hart); to $2796 \mathrm{ft}$. in Down (Flor. Olst.); to $3120 \mathrm{ft}$. in Kerry (Hart).

Var. LeesI Ridley-I. On Carrantuohill: Druce I89I.

30. C. præcox Jacq.-Spring Sedge.

C. verna Chaix.

Districts I. II. III. IV. V. VI. VII. VIII. IX. X. XI. XII. Lat. 51 $\frac{1}{2}^{\circ}-55 \frac{1}{4}^{\circ}$. Throughout Ireland. Type, British.

Heaths and dry pastures; frequent and locally abundant. Fl. April-May.

Sea-level in Derry and in S. Cork, To $1280 \mathrm{ft}$. in Donegal, and to $1500 \mathrm{ft}$. in Tipperary (Hart). 


\section{C. pallescens Linn.-Pale Sedge.}

Districts I. II. III. IV. - VI. - VIII. IX. X. XI. XII. Lat. $51 \frac{1}{2}^{\circ}-55 \frac{1}{4}$. From South to North. Type, British.

Heaths, thickets, and moist pastures, chiefly in mountain districts; not infrequent. $F l$. June-July.

I., II., X., and XII. Rather frequent, occurring in many stations in Kerry, Cork, Monaghan, Armagh, Fermanagh, Cavan, Antrim, Down, and Derry.-III. Right bank of the Barrow above Tinnehinch Bridge, near Mountmellick, Queen's Co. : Hart I885.IV. Near the Seven Churches, Glendalough (Moore): Cyb. Annamoe river near Annamoe, Wicklow, 1884 ; Hart.-VI. Dromore near Ennis, Clare: Corry I 880.-Gleninagh, Clare; and-VIII. Carn Seefin, Lough Corrib, Galway: P.\& C. 1805 . Twelve Bens, Galway; Mweelrea and Delphi, Mayo: Hart 1883 a.-IX. Near Foxford, Mayo (Moore): Cyb. Near Dromod, Leitrim (W.T.Dyer): Rec. Add.-XI. On a hill near Killybegs (More): Cyb. Near Eske river : Corry 1882. Lough Columbkill near Milford: Hart 1880. At Ardnamona : Hart $1885 \%$.

To $1200 \mathrm{ft}$. in Cavan (Stewart) and in Kerry (R. W. S.).

\section{C. panicea Linn.-Pink Sedge.}

Districts I. II. III. IV. V. VI. VII. VIII. IX. X. XI. XII. Lat. $51 \frac{1}{2}^{\circ}-55 \frac{1}{4}^{\circ}$. Throughout Ireland. Type, British.

Bogs and marshy places; common. Fl. May-June.

Sea-level in N. Derry and S. Cork. To $1160 \mathrm{ft}$. in Donegal (Hart); to $1700 \mathrm{ft}$. in Ben Bulben district (B.\& V.); to $2400 \mathrm{ft}$. in Mayo, and to $2550 \mathrm{ft}$. in Kerry (Hart).

\section{C. pendula Huds.-Great pendulous Sedge.}

Districts I. II. III. "IV. V. VI. VII. - IX. X. XI. XII. Lat. $51 \frac{1}{2}^{\circ}-55^{\circ}$. Throughout Ireland, probably. Type, BritishEnglish.

Lowland. Moist woods, and by river and ditch banks; rather rare. Fl. May-June.

I. II. IV. and V. Frequent, occurring in many stations in Kerry, Cork, Waterford, Wicklow, Wexford, and Dublin.-III. Woodstock by the edge of the Nore; thickets opposite St. Mullins above New Ross on the banks of the Barrow: Hart $1885 \delta \&$ 1885VI. Lisdoonvarna, Clare: Corvy 3880 . Chery Chace, Galway: 
Hart I873.-VII. Clonad wood, King's Co., 1896; Praeger.IX. Hazelwood, Lough Gill, Sligo; and woods above the south shore of Glencar Lake, Leitrim, 1896; N.C.-X. Near Swanlinbar, Cavan: Mack. Rar. Marble Arch, Co. Fermanagh : Stewart I882. Favour Royal, Tyrone: Hart 1887.-XI. By the river Eske above Donegal; and by the Eanymore water above Inver : Hart I885 $\gamma$ XII. Near Glenarm and Colin glen, Antrim (Moore): Cyb. Woodburn glen: S.\& P. 1895 . Glenariff, Antrim: Shoolbred 1894. Grounds of Montalto at Ballinahinch (Stewart): Flor. N.-E.

Frequently planted for ornament in parks and woods, and no doubt introduced in many of its Irish stations.

\section{C. strigosa Huds.-Loose-flowered Sedge.}

Districts I. II. III. IV. V. - - - IX. X, XI. XII. Lat. 52 $\frac{1}{4}^{\circ}-55^{\circ}$. From South to North. Type, English.

Lowland. Hedge banks and moist woods; rare. Fl. May-June.

I. Very abundant at Ballyseedy, and sparingly at Chute Hall, Kerry : $R . W . S .2889$. North side of the river near Listowel, Kerry: R.W.S. 1891. -II. Dreenagh wood in Doneraile Park (C. Longfield): Allin's Cork.-III. In Sir Robert Staple's demesne, Queen's Co.: Mack. Rar.-IV. In the Dargle: Wade Rar. Plentiful about a mile north of Courtown, Wexford: Marshall $1898 .-\mathrm{V}$. In Luttrellstown wood [Woodlands]: Wade Rar. In hedges near Drimnagh; and near Kilsallaghan, Co. Dublin: N. C. I893.IX. Roadside at the west end of Glencar, Sligo: B.\&V. I885.X. In several places about Favour Royal, Tyrone: Hart 1887. Airdmore, Armagh (Rev. H. W. Lett) : Praeger 1803.-XI. Abundant at the Hall, Mount Charles; by the Erne, on an island opposite Cliff : Hart 2885 \% \& I886.-XII. Colin glen; on the Knockagh; Woodburn glen; Crawford's burn; near Shane's Castle; at Glenarm: Flor. Ulst. Belvoir Park, Antrim: B.N.F.C. Proc. 1870. By the Lagan canal at the lower side of Drumbridge (Stewart): Flor. N.-E. Near Muckamore, Antrim : Ir. Nat. I893, p. 197.

\section{C. sylvatica Huds.-Wood Sedge.}

Districts I. II. III. IV. V. VI. VII. VIII. IX. X. XI. XII. Lat. $51_{\frac{1}{2}}^{\circ}-55 \frac{1}{4}^{\circ} \quad$ Throughout Ireland. Type, British-English.

Woods and hedges; frequent. Fl. May-June.

Sea-level in N. Derry and S. Cork. To $1850 \mathrm{ft}$. in Ben Bulben $\operatorname{district}\left(B . \& P_{\text {. }}\right)$. 


\section{C. lævigata Smith-Smooth Sedge.}

Districts I. II. III. IV. V. VI. VII. VIII. IX, X. XI. XII. Lat. $51 \frac{1}{2}^{\circ}-554^{\circ}$. Throughout Ireland. Type, British-English.

Marshy woods, and in hedgerows and wet bogs; rather frequent. Fl. June.

I. and II. Frequent, occurring in many stations in Kerry, Cork, and Waterford.-III. North-east base of Mount Leinster, Carlow : Hart I884. By the Barrow below Borris: Hart 1885. Ryland's wood near Newtownbarry, Carlow (R. Clayton Brown): Rec. Add.IV. In Glencree : Ball I839-and in $1896 ; R$.W. S.-V. Kelly's Glen, Dublin (Moore) : Cyb. On Kilmashogue mountain, Dublin : N. C. 1895.-VI. Lisdoonvarna, Clare: Corry 1880 . Chery Chace, Co. Galway : Hart 1873.-VII. Clonad wood, near Tullamore, King's Co.: Praeger 7897 --VIII. In Drumman wood, Lough Cullin, Mayo (More): Cyb. Between Clonbur and Mt. Gable, Galway : M. \& S. I896.-IX. Near Foxford, Mayo (More): Cyb. Woods near the base of Ben Bulben; and near Kinlough: B. \& V. 1885 -X. Crum Castle, Lough Erne, rare: Barrington 1884. Common in Favour Royal woods, Tyrone: Hart 1887.XI. Near Killybegs (More): Cyb. At Leatbeg, Fanet: Hart 1879. Abundant in woods about Lough Eske Castle: Hart I885 $\gamma$.-XII. In the wood at Belvoir, Down, 1814: Templeton MS. Near Ballycastle, Antrim (Moore): Cyb. By the Quoile at Downpatrick; and very luxuriant by the Spinkwee river, Tollymore Park (Stewart) : Flor. N.-E. Bond's Glen, parish of Upper Cumber, Derry: Moore MS. Dungiven, Derry (Mrs. Leebody): S. \&P. $x 895$.

Sea-level in N. Derry and S. Cork. To $750 \mathrm{ft}$. in Dublin $(N . C$.$) ; but usually lowland.$

\section{C. binervis Smith-Green-ribbed Sedge.}

Districts I. II. III. IV. V. VI. VII. VIII. IX. X. XI. XII.

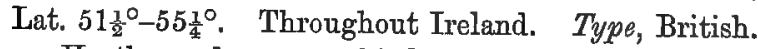

Heaths and moors, chiefly in mountain districts; frequent. Fl. May-June. Calcifuge $A$.

Sea-level in Derry and in S. Cork. To $2000 \mathrm{ft}$. in Donegal (Hart); to $2390 \mathrm{ft}$. in Down (S. \& P.); to $2680 \mathrm{ft}$. in Mayo (Hart); to $2750 \mathrm{ft}$. in Wicklow (N. C.). 
38. C. distans Linn.-Distant-Spited Sedge.

Districts I. II. - IV. V. VI. - VIII. IX. X. XI. XII. Lat. $51 \frac{1}{2}^{\circ}-551^{\circ}$. Coasts of all Ireland. Type, British.

Salt marshes and moist rocky or stony ground by the sea; frequent. Fl. May-June.

\section{C. punctata Gaud.-Dotted Sedge.}

C. diluta Bieb.

Districts I.

Lat. $51 \frac{1}{2}^{\circ}-52 \frac{1}{4}^{\circ}$. South-West, Kerry and Cork only.

Sea cliffs, marshy ground, and damp stony places, by the sea; locally abundant. Fl. June.

I. Near the mouth of Dingle Harbour, Kerry (D. Oliver): Phytol. $1853, p$. 1095. At Sneem, Kerry ( $J$. Woods): Cyb. On wet rocky ledges, Kerry Head; sparingly near Hog's Head, Waterville; and very abundant about Derrynane and along Kenmare Bay; base of cliffs east side of Ventry Harbour: R.W.S. I 889, I800 \& I80I. Shore at Glengariff, sparingly; in greater quantity near Dunboy, Berehaven, Cork, 1853 : Carroll 1854. Plentiful in boggy or marshy meadows near Ardgroom at some little distance from the sea (More): Rec. Add. Shore of Oysterhaven inlet; by the Bandon river below Kilgobbin; at Toe Head; Lough Hyne; near the entrance to Glandore harbour; near Myros wood: Allin's Cork. Near Kinsale, 1892 ; at Adrigole, 1894; and at Ballydehob, 1896 ; Phillips. At Glandore, 1896 ; J. Groves.

First found by Daniel Oliver, at Dingle, in 1853.

\section{C. Hornschuchiana Hoppe-Tawny Sedge.}

C. speriostachya Smith.

Districts I. II. III. IV. V. VI. VII. VIII. IX. X. XI. XII. Lat. $51 \frac{3}{4}^{\circ}-55 \frac{1}{4}^{\circ}$. Throughout Ireland. Type, British.

Boggy and heathy ground, chiefly in mountain districts; frequent. Fl. May-June.

Sea-level in Derry and in Kerry. To $1700 \mathrm{ft}$. in Down (S.\&P.); to $1800 \mathrm{ft}$. in Kerry (Druee $189 \mathrm{I}$ ).

\section{C. extensa Good.-Bracteated Sea-Sedge.}

Districts I. II. III. IV. V. VI. - VIII. - - XI. XII. Lat. $51 \frac{1}{2}^{\circ}-55 x_{4}^{\circ}$. Coasts of all Ireland, probably. Type, British.

Salt marshes; frequent. Fl. June. 


\section{C. flava Linn.-Yellow Sedge.}

Districts I. II. III. IV. V. VI: VII. VIII. IX. X. XI. XII.

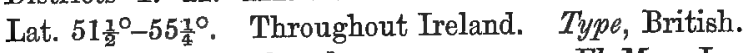

Boggy and marshy places; common. Fl. May-June.

Sea-level in N. Derry and S. Cork. To $1800 \mathrm{ft}$. in Donegal and to $2050 \mathrm{ft}$. in Mayo (Hart); to $2350 \mathrm{ft}$. in Wicklow ( $N . C$. ); to. $2650 \mathrm{ft}$. in Kerry (\#art).

The Irish plant is usually $V$ ar. LEPIDOCARPA $($ Tausch $)=\nabla a r$. ELATIOR Schlecht.

Var. CYPEROIDES Marsson-(C. Edderi Auct.)(?)-Though perhaps. rarer than $V$ ar. LEPIDOCARPA, this has been recorded for Districts. I., IV., V., VI., VII., VIII., IX., X. and XII. and probably occurs throughout Ireland.

C. xanthocarpa Degl.-C. Alava $\times$ Hornschuchiana (?)-I. At Gouganebarra and at Lough Allua, 1897; Phillips.

\section{C. filiformis Linn.-Slender-leaved Sedge.}

Districts I. - III. - V. VI. VII. VIII. IX. X. XI. [XII.] Lat. $51_{2}^{1}-54_{4}^{30}$. From South to North. Type, Scottish-British.

Lowland. Ditches in peat bogs, and lake and river margins; rather rare. $F l$. May-June.

I. At the south end of Upper Lake, Killarney, and abundant round a small lake near it; abundant near the railway where it crosses the river Brick near Lixnaw, Kerry: R.W. S. I89o $\$ I 80 I$. Ballyphehane bog, Cork: Drummond 1820 . Abundant in a lake at the head of Glengariff: Allin $187 \pi$. Lake near Sheep's Head: Allin's Cork. By Lough Allua, 1897; Phillips.-III. Marsh near Maryborough, Queen's Co.: Praeger $1897 .-\mathrm{V}$. Bog between Navan and Drogheda in Meath (Moore) : Cyb.-VI. Monmore Bog, Clare; and bog ditches near Portumna and near Lough Derg (Moore): Cyb. Near Boonaveen Point, Lough Derg, and abundant by the Shannon near Portumna: N. C. 1897.-VII. Bog at Ladiston, Mullingar (Moore): $C y b$. East shore of Lough Ree, by the inner lough and plentiful on Temple island, Westmeath; and at Rathcline, Longford: $B . \& V .{ }_{1} 887$. Scraw bog, Loughanstown, Westmeath, locally plentiful : Levinge I894.-VIII. On the west side of Lough Corrib.: Graham 2840 . Near Woodstock, four miles from Galway, 1838 : Mack. App. to Fraser. Near Lough Cregduff, Roundstone; More. About the base of Mweelrea and Nephin; and by the Erriff 
river in Mayo: Hart 1883 a. Oughterard, Galway (Miss M. C. Knowles ): P.\&C. 1895 . Lakes near Cloonacartan Recess, 1897; N. C. Between Maam and Lough Corrib, Galway; and-IX. Near Cong, Mayo : M. \& S. I896. Near Hollymount, Mayo (More) : Cyb. Lough Key, Roscommon ; Praeger.-X. In lakes on the west margin of Fermanagh: Hart $1885 \%$-XI. Bog near Killybegs (More): $C y b$. Lough Eske; Lough Unshin; Lough Golagh, and other lakes in south-west Donegal : Bart I $885 \%$. Lake near Cliff; and stream from Sheskinmore Lake north-west of Ardara: Hart 1886.XII. At Selshan near Deer Park, side of Lough Neagh, 1832: Herb. Moore-perhaps extinct now through drainage: S. \& P. 1895 . Not infrequent in the West, rare in the East and North-East.

\section{C. hirta Linn.-Hairy Sedge.}

Districts I. II. III. IV. V. VI. VII. VIII. IX. X. XI. XII. Lat. $52^{\circ}-551^{\circ}$. Throughout Ireland. Type, British-English.

Wet pastures and marshy places ; frequent. Fl. May-June.

To $800 \mathrm{ft}$. in Dublin (N. C.); but usually lowland.

\section{C. Pseudo-cyperus Linn.-Cyperus-like Sedge.}

Districts I. II. III. IV. V. VI. VII. VIII. IX. X. - XII. Lat. $52^{\circ}-541^{\circ}$. Throughout Ireland, almost. Type, English.

Lowland. Marshy and watery places; widespread but rare. Fl. June.

I. Marshy ground near the Lee, Cork: Drummond 1820 . Between Ballyphehane bog and Douglas: Flor. Cork. Near Ballincollig, 1894; Phillips.-II. Inchacummawn bog, Blarney: Flor. Cork. Ballycotton (Carroll): Cyb. Dunsfort Bog, Midleton (Rev. T. Allin): Ree. Add. Sparingly in a bog near Youghal, 1896 ; Phillips \& R. W. S.-III. Marsh in Sir Robert Staples woods [Dunmore], Queen's Co.: Mack. Rar. By the canal at Mountmellick, Queen's Co.. Praeger 1897.-TV. At the old Dargle, Wicklow : Wade Rar. Marshes near Newcastle, Wicklow (More): Rec. Add.-V. Brackenstown wood; and at Curragha, Dublin: Wade Rar. Bog drains by the canal three miles east of Enfield: Praeger 1897.-VI. At Plassy near Limerick (Carroll): Cyb. Dromoland demesne, Newmarket, Clare: Corry I880. Abundant at Ballycar and Ennis, Clare: Stewart 1890. Shores of Lough Derg at Rinmaher, Galway; and-VII. At Slevoir Point, and Gortmore, Tipperary: N. C. 1897. At Shannon Harbour near 
Portumna (Moore): Cyb. Ballymackeogh bog near Newport, Tipperary : Hart I88I $\gamma$ - -VIII. By the railway between Galway and Moycullen: M. \& S. $2896 .-$ IX. Near Ballybay, Lough Ree, Roscommon: B.\&V. $1887 .-\mathrm{X}$. Abundant in bogs near Belturbet, Cavan (Moore): Cyb. Derrywhinny bog and Farnham lake, Cavan: Ir. Nat. I896, p. zq6. Tartaraghan Glebe; and near Lurgan, Armagh (Rev. G. Robinson) : Praeger 1893.-XII. Sides of drains in the Bog meadows, 1797 (Templeton): Whitla MS.a very few plants still there in 1886 (Praeger): Flor. N.-E.

\section{C. paludosa Good.-Lesser Bank-Sedge.}

C. acutiformis Ehrh.

Districts I. II. III. IV. V. VI. VII. - IX. X. - XII. Lat. $51 \frac{3}{4}^{\circ}-55 \frac{1}{4}^{\circ}$. From South to North. Type, British.

Lowland. Banks of rivers and lakes, ditches, and marshy places; rather frequent. Fl. May-June.

I. Gearagh, near Macroom 1897; Phillips. Near Dunmanway; and-II. Dunfort Bog, Midleton, Cork : Allin I87x. Clonea near Dungarvan, Waterford; and Cloon bridge above Thurles by the Suir, Tipperary : Hart 2885 a.-III. Marshes in Sir Robt. Staples' woods [Dunmore], Queen's Co.: Mack Rar. By the Slaney in several places between Coolmoney and Tullow, Carlow; Hart. By the Nore below Abbeyleix and near Ballyragget : Hart $I 885 \delta$. By the Barrow below Athy, in Queen's Co. ; R.W. S.-IV. Marshes near the Murrough of Wicklow (More): Rec. Add. By the Slaney between Scarawalsh bridge and Enniscorthy; Ballymader on the Wexford coast; Hart.-V. Banks of the Grand Canal in Dublin and Kildare, plentiful (Moore): Cyb. By the Tolka river above Blanchardstown, and ditches near Drimnagh, 1893 ; by the Ward river at Knocksedan, 1894; at Lucan, 1897, \&c.; frequent in Co. Dublin; N. C.-VI. Near Ennis, Clare: Corry 1880.VII. Bog near Multyfarnham, Westmeath (More): Rec. Add. Donore; Derevaragh Lake; and Quarry Bog, Westmeath : Levinge 1894. Upper reaches of the Suir and by the Barrow in several places: Hart $I 88 I$ a and 7885 (as C. acuta).-IX. Marsh near Diffreen river, Glencar, Leitrim: $N . C$. 1896. Lough Key, Roscommon; Praeger.-X. Side of the lake at Loughgall manor, Armagh: More 1860. Tynan Abbey demesne; marsh a mile north-east of Loughgall, Armagh: Praeger r893.--XII. Side of the river Bann below Coleraine: Herb. Moore. Extremely rare in north-east Ireland: Flor. N.-E. 


\section{C. riparia Curtis-Greater Bank-Sedge.}

Districts I. II. III. IV. V. VI. VII. - - X. XI. XII. Lat. $51 \frac{1}{2}^{\circ}-55 \frac{1}{4}^{\circ}$. From South to North. Type, British-English.

Lowland. Banks of ditches, rivers, and lakes; rather rare. Fl. May.

I. At Muckross; near Tralee, \&c.; widespread in Kerry: R.W. S. $1889 \&$ I89I. Ballyphehane Bog, Cork : Drummond I8zo. Near Gurrane lake, Dunmanway: Allin's Cork. Kilkerrin lake near Castlefreke, $1896 ; R . W$. S.-II. Shanagarry bog, Ballycotton (Carroll): Cyb. Carbanagh lake near Millstreet: Allin's Cork. Bog near Youghal, $1896 ;$ R.W.S. By the Blackwater below Williamstown: Hart I885 $\delta$. By the Suir between Thurles and Turtulla hill : Hart 1885 a.-III. By the Barrow below St. Mullins; by the Nore between Woodstock and New Ross : Hart $1885 \& 1885 \delta$. At Maryborough ; Praeger.-IV. Ditches on the Murrough of Wicklow (Moore): Cyb. By the Slaney below Enniscorthy; Morris Castle, coast of Wexford : Hart I 881 a.-V. Ditches near the shore at Donabate, Co. Dublin (Moore) : Cyb. Abundant at Donabate and Turvey, 1893; at Dunsoghly Castle and by the Ward river at Coolatrath, 1894; at Baldoyle, 1892, and other stations in Co. Dublin; N.C. Willowbrook near Ballitore, Kildare (Carroll): Cyb.-VI. Headford, Galway (R. J. Shuttleworth): Cyb. Ennis and Ballycar, Clare; and Rinekirk, Limerick, frequent: Stewart I890.-VII. Near Portumna (Moore) : Rec. Add. Knockane bridge above Thurles by the Suir: Hart 1885 a. Drain by the Inny below Ballymahon, Longford: B.\& V. I887.-X. Banks of the river Finn in Tyrone (Admiral Jones) : Cyb.-XI. At St. John's Point; and near Carrickfad, S. Donegal : Hart I 885 \%.-XII. Shores of Lough Neagh, and by the Carrickfergus road near Whitehouse, Antrim, 1804; in a lake two miles south-east of Kilmore, Down, 1810: Templeton MS. Portmore Lough, Antrim (Moore): Cyb. and S. \& P. I895. By the Six-Mile river near Templepatrick (Stewart): Cyb. Abundant in several spots by the Bann, Co. Derry, between Coleraine and the sea: $S . \& P .1895$.

\section{C. ampullacea Good.-Bottle Sedge.}

C. rostrata Stokes.

Districts I. II. III. IV. V. VI. VII. VIII. IX. X. XI. XII. Lat. $51 \frac{1}{2}^{\circ}-55 \frac{1}{4}^{\circ}$. Throughout Ireland. Type, British.

Ditches, lake-margins, bogs, \&c. ; frequent. $F l$. May-June. 
Sea-level in N. Antrim and S. Cork. To $1500 \mathrm{ft}$. in Donegal and in Tipperary (Hart); to $2050 \mathrm{ft}$. in Wicklow (N.C.).

\section{C. rhynchophysa C. A. Meyer.}

C. ampullacea var. robusta Weinmann.

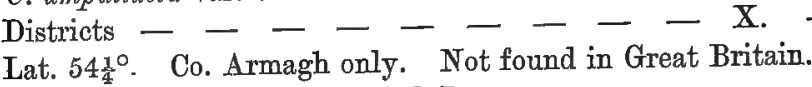

Bog drains; very rare. $F l$. June.

$\mathrm{X}$. In a deep drain communicating with Mullaghmore Lake, Co. Armagh, 1892 (Praeger) : Journ. of Bot. 1893, p. 33.

A plant of Northern Europe first discovered in the British Isles. by R. Ll. Praeger in 1892.

\section{C. vesicaria Linn.-Bladder Sedge.}

Districts I. II. III. IV. V. VI. VII. VIII. IX. X. XI. XII. Lat. 52 $2^{\circ}-55 \frac{1}{4}^{\circ}$. Throughout Ireland. Type, British-English.

Lowland. Boggy and watery places, sides of rivers and lakes; not infrequent. Fl. May-June.

I. Killarney Lakes (Moore) : Cyb.\& $R . W . S$. 1888. Frequent about Killarney; R. W. S. Ballyphehane bog: Mack. Rar.II. Frequent near Doneraile and Buttevant (Carroll); near Midleton and Mallow: Allin's Cork. By the Suir in many places, as at Thurles, Aughakillen, \&c. : Hart 1885 a. By the Blackwater above Lismore: Hart 1885 8.-III. Near Cullenagh, Queen's Co. : Maok. Rar. Frequent by the Barrow in Queen's Co. and Carlow (Moore) : Cyb. \& Hart 1885.-IV. By the Slaney between Enniscorthy and Edermine, Wexford: Hart I88Ia. By the river below Lough Dan and by the coast between Wicklow and Arklow ; Hart.V. Glack Bog, near Castlebellingham, Louth; Cecil Butler. By the Black river near Monasterevan, Kildare : Hart 1885 - - VI. Rinekirk, Limerick: Stewart 1890. Castletown and Carran, Clare; P. $B$. O'Kelly. On the shore of Lough Derg near Portumna (Moore) : Cyb.-and in $1896 ; N . C .-$ VII. By the Suir at Knock-

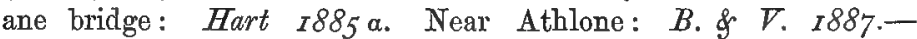
VIII. Banks of the Moy near Foxford, Mayo; and-IX. River below Hollymount, Mayo (More): Cyb. Near Dromod, Leitrim (W. T. Dyer): Rec. Add. Frequent at the south end of Lough Allen: Stewart $1885 .-\mathrm{X}$. and XII. Not infrequent, occurring in many stations in Fermanagh, Cavan, Armagh, Monaghan, Tyrone, 
Antrim, Down, and Derry.-XI. By the Erne below Belleek: Hart ${ }_{1} 885 \gamma$. By the Lennan river out of Lough Fern; Hart.

ORDER LXXVII.-GRAMINE曆.

\section{PHALARIS Linn.}

1. P. arundinacea Linn.-Reed Grass.

Baldinghera arundinacea Dum.-Digraphis arundinacea Trin.

Districts I. II. III. IV. V. VI. VII. VIII. IX. X. XI. XII. Lat. $51 \frac{1}{2}^{\circ}-55 \frac{1}{4}^{\circ}$. Throughout Ireland. Type, British.

Ditches, riversides, \&c. ; locally abundant. Fl. June-July.

To $700 \mathrm{ft}$. in Dublin (N.C.); but usually lowland.

\section{ANTHOXANTHUM Linn.}

1. A. odoratum Linn.-Dernal Grass.

-Districts I. II. III. IV. V. VI. VII. VIII. IX, X. XI. XII. Lat. $51 \frac{1}{2}^{\circ}-55 \frac{1}{4}^{\circ}$. Throughout Ireland. Type, British.

Pastures, heaths, and woods; common. Fl. May-June.

Sea-level in N. Antrim and S. Cork. To $2390 \mathrm{ft}$. in Down (S. $\&$ P.) ; to $2680 \mathrm{ft}$. in Mayo, and to $3030 \mathrm{ft}$. in Kerry (Hart).

\section{ALOPECURUS Linn.}

1. A. geniculatus Linn.-Floating Fox-tail.

Districts I. II. III. IV. V. VI. VII. VIII. IX. X. XI. XII. Lat $511_{\frac{1}{2}}^{\circ}-55 \frac{1}{4}$. Throughout Ireland. Type, British.

Ditches and marshy places; frequent. Fl. June-July.

Sea-level in Derry and in Cork. To $1150 \mathrm{ft}$. in Dublin ( $N . C$.).

\section{A. pratensis Linn.-Deadow Fox-tail.}

Districts I. II. III. IV. V. VI. VII. VIII. IX. X, XI. XII. Lat. $51 \frac{1}{2}^{\circ}-55 \frac{1}{4}^{\circ}$. Throughout Ireland. Type, British.

Moist meadows; frequent and locally abundant. Fl. May-June.

Sea-level in N. Derry and in Kerry. To $1200 \mathrm{ft}$. in Dublin (N.C.). 


\section{MILIUM Linn.}

\section{M. effusum Linn.-Millet Grass.}

Districts I. II. III. IV. - - VII. VIII. IX. X. XI. XII. Lat. $51 \frac{1}{2}-54 \frac{3}{4}$. From South to North. Type, British-English.

Lowland. Shady woods; rather rare. Fr. June.

I. Woods at Muckross, Killarney (Moore) : Cyb. By the Upper Lake and in the Deer-park, Killarney; by Caragh lake ; at Tralee ; Ballinruddery woods, Listowel ; and Fermoyle woods west of Castlegregory, Kerry: R.W.S. I889 \& I89I. Dunderrow wood, Cork : Allin 1874. At Castlefreke Cork, 1890 : Phillips 1895 .-II. Wood at Castle-hyde, Cork: Drummond 1818 . Dunscombe's wood, Cork: Flor. Cork. Lota wood, Glanmire : Phillips 1895. Near Clonmel (Miss A. Taylor): Cyb. Woods of Lismore Castle, Waterford: Ir. Nat. 1894, p. 184 .-III. Borris demesne and woods opposite St. Mullins on the Barrow: Hart 1885.-IV. In the wood at Luggylaw, 1802 : Templeton MS. Dargle and Powerscourt: Flor. Hib. Newtown Mount-Kennedy, Wicklow (Moore); and wood at Tinnehinch (White) : Cyb.-VII. Knock Ross, Westmeath : Levinge 1894.-VIII. Drumman wood near Lough Cullin and wood on the shore of Lough Conn (More): Cyb.-IX. Woods near Sligo. (J. Wynne): Cyb.-X. Dunamanagh, Tyrone (Admiral Jones): Cyb. Woods at Favour Royal, Tyrone: Hart 1887. Abundant in Strabane glen, Tyrone (Miss M. C. Knowles) : Ir. Nat. 1897. Killooney near Armagh (Rev.W. F. Johnson); Ivy Lodge near Newry (Rev. H. W. Lett) : Praeger 7893.-XI. Ardnamona, Lough Eske; by the Eanymore water, below Drumagraa bridge: Hart $1885 \%$. XII. Tollymore Park: Hart 1884 . Killeen glen and Stormount glen, Down (Stewart): Flor. N.-E. Wooded shore of lough south of Rostrevor: S. \& P. 1892 .

\section{PHLEUM Linn.}

\section{P. pratense Linn._Timothy Grass.}

Districts I. II, III. IV. V. VI. VII, VIII. IX. X. XI. XII. Lat. $51 \frac{1}{2}^{\circ}-55 \frac{1}{4}^{\circ}$. Throughout Ireland. Type, British-English.

Meadows and pastures; frequent. Fl. July-August.

Sea-level in N. Antrim and S. Cork. To 1000 ft. in Dublin (N. C.).

Widely distributed, but rather rare in many parts of Ireland. 


\section{P. arenarium Linn.-Sea Cat's-tail Grass.}

Districts I. II, - IV. V. VI. - - IX. - XI. XII. Lat. $51 \frac{3}{4}^{\circ}-55 \frac{1}{4}^{\circ}$. Coasts of all Ireland, probably. Type, EnglishBritish.

Sandy seashores; rather rare. Fl. May-June.

I. Castlegregory, Kerry (Moore): $C y b$. At Banna sand-hills; and abundant at Castlegregory: R.W.S. I889.-II. Near Clay Castle, Youghal; and at Ballycotton: Flor. Cork. Sparingly at the mouth of Fannisk river: Allin's Cork. Coast of Waterford (Carroll): Cyb.-IV. Murrough of Wicklow (Moore): Cyb. Sand-hills at Arklow and northwards (More): Ree. Add. Cahore Point; Raven Point; and Rosslare, Wexford: Hart $7883 \beta$. Shore near Duncannon fort, Wexford (Dr. Barker): Templeton MS.-V. Plentiful between Baldoyle and Howth, 1806 : Mack. Rar. Frequent at Sandymount and Portmarnock: Mack. Cat. On the Cosh and at the Quarry, Howth; on Ireland's Eye: Flor. Howth. Abundant at Rush and Portrane, 1893; on the North Bull, 1895; N. C. Gormanstown, Meath (More): Reo. Add.-VI. Aranmore, Galway Bay (Hart): Rec. Add.-IX. Strand hill and Rosses, Sligo; Praeger.-XI. Doaghmore and Glinsk; Carrigart; Glen Bay; near Ardara; Ballyvickstocker strand; between Greencastle and Inishowen Head, and in many other stations in Donegal: Hart I879, \&6.-XIT. On the sands at Newcastle, 1797 (Templeton): Whitla MSS. Dundrum sand-hills and abundant at Portrush (Stewart): Flor. N.-E. Abundant along the Derry coast from Lough Foyle to Portstewart (Moore): Cyb.

\section{AGROSTIS Linn.}

\section{A. canina Linn.-Brown Bent.}

Districts I. II. III. IV. V. VI. VII. VIII. IX. X. XI. XII. Lat. 51 $\frac{1}{2}^{\circ}-55 \frac{1}{4}^{\circ}$. Throughout Ireland. Type, British.

Heaths, moors, and bogs; frequent. Fl. July-August. Calcifuge $B$.

Sea-level in Antrim and in Kerry. To $2300 \mathrm{ft}$. in Down $\left(S . \& P_{.}\right.$); to $3400 \mathrm{ft}$. in Kerry (More).

Much less abundant in Ireland than the other species of Agrostis and quite rare over considerable areas. 


\section{A. alba Linn.-Marsh Bent; Fiorin.}

Districts I. II. III. IV. V. VI. VII. VIII. IX. X. XI. XII. Lat. $51 \frac{1}{2}^{\circ}-55 \frac{1}{4}^{\circ}$. Throughout Ireland. Type, British.

Moist meadows and pastures, and rocks by the sea; common. Fl. July.

Sea-level in N. Derry and S. Cork. To $1000 \mathrm{ft}$. in Donegal and to $1650 \mathrm{ft}$. in Kerry (Hart).

\section{A. vulgaris With.-Fine-leaved Bent.}

Districts I. II. III. IV. V. VI. VII. VIUI. IX. X. XI. XII. Lat. $51 \frac{1}{2}^{\circ}-55 \frac{11}{4}$. Throughout Ireland. Type, British.

Dry pastures and heaths; common. Fl. July.

Sea-level in N. Derry and S. Cork. To $2460 \mathrm{ft}$. in Donegal (Flor. Ulst.); to $2680 \mathrm{ft}$. in Mayo, to $3000 \mathrm{ft}$. in Wicklow, and to $3400 \mathrm{ft}$. in Kerry (Hart).

Var. PUMrra (Linn.)-I. Not rare in S. Kerry; and-VI. Near Abbeyfeale, Co. Limerick; R.W.S.-VIII. On Inishbofin; frequent on the higher parts of the hills : More I876.-X. At Cam Lough and on the railway south of Newry, Armagh: Praeger 1893. Hay Island, Lough Erne; Praeger.-XII. Sandhills at Newcastle, also on Slieve Bingian and Eagle mountain, Down, reaching to $1600 \mathrm{ft}$. : S.\& P. I892. Ballycastle; Magilligan; Kilrea, \&c.: S. \&.P. 1895 .

\section{CALAMAGROSTIS Adans.}

\section{C. Epigeios Roth-Wood Reed.}

Arundo Epigeios Linn.

Districts - - - - VI. - VIII. - - - XII. Lat. $53^{\circ}-55^{\circ}$. West and North. Type, English-British.

Lowland. Moist, rocky thickets; very rare. Fl. July.

VI. Near Killeany, Aranmore Island, in two places, 1869 (Hart): Rec. Add. Near Killeany (Miss M. C. Knowoles); near Port Cowrugh and frequent. at intervals from Port Murvy to the Seven Churches, Aranmore: Praeger I895.-VIII. Sparingly on rocky banks near the harbour, Inishbofin: More $1876 .-\mathrm{XII}$. Shady, moist, rocky places on Formoyle Hill, parish of Dunboe, Derry: Moore MS. \& Flor. Hib.- apparently extinct here: S. \& P. 1895 . Between Maghera and Garvagh, Derry (Moore): $C y b$.

First found in Treland by David Moore in 1835. 


\section{C. stricta Nutt.-Narrow Reed.}

C. lapponica Hook.-C. neglecta Fr.-Deyeuxia neglecta Kunth. Districts - - - - - - - X. - XII. Lat. $54^{\frac{1}{2}}-54^{\circ}{ }^{\circ}$. North-East only. Type, Local-Intermediate.

Lowland. Gravelly and stony lake shores; very rare. $F$. June-July.

$X$. Scawdy island in Lough Neagh near Maghery, Tyrone (Rev. G. Robinson): Flor. Olst. \& Rec. Add. Still on Scawdy island in 1887, and also observed near Washing Bay, Tyrone, by Rev. G. Robinson: Flor. N.-E. Abundant in a low meadow by the shore of Lough Neagh near the entrance of the Lagan canal, Armagh : Praeger I893.-XII. On a small island in Lough Neagh, in July, 1836, and in several localities along the shores of the lough near Antrim, in July, 1837 (Moore) : Colby I837. Shore of Lough Neagh near Shane's Castle (Prof. Babington): Cyb. \& Flor. N.-E. Still at Shanes Castle, 1886 (Praeger): Flor. N.-E. Island in Lough Neagh, near Toome (Moore): Flor. Olst. By the shore of Lough Beg, north-west of Toome, Derry (Stewart): Flor. $N$.-E.

Only on the shores and islands of Lough Neagh in the counties of Antrim, Derry, Tyrone, and Armagh. The Irish plant is Var. HookrRI (Syme), which appears to be peculiar to Ireland.

First found in Ireland by David Moore in 1836.

\section{PSAMMA Beauv.}

1. P. arenaria Roem. \& Schult.—Marram; Sea Mat-Grass. P. littoralis P. B.-Ammophila arundinacea Host. Districts I. II. - IV. V. VI. - VIII. IX. - XI. XII. Lat. $51 \frac{1}{2}^{\circ}-55 \frac{1^{\circ}}{}{ }^{\circ}$. Coasts of all Ireland. Type, British.

Sandy sea-shores; frequent and locally abundant. Fl. July.

\section{AIRA Linn.}

\section{A. caryophyllea Linn._Sitvery Hair-Grass.}

Airopsis caryophyllea Fries-Avena caryophyllea Web. Districts I. II. III. IV. V. VI. VII. VIII. IX. X. XI. XII. Lat. $51 \frac{1}{2}^{\circ}-55 \frac{1}{4}^{\circ}$. Throughout Ireland. Type, British.

Heaths and dry banks; frequent. $F l$. May-June. Caleifuge $B$. Sea-level in N. Antrim and S. Cork. To $1850 \mathrm{ft}$. in Down (Hart). 


\section{A. præcox Linn,-Early Hair-Grass.}

Airopsis pracox Fries-Avena pracox Beauv.

Districts I. II. III. IV. V. VI. VII. VIII. IX. X. XI. XII. Lat. $51_{2}^{\circ}-55_{1}^{\circ}$. Throughout Ireland. Type, British.

Heaths and dry banks; frequent. $F l$. May. Calcifuge $B$.

Sea-level in N. Derry and S. Cork. To $1660 \mathrm{ft}$. in Down

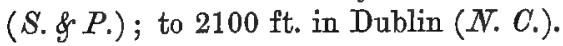

\section{DESCHAMPSIA Beauv.}

\section{D. cæspitosa Beauv.-Tufted Hair-Grass.}

Aira caspitosa Linn.

Distriets I. II. III. IV. V. VI. VII. VIII. IX. X. XI. XII. Lat. $51 \frac{1}{2}^{\circ}-55 \frac{1}{4}^{\circ}$. Throughout Ireland. Type, British.

Damp and boggy meadows, woods, \&c. ; frequent. Fl. July-Aug.

Sea-level in N. Derry and in S. Cork. To $2680 \mathrm{ft}$. in Mayo, and to $3000 \mathrm{ft}$. in Wicklow (Hart).

Var. PSEOdo-ALPRNA Syme.-I. On Slieve Mish and on Mangerton, Kerry : R.W.S. 1889 .

Aira alpina Linn.

D. alpina Rœm. \& Schult.

Districts I. - - - - - - VIII. - - - Lat. $52^{\circ}-537_{2}^{\circ}$. Kerry and Mayo only. Type, Highland.

Damp, rocky places on mountains; very rare. Fl. July.

I. Near the summit of Carrantuohill (More): Rec. Add. Frequent on the cliffs of Magillicuddy's Reeks : Hart I882. On Baurtregaum, Kerry : Hart I88I $\alpha$. On Brandon mountain : Linton I880. Upper part of the Horse's Glen, Mangerton ( $H$. N. Ridley): Journ. of Bot. 1884.-VIII. On Mweelrea, Mayo: Hart 1883 a.

From $2500 \mathrm{ft}$. to $2100 \mathrm{ft}$. in Mayo (Hart); $3370-2550 \mathrm{ft}$. in Kerry (More \& Hart).

There is reason to suspect that some of the foregoing records are referable to the variety PSEUDO-ALPINA of the preceding species.

2. D. discolor Rœm. \& Schult.-Marsh Hair-Grass.

Aira uliginosa Weihe-Aira setacea Huds,

Districts - - - - - - - VIII. - - - Lat. $53 \frac{1}{4}^{\circ}-53 \frac{1}{2}^{\circ}$. County Galway only.

Lowland. Marshy places; very rare. Fl. July. 
VIII. On the swampy borders of Lough Cregg-duff near Roundstone, Connemara (More): Journ. of Bot. 1869, p. 265. In many localities from Clifden to Kilkieran, Connemara (More): Rec. Add.

First found in Ireland by A. G. More in 1869.

\section{D. flexuosa Trin.-Waved Hair-Grass.}

Aira flexuosa Linn.

Districts I. II. III. IV. V. VI. VII. VIII. IX, X. XI. XII. Lat. $51 \frac{3}{4}^{\circ}-55 \frac{1}{4}^{\circ}$. Throughout Ireland. Type, British.

Heaths and moors, especially in mountain districts; frequent. Fl. June-July. Caleifuge $A$.

Descends to sea-level in Derry and to about $100 \mathrm{ft}$. in Kerry. Ascends to $2000 \mathrm{ft}$. in Derry (Hart); to $2796 \mathrm{ft}$. in Down (S.\& P.); to $3000 \mathrm{ft}$. in Wicklow, and to $3414 \mathrm{ft}$. in Kerry (Hart).

\section{HOLCUS Linn.}

1. H. mollis Linn.-Creeping Soft-Grass.

Districts I. II. III. IV. V. VI. VII. VIII. IX. X. XI. XII. Lat. $51 \frac{1}{2}^{\circ}-55 \frac{1}{4}^{\circ}$. Throughout Ireland. Type, British.

Woods, heaths, \&c.; not infrequent. Fl. June-Aug. Calcifuge $C$.

Sea-level in N. Derry and in Kerry. To $1650 \mathrm{ft}$. in Dublin (N.C.).

Rare in many parts of Ireland and nowhere so abundant as the following species.

\section{H. lanatus Linn.-Meadow Soft-Grass.}

Districts I. II. III. IV. V. VI. VII. VIII. IX. X. XI. XII. Lat. $51 \frac{1}{2}^{\circ}-55 \frac{1}{4}^{\circ}$. Throughout Ireland. Type, British.

Meadows, waste places, \&c.; common. Fl. June-July.

Sea-level in N. Antrim and S. Cork. To $1350 \mathrm{ft}$. in Down (S.\&P.); to $1600 \mathrm{ft}$. in Dublin (N.C.).

\section{TRISETUM Pers.}

\section{T. flavescens Beaur.-Yellow Oat-Grass.}

T. pratense Pers.-Avena flavescens Linn.

Districts I. II. III. IV. V. VI. VII. VIII. IX. X. - XII. Lat. $51 \frac{1}{2}^{\circ}-55^{\circ}$. Throughout Ireland, probably. Type,English-British. Dry pastures; frequent. $F l$. Suly. Calcicole $B$. 
Sea-level in Antrim and in Kerry. To $1000 \mathrm{ft}$. in Dublin (N.C.).

Not yet recorded for Donegal, where it may be expected to occur on the limestone in the south; rather rare in the North-East.

\section{AVENA Linn.}

\section{A. pubescens Huds.-Downy Oat-Grass.}

Districts I. II. III. IV. V. VI. VII. VIII. IX. X. XI. XII. Lat. $51 \frac{3}{4}^{\circ}-55 \frac{1}{4}^{\circ}$. Throughout Ireland. Type, British.

Dry banks and pastures ; frequent. $F$. May-June. Caloicole $B$.

To $1500 \mathrm{ft}$. in Sligo (N.C.); but usually lowland.

\section{ARRHENATHERUM Beaur.}

1. A. avenaceum Beauv.-Tall Oat-Grass.

Districts I. II. III. IV. V. VI. VII. VIII. IX. X. XI. XII. Lat. $51 \frac{1}{2}^{\circ}-554^{\circ}$. Throughout Ireland. Type, British.

Fields, banks, hedges, \&c.; common. Fl. June-July.

Sea-level in N. Derry and S. Cork. To $1250 \mathrm{ft}$. in Dublin (N.C.).

TRIODIA R. Br.

\section{T. decumbens Beauv.-Heath-Grass.}

Sieglingia decumbens Bernh.-Danthonia decumbens DC.

Districts I. II. III. IV. V. VI. VII. VIII. IX. X. XI. XII. Lat. $51 \frac{1}{2}^{\circ}-55 \frac{10}{4}$. Throughout Ireland. Type, British.

Heaths and moors, chiefly in uplands; frequent. Fl. June-July.

Sea-level in N. Derry and S. Cork. To $1800 \mathrm{ft}$. in Donegal (Hart); to $2050 \mathrm{ft}$. in Wicklow (N.C.).

\section{PHRAGMITES Trin.}

\section{P. communis Trin.-Common Reed.}

Arundo Phragmites Linn.

Hibernicé biolcać (Gydle-cuck).

Districts I. II. III. IV. V. VI. VII. VIII. IX. X. XI. XII. Lat. $51 \frac{1}{2}^{\circ}-55 \frac{1}{4}^{\circ}$. Throughout Ireland. Type, British.

Sides of lakes, in ditchés, marshes, \&c. ; common. Fl. July-Aug.

Sea-level in N. Antrim and. S. Cork. To $800 \mathrm{ft}$. in Donegal, and to $700 \mathrm{ft}$. in Kerry (Hart); but usually lowland. 
SESLERIA Scop.

1. S. cærulea Arduin.-Blue Moor-Grass.

Districts - - - - VI. VII. VIII. IX. X. XI. Lat. $53^{\circ}-54 \frac{3}{4}^{\circ}$. West of Ireland. Type, Highland-Intermediate.

Rocky pastures and mountains; locally abundant. Fl. AprilMay. Calcicole $A$.

VI. Forms the principal part of the pasture in the Marquis of Clanrickarde's demesne, Portumna (Moore): Phytol. I845, p. I30. Abundant on the west shore of Lough Derg near Portumna (Moore): Cyb. On Ilaunmore, Lough Derg: N. C. 7897 . Plentiful about Castle Taylor and other places in East Galway: More 1855\&Cyb. In the Great Island of Aran (Prof. Balfour): Phytol. 1853. In all three Isles of Aran: Hart 1875 . Common in Burren, Clare, 1892 ; Levinge.-VII. Meadows by the Shannon at Athlone; $\boldsymbol{R}$. P. Vowell. Shores of Lough Derg at Derry Island;

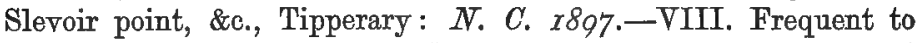
the west of Galway (Prof. Melville): $C y b$. On the west side of the creek at Ballina, Mayo (Moore): Cyb. South of Lough Mask: M. \& S. 1896 -extending here into-IX. Shores of Lough Carra, Mayo: More 1860. On all the calcareous mountains of Leitrim and Sligo: Murphy 1829. . Knocknarea, Sligo; Praeger.X. Shean Hill, Poulaphuca, Lough Erne: Barrington 1889.XI. On the banks of the Erne at Ballyshannon (More): Cyb. Abundant between Ballyshannon and Bundoran; about Lough Gorman; St. John's Point; south-east shore of Lough Eske; by the Eanymore Water in several places; banks by the sea a little north of Bundoran : Hart I $885 \%$.

Sea-level in Galway, Mayo, and Donegal. To $1100 \mathrm{ft}$. in Ben Bulben district $(B . \& V$.); to $1000 \mathrm{ft}$. in Clare $(N . C$.$) ; but chiefly$ lowland in Ireland.

\section{CYNOSURUS Linn.}

1. C. cristatus Linn.-Dog's-tail Grass.

Districts I. II. III. IV. V. VI. VII. VIII. IX. X. XI. XII. Lat. $51 \frac{1}{2}^{\circ}-55 \frac{1}{4}^{\circ}$. Throughout Ireland. Type, British.

Pastures; common. Fl. July-August.

Sea-level in N. Derry and S. Cork. To $1500 \mathrm{ft}$. in Derry (Flor. N.-E.); to $1600 \mathrm{ft}$. in Dublin (N.C.). 


\section{KOELERIA Pers.}

1. K. cristata Pers.-Crested Hair-Grass.

Districts I. II. - IV. V. VI. VII. VIII. IX. - XI. XII. Lat. $51^{\frac{3}{4}}-541^{\circ}$. From South to North. Type, British.

Dry pastures, banks, and rocky places; not infrequent. Fl. June-July.

Sea-level in N. Derry and in Kerry. To $1000 \mathrm{ft}$. in Derry (Moore); to $1500 \mathrm{ft}$. in Donegal (Hart).

Much more frequent near the sea than in inland stations.

MOLINIA Schrank.

1. M. cærulea Mønch-Purple Moor-Grass.

Districts I. II. III. IV. V. VI. VII. VIII. IX. X. XI. XII. Lat. $51 \frac{1}{2}^{\circ}-551_{4}^{\circ}$. Throughout Ireland. Type, British.

Heathy and boggy places; frequent and locally abundant. Fl. July-August. Calcifuge $C$.

Sea-level in N. Derry and S. Cork. To $1700 \mathrm{ft}$. in Donegal (Hart); to $2450 \mathrm{ft}$. in Down (S.\& P.); to $2250 \mathrm{ft}$. in Kerry (Hart).

\section{CATABROSA Beauv.}

1. C. aquatica Beauv.-Water Whorl-Grass.

Districts I. II. III. IV. V. VI. VII. VIII. IX. X. XI. XII. Lat. $52^{\circ}-55 \frac{1}{4}$. Throughout Ireland. Type, British.

Ditches, pools, and watery places, usually in clay soils ; frequent. Fl. June-July.

To $850 \mathrm{ft}$. in Dublin (N.C.); but usually lowland.

Though widespread, a rare species in many parts of Ireland.

\section{MELICA Linn.}

1. M. uniflora Retz.-Wood Melick-Grass.

Districts I. II. III. IV. V. VI. VII. VIII. IX. X. XI. XII. Lat. $51 \frac{3}{4}^{\circ}-55 \frac{1}{4}^{\circ}$. Throughout Ireland. Type, English-British.

Lowland. Woods, hedge-rows, and shady places; frequent and locally abundant. Fl. May-June. 


\section{DACTYLIS Linn.}

\section{D. glomerata Linn.-Cock's-foot Grass.}

Districts I. II. III. IV. V. VI. VII. VIII. IX. X. XI. XII. Lat. 51 $\frac{1}{2}^{\circ}-55 \frac{1}{4}^{\circ}$. Throughout Ireland. Type, British.

Pastures, waste places, \&c.; common. Fl. June-July.

Sea-level in N. Antrim and S. Cork. To $1200 \mathrm{ft}$. in Dublin (N. C.), and in Kerry (Hart).

\section{BRIZA Linn.}

\section{B. media Linn.-Quaking-Grass.}

Bistricts I. II. III. IV. V. VI. VII. VIII. IX. X. XI. XII. Lat. $51 \frac{1}{2}^{\circ}-55 \frac{1}{4}^{\circ}$. Throughout Ireland. Type, British-English.

Dry banks and pastures; locally abundant. Fl. June-July.

Sea-level in Derry and Kerry. To $1400 \mathrm{ft}$. in Wicklow (N.C.).

\section{POA Linn.}

1. P. annua Linn.-Annual Meadow-Grass.

Districts I. II. III. IV. V. VI. VII. VIII. IX. X. XI. XII. Lat. $51 \frac{1}{2}^{\circ}-55 \frac{1}{4}^{\circ}$. Throughout Ireland. Type, British.'

Roadsides, waste places, \&c.; common. $F l$. Throughout the year.

Sea-level in N. Antrim and S. Cork. To $2200 \mathrm{ft}$. in Derry (Hart); to $2450 \mathrm{ft}$. in Down (S.\& P.); to $2500 \mathrm{ft}$. in Mayo, and to $3000 \mathrm{ft}$. in Tipperary (Hart); to $3000 \mathrm{ft}$. in Wicklow (N. C.); to $3200 \mathrm{ft}$. in Kerry (More).

\section{P. alpina Linn.-Mountain Meadow-Grass.}

Districts I. - - - - - - - IX. - - Lat. $52 \frac{1}{4}^{\circ}-54 \frac{1}{4}^{\circ}$. Kerry and Sligo. Type, Highland.

Rocks on high mountains; very rare. Fl. July-August.

I. Near the well on the top of Brandon mountain, Kerry, 1804 : Mack. Rar. Still on the top of Brandon in 1885; N.C.-IX. On Ben Bulben and other mountains in Sligo: Mack. Rar. Frequent at the summit of Ben Bulben and at Annacoona: B.\&. T. 1885 .

From $1500 \mathrm{ft}$. to $1950 \mathrm{ft}$. in Sligo $(B . \& V$.); to $3100 \mathrm{ft}$. in Kerry ( $C y b$. $)$. 


\section{P. nemoralis Linn.-Wood Meadow-Grass.}

Districts I. - - IV. V. VI. VII. - - - XII. Lat. $51_{\frac{3}{4}}^{\circ}-55^{\circ}$. East and North-East, chiefly. Type, British.

Woods and thickets; rare. Fl. June-July.

I. Woods at Castle Bernard, S. Cork, 1897; Phillips.IV. Plentiful at the Dargle, Wicklow : Mack. Cat.-V. Between Luttrellstown [Woodlands] and Lucan: Wade Rar. Wall tops at Woodlands, 1893; in Lucan demesne, 1894; N. C. In Kildare, at Ballitore (Carroll); and near Straffan (J. Douglas): Cyb. By the river at Poulaphuca, Kildare, 1896 ; and near Navan, Meath, 1897 ; R.T. S.-VI. Woods at Ballyvalley, near Killaloe, Clare: $N$. C. 1897.-VII. Tóps of old walls at Knock Drin, Westmeath, thoroughly established if not indigenougs: Levinge 1894.-XII. In a wood on Knock-cree mountain, Down (John White): Wade Rar. Woods about Rosstrevor and wooded mountains about Knappen, Antrim (John White) : Cyb. North branch of Glenarve river about five miles south-west of Cushendall, 1809 : Templeton MSS. Woods and thickets about Limavady, Derry, but not common in the county: Moore MS. Very rare in the North-East and not seen recently: Flor. $N$. $E$.

\section{P. pratensis Linn.-Smooth Meadow-Grass.}

Districts I. II. III. IV. V. VI. VII. VIII. IX. X. XI. XII. Lat. $51 \frac{1}{2}^{\circ}-55 \frac{1}{4}$. . Throughout Ireland. Type, British.

Pastures, banks, walls, \&c.; common. Fq. June-July.

Sea-level in Derry and S. Cork. To $1600 \mathrm{ft}$. in Derry (Cyb.); to $2200 \mathrm{ft}$. in Tipperary, and to $3000 \mathrm{ft}$. in Kerry (Hart).

\section{P. palustris Linn.-Marsh Meadow-Grass.}

Distriets - - - V. - - - - - Lat. $53^{\circ} 40^{\prime}$. County of Meath only.

Lowland. River banks; very rare. Fl. July.

V. On the reedy northern edge of the Boyne at Beauparc, Meath : Praeger 1897.

The first record for Ireland. The only previously known station for this critical plant in the British Isles is the banks of the Tay below Perth where it was found in 1889.

First found in Ireland by R. Ll. Praeger in 1896. 


\section{P. trivialis Linn.-Rough Meadow-Grass.}

Districts I. II. III. IV. V. VI. VII. VIII. IX. X. XI. XII. Lat. $51 \frac{1}{2}^{\circ}-55 \frac{1}{4}^{\circ}$. Throughout Ireland. Type, British. July.

Pastures, ditch-banks, waste places, \&c.; common. Fl. June-

Sea-level in N. Antrim and S. Cork. To $1200 \mathrm{ft}$. in Dublin (N. C.) ; to $1650 \mathrm{ft}$. in Kerry (Hart).

\section{GLYCERIA R. Br.}

1. G. fluitans R. Br.-Flloating Grass.

Districts I. II. III. IV. V. VI. VII. VIII. IX. X. XI. XII. Lat. $51 \frac{1}{2}^{\circ}-55 \frac{1}{4}^{\circ}$. Throughout Ireland. Type, British.

Ditches and pools; common. Fl. June-July.

Sea-level in N. Derry and S. Cork. To $1150 \mathrm{ft}$. in Down $(S . \& P$.$) ; to 1250 \mathrm{ft}$. in Dublin $\left(N . C_{.}\right)$; to $2150 \mathrm{ft}$. in Wicklow (More.)

\section{G. plicata Fries.}

Districts I. II. III. - V. VI. VII. VIII. IX. X. - XII. Lat. $51 \frac{3^{\circ}}{4}-55^{\circ}$. Throughout Ireland, probably. Type, EnglishBritish.

Lowland. Ditches and pools; common. Fl. June-July.

I. Ditches near Waterville; by roadsides at Kilmorna near Abbeyfeale, \&c., Kerry; widely scattered through the county; R.W. S.-II. Near Cork; Phillips.-III. Maryborough, Queen's Co.; and-V. Carbury and Leixlip, Co. Kildare; Oldcastle and Bective, Co. Meath; Soldier's Point, Louth: Praeger 1897. Near Glasnevin and Dublin (More): Cyb.-VI. About Castle Taylor, Galway : More 1855--VII. Knock Drin, Westmeath: Linton 1896.-VIII. Inish Bofin, Galway: More 1876.IX. Near Hollymount, Mayo (More): Cyb. About Ben Bulben, Sligo: B.\&V. $7885 .-\mathrm{X}$. Near Castle Hume, Lough Erne: Barrington 1884. Near Omagh, Tyrone (Miss M. C. Knowles): Ir. Nat. 1897 . Lough Ramor, Cavan; and-XII. Ditch near Formoyle, Derry : Praeger 1897 .

Often confounded with the preceding species and no doubt extends throughout Ireland. 


\section{G. aquatica Smith-Reed Meadow-Grass.}

G. spectabilis Mert. et Koch.

Districts I. II. III. IV. V. VI. VII. - IX. - - XII. Lat. $51 \frac{3}{4}^{\circ}-541_{4}^{\circ}$. Centre and East, chiefly. Type, English-British.

Lowland. Sides of rivers, canals, and ditches ; locally abundant. Fl. July-August.

I. In a stream running into the Lee, near Cork (J. Sullivan): Cyb.-still there, 1896; Phillips.-II. Clonea, near Dungarvan, Waterford: Hart I883 $\beta$.-III. In the Barrow below Carlow (R. Clayton Browne): Rec. Add. By the Nore between Ballyneale

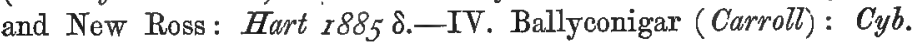
Near Morris Castle and Tinnyberna, east coast of Wexford: Hart I88I a. In Wexford, near Alderton; Killowen; and New Ross: B.-H.\& G. ${ }_{2} 889$. Ditches on the Murrough of Wicklow (Moore): Cyb.-V. Royal Canal near Dublin : Templeton MS. On the banks of the Grand Canal (J.White): Cyb. Plentiful in the canals near Dublin, extending to Kildare (Moore): Cyb. Along the Liffey (J. White) : Cyb. By the Liffey at Chapelizod (More): Cyb. Near Ballitore (Carroll); and Straffan, Kildare (J. Douglas): Cyb. Plentiful along the Barrow above Athy: Hart 2885 . Plentiful along the Boyne near Navan, $1897 ; R . W$. S.-VI. By the Shannon at Portumna, Co. Galway: N. C. 1897.-VII. Ditches near Belvedere Lake, Mullingar (Moore): Cyb. Canal at Mullingar: Levinge 1894. Royal Canal at Lough Ree, and Shannon at Athlone, the latter locality extending to-IX. : B.\&V. 1887.-XII. By the Quoile, between Downpatrick and the bridge (Stewart): Flor. N.-E.

\section{G. maritima Mert. \& Koch-Sea Meadow-Grass.}

Sclerochloa maritima Lindl.

Districts I. II. III. IV. V. VI. - VIII. IX. X. XI. XII. Lat. $51 \frac{1}{2}^{\circ}-55 \frac{1}{4}^{\circ}$. Coasts of all Ireland. Type, British.

Salt marshes and muddy seashores; frequent. Fl. June-July.

\section{G. distans Wahlenb.-Reflexed Meadow-Grass.}

Sclerochloa distans Bab.

Districts I. - - IV. V. - - - - X. XI. XII. Lat. $52^{\circ}-554^{\circ}$. Coasts in the East and North, chiefly. Type, English-British.

Salt marshes and waste ground near the sea; local. Fl. June-July. 
I. River side below Cork (Drummond); and near Douglas: Flor. Cork. At Rochestown; R.W.S.-IV. Near Alderton and Ballyvarna, Wexford: B.-H.\&G. I889: Marsh north of Wexford harbour: Marshall $1896 .-\mathrm{V}$. At Howth and North Wall, Dublin : Wade Rar. Ringsend: Mack. Cat. In several stations along Dublin Bay, 1880; at Baldoyle, 1883; More. Near Kingstown (Moore) : Cyb.-X. Shore near Narrow-water: Praeger 1893.XI. By the Foyle and Swilly; but very rare in Donegal; Hart.XII. Kinnegar and Victoria Park: Flor. Belf. Abundant about Belfast (Moore): Cyb. Portaferry: Flor. Olst. Warrenpoint: S. \& P. I892. Frequent in the North-East: Flor. $N .-E$.

Not yet found in the West of Ireland.

\section{G. Borreri Bab.-Borrer's Sea Meadow-Grass.}

Selerochloa Borreri Bab.

Districts - - - IV. V. - - - - - - Lat. $52 \frac{1}{4}^{\circ}-53 \frac{1}{2}^{\circ}$. Wexford and Dublin only. Type, Germanic.

Salt marshes and waste ground near the sea; very rare. Fl. June-August.

IV. Plentiful in a salt marsh near Wexford station, and in marshes north of the Harbour: Marshall $1806 .-\mathrm{V}$. Plentiful in the North Lotts, near the mouth of the Liffey; at Sandymount and along Dublin Bay (Moore) : Cyb. Still in the North and South Lotts, $1890 ; R . W . S$. In the new Park, Blackrock, with G. distans; More. tima.

Usually found growing in company with G. distans and G. mari-

\section{FESTUCA Linn.}

\section{F. rigida Kunth-Hard Fescue.}

Sclerochloa rigida Link-Poa rigida Linn.

Districts I. II. III. IV. V. VI. VII. VIII. IX. X. XI. XII. Lat. $51 \frac{1}{2}^{\circ}-55 \frac{1}{4}^{\circ}$. Throughout Ireland. Type, British-English.

Dry banks, rocks, walls, \&c.; frequent but local. Fl. JuneJuly. Calcicole $C$.

XI. Rocks at Glen Columbkill (Admiral Jones): Cyb. In Fanet and Rathmullan, but very rare in Donegal; Hart.-XII. By the sea two miles north of St. John's Point (Stewart); and near -Newcastle, Down (Corry): Flor. N.-E. Sea walls at Ardglass and 
Killough, Down; and Magheramorne, Antrim (Praeger): S. \& $P$. 1895.

Sea-level in Antrim and S. Cork, to $800 \mathrm{ft}$. in Dublin (N.C.); but usually lowland.

Common in the South, in the East, and in the midlands; infrequent in the West; and rare in the extreme North.

\section{F. rottbcllioides Kunth-Dwarf Sea Fescue.}

Scleroehloa loliacea Woods-Catapodium loliaceum Link-Desmaseria loliacea Nym.-Triticum loliaceum Smith.

Districts I. II. - IV. V. VI. - VIII. IX. - XI. XII. Lat. $51_{2}^{10}-55_{4}^{10}$. Coasts of all Ireland. Type, English.

Sandy and gravelly seashores, walls, \&c.; rather frequent but. local. Fl. June-July.

\section{F. uniglumis Soland.-Single-glumed Fescue.}

Vulpia uniglumis Rchb. $-V$. membranacea link.

Districts - - - IV. V. - - - - - - Lat. $52 \frac{1}{2}^{\circ}-53 \frac{3}{4}^{\circ}$. East coast of Ireland. Type, English-Atlantic.

Sandy seashores; local and rare. Fl. June.

IV. Sandhills south of Cahore Point; at Courtown; and at Raven Point, Wexford: Hart I88I a. Sandhills from Courtown to Arklow, and northwards to Rockfield, Wicklow (More): Ree. Add.-V. Portmarnock sands, 1824: Mack. Cat. Sandhills at Portrane near Malahide, and on the south side of the Boyne near Drogheda (Moore); Ireland's Eye, opposite Howth (More): Cyb. On Howth, 1891 ; Levinge. Sandhills at Baltray, Louth: Praeger I897.

\section{4. † F. Myuros Linn.-Capon's-tail Fescue.}

Fulpia Myuros Gmel.

Districts I. II. III. IV. V. VI. - - IX. - - Lat. $51 \frac{1}{2}^{\circ}-53 \frac{1}{2}^{\circ}$. South and Middle of Ireland. Type, English.

Lowland. Walls and dry banks; not infrequent, but local. Fl. June.

I. Walls at Dingle and Milltown, Kerry (More): Rec. Add. Killarney; Tralee, \&c.; widely distributed in Kerry: $R . W . S$. 1889. Near Skibbereen and Baltimore, Cork; and-II. Glanmire; Carrigtuohill, \&c.; Phillips. Fermoy : Herb. Chandlee. Tipperary and Fethard; R.W.S.-III. Ferrybank, Kilkenny: $M . \& S$. 
1896.-IV. Enniscorthy, Wexford (J. Morrison); Arklow and Wicklow (More): Reo. Add. Near Wexford and Gorey : Marshall I898.-V. Bray; Golden Ball; and Donnybrook, Dublin; More. Walls at Lispopple, Co. Dublin, sparingly: N. C. 1895 . VI. Near Ballyvaughan (Allin): Rec. Add. Glin, Co. Limerick; R.W.S.IX. Banks of the Robe, a little below Hollymount, Mayo (More): Cyb.

Apparently little more than a casual in Districts V. and VI.; but perhaps often confounded with the following species.

\section{F. sciuroides Roth-Barren Fesoue.}

Vulpia sciuroides Gmel.

Districts I. II. III. IV. V. VI. VII. VIII. IX. X. XI. XII. Lat. $51 \frac{1}{2}^{\circ}-55 \frac{1}{4}^{\circ}$. Throughout Ireland. Type, British.

Dry banks, pastures, walls, \&c.; frequent. Fl. June. Caleifuge $B$.

Sea-level in N. Derry and S. Cork. To $950 \mathrm{ft}$. in Dublin (N. C.).

6. F. ovina Linn.-Sheep's Fescue.

Districts I. II. III. IV. V. VI. VII. VIII. IX. X. XI. XII. Lat. $51 \frac{1}{2}^{\circ}-55 \frac{1}{4}^{\circ}$. Throughout Ireland. Type, British.

Dry pastures, heaths, seashores, \&c. ; common. Fl. June-July.

Sea-level in N. Antrim and S. Cork. To 2796 feet in Down (Flor. Ulst.); to $3000 \mathrm{ft}$. in Wicklow (Eart); to $3414 \mathrm{ft}$. in Kerry (More).

\section{F. rubra Linn.-Creeping Fescue.}

Districts I. II. III. IV. V. VI. VII. VIII. IX. X. XI. XII. Lat. $51 \frac{1}{2}^{\circ}-55 \frac{1}{4}^{\circ}$. Throughout Ireland. Type, British.

Dry banks, sandy shores, \&c.; frequent. Fl. June.

Sea-level in Donegal and S. Cork. To $1600 \mathrm{ft}$. in 'Down (S.\&.P.).

Var. arenaRIa (Osbeck)-F. oraria (Dum.)-Frequent on sandhills.

\section{F. sylvatica Vill.-Reed Fesoue.}

Districts I. II. III. IV. - VI. VII. VIII. IX. 'X. XI. XII. Lat. $52^{\circ}-55^{\circ}$. Throughout Treland, almost. Type, Scottish.

Lowland. Rocky woods and glens; rare. Fl. July.

I. Cromaglaun woods, near the lake at Killarney (Moore): Cyb.- still there in $1894 ; R . W . S$. Rocky wood near Listowel, 
Kerry, $1890 ; R . W . S .-I I$. In a wood at Glanmire, Cork ( $R$. W.S.): Journ. of Bot. 1893, p. 56. Woods at Lismore Castle: Ir. Nat. r894, p. I84. Near Morgan's Glen, Waterford (Miss S. Grubb): Cyb.-III. Woods at Woodstock, Kilkenny: Mack. Rar. Cullenagh mountain, Queen's Co.; Praeger.-IV. Wood at NewtownBarry, Wexford; and in the Dargle, Wicklow: Wade Rar. Plentiful near the Waterfall, Co. Wicklow, where Mr. Templeton and others observed it several years ago : Mack. Rar. Devil's Glen (Moore) : Cyb.-VI. Dalystown, south-east Galway; Praeger.VII. Knock Ross, on Lough Derevaragh, Westmeath: Levinge 1894.-VIII. In Drumman wood, near Lough Cullin; and on the shores of Lough Conn, Mayo (More): Cyb.-IX. Knocknarea, Sligo; Praeger.-X. Strabane Glen, Tyrone (Admiral Jones): Cyb. - still plentiful there and at Omagh (Miss M. C. Knowles): Ir. Nat. 1897. In Tanderagee lower demesne, Co. Armagh: Praeger 1893.-XI. Glenalla wood, Rathmullan: Hart 1880. Ned's Point, Buncrana; and near Glenties : Hart $188 \mathrm{I} \beta$. By the Eske, above Donegal : Hart 1885 \%.-XII. Woods at Rosstrevor : Wade Rar. Abundant by the Shimna and Spinkwee rivers in Tollymore Park, Down: S.\&P. I892. Colin Glen: Templeton $M S$. Glendun and Glenarm, Antrim; and in Mount-sandy wood by the Bann in Derry (Moore) : Cyb. Ness Glen, near Cumber; and near Londonderry: Templeton MS.

\section{F. elatior Linn.-Tall Fescue.}

F. pratensis Huds.

Districts I. II. III. IV. V. VI. VII. VIII. IX. X. XI. XII. Lat. $51 \frac{1}{2}-55 \frac{1}{4}{ }^{\circ}$. Throughout Ireland. Type, British.

Lowland. Moist meadows, shady places, \&c.; frequent. Fl. June-July.

$F$. loliacea Huds. $-F$. elatior $\times$ Lolium perenne-III. By the Barrow below Leighlin Bridge: Hart 1885.-VI. Near Clonbrock, East Galway: Praeger 1806.-VII. Knock Ross, Westmeath: Levinge 1894.-XII. At Cranmore, and by the Lagan canal (Templeton): Filor. N.-E.

\section{F. arundinacea Schreb.-Coarse Fesoue.}

Districts I. II. III. IV. V. VI. VII. VIII. IX. X. XI. XII. Lat. $51 \frac{3}{4}^{\circ}-55 \frac{1}{4}^{\circ}$. Throughout Ireland. Type, British.

Lowland. Damp pastures, river sides, and banks near the sea; not infrequent. Fl. June-July. 


\section{BROMUS Linn.}

1. B. giganteus Linn.-Tall Wood Brome-Grass.

Festuca grgantea Vill.

Districts I. II. III. IV. V. VI. VII. VIII. IX. X. XI. XII.

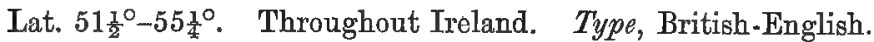

Lowland. Woods, thickets, and hedges; frequent. Fl. JulyAugust.

\section{B. asper Murr.-Hairy Wood Brome-Grass.}

B. ramosus Huds.

Districts I. II. III. IV. V. VI. VII. VIII. IX. X. XI. XII. Lat. $51 \frac{1}{2}^{\circ}-55 \frac{1}{4}^{\circ}$. Throughout Ireland. Type, British-English.

Woods, thickets, and hedges; frequent. Fl. July.

Sea-level in N. Derry and S. Cork. To $600 \mathrm{ft}$. in Dublin $(N . C$.$) ; but usually lowland.$

\section{3. † B. erectus Huds.- Opright Brome-Grass.}

Districts - - III. IV. V. VI. VII. - - - [XI.] Lat. $53^{\circ}-53 \frac{1}{2}^{\circ}$. Middle of Ireland. Type, Germanic-English.

Lowland. Dry pastures and banks; rare but locally abundant and spreading in Ireland. Fl. June.

III. Railway banks near Portarlington; and-IV. Banks on north side of Bray Head, Co. Wicklow (More): Rec. Add.V. Found under hedges near Finglass (Dr. Scott): Mack. Rar. Santry wood; between Coolock and Balgriffin, common $(J$. Onderwood): Templeton MS. Along the Royal Canal and river Tolka, Dublin (White) : Cyb. By the Liffey above Leixlip; More. Fields near Portmarnock (Moore): Cyb. Roadside banks at Auburn, Malahide, \&c.; Hart. Abundant along the railway from Raheny to Balbriggan; $N . C$. Loughlinstown, Co. Dublin; R.W.S.VI. Abundant in Garryland wood near Gort, Galway: More $1855 \&$ $C y b$. Abundant in old pastures at Glenforth, Ballyvaughan, Clare; P. B. O'Kelly.-VII. In meadows at Knock Drin, Mullingar: Levinge 1894.-[XI. Along the northern railway near Derry; Hart.]

First found by Dr. Scott, at Finglas, before 1806. 


\section{4. $\ddagger$ B. madritensis Linn.-Stiff Brome-Grass.}

B. diandrus Curt.

Districts - II. - - - - - - - - - -

Lat. $521^{\circ}$. Tipperary [and Waterford]. Type, Atlantic.

Lowland. Dry banks, walls, and waste places; very rare. Fl. June-July.

II. By the river at Carrick-on-Suir, Co. Tipperary (Miss $S$. Grubb): Carroll I854. Rather plentiful on the old castle at Carrick-on-Suir, said to have been built in the 12th century; also at the foot of several old walls adjacent, and on the bridge which connects the counties of Tipperary and Waterford (Miss.S. Grubb): $C y b$. Waste ground at the Waterford-Tramore railway station, introduced: B.-H.\& G. 1889 .

As the plant is almost confined to walls and ruins in its chief Irish station at Carrick, there is reason to suspect that it has been introduced.

First found by Miss S. Grubb about 1848.

\section{B. sterilis Linn.-Barren Brome-Grass.}

Districts I. II. III. IV. V. VI. VII. VIII. IX. X. XI. XII. Lat. $51 \frac{1}{2}^{\circ}-55 \frac{1}{4}^{\circ}$. Throughout Ireland. Type, British-English.

Lowland. Dry banks, walls, roadsides, \&c.; local and rather rare. $F l$. June-July.

A widespread species, common near Cork, Dublin, and other towns, but rare and obviously introduced in many parts of the country.

\section{6. * B. secalinus Linn.-Rye Brome-Grass.}

Districts I. II. - - V. VI. - - - X. - XII. Lat. $51 \frac{1}{2}^{\circ}-54 \frac{3}{4}^{\circ}$. South and East, chiefly. Type, British-English.

Lowland. Corn-fields; rare and uncertain. Fl. July-August.

I. Plentiful in a corn-field at Castlefreke, 1890: Phillips 1895.-II. Fields near Fermoy : Drummond 1818 . Oat-field near Ballyvolane Cross, plentiful (Carroll): Allin's Cork. At Tivoli, Cork; Phillips-V. Sandy meadows between Clontarf and Howth (J. White): Mack. Cat. Corn-fields about Collon, Louth: Ir. Flor. At Queensborough, Louth : Praeger 1897.-VI. Recorded for this District in 1st Ed. Cyb., but no locality available.-X. Hedges near Strabane, Tyrone (Miss M. C. Knowles): Ir. Nat. 1897.- 
XII. Cranmore, 1796 : Templeton MS. Ballyronan and Lambeg: Flor. Ulster. Casual at Hollywood, 1886 (Praeger); introduced with seed: Flor. N.-E.

Fully established in District I.; perhaps little more than a casual elsewhere.

\section{B. racemosus Linn.-Smooth Brome-Grass.}

Districts I. II. - IV. V. VI. VII. VIII. IX. - - XII. Lat. $51 \frac{3}{4}^{\circ}-55 \frac{1}{4}^{\circ}$. From South to North. Type, British.

Lowland. Moist meadows and pastures; frequent. Fl. June.

Not always distinguished from $B$. mollis: though much rarer than that species it will probably be found in every district.

\section{B. commutatus Schrad.}

Districts I. II. III. IV. - VI. VII. - IX. X. XI. Lat. $51 \frac{3}{4}^{\circ}-54 \frac{3}{4}^{\circ}$. From South to North. Type, British.

Lowland. Meadows, roadsides, and by rivers; rare. $F l$. June-July.

I. Plentiful in Ballyphehane bog and in a meadow at Balleagh Castle, Carrigaline (Carroll): Cyb. \& Allin's Cork.-II. Ballyvolane (J.Cook); and Youghal: Allin's Cork. Near Fermoy (T. Chandlee): Carroll I854. Meadows at Ballycotton and waste ground at Donoughmore, Co. Cork, 1896; Phillips. By the Suir above Golden, Tipperary: Hart 1885 a.-III. By the Barrow near Mountmellick: Hart 1885. Near Maryborough, Queen's Co.: Praeger 1897.-IV. Meadow about two miles south of Wexford: Marshall 1898 . - VI. In wooded and bushy places along the Shannon, near Portumna (Moore): Cyb. At Castle Taylor, Galway: More 1855. Near Clonbrock: Praeger 1896.-VII. By the Barrow above Baylough bridge near Monasterevan: Hart 1885 . Meadows at Knock Drin, Mullingar: Leinge $7895 .-I X . N e a r$ Milltown, Co. Sligo: B.\&T. $1885 .-\mathrm{X}$. In fields of sown grass in Loughgall, \&c., Armagh: More 1860 . Mullinure meadows, Armagh (Rev. W. F. Johnston); shore of Lough Ramor, Cavan: Praeger I893\& I897. Roadsides at Strabane, Tyrone (Miss $M$. Knowles): Ir. Nat. 2897.-XI. Shore of Milford Lake and left bank of the Finn; very rare in Donegal; Hart.

There is reason to fear that this plant and the preceding have not been sufficiently discriminated by observers. 
8. B. mollis Linn.-Soft Brome-Grass.

Districts I. II. III. IV. V. VI. VII. VIII. IX. X. XI. XII. Lat. $51 \frac{1}{2}^{\circ}-554^{\circ}$. Throughout Ireland. Type, British.

Meadows, banks, roadsides, \&c.; common. Fl. June-July.

Sea-level in Donegal and in S. Cork. To $1500 \mathrm{ft}$. in Dublin (N.C.).

\section{BRACHYPODIOM Beaur.}

1. B. sylvaticum Rœm. \& Schult.-False Brome-Grass.

B. gracile Beaur.

Districts I. II. III. IV. V. VI. VII. VIII. IX. X. XI. XII. Lat. $51 \frac{1}{2}^{\circ}-551^{\circ}$. Throughout Ireland. Type, British.

Woods, hedges, and rocky places; frequent. Fl. July-August.

Sea-level in N. Antrim and S. Cork. To $700 \mathrm{ft}$. in Dublin (N. C.); to $960 \mathrm{ft}$. in Kerry (More).

\section{LOLIUM Linn.}

\section{L. perenne Linn.-Rye-Grass.}

Districts I. II. III. IV. V. VI. VII. VIII. IX. X. XI. XII. Lat. $51 \frac{1}{2}^{\circ}-55 \frac{1}{4}^{\circ}$. Throughout Ireland. Type, British.

Meadows, waysides, and banks; common. $F$. June-July.

Sea-level in N. Antrim and S. Cork. To $1500 \mathrm{ft}$. in Dublin: $(N . C$.$) .$

\section{2. $\nmid$ L. temulentum Linn.-Darnel.}

Districts I. II. III. IV. V. VI. VII. VIII. - X. XI. XII. Lat. $51 \frac{1}{2}^{\circ}-55 \frac{1}{4}^{\circ}$. Throughout Ireland, probably. Type, BritishEnglish.

Lowland. In cultivated fields; not infrequent. Fl. JuneAugust.

AGROPYRON J. Gærtn.

1. A. caninum Beauv.-Tufted Theat-Grass.

Triticum caninum Huds.

Districts I. II. III. IV. V, VI. VII. - - X. XI. XII. Lat. $52^{\circ}-55^{\circ}$. From South to North. Type, British.

Lowland. Woods and banks : apparently rare. Fl. July. 
I. Coolmore, near Cork; and-II. Blarney wood: Flor. Cork. At Carrickabrick and other places near Fermoy ( $T$. Chandlee \& Carroll): Allin's Cork. - III. Near Kilmacow, Killkenny ( $T$. Chandleo): Cyb. Ballintemple below Tullow: Hart 1881 a.IV. Powerscourt woods, Wicklow (Moore) : Cyb.-V. Plentiful at Woodlands, Dublin: Mack. Cat. 1825-still there, and at St. Catherine's, $1895 ;$ N.C. Knockmaroon and Leixlip: Ir. F'lor. Glendruid, Carrickmines; More-DI. Garryland wood near Gort (More) : Cyb. Frequent on the shores of the Shannon estuary: Stewart I89o. Near Black Fort, Aranmore: Nowers \& Wells 1892. -VII. Knock Ross, Westmeath; rare: Levinge I894.-X. By Mullaghmore Lake, Armagh: Praeger 1893. Left bank of the Erne below Belleek (More), this locality extending to-XI. At Cliff on the Erne: Hart $1885 \gamma$. Woods at Buncrana, Donegal; Hart.XII. About the river at Montalto, Co. Down; in Grogan's Glen and in Glenarm deer park, Antrim: Templeton MS. Near Newcastle and Kilkeel, Down: S.\&P. 1892. Sandy shore at Groomsport (Stewart): S.\&P. 1895 .

Often confounded with the following species and probably more frequent in Ireland than would appear from the above records.

\section{A. répens Beauv.-Couch-Grass.}

Triticum repens Linn.

Districts I. II. III. IV. V. VI. VII. VIII. IX. X. XI. XII. Lat. 51 $\frac{1}{2}-55 \frac{1}{4}^{\circ}$. Throughout Ireland. Type, British.

Fields, banks, waste places, \&c.; common. Fl. July.

Sea-level in N. Antrim and S. Cork. To $800 \mathrm{ft}$. in Dublin (N. C.).

\section{A. pungens Rom. \& Schult.}

Triticum pungens Pers.

Districts - II. - IV. V. - - - - - - Lat. $52^{\circ}-53 \frac{1}{2}^{\circ}$. South and East coasts.

Seashores; probably not infrequent. Fl. July-A ugust.

II. Little Island, Cork Harbour, 1891; Phillips. Waterford: Babington in Herb.-IV. Sea wall north of Wexford Harbour: Marshall 1896. Frequent on the Murrough of Wicklow: Rec. Add.-V. On the shore near Rush, a large form which has been cultivated for many years in the Botanic Gardens, Glasnevin, under the name Triticum Moorei: Rec. Add. 
There are but few trustworthy records available for this critical plant (A.pungens) which may be expected to occur all round the Irish coasts.

A. acutum Rœm. \& Schult.

Triticum acutum DC.

Districts I. II. - IV. V. - - - IX. - XI. XII. Lat. $521^{\circ}-55^{\circ}$. From South to North.

Sandy seashores; frequent. Fl. July-August.

A large and very glaucous form grows on the Murrough of Wicklow and at the mouth of the Boyne, near Drogheda: $C y b$.

3. A. junceum Beauv.-Sea Wheat-Grass.

Triticum junceum Linn.

Districts I. II. - IV. V. VI. - VIII. IX. - XI. XII. Lat. $511^{\circ}-55 \frac{1}{4}^{\circ}$. Coasts of all Ireland. Type, British.

Sandy seashores; frequent and locally abundant. Fl. JulyAugust.

\section{LEPTURUS R. Br.}

\section{L. filiformis Trin.-Sea Hard-Grass.}

Rotbocllia fliformis Roth.

Districts I. II. - IV. V. VI. - VIII. IX, X. XI. XII. Lat. $51 \frac{1}{2}^{\circ}-55 \frac{1}{4}^{\circ}$. Coasts of all Ireland. Type, English.

Salt marshes and waste ground near the sea; not infrequent. Fl. July-August.

\section{NARDUS Linn.}

1. N. stricta Linn.-Mat Grass.

Districts I. II. III. IV. V. VI. VII. VIII. IX. X. XI. XII. Lat. $51 \frac{1}{2}^{\circ}-551^{\circ}$. Throughout Ireland. Type, British-English.

Heaths, moors, and mountains; frequent. Fl. June-July. Calcifuge $A$.

Sea-level in N. Donegal and N. Kerry. To $2449 \mathrm{ft}$. in Down (S. \& P.); to $2680 \mathrm{ft}$. in Mayo (Hart); to $2650 \mathrm{ft}$. in Wicklow (N.C.); to $3200 \mathrm{ft}$. in Kerry (More). 


\section{HORDEUM Linn.}

\section{H. secalinum Schreb.-Meadow Barley.}

H. pratense Huds.

Districts I. II. III. IV. V. VI. - - - X. - XII. Lat. $52^{\circ}-54 \frac{3}{4}^{\circ}$. Chiefly in the South. Type, English.

Wet meadows and banks, usually near the sea; rare and local. Fl. June-July.

I. Marshes below Douglas: Flor. Cork. Blackrock end of Cork Park: Phillips 1895.-II. Roadside near Brickfields, Cork (Drummond); and marsh next the Little Island bridge, Cork (MFr. Alexander): Flor. Cork. Still in the latter station: Phillips 1895. Marsh under Blenheim Hill, Waterford; and-III. Ballinlaw Ferry, River Barrow: B.-H. \& G. I889. Embankment and fields by the Nore between Woodstock and Ballyneale: Hart I885 8 .-IV. Murrough of Wicklow (Moore): Cyb. Frequent about Kilmanock, \&c., Wexford : B.-H. \& G. $1889 .-\mathrm{V}$. Meadows about Dublin: Flor. Hib. By the canal towards Castlenock (J. White): fields at Glasnevin and Portmarnock (Moore): Cyb. Abundant at Broad Meadow, north of Swords, 1891 ; Barrington.VI. Meadows near Limerick (Carroll): Rec. Add. Abundant in a salt marsh at Ringmoylan, Co. Limerick: Stewart 1890.X. Tartaraghan, Armagh (Rev. G. Robinson): Herb. Stewart.XII. Meadows near Connswater, Down; and roadside near Whitehouse, Antrim: Templeton IIS. Ditch bank near Whitehouse, 1869 (J. MacMillan); by Springfield road near Forth River kridge, 1866-1886 (Stewart): Flor. N.-E.

\section{2. † H. murinum Linn.-Wall Barley.}

Districts I. II. III. IV. V. VI. - - IX. - - [XII.] Lat. $51 \frac{3}{4}^{\circ}-53 \frac{1}{2}^{\circ}$. South and East, chiefly. Type, English-British. Lowland. Waste ground, waysides, walls, \&c.; rare. Fl. June-August.

I. On a wall near Douglas bridge (D. Murray): Flor. Cork.II. At Haulbowline, Cork, on rocks, but very rare (J. Sullivan): $C y b$. Abundant on rocks at Haulbowline, and plentiful at Fort Carlisle, Cork Harbour: Phillips z 895. Near Clonmel, sparingly (Moore): Cyb.-III. On the walls of the old church at Gowran, Kilkenny, 1896; Rev. E. Hewson.-IV. Murrough of Wicklow 
(Moore): Cyb. At Bray; More.-V. Sides of the highway and walls leading to Bagotrath: Threlkeld. Walls, paths, almost everywhere: Wade Dubl. Shore at Swords and Rush (Moore); Killiney (More): Cyb. Lucan; Skerries; Balbriggan, \&c. ; frequent in the eastern parts of county Dublin; N.C. Carlingford Castle walls (Hyndman): Flor. Ulst.-VI. Under walls at Ballinasloe; and-IX. At Athlone (F.J. Foot) : Cyb.-[XII. Garron Point, Antrim, 1861 (Rev. H. W. Lett) : S.\&. P. I895.]

Far more abundant in the county of Dublin than elsewhere in Ireland.

\section{ELYMUS Linn.}

1. E. arenarius Linn.-Sea Lyme-Grass.

Districts - - IV. V. - - - IX. - XI. Lat. $521^{\circ}-551^{\circ}$. South-East and North-West, chiefly. Type, Scottish-British.

Sandy seashores; rare and local. Fl. July.

IV. Curracloa, Wexford (Carroll): Cyb. Raven Point, Wexford: Hart I88 $\mathrm{x}$ a. Rosslare Point and Greenore Point, Wexford; not looking native: Hart $1883 \beta$. Several places on north and south sides of Wexford Harbour: Marshall I896.- $\nabla$. Skerries, Co. Dublin (Hart) : Journ. of Bot. 1883, p. 246.-IX. Mullaghmore (Admiral Jones): Cyb. Coast between Ballyshannon and Sligo; and-XI. On Aranmore Island, Donegal: Murphy $5820-$ still there in $1879:$ Hart $I 88 \mathrm{I}$. On the sea sands in many places in Donegal (Admiral Jones): Cyb. Sand-hills at Horn Head and north of Inishowen Head: Flor. Olst. Inishowen Head; Rinn of the Largy, and a little west of it near Killybegs : Hart $2883 \&$ I $885 \mathrm{\gamma}$.

Also recorded for Districts I. and II. from the western extremity of Bere (Flor. Hib.) and Ballycotton (Flor. Cork), but probably in error for Psamma arenaria. 


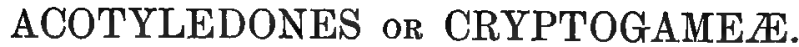

\section{ORDER LXXVIII.-FIIICES.}

\section{HYMENOPHYLLUM Smith.}

\section{H. tunbrigense Smith-Tunbridge Filmy-Fern.}

Districts I. II. III. IV. V. VI. VII. VIII. IX. X. XI. XII. Lat. $511_{2}^{\circ}-55^{\circ}$. Throughout Ireland. Type, Atlantic.

Damp rocks, tree trunks, \&c.; local and rather rare. Frt. July-October.

I. Frequent and locally abundant in Kerry, as about Killarney; Sneem; Dereen, \&c.; R.W.S. At Ballinhassig, Cork (Drummond): Flor. Cork. On Priest Leap Mountain (Carroll); near Ardgroom (More); at Killinear, Bandon (R. L. Allman): Allin's Cork. Near Ballydehob, 1897 ; Phillips.-II. Glenbower, Cork, in great luxuriance: Flor. Cork. Mountains near Millstreet: Allin's Cork. Glandine and Portlaw, and abundant in Curraghmore wood, Waterford: Kinahan 1858. On Galtymore, Tipperary: Hart 1881.-III. Rocks near Brandondale, Kilkenny; Miss $E$. M. Farmer.-IV. Near Belmont, Wexford; G. Barrett-Hamitton. Taragh Hill near Courtown, Wexford (H. G. Cuthlert): Ir. Nat. I892.-V. Glen on Ferry Hill above Narrow-water: Praeger 1893.-VI. Near Ennis, Clare: Corry 1880. Glenstal, Limerick: Hart I 881 \%.-VII. On conglomerate rocks in the neighbourhood of Longford: Foot. I865.-VIII. By a lake shore, west of Half-Way House, Connemara: Graham 1840. Killaguile mountain, Galway; Miss M. F. Jackson.-IX. South side of Lough Gill, Sligo: Foot 1865.-X. Glen between Aughnacloy and Clogher, Tyrone ( $E$. Waller); mountains near Florence Court (Rev. S. A. Brenan): Rec. Add.-XI. By the lake in Glenveagh: Hart 1879.XII. Glendun, Antrim (Rev. S. A. Brenan): Flor. N.-E.

Sea-level in S. Kerry. To $1430 \mathrm{ft}$. in Mayo, and to $2500 \mathrm{ft}$. in Tipperary (Hart). 
Chiefly southern and south-western in its Irish distribution, becoming very rare towards the North and East. In the extreme North the only stations known are those in Glenveagh and Glendun.

First recorded by Wade, from Killarney, in 1804.

\section{H. unilaterale Bory-Witson's Filmy-Fern.}

H. Wilsoni Hook.

Districts I. II. III. IV. V. VI. - VIII. IX. X. XI. XII. Lat. $51_{\frac{1}{2}}^{\circ}-55 \frac{1}{4}^{\circ}$. Throughout Ireland, probably. Type, AtlanticHighland.

Damp rocks and mossy trunks of trees; frequent. Frt. JulyOctober.

Descends to about $300 \mathrm{ft}$. in N. Antrim (Rev. C. F. d'Aroy). Ascends to $2200 \mathrm{ft}$. in Donegal, to $2700 \mathrm{ft}$. in Wicklow, and to 3300 ft. in Kerry (Hart).

\section{TRICHOMANES Linn.}

1. T. radicans Swartz-Bristle Fern; Killarney Fern.

Districts I. II. - IV. - VI. VII. - - X. XI. -

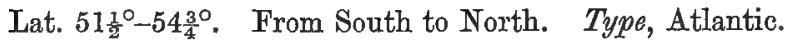

Damp shady rocks and along mountain streams; very local and now very rare. Frt. August-October.

I. Near the waterfall between Mangerton and Turk mountains, 1804: Mack. Rar. Abundant on Turk mountain: Kinahan 1858 . By the lake at Waterville: Babington in Herb. Glouin [Glen] Caragh (Mr. Andrews); Mount Eagle near Dingle (Mr. Moore); Gortagaree between Killarney and Kenmare (Dr. Taylor) : Newman 1844. Near Lough Brin and under Brandon Peak, 1885; Rev. C. F. d'Aroy. Seen on Ture as late as 1889 , but seems to have been nearly, if not quite, exterminated in the districts of Killarney and the Reeks; $R . W$. S. On the Clashgariffe river, Cork: Drummond 1820. On the banks of several of the lakes near Bantry (Babington); near Glandore (G.J.Allman): Flor. Cork. Near Bandon: Newman 1844. Caher mountain near Glengariff ( $F . J$. Hanbury); in Keiman-Eigh Pass, and near Gouganebarra (Mr. Barrett); Mrros wood (C. Donovan): Allin's Cork. Sparingly on two mountains near Adrigole: Phillips 1894.-II. Near the summit of Carrigeena, Kildorrery, north of Cork: Carroll I854. Glenbower, Killeagh (J. A. Fisher) : Newman 1844. Glendine wood, Waterford (Mr. 
Ball): Newman 1840. Templemichael Glen (D. Murray): Flor. Cork. In the valley of the Blackwater, Waterford: Kinahan 1858-now extinct in most of the above localities.-IV. Near the Waterfall, Co. Wicklow (Dr. Stokes): Mack. Rar. Hermitage Glen, Wicklow (John Nuttal): Mack. Cat.-now probably extinct in Co. Wicklow.-VI. Glenstal, Barrington's Bridge, near the Keeper mountain, Limerick (G. A. Pollock): Phytol. 1852, p. 724 . On the banks of the Clare river, three miles south of Newport, Tipperary (G. H. Kinahan): Cyb. Sparingly near Ennis, Clare: Corry 1880. Still near Glenstal in Co. Limerick; and-VII. Extending to two stations in Co. Tipperary (C. B. Barrington): Hart I88I $\gamma .-X$. Within five miles of Strabane, Tyrone, sparingly (G.J. Delap) : Journ. of Bot. I892, p. I21.-XI. In a valley in north-west Donegal (Pierce Mahony): Journ. of Bot. I884, p. 230. Ardnamona, Lough Eske, Donegal; very rare: Hart $1885 \gamma$.

Sea-level in S. Cork. To $1000 \mathrm{ft}$. in N. Cork (Carroll); to 800 ft. on Brandon (N. C.).

First found by Dr. Stokes, at Powerscourt Waterfall, before 1804.

Formerly abundant in parts of Kerry, but now become very rare there, and is most probably exterminated in many of the localities given above.

Var. Andokwstr Newm.-I. Glouin [Glen] Caragh, Kerry ( $\mathbb{M r}$. Andrews): Newman I844. Near Killarney (Carroll): Cyb.-now extinct in both of these stations.

\section{ADIANTUM Linn.}

1. A. Capillus-Veneris Linn.-Maiden-hair.

Hibernicé Oub copać (Dhoo-hoosuck), Black-foot.

Districts - - - - VI. - VIII. IX. - XI. Lat. $53^{\circ}-54_{4}^{3 \circ}$. West Ireland. Type, Atlantic.

Moist rocks, chiefly near the coast; very rare. Frt. JulyOctober. Calcicole $B$.

VI. "In the Isle of Aran near Galloway we found a great plenty of the Adiantum verum" (Lhwyd): Phil. Trans. vol. 27, p. 524. Now become rare in Aranmore Island, but frequent in Inishmaan and Inisheer in $1892 ; N . C$. South of Black Head; at Ballyalaban; at Muckinish; at Pouldoody Creek; near Finnavara, and other stations in Burren, Clare: Foot 1864. Near Lisdoonvarna (Rev. T. Warren): Cyb. Appears to be now rather rare round Ballyvaughan, but occurs in some quantity at Black Head 
and at Muckinish Lake, 1895 ; N.C.-VIII. At Lough Bulard near Urrisbeg, Connemara: Babington 1836-still there in 1893 (Prof. T. Johnson) : Ir. Nat. 1893. Hill near Sheffey, five miles from Killary Harbour (G. H. Kinahan): Rec. Add. Cliff on northwest side of Achill Island, Mayo (Mrs. Boycatt): More 2873 \& Hart I883.- IX. At Glencar, Leitrim, and within four miles of the town of Sligo ( $J$. Wynne): Cyb. Sparingly at Glencar in 1884: B.\&.T. I885. Banks of a river near Dromore West, Sligo, 1891 ; $R$. Warren. Back Rosses and coast near Grange, Sligo; Mrs. Yeates. Shore at Drumcliff, Sligo; Miss M'Munn.-XI. In one place on the cliffs of Slieve League ( $\left.L . O^{\prime} B r i e n\right): R e c . A d d$. Slieve League, and several places to the south of it: Hart I885 $\gamma$.

Also recorded for District I.- "On the Cahirconree range between Tralee and Dingle, Kerry" ( $W$. Andrews): Cyb. The plant has not since been observed there, though repeatedly sought for, and it is to be feared that the record is erroneous.

From sea-level to $800 \mathrm{ft}$. in Clare $(F o o t)$. To $700 \mathrm{ft}$. on Ben Bulben (B.\&V.).

First found by Lhwyd, in the Aran Islands, not later than 1699.

\section{PTERIS Linn.}

\section{P. aquilina Linn.-Common Brake; Bracken.}

Hibernicé Raı̇̇neać (Rāhen-yaok).

Districts I. II. III. IV. V. VI. VII. VIII. IX. X. XI. XII. Lat. $51 \frac{1}{2}^{\circ}-55 \frac{1}{4}^{\circ}$. Throughout Ireland. Type, British.

Heaths, woods, sandy sea-shores, \&c.; very common. Frt. JulyOctober. Calcifuge $B$.

Sea-level in N. Antrim and S. Cork. To $800 \mathrm{ft}$. in Donegal (Hart); to $1400 \mathrm{ft}$. in Down (S.\&P.); to $1750 \mathrm{ft}$. in Dublin and Wicklow $(N . C$.$) ; to 1700 \mathrm{ft}$. in Kerry (Hart).

\section{CRYPTOGRAMME R. Br.}

\section{C. crispa R. Br.-Parsley Fern.}

Allosorus crispus Bernh.

Districts - - - V. - - - X. XI. XII. Lat. $54^{\circ}-55 \frac{1}{4}^{\circ}$. North Ireland, chiefly. Type, Highland.

Stony places on mountains; very rare. Frt. July-September. V. On Carlingford mountain, Louth, 1836: Neroman I844 \& 
B. N. F.C. Proc. 7878 . - X. On the east side of Caulteach [Cuilcagh] mountain near Florencecourt, sparingly (J. McDonald): $C y b$. XI. Mountain near Ardara, very sparingly: Hart I886.XII. Slieve Bingian, Kilkeel, 1808 (Templeton, Stokes \& Mackay) : Herb. Belf. Mus. Re-found recently on Slieve Bingian (Rev. H. W. Lett \& Praeger): Flor. N.-E. Plentiful on the Mourne mountains: Mack. Cat. 1825. Cliffs between Cove and Commedagh mountains, and south-east of Blue Lough, Down (Praeger): Flor. $N$.-E. Shanlieve; Slievenabrock; and north side of Donard, Down (Rev. H.W. Lett) : B. N. F.C. Proc. 1885-86. Now become very rare in the Mourne mountains and found on granite only: S. \&P. 1892 and 1895 . On Slievenanee, Antrim: Flor. Ulst. 2864 -still there in 1884 (Rev. S. A. Brenan) : Flor. N.-E. On Clontygeragh mountain, Derry: Moore MS. In the liberties of Carrickfergus (Moore): Newman 1840. On the north side of Knocklayd near Ballycastle, Antrim (Moore): Cyb. Among fallen rocks below Fair Head, Antrim, 1897 ; Rev. C. F. d'Aroy.

From about $300 \mathrm{ft}$. in Antrim (Rev.C. F. d'Arcy) to $750 \mathrm{ft}$. in Donegal (Hart); to $1700 \mathrm{ft}$. in Down (S.\& P.).

First found by Templeton, Stokes, and Mackay, on Slieve Bingian, in 1808.

\section{BLECHNUM Linn.}

\section{B. Spicant Roth-Hard Fern.}

$B$. boreale Swartz-Lomaria Spicant Desv.

Districts I: II. III. IV. V. VI. VII. VIII. IX. X. XI. XII. Lat. $51 \frac{1}{2}^{\circ}-55 \frac{1}{4}^{\circ}$. Throughout Ireland. Type, British.

Woods, banks, heaths, \&c.; common. Frt. July-October. Calcifuge $\mathcal{A}$.

To sea-level in Derry and in S. Cork. To $2150 \mathrm{ft}$. in Donegal (Hart); to $2400 \mathrm{ft}$. in Down (S.\& P.); to $3000 \mathrm{ft}$. in Wicklow (N. C.); to $2550 \mathrm{ft}$. in Tipperary, and to $3150 \mathrm{ft}$. in Kerry (Hart).

\section{ASPLENIUM Linn.}

1. A. lanceolatum Huds.-Hudson's Spleenwort.

Districts I. II. - - - - - - - - - Lat. $51 \frac{1}{2}^{\circ}-52 \frac{1}{4}^{\circ}$. Cork and Kerry only. Type, Atlantic.

Lowland. Banks and walls, usually near the sea; very local and rare. Frt. July-October. 
I. Near the village of Camp, Tralee Bay, Kerry (R.W.S.): Journ. of Bot. 1893, p. 20. Near Kinsale, Cork (J. Woods): Phytol. 1855, p. 122. On both sides of the town of Kinsale (Carroll): Cyb. Still plentiful at Kinsale in 1893; on banks and walls near Adrigole, 1894 ; near South Harbour, Cape Clear Island, 1896 ; near Ballingeary, 1897 ; Phillips. In small quantity west of Bandon, 1880 (C. Longfield): Allin's Cork \& Herb. T.C.D.II. Near Coachford, Macroom, 1878 (Rev. T. H. Jellett): Herb. T.C.D. - and in 1897 ; Phillips.

First found in Ireland, at Kinsale, by J. Woods in 1855.

2. A. Adiantum-nigrum Linn.-Black Spleenwort.

Districts I. II. III. IV. V. VI. VII. VIII. IX. X. XI. XII. Lat. $51 \frac{1}{2}^{\circ}-55 \frac{1}{4}^{\circ}$. Throughout Ireland. Type, British.

Rocks, walls, and banks ; frequent. Frt. July-October.

Sea-level in N. Derry and S. Cork. To $1600 \mathrm{ft}$. in Derry (Moore MS.) and in Down (S.\& P.); to $1500 \mathrm{ft}$. in Kerry (Hart).

Var. ACUTUM (Bory)-I. On limestone rocks at Muckross, 1805 (Mrackay); Cahirconree mountain (W. Andrews): Flor. Hib. Turc mountain and Purple mountain (J.R.\&G. H. Kinahan): $C y b$. Caragh Lake, Kerry; Miss Battersby. Union Hall; Lough Hyne: Allin's Cork. Three miles from Cork on the Kinsale road; Phillips. Inishannon (T. Chandlee); and-II. Aghada, Cork (Carroll): Cyb. Garrycloyne (F. Townsend): Allin's Cork.IV. Dunran wood near Newtownmountkennedy, Wicklow (D. Orr): $C y b$. - still there, but almost exterminated in $1886 ; R$. P. Vowell.VI. By the Shannon near Foynes (Miss G. C. O'Brien): Ree. Add. - VIII. Frequent in Connemara and south-west Mayo (G. H. Kinahan): Ree. Add.-IX. Between Cross and Kilmain, and near the Rectory, Cong, Co. Mayo; Miss M. F. Jackson.XII. Sparingly on a hedge bank near Newtownards, Down (Praeger): Flor. N.-E.

First noticed as a variety by Mackay in 1805 .

\section{A. marinum Linn.-Sea Spleenwort.}

Districts I. II. III. IV. V. VI. - VIII. IX. - XI. XII. Lat. $51 \frac{1}{2}^{\circ}-55 \frac{1}{4}^{\circ}$. Coasts of all Ireland. Type, British-Atlantic.

Sea cliffs ; frequent. Frt. July-October.

Ascends to $500 \mathrm{ft}$. on sea cliffs in Kerry (Kinahan).

Occurs very rarely at some distance inland, as-I. Under Turk 
mountain on the way from Killarney towards Kenmare: Newman 1840-still in this locality, which is beside the Upper Lake, in $1894 ; R . W . S .-I I I$. On the estuary of the River Suir near Snow Hill, Kilkenny ; Barrett-Hamilton.

\section{A. viride Huds.-Green-stalled Spleenwort.}

Districts I. II. ---- VIII. IX. X. XI. Lat. $51 \frac{3}{4}^{\circ}-55^{\circ}$. West of Ireland. Type, Highland.

Mountain cliffs; local. Frt. July-October.

I. About Killarney; Dunkerron, \&c.: Smith's Kerry. Turc mountain, Killarney; and on M'Gillicuddy's Reeks, 1805: Mack Rar. Common on the higher parts of the Reeks : Hart I882. On Mangerton and on Brandon mountain (Carroll): Cyb. On the Iveragh mountains, Kerry (Moore): Cyb.-and in $1892 ; N . C . \&$ R.W.S. On Hungry Hill, Cork, sparingly (Drummond): Flor. Cork.-II. Rocks above Gurthaveha Lake, Millstreet (More): Ree. Add. On an old bridge on the Co. Waterford side of the Knockmealedown mountains, 1894; Miss M. Chearnley. Abundant on Galtymore, Tipperary (Moore): Cyb.-and in 1880: Hart 7881 .VIII. On Ben Lettery, Connemara (Carroll): Cyb. - still there in 1882, also on Muckanaght, Galway, and on Croagh Patrick, Mayo: Hart 1883 a. Lissoughter; Glenlosh; and Bengower, Galway; and south-west of Dromin Chapel, Mayo (G.H. Kinahan): Rec. Add.-IX. On Ben Bulben, Sligo: Mack. Rar. Glenade, Leitrim (Admiral Jones): Cyb. Abundant on many of the cliffs in Ben Bulben district: B.\&V. I885. On Kesh Corran, Sligo (Foot): Cyb.-X. Mountain near Florence court (T. Plunkett): Phillips \& Praeger 1887.-XI. On the Donegal mountains near Lough Eske (E. Murphy): Flor. Hib. \& Cyb. On the north side of Slieve League (H.W.D. Dunlop) : Ree. Add. On Muckish, and on Lough Salt mountain, Donegal : Hart I879.

From 700 to $1600 \mathrm{ft}$. in Donegal (Hart) and in Sligo (B.\&V.); 1470-1900 ft. in Galway, and 1850-3150 ft. in Kerry (Hart).

\section{A. Trichomanes Linn.-Black Maiden-hair.}

Districts I. II. III. IV. V. VI. VII, VIII. IX. X. XI. XII. Lat. $51 \frac{1}{2}^{\circ}-55 \frac{1}{4}^{\circ}$ Throughout Ireland. Type, British.

Rocks, walls, and banks; frequent. Frt. July-October.

Sea-level in N. Derry and S. Cork. To $1800 \mathrm{ft}$. in Donegal, and to $2850 \mathrm{ft}$. in Kerry (Hart). 


\section{A. Ruta-muraria Linn.-Wall Rue.}

Districts I. II. III. IV. V. VI. VII. VIII. IX. X. XI. XII. Lat. $51 \frac{1}{2}^{\circ}-55 \frac{1}{4}$. Throughout Ireland. Type, British.

Old walls and on rocks; common. Frt. July-October.

Sea-level in Antrim and S. Cork. To $1150 \mathrm{ft}$. in Derry (Hart); to $1450 \mathrm{ft}$. on Ben Bulben $\left(B . \& V_{\text {. }}\right)$.

\section{ATHYRIUM Roth.}

\section{A. Filix-fœmina Roth-Lady Fern.}

Asplenium Filix-foemina Bernh.

Districts I. II. III. IV. V. VI. VII. VIII. IX. X. XI. XII. Lat. $51 \frac{1}{2}^{\circ}-55 \frac{1}{4}^{\circ}$. Throughout Ireland. Type, British.

On moors, by streams, in wet places, \&c.; common. Frt. JulySeptember. Calcifuge $A$.

Sea-level in Derry and Cork. To $1600 \mathrm{ft.}$ in Donegal (Hart); to $2449 \mathrm{ft}$. in Down (S.\&.P.); and to $2650 \mathrm{ft}$. in Kerry (Hart).

\section{CETERACH Willd.}

\section{C. officinarum Willd.-Scaly Fern.}

Asplenium Ceterach Linn.

Districts I. II. III. IV. V. VI. VII. VIII. IX. X. XI. XII. Lat. $51 \frac{1}{2}^{\circ}-55^{\circ}$. Throughout Ireland. Type, English.

On rocks and old walls; frequent and locally abundant. Frt. July-October. Calcicole $B$.

Sea-level to $600 \mathrm{ft}$. in Dublin, and sea-level to $1000 \mathrm{ft}$. in Clare (N.C.).

Far more abundant on limestone in the West than elsewhere; quite rare in the extreme North. The Var. Crenatum Milde appears to be the prevailing form in the Midlands and in the West and North.

\section{SCOLOPENDRIUM Smith.}

\section{S. vulgare Smith-Hart's-tongue.}

Hibernicé Cpeam mulce plä (Cray mickè feeä), Wild Pig's Garlic. Districts I. II. III. IV. V. VI. VII. VIII. IX. X. XI. XII. Lat. $51 \frac{1}{2}^{\circ}-551^{\circ}$. Throughout Ireland. Type, British-English.

Banlss, rocks, and damp shady places; common. Frt. July-Oct. 
Sea-level in N. Derry and S. Cork. To $1200 \mathrm{ft}$. in Derry (Flor. $N .-E$.) ; to $1400 \mathrm{ft}$. in Tipperary (Hart).

This species is especially abundant on the limestone of the Burren district where many of the more striking varieties occur.

\section{CYSTOPTERIS Bernh.}

\section{C. fragilis Bernh.-Brittle Fern.}

Districts I. II. III. IV. V. VI. VII. VIII. IX. X. XI. XII. Lat. $52^{\circ}-55 \frac{1}{4}^{\circ}$. Throughout Ireland. Type, British-Highland.

Damp rocks, and on walls; local. Frt. July-October.

I. Common on the Kerry mountains; $R$.W. S. At Glengariff (Miss A. Taylor): Allin's Cork.-II. Near Millstreet, Cork (More); Dunmore East, Waterford (H. Fitzsimons): Rec. Add. Cliffs above Coumshingan Lake in the Commeraghs: Hart 1884. On Galtymore, Tipperary : Hart $188 \%$.-III. By the Barrow on the flanks of the Slieve Bloom mountains: Hart 1885.-IV. Near Maulin mountain, Wicklow ( $W$. Archer) : Cyb.-V. Abundant on the Barrow bridge at Monasterevan (Mrs. Cooke Trench): Rec. Add. \& Hart 1885 . - VI. Abundant on the limestone in Burren and in part of Galway (More) : Cyb.-VII. Near Ballymore, Westmeath (Foot) : Cyb. Sparingly on Keeper mountain : Hart 1881 \%.VIII. Connemara: Newman I840. Twelve Bens and Maam Turk, Galway : Hart 1883 a. Near Cong, both in Galway, and-IX. In Mayo: M.\&S. 1896 . Common all over the mountains in Ben Bulben district: $B . \& V . \quad 1885$. Abundant in several parts of Roscommon: Foot 1865.-X. Dart mountain, Tyrone (Admiral Jones): Cyb. Common in the mountainous part of Cavan and Fermanagh : Stewart $1882 .-\mathrm{XI}$. Very local in Donegal, but occurs near Lough Belshade; at Moynalt; near Ardara, \&c.: Hart r88 $\mathrm{I}$ \& $\mathrm{r} 886$. - XII. Locally abundant, occurring in Down, Antrim, and Derry: Flor. N.-E.\& S.\&P. 1895 .

To $1800 \mathrm{ft}$. in Donegal (Hart); 800-2000 ft. in Down (S.\&P.); 1100-2400 ft. in Mayo (Hart); sea-level (R.W.S.) to $3150 \mathrm{ft}$. in Kerry (Hart).

Abundant on limestone in many parts of the West, local in the East and South, and very rare in Cork.

Var. DENTATA Hook.-I. Brandon mountain, Kerry (Rev.W. M. Hind): Cyb.\& Linton 1886.-X. Frequent, with the type, in Cavan and Fermanagh, west of Lough Erne: Stewart 1882.-XII. Head. of Glenariff, Antrim; Moore. 


\section{ASPIDIUM Swartz.}

\section{A. Lonchitis Swartz-Holly Fern.}

Polystichum Lonohitis Roth.

Districts I. - - - - - VIII. IX. - XI. Lat. $52^{\circ}-54 \frac{3}{4}^{\circ}$. West and North-West. Type, Highland.

On mountain cliffs; very rare and local. Frt. AugustOctober.

I. Moist rocks in "Horse's Glen," Mangerton : Carroll 1857still there sparingly in 1888: R.W. S. 1889 . On Brandon Hill (S. P. Woodward) : Newman 1844-and in 1883: Hart 2884. Cliffs above Lough Goagh, Macgillicuddy's Reeks: Hart 1882. Mullaghanattin mountain, Glencar, Kerry, 1885 ; Rev. W. Colgan.-VIII. Muckanaght, Twelve Bens, Galway : Hart I883 $\alpha$.-IX. On Ben Bulben and other mountains in Sligo; on Glenade mountain, Leitrim: Murphy I829. Rare on Ben Bulben, but common on parts of Glenade, \&c.: B.\&V. $2885 .-\mathrm{XI}$. On Slieve League, Donegal : Hart $x 885 \gamma$.

From 1470 to $1850 \mathrm{ft}$. in Donegal (Hart); $1150-1600 \mathrm{ft}$. on Ben Bulben $\left(B . \& V_{0}\right)$; at $1200 \mathrm{ft}$. in Galway, and 2000-2800 ft. in Kerry (Hart).

First found by Edmund Murphy, on Ben Bulben, in 1826.

\section{A. aculeatum Swartz-Stiff Prickly Fern.}

Polystichum aculeatum Roth.

Districts I. II. III. IV. V. VI. VII. VIII. IX. X. XI. XII. Lat. $51 \frac{1}{2}^{\circ}-55 \frac{1}{4}^{\circ}$. Throughout Ireland. Type, British.

Banks, rocks, and stony places; not infrequent, but local. Frt. July-October.

Sea-level in Antrim and S. Cork. To $950 \mathrm{ft}$. in Donegal, $1500 \mathrm{ft}$. in Galway, and $2470 \mathrm{ft}$. in Kerry ( Hart).

Far. LOBatum (Swarts)-Polystichum lobatum Presl-I. and II. Stated by Carroll to be the usual form in Cork: Allin's Cork.VI. Abundant in Burren: Foot 1864.-VIII. Muckanaght and Maumeen, Galway: Hart 1883 a.-XI. Blue Stack mountains, Donegal (Hart): Journ. of Bot. I882.-XII. Occurs in the NorthEast (Flor. N.-E.), but no localities given.

Not often separated from $A$, aouleatum, and probably not infrequent in Ireland. 


\section{A. angulare Kit.-Soft Prickly Fern.}

Polystichum angulare Presl.

Districts I. II. III. IV. V. VI. VII. VIII. IX. X. XI. XII. Lat. $51 \frac{1}{2}^{\circ}-551^{\circ}$. Throughout Ireland. Type, English.

Woods, shady banks, \&c. ; frequent. Frt. July-October.

To $800 \mathrm{ft}$. in Dublin $\left(N . C_{.}\right)$; but usually lowland.

\section{LASTR Aa Presl.}

\section{I. Thelypteris Presl-Marsh Fern.}

Polystichum Thelypteris Roth.

Districts I. - - IV. V. VI. VII. VIII. IX. X. XI. XII. Lat. $52^{\circ}-54 \frac{3}{4}^{\circ}$. West and North, chiefly. Type, English.

Lowland. Wet places; rare and local. Frt. July-September.

I. Between Muckross House and the Mines: Mack. Rar. Ross Island, Killarney (Moore) : Cyb. Near the Upper Lake, Killarney; and still abundant in Mackay's and Moore's statioris: R.W.S. $1889 .-$ IV. Marshes in Glencree, Wicklow : Mack. Cat.-V. At Lullybeg, Co. Kildare (Mrs. Cooke Trench); at Drumconrath, Meath (Rev. S. A. Brenan): Rec. Add.-VI. By the river Fergus near Ennis, Clare: Mack. Rar. On the "Hunting Course" field at Castle Taylor, Galway: More I885\& Cyb. -still there, 1896; Miss $M$. F. Jackson. In the demesne at Portumna, and by Lough Derg, further south (Moore): Phytol. 1845, p. 130.-VII. Lisclogher bog, Westmeath (Miss E. Reynell): Cyb.-still there, and in - Quarry bog near Lough Drin: Levinge I894. Rockingham, Roscommon (Moore): Rec. Add.-VIII. Near Moore Hall, Lough Carra, Mayo (J. Ball) : Cyb.-IX. Lake View (Cloonee), Lough Carra, Mayo, 1896; Miss M. F. Jackson.-X. Near Belturbet, Cavan (Moore): Cyb. Near Caledon, Tyrone (E. Wallis): Rec. Add. At Omagh and Gorteen Gap, Tyrone (G. H. Kinahan): Phillips \& Praeger 1887.- XI. By the Erne a little way above Ballyshannon (More) : Cyb. Right bank of the Erne immediately below Belleek: Hart I886.-XII. Plentiful about Portmore Park and wood, 1794 (Templeton): Whitla MS. \& (Moore): Cyb. Banks of the Sixmilewater near Ballyclare, Antrim: Flor. Olst. Now destroyed by drainage operations in this district: S.\& P. 2895 .

First found in Ireland by John Templeton in 1794. 


\section{L. Oreopteris Presl-Sweet Mountain Fern.}

Aspidium Oreopteris Swartz-Nephrodium Oreopteris Desv. Districts I. II. III. IV. V. VI. VII. VIII. IX. X. XI. XII. Lat. $51_{\frac{3}{4}}^{\circ}-55 \frac{1^{\circ}}{4}$. Throughout Ireland. Type, British.

Meountains and moors; not infrequent, but local. Frt. JulySeptember. Calcifuge $B$.

From $20 \mathrm{ft}$. to $2000 \mathrm{ft}$. in Down (S. \& P.); from $50 \mathrm{ft}$. (R.W.S.) to $1600 \mathrm{ft}$. in Kerry (Druce I89I).

A very unequally distributed species, rare or absent over wide areas and chiefly confined to mountain districts.

\section{L. Filix-mas Presl-Male Fern.}

Polystichum Filix-mas Roth - Aspidium Filix-mas Swartz Nephrodium Fitix-mas Rich.

Districts I. II. III. IV. V. VI. VII. VIII. IX. X. XI. XII. Lat. $51 \frac{1}{2}{ }^{\circ}-55 \frac{1}{4}^{\circ}$. Throughout Ireland. Type, British.

Woods, banks, \&c. ; common. Frt. July-September.

Sea-level in N. Derry and S. Cork. To $1800 \mathrm{ft}$. in Donegal, to $2380 \mathrm{ft}$. in Mayo, to $2850 \mathrm{ft}$. in Tipperary, and to $3150 \mathrm{ft}$. in Kerry (Hart).

\section{L. spinulosa Presl-Lesser Broad Fern.}

Polystichum spinulosum DC. - Aspidium spinulosum Swartz Nephrodium spinulosum Desv.

Districts I. II. III. IV. V. VI. VII. VIII. IX. X. XI. XII. Lat. $51 \frac{1}{2}^{\circ}-55^{\circ}$. Throughout Ireland. Type, English-British.

Lowland. Woods and damp places; rare. Frt. July-September.

I. Killarney: T. Moore I855. Muckross, $1894 ;$ R.W.S. Near Cahirciveen, Co. of Kerry, 1856 ; and-II: Curraghmore, Portlaw, Co. Waterford: Kinahan 1858.-III. Woods south of Maryborough: Praeger 1897.-IV. Shillelagh, Co. Wicklow; A. Ellison.V. South of Thomastown, Kildare; bog between Athboy and Navan, \&c., Meath; and-VI. Abundant near Clonbrock, Galway : Praeger 7806 \& -97 . Bog drains, Annagh Inch, near Birr, Co. Tipperary: Kinahan 1858.-VII, Ladiston, Mullingar (Moore): Cyb. Quarry and Lisclogher bogs, Westmeath: Levinge 1894.VIII. Connemara: T. Moore I855. Drumman wood near Lough Cullen; and-IX. Holymount, Mayo (More); Hazelwood, Sligo, rare 
(J. Wynne): Cyb. Lough Arrow, Sligo; Praeger.-X. Near Verner's bridge, Tyrone; Mrs. Leebody. Dartry, Monaghan (Neroman): Cyb.-XI. Woods at Lough Eske, Donegal: Hart $1885 \%$.-XII. Frequent by the Roe near Dungiven, Derry: Moore MS. Bogs south of Kilrea, Derry (Praeger): S.\&P. 1895 .

\section{L. dilatata Presl-Broad Fern.}

Aspidium dilatatum Swartz-Nephrodium ditatatum Desv.

Districts I. II. III. IV, V. VI. VII. VIII. IX. X. XI. XII. Lat. $51 \frac{1}{2}^{\circ}-55 \frac{1}{4}^{\circ}$. Throughout Ireland. Type, British.

Woods, heaths, mountains, \&c.; common. Frt. July-September. Calcifuge $A$.

Sea-level in N. Derry and S. Cork. To $2150 \mathrm{ft}$. in Donegal (Hart); to $2449 \mathrm{ft}$. in Down (S.\&P.); to $2700 \mathrm{ft}$. in Wicklow (N.C.); to $2640 \mathrm{ft}$. in Mayo, and to $3000 \mathrm{ft}$. in Kerry (Hart).

\section{L. æmula Brackn.-Bree's Broad Fern.}

L. recurva Newm. - L. fenisecii Lowe - Nephrodium amulum Baker-Aspidium amulum Swartz.

Districts I. II. III. IV. V. VI. VII. VIII. IX. X. XI. XII. Lat. 51 ${ }^{\circ}-551_{4}^{\circ}$. Throughout Ireland. Type, Atlantic-British.

Woods and banks; frequent and locally abundant. Frt. JulySeptember.

From $100 \mathrm{ft}$. to $1430 \mathrm{ft}$. in Down $(S . \& P$.); to $2100 \mathrm{ft}$. in Kerry (Hart).

This is one of the plants most characteristic of the west of Ireland. In some of the shady thickets around Lough Corrib and about Killarney it may be seen to perfection attaining the height of nearly three feet $(C y b$.$) . Much rarer on the east side of Ireland$ than on the west.

\section{POLYPODIUM Linn.}

\section{P. vulgare Linn.-Polypody.}

Districts I. II. III. IV. V. VI. VII. VIII. IX. X. XI. XII. Lat. $51 \frac{1}{2}^{\circ}-55 \frac{1}{4}^{\circ}$. Throughout Ireland. Type, British.

Banks, walls, trunks of trees, \&c.; common. Frt. JulySeptember.

Sea-level in N. Donegal and S. Cork. To $1100 \mathrm{ft}$. in Donegal 2 \& 2 
(Hart); to $2449 \mathrm{ft}$. in Down (S. \& P.); to $2600 \mathrm{ft}$. in Wicklow, and to $2800 \mathrm{ft}$. in Kerry (N.C.).

The variety SERRATUM $W_{i} i l d$ : and other allied forms have been gathered in many localities in Cork, Kerry, Clare, Galway, Donegal, Wexford, Wicklow, Westmeath, and Antrim.

2. P. Dryopteris Linn.-Oak Fern.

Phegopteris Dryopteris Fée.

Districts - - - IV. - VI. - - IX. - - [XII.] Lat. $53^{\circ}-55 \frac{1}{4}^{\circ}$. Wicklow, Clare, Sligo, Leitrim [and Antrim]. Type, Scottish.

Rocky places on mountains; very rare. Frt. July-September.

IV. At Sheenabeg near Aughrim, Wicklow, very sparingly, 1879 ; G. H. Kinahan.-VI. Roadside between Broadford village and the cliffs of Moher, Clare; T. H. Wright.-IX. On Benbo mountain, near Manor Hamilton in Leitrim $(J . W y n n e): C y b$. Near Lough Talt on the Ox mountains, Sligo (R. Warren): Rec.Add.[XII. A single plant on the north side of Knocklayd mountain, Antrim (Moore): Newman $1840 \& C y b$. Probably extinct in this station: S.\&.P. r895.].

At $800 \mathrm{ft}$. in Leitrim ( Wynne); and about $1800 \mathrm{ft}$. in Antrim (Moore).

First found in Ireland by David Moore, on Knocklayd, about 1840.

\section{P. Phegopteris Linn.-Beech Fern.}

Phegopteris polypodioides Fóe.

Districts I. II. III. IV. V. VI. - VIII. IX. X. XI. XII. Lat. $51 \frac{3}{4}^{\circ}-55 \frac{1}{4}^{\circ}$. Throughout Ireland, almost. Type, ScottishBritish.

Wet rocks; not infrequent, but local. Frt. July-September.

I. Between Killarney and Kenmare, \&c. (Mr. Moore): Nevoman 1844. Near Glencar and in Glanbehy; Rev. C. F. d'Arcy. Mountains north of Sneem, \&c., Kerry; R.W. S. On Hungry Hill and in the Pass of Keim-an-Eigh (T. Wright): Cyb. Near Glengariff: Allin's Cork.-II. Rocks above Gurthaveha Lake, near Mill-street, Cork (Moore): Rec. Add.-III. Glendine Gap, Slieve Bloom, Queen's Co. ; Prasger.-IV. Powerscourt Waterfall, righthand side (M. J. O'Felly): Ir. Flor. Near Maulin mountain (W. Archer): Cyb. Near Lough Dan; on Lugnaquilla; and at Lugduff Prisons, Wicklow; Rev. C. F. d'Aroy.-V. Seecawn mountain, 
Glenasmole, Co. Dublin, 1883 (Rev. C.F. d'Arcy): N.C. I893. On Carlingford mountain, Louth: Wade Rar.-and in 1893: Ir. Nat. I893, p. 227.-VI. Slieve Callan, Clare (Foot); and in Glendree, south-west of Slieve Aughtra (G. H. Kinahan): Cyb.-IX. On Glenade, Leitrim, very rare (J. Wynne): Cyb.-X. Deer Park, Brookboro, Fermanagh (Rev. S. A. Brenan): Rec. Add. Woods near Killeavy Church, Armagh (Rev. H. W. Lett): Praeger $1893 .-$ VIII. XI. and XII. Not infrequent, occurring in sevaral stations in Galway, Mayo, Donegal, Down, Antrim, and Derry.

To $2100 \mathrm{ft}$. in Donegal (Hart); 800-2000 ft. in Down (S.\&P.); to $1700 \mathrm{ft}$. in Wicklow (N.C.); from $500 \mathrm{ft}$. (N.C.) to $1500 \mathrm{ft}$. in $\operatorname{Kerry}(R, W . S$.$) .$

OSMUNDA Linn.

\section{0. regalis Linn.-Royal Fern.}

Districts I. II. III. IV. V. VI. VII. VIII. IX, X, XI, XII. Lat. $511_{2}^{\circ}-55 \frac{1}{4}^{\circ}$. Throughout Ireland. Type, British.

Boggy places and by streams ; frequent and locally abundant in the West, rare in the East. Frt. July-September. Calcifuge $A$.

IV. In the Devil's Glen, and at the Rock of Arklow (Dr. Stokes): Mack. Rar. Arklow Head, and near Scarawalsh Bridge, Wexford: Hart I88I a. Plentiful by the lake at the Seven Churches : Mack. Cat. Above the Upper Lake, Glendalough, sparingly, $1888 ;$ N.C. Between Rathdrum and Laragh; and Annamoe river, 1884; Hart. On Lough Dan, Co. Wicklow: Newman 840 . Maulin mountain, Glencree; R. P. Vowell.-V. Kelly's Glen, Co. Dublin : Mack. Cat. Howth Head, very sparingly: Flor. Howth. Very sparingly south of Thomastown, Kildare: Praeger 1897. Abundant in a bog near Castlebellingham, Louth, $1895 ;$ N.C.

Sea-level in Antrim and in S. Cork. To $700 \mathrm{ft}$. in Donegal, $900 \mathrm{ft}$. in Mayo, and $1000 \mathrm{ft}$. in Waterford (Hart); to $920 \mathrm{ft}$. in $\operatorname{Kerry}(R . W . S$.$) .$

\section{OPHIOGLOSSUM Linn.}

\section{0. vulgatum Linn.-Adder's-tongue.}

Districts I. II. III. IV. V. VI. VII. VIII. IX. X. XI. XII. Lat. $51 \frac{1}{2}^{\circ}-55 \frac{1}{4}^{\circ}$. Throughout Ireland. Type, British.

Damp meadows and pastures; frequent. Frt. June-July.

Sea-level in N. Derry and in S. Kerry. To $700 \mathrm{ft.}$ in Donegal (Hart); to $1000 \mathrm{ft}$. in Dublin (N.C.). 
A peculiar dwarf form, for which the name Hartii has been proposed by the late A. G. More, has been found by Mr. H. C. Hart at-I. Deelick Point, Brandon Head; and on the Three Sisters Head, Dingle promontory, Kerry : Hart 1884 ; and-XI. On Carrigan Head, Slieve League; and on Horn Head, Donegal: Hart $1879 \&-85 \gamma$. This plant, which at first was taken to be var. PoLYPHYLLOM, flowers about the same time as the type, and may prove to be merely a form dwarfed by growth in exposed situation.

\section{BOTRYCHIUM Swartz.}

\section{B. Lunaria Swartz-Moon-wort.}

Districts I. II. III. IV. V. VI. VII. VIII. IX. X. XI. XII. Lat. $51 \frac{1}{2}-551^{\circ}$. Throughout Ireland. Type, British-Scottish.

Grassy places; not infrequent. Frt. May-July.

Sea-level in Antrim and S. Cork. To $1750 \mathrm{ft}$. in Derry (Hart); $1479 \mathrm{ft}$. in Dublin (N.C.); to $1500 \mathrm{ft}$. in Sligo (R.W. S.).

Widespread in Ireland, but much less abundant than the preceding species.

\section{ORDER LXXIX.-EQUISETACE无.}

EQUISETUM Linn.

1. E. maximum Lamk.-Great Horse-tail.

E. Telmateia Ehrh.

Districts I. II. III. IV. V. VI. VII. VIII. IX. X. XI. XII. Lat. $51^{\frac{3}{4}}-554^{\circ}$. Throughout Ireland. Type, English-British.

Wet banks, \&c. ; locally abundant. Frt. April.

Sea-level in Donegal and Kerry. To $850 \mathrm{ft}$. in Dublin ( $N . C_{\text {. }}$ ).

2. E. arvense Linn.-Field Horse-tait.

Districts I. II. III. IV. V. VI. VII. VIII. IX. X. XI. XII. Lat. 51 $1^{\circ}-55 \frac{1}{4}^{\circ}$. Throughout Ireland. Type, British.

Way sides, ditches, waste ground, \&c.; common. Frt. April.

Sea-level in N. Derry and S. Cork. To $1000 \mathrm{ft}$. in Derry (Hart); to $1100 \mathrm{ft}$. in Dublin (N. C.). 


\section{E. pratense Ehrh.-Blunt-topped Horse-tail.}

E. umbrosum Willd.-E. Drummondii Hook.

Districts - - - - - - - - XI. XII. Lat. $54 \frac{1}{2}^{\circ}-55 \frac{1}{4}^{\circ}$. Donegal and Antrim only. Type, Scottish.

Mountain glens and damp heaths; very rare and local. Frt. April-May.

XI. At Culdaff; near an old mine between Dunfanaghy and Gweedore; at Mount Charles, and also near the town of Donegal: Flor. Olst.-XII. At Wolf-bill near Belfast (T. Drummond) : Flor. Hib. (as $\boldsymbol{E}$. Drummondii Hook.). Wolfhill and Woodburn glens (W. Millen): Hind I854. Glendoon, near Cushendall (Moore): Newman 1844. Loonburn (west side) near Donegore, \&c.: Flor. Ulst. Not infrequent in the mountain glens of Antrim, as near the base of Slemish above Buckna; head of Glenariff; head of Glenballyeamon, \&c. (Moore) : Cyb. Glenocum; and near the head of Glenbush (Herb. Moore); Carnlough (Herb. Canon Grainger); and near Grarron Point (Praeger): S. \& P. I805.

First found by T. Drummond, in Wolfhill Glen, before 1836.

\section{E. sylvaticum Linn.-Wood Horse-tait.}

Districts I. II. III. IV. V. VI. VII. VIII. IX. X. XI. XII. Lat. $51 \frac{1}{2}^{\circ}-55 \frac{1}{4}^{\circ}$. Throughout Ireland. Type, British.

Moist woods and banks, \&c.; frequent. Frt. April-May. Calcifuge $B$.

Sea-level in N. Donegal and S. Cork. To $1600 \mathrm{ft.}$ in Leitrim (Stewart); to $1150 \mathrm{ft}$. in Dublin $(N . C$.) ; to $1600 \mathrm{ft}$. in Queen's Co. (Hart).

- Much more common in the North than in the South; local in the East, and generally preferring mountainous districts.

\section{E. palustre Linn.-Marsh Horse-tait.}

Districts I. II. III. IV. V. VI. VII. VIII. IX. X. XI. XII. Lat. 51 $\frac{1}{2}^{\circ}-551^{\circ}$. Throughout Ireland. Type, British.

By streams and damp places; common. Frt. May-July.

Sea-level in N. Antrim and S. Cork. To $1400 \mathrm{ft}$. in Sligo (B. $\&$.); to $2000 \mathrm{ft}$. in Mayo (Hart).

Var. polystachyom Auct.-I. Darrynane, Kerry; and-V. Near 
Portrane, Dublin; R.W.S.-XII. Portrush sandhills, and at Shane's Castle, Lough Neagh, Antrim (Praeger): S.\&. P. 7895.

Var. NUDOM Newm.-XII. Shane's Castle, Lough Neagh (Praeger): S.\&P. 1895 .

\section{E. limosum Linn.-Water Pipes.}

Districts I. II. III. IV. V. VI. VII. VIII. IX. X. XI. XII. Lat. $51 \frac{1}{2}^{\circ}-55 \frac{10}{4}$. Throughout Ireland. Type, British.

Ditches, sides of lakes and rivers; common. Frt. May-June.

Sea-level in N. Derry and S. Cork. To $1000 \mathrm{ft}$. in Down ('S.\&P.); to $1250 \mathrm{ft}$. in Dublin (N.C.); to $1425 \mathrm{ft}$. in Kerry (Hart).

Var. Fluviatne ( $\operatorname{inn}$.)-I. In Kerry; and-VIII. West Galway: Linton $7896 .-X I I$. Common in the North-East: Flor. N.-E.-no doubt widely distributed in Ireland.

7. E. hyemale Linn.-Shave-grass; Dutch Rushes.

Districts I. - III. IV. V. - VII. - - X. XI. XII. Lat. $52^{\circ}-55 \frac{1}{4}^{\circ}$. From South to North. Type, Scottish-British.

Wet shady places and riversides; rare. Frt. June-July.

I. By the river Brick near Lixnaw: Smith's Kerry. By the rivers Flesk and Laune, Killarney, in several places: $R$. W. S. 1.889 \& 89. By the river Lee, Cork: Drummond 1820 . Near Ballincollig and the Ovens: Flor. Cork.-III. Abundant in Sir Robert Staples' woods, [Dunmore], Queen's Co.: Mack. Rar. Mountrath, Queen's Co., 1897; Praeger.-IV. In Powerscourt woods, Wieklow (Dr. Stokes): Mack. Rar. Banks of the Cookstown river above Enniskerry bridge, $1898 ; R . W . S$. Hollybrook, Bray; and-V. Killakee, Dublin; Greenwood Pim. In Finglas wood: Rutty's Dublin. In Luttrellstown woods: Mack. Rar. Banks of the Liffey opposite Woodlands: Ir. Flor. 1833-and in 1895; N. C. Wood at Leixlip: Babington 1836 -VII. Near Tullamore, King's Co.: Praeger 1897.-X. Banks of the Colebrooke river, Fermanagh (T. O. Smith): Rec. Add. Near Victoria bridge, North Tyrone; J. R. Leebody.-XI. Right bank of the river Eske, Donegal: Hart $1885 \%$-XII. By the side of Lough Neagh near Shane's Castle: Templeton MS. Glenarm, and many places in Antrim (Moore): Cyb. In Crow Glen; and by a stream from Hannahstown to Colin Glen (Stewart): Flor. N.-E. Glen above Hightown, north of Squire's Hill, Antrim (Rev. C. H. 
Waddell) : S.\&P. 8895 . Woods at Mount Sandys above Coleraine; and woods by the Agivey river, Derry: Moore MS. Glen near Magilligan (Mrs. Leebody): S. \& P. 1895. By Kilbroney river; by the Yellow water, and other stations in the Mourne Mountains: S. \& P. 1892 .

From sea-level in Derry, to $1700 \mathrm{ft}$. in Down (S. \& P.).

Appears to be more frequent in the North-East than elsewhere in Ireland.

\section{E. Moorei Newm.}

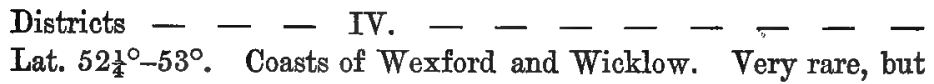
locally abundant.

IV. On wet rocky banks facing the sea and on open sandhills a little south of Rockfield, and not far from Dunganstown, Wicklow (Moore) : Phytol. 1854\& Cyb. Sandhills north of Courtown, Wexford, and thence northwards to three miles south of Wicklow (More): Rec. Add. Raven Point and sandhills between Cahore Point and Morris Castle, Wexford; not seen south of Wexford Harbour: Hart I $88 \mathrm{I}$ a \& $\mathrm{r} 88_{3} \beta$.

This plant is apparently peculiar to Ireland.

First found by D. Moore and J. Melville, at Rockfield, in 1851.

\section{E. trachyodon Braun.}

\section{E. Mackaii Newm.}

Districts I. II. - - - VI. - VIII. IX. - - XII. Lat. $52^{\circ}-55^{\circ}$. West and North-East, chiefly. Rare and local.

I. By the Laune near Ballymalis Castle, Kerry: R.W.S. 1889.-II. Near St. Ann's, Blarney (R. Mills): Allin I871.VI. Chevy Chase near Gort, Galway: Hart 1873.-VIII. In Drumman wood and shores of Lough Cullin, Mayo (More): Cyb.IX. Glencar, Sligo: $B . \& V$. I885-XII. Colin Glen, near Belfast, 1793 : Templeton MS. (as E. hyemale). Near a waterfall at the upper end of Colin Glen, 1833 (Mackay \& F. Whitla) : Flor. Hib. (as E. variegatum). Still in Colin Glen: Flor. N.-E. r888. In several glens near Glenarm, Antrim; and in Ballyharrigan Glen near Dungiven, Derry (Moore): Cyb. Still in the latter locality (Mrs. Leebody): S.\&P. 1895 .

First recognised as distinct by F. Whitla before 1830, and pointed out by him to Mackay in 1833 (Flor. Hib. \& Flor. N.-E.). First described by Newman in Phytol. 1842, p. 304. 


\section{E. variegatum Schleich.-Variegated Horse-tail.}

Districts I. - III. - V. VI. VII. VIII. IX. - XI. XII. Lat. $52^{\circ}-55 \frac{1}{4}^{\circ}$. From South to North. Type, Scottish.

Lowland. On lake margins, by canals and river sides, and on damp, sandy ground; rather rare. Frt. July-August.

I. Damp cliffs on Paps mountain, Kerry: R.W. S. 1890 (as Var. Wirsons).--III. By the Barrow near Mountmellick: Hart 1885 . Near Maryborough: Praeger 7897 . In Queen's Co. near Athy; R.W.S.-V. Abundant along the Royal Canal, east of Clonsilla (Moore); and near Glasnevin (More) : Cyb. Abundant at intervals along the Royal Canal from Lucan station to Glasnevin, $1893 ;$ N.C. Along the Dodder river at Rathfarnham, and at Bohernabreena: N.C. $8893-$-VI. By a pool on the "Hunting Course" field near Castle Taylor, Galway (More): Cyb.-VII. Canal near Mullingar (R.W.Rawson): Moore's Brit. Ferns, I862. Edge of Lough Drin and banks of canal near Killucan, Westmeath: Levinge 1894. By the Tullamore river near Ballinagar, King's Co. : Praeger $1897 .-$ VIII. Shores of Lough Bulard, near Roundstone (More): Rec. Add.-IX. Shores of Lough Talt, Ox mountains, Sligo: N.C. I896.-XI. By the Eske River, and by Lough Eske, between Ardnamona and the Castle, Donegal : Hart $1885 \gamma$.

To $1500 \mathrm{ft}$. in Kerry (R.W.S.); but usually lowland.

The foregoing records are to be referred to Var. Masos Syme here taken as the type. Many of them were originally attributed to Var. Wrisons Newm., which there is reason to believe is confined to Killarney, but recent specimens from districts III., V., VII., and IX., have been identified as $V a r$. ms Jus, which is especially abundant along the Royal Canal.

Var. iarenariom Newm.-V. On the sandhills at Portmarnock where it was first found by Dr. Taylor: Mack. Cat. 1825. Sandhills at Portrane, Dublin (Moore): Cyb. Sandhills opposite Malahide, Dublin ; R.W.S.-IX. Sandhills at Mullaghmore, north of Ben Bulben, Sligo (Moore): Cyb.-XII. Sandy shore at Benone, Magilligan, Derry : Moore MS.

This variety is apparently quite rare in Ireland.

Var. Wrisoni Newm.-I. Ditches bordering on the lake in Muckross demesne, Killarney (W. Wilson): Brit. Flor. Eds. II. and IV. $1831 \& 1838$, - and in 1885 : Linton I886. Ross Bay, Killarney Lakes, $1890 ; R . W . S$. 


\title{
ORDER LXXX.-IYCOPODIACE
}

\author{
LYCOPODIUM Linn.
}

\section{I. Selago Linn.-Fir Club-moss.}

Hibernicé Cpubını́ंe Siannać (Croob-ee-nee Shinnack), Fox's Paws.

Districts F. II. III. IV. V. VI. VII. VIII. IX. X. XI. XII. Lat. $51 \frac{1}{2}^{\circ}-551^{\circ}$. Throughout Ireland. Type, British-Highland.

Mountain heaths and cliffs, and more rarely in lowland bogs; frequent. Frt. July-October.

Sea-level in N. Donegal and S. Kerry. To $2400 \mathrm{ft}$. in Donegal (Hart); to $2796 \mathrm{ft}$. in Down (S.\&P.); to $3000 \mathrm{ft}$. in Wicklow (N.C.); to $3370 \mathrm{ft}$. in Kerry (More).

2. L. inundatum Linn._Marsh Club-moss.

Districts I. - - - - - - VIII. - - - Lat. $51 \frac{3}{4}^{\circ}-53 \frac{1}{2}^{\circ}$. Kerry, Cork, and Galway. Type, British-English.

Wet heaths and ditches; very rare. Frt. July-October.

I. On the shore of Lough Guitane, near Killarney (More): Journ. of Bot. I876, p. 373-still there in $1896 ; R$.W.S. Plentiful in the townlands of Ardkitbeg and Ardkitmore, parish of Desertserges; and near Churchill, Co. Cork (C. Longfield): Allin's Cork. Enniskeane, Cork: Herb. Allin.-VIII. In turfy ditches along the public road between Oughterard and the "Recess": Wade Gallovid, I80r. Plentiful over a considerable area of wet heath immediately west of Maam, Galway: M.\& S. I896-a locality very near Wade's station. On the borders of a small lake near Letterfrack, Connemara (H. Seebohm) : Nat. Hist. Rev. 1859, p. 159, \& Cyb.

\section{I. clavatum Linn.-Common Club-moss.}

Districts I. [II.] III. IV. V. - VII. VIII. IX. X. XI. XII. Lat. $52^{\circ}-55 \frac{1}{4}^{\circ}$. Throughout Ireland, almost. Type, British.

Heaths and mountains; rare and local. Frt. July-October.

I. "Plentifully in all the southern baronies of this county": Smith's Kerry. In several places on Mangerton, but very rare in Kerry : R.W. S. $1888 \&-89$. Rochestown Hill, between Cork and Passage (Mr. Alexander); on a bank at Willsville by the new 
Carrigaline and Cork road (D. Murray);-both stations probably destroyed: Flor. Cork.-I. or II. Dunbulloge Glen, Cork ( $J$. Sullivan): Annot. in Flor. Cork.-III. On Mount Leinster, Carlow (R. Clayton Brown) : Ree. Add.-IV. At the base of Lugnaquilla, Glenmalure, Wicklow ; Hart.-V. Kelly's Glen, Ballynascorney, and other places on the Dublin mountains: Ir. Flor. Abundant on Slieve Thoul, and at head of Glenasmole, Dublin : N. C. I895.VII. Kilduff, Devil's Bit mountain : Hart 1885 a.-VIII. Near Leenane Hotel, Killary, Mayo : Hart 1883 a. Killaguile, Galway; Miss M. F. Jackson.-IX. In Co. Sligo, rare: Cyb.-X. Slieve Glah, Co. Cavan: Ir. Nat. 1806, p. I99. Brackagh bog, Armagh: Praeger 1893.-XI. Aghla and Barnesmore mountains: Murphy 1829. Mountains near Pettigoe (Miss Young); Stoolary Hill south of Carndonagh; and on the Scalp, Inishowen: Hart I $885 \gamma \&$ I883.XII. Mountains of Mourne: Harris's Down. Slieve Commedagh (Rev. H.W. Lett); Slieve Donard, Down: S.\&P. 1895. Top of Black mountain, 1798, and on Agnew's Hill, Antrim, 1804 (Templeton): Whitla MS. Banks of stream between Divis and Black mountain; heath at Loughmourne, \&c., Antrim; Slieve Gallion, and Benbradagh, Derry (Stewart): Flor. N.-E. Evish mountain near Parkmore, \&c. (Rev. H. W. Lett): S. \& P. I895. Crockmore, Draperstown, Derry (Praeger): Journ. of Bot. 2892.

Descends to $50 \mathrm{ft}$. in Armagh (Praeger); and to $100 \mathrm{ft}$. in Kerry $(R . W . S$.$) . Ascends to 2450 \mathrm{ft}$. in Down (S.\&.P.); to $1900 \mathrm{ft}$. in Mayo, and to $1950 \mathrm{ft}$. in Wicklow (Hart); to $2568 \mathrm{ft}$. in Kerry (R.W.S.).

Appears to be more frequent in the North-East and East than in other parts of Ireland.

\section{L. alpinum Linn.-Mountain Club-moss.}

Districts I. - - IV. - - - VIII. IX. X. XI. XII. Lat. $52^{\circ}-55 \frac{1}{4}^{\circ}$. North of Ireland, chiefly. Type, Highland.

Mountain heaths; rather rare and local. Frt. July-October.

I. On Mangerton, Kerry : Flor. Hib. On Carrantual, Macgillicuddy's Reeks; More.-IV. Ċliffs of Thoulagee, above Lough Ouler (Hart): Journ. of Bot. 1883, p. 153. Maulin mountain; Rev. C. F. d'A Arcy. Lugnaquilla; R. P. Vowell. Table mountain, Wicklow ; N. C.-VIII. On Lettery mountain, and on Maam Turk, Connemara: Wade Gallovid. Still in the latter locality; on Mweelrea; Loughty mountain; and Curraun Achill in Mayo: 
Hart 1883 a.-IX. On mountains of Sligo, but rare (J. Wynne): $C y b$. - X. On Aghla, Tyrone (Admiral Jones) : Cyb.-XI. Plentiful on the summit of Barnesmore mountains, Donegal: Mack. Rar. On several mountains in Donegal, but rare in the county : Hart 1879 , $1885 \mathrm{\gamma}, \mathrm{\& c}$.-XII. On the mountains of Down: Harris's Down (recorded as "Savin"). Slieve Donard: Templeton MS. On most of the Mourne summits: S. \& P. 1895 . On the top of Black mountain, Antrim, 1793 (Templeton): Whitla MS.-still there : Flor. N.-E. 2888 . Several other localities in Down and Antrim are given in Flor. N.-E. and S.\&.P. r895. In Derry, only seen on Dart and on Slieve Gallion (Moore): $C y b$.

From 1400 to $2219 \mathrm{ft}$. in Donegal (Hart); 1900-2796 ft. in Down (S. \& P.) ; 1560-2500 ft. in Mayo (Hart); and at $2650 \mathrm{ft}$. in Kerry (More).

\section{ORDER LXXXI.-SELAGINELLACE压.}

\section{SELAGINELLA Spring.}

\section{S. selaginoides Gray-Little Prickly Club-moss.}

S. spinulosa Braun-Lycopodium selaginoides Iinn.

Districts I. - III. IV. V. VI. VII. VIII. IX. X. XI. XII. Lat. $51 \frac{3}{4}^{\circ}-551_{4}^{\circ}$. South to North. Type, Highland.

Moist places on mountains, heaths, sandhills, \&c.; frequent. Frt. June-August.

Sea-level in N. Antrim and in Dublin. To $1800 \mathrm{ft}$. in Donegal, and to $2100 \mathrm{ft}$. in Mayo (Hart).

Like most of the Club-mosses, this is very rare in the southwest. "Near Bantry": Drummond I820 is the only record we are aware of. It is frequent over the rest of Ireland even at low levels, and occurs on sandhills by the sea in Dublin, Antrim, and Derry.

\section{ISOETES Linn.}

\section{I. lacustris Linn.-Quill-wort.}

Districts. I. II. - IV. - - - VIII. IX. X. XI. XII. Lat. $51 \frac{1}{2}^{\circ}-55 \frac{1}{4}^{\circ}$. South to North. Type, Highland.

In lakes, chiefly in mountainous districts; frequent. Frt. June-Aug. 
Frequent in the South-West, West, and North of Ireland; rare in the South and East, but occurs in the counties of Waterford and Wicklow.

From sea-level to $1500 \mathrm{ft}$. in Donegal; to $2338 \mathrm{ft}$. in Kerry (Hart).

Var. Morei Syme.-IV. In Upper Lough Bray, Wicklow (More) : Reo. Add.-still abundant there in $1890 ; R . W . S$.

Of this variety, which is described and figured in Journ. of Bot.

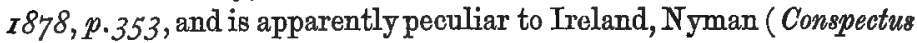
Supp. $p$. 349) says: " $\operatorname{Var}(?)$ memorabilis a typo speciei habitu valde recedens."

\section{I. echinospora Dur.}

Districts I. - - - - - - VIII. - - - Lat. $51 \frac{3}{4}^{\circ}-53 \frac{1}{2}^{\circ}$. Kerry and Galway. Very rare.

I. Lakes near the Gap of Dunloe; and in the Opper Lake of Killarney near Glenagh Cottage (Moore): $C y b$. Still near Glena Cottage (which is on the Lower Lake, not Upper); near the Meeting of the Waters, and several places about Killarney; in most of the lakes between Glencar and Killorglin, \&c. : $R$. W. S. $1888 \&$ -89.-VIII. Inish Bofin, Galway: More I 876.

Sea-level to $560 \mathrm{ft}$. in Kerry $(R . W . S$.$) ; but usually lowland.$

\section{ORDER LXXXII.-MARSILEACE正.}

\section{PILULARIA Linn.}

1. P. globulifera Linn.-Pill-wort.

Districts I. - - - - - VIII. - X. - XII. Lat. 52 $-551^{\circ}$. West and North-East, chiefly. Type, British.

Lowland. In shallow water and on marshy ground; rare and local. Frt. June-August.

I. Sparingly at the south end of Upper Lake, Killarney : R.W.S. 1890.-VIII. In the gravelly watery spots near the bridge of Ballynamore: Wade Gallovid: Near the Salmon Leap at Ballinahinch, Connemara: Wade Rar. In abundance at the western end of Glendalough (Praeger): Ir. Nat. 1895, p. 165. Several localities about Lough Mask: R. P. Vowell and M. \& S. I8g6. Between Letterfrack and Kylemore, sparingly (H. Seebohm): Cyb.- 
X. Swampy ground near the Blackwater, Lough Neagh ( $J$. Campbell): Flor. Hib. Abundantly about one mile north of Washing Bay, Lough Neagh;-apparently the same locality as the preceding (Miss M. C. Knowles) : Ir. Nat. 1897.-XII. In a ditch by the river Bann, a little below Jackson's Hall, Coleraine (David Moore): Flor. Hib. Selshan Harbour, Lough Neagh (Hyndman): Flor. Ulst. Drain by Portmore Lough, Antrim : Herb. Moore.

\section{ORDER IXXXIII.-CHARACEE.}

\section{CHARA Linn.}

\section{C. fragilis Dest.}

Districts I. II. III. IV. V. VI. VII. VIII. IX. X. XI. XII. Lat. $51 \frac{1}{2}^{\circ}-55 \frac{1}{4}^{\circ}$. Throughout Ireland.

Lakes, pools, streams, ditches, \&c.; the typical plant is common. Frt. June-August.

Sea-level in N. Antrim and S. Cork. To $1100 \mathrm{ft}$. in Kerry (R.W.S.).

Var. BaRBata Gant.-I. Near Ventry, Kerry (D. M'Ardle): Groves 1895.-IV. Murrough of Wicklow (Moore): Groves 1880.VI. Drains by the Shannon at Killaloe: N. C. 1897.-VII. Mullin$\operatorname{gar}$ (Moore): Groves I 880. Scraw bog, Loughanstown, Westmeath: Levinge 1894. Geashill, King's Co. (Praeger): Groves 1895.-IX. Stream at Cong, and south-east end of Lough Mask: M. \& S. I896. -XII. Lough Beg, Antrim (Thompson): Groves I885. Holywood Hills; Clandeboye lower lake; near Craigauntlet (Praeger); and Tardree Hill, Down (Canon Grainger): S. \& P. 1895 .

$V a r$. Capilliacea Coss \& G.-I. Long Range, Killarney, \&c. : R.W.S. I888.-V. Howth, Dublin (Praeger): Groves I895. Killencoole, Co. Louth : Praeger I807.-VIII. Renvyle, Galway, $1832(\boldsymbol{R}$. Shuttleworth): Groves I895.-XII. Holywood, Down (Praeger): Groves 1886 .

Var. Hedwigr Kuetz-V. Lucan, Co. Dublin (Praeger): Groves 1895.-VIII. Cong, Galway (C. Bailey): Groves $7886-$ this station extends into-IX. Lough Gill river, Sligo: $B$. \& $V$. 1885.-XII. Holywood Hills, Down (Praeger): Groves 1895.

Var. DELICATULA Braun-This is recorded from Districts III., 
V., VIII., IX., X., XI., and XII., and is probably frequent throughout Ireland.

\section{C. connivens Braun.}

Districts - - IV.

Lat. $52^{\circ} 20^{\prime}$. Wexford only.

Lowland. Brackish pools and lakes; very rare. Frt. JulyAugust.

IV. In a lagoon north of Wexford Harbour: Marshall 1806.

An interesting addition to the Irish Characece, occurring elsewhere in the British Isles only in South and East England.

\section{C. aspera Willd.}

Districts I. - III. IV. V. VI. VII. VIII. IX. X. XI. XII. Lat. $511^{\circ}-55 \frac{1}{4}^{\circ}$. Throughout Ireland, probably.

Lowland. Lakes, canals, and brackish pools; the typical plant is frequent. Frt. July-August.

Var. conta Braun-VI. Lough Derg, Galway (Bolton King): Groves $\mathbf{I} 88 \mathrm{I}$.

Var. LAcustris H. \& J. Groves-VIII. Lough Cullen, Mayo (More): Groves I880. Roundstone, Galway (J. Woods): Groves 1884.-X. Lough Neagh, near Lurgan, Armagh: Praeger 1893. Arboe, Tyrone (Rev. S. A. Brenan); and-XII. Lough Neagh, near Crumlin, Antrim (Stewart): Groves 1895 .

Var. sUbINERMIS Kuets-I. Bog near Lough Hyne, Co. Cork, 1896; Groves and Phillips.-IV. Lagoon, north of Wexford Harbour : Marshall I896.-IX. Lough Gill river, Sligo ; Glenade Lake, Leitrim: $B . \& W$. I885.-X. Lough Neagh, Armagh: Praeger 1893.-XII. Lough Neagh, Antrim (Rev. H. W. Lett): Groves r886. River Bann, Derry (Praeger); Rathlin Island (Moore): Groves $I 895$.

4. C. polyacantha Braun.

Districts - II. III. IV. V. VI. VII. VIII. IX. X. - Lat. $52^{\circ}-542_{2}^{\circ}$. Central Ireland, chiefly.

Lowland. Bog-holes, lakes, \&c.; rare. Frt. June-August.

II. Shanagarry bog, Cork (Carroll) : Groves I880.-III. Canal at Monasterevan, Queen's Co. (Praeger);-IV. Near Newcastle, Wicklow (Barrington); and-V. Canal near Monasterevan, Co. 
Kildare (Praeger): Groves I893 \& 1895. Lough Crew near Oldcastle, Meath: Praeger 2897.-VI. Headford, Gralway ( $R$. Shuttleworth): Groves 1880. Lough Derg, Galway (Linton): Groves 1886.-VII. Scraw bog and Lough Owel, Westmeath (Levinge and Groves): Groves r893.-VIII. Moycullen, Galway: Groves 1895.-IX. Foxford, Mayo (Mrore): Groves I880.X. Loughgall Lake, Armagh: Praeger 1893.

First gathered in Great Britain by Sherard in turf bogs in Ireland, and figured from his specimens by Plukenet in 1691 .

\section{C. contraria Kuetz.}

Districts I. - III. - V. VI. VII. VIII. IX. X. - XII. Lat. $52^{\circ}-55 \frac{1}{4}^{\circ}$. From South to North.

Lakes, canals, ponds, \&c.; not infrequent. Frt. June-August.

I. Near Black Point, Rossbehy, Kerry: R. W. S. I889.III. Canal near Monasterevan, Queen's Co. (Praeger): Groves I895-this locality extends into-V. Near Glasnevin, Dublin, 1882 (D. MrAdle): Groves r885. Near Oldcastle, Co. Meath: Praeger 1897.-VI. Lough Derg, Galway (Linton): Groves 7886. Rinmaher Point and mouth of Woodford river, Lough Derg: $N$. $C$. 1897.-VII. Lough Owel (Levinge and Groves): Groves I893. Lough Ennel, Westmeath: Groves I895. Canal at Edenderry, King's Co.: Praeger 1897.-IX. Lough Allen, Leitrim, 1883 (Stewart): Groves 1884 . River Suck at Bellagill bridge, Roscommon: Praeger 1897.--X. At Croaghan Island, Lough Neagh, Armagh (Rev. H.W. Lett) : Praeger I89.3. Lough Sheelin, Cavan; Praeger.-XIJ. Clandeboye Lower Lake, Down; near Limavady Junction, Derry (Praeger \& Donnan): B. N. F. C. Proc. 189o-93.

Var. HISPIDULA Braun-VII. Brittas Lake, Westmeath (Levinge and Groves): Groves 1895.-VIII. and IX. Near Cong, in both Galway and Mayo (C. Baitey): Groves 1886.

First found in Ireland by David M'Ardle, near Glasnevin, in 1882.

\section{C. denudata Braun.}

C. dissoluta Leonh.

Districts $----\overline{-}--$ VII. $--\overline{-}-\overline{\text { Frt. July-Aug. }}$
Lat. $53 \frac{1}{2}^{\circ}$. Westmeath lakes only. Very rare.

VII. Brittas Lake, Knock Drin, Westmeath (Levinge): Groves I895. 
First found by H. C. Levinge in 1892. The Westmeath station is, so far, the only one known for the British Isles.

Messrs. H. \& J. Groves suggest (Groves 1895) that this plant, which is described and figured in Journ. of Bot. I895, p. 290, may be only a degraded form of the preceding species.

\section{C. tomentosa Linn.}

Districts - - - - VI. VII. - IX. - - Lat. $53^{\circ}-53 x^{\circ}$. Galway, Roscommon, and Westmeath.

Lowland. Lakes and rivers; locally abundant. Frt. July-Aug.

VI. River Shannon below Portumna, Galway, 1843 (Moore): Groves 2880 . Near the mouth of theWoodford river, Lough Derg: N. C. $1897 .-$ VII. Belvidere Lake [L. Ennell], Westmeath, 1841 (Moore) : Lond. Journ. of Bot. 1842 (as C. latifolia, Willd.). Lough Derevaragh and Lough Owel, Westmeath (Levinge and Groves): Groves 1893. Coosan Lough; and-IX. Near Ringdown Castle, \&c., Lough Ree : B.\&V. 1887 .

All the localities so far found for this plant belong to the Shannon drainage. It may be expected, however, to spread to East Ireland by means of the Royal or Grand Canals which connect the Shannon with the Liffey. While extending over the greater portion of Europe, this species seems in the British Isles to be confined to Ireland, the Norfolk plant formerly referred here being now considered by the Messrs. Groves to be a hybrid between C. hispida and C. contraria (see Groves 1895 a). This species is very Iuxuriant in many of the Irish lakes, often attaining to a length of three or four feet.

First discovered by David Moore, in Belvidere Lake, in 1841.

\section{C. hispida Linn.}

Districts I. II. III. IV. V. VI. VII. VIII. IX. X. - XII. Lat. $52^{\circ}-551^{\circ}$. Throughout Ireland, probably.

Lakes, canals, ponds, \&c.; the typical plant is frequent. Frt. June-August.

Var. MACRACANTHA Braun-IV. Wicklow (Moore): Groves I880.-V. Maynooth, Co. Kildare (D. M Ardle): Groves 1895.

Var. RoDIs Braun-This is recorded from Districts III., V., VI., VII., VIII., IX., X., and XII., and will probably be found to occur throughout Ireland. 


\section{C. vulgaris Linn.}

Districts I. II. III. IV. V. VI. VII. VIII. IX. X. XI. XII. Lat. $51 \frac{1}{2}^{\circ}-55 \frac{1}{4}^{\circ}$. Throughout Ireland.

Pools, ditches, damp places, \&c. ; frequent. Frt. May-August.

$V a r$. LONGIBRacteata Kuets is recorded from all the districts except III., VIII., X., and XI., and will probably be found to be as widely distributed in Ireland as the type.

Var. PAPILATA Wallr.-I. Near Inny Ferry, Waterville, Kerry : R.W. S. 1890.-III. Near Farmhill, Athy, Queen's Co. (R.W. S.): Groves 1895.-IV. Lagoon, north of Wexford Harbour: Marshall I896.-VII. or IX. Lough Ree, Westmeath, or Rascommon (Barrington): Groves 1895 .

Sea-level in N. Derry and S. Cork. To $700 \mathrm{ft}$. on Slieve Elva, Co. Clare $\left(N . C_{.}\right)$.

10. C. canescens Loisel.

Districts I. - - IV. - - - - - - - Lat. $52^{\circ} 10^{\prime}-52^{\circ} 20^{\prime}$. Kerry and Wexford only.

Lakes near the sea; very rare. Frt. July-August.

I. Castlegregory Lake, Kerry, in some abundance $(R . W . S$.$) :$ Groves 1895.-IV. Lagoon, north of Wexford Harbour: Marshall I896.

Known elsewhere in the British Isles only from Suffolk, Dorset, and Cornwall.

First found in Ireland by $R . W . S .$, at Castlegregory, in 1894.

\section{TOLYPELLA Leonh.}

\section{T. glomerata Leonh.}

Disitricts - - IV. V. VI. VII. - IX. - - Lat. $52 \frac{1}{4}^{\circ}-541^{\circ}$. Central Ireland, chiefly.

Canals, lakes, \&c, ; local, but perhaps often overlooked. Frt. April-June,

IV. Lagoon, north of Wexford Harbour: Marshall $7896 .-$ V. Canal near Glasnevin (Moore): Groves 2880. Abundant in both the Royal and Grand Canals near Dublin, $1890 ; R . W . S$. Maynooth, Co. Kildare (Praeger): Groves 1895.-VI. Rinmaher Point; and-VII. Slevoir Point, Lough Derg: N. C. 1897. Lough Derevaragh (Levinge \& Groves): Groves 1893. Lough Ennell, 2 표 2 
Westmeath : Groves 1805 .-IX. Glencar Lake, Sligo ; and Glenade Lake, Leitrim : B.\&.V. 1885 .

\section{T. prolifera Leonh.}

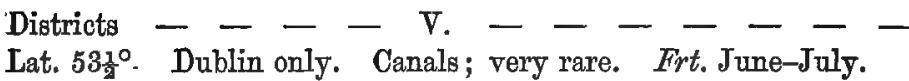
V. Royal Canal near Glasnevin, Co. Dublin (Moore): Groves I880.

This rare species has only been found in a few scattered localities in Central and Southern Europe, and in North and South America; in Great Britain it is apparently confined to a few counties in the east of England. It has not been recently gathered in Ireland.

First found in Ireland by் David Moore before 1860.

\section{T. intricata Leonh.}

Districts - - - V. - - - - - Lat. 53공. Dublin only. Canals; very rare. Frt. April-May.

V. Royal Canal near Glasnevin, Co. Dublin, before 1860 (IIoore): Groves I880-still there in $1896 ; F . W$. Moore and D. M'Ardle.

Like the preceding species, this is apparently confined in Great Britain to the eastern parts of England.

First found by David Moore previous to 1860.

NITELLA Agardh.

1. N. Nordstedtiana H. \& J. Groves.

Districts I. - - - - - - - - - Lat. $52^{\circ}$. Kerry only. Lakes; very rare. Frt. July-August.

I. South end of Caragh Lake; near the Muckross shore of the Lower Lake, Killarney: $R$.W. S. I890 \&-QI (as N. gracitis Agardh). Near Swallow Island, Killarney, 1892 (R.W. S.): Groves I 895.

A very minute plant, rarely much exceeding an inch in height. While widespread in Europe, and occurring in North America and Australia, in Great Britain it has, so far, been found only in the Outer Hebrides. Occurs in some abundance in the Killarney stations.

First found in Ireland, at Caragh Lake, by R. W. S. in 1889. 


\section{N. tenuissima Kuetz.}

Districts - - - - - VI. VII. - - - - Lat. $53^{\circ} 20^{\prime}-53^{\circ} 35^{\prime}$. Galway and Westmeath.

Bog-holes and ditches; probably widely distributed. Frt. JuneAugust.

VI. Near Ballindooley, east of Lough Corrib, Galway: Groves r893.-VII. Scraw bog near Lough Owel, Westmeath (Levingo \& Groves): Groves 1893 .

As the Messrs. Groves discovered this inconspicuous plant in the only two sets of bog-holes they had the opportunity of examining, they have little doubt that it will be found to be much more generally distributed in Ireland when the many suitable localities the country affords have been investigated. In Great Britain the plant has been found only in Cambridgeshire and Anglesea.

First found in Ireland. by Messrs. Groves and H. C. Levinge, near Lough Owel, in 1892.

\section{N. gracilis Agardh.}

Districts - - - IV. - - - - - - - Lat. $53^{\circ} 5^{\prime}$. Co. Wicklow only. Lakes; very rare. Frt.JulyAugust.

IV. On sand in Lough Luggala and Lough Dan, Wicklow (Barrington \& Groves): Groves 1893 .

Also recorded from Glencullen, Co. Dublin, but not recently confirmed.

While occurring nearly throughout Europe, $N$. gracilis seems in Britain to be confined to a few localities in the southern counties.

4. N. translucens Agardh.

Districts I. - - - - - VIII. - X. - XII. Lat. $51 \frac{1}{2}^{\circ}-55 \frac{1}{4}^{\circ}$. West and North. Lakes, ponds, \&c.; rare. Frt. July-August.

I. Caragh Lake, Kerry (More): Groves 1880. Killarney (Linton): Groves ${ }^{2} 886$. In most of the larger Kerry lakes: R.W. S. $1888, \&$. Bog-hole near Ardnagashel, Bantry, Cork, 1896; Miss L. Giles.-VIII. Clifton, Galway (More): Groves 1880. Roundstone, Galway: Linton I886.-X. Cashel Lake near Crossmaglen, Armagh: Praeger 1893,-XII. Kilrea, Derry (Moore): 
Flor, Hib. \& Groves 1880. Derry Lough, Co. Down; in Rathlin Island, Antrim (Steroart): Flor. N.-E. Several further localities for this district are given in $S . \& P . \quad I 895$.

Sea-level in N. Antrim and S. Cork. To $1100 \mathrm{ft}$. in Kerry (R.W.S.).

First found in Ireland by Dr. Moore, at Kilrea, Derry, in 1836.

5. N. flexilis Agardh.

Districts I. - - - - - IX. X. - Lat. $51 \frac{1}{2}^{\circ}-54 \frac{1}{4}^{\circ}$. West Ireland, chiefly.

Lakes and rivers; rare. Frt. May-July.

I. Caragh Lake, and in most of the larger lakes in Kerry: R. W. S. I89o. Glengariff, Co. Cork (Carroll): Groves 7895 . Inchigeela and Gouganebarra lakes, Cork: Phillips 1897.IX. Cong, Mayo (Linton): Groves I886. Lough Allen, Leitrim: Stewart 1885.-X. Rossford Point, Fermanagh (W. Thompson): Groves 1885 . Camlough river, Armagh : Praeger 1893.

First found in Ireland by W. Thompson, at Rossford Point, Fermanagh, in 1837.

Var. NDIFICA Wallm.-I. Killarney, Kerry, 1861 (Carrington): Groves 1895 a.

6. N. opaca Agardh.

Districts I. II. III. IV. V. VI. VII. VIII. IX. X. XI. XII. Lat. $51 \frac{1}{2}^{\circ}-551^{\circ}$. Throughout Ireland.

Lakes, ponds, rivers, ditches, \&c. ; frequent. Frt. April-June. Sea-level in N. Antrim and S. Kerry. To $1100 \mathrm{ft}$. in Kerry (R.W.S.).

The commonest species of Nitella in Ireland. 


\section{APPENDIX.}

\section{$\rightarrow-$ \\ E X CLU D E D S E C I ES.}

Errors, casuals, and aliens not fully naturalized.

\section{RANUNCULACEA.}

Clematis Vitalba Linn.-Traveller's Joy.

IV. Sandhills at Courtown, Wexford, sparingly (More): Rec. $A d d_{n}-\nabla$. Sandhills at Portrane opposite Malahide, sparingly (Moore) : Cyb.-still there but not increasing, 1866-1880; Hart. North Bull, Dublin (D.M'Arale) : Ir. Nat. 1892, p. r25. Railway bank, Killester, Co. Dublin, 1865; Hart-well established here in $1895 ;$ N.C.

Also recorded from hedges and shrubberies in many parts of Ireland, but has nowhere established itself in quantity in thoroughly wild stations. In some localities, such as along the north side of Muckross Lake, Killarney, it has been known for many years in a semi-naturalized state and perhaps almost deserves admission to the Irish Flora. In the Appendix to Threlkeld's Synopsis, 1727, Dr. Thomas Molyneux says: "The Viorna or Travellor's Joy and the Viscus or Misseltoe (both very frequent in England), I could never meet with either in Ireland."

Anemone apennina Linn.

V. Glasnevin: Wade Rar. \& Flor. Hib.-still in the grounds of Delville, at Glasnevin: $C y b$. Among bushes by the Dodder near Templeogue Bridge, $1896 ;$ N.C.

Escaped from cultivation or planted.

Adonis autumnalis Linn.-Pheasant's Eye.

II. Little Island, Cork, once seen (J. Sullivan); and-IV. By a pathway between Enniskerry and Bray ( $P$. MCArdle): Cyb.V. "Inter segetes nonnunquam": Wade Dubl. About Dundrum (D. Orr) ; and near the Martello Tower at Howth, sparingly, 1865 (Dr. E. P. Wright) : Cy $\dot{b}$.

A casual introduced with seed, and not seen recently. 
Myosurus minimus Linn.-Mouse-tail. North of Ireland: Brit. Flor., Eds. 4 and 5.

A fraud, the specimens sent were obtained from a botanic garden : Flor. $N .-E$.

Ranunculus hirsutus Curtis.

II. Galtymore, Tipperary: Flor. Hib.-XII. At Skeig O'Neil, near Belfast (Millen); Magilligan Rocks (Moore); and Warrenpoint (Dickie) : Flor. Ulst.

Erroneous determination; some of the records should perhaps. be referred to the mountain form of $R$. acris.

Ranunculus arvensis Linn.

V. "It flowers among corn in May about Rahany and Kilsaughan": Threlkeld Synopsis 1727. Plentiful at Baldrummond, the estate of Dr. Scott near the Man of War inn: Mack. Rar. r806. In cornfields near Balbriggan (Dr. Scott): Templeton MS. In cornfields at Raheny and Malahide (Mr. Johnston): Cyb.-XII. At Agnews Hill and in a shrubbery at Inver, near Larne, introduced : Templeton MS.

Specimens of the Baldrummond plant, correctly named, are preserved in the Admiral Jones Herbarium, Science and Art Museum, Dublin. No doubt introduced with corn in all cases. Not seen recently and can hardly be regarded as permanent.

Helleborus viridis Linn.-Green Hellebore.

Recorded for many localities from South to North of Ireland, but is in all cases an escape from cultivation.

Helleborus foetidus Linn.-Fetid Hellebore.

VI. Stated by K'Eogh (Botanica) to grow on great mountains, particularly Slieve Baghtine and near Drumcullagher, in Limerick.

An error.

Delphinium Ajacis Reichb.

V. A single plant in sandy arable ground at Portmarnock, 1869 (Mors): Rec. Add.

A casual not recently observed.

\section{BERBERIDEAE.}

Berberis vulgaris Linn.-Barberry.

Occurs in many localities, but is always planted or an escape or outcast. 


\section{FUMARIACEAE.}

Corydalis lutea DC.- Fellow Fumitory.

IV. Walls at Ballyarthur, Wicklow, many years established; R. Bayly.-VI. Roxborough, Galway; Hart.-XI. Old walls at Greenfort, Fanet, many years established : Hart I880.-XII. Walis at Crumlin and Hillsborough Park: Flor. N.-E.

Appears to be naturalizing itself in many stations, chiefly on walls, but is in all cases of obvious garden origin.

Fumaria parviflora Lamk.

I. On Cape Clear Island (Drummond) : Flor. Hib. Three Castle Head (W. G. Nash); Whiddy Island (Drummond): Flor. Cork.V. In the county of Dublin (J.Ball): $C y b$.

Not confirmed for any of the stations.

\section{CRUCIFER AE.}

Arabis perfoliata Lamk.-Turritis glabra Linn.

XII. Plentiful in $\mathbf{1 8 4 7}$ in a small field or enclosure at the foot of the White Rock Mountain near Belfast (D. Orr): $C y b$.

Never confirmed; authority not reliable.

Cardamine impatiens Iinn,-Bitter Cress.

XII. At Shane's Castle near Lough Neagh: Hind 1854 .

Introduced and perhaps planted. Not found recently.

Alyssum incanum Linn.

V. One plant at Portmarnock, Dublin, 1869 (M. Dowd) : Rec. Add. A casual, not seen recently.

Alyssum campestre Linn.

II. Rubbish heap by the River Lee, Cork city (as $A$. aalycinum) (R.W.S.): Ir. Nat. 1895, p. 20 .

Introduced with foreign grain.

Alyssum calycinum Linn.

II. Plentiful in a meadow near Whitegate, Cork, 1897 ; Phillips.V. On a sandy bank at Portmarnock, Co. Dublin, in 1817, and again near the same station in 1837: Mackay Additions I859\& I860. Re-discovered at Portmarnock in 1867 by H. C. Hart, who observed it growing there for several years afterwards: Ree. $A d d$. In a sandy field at Rogerstown, Dublin, eight miles north of Portmarnock: N. C. 1895.-XII. Edge of a barley field and on sand-fences 
between Bellarena and the Roe mouth, Derry, in some quantity, 1897 ; Mrs. Leebody.

Shows a tendency to become naturalized in Ireland.

Alyssum maritimum Linn.

1. or II. About Cork on rocks and walls (Carroll): Allin's Cork.

Not confirmed.

Draba muralis Linn.

I. On a wall at Evergreen and at the Mathew Cemetery, Cork: Flor. Cork.-V. Abundant on the walls of the Botanic Gardens, Glasnevin; R.W.S.-XII. Old walls about Belfast: Flor. Olst. Plentiful on an old bridge near Armoy, Antrim; walls near a nursery at Newry: Ir. Nat. $18 q 6, p .184$.

Introduced with garden seeds or plants.

Draba rupestris $\mathrm{R}$. Br.

IX. This plant was first announced as Irish by W. Andrews in 1845 (London Journ. of Bot. Vol. IV.), and had been previously recorded in the seventh edition of Withering's Botanical Arrangement as plentiful on the limestone mountains of Leitrim and Sligo. In 1871, Dr. Moore and W. T. Dyer recorded this plant as growing very sparingly on the north side of Ben Bulben (Rec. Add.). Only two immature specimens seem to have been gathered on this occasion, and on one of them being submitted to Mr. Arthur Bennett grave doubts were thrown on the correctness of the naming. A careful search made by Messrs. Barrington and Vowell in 1884 over the Ben Bulben range, only resulted in the discovery of some dwarf forms of Draba incana not unlike $D$. rupestris at first sight; and there is but little room to doubt that some such form as this was erroneously recorded as $D$. rupestris-see $B . \& V . r 885$.

Cochlearia Armoracia Linn.-Horse Radish.

II. Along the Waterford coast : Hart $288_{3} \beta$. Between Tivoli and Glanmire, Cork, abundant for nearly two miles along a strip of waste ground: Phillips I895.-V. In many parts of Co. Dublin; N. C.-XI. Near Bundoran; Hart.

Long established in many of its stations, but is in all cases a relic of cultivation and shows little tendency to increase, rarely flowering and never fruiting in Ireland.

Hesperis matronalis Linn.-Dame's Violet. II. Rocks at Glanworth near Fermoy (T. Chandlee): Allin's Cork. Near Carrigacunna; Allin.-IV. Woods at Poulaphuca, Wicklow, 
and south side of the Dargle (Barrington): Moore \& More 1878 . Rockmount between Ferns and Enniscorthy (J. Morrison): Rec. Add.-IX. Plentiful in the woods at Rockingham, Roscommon (Moore): Rec. Add.-X. Knocknahatna, Oldcastle, Cavan (Rev. N. J. Halpin): Flor. Hib.-XII. By the river Maine; Shane's Castle, 1837; Moore. Shane's Castle grounds (Corry): Flor. $N,-E$.

Apparently semi-naturalized in some parts of Ireland, and almost deserving of a place in the Irish Flora.

Sisymbrium pannonicum Jacq.

II. Abundant on a rubbish heap by the river Lee, City of Cork (R.W. S.): Ir. Nat. 2895.-V. Rubbish heap near the Manure Works, East Wall, Dublin Harbour, 1894; N. C.-XII. Waste ground adjoining the Belfast Distillery ( $R$. Hanna): S.\& P. $\pi 895$.

Introduced with foreign grain.

Sisymbrium Columnæ Jacq.

V. Waste ground near the Manure works, East Wall, Dublin Harbour, 1894; N. C.-XII. Waste ground near Belfast Distillery, 1893-94 (R. Hanna): S.\& P. 1895 .

Introduced with ballast or foreign grain.

Erysimum cheiranthoides Linn.

II. Gravelly fields near Sunday's Well, Cork: Drummond $28 \mathrm{Iq}$. Rubbish heaps by the Lee, near Sunday's Well, Cork $(R . W . S$.$) :$ Ir. Nat. $2895 .-V$. About Templeogue : Threlkeld.-VII. For two miles along the road between Parsonstown and Portumna in Galway, and in the adjoining parts of Tipperary $(\boldsymbol{M}$, Dowd): Rec. Add. Knockdrin, Westmeath: Levinge 1894--IX. Hudson's Bay, Lough Ree, Roscommon: B.\&V. I887.-XI. Carraghblagh, Donegal, 1894 ; Hart.-XII. Between Ballinderry and Lisburn, 1837 ; Moore.

Introduced with seed, and though of not infrequent occurrence, seems to be nowhere thoroughly established.

Erysimum orientale R. Br.

I. Flax fieids near Dingle, Kerry (Babington): $C y b$. Near Shannon Vale mills, Clonakilty; and-II. Near Midleton mills: Allin's Cork. Rubbish heap by the Lee, Cork (R.W.S.): Ir. Nat. 1895.-IV. Near Enniscorthy, Wexford (J. Morrison): Cyb.$\nabla$. Kilmessan railway station; More.

A casual, nowhere established." 
Camelina sativa Crantz.

II. Rubbish heap by the river Lee, Cork city (R.W. S.): Ir. Nat. I895, p. 20.-IV. At Wexford (Carroll): Herb. T. Chandlee. Occasionally at Fassaroe: Moore and More $1878 .-\mathrm{V}$. Lands about Collon and Collonbeg, Louth: Ir. Flor. A weed at Howth, 1881; Hart.-VII. Knock Drin, Westmeath : Lovinge I894.-VIII. On the borders of Lough Corrib near Lemonfield, Oughterard, in a truly wild state: Wade Rar.-XII. Fields at Malone, 1799: Templeton MS. In several stations in Antrim, Derry, and Down: Flor. N.-E., and S.\&P. 2895 .

An introduction, usually with flax seed, and still not infrequent in the North-East.

Brassica oleracea Linn.-Cabbage.

II. On cliffs near Youghal, sparingly (Drummond): Flor. Cork.XII. Among stones on the beach in the Island of Rathlin (Miss Gage) : Flor. Olst.

Escapes from cultivation.

Brassica adpressa Boiss.

V. A single plant at Portmarnock, 1867 (Hart) : Rec.Add. Along the roadside near Sutton station, County Dublin, 1890; Cecil Butler.

A casual.

Brassica Napus Linn. and B. Rapa Linn.

Both of these plants appear to be frequent throughout Ireland in waste places, on hedge banks, and by riversides. They are, no doubt, in all cases relics of cultivation, and the different forms have seldom been discriminated.

Brassica monensis Huds.

VI. Isles of Arran (Lightfoot): Ir. Flor.

The locality is confounded with the Scottish island of Arran, for which the plant is recorded by Lightfoot in Flora Scotica.

Diplotaxis tenuifolia DC.

II. Plentiful at Haulbowline, and sparingly near Whitepoint, Great Island, Cork, 1896; W. G. Axford.-V. Portmarnock, in some plenty (T. Chandlee): Carroll 1857.-VIII. A single plant near Westport, Mayo (Babington): Cyb.-XII. Milewater, near Belfast (W. Millen): Flor, $N_{0}-E$.

Introduced, and nowhere fully established. 
Lepidium ruderale Linn.

I. In some quantity at Moragh cross-roads, near Bandon, Cork, 1896 ; C. Longfield.-II. By the Suir near Clonmel (T. Anderson): Bot. Gasette, 185I.-V. On the North Wall, Dublin: Wade Rar. Near Kilbarrack church (Dr. Osborne) : Flor. Hib.

Introduced with seed, but some of the above records are no doubt errors.

Lepidium Draba Linn.

II. One plant by the roadside at Little Island, 1897 ; Mrs. Hughes.VI. A considerable patch at Barrington's Pier, Limerick; Miss S. Grubb.-X. Near Newry dock, 1892; Praeger.

Brought with ballast or foreign grain.

Hutchinsia petræa R. Br.

I. On the walls of Mathew Cemetery, Cork, formerly a Botanic Garden : Flor. Cork.

Escaped from cultivation.

Isatis tinctoria Linn.-Woad.

This seems to have been cultivated in Co. Dublin in Rutty's time, 1772 , and is mentioned as occurring in Queen's Co. by an annotator in Threlkeld.

It is still occasionally to be found as a weed among crops.

\section{RESEDACEAE.}

Reseda alba Linn.- $R$. suffruticulosa Linn.-White Mignonette. I. Glengariff, Co. Cork ; Levinge.-V. Sandy ditch banks at Portmarnock, in great abundance, fully naturalized : Mack. Cat. $1825-$ still there (Hart): Flor. Howth 2887 . On the sandy shore south side of Howth: Carroll 1857 -still there in 1896; N.C. Mornington common near Dundalk; and-XII. Commons at Glenarm, Antrim : Ir. Flor. At Bangor and near Comber : Flor. Belf. Shore at Newcastle (Lord Clermont): Rec. Add.

In all cases an escape from cultivation, and now found but sparingly in all its stations, though long: established in some of them.

\section{CISTINEAE.}

Helianthemum vulgare Gaertn.-Rock-rose.

I. In the barony of Muskery on some limestone hills near Castlemore: Smith's Cork, 1750. Cape Clear Island (J. Drummond): 
Flor. Cork.-XI. On the limestone between Donegal and Ballyshannon (Hart): Journ of Bot. I893, p. 218.-XII. Glendarragh, near Longford Lodge, Antrim: Flor. Ulst.

The Co. Cork records have never been confirmed. In Donegal and Antrim the species was either planted or derived from cultivation.

\section{POLYGALE $A$.}

Polygala calcarea Schultz.

XII. Near Divis Mountain (Orr) : Flor. Ulst. Cave Hill (Hind) : Flor. Belf.

Errors.

CARYOPHYLLE FE.

Dianthus deltoides Linn.-Maiden Pink.

II. Dry hilly pastures near Dunscombe's Wood (Mr. Alexander): Flor. Corl.-XII. Pastures at Sandymount, near Belfast: Flor. Ulst.

Garden escapes.

Dianthus plumarius Linn.

I. In an old quarry at Blackrock; on the cliffs of Hop Island; on houses near the site of the old castle of Kinsale (Drummond) : Flor. Cork.-II. Common on the town wall of Youghal (Mackay): Cyb. The plant found by Drummond at Kinsale is probably the same as that previously recorded by Smith under $D$. caryophyllus from the old castle of Kinsale (Smith's Cork 2750).

Escapes from cultivation, and not recently recorded.

Saponaria Vaccaria Linn.

V. By the Dodder near Rathfarnham, Co. Dublin; Dr. MeWeeney.VI. At Limerick; P. B. O' Kelly.

Casually introduced.

Silene Armeria Linn.-Common Catchfly.

VI. Field near Kilrush, Clare (Mr. Andrews); and-XII. Sandy cornfield by the Roe, Derry, sparingly (Moore): Flor. Hib. Rathlin island (Dr. Marshall): Flor. N.-E.

Garden escapes and nowhere established.

Silene conica Linn.

I. In cornfields near Monkstown, Cork (J. Sullivan): Annot. in F'lor. Cork, - V. In considerable quantity on banks by the shore to the north of Portrane peninsula, Co. Dublin, in 1894: N.C. 1895 . 
Near the coast-guard station, Portrane, in $1895 ; R . W . S . \quad$ In 1837 it appeared in sandy cultivated fields at Portmarnock, Dublin, where it has not since been observed.

So far, the plant does not appear to have fully naturalized itself in Ireland, though well established in its Portrane station.

Silene dichotoma Ehrh.

V. In a turnip field near Clonsilla, Co. Dublin, 1894; N. C.XII. Abundant in several cornfields between Saintfield and Crossgar, Co. Down, 1894 (D. Redmond \& Rev. C. H. Waddell); waste ground by the Belfast Distillery, 1893-4 (R. Hanna): S.\& P. 1895 .

A native of eastern Europe, introduced with foreign grain and apparently spreading in England.

Cerastium alpinum Linn.

XII. About Ballinleg and Glenarm : Ir. Flor. Abundant on the left side of the road from Larne to Glenarm, 1833: Whitla MS.

An error in both cases.

Cerastium trigynum Vill.

I. High mountains near Bantry, rare (Miss Hutchins) : Mack. Cat.\& Flor. Hib.

Never confirmed. A decidedly alpine species confined in Great Britain to the Scotch Highlands and by no means likely to occur in south-west Cork. Though there are specimens correctly named in Dr. Mackay's Herbarium they cannot be relied on as supporting the record, as many of the plants in this collection are known to have been derived from the Botanic Gardens, and were inserted only to represent the species.

Stellaria aquatica Scop.-Malachium aquaticum Fries.

I. or II. On the banks of the Lee (Dr. Hincks): Flor. Hib. \& Flor. Cork.

A specimen in the Herbarium of the Cork Institution is attributed to Drummond by Dr. Hincks (Ann. Nat. Hist. 1841), but is not included in Drummond's list. Never confirmed, and no doubt an error.

\section{Arenaria tenuifolia Linn.}

III. Growing plentifully with Linaria minor, Sagina apetala, \&c., along the railway track at Ballybrophy, Queen's Co., for about 300 yards, 1898 ; also at Bansha, Tipperary, $1898 ; R$. A. Phillips, 
Undoubtedly introdnced, but likely to become established, and interesting as the first record for Ireland.

Sagina Linnæi Presl-Spergula saginoides Linn.

I. On mountains near Bantry (Miss Hutchins); on Bear Island ( $T$. Drummond): Fllor. Hib.

Never confirmed; the plant observed was probably S. subulata Presl, which is found in several stations in south-west Cork.

Spergula pentandra Linn.

Recorded in the 3 rd Ed. of Ray's Synopsis, p. 35I, as observed in sandy places in Ireland by Dr. G. Sherard. In Cybele Hib. p. zoq it is suggested that Sherard's plant was a species of Lepigonum (Spergularia); but Mr. G. C. Druce (Annals of Bot. Septr. 1890) shows that the original specimen given by Sherard to Dillenius and preserved in the Dillenian herbarium is true S. pentandra. Also recorded in Flor. Cork as found near Cork by Drummond and in gardens about Youghal by Miss Ball; but little confidence can be placed in the determination of the species.

A plant of Middle and Southern Europe, merely casual in Ireland.

\section{HYPERICINEAE.}

Hypericum calycinum Linn.

I. Forming extensive underwood at Dinis, Killarney, 1831 (Harvey) : Herb. Trin. Coll. Dubl. Thoroughly naturalized in the woods at Muckross: Cyb.-II. Near Ballymaloe in the barony of Imokilly, remote from any garden: Smith's Cork 1750. Near Midleton; Aghada; East Ferry, \&c., not rare in Cork : Allin's Cork. East Ferry, the roadsides and banks of the Ballinacurra river covered with it for about a mile, thoroughly naturalized in many stations: Phillips 1895 . Also recorded from other counties, as Wexford and Wicklow : Cyb.

This handsome plant, undoubtedly derived from cultivation in all its stations, has established itself more thoroughly in Kerry and Cork than elsewhere in Ireland, and seems almost deserving of a place in the Irish Flora.

\section{Hypericum elatum Ait.}

II. Banks of Suir near Clonmel : Hart 1885 a.-XII. Plantation above Donard Lodge, Down : Flor. Olst. Also stated to have been gathered near Galway by Prof. Balfour: Cyb.

Planted or an escape. 


\section{Hypericum hircinum Linn.}

I. Near Monkstown, Cork (Carrall) : Cyb. Roadsides by the sea at Crosshaven; Phillips.-II. Between Aghada and Cloyne; and thoroughly established on walls by the road under Lota Wood, Glanmire, Cork (Carroll) : Cyb. Abundant at Glanmire and Eastferry, and spreading from walls to roadsides, rocks and banks; thoroughly established in several of its localities: Phillips 1895 .

An introduced ornamental plant of Southern Europe, spreading to wilder stations than $H$. calycinum, and almost qualified for admission to the Irish flora.

Hypericum montanum Linn.

V. Howth and Dublin mountains: Wade Dubl.-XII. On Mallagh Hill in the county of Down about eight miles east of Belfast (D. Orr) : Cyb.

The first record is no doubt an error of name; in the second, the authority cannot be taken as sufficient without confirmation and this has never been given, although the locality intended, Mealough Hill, about five miles south-east of Belfast, has been frequently examinedsee Flor. N.-E. p. 292.

\section{IIALVACE $A$.}

Malva borealis Wallm.

V. Two plants at Donnybrook near Dublin, 1869 (M. Dowd): Rec. Add.-VI. Waste ground near a gate lodge, Glenstal, Co. Limerick (C. B. Barrington) : Hart $188 \mathrm{I} \gamma$.

A casual, nowhere established.

\section{LINEAE.}

Linum usitatissimum Linn,-Fllax.

Occurs not infrequently as a survival or escape from cultivation, especially in the North-East.

\section{GERANIACEZE.}

Geranium striatum Linn.

I. Abundant in shrubberies at Myrtleville, Crosshaven, Co. Cork; R.W. S.-V. Old Connaught, Co. Dublin; More. Ditch bank near Raheny, Co. Dublin ; Hart.-XII. Ditch bank nearLisburn (Moore): $C y b$. Near Templepatrick and Keady Hill (Stewart); and in Crawfordsburn, and near the railway station at Newtownards (Corry): 
Flor. N.-E. Near Comber, Down (Praeger); and Ballinderry, Antrim (W. Donnan): S. \& P. 1895 .

Garden escapes or outcasts.

Geranium nodosum Linn.

IV. Wood at Newtownbarry, Wexford, well established, 1871 ( $J$. Morrison) : Rec. Add.-X. Naturalized on a bank south of Armagh : Praeger 1803 .

Of garden origin like the preceding.

Geranium Phæum Linn.

II. At Roxboro, Midleton (Allin): Rec. Add. At Lota-Wood: Allin's Cork.- - V. In a neglected avenue near Ballybeg railway station, Co. Meath, for many years (G. Dawoson): Reo. Add.VI. At Glenstal, Co. Limerick, naturalized (C.B. Barrington): Hart 288 I $\gamma$. - $\mathbf{X}$. Hedge near Mullaghmore Lake, Armagh, an escape: Praeger 1893.-XI. Near Templecarne, Donegal (Miss Young): Hart I886.-XII. Roadside in Island Magee (R. Tate): Rec. Add. Plentiful by a stream into the lower end of Knock Glen, appearing quite wild (Stewart): Flor. N.-E.

Always originating from cultivation, but becoming naturalized in some of its stations.

Oxalis corniculata Linn.

Recorded as an escape near Belfast (FTor. N.-E.) and is not infrequently met with elsewhere about walls, \&c., in the neighbourhood of gardens.

Oxalis stricta Linn.

Recorded from Belfast, 1842 (G. O'Brien); and near Lisburn (S. Pim): Rec. Add.

Like the preceding, occurs only as an obvious garden escape.

\section{SAPINDACEAE.}

Acer campestre Linn.-Maple.

Acer Pseudo-platanus Linn.-Sycamore.

Both the Maple and Sycamore occur in hedges and woods in many parts of Ireland from South to North, but are in all cases planted or derived from plantations. The Maple appears wild in some of its stations in Antrim, Derry, and Mayo, and the Sycamore freely reproduces itself from seed in many places, occasionally spreading to peat bogs in the neighbourhood of plantations. 


\section{LEGUMINOSAF.}

Genista tinctoria Linn.-Dyer's green-weed.

V. Between Killiney Hill and Bray: Mack. Cat. \& Flor. Hib.

An error. The dwarf procumbent form of Cytisus scoparius, which grows at Killiney Hill and Howth, was probably mistaken for this species.

Ononis spinosa Linn.

I. Blackrock; and-II. At Little Island : Flor. Cork-XII. In a pasture field near Ballinahinch, Down, a casual (Stewart): Flor. N.-E.

The Flor. Cork records should probably be referred to the Var. HORRIDA of 0 . repens.

Medicago sativa Linn.-Lucorne.

II. Cliffs at Ballycroneen, Cork, established; Phillips.-V. Sandy fields at Portmarnock, perfectly naturalized : Mack. Cat. I825:and again in 1866 ; Hart. Well established on sandhills near Rush, Co. Dublin (Moore) : Cyb. 2866:-and still there in 1895; N. C.-X. Fields near Armagh and Richhill: Praeger 1893.-XII. Abundant on a railway bank near Larne in 1869 (Steroart); and again in 1877 (Corry): Flor. $N_{-}-E$.

Also occurs sparingly in numerous other stations, but is always an obvious relic of cultivation, though in some stations maintaining itself for many years.

Medicago sylvestris Fries.

V. Found in considerable quantity on dry sandy banks at the southern end of Portmarnock sandhills, Co. Dublin, by R. Ll. Praeger in 1894-96; and at Malahide, three and a-balf miles to the the northward, by Prof. G. F. Fitzgerald in 1896: Ir. Nat. 7896 , p. 249 .

As these localities are notoriously fruitful in alien species and the plant has not been recorded from any other station in Ireland, it seems inadvisable at present to admit it to the Irish Flora.

Medicago falcata Linn.

II. Roadside near Queenstown Junction, 1897 ; Phillips.-V. Portmarnock: Mack. Cat.-but not seen recently.-VI. One plant by the roadside at Killaloe, Clare, $1896 ; N . C .-\mathrm{XII}$. York-street terminus, Belfast (W. Millen): Rec. Add.

A casual, nowhere appearing in any quantity. 
Medicago denticulata Willd.

I. Bandon, Co. Cork (J. Sullivan) : Cyb.-II. Near Blarney : Flor. Cork.-V. Between Dolphin's Barn and Crumlin, Co. Dublin (Mr. Johnston): Cyb.

A casual introduction, and not seen recently.

Medicago minima Desr.

I. Cultivated fields at Bandon ( $J$. Sullivan): $C y b$.-II. One plant by the Corn Market, Cork, 1836 (Mlr. Alexander): Flor. Cork. Sandy fields near Ballycotton (J. Sullivan): Annot. in Flor. Cork.

A casual, not seen recently.

Melilotus alba Desr.-MM. vulgaris Willd.

I. Valentia, Kerry; R.W.S.-II. Roadside at Blackpool, Cork, 1891 ; J. H. Bennet. Near Whitegate, 1891 ; Phillips.-IV. By a newly-made road near Camolin, Wexford (J. Morrison): Cyb.-V. On waste ground between Howth and Baldoyle: Flor. Howth.VI. Near Limerick and Kilrush; P. B. O'Kelly.-XII. Gravel pits at Giant's Ring, 1872-88 (Stewart); and Holywood, Down (Praeger): Flor. N.-E.

An alien introduced with seed, and quite uncertain in its localities.

\section{Melilotus parviflora Lamk.}

II. Near Waterford; A. R. Friel.-X. Waste ground at Newry Docks: Praeger $2893 .-\mathrm{XII}$. Near Holywood, 1887 : Fllor. N.-E. Near Duncrue, Belfast (Praeger): S. \& P. 1805 .

\section{A casual.}

\section{Trifolium maritimum Huds.}

V. In a field near Kilbarrack churchyard: Wade Rar. In the island of Lambay (Mr. Underwood); at the end of the North Wall, Dublin: Mack. Rar.-VI. Plentifully about the border of a field near the village of Liscannor, Clare (More): Journ. of Bot. 2880 , p. 233 .

The district V. records are probably all referable to $T$. scabrum. While the authority for the Co. Clare plant places its identity beyond all doubt, we agree with Mr. More in thinking it prudent to wait for further observation before admitting this species to a place in the Irish flora.

Trifolium hybridum Linn.-Alsike Clover.

I. Not rare in pastures in Kerry; R.W.S.-V. At Castlebellingham, Louth; Cecil Butler. At Rush and Skerries and other 
stations in Co. Dublin; N.C.-VII. At Knock Drin, Westmeath; Levinge.-X. In pastures, occasionally, throughout Co. Armagh : Praeger 1803.-XII. In many stations in Antrim, Down, and Derry : S. \&P. 1895 .

Many other stations might be given, but the plant is in all cases a relic of recent cultivation, and shows little tendency to become established.

Trifolium resupinatum Linn.

II. Cork Harbour : Herb. Chandlee.-XII. Fields near Purdysburn, and the Giant's Causeway : Flor. Olst. Saintfield, Down (Rev. C. H. $W a d d e l l)$; waste ground by Belfast Distillery $(\boldsymbol{R}$. Hanna) $:$ S. \& $\boldsymbol{P}$. $\mathbf{I} 895$.

A casual.

Trifolium agrarium Linn.

XI. By the Foyle a little north of Kilderry, Donegal; Hart.XII. Drumbo, Co. Down (J. H. Davies) : Ir. Nat. 1897, p. 299.

A casual, spreading in England, and likely to appear elsewhere in Ireland.

Onobrychis sativa Lamk.-Sainfoin.

II. By the shore at Ballymore, Great Island, 1840 : Flor. Cork.V. Fields near Leixlip; $N$. C.-XII. Cherryvalley near Comber : Flor. Belf. Fields near Whitehouse (W. MacMillan): Flor. N.-E. A relic of cultivation.

Vicia sativa Linn.-Vetch.

Occurs frequently among crops, by field borders, \&c., as an escupe from, or relic of, cultivation, but is not permanent.

Lathyrus Aphaca Linn.

II. Near Ballycotton, Cork, 1855 (Carroll): Herb. Barrington.XII. Near Belfast (Millen): Phytol. 185 I. Stranmillis, 1864-72 (J. Murphy): Flor. N.-E.

A casual.

Lathyrus Nissolia Linn.

II. At the Waterworks, Cork : Herb. T. Chandlee.

A casual; native in South England.

ROSACEA.

Prunus domestica Linn.-Wild Plum.

Though recorded from Cork and other places, true $P$. domestica Linn., with oblong fruit, is not seen wild in Ireland. 
Spiræa salicifolia Linn.

I. Between Ballinhassig and Kinsale; and-II. Near Blarney Castle (Mr. Alexander) : Flor. Cork.-V. Hedges near Dundrum : Flor. Hib.-X. Abundant between Newtown Hamilton and Ballymyre, Armagh : Praeger I893.-XI. By the Finn, a little above Castle Finn, Donegal : Hart 1885 \%.-XII. By Enagh Lough, and by the Roe near Dungiven (Moore); and Hillsborough Park (Stewart): Flor. N.-E. Near Ballynahinch and near Drumbo: Flor. Ulst.

A native of North America, North Asia, and Arctic Europe, already established in some parts of Great Britain; either planted or an escape in Ireland.

\section{Fragaria elatior Ehrh.-Hautboy Strawoberry.}

Has been found in several stations such as Dunscombe's wood, Cork, and near Shane's Castle, Antrim, usually near ruins and always as a relic of cultivation.

Potentilla argentea Linn.

IV. On Sugar Loaf mountain, Co. Wicklow: Flor. Hib.

Not confirmed; no doubt an error.

Rosa stylosa Desv. var. SYstYua (Bast.).

I. and II. Hedges at Evergreen (J. Drummond); many places about Cork: Flor. Cork. -II. Rocks at Myrtle Hill, Cork (Carroll): Cyb.

Rosa pomifera Herm.

XII. In Shane's Castle Park, Antrim: S. \&P. 7895 .

Rosa cinnamomea Linn.

II. In the park at Knocklofty, Clonmel (T. Anderson): Cyb.V. Hedges on the east side of Woodlands demesne, Co. Dublin; and-XII. Near Clady, Co. Derry, naturalized: Flor. Hib. Ogilvie's demesne, Lower Cumber, but planted (Moore) : Flor. $N_{\text {. }}-\boldsymbol{E}$.

All three of these Roses were no doubt planted in the above stations; the first named is perhaps semi-naturalized near Cork.

Rosa Dicksoni Lindl.

Said to have been found in Ireland by J. Drummond, but probably sent from the Cork Botanic Garden: Flor. Hib., p. 95 .

Pyrus communis Linn.-Wild Pear.

II. On rocks below Fermoy (J. Drummond): Flor. Hib.XII. Hedge at Throne Mount near Belfast: Flor. Belf.

Planted in both stations. 


\section{SAXIFRAGEA.}

Saxifraga Andrewsii Harvey-S. Guthriana Hort.

Thought to have been found at the head of Glen Caragh, Kerry, but never confirmed. The plant is now considered to be a garden hybrid of $S$. umbrosa with one of the Aizoon group of Saxifrages, none of which is native in the British Isles. Described by W. H. Harvey as a new British Saxifrage in London Journ. of Bot., Vol. VII., I848, p. $57 I$.

An error.

Saxifraga cæspitosa Linn.

I. On a rock near the summit of Brandon mountain, 1805: Flor. Hib.-VIII. On Muckanaght, Twelve Bens, Connemara: Hart 1883 a.

It has been considered advisable to refer these plants to S. groenlandica Linn., though not without hesitation, so subtle are the distinctions between the protean forms of the hypnoid group of Saxifrages (see $p .13 l$ ).

Chrysosplenium alternifolium Linn.

I. Killarney (J. Barbour): Science Gossip, 1807, p. Ioq.X. Ballylast, Tyrone: Murphy z820.-XII. Near Belfast (Templeton): Mack. Cat. Colin Glen (Templeton): Flor. Olst. Ballymaghan Glen: Flor. Belf. By the river in Glendun, Antrim; and naturalized on a ditch bank near the Botanic Garden, Belfast (Moore) : Cyb.

The above records are all errors.

Ribes Grossularia Linn.-Gooseberry.

V. By the Royal Canal below Clonsilla, Co. Dublin; N.C.VII. Coosan Point, Lough Ree : B.\&V. $2887 .-$ VIII. South of Lough Mask: M. \& S. I896.-XI. By Lough Swilly between Drumalla and Fort Royal; Hart.-XII. Rocky heath on Rathlin Island (Stewart) : Flor. N.-E.

Ribes rubrum Linn.-Red Currant.

I. or II. "Naturalized in some parts of the Co. Cork" (Drummond): Flor. Cork.-XII. Shores of Lough Neagh near Antrim (Moore): Flor. $N .-E$. By the Roe near Limavady, Derry: Templeton MS.

Ribes nigrum Linn.-Black Currant.

I. or II. In the county Cork, in many places naturalized (Drummond): Flor. Cork.-VI. Moory ground near Castleconnell, 
Limerick, where the seed had probably been carried by birds: Flor. Hib.-XII. In different parts of Ulster : Flior. Olst.

The three preceding species occur occasionally as more or less. obvious escapes from, or relics of, cultivation. None of them is naturalized, though the Gooseberry sometimes appears in wild looking stations.

\section{CRASSULACEAE.}

\section{Sedum rupestre Linn.}

1. Rosscarbery, Cork (Carroll): Allin's Cork-on rocks here in 1891, and on old walls at Crosshaven and Douglas, 1897; PhillipsII. Rocks on Little Island; walls at Queenstown and Youghal (Carroll): Cyb. Near Fermoy (T. Chandlee); and at Midleton: Allin's. Cork. Old walls at Eastferry, 1893; at Little Island and Aghada, 1895, but nowhere fully established in Co. Cork; Phillips. About Clonmel (T. Anderson): $C y b$. - IV. An escape on walls at Laragh, Co. Wicklow, 1888; N. C.-V. Plentiful between Dundrum and Rathfarmham (Moore): Flor. Hib.-X. An escape near Keady, Armagh: Praeger 7803.-XII. Near Shane's Castle: Flor, Clst. By the side of the Foyle near Ballykelly (Moore): Cyb.

In all cases derived from cultivation. Appears to be better established in Cork than elsewhere in Ireland, and is not unlikely to become fully naturalized.

Sempervivum tectorum Linn.-Houseleek.

Occurs on cottage roofs throughout Ireland where it has long been used as a charm against fire. Always obviously planted and showing no tendency to spread.

\section{LYTHRARIE $A$.}

\section{Lythrum Hyssopifolia Linn.}

IV. Ballymadder, near Bannow, Co. Wexford (James Tardy): Flor. Hib.

A plant not unlikely to occur in the South, but the above record, the only one for Ireland, has never been confirmed, though the plant has been searched for in $1870 \mathrm{by} M r . R$. M. Barrington, and in 1882 by Mr. H. C. Hart.

Probably a mistake or a casual only.

\section{ONAGRARIEAE.}

Epilobium tetragonum Linn.- $\boldsymbol{E}$. adnatum Griesbach. V. By the roadside west of Carrickmines, Dublin (Prof. A. 
Dickson): Rec. Add.-XII. Near Hollywood, Down (Praeger): Flor, $N .-E$.

The Carrickmines specimen preserved in the Glasnevin Herbarium is too imperfect to be named with certainty, and is probably $E$. obscurum rather than tetragonum. The Hollywood plant can only be considered a casual, and the references to this species in the earlier authorities, such as Ir. Fllor., Flor. Hib., and Flor. Cork, must be transferred to $E$. obscurum.

\section{Epilobium Lamyi F. Schultz.}

I. or II. This is recorded by Mr. Arthur Bennett (Trans. Bot. Soc. Edin. $1887, p .49$ ) as found in Co. Cork, by T. Allin, and named by Haussknecht. The precise locality, however, is not given, and it seems best to treat this plant as a casual until some more definite record and particulars are given.

Enothera biennis Linn.-Evening Primrose.

V. Sparingly at Portmarnock (Barrington): Moore \& More 1878 . Railway banks near Howth, 1895-98; Miss Mahaffy.-XII. Shore of Lough Neagh at Massareene Park : Flor. N.-E.

A garden escape in these as in many other Irish stations.

\section{CUCURBITACEAE.}

Bryonia dioica Jacq.

II. Lismore 1803 (R. Davis): Herb. Grubb. On an old fence in the glebe at the Rectory, Tramore (Rev.J. Cooke) : Cyb.-III. "It was brought to me from Catherlough, or as we pronounce it Carlow": Threlkeld.-IV. Hedges by the roadside near Westaston nearWicklow; F. Moore.-V. Near the Bailey Lighthouse, Howth, 1894 ; Miss $A$. Kinahan.

Planted or an escape.

\section{UMBELLIFERA.}

Eryngium campestre Linn.

II. Sandy field near Lismore, Waterford (Drummond): Flor. Hib. A casual, not recently seen in Ireland.

Trinia vulgaris DC.

V. Near the church at Athboy, Meath: Wade Dubl.

An error; the plant observed was perhaps some form of Pimpinella Saxifraga. 
Ammi majus Linn.

V. Portmarnock sands, 1821 : Mack. Cat.-seen here for several years in succession by Mr. John Bain.

A casually introduced plant of Southern Europe, which has long since disappeared.

Petroselinum sativum Hoffm.-Carum Petroselinum BenthParstey.

I. Ardfert; Abbeydorney ruins, \&c., Kerry : R.W.S. I889. On rocks by the river side above and below Cork; on an old castle near Inchigeela; near Timoleague; and-II. Carrignavar, in a naturalized state: Drummond 18 r8. Rocks on Little Island and Haulbowline Island: Flor. Cork. Ballyhooley Castle, Fermoy (J. Chandlee): $C y b .-\mathrm{V}$. On the walls of the ruined church at Ballyboghil, Co. Dublin, 1894 ; N. C.-VI. On walls at St. Mary's Church, Limerick (Carroll) : $C y b$. Castle ruins at Askeaton, Co. Limerick, 1897 ; Rev. C. H. Waddell.-X. On Crum Castle, Lough Erne: Barrington 1884.-XI. Rathmullan Abbey, Donegal; Hart.-XII. On the walls of Londonderry (Moore): Cyb. Old castle walls at Ringhaddy, Down (Praeger): S. \&P. 1895 .

In all cases an escape from cultivation. Long established on many ruins throughout Ireland, but showing little tendency to spread.

Anthriscus Cerefolium Hoffm.-Chorophyllum satioum Gaertn. -Chervit.

Occurs occasionally as an escape from cultivation, but is nowhere permanent.

Carum Carui Linn.-Caraway.

IV. On the railway near Kilcool, Wicklow, in some plenty, 1876 ; More.-V. Fields near Kilmainham, \&c. : Flor. Hib.-VII. Railway ballast pit at Lough Kinale, Longford; Praeger.-X. Common on the railway south of Bessbrook, Armagh: Praeger 1893.-XI. At Carrablagh, introduced: Hart I879.-XII. About the ruins of Grey Abbey, Down : Ir. Flor.

Not infrequent as an introduction, and perhaps becoming naturalized in the Armagh station.

Silaus pratensis Bess.-Silaus flavescens Bernh. XII. By the Foyle above Londonderry (Moore): Cyb. Near Ballyrobin, Antrim (Orr): Flor. Olst.

The first record seems to have been an error; in the second the authority is not considered sufficient. 
Meum Athamanticum Jacq.-Baldmoney.

XII. Recorded by Templeton as plentiful on the lawn at Maryville in Malone, 1818, and on the lawn at Cranmore, "probably lately introduced."

A casual, not seen recently.

\section{Peucedanum Ostruthium Koch-Masterwort.}

II. Near Lismore and Tallow on the hill of Slatwood: Smith's Waterford.-VI. Salt marshes by the Fergus near Ballinacally, Clare; P. B. O' Kelly.-X. Roadside near Drumakilly, Co. Tyrone; Rev. T. Warren. Near Lough Gullion; Ballymyre, Camlough, and Jonesborough, Armagh: Praeger 1893.-XII. Old hedges on the townland of Ballydolaghan, Co. Down, apparently wild (Mr. Campbell): Flor. Hib. Ballintoy, Antrim: Cyb. Near Cushendall, 1872 (Rev. S. A. Brenan); near Cookstown, 1884 (W. Macmillan): Flor. N.-E. Abundant in a meadow at Cave Hill, 1886, but now disappeared (Stewart): Flor. N.-E. and S. \& P. 1805. Near Downhill, Derry (Mrs. Leebody) : S. \& P. 7895 .

Introduced in all its stations and hardly established in any.

Coriandrum sativum Linn.-Coriander.

V. On the strand between Clontarf and Howth: Wade Rar.XII. Waste ground at Malone, Belfast (Stewart) : Flor. N.-E.

A casual, not seen recently.

Daucus gummifer Lamk.

Recorded from near Hollywood, Co. Down (Millen): Flor. Olst.; and stated in $C y b$. to occur on many parts of the coast, but no authenticated Irish records are known for this critical plant.

Torilis infesta Spreng.-Caucalis arvensis Huds. I. or II. Near Cork (Rev. Dr. Hincks): Flor. Cork.-XII. Near Comber: Flor. Belf.

Errors.

\section{CAPRIFOLIACEAE.}

Viburnum Lantana Linn.-Wayfaring Tree. Occasionally seen in shrubberies and hedges, but only where planted. The Care Hill plant of Orr and Thompson (Flor. Ulst.) was V. Opulus (see Flor. N.-E.).

Lonicera Xylosteum Linn.

III. In a copse on Kippard Mountain, near Mountmellick, Queen's 
Co. ; Nat. His. Rev. 7857, p. 227.-XI. Wood at Buncrana and at Brown Hall near Donegal; Hart.-XII. Walls at Bellahill: Flor. Ulst.

An introduced shrubbery plant, nowhere naturalized.

\section{VALERIANEAE.}

\section{Valeriana pyrenaica Linn.}

XII. Near Antrim, 1885 (Rev.W. S. Smith): Flor. N.-E.

An introduced shrubbery plant of Southern France and Spain already naturalized in Great Britain.

Valerianella carinata Loisel.-Cornsalad.

XII. Diteh banks on the main road east of Dundonald, and abundant on a by-road leading thence to Hollywood Hills, Co. Down, 1871 (Stewart): Rec. Add. \& Flor. N.-E. Steadily increasing here (Praeger): S.\&P. 1895 .

A colonist, becoming naturalized at Dundonald.

\section{COMPOSITE.}

\section{Aster [lævis Linn?]}

I. Established on the banks of a river near Headford bog, east of Killarney, $1894 ; R . W . S .-I I I$. Thoroughly established by the Nore above Kilkenny, and again below Woodstock; also-X. At Glasslough, Co. Monaghan (Miss' Young): Hart 1885 \%.XI. Established by the Bundrowes river near Bundoran: Hart $\mathbf{I} 885 \boldsymbol{\gamma}$.

Mr. Hart is inclined to refer his plant to the North American $A$. lavis, and perhaps all the stations here given belong to the same. Though of undoubted garden origin it seems thoroughly established and must have been introduced at no recent date.

Antennaria margaritacea $\mathrm{R}$. $\mathrm{Br}$.

I. Cloghreen, Killarney: Wade Rar. Near Milltown, Kerry : Mack. Rar. Near Bandon (Drummond); Cape Clear Island (R. W. Townsend); and-II. Clonmult, Barrymore: Flor. Cork.III. Ditch bank between Cullenagh and Stradbally: Mack. Rar.-XI. By roadside between Gartan and Kilmacrenan, Donegal : Hart 1880 .

Other localities might be quoted, but in all cases the plant is of garden origin and not permanent in its stations. 
Gnaphalium luteo-album Linn.

XII. At Lambeg: Flor. Olst. Belfast (W. Thompson); and at Malone (D. Orr): $C y b$.

Authorities insufficient, and in any case only a casual or garden escape.

Pulicaria vulgaris Gærtn.

I. Cromane, Kerry (Herb. J. Reilly): Barrington in Journ. of Bot. 1877.

Mr. John Reilly, who was a coastguardsman, appears to have formed a collection of plants whilst living at various stations around the coast. His collection, now in the possession of Mr. R. M. Barrington, contains a specimen of this species correctly named from the above locality. The plant, however, has not been re-discovered there, though sought for, and as there is no other record for Ireland it must be regarded as a casual only.

Xanthium Strumarium Linn.

I. Common in the barony of Iraghticonnor near Listowel and other places: Smith's Kerry.-II. In a potato field at the Blarney cloth factory: Flor. Cork.

The first record should no doubt be referred to Arctium minus; in the Blarney station the plant was merely a casual.

Achillea tomentosa Linn.

XII. Near Newcastle, Co. Down (Miss Ball): Ann. of Nat. Hist. 1839. Said also to have been received from Ireland by Sir James Smith : Flor. Hib.

A garden plant from Southern Europe; an escape and not seen recently.

\section{Anacyclus radiatus Loisel.}

I. or II. Ballast heaps, Cork: Hooker Student's Fl. 1884. At Dunboy, Berehaven (W. Wilson): Allin's Cork.-V. Gravel pit near Clontarf, Dublin (Praeger): Ir. Nat. 1893.

A casual, native in Southern Europe.

Anthemis arvensis Linn.

I. Bearhaven : Babington in Herb.-IV. Near Greystones, Wicklow, introduced : Praeger $1897 .-\mathrm{V}$. Plentiful in sandy cultivated ground at Portmarnock, 1869 (Moore): Rec. Add. At Warren House and about Howth village : Flor. Howth. Lyons, Co. Dublin (T. Chandlee); and plentiful in a field at Baybush, Straffan, Kildare ( $J$. Douglas): 
Cyb.-XII. Sandy fields at Ballykinler, Co. Down (Praeger, $)$ : S. \& P. $\pi 895$.

Also occurs frequently as a casual, but appears to be nowhere fully established. The plant is so often confounded with $A$. Cotula that many of the older records must be dismissed as untrustworthy.

Chrysanthemum Parthenium Pers.-Feverfew.

I. Between Bantry and Glengariff; Glandore; Castletownsend: Allin's Cork.-II. Near Whitepoint; Eastferry, \&c. : Flor.Cork.V. Roadsides between the Naul and Baymere, Meath; on the commons at Whitewater Bridge, Louth: Ir. Flor. Near Balrothery. and the Bog of the Ring, Co. Dublin, 1894; N.C.-X. Portadown and Newry, Armagh: Praeger 1893.-XI. Established on the bridge at Belleek; Hart.-XII. Abondant in a freestone quarry near Moneymore, Derry: Moore MS. Frequent in waste places in N.-E. Ireland: Flor. N.-E.

Occurs frequently as an escape from cottage gardens, but does not appear to have anywhere thoroughly established itself in wild localities.

\section{Matricaria discoidea DC.}

V. Roadside by the Rathmines waterworks, Glenasmole; waste ground at Lispopple cross-roads; abundant on the footpath of Glenamuck road, Carrickmines, Dublin, 1894 (N.C.): Ir. Nat. I894, $p$. 215. Spreading for half a mile along the roadside at Carrickmines and freely reproducing itself by seed, $1895 ; R . W . S . \&$ N.C. Waste ground by a roadside at Howth, 1896 (Praeger): Ir. Nat. 1896, p. 298.

A native of western North America which has spread rapidly through the United States, and has long since fully established itself in Germany and Scandinavia. So far, it is apparently confined in Ireland to county Dublin, but is not unlikely to become fully naturalized in the country.

\section{Artemisia campestris Linn.}

I. In a field near Castle Island: Smith's Kerry.-XII. At the foot of the Milewater near Belfast (W. Millen): Flor. N.-E.

The first record was an error, in the second the plant was a casual.

Artemisia Stelleriana Bess.

V. Naturalized in a thoroughly wild station among sandhills on the North Bull, Dublin Bay, 1891 (Miss A. G. Kinahan): and 
again close by this station in greater abundance, 1892 (C.B.Moffat): Journ. of Bot. 1894, pp. 22 \& 104. Spreading on the North Bull in $1898 ; N . C$.

A native of Kamtschatka frequently cultivated in gardens in Europe and North America and reported from sandhill stations in Scandinavia and in Rhode Island U.S. On the North Bull, where it grows freely in association with Psamma arenaria over a considerable space and looks quite wild, the plant is undoubtedly derived from cultivation on the adjacent mainland, a mile distant.

Petasites albus Gærtn.

XII. Shady bank at Ballymenock near Hollywood, Down (Praeger): Flor. N.-E.

A garden escape or outcast.

Doronicum Pardalianches Linn.-Leopard's Bane. VII. Killynon, Westmeath, well established (Miss E. Reynell): Levinge 1894.-X. Naturalized near Tynan, Armagh: Praeger 1893.-XII. Ballymacash: Phytol. O. S., Dol.D. Near Ballylesson; by Drumbo Church; and near Broughshane (Stewart); Beech Hill near Antrim (Rev. W. S. Smith) : Flor. N.-E.

Garden escapes.

Cineraria maritima Linn.-Seneoio Cineraria DC.

V. Abundant and luxuriant along the sea cliffs and drift banks for a quarter of a mile west of Sorrento Point, Dalkey, Co. Dublin; also spreading to adjacent walls, roadsides, railway banks, and waste places, $1898 ;$ N.C.

A native of southern Europe, now so well established in the peculiarly favourable station on Sorrento cliffs, as perhaps to deserve full admission to the Irish flora. Sir Francis W. Brady informs us that this vigorous settlement of a most interesting alien species originated with a packet of seeds sown by him in his garden at Sorrento Cottage, in or about the year 1875. At that time he observed no trace of the plant on any part of the cliffs of which it now forms so conspicuous an ornament, and having had ample opportunity of watching its gradual increase, he has no hesitation in attributing its extension east and west along the rocky coast adjacent to his garden, solely to the agency of wind-borne seeds. The extreme limits of the plant at present appear to be Sorrento Point on the east and the South Vico bathing-place on the west.

Senecio saracenicus Linn.

I. Roadside near Bantry (Allin): Rec. Add. In a field near 
Goleen, Co. Cork, 1896 ; Phillips.-II. By the Suir below Cahir and below Ardfinnan: Hart I885 a.-VI. Near Corofin, Clare; and Pallas, Galway: $K^{\prime} E o g h$. At Cahiracon, Clare; P. B. O'Kelly.X. Near Keady, Armagh : Proeger 2893.-XI. Established by the river between Pettigoe and Lough Erne: Hart 1885 \%.-XII. By a stream near Cushendall coastguard station (Dr. J. S. Holden), \&c. : Flor. N.-E. Roadsides at Magilligan (Praeger); and near Culmore, Derry (Mrs. Leebody): S.\&P. 1895 .

Derived from cultivation in all its stations, and does not appear so far to have fully naturalized itself in any.

Centaurea solstitialis Linn.

II. Two plants in a meadow near Whitegate, Cork, 1896; Phillips.-V. Sandy field at Portmarnock, 1821 (Dr. Charles Croker): Mack. Cat. A single plant in a lucerne field near Kilbarrack, 1862 ; Levinge.-VI. In ballast at Kilrush, Clare; P. B. O'Kelly.

A casual introduced with seed.

Picris hieracioides Linn.

I. or II. Near Cork (Drummond) : Flor. Cork.-V. Portmarnock sands, sparingly : Mack. Cat.

A casual not seen recently.

Crepis setosa Haller $f l$.

III. Field between Browne's Hill and Carlow (R. Clayton Browne): Rec. Add.-V. Field between Drumleck and the Needles, Howth (Miss Mahaffy) : Ir. Nat. x895, p. r77.

Crepis nicæensis Balb.

X. Sparingly on the railway near Armagh : Praeger 1893.

Casuals introduced with seed.

Crepis succisæfolia Tausch-Hieracium molle Jacq.

I. Moist rocks on Magillicuddy's Reeks and other mountains in Kerry, 1805: Flor. Hib. Rocks near the river Sullane, Cork (J. Drummond): Flor. Cork.-IV. Devil's Glen, Wicklow: Flor. Hib.

Never confirmed, and no doubt an error in all cases.

Hieracium aurantiacum Linn.

I. Muckross, Killamey; $R$.W. S. On walks at Lissard, Skibbereen, 1890 ; Phillips.-VI. Moat lodge, Menlough, Galway; R. Bayly.XI. On a wall near Ards House, Donegal (C. Moor $b$ ) : Cyb.- 
XII. On the ruins of Portavo (Dr. H. Burden); and by the Belfast waterworks (Stewart): Flor. N.-E.

An escape from cultivation.

Hypochæris glabra Linn.

I. Gravelly shore near the upper end of the bay of Castlemain; and between Passage and Cove, 1804: Mack. Rar.-II. Limestone rocks on Little Island, Cork, 1853 (J. Sullivan) : Cyb.-III. Roadsides near Kilkenny, 1805; and-V. Near Dublin (Dr. Stokes): Mack. Rar.

Mackay's earlier records in Mack. Rar. are not repeated in his Flor. Hib. and were no doubt errors; in the Little Island station the plant, perhaps, appeared as a casual.

\section{Lactuca virosa Linn.}

Recorded by Mackay in his Additions to the Plants of Ireland as found between Blackrock and Kingstown.

An error, the plant preserved in Mackay's Herb. belongs to L. sativa, the Garden Lettuce (Cyb.).

\section{Tragopogon porrifolius Linn.-Salsify.}

I. Near Lixnaw, on the banks of the River Brick: Smith's Kerry.-II. Abundantly on Spike Island, Cork Harbour (Carroll): Annot. in Flor. Cork. Cusquinny, Great Island, Cork (Dr. Scott): Flor. Cork. In a shrubbery at Cork Beg, 1895; Phillips.XII. Railway banks at Sydenham: Flor. Belf. Abundant on railway banks from Whitehouse to Macedon, 1873 (Stewart); in plenty at Knock station, 1880 (Corry); at Marino, 1886 (Praeger): Flor. N.-E. Still abundant at Macedon, Sydenham, and Knock, and has spread to the railway bank at Kinnegar, Holywood, where it has been abundant for the last two years (Praeger): S.\& P. 7895 .

Perhaps naturalized on railways about Belfast, but not recently seen in Kerry.

\section{CAMP ANOLACEAE.}

Campanula latifolia Linn.-Giant Bell-flower.

III. or IV. Woods by the river Barrow above New Ross: Mack. Cat.-XI. Two plants by the Letter river near Pettigoe; Hart.XII. Abundant in the woods of Gilhall, 1883 (C. Dickson): Flor. N.-E.

Mackay's plant was almost certainly $C$. Trachelium; an escape in XI., planted in XII. 
Campanula rapunculoides Linn.

III. By the river Bregagh near Kilkenny, 1860-94; J. G. Robertson. -V. Well established for about 100 yards along a roadside bank S.W. of Rush, Co. Dublin, 1893: N.C. 1895 -X. Roadside near Dungannon, Tyrone (Miss Knowles): Ir. Nat. 1897.-XII. In sandhills near Newcastle station, Down, 1871 (Stewart): Rec. Add. - still there in 1891, and in fields near Rostrevor, Down : $S . \& P$. 1892. In a sandpit near Broughshane and near Kilrea (Praeger): S. \& P. 1895 .

A garden outcast or escape, apparently becoming naturalized.

Campanula Rapunculus Linn.-Rampion.

XII. Banks by the old Lisburn road near Ballydrain : Flor. Olst.

A casual, not since recorded.

Campanula patula tinn.

III. Roadside bank near Ballycallan Church, Kilkenny, 1861-62 (Rev. S. Madden): Cyb.

A garden outcast or escape.

Specularia hybrida A. DC.

I. In a field near Monkstown : Flor. Cork.-V. Several plants in a wheat-field by the Howth line near Baldoyle, Co. Dublin (N.C.): Ir. Nat. 1892, p. 144 .

A casual, interesting as spreading in the east of England.

\section{ERICACEAE}

Erica ciliaris Linn.

VIII. "Found by Mr. J. F. Bergin at Craigamore between Clifden and Roundstone on the 14th September, 1846": Mackay I859. In some quantity on Craigamore in 1852 (Professor Balfour): Phytol. ${ }^{2} 853, p .1007$. A correctly named specimen in the Herbarium of Trinity College, Dublin, is thus labelled: "Part of the original specimen gathered by me on Monday, the 14th September, 1846, between Clifden and Roundstone, I think the particular locality is called Craiga-a-more. The species was determined first by William Mc Alla, and confirmed by Mr. Mackay, to whom I have much pleasure in presenting this specimen; J. F. Bergin, 10th October, 1846."

Every effort to verify these definite records has ended in disappointment. The country around Craigga More has been carefully examined by Professor Babington, by Dr. David Moore, by A. G. 
More, and, finally, by Professor Balfour himself, without a trace of the plant being discovered. If the two records, separated by an interval of six years, and each of them supported by correctly named specimens, be both erroneous, as they would seem to be, we can only assume that $\mathrm{Mr}$. Bergin was the victim of an imposition, and that Professor Balfour's specimens were somehow mislabelled in the Edinburgh herbarium. Such a double assumption has no doubt all the appearance of an ingenious device to explain away very positive evidence, yet this evidence as it now stands is unquestionably insufficient to justify the admission of $E$. vitiaris to the Irish flora.

Erica vagans Linn.-Cornish Heath.

II. Islet [error for Islandicane] on the coast of Waterford, near Tramore: Hooker's Brit. Flor. I842. On the cliffs in the townland of Islandicane west of Tramore, Waterford; Dr. Burkitt, (fide the late $D r . B a l l): C y b$.

Never confirmed, though the locality has been carefully examined.

Erica stricta Andr.

North of Ireland, 1834 (Dr. Lloyd): Spec. in Herb. Hooker. This is also cited in De Candolle's Prodromus (see Britten in Journ. of Bot., $1872, p .25$ ).

A Mediterranean species; the specimen was either mislabelled or gathered in a garden.

Ledum palustre Linn.

Stated in Hooker's Student's Flora of the British Isles, Ed. III. p. 533, to have been reported for north-west Ireland, but never confirmed.

We have not been able to trace the authority for this report, which is undoubtedly an error, unless it refer to an intentional introduction.

\section{APOCYNACEAE.}

Vinca major Linn.-Periwinkle.

Vinca minor Linn.-Lesser Periwinkle.

Both plants are of not infrequent occurrence in Ireland as garden escapes or outcasts; the latter spreads occasionally to wild-looking stations, and increases rapidly when planted in woods or shrubberies.

\section{GENTIANEAE.}

Erythræa littoralis Fries.

V. Portmarnock sands: Mack. Cat.-XII. Rocky ground below 2 к 2 
Bangor : Templeton MS. Shore west of Groomsport (Mr. Mitlen): Flor. Olst.

No doubt the plant gathered was in all cases a form of $\boldsymbol{E}$. Centaurium.

Limnanthemum peltatum S. P. Gmel._Vitlarsia nymphooides Vent.

I. In a drain near Vernonmount gate, Cork: Flor. Cork.-II. In a stream near Shanbally, Tipperary; and-V. In the river Tolka at Glasnevin : Cyb.-XII. Naturalized in the Lagan a little above the Belfast Botanic Garden, and near Lurgan: Flor. Hib. In the Lagan, and various parts of Lough Neagh: Flor. Olst. In the Bog Meadows (R. Hanna): Flor. N.-E.

Planted in all cases.

\section{POLEMONIACEAE.}

Polemonium cæruleum Linn.-Jacob's Ladder.

I. In a meadow near Castleisland: Smith's Kerry.-II. Between Cork and Ballygarvan: Flor. Cork. Along the north bank of the Blackwater between Cappoquin and Lismore: Smith's Waterford.V. Knockmaroon hill near Dublin: Flor. Hib.-XII. Near Bellaghy, \&c.: Flor. Olst.

Garden escapes or outcasts, nowhere established.

\section{BORAGINEAE.}

Cynoglossum germanicum Jacq.-C. montanum Linn. V. Near Balbriggan or at Hampton (Dr. Scott): Mack. Cat. Again near Balbriggan ( $R$. Hewson) : $C y b$. Along a garden wall belonging to the surveyor of Slerries: Spec. in Herb. Jones, Science \& Art Mus., Dublin.

A garden escape or outcast.

Symphytum tuberosum Linn.

I. About Ballyphehane House, and near Evergreen, Cork: Flor. Cork. - V. By the Shanganagh river above Loughlinstown, Dublin, 1895 ; W. H. Bloomer.-XII. Plentiful in a wood at Clandeboye, 1887 (Rev. G. Robinson): Flor. N.-E.-quite naturalized here, though probably of garden origin: S.\&P. I895.

Often cultivated, and introduced in all of its stations.

Borago officinalis Linn.-Borage.

Occurs not infrequently about ruins, old gardens, rubbish heaps, 
\&c., throughout Ireland, but always sparingly and only as an escape from, or relic of, cultivation.

\section{Anchusa officinalis Linn.}

IV. In sandy wastes at Rosslare Point, Wexford: Hart $1883 \beta$.

An alien, probably introduced with ballast.

Myosotis sylvatica Hoffm.

II. A single plant in a shrubbery at Castle Widenham, Castletownroche, Cork, 1897 ; Phillips.-XII. Cave Hill, \&c. (Templeton); Wolfhill (Thompson): Flor. Olst.

Further information is desirable before admitting this to the Irish Flora; the records for Dist. XII. are no doubt referable to the form umbrosa Bab. of $M$. arvensis.

\section{CONVOLVOLACEAE.}

Cuscuta Epilinum Weihe-Flax Dodder.

Occurs sporadically in flax in many parts of Ireland, but is growing rare with the decline in the cultivation of that crop.

\section{SOLANACEAR.}

Lycium barbarum Linn.-Tea plant.

IV. Established at Rosslare Point, Wexford: Hart I883 $\beta$.V. Thoroughly established in sandy ground, and by the roadside between Greenfield and Sutton, Co. Dublin: Flor. Howth.XI. Established by the Bundrowes river near Bundoran: Hart $\mathbf{1 8} 85 \mathrm{\gamma}$.

A North African and Mediterranean species often cultivated in cottage gardens and tending to become naturalized on sandy shores in Ireland as it has already done in England.

Atropa Belladonna Linn.-Deadly Nightshade.

III. Abundantly by the brook-side where an old monastery stood at Stradbally, Queen's Co.: Wade Rar. and (T. Chandlee): Cyb. Among ruins at Kells, Kilkenny $(P . D u f y): C y b .-X I$. Abundantly in an exposed rocky place above tide-mark on the south side of Gweebarra Bay, east of Iniskeel, Donegal, remote from any ruin or dwelling: Hart 1886.

Also recorded from Districts I. V. VI. and XII., but the foregoing stations are the only ones in which this relic of cultivation has been found in wild-looking localities. 
Datura Stramonium Linn.-Thorn-apple.

Recorded in Flor. Hib. as growing occasionally in waste ground near towns, having been much used at one time as an asthma cure, also in Wade Rar. as growing abundantly by the river Lions, King's Co.

An escape from cultivation, now extinct.

\section{SCROPHULARINEA.}

Verbascum nigrum Linn.

II. Suir Island, Clonmel (Miss Grubb): Cyb.

A casual.

Verbascum virgatum Stokes.

I. Near Kenmare: Mack Rar._but not seen recently. In an old quarry near Blackrock, and on a wall near Goleen, Cork, 1896; Phillips.-II. Cusquinny (T. Wright): Cyb. Nearly a hundred plants in two large meadows at Little Island, Cork, 1897; Phillips $\&$ R.W.S.-IX. One plant near Ballybrine wood, Cong, Mayo, 1896 ; Miss $M$. $F$. Jackson.

An alien becoming established at Little Island, Cork.

Verbascum Blattaria Linn.-Moth Mullein.

I. By the old town wall of Bandon, 1858 (J. Sullivan): Annot. in Flor. Cork. In a pasture field opposite Monkstown (Carroll): $C y b$.-II. Abundant on rubbish and about quarries at Queenstown (J. Sullivan): Cyb. Near Cloyne: Allin's Cork. One plant at Little Island, 1892, and plentiful in waste ground at Muskerry railway terminus, 1895 ; Phillips. Ballydine, Tipperary (Miss $S$. $G r u b b)$; Clonmel $(C$. Jacob): $C y b$. Waste ground at the Waterford-Tramore terminus: $B . H . \& G$. . $889 .-\mathrm{IV}$. On rough stony ground a little north of Wicklow (More): Rec. Add.

An alien recurring frequently about Cork, but uncertain in its appearances and not sufficiently established to justify its admission to the Irish Flora.

Erinus alpinus Linn.

I. Introduced and spreading on an old garden wall at Douglas, Cork: Allin's Cork, ${ }_{1883}$. Spreading rapidly at Blackrock; Douglas; and Victoria Cross in the suburbs of Cork City, and appearing as well established as Linaria Cymbalaria, 1895; on old walls near Crosshaven, 1897; Phillips.-II. Waste ground near the shore at Queenstown, $1892 ; N . C$. Quite established between 
Golden and Cashel, Tipperary, 1883, though clearly a garden escape; Greenwood Pim.-XII. Growing freely on the wall of Dowapatrick Gaol, 1890 (Praeger): B.N. F. C. Proc, I892-93.

A sub-alpine species of Southern Europe often cultivated in gardens, and already established in north England. Not unlikely to become fully naturalized in south Ireland.

Antirrhinum majus Linn.-Snap-dragon.

I. Old ,walls at Blackrock: Flor. Cork 1845. At Blackrock, 1896, and at Bandon, 1891; Phillips.-II. At Sunday's Well: Flor. Cork. At Cork. 1896; Youghal, 1895, \&c.; Phillips.V. Garden walls about Dublin, noticed by Threlkeld as early as 1727. Old walls at Mellifont Abbey, Louth; and-XII. Ruins of Grey Abbey, Down : Ir. Flor. Perhaps naturalized on old walls in the North-East: Flor. N.-E.

An escape from cultivation, long persistent in many stations, but always occurring close to gardens.

\section{Scrophularia Scorodonia Linn.}

I. On the sea-coast near the Magherie Islands in Tralee Bay: Smith's Kerry. Marshes near Tralee as stated by Smith in his History of Kerry : Flor. Hib.-XII. Cave Hill and Crawfordsburn: Flor. Olst.

Never confirmed, though not unlikely to occur in south-west Ireland as it does in south-west England. In both Kerry and Antrim the plant observed was no doubt $S$. aquatica.

\section{Veronica triphyllos Linn.}

V. Strand near Sandymount (Dr. Scott): Mack. Cat. Between Dublin and Merrion by the roadside: Ir. Fl.

Not confirmed, probably a form of $\mathcal{V}$. hederifolia was mistaken for it.

\section{LABIATEE.}

\section{Mentha alopecuroides Hull.}

XII. Stream by roadside at Saul, Down (Rev. C. H. Waddell): Watson B. Ex. C. Rep. 1893 .

Escaped from cultivation.

Mentha sylvestris Linn.-M. longifolia Huds.-Horsemint. I. By the stream below Cahirdaniel, Darrynane, Kerry, 1889-96; R.W.S. Roadside near Timoleague: Allin's Cork.-V. Plentiful 
on banks by an old quarry at Sutton, Co. Dublin : Flor. Howth. By the Dodder near Rathfarnham, Co. Dublin, $1893 ; N$. $C$.

In all cases derived from cultivation.

Mentha viridis Linn.-Spear-mint.

VII. On the edge of a bog between Robertstown and Phillipstown, King's Co. : Ir. Flor. Naturalized by the river Gaine, Knock Drin, Westmeath: Levinge 1894.-XI. On the left bank of the Finn above Liscooly bridge, thoroughly established apart from cultivation: Hart $1885 \gamma$-XII. Waste ground at Ballygowan: Flor. Belf. Stream by the roadside at Saul, Co. Down (Rev. C. H. Waddell) : S.\&P. 1805 .

An escape from cultivation.

Mentha Requieni Benth.-Thymus carsicusViv.-Corsican Mint. I. Abundant in the street of Castletownsend, Cork (Rev. T. Allin): Rec. Add. Abundant on roadsides at Castletownsend, 1883; $W . F$. de $T$. Kane. Still abundant here in 1897; Phillips. Near the back wall of Bantry demesne, far from any garden (Carroll): Spec. in Herb. Queen's College, Cork. On old walks and pavements in Bantry demesne, 1892; and in similar habitats in Castlefreke demesne, 1891, freely in both places; Phillips.

A native of Corsica and Sardinia escaped from cultivation and apparently becoming naturalized in South Cork.

Calamintha Clinopodium Spenn. - Clinopodium vulgare Linn.-Wild Basil.

I. On several of the islands in the Lower Lake, Killarney, and by the side of the road near Kenmare: Mack. Rar. Only seen on one limestone knoll near the Muckross lake: R.W. S. I890.-III. Tullatyne, Johnswell mountains; and Inch, Kilkenny (Rev. S. Madden): Cyb.-IV. Near Arthurstown, close to the Hook, Wexford (BarrettHamitton): Journ. of Bot. $1887, p .348$. A patch near Kilmanock, observed some years and spreading; and another patch near Tintern, Wexford: $B .-H . \& G . I 889 .-\mathrm{V}$. A few patches by the roadside near a farm-house at Portersize, Kildare, $1892 ; T$. Chandlee.XI. Sparingly on the west bank of the Foyle near Londonderry (Moore) : Cyb.

An introduced plant, as yet hardly established in a wild state.

Calamintha Nepeta Savi-C. parviflora Lamk.

I. Near Killarney (Babington): Cyb. About Glandore ( $R . W$. Townsend): Flor. Cork.

Errors. 
Melissa officinalis Linn.

I. Strand at Carrigaline: Flor. Cork. Limestone rocks at Ringaskiddy : Cyb.-II. Near the rope-walk, Sunday's Well, and near Belvelly Castle, Great Island: Flor. Cork.-X. Near a garden on Trasna Island, Lough Erne : Barrington 1884.

A garden escape, not established.

\section{Leonurus Cardiaca Linn.}

I. Near Carrigaline; and-II. on Great Island; between Foata and Cork: Flor. Cork.-V. Under a wall at Roper's-rest, Dublin : Threlkeld.

An escape, not seen recently.

Teucrium Chamædrys Linn.

II. On the Cork Fair-field, 1840 : Flor. Cork.-still there in 1897; $J$. Noonan \& Phillips.-V. Borders of fields at Greenhills, on the road leading to Tallaght, Co. Dublin: Wade Rar.-not seen recently. On walls near the river at Trim, Co. Meath; $A$. Balfe.

An introduction, clinging tenaciously to its Cork station.

\section{PLANTAGINEAE.}

Plantago argentea Linn.

A plant of Southern Europe recorded in Hooker's Student's Flora, $E d . I I I . p .533$, as occurring casually in Ireland; but no authority or locality is given nor have we been able to discover any.

\section{ILLECEBRACEAE.}

Corrigiola littoralis Linn.

V. On the Sutton side of Howth : Wade Rar.

Never confirmed; the plant observed was probably a form of Polygonum aviculare.

\section{CHENOPODIACEAE.}

Chenopodium polyspermum Linn.

II. Lakelands, Cork (Dr. Hincks) : Flor. Cork.-V. In sea-marshes near the North Wall: Wade Dubl.-XII. Cultivated ground at Hollywood, Sydenham, and Knock: Flor. Belf.

Not seen recently. Perhaps a casual at Cork, errors in districts V. and XII.

Chenopodium Vulvaria Linn.-C. olidum Curtis. I. or II. In the county of Cork; but no station given (Drummond): Flor. Cork.-II. Tramore, Waterford (Rev. S. Madden): Cyb.- 
V. At the North Wall, a little before you come to Ballybough Bridge (Mr. Moldon): Templeton MS. Found on the Strand Road leading from the Custom House to Annesley Bridge, several years back (Dr. Scott) : Mack. Rar. I806. Sparingly near Sandymount; not found lately: Mack. Cat. 1825. Growing along the wall at St. Mark's Church: Ir. Flor. $1833 .-\mathrm{XII}$. In the neighbourhood of Belfast (Templeton): Flor. Olst.

An escape, long extinct; formerly cultivated as a medicinal herb.

Chenopodium ficifolium Smith.

II. Near Timoleague (Drummond): Flor. Cork.-V. About Glasnevin : Ir. Flor. Drumcondra; Raheny, \&c. : J.White MS. Banks of Grand Canal, near the tenth lock, specimen immature (T.Chandlee): $C y b .-X I I$. Near Belfast, sparingly $(D$. Orr $): C y b$.

Not confirmed. The records are probably all errors.

Chenopodium murale Linn.

I. Near Iniscara (Carroll): Allin's Cork.-V. On the commons at Howth; wayside going to Clontarf: Ir. Flor. Frequent near Dublin: Flor. Hib. Near the Chapel and on the Burrow, Howth : Ir. Nat. 1895. Near Portobello (More): Cyb. At Rathfarnham; Praeger. South Lotts; $R$.W.S. Roadside at Old Court, foot of Montpelier, Dublin: N.C. I895.-XII. By the Lisburn road (Thompson): Flor.Ulst.

A casual; formerly frequent about Dublin, but now quite rare.

Chenopodium hybridum Linn.

XII. On the ruins of a cottage near the Lisburn road, Belfast: Flor. Ulst.

A casual, if not an error.

Chenopodium urbicum Linn.

V. About Wellesley Chapel, Dublin: Ir. Flor. In the College Park, and other places about Dublin: Flor. Hib. Once found at Milltown (Carroll); and on a mud wall at the top of Dominick St. (Moore): Cyb. Frequent by roadsides and ditch-banks: Wade Dubl.-XII. At the junction of the roads to Carrickfergus and Templepatrick, and on Belfast dung-hills, 1807 : Templeton MS.

Not confirmed, and probably all the records are founded on erroneous identification.

Atriplex pedunculata Linn.

VIII. Salt marshes, Cushtrower Bay near Ballinahinch, Connemara: Wade Gallovid.

Not confirmed. 
Salicornia radicans Smith.

I. Dunbeacon, Carbery (R.W. Townsend); not confirmed: Flor. Cork. -V. Seashore, Howth: Spee. in Herb. Mackay.-XII. Strand at Narrow Water below Newry: Mack. Cat. Hollywood and Cherryvalley near Comber: F'lor. Belf.

Not confirmed for any of the stations. Mackay's specimen, though correctly named, is of little authority as regards the locality; and the records for Districts I. and XII. should no doubt be referred to the Var. PRocdMBENs of $S$. herbacea.

\section{Polygonum maritimum Linn.}

II. Ballycotton; Ringpoint, Youghal; and on the Cunnegar of Dungarvan, Co. Waterford: Flor. Cork.-XII. Hollywood shore: Flor. Ulst.

Errors, the plant gathered was probably $P$. Raii or a form of $P$. aviculare.

\section{Fagopyrum esculentum Mœnch-Buckwheat.}

Occurs occasionally about field borders or among crops as a casual introduction or escape from cultivation, but is nowhere established.

Rumex palustris Smith- $R$. limosus Thuill.

II. Marshy ground near Youghal (Drummond): Mack. Cat. Bogs near Ballycotton: Flor. Cork,-V. Marshes at Howth : Wade Rar. -XII. Portmore and by the Bann at Portglenone: Templeton MS. Between Portstewart and Portrush (Dr. Moore): Fllor. Olst.

Errors.

Rumex scutatus Linn.-French Sorrel.

VI. On an old wall near Lisdoonvarna, $1896 ; P$. B. O' Kelly.

An escape from an ancient kitchen-garden.

\section{ELEAGNACEAE.}

Hippophæ rhamnoides Linn.-Sea Buckthorn.

IV. Thoroughly established on the sandhills at Kiltennel, north of Courtown, Wexford, where it was planted about 1842 (Miss Farmer): Rec. $A d d$. Extending here for about three-quarters of a mile, in some places forming impervious thickets: Hart $r 88 \mathrm{ra}$. Two large patches on the cliffs near Ardmine Church, Wexford, 1897: Marshall r898.-V. Planted at Rush, Co. Dublin: Rec. Add. Apparently spreading on the Rush sandhills, $1893 ;$ N.C.

Its standing on the Wexford coast almost entitles this plant.to a place in the Irish flora. 


\section{LORANTHACEAE.}

Viscum album Linn.-Mistletoe.

V. Found on a crab tree at Island Bridge: Rutty's Dublin, I772. "Grows on an old apple tree in the physicians garden of the old Man's Hospital, Kilmainham. By what I could learn, the apple tree on which it grows was brought from England": Wade Rar.IX. "In Betulis, Castle-mac-Garrett, tantum" : Brown Fasciculus, 1788 .

Nowhere native in Ireland and extremely rare as a casual introduction. In the Castle-mac-Garrett station, Co. Mayo, it is probable that Brown mistook for mistletoe the bushy, nest-like excrescence so frequent on the birch. Dr. Molyneux, in Threlkeld's Synopsis, 1727, states that he could never meet with the mistletoe in Ireland.

\section{EUPHORBIACEAE.}

Euphorbia Cyparissias Linn.

VII. In a lane near Horse Leap, Clara, King's Co. (Miss $\boldsymbol{M}$. Goodbody): Ir. Nat. 1893, p. 250.-VII. In a plantation near Derrynagease Point, Lough Ree, Co. Longford, introduced : $B . \& V$. 1887.-XII. Crawfordsburn : Flor. Olst.

Euphorbia Lathyris Linn.-Caper Spurge.

XII. By the side of an old road near Carnmoney: Flor. Olst. Introduced at Ballytweedy (Rev.W. S. Smith): Flor, N.-E.

Both species are in all cases planted or escaped from cultivation.

\section{URTICACEAE.}

Ulmus suberosa Ehrh.-Common Elm.

Occurs in hedges and thickets throughout Ireland, but is very rarely found in wild-looking stations and appears to be planted in all cases.' According to Hooker (Student's Flora, 3rd Ed., p. 362) this species never seeds in Great Britain.

Urtica pilulifera Linn.

I. "Sent to me from Ballylickey by Miss Hutchins": Mack. Cat. At Glandore and Derry, Carbery (R. W. Townsend): Flor. Cork.V. By a ruined cottage on Howth Head: Journ. of Bot. I891, p. 377 .

A casual. 


\section{SALICINE $A$.}

Salix decipiens Hoffim.-S. triandra $\times$ fragilis.

XII. Hedges near Newtown-Limavady (Moore): Cyb.

Salix undulata Ehrh.-S. triandra $\times$ viminalis.

XII. Not rare near Coleraine, and by the side of the Roe in Derry; abundant near Ballymoney, Antrim (Moore): $C y b$.

Salix Russeliana Smith-S. fragilis $\times$ alba.

XIJ. Near Kilkeel: Mack. Cat. Shane's Castle, Antrim; and near Dungiven, Derry (Moore): Cyb.

Salix laurina Smith.-S. phylicifolia $\times$ caprea.

I. Near Carrigaline (Drummond): Flor. Cork.-XII. Sparingly between Castle Dawson and Bellaghy, Derry; and on the shore of Lough Neagh near Massarene Park, Antrim (Moore): Cyb.

None of these four willows can be accepted as native or even fully established in wild stations in Ireland. In many of the localities given above they were obviously planted; in others the specimens were probably incorrectly named.

Salix acuminata Smith.

I. and II. Common near Cork: Flor. Cork.-IV. Frequent in Wicklow: Flor. Hib.-XII. By the Lagan near Belfast: Flor. Ulst.

Not confirmed, and the authorities are insufficient.

Salix procumbens Forbes.

IX. On the north side of Ben Bulben, Sligo, at $1500 \mathrm{ft}$. (Moore): Cyb.

An error; the plant gathered was $S$. phylicifolia.

Salix rubra Huds. - S. purpurea $\times$ viminalis.

Recorded from several stations in Districts I. II. XI. and XII., in all of which it was probably planted.

Populus alba Linn.-White poplar.

Populus nigra Linn.-Black poplar.

Both poplars are of frequent occurrence in Ireland in plantations and near houses, but nowhere occur in a wild state.

\section{CERATOPHYLLEA}

Ceratophyllum submersum Linn. VIII. Ballinahinch, \&c., common in Connemara : Wade Gallovid.- 
XII. Ballinahinch Lake: Templeton MS. Lake near Ballinahinch, Co. Down, 1808 (Mackay \& Templeton): Flor. Hib.

The county Down plant was C. demersum. Wade's Connemara record has not been confirmed.

\section{CONIFERAR.}

\section{Juniperus Sabina Linn.-Savin.}

I. Found by an apothecary on one of the islands in Lough Lane, Killarney: Dr. Molyneux, Philos. Trans., No. 227, 1697.-XII. On Slieve Donard, Mourne mountains : Harris's Down, 1744.

Errors. The plant gathered at Killarney was no doubt a form of the common juniper; the Slieve Donard plant was either Iycopodium alpinum or Juniperus nana, Willd.

Pinus sylvestris Linn.-Scotch Fir.

I. (?) "Found by Mr. Harrison in Ireland, who relates that the two foregoing plants [the Spruce and the Silver Fir] were found in the county of Kerry (where the arbutus grows) by a person of good integrity and skill in the knowledge of plants": Ray Synopsis, 1696. "These trees have been much destroyed of late years, for except a small shrub here and there among the rocks there are none standing at present of any large size": Smith's Kerry, I756.-VII. In the woods in the King's Co. (Dr. Molyneux): Threlleeld.-VIII. "I found it scattered in a few places in Connemara of a diminutive stunted growth, although apparently very old: Wade Gallovid 180x. The trees observed by Wade were probably yews, as after diligent search $\mathrm{Mr}$. A. G. Kinahan has failed to find any wild firs in Connemara: $C y b$. "I saw a solitary tree at the foot of Nephin which I was told was the only remains of the pine forest in that quarter": Mack. Cat. 1825 . There is one large and old tree, supposed to be a last relic of the ancient forests, still growing on an open bog near Crossmolina, at the head of Lough Conn in Mayo; and this tree, which is probably the same referred to by Mackay as growing near Nephin, has been lately fenced in, and is carefully preserved by the Earl of Arran, who is the owner of the land: $C_{y b}$. $1866 .-\mathrm{XII}$. In Waringstown in the county of Down: Threlkeld.

There can be no doubt that the Scotch Fir was formerly native and abundant in Ireland. Its roots and trunks are frequently dug up from the bogs, and Professor Melville (Memoirs Geolog. Survey, Ireland, Nos. II5 \&II6, p. 29) states that cones of both the Scotch 
Fir and the Common Spruce were found buried in the bog at Cappard. However, the absence, both from the spoken language and from the place-names of Ireland, of any native name for the tree would tend to prove that it had become quite rare if not extinct in very early times. Whether the records given above refer to relics of a former abundance, or merely to introductions, must remain doubtful; but there is no reason to believe that any indigenous Scotch fir now exists in Ireland.

\section{ORCHIDEAE.}

Cephalanthera pallens Rich.-C. grandiflora Bab.

I. Woods of Glengariff, Co. Cork (Dr. Hincks): Flor. Cork.XII. On a bog in the county of Antrim (MIr. Sherard): Threlleeld. At Duneane near Antrim (Whitla): Flor. Ulst.

Not confirmed; errors.

Orchis hircina Scop._Lizard Orchis.

VI. In shady thickets in the barony of Tullagh, Clare: Wade Rar. Orchis ustulata Linn.

II. A single plant at Clay Castle, Youghal (Drummond): Flor. Cork.-V. Between Sandymount and Merrion: Wade Dubl.

Orchis purpurea Huds.-O. fusca Jacq.

I. Summerstown bog near Cork (Drummond); and near Cork, but no station given (Dr. Hincks): Flor. Cork.

None of the Irish records for the three foregoing species has had any confirmation and no doubt all are errors.

\section{IRIDEAF.}

Iris tuberosa Linn.

I. On a ditch bank near the Botanic Garden, Cork : Flor. Hib. At Evergreen near Cork, not even naturalized : F'lor. Cork.

Garden outcasts or escapes.

Crocus vernus All.

IV. Plentiful near the old eastle at Dunganstown, Wicklow : Flor. Hib.

A relic of cultivation.

\section{AMAR YLLIDEAE.}

Narcissus Pseudo-narcissus Linn.-Daffodit.

I. Near Carrigrohane and Pouladuff; and-II. Banks of the Lee under Mount Desart: Flor. Cork.-III. In Castle Inch church- 
yard; at Domville; Kilmanagh and other places in Kilkenny (Rev. S. Madden): Cyb.-V. Simmon's Court, between Ball's Bridge and Merrion; Ballygall, \&c.: Wade Dubl.

Narcissus major Curtis.

V. Fields near Templeogue, Co. Dublin: Mack. Cat. \& Flor. Hib.

Narcissus poeticus Linn.

I. About Carrigrohane Castle and old abbeys occasionally: Flor. Cork.-V. Rocky pastures near Killiney obelisk and wet meadows near Newtown Park and Cabinteely : Wade Dubl.

These three species of Narcissus were no doubt planted in all of the above stations.

Galanthus nivalis Linn.-Snowdrop.

IV. Established at St. John's, Wexford; Miss E. M. Farmer.V. Banks of the Tolka, Dublin: Ir. Flor,-VII. Established for at least 60 years in the Yew Walk Wood at Knock Drin, Westmeath; Levinge.

Planted in all cases.

Leucojum æstivum Linn.-Snow-flake.

IV. Some sixty or eighty specimens in a swamp near the Slaney river, a little north of Macmine Junction, Co. Wexford (Rev. $\boldsymbol{E}$. $\boldsymbol{S}$. Marshall): Ir. Nat. 1897, p. 219 .

Considered by the finder to be native in Oxford, Berks, and Kent, and equally so in the Wexford station. Ourpresent knowledge of the Irish distribution of this cultivated ornamental plant does not, however, seem to justify its admission to the flora, even as a fully naturalized species.

\section{DIOSCOREAE.}

Tamus communis Linn.-Black Bryony.

IX. On a bushy hill in Hazelwood demesne by Lough Gill, Sligo, 1866 (Dr. J. E. Little) : Rec. Add. Slish wood, Lough Gill (Rev. C. H.Waddell): Ir. Nat. 2892, p. 102.

Planted, but seems to be establishing itself about Lough Gill.

\section{LILIACEAE.}

Ruscus aculeatus Linn.-Butcher's Broom.

I. Grows wild near Muckross and in the jslands of Lough Lane: Smith's Kerry, 1756-still in Muckross shrubberies, $1897 ;$ R.W. S. 
Near Brinny, between Cork and Bandon: Smith's Cork.-II. In Dungourney Glen near Midleton: Flor. Cork.

Planted, but has held its ground at Muckross for nearly 150 years.

\section{Polygonatum multiflorum All.-Solomon's Seal.}

II. In a grove at Blarney (D. Murray): Flor. Cork. Lota wood, Glanmire, Cork, 1892-95, becoming naturalized; Phillips. VII. Donore, Lough Derevaragh, Westmeath; Levinge.

An escape, or planted.

Convallaria majalis Linn.-Lity of the Valley.

I. In the island of Inisfalen in Lough Lane, Killarney, and in the woods round that lake: Smith's Kerry. In one spot in Muckross woods: $R$.W. S. 7890 . Castle Bernard Park, near the river Bandon: Smith's Cork.-II. In a wood by the side of the river Collygan: Smith's Waterford.-IV. In a dell near the mouth of the Courtown river, Wexford, 1881 ; G. H. Kinahan.-IX. In a wood at Chaffpool near Ballymoate, Sligo: Flor. Hib.

Planted.

Allium carinatum Linn.

V. Site of an old garden near Castle Bellingham, Co. Louth: Butler 1890. Near the Royal Canal above Phibsborough bridge (Dr. Scott): Flor. Hib.

A relic of cultivation; the latter record was probably an error.

Allium triquetrum Linn.

I. At Monkstown, 1896 (W. G. Axford); and-II. About 25 plants in a grassy hollow near Dunkettle, Cork, 1890 (Phillips): Ir. Nat. I896, p. 167 .

Probably introduced with seeds.

Muscari racemosum Mill.-Grape Hyacinth.

II. Established on the banks of the Blackwater near Fermoy (J. Sim): Phytol. N.S. III., p. 35.

An error.

Ornithogalum umbellatum Linn.-Star of Bethlehem.

V. Between Finglas bridge and Drumcondra, Dublin, a single specimen: Threlkeld.-VII. Thoroughly established on ditch banks and meadows at Rockview near Delvin, Westmeath: Levinge 1895.

Escapes from cultivation. 
Paris quadrifolia Linn.-Berb Paris.

I. In the wood near Ross Castle, Killarney: Smith's Kerry.

Never confirmed.

\section{JUNCACEA.}

Juncus compressus Jacq.

The many Irish records for this plant must all be referred to $J$. Gerardi (Loisel). True J. compressus has not yet been satisfactorily shown to occur in Ireland.

Juncus trifidus Linn.

I. Mangerton, Kerry: Wade Rar.-VIII. In Connemara: Wade Gallovid.

Juncus biglumis Linn.

V. Kilgobbin, Co. Dublin : Wade Dubl.

Juncus triglumis Linn.

V. Dublin mountains with $J$. filiformis, common: Wade Dubl.

Three alpine Junci, Wade's Irish records for which have never been confirmed. No doubt, errors.

Luzula Borreri Blomf.-L. Forsteri $\times$ vernalis.

IV. Devil's Glen, Co. Wicklow : Cyb.

As $L$. Forsteri is not known to occur in Ireland, it is highly desirable that the above record should be confirmed.

\section{ALISMACEA.}

Elisma natans Buchen.-Alisma natans Linn.

I. Ditches near the Upper Lake of Killarney (Moore): Cyb. Lough Allua at the source of the Lee, Cork (Drummond): Flor. Cork.V. Drains near Balruddery: Wade Rar. Hill of Howth : Flor. Hib.VI. In pools on Monmor bog between Miltown Malbay and Kilrush, Clare (C. Carter) : Cyb. Plentiful in ditches adjoining Lough Derg near Portumna, Galway (Moore) : Cyb.-VIII. In a few lakes near Ballinahinch: Wade Gallovid. Plentiful in Connemara: Flor. Hib. In Lough Mask (Prof. Melville): Cyb.-XII. County Down: Flor. Hib.

Errors; all the records should be referred to barren floating forms of Alisma ranunouloides.

Damasonium stellatum Pers.-Actinocarpus Damasonium Br. V. Near Templeogue, Dublin: Threlkeld.-VIII. Ballinahinch: Wade Gallovid.

Not confirmed, errors. 


\section{NAIADACEA.}

Potamogeton Lonchitis Tuckerm.

V. In the Boyne below Navan: Cyb. \& Rec. Add.

An error of name; the Irish plant is P. heterophyllus Schreb. var. GRAMINIFonIUs Fries, not the American $P$. Lonchitis.

Potamogeton zosteræfolius Schum.

XII. Bow lake near Saintfield (Stewart) : Flor. Belf. In a pool to the right of the road from Newtownards to Bangor, Down (Orr): Flor. Olst.

The first record was an error; the authority for the second is not reliable.

Potamogeton trichoides Cham.

XII. Pools, Conlig Hill, Co. Down (Orr): Journ. of Bot. I88x, p. 312 .

Authority unreliable.

\section{CYPERACEAE.}

Scirpus Caricis Retz-Blysmus compressus Panz.

I. Bogs near Glengariff (R.W.Townsend) : Fllor. Cork.

Not confirmed; probably an error.

Eriophorum alpinum Linn.

II. North shore of Gurtaveeha Lake, near Millstreet, Co. of Cork (Mr. Ryder) : Dubl. Nat. Hist. Socy. Proc. Vol. V., p. Irz.

Not confirmed, although the locality was examined both by A. G. More and by David Moore.

Carex Davalliana Smith.

XII. Spongy bogs in the county of Down (Sherard): Ray's Synopsis. Kirkiston bog, and frequent in boggy situations: Templeton MS.; Ir. Flor., \&o.

No doubt an error for $C$. dioica.

\section{GRAMINEAE.}

Panicum sanguinale Linn.-Digitaria sanguinalis Scop. VI. Sandhills at Dough, Clare: Wade Rar.

Never confirmed, no doubt an error.

Panicum Crus-galli Linn.

IV. On a newly-made ditch bank near Camolin, Wexford, 1847 (J. Morrzson): Cyb. At Springhill, Enniscorthy, Wexford, 1865; 2 工 2 
J. Morrison.-XII. Waste ground near the Belfast Distillery, 1893-94 (R. Hanna): S. \&P. 1895 .

A casual.

Phalaris canariensis Linn.-Canary grass.

Occurs not infrequently about houses, roadsides, and rubbish heaps, but is always introduced with seeds, and is nowhere permanent.

Alopecurus agrestis Linn.-A. myosuroides Huds.

I. In City Park, Cork, 1858: Cyb.-II. Great Island, Cork: Annot. in Flor. Cork.-IV. Several plants near Alderton, Wexford: B.-H. \& G. I889.-VI. Castle Taylor, Galway, 1854: Cyb.

A casual.

\section{Alopecurus bulbosus.}

I. Salt marsh, near Douglas, Cork (Drummond): Flor. Cork.

Not observed recently, no doubt an error.

Phleum alpinum Linn.

VIII. Near the top of Lettery mountain, Connemara: Wade Rar.

Mibora verna Beauv.-Knappia agrostidea Smith.

VIII. Lettery mountain, near the summit : Wade Rar.

Neither of these records has been confirmed, and no doubt both are errors.

Agrostis setacea Curtis.

I. Ballyphehane and other bogs (Drummond): Flor. Cork.

An error.

Polypogon monspeliensis Desf.

II. Strand at Saleen, Cork, 1893, and strand at Cork Beg, 1897; Phillips.-V. Sandy field, North Bull, Dublin, 1894 (R.W. S.) : Ir. Nat. 1895, p. 20.

A casual.

Calamagrostis lanceolata Roth. - Arundo Calamagrostis Linn.

XII. Banks of the Lagan (Templeton): Ir. Flor. An error.

Apera spica-venti Beauv.-Anemagrostis spica-venti Trin. I. Ballyphehane Bog, $\operatorname{Cork}($ Drummond $)$ : Flor. Cork.-V. Near the Scots' church, Sandymount: Mackay 1859.

An error; the plant gathered was probably some species of Agrostis. 
Avena pratensis Linn.

I. Blackrock; Glasheen; and-II. Whitepoint and Little Island : Flor. Cork.-V. Near Dublin (Mr. Underwood): Cyb.-XI. Coast near Culdaff, Donegal; and-XII. By the New Lodge road, Belfast : Flor. Ulst.

Most probably errors in all cases.

Avena strigosa Schreb.

Occurs as a weed of cultivation nearly throughout Ireland, but is uncertain in its appearances and nowhere permanent.

Avena fatua Linn.-Wild Oat.

I. Corn fields near Dingle, Kerry (Moore) : $C y b$.-I. and II. Not infrequent about Cork (Carroll): Cyb.-V. Portmarnock, Dublin (D. Orr) : Cyb.-VIII. Inishbofin and Inishark: More I876.XII. Cornfields and waysides: Flor. Belf.

A casual.

Cynosurus echinatus Linn.

III. In a field at Sandbrook, Carlow (R. Clayton Browne): Rec. Add.

A casual.

Briza minor Linn.

I. In a field near Douglas (Drummond) : Flor. Cork. In considerable quantity in a field near the railway station at Blackrock, Cork, 1859 (T. Sullivan): Cyb.

A casual, not seen recently.

Poa compressa Linn.

IV. On an old wall near Aughnagoppal Bridge, Wexford: Moffat I889.- V. Rocky ground at the foot of the Dublin mountains (White) : Cyb. About Tighmhuillin and Tullyallen, Louth; andVI. Walls and dry banks between Galway and Tuam: White I808.-X. Roadside between Portadown and Lurgan(W. Mo Mitlen): Rec. $A d d$. XI. In several places on the old walls of Londonderry (Moore) : Cyb.-still there sparingly in 1888; Stewart.-XII. Roadside between Ballycastle and Ballintoy, Antrim (More): Rec. Add.

Introduced in all of its stations and nowhere established in any considerable quantity, though it has maintained itself on Derry walls for many years. 
Festuca procumbens Kunth.-Selerochloa procumbens Beauv. I. Salt marsh below Cork (Drummond): Flor. Cork. City Park and near the Gas Works, Cork, 1857 (J. Sullivan): Annot. in Flor. Cork.-II. Sparingly on sandy ground by the pier, East Ferry, Cork, 1893; Phillips.-V. North Lotts, Dublin; at Sandymount and along Dublin Bay (Moore): Cyb.-XII. Comber, Co. Down: Flor. Belf. Near Larne, Antrim: Flor. Olst. Albert Quay, Belfast, 1870 , and plentiful for some years until the spot was paved (Stewart) : Flor. N.-E.

The county Dublin records and that for Comber were errors; in none of the other stations was the plant more than a casual.

Desmazeria sicula Dum.

I. In some quantity by roadsides in Kerry : Journ. of Bot. Vol. III., p. 156 .

A Mediterranean species, casually introduced in Kerry and not seen recently.

\section{Bromus tectorum Linn.}

II. Rubbish heap by the river Lee, Cork city, 1891 (R.W.S.) : Ir. Nat. $8895, p .20$-XII. Waste ground near the Belfast Distillery, 1893-94 (R. Hanna): S.\&P. I895.

Introduced with foreign grain.

\section{Bromus arvensis Linn.}

I. Field near Evergreen (Mr. Alexander): Flor. Cork. Fields at Douglas, Blackrock (J. Sullivan): Annot. in Flor. Cork.III. Moist meadows near Cullenagh, Queen's Co.; and-V. Fields at Sandymount, Dublin: Flor. Hib.-XII. Springfield meadows: Templeton MS. Sandy cultivated land at Malone, Belfast: Cyb.

A casual, not seen recently.

\section{Brachypodium pinnatum Beauv.}

I. Hedges near Kinsale (Drummond) : Flor. Hib.-II. Sandhills at Tramore, Co. Watexford, 1898 ; Phillips:-III. Hedges in Queen's Co. (Mr. Bradburry): Flor. Hib.

The first and third records were, no doubt, errors. At Mr. Phillips' recently discovered Tramore locality, the plant covers more than an acre of surface in the sandhill hollows, growing with exclusively native species, remote from any cultivation, and is considered by the finder to be undoubtedly indigenous. Further 
investigation may show that this plant is entitled to a place in the Irish flora.

\section{Hordeum sylvaticum Huds. ·}

V. In a thicket or copse bordering on the terrace at Mount Merrion Dublin (J. Bain): Cyb.

An alien, growing in some quantity and still persisting in the above locality, to which it was no doubt introduced.

Hordeum marinum Huds.-H. maritimum With.

II. Said to have been found near Clay Castle, Youghal, and on the strand at Ballycotton: Flor. Cork.-V. On the shore between Swords and Rush (J. White): Flor. Hib.

Errors.

\section{Lolium italicum Braun.}

Occurs throughout Ireland as an escape from, or relic of, cultivation.

Lolium linicola Sonder.

XII. A weed among flax in the counties of Derry and Down (Moore): Cyb. Field by Belfast road, west of Newtownards, Down (Rev. E. F. Linton): Flor. N.-E.

Introduced with seed.

Asplenium Petrarchæ Newm.-A. Clermonta Syme.

V. Recorded from Flurry Bridge, Louth, where it was found growing on the outside of the garden wall of Ravensdale Park. It has since been exterminated. The plant is considered by Syme to be a hybrid between $A$. Triohomanes and $A$ Ruta-muraria.

Lastræa rigida Presl.

V. On a wall at Townley Hall near Drogheda: $C y b$. No doubt planted.

\section{Lastræa cristata Presl.}

I. or II. Shady ditch banks in the county Cork, no locality given (Drummond): Flor. Cork.-II. In the desmesne at Rathronan near Clonmel (G. S. Gough) : Flor. Hib.

Errors. 


\section{CHARACEAE.}

Tolypella nidifica Leonh.

XII. Lough Neagh near Longford Lodge, Co. Antrim (Dr. Moore) : Braun Monog. der Characeen.

Nitella capitata Agardh.

I. At Killarney (Mr. Harvey) fide Braun: Groves 1880 .

For both of these species Messrs H. \& J. Groves consider that further confirmation is desirable.

\section{ADDENDUM.}

\section{Euphorbia Peplis Linn.}

II. Garraris Cove, near Tramore, Waterford (Miss Trench): Mackay 2859-and spec. in Herb. Mackay.

First found by Miss Trench in 1839, but not since seen, though sought for by R. M. Barrington in 1870 and 1871, and by H. C. Hart in 1882. No doubt extinct.

A notice of this plant was omitted in error from p. 508. 


\section{N D EX.}

[Synonyms are printed"in italics. Phonetic renderings of Irish names in heavy type. Varieties are marked thus : (var.). The numbers refer to the pages.]

A.

Acer, 482 . campestre, 482 . Pseudo-platazus, 482 .

Aceras, 347. densiflora, 347 .

Achillea, $18 \mathrm{x}$.

Millefolium, $r 8 r$.

Ptarmica, $18 \mathrm{r}$.

tomentosa, 493,

Acorus, 367 .

Calamus, 367 .

Acotyledones, 439 .

Actinocarpus, 5 I4. Damasonium, 514 .

Adder's-tongue, 453 .

Adiantum, 44I. Capillus-Veneris, $44 \mathrm{r}$.

Adonis, $47 \pi$. autumnalis, $47 \mathrm{r}$.

Adoxa, I6r. Moschatellina, I6r.

AEgopodium, 150. Podagraria, I50.

Fthusa, 157 . Cynapium, 157.

Agraphis, 357. nutans, 357 .

Agrimonia, II6. Eupatoria, 116. odorata, II6.

Agrimony, II6. hemp, I73.

Agropyron, 434. acutum, 436 . caninum, 434. junceum, 436. pungens, 435 . repens, 435 .

Agrostemma, 5 I. Githago, 5I.

Agrostis, 415. alba, 4I6. canina, 415. pumila (var.), 456. setacea, 516 . vulgaris, 4IE.
Aira, 4I7.

alpina, $4 \mathrm{I8}$. cespitosa, 4I8. caryophyllea, $4 \mathrm{I}$. fiexuosa, 4I9. pracox, 4I7. setacea, 4 I8. uliginosa, $4 \mathrm{I} 8$.

Air-i-good loo-ack-ra, 98 . Airopsss, 4 I 7. caryophyllea, 4I7. pracox, 4I7.

Ajuga, 296. pyramidalis, 296. Ieptans, 296.

Alchemilla, II5. alpestris (var.), $x \times 5$. alpina, 115. arvensis, 115 . filicaulis (var.), II5. vulgaris, 115 .

Alder, 32 I. buckthorn, 78 .

Alexanders, 147.

Alismacea, 369 .

Alisma, 369 . natans, 514 . Plantago, 369. ranunculoides, 370 . repens (var.), 370 .

Alkanet, 24r.

All-good, 300 .

All-seed, 68.

Alliaria, 30. officinalis, 30 .

Allium, 354 . Ampeloprasum, 354 .

arenarium, 355 . Babingtonif, 354 . carinatum, $5 I_{3}$.

Halleri, 354. Scorodoprasim, 355 . triquetrum, 513 . ursinum, 356 . vineale, 355 .

Allosoriss, 442. crispus, 442.

Alnus, 321 .
Alnus

glutinosa, $32 x$.

Alopecurus, $4 \mathrm{I} 3$. agrestis, 516 . bulbosus, 516 . geniculatus, 4I3. myosuroides, 516 . pratensis, 4I3.

Alsike Clover, 484 . Alsine, 54 . pallida, 54. verwa, 55 .

Althiza, 65 . officinalis, 65 .

Alyssum, 473 . calycinum, 473 . campestre, 473 . incanum, 473 . maritimum, 474 .

Amaryllidex, 353 .

Ammi, 490. majus, 490 .

Ammophila, 4I7. arundinacea, 417. Anacamptis, 343 . pyramidalis, 343 .

Anacharis, 332. Alsinastym, 332.

Anacyclus, 493. radiatus, 493.

Anagallis, 234 . arvensis, 234. carulea (var.), 234. tenelia, 234.

Anchusa, 24I. arversis, 242. officinalis, 5or. sempervirens, 24I.

Andromeda, 222. Polifolia, 222.

Anemagrostis, 516 . spica-venti, 5 I6.

Anemone, 3 . apennina, 4/I nemorosa, 3 .

Angelica, 158 . sylvestris, $15^{8}$.

Antennaria, I76. 
Antennaria

dioica, 176 .

margaritacea, 492.

Anthemis, 182 . arvensis, 493 .

Cotula, I82, nobilis, 182 .

Anthoxanthum, 413 . odoratum, $4 \mathrm{~J}_{3}$.

Anthriscus, 153 . Cerefolium, 490. sylvestris, I 54 . vulgaris, 153 .

Anthyllis, 80. Dillenii (var.), 89. Vulneraria, 89.

Antirrhinum, 257 . majus, 503 . Orontium, 257.

Apargia, 2II. autumnalis, $2 \mathrm{I2}$. hispida, $2 \mathrm{Ir}$. Taraxaci, 2 I2.

Apera, 516 . spica-venti, 516 .

Apium, I47. graveolens, 147. inundatum, $\mathrm{I}_{48}$. Moorei (var.), I48. nodiflorum, I47. ocreatum (var.), I47. repens (var.), 147.

Apocynacea, 499.

Apple, crab, I23.

Aquilegia, II. vulgaris, II.

Arabis, 23.

ciliata, 24.

glabrata (var.), 23.

hirsuta, 23.

perfoliata, 473 .

petræa, 23 .

Thaliana, 28.

Araliacere, I60.

Arbutus, 220. Unedo, 220.

Uva-ursi, 22т.

Arctium, Igo. intermedium, Igr.

Lappa, Igo.

majus, Igo.

minus, IQI.

nemorosum, IQI.

Arctostaphylos, 221 . Uva-ursi, 221.

Arenaria, 55.

ciliata, 57.

leptoclados (var.), 56 .

marginata, 60.

peploides, 57 .

rubra, 59 .

serpyllifolia, 56 .

tenuifolia, 479 .

trinervia, 56 .

verna, 55

Armeria, 230. maritima, 230.

Armoracia, $2 \mathrm{x}$ amphibia, $2 \mathrm{r}$.

Aroider, 367.

Arrhenatherum, 420 . avenaceum, 420 .

Arrow-head, 370 . grass, 372 .
Artemisia, r84.

Absinthium, $x 84$.

campestris, 494 .

maritima, 185 .

Stelleriana, 494.

vulgaris, $x 85$.

Arum, 367 . maculatum, 367 .

Arundo, 4I6. Epigeios, 4I6.

Phragmites, 420 .

Ash, 236. mountain, 123 .

Asparagus, 353 officinalis, 353 .

Aspen, 328.

Asperula, 168 . cynanchica, 168. odorata, 168.

Asphodel, bog, 358 .

Aspidium, 448 . aculeatum, 448 .

amulum, 45I.

angulare, 449 .

dilatatum, $45 \mathrm{I}$.

Fizix-mas, 450 .

lobatum (var.), $44^{8}$

Lonchitis, 448 .

Oreopteris, 450 .

spinulosum, 450 .

Asplenium, 443 .

acutum (var.), 444.

Adiantum-nigrum, 444 .

Ceterach, 446 .

Clemonta, 5 IO

Filix-formina, 446.

lanceolatum, 443 .

marinum, 444.

Petrarcha, 5I9.

Ruta-muraria, 446 .

Trichomanes, 445 .

viride, 445 .

Aster, 174

laevis (?) 492

Tripolium, 174 .

Astragalus, 9o.

danicus, go.

hypoglottis, 90 .

Atriplex, 3 or.

angustifolia (var.), 302 .

arenaria, 302 .

Babingtonii, 302.

deltoidea (var.), 302

erecta, 302.

farinosa, 302 .

hastata, 302

Zaciniata, 302 .

littoralis, $30 \mathrm{r}$

patula, 302.

pedunculata, 506 .

portulacoides, 303 .

Atropa, 5or. Belladonna, 50 .

Ath-thenn, 79 .

Athyrium, 446. Filix-fcemina, 446 .

Avena, 420 caryothyllea, 417. fatua, 517 .

favescens, $4 \mathrm{rg}$.

pracox, 4 18.

pratensis, 5I7.

pubescens, 420 .

strigosa, 517 .
Avens, IIr.

water, II2.

Awher holloon, I8r.

Awl-wort, 30.

\section{I.}

Baldinghera, 4I3. arundinacea, $4 \mathrm{I}_{3}$

Baldmoney, 49 .

Ballota, 294.

foetida, 295 .

nigra, 294.

Bannye bo blackthawn, 23 I.

Bannye kweean, 314

Barbarea, 22. arcuata (var.), 22. intermedia, 22. -pracox, 23. vulgaris, 22.

Barberry, 472.

Barkhausia, Ig9. taraxacifolia, I99.

Barley, 437 .

Barnawn lockawn, 240.

Barren strawberry, II3

Bartsia, 266

Odontites, 266. serotina (var.), 266. viscosa, 266.

Basil thyme, 28I. wild, 504 .

Bastard pimpernel, 234 .

Batrachium, 4. Baudotiz, 6 .

divaricatum, 4 .

hederaceum, 7 . trichophyllum, 4 . truncatum, 5 .

Bay, 320.

Beak-rush, 39 .

Beam, white, 122

Bear-berry, 22I.

Bedstraw, 164

Beech, 322. fern, 452 .

Bee orchis, 345 .

Beet, sea, 30r.

Bell-flower, 216.

Bellis, I74. perennis, I74

Bent grass, 4I5.

Berberis, 472. vulgaris, 472 .

Berry tree, I23.

Berula, I50. angustifolia, 150 .

Beta, 3or. maritima, 3 or.

Betonica, 287. officinalis, 287 .

Betony, 287.

Betula, 320. alba, 320.

glutinosa, 321. pubescens, 321. verrucosa, 32 .

Bidens, 180 . cernua, 180 . radiata (var.), 180. tripartita, I8r.

Bilberry, 219.

Bindweed, 247. black, 304. 
Biolar, 20.

Biolar trawhל, 26.

Birch, 320.

Bird cherry, 97.

Bird's-foot, 90 . trefoil, 81, 89, 90 .

Bird's-nest, 336 . yellow, 228 .

Bistort, 307.

Bitter cress, 473.

Bitter-root, 252.

Bitter-sweet, 250.

Black bindweed, 304 . bryony, 5 T2. horehound, 294. knapweed, I96. night-shade, 25 I.

Black-foot, 44r.

Blackberry, 99 .

Blackstonia, 237. perfoliata, 237.

Blackthorn, 96.

Blaw-purrthock, 390 .

Bladder sedge, 4I2.

Bladderwort, 272.

Blechnum, 443 . boreale, 443 . Spicant, 443 .

Blind nettle, 292.

Blinks, water, 6 I.

Blite, sea, 304 .

Blue-bell, 357 . thimble, $2 \pi 7$.

Blue-bottle, corn, 197.

Blue-eyed grass, 35 I.

Blysmus, 389. compressus, 515 mufus, 380 .

Bog asphodel, 358 . bean, 240 . bloom, 390.

dew, 136 . myrtle, 320 . orchis, 335 . rush, 392 .

Book-a-lawn bwee, 180 .

Boraginea, 240.

Borago, 500 . officinalis, 500 .

Borage, 500 .

Botrychium, 454. Lunaria, 454.

Bottle sedge, 4II.

Bracken, 442.

Brachypodium, 434. gracile, 434 . pinnatum, 5 I8. sylvaticum, 434 .

Brake, 442.

Bramble, 99. stone, Iog.

Brassica, 31. adpressa, 476. alba, 32 . moneusis, 476 . Napus, 476 .

nigra, 31 . oleracea, 476 . Rapa, 476 . sinapioides, $3 \mathbf{I}$. Sinapis, 32. Sinapistrum, 32.

Brathoge-Mwirrĕ, II5. Briar, sweet, I20.
Brill-yōge, 218.

Brisk-el-awn, II 4 .

Bristle fern, 440 .

Brittle fern, 447 .

Briza, 423 .

media, 423 . minor, 517 .

Broad fern, 45 I.

Brome-grass, 43 I.

Bromus, 43I. arvensis, $5 \mathrm{r} 8$.

asper, $43 I$. commutatus, 433 .

diandrus, 432 .

erectus, 431 .

giganteus, 43 I.

madritensis, 432 .

mollis, 434 .

racemosus, 433 .

ramosus, 431 .

secalinus, 432 .

sterilis, 432 .

tectorum, 518 .

Brooklime, 264

Brook-weed, 235.

Broom, 80. butcher's, 5 r2.

Broom-rape, 268 .

Bryonia, 489.

dioica, 489 .

Bryony, black, 5 I2.

Buck's horn plantain, 298.

Buck-bean, 240.

Buck-evvin, 388 .

Buckthorn, alder, 78 . purging, 77 . sea, 507 .

Buckwheat, 507 .

Hugle, 296.

Bugloss, field, 242. vipers, 247.

Bullace, 96 .

Bull-rush, 388.

Bunizm, I52. flexuosum, ${ }^{52}$.

Bur-marigold, I80.

Bur-reed, 365 .

Burdock, Igo.

Burnet, II7. saxifrage, I5I.

Butcher's broom, 512 .

Butomus, 37 . umbellatus, $37 \mathrm{I}$.

Butter-bur, 186 .

Buttercup, 9.

Butterfy orchis, 349 .

Butterwort, 274.

Bwee more, 4I.

\section{c.}

Cabbage, 476 . fox's, I27.

Good People's, I27. St. Patrick's, I27.

Cabawsthé wadha roo-ee, I27. dheenee maw-hĕ, I27.

Cakile, 39 . maritima, 39.

Calamagrostis, $4 \mathrm{r} 6$ Epigeios, $4 \mathrm{I} 6$. Hookeri (var.), 4I7. lanceolata, $5 \mathrm{I} 6$. lapponica, 417.
Calamagrostis neglecta, 417. stricta, 4I7.

Calamint, 282.

Calamintha, 28I. Acinos, 28r. arvensis, $28 \mathrm{x}$. Clinopodium, 504 . Nepeta, 504 . officinalis, 282 . parviflora, 504 .

Callitriche, I39. autumnalis, r4o.

hamulata, I39.

obtusangula, I4o. pedunculata (var.), I40 stagnalis, 139 . truncata (var.), I4I. verna, 139. vernalis, I39.

Calluna, 223. Erica, 223 incana (var.), 223. vulgaris, 223.

Caltha, Io.

Guerangerii (var.), Io. palustris, Io. procumbens (var.), Io. radicans, to.

Calystegia, 247 . sepium, 247. Soldanella, 248 .

Camelina, 476 . sativa, 476

Campanula, 217. arctica (var.), 257. hederacea, 216.

hirta (var.), 2 I8. lancifolia (var.), 218. latifolia, 497 . patula, 498 . rapunculoides, 498 . Rapunculus, 498. rotundifolia, 21 7 . speciosa (var.), 2I7. Trachelium, 217.

Campanulace 2,215 .

Campion, bladder, 47 . mossy, 49 .

red, 50

sea, 48 .

white, 50 .

Canary grass, 516 .

Canna-vawn mona, 390.

Caper spurge, 508 .

Caprifoliacex, $16 \mathrm{r}$

Capsella, 34 . Bursa-pastoris, 34 .

Caraway, 490. whorled, I49.

Cardamine, 24. amara, 24 . flexuosa, 25 . hirsuta, 25 . impatiens, 473 . pratensis, 24. sylvatica, 25.

Carduus; 192. acanthoides (var.), 193. crispus, 193. nutans, 192. polyanthemos (var.), 193. pycuocephalus, x92. tenuiflorus, I92. 
Carex, 393.

acuta, 399.

acutiformis, 410

ampullacea, 4Ix.

aquatilis, $40 x$.

arenaria, 394.

axillaris, 397 .

binervis, 406 .

Boenninghauseniana, 397 .

Buxbaumii, 399.

cespitosa, 399, 402.

canescens, 398 .

curta, 398.

cyperoides (var.), 408.

Davalliana, 5r5.

diluta, 407

dioica, 393.

distans, 407 .

disticha, 394

divisa, 393 .

divulsa, 396 .

echinata, 397.

elatior (var.), 401.

elatior, 408.

elongata, 398 .

extensa, 407 .

filiformis, 408 .

flacca, 402

flava, 408 .

glauca, 402.

Goodenowit, 402 .

hibernica, 401 .

hirta, 409 .

Hornschuchiana, 407.

Hudsonii, 399 .

intermedia, 394.

juncella (var.), 402 .

lavigata, 406 .

Leesii (var.), 403 .

Iepidocarpa (var.), 408.

Zeporina, 399.

limosa, 402 .

minor (var.), 400 .

muricata, 396.

CEderi, 408 .

ovalis, 399

pallescens, 404 .

paludosa, 4 Io.

panicea, 404 .

paniculata, 395 .

paradoxa, 395.

pauciflora, 393.

pendula, 404 .

pilulifera, 403.

pracox, 403 .

Pseuda-cyperus, 409.

pulicaris, 393 .

punctata, 407 .

recurva, 402 .

remota, 397

rhynchophysa, 4I2.

rigida, 400 .

riparia, 41r.

robusta, 4I2.

rostrata, 4II.

speriostachya, 407.

stellulata, 397.

stictocarpa (var.), 402.

stricta, 399.

strigosa, 405.

sylvatica, 405

teretiuscula, 394 .

tricostata, 400 .

trinervis, 400 .

\section{Carex}

verna, 403 .

vesicaria, 4I2.

virescens (var.), 40r.

vulgaris, 402 .

vulpina, 395.

Watsoni (var.), 40r.

xanthocarpa, 408 .

Carlina, Igo.

vulgaris, rgo.

Carline thistle, rgo.

Carrot, I59.

Carum, $x 49$.

Carui, 490 .

Petroselinum, 490.

verticillatum, 149 .

Caryophyllea, 47

Catabrosa, 422. aquatica, 422 .

Catapodium, 428 . ioliaceum, 428 .

Catch-fly, English, 48. night-flowering, 49 .

Cat-mint, 284.

Cat's-ear, 2 II.

Cat's-tail grass, 4I5.

Caucalis, $\mathbf{r}_{59}$ Anthriscus, 159 . andensts, $49 \mathrm{I}$. nodosa, 159.

Caulinia, 383.

flexilis, 383

Cawsh-ther-vawn, 212.

Celandine, 16 .

lesser, Io.

Celastrinex, 77.

Celery, I47.

Centaurea, 196.

Cyanus, I97.

decipiens, 196 .

nigra, Ig6.

Scabiosa, I96.

solstitialis, 496 .

Centaury, 238.

Centranthus, 170 . rubra, 170 .

Centunculus, 234 minimus, 234 .

Cephalanthera, 340. ensifolia, 340 . grandiflora, $5 \mathrm{Ix}$. pallens, 5 II.

Cerastium, 52 . alpinum, 479 .

arvens $\theta, 53$

glomeratum, 52 . holosteoides (var.), 53 pentandrum (var.), 53 semidecandrum, 52 . tetrandrum, 52 . trigynum, 479 . triviale, 52 .

Ceratophyllea, 329 .

Ceratophyllum, 329 . demersum, 329 . submersum, 509 .

Ceterach, 446. crenatum (var.), 446. officinarum, 446 .

Charophyllum, 153. sativum, 490. syleestre, 154. ternulum, I53.

Chamanerion, 142.
Chamanerion

angustifolium, 142.

Chamomile, 182 .

Chara, $46_{3}$.

aspera, 464 .

barbata (var.), 463 .

canescens, 467 .

capillacea (var.), 463.

connivens, 464 .

contraria, 465 .

curta (var.), 464

delicatula (var.), 463 .

denudata, 465 .

dissoluta, 465 .

fragilis, 463 ,

Hedwigii (var.), 453 .

hispida, 466.

hispidula (var.), 465 .

lacustris (var.), 464 .

longibracteata (var.), 467.

macracantha (var.), 466 .

papillata (var.), 467 .

polyacantha, 464 .

rudis (var.), 466 .

subinermis (var.), 464 .

tomentosa, 466 .

vulgaris, 467 .

Characex, 463 .

Charlock, 32.

Cheiranthus, 19.

Cheiri, I9.

Chelidonium, I6. majus, I6.

Chenopodiacea, 299

Chenopodium, 299.

album, 299

Bonus-Henricus, 300.

candicans (var.), 290.

ficifolium, 506.

hybridum, 506 .

murale, 506 .

olidum, 505 .

polyspermum, 505.

pseudo-botryoides (var.), 300.

rubrum, 300 .

urbicum, 506.

viride (var.), 299.

Vulvaria, 505.

Chenopodina, 304. maritima, 304

Cherry, 96.

bird, 97 .

dwarf, 97 .

Chervil, 490. rough, 153 .

Chickweed, 53.

Chicory, 197

Chlora, 237. perfoliata, 237.

Chrysanthemum, 183 . Leucanthemum, 183 . Parthenium, 494. segetum, 183 .

Chrysosplenium, 131.

alternifolium, 487. oppositifolium, I31.

Cicely, sweet, 152.

Cicendia, 236. filiformis, 236 .

Cichorium, 197. Intybus, 197.

Cicuta, 148.

virosa, I 48 
Cineraria, 495 . maritima, 495 .

Cinque-foil, II4.

Circzea, $r_{44}$. alpina, I45. intermedia (var.), I45. lutetiana, I44.

Cirsium, r93. anglicum, $\mathrm{I} 94$

arvense, I94. lanceolatum, I93. palustre, 194.

Cistinez, 4I.

Cladium, 392. germanicum, 392. mariscus, 392.

Clary, 283.

Cleavers, $x 68$.

Clematis, 47I. Vitalba, $47 x$.

Clinopodium, 504. vulgare, 504 .

Cloud-berry, rio.

Clover, 83 . Alsike, 484 . Dutch, 87.

Club-moss, 459.

Club-rush, 389 .

Cnicus, r93.

arvensis, I94.

Forsteri, I94.

lanceolatus, I93.

palustris, x94.

pratensis, 194. setosus (var.), 194.

Cochlearia, 26. alpina (var.), 26. anglica, 27.

Armoracia, 474 .

danica, 27.

grcenlandica (var.), 27. Hortii (var.), 28. officinalis, 26 .

Cock's-foot grass, 423 .

Creloglossum, 349 . viride, 349 .

Colchicum, 357. autumnale, 357 .

Colleg-ruek, 392.

Coltsfoot, 186.

Columbine, Ir.

Comarum, II5. palustre, IIs.

Comfrey, $24 I$.

Compositæ, I73.

Coniferæ, 329.

Conium, I46. maculatum, I46.

Conopodium, $\times 52$. denudatum, 152 .

Convallaria, 5 I3. majalis, $5 \mathbf{I}_{3}$.

Convolvulacea, 247.

Convolvulus, 248. arvensis, 248. sepium, 247. Soldanella, 248.

Copp-oge srawd-ye, 31 r.

Coriander, 49I.

Coriandrum, 49 I. sativum, $49 I$.

Corn Blue-bottle, rg7. cockle, $5 \mathrm{~T}$. marigold, 183 .
Corn salad, r7o.

Cornacee, $\mathbf{6} 6$.

Cornel, 161.

Cornish heath, 499 .

Cornus, $16 r$. sanguinea, I6I.

Coronopus, 34 . didymus, 34 . procumbens, 35 Ruellii, 35 .

Corrigiola, 505 . littoralis, 505 .

Carsican Mint, 504.

Corydalis, I7. cla viculata, $\mathbf{r} 7$. lutea, 473 .

Corylus, 32I. Avellana, 32r.

Cotton-grass, 390.

Cotyledon, 132 . Umbilicus, 132 .

Couch-grass, 435 .

Cow-parsley, I54.

Cow-parsnep, I59.

Cow-wheat, 267 .

Cowberry, 218.

Cowl, 32x.

Cowslip, 232.

Crab apple, I23.

Crambe, 38 . maritima, 38 .

Cranberry, 2I9.

Crane's-bill, 70 . dove's foot, 72 .

Crassulacea, I32.

Cratæegus, I24. Oxyacantha, I24.

Cray micks feer, 446 .

Cray-uk-thuok, I4I.

Crepis, Ig9.

biennis, 200 .

nicæensis, 496 .

paludosa, 200.

setosa, 496.

succisæfolia, 496 .

taraxacifolia, 199 .

virens, 200.

Cress, 20.

bitter, 24 .

mountain, 23.

penny, 37 .

rock, 23 .

swine's, 34 .

Thale, 28.

winter, 22.

Crithmum, I55. maritimum, I55.

Crocus, 5 II. verous, 5 II.

Croob-ee-nee shinnack, 459 .

Cross-wort, I64.

Crow garlic, 355 .

Crow-berry, 328 .

Crow-foot, 7 .

Crucifera, I9.

Cryptogamere, 439.

Cryptogramme, 442 . crispa, 442.

Cuckoo-pint, 367.

Cucurbitacea, 480 .

Cudweed, 175 . sea, $18 \mathrm{r}$.

Cull, 321 .

Cullen, 77 .
Cullen traw, 146.

Cupulifera, 320 .

Currant, black, 487 . red, 487 .

Cuscuta, 249.

Epilinum, 50r.

Epithymum, 249. Trifolit (var.), 249.

Cushion pink, 49 .

Cynoglossum, 240. germanicum, 500 . montanum, 500 . officinale, 240.

Cynosurus, 42 I.

cristatus, 421. echinatus, 517 .

Cyperacea, 385 .

Cytisus, 80. prostratus (var.), 80 . scoparius, 80.

Cystopteris, 447 : dentata (var.), 447 fragilis, 447.

I

Dabeocia, 225. polifolia, 225.

Dactylis, 423. glomerata, 423 .

Daffodil, 5 Ir.

Daisy, 174 $\operatorname{dog}, 183$. ox-eye, $\mathrm{I}_{3}$.

Damasonium, $5 \times 4$. stellatum, 5 I4

Dame's violet, 474.

Dandelion, 2I2.

Danewort, I62.

Danthonia, 420. decumbens, 420 .

Darnel, 434 .

Darr, 322.

Datura, 502. Stramonium, 502.

Daucus, I59. Carota, 159. gummifer, $49 \mathrm{r}$.

Dead-nettle, 292.

Deadly Nightshade, 5or.

Delphinium, 472 . Ajacis, 472 .

Deschampsia, 4 I8. alpina, 418 . crespitosa, 4I8. discolor, 418 . flexuosa, 4I9. pseudo-alpina, (var.), 4 I8.

Desmazeria, 428, 5 r8. loliacea, 428 . sicula, 5 I8.

Devil's Bit scabious, I73.

Dew-berry, Iog.

Deyeuxia, 417 . neglecta, $4 \mathrm{I} 7$.

Dhillisk an $0 \mathrm{w}$-ann, 372 .

Dhill-yo-gee vaw-itch-ee, I3.

Dhoo-hoosuck, 44I.

Dhray-mirĕ II wirrĕ, 238.

Dhree-ann, 96.

Dhriss, 99 .

Dhroo-iek-dheen mona, I36. 
Dianthus, 478 . caryophyllus, 478 . deltoides, 478 . plumarius, 478 .

Digitalis, 26r. purpurea, 26r.

Digitaria, 515 . sanguinalis, 515 .

Digraphis, 4r3. arundinacea, 413.

Dioscorea, 512.

Diotis, I8I. candidissima, $18 \mathrm{r}$. maritima, 181 .

Diplotaxis, 33 . Babingtonii (var.), 34 . muralis, 33 . tenuifolia, 476 .

Dipsacea, $I 72$

Dipsacus, I72. sylvestris, I72.

Dittander, 35 .

Dock, 3 Io. fiddle, 3 Ir. golden, 3 II. water, 3 I2

Dodder, 249 flax, 501 .

Dog daisy, 183 . rose, IzI.

Dog's Mercury, 316.

Dog's-tail grass, $42 \mathrm{r}$.

Dogwood, I6I.

Doronicum, 495 . Pardalianches, 495 .

Draba, 25. confusa (var.), 26. incana, 25. muralis, 474 . rupestris, 474 . verna, 26.

Dropwort, 98 . water, I55

Drosera, 136 . anglica, 136 . intermedia, 137 . Zonpifolia, 136 . obovata, 137. rotundifolia, $x_{3} 6$

Droseracex, 136 .

Drowned leaves, I3.

Dryas, III. octopetala, III.

Duckweed, 368.

Dulse, river, 372.

Dutch clover, 87 . rushes, 456 .

Dwarf elder, I62.

Dyer's green-weed, 483 .

\section{E.}

Earth father, 281 .

Echium, 247. vulgare, 247.

Elatine, 6r. hexandra, $6 \mathrm{r}$. Hydropiper, 62 .

Elatinea, 6I.

Elder, 162 . dwarf, 162 .

Eleagnacea, 507

Elecampane, 578
Eleocharis, 385 . acicularis, 385 . longicaulis (var.), 386 . multicaulis, 387 . palustris, 386 . uniglum is, 386 . Watsoni (var.), $3^{87}$.

Elisma, 5I4. natans, $5 \mathrm{I} 4$

Ellis-thrum, 35 I.

Elm, 508. wych, 318 .

Elodea, 332 . canadensis, 332 .

Elodes, 64. palustris, 64 .

Elymus, 438. arenarius, 438 .

Empetracea, 328 .

Empetram, 328. nigrum, 328 .

Enchanter's nightshade, I 44 .

Endymion, 357 . nutans, 357 .

Epilobium, I42. adnatum, 488 .

alsinefolium, I44. angustifolium, I42. hirsutum, I43.

Lamyi, 489 . montanum, I43. obscurum, I44

palustre, I44. parviflorum, I43. roseum, 143. spicatum, 142. tetragonum, 488 virgatum, I44.

Epipactis, 340 atto-rubens, 342 . latifolia, 340 .

media, 34I.

ovalis, 342 .

palustris, 342 .

rubiginosa, 342 .

Equisetacea, 454.

Equisetum, 454

arenarium (var.), 458 .

arvense, 454 .

Drummondii, 455 .

fluviatile (var.), 456 .

hyemale, 456 .

limosum, 456 .

Mackaii, 457 .

majus (var.), $45^{8}$.

maximum, 454 .

Moorei, 457.

nudum (var.), 456.

palustre, 455 .

polystachyum (var.), 455 .

pratense, 455 .

sylvaticum, 455 .

Telmateia, 454 .

trachyodon, 457 .

umbrosum, 455 .

variegat um, 458 . Wils oni (var.), 458 .

Erica, 223.

ciliaris, 498 .

cinerea, 224.

dabeocii, 225.

hibernica, 224.

Mackaiana, 223.

Mackaii, 223.
Erica.

mediterranea, 224

stricta, 499.

Tetralix, 223.

vagans, 499 -

vulgaris, 223.

Ericaceae, 220.

Erigeron, I74. acre, 174.

Erinus, 502 . alpinus, 502 .

Eriocaulon, 384 . septangulare, $3^{8} 4$.

Eriocaulonea, 384 .

Eriophorum, 390. alpinum, 5I5. angustifolium, 390. latifolium, 39I. vaginatum, 390 .

Erodium, 75. cicutarium, 75 . maritimum, 76 moschatum, 75 .

Erophila, 26. vulgaris, 26 .

Ervum, 9I. hirsutum, $9 \mathrm{I}$ tetraspermum, $9 \mathrm{r}$.

Eryngium, I46. campestre, 480 . maritimum, $\mathbf{I}_{4} 6$.

Erysimum, 475. cheiranthoides, 475 . orientale, 475 .

Erythraea, 238. capitata (var.), 238.

Centaurium, 238. latifolia (var.), 238. littoralis, 499. pulchella, 238 .

Eufoagria, 266 . viscosa, 266

Euonymus, 77. europaus, 77 .

Euphorbia, 31 3 . amygdaloides, 3I5. Cyparissias, 508. exigua, 316 . Helioscopia, 3 r3. hiberna, 34.

Lathyris, 508. Paralias, 3 I5. Peplis, 520 .

Peplus, 316. portlandica, 315.

Euphorbiacex, 313 .

Euphrasia, 265. borealis (var.), 265 . brevipila (var.), 265 . gracilis (var.), 265. nemorosa (var.), 265. Odontites, 266.

officinalis, 265 .

Rostkoviana (var.), 265.

Salisburgensis, 265 .

Evening primrose, 489 .

Evvin, 160 .

Eyebright, 265 .

\section{F.}

Fagopyrum, 507 . esculentum, 507. 
Fagus, 322. sylvatica, 322.

Fairy fingers, $26 \mathbf{r}$.

Farn-oge, 32I.

Farra bawn, 9 .

Fay-lōge, I63.

Feeo-kay-dhawn, I93.

Felwort, 239.

Fennel, 154 .

Fern, adder's-tongue, 453.

beech, 452.

brittle, 447 .

bristle, 440 .

filmy, 439

hard, 443 .

harts-tongue, 446 .

holly, 448.

Killarney, 440.

lady, 446 .

maiden-hair, 44I.

male, 450 .

oak, 452 .

parsley, 442.

royal, 453 .

Fescue grass, 427.

Festuca, 427.

arenaria (var.), 429.

arundinacea, 430

elatior, 430 .

gigantea, $43 \mathrm{I}$.

loliacea, 430 .

Myuros, 428 .

oraria, 429 .

ovina, 429.

pratensis, 430.

procumbens, 518 .

rigida, 427 .

rottbcellioides, 428 .

rubra, 429 .

sciuroides, 429

sylvatica, 429 .

uniglumis, 428 .

Feverfew, 183 .

Ficaria, ro. ranunculoides, I0. verna, to.

Fiddle dock, 3 II.

Figwort, 257.

Filago, 175 . germanica, 175 . minima, I75

Filices, 439 .

Filmy-Fern, 439

Finshōge, 236 .

Fiorin, 416 .

Fir, Scotch, 5ro.

Flag, sweet, 367 yellow, 35I.

Flax, 48x.

dodder, 5or.

pale-flowered, 69 . purging, 69 .

Flea sedge, 393 .

Flea-bane, I80. blue, 174 .

Flih, 53 .

Flix-weed, 29.

Flowering rush, 37 .

Fluellin, 254.

Fly orchis, 346 .

Foeniculum, I54 officinale, I54

Fohen-awn, 193.

Fool's parsley, 157 .
Forget-me-not, 244 .

Fox-glove, 26r.

Fox-tail, 4I4.

Fox's cabbage, I27.

Fox's paws, 459 .

Fragaria, II2. elatior, 486 . steritis, II3. vesca, II2.

Frangula, 78. vulgaris, 78 .

Fraxinus, 236. excelsior, 236

Fray-ack, 223, 224. gawldh 225 . na-hain cushĕ, 225 .

Fray-ack-awn, 2 19.

French sorrel, 507 .

Frog orchis, 349 .

Frog-bit, 333 .

Fumaria, 17 .

Borai (var.), 18.

capreolata, 17 .

confusa, 18 .

densiflora, 18 .

micrantha, 18 .

muralis, $x 8$.

officinalis, IQ.

pallidiflora, I7.

parviflora, 473 .

Fumariacea, I7

Fumitory, 17

Furze, 79 .

dwarf, 80.

Irish, 79 .

G.

Galanthus, 512 . nivalis, 5 xz.

Galeobdolon, 293. lutexm, 293.

Galium, I64.

Aparine, 168.

boreale, 164.

Cruciata, I64.

cruciatum, 164 .

elongatum (var.), 167 .

erectum, 165 .

insubricum (var.), I66.

Mollugo, r66.

ochroleucum (var.), 166.

palustre, 167 .

pusillum, 167.

saxatile, $x 66$.

sylvestre, $\mathbf{1 6 7}$

uliginosum, I67.

verum, 165.

Witheringii (var.), I67.

Galeopsis, 289. arigustifolia, 289

bifida (var.), 291.

Ladanum, 280 .

speciosa, 290.

Tetrahit, 290.

versicolor, 290

Garlic, 355

Gawr-lee-yoge, 356.

Geen-ack, 363 .

Genista, 483.

tinctoria, 483 .

Gentian, 238 .
Gentiana, 238 .

Amarella, 239.

campestris, 240 .

verna, 238 .

Gentianeæ, 236.

Gentianella, 236.

Geraniaceæ, 70.

Geranium, 70 . columbinum, 73 .

dissectum, 73 .

lucidum, 74.

molle, 72 .

nodosurn, 482.

perenne, $7 \mathrm{~K}$.

Phaum, 48 .

pratense, $7 \mathrm{r}$.

purpureum (var.), 74 .

pusillum, 72.

pyrenaicum, $7 x$.

Robertianum, 74 .

rotundifolium, 73 .

sanguineum, 70

striatum, 48I.

sylvaticum, 70 .

Germander speedwell, 263. water, 295.

Geum, II2.

intermedium, II2.

rivale, Ir2,

urbanum, IIs.

Gipsy-wort, 280.

Githago, 5I. segetrm, $5 \mathrm{I}$.

Gladdon, $35^{\circ}$

Glass-wort, 304 .

Glaucium, I6.

flavum, I6.

luteum, 16 .

Glaux, 233.

maritima, 233.

Glechoma, 284 . hederacea, 284

Globe flower, Ir.

Gloon-yack dharrig, 307.

Gloon-yack tchai, 305.

Glyceria, 425 . aquatica, 426 .

Borreri, 427.

distans, 426 .

fluitans, 425 .

marilima, 426 .

plicata, 425. spectabilis, 426 .

Gnaphalium, I77. dioicum, 176 .

luteo-album, 493.

sylvaticum, 177 . uliginosum, I77.

Goat's-beard, 214.

Golden dock, 3 II. rod, 174 . samphire, $\mathbf{1 7 9 .}$

Goldailocks, 8.

Good People's cabbage, I27 ${ }^{7}$

Goose grass, 168.

Goose-foot, 299.

Gooseberry, 487 .

Gorse, 79.

Gout-weed, I5o.

Gramineæ, 4I3.

Grape hyacinth, $5 \times 3$.

Grass, barley, 437.

blue-cyed, $35 \mathrm{r}$.

brome, 43I. 
Grass

canary, 516

cat's-tail, 4I5.

cock's-foot, 423 .

couch, 435 .

darnel, 434 .

dog's-tail, 42 .

fescue, 427 .

fox-tail, 413.

lyme, $43^{8}$.

marram, 417 .

mat, 436 .

millet, 4I4.

of Parnassus, I3I.

quaking, 423. :

Ieed, 4I3.

rye, 434 .

Timothy, 4I4.

vernal, 4I3.

wrack, 383 .

yellow-eyed, 352 .

Great daisy, I83. plant, $26 \mathrm{I}$.

Gromwell, 245 . sea, 242 .

Ground fruit, II2. ivy, 284 .

Groundsel, I86.

Guelder rose, $\mathbf{1} 62$.

Gymnadenia, 347 . albida, 348 . conopsea, 347

Gyole-ousk, 420.

B.

Habenaria, 347.

albida, 348 .

bifolia, 349 .

chlorantha, 349 .

chloroleuca, 349

conopsea, 347 .

intacta, 347 .

viridis, 349 .

Hair-grass, 4I7.

Halimus, 303 portulacoides, 303

Haloragere, I37.

Haloscias, I57. scoticum, I57.

Hard fern, 443

Hard-grass, $43^{6}$.

Hare bell, 217

Hare's-foot trefoil, 84 .

Hart's-tongue, 446.

Hawkbit, 2II.

Hawk's-beard, I9g.

Hawkweed, $20 x$.

mouse-ear, 201.

Hawthorn, 124.

Hazel, $32 \mathrm{x}$.

Healing plant, 297.

Heath, 224

Cornish, 499.

cross-leaved, 223.

foreign, 225 .

Mediterranean, 224.

one-footed, 225.

St. Dabeoc's, 225.

Hedera, 160 .

Helix, 160

Hedge mustard, 29. parsley, I59.
Helianthemum, 4T.

Breweri (var.), $4 \mathrm{I}$.

canum, 41.

guttatum, 41 .

marifolium, 4I.

vineale, 41.

vulgare, 477 .

Heliotrope, winter, 186 .

Hellebore, 472.

Helieborine, 340 . white, 340 .

Helleborus, 472. foetidus, 472 . viridis, 472 .

Helminthia, 198 . echioides, 198.

Helosciadium, I47. inundatum, 148. nodiflorum, 147 . repens, 147 .

Hemlock, I46 stork's-bill, 75 . water, 148 .

Hemp Agrimony, 173. nettle, 289 .

Henbane, 252 .

Henbit, 29r.

Heracleum, I 59 . Sphondylium, 159.

Herb Paris, 514 Robert, 74.

Hesperis, 474. matronalis, 474 .

Hieracium, 201. acutifolium (var.), 202. anglicum, 202. argenteum, 204. aurantiacum, 496. auratum, 209.

boreale, 209. cerinthiforme, 202.

cinerascens, 204.

caesium, 206. coronopifolium (var.), 2 II. corymbosum, 208.

crinigerum, 204.

crocatum, 209.

euprepes, 205.

Farrense, 204.

filifolium (var.), 2 II.

flocculosum, 203.

Gibsoni, 206.

gothicum, 207.

Hartii (var.), 202.

hibernicum, 205.

hypocheroides, 206.

iricum, 202.

lasiophyllum, 204.

latifolium (var.), 207.

Leyi, 204.

longibracteatum (var.), 202.

microcladium (var.), 205.

molle, 496.

murorum, 205.

pachyphyllum (var.), 205.

pallidum, 203.

paludosum, 200.

Pilosella, 2or.

prenanthoides, 208.

rigidum, 208.

rigidum, 208.

rubicundum, 204.

sabaudum, 2og.

Schmidtii, 203.
Hieracium

sciapbilum, 207.

scoticum, 205.

Sommerfeltii, 205

stenolepis, 206.

Stewartii (var.), 207.

strictum, 208.

sylvaticum, 206.

tridentatum, 208.

umbellatum, 2 IO. vulgatum, 206.

Hippophæ, 507.

rhamnoides, 507 .

Hippuris, I37. vulgaris, 137 .

Holcus, 419 . lanatus, $4 \mathrm{Ig}$ mollis, 4rg.

Holly, 77. fern, 448 . sea, I46.

Honeysuckle, $\pi 6_{3}$.

Honkeneja, 57. peploides, 57

Hop, 318 trefoil, 88.

Hordeum, 437 marinum, 518. maritimum, $5 \mathrm{I} 8$. murinum, 437 . pratense, 437 . secalinum, 437 . sylvaticum, 5 I9.

Horebound, black, 294. white, 286.

Horned pond-weed, 382 . poppy, 16.

Hornwort, 329 .

Horse radish, 474.

Horsemint, 503 .

Horse-tail, 454.

Hottonia, $23 \mathrm{I}^{*}$ palustris, $23 \mathrm{r}$.

Hound's-tongue, 240.

Houseleek, 488 .

Humulus, 318 . Lupulus, 318.

Hutchinsia, 477 . petraa, 477 .

Hyacinth, grape, 513 . wild, 357.

Hyacinthus, 357. non-scriptus, 357 .

Hydrocharidexe, 332

Hydrocharis, 333 . Morsus-ranae, 333 .

Hydrocotyle, I46. vulgaris, 146 .

Hymenophyllum, 439 . tunbridgense, 439 . unilaterale, $44^{\circ}$. Wi soni, 440.

Hyoscyamus, 252. niger, 252.

Hypericinea, 62

Hypericum, 62.

Androsæmum, 62

calycinum, 480 .

dubium, 63 .

elatum, 480 .

elodes, 64

hircinum, $48 \mathrm{I}$.

hirsutum, 64 .

humifusum, 64 
Hypericum

maculatum (var,), $\sigma_{3}$. montanum, $48 \mathrm{I}$. perforatum, 63 . pulchrum, 64 . guadrangulum, 63,64 . quadiatum, 64 . tetrapterum, 64

Hypochoris, 2 II. glabra, 497 radicata, $21 \mathrm{I}$.

Hypopithys, 228. multifiora, 228 .

Hypopitys, 228 .

Monotropa, 228.

I.

Ilex, 77

Aquifolium, 77 .

Ilicineæ, 77 .

Illecebraceæ, 299.

Inula, I78. $^{8}$

crithmoides, $x 79$.

dysenterica, 180 .

Helenium, I78.

salicina, 179 .

Iridex, 350 .

Iris, 350 .

acoriformis (var.), 35I.

fotidissima, 350 .

Pseud-acorus, 35I.

tuberosa, $5 \mathrm{II}$.

Isatis, 477 . tinctoria, 477 .

Isoetes, $46 \mathrm{I}$.

echinospora, 462 .

lacustris, $46 \mathrm{x}$.

Ivy, 160 .

Morei (var.), 462.

ground, 284

Irish, I6o.

Ivy-leaved Bell-flower, 2 r6.

\section{J}

Jack by the Hedge, 30 .

Jacob's ladder, 500 .

Jasione, 2I5. montana, 215.

John's-wort, Saint, 63 .

Juncaces, 358 .

Juncus, 358 .

acutiflorus, 363 .

acutus, $36 \mathrm{I}$.

biglumis, $5^{I} 4$

bufonius, 358 .

compressus, 5 I4

conglomeratus, 360 .

diffusus, $36 \mathrm{I}$.

effusus, 360 .

fasciculatus (var.), 358

filiformis, $5 \pi 4$.

fluitans, 362 .

Gerardi, 359.

glaucus, 360 .

lamprocarpus, 363 .

maritimus, $36 \mathrm{r}$.

obtusiflorus, 362 .

silvaticus, 363 .

squarrosus, 358

supinus, $36 \mathrm{x}$.

tenuis, 359 .
Juncus

trifidus, $5 \mathrm{I} 4$.

triglumis, 514.

Juniper, 329.

Juniperus, 329.

communis, 329 .

nana (var.), 330.

Sabina, 5ro.

\section{K.}

Knappia, 5 I6. agrostidea, $5 x 6$.

Knapweed, I96.

Knautia, I 73 .

arvensis, 173.

Kidney vetch, 89 .

Kidney-leaved saxifrage, r25.

Killarney fern, $44^{\circ}$.

Knawel, 299.

Kneed-plant, 305 .

Knot-grass, 305 .

Koleria, 422 . cristata, 422

Kweer-ann, 123.

\section{I.}

Labiatæ, 276 .

Lactuca, 213. muralis, 213. virosa, 497 .

Lady fern, 446.

Lady's mantle, II5. smock, 24 . tresses, 338.

Lamb's-tongue, 297

Lamium, 29I.

album, 293.

amplexicaule, 29 r.

Galeobdolon, 293

hybridum, 292.

incisum, 292.

intermedium, 292.

purpureum, 292

Lastræa, 449.

amula, 45I.

cristata, 5 rg.

dilatata, $45 \mathrm{I}$.

Filix-mas, 450

forrisecii, 45 I.

Oreopteris, 450.

recurva, $45 \mathrm{I}$.

rigida, 5 Ig.

spinulosa, 450 .

Thelypteris, 449 .

Lappa, Igo. major, 190.

minor, IOI.

Lapsana, $I 98$. communis, Ig8.

Lathræa, 271. Squamaria, 27 I.

Lathyrus, 94.

Aphaca, 485 .

macrorrhizus, 95 .

maritimus, 95 .

montanus, 95 .

Nissolia, 485 .

palustris, 94 .

pratensis, 94 .

tenuifolius (var.), 95.
Lavatera, 65 . arborea, 65.

Lay ishgr, 274 .

Iay-theon, III.

Ledum, 499. palustre, 499.

Leek, 354 .

Leguminosa, 79

Lemna, 368 . gibba, 368 . minor, 368 . polyrhiza, 369 trisulca, 368

Lemnacez, 368 .

Lentibulariea, 272.

Leontodon, 2II.

autumnalis, 212

hirtus, 2 II.

hispidus, 2 xI.

pratensis (var.), 212.

Taraxacum, 212.

Leonurus, 505.

Cardiaca, 505

Leopard's bane, 495 .

Lepidium, 35 .

campestre, 36 .

Draba, 477 .

birtum, 36 .

latifolium, 35 .

ruderale, 477 .

Smithiz, 36 .

Lepigonum, 50 marinum, 60 . marginatum, 60 .

rubrum, 59.

rupestre, 60.

mupicola, 60

salinum, 60 .

Lepturus, 436. filiformis, 436 .

Lettuce, wall, $2 I_{3}$

Leucanthemum, 183 . vulgare, 183 .

Leucojum, 5 I2. estivum, 512 .

Ligusticum, I57. scoticum, ${ }_{57}$.

Ligustrum, 236 . vulgare, 236 .

Liliacere, 353.

Lily of the valley, $55_{3}$.

Limnanthernum, 500 . peltatum, 500

Limosella, 260 . aquatica, 260 .

Linaria, 253. Cymbalaria, 253.

Elatine, 254

minor, 256 .

repens, 254.

sepium, 255 .

striata, 254

viscida, 256 .

vulgaris, 255 .

Linea, 68.

Ling, 223.

Linum, 69 . angustifolium, 69. catharticum, 60 . usitatissimum, $48 \mathrm{x}$.

Listera, 337. cordata, 337 .

ovata, 338

Lithospermum, 245* 
Lithospermum, 245 . arvense, 246. maritimum, 242. officinale, 245.

Littorella, 298. juncea, 298 . lacustris, 298.

Live-long, 133 ,

Lizard orchis, $5 \mathrm{II}$.

Lobelia, 215. Dortmanna, 2I5.

Iolium, 434

italicum, 519 .

linicola, 5 I9.

perenne, 434 . temulentum, 434 .

Lomaria, 443 Spicant, 443

London pride, I27. rocket, 29.

Lonicera, 163 . Periclymenum, I63. Xylosteum, 491.

Too-ack-ar, 360 .

Loos-earriv, r68.

Ioos more, 261 .

Loose-strife, 232. purple, I4I.

Loranthacex, 508.

Lotus, $8 \mathrm{~g}$.

corniculatus, 80 . crassifolius (var.), 8g. major, go.

tenuifolzus, 89.

tenuis, 89 .

uliginosus, go.

villosus (var.), 89 .

Lovage, 157 .

Lucerne, 483

Luzula, 363 .

Borreri, 514

campestris, 364 .

erecta (var.), 364

maxima, 363

multiflora, 364 .

pilosa, 363

syleatica, 363

vernalis, 363 .

Lycium, 50I.

barbarum, 501.

Lychnis, 50.

alba, 50

dioica, 50 .

diurna, 50

Flos-cuculi, $5 \mathrm{I}$

Githago, 5I.

vespertina, 50 .

Lycopodiacex, 459

Lycopodium, 459.

alpinum, 460 .

clavatum, 459 .

inundatum, 450

selaginoides, $46 \mathrm{r}$.

Selago, 459

Lycopsis, 242. arvensis, 242.

Iycopus, 280.

europzus, 280 .

Lyme-grass, 438 .

Lysimachia, 232.

nemorum, 233.

Nummularia, 233.

vulgaris, 232 .

Lythrariez, I4I.
Lythrum, I4I.

Hyssopifolia, 488 .

Salicarid, I4I.

\section{M}

Madder, field, 169. wild, I63.

Maiden pink, 478 .

Maiden-hair, 44r.

Iilairy-cawn dharrig, $26 \mathrm{I}$.

gorrtim, $2{ }^{2}$

Mair-een-yee phoo-ka, 26r

MaZachium, 479.

aquaticum, 479 .

Malaxis, 335 .

paludosa, 335

Male fern, 450.

Mallow, 67 .

dwarf, 67 .

marsh, 65

musk, 66 .

tree, 65 .

Malva, 66

borealis, $48 \mathrm{x}$.

moschata, 66

neglecta, 67

rotundifolia, 67

sylvestris, 67

vulgaris, 67 .

Malvacea, 65 .

Maple, 482.

Mare's-tail, I37

Marigold, corn, $\mathrm{I}_{3}$. marsh, Io.

Marjoram, 280.

Marram, 4I7.

Marrubium, 286. vulgare, 286.

Marsh cress, 20.

fern, 449 .

mallow, 65

marigold, to.

pennywort, 146 .

sedge, 393

wort, 148 .

Marsileacea, 462 .

Mary's ladder, 238.

Masterwort, 491.

Mat-grass, 4I7, 436 .

Mathiola, Ig. sinuata, I9.

Matricaria, 183 .

Chamomilla, $x 84$

discoidea, 494 .

inodora, 183 .

maritima, 184 salina (var.), 184

Meadow-rue, I. saffron, 357 . sweet, 98 .

Meconopsis, I5. cambrica, I5

Medicago, 8r. arabica, 82

denticulata, 484 .

falcata, 483 .

lupulina, 81.

maculata, 82

minima, 484 .

sativa, 483 .

sylvestris, 483 .
Medick, black, 8 I. spotted, 82 .

Meeshack, 69 .

Melampyrum, 267 ericetorum (var.), 268

latifolium (var.), 268.

montanum (var.), 268. pratense, 267. sylvaticum, 268 .

Melandrium, 50 . pratense, 50. sizvestre, 50.

Melica, 422.

uniflora, 422 .

Melilot, $8 z$.

Melilotus, 82 .

alba, 484 .

arvensis, 83 .

officinalis, 82 .

parviflora, 484 .

vulgaris, 484 .

Melissa, 282 .

Calamintha, 282.

officinalis, 505 .

Mentha, 276.

alopecuroides, 503.

aquatica, 278.

arvensis, 279.

gentilis (var.), 279.

gracilis (var.), 279.

hirsuta, 278.

Zongifolia, 503 .

paludosa (var.), 278.

piperita, 277.

Pulegium, 279.

Requieni, 504 .

rotundifolia, 276 .

rubra (var.), 278 .

sativa, 278 .

subglabra (var.), 278 .

sylvestris, 503

viridis, 504 .

Menyanthes, 240. trifoliata, 240

Menziesia, 225 polifolia, 225.

Mercurialis, 316. annua, 317. perennis, $3 I 6$.

Mercury, 316.

Mertensia, 242. maritima, 242.

Meum, 49x. Athamanticum, $49 \mathrm{I}$.

Mibora, 516 verna, 516

Microcala, 236. filiformis, 236 .

Mignonette, 40 .

Mild milk, 314 .

Milfoil, $18 \mathrm{~s}$. water, 138 .

Milium, 4I4. effusum, 4 r4

Milk thistle, I95.

Milk-vetch, go.

Milk-wort, 46 . sea, 233 .

Millet grass, 4T4.

Mimulus, 259. argutus (var.), 259. guttatus, 259. Langsdorfiz, 259. luteus, 259. 
Mint, 276 .

cat, 284 .

Corsican, 5046

horse, 503 .

spear, 504

Mishimeen dharrig, 278 .

Mistletoe, 508 .

Mcehringia, 56. trinervia, 56

Molinia, 422. carulea, 422

Moneywort, 233.

Monkey-flower, 259.

Monocotyledones, 332.

Monotropa, 228 Hypopitys, 228.

Monotropere, 228.

Montia, 6r.

fontana, $6 r$.

minor (var.), 6 I.

rivularis (var.), 6r.

Moon-wort, 454 .

Moschatel, I6r.

Mossy saxifrage, I30.

Moth mullein, 502 .

Mountain ash, 123. avens, III. fern, 450 . sorrel, 309.

Mouse-ear, 53. hawkweed, $20 I$.

Mouse-tail, 472.

Mudwort, 260

Mugwort, 185 .

Mullein, 253. moth, 502 .

Muscari, 5 I3. racemosum, $5 \mathrm{I}_{3}$.

Musk mallow, 66 . thistle, ro2.

Mustard, black, $3 I$. hedge, 29 . wall, 33 white, 32 .

Myosotis, 243. arvensis, 244. cospitosa, 243. collina, 244 . intermedia, 244 . palustris, 244. repens, 244: strigulosa (var.), 244. sylvatica, 5or. umbrosa (var.), 244. versicolor, 245.

Myosurus, 472 . minimus, 472 .

Myrica, 320. Gale, 320.

Myricacea, 320.

Myriophyllum, I38. alterniflorum, $\times 39$. pectinatum (var.), 138. spicatum, 138 . verticillatum, ${ }_{3} 8$.

Myrrhis, I52. odorata, I52.

Myrtle, bog, 320 .

\section{N.}

Naiad, slender, $3^{8} \mathbf{3}$ Naiadacea, 372 .
Naias, 383 .

flexilis, 383 .

Narcissus, 353 .

biflorus, 353 .

major, 5 I2.

poeticus, 5 I2.

Pseudo-narcissus, $5 \mathrm{II}$.

Nardosmia, 186.

fragrans, 186.

Nardus, 436 . stricta, 436.

Narthecium, 358. ossifragum, 358 .

Nasturtium, 20 . amphibium, $2 I$. officinale, 20. palustre, 20.

sylvestre, 20. terrestre, 20.

Nee-an-thoge, 3ro. kweeock, 292.

Neotinea, 347 . intacta, 347.

Neottia, 336 . gemmipara, 339 . Nidus-avis, 336 .

Nepeta, 284. Cataria, 284. Glechoma, 284.

Nephrodium, 450 . amulum, 45r. dilatatum, $45 \mathrm{I}$. Filix-mas, 450 . Oreopteris, 450. spinutosum, 450 .

Nettle, 319 . blind, 292. dead, 292 .

Night-shade, black, $25 \mathrm{I}$. deadly, 5 or. enchanters, 144.

Nipplewort, I98.

Nitella, 468 . capitata, 520 . flexilis, 470 . gracilis, 469 . nidifica (var.), 470 . Nordstedtiana, 468 . opaca, 470 . tenuissima, 469 . translucens, 469 .

No-nyeen, I74. more, I83.

None so pretty, 127.

Nuphar, I2.

intermedium (var.), I2. luterm, I2.

Nymphaea, 13. alba, I3.

Nymphaacez, I2.

\section{0.}

Oák, 322. fern, 452

Oat, wild, 5 I7.

Oat-grass, 4rg.

Obione, 303 . portulacoides, 303.

Odontites, 266. rubra, 266. verna, 266.

Enanthe, 155. crocata, 156.
CEnanthe

fistulosa, 155 .

fluviatilis (var.), I57.

Lachenalii, $x 56$.

Phellandrium, I56.

pimpinelloides, 156.

CEothera, 489. biennis, 489 .

Oleaceæ, 236 .

Onagrariez, I42.

Onobrychis, 485 . sativa, 485 .

Ononis, 8o. horrida (var.), 8I. repens, 80. spinosa, 483 .

Ophioglossum, 453 . Hartii (var.), 454 vulgatum, 453 .

Ophrys, 345. apifera, 345 . muscifera, 346 .

Opium poppy, 13.

Orache, 302 sea, 301 .

Orchidex, 335 .

Orchis, 343 angustifolia (var.), 345 . atlantica, 347.

bee, 345 .

bog, 335 .

butterfly, 349 .

fly, 346 .

frog, 349 .

fusca, $5 x x$.

hircina, 5 II. incarnata, 345 . intacta, 347 .

lizard, 511 . maculata, 345 . mascula, 344 .

Morio, 344. purpurea, 5rI. pyramidalis, 343 . ustulata, SII.

Origanum, 280 . vulgare, 280

Ornithogalum, 513. umbellatum, $5 \mathrm{I}_{3}$.

Ornithopus, go. perpusillus, 90

Orobanche, 268 . Epithymum, 260. Hederæ, 270 major, 268 . minor, $27 I$. Rapum, 268. rubra, 260.

Orobanchez, 268.

Orobus, 92. sylvaticus, 92. tuberosus, 95 .

Orpine, I33:

Osier, 326.

Osmunda, 453. regalis, 453 .

Ox-eye, I83.

Ox-tongue, 198.

Oxalis, 76 . Acetosella, 76 . corniculata, 482 . stricta, $4^{82}$.

Oxycoccus, 219. palustris, 2 I9. 
Oxyria, 309.

digyna, 309 .

reniformis, 309 .

P.

Panicum, 515.

Crus-galli, 5 I5.

sanguinale, 555 .

Pansy, 45.

Papaver, I3.

Argemone, I4.

dubium, I4.

hybridum, 15.

Lamottii (var.), I4.

Lecogii (var.), I4.

Rhoeas, I3.

somniferum, 13 .

Papaveracexe, 13.

Parietaria, 320 .

diffusa, 320 . officinalis, 320 .

Paris, 5I4 quadrifolia, 5I4*

Parnassia, rzi. palustris, I3I.

Parnassus, grass of, I $3 \mathrm{I}$.

Parsley, 490.

beaked, 153 .

cow, 154 .

fern, 442 .

fool's, 157

heđge, $x 59$.

Parsley-piert, II5.

Farsnep, cow, I59. water, $147,150$. wild, I58.

Pastinaca, 158 . sativa, 158 .

Pea, heath, 95. sea, 95 .

Pear, 486 .

Pearlwort, 57 .

Pedicularis, 267. palustris, 267. sylvatica, 267

Pellitory, wall, 320 .

Penny cress, 37 .

Penny-royal, 279 .

Yennywort, I3z. marsh, I46.

Peplis, I4I.

Portula, I4r.

Peppermint, 277.

Pepperwort, 36 .

Periwinkle, 499.

Petasites, 186 . albus, 495 . fragrans, 186. officinalis, 186 . vulgaris, 186 .

Petroselinum, 490. sativum, 490.

Peucedanum, 158. Ostruthium, 49. sativum, 158 ,

Phalaris, 4r 3 . arundinacea, $4 \mathrm{I} 3$. canariensis, 516 .

Pheasant's eye, $47 \mathrm{I}$.

Phegopteri', 452. Dryopteris, 452. polypodioides, 452.
Phellandrium, I56. aquaticum, 156 .

Phleum, 414.

alpinum, 516.

arenarium, 4र5. pratense, 4I 4.

Phragmites, 420. communis, 420 .

Picris, Ig8.

echioides, 198

hieracioides, 496 .

Pig-nut, I52.

Pill-wort, 462 .

Pilularia, 462. globulifera, 462 .

Pimpernel, 234. bastard, 234.

Pimpinella, I5I. magna, $x_{5} \mathrm{I}$. major, I5I. Saxifraga, $15 x$.

Pinguicula, 274. grandiflora, 274. Iusitanica, 275. vulgaris, 274.

Pink, maiden, 478. sea, 230.

Pinus, 510 sylvestris, 5 Io.

Pipe-wort, 384 .

Pisum, 95. maritimum, 95 .

Plantaginea, 297.

Plantago, 297. argentea, 505 .

Coronopus, 298.

intermedia (var.), 297.

lanceolata, 297.

major, 297

maritima, 298 media, 297.

Plantain, 297. water, 369

Platanthera, 349 . bifolia, 349 . chlorantha, 349 .

Plum, 485.

Plumbaginea, 229.

Poa, 423. alpina, 423.

annua, 423 .

compressa, 5 I 7

nemoralis, 424 .

palustris, 424 .

pratensis, 424 .

rigida, 427.

trivialis, 425 .

Polemoniacere, 500.

Polemonium, 500 . caeruleum, 500

Polygala, 46 . calcarea, $47^{8}$.

depressa, 47.

grandiflora (var.), 47.

oxyptera, (var.), 47.

serpyllacea, 47 . vulgaris, 46 .

Polygalex, 46.

Polygonacex, 304.

Polygonum, 304 . amphibium, 307.

arenastrum (var.), 305

aviculare, 305 .

Bistorta, 308 .
Polygonum

Convolvulus, 304 .

Hydropiper, 305 .

lapathifolium, 307 .

Laxum, 307.

littorale (var.), 305,

maculatum, 307 .

maritimum, 507.

minus, 306 .

mite, 306.

nodosum, 307.

Persicaria, 307.

Raii, 305.

Roberti, 305 .

rurivagum (var.), 305.

saggitifolium, 309 .

terrestre (var.), 307.

viviparum, 308 .

Polygonatum, 513. multiflorum, $5{ }^{3} 3$.

Polypodium, 45I.

Dryopteris, 452 .

Phegopteris, 452.

serraturı (var.), 452 .

vulgare, 45I.

Polypody, 451.

Polypogon, 516. monspeliensis, 516 .

Polystichum, 448 . aculeatum, 448 . angulare, 449 .

Filix-mas, 450 .

Zobatum, 448 .

Lonchitis, 448 .

spinulosum, 450 .

Thelypteris, 449 .

Pond-weed, 372 . horned, 382 . tassel, $38 \pi$.

Poob-bole, I86.

Poplar, black, 509. white, 509 .

Poppy, I3.

horned, 16.

opium, 13.

Welsh, 15 .

Populus, 328.

alba, 509 .

nigra, 509 .

tremula, 328 .

Portulacea, 61 .

Potamogeton, 372. alpinus, 374. angustifolius, 376 .

Babingtonii, 378 .

coloratus, 373 .

crispus, 378 .

decipiens, 376 .

densus, 378 .

filiformis, $38 \mathrm{I}$.

flabellatus, 380 .

fluitans, 373 .

Friesii, 380 .

graminews, 375, 379.

graminifolius (var.), 375 .

heterophyllus, 375 .

hibernicus (var.), 375=

intermutus, 380 .

Tacksoni (var.), 378 .

Kirkii, 373.

lanceolatus, 375 .

latifolius (var.), 376 .

Lonchitis, 5 I5.

Longifolizes, 378 . 
Potamogeton

lucens, 376

marinus, $38 \mathrm{r}$.

natans, 372 .

nitens, 376 .

obtusifolius, 379 .

pectinatus, 380 .

perfoliatus, 378 .

plantagineus, 373.

polygonifolius, 372 .

prælongus, 377 .

pseudo-fluitans (var.), 373.

pusillus, 380 .

rivularis (var.), 373-

rufescens; 374:

serratus (var.), 378 .

sparganizfolizs, 373 .

trichoides, 515 .

undulatus, 378 .

Zizii, 376 .

zosteræefolius, 515 .

Potentilla, Ir 3 .

Anserina, II4.

argentea, 486.

Comarum, II4.

Fragariastrum, II3.

fruticosa, II4.

nemoralis, II 3 .

palustris, I I 4 .

procumbens, II 3 .

reptans, II4.

Tormentilla, II3.

Poterium, II7.

dictyocarpum, II7.

officinale, I 77 .

Sanguisorba, Ir 7 .

Prash-ack-bwee, 32

Prickly fern, 448 .

Primrose, 23I. evening, 489 .

Primula, 23I. acaulis, $23 \mathrm{I}$. officinalis, 232. veris, 232.

vulgaris, $23 \mathrm{~T}$.

Primulacex, 231.

Privet, 236.

Prunella, 286. vulgaris, 286.

Prunus, 96.

Avium, 96.

Cerasus, 97.

domestica, 485 .

insititia, 96 .

Padus, 97.

spinosa, 96 .

Psamma, 4I7.

arenaria, 4I7.

Iittoralis, $4 \mathrm{I} 7$.

Ptarmica, I8r. vulgaris, $x 8 \mathrm{I}$.

Pteris, 442.

$$
\text { aquilina, 442. }
$$

Pulicaria, 180. dysenterica, '180. vulgaris, 493 .

Pulmonaria, 242. maritima, 242.

Purging buckthorn, 77 . Alax, 69 .

Purslane, sea, 57, 303. water, I4I.

Pyrethrum, 183 . inodorum, 183 .
Pyrola, 226.

media, 227.

minor, 227.

rotundifolia, 226 .

secunda, 228 .

Pyrus, 122.

Aria, I22.

Aucuparia, I23.

communis, 486.

Malus, I23.

rupicola (var.), I23.

\section{Q.}

Quaking-Grass, 423.

Quercus, 322. pedunculata, 322.

Robur, 322.

sessilifiora (var.), 322.

Quicken tree, I23.

Quill-wort, 46I.

\section{R.}

Radiola, 68 .

linoides, 68 .

mizZegrana, 68 .

Radish, 39 .

horse, 474 .

water, 2 I.

Ragged Robin, 5 I.

Ragwort, 189 .

Rampion, 498.

Ramsons, 356.

Rahen-Jack, 442,

Ranunculacea, $I$.

Ranunculus, 4

acris, 8.

arvensis, 472 .

auricomus, 8.

Baudotii, 6 .

Borcanus, 8.

bulbosus, 9 .

circinatus, 4

connosus, 6 .

confusus (var.), 6 .

divaricatus, 4

Drouetii (var.), 5 -

Ficaria, Io.

Flammula, 7 .

fluitans, 4 .

Friesianus (var.), 9.

Godronii (var.), 5 .

hederaceus, 7 .

heterophyllus, 5 .

hirsutis, 472.

incumbens (var.), ro.

intermedius (var)., 6 .

Lenormandi, 6 .

Lingua, 7.

parviflorus, 9 .

peltatus, 5 .

penicillatus, 5 .

petiolaris, 7 .

pseudo-fiuitans, 5 .

pseudo-reptans (var.), 7 .

radians (var.), 5 .

repens, 9 .

reptabundus, 9 .

sceleratus, 7 .

tenuisectus (var.), 9 .

tomophyllus (var.), 8.
Rantnculus

trichophyllus, 4.

tripartitus, 6 .

triphyllos (var.), 5 . truncatus (var.), 5 vulgatus, 9 .

Raphanistrum, 39 . innocurem, 39 . maritimum, 39.

Raphanus, 39 . maritimus, 39 . Raphanistrum, 39.

Raspberry, 99.

Rattle, red, $26 \%$. yellow, 267.

Red Rattle, 267.

Reed, 420 .

grass, 413 .

wood, 416 .

Reed-mace, 364 .

Reseda, 40.

alba, 477 .

litea, 40.

Luteola, 40.

suffruticulosa, 477 .

Resedacex, 40.

Rest-harrow, 8o.

Rhamnex, 77 .

Rhamnus, 77 . catharticus, 77.

Frangula, 78 .

Rhinanthus, 267.

Crista-galli, 267.

fallax (var.), 267. minor, 267 .

$R$ hodiola, 132 . rosea, 132 .

Rbynchospora, 39 r.

alba, 392.

fusca, 39 r.

Rib-wort plantain, 297

Ribes, 487

Grosstularia, 487 .

nigrum, 487 .

rubrum, 487 .

Rill-yōge, 320 .

lRiver dulse, 372 .

Roadside leaf, 3 Ir.

Rock-cress, 23. rose, $4 \mathrm{I}$.

Rocket, London, 29.

Roripa, 20. amphibia, $2 \mathrm{I}$. palustris, 20.

Rosa, II8. andevagensis (var.), r2I. arvensis, I22.

bibracteata (var.), I22. blondxana (var.), Izr.

canina, r2r.

cinnamornea, $4^{86}$.

coriifolia (var.), I22.

Dicksoni, 486.

Doniana, (var.), Irg.

dumalis (var.), raI.

dumetorum (var.), I2I

glabra (var.), rig.

glauca, 122.

gracilescens (var.), IIg.

gracilis (var.), Irg.

bibernica, Irg.

involuta, II8.

lavigata (var.), rig.

lutetiana (var.), I2I. 
Rosa

micrantha, I2r.

mollis, IIg.

mollissima, IIg.

Moorei (var)., Irg.

pimpinellifolia, $\mathrm{II} 8$.

pomifera, 486.

pruinosa (var.), I2I.

Robertsoni (var), IIg.

rubiginosa, I20.

Sabini (var.), II8.

scabriuscula (var.), L2o.

sepium, I2I.

spinosissima, II8.

subcristata (var.), I22.

systyla, 486 .

tomentella (var.), I2r.

tomentosa, I2o.

urbica (var.), I2I.

verticillacantha (var.), I2I. villosa, IIg.

Wilsoni (var.), I19.

Rosaceæ, 96 .

Rose bay, I42.

burnet, II8.

dog, 12x.

Guelder, I62.

Irish, II9.

rock, $4 \mathrm{r}$.

Rose-root, ${ }_{32 .}$

Rot-water, 274.

Rotballia, 436 . filiformis, 436 .

Rough chervil, 153 plant, 168.

Royal fern, 453.

Rubia, I63. peregrina, $\mathrm{I}_{3}$.

Rubiacere, 163.

Rubus, 99 .

adornatus, 106.

affinis, too.

amplificatus (var.), I03.

anglosaxonicus, I05.

argentalus, I02.

arvensis (var.), rog.

asperrimus (var.), 99 .

Babingtonii, 106.

Balfourianus, 109

Bellardii, xo8.

Bloxamii, ro6.

Borzeanus, I05.

Borreri, I03.

casius, rog.

calvatus (var.), 102.

cariensis, Ioo.

carpinifolius, 100.

chamzemorus, IIo.

cognatus (var.), ro7.

conjungens (var.), rog.

corylifolius, I08.

cyclophyllus (var.), Iog.

danicus, $\mathrm{IO}_{3}$.

discolor, 102 .

diversifolius (var.), Io8.

Drejeri, I04.

dumetorum, io8.

dumnoniensis, ror.

echinatoides (var.), ro5.

echinatus, ro5.

erythrinus, roI.

fasciculatus (var.), 108.

ferox, 108.

fissus, 99 .
Rubus

flexuosus, 106.

foliosus, 106 .

fruticosus, 99 .

fuscus, 106.

Gelertii, I05.

gratus, ro2.

Gunthert", 106.

hemistemon (var.), roo.

hesperius, I02.

hirtifolius, IO4.

hirtus, I07.

hystrix (var.), Io?.

Idæus, 99 .

incurvatus, 100

infestus, 105.

intermedius (var.), rog.

iricus, I03.

Kaltenbachii (var.), I07.

Kœhleri, I07.

leucostachys, ro4.

Leyanus, IO4.

ligerinus, Iog.

Lindleianus, Ior.

macrophyllus, $\mathrm{IO}_{3}$

macrostachys (var.), 106

micans, ro3.

mucronatus, x04.

nemoralis, ror.

Nezubouldit, I05.

nitidus, Ioo.

obscurus, 106

oigoclados, 105.

opacus, roo.

pallidus (var.), ro7.

plicatus, roo.

pubescens, 102

pulcherrimus, ror.

purpureus, 108.

pyramidalis, Io3.

radula, ro5.

rhamnifolius, Ior.

rhombifolius, I02.

Rogersii, roo.

rosaceus, I07.

rubiginosus (var.), 108.

rudis, 105 .

rusticanus, I02.

Salteri, IOz.

saxatilis, Iog.

saxicolus, 108 .

scaber, ro6.

scabrosus, 108.

Schlechtendalii (var.), ro3.

Selmeri (var.), roz.

silvaticus, I02.

Sprengelii, Io 3

suberectus, 99 .

sublustres, 108.

tenuis (var.), roo.

tuberculatus (var.), to8. vestitus, ro4.

villicaulis, rox.

viridis, 108.

Rue, meadow, $x$. wall, 446 .

Rumex, 3 I0.

Acetosa, $3 \mathrm{r}_{3}$.

Acetosella, $3 \mathrm{r}_{3}$

acutus (var.), 3 I2.

conglomeratus, 3 ro.

crispus, 3 I2.

Hydrolapathum, 312.

linuosus, 507.
Rumex

maritimus, 3 II.

nemorosus, 310 .

obtusifolius, 3 II.

palustris, 507 .

pulcher, 3 II.

sanguineus, 3 Io.

scutatus, 507 .

trigranulatus (var.), 3 I2.

viridis, 3 ro.

Ruppia, 38I.

maritima, $38 \mathrm{r}$.

rostellata, 381 .

spiralis, $38 \mathrm{r}$.

Ruscus, 5I2.

aculeatus, $5^{\mathrm{I} 2}$.

Rush, 358 .

beak, 39 I.

bog, 392 .

bull, 388 .

club, $3^{89}$.

flowering, 37 I.

toad, $35^{8}$.

twig, 392.

wood, 363 .

Rye-grass; 434.

s.

Saffron, meadow, 357 .

Sage, wood, 296.

Sagina, 57.

apetala, 57 .

ciliata, 58 .

densa (var.), 58.

Linnai, 48o.

maritima, 58 .

nodosa, 59 .

procumbens, 58 .

subulata, $5^{8}$.

Sagittaria, 370.

sagittifolia, 370 .

Sainfoin, 485 .

Salad, corn, I70.

Salicinez, 322.

Salicornia, 304.

herbacea, 304.

procumbens, 304 . radicans, 507 .

Salix, 322

acuminata, 509 .

alba, 324.

ambigua, 325 .

aurita, 324 .

caprea, 325 .

capreola, 324.

cinerea, 324 .

decipiens, 5og.

fragilis, 324 .

Helix, 328 .

herbacea, 326.

laurina, 509 .

lutescens, 324.

Moorei, 327.

nigricans, 326 .

pentandra, 323 .

phylicifolia, 325.

procumbens, 509 .

purpurea, 327 .

repens, 325.

rubra, 509.

Russeliana, 509.

Smithiana, 326 . 
Salix

triandra, 322.

undulata, 500

viminalis, 326 .

Sallow, 324 .

Salsify, 497.

Salsola, 304.

$\mathrm{Kali}, 304$.

Salt-wort, 304 .

Salvia, 283 .

Verbenaca, 283 .

Sam-vah-curra, $x 89$.

Sambucus, I62.

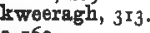
Ebulus, 162 . nigra, 162

Samolus, 235. Valerandi, 235.

Samphire, I55. golden, I79

Sand garlic, 355 .

Sandwort, 55,59 .

Sanguisorba, II7. offoisalis, II7.

Sanicle, 146 .

Sanicula, 146 . europaea, I46.

Saponaria, 47 officinalis, 47 Vaccaria, 478 .

Sarothamnus, 80 . scoparius, 80. vulgaris, 80.

Saussurea, I95. alpina, I95.

Savin, 510.

Saw-wort, r95.

Saxifraga, r24. affinzs, I30. aizoides, I29. Andrewsii, 487 . crespitosa, 487 . decipiens (var.), r3r. elegans (var.), 126. gemmifera (var.), I 30. Geum, 125 . granulata, rag. grcenlandica (var.), I3I. Guthriana, 87 Hirculus, I28. hirsuta (var.), I26. hirta, I30, I3I. hypnoides, I30. nivalis, r25.

oppositifolia, I24. punctata (var.), I 28 . quinguefida, 130 . serratifolia (var.), I28. sponhemica (var.), I3o. stellaris, r25.

Sternbergil (var.), I3I. tridactylites, I 29 . umbrosa, I27.

Saxifrage, burnet, I5I. golden, I3I. kidney-Ieaved, I25. mossy, I3o. purple, I24.

Saxifrageze, 124 .

Scabiosa, I73. arvensis, I73. Succisa, 173 .

Scabious, Devil's Bit, 173 . sheep's, 215.
Scaly fern, 446 .

Scandix, 153 .

Pecten-Veneris, 553 .

Schoberia, 304. maritima, 304 .

Schoenus, 392. nigricans, 392.

Scilla, 356

festalis, 357 .

nutans, 357 .

verna, 356

Scirpus, 387 . caespitosus, 387 .

Caricis, 515 .

cernutus, 388 .

fluitans, 388 .

lacustris, 388 .

maritimus, 389 .

nanus, 387 .

parvulus, 387

pauciflorus, 387 .

rufus, 380 .

Savii, $3^{88 .}$

setaceus, $3^{88}$.

sylvaticus, 380 .

Tabernaemontani, 388 .

Scleranthus, 299 .

annuus, 299.

Scterochloa, 426 .

Borreri, 427 .

distans, 426 .

loliacea, 428

maritima, 426 .

procumbens, 518 .

rigida, 427.

Scolopendrium, 446 .

vulgare, 446 .

Scorpion-grass, 243.

Scotch fir, 5 IO.

Scrophularia, 257 .

alata, 258.

aquatica, 257.

cinerea (var.), 258

Ehrhartit, 258.

nodosa, 258 .

Scorodonia, 503.

umbrosa, 258.

Scrophularinez, z53.

Scurvy-grass, 26 .

Scutellaria, 285.

galericulata, 285 .

minor, 285

Nicholsoni, 285 .

Sea beet, 30 r.

blite, 304

buckthorn, 507.

campion, 48.

cudweed, $18 \mathrm{x}$.

gromwell, 242

holly, I46.

kale, 38 .

lavender, 229.

milkwort, 233

Orache, 301.

pea, 95.

pink, 230.

purslane, 57, 303.

radish, 39 .

rocket, 39.

starwort, $\pi 74$ stock, I9.

Sedge, 393

bladder, 4I 2.

bottle, 4II.
Sedge

flea, 393 .

Sedum, $x_{32}$.

acre, 135 .

album, I34.

anglicum, I34.

dasyphyllum, I34.

maximum, I33.

micranthum (var.), 134 .

reflexum, I35.

Rhodiola, I32.

roseum, $\mathrm{I} 32$.

rupestre, 488 .

Telephium, I33

Selaginella, $46 \mathbf{r}$.

selaginoides, $46 \mathrm{I}$. spinulosa, 46I.

Selaginellacea, 46 r.

Selt-heal, 286.

Sempervivum, 488. tectorum, 488 .

Senecio, 186.

aquaticus, 189.

Cineraria, 495.

crassifolius, I87.

erucifolius, 188 .

flosculosus (var.), I89.

hibernica (var.), 187 .

Jacobæa, 189 .

radiatus (var.), 187.

saracenicus, 495 .

squalidus, 188 .

sylvaticus, 187 .

vernalis, $\mathbf{I} 87$.

viscosus, 187 .

vulgaris, $r 86$.

Senebiera, 34

Coronopus, 35 .

didyma, 34 .

pinnatifida, 34.

Sesleria, $42 \mathrm{I}$.

ccerulea, 421 .

Sham-rōge, 87,88.

Sham-sōge, 67 .

Shamrock, 87 .

Shave-grass, 456

Sheep's scabious, 2 I5. sorrel, 313.

Shellis-thrum, 35T.

Shepherd's needle, I53 purse, 34 .

Sherardia, 169 . arvensis, I6g.

Shore-weed, 298.

Sibthorpia, 260. europæa, 260 .

Sieglingria, 420. decumbens, 420 .

Silaus, 490 .

flavescens, 490.

pratensis, 490.

Silene, 47.

acaulis, 49 .

anglica, 48 .

Armeria, 478 .

conica, 478 .

Cucubalus, 47 .

dichotoma, 479

infiata, 47.

maritima, 48 .

noctiflora, 49

puberula (var.), 47.

Silver of rushes, 98 .

Silver weed, rI4. 
Silybum, 195. Marianum, 195.

Simethis, 354 bicolor, 354.

Sinapis, 3x. alba, 32 . arvensis, 32 nigra, $3 \mathrm{I}$.

Sisymbrium, 28. Alliaria, 30. Columnxe, 475 . Irio, 29. officinale, 29. pannonicum, 475 Sophia, 29. Thalianum, 28.

Sisyrinchium, 35I. anceps, 35I. angustifolium, 35 工. Bermudiana, 35 I. californicum, 352.

Sium, 150 . angustifolium, I5o. erectum, I5O. latifolium, I5O.

Skay-ack gee-yal, I24.

Skull-cap, 285 .

Slawn loos, 297.

Smyrnium, r47. Olusatrum, 147 .

Snake-weed, 308.

Snap-dragon, 257.

Sneeze-wort, I8I.

Snow-flake, 5 I2.

Snowdrop, 5 I2.

Soapwort, 47

Solanaceæ, 250.

Solanum, 250.

Dulcamara, 250. marinum, $25 \mathrm{I}$. nigrum, $25 \mathrm{I}$.

Solidago, 174 angustifolia (var.), I74 cambrica (var.), I74. Virgaurea, I74.

Solomon's Seal, 5I3.

Sonchus, 213. arvensis, 214 asper, 2I4. oleraceus, 213.

Booth thall-00-an, II2.

Sorbus, I22. Aria, 122 Aucuparia, I23.

Sorrel, 3I3. French, 507. mountain, 309 . sheep's, 3 I3. $_{3}$. wood, 76 .

Sowthistle, 213.

Sparganiurn, 365. affine, 365 microcarpum (var.), 365 , minimum, 366 . natans, 365 neglectum (var.), 365 . ramosum, 365 . simplex, 365

Spearmint, 504 .

Spearwort, 7. Specularia, 498. hybrida, 498 .

Speedwell, $26 r$. Spergula, 59 .
Spergula

arvensis, 59 .

pentandra, 480 saginoides, 480 . sativa, 59 . vulgaris, 59

Spergularia, 59 . media, 60 .

rubra, 59 . rupestris, 60 . sativa, 60 ,

Spike-rush, 385 .

Spindle-tree, 77 .

Spiræa, 98.

Fitipendula, 98 . salicifolia, 486 . Ulmaria, 98 .

Spiranthes, 338. autumnalis, $33^{8}$. gemmipara, 339. Romanzoffiana, 339 .

Spirodela, 369 . polyrh zza, 369 .

Spleen wort, 443

Spurge, 313. caper, 508

Spurrey, 59. knotted, 59 .

Squill, vernal, 356 .

Squinancy-wort, I68.

St. Dabeoc's heath, 225.

St. John's-wort, 63 .

St. Mary's cloak, II5.

St. Patrick's cabbage, 127.

Stachys, 287 .

ambigua, 288

arvensis, 280 .

Betonica, 287.

palustris, 288 .

sylvatica, 288 .

Star of Bethlehem, $5^{\text {I3 }}$.

Star-wort, sea, 174 . water, 139.

Statice, 229.

Bahusiensis, 229.

binervosa, 230.

Dodartil (var.), 230.

intermedia (var.), 230. occidentalis, 230 . rarifiora, 229.

Stellaria, 53 aquatica, 479. Boræana (var.), 54 , glauca, 54.

graminea, 55 .

Holostea, 54

media, 53 .

neglecta (var.), 54 .

palustris, 54. uliginosa, 55 .

Stitch-wort, 54 .

Stock, sea,

Stone bramble, Iog.

Stonecrop, I34.

Stork's bill 75 .

Strand holly, 146

Stratiotes, 334 . aloides, 334

Strawberry, barren, II3. Hautboy, 486 wild, II2.

Strawberry tree, 220.

Suada, 304.

maritima, 304 .
Subularia, jo.

aquatica, 30 .

Succisa, I73. pratensis, 173.

Sun of the Marsh, 189.

Sundew, 136 .

Sweet briar, Izo.

cicely, 152 .

flag, 367 .

Swine's cress, 35

Sycamore, 482.

Symphytum, 24I.

officinale, 243.

tuberosum, 500 .

\section{$\mathbf{T}$}

Tamus, 512

communis, 512 .

Tanacetum, 184 . vulgare, 184

Tansy, I84.

Taraxacum, 2 I2.

erythrospermum (var.), 213 .

officinale, 2 r2.

palustre (var.), 2r3.

udum (var.), $2 x_{3}$

Tare, $9 x$.

Tassel pond-weed, ${ }_{3}^{81 .}$

Taxus, 330 . baccata, 330

Tea plant, 5 or.

Tear-thumb, 309.

Teasel, 172 .

Teesdalia, 37 nudicaulis, 37 .

Teucrium, 295. Chamzedrys, 505 . Scordium, 295. Scorodonia, 296.

Thale cress, 28 .

Thalictrum, $\mathbf{r}$. alpinum, I. calcareum, 3 . collinum, 2. dunense, 2. flavum, 3 . flexuosum, 3 . Kochizi, 3 . majus, 3 . minus, 2. montanum, 3 .

Thimble, red, 261 .

Thistle, Ig2. Carline, rgo.

milk, I95. musk, 192. spear, I93.

Thlaspi, 37. arvense, 37.

Thorn-apple, 502.

Thrincin, $2 \mathrm{II}$. hirta, $2 \mathrm{Ir}$. hispida, $2 \mathrm{II}$.

Thrift, 230

Thyme, basil, $28 \mathrm{r}$. water, 332. wild, $28 \mathrm{I}$.

Thymus, 28I.

Chamadrys, 28I. corsicus, 504 . Serpyllum, 28 I.

Timothy grass, 4I4. 


\section{INDEX.}

Timad, 347. cylindsacea, 347 .

Tithymalus, 3 I 4 . hibernicus, 314 .

Toad rush, 358 .

Toad-flax, 253

Tolypella, 467. glomerata, 467. intricata, 468 . nidifica, 520 , prolifera, 468 .

Tooth-wort, 271

Toritis, I59. Anthriscus, I59. infesta, $49 \mathrm{I}$. rodosa, 159.

Tormentil, Ir3.

Tormentilla, II3. erecta, $x_{3}$. reptans, II 3.

Tragopogon, 2I4. minor (var.), 214. porrifolius, 497 pratensis, 2I4.

Traveller's joy, 47x.

Tree Mallow, 65 .

Trefoil, 83 . bird's-foot, 8r, 89 . hare's-toot, 84 . hop, 88. strawberry-headed, 87 .

Trichera, I73. arvensis, 173 .

Trichomanes, 440 Andrewsil (var.), 44r. radicans, 440 .

Trifolium, 83 agrarium, 485 . arvense, 84 . dubium, 88 . filiforme, 88 . fragiferum, 87 . glomeratum, 86 . hybridum, 484 . maritimum, 484 . medium, 84 . minus, 88. ornithopodioides, 8r. pratense, 83 . procumbens, 88. repens, 87 . resupinatum, 485 . scabrum, 86. striatum, 85 . subterraneum, 83 .

Triglochin, 372. maritimum, 372 . palustre. 372 .

Trigonella, 8r. ornithopodioides, $8 \mathrm{t}$. purpurascens, $8 \mathrm{r}$.

Trinia, 489 . vulgaris, 489 .

Triodia, 420 . decumbens, 420 .

Trisetum, 4I9. flavescens, 4I9. pratense, 4 I9.

Triticum, 428 . acutum, 436 . caninum, 434 . junceum, 436 loliaceum, 428. Moorei, 435 .
Triticum

pungens, 435 .

repens, 435

Trixago, 266 . viscosa, 266.

Trollius, II. europaus, $I x$.

Turritis, 473 . glabra, 473.

Tussilago, I86. Farfara, 186.

Tutsan, 62 .

Twayblade, 338 .

Twig rush, 392 .

Typha, 364 . angustifolia, 364 . latifolia, 364 ,

Typhacex, 364 .

ช.

Ulex, 79 . europæus, 79. Gallii, 80 . strictus, 79 .

Ulmus, 3 I8. montana, 378 . suberosa, 508 .

Umbellifera, 146.

Umbilicus, I32. pendulinus, 132

Urtica, 319. dioica, 319. pilulifera, 508 . urens, 319 .

Urticacea, 318.

Utricularia, 272 intermedia, 273. minor, 273. neglecta, 273 . vulgaris, 272.

v.

Vacciniex, 218.

Vac cinium, 218 . cantabricum, 225 . Myrtillus, 2I9. Oxycoccus, 2Ig. Vitis-Idaea, 218 .

Valerian, 169. red, 170 .

Valeriana, I69. Mikanii, I7o. officinalis, 169 . pyrenaica, 492 . sambucifolia, 169.

Valerianex, 169 .

Valerianella, I70. Auricula, I 7 r. carinata, 492. dentata, 171 . Morrisoniz, 171. olitoria, I7o. rimosa, I7I.

Verbascum, 253. Blattaria, 502 . nigrum, 502 Thapsus, 253. virgatum, 502

Verbena, $\mathbf{2 7} 6$. officinalis, 276 .

Verbenaces, 276 .
Vernal grass, 4r3. squill, $35^{6}$.

Veronica, 26r. agrestis, $26 \mathrm{r}$. Anagallis, 264 . arvensis, 262 . Beccabunga, 264 Buxbaumi:, 262. Chamadrys, 263 . hederzefolia, $26 \mathrm{I}$. montana, 263 officinalis, 262. peregrina, 264 . persica, 262. polita, 262 . scutellata, 263 . serpyllifolia, 262. Tournefortifi, 262. triphyllos, 503 .

Vervain, 276.

Vetch, 485 .

bitter, 92

bush, 92.

kidney, 89 .

tufted, 9 .

wood, 92 .

Vetchling, 94 .

Viburnum, I62

Lantana, 49 .

Opulus, I6z.

Vicía, gI.

angustifolia, 93 .

Cracca, 9 r.

gemelia, $9 \mathrm{I}$.

hirsuta, 9 .

lathyroides, 93 .

Orobus, 92.

sativa, 485 .

sepium, 93 .

syivatica, 92 .

tetraspernia, 9 r.

Villarsia, 500 .

nympheoides, 500.

Vince, 490 .

major, 499 .

minor, 499 .

Viola, 42 .

arvensis, 45 .

canina, 44 .

Curtisit, $4^{6}$.

hirta, 43 .

lutea, 46 .

odorata, 42.

palustris, 42

persicafolia, 45 .

Reichenbachiana, 44.

Riviniana, 43.

stagnina, 45 .

syluatica, 43 .

sylvestris, 44

tricolor, 45 .

Violacea, 42 .

Violet, 42.

dog, 44 .

sweet, 42.

water, 231.

Viper's bugloss, 247.

Viscum, 508 . album, 508

Vuipia, 428 . membranacea, 428 .

Myuros, 428.

sciuroides, 429 .

zuniglumis, 428 . 


\section{w.}

Wahlenbergia, a 26 . hederacea, 216 .

Wall, lettuce, 213 . mustard, 33. pellitory, 320 .

pepper, 135 .

rue, 446 .

Wallflower, Ig.

Water, avens, $x \mathbf{r 2}$.

blinks, $6 I$.

cress, 20.

crowfoot, 4

dropwort, I55.

germander, 295.

hemlock, 148 .

lily, 12 .

lobelia, 2 I5.

milfoil, 138 .

parsnep, 147, I50.

pipes, 456 .

plantain, 369 .

purslane, $14 t$.

soldier, 334 .

starwort, 139

thyme, 332.

violet, 23 .

wort, 6I.

Way-bread, 297.

Wayfaring tree, $49 x$.

Weasel-snout, 293.
Weld, 4I.

Welsh poppy, $\mathbf{x} 5$.

Wheat-grass, 434 .

Whin, 79 .

White helleborine, 340 .

horehound, 286 . mignonette, 477 .

White-thorn, I24.

Whitlow-grass, 26 .

Whortleberry, 2rg.

Willow, 322.

almond-leaved, 322 .

bay, 323 .

crack, 324 .

herb, I43.

rose, 327 .

tea-leaved, 325.

white, 324

Winter heliotrope, I86.

Winter-green, 226 .

Woad, 477 .

Wood Avens, II2.

reed, 416 .

rush, $3^{6} 3$.

sage, 296.

sorrel, 76.

Woodbine, 163 .

Woodruff, 168.

Worm - wood, 184.

Wound plant, I4I.

Woundwort. 288.

Wych elm, 318. $\mathbf{x}$.

Xanthium, 493.

Strumarium, 493.

$\mathbf{Y}$.

Yellow bird's-nest, 228.

boy, 180 .

flag, 35I

monkey-flower, 259

rattle, 267.

weed, 4I,

wort, 237.

Yellow-eyed grass, 352.

Yew, 330 .

Yure, 330.

B.

Zannichellia, 382 .

brachystemon, $3^{82}$.

palustris, 382 .

pedunculata, 382 .

polycarpa, 383

Zostera, 383 .

marina, $3_{3}$.

nana, 383 . 





